UNITED STATES DEPARTMENT OF THE INTERIOR

Ray Lyman Wilbur, Secretary

GEOLOGICAL SURVEY

George Otis Smith, Director

Water-Supply Paper 617

\title{
UPPER COLORADO RIVER AND ITS UTILIZATION
}

BY

ROBERT FOLLANSBEE
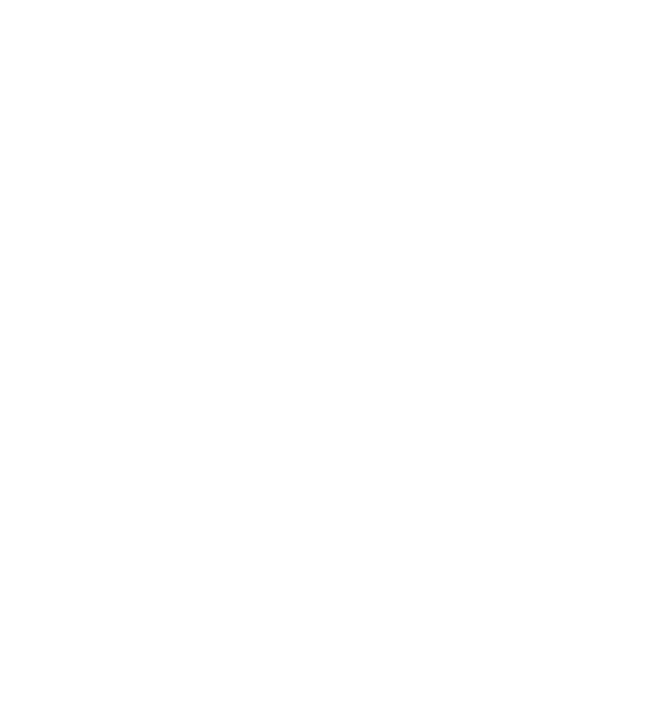

UNITED STATES

GOVERNMENT PRINTING OFEICE

WASHINGTON : 1929 
$\checkmark$ 


\section{CONTENTS}

Page

Preface, by Nathan C. Grover.

Synopsis of report.... XI

Introduction .........

Soope of report

Index system .......... 2

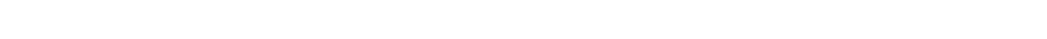

Bibliography _.......... 3

Physical features of basin . .

Location and accessibility ...

Topography _...

Plateaus and mountains

The main river. . . . . .

Tributaries above Gunnison River...... 8

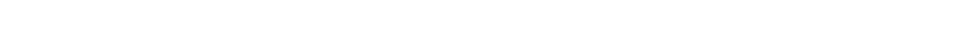

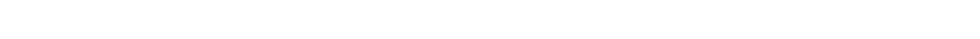

Forestation........

Bcenic and recreational features.

General features.

Mountain peaks.

Lakes . . . .

Flora and fauna............ 21

Resort centers. ........... 22

Climate

Distinctive features.

Temperature . .

Precipitation. .

Evaporation ......... 30

Available records......... 30

Factors influencing rate of evaporation 39

Comparison of records.

Variation in annual evaporation

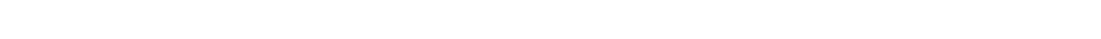

Mean annual discharge...... 41

Variations in annual discharge.... 43

High-water discharge.

Low-water discharge...... 47

Transmountain diversions. . .

Present development.

Future development. .

46018-29 III 
Storage-

Storage

Developed sites....

Undeveloped sites.... 68

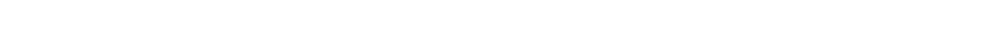

Tributaries above Gunnison River... 79

Gunnison River Basin. . . . .

Dolores River Basin. 101

Irrigation and agriculture

Eariy history $\ldots \ldots \ldots$

Present development.

Character of agriculture $\ldots \ldots \ldots$

Summary of irrigated areas.

The main river... 119

General conditions $\ldots$

Irrigation in Grand Valley

Tributaries above Gunnison River. _.

Gunnison River Basin . . .

Dolores River. . 136

Future extension of irrigation. 140

General conditions . . .

The main river.

Tributaries above Gunnison River.

Gunnison River Basin . .

Dolores River Basin.

Effect on discharge of Colorado River. 147

Water power........... 148

Factors affecting development.

Topography _..

Necessity for storage $\ldots$

Climate..................... 149

Competition of steam power.... 149

Factors affecting hydraulic structures...

Ice

Floods_...

Sediment............ 154

Basis of estimates of power capacity

Markets . . . . . . . .

Population and industry $\ldots$

North-central Colorado

Railroad electrification...

Developed power. 161

General features.

History of development. 162

Water-power plants. 165

Summary ....

Undeveloped power

Scope of investigations.

The main river. 182

Tributaries above Gunnison River.

Gunnison River.... 193

Dolores River. 199

Recapitulation............. 204

Appendix. Records of stream flow... 205

Index . . . 
Prate 1. Map of upper Colorado River Basin showing utilization of water resources and lines of equal precipitation In pocket.

2. Contour map of Hine No. 2 Reservoir site, on Colorado River_ 68

3. Contour map of Dewey Reservoir site, on Colorado River...-. 74

4. Contour map of Hine No. 1 Reservoir site, on Williams River-- 80

5. Contour map of Taylor Park Reservoir site, on Taylor River.- $\quad 90$

6. Contour map of Dolores Reservoir site, on Dolores River..- 102

7. Contour map of Bedrock Reservoir site, on Dolores River... 102

8. Contour map of Fiftymile Reservoir site, on Dolores River... 102

9. Colorado River diversion dam, Grand Valley project....... 120

10. $A$, Cut on High Level Canal, Uncompahgre project; $B$, Albin

ranch, 1 mile south of Table Mountain _..... 121

11. Effect of snow on transmission lines of Western Colorado Power

Co. at altitude of 13,000 feet.

12. Transmission-line tower of Public Service Co. of Colorado protected against snowslides by pier.

13. $A$, Shoshone plant of Public Service Co. of Colorado; $B$, Snowslide covering on timber flume from Trout Lake Reservoir of Western Colorado Power Co..................................

Frgure 1. Variation in annual precipitation at Meeker, Grand Junction,

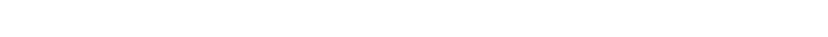

2. Variation in annual run-off at Hot Sulphur Springs, Glenwood Springs, and Palisade, Colo.

149

164

29

45

3. Flood discharge of Colorado River at Yuma, Ariz., as it would be modified by operation of Dewey Reservoir.

4. Hydrographs of Cache la Poudre River for 1884 and a normal year (1912)

152

5. Duration curve for Colorado River at Glenwood Springs, Colo. 



\section{PREFACE •}

By Nathan C. Grover 1

This report is one of a series of reports treating of the value and utilization of the Colorado River and its tributaries. The first of these reports, Colorado River and Its Utilization, by E. C. LaRue, published in 1916 as Water-Supply Paper 395, has been regarded as authoritative with respect to facts pertaining to the river and its tributaries that were available at that time. The introduction of that report contained the following statement:

Mr. LaRue has attempted the pioneer work of assembling the principal facts relating to the subject, and especially of studying the possibilities of controlling the flow of the whole river by means of storage reservoirs in order to avoid further danger of overflow to the Salton Sink and to render available for profitable use the enormous quantity of water which now flows unused and largely unusable to the Gulf of California in the form of floods.

After that report was published many investigations and surveys were made, the canyons were accurately mapped, possible sites for dams were studied, and additional reliable records of river discharge were collected. That part of the new information which related to the Colorado below the Green was published in 1925 as Water-Supply Paper 556, entitled "Water Power and Flood Control of Colorado River Below Green River, Utah," by E. C. LaRue. The following paragraph is quoted from the introduction of that report:

The Geological Survey is not attempting to promote any particular project but is endeavoring to collect and make available the information needed as the basis for outlining a proper scheme for full development of the river and for selecting the site for first development. It recognizes the fact that the final choice of any project will represent a compromise of conflicting interests, in which many factors-engineering, economic, and perhaps political-must be evaluated and given proper weight. The survey hopes that this report, which contains the latest compilation of data relating to the water supply of the basin and the results of all surveys of sites for reservoirs and power dams, may aid in the solution of these important problems.

The Geological Survey has now prepared two more reports which will be published in succession-this report, Water-Supply Paper 617, entitled "Upper Colorado River and Its Utilization," by Robert Follansbee, and a companion report, Water-Supply Paper 618, entitled "Green River and Its Utilization," by Ralf R. Woolley. 
In addition to these published reports, the following manuscript reports have been prepared and are open to public inspection, as indicated:

Water utilization in the San' Juan River Basin, by E. C. LaRue, open for inspection in the offices of the Geological Survey in Washington, D. C., and Denver, Colo.

Probable future stages of Salton Sea, by George F. Holbrook, open for inspection in the offices of the Geological Survey in Washington, D. C., and San Francisco, Calif.

Although this report by Mr. Follansbee is one of a group of similar reports, it is complete in itself, relates to an integral part of the Colorado River drainage basin, and overlaps none of the other reports except that the original LaRue report (Water-Supply Paper 395) presented the salient facts available in 1916 relative to this part of the basin of the Colorado River, which was then known as the Grand River, as well as to other parts of the basin. This report may therefore be regarded as supplementary to Water-Supply Paper 395 and complementary to Water-Supply Papers 556 and 618 and the manuscript reports on the San Juan River and Salton Sea to which reference has already been made.

The upper Colorado and Green Rivers, which discharge yearly at their junction essentially equal quantities of water, drain mountainous regions of great extent, on which there is heavy precipitation. These two rivers, which yield 82 per cent $(12,500,000$ acre-feet) of the average measured run-off at Lees Ferry, Ariz. (15,200,000 acre-feet), are of great importance in the development of several States through or near which the Colorado flows.

The headwaters of the upper Colorado River are situated in the high mountains that form the Continental Divide, at altitudes of more than 14,000 feet, on which the annual precipitation may exceed 50 inches in depth. The run-off of the Colorado is accumulated into rivers of considerable size at an altitude of 7,600 feet, and from points of such accumulation it falls 3,700 feet to an altitude of about 3,900 feet at the mouth of the Green in a distance of about 380 miles, or at the average rate of about 10 feet to the mile. The fall of tributary streams is similarly notable. There are therefore within this basin great power sites that have a combined estimated capacity of more than 400,000 horsepower with storage development, of which 47,000 horsepower has been developed.

The basin cont ains 545,000 acres of irrigated land and 669,000 acres additional which may be irrigated within the next half century.

There are six diversions across the Continental Divide at altitudes above 10,000 feet from drainage areas aggregating 30 square miles. The diverting ditches have capacities ranging between 10 and 220 cubic feet per second and aggregating 343 cubic feet per second. 
The quantity of water diverted varies from year to year and averages about 20,000 acre-feet.

Several ambitious projects for tunnels and collecting ditches have been considered. It is estimated that the ultimate limit of additional diversions from tributaries of the Colorado through the Continental Divide may be about 275,000 acre-feet, or approximately 4 per cent of the mean annual discharge above the mouth of the Green.

Storage of waters is closely related to the future development of the water resources of the basin. Such development has not progressed far, relatively, as shown by this report, which lists 166 possible reservoir sites with an aggregate capacity of $16,500,000$ acre-feet but describes only 42 constructed reservoirs with an aggregate capac- . ity of only 88,580 acre-feet.

It is the essential purpose of the report to present the important facts relating to the water resources of the upper Colorado River and its tributaries, so as to afford a basis for comprehensive consideration of their development and utilization not only within the basin specifcally treated but within the entire Colorado River Basin, in so far as coordination of utilization and development may be desirable. It is believed that the report fulfills this purpose in high measure. 
,

、 


\section{SYNOPSIS OF REPORT}

\section{PHYSICAL FEATURES OF BABIN}

Location.-The upper Colorado River Basin, above the Green River, includes about half of the western half of Colorado. It lies midway between the northern and southern boundaries of the State and extends from the Continental Divide to the mouth of the Green River. The entire area comprises 26,500 square miles, of which 4,300 miles is in Utah.

Topography.-The topography of the entire basin is extremely rugged. The main ranges of the Rocky Mountain system, containing hundreds of peaks exceeding 13,000 feet in altitude and several exceeding 14,000 feet, cross the upper part of the basin. Farther west, these rugged mountains give way to flat-topped mesas in which the main river and its numerous tributaries have deeply intrenched themselves in relatively narrow valleys.

Forestation.-Forests are found only in the mountains, where the precipitation is sufficient to support their growth. The altitude of the lower limit of forestation is 7,500 feet, and the upper limit ranges from 11,600 to 12,000 feet. This upper limit, however, is not due to insufficient precipitation. The total protection stand of timber is $9,457,000,000$ feet board measure, covering 6,018 square miles.

\section{CLIMATE}

The most distinctive climatic feature of the basin, especially in the valleys, is the comparative uniformity of weather conditions from day to day, with few sudden changes.

Temperature.-The wide range of altitude in the basin causes a corresponding wide range in temperature. The recorded mean monthly maximum temperature ranges from $70^{\circ}$ at Whitepine, Colo. (altitude 10,000 feet), to $95^{\circ}$ at Moab, Utah (4,000 feet), and the mean monthly minimum temperature ranges from $-9^{\circ}$ at Gunnison, Colo. (7,680 feet), to $17^{\circ}$ at Moab. The maximum temperature recorded was $109^{\circ}$ at Delta, Colo. (4,980 feet), and the minimum, $-47^{\circ}$ at Gunnison. The diurnal variation in temperature ranges from $25^{\circ}$ to $40^{\circ}$ throughout the year and is practically the same for all stations. The wide variation in temperature causes a corresponding variation in the average period between killing frosts, the extreme being 13 days at Breckenridge, Colo. (altitude 9,530 feet), and 184 days at Grand Junction, Colo. (4,570 feet).

Precipitation.-The mean annual precipitation ranges from less than 10 inches in the sheltered valleys to more than $\mathbf{5 0}$ inches in the higher parts of some mountain areas. In general the areas of highest precipitation are not on the Continental Divide but on the mountain masses that form the western edge of the Rocky Mountain system. The seasonal distribution is fairly uniform. From $\mathbf{4 0}$ to $\mathbf{5 0}$ per cent occurs from December to April, and 30 to 35 per cent during the irrigation season-June to September. The winter precipitation is in the form of snow, which forms the great natural reservoir for stream flow during the summer. The summer rainfall takes the form of showers, occurring usually in the afternoons. In the western foothill region the showers occasionally reach "cloudburst" intensity. 


\section{EVAPORATION}

In considering evaporation use has been made of all records in the entire Colorado River Basin. Records at 19 points in and adjacent to the basin have been compiled by different organizations, using pans of varying types and exposures. These records have been reduced to so-called reservoir equivalents and represent the evaporation from reservoir surfaces. The mean monthly determinations are presented for each station together with air temperatures and wind velocities. In addition computed records of evaporation at Lander, Wyo., are given. The mean annual reservoir equivalent of evaporation ranges from 22 inches at Wagonwheel Gap, Colo. (altitude 9,610 feet), to 79 inches near Yuma, Ariz. (220 feet). About 50 per cent of the yearly evaporation occurs from June to September.

\section{WATER SUPPLY}

Mean annual discharge.-Records of discharge at nine gaging stations on the main river ranging from 3 to 31 years, are available. By consideration of the comparatively uniform variation in annual run-off throughout the basin and the 31-year record at Palisade, Colo., the 31-year mean discharge has been computed for seven stations. At the Cisco station, which represents closely the run-off originating in Colorado, the mean annual discharge is 6,600,000 acre-feet.

Variation in annual discharge.-In the 31 years covered by the records at Palisade the variation in annual run-off has ranged from 54 per cent of the mean in 1902 to 143 per cent in 1917 . The year 1902 was in the middle of an 8-year period of which every year except one had less run-off than the 31-year mean, the mean for the 8 years being 83 per cent. From a comparison of levels of Great Salt Lake it appears that 1902 was the year of lowest flow in a period of possibly 75 years. At Hot Sulphur Springs the variation indicated by the records has ranged between 199 per cent of the mean in 1914 and 62 per cent in 1919 , but no record is available for the minimum year of 1902 .

High-water discharge.-The upper Colorado River and its principal tributaries are not subject to floods in the commonly understood sense of the term. High water, which is due to melting snow, occurs with great regularity each year, but the run-off per square mile is low, ranging from 18 to 3.2 second-feet on the main river and from 33 to 2.7 second-feet on the tributaries.

Low-water discharge.-Except for those streams whose summer discharge is seriously depleted by irrigation requirements, the period of minimum discharge occurs during the winter, when precipitation takes the form of snow and the only source of supply is the ground water. The minimum run-off per square mile ranges from 0.68 to 0.07 second-foot.

\section{TRANSMOUNTAIN DIVERSIONS}

At six points water for irrigation is being diverted from the headwaters of the Colorado to other basins, chiefly the South Platte. The mean annual amount diverted is 20,400 acre-feet. These developments represent practically the limit of transmountain diversions by relatively inexpensive open ditches. Additional developments must be made by means of tunnels and long collection ditches leading to them. Developments to divert water from the Fraser, Williams, Blue, and Eagle Rivers and Fryingpan Creek-the only streams that the writer believes are so situated that they can be seriously considered for many yearshave been proposed. The estimated annual diversion by these proposed developments amounts to 262,000 acre-feet. The discharge of the Colorado River during the diversion period would be reduced 20 per cent at Kremmling, 15 per cent at Glenwood Springs, 8 per cent at Palisade, and 5 per cent at Cisco. 


\section{WORAGD}

Developed sites.-The storage of water in the upper Colorado River Basin is in an elementary stage. The water supply, of the larger streams is sufficient for the present irrigation requirements, and it is only on a few of the smaller tributaries that storage has become necessary. Forty-one reservoirs, each having a capacity exceeding 500 acre-feet, have a total capacity of 88,000 acre-feet.

Undeveloped sites.-Large reservoir sites are scarce, but there are many sites ranging in capacity from a few acre-feet to 50,000 acre-feet, and a few still larger. During the last 25 years engineering arganizations have been actively engaged in surveying possible and impossible reservoir sites and have filed the results of these surveys in the State engineer's office. A few of the largest sites have been surveyed by the United States Bureau of Reclamation. From a study of these data and of available water supply, augmented by field examinations at a few places, 38 sites having a capacity of more than 4,000 acre-feet each and a total capacity of 8,940,000 acre-feet have been selected for discussion. Of these, 17 sites having a total capacity of $8,180,000$ acre-feet appear suited to power development, and 22 sites having a total capacity of 761,000 acre-feet appear to. be suited to irrigation development. The increase in power that would beprovided by these reservoirs under different methods of operation is estimated at 179,000 to 205,000 horsepower for 90 per cent of the time and at 174,000 to 188,000 horsepower for 50 per cent of the time. The use of the sites having value chiefly for irrigation will result in the irrigation of an additional 250,000 acres. The largest site is at Dewey, Utah, on the Colorado a few miles west. of the Colorado-Utah line. This site has a possible capacity of $4,000,000$ acrefeet and would be of value not only for the development of power but also in: reducing the peak of flood flows at Yuma, Ariz.

\section{IRRIGATION AND AGRICULTURE}

Early history. - Irrigation in this area dates practically from the settlement of the upper end of the basin, about 1860. The first irrigation was on the headwaters near the mining camps, and as settlement increased new ditches were: constructed along the streams, gradually approaching the mouth. Grand Junction was founded in 1882, and in the following year the Grand Valley Canal was started by a mutual organization to irrigate a large area in Grand Valley. With this exception, the early ditches were small individual or partnership affairs, many being little more than plow furrows. The few diversion dams built were either loose-rock or brush-filled structures. This condition is still true for a great number of the ditches in the upper basin.

Present development.-In and near Grand Valley and in the Uncompahgre Valley the large areas of irrigable land and the need for constructing expensive headworks in the streams made necessary the formation of mutual companies. After the passage of the reclamation act, in 1902, the Federal Government, at the request of the landowners, took over the Uncompahgre project and greatly enlarged it. Later the high-line canal in Grand Valley was built. Mutual companies irrigate land in Montezuma Valley and mesa lands on the North Fork of the Gunnison and one or two smaller tributaries. The abundance of water has made it unnecessary to construct reservoirs except on some of the smaller tributary streams. The total area under ditches is 926,000 acres, of which 564,000 acres is irrigated. The principal crops are alfalfa and native hay, smalt grains, sugar beets, and potatoes.

Future extension.-The future extension of irrigation will be brought about by a complete settlement of existing projects, the enlargement of some of the projects to cover additional lands, and the construction of new projects. The 
magnitude of the extension is a subject upon which there is a wide difference of opinion. It is believed that 75 per cent of the land under existing ditches will ultimately be irrigated, and that the enlargement of existing ditches will cover 15 per cent additional land. It is believed that within a period of possibly 50 years the new projects built will bring the total additional area irrigated up to 669,000 acres. Many of the new projects will require the construction of large reservoirs. The effect of this additional irrigation will be to reduce the discharge of the Colorado River at the Cisco station by 1,000,000 acre-feet, or 15 per cent.

\section{WATER POWER}

Factors affecting development.-The topography of the basin is fairly well suited to water-power development, but large reservoir sites are scarce. As water-power sites are generally above irrigated areas, little conflict will arise between these two uses when direct flow only is used. If storage of considerable magnitude is required a conflict may arise during years of very low flow, but this conflict will occur at such infrequent intervals that it can best be avoided by releasing the natural flow during those years. The low-water discharge taken as that for 90 per cent of the time, is about half that for 50 per cent of the time and one-fifth that of the yearly mean. With unregulated flow the value of the streams for primary power is relatively small, but with storage this can be greatly increased.

Power development, with electrical transmission to markets, is attended with considerable difficulty in this area, owing to the wide range of annual temperature, electric disturbances, heavy snowfall, rock slides, and high wind velocities. Moreover, the abundance of coal in nearly all parts of Colorado makes it possible to develop steam power close to the markets at a cost which, taken in connection with the elimination of long transmission lines, is generally cheaper at the present time than the development of water power.

Factors affecting hydraulic structures.-Except where local hot springs prevent freezing, all the streams are subject to freezing during the winter, and precautions against ice are necessary. Though the streams are not usually subject to severe floods, such floods have occurred. The highest known stage of the Colorado River occurred July 4, 1884, when the discharge at Fruita was determined as 125,000 second-feet. All streams in the basin were very high during that flood. In the past 20 years four periods of heavy general rain have occurred in the basin-September 30, 1909; October 4-6, 1911; and June 3-7 and 14-15, 1921. The resulting floods were especially severe in the southwestern part of the basin, in the San Juan Mountains.

The quantity of sediment in the upper Colorado River and its tributaries is small compared with that in the lower basin. The annual amount has been estimated at 167 acre-feet at Kremmling, 950 acre-feet at Palisade, and 8,175 acre-feet in the Dewey reservoir site.

Markets.-In the 10-year period ending 1920 the total population of the upper Colorado River Basin was practically stationary, being about 84,000 . In the past mining has been the chief industry, but it is now at low ebb, and its future is problematic. The existing power plants will probably be able to care for much of the market afforded by a revival of this industry. The slow growth of the population indicates a slow expansion for public utilities, at least for some years. The future market for power will probably be the region in north-central Colorado east of the Continental Divide and the electrification of railroads that traverse the basin.

Developed power.-The installed capacity of water wheels in 41 plants is 47,352 horsepower, of which 7 public-utility plants, chiefly urban, for use in northeastern Colorado, have 19,034 horsepower; 7 public-utility plants, chiefly mining, 18,050 
horsepower; 20 individual mining plants, 6,718 horsepower; 4 irrigation pumping plants, 3,350 horsepower; 2 flour mills, 100 horsepower; and 1 private plant, 100 horsepower. Of the total installation 29,450 horsepower is included within the systems of the Public Service Co. of Colorado, and the Western Colorado Power Co.

Undeveloped power. - In determining the future development of power all streams in the basin for which information relative to fall and discharge are available have been considered. In all 40 sites, having 117,000 horsepower available for 90 per cent of the time and 222,000 horsepower for 50 per cent of the time, are believed to offer conditions that make such development feaslble. These capacities are with natural flow only. The increased power due to storage is discussed under undeveloped storage sites. 



\title{
UPPER COLORADO RIVER AND ITS UTILIZATION
}

\author{
By Robert Follansbee
}

\section{INTRODUCTION}

\section{SCOPE OF REPORT}

This report presents, in form for ready reference, the available data pertaining to the present and future utilization of the surface waters of the upper Colorado River Basin, above the Green River, and includes information relating to topography, climate, evaporation, water supply, transmountain diversions, storage, irrigation and agriculture, and water power as they existed in 1927.

The data concerning developed storage were obtained either from the operators of the reservoirs or from the State water officials having jurisdiction over them. The discussion of undeveloped storage includes all known sites having a capacity of about 4,000 acre-feet or more, except such sites as appear to the writer unfeasible. The unfeasible sites have been listed separately, and the reasons for such classification have been given.

The discussion of irrigated areas is based on the annual reports of the State water commissioners, investigations by many Government and State organizations, and personal inspection of the larger areas by the writer. The descriptions of the larger projects have been obtained from officials directly connected with them. In considering additional irrigation in the future all proposed projects have been studied, and those that do not appear feasible on account of deficient water supply or excessive cost have been eliminated.

Information concerning developed water power was obtained from the managers of power plants and by personal inspection. Estimates of undeveloped water power are based on profile surveys of the principal streams in the basin and stream-flow records. No attempt has been made to estimate the total potential power in the basin, as much of the power is scattered along stretches of the streams where the slope is too small to make its development feasible.

Records of monthly discharge for all gaging stations maintained for any considerable time in the basin are given in the appendix of this report. Many of the stations have been maintained by the State engineer, and the records are published in his bibnnial reports. All 
records for the stations maintained by the United States Geological Survey are published in the annual stream-flow reports of the Geological Survey.

\section{INDEX STSTEM}

For the purpose of indexing data pertaining to the water resources of the United States, the Geological Survey has divided the country into 12 major divisions, conforming to the principal drainage basins. Each of these is subdivided according to minor drainage basins.

In this system the Colorado River Basin is known as division 9, and the Colorado River above the mouth of the Green comprises subdivisions D (including all the Colorado River Basin above the mouth of the Green River except the Gunnison River Basin) and $\mathbf{E}$ (the Gunnison River Basin). Each of these principal subdivisions is again divided into smaller ones as follows:

9D Colorado River Basin excluding the Gunnison River:

9DA Colorado River Basin from source to the Blue River.

9DB Blue River Basin.

9DC Colorado River Basin from the Blue River to the Eagle River.

9DD Eagle River Basin.

9DE Colorado River Basin from the Eagle River to the Roaring Fork.

9DF Roaring Fork Basin.

9DG Colorado River Basin from the Roaring Fork to Roan Creek.

9DH Roan Creek Basin.

9DJ Colorado River Basin from Roan Creek to the Gunnison River.

9DK Dolores River Basin from and including the San Miguel River Basin to the Colorado River.

9DL Dolores River Basin from the source to the San Miguel River.

9DM Colorado River Basin from the Gunnison River to the Green River.

9E Gunnison River Basin:

9EA Gunnison River Basin from the source to Tomichi Creek.

9EB Tomichi Creek Basin.

9EC Gunnison River Basin from Tomichi Creek to the North Fork of the Gunnison River.

9ED North Fork of the Gunnison River Basin.

9EE Gunnison River Basin from the North Fork to the Uncompahgre River. 9EF Uncompahgre River Basin.

9EG Gunnison River Basin from the Uncompahgre River to the Colorado River.

The designation 9DA 1 is explained as follows: The figure 9 is the number of the major division of the United States-the Colorado River Basin; the letter D, the first letter following the number, refers to that stretch of the Colorado River above the mouth of the Green River; the letter A represents the specific area between the source of the Colorado River and the Blue River; the figure 1 is the item number given, to the Monarch mine power plant. Other power plants in the minor drainage area would be indicated by numbers 9DA 2, 9DA 3, etc. The same system is applied to reservoirs, reservoir sites, and power sites, the items being numbered consecutively beginning with 1 for the site farthest upstream. 


\section{ACKNOWLEDGMENTS}

The writer wishes to express his appreciation of the helpful services of the engineers and others who have rendered assistance in collecting the data on which this report is based. Special acknowledgments are due to Mr. H. C. Diesem, of the Wichita Federal Land Bank, Mr. R. I. Meeker, special deputy State engineer, and Mr. E. B. Debler, of the Bureau of Reclamation, for making available their separate extensive studies on irrigation; to Mr. S. O. Harper and Mr. L. J. Foster, of the Bureau of Reclamation, for the very complete descriptions of the Grand Valley and Uncompahgre irrigation projects; to Mr. M. C. Hinderlider, State engineer, and Mr. J. H, Baily, chief hydrographer of the State, for the valuable assistance rendered in the use of records of water rights, decrees, and filings and the stream-flow records; to Mr. H. C. Getty, State division irrigation engineer, for records of completed reservoirs; to Mr. E. C, Jansen, of the Public Service Co., of Colorado, for maps of reservoir surveys and description of the Shoshone plant and transmission line; to Mr. W. N. Clark, of the Southern Colorado Power Co., for information regarding flow of water through wood-stave pipes during. winter; to Mr. P. R. Jakway, of the Western Colorado Power Co., for descriptions of power plants of that company; to Mr. A. O. Ridgway, chief engineer, Denver \& Rio Grande Western Railroad, for data on the flood of 1884 and railroad profiles along many streams; and to Mr. H. B. Barnes, of Denver, for descriptions of power plants including some early developments.

The writer also wishes to acknowledge his indebtedness to $\mathrm{Mr}$. Herman Stabler and other members of the conservation branch of .the Geological Survey for their constructive criticisms and suggestions during the preparation of the report. Use has been made of reports by Mr. Edward E. Jones based on preliminary reconnaissance surveys on the Blue River from Breckenridge to the mouth, the Eagle. River from Redcliff to the mouth, the Roaring Fork from Snowmass to the mouth, the Dolores River from Paradox Valley to the mouth, and the San Miguel River from Sawpit to the mouth. Acknowledgments are also due to Messrs. Depue Falck and Oscar Stanton, who prepared the data relative to agricultural conditions.

Mr. Paul V. Hodges, of the water-resources branch of the Geological Survey, made many of the storage studies used in the report.

\section{BIBLIOGRAPHY}

The following reports, in addition to the stream-flow publications of the United States Geological Survey, have been used in preparing the data presented herein. 
FLOODS

Follansbee, Robert, and Hodges, P. V., Some floods in the Rocky Mountain region: U. S. Geol. Survey Water-Supply Paper 520, pp. 105-129, 1025.

Frandan, W. B., Flood in San Juan Valley, September 5 and 6, 1909: U. S. Geol. Survey Water-Supply Paper 269, pp. 187-191, 1911.

Rossell, G. H., and Gray, G. A., Flood of October, 1911, in the region of the San Juan, San Miguel, and La Plata Mountains: U. S. Geol. Survey WaterSupply Paper 309, pp. 246-249, 1914.

\section{IRRIGATION}

Fourteenth Census of the United States, 1920.

Water commissioner's reports to State engineer of Colorado (unpublished).

Problems of Imperial Valley and vicinity: 67th Cong., 2d sess., S. Doc. 142, 1922.

Problems of Imperial Valley and vicinity (unpublished): U. S. Bureau of Reclamation, 1924.

\section{MARKWTS}

Fourteenth Census of the United States, 1920.

Henderson, C. W., Mining in Colorado: U. S. Geol. Survey Prof. Paper 138, 1926:

Lowith, C. F., Hydroelectric power development as related to the electrification of railroads: Am. Soc. Civil Eng. Trans., vol. 86; pp. 829-835, 1923.

Traffic density of Denver \& Rio Grande Western and Denver \& Salt Lake Railroads: Moody's Manual of Investments-Railroad securities, 1928.

\section{POWER PLANTS}

Shoshone plant: Electrical Rer., Jan. 5, 1907; Fng. Rec., June 25, 1910; Electrical World, Jan. 27, 1910.

Halm, Irving, Electric mining in the Rocky Mountain region: Am. Inst. Min. Eng. Trans., vol. 26, pp. 402 et seq., 1897.

Early development of the Telluride Power Co.: The Bulletin, February, 1918 (official publication of Utah Power \& Light Co.).

Nons, P. N., Pioneer work of the Telluride Power Co.: Internat. Electrical Cong., St. Louis, 1904, Trans., vol. 2, p. 410.

Roaring Fork Electric Light \& Power Co.'s plant: Electrical Rev., Jan. 5, 1907.

Rrckard, T. A., Across the San Juan Mountains: Eng. and Min. Jour., July 18, 1903.

McDonatd, V. M., Operations and maintenance of Rocky Mountain transmigsion lines: Electrical West, vol. 60, No. 7, June, 1928.

\section{PRECIPITATION, EVAPORATION, AND TEMPERATURE}

U. S. Weather Bureau, Climatological data, Arizona, Colorado, New Mexico, and Utah sections.

$$
\text { PRECIPITATION AND RUN-OFF }
$$

Bates, C. G., and Henry, A. J., Stream-flow experiment at Wagonwheel Gap, Colo.: Monthly Weather Review, Supplement 17, p. 42, 1922.

\section{SEDIMENTATION}

Stabler, Hrrman, Some stream waters of the Western United States: U. S. Geol. Survey Water-Supply Paper 274, 1911. 


\section{TOPOGRAPHY}

Campbert, M. R., Guidebook of the Western United States, Part E, The Denver \& Rio Grande Western Route: U. S. Geol. Survey Bull. 707, 1922.

Cross, Whitman, and others: U. S. Geol. Survey Geol. Atlas, Silverton folio (No. 120), 1905.

GALE, H. S., Coal fields of northwestern Colorado and northeastern Utah: U. S. Geol. Survey Bull. 415, 1910.

HAyDEN, F. V., U. S. Geol. and Geog. Survey Terr. Eighth and Ninth Ann. Repts., 1874 and 1875.

Jones, E. E., Power resources of Blue River, 1924; Eagle River, 1925; of Roaring Fork, Snowmass to mouth, 1925; Dolores River, 1925; and San Miguel River, 1925. (Unpublished reports based on preliminary reconnaissance surveys.)

Richardson, G. B., The Book Cliffs coal field, between Grand River, Colo., and Sunnyside, Utah: U. S. Geol. Survey Bull. 316, pp. 302-320, 1907.

\section{PHYGICAL FEATURES OF BASIN}

\section{LOCATION AND ACCESSTBILITY}

The part of the Colorado River Basin considered in this report is that part drained by the upper river and its tributaries above Green River. (See pl. 1.) By joint resolution of Congress of July 25, 1921, and by State enactments, the name of the river above the mouth of the Green River was changed from Grand to Colorado. The basin includes about half of the western half of Colorado midway between the north and south boundaries of the State, extending from the Continental Divide to the Utah line, and in addition an area of 4,300 square miles in eastern Utah, reaching from the Colorado line to the mouth of the Green River. The entire area comprised within the basin is 26,500 square miles. With the possible exception of Imperial Valley, which may be considered a part of the Colorado River Basin, the upper basin as a whole is the most accessible part of the entire Colorado River Basin, as it contains a larger population per square mile than any other section and in consequence has better railroad facilities. The main line of the Denver \& Rio Grande Western Railroad traverses the length of the Eagle Valley and follows the Colorado closely from the Eagle to Cisco, Utah. In addition, a branch line of this railroad system traverses the valley of each major tributary. The upper part of the basin, reaching from the head of the Fraser River to State Bridge, below Gore Canyon, is traversed by the Denver \& Salt Lake Railroad, which extends from Denver to Craig, in Moffat County. In addition to the railroads, the excellent highways crossing the mountain ranges at numerous passes make all but the more rugged areas easily accessible during the summer. 


\section{TOPOGRAPHY 1}

\section{plateaus aNd MOUNTAINS}

The northern boundary is a high plateau, the higher eastern half of which is known as the White River Plateau and the lower western half as the Roan or Book Cliffs Plateau. So deeply cut are these plateaus that in some places the boundary separating the basin of the Colorado from that of the White is not more than 40 feet wide.

The eastern boundary is the Continental Divide, which is made up of a number of distinct mountain ranges connected with one another. With the exception of that portion of the divide which is formed by the Colorado or Front Range, at the head of the main river and the Fraser, the ranges forming the Continental Divide are a part of that chain of mountains which crosses the State from north to south parallel to the Front Range and to which the name Park Range has been given. The divide west of Leadville is known as the Sawatch Range, and this is a broad, oval mountain mass deeply indented by the gorges of the streams that drain it.

From the lower end of the Sawatch Range, near Marshall Pass, the Continental Divide is formed by the Cochetopa Hills, a more gently sloping mountain mass with a crest altitude ranging from 10,000 to 12,000 feet, which extends southwest and joins the outlying spurs of that great group of mountains known collectively as the San Juan Mountains. Within this group are hundreds of summits exceeding 13,000 feet in altitude and several that exceed 14,000 feet. From the San Juan Mountains and the outlying spur known as the La Plata Mountains the boundary of the basin as far as the mouth of the Green River is a high plateau deeply cut by the streams that drain it.

West of the Park Range the drainage basin consists of a succession of broken plateaus or mesas, which gradually become lower toward the west. The plateau region is in reality only a border of the large plateau province that extends in its more typically desert-like character west and southwest from the Rocky Mountains into Utah, Arizona, and New Mexico. The general plateau level is interrupted at short intervals by higher summits and ranges of mountains and is cut by deep valleys and canyons.

The region between the Colorado and Gunnison Rivers consists of the eastern part of the Elk Mountain system, which with its spurs occupies the entire area between the Eagle River and that part of the Colorado between the Eagle and Roaring Fork, on the north, and the Gunnison from its head to the mouth of the North Fork, on the south and west. The principal part of the Elk Mountain system is in the

\footnotetext{
1 Abstracted chiefly from U. S. Geol. and Geog. Survey Terr. Eighth and Ninth Ann. Repts.
} 
form of parallel ridges connected transversely by low saddles and having a general direction parallel to the Sawatch and Park Ranges.

THE MAIN RIVER

The Colorado River rises in Middle Park, on the east slope of Mount Richthofen, which attains an altitude of 13,000 feet on the Continental Divide, here separating the Colorado River Basin from that of the North Platte in North Park. Another headwater stream rises near La Poudre Pass, which separates the Colorado Basin from that of the Cache la Poudre, a tributary of the South Platte. From its source the river flows south for 28 miles through a gradually widening valley that has gently sloping sides. In this stretch it is joined by the waters from Grand Lake, which drains the western slope of the Continental Divide, in the Rocky Mountain National Park. Near the mouth of Arapaho Creek the Colorado makes a sharp turn and flows westward for 54 miles across the main part of Middle Park. The topographic features of Middle Park comprise ridges separating the tributary streams and rising from 2,000 to 4,000 feet above them. The river thus flows alternately across flat, open, treeless areas and in shallow canyons cut through the separating ridges. From Parshall to the entrance to Gore Canyon, beyond Kremmling, a distance of 20 miles, the river flows through an extensive basin, much of which may be called river bottom land, subject to overflow during flood stages. Here the fall of the stream is only 8 feet to the mile, and the channel is very winding. In Middle Park the river is joined by a number of tributaries, the chief of which are the Fraser, Williams, and Blue Rivers from the south and Willow, Troublesome, and Muddy Creeks from the north.

At the western edge of Middle Park the river has cut its way across the Gore Range, one of the subdivisions of the Park Range, which forms the western boundary of the park, and flows through Gore Canyon. The sides of this canyon are vertical for several hundred feet, above which they recede in a moderately steep slope to the average altitude of the range. Through the canyon the river rushes in a tumbling torrent, falling 360 feet in 5 miles, the greatest drop in the upper river below the headwaters. From the end of Gore Canyon to Glenwood Springs the river flows through a series of canyons interspersed with narrow valleys. In this stretch the principal tributary is the Eagle River.

Below the mouth of the Roaring Fork, at Glenwood Springs, the river is in a narrow valley for about 3 miles, with very high hills rising abruptly on each side. Then it enters a cl osed canyon, through which it flows for 12 miles; below this is a broad valley, which extends from a point a few miles west of Newcastle to Rulison, a distance of 30 miles east and west, and whose maximum width from north to south 
is $\mathbf{2 0}$ miles. Below this valley the high plateau forming the northern boundary of the basin approaches the river and reappears on the opposite side as the Battlement Mesa. Through this section the river flows for a distance of 40 miles in a canyon having a maximum depth of 3,000 feet, and then it emerges onto a broad valley, known as Grand Valley, which reaches from Palisade nearly to the Utah line.

Grand Valley is bounded on the north by the Roan or Book Cliffs, which form the northern boundary of the basin, and on the south by Grand Mesa and the Uncompahgre Plateau, both of which are mighty. escarpments as viewed from the valley. Below the mouth of the Gunnison, at Grand Junction, the valley has a width of 10 miles. Here the river hugs the base of the Uncompahgre Plateau, which rises 4,000 feet above the valley floor and flows through a bottom 1 mile or more in width. The bench land of the valley lying north of the river lies 100 feet higher than the river's edge and gradually rises toward the northern cliffs. On the south the bench land rises rapidly to the steep slopes of the Uncompahgre Plateau. Near Mack, 20 miles below Grand Junction, Grand Valley terminates, and the river enters a low canyon from 50 to 200 feet deep, through which it flows as far as the mouth of the Dolores River. At that point it buries itself in a short canyon, which is deep and winding and from which it emerges into a narrow valley surrounded by cliffs from 1,600 to 2,500 feet high carved in fantastic forms. Below this valley the Colorado flows alternately in canyons and across narrow transverse valleys until it is joined by the Green River, at an altitude of 3,876 feet above sea level.

TRIBUTARIES ABOVE GUNNISON RIVER

Grand Lake, which has an area of 530 acres, lies at an altitude of 8,370 feet on the western slope of the Continental Divide, which is here the Front Range in the Rocky Mountain National Park. Numerous streams rise near the crest of the divide at altitudes exceeding 12,000 feet and unite in three principal tributaries-known as East and North Inlets and Tonahutu Creek-which flow through deep gorges and narrow valleys to Grand Lake and drain many small mountain lakes. From Grand Lake an outlet stream flows 6 miles through an open valley to the Colorado.

The Fraser River rises on the north side of Berthoud Pass and draing the western slope of the Continental Divide from the Arapaho Peaks to Vasquez Peak, a distance of 30 miles, in a region of rugged canyons and far-stretching mountain spurs. From its source nearly to the town of Fraser the river flows through a narrow valley, which broadens to an average width of $21 / 2$ miles between Fraser and Tabernash. Below Tabernash the river forces its way through a spur of the Continental Divide and flows in a canyon 600 feet deep to a point 5 miles 
from the river's mouth and below Granby. The chief tributaries are Vasquez, St. Louis; and Ranch Creeks.

The area drained by the Williams River lies in the southern part of Middle Park, between the basins of the Fraser and Blue Rivers. It is separated from them by spur ranges that jut out from the mountain walls and form the southern boundary of the park. The river rises near Jones Pass, on the west slope of Vasquez Peak. The principal source receives its water from four branches that issue from canyons which unite in a deep valley at the foot of Ute Peak. From the junction of these streams the Williams River flows through a valley whose side slopes gradually become gentler and farther apart, until at a point 10 miles above its mouth it attains a maximum width of 2 miles, which continues for a distance of 8 miles. Then the river forces its way through a connected ridge of buttes, forming the southern margin of the valley of the Colorado, in a canyon 21/2 miles long, which ends very close to the mouth near Parshall.

The East and West Forks of Troublesome Creek drain the southern slope of the Rabbit Ears Range, forming the Continental Divide, which is here the boundary between North and Middle Parks. The East Fork flows through a narrow valley, which closes in to a canyon from 800 to 1,000 feet deep and 2 miles long. Immediately below the canyon the East Fork unites with the West Fork, which flows through an open valley. From the junction Troublesome Creek flows southward for 9 miles and joins the Colorado 5 miles east of Kremmling. Its valley gradually broadens to several miles in width at the mouth, and through this stretch the creek is bordered by a series of high terraces. The two forks are separated by a steep ridge, ranging from 1,600 to 1,800 feet in height.

Muddy Creek drains the northwest corner of Middle Park. Its basin is bounded on the west by the Gore Range, which is the western boundary of Middle Park, and on the north by the Rabbit Ears Range. Both ranges furnish numerous short tributaries. Throughout most of its course Muddy Creek meanders in a broad valley bottom of varying width and is bordered on each side by a series of terraces, which on the west side ascend to the summit of the broad Gore Range. Near the mouth of the stream the meanders become greater in extent until at last the streams bend in a huge curve to meet the Colorado at Kremmling.

The Blue River and its principal tributaries, the Snake River and Tenmile Creek, drain a comparatively narrow strip in the southwest corner of Middle Park, separated from the Williams River Basin on the east by the Williams River Mountains. These form a compact mountain mass unmarked by deep drainage channels on either slope and having an altitude between 11,000 and 12,000 feet. The western boundary of the basin is the rugged Gore Range, the sides of which 
contain deeply eroded amphitheaters and sharp-crested spurs. The headwater streams drain the western slope of the Continental Divide, extending from a point 6 miles northwest of Grays Peak to the head of the Arkansas River near Leadville, a distance of 50 miles, and including several peaks exceeding 14,000 feet in altitude. For 20 miles north, from Hoosier Pass to Dillon, the Blue flows through a narrow but fairly open and gravel-filled valley. In this distance the river receives many short tributaries from the west, draining the steep slopes of the Tenmile Range, which separates the Tenmile Creek Basin from that of the Blue. From the east the Blue is joined by the Swan River and French Creek, which drain the rugged area of the upper basin. Just above Dillon the valley attains a width of 1 mile or more, with a level floor, and in this valley the Blue receives its two chief tributaries. The Snake River rises on the steep slopes of Grays Peak in a snow-filled amphitheater and flows westward through a narrow valley to the Blue. Tenmile Creek rises at Fremont Pass, near the heads of the Eagle and Arkansas Rivers, and flows northward through a narrow valley, terminating in a canyon, from which the creek emerges into comparatively open country.

It flows for 4 miles through this open country and enters the Blue a short distance below the Snake River at Dillon. Below Tenmile Creek the Blue River flows northwestward for 35 miles and joins the Colorado near Kremmling. For the greater part of the distance its course leads through the narrow Blue River Valley, in which the channel is cut from 40 to 80 feet below the natural valley floor. Between the river and the steep slopes of the Gore Range on the west morainal deposits covered with a dense growth of pine and having an average width of several miles form an intermediate zone between river and mountains. Many small tributaries rise in this zone. On the east the sides of the valley rise abruptly to the steep slopes of the Williams River Range, on which a few tributary streams have their sources. A semi-isolated butte, known as Green Mountain, rises in the center of the valley, 12 miles above the mouth of the Blue River, and partly cuts it off by a low saddle extending to the eastern boundary. Below this point the lower valley has uniform characteristics of the regular, gradually rising, terraced slopes of its margins.

The Eagle River Basin lies west of the Blue River, from which.it is separated by the Gore Range. On the south the basin is bounded by the Continental Divide, which separates it from the Arkansas Basin, and reaches a maximum altitude of 13,227 feet in Homestake Peak. The lowest point is Tennessee Pass, 10,240 feet in altitude. On the west the boundary is the Sawatch Range, in which the Mount of the Holy Cross reaches an altitude of about 14,000 feet. Eagle River is formed by the East Fork and Piney Creek. The East Fork 
has its source in two tiny lakes on the north slope of Buckeye Peak, at an altitude of 12,000 feet. For the first 6 miles the stream curves to the west and then it enters a flat valley half a mile wide and 4 miles long, known as Eagle Park. Near the upper end of the park the East Fork is joined by Piney Creek, which rises near Tennessee Pass. The Eagle River pursues a winding course through the park and then enters a narrow canyon, through which it flows for 3 miles. Just below the canyon at Redcliff the Eagle River is joined by Turkey Creek from the east and by Homestake Creek-one of the chief tributaries - from the west. At this point the Eagle again plunges into a canyon, through which it flows to Minturn, a distance of 8 miles. This canyon is one of the most picturesque in the Rocky Mountain region; the nearly vertical walls are 500 feet high and only $\mathbf{1 0 0}$ feet apart in the narrowest section. The fall of the Eagle is here 100 feet to a mile, and miniature cascades are formed in many places. Below Minturn the valley loses its canyon characteristics but alternately widens and contracts. Gore Creek enters the Eagle 1 mile below Minturn, and at that point the river changes its course abruptly and flows westward to its junction with the Colorado. Near Avon the valley is 1 mile wide. Below Wolcott the north side of the vailey is marked by high cliffs of brilliantly colored rocks, and the opposite side is nearly flat. Near the town of Eagle the river has cut into the floor of the valley, leaving a terrace from 60 to 80 feet high and from half a mile to several miles in width, where Brush Creek joins the Eagle River a short distance below the town. This terrace extends for a distance of 6 miles below Eagle and in places is bordered by a second terrace 50 feet higher. Another break in the south wall of the valley occurs at Gypsum, where the valley of Gypsum Creek merges with the Eagle Valley. A short distance below this point the river again enters a canyon, through which it flows for 5 miles to its mouth.

The Roaring Fork, one of the chief tributaries of the upper Colorado, drains an area lying on the west slope of the Sawatch Range, which separates the Roaring Fork and Eagle Basins. It also drains the northern slope of the Elk Mountains, which form the southern and eastern boundary of the basin, separating it from that of the Gunnison. The eastern part of the basin is drained by Fryingpan Creek, the principal tributary, which is bordered on both sides by broad, high mountain ridges that reach altitudes of more than 11,000 feet. The same broad, massive character is shown by the ridges separating the branches of the Roaring Fork as far west as Castle Creek. Here is the principal range of the Elk Mountains, and the character of the mountain forms changes materially, the broad, massive ridges giving way to sharp, conical peaks, ragged ridges, pinnacles, and spires, which extend northward as far as the Crystal River. Beyond that 
point the mountains are succeeded by the flat-topped mesas typical of western Colorado.

The Roaring Fork rises in several streams that have their sources in tiny lakes on the western slope of the Continental Divide, at an altitude of 12,000 feet. These streams all flow through canyon-like valleys to join the Roaring Fork, which in turn flows through a similar valley. This valley begins to widen at a point 2 miles above Aspen and continues to widen gradually until it reaches a maximum width of 4 miles at the mouth of the stream at Glenwood Springs. As the Elk Mountains are subject to very heavy precipitation, many large tributaries enter the Roaring Fork from the west; the chief ones are Castle, Maroon, and Snowmass Creeks and the Crystal River. Except for Fryingpan Creek the tributaries from the east are short and relatively unimportant.

Elk Creek is formed by three branches-the West, Middle, and East Forks-which rise on the southern edge of the White River Plateau at an altitude of about 10,000 feet and flowing south unite in one stream a few miles above the mouth at Newcastle. High ridges separate the different branches, forming narrow valleys through which they flow.

Divide Creek has two main branches, East and West Divide Creeks. It drains an area lying south of the Colorado and just west of the Roaring Fork Basin. This area comprises the northern slope of a high mesa that reaches an altitude of 10,000 feet. This mesa may be considered a northeastern extension of Grand Mesa. Beyond the junction of the two branches the creek flows north for 6 miles and enters the Colorado 1 mile east of Silt.

Parachute and Roan Creeks drain the Book Cliffs, the southern edge of the Book Plateau, which is the northern boundary of the Colorado Basin. Parachute Creek rises at an altitude of 8,000 feet, flows south and west through a narrow valley for a distance of 20 miles and enters the Colorado at Grand Valley. Roan Creek is joined by numerous tributaries that rise near one another and flow through narrow, parallel valleys. Below the junction of the principal headwater streams Roan Creek flows southeastward through a broad valley and enters the Colorado at De Beque.

Plateau Creek drains the southern half of Battlement Mesa and the northern half of Grand Mesa. Grand Mesa, which is the larger of the two table-lands, has a general altitude of 10,000 feet, or from 4,000 to 5,000 feet higher than the valleys at its base. The sides of the mesa consist of nearly vertical cliffs from 1,000 to 2,000 feet high, below which are steep talus slopes, gradually becoming gentler as the valleys are reached. The sparsely timbered top of the mesa has a rolling surface rising to a peak 11,000 feet in altitude at the east end and is interspersed with many small lakes and marshy areas. 
Plateau Creek rises on the north slope of Elk Mountain, the highest point of Grand Mesa, and flows northwestward down the steep slope to the valley, where it turns sharply and flows southwestward to its junction with the Colorado, 6 miles above Palisade. The valley is broad and shallow on the top of the mesa; but as the creek flows downward it cuts deeper into the side of the mesa until near the entrance to the main Plateau Valley, the area between Grand and Battlement Mesas, it flows in a canyon. Through the main valley Plateau Creek is bordered by high terraces separating the numerous tributaries that drain the sides of both mesas. These streams have nearly parallel courses and form very regular drainage systems. The principal tributary, Buzzard Creek, drains the western slope of the high ridge joining Battlement and Grand Mesas. For 6 miles above its mouth at Collbran Buzzard Creek pursues a course parallel to Plateau Creek at a distance of less than a mile but separated from it by a high terrace.

\section{GUNNISON RIVER}

The Gunnison River, the principal tributary of the upper Colorado, drains an area lying south of the Colorado and embracing some of the most rugged country in the entire Colorado River Basin. The Gunnison Basin is bordered on the north by Grand Mesa and the Elk Mountain group, on the east by the Sawatch Range, on the south by the Cochetopa Hills and the San Juan Mountain group, and on the west by the Uncompahgre Plateau. Altitudes along the boundary range from 9,000 to 14,000 feet. Within the basin are flat-topped mesas through which the streams have cut deep canyons. At the lower ends of the courses, however, these canyons gradually widen to broad valleys that have steeply sloping sides.

The Gunnison River is 'formed by the Taylor River, which drains the northern slope of the Sawatch Range, and the East River, which drains the southern slopes of the main Elk Mountain mass. The Taylor River, the main source, rises at an altitude of 12,000 feet and describes an arc, bending westward until it unites with the East River at Almont. The Taylor River flows in a narrow valley for several miles below its source, but near the mouth of Red Mountain Creek the valley widens into Taylor Park, across which the river flows for a distance of 10 miles. At the lower end of the park the river enters a canyon, which has an average depth of 1,200 feet and a length of 16 miles and extends to the junction with the East River.

From Almont to the mouth of Tomichi Creek, 2 miles below the town of Gunnison, the Gunnison River flows through a flat valley 5 miles wide and is joined by Ohio Creek, which drains the eastern slope of the West Elk Mountains, and by Tomichi Creek, which drains the slopes of the Sawatch Range and the Cochetopa Hills. The broad 
valley of the Gunnison extends several miles un both Ohio and Tomichi Creeks, with broad bottoms on each. Below tne mouth of the Tomichi the valley narrows to a width of 1 mile, which is all bottom land, extending down the river for 4 miles. North of the valley the country rises to the West Elk Mountains in a sloping plateau, which is cut into long tongues by tributary streams having parallel courses. At the mouths of the Beaver Creeks the long tongues of mesa run down to the river, forming a canyon from 100 to 200 feet deep, which, except for a few small patches of meadow land, extends to the mouth of Lake Fork. South of the valley the country is very broken but in general rises gradually to the outlying spurs of the San Juan Mountains.

Near the mouth of Lake Fork the land rises rapidly on both sides of the river to a high plateau. On the south side the plateau is flat, with an altitude of 9,000 feet, but on the north side it starts at an altitude of 9,000 feet near the river and gradually rises toward the northwest. Through this plateau the Gunnison has cut what is known as the Black Canyon, which is 56 miles long and has a maximum depth of 3,000 feet. The plateau consists of gneiss topped with 1,000 to 2,000 feet of stratified rocks that lie in nearly horizontal beds. The canyon is cut through the stratified rocks and deep into the gneiss, increasing in depth with the fall of the river. This part of the canyon has rough, ragged, nearly vertical walls, with no beach at the river. On top of the gneiss is a sloping bench, marking the line between gneiss and stratified rocks, and above the bench are the steeply sloping walls of stratified rocks, generally ending with 100 or 200 feet of vertical cliff just below the summit of the mesa. The tributaries in this plateau have cut but slightly into the gneiss and have a very heavy fall just before reaching the river. A short distance above the mouth of Crystal Creek the plateau north of the river ends in a well-defined terrace 10 miles long and 1,800 to 2,000 feet high. In its place is a lower, wider plateau, known as Black Mesa, with its edge to the Gunnison and sloping downward toward the North Fork. The plateau south of the river is nearly horizontal.

The river turns abruptly at a point 20 miles below the mouth of Crystal Creek and flows northward for 12 miles to its junction with the North Fork, where it makes another abrupt turn and resumes its westward course. For 10 miles above the mouth of Smith Fork there is a canyon within a canyon; the inner one, cut into the gneiss, is merely a narrow cleft in the rocks with smooth, vertical sides, between which the river rushes. At Smith Fork the river canyon is only 300 feet deep, with the stratified rocks rising nearly 1,000 feet above it; but below Sinith Fork the river runs out of the gneiss and becomes a placid stream, meandering about on the broad valley floor from one wall to the other, leaving on the opposite side patches of beautiful 
bottom land. The canyon terminates a few miles below the North Fork, and the river emerges into the lower end of the Uncompahgre Valley. As far as the mouth of Roubideau Creek the river bottom is 2 miles or more in width. In this stretch the river does not occupy the lowest part of the valley, which lies between the river and the west end of Grand Mesa, but flows in a canyon closely hugging the Uncompahgre Plateau, to which the west side of the valley rises. This canyon, known as Unaweep Canyon, has an average depth of 800 feet, and its vertical walls consist of stratified rocks of the most brilliant coloring. The river bottom is broad, and the sluggish river meanders from one wall to the other. . It joins the Colorado at Grand Junction.

Tomichi Creek rises on the western slope of the Sawatch Range in sec. 11, T. 50 N., R. 5 E. New Mexico principal meridian, and flows south through a narrow valley for a distance of 16 miles to a point where it is joined by Marshall Creek, which rises on the western slope of Marshall Pass. Tomichi Creek then turns and flows northwestward to its junction with the Gunnison, 2 miles below the town of Gunnison. The Tomichi Valley gradually widens, and between Quartz Creek and the mouth its average width is 2 miles.

Sapinero Creek rises on the west slope of the West Elk Mountains at an altitude of 9,500 feet and flows through a narrow valley to its mouth near Sapinero.

The Lake Fork of the Gunnison River drains the northeast slopes of the San Juan Mountains. It rises in a tiny lake below Handies Peak at an altitude of 13,000 feet. Its course is northwestward through a canyon, which gradually widens into a narrow valley that contains Lake San Cristobal, which has an area of 322 acres. Below the lake the Lake Fork flows northward through a narrow valley, which finally closes into a canyon 12 miles long, cut through the gneisses forming the south wall of the Gunnison River Canyon. The Lake Fork joins the Gunnison 1 mile west of Sapinero. Its chief tributary is Henson Creek, which rises in the San Juan Mountains just north of the Lake Fork and flows through a canyon to its junction with that stream at Lake City.

Cimarron Creek drains a northern spur of the San Juan Mountains. It rises below Matterhorn Peak at an altitude of 12,000 feet and flows northward through a narrow valley. This valley contraets at the lower end to a canyon 1 mile long, through which the creek falls nearly 300 feet to the Gunnison, entering it in the Black Canyon.

Crystal Creek drains the southwest spur of the West Elk Mountains. It rises about in sec. 15, T. 50 N., R. 5 W. New Mexico principal meridian, and flows southwestward to the Gunnison, entering it 4 miles above the portal of Gunnison Tunnel. For the first 8 miles its course is in a canyon, which ends where the creek leaves the mountains 
and crosses Black Mesa. Here its valley is shallow for a few miles, and then the creek enters another canyon, which rapidly becomes deeper as the creek makes a quick descent to the Gunnison in the Black Canyon, the north wall of which is 3,000 feet high at this point.

The North Fork, the principal tributary of the Gunnison, drains an area comprising the southern slope of Grand Mesa, the western slope of the West Elk Mountains, the northern slope of Black Mesa, and the region of smaller, flat-topped mesas cut by canyons between the boundaries mentioned. The North Fork is formed by Muddy, Anthracite, and Coal Creeks, which flow through deep canyons to their junction in T. 12 S., R. 89 W. Below the junction the North Fork flows in a canyon as far as Somerset, a distance of 8 miles, and there the canyon gives way to a gradually widening valley, in which the river is bordered by gravel terraces. These terraces rise higher. above the stream as it proceeds toward its mouth, but just above its mouth the North Fork flows through a low canyon, in which it joins the Gunnison 13 miles east of Delta. In addition to the headwater streams the chief tributaries of the North Fork are Minnesota Creek from the south and a number of streams rising on Grand Mesa, of which the largest is Leroux Creek. This tributary rises at the southern odge of Grand Mesa, in a region of many small lakes, at an altitude of 10,000 feet, and flows southward, descending the steep slope of the mesa in a canyon that extends nearly to its mouth near Hotchkiss.

Surface Creek, which is tributary to the Gunnison through Forked Tongue Creek, rises on Grand Mesa just west of Leroux Creek, near Leon Peak. It descends the steep slopes of Grand Mesa in a canyon, which gives way near Cedaredge to a valley 1 mile or more in width. In this valley the creek itself is bordered by gravel terraces, which at the lower end reach the heights of mesas.

The Uncompahgre River drains the northern slope of the San Juan Mountains and the northeastern slope of the Uncompahgre Plateau, which may be considered the boundaries of the Uncompahgre Valley. This valley, which is 40 miles long, is triangular in shape, with its apex at Ridgway, near the mouth of the canyon section, and its 30 mile base near Delta, where it merges into the valley of the Gunnison. The Uncompahgre River rises in a number of tiny lakes on the north slope of Hurricane Peak, in the heart of the San Juan Mountains, at an altitude of 12,000 feet, and flows northward to its junction with the Gunnison at Delta. Above Ridgway the river flows through deep canyons and narrow valleys, but at Ridgway the mountain walls give way on the west to the gently sloping side of Uncompahgre Plateau, which decreases in height from 10,000 feet at the upper end to 8,600 feet opposite Delta. The east side of the valley is the 
steep and deeply eroded slope of the northern spur of the San Juan Mountains, here called Cimarron Ridge, which has a maximum altitude of 12,000 feet. Through the valley the Uncompahgre River flows in a broad bottom, above which-at an altitude of 200 feetperfectly flat bench lands rise in regular steps. The only sizable tributaries are Red Mountain and Canyon Creeks, which join the Uncompahgre before it leaves the mountains. Irrigation is carried on so extensively in the Uncompahgre Valley that the streams rising on the slopes contribute but little water to the main river.

Kahnah Creek drains the western slope of Grand Mesa, which rises 5,000 feet above the valley of the Gunnison, in tongues of sloping mesas that give way to steep timbered ridges and end in a vertical cliff 200 feet high. Kahnah Creek rises on the mesa, in a number of small lakes, and flows down its steep sides in a deep canyon that gives way to the gently sloping floor of the Gunnison Valley, into which it has cut a narrow channel. Kahnah Creekenters the Gunnison 20 miles above Grand Junction.

\section{DOLORES RIVER}

The drainage basin of the Dolores River lies west of the Uncompahgre Basin and north of the San Juan Basin, in the extreme western part of Colorado, with a triangular tongue extending to the Colorado River in eastern Utah. The upper part of the basin, lying on the western slopes of the San Juan Mountains, is extremely rugged, and many peaks reach an altitude of 13,000 feet. Extending northwest from the mountains nearly to the Colorado River is a spur known as the Uncompahgre Plateau, which decreases gradually in height as it recedes from the mountains from 10,000 feet at its head to 8,600 feet near its lower end. This plateau slopes gradually upward from the Uncompahgre Valley to its crest and then breaks off abruptly in a succession of two or three steps to the canyon of the San Miguel River, the chief tributary of the Dolores. West of the San Miguel are broad stretches of plateau intersected by steepwalled canyons, the general altitude ranging from 6,000 to 9,000 feet. Except at the base of the San Juan Mountains, this country is almost destitute of water other than the Dolores River. One or two small streams have a small perennial flow, but the water is generally alkaline.

The Dolores River rises on the southwestern slope of the San Juan Mountains, below Grizzly Peak, at an altitude of 13,000 feet. Its general course is southwest through a canyon, until it emerges from the mountains near the mouth of the West Fork. Here it turns south, then turning back almost upon itself flows northward against the slope of a plateau, in which it buries itself deeper and 
deeper. So close to the southern edge of the plateau has the Dolores cut its channel that near the town of Dolores, where it turns abruptly. to the north, a tunnel 5,480 feet long diverts water from the river into the San Juan Basin for irrigation in Montezuma Valley. Near the San Miguel-Dolores County line the river reaches the edge of the plateau, and by a succession of zigzags alternately with the dip and strike of steeply inclined beds it reaches the valleys of Disappointment and Gypsum Creeks, which have an elongated saucer shape, being surrounded on all sides and separated from each other by beds dipping toward their centers. The Dolores flows around the west and north sides of these valleys on the outside of the rim, most of the way in a canyon between the rim and the wall of the plateau. Below Gypsum Valley the river enters a canyon cut through another plateau and flows between walls of sandstone from 500 to 1,000 feet high in a course that is extremely tortuous, owing to its slight fall. Having cut through the plateau Dolores River crosses Paradox Valley transversely for a distance of $4 \frac{1}{2}$ miles and again enters a canyon, cut through the plateau forming the western boundary of the San Miguel River Basin; in this canyon it is joined by the San Miguel.

Below the mouth of the San Miguel the Dolores River turns and pursues a winding course through canyons cut in the predominant sandstone of this region. The strata rise toward the north, so that at the mouth of the San Miguel the channel of the Dolores is confined within the sandstone, but at Gateway, 25 miles downstream, the sandstone forms an escarpment 250 to 300 feet high, at the top of the valley. The side canyons have eroded shallow channels along the tops of the plateau region but drop vertically into the river valley over the capping of massive sandstone. Just above Gateway the west wall of the canyon gives way to a slope that rises 300 feet in a width of $1 \frac{1}{2}$ miles. The palisades at Gateway form the last of the escarpment on the north side of the valley, which gives way to a gently sloping plain extending back 1 to 3 miles from the river. Near the Utah-Colorado line the sides close in again, and the river flows through a canyon to its junction with the Colorado."

The San Miguel River, the principal tributary of the Dolores, drains the northwestern slope of the San Juan Mountains. It is formed by anumber of streams that rise in so-called mountain basins east of Telluride, at an altitude of 13,000 feet, and unite near Telluride. From this point the San Miguel flows westward through a narrow valley, which becomes a canyon near the mouth of the Lake Fork, the principal mountain tributary. Leaving the mountains the San Miguel flows northwestward to its junction with the Dolores,

- Description of river below the San Miguel River taken chiefly from an unpublished report by E. E. Jones on the power resources of the Dolcres River (U. S. Geol. Survey, 1925). 
following the southwestern foot of the Uncompahgre Plateau with its abrupt slope in steps. Its course is entirely in a canyon, and there are only a few small areas of bottom land. The plateau along its course, a lower extension of the Uncompahgre Plateau, is very flat and uniform, gradually descending from an altitude of 8,000 feet near the source of the river to 6,000 feet at its mouth. The rugged canyon walls range from 200 to 2,000 feet in height, with an average of 1,000 feet. Between the San Miguel and the Dolores the country. consists of broken plateaus, here and there thrown up into ridges.

\section{FORESTATION 2}

In the Colorado River Basin forests, or large bodies of trees, as distinguished from the scattered growths seen chiefly along the streams, are found only in the mountains, where the precipitation is sufficient to support their growth. The lower limit of forestation is 7,500 feet. Although precipitation increases in general with increase in al titude, forests do not grow at the higher altitudes in the mountaing but stop at a more or less definite limit known as timber line. The altitude of timber line ranges from 11,600 feet in the northern part of the basin to 12,000 feet in the southern part. Practically all the forested area is included in national forests, which cover the greater part of the mountainous portion of the basin.

Within the forests are large nonforested tracts, comprising areas. above timber line, grasslands, mountain meadows, and barren lands where the topography is too rugged for tree growth. There are also considerable areas of burned-over land, but as most of these are in various stages of reproduction they are not included in the nonforested areas.

In the following table the "protection area" consists of timberland, woodland, and burned-over land:

National forest areas in Colorado River Basin

\begin{tabular}{|c|c|c|c|c|c|}
\hline \multirow[b]{2}{*}{ Forest } & \multirow[b]{2}{*}{ Streams draining- } & \multirow[b]{2}{*}{$\begin{array}{c}\text { Net area } \\
\text { (square } \\
\text { miles) }\end{array}$} & \multirow[b]{2}{*}{$\begin{array}{l}\text { Protec- } \\
\text { tion area } \\
\text { (square } \\
\text { miles) }\end{array}$} & \multicolumn{2}{|c|}{$\begin{array}{l}\text { Protection stand } \\
\text { (M foet b. m.) }\end{array}$} \\
\hline & & & & Totel & $\begin{array}{l}\text { Per } \\
\text { square } \\
\text { mile of } \\
\text { protec- } \\
\text { tion area }\end{array}$ \\
\hline 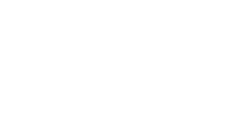 & $\begin{array}{l}\text { Upper tributaries of the Colorado... } \\
\text { Blue and Eagle Rivers } \\
\text { Roaring Fork and Eagle River } \\
\text { Minor tributaries of Colorado River.. } \\
\text { Colorado and North Fork of Gunnison }\end{array}$ & $\begin{array}{r}992 \\
443 \\
1,880 \\
464 \\
1,010\end{array}$ & $\begin{array}{r}809 \\
249 \\
1,380 \\
280 \\
712\end{array}$ & $\begin{array}{r}2,918,600 \\
237,000 \\
1,777,310 \\
439,000 \\
333,667\end{array}$ & $\begin{array}{r}3,600 \\
950 \\
1,290 \\
1,570 \\
-469\end{array}$ \\
\hline $\begin{array}{l}\text { Gunnison } \\
\text { Uncompahgre........... } \\
\text { Montezuma }\end{array}$ & $\begin{array}{l}\text { Gunnison River } \\
\text { Gunnison and Dolores Rivers } \\
\text { Dolores River. }\end{array}$ & $\begin{array}{l}1,420 \\
1,230 \\
1,090\end{array}$ & $\begin{array}{r}1,010 \\
990 \\
588\end{array}$ & $\begin{array}{r}724,750 \\
1,492,011 \\
1,534,806\end{array}$ & $\begin{array}{r}718 \\
1,510 \\
2,610\end{array}$ \\
\hline Total. & & 8,479 & 6,018 & $9,457,144$ & $\therefore 1,570$ \\
\hline
\end{tabular}

2 Compiled chlefiy from data furnished by U. S. Forest Service. 


\section{SCENIC AND RECREATIONAL FEATURES *}

General features.-The rugged topography of the upper Colorado River Basin affords so many scenic and recreational features that the entire region may be named the playground of America. The Rocky Mountains have been for many years the Mecca of eastern mountain lovers, and their name has summed up European ideas of American mountain grandeur. The higher mountains in the basin are included within the boundaries of the Rocky Mountain National Park and eight national forests.

The upper end of the drainage basin, lying within the national park, is a region of loveliness and wildness-diversified by imposing mountaina, innumerable streams, and lakes of great charm. Just at timber line, where the winter temperature and fierce, icy winds make it impossible for trees to grow tall, the spruces lie flat on the ground like vines; presently they give place to low birches, which in turn give place to small piny growths, and finally to tough, straggling grass, hardy mosses, and tiny alpine flowers. Grass grows in sheltered spots even on the highest peaks, a fortunate circumstance for the large curve-horned mountain sheep that seek these high, open places to escape their special enemies, the mountain lions. Nowhere else is the timber line struggle between the trees and the winds more grotesquely exemplified or its scene more easily accessible to tourists of average climbing ability.

Mountain peaks. - Including the boundaries of the Colorado River Basin, there are 50 peaks that are greater than 13,000 feet in altitude, and of these 11 reach above 14,000 feet. The highest is Mount Massive, with its crest at an altitude of about 14,400 feet, near Leadville. Probably the most famous of these mountains is the Mount of the Holy Cross, in the Eagle River Basin. To quote Campbell: ${ }^{5}$

This wonderful peak, hidden away in the mountain fastnesses, far from the ordinary routes of travel, bears a shining symbol of the Christian religion. The snowy cross is so protected by clefts in the rock that it never disappears, no matter how long and how hot the summer may be.

Another famous peak is Lizard Head, in the southeastern part of the Colorado Basin near Telluride. This has been described as "a sheer rock pinnacle reaching over 13,000 feet and resembling the uplifted nose of a gigantic reptilian monster." This peak, which is generally considered inaccessible, was supposed to have been scaled by a team of professional climbers, who left a tobacco can containing a statement of that fact. As no one since that time has reached the summit the proof has not been discovered. Other peaks in the basin,

\footnotetext{
- Based largely on publications of the National Park Service and U. S. Forest Service.

- Campbell, M. R., Guidebook of the western United States, Part E, The Denver \& Rio Grande Western Route: U. S. Geol. Survey Bull. 707, pl. 53, 1922.
} 
though less inaccessible than Lizard Head, afford interesting and difficult climbs and give all the thrills of the Swiss Alps. From the summit of Uncompahgre Peak the observer may look into the four States of Arizona, New Mexico, Colorado, and Utah, which meet at square corners, not far beyond the upper Colorado River Basin.

A mountain region that can not be passed over without mention is Grand Mesa, which lies between the Colorado and Gunnisan Rivers near their junction. This mesa, which is an enormous flattopped mountain rising a mile above the valleys at its base, has an area of about 1,000 square miles and is one of the largest flat-topped mountains in the world. From its edge at the top of the vertical cliffs magnificent views of the valleys are obtained, and the small holdings into which the valley lands are divided give the appearance . of a huge checkerboard. Grand Mesa is easily reached by good automobile roads on both north and south sides, and the rise of nearly 6,000 feet may be made so rapidly that one may pick peaches in the valley orchards and three hours later enjoy the summer sport of throwing snowballs from the rim of the mesa.

The lofty peaks with the awe-inspiring views obtained from them may be considered as being at one end of the scale of Nature's marvels, while at the other end are the natural monuments within the Colorado National Monument, near Grand Junction. These, are a series of enormous and unusual monoliths not duplicated elsewhere. Some of them rise to a height of 400 feet or more, from bases ranging from 75 to 100 feet in diameter. There are more than a score of these enormous monoliths and any number of smaller ones, besides multitudes of queer freaks of nature.

Lakes.-Hundreds of lakes, ranging from tiny pools of water nestling under the beetling crags of the loftier mountains to lakes several hundred acres in extent are scattered through the basin. The largest and deepest is Grand Lake, which has an area of 530. acres, and lies just outside the Rocky Mountain National Park. Upon it the Grand Lake Yacht Club annually competes for the Lipton eup, given by Sir Thomas Lipton some years ago. As the altitude of Grand Lake is 8,360 feet, it is the highest course in the world for yacht races. A lake in the oddest setting is the celebrated Hanging Lake; it is situated in a niche in the canyon walls of the Colorado 1,200 feet above the river and 12 miles from Glenwood Springs. On Grand Mesa are hundreds of smáll lakes, many of which are used as reservoirs for irrigation in the valleys below (p. 63).

Flora and fauna.-Even at the highest altitudes gorgeously colored wild flowers grow in profusion in sheltered gorges. Large and beautiful blue and white columbines (Aquilegia coerulea, the State flower of Colorado) are found in the lee of protecting snow banks. More than 
300 distinct species of flowering plants have been collected within the basin, and doubtless many more await discovery and identification.

The loftier peaks of the region are the natural home of the celebrated Rocky Mountain sheep or bighorn. They are much larger and more agile than domestic sheep and when fleeing from enemies make remarkable descents down seemingly impassable slopes. They are more agile even than the celebrated chamois of the Swiss Alps and are larger, more powerful, and much handsomer. In the southwestern part of the basin, in the vicinity of Ouray, the winter snows are so heavy that the mountain sheep are forced to descend to the valleys, and for the past 15 years the hospitable citizens of Ouray have provided hay and salt on the uutskirts of the town for these annual guests.

In addition to the mountain sheep beavers are found along the many streams at middle altitudes, elk inhabit a few places, and deer are widely distributed and at places fairly common. Coyotes are occasionally seen, and a few brown or black bear inhabit the wilder parts of the basin; but these-like the mountain lion, bobcat, and smaller carnivorous animals-are not only rare, but so shy and wary that they are seldom seen. Since 1923 the State of Colorado has created game reserves in several parts of the basin, for the better protection of birds and animals and for the establishment of breeding places. To these reserves is attributed the increase in game during the last few years, as elk and deer, especially, have quickly learned to take advantage of the protection thus afforded.

Excellent fishing may be had in nearly all the streams and lakes at the higher altitudes, as these are stocked each year with eastern brook, native, and rainbow trout.

Resort centers.-Although the entire region may be considered one vast summer resort, ideally suited to camping, fishing, and hiking, with excellent highways leading in all directions, the chief centers of the vacation seeker are Grand Lake, Glenwood Springs, Gunnison, and Ouray. Grand Lake, as its name implies, is situated on the shores of Grand Lake. Glenwood Springs, nestling in the narrow valley of the Colorado at the mouth of the Roaring Fork, is almost surrounded by mountains and is noted for its hot springs, vapor caves, and large open-air swimming pool. It also contains one of the largest summer hotels in Colorado. Gunnison, situated in the Gunnison Valley, which is here several miles wide, is the center of a region noted for its fishing. Ouray, at the upper end of the Uncompahgre Valley, lies at the base of the San Juan Mountains, "set in a titanic bowl lined with red granite, seemingly surrounded by 13,000 -foot walls of the great amphitheater." One of the attractions near Ouray, of which there are many, is Box Canyon, half a mile long, from 30 to 60 
feet wide and more than 300 feet deep. It is filled with the roar of Canyon Creek Falls, which have a sheer drop of 150 feet at the lower end of the gorge.

The Rocky Mountains are thought of chiefly as a summer vacation land, but they make their appeal in all seasons. In autumn the leaf coloring is remarkably beautiful. The aspens start to turn early in September, and from that time until the middle of October the mountain sides are streaming in golden colors interspersed with the dark green of the conifers, presenting the effect of an enormous Persian rug. The winter sports include snowshoeing, and skiing, courses for skiing being available near Grand Lake, Hot Sulphur Springs, and Dillon. In the spring the snow line may be seen climbing steadily up the mountain slopes, and birds and early flowers appear in the valleys while winter still reigns in the higher mountains.

\section{CLImate}

\section{DISTINOTIVE FEATURES}

The most distinctive climatic feature of the upper Colorado River Basin, especially in its lower valleys, is the comparative uniformity of the weather from day to day. This is due to the high mountains that surround the basin on three sides and deflect the course of lowpressure conditions. A storm approaching from the west will usually cross the Continental Divide either to the north or to the south of Colorado, where the height of the mountains is less, and consequently the sudden changes that attend the passing of a low center are rarely experienced. Severe cold waves, such as are so common on the eastern plains, are comparatively rare here. There is, on the contrary, a tendency for a stationary area of high pressure to form over the basin in winter and remain for days and even weeks. When one of these high-pressure areas controls the weather the sky is clear, the day temperatures are moderately high and remarkably uniform, and the nights are cold but seldom excessively cold except when the ground is covered with snow and where the air drainage is poor. ${ }^{6}$ The effect of these conditions is remarkably shown by the records on pages 24-25. The lowest monthly temperatures are recorded at Gunnison, at an altitude of 7,680 feet. These low temperatures are probably due to the lack of air drainage, as the wind movement in that region is very slight during-the-winter. The records for eight stations at higher altitudes than Gunnison all show considerably higher minimum temperatures. At Fraser, at an altitude of 8,670 feet, although the minimum temperatures do not equal those at Gunnison, they are among the lowest and show an average growing season of only 13 days between killing frosts. At this station the presence of snow on the ground is as much a factor as the slight wind movement.

- Abstracted from Summary of climatological data, U. S. Weather Bureau. 
At the lower levels the wind movement is light and is commonly of the mountain and valley type. The wind blows toward the mountains from the middle of the forenoon until late in the afternoon and in some localities attains considerable velocity. After sunset the wind subsides, and early in the night a light breeze springs up from the mountains toward the lower levels. At the summits of the mountains the winds are generally from the west, and during the winter and spring are frequently very strong.

\section{. TEMPERATURE}

The wide range of altitude in the upper Colorado River Basin causes a correspondingly wide range in temperature, as shown by the following tables. All the stations listed in these tables are in Colorado except Moab, Utah.

Mean monthly temperaturas (ํ) in upper Colorado River Basin

Brelusive of Gunnison and Dolores Rivers

\begin{tabular}{|c|c|c|c|c|c|c|c|c|c|c|c|c|c|c|}
\hline Station & County & 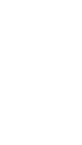 & 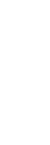 & 蛋 & 혼 & 范 & 总 & $\underset{\text { 点 }}{\mathbb{E}}$ & 点 & $\begin{array}{l}\text { 苞 } \\
\text { 忽 } \\
\end{array}$ & 总 & $\begin{array}{l}4 \\
\frac{8}{0} \\
8 \\
0\end{array}$ & $\begin{array}{l}\text { 岁 } \\
\text { 总 } \\
\text { 号 } \\
2\end{array}$ & 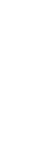 \\
\hline $\begin{array}{l}\text { Breckenridge } \\
\text { Ashcroft. } \\
\text { Fraser } \\
\text { Marble } \\
\text { Eagle } \\
\text { Collbran } \\
\text { Grand Valley } \\
\text { Grand Junction. } \\
\text { Moab }\end{array}$ & $\begin{array}{l}\text { Summit } \\
\text { Pitkin } \\
\text { Grand. } \\
\text { Gunnison } \\
\text { Eagle. } \\
\text { Mesa } \\
\text { Garfield } \\
\text { Mesa } \\
\text { Grand }\end{array}$ & $\begin{array}{l}9,530 \\
9,500 \\
8,670 \\
7,950 \\
6,590 \\
6,000 \\
5,110 \\
4,570 \\
4,000\end{array}$ & $\begin{array}{l}16 \\
18 \\
11 \\
22 \\
21 \\
23 \\
24 \\
24 \\
29\end{array}$ & $\begin{array}{l}16 \\
19 \\
14 \\
22 \\
24 \\
28 \\
30 \\
33 \\
36\end{array}$ & $\begin{array}{l}\mathbf{2 3} \\
25 \\
\mathbf{2 1} \\
\mathbf{3 2} \\
\mathbf{3 6} \\
\mathbf{3 7} \\
30 \\
\mathbf{4 3} \\
\mathbf{4 3}\end{array}$ & $\begin{array}{l}30 \\
34 \\
30 \\
38 \\
42 \\
45 \\
49 \\
52 \\
55\end{array}$ & $\begin{array}{l}39 \\
42 \\
39 \\
47 \\
48 \\
54 \\
57 \\
61 \\
66\end{array}$ & $\begin{array}{l}48 \\
51 \\
48 \\
56 \\
55 \\
63 \\
66 \\
71 \\
77\end{array}$ & $\begin{array}{l}63 \\
55 \\
53 \\
60 \\
62 \\
68 \\
73 \\
78 \\
81\end{array}$ & $\begin{array}{l}53 \\
55 \\
50 \\
59 \\
62 \\
67 \\
71 \\
69 \\
80\end{array}$ & $\begin{array}{l}47 \\
48 \\
45 \\
55 \\
55 \\
69 \\
62 \\
66 \\
69\end{array}$ & $\begin{array}{l}36 \\
38 \\
34 \\
43 \\
43 \\
48 \\
50 \\
53 \\
58\end{array}$ & \begin{tabular}{l|}
$\mathbf{2 6}$ \\
29 \\
$\mathbf{2 2}$ \\
33 \\
$\mathbf{3 3}$ \\
$\mathbf{3 6}$ \\
$\mathbf{3 7}$ \\
$\mathbf{2 9}$ \\
$\mathbf{4}$ \\
\end{tabular} & $\begin{array}{l}18 \\
19 \\
12 \\
19 \\
18 \\
24 \\
25 \\
28 \\
30\end{array}$ \\
\hline
\end{tabular}

\begin{tabular}{|c|c|c|c|c|c|c|c|c|c|c|c|c|c|c|}
\hline $\begin{array}{l}\text { Whitepine } \\
\text { Crested Butte. } \\
\text { Lake City } \\
\text { Sapinero (near) } \\
\text { Gunnison } \\
\text { Cedaredge.... } \\
\text { Montrose } \\
\text { Paonia } \\
\text { Delta }\end{array}$ & $\begin{array}{l}\text { Gunnison } \\
\text { Hinsdale } \\
\text { Gunnison } \\
\text { Deito } \\
\text { Montrose } \\
\text { Delta }\end{array}$ & $\begin{array}{r}10,000 \\
8,870 \\
8,680 \\
8,120 \\
7,680 \\
6,180 \\
5,800 \\
5,680 \\
4,970\end{array}$ & $\begin{array}{r}15 \\
11 \\
17 \\
15 \\
7 \\
26 \\
24 \\
26 \\
25\end{array}$ & \begin{tabular}{l|}
16 \\
15 \\
19 \\
19 \\
12 \\
30 \\
31 \\
32 \\
32
\end{tabular} & $\begin{array}{l}23 \\
23 \\
29 \\
28 \\
26 \\
39 \\
40 \\
40 \\
41\end{array}$ & $\begin{array}{l}32 \\
31 \\
38 \\
36 \\
39 \\
47 \\
49 \\
48 \\
50\end{array}$ & $\begin{array}{l}39 \\
42 \\
47 \\
45 \\
47 \\
55 \\
58 \\
57 \\
59\end{array}$ & $\begin{array}{l}49 \\
51 \\
55 \\
64 \\
58 \\
64 \\
65 \\
65 \\
68\end{array}$ & $\begin{array}{l}53 \\
56 \\
61 \\
59 \\
61 \\
70 \\
70 \\
71 \\
74\end{array}$ & $\begin{array}{l}53 \\
54 \\
60 \\
58 \\
60 \\
68 \\
68 \\
69 \\
72\end{array}$ & $\begin{array}{l}46 \\
46 \\
54 \\
51 \\
52 \\
60 \\
61 \\
62 \\
63\end{array}$ & $\begin{array}{l}36 \\
36 \\
43 \\
41 \\
41 \\
49 \\
49 \\
50 \\
50\end{array}$ & $\begin{array}{l}26 \\
25 \\
32 \\
30 \\
28 \\
38 \\
37 \\
40 \\
39\end{array}$ & $\begin{array}{l}14 \\
12 \\
17 \\
17 \\
11 \\
27 \\
26 \\
27 \\
26\end{array}$ \\
\hline
\end{tabular}

Dolores Rtver Basin

\begin{tabular}{|c|c|c|c|c|c|c|c|c|c|c|c|c|c|c|c|c|}
\hline 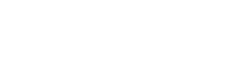 & $\begin{array}{l}\text { Montezuma } \\
\text { San Míguel }\end{array}$ & $\begin{array}{l}6,960 \\
6,750\end{array}$ & $\begin{array}{l}26 \\
21\end{array}$ & $\begin{array}{l}30 \\
24\end{array}$ & $\begin{array}{l}37 \\
28\end{array}$ & $\begin{array}{l}42 \\
36\end{array}$ & $\begin{array}{l}52 \\
48\end{array}$ & & $\begin{array}{l}62 \\
54\end{array}$ & $\begin{array}{l}68 \\
69\end{array}$ & 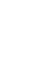 & & $\begin{array}{l}58 \\
51\end{array}$ & & & $\begin{array}{l}37 \\
32\end{array}$ \\
\hline
\end{tabular}


Mean monthly maximum and minimum temperatures $\left({ }^{\circ} \mathrm{F}.\right)$ in uppor Colorado River Basin

Exclusive of Gunnison and Dalores Rivers

\begin{tabular}{|c|c|c|c|c|c|c|c|c|c|c|c|c|c|c|}
\hline Station & County & 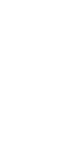 & 䔅 & 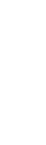 & 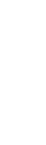 & 范 & 窟 & 喣 & 点 & $\begin{array}{l}\text { 骂 } \\
\text { 照 } \\
\frac{9}{4}\end{array}$ & 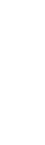 & $\begin{array}{l}\text { 薯 } \\
\text { है }\end{array}$ & 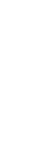 & 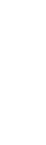 \\
\hline Breckenridge....... & Summit... & 9,530 & & 30 & $\begin{array}{r}37 \\
8\end{array}$ & 44 & $\begin{array}{l}53 \\
25\end{array}$ & $\begin{array}{l}65 \\
32\end{array}$ & $\begin{array}{l}70 \\
37\end{array}$ & $\begin{array}{l}70 \dagger \\
36\end{array}$ & $\begin{array}{r}64 \\
29\end{array}$ & $\begin{array}{l}52 \\
20\end{array}$ & $\begin{array}{l}41 \\
10\end{array}$ & 30 \\
\hline Ashoroft.. & Pitkin..... & 9,500 & $\begin{array}{r}30 \\
4\end{array}$ & $\begin{array}{r}32 \\
5\end{array}$ & $\begin{array}{l}37 \\
11\end{array}$ & $\begin{array}{l}47 \\
20\end{array}$ & $\begin{array}{l}57 \\
27\end{array}$ & $\begin{array}{l}69 \\
34\end{array}$ & $\begin{array}{l}72 \\
38\end{array}$ & $\begin{array}{l}70 \\
38\end{array}$ & $\begin{array}{l}\mathbf{6 5} \\
\mathbf{3 7}\end{array}$ & $\begin{array}{l}52 \\
23\end{array}$ & $\begin{array}{l}42 \\
12\end{array}$ & 28 \\
\hline Fraser.... & Grand.... & 8,670 & 27 & $\begin{array}{r}29 \\
-2\end{array}$ & $\begin{array}{r}36 \\
4\end{array}$ & $\begin{array}{l}46 \\
16\end{array}$ & $\begin{array}{l}55 \\
22\end{array}$ & $\begin{array}{l}66 \\
29\end{array}$ & $\begin{array}{l}70 \\
35\end{array}$ & $\begin{array}{l}69 \\
32\end{array}$ & $\begin{array}{l}62 \\
26\end{array}$ & $\begin{array}{l}51 \\
17\end{array}$ & $\begin{array}{r}40 \\
7\end{array}$ & $\begin{array}{r}26 \\
-5\end{array}$ \\
\hline Marble. & Gunnison... & 7,950 & $\begin{array}{r}36 \\
7\end{array}$ & $\begin{array}{r}38 \\
8\end{array}$ & $\begin{array}{l}45 \\
16\end{array}$ & $\begin{array}{l}53 \\
26\end{array}$ & $\begin{array}{l}62 \\
32\end{array}$ & $\begin{array}{l}73 \\
37\end{array}$ & $\begin{array}{l}77 \\
42\end{array}$ & $\begin{array}{l}76 \\
42\end{array}$ & $\begin{array}{l}62 \\
36\end{array}$ & $\begin{array}{l}87 \\
27\end{array}$ & $\left.\begin{array}{l}47 \\
17\end{array}\right]$ & $\begin{array}{r}34 \\
4\end{array}$ \\
\hline Eagle_. & Eagle... & 6,590 & $\begin{array}{r}36 \\
6\end{array}$ & $\begin{array}{r}39 \\
9\end{array}$ & $\begin{array}{l}49 \\
22\end{array}$ & $\begin{array}{l}57 \\
26\end{array}$ & $\begin{array}{l}64 \\
32\end{array}$ & $\begin{array}{l}74 \\
36\end{array}$ & $\begin{array}{l}82 \\
42\end{array}$ & $\begin{array}{l}81 \\
42\end{array}$ & $\begin{array}{l}74 \\
36\end{array}$ & $\begin{array}{l}62 \\
24\end{array}$ & $\begin{array}{l}51 \\
16\end{array}$ & $\begin{array}{r}34 \\
3\end{array}$ \\
\hline Collbran.. & Mesa & 6,000 & $\begin{array}{l}35 \\
11\end{array}$ & $\begin{array}{l}41 \\
16\end{array}$ & $\begin{array}{l}50 \\
24\end{array}$ & $\begin{array}{l}60 \\
32\end{array}$ & $\begin{array}{l}68 \\
38\end{array}$ & $\begin{array}{l}79 \\
46\end{array}$ & $\begin{array}{l}85 \\
52\end{array}$ & $\begin{array}{l}83 \\
51\end{array}$ & $\begin{array}{l}75 \\
43\end{array}$ & $\begin{array}{l}63 \\
32\end{array}$ & $\begin{array}{l}50 \\
23\end{array}$ & 136 \\
\hline Grand Valley.- & Garfield. & 5,110 & $\begin{array}{l}38 \\
12\end{array}$ & $\begin{array}{l}43 \\
17\end{array}$ & $\begin{array}{l}54 \\
25\end{array}$ & $\begin{array}{l}66 \\
33\end{array}$ & $\begin{array}{l}75 \\
40\end{array}$ & $\begin{array}{l}85 \\
47\end{array}$ & $\begin{array}{l}91 \\
52\end{array}$ & $\begin{array}{l}89 \\
51\end{array}$ & $\begin{array}{l}801 \\
43\end{array}$ & $\begin{array}{l}67 \\
31\end{array}$ & $\begin{array}{l}58 \\
22\end{array}$ & $\begin{array}{l}38 \\
12\end{array}$ \\
\hline Grand Junction.. & Mesa..... & 4,670 & $\begin{array}{l}36 \\
15\end{array}$ & $\begin{array}{l}43 \\
22\end{array}$ & $\begin{array}{l}55 \\
32\end{array}$ & $\begin{array}{l}66 \\
40\end{array}$ & $\begin{array}{l}74 \\
47\end{array}$ & $\begin{array}{l}86 \\
56\end{array}$ & $\begin{array}{l}91 \\
64\end{array}$ & $\begin{array}{l}89 \\
62\end{array}$ & $\begin{array}{l}80 \\
53\end{array}$ & $\begin{array}{l}66 \\
40\end{array}$ & $\begin{array}{l}62 \\
29\end{array}$ & $\frac{38}{17}$ \\
\hline Moab.. & Grand... & 4,000 & $\begin{array}{l}41 \\
17\end{array}$ & $\stackrel{49}{28}$ & $\begin{array}{l}62 \\
32\end{array}$ & $\begin{array}{l}72 \\
39\end{array}$ & $\begin{array}{l}81 \\
46\end{array}$ & $\begin{array}{c}91 \\
53\end{array}$ & $\begin{array}{l}95 \\
60\end{array}$ & $\begin{array}{l}93 \\
58\end{array}$ & $\begin{array}{l}84 \\
49\end{array}$ & $\begin{array}{l}70 \\
37\end{array}$ & $\begin{array}{l}56 \\
27\end{array}$ & $\frac{42}{18}$ \\
\hline
\end{tabular}

Gunnison River Basin

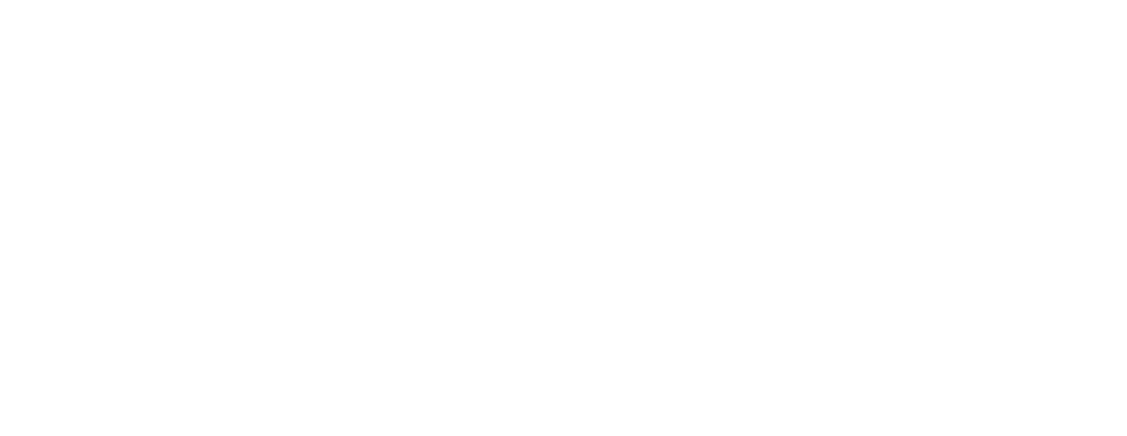

Dolores River Basin

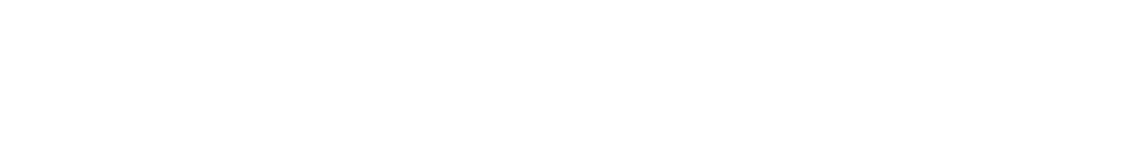

Not only is there a wide variation in monthly temperature throughout the basin, the mean maximum ranging from $70^{\circ}$ at Whitepine to $95^{\circ}$ at Moab, and the mean minimum from $-9^{\circ}$ at Gunnison to $17^{\circ}$ at Moab, but there is an even greater diurnal variation at each station. This diurnal variation ranges from $25^{\circ}$ to $40^{\circ}$ throughout the year and is practically the same for all stations, being from $25^{\circ}$ to $30^{\circ}$ during the winter and from $30^{\circ}$ to $40^{\circ}$ during the summer. This variation is due to the high altitude, absence of clouds, and low relative humidity, which eause the sun's rays to have a greater heating effect during the day time than in more humid regions at lower altitudes. At night the radiation from the earth and the lowest stratum of air is also greater, causing a greater drop in temperature. 
The maximum temperature recorded in the basin was $109^{\circ}$, at Delta, and the minimum $-47^{\circ}$, at Gunnison.

The wide variation in temperature causes a correspondingly wide variation in the growing season throughout the basin, which is indicated in the following table:

Average periods between killing frosts in upper Colorado River Basin

Bxclusive of Gunnison and Dolores Rivers

\begin{tabular}{|c|c|c|c|c|c|c|c|c|}
\hline \multirow{2}{*}{ Station } & \multirow{2}{*}{ County } & \multirow{2}{*}{$\begin{array}{l}\text { Alti- } \\
\text { tude } \\
\text { (feet) }\end{array}$} & \multirow{2}{*}{$\begin{array}{c}\text { Num- } \\
\text { ber } \\
\text { of } \\
\text { years } \\
\text { of } \\
\text { rec- } \\
\text { ords }\end{array}$} & \multicolumn{2}{|c|}{$\begin{array}{l}\text { Date of last killing } \\
\text { frost in spring }\end{array}$} & \multicolumn{2}{|c|}{$\begin{array}{c}\text { Date of earliest } \\
\text { killing frost in } \\
\text { autumn }\end{array}$} & \multirow{2}{*}{$\begin{array}{c}\text { Aver- } \\
\text { age } \\
\text { num- } \\
\text { ber } \\
\text { of days } \\
\text { be-- } \\
\text { tween } \\
\text { kill- } \\
\text { ing } \\
\text { trosts }\end{array}$} \\
\hline & & & & Average & Latest & Average & Earliest & \\
\hline $\begin{array}{l}\text { Breckenridge } \\
\text { Ashcroft } \\
\text { Nast. } \\
\text { Fraser } \\
\text { Blue Vailey Ranch } \\
\text { Marble } \\
\text { Eagle } \\
\text { Collbran } \\
\text { Silt } \\
\text { Grand Valley } \\
\text { Palisade } \\
\text { Grand Junction } \\
\text { Moab. }\end{array}$ & $\begin{array}{l}\text { Summit } \\
\text { Pitkin } \\
\text { Grand } \\
\text { Gunnison } \\
\text { Eagle. } \\
\text { Mesa } \\
\text { Garfield } \\
\text { Mesa } \\
\text { Grand }\end{array}$ & $\begin{array}{l}9,530 \\
9,500 \\
9,060 \\
8,670 \\
8,000 \\
7,950 \\
6,590 \\
6,000 \\
5,430 \\
5,110 \\
4,730 \\
4,570 \\
4,000\end{array}$ & $\begin{array}{r}20 \\
20 \\
11 \\
12 \\
6 \\
9 \\
6 \\
22 \\
13 \\
20 \\
9 \\
31 \\
28\end{array}$ & $\begin{array}{lr}\text { July } & 15 \\
\text { June } & 28 \\
\text { June } & 23 \\
\text { July } & 25 \\
\text { June } & 13 \\
\text { June } & 15 \\
\text { June } & 11 \\
\text { May } & 19 \\
\text { May } & 10 \\
\text { May } & 3 \\
\text { May } & 4 \\
\text { Apr. } & 19 \\
\text { Apr. } & \mathbf{2 6}\end{array}$ & $\begin{array}{lr}\text { July } & 31 \\
\text { July } & 28 \\
\text { July } & 12 \\
\text { July } & 31 \\
\text { June } & 29 \\
\text { June } & 27 \\
\text { June } & 29 \\
\text { July } & 3 \\
\text { June } & 19 \\
\text { May } & 27 \\
\text { May } & \mathbf{2 6} \\
\text { May } & 14 \\
\text { June } & 17\end{array}$ & $\begin{array}{l}\text { Aug. } 1 \\
\text { Sept. } 1 \\
\text { Sept. } 8 \\
\text { Aug. } 7 \\
\text { Sept. } 2 \\
\text { Sept. } 7 \\
\text { Sept. } 4 \\
\text { Sept. } 29 \\
\text { Oct. } 3 \\
\text { Sept. } 29 \\
\text { Oct. } 11 \\
\text { Oct. } 20 . \\
\text { Oct. } \quad 4\end{array}$ & $\begin{array}{l}\text { Aug. } 1 \\
\text { Aug. 1 } \\
\text { Aug. 18 } \\
\text { Aug. 1 } \\
\text { Aug. 13 } \\
\text { Aug. 7 } \\
\text { Aug. 22 } \\
\text { Sept. 12 } \\
\text { Sept. 15 } \\
\text { Sept. 11 } \\
\text { Sept. 15 } \\
\text { Sept. 14 } \\
\text { Sept. 12 }\end{array}$ & $\begin{array}{r}35 \\
65 \\
77 \\
13 \\
81 \\
84 \\
85 \\
133 \\
146 \\
149 \\
160 \\
184 \\
161\end{array}$ \\
\hline
\end{tabular}

Gunnison River Basin

\begin{tabular}{|c|c|c|c|c|c|c|c|c|}
\hline $\begin{array}{l}\text { Whitepine } \\
\text { Crested Butte. } \\
\text { Lake City } \\
\text { Gapinero } \\
\text { Gunnison } \\
\text { Cedaredge } \\
\text { Montrose } \\
\text { Paonia } \\
\text { Delta }\end{array}$ & $\begin{array}{l}\text { Gunnison } \\
\text { Hinsdale. } \\
\text { Gunnison } \\
\text { Deita } \\
\text { Dontrose } \\
\text { Delta }\end{array}$ & $\begin{array}{r}10,000 \\
8,870 \\
8,680 \\
8,120 \\
7,680 \\
6,180 \\
5,800 \\
5,680 \\
4,970\end{array}$ & $\begin{array}{r}8 \\
12 \\
10 \\
18 \\
29 \\
21 \\
30 \\
18 \\
28\end{array}$ & $\begin{array}{lr}\text { July } & 2 \\
\text { July } & 17 \\
\text { June } & 11 \\
\text { June } & 14 \\
\text { June } & 25 \\
\text { May } & 15 \\
\text { May } & 9 \\
\text { May } & 8 \\
\text { May } & 11\end{array}$ & $\begin{array}{l}\text { July } \\
\text { July } \\
\text { June } 2 \\
\text { July } \\
\text { July } 2 \\
\text { June } \\
\text { June } \\
\text { June } \\
\text { June }\end{array}$ & $\begin{array}{l}\text { Sept. } 4 \\
\text { Aug. } 15 \\
\text { Sept. } 17 \\
\text { Sept. } 15 \\
\text { Sept. } 2 \\
\text { Sept. } 28 \\
\text { Oct. } 1 \\
\text { Oct. } 13 \\
\text { Sept. } 28\end{array}$ & $\begin{array}{l}\text { Aug. } 22 \\
\text { Aug. } 1 \\
\text { Sept. } 6 \\
\text { Sept. } 6 \\
\text { Aug. 1 } \\
\text { Sept. 10 } \\
\text { Sept. 14 } \\
\text { Sept. 21 } \\
\text { Sept. 11 }\end{array}$ & $\begin{array}{r}64 \\
29 \\
67 \\
91 \\
69 \\
121 \\
145 \\
157 \\
140\end{array}$ \\
\hline
\end{tabular}

Dolores River Basin

\begin{tabular}{|c|c|c|c|c|c|c|c|c|}
\hline $\begin{array}{l}\text { Dolores } \\
\text { Telluride-_. }\end{array}$ & $\begin{array}{l}\text { Montezuma } \\
\text { San Miguel }\end{array}$ & $\begin{array}{l}6,960 \\
6,750\end{array}$ & $\begin{array}{r}8 \\
15\end{array}$ & $\begin{array}{l}\text { May } 24 \\
\text { June } 24\end{array}$ & $\begin{array}{l}\text { June } 5 \\
\text { July } 27\end{array}$ & $\begin{array}{ll}\text { Oct. } & 1 \\
\text { Sept. } & 5\end{array}$ & $\begin{array}{l}\text { Sept. } 21 \\
\text { Aug. 17 }\end{array}$ & $\begin{array}{r}132 \\
73\end{array}$ \\
\hline
\end{tabular}

\section{PRECIPITATION}

For the high mountain areas, the region of greatest precipitation, few records are available; and it is necessary to augment these with estimates of precipitation based on the many records of measured run-off of the mountain streams, to which have been added the losses due to transpiration and evaporation from vegetation and the percolation that does not reenter the streams.

In preparing the rainfall map (pl. 1) all available precipitation records of the Weather Bureau were utilized. The snow-scale readings were expanded to full-year records by comparison of monthly percentages with records at near-by precipitation stations. In addition each run-off record of a mountainous area was used by adding to the mean run-off expressed in depth in inches a quantity reprosenting annual losses between precipitation and run-off. This quantity, which was taken as 15 inches, was based on extensive. 
experiments carried on by the Forest Service and the Weather Bureau at the Wagonwheel Gap experiment station ${ }^{7}$ and was roughly checked by the writer through a comparison of measured precipitation and run-off in the Pikes Peak region. It is obvious that for plains areas where the annual precipitation is 15 inches or less the constant loss of 15 inches does not apply. For these areas there is no definite relation between precipitation and run-off, the run-off depending wholly upon the intensity of the precipitation.

Each drainage basin for which run-off records are available was analyzed by percentages between each 1,000-foot contour. The results of these analyses and the mean annual precipitation are given in the following table.

Analyses of drainage basins and mean precipitation in upper Colorado River Basin

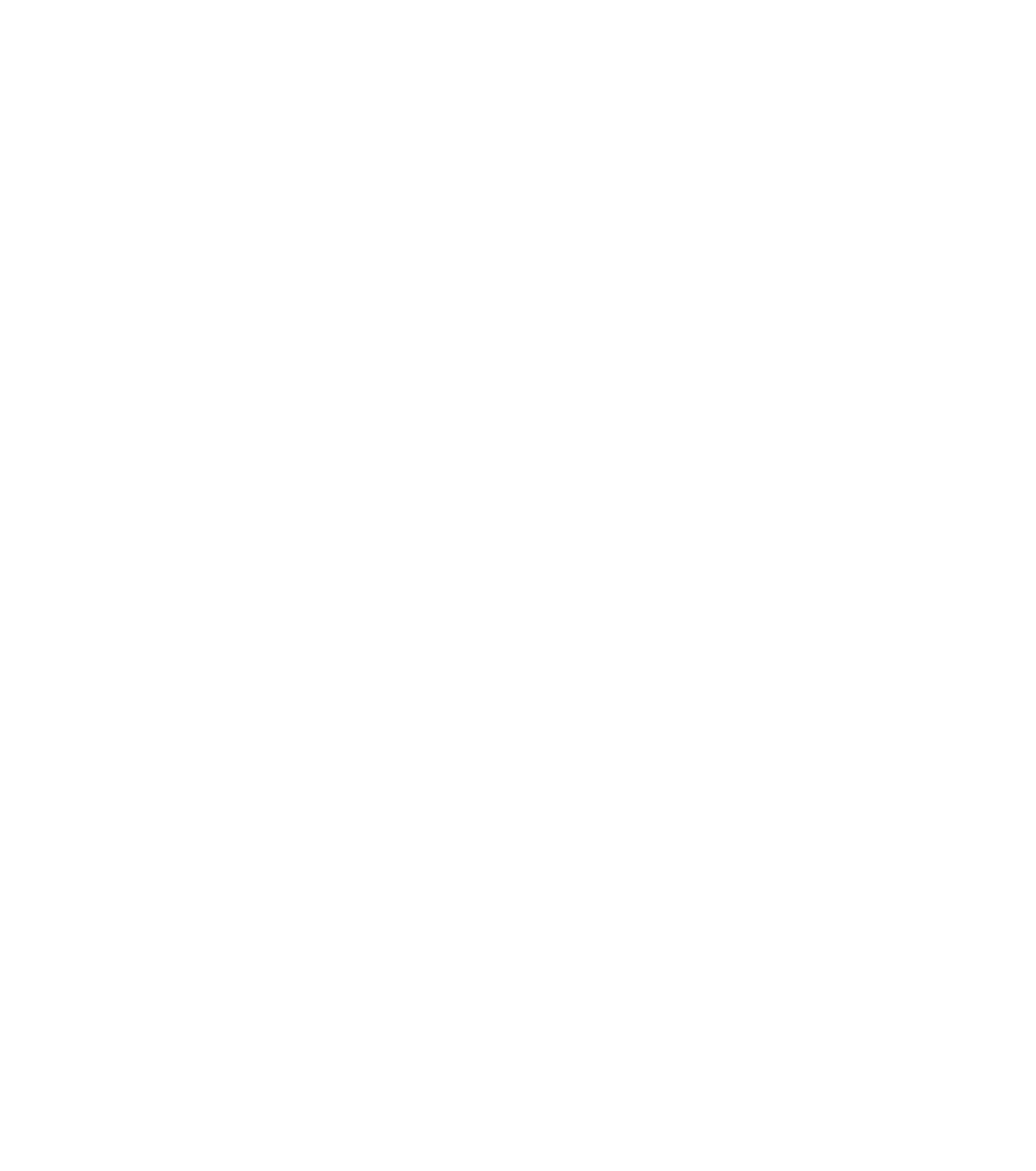

Bates, C. G., and Henry, A.J., Stream-flow experiment at Wagonwheel Gap, Colo.: Monthly Weather, Rev., Suppl. 17, p. 42, 1922. 
The mean precipitation for a drainage basin having been determined, computations of precipitation between each pair of 1,000 -foot contours were made. For this purpose a precipitation record was usually available near the lower end of the basin and one or more expanded snow-scale records at higher points. In the computations the precipitation was increased with altitude in such a way that the sum of the products of precipitation at the mid-points between contours multiplied by the percentages of the total area lying between the corresponding, contours approximately equaled the mean precipitation.

The computations for the drainage basin of the Roaring Fork above Aspen may be given as an illustration. As the mean annual precipitation at Aspen (altitude, 8,000 feet) is 18 inches, and as the snowscale readings at an altitude of 10,000 feet indicate a mean annual precipitation of 30 inches, the following computations were made:

Computation of precipitation in basin of Roaring Fork above Aspen

\begin{tabular}{|c|c|c|c|}
\hline Altitude (feet) & $\begin{array}{l}\text { Per vent } \\
\text { of area }\end{array}$ & $\begin{array}{c}\text { Assumed } \\
\text { precipi- } \\
\text { tation } \\
\text { (inches) }\end{array}$ & $\begin{array}{l}\text { Product } \\
\text { (inches) }\end{array}$ \\
\hline \multirow[t]{2}{*}{ 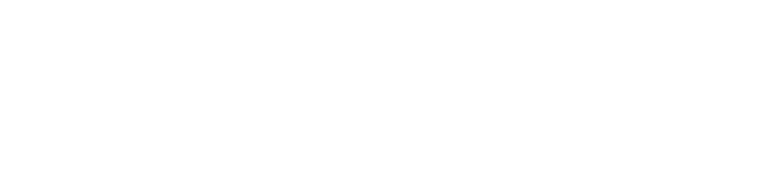 } & $\begin{array}{r}0.03 \\
.15 \\
.28 \\
.34 \\
.15 \\
.05\end{array}$ & $\begin{array}{l}60 \\
55 \\
45 \\
35 \\
25 \\
18\end{array}$ & $\begin{array}{r}1.80 \\
8.25 \\
12.60 \\
11.90 \\
3.75 \\
.90\end{array}$ \\
\hline & 1.00 & ........... & 39.20 \\
\hline
\end{tabular}

The assumed figures for precipitation were then plotted on the topographic map at altitudes midway between the corresponding 1,000 foot contours, and lines were drawn to connect points of equal precipitation for each 10-inch difference. Below 20 inches, an interval of 5 inches was used. At the lower altitudes, where stations are maintained, the lines of equal precipitation were based directly on the precipitation records.

The mean annual precipitation ranges from 10 inches in the sheltered valleys to 50 inches or more at the higher altitudes of some mountain areas. In general, the areas of highest precipitation are not on the Continental Divide, but on those mountain masses that form the western edge of the Rocky Mountain system, such as the high divide between the Colorado and White Rivers east of Meeker, the Elk Mountains west of Aspen, and the San Juan Mountrins in the southwest corner of the basin. Along the Continental Divide the only area having an annual precipitation of 50 inches is a narrow strip near Corona, at the head of the Fraser River. The relatively smaller precipitation along the Continental Divide is due not so much to lower altitude as it is to the fact that the mountain masses 
farther west intercept the storms from the Pacific and receive the greater part of their moisture. The area of lowest precipitation comprises the lower parts of the Uneompahgre and Gunnison Valleys, reaching from Montrose to a paint between Grand Junction and Fruita. Within this area Delta has a 36-year mean of 7.84 inches and Grand Junction a 32-year mean of 8.30 inches. The valley of the Colorado from the Green River to the Roaring Fork and from State Bridge to the east end of Middle Park has an anaual precipitation of less than 15 inches. Other areas having aimilar precipi-

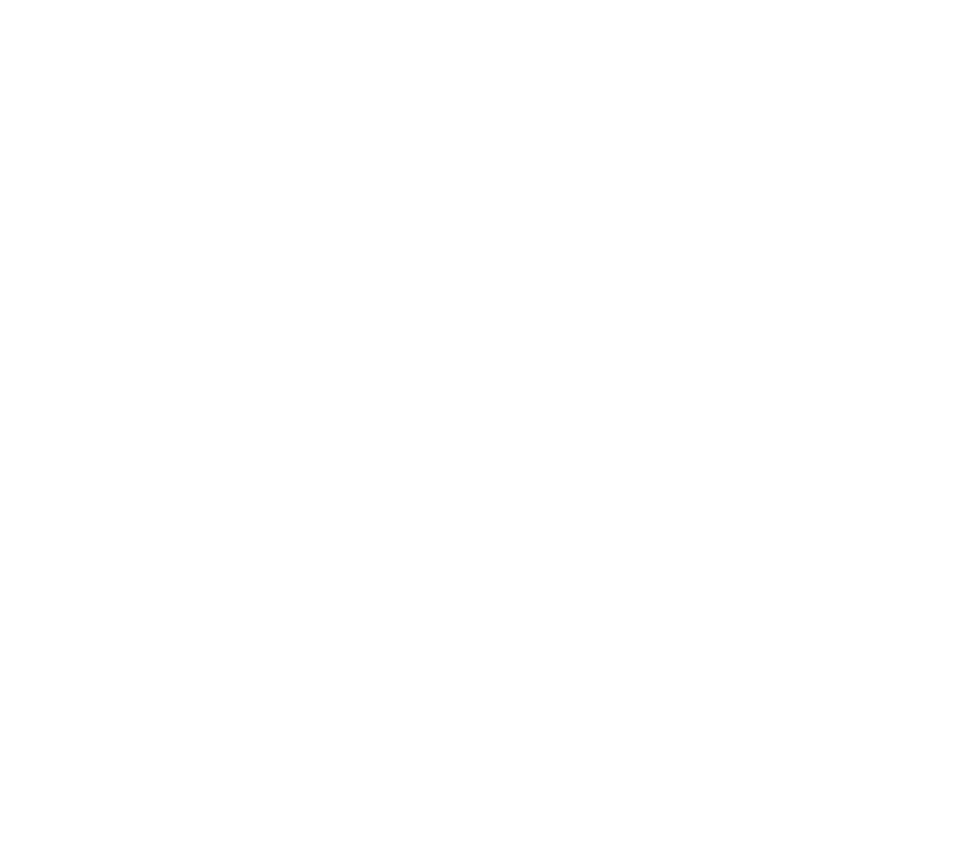

Frgure 1.-Variation in anaual prechpitation at Meeker, Grand Junction, and Mancos, Colo.

tation are the Gunnison Valley from Sargent to Iola, the Blue River Valley below Dillon, the lower Eagle River Valley, and the lower end of the Dolores River Basin in San Miguel and Montrose Counties.

The longest precipitation records in or adjacent to the basin are those obtained at points in the western part, there being none in the upper part of the basin comparable to these in length. To show the annual variation of precipitation records at Meeker, Grand Junction, and Mancos have been used, and for each station the yearly means and progressive 5-year means have been plotted. (See fig. 1.) The 
resulting graphs show that the precipitation in the period from about 1898 to 1905 was the lowest recorded, the lowest 5 -year mean at Meeker being 84 per cent of the 33-year mean, at Grand Junction 76 per cent of the 35-year mean, and at Mancos 70 per cent of the 21year mean. These percentages indicate that the deficiency in precipitation during that period was more acute in the southern part of the basin than in the northern part. It appears probable that the precipitation for the period 1898 to 1905 was also low throughout the upper basin, although records to prove this inference are lacking. A study of the variation in annual run-off of streams in the Colorado River Basin ${ }^{8}$ shows that the streams rising in the central mountain region have a smaller annual variation than those rising on the western edge, and this fact indicates that the annual variation in precipitation is correspondingly less.

The seasonal distribution of precipitation is fairly uniform. From 40 to 50 per cent occurs from December to April, and from 30 to 35 per cent during the irrigation months, June to September. The winter precipitation is in the form of snow, which constitutes the great natural reservoir for stream flow during the summer. The summer rainfall takes the form of showers, occurring usually in the afternoon and frequently accompanied by electrical disturbances. In the western foothill region-particularly in the upper Uncompahgre River Valley and on the slopes of the Uncompahgre Plateau, Grand Mesa, Grand Hogback, and Book Cliffs-the showers occasionally reach "cloudburst" intensity.

\section{EVAPORATION}

\section{AVATIABIE RECORDS}

Records of evaporation are available for 19 points in and adjacent to the Colorado River Basin, and records have been computed for Lander, Wyo., adjacent to the upper Green River Basin. The former represent evaporation measured in pans of different sizes either set in the ground, resting on top of it, or floating in ponds and reservoirs. None of these records represent directly the evaporation to be expected from a reservoir surface; each has to be corrected by an amount depending upon the type of pan. So far as the writer knows, the only comprehensive experiments carried on to determine the proper reduction factors for pans of various diameters, depths, and

\footnotetext{
- Follansbee, Robert, Variation in annual run-off in the Rocky Mountain region: U. S. Geol. Survey Water-Supply Paper 520, pp. 1-14, 1923.
} 
immediate surroundings were those made by the Office of Public Roads and Rural Engineering in Denver during 1915 and 1916. ${ }^{\circ}$ In this investigation evaporation was measured simultaneously in pans of the varying dimensions and surroundings most commonly used. In addition, measurements of evaporation in a 12-foot pan were made, as these were considered to represent closely the evaporation from a reservoir surface. Although the investigation lasted only from November, 1915, to November, 1916, it was carefully made and determined the relative effect of the different pans under conditions existing at the open air laboratory in Denver. The comparison between a class $A$ Weather Bureau pan 4 feet in diameter and the 12-foot pan has been checked by observations made by the United States Geological Survey in the Escalante Valley, near Milford, Utah, since the summer of 1925 .

By means of the coefficients determined during the Denver investigation, the records in and adjacent to the Colorado River Basin have been reduced to reservoir equivalents. The mean monthly equivalents for each station, together with observed temperatures and wind velocities, so far as available, are also presented in the following table. The records of temperature and wind velocity, except for Farmington, which were based on Weather Bureau records at Albuquerque, were taken close to the evaporation pan, the anemometer being only a foot or two above the ground. They are not directly comparable with records at regular Weather Bureau stations, which are usually taken on the tops of buildings from 35 to 60 feet above the ground. Temperatures at the higher positions do not differ widely from those near the ground, but comparisons of wind velocity show wide variations between the two positions. (See table on p. 39.) The reservoir equivalents represent gross quantities from which precipitation has not been deducted. For example, if the water surface in the pan shows no change since the last visit, and the rain gage shows precipitation amounting to $0.5 \mathrm{inch}$, it is evident that the evaporation has just equaled the precipitation, and in that case it is recorded as 0.5 inch. Practically no records of relative humidity that are applicable to the atmosphere directly above the water surface of the pans are available, those published by the Weather Bureau being taken at regular stations, usually located on the tops of buildings. The figures in parentheses are estimated.

I Jour. Agr. Research, vol. 10, pp. 209-242, 1917. 


\section{Mean monthly reservoir equivalents for evaporation stations in and adjacent to} Colorado River Basin

Wagonwheel Gap, Colo. (1920-1924) •

\begin{tabular}{|c|c|c|c|c|}
\hline \multirow{2}{*}{ Month } & \multirow{2}{*}{$\begin{array}{l}\text { Temper- } \\
\text { ature of } \\
\text { sit }\left({ }^{\circ} .\right)\end{array}$} & \multirow{2}{*}{$\begin{array}{l}\text { Wind } \\
\text { veleoity } \\
\text { (miles } \\
\text { per } \\
\text { hour) }\end{array}$} & \multicolumn{2}{|c|}{$\begin{array}{l}\text { Resorvoir equiv- } \\
\text { alent }\end{array}$} \\
\hline & & & Inches & $\begin{array}{l}\text { Per cent } \\
\text { of annues }\end{array}$ \\
\hline $\begin{array}{l}\text { January } \\
\text { Pethruary } \\
\text { Aaren } \\
\text { Aprit } \\
\text { Jay } \\
\text { Julp } \\
\text { Angust } \\
\text { September } \\
\text { October } \\
\text { November } \\
\text { December. }\end{array}$ & $\begin{array}{l}15 \\
18 \\
22 \\
29 \\
42 \\
58 \\
55 \\
52 \\
46 \\
35 \\
24 \\
17\end{array}$ & $\begin{array}{l}1.7 \\
1.8 \\
2.2 \\
2.4 \\
2.6 \\
2.6 \\
2.2 \\
1.8 \\
1.7 \\
1.7 \\
1.5 \\
1.4\end{array}$ & $\begin{array}{r}(0.85) \\
(.77) \\
(1.21) \\
(1.85) \\
(2.83) \\
3.36 \\
3.04 \\
2.56 \\
2.10 \\
1.35 \\
(1.17) \\
(.78)\end{array}$ & $\begin{array}{r}3.9 \\
8.5 \\
5.6 \\
9.0 \\
13.0 \\
15.4 \\
14.0 \\
10.8 \\
9.6 \\
6.2 \\
5.4 \\
3.6\end{array}$ \\
\hline Annual & 34 & 20 & 27.77 & 100 \\
\hline
\end{tabular}

Provo, Utah (1908-1916, 1918-1926) 。

\begin{tabular}{|c|c|c|c|c|}
\hline $\begin{array}{l}\text { January. } \\
\text { Fobruary } \\
\text { March } \\
\text { April } \\
\text { Muye } \\
\text { July } \\
\text { August } \\
\text { September } \\
\text { Octotser. } \\
\text { November } \\
\text { December }\end{array}$ & $\begin{array}{l}27 \\
33 \\
40 \\
46 \\
57 \\
65 \\
72 \\
69 \\
61 \\
49 \\
38 \\
29\end{array}$ & $\begin{array}{r}(1.0) \\
(1.2) \\
1.8 \\
1.9 \\
1.5 \\
1.9 \\
.9 \\
.9 \\
.9 \\
.9 \\
.7 \\
(.9)\end{array}$ & $\begin{array}{r}(0.68) \\
(.77) \\
2.40 \\
2.84 \\
3.74 \\
4.20 \\
4.46 \\
3.95 \\
2.75 \\
1.62 \\
.83 \\
(.60)\end{array}$ & $\begin{array}{r}2.4 \\
2.7 \\
8.4 \\
9.0 \\
13.1 \\
14.5 \\
15.5 \\
13.8 \\
9.6 \\
6.6 \\
2.9 \\
2.1\end{array}$ \\
\hline Annual & 49 & 1.2 & 28.84 & 160 \\
\hline
\end{tabular}

Lander, Wro.

\begin{tabular}{|c|c|c|c|c|}
\hline $\begin{array}{l}\text { January. } \\
\text { February. } \\
\text { March } \\
\text { April. } \\
\text { May } \\
\text { June } \\
\text { August } \\
\text { September } \\
\text { Oetober } \\
\text { November } \\
\text { December. }\end{array}$ & $\begin{array}{l}20 \\
22 \\
28 \\
41 \\
51 \\
59 \\
66 \\
65 \\
56 \\
44 \\
32 \\
20\end{array}$ & $\begin{array}{l}3.4 \\
3.4 \\
4.8 \\
5.2 \\
5.1 \\
4.7 \\
4.2 \\
3.9 \\
4.4 \\
3.4 \\
3.7 \\
3.2\end{array}$ & $\begin{array}{r}0.52 \\
.62 \\
1.12 \\
2.28 \\
3.21 \\
4.72 \\
6.13 \\
5.71 \\
3.97 \\
1.97 \\
1.07 \\
.48\end{array}$ & $\begin{array}{r}1.6 \\
2.0 \\
3.5 \\
7.8 \\
10.1 \\
14.8 \\
19.3 \\
17.9 \\
12.5 \\
6.8 \\
3.4 \\
1.6\end{array}$ \\
\hline Annual ..... & 42 & 4. 1 & 31.80 & 160 \\
\hline
\end{tabular}

- Unpublished records furnished through courtesy of Weather Bureau and Forest Service.

- Reeords by U. S. Bureau of Reclamation.

Wagonwheel Gap: Mean of records for two class A Weather Bureau stations on near-by slopes, one having a northern exposure and the other a southern exposure (coefferent, 0.66).

Provo: On vacant rity lot fully exposed. From 1908 to 1916, records taken by pan 3 feet square and 17. inches deep set in ground; coefficient taken as 0.78. Class A Weather Bureau stations installed in 1018 (coefficient 0.66).

Lander: Records computed by Dalton-Meyer formula; description of computations given in Follansbee, Robert, Surface waters of Wyoming and their utilization: U. 8. Geol. Survey Water-Supply Paper 469, pp. 323 et seq., 1923 
Mean monthly reservoir oquivalents for evaporation stations in and adjacent to Colorado River Basin-Continued

Myton, Utah (1918-1926) •

\begin{tabular}{|c|c|c|c|c|}
\hline \multirow[t]{2}{*}{ - } & \multirow{2}{*}{$\begin{array}{l}\text { Temper- } \\
\text { ature of } \\
\text { air ( } \\
\text { ( F.) }\end{array}$} & \multirow{2}{*}{$\begin{array}{l}\text { Wind } \\
\text { velocity } \\
\text { (miles } \\
\text { per } \\
\text { hour) }\end{array}$} & \multicolumn{2}{|c|}{$\begin{array}{l}\text { Reservoir equiv- } \\
\text { alent }\end{array}$} \\
\hline & & & Inches & $\begin{array}{l}\text { Per cent } \\
\text { of annual }\end{array}$ \\
\hline $\begin{array}{l}\text { January } \\
\text { February } \\
\text { March } \\
\text { April } \\
\text { May } \\
\text { Jund } \\
\text { July } \\
\text { Auguist } \\
\text { September } \\
\text { October } \\
\text { November } \\
\text { December. }\end{array}$ & $\begin{array}{l}14 \\
23 \\
36 \\
46 \\
57 \\
66 \\
72 \\
70 \\
61 \\
48 \\
34 \\
20\end{array}$ & $\begin{array}{l}(3.1) \\
(3.6) \\
4.3 \\
4.1 \\
3.4 \\
2.9 \\
2.4 \\
2.4 \\
2.6 \\
2.5 \\
2.1 \\
(1.6)\end{array}$ & $\begin{array}{r}(0.43) \\
(.65) \\
(1.68) \\
4.14 \\
5.92 \\
6.94 \\
6.42 \\
5.55 \\
4.25 \\
2.48 \\
(1.20) \\
(.40)\end{array}$ & $\begin{array}{r}1.1 \\
1.6 \\
4.2 \\
10.4 \\
14.8 \\
17.0 \\
16.4 \\
13.9 \\
10.4 \\
6.2 \\
3.0 \\
1.0\end{array}$ \\
\hline Annual. & 46 & 3. 0 & 39.86 & 100 \\
\hline
\end{tabular}

Utah Lake outlet, Utah (1901-1986, 1823-1927) d

\begin{tabular}{|c|c|c|c|c|}
\hline 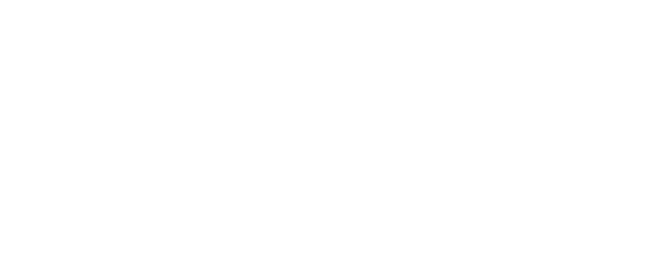 & $\begin{array}{l}26 \\
31 \\
39 \\
48 \\
56 \\
65 \\
72 \\
69 \\
60 \\
50 \\
40 \\
27\end{array}$ & 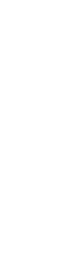 & $\begin{array}{l}(0.90) \\
(1.10) \\
1.88 \\
3.42 \\
5.30 \\
6.57 \\
7.06 \\
6.10 \\
4.82 \\
2.80 \\
1.10 \\
(.80)\end{array}$ & $\begin{array}{r}2.2 \\
2.6 \\
4.5 \\
8.2 \\
12.6 \\
15.8 \\
16.9 \\
14.5 \\
11.5 \\
6.7 \\
2.6 \\
1.9\end{array}$ \\
\hline Annual & 49 & 4. 5 & 41.85 & 100 \\
\hline
\end{tabular}

Santa Fe, N. Mex. (1913-1914, 1916-1927) •

\begin{tabular}{|c|c|c|c|c|}
\hline 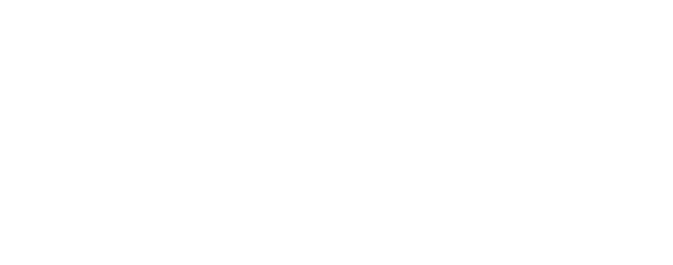 & $\begin{array}{l}30 \\
34 \\
38 \\
46 \\
56 \\
66 \\
69 \\
66 \\
61 \\
50 \\
40 \\
30\end{array}$ & $\begin{array}{l}2.7 \\
3.1 \\
3.5 \\
3.7 \\
3.4 \\
2.9 \\
2.0 \\
1.7 \\
1.8 \\
2.2 \\
2.5 \\
2.5\end{array}$ & $\begin{array}{l}1.09 \\
1.52 \\
2.73 \\
4.18 \\
5.97 \\
6.90 \\
5.84 \\
5.28 \\
4.41 \\
3.35 \\
1.97 \\
1.01\end{array}$ & $\begin{array}{r}2.5 \\
3.4 \\
6.2 \\
9.5 \\
13.5 \\
15.5 \\
13.2 \\
11.8 \\
110.0 \\
7.6 \\
4.5 \\
2.3\end{array}$ \\
\hline Annual & 48 & 2.7 & 44. 20 & 100 \\
\hline
\end{tabular}

- Records by U. S. Indian Service.

Records by water commissioner.

- Records by U. S. Weather Bureau

Myton: Class A Weather Bureau station (coefficient, 0.66).

Utah Iake outlet: From' 1901 to 1906, records taken by pan 3 feet in diameter and 3 feet deep sunk 3 feet in groand a few feet from shore of Utah Lake at pumping plant 5 miles southwest of Lehi (coeffieient; 0.80 ). Beginning 1923, Class A Weather Bureau station on island in Jordan River 300 feet north of lake shore (coefticient, 0.66).

Santa Fe: Records 1913-1914 taken by floating pan in reservoir 1 mile west of city (coefficient, 0.91 ).

Cless A Weather Bureau station established in open space on edge of city in 1916 (coefficient, 0.66).

$$
46013-29-4
$$


Mean monthly reservoir equivalents for evaporation stations in and adjacent to Colorado River Basin-Continued

Farmington, N. Mex. (1915-1927)'

\begin{tabular}{|c|c|c|c|c|}
\hline \multirow{2}{*}{ Month } & \multirow{2}{*}{$\begin{array}{l}\text { Temper- } \\
\text { ature of } \\
\left.\text { air ( }{ }^{\circ} \mathrm{F} .\right)\end{array}$} & \multirow{2}{*}{$\begin{array}{l}\text { Wind } \\
\text { velocity } \\
\text { (miles } \\
\text { per } \\
\text { hour) }\end{array}$} & \multicolumn{2}{|c|}{$\begin{array}{l}\text { Reservoir equit- } \\
\text { alent }\end{array}$} \\
\hline & & & Inches & $\begin{array}{l}\text { Per cont } \\
\text { of annual }\end{array}$ \\
\hline $\begin{array}{l}\text { January } \\
\text { February } \\
\text { March } \\
\text { April. } \\
\text { May } \\
\text { Jane } \\
\text { July } \\
\text { August } \\
\text { September } \\
\text { October } \\
\text { November } \\
\text { December }\end{array}$ & $\begin{array}{l}36 \\
41 \\
48 \\
55 \\
64 \\
71 \\
75 \\
72 \\
65 \\
55 \\
44 \\
37\end{array}$ & 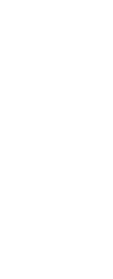 & $\begin{array}{r}0.74 \\
1.39 \\
3.05 \\
4.84 \\
6.38 \\
6.96 \\
7.17 \\
5.62 \\
4.38 \\
3.26 \\
1.80 \\
.96\end{array}$ & $\begin{array}{r}1.6 \\
3.0 \\
6.5 \\
10.4 \\
13.7 \\
15.0 \\
15.4 \\
12.1 \\
9.4 \\
7.0 \\
3.9 \\
2.0\end{array}$ \\
\hline Annual & 55 & 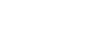 & 46.55 & 100 \\
\hline
\end{tabular}

Piute Dam, Utah (1918-1927) 2

\begin{tabular}{|c|c|c|c|c|}
\hline $\begin{array}{l}\text { January } \\
\text { February } \\
\text { March. } \\
\text { April. } \\
\text { May } \\
\text { June } \\
\text { July } \\
\text { August } \\
\text { September. } \\
\text { October } \\
\text { November } \\
\text { December }\end{array}$ & $\begin{array}{l}27 \\
32 \\
37 \\
45 \\
56 \\
65 \\
71 \\
68 \\
60 \\
48 \\
37 \\
27\end{array}$ & $\begin{array}{l}(3.4) \\
(3.5) \\
(3.8) \\
3.9 \\
3.5 \\
3.2 \\
2.7 \\
2.7 \\
3.0 \\
2.9 \\
2.8 \\
(3.0)\end{array}$ & $\begin{array}{l}(0.94) \\
(1.03) \\
(1.79) \\
4.84 \\
6.12 \\
7.72 \\
7.03 \\
6.31 \\
5.25 \\
3.40 \\
1.40 \\
(.80)\end{array}$ & $\begin{array}{r}2.0 \\
2.2 \\
3.8 \\
10.4 \\
13.0 \\
16.8 \\
15.2 \\
13.5 \\
11.1 \\
7.2 \\
3.1 \\
1.7\end{array}$ \\
\hline Annual & 48 & 3. 2 & 46. 63 & 100 \\
\hline
\end{tabular}

Nephi, Utah (1908-1927)。

\begin{tabular}{|c|c|c|c|c|}
\hline $\begin{array}{l}\text { January } \\
\text { February } \\
\text { March. } \\
\text { April } \\
\text { May. } \\
\text { June } \\
\text { July } \\
\text { A.ugust } \\
\text { September } \\
\text { October } \\
\text { November. } \\
\text { December. }\end{array}$ & $\begin{array}{l}(25) \\
(30) \\
(37) \\
45 \\
54 \\
64 \\
72 \\
70 \\
60 \\
50 \\
\left(\begin{array}{c}40) \\
25)\end{array}\right.\end{array}$ & $\begin{array}{r}(3.0) \\
(3.8) \\
(4.5) \\
4.3 \\
4.2 \\
4.0 \\
3.6 \\
3.5 \\
3.6 \\
3.7 \\
(3.3) \\
(8.2)\end{array}$ & $\begin{array}{c}(0.60) \\
(1.10) \\
(2.00) \\
3.50 \\
5.78 \\
7.87 \\
8.51 \\
7.95 \\
5.64 \\
3.11 \\
(1.50) \\
(.75)\end{array}$ & $\begin{array}{r}1.2 \\
2.3 \\
4.1 \\
7.4 \\
12.0 \\
16.3 \\
17.6 \\
16.4 \\
11.7 \\
6.4 \\
3.1 \\
1.5\end{array}$ \\
\hline Annual & 48 & 3.7 & 48.87 & 100 \\
\hline
\end{tabular}

- Records by water commissioner.

$f$ Records by State engineer.

- Records by Experiment Station.

Farmington: Floating pan on slough near city (coefficient, 0.91 ).

Piute Dam: Class A Weather Bureau station in Sevier River bottom 8 miles south of Marysvalo (coetficient, 0.66). Piute Reservoir 500 feet south, and Sevier River 200 foet southeast.

Nephi: Circular pan 6 feet in diameter and 2 feet deep sunk 18 inches in ground at cooperative axperf ment station, 5 miles south of Nephi (coefficient, 0.90$)$. 
Mean monthly reservoir equivalents for evaporation stations in and adjacent to Colorado River Basin-Continted

Mess Dxperiment Farm, Ariz. (1917-1927),

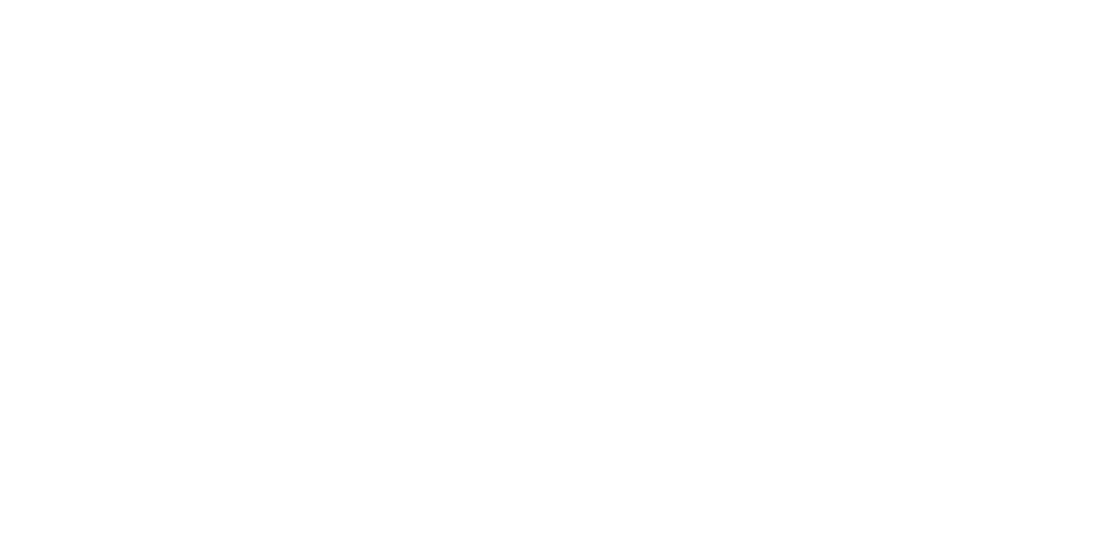

Yuma evaporation, Ariz. (1917-1927)

\begin{tabular}{|c|c|c|c|c|}
\hline $\begin{array}{l}\text { January. } \\
\text { February } \\
\text { March. } \\
\text { April. } \\
\text { May } \\
\text { June } \\
\text { July } \\
\text { August. } \\
\text { September } \\
\text { Oetober. } \\
\text { November. } \\
\text { December. }\end{array}$ & $\begin{array}{l}51 \\
56 \\
59 \\
65 \\
71 \\
80 \\
87 \\
86 \\
80 \\
69 \\
58 \\
52\end{array}$ & $\begin{array}{l}1.3 \\
1.5 \\
1.7 \\
1.8 \\
1.2 \\
1.0 \\
1.2 \\
1.4 \\
1.2 \\
1.0 \\
1.0 \\
1.2\end{array}$ & $\begin{array}{l}2.10 \\
2.76 \\
3.98 \\
5.02 \\
5.80 \\
6.23 \\
7.03 \\
6.82 \\
5.38 \\
3.68 \\
2.33 \\
1.83\end{array}$ & $\begin{array}{r}4.0 \\
5.2 \\
7.5 \\
9.5 \\
10.9 \\
11.7 \\
13.4 \\
12.9 \\
10.2 \\
6.9 \\
4.4 \\
3.4\end{array}$ \\
\hline Annual $\ldots$ & 68 & 1.3 & 52.96 & 100 \\
\hline
\end{tabular}

Roosevelt Dam, Aria. (1916-1927) h

\begin{tabular}{|c|c|c|c|c|}
\hline $\begin{array}{l}\text { January } \\
\text { February } \\
\text { March } \\
\text { April } \\
\text { May. } \\
\text { June } \\
\text { July } \\
\text { August } \\
\text { September. } \\
\text { October } \\
\text { November } \\
\text { December. }\end{array}$ & $\begin{array}{l}48 \\
54 \\
58 \\
64 \\
74 \\
84 \\
87 \\
86 \\
80 \\
69 \\
58 \\
49\end{array}$ & $\begin{array}{l}1.4 \\
1.5 \\
1.8 \\
1.8 \\
1.8 \\
1.7 \\
2.0 \\
1.7 \\
1.4 \\
1.2 \\
1.1 \\
1.3\end{array}$ & $\begin{array}{l}1.50 \\
2.16 \\
3.47 \\
4.79 \\
6.89 \\
8.23 \\
8.07 \\
6.90 \\
5.70 \\
3.71 \\
2.27 \\
1.42\end{array}$ & $\begin{array}{r}2.7 \\
3.9 \\
6.3 \\
8.7 \\
12.5 \\
15.0 \\
14.7 \\
12.5 \\
10.3 \\
6.7 \\
4.1 \\
2.6\end{array}$ \\
\hline Annual & 68 & 1.6 & 55. 11 & 100 \\
\hline
\end{tabular}

- Records by Experiment Station.

- Records by University of Arizona.

Mesa Experiment Farm: Class A Weather Bureau station in alfalfa fleld, 1 mile west of Mesa, in Salt River Valley (coefficient, 0.66 ).

Yuma evaporation: Class A Weather Bureau station in center of alfalfa field, 1 mile west of city (coe' ficlent, 0.60 ). Colorado River 1 mile north of station.

Roosevelt Dam: Class A Weather Bureau station 1 mile east of dam and south of reservolr on steer. gravelly slope, having little or no vegetation (coefficient, 0.66 ). 
Mean monthly reservoir equivalents for evaporation stations in and adjacent to Colorado River Basin-Continued

Agricultural College, N. Mex. (1918-1927) .

\begin{tabular}{|c|c|c|c|c|}
\hline \multirow{2}{*}{ Month } & \multirow{2}{*}{$\begin{array}{l}\text { Temper- } \\
\text { ature of } \\
\text { air ( }{ }^{2} . \text { ) }\end{array}$} & \multirow{2}{*}{$\begin{array}{l}\text { Wind } \\
\text { velocity } \\
\text { (miles } \\
\text { per } \\
\text { hour) }\end{array}$} & \multicolumn{2}{|c|}{$\begin{array}{c}\text { Reservoir equiv- } \\
\text { alent }\end{array}$} \\
\hline & & & Inches & $\begin{array}{l}\text { Per eont } \\
\text { of annual }\end{array}$ \\
\hline $\begin{array}{l}\text { January. } \\
\text { February } \\
\text { March. } \\
\text { April. } \\
\text { May } \\
\text { June } \\
\text { July } \\
\text { August } \\
\text { September. } \\
\text { October. } \\
\text { November } \\
\text { December. }\end{array}$ & $\begin{array}{l}43 \\
46 \\
51 \\
59 \\
68 \\
76 \\
79 \\
76 \\
71 \\
60 \\
49 \\
40\end{array}$ & $\begin{array}{l}2.0 \\
2.7 \\
3.3 \\
3.2 \\
2.2 \\
1.9 \\
1.8 \\
1.3 \\
1.4 \\
1.4 \\
1.7 \\
1.8\end{array}$ & $\begin{array}{l}1.92 \\
2.91 \\
4.89 \\
6.17 \\
7.33 \\
7.71 \\
7.27 \\
6.31 \\
5.07 \\
3.91 \\
2.54 \\
1.64\end{array}$ & $\begin{array}{r}3.3 \\
5.1 \\
8.5 \\
10.7 \\
12.7 \\
13.4 \\
12.6 \\
10.9 \\
8.8 \\
6.8 \\
4.4 \\
2.8\end{array}$ \\
\hline Annual & 60 & 2.1 & 57.67 & 100 \\
\hline
\end{tabular}

Lees Ferry, Ariz. (1922-1927) •

\begin{tabular}{|c|c|c|c|c|}
\hline $\begin{array}{l}\text { January. } \\
\text { February } \\
\text { Merch } \\
\text { April } \\
\text { May } \\
\text { June } \\
\text { July. } \\
\text { August } \\
\text { September. } \\
\text { October } \\
\text { November } \\
\text { December }\end{array}$ & $\begin{array}{l}34 \\
44 \\
50 \\
60 \\
72 \\
80 \\
86 \\
82 \\
74 \\
61 \\
48 \\
\mathbf{3 7}\end{array}$ & $\begin{array}{l}1.4 \\
1.4 \\
2.9 \\
2.7 \\
2.8 \\
2.5 \\
2.3 \\
2.0 \\
1.9 \\
1.9 \\
1.6 \\
1.8\end{array}$ & $\begin{array}{r}1.15 \\
1.91 \\
3.89 \\
5.14 \\
7.96 \\
9.03 \\
9.10 \\
7.46 \\
5.83 \\
3.99 \\
1.91 \\
1.32\end{array}$ & $\begin{array}{r}2.0 \\
3.4 \\
6.6 \\
8.8 \\
13.4 \\
15.4 \\
15.5 \\
12.8 \\
9.0 \\
6.8 \\
3.2 \\
2.2\end{array}$ \\
\hline Annual & 61 & 2.1 & 58. 69 & 100 \\
\hline
\end{tabular}

Milford, Utah (1926-27)

\begin{tabular}{|c|c|c|c|c|}
\hline $\begin{array}{l}\text { January. } \\
\text { February } \\
\text { March } \\
\text { April } \\
\text { May } \\
\text { Jume } \\
\text { July. } \\
\text { August } \\
\text { September } \\
\text { October } \\
\text { November } \\
\text { December }\end{array}$ & $\begin{array}{l}28 \\
38 \\
41 \\
49 \\
56 \\
66 \\
72 \\
70 \\
62 \\
48 \\
42 \\
25\end{array}$ & $\begin{array}{l}(3.4) \\
(3.9) \\
(4.4) \\
4.6 \\
4.9 \\
4.8 \\
4.2 \\
4.8 \\
5.2 \\
4.0 \\
(3.4) \\
(3.5)\end{array}$ & $\begin{array}{c}(1.20) \\
(1.80) \\
2.42 \\
4.15 \\
7.40 \\
9.70 \\
9.27 \\
8.86 \\
7.10 \\
4.35 \\
(2.10) \\
(1.10)\end{array}$ & $\begin{array}{r}2.0 \\
2.5 \\
4.1 \\
7.0 \\
12.5 \\
16.4 \\
15.6 \\
15.0 \\
12.0 \\
7.4 \\
\mathbf{3 . 6} \\
1.0\end{array}$ \\
\hline Annual . . & 50 & 4.3 & 59.15 & 100 \\
\hline
\end{tabular}

- Records by U. S. Weather Bureau.

- Records by Experiment Station.

$i$ Records by U. S. Geological Survey.

Agricultural College: Class A Weather Bureau station on campus near Las Cruces $($ coefficient, 0,66 ) Lees Ferry: Class A Weather Bureau station in canyon of Colorado River 10 miles south of Utah line (coefficient, 0.66). Walls of canyon 100 and 250 yards distant, river 400 to 600 feet wide and 140 foet distanpo from pan.

Milford: ,Class A Weather Bureau pan at Geological Survey experimental plant (coeffleient ,0.66). 
Mean monthly reservoir equivalents for evaporation stations in and adjacent to Colorado River Basin-Continued

Willeox, Ariz. (1917-1921, 1923-1925, 1927) $?$

\begin{tabular}{|c|c|c|c|c|}
\hline \multirow{2}{*}{ Month . } & \multirow{2}{*}{$\begin{array}{l}\text { Temper- } \\
\text { ature of } \\
\text { air ('F.) }\end{array}$} & \multirow{2}{*}{$\begin{array}{l}\text { Wind } \\
\text { velocity } \\
\text { (miles } \\
\text { per } \\
\text { hour) }\end{array}$} & \multicolumn{2}{|c|}{$\begin{array}{c}\text { Reservoir equiv- } \\
\text { alent }\end{array}$} \\
\hline & & & Inches & $\begin{array}{l}\text { Per cont } \\
\text { of annual }\end{array}$ \\
\hline $\begin{array}{l}\text { January. } \\
\text { February. } \\
\text { March } \\
\text { April. } \\
\text { May } \\
\text { June } \\
\text { July } \\
\text { August. } \\
\text { September } \\
\text { October } \\
\text { November } \\
\text { December }\end{array}$ & $\begin{array}{l}40 \\
44 \\
48 \\
54 \\
63 \\
72 \\
76 \\
74 \\
69 \\
58 \\
48 \\
41\end{array}$ & $\begin{array}{l}3.7 \\
3.9 \\
4.3 \\
4.5 \\
3.5 \\
2.8 \\
2.5 \\
2.0 \\
2.1 \\
2.2 \\
2.8 \\
3.7\end{array}$ & $\begin{array}{l}2.20 \\
3.13 \\
4.98 \\
6.78 \\
7.77 \\
7.86 \\
6.79 \\
5.74 \\
5.10 \\
4.28 \\
3.18 \\
2.18\end{array}$ & $\begin{array}{r}3.7 \\
5.2 \\
8.3 \\
11.3 \\
12.8 \\
13.0 \\
11.3 \\
9.8 \\
8.6 \\
7.1 \\
5.3 \\
3.6\end{array}$ \\
\hline Annual . & 57 & 3.2 & 89.99 & 100 \\
\hline
\end{tabular}

Deming, N. Mex. (1914-1927)

\begin{tabular}{|c|c|c|c|c|}
\hline $\begin{array}{l}\text { January } \\
\text { Iebruary } \\
\text { March. } \\
\text { April } \\
\text { May } \\
\text { June } \\
\text { July } \\
\text { August } \\
\text { September. } \\
\text { October. } \\
\text { November. } \\
\text { Deeember }\end{array}$ & $\begin{array}{r}43 \\
46 \\
58 \\
60 \\
66 \\
70 \\
73 \\
72 \\
69 \\
63 \\
51 \\
45\end{array}$ & 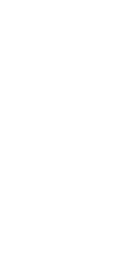 & $\begin{array}{l}2.60 \\
3.16 \\
5.21 \\
6.54 \\
7.38 \\
7.74 \\
6.03 \\
5.38 \\
5.25 \\
4.93 \\
3.74 \\
2.64\end{array}$ & $\begin{array}{r}4.3 \\
5.2 \\
8.8 \\
10.8 \\
12.2 \\
12.8 \\
10.0 \\
8.9 \\
8.7 \\
8.1 \\
6.2 \\
4.2\end{array}$ \\
\hline Annual & 59 & & 60.60 & 100 \\
\hline
\end{tabular}

Blephant Butte Dam, N. Mex. (1916-1927) b

\begin{tabular}{|c|c|c|c|c|}
\hline $\begin{array}{l}\text { January } \\
\text { February } \\
\text { March. } \\
\text { April } \\
\text { May } \\
\text { Jane. } \\
\text { July } \\
\text { August } \\
\text { September. } \\
\text { October. } \\
\text { November } \\
\text { December. }\end{array}$ & $\begin{array}{l}42 \\
48 \\
52 \\
69 \\
69 \\
79 \\
79 \\
78 \\
73 \\
63 \\
61 \\
41\end{array}$ & $\begin{array}{l}\text { 3. } \\
4.4 \\
5.2 \\
5.3 \\
5.0 \\
4.6 \\
3.9 \\
3.2 \\
3.6 \\
4.4 \\
3.6 \\
3.8\end{array}$ & $\begin{array}{r}1.86 \\
2.97 \\
5.12 \\
6.86 \\
8.76 \\
9.21 \\
8.07 \\
7.04 \\
5.91 \\
5.05 \\
2.71 \\
1.87\end{array}$ & $\begin{array}{r}2.8 \\
4.4 \\
7.8 \\
10.5 \\
13.5 \\
14.2 \\
12.3 \\
10.7 \\
9.1 \\
7.7 \\
4.1 \\
2.9\end{array}$ \\
\hline Annual & 61 & 4.2 & 65.43 & 100 \\
\hline
\end{tabular}

- Records by U. S. Bureau of Reclamation.

- Records by State engineer.

$f$ Records by U. S. Weather Bureau.

Willcox: Class A Weather Bureau station in alfalfa field 3 miles northwest of town in north-central part of Sulphur Spring Valley, which has nearly level floor 9 miles wide (coefficient, 0.66 ).

Deming: Floating pan in pond of considerable size (coefficient, 0.91).

Elephant Butte Dam: Class A Weather Bureau station 200 feet from reservoir, near east end of dam, on hill 75 feet above reservoir (coefficient, 0.66 ). 
Mean monthly reservoir equivalents for evaporation stations in and adjacent to Colorado River Basin-Continued

Yuma Regervoir, Ariz. (1993) ;

\begin{tabular}{|c|c|c|c|c|}
\hline \multirow{2}{*}{ Month } & \multirow{2}{*}{$\begin{array}{l}\text { Temper- } \\
\text { atrare of } \\
\left.\text { air ( }{ }^{\circ} \mathrm{F} .\right)\end{array}$} & \multirow{2}{*}{$\begin{array}{l}\text { Wind } \\
\text { velocity } \\
\text { (miles } \\
\text { per } \\
\text { hour) }\end{array}$} & \multicolumn{2}{|c|}{$\begin{array}{c}\text { Reserv gir equiv- } \\
\text { alent }\end{array}$} \\
\hline & & & Inches & $\begin{array}{l}\text { Per cent } \\
\text { of annual }\end{array}$ \\
\hline $\begin{array}{l}\text { January. } \\
\text { February } \\
\text { March. } \\
\text { April. } \\
\text { May. } \\
\text { June. } \\
\text { July } \\
\text { August } \\
\text { September } \\
\text { October. } \\
\text { November } \\
\text { December }\end{array}$ & 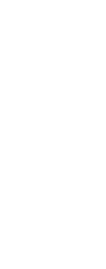 & (n) & $\begin{array}{l}\text { 3. } 02 \\
\text { 3. } 16 \\
\text { 4. } 80 \\
\text { 6. } 55 \\
\text { 8. } 92 \\
\text { 9. } 82 \\
\text { 9. } 78 \\
\text { 9. } 75 \\
\text { 8. } 22 \\
\text { 5. } 26 \\
\text { 3. } 46 \\
\text { 3. } 08\end{array}$ & $\begin{array}{r}4.1 \\
4.2 \\
6.4 \\
8.7 \\
11.9 \\
12.4 \\
12.9 \\
12.8 \\
10.9 \\
7.0 \\
4.6 \\
4.1\end{array}$ \\
\hline Annual . . ..... & & - & 75.32 & 100 \\
\hline
\end{tabular}

Yama citrus, Ariz. (1921-1927) *

\begin{tabular}{|c|c|c|c|c|}
\hline $\begin{array}{l}\text { January } \\
\text { Tebruary } \\
\text { March. } \\
\text { April. } \\
\text { May } \\
\text { June. } \\
\text { July } \\
\text { August } \\
\text { September. } \\
\text { October. } \\
\text { November. } \\
\text { December. }\end{array}$ & $\begin{array}{l}54 \\
60 \\
63 \\
68 \\
77 \\
85 \\
89 \\
90 \\
85 \\
73 \\
63 \\
54\end{array}$ & $\begin{array}{l}1.7 \\
2.4 \\
2.8 \\
3.1 \\
3.0 \\
2.9 \\
3.2 \\
2.8 \\
2.3 \\
1.7 \\
1.6 \\
1.8\end{array}$ & $\begin{array}{r}2.73 \\
3.74 \\
5.38 \\
6.95 \\
9.37 \\
10.33 \\
11.44 \\
9.94 \\
7.83 \\
5.51 \\
3.59 \\
2.45\end{array}$ & $\begin{array}{r}3.4 \\
4.7 \\
6.8 \\
8.8 \\
11.8 \\
13.1 \\
14.4 \\
12.5 \\
9.0 \\
7.0 \\
4.5 \\
3.1\end{array}$ \\
\hline Annual & 72 & 2.6 & 79.20 & 100 \\
\hline
\end{tabular}

h Records by University of Arizona.

$i$ Records by J. B. Lippincott, of Los Angeles.

Yuma Reservoir: Floating pan on railroad reservoir (coefficient, 0.91).

Yuma citrus: Class A Weather Bureau station on barren mesa 8 milles southwest of Yuma, and 100 feet higher (coefficient, 0.66 ).

A study of the foregoing table shows that at all the stations an average of 50 per cent of the annual evaporation occurs in the four months from June to September, the extremes ranging from 59 per cent at Myton, Utah, to $\mathbf{4 3}$ per cent at Willcox, Ariz: 
Mean annual reservoir equivalents of evaporation in and adjacent to Colorado River Basin

[Arranged in order of magnitude]

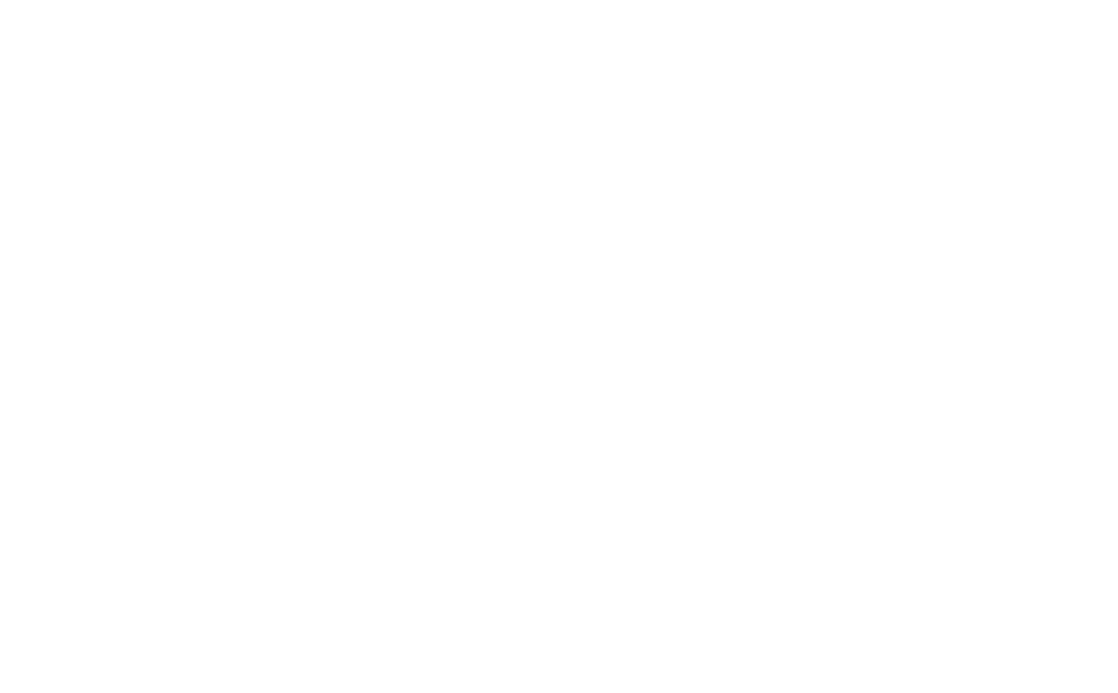

NOTH.-Records of temperature and wind velocity at near-by Weather Bureau stations where available are presented for the purpose of comparison with the records taken close to the evaporation pans.

\section{FACTORS INFLUENCING RATE OF EVAPORATION}

The rate of evaporation is governed by the difference between the vapor pressure of the water surface and that of the air adjacent to it. For any given temperature the difference in vapor pressure is dependent upon the relative humidity or percentage of possible saturation of the air. The greater the relative humidity the nearer to saturation is the vapor in the air, the nearer its pressure approaches the vapor pressure of the water surface, which is at the saturation piont, and the less rapidly are the water particles given off into the air as evaporation. An increase in temperature decreases the vapor pressure of the air and increases that of the water surface. This increase in difference of pressure increases the rate of evaporation. If the air is still, a blanket of vapor is soon formed after evaporation begins, and inasmuch as this blanket increases the humidity of the air, the rate of evaporation decreases. If, on the other hand, the wind is blowing, it carries away the vapor blanket, replacing it with drier air, which keeps down the relative humidity of the air, and the original rate of evaporation is more nearly maintained. Any increase in wind velocity beyond that necessary to keep the air dry above the water surface does not affect the rate of evaporation except that the formation of waves may throw spray into the air and thus increase evaporation slightly. 


\section{COMPARISON OF RECORDS}

From the foregoing discussion it is evident that the chief factors influencing the difference in vapor pressure of the air and water surface are relative humidity, temperature, and wind velocity. These three factors are so interdependent that it is impossible to make, with any considerable degree of accuracy, a comparison between the evaporation at different points based on a single factor.

The combined effect of relative humidity and wind velocity is shown by the records of the Yuma evaporation and Yuma citrus stations, the mean annual temperstures for which vary by only $4^{\circ}$. Although actual records of relative humidity are not available, it must be considerably higher at the evaporation station than at the citrus station, for the former is in an alfalfa field and the latter on a barren mesa where the absence of vegetation and a wind velocity 85 per cent greater than at the evaporation station must cause low relative humidity. The effect of the difference in humidity and wind velocity is shown by the difference in recorded evaporation (reduced to reservoir equivalent), which amounts to 52.96 inches and 79.20 inches, respectively.

The effect of relative humidity is strikingly shown by comparison of monthly records for different years at the same station. At Santa Fe the evaporation for May, 1927, was 8.08 inches, which is 160 per cent of the mean evaporation for that month. Temperature and wind movement were less than 10 per cent above normal, while the relative humidity, as measured at the regular Weather Bureau station near by, was only 56 per cent of normal.

The evaporation at the higher altitudes is influenced greatly by the slope on which the records are taken. The records at Wagonwheel Gap (altitude 9,610 feet) are the combined results of measurements made on a slope having a northern exposure and one having a southern exposure. The former receives the direct rays of the sun for a shorter period than the latter, and the resulting difference in temperature and relative humidity is strikingly shown by the evaporation on the two slopes during the period from June to October, for which it is possible to measure evaporation without interference from freezing. The following table, covering five years' records; shows the mean monthly evaporation for the two slopes. 
Evaporation (reservoir equivalent) on slopes of northern and southern exposure at Wagonwheel Gap, Colo.

\begin{tabular}{|c|c|c|}
\hline \multirow{2}{*}{ Month } & \multicolumn{2}{|c|}{$\begin{array}{l}\text { Reservoir equivalent } \\
\text { (inches) }\end{array}$} \\
\hline & $\begin{array}{l}\text { Northern } \\
\text { exposure }\end{array}$ & $\begin{array}{l}\text { Southern } \\
\text { exposure }\end{array}$ \\
\hline \multirow[t]{2}{*}{$\begin{array}{l}\text { June } \\
\text { July } \\
\text { August } \\
\text { Beptember } \\
\text { October- }\end{array}$} & $\begin{array}{r}2.91 \\
2.39 \\
1.59 \\
1.23 \\
.45\end{array}$ & $\begin{array}{l}\text { 8.82 } \\
3.69 \\
\text { 3.12 } \\
2.96 \\
1.89\end{array}$ \\
\hline & 8. 57 & 15.48 \\
\hline
\end{tabular}

Reservoirs of any considerable size at the higher altitudes are usually surrounded by slopes of both exposures, and the evaporation from the water surface will approximate the mean of the figures for the slopes.

\section{VARIATION IN ANNUAT EVAPORATION}

In the arid Southwest the factors influencing evaporation for any given month have a relatively small variation from year to year, and evaporation itself is similarly affected. The following table shows the percentage of mean evaporation measured each year at Elephant Butte Dam, N. Mex., and Mesa, Ariz.:

Variation in annual evaporation at Elephant Butte Dam, N. Mex., and Mesa, Ariz., $1916-1927$

\begin{tabular}{|c|c|c|c|c|}
\hline \multirow[b]{2}{*}{ Year } & \multicolumn{2}{|c|}{ Elëphant Butte } & \multicolumn{2}{|c|}{ Mesa } \\
\hline & $\begin{array}{c}\text { Evapo- } \\
\text { ration } \\
\text { (inches) }\end{array}$ & $\begin{array}{l}\text { Per cent } \\
\text { of mean }\end{array}$ & $\begin{array}{c}\text { Evapo- } \\
\text { ration } \\
\text { (inches) }\end{array}$ & $\begin{array}{l}\text { Per cent } \\
\text { of mean }\end{array}$ \\
\hline 19010 & $\begin{array}{l}65.76 \\
72.40 \\
69.66 \\
61.59 \\
66.79 \\
68.10 \\
69.40 \\
65.91 \\
64.99 \\
61.92 \\
65.55 \\
63.22\end{array}$ & $\begin{array}{r}103 \\
110 \\
106 \\
94 \\
102 \\
104 \\
106 \\
101 \\
99 \\
95 \\
85 \\
97\end{array}$ & $\begin{array}{l}44.21 \\
51.52 \\
51.86 \\
54.76 \\
58.63 \\
51.27 \\
52.85 \\
54.97 \\
46.13 \\
44.17 \\
44.64\end{array}$ & $\begin{array}{r}88 \\
102 \\
108 \\
108 \\
116 \\
101 \\
105 \\
109 \\
91 \\
87 \\
88\end{array}$ \\
\hline
\end{tabular}

\section{WATER SUPPLY}

Mean annual discharge.-Records of discharge of the Colorado River above the Green are available as follows:

Colorado River near Grand Lake, Colo. (1904-1909, 1911-1918).

Colorado River near Granby, Colo. (1908-1911).

Colorado River at Hot Sulphur Springs, Colo. (1904-1909, 1910-1924, 1926-27).

Colorado River near Kremmling, Colo. (1904-1918).

Colorado River at State Bridge, Colo. (1906-1908).

Colorado River at Glenwood Springs, Colo. (1900-1927). 
Colorado River near Palisade, Colo. (1902-1927).

Colorado River at Grand Junction, Colo. (1897-1899).

Colorado River near Fruita, Colo. (1908-1923).

Colorado River near Cisco, Utah (1914-1917, 1923-1927).

These records cover periods that are not directly comparable. To obtain a basis of comparison, the records of the Colorado River near Palisade have been used. As diversions for irrigation in Grand Valley have increased materially during the period covered by these records, the amounts diverted from the river just above the station have been added to the measured discharge, thus giving the river discharge above the diversions. The increase in diversions from the Colorado River above those for Grand Valley has been too small to affect the records materially. This is shown by the irrigated areas above Grand Valley for 1899, 76,700 acres; 1909, 150,000 acres; $1927,166,000$ acris - an increase of less than 90,000 acres.

Annual discharge, in acre-fest, of Colorado River above diversions for Grand Valley near Palisade, 1897-1927

\begin{tabular}{|c|c|c|c|c|c|c|}
\hline \multirow[b]{2}{*}{ Yoar } & \multirow[b]{2}{*}{$\begin{array}{l}\text { River as } \\
\text { measured }\end{array}$} & \multicolumn{3}{|c|}{$\begin{array}{c}\text { Diversions above gaging } \\
\text { station }\end{array}$} & \multirow{2}{*}{$\begin{array}{l}\text { Total, } \\
\text { including } \\
\text { diver- } \\
\text { sions * }\end{array}$} & \multirow{2}{*}{$\begin{array}{c}\text { Per } \\
\text { cent } \\
\text { of } \\
\text { mean }\end{array}$} \\
\hline & & $\begin{array}{l}\text { Price } \\
\text { and } \\
\text { Stub } \\
\text { ditches }\end{array}$ & $\begin{array}{c}\text { Orchard } \\
\text { Mesa } \\
\text { ditch }\end{array}$ & $\begin{array}{l}\text { Grand } \\
\text { Valley } \\
\text { main } \\
\text { canal }\end{array}$ & & \\
\hline 1901001 & $\begin{array}{l}4,590,000 \\
2,750,000 \\
5,070,000 \\
3,310,000 \\
3,340,000 \\
2,150,000 \\
3,070,000 \\
3,330,000 \\
3,570,000 \\
4,380,000 \\
4,610,000 \\
2,810,000 \\
4,980,000 \\
3,260,000 \\
3,520,000 \\
5,160,000 \\
3,090,000 \\
4,970,000 \\
2,880,000 \\
4,090,000 \\
5,550,000 \\
4,520,000 \\
2,770,000 \\
4,720,000 \\
4,970,000 \\
3,640,000 \\
4,360,000 \\
3,540,000 \\
3,080,000 \\
4,020,000 \\
4,170,000\end{array}$ & 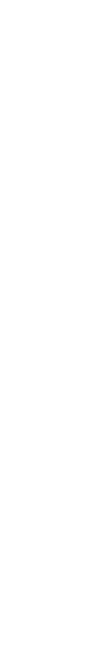 & $\begin{array}{r} \\
\\
\hdashline\end{array}$ & $\begin{array}{r} \\
\\
\end{array}$ & $\begin{array}{l}4,600,000 \\
2,760,000 \\
5,080,000 \\
3,320,000 \\
3,350,000 \\
2,160,000 \\
\mathbf{3}, 080,000 \\
3,340,000 \\
3,580,000 \\
4,400,000 \\
\mathbf{4}, 630,000 \\
2,840,000 \\
\mathbf{5}, 000,000 \\
3,300,000 \\
3,620,000 \\
5,280,000 \\
3,210,000 \\
5,080,000 \\
3,010,000 \\
4,230,000 \\
\mathbf{5}, 710,000 \\
4,700,000 \\
2,990,000 \\
4,940,000 \\
5,280,000 \\
3,880,000 \\
4,620,000 \\
3,8200,000 \\
3,330,000 \\
4,330,000 \\
4,470,000\end{array}$ & $\begin{array}{r}115 \\
69 \\
128 \\
83 \\
84 \\
54 \\
77 \\
84 \\
90 \\
110 \\
116 \\
71 \\
125 \\
83 \\
91 \\
132 \\
80 \\
128 \\
75 \\
106 \\
143 \\
118 \\
75 \\
124 \\
132 \\
97 \\
116 \\
96 \\
83 \\
109 \\
112\end{array}$ \\
\hline Mean......... & $3,890,000$ & & & & $4,000,000$ & \\
\hline
\end{tabular}

- Figures rounded.

Norr.-These records have been extended back from 1902 to 1897, as follows: For 1897 to 1899 the discharge was taken as that at Grand Junction plus 50,000 acre-feet for the diversion of Grand Valley canal, which heads below Palisade. For 1900 and 1901 the discharge was taken as 175 per cent of the discharge at Glenwood Springs. Beginning with 1919 the Grand Valley main canal included discharge of Price and stub ditches. and beginning with 1923 it included also the discharge of Orchant-Mesa diteh. 
The shorter records at different points on the river have been referred to the 31-year mean through the use of the percentages that the 31-year mean at the Palisade station bears to the means for the periods covered by the shorter records. This procedure is based on the assumption that the yearly variation in run-off is similar in different parts of the drainage basin. An inspection of Figure 2 shows this assumption to be substantially correct.

Mean annual discharge at principal gaging stations on upper Colorado River

\begin{tabular}{|c|c|c|c|c|}
\hline Point on river & $\begin{array}{c}\text { Drainsge } \\
\text { area } \\
\text { (square } \\
\text { miles) }\end{array}$ & $\begin{array}{l}\text { Measured } \\
\text { mean } \\
\text { (acre-feet) }\end{array}$ & $\begin{array}{l}\text { Per eent } \\
\text { of } \\
\text { 31-year } \\
\text { mean to } \\
\text { mean for } \\
\text { period of } \\
\text { shorter } \\
\text { record }\end{array}$ & $\begin{array}{l}\text { Computed } \\
\text { 31-year } \\
\text { mean } \\
\text { (acre-feet) }\end{array}$ \\
\hline $\begin{array}{l}\text { Near Grand Lake } \\
\text { Hot Buiphur Bprings } \\
\text { Kremmiling } \\
\text { Glenwopd Springs } \\
\text { Palisade } \\
\text { Fruita } \\
\text { Cisco }\end{array}$ & $\begin{array}{r}101 \\
785 \\
2,360 \\
4,660 \\
8,790 \\
17,100 \\
24,100\end{array}$ & $\begin{array}{r}104,000 \\
578,000 \\
1,330,000 \\
2,270,000 \\
4,000,090 \\
6,320,000 \\
7,100,000\end{array}$ & $\begin{array}{r}94 \\
94 \\
96 \\
100 \\
100 \\
95 \\
93\end{array}$ & $\begin{array}{r}97,800 \\
543,000 \\
1,280,000 \\
2,270,000 \\
4,000,000 \\
6,000,000 \\
6,600,000\end{array}$ \\
\hline
\end{tabular}

- Including diversions for irrigation fust above station.

- Records partly estimated for years 1918-1922.

The records for the Cisco station represent closely the discharge of the Colorado River originating in Colorado, as 93 per cent of the drainage area above the station lies in Colorado, and the 7 per cent in Utah has a low unit run-off.

Variations in annual discharge.-The following table shows the annual variation in run-off at Hot Sulphur Springs, Glenwood Springs, and Palisade stations, representing the upper, middle, and lower sections of the upper Colorado River. 
Variation in annual discharge at principal stations on upper Colorado River

\begin{tabular}{|c|c|c|c|c|c|c|}
\hline \multirow{2}{*}{ Year } & \multicolumn{2}{|c|}{$\begin{array}{l}\text { Hot Sulphur } \\
\text { Springs }\end{array}$} & \multicolumn{2}{|c|}{ Glenwood Springs } & \multicolumn{2}{|c|}{ Palisade * } \\
\hline & Acre-feet & $\begin{array}{l}\text { Per } \\
\text { cent of } \\
\text { mean }\end{array}$ & Acre-feet & $\begin{array}{c}\text { Per } \\
\text { cent of } \\
\text { mean }\end{array}$ & Acre-feet & $\begin{array}{l}\text { Per } \\
\text { cont of } \\
\text { mean }\end{array}$ \\
\hline $\begin{array}{l}1897 . . \\
1898 . .\end{array}$ & & & 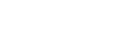 & & $\begin{array}{l}4,600,000 \\
2,760,000\end{array}$ & $\begin{array}{r}115 \\
60\end{array}$ \\
\hline $1899=$ & & & $2,180,000$ & 96 & $\begin{array}{l}\overrightarrow{5}, 080,000 \\
3,320,000\end{array}$ & $\begin{array}{r}123 \\
83\end{array}$ \\
\hline 1901. & & $\ldots . . . . .$. & $2,200,000$ & 96 & $3,350,000$ & 84 \\
\hline 902. & & $\cdots$ & $1,510,000$ & 66 & $2,160,000$ & 54 \\
\hline & & & $1,970,000$ & $\begin{array}{l}86 \\
94\end{array}$ & $3,080,000$ & $\begin{array}{l}77 \\
84\end{array}$ \\
\hline 1905 & $\begin{array}{l}556,000 \\
566,000\end{array}$ & $\begin{array}{l}96 \\
98\end{array}$ & $\begin{array}{l}2,120,000 \\
2,620,000\end{array}$ & $\begin{array}{r}93 \\
115\end{array}$ & $\begin{array}{l}3,580,000 \\
4,400,000\end{array}$ & $\begin{array}{r}90 \\
110\end{array}$ \\
\hline 1907 & $\begin{array}{l}720,000 \\
343,000 \\
692,000\end{array}$ & $\begin{array}{r}125 \\
59 \\
120\end{array}$ & $\begin{array}{l}3,010,000 \\
1,610,000 \\
2,860,000\end{array}$ & $\begin{array}{r}132 \\
71 \\
125\end{array}$ & $\begin{array}{l}4,630,000 \\
2,840,000 \\
5,000,000\end{array}$ & $\begin{array}{r}116 \\
71 \\
125\end{array}$ \\
\hline $1910 \ldots$ & $002 \%, 000$ & & $1,720,000$ & 75 & $3,300,000$ & 83 \\
\hline 1911 -...- & $\begin{array}{l}497,000 \\
672,000\end{array}$ & $\begin{array}{r}86 \\
116\end{array}$ & $\begin{array}{l}2,090,000 \\
2,890,000\end{array}$ & $\begin{array}{r}92 \\
127\end{array}$ & $\begin{array}{l}3,620,000 \\
5,280,000\end{array}$ & $\begin{array}{r}91 \\
132\end{array}$ \\
\hline $1913 \ldots$ & 407,000 & 70 & $1,720,000$ & 75 & $3,210,000$ & 80 \\
\hline 914 & $1,150,000$ & 199 & $3,000,000$ & 132 & $5,080,000$ & 128 \\
\hline $915 \ldots$ & $\begin{array}{l}423,000 \\
469,000\end{array}$ & $\begin{array}{l}73 \\
81\end{array}$ & $1,730,000$ & $\begin{array}{l}76 \\
97\end{array}$ & $3,010,000$ & 75 \\
\hline & 675,000 & 117 & $2,940,000$ & 129 & 5,$710 ; 000$ & 143 \\
\hline 1918. & 639,000 & 111 & & 122 & $4,700,000$ & 118 \\
\hline 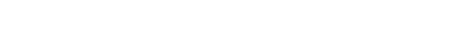 & 360,000 & 62 & $\overrightarrow{1}, 600,000$ & 70 & $2,990,000$ & 75 \\
\hline & $\begin{array}{l}689,000 \\
697,000\end{array}$ & 119 & $2,710,000$ & $\begin{array}{l}119 \\
126\end{array}$ & $4,940,000$ & 124 \\
\hline $1922 \ldots$ & 376,000 & $\begin{array}{r}121 \\
65\end{array}$ & $\begin{array}{l}2,880,000 \\
1,970,000\end{array}$ & 87 & $\begin{array}{l}5,180,000 \\
3,880,000\end{array}$ & 97 \\
\hline $1923--$ & 539,000 & 93 & $2,490,000$ & 109 & $4,620,000$ & 116 \\
\hline & 492,000 & & $\begin{array}{l}2,180,000 \\
1,707,000\end{array}$ & $\begin{array}{l}90 \\
78\end{array}$ & $\begin{array}{l}3,820,000 \\
3,330,000\end{array}$ & \\
\hline 1926. & 656,000 & 113 & & 113 & $4,330,000$ & 109 \\
\hline $1927 \ldots$ & 521,000 & 90 & $2,390,000$ & 105 & $4,470,000$ & 112 \\
\hline Mean........ & 578,000 & & $2,270,000$ & $\ldots . .$. & $4,000,000$ & $m-$ \\
\hline
\end{tabular}

- Includes diversions for irrigation in Grand Valley.

Nore.-Had the records at Hot Sulphur Springs covered the period from 1898 to 1904 the mean would have been reduced, and this would have increased the annual percentages, which are less then those for the longer records. Additional station records are presented as follows: Colorado River near Kremmling, p. 73; Colorado River near Cisco, p. 75.

The percentages in the preceding table are shown graphically in Figure 2. The year of lowest record was 1902, the discharge for which was 54 per cent of the mean at Palisade and 66 per cent at Glenwood Springs. This was in the middle of an 8-year period of which every year but one had a discharge less than the 31-year mean, the 8-year mean being 84 per cent.

Fluctuations of Great Salt Lake, which have been recorded since $1851,{ }^{10}$ show that from 1885 to 1905 the mean lake level steadily receded, reaching in 1905 the lowest point in the 74 years. Since 1905 the level has risen. This record indicates that throughout the Great Basin a prolonged period of deficient precipitation terminated about 1904, and this indication is confirmed by the records of precipitation at points in the Great Basin. As the Great Basin is adjacent to the Colorado River Basin, it is probable that the deficiency in precipitation occurred in the latter basin also and that the minimum of 1902 was the lowest for a period of possibly 75 years. Also, as the 8-year period 1898-1905 occurred at the end of the period of deficient

10 Woolley, R. R., Water powers of Great Salt Lake Basin: U. S. Geol. Survey Water-Supply Paper 517, pl. 2, 1924. 
precipitation, it may be considered a minimum that will not be reached again for many years.

High-water discharge.-Upper Colorado River and its principal tributaries are not subject to floods in the commonly understood sense of the term. The high water is due to the melting of mountain snow and occurs with great regularity each year. The following table shows the dates of maximum discharge at different points on

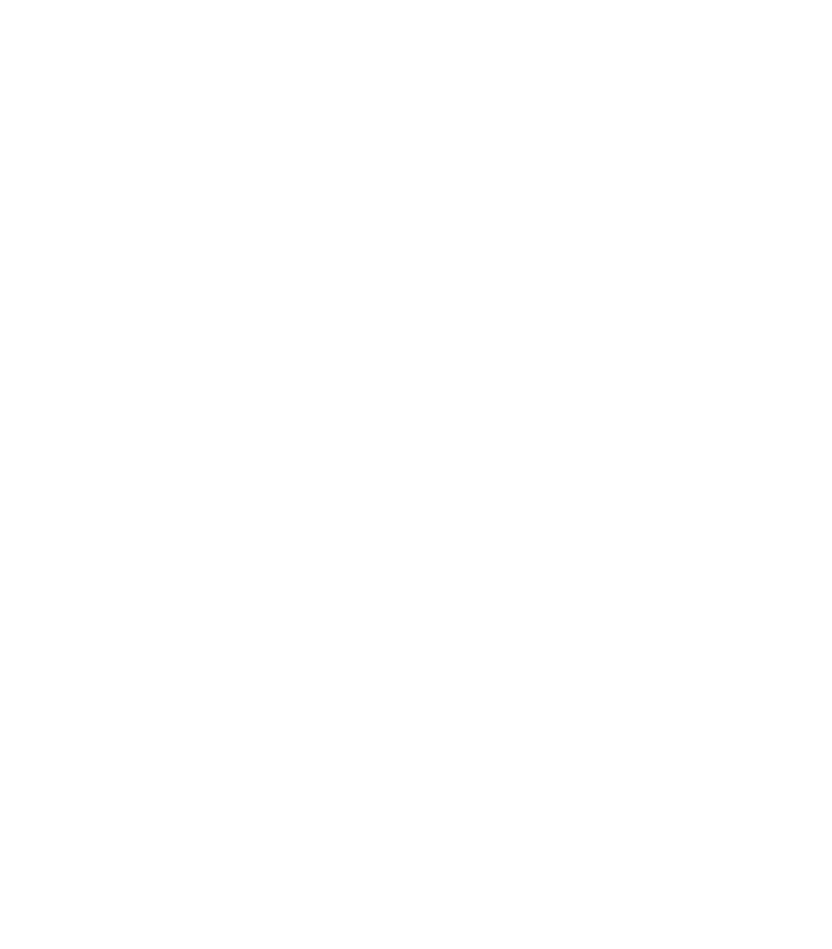

Figure 2.-Variation in annual run-off at Hot Sulphur Springs, Glenwood Springs, and Palisade, Colo.

the main river and its principal tributaries, arranged in descending order, for 1915 to 1924 :

Dates of maximum discharge on Colorado River and principal tributaries, 1915-1924

\begin{tabular}{|c|c|c|c|c|c|c|c|}
\hline Year & $\begin{array}{c}\text { Colorado } \\
\text { River at } \\
\text { Hot Sul- } \\
\text { phur } \\
\text { Springs }\end{array}$ & $\begin{array}{c}\text { Eagle } \\
\text { River at } \\
\text { Eagle }\end{array}$ & $\begin{array}{c}\text { Colorado } \\
\text { River at } \\
\text { Glenwood } \\
\text { Springs }\end{array}$ & $\begin{array}{c}\text { Roaring } \\
\text { Fork at } \\
\text { Glenwood } \\
\text { Springs }\end{array}$ & $\begin{array}{c}\text { Colorado } \\
\text { River near } \\
\text { Palisade }\end{array}$ & $\begin{array}{c}\text { Gunnison } \\
\text { River near } \\
\text { Grand } \\
\text { Junction }\end{array}$ & $\begin{array}{l}\text { Colorado } \\
\text { River near } \\
\text { Fruita }\end{array}$ \\
\hline $\begin{array}{l}1915 \\
1916 \\
1917 \\
1918 \\
1919 \\
1920 \\
1921-\ldots \\
1922 \\
1923 \\
1924\end{array}$ & 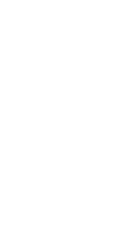 & 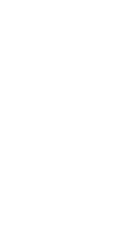 & $\begin{array}{l}\text { June 21... } \\
\text { June 14... } \\
\text { June 19... } \\
\text { June 14, 15. } \\
\text { June 1.... } \\
\text { June 1.... } \\
\text { June 15, 16. } \\
\text { June 9. } \\
\text { June 17. } \\
\text { June 15, 16. }\end{array}$ & 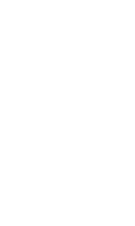 & 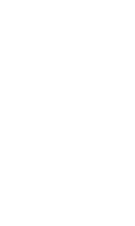 & $\begin{array}{l}\text { June } 18 \\
\text { June 14,15 } \\
\text { May 22. } \\
\text { May } 23 . \\
\text { June } 15 \\
\text { May } 7 \\
\text { May } 28 \\
\text { June } 7 \\
\end{array}$ & $\begin{array}{l}\text { June 21. } \\
\text { June 14. } \\
\text { June 20. } \\
\text { June 15. } \\
\text { May 29,30. } \\
\text { May 23. } \\
\text { June 16. } \\
\text { May 29. } \\
\text { May 29. } \\
\text { - June 16. }\end{array}$ \\
\hline Mean. & June 15. & June 11 & June 13 & June 14..... & June 11.... & June 2...... & June 9. \\
\hline
\end{tabular}


A study of this table shows that the average date of maximum discharge is latest at the station farthest upstream and is only a few days earlier at lower points as far downstream as Palisade, but for the Gunnison River it is about 10 days earlier. This difference in dates is due to the difference in mean altitude of the drainage basins above each point, the snow melting earlier at the lower altitudes. The average date for the Fruita station falls between those for the Palisade and Gunnison stations and shows the combined effect of the maximum discharges at those points. The difference between the maximum discharge of the Gunnison River and its discharge on the dates of the maximum discharge at Palisade is so small that the discharge at Fruita would only be increased by an average of 1,900 second-feet if the maximum dates for the Palisade and Gunnison stations coincided. In years of high run-off the dates for the two stations are nearly the same.

At any one point on the river the date of the maximum discharge is dependent not only upon the depth of snow in the drainage basin but also upon the temperature, as a direct relation exists between temperature and maximum discharge. A detailed discussion of this relation has been given in another publication. ${ }^{11}$

That the run-off per square mile corresponding to the maximum discharge recorded on the larger streams is low is shown by the following table, which contains all the gaging-station records available for the upper basin except those which are too short or fragmentary to be of value. This low unit run-off, together with the great regularity of high water, which prevents encroachment upon river channels, has resulted in little or no overflow from the principal streams, except during 1921 (p. 154).

Maximum recorded discharge in upper Colorado River Basin

\begin{tabular}{|c|c|c|c|c|c|}
\hline \multirow{2}{*}{ - Station } & \multirow{2}{*}{$\begin{array}{c}\text { Drain- } \\
\text { age } \\
\text { area } \\
\text { (square } \\
\text { miles) }\end{array}$} & \multirow[b]{2}{*}{ Date } & \multicolumn{2}{|c|}{$\begin{array}{c}\text { Discharge } \\
\text { (second-feet) }\end{array}$} & \multirow{2}{*}{$\begin{array}{l}\text { Period of } \\
\text { records }\end{array}$} \\
\hline & & & Total & $\begin{array}{l}\text { Per } \\
\text { square } \\
\text { mile }\end{array}$ & \\
\hline 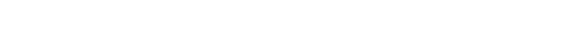 & 101 & June 16,1918 & 1,840 & 18. 2 & $\{1904-1909$ \\
\hline Colorado River at Hot Sulphur Springs. & 785 & June 15,1921 & 10,300 & 13. 1 & $1904-1909$ \\
\hline $\begin{array}{l}\text { Colorado River near Kremmling } \\
\text { Colorado River at Glenwood Springs } \\
\text { Colorado River near Palisade }\end{array}$ & $\begin{array}{l}2,360 \\
4,560 \\
8,790\end{array}$ & $\begin{array}{l}\text { June } 9,1912 \\
\text { June } 14,1918 \\
\text { June } 16,1921\end{array}$ & $\begin{array}{l}21,500 \\
30,100 \\
52,400\end{array}$ & $\begin{array}{l}9.1 \\
6.6 \\
6.0\end{array}$ & $\begin{array}{l}1904-1918 \\
1900-1927 \\
1902-1927\end{array}$ \\
\hline Colorado River near Fruita & 17,100 & $\left\{\begin{array}{r}\text { June } 16,1924 \\
\text { July } \\
4,1884\end{array}\right.$ & $\begin{array}{r}81,000 \\
125,000\end{array}$ & $\begin{array}{l}4.8 \\
7.3\end{array}$ & 1908-1923 \\
\hline Colorado River near Cisco, Utah.. & 24,100 & June 19,1917 & 76,800 & 3. 2 & $\left\{\begin{array}{l}1914-1917 \\
1923-1927\end{array}\right.$ \\
\hline Fraser River near West Portal & 28 & June 13,1918 & 820 & 29.3 & $\left\{\begin{array}{l}1907-1909 \\
1911-1927\end{array}\right.$ \\
\hline $\begin{array}{l}\text { Williams River near Scholl } \\
\text { Williams River near Parshall } \\
\text { Blue River at Dillon }\end{array}$ & $\begin{array}{l}143 \\
196 \\
129\end{array}$ & $\begin{array}{l}\text { June } 2,1914 \\
\text { June } 14,1918 \\
\text { June } 14,1924\end{array}$ & $\begin{array}{l}1,680 \\
2,520 \\
1,180\end{array}$ & $\begin{array}{r}11.7 \\
12.9 \\
9.1\end{array}$ & $\begin{array}{l}1911-1917 \\
1904-1927 \\
1911-1927\end{array}$ \\
\hline
\end{tabular}

- High-water mark.

11 Follansbee, Robert, Some characteristics of run-off in the Rocky Mountain region: U. S. Geol. Survey Water-Supply Paper 500, pp. 27-29, 1922. 
Maximum recorded discharge in upper Colorado River Basin-Continued

\begin{tabular}{|c|c|c|c|c|c|}
\hline \multirow[b]{2}{*}{ Station } & \multirow{2}{*}{$\begin{array}{c}\text { Drain- } \\
\text { age } \\
\text { area } \\
\text { (square } \\
\text { miles) }\end{array}$} & \multirow[b]{2}{*}{ Date } & \multicolumn{2}{|c|}{$\begin{array}{l}\text { Discharge } \\
\text { (second-feet) }\end{array}$} & \multirow{2}{*}{$\begin{array}{l}\text { Period of } \\
\text { records }\end{array}$} \\
\hline & & & Total & $\underset{\substack{\text { Pquare } \\
\text { mile }}}{c}$ & \\
\hline $\begin{array}{l}\text { Snake River at Dillon } \\
\text { Tenmile Creek at Dillon } \\
\text { Eagle River at Redeliff. } \\
\text { Eagle River at Eagle } \\
\text { Turkey Creek at Redeliffict } \\
\text { Roaring Fork at Aspen }\end{array}$ & $\begin{array}{r}90 \\
109 \\
74 \\
650 \\
27 \\
109\end{array}$ & $\begin{array}{lr}\text { June } & 15,1918 \\
\text { June } & 16,1917 \\
\text { June } & 5,1912 \\
\text { June } & 3,1914 \\
\text { June } & 13,1918 \\
\text { June } 18,1917\end{array}$ & $\begin{array}{l}1,170 \\
1,630 \\
1,010 \\
6,760 \\
670 \\
3,170\end{array}$ & $\begin{array}{l}13.0 \\
15.0 \\
13.7 \\
10.4 \\
24.8 \\
29.0\end{array}$ & $\begin{array}{l}1911-1919 \\
1911-1919 \\
1911-1925 \\
1911-1924 \\
1913-1921 \\
1911-1921\end{array}$ \\
\hline Roaring Fork at Glenwood Springs.. & 1,460 & June 14,1921 & 17,600 & 12.0 & \\
\hline $\begin{array}{l}\text { Maroon Creek near Aspen } \\
\text { Castle Creek near Aspen } \\
\text { Fryingpan Creek at Norrie } \\
\text { Fryingpan Creek at Thomasvilie } \\
\text { Parachute Creek at Grand Valley } \\
\text { Roan Creek near De Beque } \\
\text { Plateau Creak near Collbran } \\
\text { Buzzard Creek near Collbran } \\
\text { Crystal River at Marble } \\
\text { Taylor River at Almont } \\
\text { Gunnison River near Gunnison }\end{array}$ & $\begin{array}{r}42 \\
62 \\
92 \\
175 \\
196 \\
210 \\
88 \\
136 \\
77 \\
440 \\
1,010\end{array}$ & $\begin{array}{l}\text { June } 13,1911 \\
\text { June } 15,1918 \\
\text { June } 25,1912 \\
\text { June } 18,1917 \\
\text { May } 9,1922 \\
\text { May } 21,1922 \\
\text { May } 28,1922 \\
\text { May } 18,1922 \\
\text { June } 19,1914 \\
\text { June } 9,1920 \\
\text { June } 13,1918\end{array}$ & $\begin{array}{r}420 \\
1,090 \\
1,440 \\
2,780 \\
1,790 \\
1,110 \\
2,800 \\
1,270 \\
1,960 \\
3,760 \\
11,400\end{array}$ & \begin{tabular}{r|}
10.0 \\
17.6 \\
15.6 \\
15.9 \\
4.0 \\
5.3 \\
31.8 \\
9.3 \\
25.4 \\
8.5 \\
11.3
\end{tabular} & $\begin{array}{l}1911-1917 \\
1912-1920 \\
1911-1916 \\
1911-1920 \\
1921-1927 \\
1921-1927 \\
1921-1927 \\
1921-1927 \\
1911-1917 \\
1910-1927 \\
1911-1927\end{array}$ \\
\hline Gunnison River near Grand Junction.. & 8,020 & May 23,1920 & 35,700 & 4.5 & \\
\hline East River at Almont... & 295 & June 12,1918 & 6,000 & 20.3 & $1905,1911-$ \\
\hline Tomiohi Creek at Sargents.. & 165 & June 9,1921 & 792 & 4.8 & $1917-1922$ \\
\hline Lake Fork at Lake City & 126 & $\left\{\operatorname{June}_{1921} 16,17,\right\}$ & 1,560 & 12.4 & $1918-1924$ \\
\hline $\begin{array}{l}\text { Crpital Creek near Maher. } \\
\text { Leroux Creek near Lazear } \\
\text { Surface Creek at Cedaredge } \\
\text { Uneompahgre River at Ouray }{ }^{\circ} \\
\text { Uncompahgre River below Ouray } \\
\text { Uncompahgre River near Colona } \\
\text { Canyon Creek at Ouray } \\
\text { Kahnah Creek near Whitewater }\end{array}$ & $\begin{array}{r}26 \\
52 \\
43 \\
44 \\
76 \\
403 \\
26 \\
55\end{array}$ & $\begin{array}{lr}\text { July } & 13,1917 \\
\text { May } & 29,1921 \\
\text { May } & 24,1920 \\
\text { Oct. } & 5,1911 \\
\text { June } & 14,1918 \\
\text { June } & 13,1921 \\
\text { June } & 21,1915 \\
\text { June } & 6,1921\end{array}$ & $\begin{array}{r}419 \\
1,420 \\
715 \\
1,980 \\
2,530 \\
4,080 \\
580 \\
1,630\end{array}$ & $\begin{array}{l}16.2 \\
27.3 \\
16.6 \\
45.0 \\
33.3 \\
10.1 \\
22.3 \\
29.6\end{array}$ & $\begin{array}{l}1917-1919 \\
1917-1927 \\
1917-1927 \\
1911-1927 \\
1913-1927 \\
1917-1927 \\
1911-1915 \\
1918-1927\end{array}$ \\
\hline Dolores River at Dolores. & 514 & May 4,1922 & 7,400 & 14.4 & $1911-1$ \\
\hline $\begin{array}{l}\text { Dolores River at Bedrock } \\
\text { San Miguel River at Naturita }\end{array}$ & $\begin{array}{l}2,040 \\
1,080\end{array}$ & $\begin{array}{ll}\text { May } & 1,1922 \\
\text { May } & 4,1921\end{array}$ & $\begin{array}{l}5,460 \\
6,000\end{array}$ & $\begin{array}{l}2.7 \\
5.6\end{array}$ & $\begin{array}{l}1918-1929 \\
1918-1927\end{array}$ \\
\hline
\end{tabular}

- The discharge for the Uncompahgre River at Ouray was caused by the heavy rains in the San Juan Mountains.

In this region the summer is a period of very light rainfall, which is not general but broken up into local showers by the rugged topography. During the spring and fall, when the precipitation is heavier, it takes the form of snow at the higher altitudes, so that the area subject to rainfall is greatly reduced. Within the last 20 years there have been four periods of heavy rains, which with their resulting floods are described on page 153 .

Low-water discharge.-Except for those streams whose summer discharge is seriously depleted by irrigation requirements, the period of minimum flow occurs during the winter, when the precipitation takes the form of snow and practically the only source of supply is the ground water. As a basis for a study of the low-water discharge, records covering several years for 29 stations in different sections of the upper Colorado River Basin have been compiled. Only those stations which have no considerable natural or artificial headwater storage and whose winter records are based on current-meter measurements have been selected. 
Mean monthly unit run-off during low-water period in upper Colorado River Basin

\begin{tabular}{|c|c|c|c|c|c|c|}
\hline \multirow[b]{2}{*}{ Station } & \multirow{2}{*}{$\begin{array}{l}\text { Drain- } \\
\text { age area } \\
\text { (square } \\
\text { miles) }\end{array}$} & \multicolumn{4}{|c|}{ Second-foot per square mile } & \multirow{2}{*}{$\begin{array}{c}\text { Mean } \\
\text { annual } \\
\text { run-off } \\
\text { (acre-feet } \\
\text { per } \\
\text { square } \\
\text { mile) }\end{array}$} \\
\hline & & $\begin{array}{c}\text { Decem- } \\
\text { ber }\end{array}$ & January & February & March & \\
\hline 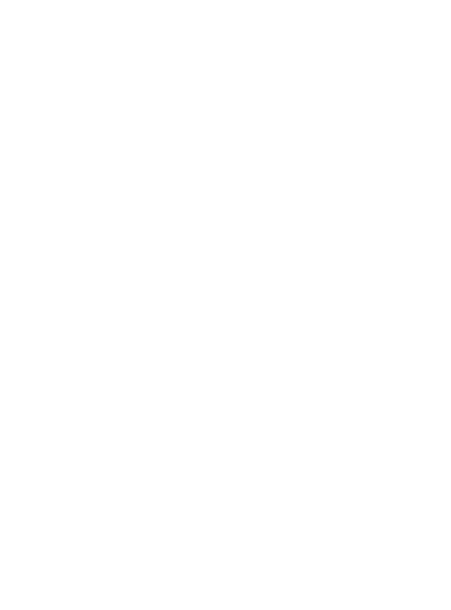 & $\begin{array}{r}101 \\
785 \\
2,369 \\
4,560 \\
17,100 \\
47 \\
28 \\
185 \\
129 \\
109 \\
74 \\
650 \\
109 \\
42 \\
62 \\
77 \\
92 \\
(a) \\
1,460 \\
440 \\
295 \\
1,010 \\
8,020 \\
76 \\
55 \\
83 \\
514 \\
280 \\
1,080\end{array}$ & $\begin{array}{l}0.278 \\
.150 \\
.139 \\
.165 \\
.160 \\
.146 \\
.378 \\
.278 \\
.263 \\
.259 \\
.167 \\
.182 \\
.379 \\
.814 \\
.612 \\
.502 \\
.390 \\
.249 \\
.345 \\
.287 \\
.266 \\
.224 \\
.128 \\
.416 \\
.091 \\
.291 \\
.168 \\
.250 \\
.072\end{array}$ & $\begin{array}{r}0.236 \\
.143 \\
.146 \\
.161 \\
.149 \\
.125 \\
.273 \\
.247 \\
.223 \\
.222 \\
.165 \\
.163 \\
.334 \\
.679 \\
.521 \\
.389 \\
.282 \\
.208 \\
.311 \\
.284 \\
.217 \\
.212 \\
.117 \\
.377 \\
.188 \\
.228 \\
.136 \\
.266 \\
.081\end{array}$ & $\begin{array}{r}0.211 \\
.139 \\
.149 \\
.161 \\
.151 \\
.104 \\
.253 \\
.234 \\
.193 \\
.178 \\
.172 \\
.168 \\
.326 \\
.691 \\
.506 \\
.348 \\
.284 \\
.231 \\
.277 \\
.308 \\
.227 \\
.218 \\
.125 \\
.373 \\
.206 \\
.243 \\
.143 \\
.262 \\
.115\end{array}$ & $\begin{array}{r}0.264 \\
.156 \\
.199 \\
.213 \\
.194 \\
.113 \\
.252 \\
.299 \\
.195 \\
.218 \\
.200 \\
.234 \\
.349 \\
.553 \\
.514 \\
.399 \\
.375 \\
.342 \\
.332 \\
.333 \\
.262 \\
.254 \\
.146 \\
.458 \\
.244 \\
.318 \\
.342 \\
.276 \\
.135\end{array}$ & $\begin{array}{r}1,150 \\
743 \\
581 \\
502 \\
399 \\
1,360 \\
1,220 \\
687 \\
758 \\
1,000 \\
709 \\
724 \\
1,260 \\
1,560 \\
1,230 \\
2,360 \\
1,160 \\
1,110 \\
850 \\
687 \\
1,010 \\
624 \\
278 \\
1,580 \\
667 \\
-9624 \\
807 \\
251\end{array}$ \\
\hline
\end{tabular}

- 175 square miles at upper station and 190 square miles at lower station.

- Includes diversion to Grand Junction.

The unit records in the preceding table may be divided into two classes. In one class there is a continual diminution through the winter until the melting snow in March increases the flow. In the other class the December or January discharge is the lowest, and after that the flow increases. This classification refers to mean monthly discharge and not to minimum discharge for a period of a few days, which frequently occurs during the first sudden drop in temperature at the beginning of the winter.

The minimum run-off per square mile shows a wide range tor the stations in the Colorado River Basin, the limits being 0.679 second-foot for Maroon Creek near Aspen and 0.072 second-foot for the San Miguel River at Naturita. In general, the higher run-off per squure mile occurs at stations having the greater total yearly run-off, but this relation is not invariable, as a study of the table will disclose. The winter run-off for the Crystal River at Marble, which has the highest annual run-off, is exceeded by that for Maroon and Castle Creek, both of which have a considerable smaller annual run off. The winter run-off of North Inlet to Grand Lake is one of the lowest recorded, but its total annual run-off is above the average. Thus it is evident that although total annual run-off is the prinsipal factor in determining the low-water run-off, it is not the only one, because soil and geologic structure are also influential. 


\section{TRANGMOUNTAIN DIVEREIONF}

\section{PRESENT DEVELOPMIHNT}

The scarcity of water in the older irrigated regions in Colorado, chiefly east of the Rocky Mountains, has led to the construction of ix transmountain diversions as follows:

Transmountain diversions from upper Colorado River Basin

\begin{tabular}{|c|c|c|c|c|c|c|}
\hline \multirow[b]{2}{*}{. Ditch } & \multirow[b]{2}{*}{$\begin{array}{l}\text { Alti- } \\
\text { tude of } \\
\text { diver- } \\
\text { sion } \\
\text { (feet) }\end{array}$} & \multirow{2}{*}{$\begin{array}{c}\text { Drain- } \\
\text { age } \\
\text { area } \\
\text { from } \\
\text { which } \\
\text { run-off } \\
\text { is inter- } \\
\text { cepted } \\
\text { (square } \\
\text { miles) }\end{array}$} & \multicolumn{2}{|c|}{ Diversion } & \multicolumn{2}{|c|}{ Conduth } \\
\hline & & & From- & To- & $\begin{array}{l}\text { Length } \\
\text { (miles) }\end{array}$ & $\begin{array}{l}\text { Capas: } \\
\text { ity } \\
\text { (second } \\
\text { feet) }\end{array}$ \\
\hline $\begin{array}{l}\text { Grand River... } \\
\text { Busk-Ivanhoe Tunnél } \\
\text { Eving } \\
\text { Tarbeli } \\
\text { Berthoud } \\
\text { Boress Pass }\end{array}$ & $\begin{array}{l}10,200 \\
10,950 \\
10,500 \\
10,000 \\
10,300 \\
11,500\end{array}$ & $\begin{array}{r}12 \\
5 \\
5 \\
4 \\
2 \\
2\end{array}$ & $\begin{array}{l}\text { Colorado River } \\
\text { Fryingpan Creek } \\
\text { Eagle River } \\
\text { Cochetopa Creek } \\
\text { Fraser River } \\
\text { Blue River.... }\end{array}$ & $\begin{array}{l}\text { Cache la Poudre River } \\
\text { Arkansas River: } \\
\text { Rio Grande } \\
\text { Clear Oreek } \\
\text { South Platte River... }\end{array}$ & $\begin{array}{l}8 \\
2 \\
5 \\
2 \\
4 \\
1\end{array}$ & $\begin{array}{r}229 \\
100 \\
20 \\
70 \\
58 \\
10\end{array}$ \\
\hline
\end{tabular}

Grand River ditch.-The Grand River ditch, owned by the Water Supply \& Storage Co., was built about 1903 to augment the flow of Cache la.Poudre River for irrigation in that basin. It diverts water from the headwaters of Colorado River and carries it across La Poudre Pass into Long Draw, a tributary of the Cache la Poudre. The main ditch heads in sec. 1, T. 5 N., R. 76 W. sixth principal meridian, and follows the contour across the pass at an altitude of about 10,200 feet. A secondary feeder diverts water from a tribatary stream in sec. 29, T. 6 N., R. 75 W.; and extends northward, joining the main ditch at the pass. The 12 square miles of drainage area above the ditch is very rugged, with altitudes ranging from 10,200 to 12,800 feet.

The flow in the ditch is measured near the lower end and does not represent the total amount intercepted. Seepage losses in the ditch are heavy, owing to the location of a considerable part of the ditch in loose rock on a steep slope.

The average period of diversion is from the middle of May to the first of September. Owing to the heavy snowfall it is necesisary to open the ditch at the beginning of each season, and this is done by hand labor. It usually takes a crew of a dozen men a month to elear the ditch by digging a narrew trench along 5 miles of itte eititire length of 8 miles, the remaining 3 miles being eovered with timber at points of heaviest snowfall. Very little ice is encountered, as the ditch head gates are closed during the winter and the water from crom-drainage channels is excluded. 
Diversion, in acre-feet, through Grand River ditch, 1903-1927

\begin{tabular}{|c|c|c|c|c|c|c|c|c|}
\hline Year & $\begin{array}{c}\text { Opening } \\
\text { date }\end{array}$ & May & June & July & August & $\begin{array}{l}\text { Septem- } \\
\text { ber }\end{array}$ & $\begin{array}{c}\text { Closing } \\
\text { date }\end{array}$ & $\begin{array}{c}\text { Total } \\
\text { diversion }\end{array}$ \\
\hline \multicolumn{8}{|l|}{1903} & 1,710 \\
\hline \multirow{2}{*}{\multicolumn{8}{|c|}{$1905-1906$}} & $\begin{array}{l}1,800 \\
6,170\end{array}$ \\
\hline & & & & & & & & 12,000 \\
\hline \multicolumn{8}{|l|}{1907} & 12,600 \\
\hline \multirow{2}{*}{\multicolumn{8}{|c|}{1908}} & 16,800 \\
\hline & & & & & & & & 15,600 \\
\hline \multicolumn{9}{|l|}{$\begin{array}{l}1909 \\
1910\end{array}$} \\
\hline \multicolumn{8}{|l|}{1910} & \multirow{2}{*}{13,400} \\
\hline \multicolumn{8}{|l|}{1912} & \\
\hline 1913 & \multirow{2}{*}{ June 11} & 0 & 5,810 & \multirow{2}{*}{$\begin{array}{l}2,430 \\
4,600\end{array}$} & 426 & 0 & \multirow{2}{*}{ Aug. 19a } & \multirow{2}{*}{$\begin{array}{r}12,400 \\
8,670 \\
7,320\end{array}$} \\
\hline \multirow{2}{*}{1914} & & \multirow{2}{*}{$\begin{array}{r}0 \\
1,980\end{array}$} & 1,630 & & 1,090 & \multirow{2}{*}{$\mathbf{0}$} & & \\
\hline & \multirow{2}{*}{$\begin{array}{l}\text { Apr. } 26 \\
\text { May }\end{array}$} & & 5,050 & $\begin{array}{l}4,600 \\
4,380\end{array}$ & 721 & & Aug. 21a & \multirow{3}{*}{$\begin{array}{r}12,400 \\
14,400 \\
8,230\end{array}$} \\
\hline & & 1,250 & 6,660 & 4,850 & 1,620 & & Sept. 9 & \\
\hline \multirow{2}{*}{1917} & \multirow{2}{*}{$\begin{array}{lr}\text { July } & 1 \\
\text { May } & 19\end{array}$} & \multirow{2}{*}{$\begin{array}{r}0 \\
768\end{array}$} & & $\begin{array}{l}4,850 \\
6,270\end{array}$ & 1,590 & $\begin{array}{r}62 \\
366\end{array}$ & Sept. 22 & \\
\hline & & & 8,270 & 4,460 & 1,020 & o & Aug. 24 & \multirow{2}{*}{14,500} \\
\hline 1919 & & \multirow{3}{*}{172} & 4,170 & 2,180 & 618 & & Aug. 19 & \\
\hline \multirow{2}{*}{$1920-0$} & May 30 & & 6,840 & 6,330 & 1,790 & 111 & Sept. 4 & 15,200 \\
\hline & May 23 & & - 1,660 & 4,310 & 1,810 & 300 & Sept. 10 & 9,130 \\
\hline $1922 \ldots$ & May 13 & 1,250 & 7,140 & 2,680 & 1,170 & 144 & Sept. 9 & 12400 \\
\hline $1923 \ldots$ & May 20 & 1,130 & d 3,940 & 6,890 & 1,970 & 162 & Sept. 8 & 14,100 \\
\hline 1924 & May 16 & 1,490 & 500 & 5,040 & 821 & 0 & Aug. 23 & 7,850 \\
\hline 1925.. & May 1 & 2,870 & 6,310 & 4,350 & 2,200 & 904 & Oet. 5 & 16,700 \\
\hline 1926. & May 22 & 1,560 & 5,200 & 6, 070 & 1,470 & 0 & Aug. 23 & 14,300 \\
\hline $1927 \ldots . .$. & May 18 & 1,530 & 8,210 & 5,630 & 980 & $\mathbf{0}$ & Aug. 24 & 16,400 \\
\hline Mean 0. & $\ldots \ldots$ & 1,190 & 4,800 & $4 ; 640$ & 1,340 & 137 & ...... & 11,400 \\
\hline Per cent of mean, 1912- & & & & & & & & \\
\hline $1927 \ldots$ & & 10 & 40 & 38 & 11 & 1 & & 100 \\
\hline $\begin{array}{l}a \mathrm{C} \\
\circ 25 \\
0 \mathrm{~N}\end{array}$ & & & & & & obe & & re-feet. \\
\hline
\end{tabular}

The mean annual diversion of 12,100 acre-feet for the 16-year period (1912-1927) does not represent the total available water supply with the present capacity and location of the ditch, because, in addition to the considerable seepage losses, reservoir capacity was not available during the periods of heaviest run-off in May and June, 1914, 1917, 1921, 1923, and 1924. Although no records of discharge of Colorado River tributaries near the point of diversion are available, the actual diversion made represents a run-off of 1,000 acre-feet per square mile from the middle of May to the first of September, which is slightly higher than the recorded run-off from any comparable area in the upper Colorado River Basin. It therefore appears that owing to the losses due to seepage and the inability to divert water during portions of the high-water period in wet years through lack of storage capacity, very little additional run-off is available with the present location of the head gates. It is proposed to extend the Grand River ditch 7 miles farther to Baker Gulch. This extension will intercept the run-aff from an additional area of 12 square miles, the mean runoff from which during the diversion season is estimated as 12,000 acre-feet.

Busk-Ivanhoe tunnel.-About 1922 A. E. Carlton, trustee for the Colorado Midland Railroad stockholders, began the construction of a project to divert water from the head of Fryingpan Creek to the 
Arkansas Valley. The abandonment of the Busk-Ivanhoe tunnel by the Celorado Midland Railroad when it ceased operation gave an opportunity to divert water through the Continental Divide at an altitude of 10,950 feet. The tunnel, which is in sec. 13, T. 9 S., R. $82 \mathrm{~W}$. sixth principal meridian, 11 miles west of Leadville, is 10,300 feet long and has an eastward slope of $15: 1,000$. It is now used as a highway, but along one side Mr. Carlton has constructed a semicircular metal flume having a capacity of 100 second-feet, within $\mathrm{a}$ rectangular timber flume. The west end of the conduit is connected with Lake Ivanhoe, which lies a short distance beyond the west portal. Here a reservoir having a capacity of 1,400 acre-feet has been created by means of a 20-foot dam across the lake outlet. A collection ditch having a capacity of 200 second-feet has been constructed to Lyle Creek, a distance of 2 miles. The project was placed in operation in 1925, when 2,000 acre-feet was diverted between May 20 and September 20. During 1926, 3,490 acre-feet was diverted between May 21 and September 4, and during 1927, 5,630 acre-feet between May 1 and September 10. The water is used for irrigation in the Arkansas Valley between Pueblo and La Junta. From a study of the run-off tributary to Lake Ivanhoe (p. 61) the mean annual run-off available for diversion is estimated as 6,500 acre-feet.

Two possibilities exist for obtaining an additional water supply for the project. One is by extending the collection ditch from Lyle Creek to the North Fork of Fryingpan Creek, a distance of 19 miles, and the other by constructing a collection ditch 14 miles long to Fryingpan Creek. By the first plan the run-off from an additional area of 10 square miles would be intercepted, and by the second the run-off from 12 square miles. As the unit run-off of Fryingpan Creek is similar to that of the North Fork, the second plan appears to be more feasible. Records of Fryingpan Creek at Norrie (altitude 8,840 feet) from 1911 to 1916 show the mean run-off from April 1 to Seṕtémber 30 to be $1,040^{\circ}$ acré-feet per square mile: Abovere the proposed collection ditch the altitude ranges from 11,000 to 13,500 feet, and the unit run-off is estimated as 1,300 acre-feet per.square mile, or 15,600 acre-feet for the 12 square miles. If this extension is constructed, the total amount available to the project for diyersion will be 17,700 acre-feet at an operating efficiency of 80 per cent.

Ewing ditch.-The Ewing ditch, which is the oldest transmountain ditch from the Colorado Basin, was originally constructed in 1880 for placer mining but has been used to divert water to the Arkansas Basin for irrigation since about 1912. It diverts water from Piney Creek, a branch of the Eagle River, in sec. 11, T. 8 S., R. 80 W. sixth principal meridian, at an altitude of 10,500 feet, and crosses Tennessee Pass, ending in a tributary of Tennessee Fork. It intercepts the run-off from 5 square miles of bare mountain side ranging 
in altitude from 10,500 to 12,600 feet. Records of diversion through this ditch are available from 1916 to 1927 , except for 1924 and 1925 , and are presented in the following table:

Diversion through Ewing ditch, 1916-1927, in acre-feet

\begin{tabular}{|c|c|c|c|c|c|c|c|c|c|c|c|c|c|}
\hline Year & Jan. & Feb. & Mar. & Apr. & May & June & July & Aug. & Sept. & Oet. & Nor. & Deo. & Total \\
\hline 92628 & $\begin{array}{l}90 \\
89 \\
82 \\
81 \\
63 \\
64 \\
78 \\
68 \\
0 \\
55\end{array}$ & $\begin{array}{l}80 \\
80 \\
72 \\
73 \\
57 \\
58 \\
72 \\
64 \\
0 \\
50\end{array}$ & $\begin{array}{l}95 \\
84 \\
90 \\
81 \\
65 \\
68 \\
82 \\
74 \\
0 \\
55\end{array}$ & $\begin{array}{r}123 \\
104 \\
93 \\
94 \\
87 \\
70 \\
89 \\
75 \\
0 \\
54\end{array}$ & $\begin{array}{l}515 \\
314 \\
472 \\
501 \\
277 \\
188 \\
355 \\
423 \\
234 \\
\mathbf{4 8 0}\end{array}$ & $\begin{array}{l}790 \\
810 \\
753 \\
396 \\
534 \\
731 \\
\mathbf{4 3 1} \\
\mathbf{7 7 4} \\
\mathbf{7 2 6} \\
\mathbf{5 7 1}\end{array}$ & $\begin{array}{l}280 \\
391 \\
259 \\
167 \\
207 \\
210 \\
148 \\
278 \\
283 \\
228\end{array}$ & $\begin{array}{l}185 \\
187 \\
123 \\
108 \\
108 \\
109 \\
97 \\
153 \\
135 \\
117\end{array}$ & $\begin{array}{r}101 \\
77 \\
87 \\
79 \\
71 \\
94 \\
93 \\
116 \\
166 \\
83\end{array}$ & $\begin{array}{r}100 \\
55 \\
80 \\
99 \\
97 \\
99 \\
99 \\
58 \\
118 \\
74 \\
92\end{array}$ & $\begin{array}{r}108 \\
67 \\
82 \\
82 \\
62 \\
81 \\
64 \\
(90) \\
71 \\
80\end{array}$ & 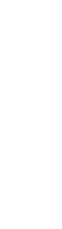 & $\begin{array}{l}2,580 \\
2,320 \\
2,280 \\
1,850 \\
1,660 \\
1,850 \\
1,800 \\
2,210 \\
1,660 \\
1,960\end{array}$ \\
\hline Mean & $\begin{array}{r}67 \\
3\end{array}$ & $\underset{3}{61}$ & & & $\begin{array}{r}376 \\
19\end{array}$ & $\begin{array}{r}652 \\
33\end{array}$ & $\begin{array}{r}245 \\
12\end{array}$ & $\begin{array}{r}132 \\
7\end{array}$ & 4 & $\begin{array}{r}84 \\
4\end{array}$ & 80 & $\begin{array}{r}78 \\
4\end{array}$ & $\begin{array}{r}2,000 \\
100\end{array}$ \\
\hline
\end{tabular}

Unlike the Grand River ditch, the Ewing ditch diverts water during the entire year, it being possible, owing to its 'small size and short length, to maintain an open channel under the snow cover, which is not as great as in the region of the Grand River ditch. Although the mean annual diversion of 2,000 acre-feet represents a very low unit run-off of 408 acre-feet per square mile, the ditch diverts practically all the water passing its head gate. Much of the snow falling upon the barren area, which slopes toward the northwest, is blown across the divide and is lost to the Piney Creek Basin. The low run-off from this immediate area is not favorable to an extension of the Ewing ditch.

Tarbell ditch.-The Tarbell ditch was constructed as a partnership project in 1913 and first used the following year. At a point about in sec. 12, T. 43 N., R. 1 E. New Mexico principal meridian, it diverts water from Lake Creek, a tributary of Cochetopa Croek, in the Gunnison River Basin, and conveys it half a mile to the divide, where it is discharged into the Middle Fork of the Saguache River, in the Rio Grande Basin. The drainage area above the headgate is 4 square miles of extremely rugged country ranging in altitude from 10,000 to 13,000 feet. The annual diversion is about 2,000 acre-feet. Although no records of run-off are available it is believed that at least 3,000 acre-feet is available for diversion.

Berthoud ditch.-The Berthoud ditch, also known as the Church ditch, is owned by the Farmers Reservoir \& Irrigation Co. It was built in 1909 and is used to bring water from the Fraser River Basin to the Clear Creek Basin. Water is diverted from First Creek about in sec. 34, T. 2 S., R. 75 W. sixth principal meridian, and carried 4 miles to Berthoud Pass, crossing Current Creek. The ditch has a capacity of 53 second-feet. At Berthoud Pass (altitude 11,300 feet) it gives way to 462 feet of 30 -inch riveted steel pipe, which empties into the West Fork of Clear Creek. The drainage area above the ditch, 
which is 2 square miles, ranges in altitude from 11,300 to 12,500 feet. Since about 1916, owing to the difficulty of keeping the ditch open in the extremely rugged region beyond Current Creek, only 2 miles of the ditch, extending from that point to Berthoud Pass, has been operated. This portion intercepta the run-off from 0.9 square mile. The following table shows the total amount diverted each year:

Annual diversion through Berthoud ditch, 1910-1927, in acre-feet

\begin{tabular}{|c|c|c|c|c|c|}
\hline $1910_{-}$ & 420 & $1917 \ldots \ldots$ & 504 & $1924 \ldots$ & 1,160 \\
\hline 1911 & 434 & $1918 \ldots \ldots$ & 868 & 1925 & 1,050 \\
\hline $1912_{-}$ & 210 & 1919 & 476 & 1926 & record \\
\hline $1913 \ldots \ldots \ldots$ & 1,160 & $1920 \ldots$ & 0 & 1927 & 420 \\
\hline $1914 \ldots$ & 476 & $1921 \ldots \ldots$ & 100 & & \\
\hline 1915 & 650 & $1922 \ldots$ & $\mathbf{5 7 6}$ & Mean (exclusive of & \\
\hline 916 & 832 & $1923 \ldots$ & 1,370 & 1920 and 1926$)$ & \\
\hline
\end{tabular}

The quantity of water diverted each year is not the total run-off aviailable. Records of the Fraser River near West Portal (19111927), the drainage area of which ranges in altitude from 9,300 to 12,500 feet, indicate a unit run-off for the period from April 1 to September 30 of 1,060 acre-feet per square mile. Above the Berthoud ditch the unit run-off is estimated at 1,200 acre-feet, or 2,400 acrefeet from the 2 square miles of drainage area. Owing to the extremely rigged topography and the small areas whose run-off would be intercepted by an extension of the present ditch such an extension does: not appear feasible.

- Boreas Pass ditch.-A small ditch diverts water from the head of Indiana Creek, a tributary of the Blue River, in sec. $26, \mathrm{~T} .7 \mathrm{~S} ., \mathrm{R}$. $77 \mathrm{~W}$. sixth principal meridian, at Boreas Pass (altitude 11,500 feet), into the head of Tarryall Creek for the irrigation of hay lands in. South Park. It was built about 1909 and diverts an average of less than 4 second-feet for 90 days, or 600 acre-feet for the season.

Summary of annual diversions.-The existing diversions may be summarized as follows:

Mean annual transmountain diversions from upper Colorado River Basin, in acre-feet. Grand River ditch 11,400

Berthoud ditch. 685

Busk-Ivanhoe tunnel

3,710

Ewing ditch.

2,000

Tarbell ditch

2,000

Boreas Pass ditch

600

20,400

\section{FUTURE DEVELOPMENT}

Feasibility.-The six developments above described represent practically the limit of transmountain diversions by the relatively inexpensive open ditches, except for the proposed extension of the Grand River ditch. Additional developments must be of greater magnitude and expense and must be made by means of tunnels and collection ditches leading to them. 
The need for additional water on the eastern slope has led water users to propose diversions from the Fraser, Williams, Blue, and Eagle Rivers, the only streams so situated that diversions from them to the eastern slope can, in the opinion of the writer, be seriously considered for many years to come. The Traser and Blue River diversions. would be on a scale so large that they cauld only be undertaken by a municipality like Denver, where the cost of the project would be less of a governing factor than the necessity for obtaining additional water to provide for the city's future needs. It therefore appears entirely probable that when these projects are finally undertaken and carried to completion, the systems will be so planned and constructed that they will collect about 80 per cent of the available water. In fact, the city's engineers charged with planning its future water supply are contemplating an efficiency of 90 per cent. To obtain this high efficiency, the collection ditches in earth and loose rock must be lined, and drainage ditches must be built along the side above the collection ditches to collect the surface run-off and carry it to the cross drainage channels that will empty into the main ditch. Provision must also be made to clean the snow from the ditches by machines early in the spring. The experience gained from the operation of the Grand River and Skyline ditches. shows that it will be possible to exclude during the winter the run-offfrom the intercepted streams entering the main ditches and thus prevent the formation of any great amount of ice. It may also be necessary to cover some portions of the ditches. The storage capacities required will depend on the capacities of the tunnels and ditches. Ditches on south slopes will obtain water fully two weeks earliex than those on north slopes; the peak flow will be higher and its subsidence more rapid. Open ditches at lower altitudes will encounter less slide rock and will be subject to less danger from heaving due to frost action. The period during which water can be diverted is taken as April 1 to September 30, as that is the average period during which the proposed diversions can be made without interference with the right of the hydroelectric plant at Shoshone, on the Colorado River (p. 165). In determining the available water supply no consideration has been given to the conflict with water rights immediately below the proposed diversions, as these must be acquired and extinguished.

Fraser River.-With the completion of the Moffat water tunnel, which parallels the railroad tunnel at a distance of 75 feet and has an altitude of 9,300 feet at its midpoint, the city of Denver has planned to construct a system to divert water to the South Platte Basin: From the west portal of the water tunnel, in the NE. $1 / 4$ sec. 10, T. $2 \mathrm{~S}$, R. $75 \mathrm{~W}$. sixth principal meridian, two collection ditches are to: be constructed, one 27 miles long reaching West St. Louis Creek, and 
the other 9 miles long reaching North Ranch Creek. This: system will intercept the run-off from 107 square miles of drainage area ranging in altitude from 9,300 to 12,500 feet. From the records of the Fraser River near West Portal (1911-1927) the unit run-off for the period from April 1 to September 30 is estimated as 1,060 acre-foet per square mile, or 113,000 acre-feet from the entire area. At an efficiency of 80 per cent, the mean annual diversion would be 90,400 acre-feet. A study of the 31-year record of the Colorado River near Palisade (p. 42) indicates that the mean for that period is 94 per cent of the 17-year mean from 1911 to 1927. On this basis the mean annual diversion would be reduced to 85,000 acre-feet. The annual variation in the proposed diversion is suggested by the following table, based on the annual percentages for the Fraser River near West Portal and the mean diversion of 90,400 acre-feet:

Annual diversion that would have been possible from Fraser River Basin, 1911-1927

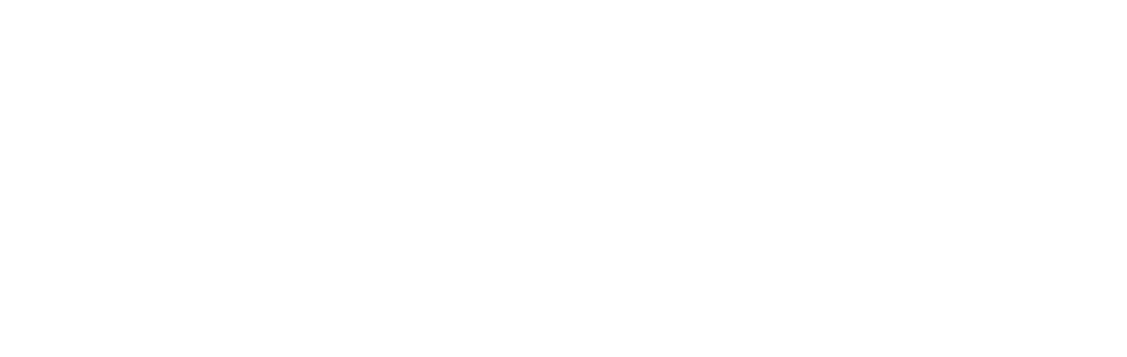

In the year of lowest run-off during the 17-year period the diversion would have been only 63,200 acre-feet. To carry the maximum discharge of the wettest year a tiand elpacity of 3,100 second-feet would be required. However, it is possibile to obtain some storage above the proposed diversions and thus reduce the required tunnel capacity. A capacity of 1,000 second-feet would have required annual storage as follows, in acre-feet:

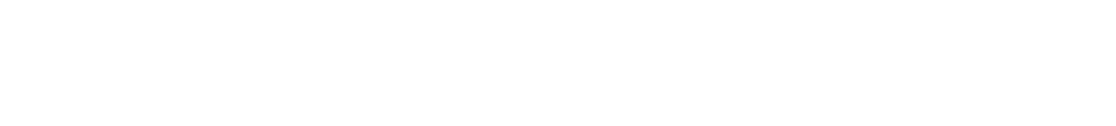

The records before 1914 are too fragmentary to determine storage required.

Williams River.-Several surveys have been made to divert water from the Williams River to Clear Creek, in the South Platte Basin. The most comprehensive survey has been made by the city of Denver, which proposes to bore a tunnel 3 miles long at an altitude of 10,300 feet. This is about the lowest altitude believed to be feasible for a water tunnel on this project, as the slopes on both sides of the Continental Divide are such that a tunnel at 9,300 feet, the altitude of the Fraser River diversion, would be 11 miles long. The west portal will 
be on Bobtail Creek; a tributary of the Williams River, and the east portal on the West Fork of Clear Creek. From the west portal one collection ditch will extend to an unnamed creek beyond McQueary Creek, a distance of 4 miles, and another will extend to the South Fork of the Williams River, a distance of 18 miles. These ditches will intercept the run-off from 29 square miles of drainage area, ranging in altitude from 10,400 to 12,500 feet. No records of upper Williams River are available, but by a comparison with the Fraser River records the unit run-off above an altitude of 10,400 feet from April 1 to September 30 is estimated as 1,100 acre-feet per square mile, or 32,000 acre-feet for the entire 29 square miles. At an efficiency of 80 per eent the mean annual diversion would be 25,600 acre-feet. A tunnel capacity of 600 second-feet will be required to divert this quantity of water unless storage is provided on the western slope. The 31-year mean at Palisade is 94 per cent of the 17-year mean for 1911-1927. On this basis the mean annual diversion from the Williams River would be reduced to 24,000 acre-feet.

Btue River.-The basin of the Blue River is so situated with reference to the eastern slope that a number of diversions are possible. Surveys have been made by the city of Denver for diversions at altitudes of $10,300,9,500,9,112$, and 8,842 feet, and the writer has made a preliminary study for-one at 9,800 feet. The following table shows the possibilities at each of these altitudes:

Proposed diversions from Blue River Basin at certain altitudes

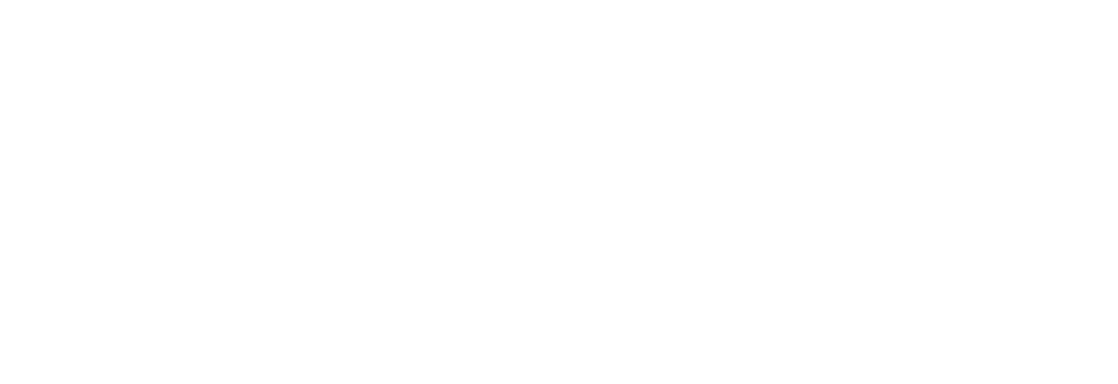

- The city of Denver has proposed to construct a 4-mile tunnel to Tenmile Creek, tapping that stream at the mouth of West Fork, thus increasing the possible diversion by 36,000 acre-feet. The writer believes that eventually the need for additional water in the Arkansas Valley will be so great that water from Tenmile Creek will be diverted to that drainage basin rather than to the South Platte. (For description of that possible diversion see p. 58.)

The quantity of water that can be diverted will depend upon the length of collection ditches built from the receiving portal of the tunnel along the mountain sides. As the diversion of a given quantity of water requires a shorter collection ditch the lower the altitude of the tunnel, it follows that for the same length of collection ditch the quantity of water that can be diverted will increase with a decrease in altitude. The preceding table shows that for 26 miles of ditches the 
diversions would increase from 28,000 to 96,000 acre-feet with an increase in tunnel length from 3 to 12.9 miles. The projects requiring tunnel lengths of 18.9 and 22.8 miles make available such large quantities of water for diversion that a study showing the available diversions on these projects if ditches 26 miles long were provided has not been made. As the city of Denver is the only water user that can afford to make a diversion from the Blue River, at least within the period of time that a forecast of future use can safely be made, and as a tunnel 12.9 miles long will yield a quantity of water sufficient for Denver's needs for the same period and is within the realm of present-day engineering practice, the diversion of 96,000 acre-feet at an altitude of 9,500 feet has been selected for consideration in this report.

The west portal would probably be on the Swan River in the SE. $1 / 4$ sec. 15, T. 6 S., R. 77 W. sixth principal meridian, 1 mile below Tiger. Collection ditches extending from the North Fork of the Snake River on the north to North Barton Creek on the south would have a total length of 26 miles and intercept the run-off from 181 square miles of drainage area ranging in altitude from 9,500 to 13,500 feet. Stream-gaging records are available for the Blue Rivier at Dillon (1911-1927) and for the Snake River at Dillon (1911-1919): For the 9-year period 1911-1919 the inean run-off from April 1 to September 30 is 148,000 acre-feet, or 676 acre-feet per square mile for 219 square miles ranging in altitude from 8,850 to 13,500 feet. As the unit run-off increases with the altitude, that for the area above 9,500 feet will be slightly greater and has been taken as 718 acre-feet. This gives a total run-off of 130,000 acre-feet for the 181 square miles lying above the collection ditches. Deducting 10,000 acre-feet for the portion of the Summit County Power Co.'s water supply originating in the Snake River Basin above 9,500 feet leaves an atailable run-off of 120,000 acre-feet. At an efficiency of 80 per cent the mean annual diversion will be 96,000 acre-feet. A study of the 31-year record of the Colorado River near Palisade (p. 42) indicates that the mean for that period is 95 per cent of that for the 9-year period covered by the Blue and Snake River records. On this basis the mean annual diversion from the Blue River would be 91,200 acre-feet.

The variation in run-off that would have been available for ditersion from April 1 to September 30 each year at an altitude of 9,500 feet is shown by the following table, which is based on a mean run-off of 96,000 acre-feet and annual percentages determined from April to September run-off at the gaging station on the Blue River at Dillon. 
Annual diversion that would have been possible from Blue River Basin, 1911-1987

\begin{tabular}{|c|c|c|c|c|c|}
\hline Year & Acre-feet & $\begin{array}{l}\text { Per cent } \\
\text { of mean }\end{array}$ & Year & Acre-feet & $\begin{array}{l}\text { Per cent } \\
\text { of mean }\end{array}$ \\
\hline $\begin{array}{l}1911 \\
1912 \\
1913 \\
1914 \\
1916\end{array}$ & $\begin{array}{r}82,500 \\
115,000 \\
86,500 \\
134,000 \\
82,500 \\
85,500 \\
106,000\end{array}$ & $\begin{array}{r}86 \\
120 \\
90 \\
140 \\
86 \\
89 \\
111\end{array}$ & $\begin{array}{l}1921 \\
1922 \\
1923 \\
1924 \\
1926 \\
1927\end{array}$ & $\begin{array}{r}121,000 \\
72,000 \\
111,000 \\
87,200 \\
72,000 \\
119,000 \\
90,400\end{array}$ & $\begin{array}{r}126 \\
75 \\
116 \\
91 \\
75 \\
124 \\
95\end{array}$ \\
\hline 191902 & $\begin{array}{r}11,000 \\
69,000 \\
87,300\end{array}$ & $\begin{array}{r}116 \\
72 \\
91\end{array}$ & Mean................ & 96,000 & \\
\hline
\end{tabular}

In the year of lowest run-off during the 17-year period the diversion would have been only 69,000 acre-feet. The maximum discharge at the tunnel site during the years of record was 1,880 second-feet. With a tunnel capacity of 1,000 second-feet, the storage that would have been required to care for the excess run-off is as follows:

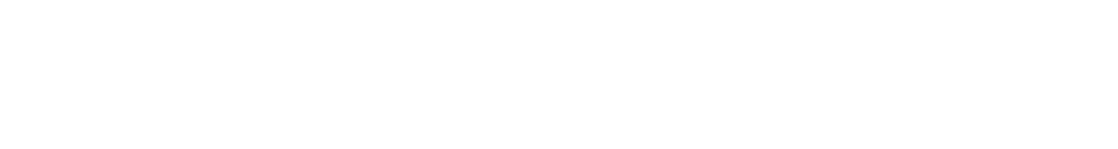

Eagle River.-At Tennessee Pass, which separates the Eagle and Arkansas drainage basins, an opportunity is afforded for the diversion of water from the Eagle River. A tunnel at an altitude of 10,200 feet would be 2 miles long, and one at 9,800 feet would be 6 miles long. As the slope of the Eagle River Basin precludes the interception of run-off from any area comparable in size with the areas in the Fraser and Blue drainage basins, it is evident that for the quantity of water available a length of tunnel greater than 2 miles would not be warranted. With the tunnel at 10,200 feet and 15 miles of collection ditches, reaching Bennett Creek on the west side and the East Fork on the east, the run-off from an area of 30 square miles would be intercepted, ranging in altitude from 10,200 to 13,000 feet. Records of the Eagle River at Redcliff from 1911 to 1925 show the mean run-off from April 1 to September 30 to be 594 acre-feet per square mile. For the area above an altitude of 10,200 feet the unit run-off is estimated at 700 acre-feet per square mile, or 21,000 acre-feet for the 30 square miles. At an operating efficiency of 80 per cent 16,800 acre-feet could be diverted.

A low divide between the Eagle River and Tenmile Creek drainage basins makes possible a diversion at 10,900 feet by a tunnel a quarter of a mile long. Lowering the altitude of the tunnel 100 feet would increase its length to $1 \frac{1}{2}$ miles. A ditch $3 \frac{1}{2}$ miles long on the west side reaching Searles Gulch and one $6 \frac{1}{2}$ miles long on the east side reaching Mayflower Gulch will intercept the run-off from an area of 20 square miles, ranging in altitude from 10,900 to 13,500 feet. Records of Tenmile Creek at Dillon from 1911 to 1919 show the mean 
run-off from April 1 to September 30 to be 872 acre-feet per square mile. For the area above 10,900 feet the unit run-off is estimated at: 1,000 acre-feet per square mile, or 20,000 acre-feet for the entire area. At an efficiency of 80 per cent 16,000 acre-feet could be diverted. The water diverted from Tenmile Creek would be taken to the eastside collection ditch of the Eagle River system. The annual variation that would have occurred from 1911 to 1925 in the combined diversions proposed from the Eagle and Tenmile Basins is shown in the following table, which is based on a mean discharge of 32,800 acrefeet varied according to the variation at the Eagle and Tenmile gaging stations:

Annual diversion that would have been possible from Eagle River and Tenmile Creek Basin, 1911-1925

\begin{tabular}{|c|c|c|c|c|c|}
\hline Year & Acre-feet & $\begin{array}{l}\text { Per cent } \\
\text { of mean }\end{array}$ & Year & Acre-feet & $\begin{array}{l}\text { Per cent } \\
\text { of mean }\end{array}$ \\
\hline \multirow{2}{*}{$\begin{array}{l}1911 \\
1912 \\
1914 \\
1915 \\
1916 \\
1917 \\
1918\end{array}$} & \multirow{2}{*}{$\begin{array}{l}39,000 \\
42,600 \\
25,600 \\
41,300 \\
23,300 \\
31,800 \\
33,800 \\
41,300 \\
24,300\end{array}$} & \multirow{2}{*}{$\begin{array}{r}119 \\
130 \\
78 \\
126 \\
71 \\
97 \\
103 \\
126 \\
74\end{array}$} & \multirow{2}{*}{\begin{tabular}{|l}
1920 \\
1921 \\
1922 \\
1923 \\
1924 \\
Mean
\end{tabular}} & $\begin{array}{l}33,400 \\
41,300 \\
23,000 \\
34,400 \\
27,600 \\
22,700\end{array}$ & $\begin{array}{r}102 \\
126 \\
70 \\
105 \\
84 \\
69\end{array}$ \\
\hline & & & & 32,800 & $-\ldots$ \\
\hline
\end{tabular}

In the year of lowest run-off during the 15-year period the diversion would have been only 22,700 acre-feet. Without storage on the western slope, a tunnel capacity of 700 second-feet would be required.

From the Palisade records it appears that the 31-year mean for 1897-1927 is 94 per cent of the 15-year mean for 1911-1925, and on this basis the mean run-off available for diversion would be 30,800 acre-feet.

Summary of future development.-The developments just described may be summarized as follows:

Summary of future transmountain diversions from upper Colorado River Basin

\begin{tabular}{|c|c|c|c|c|c|c|}
\hline \multicolumn{2}{|c|}{ Diversion } & \multirow{2}{*}{$\begin{array}{c}\text { Drainage } \\
\text { area from } \\
\text { which run- } \\
\text { off will be } \\
\text { intercepted } \\
\text { (square } \\
\text { miles) }\end{array}$} & \multirow{2}{*}{$\begin{array}{c}\text { Elevation } \\
\text { of tunnel } \\
\text { (feet) }\end{array}$} & \multicolumn{2}{|c|}{$\begin{array}{l}\text { Length of con- } \\
\text { duit (miles) }\end{array}$} & \multirow{2}{*}{$\begin{array}{l}\text { Annual } \\
\text { diversion } \\
\text { (acre- } \\
\text { feet) }\end{array}$} \\
\hline From & To & & & Tunnel & Ditch & \\
\hline \multirow{6}{*}{$\begin{array}{l}\text { Grand River ditch exten- } \\
\text { sion. } \\
\text { Fraser River } \\
\text { Williams River } \\
\text { Blue River } \\
\text { Eagle River } \\
\text { Fryingpan Creek }\end{array}$} & \multirow{6}{*}{$\begin{array}{l}\text { Cache Ia Poudre } \\
\text { South Boulder Creek } \\
\text { West Clear Creek } \\
\text { South Platte. } \\
\text { Arkansas River }\end{array}$} & 12 & a 10,200 & & 7 & 12,000 \\
\hline & & 107 & 9,300 & 6 & 36 & 90,400 \\
\hline & & 29 & 10,300 & 3 & 22 & 25,600 \\
\hline & & $\begin{array}{l}181 \\
650\end{array}$ & $\begin{array}{r}9,500 \\
10,200\end{array}$ & $\frac{12.9}{2}$ & $\begin{array}{l}26 \\
15\end{array}$ & $\begin{array}{l}96,000 \\
32,800\end{array}$ \\
\hline & & 17 & 10,950 & 2 & 16 & 17,700 \\
\hline & & 396 & -.... & 25.9 & 122 & 274,000 \\
\hline
\end{tabular}

- Open ditch.

- Including diversions from Tenmile Creek.

- Partly constructed. 
From the magnitude of the work involved, it will probably be many years before these diversions are completely developed.

Effect of possible diversions on flow of Colorado River.-To determine the effect of the possible transmountain diversions on the flow of Colorado River at various points, it is necessary to compute the monthly quantities to be diverted. For that purpose, the period 1911-1927 was selected for each stream so far as records were available and the monthly percentages of the entire discharge for the period from April 1 to September 30 were determined. These percentages were then applied to the mean run-off available for diversion.

Mean monthly discharge of proposed transmountain diversions from upper Colorado River Basin, in acre-feei

\begin{tabular}{|c|c|c|c|c|c|c|}
\hline & April & May & June & July & August & $\begin{array}{c}\text { Septem- } \\
\text { ber }\end{array}$ \\
\hline \multirow[t]{2}{*}{$\begin{array}{l}\text { Grand River ditch extension } \\
\text { Fraser River } \\
\text { Williams River } \\
\text { Blue River- } \\
\text { Eagle River } \\
\text { Fryingpan Creek }\end{array}$} & $\begin{array}{r}2,0 \\
2,710 \\
1,020 \\
3,840 \\
1,970 \\
885\end{array}$ & $\begin{array}{r}1,200 \\
17,200 \\
4,850 \\
19,200 \\
9,520 \\
4,240\end{array}$ & $\begin{array}{r}4,560 \\
40,700 \\
11,000 \\
36,500 \\
12,500 \\
7,440\end{array}$ & $\begin{array}{r}4,680 \\
18,100 \\
5,370 \\
21,100 \\
5,240 \\
3,190\end{array}$ & $\begin{array}{l}1,440 \\
7,220 \\
2,050 \\
9,600 \\
2,290 \\
1,240\end{array}$ & $\begin{array}{l}120 \\
4,520 \\
1,280 \\
5,760 \\
1,300 \\
705\end{array}$ \\
\hline & 10,400 & 56,200 & 113,000 & 57,700 & 23,800 & 13,700 \\
\hline
\end{tabular}

The effect of these diversions upon the flow of the Colorado River is shown by deducting from the mean monthly recorded flow for the period 1911-1927, the computed quantities given in the preceding table and expressing the differences as percentages of the recorded flow. These percentages are given in the following tables for each principal gaging station above the Green River and at Yuma:

Disharge of Colorado River as modified by proposed transmountain diversiows from uppor basin, in pereentages of measuted discharge

\begin{tabular}{|c|c|c|c|c|c|c|}
\hline Gaging station & April & May & June & July & August & $\begin{array}{l}\text { Septem- } \\
\text { ber }\end{array}$ \\
\hline $\begin{array}{l}\text { Kremmling }{ }^{a} \\
\text { Glenwood Springs } b_{2} \\
\text { Palisade } \\
\text { Cisco__a } \\
\text { Yuma }\end{array}$ & $\begin{array}{l}91 \\
93 \\
96 \\
98 \\
99.3\end{array}$ & $\begin{array}{l}85 \\
90 \\
94 \\
96 \\
97.8\end{array}$ & $\begin{array}{l}82 \\
87 \\
92 \\
95 \\
97.8\end{array}$ & $\begin{array}{l}78 \\
84 \\
90 \\
93 \\
97.8\end{array}$ & $\begin{array}{l}76 \\
83 \\
90 \\
93 \\
98.3\end{array}$ & $\begin{array}{l}77 \\
85 \\
91 \\
94 \\
97.7\end{array}$ \\
\hline
\end{tabular}

- Above diversions from Eagle River and Fryingpan Creek.

- Above diversions from Fryingpan Creek.

- Above diversions from Grand Valley.

The effect of the proposed diversions of the flow of Colorado River will be a maximum at the Kremmling station and will decrease at points farther downstream, where the discharge is successively greater. Owing to the substantial uniformity of annual variation in discharge throughout the upper basin, it is believed that the percentages given in the preceding table will apply each year.

Additional possible transmountain diversions.-Two additional large-scale diversions have been proposed, one to take water from 
the upper Colorado River Basin above Grand Lake into the Cache la Poudre Basin by means of a tunnel about 12 miles long and the other to take water from the Taylor River into the Arkansas Basin either by a tunnel 6 miles long at an altitude of 10,000 feet or by a tunnel 9 miles long at 9,800 feet. As the very heavy expense of these diversions would have to be borne chiefly by irrigation interests, it appears to the writer extremely improbable that they will be constructed for many years to come.

\section{STORAGE}

\section{DEVELOPED SITES}

The storage of water is in an elementary stage in the upper Colorado River Basin. The water supply of the larger streams is suffcient without storage for the present irrigation requirements, and it is only on a few of the smaller tributaries that storage has become necessary. Consequently, of the 41 reservoirs having a capacity of 500 acre-feet or more only two exceed 5,000 acre-feet, and one of these was virtually abandoned before completion, owing to unsatisfactory physical conditions. With the exception of Lake Hope and Trout Lake, which are used for power, the reservoirs are used to store water for irrigation but are too small to carry over water from one year to the next. Not included in this report are numerous smaller reservoirs, many of which are merely earth embankments thrown across natural depressions in the ground surface. All available information relative to these sites is presented in the following pages:

\section{ITAIFHOE RRSERVOIR (9DF 1)}

About 1922 A. E. Carlton, trustee for the Colorado Midland Railroad stockholders, constructed the Ivanhoe Reservoir, which lies close to the Continental Divide at an altitude of 10,900 feet. Lake Ivanhoe, in secs. 12 and 13, T. 9 S., R. $\$ 2$. sixth principal meridian, is drained by Tvanhere Creek, a tributary of Fryingpan Creek, which in turn empties into the Roaring Fork. The original plan contemplated the construction of $a \mathrm{dam} 30$ feet high and 630 feet long acress the lower end of the lake and a dam 30 feet high and 30 feet long across the upper end. 'This would have created a reservoir' holding 1,920 acre-feet with an area of 100 acres. The dam has been constructed to a height of 20 feet, which affords a storage capacity of 1,400 acre-feet: In addition to the run-eff from Ivanhoe Creek, an inlet ditch 2 miles long from Lyle Creek, having a capacity of 200 secondfeet, makes available the run-off from a total area of 5 square miles.

Records of Fryingpan Creek above Forris, the drainage area of which ranges in altitude from $8,840^{\prime}$ to 13,500 feet, indicates a unit run-off of 1,040 acre-feet per'square mile. For the area tributary to Lake Ivarhoe, which is above 11,000 feet; the unit run-off is estimated at 1,300 acre-feet per square mile, or 6,500 acrefeet from 5 square miles.

The water stored in Lake Ivantroe is conveyed through the Busk-Ivarhoe Tunnel to the headwaters of the Arkansas and used for irrigation in the Arkansas Valley between Ptreblo and La Junta. 


\section{SPRING PARK RESERVOIR (9DF 2)}

During 1911 the Carbondale Reservoir \& Irrigation Co. constructed the Spring Park Reservoir south of Cattle Creek, in secs. 15 and 22, T. 7 S., R. 87 W. sixth principal meridian. An earth dam 27 feet high and 1,660 feet long at the crest creates a reservoir having a capacity of 2,820 acre-feet with an area of 292 acres. Water is supplied by Mountain Meadows ditch, which diverts water from Cattle Creek in sec. 1, T. 7 S., R. 87 W., and conveys it 2 miles to the reservoir. An outlet ditch intercepts water brought by laterals from the Mountain Meadows ditch, which drains 3,000 acres lying on the mesa above the main Roaring Fork Valley.

The original filing for the reservoir contemplated a capacity of 22,000 acre-feet. It is impossible to estimate closely the available water supply for additional storage, as no records of run-off for Cattle Creek or comparable streams are available. The drainage area above the intake for the reservoir is 31 square miles, ranging in altitude chiefly from 8,000 to $9,0,00$ feet, and the unit run-off is estimated as 700 acre-feet per square mile. This gives a total run-off of 21,700 acre-feet. As 7,500 acres is under ditch from Cattle Creek, of which 5,800 acres is irrigated, the diversion requirement for this area will be about 12,000 acre-feet, leaving a surplus of 9,700 acre-feet for additional storage.

\section{GRASS VALLEY RESERVOIR (ODG 1)}

About 1910 the Antlers Orchard Development Co. constructed the Grass Valley Reservoir at Harvey Gap, in sec. 13, T. 4 S., R. 92 W. sixth principal meridian. Within 10 years before the construction of this reservoir two dams at the same site had failed, and special care was taken in constructing the present dam. At the dam site the hills forming the abutments are very steep, and the dam, which is constructed of earth with two layers of rock facing, has nearly its maximum height of 60 feet throughout its length, which is 800 feet at the crest. The capacity is 4,130 acre-feet, and the area 160 acres. The reservoir is supplied by the Grass Valley ditch, which diverts water from East Rifle Creek just below the falls in sec. 27, T. 4 S., R. 92 W., 7 miles above the reservoir. From the reservoir, which is now owned by the Farmers Irrigation Co., water is released to the Grass Valley ditch, which extends a short distance beyond the reservoir and irrigates 3,780 acres.

\section{ONION VALIEY RESERVOIR (9EC 1)}

The Fruitland Irrigation Co., a stock company originally formed in 1901, began the construction of the Onion Valley Reservoir in the valley of Onion Creek in secs. 7, 17, and 18, T. 50 N., R. 6 W. New Mexico principal meridian, to irrigate the lands of the company in the vicinity of Crawford (p. 131). The dam, which was started in 1903, was constructed by the hydraulic-fill method. Owing to the fact that water for construction was available only a comparatively short time each year and to financial difficulties, the work proceeded so slowly that by 1911 the capacity of the reservoir was only 1,600 acre-feet. This was increased to 2,300 acre-feet in 1913 and to 4,770 acre feet in 1924, when work ceased. The present height of the dam is about 70 feet and the maximum length 100 feet. It was originally intended to create a capacity of 20,000 acre-feet.

The principal source of supply is Crystal Creek, from which water is diverted in sec. 34, T. 50 N., R. 6 W., and conveyed 7 miles to the reservoir by a ditch having a capacity of 80 second-feet. With this inlet capacity the mean annual run-off available for storage, based on three years' records just above the intake, is 15,000 acre-feet. If the inlet capacity were enlarged to take practically the entire flow of Crystal Creek the available supply would be about 27,000 acre-feet. 
OTERTAIT RESERTOIR (OED 1)

About 1903 the Overland Ditch \& Reservoir Co. constructed the Overland Reservoir near the top of Grand Mesa, chiefly in sec. 23, T. 11 S., R. 92 W. sixth principal meridian. At this point the sources of Cow and Hubbard Creeks are close together, and the construction of an earth dam 45 feet high with a crest length of 1,300 feet has formed a reservoir having a capacity of 4,000 acre-feet. The drainage area of the two creeks above the reservoir is 10 square miles, and as this is in a region of very heavy run-off, the mean annual run-off is probably more than 10,000 acre-feet. From the reservoir water is released into Hubbard Creek and then diverted to the Overland ditch for the irrigation of 4,000 acres between Leroux Creek and the North Fork (p. 133).

\section{FRUIT GROWERS RESERVOIR (OEE 3)}

In 1898 the Fruit Growers Reservoir Co. constructed a reservoir on Alfalfa Run, an intermittent stream, chiefly in sec. 18, T. 14 S., R. 94 W. sixth principal meridian. It is formed by an earth dam 36 feet high with a crest length of 500 feet and has a capacity of 3,420 acre-feet. The intake is the Alfalfa ditch, which diverts water from Surface Creek in sec. 29, T. 13 S., R. 97 W., 7 miles above the reservoir. In addition to supplying the Fruit Growers Reservoir, the intake canal irrigates 2,200 acres above the reservoir. The water is used to irrigate land between the reservoir and the North Fork of the Gunnison River near Cory.

RESERVOIRS ON GRAND MIESA (ODJ 1-8, 9ED 2, 9EE 1-2, 4-10, 9EG 1-5)

The reservoirs in the Plateau Creek Basin and practically all of those in the Gunnison River Basin lie on Grand Mesa, which is a region of many small lakes at a general altitude of 10,000 feet. On the Plateau Creek side eight of these creeks have been converted into reservoirs having individual capacities of $\mathbf{5 0 0}$ acre-feet or more and a total of 12,000 acre-feet. In addition, there are 45 smaller reservoirs having a total capacity of 14,000 acre-feet. On the Gunnison River side 15 reservoirs of more than 500 acre-feet each have a combined capacity of 19,300 acre-feet, and 94 smaller reservoirs have an additional capacity of 14,000 acre-feet. J. W. Johnson, deputy State engineer, has given the following description of the dams forming these reservoirs. ${ }^{12}$

"The dams are built across the natural stream bed and are either of earth or earth and rock combined. Where plenty of rock was available a heavy wall was built on the downstream side. $* * *$ When rock is not used the lower slope is usually very steep, $1 \frac{1}{2}$ or at most 2 to 1 . The crests are uniformly narrow, few being 12 feet in width. The inside slopes vary from 2 to 1 up to 3 to 1 . Most of them are unprotected, some few being protected by riprap. * * * Spillways are made by cutting a narrow trench through the natural gound so as to lead the overflow away from the dam. *** Some few of the larger dams have 5 feet freeboard, but this is exceptional. * * * The outlets are wooden boxes provided with wooden or steel gates at the intake ends. The gates are ordinarily lifted by a vertical wooden stem operated from a tower reached by a wooden footbridge."

The water from these reservoirs is used by the numerous ditches that irrigate land in the valleys at the base of Grand Mesa.

\section{ROBY IEE RESERVOIR (日DII 1)}

This reservoir was constructed but abandoned owing to the great quantity of silt deposited.

12 Colorado State Engineer Sixteenth Bienn. Rept., p. 53, 1913. 


\section{NARRAQUIMHEP IISERTOIR (OGR 2)}

One of the first irrigation districts formed in Colorado was the Montezuma Irrigation District, which contemplated the irrigation of about 60,000 acres lying in Montezuma Valley but irrigated from the Dolores River. About 1908 the Narraguinnep Reservoir ${ }^{13}$ was built near the upper boundary of the distriet, chiefly in sec. 4, T. 37 N., R. 16 W. New Mexico principal meridian. Aeross a natural depression two earth dams having a total length of 1,320 feet and a maximum height of 70 feet ereated a reservoir with a capacity of 9,300 acre-feet and an area of 357 acres. (For description of intake see p. 137.) From the reservoir water is released into the ditch system of the Montezuma Valley Irrigation Co., which succeeded the Montezuma Irrigation District in 1920. Not only is the water supply sufficient for the reservoir, but the company contemplates the creation of further storage by the construction of the Dawson Reservoir, having a capacity of 60,000 acre-feet.

\section{TOTTON IAKE ((9DH 1)}

Surveys for the Totton Lake Reservoir, in sec. 20, T. 36 N., R. 15 W. New Mexico principal meridian, were made in 1898 by the United States Geological Survey. A dam 33 feet high having' a length of 8,000 feet would create storage amounting to 9,300 acre-feet with a depth of 25 feet and have a maximum area of 830 acres.

About 1910 the Montezuma Irrigation District began the construction of this reservoir and completed it to a capacity of 1,000 acre-feet. The earth dam ranges in height from 2 to 10 feet and has a total length of about 3,000 feet. The maximum area is $\mathbf{8 5}$ acres. The reservoir is used as a service reservoir for lands on the lower part of the Montezuma Valley Irrigation Co.'s project and is supplied by water from the canals of that system. The company states that at the present time the reservoir is of little use.

\section{SUMMIT, JOE MORE, AND PUITT RESERVOIRS (9DI 2-4)}

The Summit, Joe More, and Puitt Reservoirs, whick are close together on the main ditch of the Summit Reservoir \& Irrigation Co., are in secs. 32 and 34, T. 37 N., and sec. 3, T. 36 N., R. 14 W. New Mexioo principal meridian. They are formed by low earth dams aeross natural depressions and have a combined capacity of 4,000 acre-feet. The Summit ditch diverts water from the head of Lost Canyon Creek in sec. 35, T. 38 N., R. 12 W., and taps several tributary streams in its course of 17 miles to the reservoirs. The water is used for the irrigation of 3,500 acres lying 12 miles below the reservairs.

\section{IAKE HOPE (9DK 1)}

In the late ninetie the Telluride Power Co. converted Lake Hope, in sec. 27, T. 41 N., R. 9 W. New Mexico principal meridian, into a reservoir for developing power. It lies in an old voloanic orater on the headwaters of the Lake Fark, at an altitude of 11,100 feet, and across its outlet a rock-fill dam 10 feet high and 100 feet long was built. The outlet is a tunnel 5 by 6 feet driven 971 foet through solid rock, 113 feet beiow the natural lake level. The resulting draft on the lake makes available a storage cepacity of 2,300 acre-feet with a maximum area of $\mathbf{4 4}$ acres. Water is released from the reservoir into Lake Fork for use at the Ames and Ilium power plants of the Western Colorado Power Co. (pp. 177-178), which succeeded the Telluride Co. The drainage area above the reservoir outlet is slightly less than 1 square mile, but as it ranges in altitude from 11,000 to 13,000 feet and is within a region of very heavy precipitation, the mean annual run-off is estimated as 1,500 acre-feet.

${ }^{13}$ U. S. Geol. Survey Twentieth Ann. Rept., pt. 4, p. 420, 1900. 
TROUT LAKE (9DK 2)

In secs. 8 and 17, T. 41 N., R. 9 W. New Mexico principal meridian, 4 miles below Lake Hope, lies Trout Lake, at an altitude of 9,700 feet in the ohannel of the Lake Fork. In 1894 the Telluride Power Co. converted the lake into a reservoir by the construction of a low earth dam. This was destroyed by the severe flood of September, 1909, and was replaced by the present earth dam, which is 36 feet high and 1,175 feet long. A storage capacity of 2,740 acre-feet with an area of 142 acres was thereby created. From the reservoir water ia discharged through a 40-inch pipe line into the covered timber flume leading to the Ames and Ilium power plants (pp. 178-179) of the Western Colorado Power Co., which succeeded the Telluride Power Co. The period of release is usually from August to April. The drainage area above the reservoir outlet, which is 14 square miles, ranges in altitude from 9,700 to 13,000 feet, and as it is within a region of very heavy precipitation the mean annual run-off is estimated as 17,000 acre-feet. This includes the run-off tributary to Lake Hope.

LONE CONE RESERVOIR (9DK 3)

In 1912 the Lone Cone Ditch Co. constructed the Lone Cone Reservoir, 2 miles north of Lone Cone, in secs. 1 and 12, T. 43 N., R. 13 W. New Mexico principal meridian. A small reservoir having an earth dam 10 feet high, which had been constructed several years previously, was enlarged. The dam, which forms the inner toe of the enlarged structure, was raised to a maximum height of 27 feet and given a total length of 2,600 feet. The capacity is 1,830 acre-feet with an area of 149 acres. ${ }^{14}$ The inlet is Lone Cone ditch, which diverts water from Naturita Creek in sec. 10, T. 42 N., R. 13 W., and conveys it a short distance to the reservoir. Water from the reservoir is used to irrigate 3,470 acres between Norwood and Redvale.

As no records of Naturita Creek or comparable streams are available, no estimate of water supply has been made.

\section{GURLEY RESERVOIR (9DK 4)}

The Gurley Reservoir, controlled by the Farmers Water Development Co., is in sec. 36, T. 44 N., R. 13 W. New Mexico principal meridian. An earth dam 42 feet high and 1,150 feet long creates 3,200 acre-feet of storage with an area of 217 acres. The inlet is a branch of Naturita Canal, which diverts wate: from the headwaters of Beaver Creek in T. 42 N., R. 12 W. Water from the reservoir is released into Maverick Draw and diverted on Norwood Mesa.

As no records of Beaver. Creek or comparable streams are available, no eatimate of water supply has been made.

\section{BUCKEYT RESTEOTR (9DL 5)}

About 1907 the Paradox Valley Irrigated Land \& Development Co. constructed the Buckeye Reservoir as the first unit in a system of three reservoirs designed to store the run-off of the tributary streams of West Paradox Creek, heading in the La Sal Mountains The reservoir is on unsurveyed land in Buckeye Park, about in sec. 2, T. 48 N., R. 20 W. New Mexico principal meridian, within a mile of the Utah line. An earth dam 40 feet high across the lower end of the park creates a storage capacity of 3,000 acre-feet. An inlet ditch 10 miles long diverts water from Deep and Geyser Creeks in Utah and conveys it to the reservoir. Water from the reservoir is released into a tributary of West Paradox Creek, from which it is diverted by the company's ditches for the irrigation of 1,500 acres in West Paradox Valley. The other reservoirs contemplated have not been constructed.

14 For detailed description of construetion see Colorado State Eng. Sixteenth Bienn. Rept., p. 103, 1913, $46013-29-6$ 


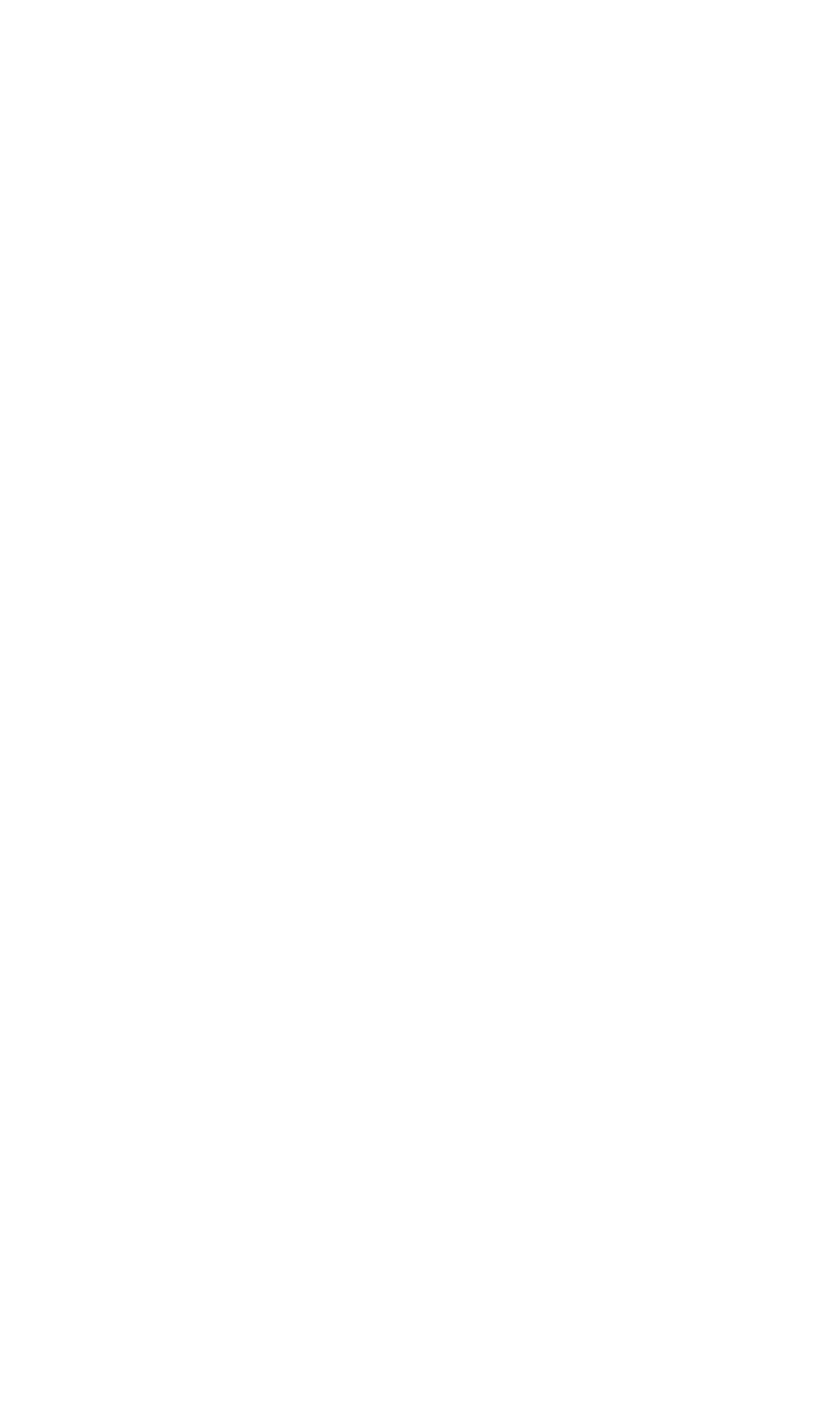




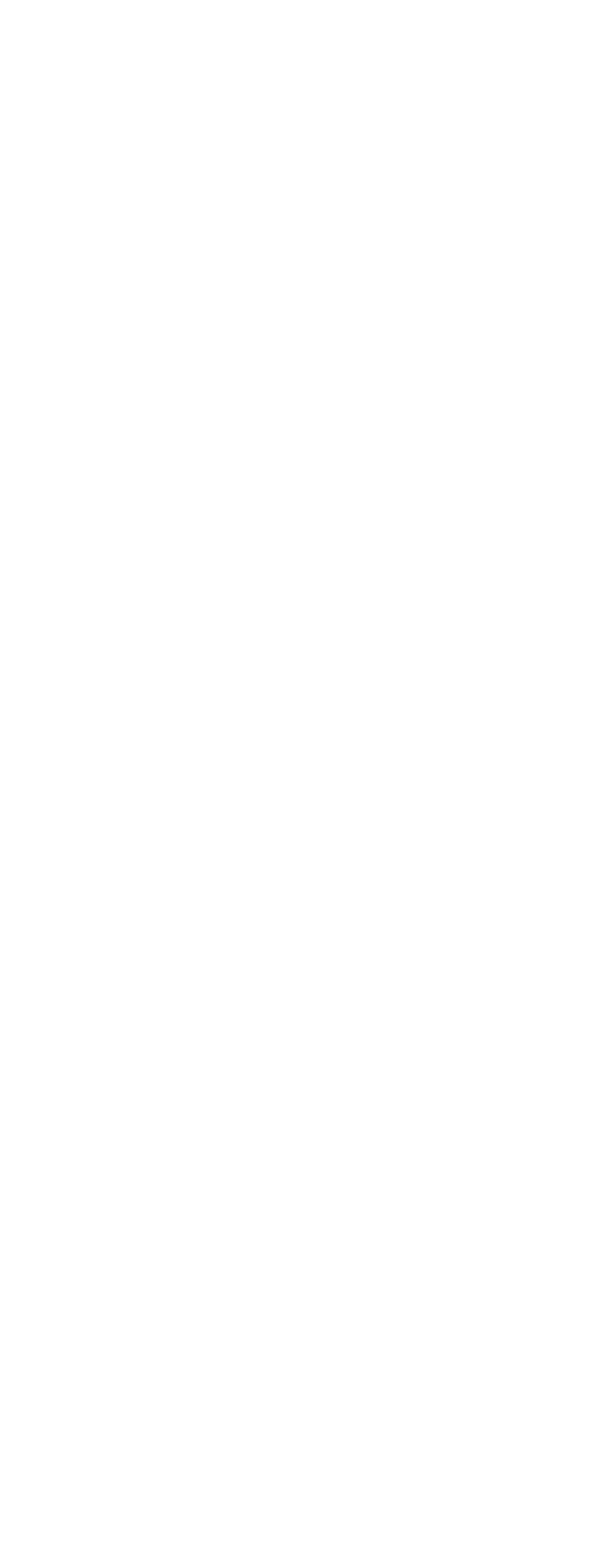




\section{UNDEVELOPED SITES}

Owing to the narrow, steep-sided valleys through which most of the streams of this area flow, large reservoir sites are scarce. There are, however, many sites of small and moderate capacity. During the last 25 years engineering organizations have been actively engaged in surveying possible and impossible reservoir sites in the upper Colorado River Basin. As there are a great many sites ranging in capacity from a few acre-feet to 50,000 acre-feet and a few still larger, it has been necessary to set an arbitrary lower limit upon the size of those to be considered in this report. A study has been mado. of the sites whose capacity exceeds 4,000 acre-feet and of the available water supply, and a few of the sites were examined in the field. The sites that are considered feasible, in a liberal sense of the term, are discussed in the following pages. For each site the available. water supply at the intake is estimated, but for some sites the estimate does not take into account prior rights to the water, the effect of which may vary according to the actual use of the reservoir. Theprobable use, so far as it can be foreseen at this time, is diseussed, and for many of the sites detailed studies of the effect upon irrigation. or power development are presented. The description of feasible sites is followed by a summary of surveyed sites that are considered unfeasible.

\section{THE MAIN RIVER}

The topography along the main river is favorable for storage at. seven sites-Maxwell, Hine No. .2, Park, Kremmling, Hartman, Dotsero, and Dewey. The presence of a railroad through the Park and Kremmling sites makes their feasibility questionable. No usefor the Maxwell site is apparent, and the cost of relocating the railroads that run through the Hartman and Dotsero sites makes thosesites unfeasible.

HINE NO. 2 (WHANT) STIE (2DA 2)

Location.-In the valleys of the Colorado River and Armpaho and Stillwater Creeks; the dam site is in the F. 1/2 sec. 11, T. 2. N., R. 76 W. sixth principal meridian, 6 miles northeast of Granby. (See pl. 2.)

Description.-Near the southwest corner of the Rocky Mountain National Park the Colorado River emerges from a narrow valley and flows for a distance of 1 mile across a basin which extends for 6 miles at right angles to the courseof the river and through which flow Arapaho and Stillwater Creeks to join the Colorado. After crossing this basin the river again enters a short canyon, in which is the dam site. There is a possible spillway 1 mile south west of the dam. site.

Dam site.-The width of the proposed dam is 60 feet at the water surface, 210 feet at a height of 100 feet, and gradually increasing to 630 feet at a height of 175 feet. Four borings made at the dam site show that bedrock lies from 30 ; to 60 feet below the surface; the overlying material consists of sand and boulders.

Capacity. - The Central Colorado Power Co. made a topographic survey of the reservoir site in 1906, and from that survey the following table has been computed: 


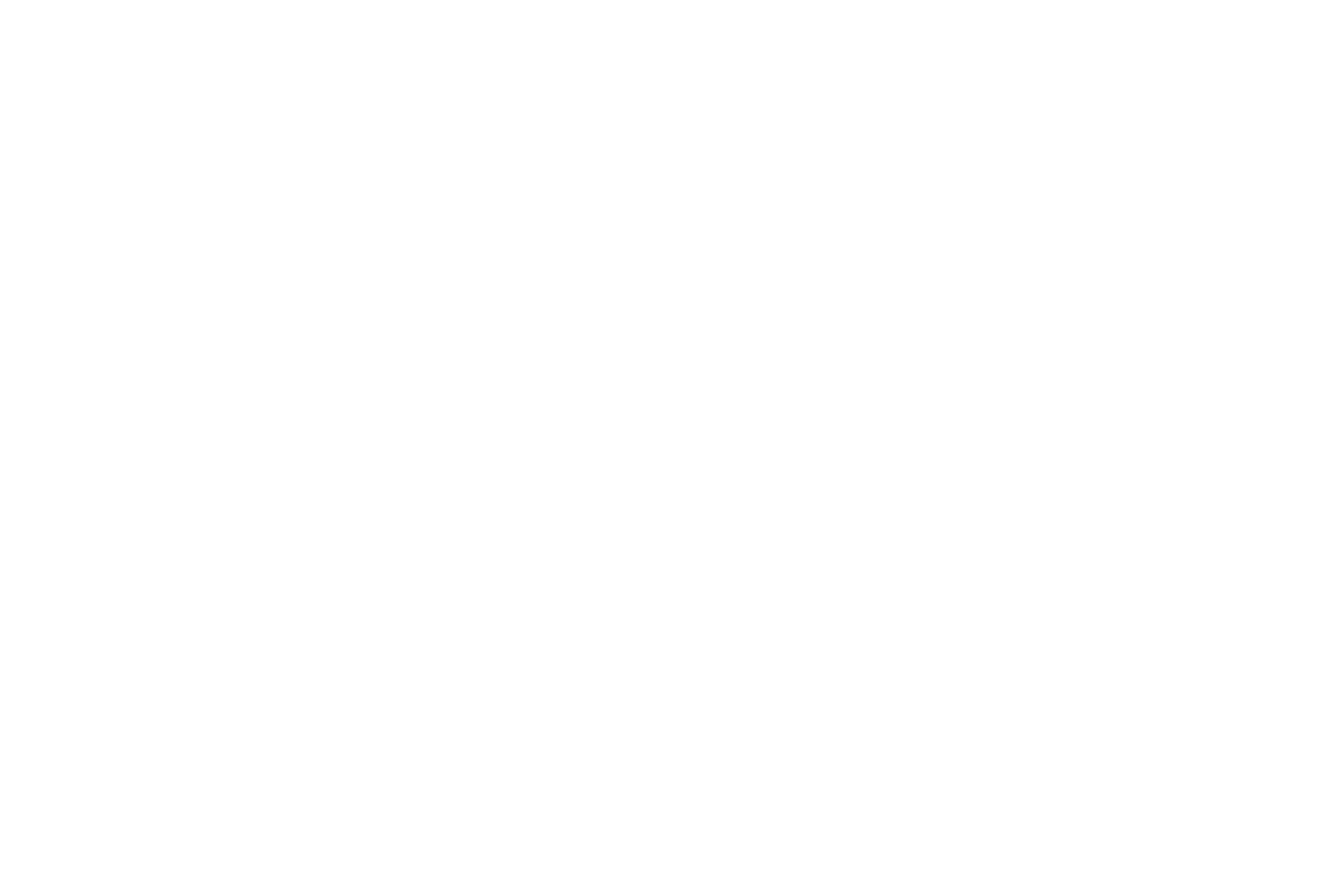


Area and capacity of Hine No. 2 Reservoir for different heights of dam

\begin{tabular}{|c|c|c|c|c|c|}
\hline $\begin{array}{l}\text { Hoight } \\
\text { above } \\
\text { outlet } \\
\text { (feot) }\end{array}$ & $\begin{array}{c}\text { Area } \\
\text { (acres) }\end{array}$ & $\begin{array}{c}\text { Total ca- } \\
\text { pacity } \\
\text { (acre-feet) }\end{array}$ & $\begin{array}{c}\text { Height } \\
\text { above } \\
\text { outlet } \\
\text { (feet) }\end{array}$ & $\begin{array}{c}\text { Area } \\
\text { (acres) }\end{array}$ & $\begin{array}{c}\text { Total ca- } \\
\text { pacity } \\
\text { (acso-foet) }\end{array}$ \\
\hline $\begin{array}{r}20 \\
40 \\
60 \\
80 \\
100\end{array}$ & $\begin{array}{r}39 \\
148 \\
280 \\
530 \\
1,390\end{array}$ & $\begin{array}{r}384 \\
2,090 \\
6,330 \\
14,100 \\
32,100\end{array}$ & $\begin{array}{l}120 \\
140 \\
160 \\
165\end{array}$ & $\begin{array}{l}2,600 \\
3,390 \\
4,150 \\
4,360\end{array}$ & $\begin{array}{r}71,800 \\
132,000 \\
209,000 \\
230,000\end{array}$ \\
\hline
\end{tabular}

Water supply.-Records of the Colorado River near Granby, a short distance downstream, are available from June, 1908, to July, 1911; and at Hot Sulphur Springs from August, 1904, to September, 1909; October, 1910, to September, 1924, and May, 1926, to September, 1927. By means of the relations in flow at the two points as determined from the overlapping records, the discharge at Hot Sulphur Springs has been referred to the Granby station. These records were then extended back to 1900 by a comparison with the records at Glenwood Springs. The mean annual discharge thus determined is 265,000 acre-feet. (For the percentage variation in discharge of the Colorado River, see p. 44.)

Probable use.-The principal use of this reservoir appears to be the development of power on the Colorado River. The survey of the reservoir site indicates a capacity of 230,000 acre-feet, which is very nearly the mean annual discharge of the stream (265,000 acre-feet). To obtain additional storage the Hine No. 1 site, on the Williams River (see p. 81), which has a capacity of 75,000 acre-feet at a point where the mean annual run-off is 139,000 acre-feet, has also been considered. These two reservoirs give a total capacity of 305,000 acre-feet. Had they been constructed and operated for the purpose of maintaining a uniform flow at Gore Canyon, the chief site on the upper Colorado River, during each low-water seesson from 1892-1900 to 1926-27, the discharges indicated in the following table could have been obtained. In preparing this table an allowance was made for evaporation losses.

Rates of uniform discharge at Gore Canyon during low-water periods, 1899-1900 to 1926-27, if Hine Nos. 1 and 2 storage sites had been operated

\begin{tabular}{|c|c|c|c|c|}
\hline \multirow{2}{*}{ Period } & \multirow{2}{*}{$\begin{array}{c}\text { A vailable } \\
\text { storage } \\
\text { (acre- } \\
\text { feet) }\end{array}$} & \multicolumn{2}{|c|}{$\begin{array}{l}\text { Available water } \\
\text { supply (acre-feet) }\end{array}$} & \multirow{2}{*}{$\begin{array}{l}\text { Uniform } \\
\text { discharge } \\
\text { at Gore } \\
\text { Canyon } \\
\text { (second- } \\
\text { feet) }\end{array}$} \\
\hline & & Surplus & $\begin{array}{l}\text { De } \\
\text { en }\end{array}$ & \\
\hline 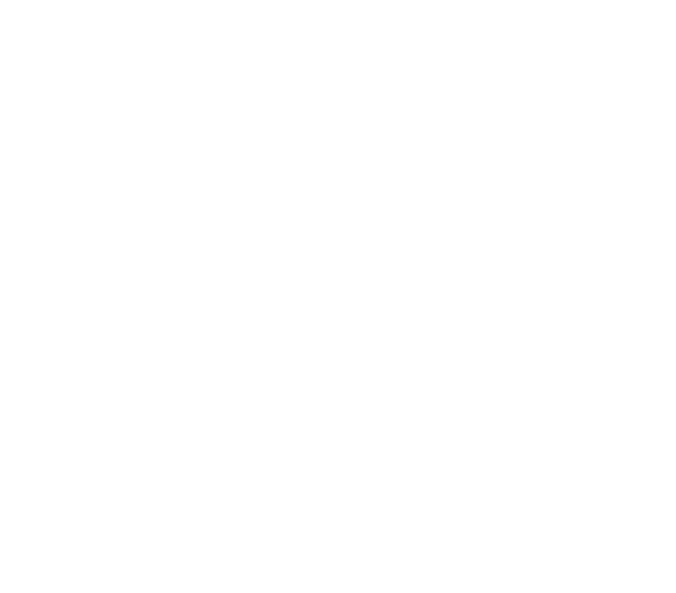 & $\begin{array}{l}305,000 \\
255,000 \\
267,000 \\
154,000 \\
246,000 \\
279,000 \\
280,000 \\
305,000 \\
305,000 \\
197,000 \\
305,000 \\
201,000 \\
284,000 \\
305,000 \\
215,000 \\
305,000 \\
255,000 \\
271,000 \\
305,000 \\
305,000 \\
161,000 \\
305,000 \\
305,000 \\
206,000 \\
305,000 \\
270,000 \\
222,000 \\
305,000\end{array}$ & $\begin{array}{r}122,000 \\
96,000 \\
18,000 \\
134,000 \\
130,000 \\
104,000 \\
92,000 \\
20,000 \\
29,700\end{array}$ & \begin{tabular}{r}
0 \\
50,000 \\
38,000 \\
151,000 \\
59,000 \\
26,000 \\
25,000 \\
\hdashline 108,000 \\
104,000 \\
21,000 \\
90,000 \\
50,000 \\
34,000 \\
144,000 \\
99,000 \\
35,000 \\
82,000 \\
\end{tabular} & $\begin{array}{r}1,230 \\
961 \\
1,160 \\
729 \\
1,060 \\
1,120 \\
1,070 \\
1,390 \\
1,180 \\
890 \\
1,410 \\
950 \\
1,210 \\
1,330 \\
1,100 \\
1,200 \\
1,070 \\
1,170 \\
1,210 \\
1,270 \\
807 \\
1,220 \\
1,250 \\
913 \\
1,300 \\
1,070 \\
1,030 \\
1,150\end{array}$ \\
\hline
\end{tabular}


With the regulation above indicated the discharges for 90 per cent and 50 per cent of the time at Gore Canyon would have been 935 and 1,220 second-feet, respectively. The only proposed transmountain diversion above the two reservoirs is that from the Williams River, amounting to 25,600 acre-feet annually. The run-off at Hine No. 1 site, on the Williams River, is so much in excess of the storage capacity that the effect of this diversion when finally made will be practically unnoticed. The available power at the principal sites on the Colorado River would have been as follows: Available power at principal sites on Colorado River with storage at Hine Nos. 1 and $\mathrm{Z}$
reservoir sites

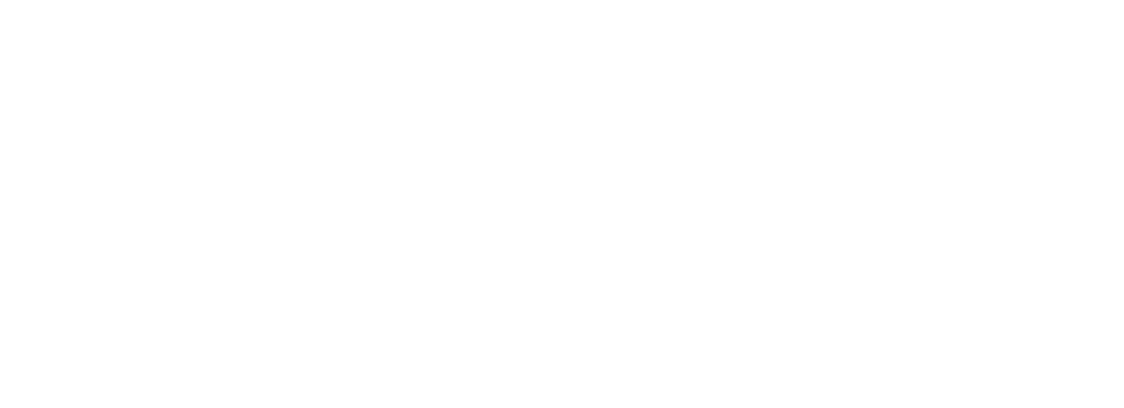

Location.-In the valleys of the Colorado and Fraser Rivers, extending from the dam site at Windy Gap, in the E. $1 / 2$ sec. 27, T. 2 N., R. 77 W. sixth principal meridian, $1 \%$ miles below the mouth of the Fraser River, to a point 6 miles upstream on the Colorado and 4 miles on the Fraser.

Description.-At a point 3 miles below the dam for Hine- No. 2 Reservoir the. Colorado River emerges from a canyon and flows for a distance of nearly 8 miles across a broad valley, which at Windy Gap is terminated by narrowing to a short canyon 300 feet wide. The Fraser River. Valley within the reservoir site contains 1,500 acres of irrigated land, on which native hay and head lettuce are raised. It is traversed by the Denver \& Salt Lake Railroad, which passes through Windy Gap.

Dam site.-The abutment at the dam site is a coarse conglomerate, the strata of which are tilted to a nearly vertical position. The right bank is a high, steep rock wall, and the left bank consists of alternate slopes and vertical escarpments. At 60 feet above the river the dam would be 812 feet long.

Capacity.-From a filing in the State engineer's office made in 1907 the following table has been computed:

Area and capacity of Park Reservoir for different depths

\begin{tabular}{|r|r|r|r|r|r|}
\hline $\begin{array}{c}\text { Depth } \\
\text { (feet) }\end{array}$ & $\begin{array}{c}\text { Area } \\
\text { (acres) }\end{array}$ & $\begin{array}{c}\text { Capacity } \\
\text { (acre-feet) }\end{array}$ & $\begin{array}{r}\text { Depth } \\
\text { (feet) }\end{array}$ & $\begin{array}{c}\text { Area } \\
\text { (acres) }\end{array}$ & $\begin{array}{c}\text { Capacity } \\
\text { (acre-feet) }\end{array}$ \\
\hline & 178 & 1,390 & 100 & 2,760 & 83,000 \\
20 & 466 & 8,070 & 120 & 3,960 & 153,000 \\
40 & 970 & 22,400 & 140 & 5,340 & 248,000 \\
60 & 1,740 & 46,200 & 150 & 6,000 & 300,000 \\
\hline 80 & & \\
\hline
\end{tabular}

Water supply.-Records of the Colorado River at Hot Sulphur Springs, a few miles below Windy Gap, give practically the discharge at the proposed reservoir. These records, which cover 21 years (1905-1909, 1911-1924, 1926-1927), show a mean annual rum-off of 578,000 acre-feet. Comparison with the 28 -year record 
at Glenwood Springs indicates that the mean for that period is 96 per cent of that covered by the records at Hot Sulphur Springs, or 555,000 acre-feet. Deducting the transmountain diversion of 90,000 acre-feet from the Fraser River (p. 55) leaves a future mean annual run-off of 465,000 acre-feet.

Probable use.-The chief use of the reservoir appears to be the development of power on the Colorado River. The survey of the site indicates a capacity of 300,000 acre-feet. As the mean annual run-off with transmountain diversions from the Fraser River is 465,000 acre-feet the reservoir capacity would not be sufficient to store all the available flow, but information is not at hand to show whether its capacity could be increased. Had the reservoir been constructed for a capacity of 300,000 acre-feet and operated for the purpose of maintaining a uniform flow at Gore Canyon, the chief power site on the upper Colorado River, during each low-water season from 1899-1900 to 1926-27, the discharges indicated below could have been obtained. In preparing this table an allowance has been made for evaporation losses.

Rates of uniform discharge at Gore Canyon during low-water seasons from 1899-1900 to 1926-27, if Park storage site had been operated

\begin{tabular}{|c|c|c|c|c|}
\hline \multirow{2}{*}{ Period } & \multirow{2}{*}{$\begin{array}{l}\text { Available } \\
\text { storage } \\
\text { (acre-feet) }\end{array}$} & \multicolumn{2}{|c|}{$\begin{array}{l}\text { Available water supply } \\
\text { (acre-feet) }\end{array}$} & \multirow{2}{*}{$\begin{array}{l}\text { Uniform fiow } \\
\text { at Core } \\
\text { Canyon } \\
\text { (second-feet) }\end{array}$} \\
\hline & & Surplus & Deficiency & \\
\hline 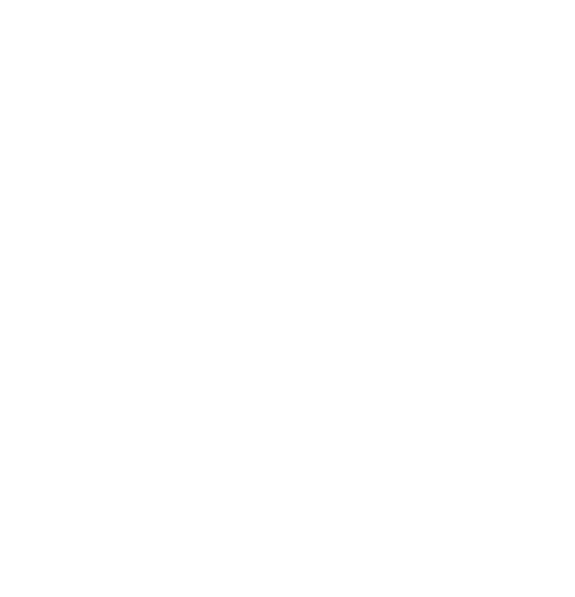 & $\begin{array}{l}300,000 \\
249,000 \\
272,000 \\
157,000 \\
236,000 \\
279,000 \\
300,000 \\
300,000 \\
300,000 \\
212,000 \\
300,000 \\
200,000 \\
300,000 \\
300,000 \\
253,000 \\
300,000 \\
268,000 \\
300,000 \\
300,000 \\
300,000 \\
217,000 \\
300,000 \\
300,000 \\
218,000 \\
300,000 \\
300,000 \\
189,000 \\
300,000\end{array}$ & $\begin{array}{r}0 \\
47,000 \\
111,000 \\
200,000 \\
148,000 \\
156,000 \\
213,000 \\
14,000 \\
175,000 \\
143,000 \\
160,000 \\
178,000 \\
68,000 \\
16,000 \\
162,000\end{array}$ & $\begin{array}{r}0 \\
51,000 \\
28,000 \\
143,000 \\
64,000 \\
21,000 \\
88,000 \\
100,000 \\
47,000 \\
32,000 \\
\end{array}$ & $\begin{array}{r}1,230 \\
950 \\
1,050 \\
729 \\
998 \\
1,100 \\
1,100 \\
1,400 \\
1,170 \\
910 \\
1,400 \\
934 \\
1,220 \\
1,320 \\
1,160 \\
1,180 \\
1,110 \\
1,250 \\
1,200 \\
1,260 \\
897 \\
1,210 \\
1,230 \\
927 \\
1,280 \\
1,140 \\
961 \\
1,080\end{array}$ \\
\hline
\end{tabular}

With the regulation above indicated the discharge at Gore Canyon for 90 per cent and 50 per cent of the time would have been 927 and 1,230 second-feet, respectively. The available power at the principal sites on the Colorado River would have been as follows:

Available power at principal sites on Colorado River with storage at Park Reservoir site

\begin{tabular}{|c|c|c|c|c|c|}
\hline \multirow{3}{*}{ Site } & \multirow{3}{*}{$\begin{array}{l}\text { Total } \\
\text { head } \\
\text { (feet) }\end{array}$} & \multicolumn{4}{|c|}{ Ruu-off and available power } \\
\hline & & \multicolumn{2}{|c|}{90 per cent of the } & \multicolumn{2}{|c|}{$\begin{array}{l}50 \text { per cent of the } \\
\text { time }\end{array}$} \\
\hline & & $\begin{array}{l}\text { Second- } \\
\text { feet }\end{array}$ & $\begin{array}{l}\text { Horse- } \\
\text { power }\end{array}$ & $\begin{array}{l}\text { Second- } \\
\text { feet }\end{array}$ & $\begin{array}{l}\text { Horse- } \\
\text { power }\end{array}$ \\
\hline $\begin{array}{l}\text { Gore Canyon. } \\
\text { Glenwood Springs }\end{array}$ & $\begin{array}{l}500 \\
205\end{array}$ & $\begin{array}{r}927 \\
1,340\end{array}$ & $\begin{array}{l}37,100 \\
22,000\end{array}$ & $\begin{array}{l}1,230 \\
1,870\end{array}$ & $\begin{array}{l}49,200 \\
30,700\end{array}$ \\
\hline
\end{tabular}


Without transmountain diversion the 90 per cent flow would be increased 100 second-feet, but the 50 per cent flow would be practically the same.

\section{KREHMTITG SITR (ODA 4)}

Location.-In the valley of the Colorado River in Middle Park, extending from Gore Canyon, in the SW. $1 / 4$ sec. 23, T. 1 N., R. 81 W. sixth principal meridian, to a point above the mouth of the Williams River, up the Blue River for an airline distance of 8 miles, and up Muddy Creek a distance of 11 miles.

Description.-The following description of the reservoir site has been given by Matthes: 15

"After a turbulent course as a mountain stream through the chasms and narrow valleys of the upper watershed, Grand [Colorado] River emerges into this large basinlike valley as a sluggish river, and its quiet waters present a strange contrast to the torrents of its upper course. In its tortuous channel it winds through vast stretches of meadow lands, with scarcely a riffle for many miles, flowing in a general westerly direction toward the massive Gore or Park Range of mountains, then to disappear suddenly into the stupendous chasm known as Gore Canyon. Here the stream resumes its former torrential aspect. For $3 \frac{1}{2}$ miles, the length of Gore Canyon, the fall averages 100 feet to the mile. Below this canyon the river widens and its fall becomes more normal."

Within the reservoir site is the town of Kremmling (population 264) and through the entire length runs the Denver \& Salt Lake Railroad. The higher bench lands subject to overflow are covered chiefly with sagebrush and native grasses and have but little value. The bottom lands are used to produce native hay and are occupied by ranches. Irrigation of these lands is accomplished mainly by natural flooding, which occurs during each high-water period.

Dam site.-In the first half mile of the canyon there are four possible dam sites within a distance of 1,000 feet. The two upper sites afford good opportunities for constructing spillways on the left bank. The lower sites are in the deeper portion of the canyon, where the walls rise nearly vertically to a height of 500 feet. Spillways at these sites can be provided only by tunneling through the canyon walls. The four sites have practically the same dimensions, being about 150 feet wide at the water surface and 300 feet wide at a height of 200 feet. The canyon walls, which are composed of dark-colored gneiss intersected by white veins of quartz, are rent by many fissures and cleavage planes. Borings with a diamond drill showed bedrock to be 96 feet below the stream bed at the upper sites and 80 feet at the lower sites. This rock is like that in the canyon walls, except that it is exceptionally sound, close-grained, hard, and free from seams or cracks. The strata are tilted to a nearly vertical position, and in places the rock is schist.

Capacity. - A detailed survey of the reservoir site was made in 1905 by the Reclamation Service, and from that survey the following table ${ }^{15}$ was computed:

Area and capacity of Kremmling Reservoir at different altitudes

\begin{tabular}{|c|c|c|c|c|c|c|c|}
\hline \multirow{2}{*}{$\underset{\text { feet }}{\text { Altitude }}$} & \multirow{2}{*}{$\begin{array}{c}\text { Area } \\
\text { (acres) }\end{array}$} & \multicolumn{2}{|c|}{ Capacity (acre-feet) } & \multirow{2}{*}{$\underset{\text { feet }}{\text { Altitude }}$} & \multirow{2}{*}{$\begin{array}{c}\text { Area } \\
\text { (acres) }\end{array}$} & \multicolumn{2}{|c|}{ Capacity (acre-feet) } \\
\hline & & Section & Total & & & Section & Total \\
\hline $\begin{array}{l}7,285 \\
7,300 \\
7,320 \\
7,340 \\
7,360 \\
7,380 \\
7,400\end{array}$ & $\begin{array}{r}0 \\
14 \\
2,111 \\
5,155 \\
6,998 \\
8,948 \\
10,948\end{array}$ & $\begin{array}{r}0 \\
140 \\
21,250 \\
72,660 \\
121,535 \\
159,465 \\
198,965\end{array}$ & $\begin{array}{r}0 \\
140 \\
21,390 \\
94,050 \\
215,585 \\
375,050 \\
574,015\end{array}$ & $\begin{array}{l}7,420 \\
7,440 \\
7,450 \\
7,460 \\
7,480 \\
7,500\end{array}$ & $\begin{array}{l}12,811 \\
14,739 \\
15,805 \\
17,103 \\
19,737 \\
22,920\end{array}$ & $\begin{array}{l}237,600 \\
275,505 \\
152,720 \\
\mathbf{1 6 4}, 540 \\
\mathbf{3 6 8}, \mathbf{4 0 5} \\
426,565\end{array}$ & $\begin{array}{r}811,615 \\
1,087,120 \\
1,239,840 \\
1,404,380 \\
1,772,785 \\
2,199,350\end{array}$ \\
\hline
\end{tabular}

" Matthes, G. H., Kremmling reservoir site: U. S. Recl. Service Fourth Ann. Rept., p. 121, 1906. 1sa Idem, p. 123. 
Water supply.-Records of the Colorado River near Kremmling, just above the entrance to Gore Canyon, are available from 1904 to 1918 , and by comparion of simultaneous records at Kremmling and Glenwood Springs subsequent to 1904 the Kremmling records have been extended back to 1900 and forward to 1927 , The following table shows the annual run-off at the Kremmling Reservoir site as computed from these records:

Annual run-off at Kremmling Reservoir site, 1900-1927

\begin{tabular}{|c|c|c|c|c|c|}
\hline - Year & Acre-feet & $\begin{array}{c}\text { Per cent } \\
\text { of mean }\end{array}$ & Year & Acre-fe日t & $\begin{array}{l}\text { Per cont } \\
\text { of meap }\end{array}$ \\
\hline 1900 & $\begin{array}{r}1,100,000 \\
1,100,000 \\
755,000 \\
987,000 \\
1,080,000 \\
1,100,000 \\
1,320,000 \\
1,620,000 \\
891,000 \\
1,660,000 \\
930,000 \\
1,180,000 \\
1,760,000 \\
1,070,000\end{array}$ & $\begin{array}{r}90 \\
90 \\
62 \\
81 \\
88 \\
90 \\
108 \\
133 \\
73 \\
136 \\
76 \\
97 \\
144 \\
88\end{array}$ & $\begin{array}{l}1915 \\
1916 \\
1917 \\
1918 \\
1920 \\
1921 \\
1922 \\
1923 \\
1924 \\
1925 \\
1928\end{array}$ & $\begin{array}{r}1,000,000 \\
1,2000,000 \\
1,630,000 \\
1,590,000 \\
798,000 \\
1,350,000 \\
1,440,000 \\
987,000 \\
1,250,000 \\
1,090,000 \\
986,000 \\
1,280,000 \\
1,200,000\end{array}$ & $\begin{array}{r}82 \\
98 \\
134 \\
130 \\
66 \\
111 \\
138 \\
81 \\
102 \\
80 \\
81 \\
105 \\
98\end{array}$ \\
\hline 1914 & $\overrightarrow{1}, 720,000$ & 141 & Mean_-n_........ & $1,220,000$ & $\cdots$ \\
\hline
\end{tabular}

If the proposed transmountain diversions are mixdel(p. 59 ) the mes ianntial run-off will be $1,000,000$ acre-feet:

Probable use.-The principal use of this reservoir appears to be for the development of power on the Golorado River, chiefly: in Gore Canyon and above Glen: wood Springs. A mass eurve shows that with the proposed transmountain diversions the maximum capacity required to equalize the annual flow of the Colorado River would be 940,000 acre-feet. . If the feservoir were constructed. for that capacity it would be drawn down to such an extent that the head on the dam for 90 per cent of the time would be about 50 feet. The rates of uniform draft that could have been obtained since 1900 are shown in the following table in which an allowance of $\mathbf{5 0}$ second-feet has been made for evaporation losses:

Rates of uniform draft that would have been possible at Kremmling Reservoir, $1900-1927$

Second-feet

July, 1900, to June, 1905 ..... 1, 200

July, 1905, to June, 1907 ..... 1, 200

July, 1907, to June, 1909_... _ _ 1, 370

July, 1909, to June, $1912 \ldots \ldots 1,370$

July, 1912, to June, 1914_..... 1, 530

Second-feet

July, 1914, to June, 1918 . . . . . 1, 470

July, 1918, to July, 1921....... 1, 310

August, 1921, to June, 1924_... 1, 230

July, 1924, to July, 1927_...... 1, 180

The discharges for 90 per cent and 50 per cent of the time would have been 1,180 and 1,310 second-feet, respectively. The available power at the principal sites on the river would have been as follows:

Available power at principal sites on Colorado River with storage at Kremmling Reservoir site

\begin{tabular}{|c|c|c|c|c|c|c|}
\hline \multirow{3}{*}{, } & \multirow{3}{*}{ Site } & \multirow{3}{*}{$\begin{array}{l}\text { Total } \\
\text { head } \\
\text { (feet) }\end{array}$} & \multicolumn{4}{|c|}{ Run-off and available power } \\
\hline & & & \multicolumn{2}{|c|}{$\begin{array}{l}90 \text { per cent of the } \\
\text { time }\end{array}$} & \multicolumn{2}{|c|}{$\begin{array}{c}50 \text { per gent of the } \\
\text { time }\end{array}$} \\
\hline & & & $\begin{array}{l}\text { Second- } \\
\text { foet }\end{array}$ & $\begin{array}{l}\text { Horse- } \\
\text { power }\end{array}$ & $\begin{array}{l}\text { Second- } \\
\text { foet }\end{array}$ & $\begin{array}{l}\text { Horse- } \\
\text { power : }\end{array}$ \\
\hline $\begin{array}{l}\text { Gore Cany } \\
\text { Glenwood }\end{array}$ & . & $\begin{array}{r}535 \\
205\end{array}$ & $\begin{array}{r}\cdot 1,180 \\
-1,610\end{array}$ & $\begin{array}{l}50,600 \\
26,400\end{array}$ & $\begin{array}{l}1,310 \\
1,980\end{array}$ & $\begin{array}{r}57,200 \\
-32,400\end{array}$ \\
\hline
\end{tabular}

- For 50 per cent of the time the total head is 546 feet. 


\section{DEWEY STTR (ODX 1) 16}

Location.-In the channel of the Colorado River, extending from the dam site in sec. 7, T. 23 S., R. 24 E. Salt Lake principal meridian, about 3 miles below the mouth of the Dolores River, to the mouth of the Little Dolores River, near the Utah-Colorado line. (See pl. 3.)

Description.-The main body of the reservoir is formed by a large basin extending east and west for 8 miles, the lowest part of which is occupied by Sagers Wash. The Colorado River, emerging from a narrow canyon, cuts through the east end of the basin and again enters a canyon, through which it flows for 5 miles before reaching the upper dam site. The Dolores River enters this canyon 3 miles above the upper dam site. The only cultivated land in the entire reservoir site is a small amount in the canyon section itself, the land in the basin of Sagers Wash not being arable.

Dam site.-Three possible dam sites exist within a distance of $1 \frac{1}{2}$ miles in the canyon section. The formation is hard red sandstone in layers that dip slightly to the north, with the result that at the upper site the dip is upstream, but at the middle and lower sites, owing to the bend of the river, the beds are nearly level. Within the sandstone are a few seams of hard shale. At the upper site, which appears to be the best, the canyon walls are 240 feet high, the right wall is nearly vertical, and the left wall has a $60^{\circ}$ slope. The canyon is free from talus at this site, and the bottom width is 400 feet. The top width is about 1,000 feet. At the middle site, half a mile downstream, the canyon walls are nearly vertical, 600 feet high on the right side and 400 feet high on the left side. The lower site, 1 mile farther downstream, also has nearly vertical walls between $\$ 300$ and 400 feet high. At the upper site seven holes were bored into bedrock, which was found at an average depth of 40 feet below the stream bed, the greatest distance being 44 feet. The bedrock is a hard fine-grained sandstone, apparently similar to that of the canyon walls.

Capacity.-The canyon portion of the site was surveyed by the United States Geological Survey in 1912, and the Sagers Wash Basin and Dolores Basin were surveyed by the Bureau of Reclamation in 1917. From these combined surveys the following table has been computed:

Area and capacity of. Dewey Reservoir at different altitudes

\begin{tabular}{|c|c|c|c|c|c|}
\hline$\underset{\text { (feet) }}{\text { Altitude }}$ & $\begin{array}{c}\text { Area } \\
\text { (acres) }\end{array}$ & $\begin{array}{l}\text { Capacity } \\
\text { (acre-feet) }\end{array}$ & $\underset{\text { (feet) }}{\text { Altitude }}$ & $\begin{array}{c}\text { Area } \\
\text { (acres) }\end{array}$ & $\begin{array}{c}\text { Capacity } \\
\text { (acre-feet) }\end{array}$ \\
\hline $\begin{array}{l}4,087 \\
4,125 \\
4.150 \\
4.175 \\
4,200\end{array}$ & $\begin{array}{r}0 \\
2,100 \\
4,800 \\
7,200 \\
10,000\end{array}$ & $\begin{array}{r}0 \\
40,000 \\
120,000 \\
270,000 \\
500,000\end{array}$ & $\begin{array}{l}4,225 \\
4,250 \\
4,275 \\
4,300\end{array}$ & $\begin{array}{l}13,500 \\
17,300 \\
21,800 \\
27,000\end{array}$ & $\begin{array}{r}810,000 \\
1,190,000 \\
1,620,000 \\
2,270,000\end{array}$ \\
\hline
\end{tabular}

The altitude of 4,300 feet is about the upper limit of storage without flooding the Denver \& Rio Grande Western Railroad track. Water would also be backed' up the canyon of the Dolores River for a distance of 20 miles. Although the reservoir survey has not been carried above an altitude of $4,300 \mathrm{feet}$, it is believed that at 4,350 feet the capacity would be about 4,000,000 acre-feet. This would necessitate raising from 5 to 7 miles of railroad track about 50 feet in the canyon section and relocating about 10 miles of track outside the canyon section.

Water supply.-Records of the Colorado River near Cisco, taken in the reservoir site, are available from 1915 to 1917 and 1923 to 1927 , and in addition records are available for 1914. near Moab, 25 miles downstream, where the run-off

16 Description and estimates of capacity based on unpublished reports of Bureau of Reclamation. 


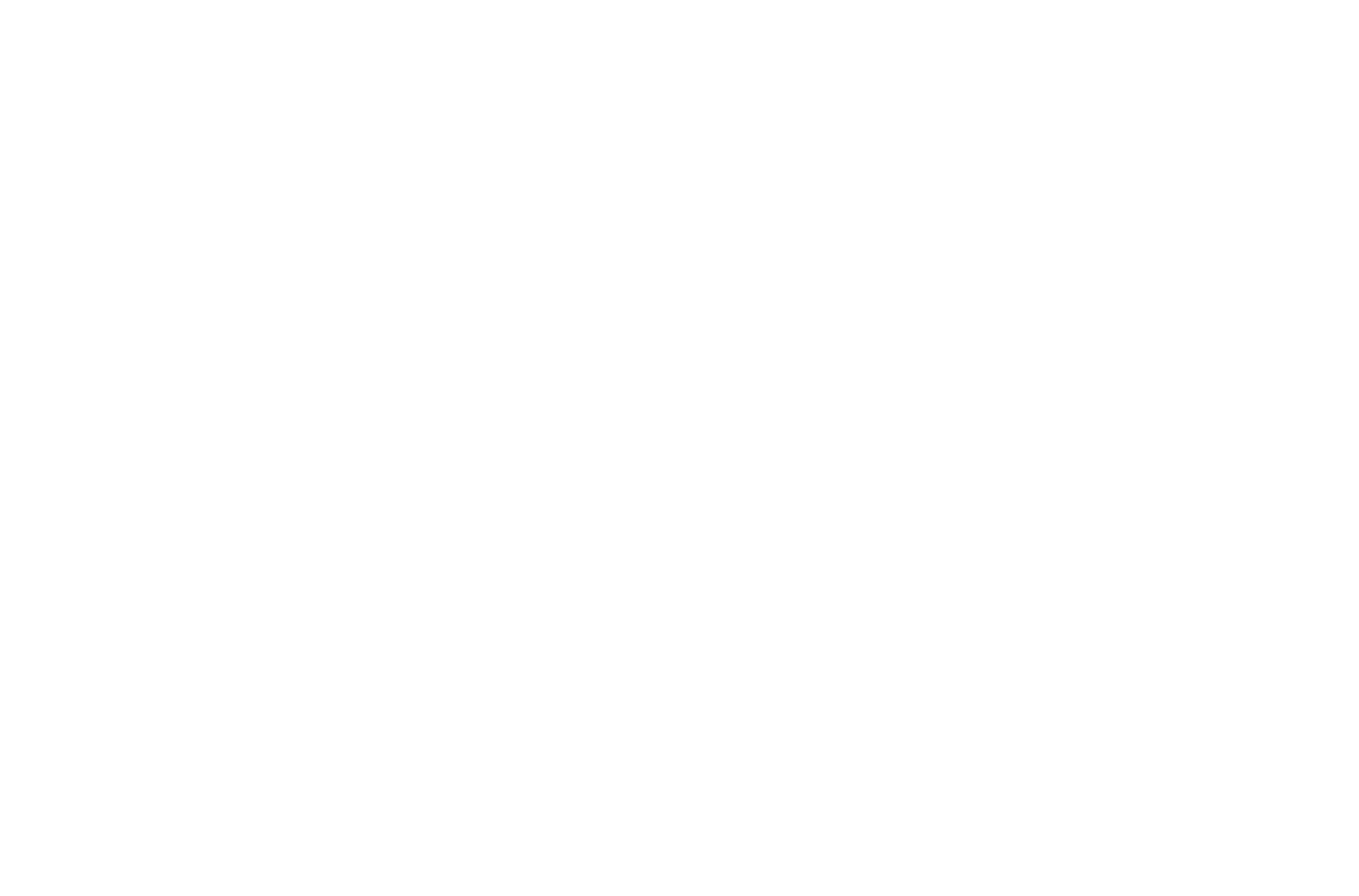


$-\ldots-$ 
is comparable. For the years 1918 to 1922 the discharge has been estimated, being based on records of the Colorado River near Fruita, the Dolores River at Bedrock, San Miguel River at Naturita, and a small allowance for minor tributaries. The following table shows the annual run-off at the reservoir site:

Annual run-off at Dewey Reservoir site, 1914-1927

\begin{tabular}{|c|c|c|c|c|c|}
\hline Year & Acre-feet & $\begin{array}{c}\text { Per } \\
\text { cent of } \\
\text { mean }\end{array}$ & Year & Acre-feet & $\begin{array}{l}\text { Per } \\
\text { cent of } \\
\text { mean }\end{array}$ \\
\hline $\begin{array}{l}1914 \\
1915 \\
1916 \\
1918 \\
1919 \\
1920\end{array}$ & $\begin{array}{l}8,530,000 \\
5,350,000 \\
7,500,000 \\
8,760,000 \\
6,600,000 \\
5,080,000\end{array}$ & $\begin{array}{r}120 \\
75 \\
106 \\
123 \\
93 \\
72 \\
128\end{array}$ & $\begin{array}{l}1922 \\
1923 \\
1924 \\
1925 \\
1927\end{array}$ & $\begin{array}{l}7,090,000 \\
7,280,000 \\
5,900,000 \\
5,020,000 \\
6,600,000 \\
7,530,000\end{array}$ & $\begin{array}{r}100 \\
102 \\
83 \\
71 \\
93 \\
106\end{array}$ \\
\hline 1921 & $9,100,000$ & 128 & Mean.- & $7,100,000$ & $\ldots$ \\
\hline
\end{tabular}

The records of the Colorado River near Palisade (p. 42) show that the discharge for the 31-year period, 1897-1927, was 93 per cent of that for the 14-year period, 1914-1927. This indicates that the mean 31-year discharge at the reservoir site was 93 per cent of $7,100,000$ acre-feet, or $6,600,000$ acre-feet.

The future depletion due to transmountain diversions is estimated as 274,000 acre-feet (p. 59), and that due to future extension of irrigation 1,000,000 aere-feet (p. 147), leaving a probable future mean annual run-off of $5,330,000$ acre-feet.

Probable use.-Storage in the Dewey Reservoir will be of value for the development of power and for the refuction of floods in the lower Colorado. Studies have been made for reservoir capacities of $2,270,000$ and 4,000,000 acre-feet. For the smaller capacity, with a use for power alone, the plan of operation sssumed is to draw down the head from 215 to 90 feet. This will regulate the flow except during the high-water months of the wettest years, on the assumption that deductions from the flow are made for evaporation losses, future irrigation (p. 147), and transmountain diversions (p. 59). For the 14-year period for which run-off records are available (1914-1927), the following rates of uniform draft and corresponding power development would have been possible:

Rates of uniform draft and power development that would have been possible at

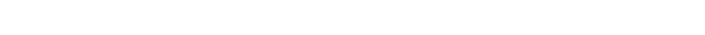

\begin{tabular}{|c|c|c|c|}
\hline \multirow[b]{2}{*}{ Period } & \multirow{2}{*}{$\begin{array}{l}\text { Uniform } \\
\text { draft } \\
\text { (second- } \\
\text { feet) }\end{array}$} & \multicolumn{2}{|c|}{ Horsepower } \\
\hline & & $\begin{array}{l}\text { With } \\
\text { average } \\
\text { head }\end{array}$ & $\underset{\text { minimum }}{\text { Wead }}$ \\
\hline $\begin{array}{l}\text { August, 1913, to June, } 1914 \\
\text { August, 1914, to June, } 1916 \\
\text { August, 1916, to June, } 1917 \\
\text { August, 1917, to June, } 1918 \\
\text { August, 1918, to May, } 1920 \\
\text { August, 1920, to May, } 1921 \\
\text { August, 1921, to May, } 1922 \\
\text { August, 1922, to June, } 1923 \\
\text { August, } 1923 \text {, to June, } 1924 \\
\text { Juy, } 1924, \text { to June, } 1926 \\
\text { August, } 1926 \text {, to June, } 1927\end{array}$ & $\begin{array}{l}\mathbf{7}, 000 \\
6,260 \\
7,670 \\
\mathbf{6}, \mathbf{7 7 0} \\
\mathbf{5}, 670 \\
\mathbf{6}, \mathbf{8 0 0} \\
\mathbf{7 , 4 2 0} \\
\mathbf{5 , 8 4 0} \\
\mathbf{7 , 3 8 0} \\
\mathbf{5 , 4 6 0} \\
\mathbf{6 , 3 1 0}\end{array}$ & $\begin{array}{r}90,200 \\
85,800 \\
104,000 \\
87,200 \\
75,800 \\
88,400 \\
99,800 \\
75,200 \\
100,000 \\
68,100 \\
80,400\end{array}$ & $\begin{array}{r}50,400 \\
45,100 \\
55,200 \\
48,800 \\
40,800 \\
49,700 \\
65,900 \\
42,000 \\
58,200 \\
39,300 \\
45,400\end{array}$ \\
\hline
\end{tabular}

If a portion of the capacity were utilized for flood control, the reservoir would be of yalue bath for flood control and for power. The plan considered for this combined use contemplates reserving the upper 25 feet, or 650,000 acre-feet, for 
flood control, and the next $\mathbf{9 5}$ feet for power regulation, leaving a minimum head: of 95 feet for power. By this arrangement the available power-regulating: capacity $(1,310,000$ acre-feet) is the maximum for which the reservoir will 'refill during the high-water season of dry years, and it would be possible to maintain a uniform discharge during all but the two or three months of highest flow each year, when water would be wasted. The entire available storage of $1,310,000$ acrefeet would be drawn on each year in regulating the discharge. The following table shows the regulated rates of uniform draft and the possible power developments:

- Rates of uniform draft and power development that would have been possible at Dewey Reservoir at altitude of 4,300 feet, 1914-1927, with storage capacity of 650,000 acre-feet for flood prevention

\begin{tabular}{|c|c|c|c|c|c|c|c|}
\hline \multirow{2}{*}{$\begin{array}{c}\text { Year ending } \\
\text { Sept. } 30\end{array}$} & \multirow{2}{*}{$\begin{array}{l}\text { Uniform } \\
\text { draft (sec- } \\
\text { ond-feet) }\end{array}$} & \multicolumn{2}{|c|}{ Horsepower } & \multirow{2}{*}{$\begin{array}{l}\text { Year ending } \\
\text { Sept. } 30\end{array}$} & \multirow{2}{*}{$\begin{array}{l}\text { Uniform } \\
\text { draft (sec- } \\
\text { ond-feet) }\end{array}$} & \multicolumn{2}{|c|}{ Horsepower } \\
\hline & & $\begin{array}{l}\text { With aver- } \\
\text { age head }\end{array}$ & $\begin{array}{l}\text { With mini- } \\
\text { mum head }\end{array}$ & & & $\begin{array}{l}\text { With aver- } \\
\text { age head }\end{array}$ & $\begin{array}{l}\text { With minl:- } \\
\text { mum head }\end{array}$ \\
\hline $\begin{array}{l}1914 \\
1915 \\
1916 \\
1917 \\
1918 \\
1919\end{array}$ & $\begin{array}{l}5,730 \\
5,840 \\
5,080 \\
6,210 \\
5,480 \\
5,180 \\
: 4,620\end{array}$ & $\begin{array}{l}69,200 \\
68,700 \\
58,100 \\
75,500 \\
62,700 \\
59,300 \\
50,600\end{array}$ & $\begin{array}{l}43,500 \\
44,400 \\
38,600 \\
47,200 \\
41,600 \\
39,400 \\
35,200\end{array}$ & $\begin{array}{l}1921 \\
1922 \\
1923 \\
1924 \\
1925 \\
1926\end{array}$ & $\begin{array}{l}5,610 \\
6,120 \\
4,770 \\
6,010 \\
4,450 \\
5,540 \\
4,890\end{array}$ & $\begin{array}{r}64,200 \\
72,000 \\
53,800 \\
\cdot \quad 72,100 \\
51,600 \\
66,500 \\
\quad 55,600\end{array}$ & $\begin{array}{l}42,600 \\
46,500 \\
36,300 \\
45,700 \\
33,800 \\
42,100 \\
37,200\end{array}$ \\
\hline
\end{tabular}

If the reservoir were constructed for a capacity of 4,000,000 acre-feet, it would be of greater value both for power and for flood control. Two plans have been considered in this connection. One is to reserve the upper $1,500,000$ acre-feet of capacity for flood control and the next 2,145,000 acre-feet for power, leaving a minimum head on the dam of 100 feet. The other plan is to reserve the upper $2,000,000$ acre-feet for flood control and the next 1,645,000 acre-feet for power development, leaving a minimum head on the dam of 100 feet.

With the reservation of $1,500,000$ acre-feet for flood control the regulated rates of uniform draft and the possible power developments would have been as follows:

Rates of uniform draft and power development that would have been possible at Dewey Reservoir at altitude of 4,350 feet; 1914-1927; with storage reservation of $1,500,000$ acre-feet for flood control

\begin{tabular}{|c|c|c|c|}
\hline \multirow[b]{2}{*}{ Period } & \multirow{2}{*}{$\begin{array}{l}\text { Uniform } \\
\text { draft } \\
\text { (second- } \\
\text { feet) }\end{array}$} & \multicolumn{2}{|c|}{ Horsepower } \\
\hline & & $\begin{array}{l}\text { With } \\
\text { average } \\
\text { head }\end{array}$ & $\underset{\text { head }}{\text { With }}$ \\
\hline 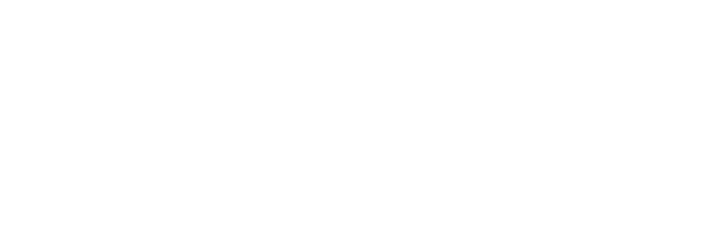 & $\begin{array}{r}7,780 \\
6,510 \\
8,040 \\
7,220 \\
5,820 \\
7,150 \\
7,770 \\
6,220 \\
7,510 \\
5,740 \\
6,630\end{array}$ & $\begin{array}{r}105,000 \\
92,800 \\
113,000 \\
98,200 \\
82,000 \\
96,800 \\
109,000 \\
84,600 \\
109,000 \\
75,300 \\
90,200\end{array}$ & $\begin{array}{r}62,309 \\
52,100, \\
64,409 \\
57,809 \\
46,609 \\
57,200 \\
62,200 \\
49,800 \\
60,100 \\
45,000 \\
53,100\end{array}$ \\
\hline
\end{tabular}

a Only 2,000,000 acre-feet available to refill reservoir.

With the reservation of $2,000,000$ acre-feet for flood control, the regulated: rates of uniform draft and the possible power developments would have been ash follows: 
Rates of uniform draft and power development that would have been possible at Dewey Reservoir at altitude of 4,350 feet, 1914-1927, with starage reservation of $2,000,000$ acre-feet for flood control

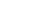

\begin{tabular}{|c|c|c|c|}
\hline \multirow{2}{*}{ Period } & \multirow{2}{*}{$\begin{array}{l}\text { Uniform } \\
\text { draft } \\
\text { (second- } \\
\text { feet) }\end{array}$} & \multicolumn{2}{|c|}{ Horsepower } \\
\hline & & $\begin{array}{l}\text { With } \\
\text { average } \\
\text { head }\end{array}$ & $\begin{array}{l}\text { With } \\
\text { minimum } \\
\text { head }\end{array}$ \\
\hline 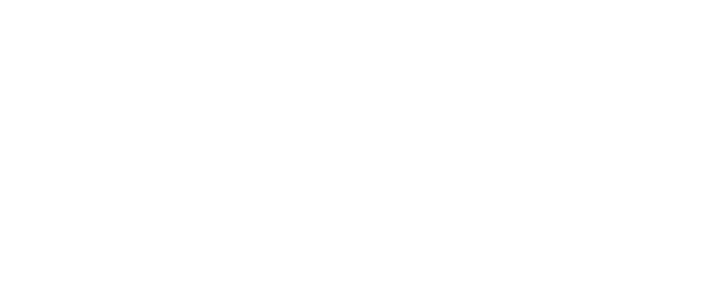 & $\begin{array}{l}6,600 \\
6,350 \\
5,740 \\
7,020 \\
6,340 \\
5,630 \\
5,280 \\
6,240 \\
6,880 \\
5,320 \\
6,790 \\
5,140 \\
5,570\end{array}$ & $\begin{array}{l}83,500 \\
86,400 \\
69,900 \\
90,000 \\
78,100 \\
72,900 \\
63,800 \\
77,500 \\
89,200 \\
64,800 \\
88,500 \\
64,100 \\
68,600\end{array}$ & $\begin{array}{l}53,500 \\
50,800 \\
45,900 \\
56,200 \\
50,700 \\
45,000 \\
42,200 \\
49,900 \\
55,100 \\
42,600 \\
54,300 \\
41,100 \\
44,600\end{array}$ \\
\hline
\end{tabular}

The value of the Dewey site in reducing floods on the lower Colorado may be shown by determining the reduction in flow at the reservoir that would be effected by filling the upper $650,000,1,500,000$, and 2,000,000 acre-feet, and the entire $4,000,000$ acre-feet of capacity during the high-water period, and applying this reduction to the corresponding discharge of the Colorado River at Yuma. To determine the years of greatest flow at Yuma, the time interval and differences between peak flows at the Dewey site and at Yuma, and the rates of peak discharge at the two points, the following table has been compiled:

Yearly peak flow at Yuma and at Dewey site, 1902-1927

\begin{tabular}{|c|c|c|c|c|c|c|c|}
\hline \multirow{2}{*}{ Year } & \multicolumn{2}{|c|}{ Yuma } & \multicolumn{2}{|c|}{ Dewey site } & \multicolumn{2}{|c|}{ Difference * } & \multirow{2}{*}{$\begin{array}{l}\text { Ratio } \\
\text { Dewey } \\
\text { to } \\
\text { Yuma }\end{array}$} \\
\hline & Date & $\begin{array}{l}\text { Second- } \\
\text { feet }\end{array}$ & Date & $\begin{array}{c}\text { Second- } \\
\text { feet }\end{array}$ & Days & $\begin{array}{c}\text { Second- } \\
\text { feet }\end{array}$ & \\
\hline $\begin{array}{l}1902 \\
1903 \\
1904 \\
1906\end{array} 1908$ & 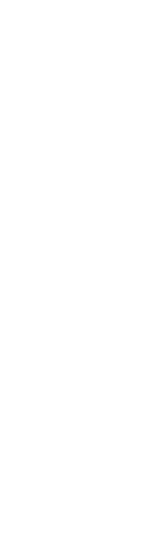 & $\begin{array}{r}59,200 \\
72,200 \\
51,200 \\
111,000 \\
99,200 \\
115,000 \\
61,700 \\
150,000 \\
70,300 \\
78,300 \\
144,000 \\
62,500 \\
137,000 \\
66,200 \\
74,800 \\
143,000 \\
94,300 \\
57,600 \\
175,000 \\
186,000 \\
115,000 \\
100,000 \\
65,800 \\
52,900 \\
73,100 \\
81,200\end{array}$ & 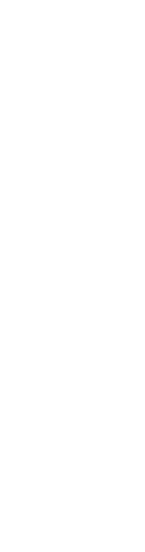 & $\begin{array}{l}31,400 \\
73,000 \\
39,200 \\
44,600 \\
66,900 \\
31,400 \\
66,700 \\
30,900 \\
46,900 \\
73,200 \\
64,500 \\
37,000 \\
79,700 \\
90,100 \\
61,000 \\
47,100 \\
49,900 \\
27,700 \\
47,500 \\
48,400\end{array}$ & $\begin{array}{r}16 \\
18 \\
8 \\
16 \\
12 \\
12 \\
10 \\
8 \\
7 \\
19\end{array}$ & \begin{tabular}{l}
30,300 \\
77,000 \\
$-33,700$ \\
77,100 \\
31,100 \\
70,300 \\
\hdashline-10 \\
\hdashline 60,800 \\
29,800 \\
20,600 \\
95,300 \\
95,900 \\
54,000 \\
52,900 \\
15,900 \\
25,200 \\
25,600
\end{tabular} & $\begin{array}{c}0.51 \\
.49 \\
.57 \\
.47 \\
.50 \\
.40 \\
. .2 \\
.51 \\
.68 \\
.64 \\
.46 \\
.48 \\
.58 \\
.47 \\
.76 \\
.52 \\
.35\end{array}$ \\
\hline
\end{tabular}

. Shown only for years whon peak flow at Dewey site preceded that at Yuma.

Nors.-For the years 1908-1915 and 1910-1922 peak flows at Fruita were inoreased about 15 per cent to represent the discharge at the Dewey site. 
The greatest floods recorded at Yuma occurred in 1920 and 1921. Studies of the effect of the Dewey Reservoir on both floods with flood-storage capacities. of $650,000,1,500,000,2,000,000$, and 4,000,000 acre-feet have been made. From mass curves of the daily discharge at the Dewey site, based on Fruita records. multiplied by factors ranging from 1.12 to 1.17 , the following uniform drafts. on the reservoir to prevent overflow during the high-water periods have been. determined:

Uniform draft from Dewey Reservoir, in second-feet, that would have been necessary. to prevent overflow during 1920 and 19,21

\begin{tabular}{|c|c|c|c|c|}
\hline \multirow[b]{2}{*}{ Year } & \multicolumn{4}{|c|}{ Uniform draft with flood-storage capacity of-: } \\
\hline & $\begin{array}{l}650,000 \\
\text { acre-feet }\end{array}$ & $\begin{array}{l}1,500,000 \\
\text { aere-feet }\end{array}$ & $\begin{array}{l}2,000,000 \\
\text { acre-feet }\end{array}$ & $\begin{array}{l}4,000,000 \\
\text { acre-feet }\end{array}$ \\
\hline 1920 & $\begin{array}{l}59,700 \\
54,300\end{array}$ & $\begin{array}{l}44,000 \\
38,000\end{array}$ & $\begin{array}{l}36,000 \\
31,000\end{array}$ & $\begin{array}{l}18,000 \\
12,300\end{array}$ \\
\hline
\end{tabular}

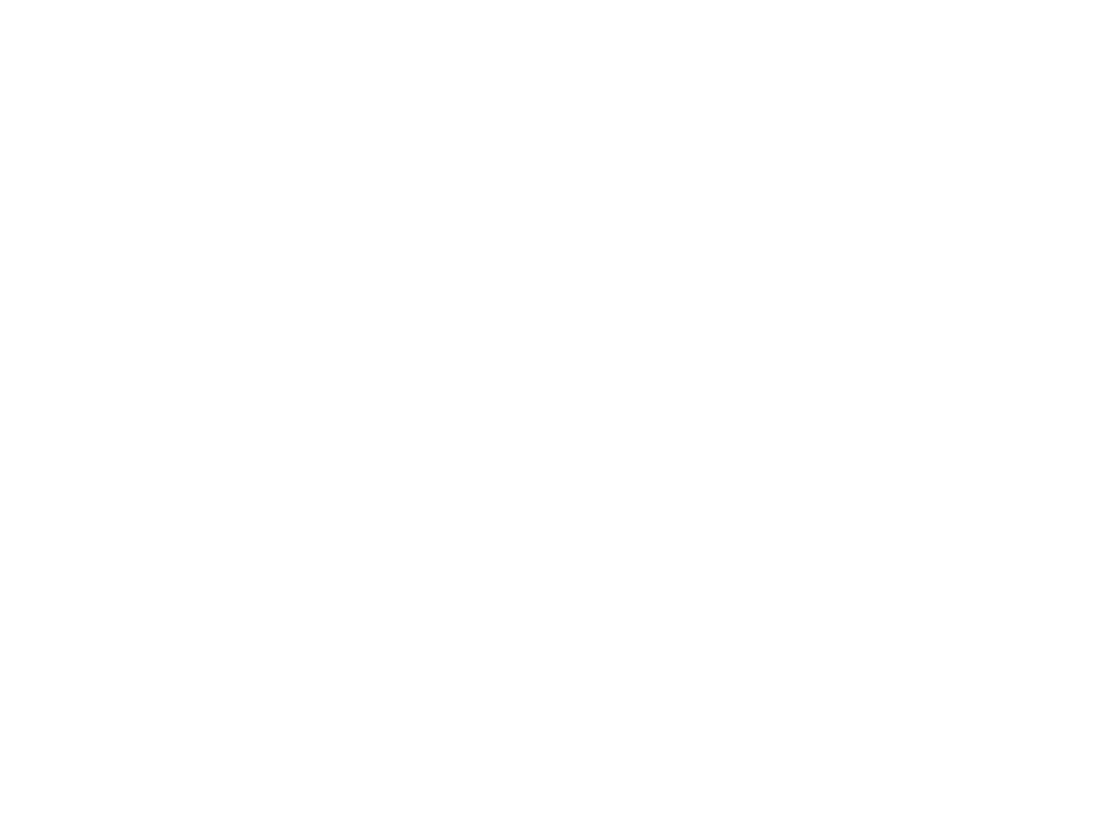

Figure 3.-Flood discharge of the Colorado River at Yuma, Ariz., as it would be modifled by operation of Dewey Reservoir

The average time interval between the reservoir and Yuma has been taken. as 12 days, and the effect on the discharge at Yuma is shown by deducting. from the daily discharge at Yuma 12 days later the difference between the inflow at Dewey and the uniform draft. The actual hydrograph of the 1920 and 1921 floods at Yuma, together with the theoretical hydragraphs with-storage capacities . of $650,000,1,500,000,2,000,000$, and $4,000,000$ acre-feet at Dewey, are shown in Figure 3.

It is probable that in actual operation of the reservoir for flood control the - outlets would be so arranged as to prevent the discharge exceeding a certain volume, thus affecting somewhat differently the discharge at Yuma than is shown in this study. The average discharge during the high-water periods of 1920 and 1921 could not have exceeded the rates of uniform draft shown here. 
The following table shows the modified peak discharges of Colorado River at Yuma due to the storage capacities considered:

Modified peak discharges, in second-feet, of Colorado River at Yuma, 1920 and 1981, if storage had been available at Dewey site

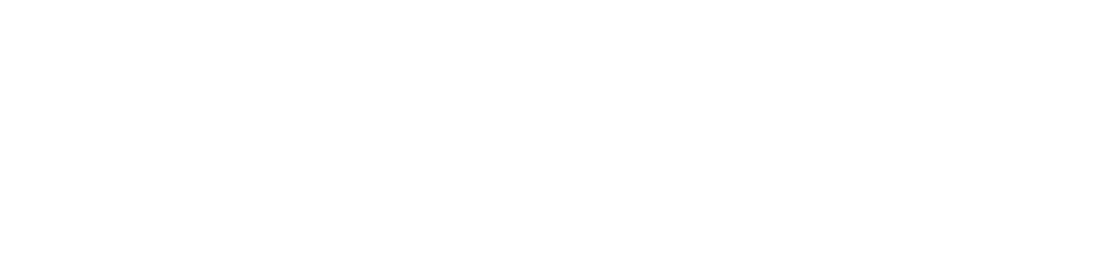

For the 1920 flood the peak discharge at Yuma could have been reduced 23,000 second-feet if the smallest reservoir had been constructed with 650,000 acre-feet reserved for flood control. If a larger reservoir had been constructed this reduction would have been increased to $38,000,46,000$, and 64,000 second-feet for capacities of $1,500,000,2,000,000$, and $4,000,000$ acre-feet, respectively. Similarly for the 1921 flood the reductions would have been $36,000,52,000,59,000$, and 78,000 second-feet respectively. The greater reduction at the time of the greater peak discharge in 1921 would have been possible because the high-water period in that year was characterized by a comparatively short, sudden rise and an even quicker subsidence, whereas the flood of 1920 , although rising more. rapidly; remained above 150,000 second feet twice as long as in 1921 . It is obvious that the longer the period of high water the less effect the operation of the Dewey Reservoir will have on the discharge at Yuma. 'Probably the greatest known flood on the Colorado River occurred in 1884. The discussion of that flood (p. 151) indicates that the high-water period lasted so long that the operation of the Dewey Reservoir would have had little effect on the flood discharge of the lower river.

The peak flow of 1927 at Yuma illustrates a type of flood against which the Dewey Reservoir would be of little protection. This flood originated in the lower basin, and during that time the discharge at the Dewey site was only 3,200 second-feet.

It is evident that to obtain the maximum power-and flood prevention the reservoir of 4,000,000 acre-feet is preferable to the smaller one, even though it

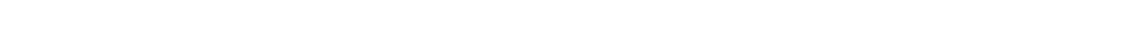
acre-feet in reducing the peak discharge at Yuma would have been only about 8,000 second-feet greater than that of the capacity of $1,500,000$ acre-feet. This slightly greater effect would have been attained at a sacrifice of about 17,000 horsepower under the average head. The utilization of the entire capacity of $4,000,000$ acre-feet would have reduced the peak flow about 18,000 second-feet more than the utilization of $2,000,000$ acre-feet and would have been accompanied by a sacrifice of all primary power, because the reservoir would have been so operated that it was empty at the beginning of the high-water period.

TRIBUTARIES ABOVE GUNNISON RIVER

GRAND LAKE BASIN

The basin of Grand Lake, on the western slope of the Continental Divide, is a region of many lakes formed by glacial action. These lakes, with the exception of Grand Lake, are too small to be of value for reservoir sites, and the mountain valleys not occupied by lakes are too small and have too steep slopes to afford reservoir sites. 


\section{GRAITD LAKN (ODA 7)}

Description.-Grand Lake, situated on a headwater tributary of the Colorado River just outside the Rocky Mountain National Park, is the largest and deepest lake in Colorado. It is a celebrated summer resort, and upon it the Grand Lake Yacht Club competes annually for the Lipton cup given by Sir Thomas Lipton some years ago. The following description of this site has been given by Matthes. ${ }^{17}$

"Grand Lake is situated in the western part of Grand County and occupies portions of secs. $4,5,6,8$, and $9, T .3 \mathrm{~N}$., R. $75 \mathrm{~W}$. sixth principal meridian. It covers an area of about 700 acres ${ }^{18}$ and has a maximum depth of 264 feet. Its drainage is into Colorado River. It owes its existence to a long, narrow terminal moraine, which effectually bars a small valley inclosed by high mountains. The lake is extremely picturesque and attracts many tourists every summer. The small town of Grand Lake is located on the northwest side of the lake, behind the moraine, and would not be affected by raising the surface of the lake from 20 to 25 feet above low-water level. A reconnaissance survey of the moraine and outlet of the lake discloses the fact that a dike 20 feet high across the outlet and short dikes across a few gaps and small depressions in the moraine is all that would be required for raising the level of the lake 20 feet for storage purposes. To store more than this depth of water would require considerable expenditure in building up the moraine to the required height and also in increasing its width at numerous points in order that it may withstand the hydrostatio pressure. The moraine, which is nearly $1 \frac{1}{2}$ miles long, is composed of glacial débris and is typically heterogeneous as regards materials. *** It is not likely that it will prove impervious under a high head of water.

"The capacity of Grand Lake as a storage reservoir would be limited to the amount stored above its present low-water level. Soundings taken near the outlet show that the lake is shallow over a considerable area and has a very sandy bottom. The depth of water near the outlet is about 3 feet at low water and increases very gradually away from the shore for a distance of several hundred feet, beyond which the depth increases very rapidly. It appears to be impracticable to deepen the outlet in order todraw off more water withoutinvolving great cost. The storage capacity with a 20 -foot dam would therefore be limited to about 140,000 acre-feet." 19

Water supply.-Records of Grand Lake outlet show the following annual run-off.

Annual run-off at Grand Lake outlet, 1905-1913

\begin{tabular}{|c|c|c|}
\hline Year & Acro-feet & $\begin{array}{l}\text { Per cent } \\
\text { of moan }\end{array}$ \\
\hline $\begin{array}{l}1905 \\
1906 \\
1907 \\
1908 \\
1909 \\
1912 \\
1913\end{array}$ & $\begin{array}{r}86,100 \\
97,400 \\
115,000 \\
67,000 \\
120,000 \\
87,400 \\
112,000 \\
65,100\end{array}$ & $\begin{array}{r}94 \\
106 \\
126 \\
73 \\
111 \\
96 \\
123 \\
71\end{array}$ \\
\hline Mean....... & 91,500 & | \\
\hline
\end{tabular}

The records of the Colorado River at Glepwood Springs show that the mean discharge for the 28 years $1900-1927$ was 99 per cent of that for the period covered

17. Matthes, G. H., Reservoir sites on upper Grand [Colorado] River: U, s. Recl, Servico Fourth And, Rept., pp, 126-127, 1906.

is Measuirements on later inaps show the area to be 530 acres.

" Changed to 106,000 . 


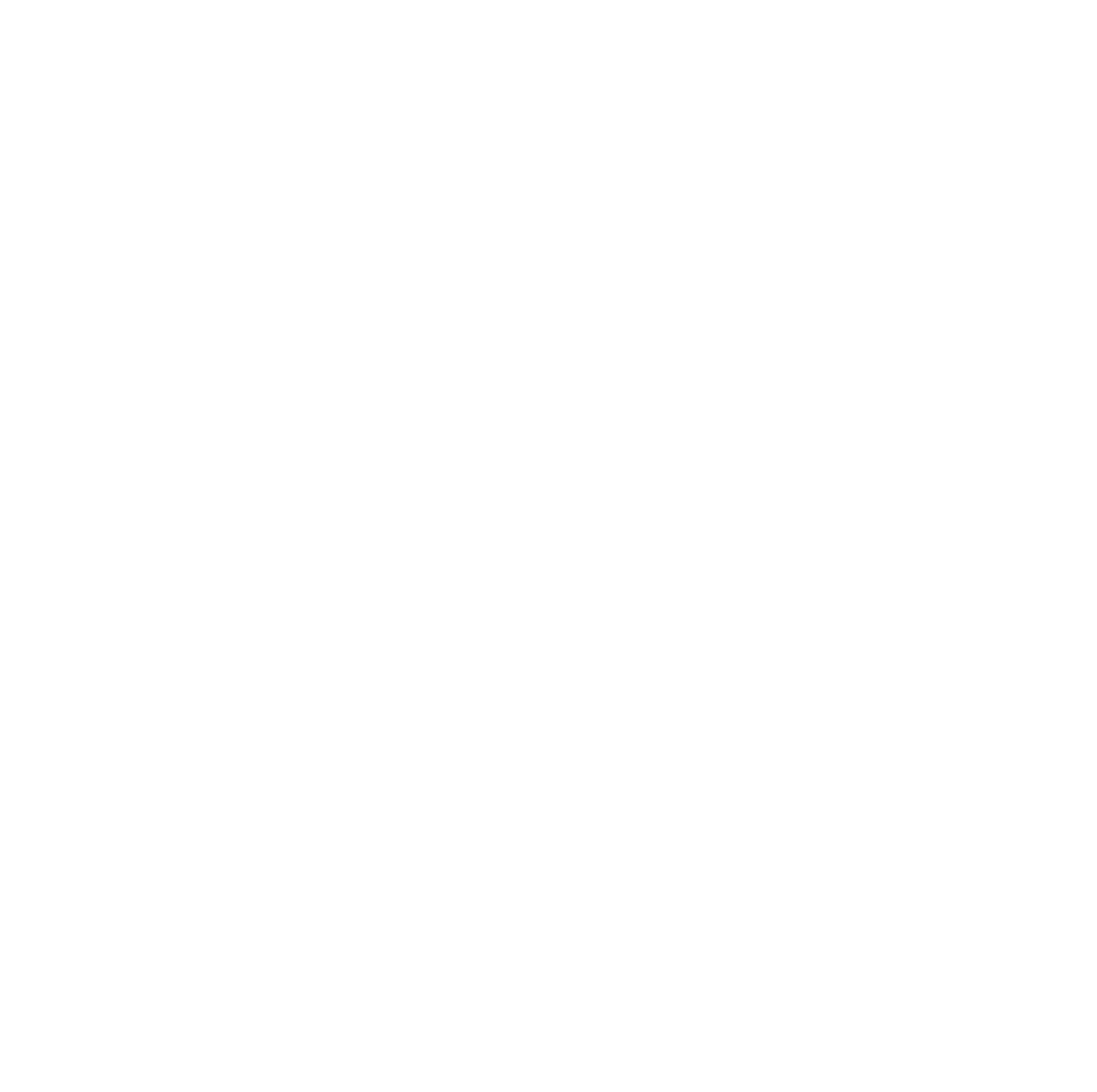




$$
\text { . }
$$


by the records at Grand Lake outlet, and on that basis the mean annual run-off at Grand Lake is 90,600 acre-feet. This is considerably less than the proposed capacity of the reservoir.

The Reclamation Service found that at a point in sec. 36, T. 2 N., R. 76 W. sixth principal meridian, 1 mile from Grand Lake, the Colorado River is 288 feet higher than the lake. If a diversion canal to Grand Lake-were constructed, the flow available for storage could be augmented by the flow of the Colorado, which had a mean annual run-off for the 28-year period 1900-1927 of 102,000 acre-feet.

Probabbe use- The only apparent use of storage on Grand Lake is for power; of which a comparatively small amount could be developed in the 18-mile stretoh between the lake and the mouth of the Fraser River. It is probable, however, that the use of Grand Lake as a summer resort will outweigh its comparatively small value for power development.

\section{WILLIAMS RIVER BASIN}

The valley of the Williams River affords no reservoir sites except near the mouth, at Hine No. 1 site. Neither do the narrow, steep valleys of the tributary streams afford such sites.

HINL NO. 1 STTTE (ODA 8)

Location.-In the valley of the Williams River, the dam site in sec. 23, T. 1 N., R. $79 \mathrm{~W}$. sixth principal meridian, 2 miles above the mouth. (See pl. 4.)

Description.-In the lower part of its course the Williams River flows through a valley $1 \frac{1}{2}$ miles wide having gently sloping sides. This valley is abruptly ended by the connected ridge of buttes forming the southern boundary of the Colorado Valley, through which the river forces its way in a canyon 2 miles long. The land within the valley is irrigated to a considerable extent, native hay being the chief crop. A spillway 1 mile above the dam exists through a natural waterway to the Colorado River.

Dam site.-The rocky walls of the canyon are 60 feet apart at the water surface, 120 feet apart at a height of 50 feet, and then gradually increase to 550 feet at a height of 175 feet. The boring of five holes shows that bedrock lies from 12 to 30 feet below the bed of the river; the overlying material is made up of sand and boulders.

Capacity.-The Central Colorado Power Co. made a topographic survey of the reservoir site in 1905 , and from that survey the following table has been computed:

\section{Area and capaeity of Hine No. 1 Reservoir for different heights of dam}

\begin{tabular}{|c|c|c|c|c|c|}
\hline $\begin{array}{l}\text { Height } \\
\text { above } \\
\text { outlet } \\
\text { (feet) }\end{array}$ & $\underset{\text { (acres) }}{\text { Area }}$ & $\begin{array}{c}\text { Total } \\
\text { capacity } \\
\text { (acro-feet) }\end{array}$ & $\begin{array}{l}\text { Height } \\
\text { above } \\
\text { outlet } \\
\text { (feet) }\end{array}$ & $\begin{array}{c}\text { Area } \\
\text { (acres) }\end{array}$ & $\begin{array}{c}\text { Total } \\
\text { capacity } \\
\text { (acre-foet) }\end{array}$ \\
\hline $\begin{array}{r}20 \\
40 \\
60 \\
80 \\
100\end{array}$ & $\begin{array}{r}19 \\
75 \\
192 \\
360 \\
534 .\end{array}$ & $\begin{array}{r}148 \\
1,170 \\
4,240 \\
9,850 \\
17,800\end{array}$ & $\begin{array}{l}120 \\
140 \\
160 \\
175\end{array}$ & $\begin{array}{r}805 \\
1,090 \\
1,260 \\
1,300\end{array}$ & $\begin{array}{l}32,800 \\
51,800 \\
67,300 \\
75,200\end{array}$ \\
\hline
\end{tabular}

Water supply.-Records of the flow of the Williams River were obtained near Parshall, within the reservoir site, from 1904 to 1924, and these have been extended back to 1900 and forward to 1927 by using the relation of the flow of the $46013-29-7$ 
Williams River to that of the Colorado at Glenwood Springs as determined from later simultaneous records. The following table shows the total run-off for each year as thus computed:

Annual run-off at gaging station in Hine No. 1 Reservoir site, 1900-1987

\begin{tabular}{|c|c|c|c|c|c|}
\hline Year & Acre-feet & $\begin{array}{l}\text { Per cent } \\
\text { of mean }\end{array}$ & Year & Acro-feet & $\begin{array}{l}\text { Per cent } \\
\text { of mean }\end{array}$ \\
\hline \multirow[t]{2}{*}{$\begin{array}{l}1900 \\
1903 \\
1904 \\
1905 \\
1908 \\
1907 \\
1908 \\
1909 \\
1910 \\
1911 \\
1912 \\
1914\end{array}$} & \multirow[t]{2}{*}{$\begin{array}{r}98,000 \\
101,000 \\
70,200 \\
93,900 \\
103,000 \\
99,300 \\
122,000 \\
141,000 \\
88,300 \\
144,000 \\
96,300 \\
101,000 \\
168,000 \\
109,000 \\
167,000\end{array}$} & \multirow[t]{2}{*}{$\begin{array}{r}82 \\
85 \\
59 \\
79 \\
86 \\
83 \\
102 \\
118 \\
74 \\
121 \\
81 \\
85 \\
137 \\
92 \\
140\end{array}$} & \multirow[t]{2}{*}{$\begin{array}{l}1915 \\
1916 \\
1918 \\
192019 \\
1922 \\
1924 \\
1925 \\
1926 \\
\text { Meen }\end{array}$} & $\begin{array}{r}122,009 \\
117,00 \\
156,000 \\
169,000 \\
96,100 \\
148,000 \\
159,000 \\
99,000 \\
122,000 \\
116,000 \\
95,700 \\
138,000 \\
110,000\end{array}$ & $\begin{array}{r}102 \\
98 \\
131 \\
142 \\
81 \\
124 \\
134 \\
83 \\
102 \\
97 \\
80 \\
116 \\
92\end{array}$ \\
\hline & & & & 119,000 & \\
\hline
\end{tabular}

Below the gaging station 47 square miles of foothill area is tributary to the reservoir, the mean annual run-off from which is estimated as 19,000 acre-feet. Thus the total mean annual run-off at the reservoir site is 138,000 acre-feet. If the proposed transmountain diversion from Williams River is made (see p. 56) the mean annual run-off will be reduced to 113,000 acre-feet.

Probable use.-The principal use of the reservoir appears to be the development of power on the Colorado River. As its capacity is too small to warrant construction by itself, the reservoir has been considered in connection with that at Hine No. 2 site, on the Colorado River, which has a capacity of 230,000 acre-feet. (For result of the combined operation see p. 69.)

\section{BLUE RIVER BASIN}

At three points in the valley of the Blue River reservoirs can be constructed. One site is the comparatively level area extending from Dillon for several miles up the Blue and Tenmile Valleys. The presence of a narrow-gage branch of the Colorado \& Southern Railroad in both valleys and the location of Dillon (population 100) at their junction make this site unfeasible. Another site is known as the Curtis No. 1 site and is in the main valley, the dam site being 12 miles below Dillon. The dam required at this site would be so large for the reservoir capacity that this site is considered unfeasible. The third site is at Green Mountain, 20 miles below the Curtis dam site and 16 miles above the mouth of the river.

The presence of small mountain lakes on Slate, Brush, Black Lake, and Cataract Creeks makes it possible to store the tributary run-off from about 20 square miles, but as no surveys of these sites have been made, detailed information regarding them is not available. 


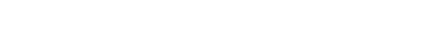

Location.-In the valley of the Blue River, beginning at dam site in sec. 10, T. 2 S., R. 80 W. sixth principal meridian, near Green Mountain, and extending 13 miles upstream:

Dam site.-In a canyon formed by the river cutting its way through Green Mountain, a semi-isolated butte which rises in the center of the valley. The right and left canyon walls, which make angles of $45^{\circ}$ and $68^{\circ}$, respectively, are composed of light-colored close-grained basalt. The width of the dam site is 100 fept at the water surface, 430 feet 100 feet above, 1,150 feet 300 feet above, and 1,260 feet at an altitude of 8,015 feet, or 333 feet above the river. No boring have been made to determine the distance to bedrock. The divide separating Green Mountain from the Williams River Mountains has an altitude of 8,015 feet. At an altitude of 8,000 feet a cut through the divide 1,600 feet long would afford a apillway into the Blue River 1/2 miles downstream.

Capacity.-The following table shows the area and capacity of the reservoir at different altitudes:

\section{Area and capacity of Green Mountain Reservoir at different altitudes}

\begin{tabular}{|c|c|c|c|c|c|}
\hline$\underset{\text { (feet) }}{\text { Altitude }}$ & $\begin{array}{c}\text { Area } \\
\text { (acres) }\end{array}$ & $\begin{array}{l}\text { Capacity } \\
\text { (acre-feet) }\end{array}$ & $\begin{array}{c}\text { Altitude } \\
\text { (feot) }\end{array}$ & $\begin{array}{c}\text { Area } \\
\text { (acres) }\end{array}$ & $\begin{array}{l}\text { Capacity } \\
\text { (acre-feet) }\end{array}$ \\
\hline $\begin{array}{l}7,682 \\
7,750 \\
7,800 \\
7,850\end{array}$ & $\begin{array}{r}0 \\
50 \\
145 \\
628\end{array}$ & $\begin{array}{r}0 \\
2,000 \\
5,000 \\
23,000\end{array}$ & $\begin{array}{l}7,900 \\
7,950 \\
8,000\end{array}$ & $\begin{array}{l}1,280 \\
2,250 \\
3,260\end{array}$ & $\begin{array}{r}86,000 \\
185,000 \\
344,000\end{array}$ \\
\hline
\end{tabular}

Of the area flooded at 8,000 feet 200 acres consists of hay meadow and 500 acres of grazing land; the remainder is land of little value.

Water supply.-Records of the Blue River near Kremmling, which is within the reservoir site, show that the mean annual discharge for 1905-1908 was 448,000 acre-feet. The records of the Colorado River at Glenwood Springs indicate that the mean annual run-off for the 28-year period 1900-1927 was 97 per cent of that for the 4-year period covered by the Kremmling records. On this basis the mean annual run-off at the Green Mountain site is 435,000 acre-feet. If the proposed transmountain diversion is made (p. 59) the mean annual runoff will be reduced to 339,000 acre-feet.

Probable use.-The chief use of the reservoir appears to be for the development of power on the Colorado River. The survey of the site indicates a capacity of 344,000 acre-feet. If the reservoir were operated for the purpose of maintaining a uniform flow at Gore Canyon during each low-water season, the capacity required to store all the water during the high-water period of the wettest years would be about 360,000 acre-feet with the transmountain diversion and 475,000 acre-feet without it.

Had the reservoir been constructed to a capacity of 344,000 acre-feet, the following rates of discharge at Gore Canyon, in which an allowance has been made for transmountain diversion and evaporation losses, could have been obtained during the years for which stream-flow records at the reservoir site are available.

\footnotetext{
* Desaription based on data in unpublished report by E. E. Jones on power resources gt the Colorado River (Geological Burvey, 1925).
} 
Rates of uniform discharge at Gore Canyon during tow water season, 1904-1908, if storage at Green Mountain Reservoir site had been available

\begin{tabular}{|c|c|c|c|c|}
\hline \multirow{2}{*}{,$\quad$ Period } & \multirow{2}{*}{$\begin{array}{l}\text { A vailable } \\
\text { storage } \\
\text { (acre-feet) }\end{array}$} & \multicolumn{2}{|c|}{$\begin{array}{l}\text { A vailable water supply } \\
\text { (acre feet) }\end{array}$} & \multirow{2}{*}{$\begin{array}{l}\text { Uniform } \\
\text { dischatrge } \\
\text { (second } \\
\text { feet) }\end{array}$} \\
\hline & & Surplus & Deficiency & \\
\hline 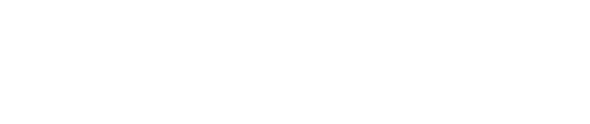 & $\begin{array}{l}344,000 \\
221,000 \\
302,000 \\
344,000 \\
172,000\end{array}$ & $\begin{array}{r}0 \\
013,000 \\
\hdashline\end{array}$ & $\begin{array}{r}0 \\
123,000 \\
42,000 \\
172,000\end{array}$ & $\begin{array}{l}1,230 \\
1,360 \\
1,230 \\
814\end{array}$ \\
\hline
\end{tabular}

With the regulation indicated above the discharges for 90 per cent and 50 per cent of the time would have been 814 and 1,230 second-feet, respectively. The available power at the principal sites on the Colorado would have been as follows:

Available power at principal sites on Colorado River with storage at Green Mountain Reservoir site

\begin{tabular}{|c|c|c|c|c|c|}
\hline \multirow{3}{*}{ Site } & \multirow{3}{*}{$\begin{array}{l}\text { Total } \\
\text { hend } \\
\text { (feet) }\end{array}$} & \multicolumn{4}{|c|}{ Run-off and available power } \\
\hline & & \multicolumn{2}{|c|}{90 per cent of the time } & \multicolumn{2}{|c|}{50 per cent of the time } \\
\hline & & Second-feat & Horsepower & Second-feet & Horsepower \\
\hline $\begin{array}{l}\text { Gore Canyon } \\
\text { Glenwood Springs }\end{array}$ & $\begin{array}{l}500 \\
205\end{array}$ & $\begin{array}{r}814 \\
1,170\end{array}$ & $\begin{array}{l}32,000 \\
19,200\end{array}$ & $\begin{array}{l}1,230 \\
1,590\end{array}$ & $\begin{array}{l}49,200 \\
26,000\end{array}$ \\
\hline
\end{tabular}

Without the transmountain diversion the 90 per cent discharge at Gore Canyon and Glenwood Springs would have been 954 and 1,310 second-feet, respectively, and the corresponding power would have been 38,000 and 21,500 horsepower. The power for 50 per cent of the time would have been practically the same as with the diversion.

Comparison with other reservoir sites.-The following table summarizes the principal features of each site considered of value for the development of power in Gore Canyon and between the Shoshone tailrace and Glenwood Springs:

Principal features of certain power sites in upper Colorado River Basin

\begin{tabular}{|c|c|c|c|c|}
\hline \multirow[b]{2}{*}{ Site } & \multicolumn{2}{|c|}{$\underset{\text { (feot) }}{\text { Dimensions of dam }}$} & \multicolumn{2}{|c|}{$\begin{array}{l}\text { Total avallable } \\
\text { horsepowat a }\end{array}$} \\
\hline & $\begin{array}{l}\text { Height } \\
\text { above } \\
\text { stream } \\
\text { bed }\end{array}$ & $\begin{array}{c}\text { Crest } \\
\text { length }\end{array}$ & $\begin{array}{c}\text { Oo per } \\
\text { cent of } \\
\text { the time }\end{array}$ & $\begin{array}{l}50 \text { par } \\
\text { cent of } \\
\text { the time }\end{array}$ \\
\hline $\begin{array}{l}\text { Kremmiling } \\
\text { Hine No. } 2 . \\
\text { Hine No. 1. } \\
\text { Park } \\
\text { Green Mountain }\end{array}$ & $\begin{array}{r}245 \\
175 \\
175 \\
160 \\
333\end{array}$ & $\begin{array}{r}410 \\
750 \\
550 \\
812 \\
1,250\end{array}$ & $\begin{array}{l}77,000 \\
61,200 \\
59,100 \\
51,200\end{array}$ & $\begin{array}{l}89,600 \\
78,300 \\
79,900 \\
75,200\end{array}$ \\
\hline
\end{tabular}

- Allowing for transmountain diversions.

- Above bedrock, which is about 90 feet below stream bed.

The site having the highest power value and requiring the shortest dam is Kremmling, but the necessity of relocating 20 miles of railroad through the reservoir and removing it from Gore Canyon, below, and of removing the town 
of Kremmling outweighs these advantages. Of the other sites, the Park site requires the relocation of 8 to 10 miles of railroad, leaving the Hine No. 1 and No. 2 and Green Mountain sites the only ones free from railroad interference.

The Hine No. 1 and No. 2 sites together have 20 per cent greater value for 90 per cent power than the Green Mountain site. Also the combined heights above the stream bed and the crest lengths of the two dams would not greatly exceed the height and crest length of the single dam at Green Mountain, thus indicating a considerably smaller total volume in the two Hine dams than in the Green Mountain dam. The only unfavorable item in the comparison appears to be the fact that of the 5,660 acres flooded by the Hine sites about 3,000 acres is irrigated, whereas at Green Mountain only 3,260 acres will be flooded, of which but a few hundred acres is irrigated. Borings have been made which show bedrock to be from 12 to 30 feet below the stream bed at Hine No. 1 and from 30 to 60 feet below the stream bed at Hine No. 2. The depth of bedrock at the Green Mountain site is not known.

\section{EAGLE RIVER BASIN}

The alternate valleys and canyons through which the Eagle River flows would be favorable for the creation of reservoirs were it not for the presence of the main line of the Denver \& Rio Grande Western Railroad throughout the length of the basin. Reservoir sites do not exist on tributary streams except at the Castle Mountain site, on Milk Creek. The long inlet and outlet ditches required for its small capacity make the site unfeasible.

\section{ROARING FORK BASIN}

The presence of a branch line of the Denver \& Rio Grande Western Railroad and an irrigated area of 5,600 acres in the Roaring Fork Valley below Aspen preclude the construction of any large reservoir in the valley. Just above Aspen the topography is favorable for storage, and here Aspen No. 1 site has been surveyed. The valleys of tributary streams, except the Crystal River and Fryingpan Creek, are too narrow and steep for reservoir sites. Two sites, Redstone No. 3 and No. 4, have been surveyed in the Crystal River Valley, but the presence of the narrow-gage line of the Crystal River Railroad leading to the marble quarries at Marble and the prohibitive cost of power development (the only apparent use) at these sites render them unfeasible. The C. M. site, on Fryingpan Creek, requires a dam too large for the capacity obtainable. A reservoir site known as Red Mesa exists on the mesa south of Castle Creek, but its only source of supply is the same as that for the Spring Park site, where a reservoir has been partly constructed.

\section{ASPEN NO. 1 STTE (ODF 1)}

Location.-In the valley of the Roaring Fork just above Aspen; the dam site is half a mile above the upper edge of the town, in T. $10 \mathrm{~S} .$, R. $84 \mathrm{~W}$.

Description.-After flowing through a canyon having a heavy fall, the river below the mouth of Difficult Creek emerges into a valley that reaches nearly to Aspen. The sides of the valley are gently sloping, and the river has a fall of only 18 feet to the mile. Most of the land within the valley is used for pasturage,

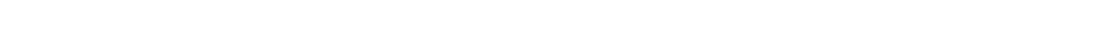


Dam site.-At the dam site the abutments, which consist of granite, are 60 feet apart at the water surface and 2,100 feet apart at a height of 70 feet.

Capacity.-In 1905 the Central Colorado Power Co. made a topographic aurvey of the reservoir site, and from that survey the following table has been computed:

Area and capacity of Aspen No. 1 Reservoir at different altitudes

\begin{tabular}{|c|r|r|r|r|r|}
\hline $\begin{array}{c}\text { Altitude } \\
\text { (feet) }\end{array}$ & $\begin{array}{c}\text { Area } \\
\text { (acres) }\end{array}$ & $\begin{array}{c}\text { Total car } \\
\text { pacity } \\
\text { (acre-feet) }\end{array}$ & $\begin{array}{c}\text { Altitude } \\
\text { (feet) }\end{array}$ & $\begin{array}{c}\text { Ares } \\
\text { (acres) }\end{array}$ & $\begin{array}{c}\text { Total ca- } \\
\text { pacity } \\
\text { (acre foet) }\end{array}$ \\
\hline 8,140 & 0 & 0 & 8,180 & 462 & 12,900 \\
8,150 & 285 & 1,580 & 8,190 & 500 & 17,700 \\
8,160 & 347 & 4,730 & 8,200 & 540 & 28,000 \\
8,170 & 408 & 8,520 & & \\
\hline
\end{tabular}

Water supply.-The records of the Roaring Fork at Aspen are taken at a point $1 \frac{1}{4}$ miles below the dam site, where the discharge is practically the same. These show that the mean annual run-off from 1911 to 1921 was 134,000 acre-feet. A comparison with the records of the Colorado River at Glenwood Springs indicates that the mean annual run-off for the period 1900-1927 is 94 per cent of the mean for 1911-1921. On that basis, the mean annual run-off at the reservoir site is 127,000 acre-feet.

Probable use.-This reservoir will probably be used prinoipally for the development of power. Water could be stored from the later part of April to August and released at such rates that the flow during the remainder of the year would be uniform. On this basis the 90 per cent and 50 per cent flows just below the reservoir would be 94 and 104 second-feet, respectively. These quantities are 65 and 49 second-feet greater than the corresponding flow unregulated. These increases have been added to the unregulated flow at points farther downstream to determine the effect of storage. With storage the increased power at the sites described on page 85 would be as shown in the following table:

Increased power at certain sites, in horsepower, due to storage in Aspen No. 1 Reservoir

\begin{tabular}{|c|c|c|c|c|c|c|}
\hline \multirow{2}{*}{ Site } & \multicolumn{3}{|c|}{90 per cent of the time } & \multicolumn{3}{|c|}{50 per cent of the time } \\
\hline & $\begin{array}{l}\text { Without } \\
\text { storage }\end{array}$ & $\begin{array}{l}\text { With } \\
\text { storage }\end{array}$ & Increase & $\begin{array}{l}\text { Without } \\
\text { storage }\end{array}$ & $\begin{array}{c}\text { With } \\
\text { storage }\end{array}$ & Increase \\
\hline 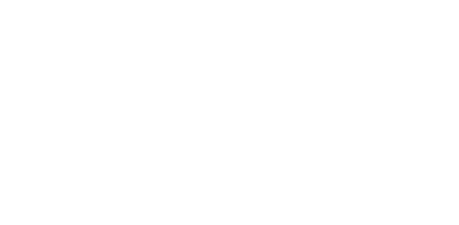 & $\begin{array}{r}940 \\
2,110 \\
3,670 \\
2,880 \\
2,350 \\
4,240 \\
4,020 \\
4,210 \\
3,160 \\
2,560\end{array}$ & $\begin{array}{l}3,050 \\
4,320 \\
6,010 \\
4,070 \\
3,040 \\
5,400 \\
5,070 \\
4,980 \\
3,700 \\
3,050\end{array}$ & $\begin{array}{r}2,110 \\
2,210 \\
2,340 \\
1,190 \\
690 \\
1,160 \\
1,050 \\
770 \\
540 \\
490\end{array}$ & $\begin{array}{l}1,780 \\
3,940 \\
6,840 \\
5,160 \\
4,390 \\
7,870 \\
7,470 \\
7,810 \\
5,870 \\
6,140\end{array}$ & $\begin{array}{r}3,370 \\
5,610 \\
8,600 \\
6,130 \\
4,910 \\
8,740 \\
8,260 \\
8,390 \\
6,270 \\
6,600\end{array}$ & $\begin{array}{r}1,590 \\
1,670 \\
1,760 \\
970 \\
520 \\
870 \\
790 \\
889 \\
400 \\
360\end{array}$ \\
\hline Total ....... & 30,100 & 42,700 & 12,600 & 56,300 & 65,800 & 9,500 \\
\hline
\end{tabular}

MINOR TRIBUTARY BASINS ABOVE GUNNISON RIVER

The topography of the minor tributary basins above the Gunnison River is so rugged that only seven reservoir sites have been located. These are described below. The Butte Mesa site is too close to tho 
Colorado River to be of value for irrigation, its only apparent use, and the size of dam required for the Colorado No. 1 site is too large for the capacity obtainable.

\section{CORRAL SITE (9DA 9)}

Location.-In sec. 1, T. 1 N., R. 79 W. sixth principal meridian, in the ehannel of Corral Creek, a tributary of the Colorado River. A dam 65 feet high would have a crest length of 300 feet.

Caparity.- From a filing in the State engineer's office the following table has been compiled:

Capacity of Corral Reservoir for different heights of dam

\begin{tabular}{|r|r||r|r|}
\hline $\begin{array}{c}\text { Height } \\
\text { above } \\
\text { outlet } \\
\text { (foet) }\end{array}$ & $\begin{array}{r}\text { Total } \\
\text { capacity } \\
\text { (acre-feet) }\end{array}$ & $\begin{array}{r}\text { Height } \\
\text { above } \\
\text { outlet } \\
\text { (foet) }\end{array}$ & $\begin{array}{r}\text { Total } \\
\text { capacity } \\
\text { (acre-foet) }\end{array}$ \\
\hline 10 & 13 & 40 & $\begin{array}{r}3,580 \\
6,680 \\
20\end{array}$ \\
30 & 158 & $\begin{array}{r}50 \\
11,100\end{array}$ \\
\hline
\end{tabular}

Water supply.-No records of Corral Creek are available, but by comparison with the records of Troublesome Creek, which drains the adjacent area on the west, the mean annual run-off from 28 square miles above the reservoir site is estimated as 8,000 acre-feet.

Probable use.-It is proposed to utilize the stored water for the irrigation of land north of the Colorado River and west of Corral Creek.

\section{MTRCTRA SITE (ODG 1)}

Location.-In the narrow valley of Meadow Creek, a tributary of Middle Elk Creek; the dam site is near the southwest corner of sec. 1, T. 4 S., R. 91 W. sixth principal meridian, and is so narrow that a dam 225 feet above the stream bed would have a maximum length of only 250 feet.

Capacity.-From a filing in the State engineer's office the following table has been compiled:

Area and capacity of Electra Reservoir for different heights of dam

\begin{tabular}{|r|r|r|r|r|r|}
\hline $\begin{array}{c}\text { Height } \\
\text { above out- } \\
\text { let (feet) }\end{array}$ & $\begin{array}{c}\text { Ares } \\
\text { (acres) }\end{array}$ & $\begin{array}{c}\text { Total ca- } \\
\text { pacity } \\
\text { (acre-fe日t) }\end{array}$ & $\begin{array}{r}\text { Height } \\
\text { above out- } \\
\text { lot (foet) }\end{array}$ & $\begin{array}{c}\text { Area } \\
\text { (acres) }\end{array}$ & $\begin{array}{r}\text { Total ca- } \\
\text { pacity } \\
\text { (acre-feet) }\end{array}$ \\
\hline 20 & 4 & 28 & 140 & 427 & 20,800 \\
40 & 50 & 383 & 160 & 555 & 30,600 \\
60 & 113 & 1,780 & 180 & 689 & 42,800 \\
80 & 172 & 4,660 & 200 & 824 & 58,000 \\
100 & 217 & 8,550 & 210 & 915 & 67,000 \\
120 & 309 & 13,600 & & & \\
\hline
\end{tabular}

For a capacity of 31,000 acre-feet a dam 170 feet high would have a crest length of about 200 feet.

Water supply.-Records of East Elk Creek near New Castle from 1911 to 1915 show a mean annual run-off of 33,800 acre-feet. With an allowance of 2,000 acre-feet for diversions above the station the total annual run-off for the 5-year period was 35,800 acre-feet. A comparison with the run-off of the Colorado River at Glenwood Springs indicates that the mean annual run-off for the 28-year 
period 1900-1927 was 99 per cent of that for the 5-year period 1911-1915. The mean annual run-off at the gaging station is therefore 35,400 acre-feet from 51 square miles, or 694 acre-feet to the square mile. The drainage area above the reservoir site is 34 square miles, and as the range in altitude is chiefly between 8,000 and 10,500 feet, as contrasted with a range from 7,000 to 10,000 feet above the gaging station, the unit run-off is estimated as 900 acre-fet to the square mile. This gives an estimated mean annual run-off at the reservoir site of 30,600 aere-feet.

Probable use.-The reservoir site was originally filed on for power, a pipe line being planned to lead from the reservoir to a power house 1 mile downstream. The head is somewhat uncertain, owing to insufficient data, but it is believed that the fall between the outlet of the reservoir and the power-house site is about 1,700 feet. A mass curve shows that to have equalized the flow during the 5-year period 1911-1915, which included 1914, one of the wettest years recorded for the upper Colorado River Basin, would have required a storage capacity of 27,000 acre-feet. This capacity would require a dam 160 feet high. The uniform draft during the entire period from June, 1911, to July, 1914, would have been 48 second-feet. With a minimum head of 1,700 feet the available power for 90 per cent of the time would be 6,350 horsepower.

\section{WOLCOTT SITE (ODA-2)}

Location.-In secs. 1, 2, 11, and 12, T. 7 S., R. 92 W. sixth principal meridian, in the channel of West Divide Creek, where a dam 110 feet high would have a crest length of 750 feet.

Capacity.-From a filing in the State engineer's office the following table has been compiled:

Area and capacity of Wolcott Reservoir for different heights of dam

\begin{tabular}{|c|c|c|c|c|c|}
\hline $\begin{array}{l}\text { Height } \\
\text { above out- } \\
\text { let (feet) }\end{array}$ & $\begin{array}{c}\text { Area } \\
\text { (acres) }\end{array}$ & $\begin{array}{l}\text { Total ca- } \\
\text { pacity } \\
\text { (acre-feet) }\end{array}$ & $\begin{array}{l}\text { Height } \\
\text { above out- } \\
\text { let (feet) }\end{array}$ & $\begin{array}{c}\text { Area } \\
\text { (acres) }\end{array}$ & $\begin{array}{l}\text { Total ca- } \\
\text { pacity } \\
\text { (acre-feet) }\end{array}$ \\
\hline $\begin{array}{l}20 \\
40 \\
60\end{array}$ & $\begin{array}{l}19 \\
43 \\
78\end{array}$ & $\begin{array}{r}130 \\
578 \\
1,480\end{array}$ & $\begin{array}{r}80 \\
100\end{array}$ & $\begin{array}{l}104 \\
122\end{array}$ & $\begin{array}{l}2,280 \\
4,900\end{array}$ \\
\hline
\end{tabular}

Water supply.-Records for West Divide Creek near the reservoir site for 1910 show an annual run-off of 21,400 acre-feet. As 1910 was a year of about 75 per cent normal run-off in the upper Colorado River Basin, the mean annual run-off at the reservoir site is estimated as 28,000 acre-feet.

Probable use.-It is proposed to utilize water stored in the Wolcott Reservoir for irrigation in the West Divide Basin.

\section{WEST MAMM CREEK SITE (9DG 3)}

Location.-In secs. 13, 14, 23, and 24, T. 7 S., R. $93 \mathrm{~W}$. sixth principal meridian, in the channel of West Mamm Creek. The dam site is in the NE. $1 / 4 \mathrm{NW} .1 / 4 \mathrm{sec}$. 24, where a dam 125 feet high would have a crest length of 945 feet.

Capacity.-From a filing in the State engineer's office the following table has been compiled:

Area and capacity of West Mamm Creek Reservoir for different heights of dam

\begin{tabular}{|c|c|c|c|c|c|}
\hline $\begin{array}{l}\text { Height } \\
\text { above out- } \\
\text { lot (feet) }\end{array}$ & $\underset{\text { (aven) }}{\text { Area }}$ & $\begin{array}{c}\text { Total ca- } \\
\text { pacity } \\
\text { (acre-feot) }\end{array}$ & $\begin{array}{l}\text { Height } \\
\text { above out- } \\
\text { let (feet) }\end{array}$ & $\begin{array}{c}\text { Area } \\
\text { (acres) }\end{array}$ & $\begin{array}{l}\text { Total ca- } \\
\text { pacity } \\
\text { (acre-feot) }\end{array}$ \\
\hline $\begin{array}{l}20 \\
40 \\
60 \\
80\end{array}$ & $\begin{array}{r}4 \\
11 \\
42 \\
79\end{array}$ & $\begin{array}{r}32 \\
230 \\
707 \\
1,390\end{array}$ & $\begin{array}{l}100 \\
110 \\
120\end{array}$ & $\begin{array}{l}119 \\
139 \\
162 .\end{array}$ & $\begin{array}{l}3,890 \\
5,190 \\
6,780\end{array}$ \\
\hline
\end{tabular}


Water supply.-The original filing for this site contemplated the diversion of water from West Divide Creek, but as that stream is extensively used for irrigation the amount available from that source will be small. It has been proposed to divert water from Buzzard Creek about in seo. 27, T. 9 S., R. 92 W. sixth principal meridian, where the drainage area is $\mathbf{5 0}$ square miles, and convey it to West Mamm Creek above the reservoir. By this scheme, it is estimated, the mean annual diversion would be 20,000 acre-feet. In addition, it is probable that 5,000 acre-feet additional is directly tributary to the reservoir.

Probable use.-Storage in the reservoir is proposed in connection with the Hunter Mesa project (p. 142).

\section{VEGA SITR (9DJ 1)}

Location.-In the channel of upper Plateau Creek. The dam site is in the NW. $1 / 4$ NE. $1 / 4$ sec. 6 , T. 10 S., R. 93 W. sixth principal meridian, 12 miles above Collbran.

Description.-For $1 \frac{1}{2}$ miles above the canyon which contains the dam site Plateau Creek flows through a valley five-eighths of a mile wide with gently sloping sides. Half a mile above the dam site the sides close in to a canyon. The area within the reservoir site consists chiefly of irrigated hay meadows.

Dam site.-A third of a mile below the entrance to the canyon, at its narrowest point, the width is 50 feet at the water surface, 620 feet at a height of 110 feet, and 1,750 feet wide at a height of 135 feet. No borings have been made to show the distance to bedrock.

Capacity.-From a topographic map filed in the State engineer's office the following table has been taken:

Area and capacity of Vega Reservoir for different heights of dam

\begin{tabular}{|r|r|r||r|r|r|}
\hline $\begin{array}{c}\text { Height } \\
\text { above } \\
\text { ontlet } \\
\text { (feet) }\end{array}$ & $\begin{array}{r}\text { Area } \\
\text { (acres) }\end{array}$ & $\begin{array}{r}\text { Total } \\
\text { capacity } \\
\text { (acre-feet) }\end{array}$ & $\begin{array}{r}\text { Height } \\
\text { above } \\
\text { outlet } \\
\text { (feet) }\end{array}$ & $\begin{array}{r}\text { Area } \\
\text { (acres) }\end{array}$ & $\begin{array}{c}\text { Total } \\
\text { capacity } \\
\text { (aere-foet) }\end{array}$ \\
\hline 10 & 2 & 16 & 80 & 326 & 7,220 \\
20 & 14 & 77 & 90 & 439 & 11,000 \\
30 & 27 & 307 & 100 & 528 & 16,000 \\
40 & 40 & 622 & 110 & 657 & 21,809 \\
50 & 78 & 1,210 & 120 & 845 & 30,000 \\
60 & 150 & 2,370 & 130 & 965 & 38,600 \\
70 & 235 & 4,350 & 135 & 1,000 & 48,600 \\
\hline
\end{tabular}

Water supply.-The water supply from Plateau Creek alone is insufficient for a reservoir of this size, as Plateau Creek has a low unit run-off, but by building feeder ditches to Leon and Park Creeks, which enter Plateau Creek below the reservoir, it will be possible to store the run-off from 75 square miles. A filing in the State engineer's office shows that a proposed diversion from Leon Creek in the SW. $1 / 4 \mathrm{SE}$. 1/4 sec. 18 to Park Creek in the SW. 1/4 SE. 1/4 sec. 7 by a ditch 1.7 miles long, and a ditch 0.5 mile long from Park Creek in the SW. $1 / 4$ NW. $1 / 4$ sec. 7 will divert water to the reservoir.

Records of Plateau Creek near Collbran for 1922-1927 show a mean annual run-off of 83,400 acre-feet. A comparison with the 11-year record of Surface Creek, which drains a somewhat similar area on the oppasite side of Grand Mesa, indicates that the mean discharge to be expected is 111 per cent of that for the 6-year period 1922-1927, or 93,000 acre-feet. Only a small quantity of water enters Plateau Creek between the gaging station and the Vega site, and the mean annual run-off at the latter point, with the Leon and Park Creek diversions, is estimated as 85,000 acre-feet.

Probable use.-The reservoir will be used for additional irrigation in Plateau Valley, probably in connection with the Sunnyside project (p. 142). 


\section{GUNNISON RIVER BASIN}

\section{HEADWATER BASINS}

On the Taylor River, the main source' of the Gunnison, there are two reservoir sites known as Dorchester and Taylor Park. On the East River, another important headwater stream, there are two sites known as East River and Oversteg. The dam required for the Oversteg site is so large as compared with the capacity obtainable that the site is considered unfeasible. The presence of branch lines of the Denver \& Rio Grande Western Railroad along the entire length of the Gunnison except for a distance of 36 miles, where the river is in a deep canyon, prevents the construction of reservoirs on the main stream. The sites in the tributary basins are described under those basins.

\section{DORCERSTER SITE (ORA 1)}

Location.-In secs. $27,33,34$, and 35, T. 12 S., R. 83 W. sixth principal meridian, in the Taylor River Valley, the upper end of the site being a quarter of a mile southeast of Dorchester. The land within the site is used chiefly for grazing.

Dam site.-In the NE. $1 / 4$ SE. $1 / 4$ sec. 34, T. $12 \mathrm{~S}$., R. $83 \mathrm{~W}$., the sides of the valley approach each other and form a shallow canyon about 50 feet deep, through which the river flows for a distance of 1,000 feet. A dam in this canyon would be 60 feet high and have a crest length of about 750 feet. To raise the water surface 55 feet a low dike and spillway 600 feet long at a point half a mile northeast of the dam site would be required. No borings have been made to determine the distance to bedrock.

Capacity.-No detailed survey of this site is available, but from the topographic map of the Taylor Park quadrangle, which has a contour interval of 50 feet, it has been computed that at an altitude of 9,800 feet the area would be 28 acres and the capacity 70 acre-feet and at 9,850 feet the area would be 406 acres and the capacity 10,900 acre-feet.

Water supply.-The only records of stream flow in the vicinity of the dam site are the few miscellaneous measurements made during 1903 and records of the Taylor River at Almont for 1911-1927. A study of these records and the characteristics of the drainage basin indicates that the run-off per square mile at the dam site is somewhat higher than at Almont. As the unit run-off at Almont is 667 acre-feet per square mile, that at the Dorohester site is estimated as 725 acre-feet. For the 40 square miles of drainage area this would give a mean annual run-off of 29,000 acre-feet.

Probable use.-There is no apparent use for this site, because the much larger Taylor Park aite is better suited to regulate the river either for irrigation or for power. In the seemingly remote possibility of the transmountain diversion from the Taylor River to the Arkansas at an altitude of 9,800 feet (p. 61), this site could be used for western-slope storage for that project.

\section{TAYIOB PARE SITE (9EA 2)}

Location.-In Taylor Park, chiefly in secs. 5, 6, 7-9, and 17-21, T. 14 S., R. 82 W., and secs. 13, 24, T. 14 S., R. $83 \mathrm{~W}$. sixth principal meridian. The dam site is in the canyon just below the park. (See pl. 5.)

Description.-Taylor Park, through which the Taylor River flows, is a high gravelly basin, 6 miles wide at its lower end. In this park Willow and Texas Creeks join the main river. Peale " has given the following description of Taylor Park: 


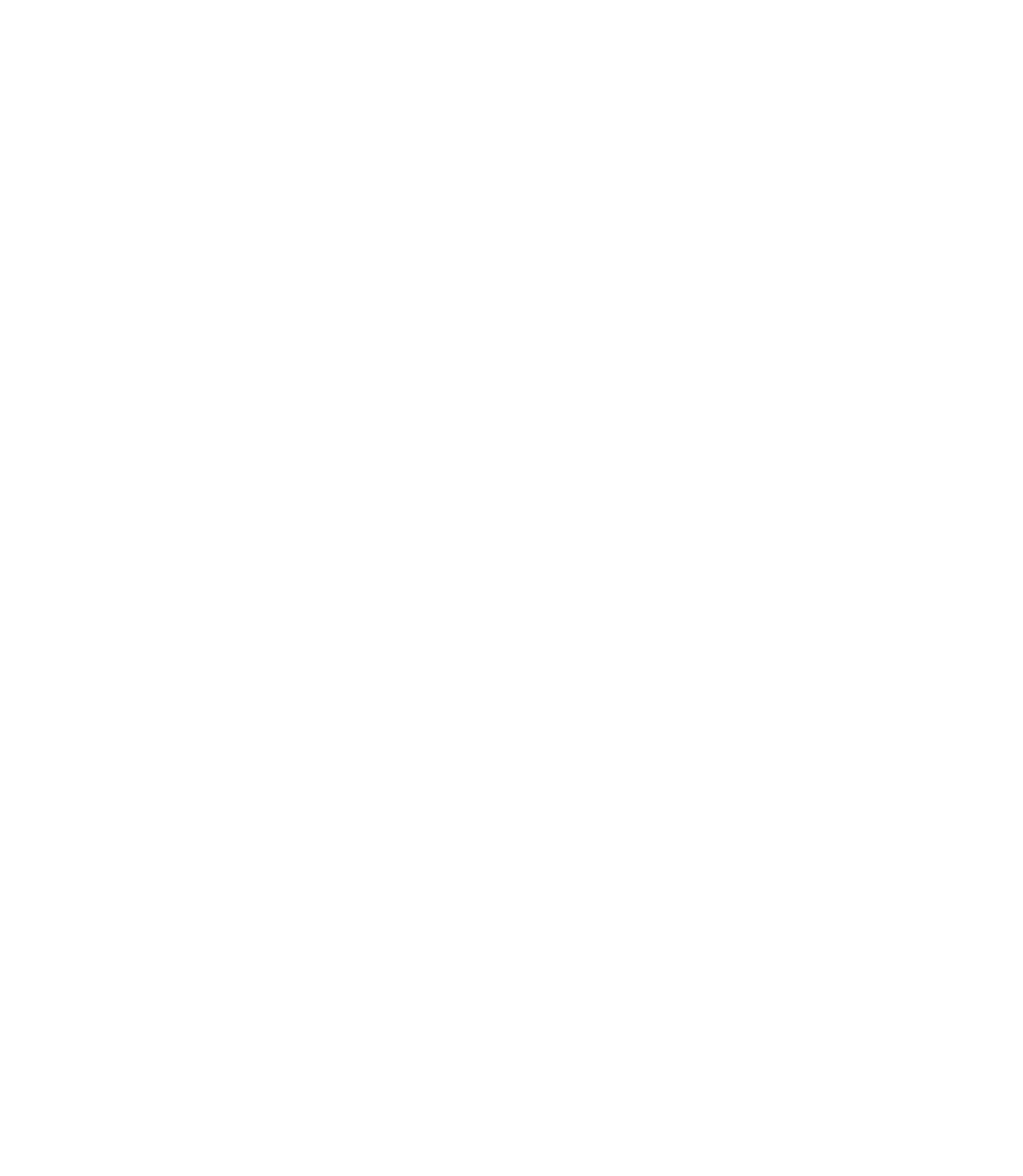



"Crossing the range at the head of Lake Creek, we descend on the west side to the waters of the Gunnison [Taylor] River, which at this point flows through a meadowlike park, called Taylor Park. This park is bounded on the west by gneissic rocks. The basis of the park is also granitic and gneissic, but it is for the most part covered with drift, probably all of glacial origin. All the creeks coming into the Gunnison [Taylor] * * * in the park present evidence of glacial action. On Texas Creek *** there are well-marked lateral moraines reaching from the edge of the mountains almost to the main river, and gradually decreasing in height. *** The main portion of the park lies on the east side of the river, which keeps close along the edge of comparatively low granite or gneissic hills. Several outcrops of granite are found throughout the park, but they are mostly covered either with glacial drift or close to the streams by alluvium."

Dam site.-There are two dam sites in the narrow rocky canyon just below Taylor Park. At the upper site the Reclamation Service made a number of diamond-drill borings in 1911 and 1912. Bedrock was found to be overlain with quartzite boulders and sand from 21 to 29 feet thick.

Capacity.-The Reclamation Service made a topographic survey of the reservoir site in 1904, and from that survey the following table has been computed:

\section{Area and capacity of Taylor Park Reservoir at different heights}

\begin{tabular}{|c|c|c|c|c|c|}
\hline $\begin{array}{c}\text { Height } \\
\text { aboveriver } \\
\text { (feet) }\end{array}$ & $\begin{array}{c}\text { Area } \\
\text { (acres) }\end{array}$ & $\begin{array}{c}\text { Total } \\
\text { capacity } \\
\text { (acre-feet) }\end{array}$ & $\begin{array}{l}\text { Height } \\
\text { aboveriver } \\
\text { (feet) }\end{array}$ & $\underset{\text { (acres) }}{\text { Area }}$ & $\begin{array}{c}\text { Total } \\
\text { capacity } \\
\text { (acre-feet) }\end{array}$ \\
\hline $\begin{array}{l}10 \\
\mathbf{3 0} \\
50 \\
70 \\
90\end{array}$ & $\begin{array}{r}27 \\
108 \\
295 \\
481 \\
730\end{array}$ & $\begin{array}{r}145 \\
1,290 \\
5,050 \\
12,700 \\
24,600\end{array}$ & $\begin{array}{l}110 \\
130 \\
150 \\
160 \\
170\end{array}$ & $\begin{array}{l}1,100 \\
1,390 \\
2,030 \\
2,260 \\
2,440\end{array}$ & $\begin{array}{r}42,500 \\
69,700 \\
106,000 \\
127,000 \\
151,000\end{array}$ \\
\hline
\end{tabular}

Water supply. -The only records of stream flow in the vicinity of the dam site are a few miscellaneous measurements made during 1903 , one year's records in 1905 at a point 16 miles downstream, several months' records at the dam site in 1913, and records at Almont, 21 miles downstream, since 1911. A study of these records and the characteristics of the drainage basin indicates that the run-off per square mile at the dam site and at Almont are practically the same. The following table has been computed from the Almont records:

Annual discharge of Taylor River at Taylor Park Reservoir site, 1911-1927

\begin{tabular}{|c|c|c|c|c|c|}
\hline Year & Acre-feet & $\begin{array}{l}\text { Per cent } \\
\text { of mean }\end{array}$ & Year & Acre-feet & $\begin{array}{l}\text { Per pent } \\
\text { of mean }\end{array}$ \\
\hline $\begin{array}{l}1911 \\
1912 \\
1913 \\
1915 \\
1916 \\
1917\end{array}$ & $\begin{array}{l}162,000 \\
150,000 \\
113,000 \\
205,000 \\
122,000 \\
177,000 \\
179,000 \\
167,000\end{array}$ & $\begin{array}{r}106 \\
98 \\
74 \\
134 \\
80 \\
116 \\
117\end{array}$ & $\begin{array}{l}1921 \\
1922 \\
1924 \\
1925 \\
1926 \\
1027\end{array}$ & $\begin{array}{l}167,000 \\
150,000 \\
164,000 \\
144,000 \\
119,000 \\
124,000 \\
154,000\end{array}$ & $\begin{array}{r}109 \\
98 \\
107 \\
94 \\
78 \\
81 \\
101\end{array}$ \\
\hline 1910 & $\begin{array}{l}118,000 \\
187,000\end{array}$ & $\begin{array}{r}77 \\
122\end{array}$ & Mean & 153,000 & -..- \\
\hline
\end{tabular}

Status of site.-This site is reserved for the use of the Bureau of Reclamation's Uncompahgre project.

Probable use.-Although the Taylor Park Reservoir appears destined to be used for irrigation, it is possible that the Uncompahgre irrigation project may 
not require this additional storage, and in that event it could be used to develop power on the Taylor River. A mass curve based on the estimated flow at the dam site for the 16-year period indicates that to equalize the flow between wet and dry years, storage amounting to 107,000 acre-feet would be required. This would have made possible the following rates of uniform draft:

Possible rates of uniform draft at Taylor Park site, 1912-1927

\begin{tabular}{|c|c|c|c|}
\hline Period & $\begin{array}{l}\text { Uniform } \\
\text { draft } \\
\text { (second- } \\
\text { feet) }\end{array}$ & $\begin{array}{l}\text { Storage } \\
\text { required } \\
\text { (acre- } \\
\text { feet) }\end{array}$ & $\begin{array}{l}\text { Mean } \\
\text { head } \\
\text { (feet) }\end{array}$ \\
\hline $\begin{array}{l}\text { July, 1912, to July, } 1914 \\
\text { August, } 1914 \text {, to July, } 1918 \\
\text { August, } 1918 \text {, to July, } 1921 \\
\text { August, 1921, to July, } 1924 \\
\text { August, 1924, to July, } 1927\end{array}$ & $\begin{array}{l}219 \\
226 \\
219 \\
215 \\
179\end{array}$ & $\begin{array}{r}105,000 \\
105,000 \\
107,000 \\
70,000 \\
70,000\end{array}$ & $\begin{array}{l}146 \\
149 \\
150 \\
157 \\
157\end{array}$ \\
\hline
\end{tabular}

The table of reservoir capacity shows that the upper 55 feet has a capacity of 105,000 acre-feet. With this section used for regulation the minimum head on the dam would be 115 feet. For 90 per cent of the time the discharge would be 179 second-feet with a mean head of 157 feet, and for 50 per cent of the time 219 second-feet with a mean head of 148 feet.

The uniform rates of draft, with an allowance for the increased flow below the reservoir, would have increased the power at the three sites described on page 196 as follows:

Increased power at certain sites, in horsepower, due to storage in Taylor Park Reservoir

\begin{tabular}{|c|c|c|c|c|c|c|}
\hline \multirow{2}{*}{ Site } & \multicolumn{3}{|c|}{90 per cent of the time } & \multicolumn{3}{|c|}{50 per cent of the time } \\
\hline & $\begin{array}{l}\text { Without } \\
\text { storage }\end{array}$ & $\begin{array}{l}\text { With } \\
\text { storage }\end{array}$ & Increase & $\begin{array}{l}\text { Without } \\
\text { storage }\end{array}$ & $\begin{array}{l}\text { With } \\
\text { storage }\end{array}$ & Increase \\
\hline $\begin{array}{l}\text { Crystal Creek } \\
\text { Spring Creek } \\
\text { Almont }\end{array}$ & $\begin{array}{l}1,610 \\
3,170 \\
2,260\end{array}$ & $\begin{array}{r}\text { a } 7,930 \\
7,220 \\
5,020\end{array}$ & $\begin{array}{l}6,320 \\
4,050 \\
2,760\end{array}$ & $\begin{array}{l}2,770 \\
5,460 \\
3,860\end{array}$ & $\begin{array}{r}a 9,600 \\
9,290 \\
6,480\end{array}$ & $\begin{array}{l}6,830 \\
3,830 \\
2,620\end{array}$ \\
\hline Total & 7,040 & 20,200 & 13,100 & 12,100 & 25,400 & 13,400 \\
\hline
\end{tabular}

a Includes development of power in 8-mile section below dam.

\section{EAST RIVER SITE (9EA 3)}

Location.-In secs. 4 and 5, T. 14 S., R. 85 W., and secs. 32 and 33, T. 13 S., R. $85 \mathrm{~W}$. sixth prinripal meridian, in the channel of the East River, 4 miles east of Crested Butte. At the dam site, in sec. 5, a dam 74 feet high would have a crest length of 1,280 feet.

Capacity.-From a survey made by the Reclamation Service in 1902 the following table has been compiled:

Area and capacity of East River Reservoir for different heights of dam

\begin{tabular}{|c|c|c||c|c|c|}
\hline $\begin{array}{c}\text { Height } \\
\text { above } \\
\text { stream } \\
\text { bed (feet) }\end{array}$ & $\begin{array}{c}\text { Area } \\
\text { (acres) }\end{array}$ & $\begin{array}{c}\text { Total } \\
\text { capacity } \\
\text { (acre-feet) }\end{array}$ & $\begin{array}{c}\text { Height } \\
\text { above } \\
\text { stream } \\
\text { bed (feet) }\end{array}$ & $\begin{array}{c}\text { Area } \\
\text { (acres) }\end{array}$ & $\begin{array}{c}\text { Total } \\
\text { capacity } \\
\text { (acre-feet) }\end{array}$ \\
\hline \begin{tabular}{c|c}
$\mathbf{4 4}$ \\
54
\end{tabular} & $\begin{array}{c}194 \\
\mathbf{3 3 3}\end{array}$ & $\begin{array}{c}3,340 \\
\mathbf{5}, 970\end{array}$ & $\begin{array}{c}64 \\
\mathbf{7 4}\end{array}$ & $\begin{array}{c}448 \\
549\end{array}$ & $\begin{array}{c}\mathbf{9}, 880 \\
\mathbf{1 4} 800\end{array}$ \\
\hline
\end{tabular}


The report of the survey states ${ }^{22}$ that the material at the dam site is earth with some loose rock. The land that would be covered is about two-thirds meadow grass and one-third pasture.

Water supply.-From the record of the East River at Almont (1905, 1911-1921) and a few miscellaneous records near the reservoir site, the unit run-off at the East River site is estimated as 1,100 acre-feet to the square mile. For the 91 square miles tributary to the reservoir site the mean annual run-off is 100,000 acre-feet.

Probable use.-No outstanding need for the reservoir is apparent at present. If power is developed on the Gunnison River, storage at this site may prove feasible.

\section{TOMICHI CREEK BASIN}

Tomichi Creek below the mouth of Marshall Creek, 16 miles from its source, flows through a valley that gradually widens out to a distance of 2 miles and is bounded by gentle mountain slopes. Although the Marshall Pass line of the Denver \& Rio Grande Western Rajlroad traverses the entire length of the valley, there are two possible reservoir sites-the Tomichi and Parlins sites. The latter has not been surveyed in detail, and its feasibility is impossible to determine. A reconnaissance made in 1902 by the Reclamation Service indicated that a dam 60 feet high, having a crest length of 1,200 feet, would give a storage capacity of about 12,000 acre-feet, which is but 9 small fraction of the available water supply.

On the tributary streams two sites exist-the Pitkin site, on Quartz Creek, and an unnamed site on Little Tomichi Creek. The dam required for the latter site is so large as compared with the capacity obtainable that the site is considered unfeasible.

TOMTCHI SITE (9EB 2)

Location.-In the valley of Tomichi Creek, in secs. 28, 29, and 32-35, T. 49 N., R. 3 E. New Mexico principal meridian.

Description.-Tomichi Creek in this section of its course has a fall of about 11 feet to the mile and pursues a winding course through a valley having a general width of half a mile. Within the reservoir site, which is occupied by irrigated hay meadows, the creek is joined by two small tributaries. The narrow-gage Marshall Pass line of the Denver \& Rio Grande Western Railroad traverses the reservoir site.

Dam site.-At a height of 54 feet above the water surface the distance between abutments is 800 feet; at 64 feet, 825 feet; and at 74 feet, 850 feet. No borings have been made to determine the distance to bedrock.

Capacity.-In 1902 the Reclamation Service made a reconnaissance survey of the site, from which the following table has been computed:

Area and capacity of Tomichi Reservoir for different heights of dam.

\begin{tabular}{|c|c|c|}
\hline $\begin{array}{c}\text { Height } \\
\text { above } \\
\text { water } \\
\text { surface } \\
\text { (feet) }\end{array}$ & $\begin{array}{c}\text { Area } \\
\text { (acres) }\end{array}$ & $\begin{array}{c}\text { Total } \\
\text { capacity } \\
\text { (acre-feet) }\end{array}$ \\
\hline $\begin{array}{l}54 \\
64 \\
74\end{array}$ & $\begin{array}{l}1,070 \\
1,270 \\
1,540\end{array}$ & $\begin{array}{l}27,000 \\
38,700 \\
52,700\end{array}$ \\
\hline
\end{tabular}

${ }_{22}^{2}$ Edwards, W. P., Reservoir sites in Gunnison River Basin: U. s. Recl. Bervice Second Ann. Rept., p. 188,1004 . 
Water supply.-Records of Tomichi Creek at Sargents from 1918 to 1922 show a mean annual run-off of 56,000 acre-feet, or 343 acre-feet to the square mile. Owing to the mountainous character of the drainage basin, the unit run-off at the reservoir site is taken as equal to that at Sargents, and the mean annual run-off is estimated as 143,000 acre-feet.

Probable use.-No outstanding need for this reservoir is apparent at present. If power is developed on the Gunnison River and if the Taylor Park site is reserved for the Uncompahgre irrigation project, storage in the Tomichi Reservoir may prove possible.

PITKIY SITE (OEB 8)

Location.-In the S. $1 / 2$ SE. $1 / 4$ sec. 2 and the N. $1 / 2$ NE. $1 / 4$ sec. 11, T. 50 N., R. $4 E_{4}$ : New Mexico principal meridian. The dam site is in the SE. $1 / 4$ SW. $1 / 4$ sec. 2. An intake ditch a quarter of a mile long will supply water from Quartz Creek.

Capacity.-A filing in the State engineer's office shows that a dam about 70 feet high would be 700 feet long and create a storage capacity of 6,000 acre-feet with a maximum area of 150 acres.

Water supply.-Records of Quartz Creek near Pitkin for 1911-1913 show a mean annual run-off of 38,400 acre-feet. Comparison with records of the Taylor River near Almont shows that the run-off for the 17-year period 1911-1927 is 109 per cent of that for the 3-year period covered by the Quartz Creek records. Therefore the mean annual run-off at the gaging station is 42,000 acre-feet, or 639 acre-feet to the square mile. As the proposed intake is farther upstream, the unit run-off is assumed as 650 acre-feet, or 13,600 acre-feet for the 21 square miles above that point.

Probable use.-The chief use proposed in the filing was the development of power by means of a pipe line 5 miles long leading to a power house in sec. 23, T. 50 N., R. 3 E. No information relative to the total head to be developed is available. The Roosevelt Tunnel power plant (p. 173) develops about 130 feet of fall on Quartz Creek below the reservoir site. It appears that the Pitkin Reservoir would be of value to augment the 90 per cent power of this plant.

CEBOLLA CREEK BASIN

The valley of Cebolla Creek is so narrow and has so steep a slope. that only one reservoir site has been located in it.

\section{CEBOLIA SITE (өEC 1)}

Location.-In secs. 11-15, 22, and 23, T. 44 N., R. 2 W. New Mexico principal meridian, in the channel of Cebolla Creek, a tributary of the Gunnison River. A dam 140 feet high at this site would have a crest length of 430 feet.

Capacity.-From a survey made by the Reclamation Service in 1902 the following table has been compiled:

Area and capacity of Cebolla Reservoir for different heights of dam

\begin{tabular}{|c|c|c|}
\hline $\begin{array}{c}\text { Height } \\
\text { above } \\
\text { stream bed } \\
\text { (feet) }\end{array}$ & $\begin{array}{c}\text { Area } \\
\text { (acres) }\end{array}$ & $\begin{array}{c}\text { Total } \\
\text { capacity } \\
\text { (acre-feet) }\end{array}$ \\
\hline 120 & 398 & 20,000 \\
130 & 480 & 24,000 \\
140 & 572 & 29,300 \\
\hline
\end{tabular}


The report of the survey states 23 that solid rock is expesed at the sides of the dam site and can probably be reached in the bottom by sinking 40 feet through gravel and earth. The land that would be covered is irrigated meadow land in the valley floor and pasture land in the hills.

Water supply.-No records of stream flow for Cebolla Creek are available. From a comparison with the discharge of Sapinero Creek at Sapinero for 19111914 the unit run-off of Cebolla Creek is assumed as 550 second-feet to the square mile. For the 136 square miles tributary to, the reservoir this would give a megh annual run-off of 74,800 acre-feet.

Probable use.-No outstanding need for the reservoir is apparent at predent. If power is developed on the Gunnison River, storage in the Cebolla Reservoir may prove feasible.

\section{LAKE FORK BASIN}

The best reservoir site in the basin of Lake Fork is Lake San Cristobal, 4 miles above Lake City. About 1 mile above Lake City the valley widens so much that a dam 100 feet high with a crest length of 800 feet would create a reservoir having a capacity of about 7,500 acre-feet. The size of dam required appears to make this site unfeasible. As a branch line of the Denver \& Rio Grande Western Railroad traverses Lake Fork from Lake City to the mouth the two possible reservoirs at points where the valley widens in the vicinity of Trout Creek and Gateview are not considered feasible. These sites have not been surveyed and can not be described in detail.

\section{LAKE SAN CRISTOBAL (9EC 2)}

Location.-A natural lake in the channel of the Lake Fork about 4 miles south of Lake City, in T. 43 N., R. 4 W. New Mexico principal meridian.

Description. - The lake, which is $13 / 4$ miles long and a third of a mile wide, has an area of 322 acres. It is bounded on each side by steep mountain slopes, which are sparsely timbered. The lake was apparently formed by a mud slide from what is now Slumgullion Gulch, blocking the narrow valley of the Lake Fork. A number of small summer cottages are located on the lake shore.

Dam site.-The natural dam forming the lake is composed largely of breccia, which is more or less porous. To raise this dam 60 feet would require a maximum length of 500 feet.

Capacity.-From a map filed in the State engineer's office the following table has been compiled:

Area and capacity of San Cristobal Reservoir at different altitudes

\begin{tabular}{|r|r|r|r|r|r|}
\hline $\begin{array}{c}\text { Altitude } \\
\text { (feet) }\end{array}$ & $\begin{array}{c}\text { Area } \\
\text { (acres) }\end{array}$ & $\begin{array}{r}\text { Total ca- } \\
\text { pacity } \\
\text { (acre-feet) }\end{array}$ & $\begin{array}{r}\text { Altitude } \\
\text { (feet) }\end{array}$ & $\begin{array}{c}\text { Area } \\
\text { (acres) }\end{array}$ & $\begin{array}{r}\text { Total ca- } \\
\text { pacity } \\
\text { (acre-feet) }\end{array}$ \\
\hline 8,997 & 322 & 317 & 9,040 & 574 & 20,800 \\
9,010 & 438 & 5,260 & 9,050 & 612 & 26,700 \\
9,020 & 495 & 9,880 \\
9,030 & 541 & 15,100 & 9,055 & 630 & 29,800 \\
\hline
\end{tabular}

Water supply.-Records of Lake Fork at Lake City, 4 miles downstream from Lake San Cristobal, for 1918-1924 give closely the flow at the outlet of the lake .

2a Edwards, W. P., Reservoir sites in Gunnison River Basin: U. S. Recl. Service Second Ann. Rept., p. $189,1901$. 
During the season of medium and low water there appears to be a loss between the lake and the gaging station, as shown by the following current-meter measurements, in second feet:

$$
\begin{aligned}
& \text { Lake ontlet } \\
& \text { July 18, 1919 } \\
& \text { Nov. 9, } 1919 \ldots \ldots \text { City } \\
& 272
\end{aligned}
$$

As an offset to the loss, there is in the spring considerable run-off between the tho points, which at that time will increase the flow at the gaging station. The

\begin{tabular}{|c|c|c|c|c|c|}
\hline Year & Acre-feet & $\begin{array}{l}\text { Per cent of } \\
\text { mean }\end{array}$ & Year & A.cre-feet & $\begin{array}{l}\text { Per cent of } \\
\text { mean }\end{array}$ \\
\hline \multirow{2}{*}{$\begin{array}{l}1918 . \\
1919 \\
19020 \\
1921 \\
1924\end{array}$} & \multirow{2}{*}{$\begin{array}{r}70,900 \\
89,600 \\
95,900 \\
128,000 \\
80,900\end{array}$} & \multirow{2}{*}{$\begin{array}{r}75 \\
95 \\
102 \\
136 \\
86\end{array}$} & \multirow{2}{*}{ Mean. } & $\begin{array}{r}100,000 \\
93,100\end{array}$ & $\begin{array}{r}106 \\
99\end{array}$ \\
\hline & & & & 94,100 & \\
\hline
\end{tabular}
melasured mean annual run-off is as follows:

Mean annual run-off at Lake San Cristobal, 1918-1924

The record of the Gunnison River near Grand Junction for a period of 19 years shows that the mean run-off for that period is 96 per cent of that for the 7-year period 1918-1924. On that basis, the mean annual run-off at Lake San Cristobal is 90,300 acre-feet.

Probable use.-The chief value of Lake San Cristobal as a reservoir appears to be in connection with the development of power on the Lake Fork. A mass curve based on the 7-year record of the Lake Fork shows that to equalize the flow between the wet and dry years a maximum storage capacity of 75,000 acrefeet would have been required. As this quantity exceeds the measured capacity by 45,000 acre-feet it is evident that the flow can not be fully equalized. It is possible that the capacity can be increased to about 40,000 acre-feet, which would have permitted the following rates of uniform draft:

Possible rates of uniform draft at Lake San Cristobal, 1918-1924

Second-feet

July, 1918, to June, 1919 _...

August, 1919, to June, 1920 _...

August, 1920, to June, $1921 \ldots \ldots \ldots \ldots$

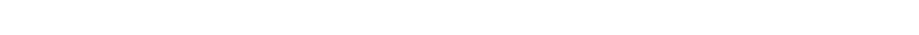

August, 1922, to June, 1923 _.. $\ldots \ldots \ldots \ldots \ldots$

August, 1923, to July, 1924 _.

These rates of draft would have made available the following increase in power

\begin{tabular}{|c|c|c|c|c|c|c|}
\hline \multirow{2}{*}{ Site } & \multicolumn{3}{|c|}{90 per cent of the time } & \multicolumn{3}{|c|}{50 per cent of the time } \\
\hline & $\begin{array}{l}\text { Without } \\
\text { storage }\end{array}$ & $\begin{array}{l}\text { With } \\
\text { storage }\end{array}$ & Increase & $\begin{array}{l}\text { Without } \\
\text { storage }\end{array}$ & $\begin{array}{l}\text { With } \\
\text { storage }\end{array}$ & Increase \\
\hline $\begin{array}{l}\text { Lake San Cristobal } \\
\text { Gateview }\end{array}$ & $\begin{array}{r}207 \\
1,270\end{array}$ & $\begin{array}{l}2,500 \\
3,590\end{array}$ & $\begin{array}{l}2,300 \\
2,320\end{array}$ & $\begin{array}{r}518 \\
3,090\end{array}$ & $\begin{array}{l}2,960 \\
5,490\end{array}$ & $\begin{array}{l}2,440 \\
2,400\end{array}$ \\
\hline Total.... & 1,480 & 6,090 & 4,620 & 3,610 & 8,450 & 4,840 \\
\hline
\end{tabular}
at the two sites discussed on pages 197-198.

Increased power due to storage at Lake San Cristobal, in horsepower 


\section{NORTH FORK BASIN}

The main valley of the North Fork contains Excelsior No. 4 site, but as this site covers irrigated land and includes a branch line of the Denver \& Rio Grande Western Railroad it is not considered feasible. Nor is there any apparent use for it, as there appears to be no feasible irrigation or power projects in the lower Gunnison Valley.

On East Muddy Creek, a headwater tributary of the North. Fork, is the East Muddy site. Between Cottonwood Creek and the North Fork, with intakes on both streams, is Excelsior No. 5 site. No detailed survey of this site has been made, and as there is no apparent use for its estimated capacity of 44,000 acre-feet, it is not considered feasible.

EAST MUDDY SITE (9ED 2)

Location and capacity.-In sec. 5, T. 12 S., R. 89 W., and sec. 32, T. 11 S., R. $89 \mathrm{~W}$. sixth principal meridian, in the channel of East Muddy Creek, tributary of the North Fork of the Gunnison River. A dam 80 feet high at this site would have a crest length of 410 feet and create a storage capacity of $4,65 \phi$ acre-feet.

Water supply.-No records of East Muddy Creek or adjacent streams in the North Fork Basin are available, but from the records of Buzzard Creek, which drains an area on the opposite side of the divide, the unit run-off for East Muddy Creek is estimated at 450 acre-feet to the square mile, or 55,000 acre-feet for the 123 square miles tributary to the reservoir site.

Probable use.-This reservoir would probably be used in connection with irrigation in the North Fork Valley.

\section{UNCOMPAHGRE RIVER BASIN}

No reservoir. sites exist in the valley of the main Uncompahgre River. On Red Mountain Creek, an upper tributary, is the Ironton Park site, and in the basin of Dallas Creek are the Willow Swamp and Von Hagen No. 1 and No. 2 sites. The Von Hagen No. 2 site is considered unfeasible, as the required dam is too large for the capacity obtainable.

\section{IRONTON PARK SITE (OEF 1)}

Location.-In secs. 29-31, T. 43 N., R. 7 W. New Mexico principal meridian; in the valley of Red Mountain Creek, a tributary of the Uncompahgre River:

Capacity.-A reconnaissance of the site made by the Reclamation Service in 1902 showed that at the dam site, 2 miles below Ironton, a dam 70 feet high would be 50 feet long on the bottom and 500 feet long at the crest and cover an area of 270 acres to an average depth of 30 feet. This would give a total capacity of 8,000 acre-feet.

Water supply.-The 19 square miles tributary to the reservoir site ranges in altitude from 9,500 to 12,800 feet, in a region of very heavy precipitation. From a comparison with the unit run-off of the Uncompahgre River at Ouray for 1914-1926 and of Canyon Creek at Ouray for 1911-1915, the drainage basins of which range in altitude from 8,000 to 13,000 feet, the unit run-off at the reservoir site is estimated at 1,900 acre-feet to the square mile. This gives a mean annua run-off of 36,000 acre-feet. As the capacity is only 8,000 acre-feet, it is evident that the reservoir can be filled each year. 
Probable use.-The chief value of the Ironton Park site appears to be in connection with the development of power on the Uncompahgre River. For that use the water would be discharged during the low-water period at such rates that the discharge at the power sites (p. 199) would be practically uniform. This would result in the 90 per cent and 50 per cent discharges being increased about 25 and 13 second-feet, respectively. The effect of the increased flow on the two power sites would be as follows:

Increased power due to storage in Ironton Park Reservoir, in horsepower

\begin{tabular}{|c|c|c|c|c|c|c|}
\hline \multirow{2}{*}{ Site } & \multicolumn{3}{|c|}{90 per cent of the time } & \multicolumn{3}{|c|}{50 per cent of the time } \\
\hline & $\begin{array}{l}\text { Without } \\
\text { storage }\end{array}$ & $\begin{array}{l}\text { With } \\
\text { storage }\end{array}$ & Increase & $\begin{array}{l}\text { Without } \\
\text { storage }\end{array}$ & $\begin{array}{l}\text { With } \\
\text { storage }\end{array}$ & Increase \\
\hline \multirow[t]{2}{*}{$\begin{array}{l}\text { Ouray } \\
\text { Bachelor switch }\end{array}$} & $\begin{array}{l}678 \\
950\end{array}$ & $\begin{array}{l}2,220 \\
1,900\end{array}$ & $\begin{array}{r}1,540 \\
950\end{array}$ & $\begin{array}{l}1,850 \\
1,900\end{array}$ & $\begin{array}{l}2,280 \\
2,390\end{array}$ & $\begin{array}{l}430 \\
490\end{array}$ \\
\hline & 1,630 & 4,120 & 2,490 & 3,750 & 4,670 & 920 \\
\hline
\end{tabular}

WHLOW SWAMP SITE (9BF 2)

Location.-In the SW. 1/4 sec. 13, T. 44 N., R. 9 W. New Mexico principal meridian, in Willow Swamp, on the East Fork of Dallas Creek, a tributary of the Uncompahgre River. A dam 120 feet high at this site would have a crest length of 532 feet.

Capacity.-From a survey made by the Reclamation Service in 1902 the following table has been compiled:

Area and capacity of Willow Swamp Reservoir for different heights of dam

\begin{tabular}{|r|r|r||r|r|r|}
\hline $\begin{array}{c}\text { Height } \\
\text { above } \\
\text { stream } \\
\text { bed (feet) }\end{array}$ & $\begin{array}{r}\text { Area } \\
\text { (acres) }\end{array}$ & $\begin{array}{r}\text { Total } \\
\text { capacity } \\
\text { (acre-feet) }\end{array}$ & $\begin{array}{r}\text { Height } \\
\text { above } \\
\text { stream } \\
\text { bed (feet) }\end{array}$ & $\begin{array}{c}\text { Area } \\
\text { (acres) }\end{array}$ & $\begin{array}{c}\text { Total } \\
\text { capacity } \\
\text { (acre-foet) }\end{array}$ \\
\hline 60 & $\begin{array}{r}64 \\
80\end{array}$ & $\begin{array}{r}1,450 \\
2,420\end{array}$ & $\begin{array}{r}100 \\
120\end{array}$ & $\begin{array}{r}101 \\
133\end{array}$ & $\begin{array}{r}4,250 \\
6,590\end{array}$ \\
\hline
\end{tabular}

The material under the dam is earth and loose rock, with possibly solid rock on the south side at a depth of 20 feet.

Water supply. - Records of Dallas Creek near Ridgway for 1923-1927, with an allowance for diversions above, indicate an average unit run-off of 500 acre-feet to the square mile. For the area tributary to the reservoir the unit run-off is estimated as $\mathbf{7 5 0}$ acre-feet to the square mile, which gives a mean annual run-off of 9,000 acre-feet.

Probable use.-This reservoir would probably be used in connection with irrigation in the Dallas Creek Basin.

\section{VON HAGEN NO. 1 SITR (9EF 3)}

Location.-In secs. 13, 14, and 24, T. 45 N., R. 10 W. New Mexico principal meridian, on the headwaters of Pleasant Valley Creek, a tributary of Dallas Creek.

Description.-Near the upper end of Uncompahgre Plateau the headwaters of Pleasant Valley Creek drain the Howard Flats, which lie close to the divide between the Uncompahgre and San Miguel Basins. In the SE. $1 / 4 \mathrm{SW} .1 / 4 \mathrm{sec}$. 13 a dam 137 feet high would have a crest length of 673 feet. 
Capacity.-A filing in the State engineer's office shows that the dam would create 11,400 acre-feet of storage with an area of 382 acres.

Water supply.-As the site lies near the divide, there are two possible sources of supply. One is a collection ditch tapping the headwaters of Dallas Creel, and the other a collection ditch tapping the headwaters of Leopard Creek, in the San Miguel Basin. The available water supply will depend upon the length of the ditch. A ditch 12 miles long extending from Hay Creek, a tributary of Leopard Creek, across the divide to the reservoir would make available the run-off from 22 square miles, of which 12 square miles lies on the nortle slope of Hayden Peak (altitude 12,900 feet). No water could be diverted during the winter and early spring, when Hay Creek would be frozen, but the mean run-off from May to October is estimated at 13,000 acre-feet. A collection ditch 10 miles long extending from the West Fork of Dallas Creek to the reservoir would make available the run-off from 23 square miles, of which 17 square miles lies on the northwest slope of Hayden Peak. The mean annual run-cff, including the run-off from Hayden Peak for May to October and that from the rest of the area for the entire year, is estimated at 16,000 acre-feet. It is probable that not all of this run-off would be available for storage, as 5,600 acres is irrigated in the Dallas Creek Basin. Prior rights would probably reduce the available supply for the reservoir to 13,000 acre-feet. If it is not feasible to increase the capacity of the reservoir above 11,400 acre-feet, either source of supply would be sufficient to fill it.

Probable use.-This reservoir would probably be used for irrigation under the proposed Montrose Chief project (p. 144).

\section{KAHNAH CREEK BASIN}

At the head of Kahnah Creek, on Grand Mesa, are a number of tiny lakes, but the capacity and run-off at these sites are too small to make them of value for storage. Two reservoir sites, the Kernahan No. 2 and Kahnah Creek, have been located in the main valley of the creek, but.these sites appear to be less favorable than the Gunnison Valley site on Indian Creek and the Wabash No. 2 site on Deer Creek, tributary streams, which would have much the same use as those on the main stream.

GUNISSON VALLEY SITR (9EG 3)

Location.-In secs. 4-6, 8, and 9, T. 3 S., R. 2 E. Ute principal meridian, in the channel of Indian Creek, a tributary of Kahnah Creek. The dam site is in the NE. $1 / 4$ SE. $1 / 4$ sec. 6 , where a dam 105 feet high would have a crest length of 890 feet. $\rightarrow$

Capacity.-From a filing in the State engineer's office the following table has been compiled:

Area and capacity of Gunnison Valley Reservoir for different heights of dam

\begin{tabular}{|c|c|c||c|c|c|}
\hline $\begin{array}{c}\text { Height } \\
\text { above out- } \\
\text { lety(feet) }\end{array}$ & $\begin{array}{c}\text { Area } \\
\text { (acres) }\end{array}$ & $\begin{array}{c}\text { Total } \\
\text { capacity } \\
\text { (acre-feet) }\end{array}$ & $\begin{array}{c}\text { Height } \\
\text { above out- } \\
\text { let (feet) }\end{array}$ & $\begin{array}{c}\text { Ares } \\
\text { (acres) }\end{array}$ & $\begin{array}{c}\text { Total } \\
\text { capacity } \\
\text { (acre-feet) }\end{array}$ \\
\hline 10 & 11 & 69 & 60 & 150 & 3,260 \\
20 & 23 & 250 & 70 & 230 & 5,120 \\
30 & 40 & 537 & 80 & 402 & 8,150 \\
40 & 71 & 1,070 & 83 & 483 & 9,650 \\
50 & 102 & 1,940 & & & \\
\hline
\end{tabular}


Water supply.-The chief source of supply is Kahnah Creek. A ditch leading from the creek about in sec. 34, T. 2 S., R. 2 E., to the reservoir would be 2 miles long. Of the 96 square miles of drainage area above the proposed intake, the gaging station in sec. 34, T. $12 \mathrm{~S}$., R. $97 \mathrm{~W}$. sixth principal meridian, measures the run-off from 55 square miles. The 9-year record (1918-1921, 1923-1927) at the gaging station shows a mean annual run-off of 33,600 acre-feet. The run-off from the additional area is estimated at 23,000 acre-feet, making a total of 56,600 acre-feet. Deducting 14,000 acre-feet for prior rights leaves a net mean annual discharge of 42,600 acre-feet.

Probable use.-This reservoir would probably be used for irrigation on the Gunnison Valley project (p. 143).

\section{WABASH NO. 2 SITE (9EG 4)}

Location.-In secs. 20, 21, 28, and 30, T. 3 S., R. 97 W. sixth principal meridian, in the channel of Deer Creek, a tributary of the Gunnison River. The dam site is in the NW. $1 / 4 \mathrm{SW} .1 / 4$ sec. 29 and the SE. $1 / 4$ NE. $1 / 4$ sec. 30 , where a dam 100 feet high would have a crest length of 2,000 feet.

Capacity.-From a filing in the State engineer's office the following table has been compiled:

Area and capacity of Wabash No. 2 Reservoir for different heights of dam

\begin{tabular}{|r|r|r|r|r|r|}
\hline $\begin{array}{c}\text { Height } \\
\text { above out- } \\
\text { let (feet) }\end{array}$ & $\begin{array}{c}\text { Area } \\
\text { (acres) }\end{array}$ & $\begin{array}{r}\text { Total ca- } \\
\text { pacity } \\
\text { (acre-feet) }\end{array}$ & $\begin{array}{c}\text { Height } \\
\text { above out- } \\
\text { let (feet) }\end{array}$ & $\begin{array}{r}\text { Area } \\
\text { (acres) }\end{array}$ & $\begin{array}{c}\text { Total ca- } \\
\text { pacity } \\
\text { (acre-feet) }\end{array}$ \\
\hline 10 & 71 & 390 & 60 & 461 & 13,000 \\
20 & 140 & 1,440 & 70 & 485 & 17,500 \\
30 & 209 & 3,190 & 80 & 555 & 22,700 \\
40 & 278 & 5,560 & 90 & 622 & 28,700 \\
50 & 347 & 8,720 & 100 & 755 & 32,800 \\
\hline
\end{tabular}

Water supply.-The chief source of supply is Kahnah Creek. A ditch leading from the creek in sec. 34, T. $12 \mathrm{~S}$, R. $97 \mathrm{~W}$, to the reservoir would be 8 miles long. Records of Kahnah Creek at a point a short distance above the intake, which are available for the 9-year period 1918-1921, 1923-1927, show a mean annual run-off of 33,600 acre-feet. As 7,000 acres is irrigated from Kahnah Creek below the station, it is probable that not more than 20,000 acre-feet of this quantity would be available for storage. In addition, the run-off of Deer Creek above the reservoir is estimated at 5,000 acre-feet, making a total mean annual supply of 25,000 acre-feet. The annual variation in run-off available for storage is shown by the following table, which is based on the yearly percentage for the Kahnah Creek gaging station:

Annual run-off that would have been available for Wabash No. 2 Reservoir, 1918-1921, 1923-1927

\begin{tabular}{|c|c|c|c|c|c|}
\hline Year & Acre-feet & $\begin{array}{l}\text { Per cent of } \\
\text { mean }\end{array}$ & Year & Acre-feet & $\begin{array}{c}\text { Per cent of } \\
\text { mean }\end{array}$ \\
\hline \multirow{2}{*}{$\begin{array}{l}1918 \\
1919 \\
1920 \\
1921 \\
1923 \\
1924\end{array}$} & \multirow{2}{*}{$\begin{array}{l}17,500 \\
22,600 \\
38,600 \\
40,700 \\
20,500 \\
19,700\end{array}$} & \multirow{2}{*}{$\begin{array}{r}70 \\
90 \\
154 \\
163 \\
82 \\
79\end{array}$} & \multirow{2}{*}{$\begin{array}{l}1925 \\
\text { Mean }\end{array}$} & $\begin{array}{l}17,700 \\
25,000 \\
23,000\end{array}$ & $\begin{array}{r}71 \\
100 \\
92\end{array}$ \\
\hline & & & & 25,000 & 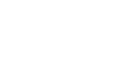 \\
\hline
\end{tabular}

Probable use.-This reservoir would probably be used fòr irrigation on the Gunnison Valley project (p. 143). 
Above Dolores the mountain valley of the Dolores River is too narrow for the existence of reservoir sites, and the presence of the narrow-gage line of the Rio Grande Southern Railroad would prevent reservoir construction except at prohibitive cost. Between Dolores and the mouth of the river there are three large sites, known as the Dolores, Bedrock, and Fiftymile sites. On tributary streams above the San Miguel River are the Dunton and John Bull sites, on the West Dolores River; the Beaver Creek site, on Beaver Creek; and the Cedar No. 4 and No. 5 and Custer sites, on Disappointment Creek. Of these the John Bull site is considered unfeasible, the required dap being too large for the capacity obtajnable.

\section{MAIN STREAM}

\section{DOLORES STTE (9DX 1)}

Location.-In Dolores River Valley, with the dam site in sec. 1, T. 38 N., \&. $16 \mathrm{~W}$. New Mexico principal meridian. (See pl. 6.)

Description.-Below the town of Dolores the river flows through a narrow valley, gradually burying itself deeper in the sandstone formations into which it has cut. With a dam as proposed the water would be backed up nearly to the Montezuma Valley Dam, 1 mile below Dolores, in a narrow body 10 miles long and half a mile wide. The water would also be backed up the canyon of Beaver Creek for a distance of 4 miles.

Dam site.-The sides of the canyon rise on a slope of $26^{\circ}$. A dam 230 feet high would be 70 feet long at the water surface and 1,100 feet long at the crest.

No borings have been made to determine the depth to bedrock.

Tapacity.-The Reclamation Service made a topographic survey of the site iu.1914, and from that survey the following table had been compiled:

\section{Area and capacity of Dolores Reservoir for different heights of dam}

\begin{tabular}{|r|r|r|r|r|r|}
\hline $\begin{array}{c}\text { Height of } \\
\text { dam above } \\
\text { water } \\
\text { surface } \\
\text { (feet) }\end{array}$ & $\begin{array}{r}\text { Area } \\
\text { (acres) }\end{array}$ & $\begin{array}{r}\text { Total } \\
\text { capacity } \\
\text { (acre-feet) }\end{array}$ & $\begin{array}{r}\text { Height of } \\
\text { dam above } \\
\text { water } \\
\text { surface } \\
\text { (feet) }\end{array}$ & $\begin{array}{r}\text { Area } \\
\text { (acres) }\end{array}$ & $\begin{array}{r}\text { Total } \\
\text { capacity } \\
\text { (acre-feet) }\end{array}$ \\
\hline 10 & 19 & 6 & 200 & 2,660 & 187,000 \\
50 & 280 & 7,500 & 210 & 2,930 & 215,000 \\
100 & 700 & 32,000 & 220 & 3,210 & 245,000 \\
150 & 1,510 & 81,000 & 230 & 3,520 & 277,000 \\
\hline
\end{tabular}

The spillway level has been selected at 220 feet above the river, as water stored at a higher level would submerge the diversion works of the Montezuma Valley project (p. 137). 
Water supply.-Records of the Dolores River at Dolores, 1 mile above the diversion for the Montezuma Valley project, are available for 16. years, and the total discharge for each year is given in the following table:

Yearly discharge of Dolores River at Dolores, Colo., 1896-1903, 1911-12, 1928-1927

\begin{tabular}{|c|c|c|c|c|c|}
\hline Year & Acre-feet & $\begin{array}{l}\text { Per cent } \\
\text { of mean }\end{array}$ & Year & Acre-feet & $\begin{array}{l}\text { Per cent } \\
\text { of mean }\end{array}$ \\
\hline 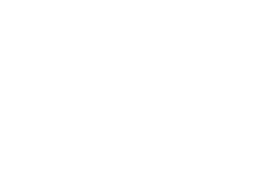 & $\begin{array}{l}174,000 \\
408,000 \\
328,000 \\
146,000 \\
180,000 \\
303,000 \\
124,000 \\
354,000\end{array}$ & $\begin{array}{r}50 \\
118 \\
95 \\
42 \\
52 \\
88 \\
36 \\
103\end{array}$ & $\begin{array}{l}1912 \\
1922 \\
1923 \\
1925 \\
1926\end{array}$ & $\begin{array}{l}402,000 \\
479,000 \\
494,000 \\
344,000 \\
313,000 \\
533,000 \\
502,000\end{array}$ & $\begin{array}{r}117 \\
139 \\
143 \\
100 \\
91 \\
155 \\
146\end{array}$ \\
\hline 1911 & 431,000 & 125 & Mean ....... & 345,000 & \\
\hline
\end{tabular}

To this mean of 345,000 acre-feet at the gaging station must be added the inflow between that point and the outlet of the reservoir, which is estimated as 21,000 acre-feet after making an allowance for evaporation. This gives a total mean annual run-off of 366,000 acre-feet at the reservoir. 'The 16 years covered by these records include the dry period of the late nineties and the first three years of the present century, and the mean discharge indicated should represent closely the mean for a long period.

Probable use.-The chief use of the Dolores Reservoir will probably be for storage in connection with the proposed Dolores project (p. 144). If sufficient storage were available to control the entire flow after deducting 120,000 acre-feet for the irrigation of the completed Montezuma Valley project (p. 144), it would be possible to irrigate 123,000 acres with a reservoir duty of 2 acre-feet to the acre, as the mean annual discharge of 366,000 acre-feet less 120,000 acre-feet amounts to 246,000 acre-feet. With the storage of 120,000 acre-feet it would be possible to irrigate in a mean year about 80,000 acres, if direct flow were used until May 31 and the storage not drawn upon until June 1. This would leave no hold-over storage for dry years during which the reservoir could not be filled. The effect of this deficiency is shown in the following table:

Available water supply and area that would have been possible of irrigation from Dolores River during years of low flow

\begin{tabular}{c|c|r|r}
\hline Year & $\begin{array}{c}\text { Available } \\
\text { water } \\
\text { supply } \\
\text { (acre-feet) }\end{array}$ & $\begin{array}{c}\text { Irrigable } \\
\text { area } \\
\text { (acres) }\end{array}$ \\
\hline 1806 & & 65,000 & 32,500 \\
17,500 \\
1890
\end{tabular}

To avoid a deficiency in the event of a recurrence of years of low flow, hold-over storage should be provided. The irrigation of 60,000 acres would require about 85,000 acre-feet of storage, which if the capacity were 120,000 acre-feet would leave in reserve 35,000 acre-feet. With this hold-over storage 50,000 acres could have been fully irrigated in 1896 and $1900,35,000$ acres in 1899 , and 23,000 acres in the record low year of 1902. 

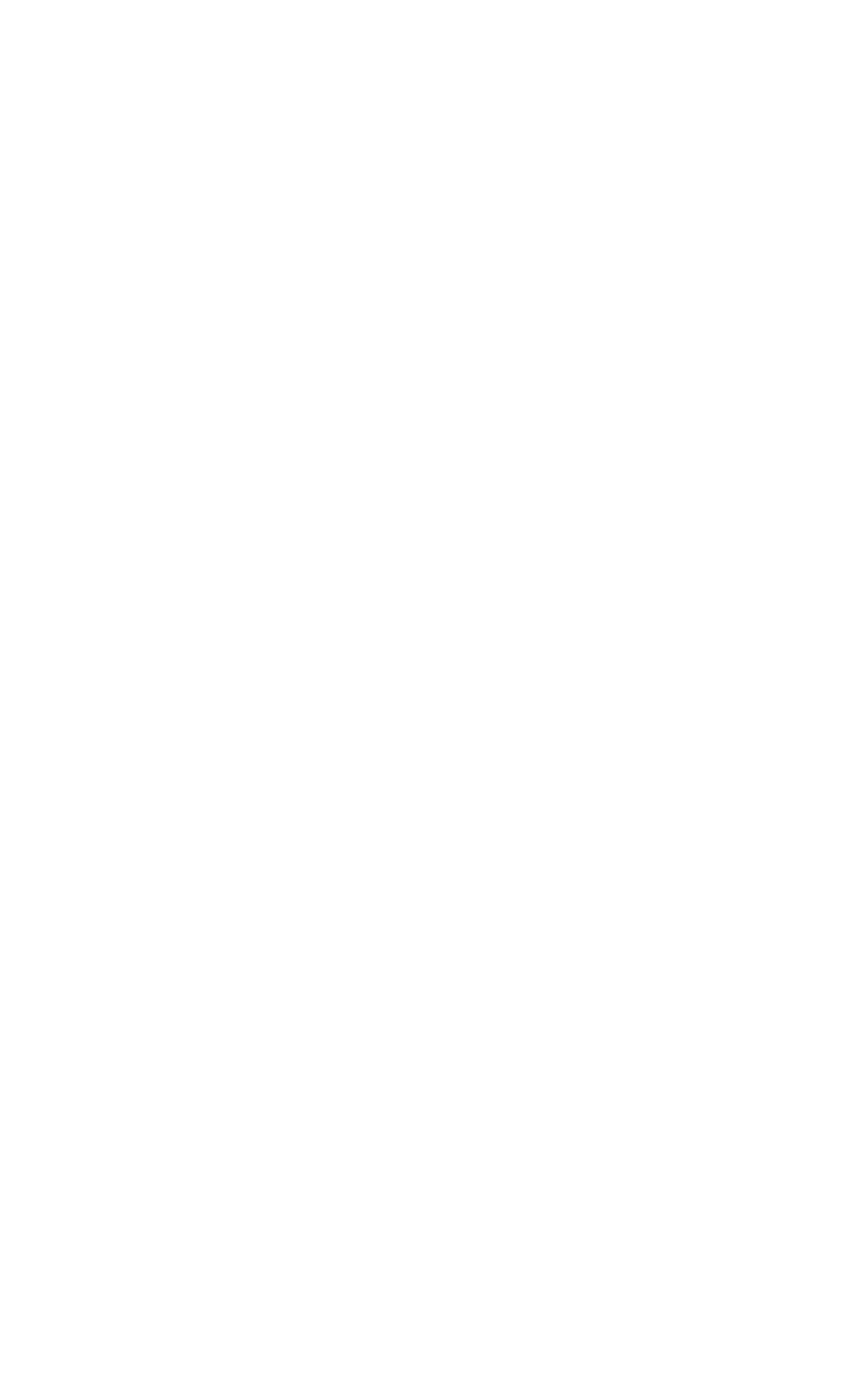


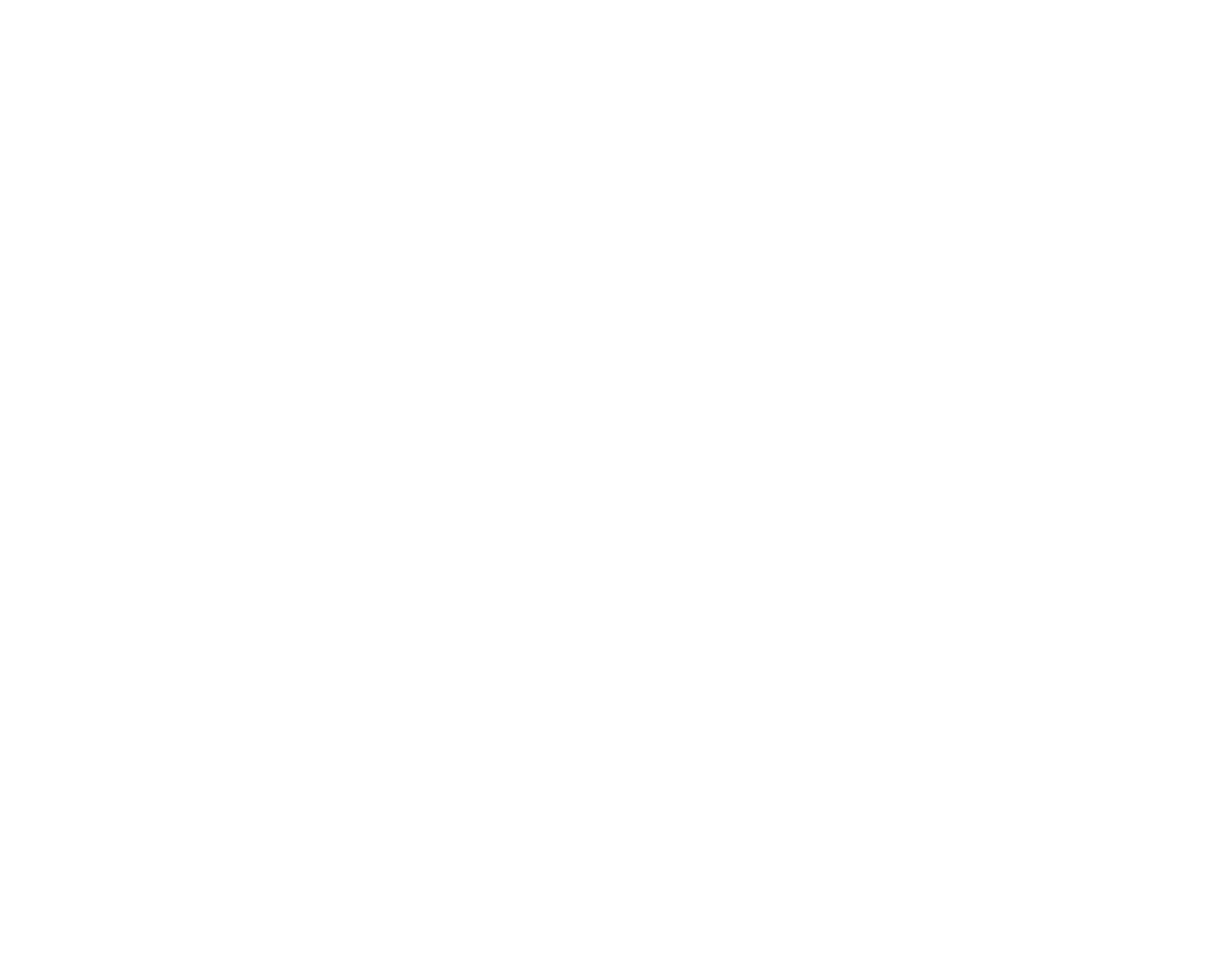




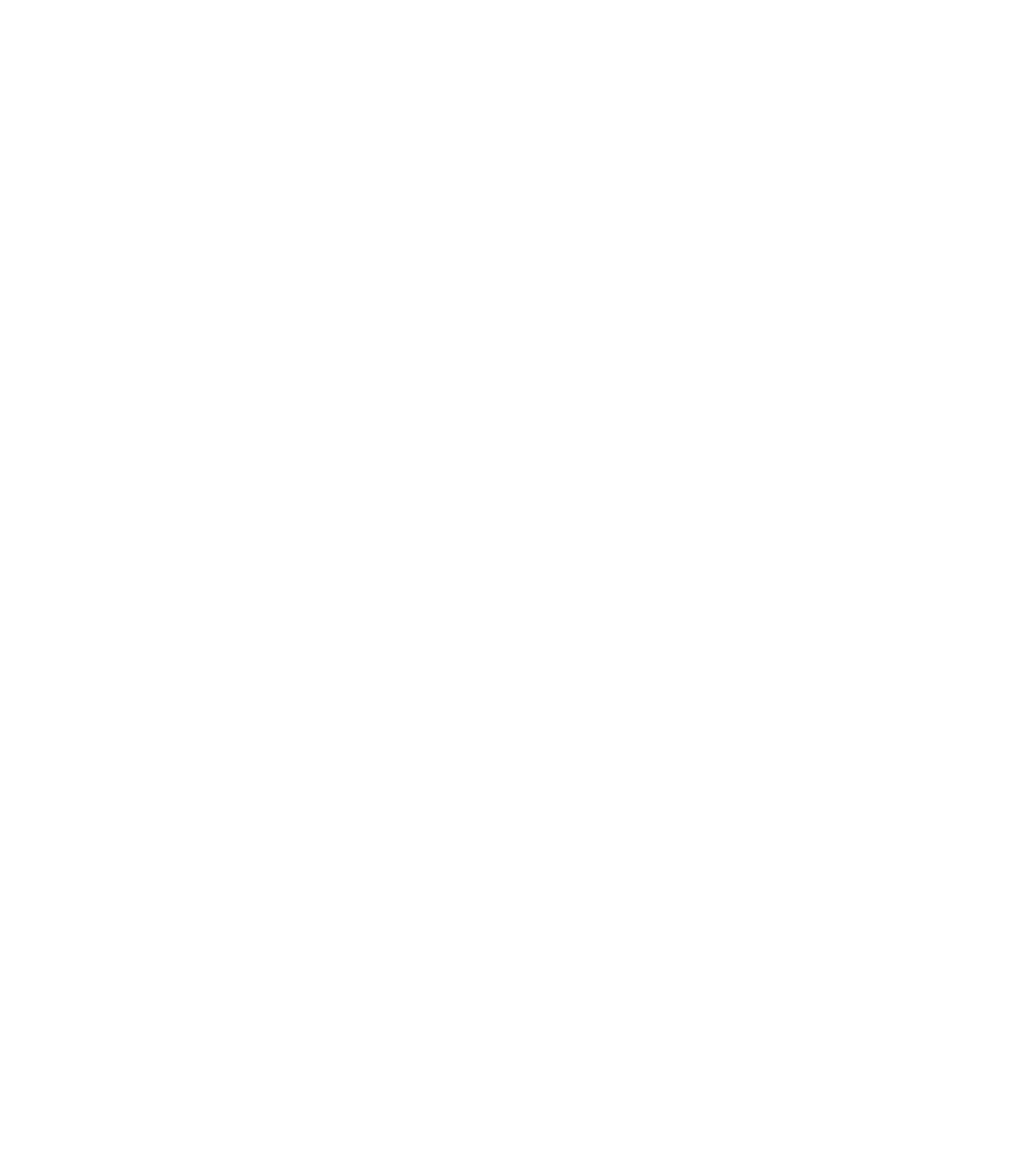





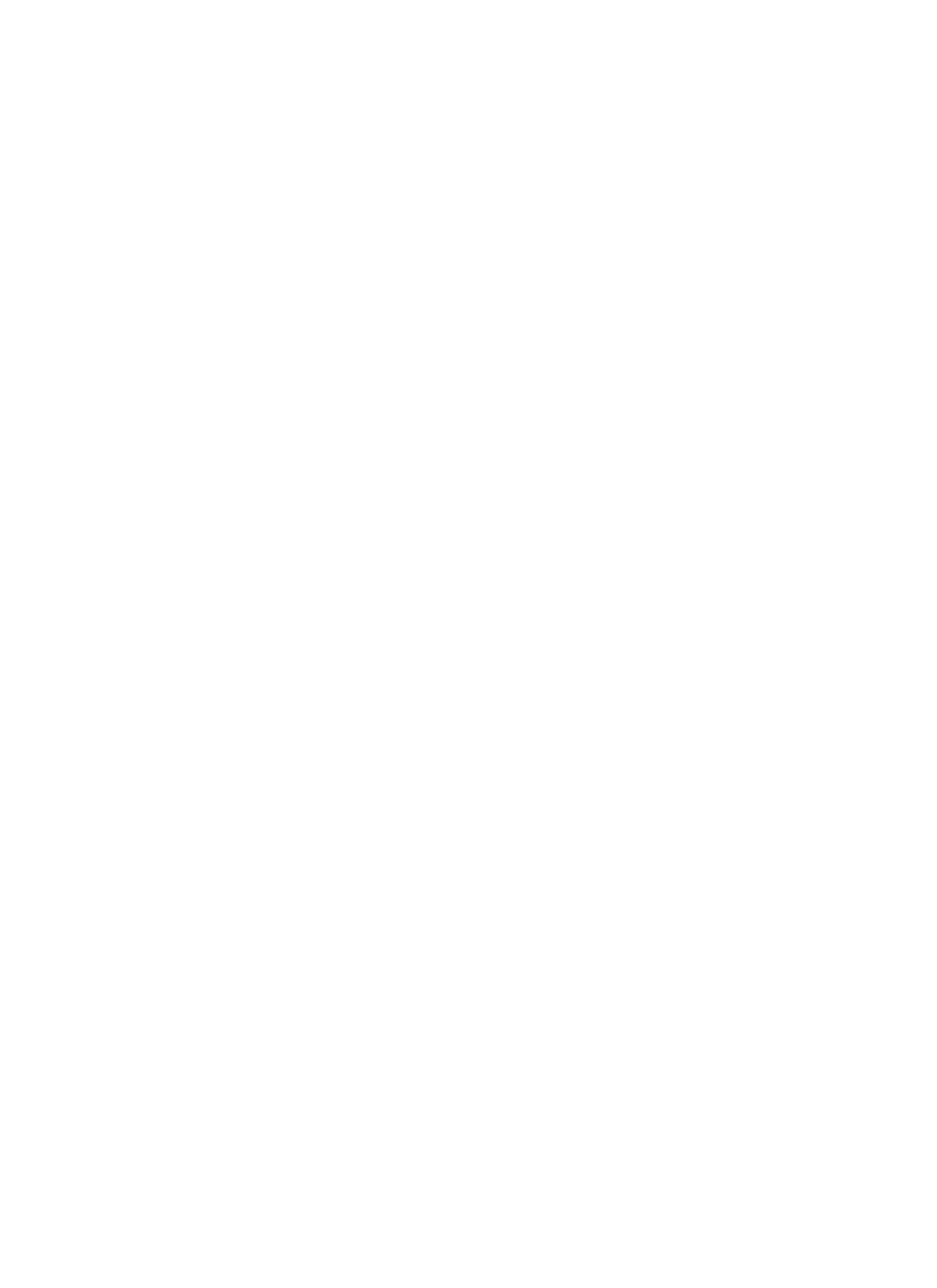


.

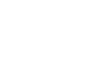

r 


\section{BEDROCK SITK (ODL 2)}

Location.-In the central part of Paradox Valley, across which Dolores River flows, with dam site in a canyon in the NE. 1/4 sec. $2, T .47$ N., R. 18 W. New Mexico principal meridian. (See pl. 7.)

Description.-The Dolores River emerges from a canyon into Paradox Valley, so named because the river flows through it transversely instead of longitudinally. The width of the valley is $4 \frac{1}{2}$ miles, but the winding course of the river between its low banks covers 9 miles, owing to its light fall of $\mathbf{1 0}$ feet to the mile. 'The area to be flooded is fairly level, and 60 per cent of it comprises hay and meadow land partly irrigated from tributary streams, chiefly West Paradox Creek. The little settlement of Bedrock and a few ranch houses are within this area.

Dam site.-In a canyon nearly a mile below the eastern edge of the valley. A dam with a spillway altitude of 5,070 feet, or 180 feet above the river surface, would have a maximum length of 730 feet. Its length at the river surface would be 130 feet. The sides of the canyon consist of sound sandstone. No borings have been made to determine the distance to bedrock, but the Bureau of Reclamation has estimated this to be less than $\mathbf{7 0}$ feet.

Capacity.-The Bureau of Reclamation has made a topographic survey of the reservoir site, from which the following table has been computed:

\section{Area and capacity of Bedrock Reservoir at different altitudes}

\begin{tabular}{|c|c|c|c|c|c|}
\hline$\underset{\text { (feet) }}{\text { Altituce }}$ & $\begin{array}{c}\text { Arraa } \\
\text { (acres) }\end{array}$ & $\begin{array}{c}\text { Total } \\
\text { capacity } \\
\text { (acro-feet) }\end{array}$ & $\underset{\text { (feet) }}{\text { Altitude }}$ & $\begin{array}{c}\text { Area } \\
\text { (acres) }\end{array}$ & $\begin{array}{c}\text { Total } \\
\text { capacity } \\
\text { (acre-feet) }\end{array}$ \\
\hline $\begin{array}{l}4,810 \\
4,910 \\
4,9: 0 \\
4,9: 0 \\
4,910 \\
4,960\end{array}$ & $\begin{array}{r}0 \\
250 \\
870 \\
1,600 \\
2,250 \\
3,010\end{array}$ & $\begin{array}{r}0 \\
600 \\
4,000 \\
9,500 \\
42,000 \\
96,000\end{array}$ & $\begin{array}{l}5,000 \\
5,020 \\
5,040 \\
5,060 \\
5,070\end{array}$ & $\begin{array}{l}\mathbf{3}, 870 \\
4,820 \\
\mathbf{5}, 820 \\
\mathbf{6}, 830 \\
7,350\end{array}$ & $\begin{array}{l}163,000 \\
252,000 \\
362,000 \\
480,000 \\
554,000\end{array}$ \\
\hline
\end{tabular}

A dam with a crist level of 5,070 feet would cause backwater above La Sal Creek, in the canyo 1 above Paradox Valley.

Water supply.-llecords of the Dolores River were obtained at Bedrock, within the reservoir site, in 1918-1922 and show the discharge of the river available for storage except for the small run-off from East and West Paradox Creeks, which enter a short distance downstream. The following table shows the annual run-off at Bedrock:

Annuıl run-off of Dolores River at Bedrock, 1918-1922

\begin{tabular}{|c|c|c|c|c|c|}
\hline Year & Acre-feet & $\begin{array}{l}\text { Per cent } \\
\text { of mean }\end{array}$ & Year & Acre-feet & $\begin{array}{l}\text { Per cent } \\
\text { of mean }\end{array}$ \\
\hline $\begin{array}{l}1918 \\
1919 \\
1920 \\
1921\end{array}$ & $\begin{array}{l}169,000 \\
277,000 \\
535,000 \\
475,000\end{array}$ & $\begin{array}{r}44 \\
72 \\
139 \\
124\end{array}$ & Mean & $\frac{468,000}{385,000}$ & 122 \\
\hline
\end{tabular}

With an allowarce of 15,000 acre-feet for additional tributary run-off, the mean annual run-olf in the reservoir site for the 5-year period was 400,000 acrefeet.

A comparison of the run-off of the San Miguel River at Naturita for the 5-year period 1918-1922 vrith that for the 16-year period covered by the San Miguel records (1896-1903, 1911-12, 1922-1927) shows that the mean for the longer 
period is $\mathbf{9 0}$ per cent of that for the shorter period. A similar comparison with the 29-year record of the Animas River at Durango (not given in this report) shows 86 per cent. At 88 per cent the mean annual run-off at the reservoir site is determined as 352,000 acre-feet.

Probable use.-The principal use of this reservoir will probably be for power, there being two possibilities, the development of 90 feet of fall within a distance of 3.7 miles below the reservoir and the development of power near the ColoradoUtah line in connection with the Fiftymile site (p. 104).

From the discharge records of Dolores River at Bedrock (1918-1922) a mass curve was constructed which showed that to have equalized the flow during the 3-year period 1918-1920, including the two dry years 1918 and 1919, would have required storage amounting to 400,000 acre-feet. This would have given a uniform draft of 440 second-feet, including an allowance for evaporation losses. The capacity table shows that the upper 70 feet of the proposed reservoir has a capacity of 391,000 acre-feet, leaving a minimum head of 110 feet on the dam. A conduit 3.7 miles long would make available a total head ranging from 200 to 270 feet. The available power would be 7,040 horsepower for 90 per cent of the time and 8,800 horsepower for 50 per cent of the time.

If the proposed Dolores irrigation project ( $p$. 144) should be constructed, the power value of this site would be practically destroyed.

\section{FIFTYMIIE SITE (9DK 1)}

Location.-In Dolores River Canyon, with the dam site in the NW. $1 / 4$ sec. 5, T. 48 N., R. $18 \mathrm{~W}$. New Mexico principal meridian, 11 miles below the mouth of the San Miguel River and $\mathbf{5 0}$ miles above the Colorado River. (See pl. 8.)

Description.-The reservoir site is in the channel of the Dolores River, which for a distance of 5 miles is a narrow valley bounded by talus slopes. Within this section Mesa and Roc Creeks enter the Dolores, and at these points the valley widens out. Above the 5-mile section the river flows through a canyon having nearly vertical walls.

Dam site.-The left side is a steep sandstone slope, and the right side is a gentle talus slope, rising 180 feet in 600 feet to join the rock wall of the canyon. No borings have been made to determine the distance to bedrock. A dam would be 150 feet long at the water surface and 800 feet long at a height of 158 feet, where it would back water to the Bedrock dam site.

Capacity.-A topographic survey of the reservoir site was made by E. E. Jones, of the Geological Survey, in 1924, and from that survey the following table has been compiled:

\section{Capacity of Fiftymile Reservoir at different altitudes of spillway}

\begin{tabular}{|c|c|c|c|c|c|}
\hline $\begin{array}{l}\text { Altitude } \\
\text { (feet) }\end{array}$ & $\begin{array}{c}\text { Total } \\
\text { capacity } \\
\text { (acre-feet) }\end{array}$ & $\underset{\text { (feet) }}{\text { Altitude }}$ & $\begin{array}{c}\text { Total } \\
\text { capacity } \\
\text { (acre-feet) }\end{array}$ & $\begin{array}{c}\text { Altitude } \\
\text { (feet) }\end{array}$ & $\begin{array}{c}\text { Total } \\
\text { capacity } \\
\text { (acre-feet) }\end{array}$ \\
\hline $\begin{array}{l}4,732 \\
4,750 \\
4,775\end{array}$ & $\begin{array}{r}0 \\
2,500 \\
11,000\end{array}$ & $\begin{array}{l}4,800 \\
4,825 \\
4,850\end{array}$ & $\begin{array}{l}27,500 \\
49,500 \\
80,000\end{array}$ & $\begin{array}{l}4,875 \\
4,890\end{array}$ & $\begin{array}{l}117,000 \\
145,000\end{array}$ \\
\hline
\end{tabular}

Water supply.-Records of the Dolores River at Bedrock for 1918-1922 and of the San Miguel River at Naturita for 1918-1927 give approximately the discharge below the mouth of the San Miguel River. By comparison of the 5-year mean on the Dolores with longer records on the San Miguel and Animas Rivers the mean annual discharge of the Dolores River at the mouth of the San Miguel was determined to be 352,000 acre-feet. By combining the records of the San 
Miguel at Fall River (1896-1899) and near Placerville (1911-12) with the Naturita records by allowing for added inflow (p. 146) and adding 23,000 second-feet to represent the inflow between Naturita and the mouth, the mean annual run-off of the San Miguel River at the mouth was determined as 290,000 acre-feet. Between the San Miguel and the dam site the estimated inflow is 11,000 acrefeet. From a combination of these figures the mean annual run-off at the dam site is estimated at 653,000 acre-feet.

Probable use.-The Fiftymile Reservoir will probably be used chiefly for power. To determine the storage required to equalize the flow at the reservoir simultaneous records of the Dolores River at Bedrock and the San Miguel River at Naturita are available from 1918 to 1922 . These records represent 85 per cent of the discharge at the reservoir site, and the remaining 15 per cent was estimated. A mass curve for the 5-year period shows that 645,000 acre-feet of storage would have been required to equalize the flow during the 3-year period from 1918 to 1920. As the capacity table shows a maximum capacity of 145,000 acre-feet, the flow could not have been equalized, and the effective regulation would have been limited to that amount of storage. The following table shows the possible rates of uniform draft, with an allowance for evaporation losses.

Rates of uniform draft that would have been possible with 145,000 acre-feet of storage in Fiftymile Reservoir, 1917-1922

July, 1917, to June, 1918
July, 1918, to April, 1919
June, 1919, to April, $1920 \ldots \begin{gathered}\text { Second. } \\ \text { feet }\end{gathered}$
July, 1920, to May, 1921
August, 1921, to April, 1922

The entire capacity of 145,000 acre-feet would be required to maintain these rates of draft, reducing the head on the dam so much that there would be very little power for 90 per cent of the time at that point. The discharge for 90 per cent and 50 per cent of the time at the Colorado-Utah line and Colorado River sites (p. 104) would have been 490 and $\mathbf{5 6 0}$ second-feet, respectively, with a small allowance for inflow below the reservoir. The corresponding power at these sites would have been as follows, in horsepower:

$$
\begin{aligned}
& \begin{array}{rr}
90 \text { per cent } & 50 \text { per cent } \\
\text { Colorado-Utah line_... } & 11,900
\end{array} \\
& \text { Colorado River (utilizing full head of } 95 \text { feet) - } \quad 3,720 \quad 4,260 \\
& 14,100 \quad \frac{4,200}{16,2}
\end{aligned}
$$

If the Bedrock Reservoir had been constructed also, the capacity of 645,000 acre-feet that would have been necessary to equalize the flow during the 3-year period 1918 to 1920 would have been obtained, and the following rates of uniform draft would have been possible, with an allowance for evaporation losses:

Rates of uniform draft that would have been possible with 645,000 acre-feet of storage in Bedrock and Fiftymile Reservoirs, 1917-1922

Second-feet

July, 1917, to June, 1920_... 805

July, 1920, to June, $1921 \ldots \ldots \ldots$ 1, 200

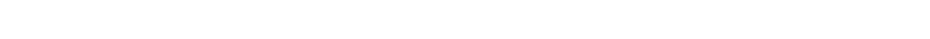


The discharges for 90 per cent and 50 per cent of the time at the two power sites would have been 810 second-feet, with a small allowance for inflow below the reservoirs. The corresponding power at these sites would have been as follows, in horsepower:

\begin{tabular}{|c|c|c|}
\hline Colorado-Utah line & $\begin{array}{c}90 \text { per cent } \\
17,200\end{array}$ & $\begin{array}{l}50 \text { per cent } \\
17,200\end{array}$ \\
\hline \multirow[t]{2}{*}{ Colorado River (utilizing full head of 95 feet) } & 6,160 & 6,160 \\
\hline & 23,400 & 23,400 \\
\hline
\end{tabular}

In the event that the Bedrock and Fiftymile reservoirs were both built, the additional head below Bedrock would be destroyed, as the Fiftymile Reservoir would reach the Bedrock Dam. If the proposed Dolores irrigation project should be completed, practically the entire discharge of the Dolores River above Bedrock would be utilized. This would reduce the diseharge at the Fiftymile site to such an extent that the capacity of that reservoir alone would equalize the flow, except for some waste during wet years similar to 1920, 1921, and 1922. The following table shows the rates of uniform draft that would have been possible during the 11-year period 1917 to 1927 under those conditions, with an allowance for evaporation losses:

Rates of uniform draft that would have been possible at Fiftymile Reservoir, 19171927, after depletion for irrigation of Dolores project

July, 1917 , to May, 1920
July, 1920, to May, 1921
Aug., 1921, to May, 1922
July, 1922, to June, 1924
July, 1924, to June, 1926.
July, 1926, to Aug., 1927

The discharges for 90 per eent and 50 per cent of the time at the two power sites would have been 350 and 395 second-feet, respectively, which would have developed the following amounts of horsepower:

\begin{tabular}{|c|c|c|}
\hline $\begin{array}{l}\text { Colorado-Utah line. } \\
\text { Colorado River }\end{array}$ & $\begin{array}{l}90 \text { per cent } \\
7,420 \\
2,660\end{array}$ & $\begin{array}{r}50 \text { per cent } \\
8,370 \\
3,000\end{array}$ \\
\hline & 10,100 & 11,400 \\
\hline
\end{tabular}

If the possible irrigation projects on the San Miguel River and its tributaries were also constructed, the water supply would be so depleted as to destroy very largely the storage value of the Fiftymile site and the value of the power sites farther downstream.

\section{TRIBUTARIES ABOVE SAN MIGUEL RIVER}

DUNTON SITE (9DL 3)

Location.-In secs. 32 and 33, T. 41 N., R. 11 W. New Mexico principal meridian, at Dunton, in the valley of the West Dolores River. Above the comparatively narrow dam site in the $\mathrm{SW} .1 / 4 \mathrm{SE}$. $1 / 4 \mathrm{sec}$. 32 the valley widens out.

Capacity.-No detailed survey of this site has been made, but a preliminary survey filed in the State engineer's office shows that a dam 160 feet high would create a reservoir having a capacity of 34,400 acre-feet.

Water supply.- No records of the West Dolores River are available, but from a comparison with records of the Dolores River at Rico and Dolores the unit run-off at the dam site is estimated as 800 aere-feet to the square mile. For the 38 square miles this gives a total mean annual run-off of 30,400 acre-feet. 
Probable use.-The filing for the site contemplated the utilization of the stored water for irrigating a part of the land included in the Dolores project (p. 144). It could also be utilized for additional storage for the Montezuma Valley Irrigation Co.'s project (p. 144).

BRAVER CREEK SITR (9DL 6)

Location.-In sec. 3 , T. 39 N., R. 14 W., and secs. 33 and 34, T. 40 N., R. 14 W. New Mexico principal meridian, on Beaver Creek, a tributary of the Dolores River. The dam site is in the S. $1 / 2 \mathrm{NW} .1 / 4$ sec. 3, where a dam 70 feet high would have a crest length of 1,630 feet.

Capacity.-A preliminary filing in the State engineer's office indicates that a dam 70 feet high at this site would create a storage capacity of 13,700 acrefeet with an area of 564 acres.

Water supply.-No records of Beaver Creek are available. As the annual precipitation over the drainage basin is only from 15 to 20 inches, the run-off is relatively low and is estimated as 10,000 acre-feet for the 40 square miles tributary to the reservoir site.

Probable use.-The proposed use of the reservoir is the irrigation of land between Beaver Creek and the Dolores River.

\section{CRDAR NO. 4 SITR (9DL 6)}

Location.-In secs. 29-32, T. 42 N., R. 15 W. New Mexico principal meridian, in the channel of Disappointment Creek, with dam site in the SW. $1 / 4 \mathbf{S W} .1 / 4$ sec. 30.

Capacity.-A filing in the State engineer's office shows that a dam 95 feet high at this site would create a reservoir capacity of 8,100 acre-feet with an area of 271 acres.

Water supply.-No records of Disappointment Creek or other streams directly -comparable are available. As the annual precipitation over the drainage basin is only 15 to 20 inches the run-off is comparatively low and is estimated as 37,000 :acre-feet for the 147 square miles above the reservoir site.

Probable use.-It is proposed to utilize stored water from this reservoir in the irrigation of land in Disappointment Valley.

CEDAR TO. B SITE (ODI 7)

Location.-In secs. 4 and 9, T. 42 N., R. 16 W. New Mexico principal meridian, in a dry gulch tributary to Disappointment Creek. The dam site is in the .SW. $1 / 4$ SW. $1 / 4$ sec. 4 , where a dam 105 feet high would have a crest length of 1,840 feet. It is proposed to fill the reservoir by means of a canal about 4 miles Jong from Custer No. 4 Reservoir, on Disappointment Creek.

Capacity.-A filing in the State engineer's office shows that at 100 feet above the stream bed the capacity would be 10,600 acre-feet, with an area of 329 acres.

Water supply.-Same as for Custer No. 4 site.

Probable use.-Same as for Custer No. 4 site.

\section{CUSTER SITE (өDL 6)}

Location.-In secs. 27, 28, 33, and 34, T. 43 N., R. 16 W. New Mexico principal meridian, on Spring Creek, a tributary of Disappointment Creek.

Description.-In the NW. $1 / 4 \mathrm{NW} .1 / 4$ sec. 33 the sides of the valley close in until the width is 300 feet 60 feet above the stream bed and 1,160 feet at a height of 110 feet. In addition to the run-off of Spring Creek it is proposed to divert water from Disappointment Creek in sec. 25, T. 42 N., R. 16 W., and convey it 4 miles to Custer Draw, which enters the reservoir site. At a point 1,200 feet north of the dam site the topography is suitable for a spillway. 
Capacity.-From a filing in the State engineer's office the following table has been compiled:

Capacity of Custer Reservoir for different heights of dam

\begin{tabular}{|r|r||r|r|}
\hline $\begin{array}{c}\text { Haight } \\
\text { above ont- } \\
\text { let (feet) }\end{array}$ & $\begin{array}{r}\text { Total ca- } \\
\text { pacity } \\
\text { (acre-feet) }\end{array}$ & $\begin{array}{r}\text { Height } \\
\text { above out- } \\
\text { let (feet) }\end{array}$ & $\begin{array}{r}\text { Total ca- } \\
\text { pacity } \\
\text { (acre-feet) }\end{array}$ \\
\hline 10 & 37 & 60 & 5,070 \\
20 & 203 & 70 & 8,120 \\
30 & $\begin{array}{r}612 \\
40\end{array}$ & 80 & 12,200 \\
50 & 2,870 & 90 & 17,400 \\
\hline
\end{tabular}

Water supply.-No records of Disappointment Creek or other streams directly comparable are available. The annual precipitation over the drainage basin is only 15 to. 20 inches, and the run-off therefore is comparatively low and is estimated at 48,000 acre-feet for the 191 square miles above the reservoir site.

Probable use.-Water from the reservoir is proposed to be used on the Disappointment Creek irrigation project (p. 145).

\section{COMPARISON OF RESERVOIR SITES ON DISAPPOINTMENT CRERK}

The Cedar Nos. 4 and 5 sites have a combined capacity of 18,700 acre-feet; the Custer site, 17,400 acre-feet. The Cedar sites require two dams, each about 100 feet high, with a combined crest length of considerably more than 2,000 feet; the Custer site requires a dam 110 feet high, with a crest length of 1,160 feet. Cedar No. 4 is a channel site, but No. 5 requires an inlet ditch about 4 miles long, the same length as the inlet for the Custer site. As the intake from Disappointment Creek for the Custer site is farther downstream, the available run-off is greater, being 48,000 acre-feet, as against 37,000 acre-feet at the upper intake. Unless comparisons of dam foundations, which have not been made, should outweigh these advantages, it is apparent that the Custer site is preferable to Cedar Nos. 4 and 5.

\section{SAN MIGUEL RIVER BASIN}

The San Miguel Valley is so narrow that no reservoir sites exist. on the main stream. The tributary streams, however, contain the Beaver Mesa site, on Saltado Creek; the Finch No. 2 site, on Horsefly Creek; the Miramonte site, on West Beaver Creek; the Stone Cabin site, on Basin Creek; and the Sand Flat site, on the North Fork of West Creek. The Beaver Mesa and Sand Flat sites are considered unfeasible owing to the uncertain water supply.

FINCH NO. 2 SITE (9DK 3)

Location.-In secs. 35 and 36, T. 46 N., R. 11 W., and sec. 31, T. 46 N., R. 10 W. New Mexico principal meridian. The dam site is in the E. $1 / 2$ sec. 35 , on Horsefly Creek, which drains the western slope of the upper end of the Uncompahgre Plateau. A dam 100 feet high at this site would have a crest length of 800 feet.

Capacity.-From a filing in the State engineer's office the following table has been compiled: 
Area and capacity of. Finch No. 2 Reservoir for different heights of dam?

\begin{tabular}{|c|c|c|c|c|c|}
\hline $\begin{array}{l}\text { Height } \\
\text { above out- } \\
\text { let (feet) }\end{array}$ & $\underset{\text { (acres) }}{\text { Ares }}$ & $\begin{array}{c}\text { Total } \\
\text { capacity } \\
\text { (acre-foet) }\end{array}$ & $\begin{array}{l}\text { aboight } \\
\text { above out- } \\
\text { let (feet) }\end{array}$ & (acres) & $\begin{array}{c}\text { Total } \\
\text { capacity } \\
\text { (aero-feat) }\end{array}$ \\
\hline $\begin{array}{l}18 \\
20 \\
30 \\
40 \\
50\end{array}$ & $\begin{array}{r}22 \\
27 \\
57 \\
128 \\
184\end{array}$ & $\begin{array}{r}138 \\
187 \\
598 \\
1 ; 200 \\
2,800\end{array}$ & $\begin{array}{l}60 \\
70 \\
80 \\
90 \\
95\end{array}$ & $\begin{array}{l}276 \\
393 \\
510 \\
635 \\
682\end{array}$ & $\begin{array}{r}5,100 \\
8,400 \\
12,900 \\
18,600 \\
21,900\end{array}$ \\
\hline
\end{tabular}

, thes.

$\therefore$

Water supply.-No records of the flow of Horsefly Creek are available, but records of Dallas Creek near Ridgway, on the opposite side of the Uncompahgre Plateau, for the 6-year period 1922-1927 show, with an allowance made for diversions above the station, a unit run-off of 500 acre-feet to the square mile. As the general altitude of the Horsefly Basin is somewhat higher than that of the Dallas Basin, the unit run-off is taken as 600 acre-feet to the square mile, which gives 15,600 acre-feet above the reservoir outlet.

Probable use.- It has been proposed to utilize the water stored at this site to irrigate land in Tps. 44 and 45 N., R. 11 W., and Tps. 44, 45, and 46 N., R. 12 W.

\section{MTRAMONTE SITE (9DK 4)}

Location.-In secs. 13, 24, and 25, T. 43 N., R. 14 W., and secs. 18-20, 29, and 30, T. 43 N., R. $13 \mathrm{~W}$. New Mexico principal meridian, in the channel of West Naturita Creek, a tributary of the San Miguel River.

Capacity.-From a filing in the State engineer's office the following table has been compiled:

Area and capacity of Miramonte Reservoir for different heights of dam

\begin{tabular}{|c|c|c|c|c|c|}
\hline $\begin{array}{l}\text { Height } \\
\text { above out- } \\
\text { lot (feet) }\end{array}$ & $\begin{array}{c}\text { Area } \\
\text { (acres) }\end{array}$ & $\begin{array}{c}\text { Total } \\
\text { capacity } \\
\text { (gore-feet) }\end{array}$ & $\begin{array}{l}\text { Height } \\
\text { above out- } \\
\text { let (feet) }\end{array}$ & $\underset{\text { (acres) }}{\text { Area }}$ & $\begin{array}{c}\text { Total } \\
\text { capacity } \\
\text { (aerefeet) }\end{array}$ \\
\hline $\begin{array}{r}0 \\
20 \\
40 \\
60\end{array}$ & $\begin{array}{r}10 \\
26 \\
62 \\
216\end{array}$ & $\begin{array}{r}0 \\
346 \\
1,140 \\
3,560\end{array}$ & $\begin{array}{r}80 \\
100 \\
120 \\
135\end{array}$ & $\begin{array}{r}482 \\
784 \\
1,210 \\
1,580\end{array}$ & $\begin{array}{l}10,500 \\
23,000 \\
42,700 \\
63,500\end{array}$ \\
\hline
\end{tabular}

Water supply.-In addition to the storage of water from West Naturita Creek it has been proposed to divert water from Beaver Creek into the reservoir. As no records of either stream are available, and as Beaver Creek is extensively used for irrigation, no estimate of water supply available for storage has been made:

Probable use.-The reservoir would probably be used in connection with the San Miguel irrigation project (p. 146).

\section{STONE CABIN SITE (9DK 5)}

Location.-In secs. 3, 9, 10, 11, and 15, T. 44 N., R. 16 W. New Mexico principal meridian, in the channel of Basin Creek, a tributary of the San Miguel River. The dam site is a narrow gorge in the NE. $1 / 4 \mathrm{SW} .1 / 4$ sec. 3, where a dam 75 feet high would have a crest length of 500 feet.

Capacity.-From a filing in the State engineer's office the following table has been compiled:

Area and capacity of Stone Cabin Reservoir for different heights of dam

\begin{tabular}{|c|c|c||c|c|c}
\hline $\begin{array}{c}\text { Height } \\
\text { above out- } \\
\text { let (feet) }\end{array}$ & $\begin{array}{c}\text { Area } \\
\text { (acres) }\end{array}$ & $\begin{array}{c}\text { Total } \\
\text { capacity } \\
\text { (acre-feet) }\end{array}$ & $\begin{array}{c}\text { Height } \\
\text { above out- } \\
\text { let (feet) }\end{array}$ & $\begin{array}{c}\text { Area } \\
\text { (acres) }\end{array}$ & $\begin{array}{c}\text { Total } \\
\text { capacity } \\
\text { (acre-feet) }\end{array}$ \\
\hline 10 & 9 & 64 & 40 & 194 & $\mathbf{1}, 800$ \\
20 & 30 & 259 & 50 & 482 & 5,370 \\
30 & 62 & 716 & 60 & 885 & 12,200 \\
\hline
\end{tabular}


A preliminary filing shows an estimated capaeity of 30,000 acre-feet, but_the detailed survey was not carried, above the capacity given in the table.

Water supply.-In addition to storing flood run-off from Basin Creek, for which no estimate is made, it is proposed to use as an intake a canal diverting water from the San Miguel River 7 miles below Placerville. A discussion of the San Miguel project (p. 146) indicates a mean annual run-off of 174,000 acre-feet. at the point of diversion.

Probable use.-The reservoir would probably be used in connection with the San Miguel irrigation project.

\section{LITTLE DOLORES RIVER BASIN}

The only known reservoir sites in the basin of the Little Dolores: River are the Little Dolores and Grebu Canyon sites. The water supply for the latter is too uncertain to make a reservoir feasible.

\section{IITTII DOLORES SITE (ODM 3)}

Location.-In secs. 13 and 24, T. 12 S., R., 103 W., and sec. 19, T. 12 S., R. $102 \mathrm{~W}$. sixth principal meridian. The dam site is in the $\mathrm{SW} .1 / 4 \mathrm{NW} .1 / 4$ sec. $19_{\text {r }}$ T. 12 S., R. $102 \mathrm{~W}$., where a dam 50 feet high would have a crest length of 1,200 feet. The main source of supply is a ditch diverting water from Little Dolores River in sec. 26.

Capacity.-From a filing in the State engineer's office the following table has been compiled:

Area and capacity of Little Dolores Reservoir for different heights of dam

\begin{tabular}{|c|c|c||c|c|c|}
\hline $\begin{array}{c}\text { Height } \\
\text { above } \\
\text { outlet (feet) }\end{array}$ & $\begin{array}{c}\text { Area } \\
\text { (acres) }\end{array}$ & $\begin{array}{c}\text { Total } \\
\text { capacity } \\
\text { (acre-feet) }\end{array}$ & $\begin{array}{c}\text { Height } \\
\text { above } \\
\text { outlet (feet) }\end{array}$ & $\begin{array}{c}\text { Area } \\
\text { (acres) }\end{array}$ & $\begin{array}{c}\text { Total } \\
\text { capacity } \\
\text { (acre-feet) }\end{array}$ \\
\hline 10 & $\begin{array}{r}29 \\
20\end{array}$ & $\begin{array}{r}331 \\
165\end{array}$ & $\begin{array}{c}30 \\
35\end{array}$ & $\begin{array}{c}250 \\
308\end{array}$ & $\begin{array}{c}3,500 \\
4,900\end{array}$ \\
\hline
\end{tabular}

Water supply.-No records of the flow of the Little Dolores River or adjacent streams are available. As the annual precipitation over the drainage basin is only about 15 inches, the run-off is comparatively low and is estimated at 20,000 acre-feet for the 80 square miles above the reservoir site.

Probable,use.-It is proposed to utilize the water stored in this reservoir in the irrigation of land in the Little Dolores River Basin. 
STORAGE

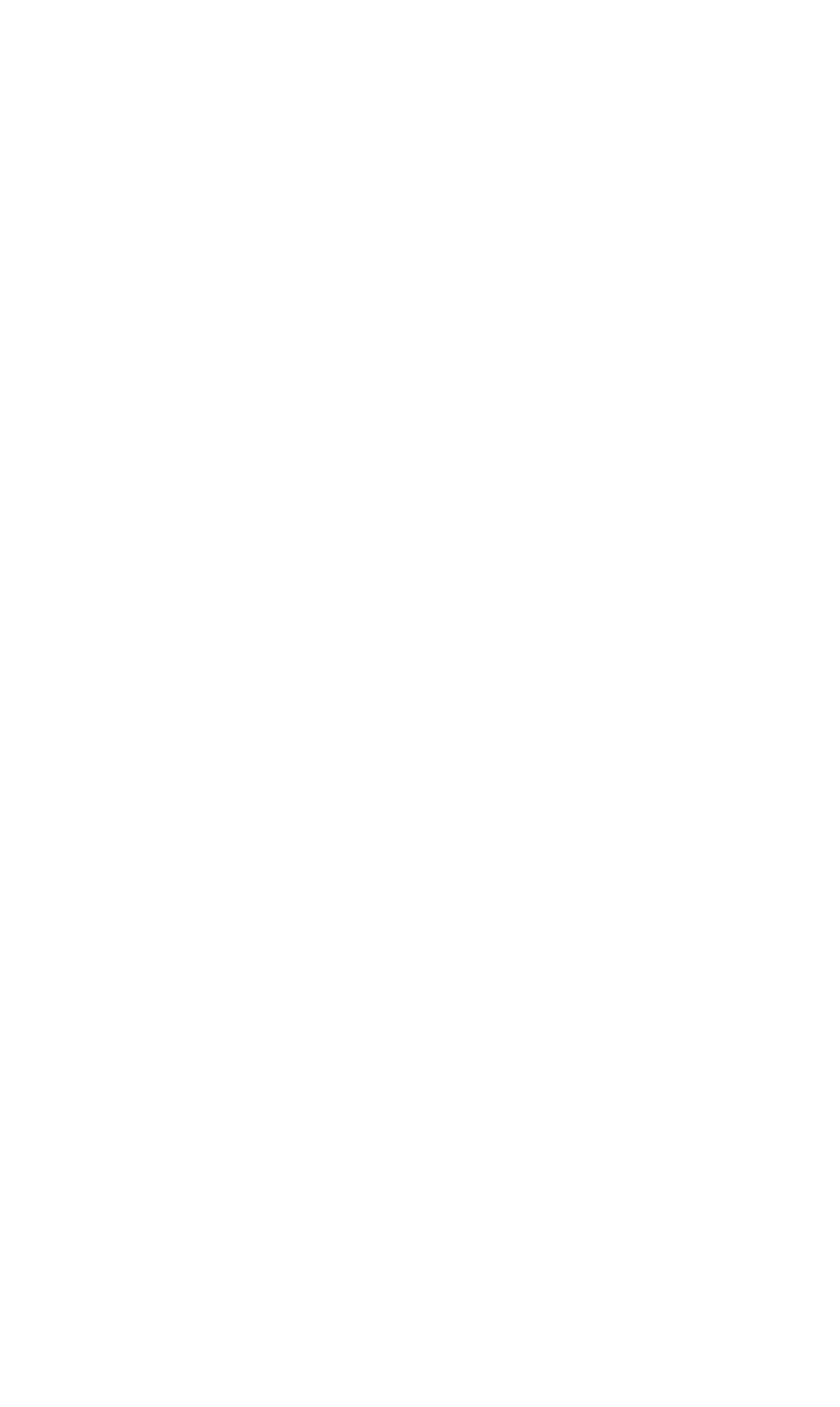




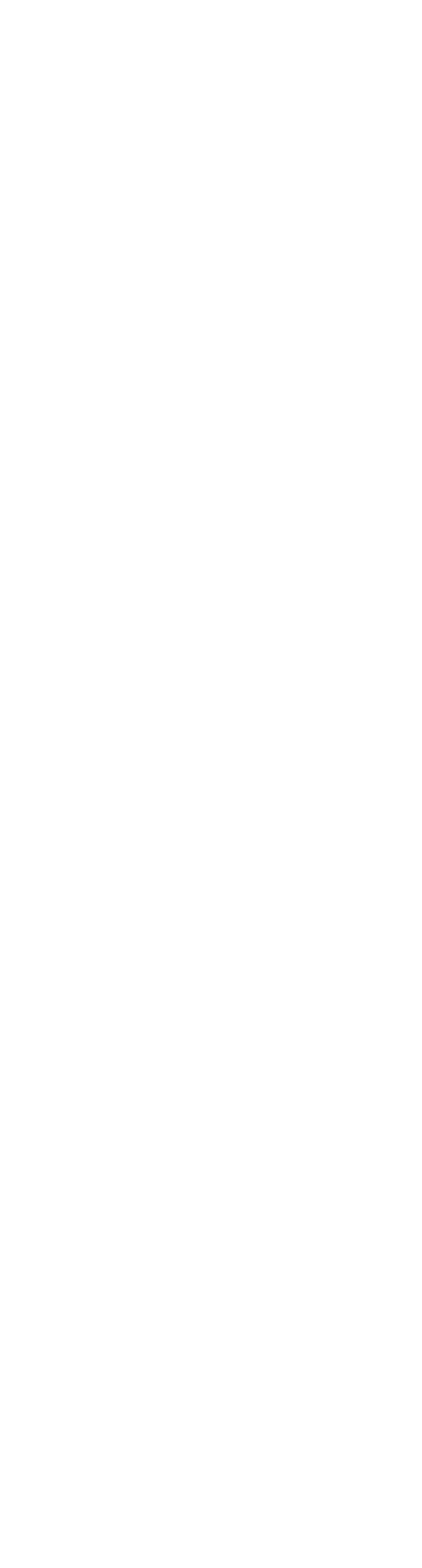

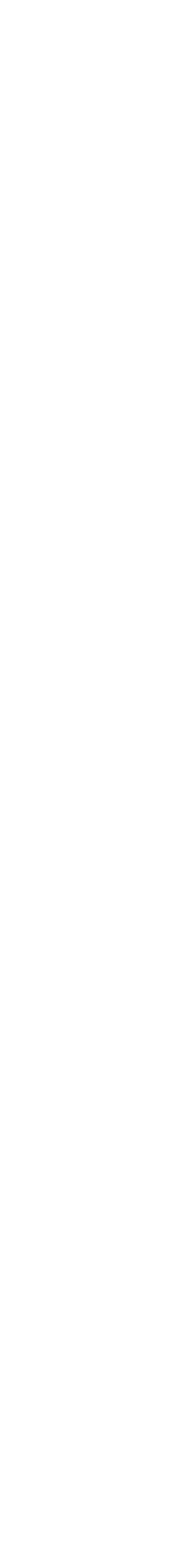

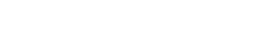

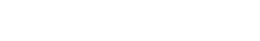

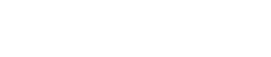

연

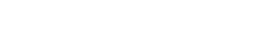

88 \&े \& \& \& \& สำ

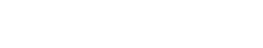

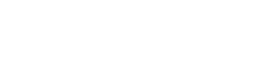

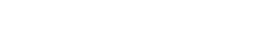
害蜜

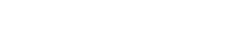

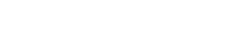

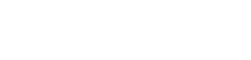
$\dot{B}=\because \dot{q}^{\infty}$ मा

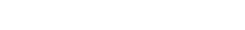

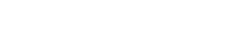
我柁 0i भî

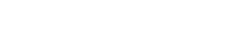

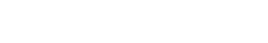

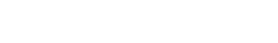

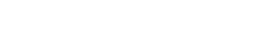

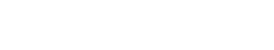

$1 ! 1 ! \vdots ! 1$

兽 施 蛋

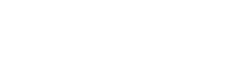

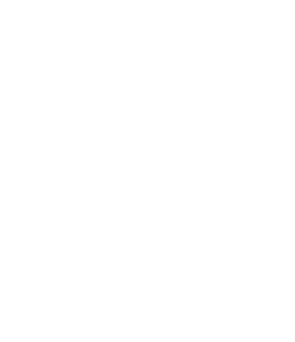




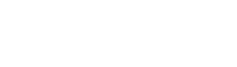

哭尽跑 哭

₹

\&

888888

เิ เั

ถู ม ส
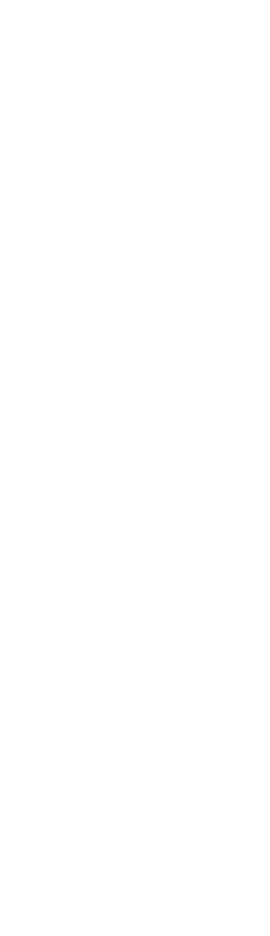

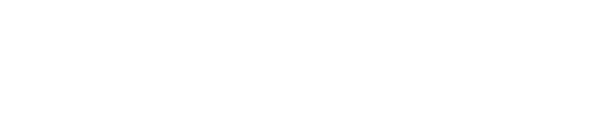
蛋

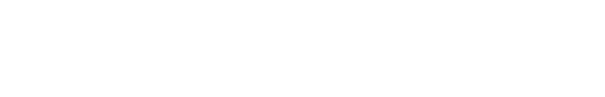

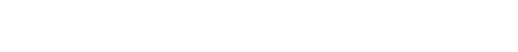

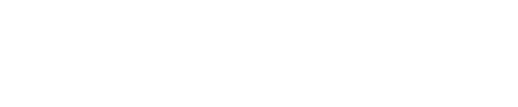

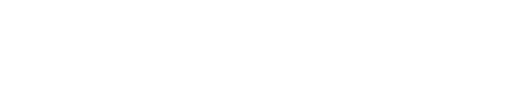

붕

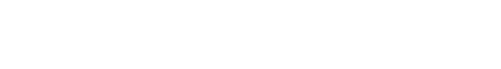
สิ๊

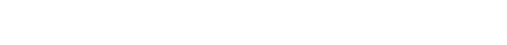

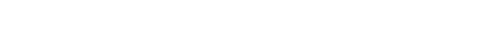
Iद

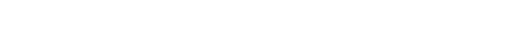

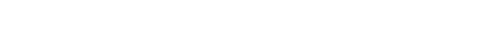

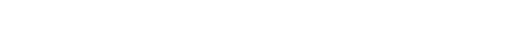

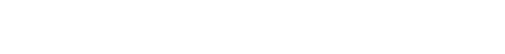

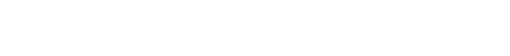
乙 स สำ 7z

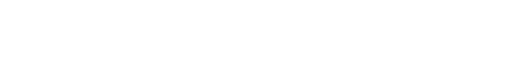

\begin{tabular}{|c|c|c|c|c|c|c|c|c|c|c|c|}
\hline 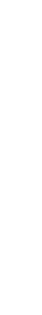 & ه & : & 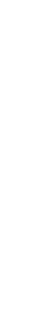 & 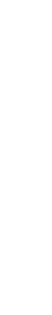 & 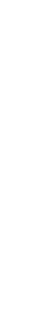 & 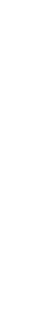 & 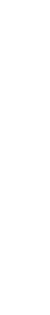 & 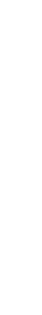 & 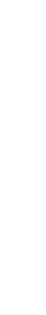 & 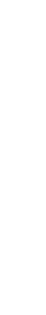 & 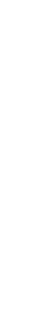 \\
\hline $\begin{array}{l}\frac{3}{3} \\
\frac{0}{8}\end{array}$ & 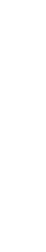 & 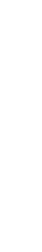 & 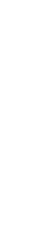 & 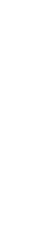 & 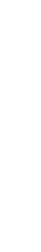 & 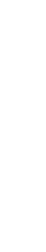 & $\begin{array}{c}\vdots \\
\vdots \\
0 \\
0 \\
0 \\
0\end{array}$ & 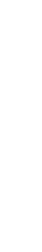 & 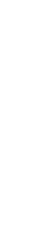 & 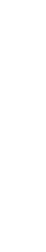 & 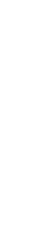 \\
\hline 홍 & $\stackrel{\sim}{\vec{\sigma}}$ & $\overrightarrow{\mathrm{a}}$ & 今 & $\stackrel{\oplus}{\hat{\theta}}$ & $\begin{array}{l}0 \\
\stackrel{2}{0}\end{array}$ & 今ે & $\begin{array}{l}\infty \\
\hat{\sigma}\end{array}$ & $\stackrel{m}{a}$ & $\stackrel{4}{a}$ & 点 & $\stackrel{\infty}{\stackrel{5}{\circ}}$ \\
\hline
\end{tabular}




\section{UPPER COLORADO RIVER AND ITS UTILIZATION}

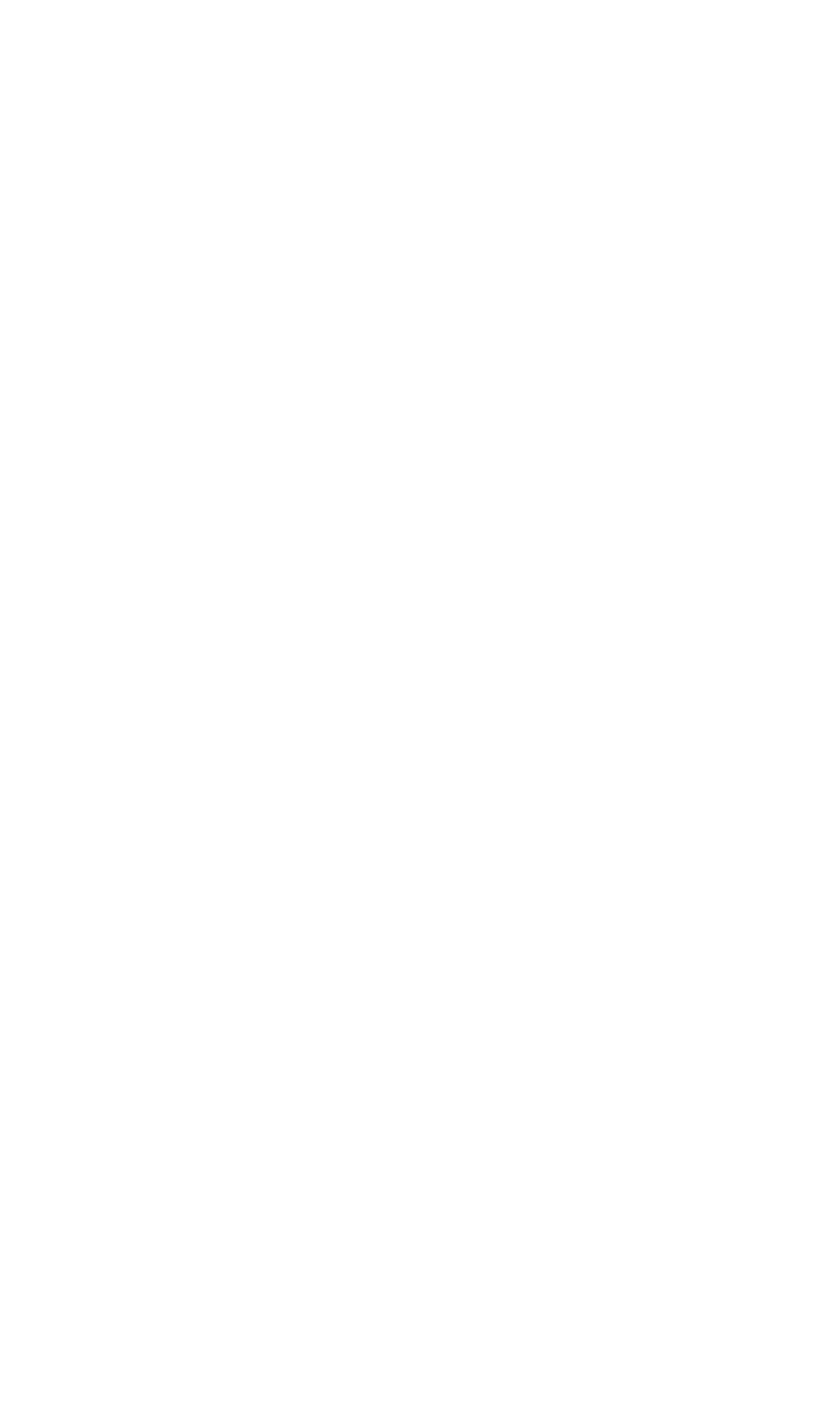

( 


\section{IRRIGATION AND AGRICULTURE}

\section{FARLY HISTORY}

Irrigation in the upper Colorado River Basin dates practically from the settlement, which was begun by prospectors and miners rushing over the mountains from the older mining districts on the eastern slope. The first settlement was made in 1860, at Breckenridge, on the upper Blue River. Most of the Colorado Basin was within the territory occupied by the Indians, and their hostile attitude toward the whites prevented further settlement for a number of years after that date. In 1873 a treaty was concluded with the Southern Utes, whereby the Government acquired the land in the southwestern part. of Colorado and opened it to entry. Immediately prospectors and: miners rushed in and, on discovering rich mineral deposits, settled: the mining camps in the San Juan region. A few years later prospectors from the camp at Leadville explored and settled the near-by region at the head of the Eagle and Roaring Fork Valleys, Redcliff being founded in 1879 and Aspen in 1880. In the meantime stock. raisers had settled in Middle Park (now Grand County), in 1874.

The Uncompahgre or Northern Ute Indians continued to occupy the territory now included in Mesa, Delta, Montrose, and Garfield Counties and prevented settlement until 1881, when they were removed to the Uinta Reservation, in eastern Utah. Immediately afterward settlers, chiefly farmers and stock raisers, came in and established homes.

On account of the scanty rainfall, irrigation was found to be necessary for successful agriculture. In the mining regions the first ditches were constructed near the settlements, which were on the headwaters of the streams. As new settlers came in, additional ditches were constructed along the streams, gradually approaching the mouths. This reversed the usual order in the development of irrigation, which generally begins at the mouth and gradually expands toward the headwaters. Grand Junction was founded in 1882, and in the next year the Grand Valley canal was started as a mutual project to irrigate a large area in Grand Valley. With this exception, the early ditches were all small individual or partnership affairs, constructed as cheaply as possible, and many of them were little more than plow furrows. The few diversion dams built were either looserock or brush-filled structures. This description holds true at the present time for most of the ditches in the upper Colorado River Basin.

On the Colorado River in the vicinity of Grand Valley and on the Uncompahgre the large areas of irrigable land and the need for constructing expensive headworks in the streams made it necessary to form mutual companies to build the required systems. After the

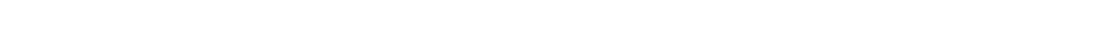


several large canals irrigating land in the Uncompahgre Valley petitioned the Government to form an irrigation project in that section and increase the available water supply in the Uncompahgre Valley by bringing water from the Gunnison River through a proposed tunnel 6 miles long. The State had undertaken this work in 1899 and made a survey of the proposed site but could not induce private enterprise to construct the tunnel. The Government acquired the larger canals in the valley and constructed the tunnel at the site previously selected (p. 129). The only other Government project in the basin was the construction of a high-line canal to irrigate land in Grand Valley lying above existing systems (p. 121). Under the State irrigationdistrict law a number of projects were started, of which the largest was that in the Montezuma Valley. Mutual companies irrigate mesa lands on the North Fork of the Gunnison, and on one or two of the smaller tributaries.

Irrigation in this region was subject to the general economic laws governing irrigation in the United States. The first great boom occurred during the late eighties and early nineties, when many large enterprises were promoted. Few of these were financially successful, although large areas were irrigated. This boom was followed by a long depression, which lasted until 1902-03. The reclamation law, passed in 1902, revived irrigation activities by private enterprise, and this revival lasted until 1910. The failure of several large private enterprises checked the work, and since that time a period of depression for large enterprises has followed. ${ }^{24}$

\section{PRESIHNT DEVELOPMENT}

Practically all the land in the valleys of the principal tributarie and considerable areas of mesa lands more remote from the streams are irrigated by many small ditehes. As the irrigable areas in the valleys of many of the streams are small the duty of water is low, ranging from 3 to 6 acre-feet to the acre. In the upper sections of the basin, where, owing to the shortness of the growing season, native hay is the chief crop, the common practice is to apply water continuously to the land until the hay is ready to be cut. Natural drainage is sufficient to prevent land becoming seeped in most sections, but in Grand, Uncompahgre, and Montezuma Valleys the drainage is less efficient, and considerable areas have become seeped.

Owing to the relative smallness of the irrigable areas the construction of reservoirs has on most tributaries been unnecessary. In the areas drained by Plateau, Surface, and Leroux Creeks, however, irrigation has reached a higher state of development, and as these areas include the slopes of Grand Mesa, on which there are many small lakes, these lakes have been converted into reservoirs to supply the ditches.

24 Toele, R. P., Irrigation in the United States, pp. 11-12, D. Appleton \& Co., 1915. 


\section{CHARACTER OF AGRICULTURE}

The rough, rugged topography of the area, which is dissected by innumerable deeply intrenched streams, causes a wide diversity irthe character of agriculture. The only tillable lands consist of more: or less extensive flood plains along the larger channels, bordered hereand there by mesas. Agriculture is further limited by the climate. In general the rainfall on the cultivable land is insufficient for crop production, and irrigation is necessary. Furthermore, the length of the growing season also varies from place to place, depending very largely on the altitude, which ranges from 4,000 feet above sea level at the lower extremity of the area to more than 12,000 feet on some of the higher peaks along the watershed. Where the altitude exceeds 7,000 feet the growing season has a maximum length of only 90 days, and native hay is practically the only crop that can be produced. Between altitudes of 6,000 and 7,000 feet the growing season is of adequate length to mature such cultivated crops as alfalfa and the hardy grain and root crops, including barley, oats, wheat, and potatoes. As the altitude falls below 6,000 feet, the growing season becomes increasingly longer, attaining 140 to 180 days in the Grand Valley and the larger irrigated districts along the Gunnison and Uncompahgre Rivers, where fruit, sugar beets, potatoes, and onions are produced extensively, as well as alfalfa, grain, or other feed crops.

The nontillable lands are used for the grazing of livestock, the most extensive agricultural activity in the region. It is possible to run stock on the range the year round by following the general practice of moving from the lower to the higher ranges and back during the appropriate seasons. The eastern part of the basin includes large areas of summer range, most of which is included in the national forests. These ranges were formerly restricted largely to cattle, but during late years sheep have been permitted to enter. The grazing season in the forests averages approximately four months. At other times cattle are grazed on the lower ranges or kept on the home ranches and fed for a few months during the winter. Sheep are partly wintered on the semidesert ranges near Grand Junction and.Delta, and some are fed locally, but most of the herds are trailed to winter ranges in eastern Utah.

\section{SUMMARY OF IRRIGATED AREAS}

The following table, compiled chiefly from State water commissioners' reports augmented by information from other reliable sources, shows the area covered by ditches and that actually irrigated: 
Irrigated area in upper Colorado River Basin, in acres

\begin{tabular}{|c|c|c|c|c|}
\hline Stream & \multicolumn{2}{|c|}{ Under ditches } & \multicolumn{2}{|c|}{ Irrigated } \\
\hline $\begin{array}{l}\text { Colorado River above Green River } \\
\text { Fraser River Basin. } \\
\text { Williams River Basin } \\
\text { Troublesome Creek Basin } \\
\text { Minor tributaries above Blue River. } \\
\text { Blue River Basin. } \\
\text { Eagle River. } \\
\text { Brush Creek Basin } \\
\text { Gypsum Creek Basin } \\
\text { Minor tributaries }\end{array}$ & $\begin{array}{l}2,850 \\
7,040 \\
5,020 \\
7,050\end{array}$ & $\begin{array}{r}124,000 \\
10,000 \\
6,000 \\
7,000 \\
17,000 \\
10,000\end{array}$ & $\begin{array}{l}2,750 \\
6,490 \\
4,430 \\
5,260\end{array}$ & $\begin{array}{r}60,000 \\
9,300 \\
5,000 \\
6,500 \\
15,900 \\
7,000\end{array}$ \\
\hline $\begin{array}{l}\text { Minor tributaries between Blue River and Roaring Fork. } \\
\text { Roaring Fork } \\
\text { Crystal River Basin } \\
\text { Cattle Creek Basin } \\
\text { Capitol Creek Basin } \\
\text { Minor tributaries }\end{array}$ & $\begin{array}{r}6,000 \\
3,500 \\
5,500 \\
3,100 \\
10,000\end{array}$ & $\begin{array}{l}22,000 \\
26,000\end{array}$ & $\begin{array}{l}5,600 \\
3,330 \\
4,740 \\
2,140 \\
9,460\end{array}$ & $\begin{array}{l}18,900 \\
14,800\end{array}$ \\
\hline $\begin{array}{l}\text { Elk Creek Basin } \\
\text { Divide Creek Basin } \\
\text { Rifle Creek Basin } \\
\text { Parachute Creek Basin } \\
\text { Minor tributaries between Roaring Fork and Roan Creek } \\
\text { Roan Creek Basin } \\
\text { Plateau Creek } \\
\text { Buzzard Creek Basin } \\
\text { Big Creek (Clearwater Creek) Basin } \\
\text { Cottonwood Creek Basin } \\
\text { Buil Creek Basin } \\
\text { Mesa Creek Basin } \\
\text { Minor tributaries }\end{array}$ & $\begin{array}{r}5,070 \\
7,250 \\
7,600 \\
8,250 \\
3,880 \\
6,620 \\
11,500\end{array}$ & $\begin{array}{r}28,100 \\
3,960 \\
15,500 \\
11,100 \\
2,960 \\
18,000 \\
13,600 \\
\end{array}$ & $\begin{array}{l}3,100 \\
2,550 \\
6,200 \\
3,600 \\
1,950 \\
4,010 \\
6,270\end{array}$ & $\begin{array}{r}25,300 \\
3,360 \\
10,100 \\
8,130 \\
1,920 \\
14,800 \\
7,760\end{array}$ \\
\hline $\begin{array}{l}\text { Gunnison River } \\
\text { Ohio Creek Basin } \\
\text { Tomichi Creek } \\
\text { Quartz Creek Basin } \\
\text { Cochetopa Croek Basin } \\
\text { Minor tributaries. }\end{array}$ & $\begin{array}{r}12,300 \\
4,500 \\
10,000 \\
5,000\end{array}$ & $\begin{array}{r}50,200 \\
33,800 \\
8,400\end{array}$ & $\begin{array}{r}12,100 \\
4,490 \\
9,620 \\
4,860\end{array}$ & $\begin{array}{r}27,700 \\
26,000 \\
8,000\end{array}$ \\
\hline $\begin{array}{l}\text { Cimarron Creek Basin } \\
\text { Grystal Creek Basin } \\
\text { Smith Fork Basin } \\
\text { North Fork } \\
\quad \text { Leroux Creek Basin } \\
\quad \text { Minor tributaries. }\end{array}$ & $\begin{array}{r}16,900 \\
19,500 \\
6,600\end{array}$ & $\begin{array}{l}31,800 \\
25,500 \\
12,000 \\
14,400\end{array}$ & $\begin{array}{r}14,100 \\
13,500 \\
6,100\end{array}$ & $\begin{array}{r}31,000 \\
10,500 \\
7,700 \\
8,800\end{array}$ \\
\hline $\begin{array}{l}\text { Surface Creek and Forked Tongue Creek } \\
\text { Uncompahgre River } \\
\text { Dallas Creek Basin } \\
\text { Cow Creek Basin } \\
\text { Minor tributaries }\end{array}$ & $\begin{array}{r}136,000 \\
6,480 \\
6,520 \\
16,200\end{array}$ & $\begin{array}{l}43,000 \\
34,200\end{array}$ & $\begin{array}{r}72,800 \\
4,470 \\
3,920 \\
5,740\end{array}$ & $\begin{array}{l}33,700 \\
22,100\end{array}$ \\
\hline $\begin{array}{l}\text { Kahnah Creek Basin } \\
\text { Minor tributaries to Gunnison River } \\
\text { Dolores River... } \\
\text { Lost Canyon Creek Basin } \\
\text { West Paradox Creek Basin } \\
\text { San Miguel River Basin }\end{array}$ & $\begin{array}{r}62,500 \\
8,300 \\
4,600 \\
59,300\end{array}$ & $\begin{array}{r}165,000 \\
12,500 \\
37,800\end{array}$ & $\begin{array}{r}21,900 \\
3,700 \\
3,460 \\
25,800\end{array}$ & $\begin{array}{r}86,900 \\
6,650 \\
28,600\end{array}$ \\
\hline Minor tributaries between Roan Creek and Green River. & & $\begin{array}{r}135,000 \\
7,300\end{array}$ & & $\begin{array}{r}54,900 \\
3,000\end{array}$ \\
\hline otal.. & & 926,000 & & 564,000 \\
\hline
\end{tabular}

ancludes Montezuma project, in San Juan Basin.

In the preceding table no allowance is made for the following irrigation diversions out of the drainage basin:

Colorado River to Cache la Poudre Basin.

Fraser River to Clear Creek Basin.

Eagle River to Arkansas River Basin.

Cochetopa Creek to Rio Grande Basin.

Data concerning these diversions are given on pages 49-53. The area irrigated by the Gunnison River does not include the diversion 
through Gunnison Tunnel, but the additional area irrigated by means of that supply is included in that irrigated by the Uncompahgre River.

Summary of irrigated areas in upper Colorado River Basin, in acres

\begin{tabular}{|c|c|c|c|}
\hline Stream & Under ditches & Irrig & ated \\
\hline $\begin{array}{l}\text { Colorado River } \\
\text { Minor tributaries. }\end{array}$ & 373,000 & $\begin{array}{r}60,000 \\
179,000\end{array}$ & \multirow{2}{*}{239,000} \\
\hline $\begin{array}{l}\text { Gunnison River-aro } \\
\text { Tributaries }\end{array}$ & $\begin{array}{r}33,800 \\
384,000\end{array}$ & $\begin{array}{r}26,000 \\
244,000\end{array}$ & \\
\hline 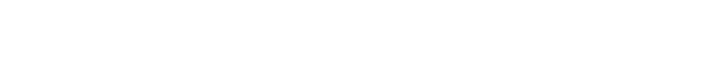 & $\begin{array}{ll}62,500 & \\
72,200 & \\
135,000 & \\
\end{array}$ & $\begin{array}{l}21,900 \\
33,000\end{array}$ & 54,900 \\
\hline Total & 928,000 & & 564,000 \\
\hline
\end{tabular}

The increase in irrigation since 1889 is shown in the following table:

Increase in irrigated area in upper Colorado River Basin, 1889-1927, in acres

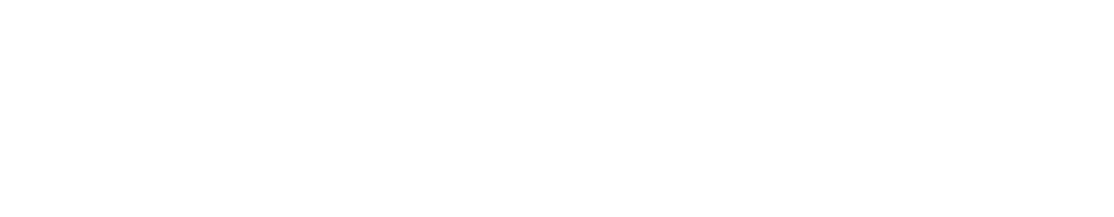

- Compiled by State engineer.

b Compiled by Bureau of the Census.

The topography of the different areas comprising the upper Colorado River Basin is described on pages 6-19.

\section{THE MAIN RIVER \\ GENERAL CONDITIONS}

The area irrigated from the main river lies chiefly in the section known as Grand Valley, which begins near Palisade and extends to the Utah line. Between the source and Glenwood Springs several thousand acres is irrigated. This land is in small tracts lying chiefly above Grand Lake outlet and in Middle Park. Between Gore Canyon, at the lower end of Middle Park, and Glenwood Springs only a few hundred acres is irrigated, as for almost the entire distance the river flows through canyons.

Between Newcastle and De Beque, a distance of 45 miles, a narrow strip of land is irrigated on the north side of the river. Near the mouths of the principal tributaries the irrigated area is wider and extends up the valleys of those streams, which supply water for irrigation. Between the tributaries the land is irrigated from the Colorado itself. The Cactus Valley ditch diverts water from the Colorado in sec. 5, T. 6 S., R. $91 \mathrm{~W}$. sixth principal meridian, 2 miles below Silt, and covers 2,5010 acres just north of the river, of which 
986 acres is irrigated. The Bluestone Valley ditch diverts water from the Colorado near the mouth of Alkali Gulch and covers 3,000 acres opposite De Beque, of which 960 acres is irrigated. Aside from these areas, very little land along the main river is irrigated except by tributary streams near their mouths.

In the valley of the Colorado above Glenwood Springs stock raising is the basic agricultural industry, owing to the relatively small areas of tillable lands and the fact that crop production is limited largely to hay and forage. The annual rainfall ranges from 12 to 20 inches and the growing season from 80 to 100 days. In the extreme upper end of the valley frost may occur in any month of the year. The irrigated lands lie along the river or on adjacent benches. Above Kremmling the soil is a coarse sandy loam. Native hay meadows occupy 90 per cent of this area, and some of them have been improved by sowing timothy or clover. The yields range from half a ton to the acre on meadows of the poorer type to 3 tons or more on the better ones. The remaining irrigated lands produce head lettuce, green peas, and barley. The climate is ideal for lettuce and peas for the late summer market. Barley does not mature during the average year but is cut for hay and fed locally to stock.

Between Kremmling and Glenwood Springs the soil of the tributary area comprises both sandy and clay loams of good fertility. Alfalfa is raised on about 70 per cent of the land and yields from 2 to 3 tons to the acre. The remaining land is devoted to native hay, timothy, and clover, with some wheat and oats, all of which are cut and fed locally. This section is one of the best in the upper Colorado River Basin for livestock and contains large areas of excellent spring, summer, and fall range. In the vicinity of Shoshone a small area is devoted to orchards of apples and cherries.

Between Glenwood Springs and Grand Valley the production of a number of cash crops has become a source of considerable revenue in addition to stock raising. About half the irrigated area is devoted to alfalfa, which yields from 2 to 4 tons to the acre. Large areas produce wheat and oats. Cash incomes are derived principally from fruit and sugar beets. This section is a recognized fruit district, where apples, cherries, peaches, and berries are produced abundantly. Sugar beets are grown on the heavier soils and are shipped to the factory at Grand Junction. Potatoes and other vegetables are raised, mainly for local consumption.

IRRIGATION IT GRAKD VALLEY 20

Irrigation systems.-The following systems irrigate the land in Grand Valley:

26 Compiled chiefly from data furnished by 8. O. Harper, superintendent Grand Valley project, Buresu of Reclamation. 


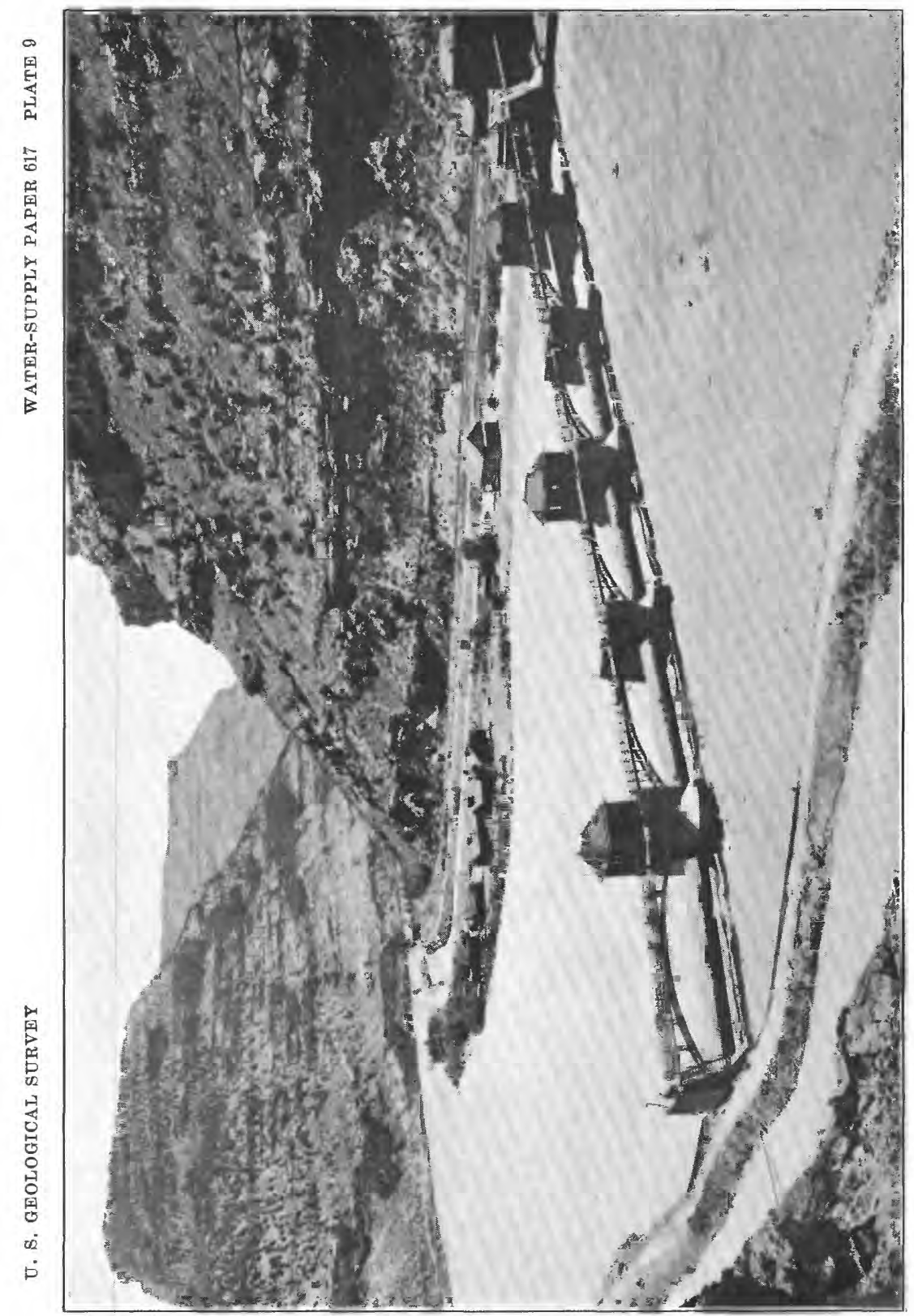

资 


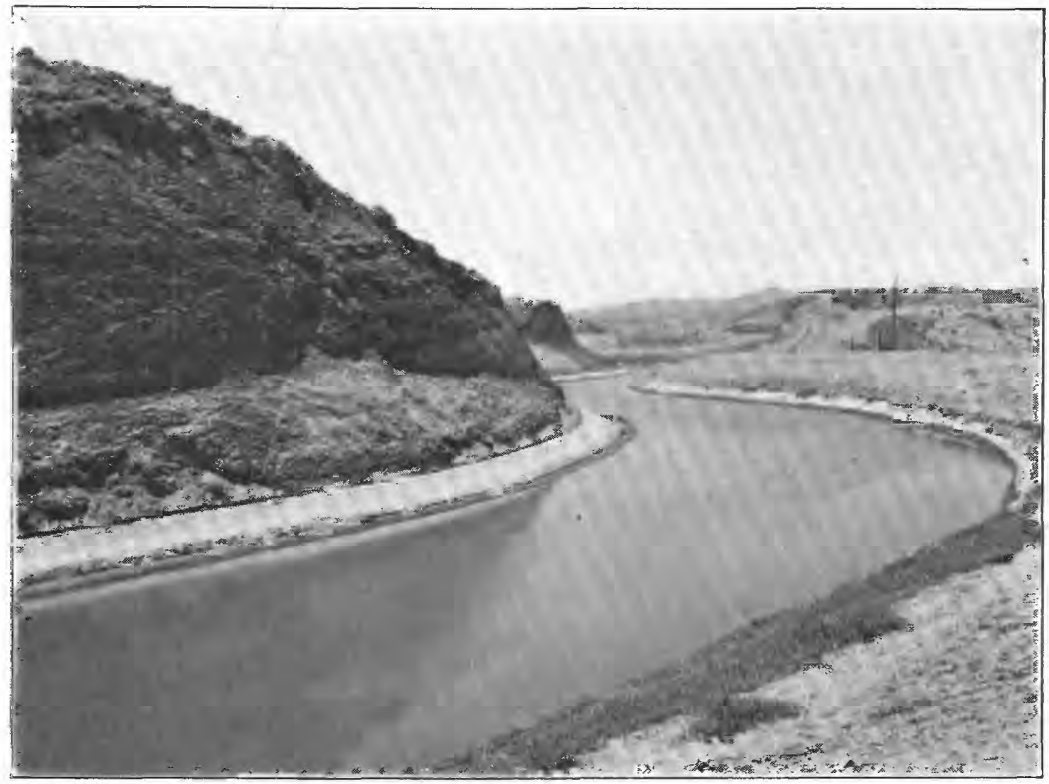

Photograph from Burear of Reclamation

A. CUT ON HIGH-LEVEL CANAL, UNCOMPAHGRE PROJECT

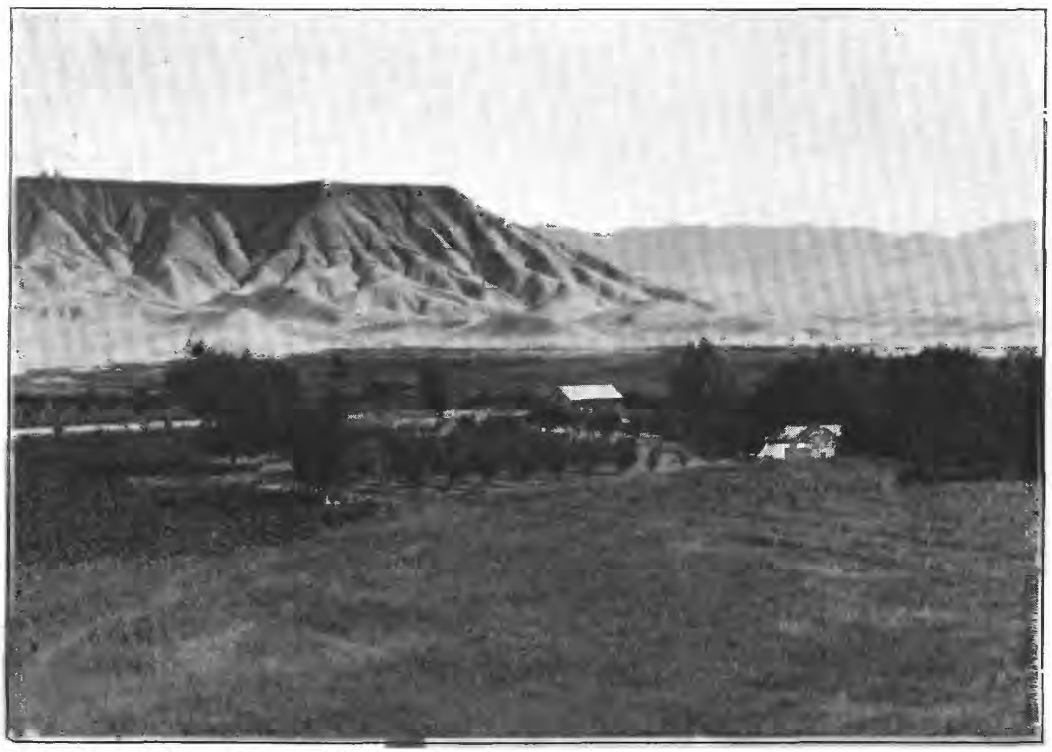

Photograph from Bureau of Reclamation

B. ALBIN RANCH, 1 MILE SOUTH OF TABLE MOUNTAIN 
Irrigation systems in Grand Valley

\begin{tabular}{|c|c|c|c|}
\hline \multirow[b]{2}{*}{ - } & \multirow[b]{2}{*}{ Method of irrigation } & \multicolumn{2}{|c|}{ Area (acres) } \\
\hline & & $\begin{array}{l}\text { Under } \\
\text { ditch }\end{array}$ & Irrigated \\
\hline \multirow[t]{2}{*}{ 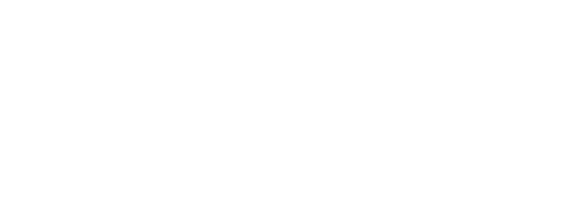 } & $\begin{array}{l}\text { Gravity (chiefly) } \\
\text { Gravity } \\
\text { Pumping } \\
\text { Gravity } \\
\text { Gravity and pumping. } \\
\text { Gravity } \\
\text { Pumping }\end{array}$ & $\begin{array}{r}-30,000 \\
35,000 \\
9,600 \\
6,000 \\
2,400 \\
630 \\
4,500\end{array}$ & $\begin{array}{r}15,000 \\
22,500 \\
5,000 \\
5,500 \\
1,600 \\
3,800 \\
3,800\end{array}$ \\
\hline & & 88,130 & 54,000 \\
\hline
\end{tabular}

The project when completed will cover 40,500 acres.

All these projects obtain their water supply from the Colorado River except the Redlands system, which is supplied by the Gunnison.

The area covered by the Grand Valley project lies on the north side of the Colorado River above the Grand Valley Irrigation Co.'s system and extends from a point near Grand Junction to the Excelsior divide, 3 miles east of the Utah line. Water is diverted from the Colorado River by means of a movable-crest diversion dam 8 miles northeast of Palisade. From the dam a main canal 55 miles long conveys the water to the land irrigated. The first 5 miles of the canal has a capacity of 1,425 second-feet. At the end of that section 800 secondfeet is delivered to the Orchard Mesa power canal and the remaining 625 second-feet is used by the Government canal for irrigation by gravity. Of the 45,000 acres to be covered by the project when completed, 35,000 acres will be supplied by gravity and 10,000 acres by pumping. No work has been done on the development of the pumping unit. In the first 6 miles the main canal is in the canyon of the Colorado, a location which necessitated the construction of three tunnels having a combined length of 12,670 feet. A notable feature of the Grand Valley project is the diversion dam (pl. 9), which consists of a solid concrete weir resting on a gravel foundation and provided with seven roller crests for regulating the height of backwater at the canal intake. Six of the roller crests span openings 70 feet wide between piers' and are 10 feet 3 inches high. The seventh is 60 feet long and 15 feet high. A dam with a movable crest was required to maintain the required water level during low water and at the same time avoid flooding the adjacent railroad track during high water.

The Grand Valley Irrigation Co. operates the Grand Valley Canal, covering 35,000 acres adjacent to the Colorado River and extending from Palisade to Loma. The system, which is the oldest in the valley, was constructed about 1883 and comprises 110 miles of canals. Water is diverted from the Colorado River just south of Palisade by means of steel head gates and a cribwork wing dam. The canal has a maximum capacity of 520 second-feet. 
The Orchard Mesa irrigation district, which comprises 9,600 acres of land on a high bench on the south side of the Colorado River, extending from Palisade to Grand Junction, is now supplied with water by the Government Grand Valley project under a contract dated February 18, 1922. The Orchard Mesa power canal, which has been reconstructed and enlarged to a capacity of 800 second-feet, is supplied from the Government canal by means of a concrete siphon 9 feet in diameter under the Colorado River, 3 miles above Palisade. Of the 800 second-feet supplied to the district, 400 second-feet is used by the district and the remaining 400 second-feet will be used by the Government project for power by the construction of a power plant near Palisade. The Orchard Mesa district uses its supply of 400 secondfeet to pump 80 second-feet against a head of 40 feet and 60 second-feet against a head of 120 feet into two distibuting canals, each 15 miles long. The Orchard Mesa power plant, across the river from Palisade, is described on page 172 .

The Palisade irrigation district covers 6,000 acres in a stretch a mile wide from Palisade to Grand Junction, a distance of 12 miles, and lies between the Grand Valley Canal and the Government main canal. The district is supplied by gravity from the Government main canal, and the 573 second-feet of power water originally decreed to the district is made available to the Government project.

The Mesa County irrigation district comprises 2,400 acres in a strip half a mile wide just above the Palisade irrigation district, extending from Palisade to Grand Junction. The Government main canal runs through the center of the strip. Water is supplied from the Government system, partly by gravity and partly by pumping. The pumping plant is on the main Government canal 1 miles east of Palisade, where the canals of the Palisade and Mesa County systems are close together. It is described on page 172. The 627 second-feet decreed to the district for power is made available to the Government project.

The East Palisade irrigation district includes 630 acres on the south side of the Colorado River just east of Palisade. It is supplied with water through the Orchard Mesa system.

The Redlands Irrigation Co., which became a mutual organization in 1925, owns an irrigation system of 4,500 acres lying on the mesa south of the Colorado River and extending westward from the Gunnison River for a distance of 10 miles. A power canal having a capacity of 500 second-feet extends from a concrete diversion dam and headgate in the Gunnison River $21 / 2$ miles above the mouth to the power house, $3 \frac{1 / 2}{2}$ miles distant, where water is pumped to the distributing system. Water from the canal is also used to generate power used in Grand Junction. The distributing system consists of five ditches at 127, 207, and 257 feet above the river, having a total length of 22 miles. The lowest or main ditch has a capacity of 35 
second-feet, is 10 miles long, and covers half the project area. The second ditch, 80 feet higher, has a capacity of 12 second-feet; is 6 miles long, and covers 1,100 acres. Small ditches at the third level irrigate about 200 acres. To irrigate this land, 40 second-feet is pumped to the lowest ditch, 12 second-feet from that to the second ditch, and 5 second-feet from the second to the third. (For description of pumping plant see p. 175.) The average quantity of water pumped is 12,000 acre-feet for 3,800 acres, a diversion duty of 3.2 acre-feet to the acre. The irrigation season is from April 15 to October 20.

Water rights and requirements.-The following table shows the amount of water decreed from Colorado River for ditches in Grand Valley:

\section{Decreed rights from Colorado River in Grand Valley}

[Arranged in order beginning upstream]

\begin{tabular}{|c|c|c|c|c|c|c|c|}
\hline \multirow{2}{*}{ Claimant } & \multicolumn{3}{|c|}{ Point of diversion } & \multirow{2}{*}{$\begin{array}{l}\text { Date of } \\
\text { priority }\end{array}$} & \multicolumn{3}{|c|}{ Second-feet } \\
\hline & Sec. & T. & R. & & $\begin{array}{c}\text { Irriga- } \\
\text { tion }\end{array}$ & Power & Total \\
\hline $\begin{array}{l}\text { Orchard Mesa irrigation dis- } \\
\text { trict. }\end{array}$ & 12 & $10 \mathrm{~g}$. & 98 W. 6th P. M.- & Oct. 25,1907 & ' 125 & 325 & 450 \\
\hline $\begin{array}{l}\text { Grand Valley project. } \\
\text { Mesa County irrigation dis- } \\
\text { trict. }\end{array}$ & $\begin{array}{r}13 \\
3\end{array}$ & $10 \mathrm{~s}$. & _... do & $\begin{array}{l}\text { Feb. } 27,1908 \\
\text { July } \quad 6,1903\end{array}$ & $\begin{array}{l}(0) \\
40\end{array}$ & 627 & $6077^{-5}$ \\
\hline $\begin{array}{l}\text { Palisade irrigation district } \\
\text { East Palisade irrigation dis- } \\
\text { trict. }\end{array}$ & $\begin{array}{l}\mathbf{3} \\
\mathbf{1}\end{array}$ & $11 \mathrm{~s}$. & (ndo do & $\begin{array}{ll}\text { Oct. } & 1,1889 \\
\text { Oct. } & 1,1900\end{array}$ & $\begin{array}{l}80 \\
10.2\end{array}$ & 573 & $\begin{array}{l}653 \\
10.2\end{array}$ \\
\hline Grand Valley Canal & 3 & $1 \mathrm{~s}$. & 2 E. Ute P. M.- & Aug. 22, 1882 & 520.8 & & 520.8 \\
\hline Orchard Mesa power canal..... & 20 & $1 \mathrm{~s}$. & 1 E. Ute P. M. & $\begin{cases}\text { Mar. } & 6,1889 \\
\text { Aug. } & 2,1898\end{cases}$ & $\begin{array}{l}6 \\
4\end{array}$ & $\begin{array}{l}105 \\
135 .\end{array}$ & 240 \\
\hline
\end{tabular}

- No definite amount decreed. Capacity of canal now 1,425 second-feet.

Water for the Orchard Mesa, Mesa County, Palisade, and East Palisade districts is supplied from the main canal of the Grand River project, which has been enlarged to a capacity of 1,425 second-feet. Land under the Orchard Mesa power canal has been consolidated with the Orchard Mesa district. The only right below the Government intake is that of the Grand Valley Canal, and as both pumping plants are above the intake for the canal the power water used for pumping is returned to the river and supplies that right. It is evident that the decreed rights from the Colorado River in Grand Valley are satisfied by 1,425 second-feet diverted by the Government canal.

On the Government project, which may be considered typical of the projects in the valley, irrigation begins late in March and lasts until the first of November. The table following is taken from a compilation by the Bureau of Reclamation. 
Monthly and annual duty of water on Grand Valley project, 1916-1925

\begin{tabular}{|c|c|c|c|c|c|c|c|c|c|c|c|c|}
\hline \multirow[b]{2}{*}{ Year } & \multirow{2}{*}{$\begin{array}{c}\text { Area } \\
\text { irri- } \\
\text { gated } \\
\text { (acres) }\end{array}$} & \multicolumn{9}{|c|}{ Water delivered to farms (acre-feet per acre) } & \multirow{2}{*}{$\begin{array}{l}\text { Preoip- } \\
\text { itation } \\
\text { April } \\
\text { to } \\
\text { Octo- } \\
\text { ber } \\
\text { (feet) }\end{array}$} & \multirow{2}{*}{$\begin{array}{c}\text { Total } \\
\text { water } \\
\text { on } \\
\text { farms } \\
\text { (acri- } \\
\text { feet) }\end{array}$} \\
\hline & & April & May & June & July & $\begin{array}{l}\text { Au- } \\
\text { gust }\end{array}$ & $\begin{array}{l}\text { Sep- } \\
\text { tem- } \\
\text { ber }\end{array}$ & $\begin{array}{c}\text { Octo- } \\
\text { ber }\end{array}$ & $\begin{array}{c}\text { No- } \\
\text { vem- } \\
\text { ber }\end{array}$ & Total & & \\
\hline $\begin{array}{l}1916 \\
1917 \\
1918 \\
1919 \\
1920 \\
1922 \\
1923 \\
1924 \\
1925\end{array}$ & $\begin{array}{r}1,742 \\
5,289 \\
8,102 \\
10,049 \\
11,734 \\
12,290 \\
12,372 \\
12,870 \\
13,456 \\
13,488\end{array}$ & $\begin{array}{l}0.00 \\
.06 \\
.13 \\
.10 \\
.00 \\
.22 \\
.09 \\
.16 \\
.25 \\
.32\end{array}$ & $\begin{array}{l}0.46 \\
.25 \\
.75 \\
.63 \\
.46 \\
.76 \\
.77 \\
.79 \\
.96 \\
.99\end{array}$ & $\begin{array}{l}0.74 \\
.70 \\
.83 \\
.95 \\
.68 \\
.73 \\
.88 \\
.75 \\
.68 \\
.87\end{array}$ & $\begin{array}{l}0.62 \\
.97 \\
.66 \\
.82 \\
.69 \\
.84 \\
.85 \\
.82 \\
.97 \\
.82\end{array}$ & $\begin{array}{l}0.21 \\
.72 \\
.53 \\
.68 \\
.63 \\
.42 \\
.59 \\
.70 \\
.92 \\
.78\end{array}$ & $\begin{array}{r}0.27 \\
.38 \\
.39 \\
.42 \\
.33 \\
.33 \\
.36 \\
.42 \\
.38 \\
.37\end{array}$ & $\begin{array}{l}0.08 \\
.22 \\
.27 \\
.21 \\
.28 \\
.28 \\
.20 \\
.13 \\
.18 \\
.23\end{array}$ & 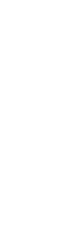 & 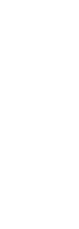 & $\begin{array}{r}0.57 \\
.39 \\
.39 \\
.35 \\
.45 \\
.72 \\
.33 \\
.44 \\
.54 \\
.61\end{array}$ & $\begin{array}{l}2.99 \\
3.93 \\
4.07 \\
4.16 \\
3.52 \\
4.30 \\
4.07 \\
4.21 \\
4.88 \\
\text { 5. } 68\end{array}$ \\
\hline Mean.... & & .13 & .68 & .78 & .81 & .62 & .36 & .21 & .04 & 3.63 & .48 & 4.11 \\
\hline $\begin{array}{l}\text { Per cent of } \\
\text { livery... }\end{array}$ & & 3.5 & 18. 7 & 21.5 & 22.4 & 17.1 & 9.9 & 6.8 & 1.1 & 100 & & \\
\hline
\end{tabular}

The mean annual duty is 3.6 acre-feet delivered to the farms, which is a relatively low duty, made possible chiefly by the abundant supply in the Colorado River. Other projects in the valley use about 4 acrefeet to the acre, except the punping project, on which the duty is about 3.2 acre-feet. The chief crops on the Government project are alfalfa, hay, and pasture, 50 per cent; sugar beets, corn, and regetables, 35 per cent; small grains, 14 per cent; peaches, 1 per cent. The yields per acre of the chief crops are corn, 16 bushels; oats, 24 bushels; wheat, 20 bushels; alfalfa, 3 tons; potatoes, 132 bushels; sugar beets, 8 tons. The beets are shipped to the sugar factory at Grand Junction.

On the older projects in the valley, which lie generally at a slightly lower altitude, fruits are raised more extensively - in fact, Grand Valley is a well-established fruit-growing district, where apples, peaches, pears, cherries, apricots, cantaloupes, and berries of high quality are produced and shipped to distant markets in large quantities.

The soil of the lower valley west of Grand Junction is a heavy clay and in places somewhat alkaline. Considerable fruit is grown but not on a scale comparable with that in the eastern part of the valley. At Moab alfalfa is the principal crop, although the climate is ideal for the production of many varieties of fruits, berries, melons, grapes, and vegetables. However, the isolated location of the settlement prevents any extensive development of cash crops, and stock raising is the principal industry. On the La Sal Mesa the average annual precipitation is 12 inches, and crops of wheat and oats are produced by dry farming on small areas with moderate success.

Drainage.-Owing to the heavy soil, the gentle slope, and the abundance of water applied, a third of the area under the Grand Valley Canal is seeped land. Very much smaller areas are similarly affected on the Government project, where the lands have been drained as this condition developed. To drain the lands in the old 
distriets the Grand Valley drainage district was organized in 1915 by the landowners and entered into contract with the Bureau of Reclamation to construct a number of main drainage ditches, which also serve as outlets from the Government project. About 40 miles of ditches have been built, and these have reclaimed 20 per cent of the seeped land. It is expected that the work will be completed at an estimated cost of $\$ 1,000,000$ by the Grand Junction drainage district, which has superseded the Grand Valley district.

\section{TRIBUTARIES ABOVE GUNNISON RIVER}

Every tributary of the upper Colorado River is utilized to some extent for irrigation, all the lands close to the streams being irrigated and also some of the mesas bordering the larger streams. $A$ few ditches cover 1,500 acres or more, and these are given in the following table:

Principal ditches on tributary streams in upper Colorado River Basin above Gunnison River

\begin{tabular}{|c|c|c|c|c|c|c|c|}
\hline \multirow[b]{2}{*}{ Name } & \multirow[b]{2}{*}{ Source of supply } & \multicolumn{3}{|c|}{ Head-gate location } & \multirow{2}{*}{$\begin{array}{l}\text { Capaeity } \\
\text { (second- } \\
\text { feet) }\end{array}$} & \multicolumn{2}{|c|}{ Area (acres) } \\
\hline & & See. & T. & $\begin{array}{l}\text { R. W. } \\
\text { Bth } \\
\text { P. M. }\end{array}$ & & $\begin{array}{l}\text { Under } \\
\text { ditches }\end{array}$ & $\underset{\text { gated }}{\text { Imi- }}$ \\
\hline Grand River... & Coloradio River....... & 1 & $5 \mathrm{~N}$ & $\begin{array}{l}76 \\
75\end{array}$ & 220 & (a) $\cdot$ & \\
\hline $\begin{array}{l}\text { Green Kountaha } \\
\text { Salvation } \\
\text { Mountain Meadows..... }\end{array}$ & $\begin{array}{l}\text { Blua River } \\
\text { \{black Creek } \\
\text { Roaring Fork } \\
\text { Cattle Oroelk (thibutary }\end{array}$ & $\begin{array}{r}19 \\
29 \\
17 \\
1\end{array}$ & $\begin{array}{l}3 \mathrm{~s} . \\
2 \mathrm{~s} . \\
10 \mathrm{~s} .\end{array}$ & $\begin{array}{l}78 \\
79 \\
84 \\
87\end{array}$ & $\begin{array}{l}50 \\
26\end{array}$ & $\begin{array}{l}1,500 \\
3,150 \\
3,000\end{array}$ & $\begin{array}{r}300 \\
1,000 \\
1,970\end{array}$ \\
\hline 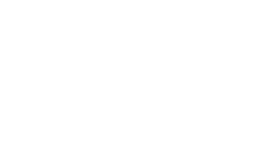 & $\begin{array}{l}\text { Weest Divide Creek } \\
\text { Divide Creek } \\
\text { East Rifle Creek } \\
\text { Rifle Creek } \\
\text { Cottonwood Creek (trib- } \\
\text { utary to Plateau } \\
\text { Creek). }\end{array}$ & $\begin{array}{l}19 \\
11 \\
27 \\
18 \\
33\end{array}$ & $\begin{array}{r}8 \mathrm{~S} . \\
7 \mathrm{~S} . \\
4 \mathrm{~S} . \\
10 \mathrm{~S} .\end{array}$ & $\begin{array}{l}91 \\
92 \\
92 \\
92 \\
95\end{array}$ & $\begin{array}{l}70 \\
54 \\
44 \\
30 \\
30\end{array}$ & $\begin{array}{l}5,200 \\
5,000 \\
6,000 \\
1,500 \\
2,560\end{array}$ & $\begin{array}{l}3,820 \\
520 \\
3,490 \\
1,100 \\
1,120\end{array}$ \\
\hline
\end{tabular}

- Water diverted for irrigation in Cache la Poudre Valley. See p. 50 for amounts diverted each year.

\section{BLUR RIVER}

The land along the Blue River and the lower sections of the tributary streams is irrigated in an almost continuous area extending from the south boundary of T. $3 \mathrm{~S}$., R. $78 \mathrm{~W}$., to the northern boundary of T. 1 S., R. $80 \mathrm{~W}$., 6 miles above the mouth. The amount of land under ditch in the Blue River Valley is not known, as no water commissioner's report is available, but H. C. Diesem, in a report to the Federal Land Bank, states that the amount of land actually irrigated is 7,000 acres. On this basis the area under ditches is estimated as 10,000 acres. The only mesa lands under ditch are those covered by the Green Mountain Canal, which lie east of Green Mountain, in T. 2 S., R. $80 \mathrm{~W}$. This canal was originally designed to have its main intake on the Blue River in sec. 19, T. 3 S., R. 78 $\mathrm{W}$., and to be constructed along the steep mountain side for 9 miles 
before reaching the top of the mesa. The original plan has not been carried out, but instead a feeder ditch from Black Creek, a tributary, has been constructed, and a 30 -inch pipe line built across the Blue River Valley, crossing the river on a bridge. The pipe line joins the Green Mountain Canal, which has been built for 4 miles below the pipe-line crossing. Only a few hundred acres of mesa land is irrigated at present, but an area of several thousand acres can be irrigated by an extension of the ditch.

The agricultural utility of the Blue River Valley is limited to stock raising by the shortness of the growing season, which is less than 90 days, and by the fact that in places frost may occur at any time during the year. The annual rainfall ranges from 10 to 20 inches below Dillon and from 20 to 30 inches in the upper valley. Practically all the cultivated land is irrigated and comprises, in addition to the areas along the river proper, many small patches on the adjoining hillsides. The soil ranges from sandy loam to clay; the heavier soil occurs in the lower valley just below Kremmling. About 90 per cent of these lands are devoted to hay production and range from the poorly kept meadow of wild grasses, which yield approximately half a ton to the acre, to excellent fields of timothy and clover which yield as much as 3 tons to the acre. Small areas of barley and oats grown in the lower valley are cut for hay and fed locally, and there are many small gardens for local use.

\section{EAGLE RIVER}

From Avon to Gypsum, in the main valley of Eagle River, the irrigated area is an almost continuous strip, chiefly on the south side of the river. The valleys of Brush, Gypsum, and Eby Creeks are extensively irrigated from these streams. The ditches are all small, the largest covering less than 700 acres and most of them, 100 acres or less. This is an extremely rough, mountainous area, and cultivation is confined to the irrigated valley lands along the Eagle River. The soils of these irrigated lands are principally silt and clay loams of good fertility. In the eastern part, above Wolcott, where the growing season is less than 90 days, most of the irrigated area is included in large stock ranches and devoted to raising wild hay, timothy, and clover, which yield from half a ton to 3 tons to the acre. Barley and oats are produced on small tracts and will mature in the average year. The yields range from 20 to 40 bushels to the acre, and practically the entire crop is used locally for feed. During recent years the growing of head lettuce as a cash crop has been tried on a small area with reasonable success. West of Eagle climatic conditions permit the production of such crops as alfalfa, which yields from $2 \frac{1}{2}$ to 3 tons to the acre, barley, oats, and wheat, all of which ripen during the average year and yield well; also potatoes. There 
are a number of cash-crop farmers in the valley between Eagle and Gypsum, and this section is especially noted for the quality of its seed potatoes.

\section{ROARING FORK}

The main valley of the Roaring Fork, which is narrow, is practically all irrigated from Aspen to the mouth at Glenwood Springs. The Salvation ditch, which diverts water from the river in sec. 17, T. $10 \mathrm{~S}$., R. $84 \mathrm{~W}$., the only ditch of considerable size in the valley, has a capacity of 50 second-feet and covers 3,150 acres in a narrow strip in the north side of the valley between Aspen and Woody. Its main source is the Roaring Fork a short distance above Aspen. It also diverts water from Woody Creek. The tributary streams, which also flow through narrow valleys, are used extensively for irrigation. Cattle Creek has the largest drainage area of all the tributaries. Its largest ditch is the Mountain Meadows ditch, in sec. 1, T. 7 S., R. 87 W., which has a capacity of 26 second-feet and covers 3,000 acres. The land irrigated lies south of Cattle Creek and includes some mesa land above the main valley. The Crystal River ditches cover 3,500 acres in a continuous area on both sides of the river, extending from Sewell to the mouth. Storage in the Roaring Fork Basin is provided by 22 small reservoirs, which have a combined capacity of 6,000 acre-feet. The two largest reservoirs, Ivanhoe and Spring Park, are described on pages 61-62.

Stock raising is the basic agricultural industry of the Roaring Fork drainage area. The region is mostly rough and suitable only for grazing, and cultivation is confined to the irrigated bottom and a few tracts of bench land along the river and its tributaries. The soil is derived from alluvial material and is principally a silt loam mixed with considerable gravel. The upper part of the area above Snowmass has a growing season of less than 90 days, and crops are thereby limited to hay and forage, which are fed locally to stock using the adjoining ranges. Wild hay, timothy, and clover are grown on most of the irrigated area and yield from half a ton to 3 tons to the acre, according to the quality of the field. Barley and oats are also produced on small tracts but are normally cut for hay. Climatic and soil conditions are favorable for the growing of head lettuce for late summer markets, but so far that crop has received little attention. In the lower part of the valley west of Snowmass there is a longer growing season, and in addition to stock raising and the production of forage crops a number of farmers make a living by producing cash crops. Alfalfa does well and yields from 2 to 3 tons to the acre; small grains, including wheat, oats, and barley, ripen during the average year with good yields. Potatoes are a favorite cash crop and are produced extensively in the vicinity of Carbondale, a locality noted for the quality of its seed potatoes. 


\section{DIVIDE CREET}

The irrigated area in the basin of Divide Creek lies in a compact body, extending from the south line of T. $7 \mathrm{~S}$. nearly to the Colorado River and covering the greater part of the mesa lands between West Divide and Mamm Creeks. The two largest ditches are the Divide Creek Highline and Multi Trina. The former, which has a capacity of 70 second-feet, diverts water from West Divide Creek in sec. 19, T. 8 S., R. 91 W., and covers 5,200 acres, of which 3,880 acres is irrigated. The Multi Trina ditch diverts water from Divide Creek in sec. $11, T .7$ S., R. 92 W., has a capacity of 54 second-feet and covers 5,000 acres, of which only 520 acres is irrigated.

\section{RIFLR CREER}

The irrigated land in the Rifle Creek Valley lies in two main bodies one in the main valley extending from the mouth of East Rifle Creek to the Colorado River and the other embracing the area between Elk and Rifle Creeks for a width of 3 miles along the Colorado. The area in the main valley is irrigated by numerous ditches, of which the largest is the Rifle Canyon ditch. The other area lies within the Grass Valley project.

The Grass Valley ditch diverts water from the East Fork of Rifle Creek in sec. 27, T. 4 S., R. 92 W., and has a capacity of 44 secondfeet for a distance of 5 miles between the point of diversion and the Grass Valley Reservoir. The reservoir is in sec. 13, T. 5 S., R. 92 W., and has a capacity of 4,130 acre-feet. Most of the 6,000 acres comprised within the project lies a short distance below the reservoir. The remaining area, amounting to a few hundred acres, is irrigated from the inlet ditch above the reservoir. The total area irrigated is 3,400 acres.

In addition to stock raising, the production of a number of cash crops has become a source of considerable revenue in this district. The mean annual rainfall is insufficient for the successful growth of dry-farm crops, and the cultivated lands comprise the irrigated bottoms and benches along the principal stream valleys. In order to supply feed for the large number of stock that use the extensive grazing areas of the district, approximately half the irrigated area is devoted to the production of alfalfa, which yields from 2 to 4 tons to the acre. Large tracts are also used for the production of wheat and oats, both of which yield well.

\section{PLATEA U CREEK}

The irrigated area in the Plateau Creek Basin lies chiefly on the south side of the creek between Collbran and Mesa. Not only are the bottom lands irrigated but the mesa lands bordering these are irrigated by the tributary streams. The ditches are small and cover a total of 50,200 acres, of which 27,700 acres is irrigated. 
The principal tributaries drajn the north side of Grand Mesa, on which there are many small lakes. These lakes have been converted into reservoirs by building low earth dams across the outlets and are used in connection with the many ditches in the Plateau Creek Valley. The 40 reservoirs have a combined capacity of 10,100 acre-feet. The principal ones are listed on page 66 .

The irrigated lands lie within an extensive range country, where stock raising and dairying are the leading industries. The cultivated area has a sandy loam soil, and about 65 per cent of it is utilized for the production of alfalfa, which yields from $2 \frac{1}{2}$ to 3 tons to the acre. Wheat and oats are next in abundance and produce good yields in the average year. A number of small orchards produce apples, cherries, peaches, and berries for local use. The climate is suitable for the production of sugar beets, but this crop is not attempted on account of the long haul to market. Similar conditions preclude the growing of potatoes other than for local use.

\section{GUNNISON RIVER BASIN}

The chief area irrigated from the Gunnison River does not lie in the Gunnison Valley but in that of the Uncompahgre, a tributary. Water is diverted through the Gunnison Tunnel, built by the United States Bureau of Reclamation Service to augment the flow of the Uncompahgre River for the ultimate irrigation of 97,000 acres. In the valley of the Gunnison itself the largest areas irtigated are near Delta and in Grand Valley, at the mouth of the river.

The following table shows the principal diversions:

Principal diversions from Gunnison River for irrigation

\begin{tabular}{|c|c|c|c|c|c|c|}
\hline \multirow{2}{*}{ Name } & \multicolumn{3}{|c|}{ - Head-gate location } & \multirow{2}{*}{$\begin{array}{l}\text { Capacity } \\
\text { (second- } \\
\text { feet) }\end{array}$} & \multicolumn{2}{|c|}{ Area (acres) } \\
\hline & Sec. & T. & R. & & $\begin{array}{l}\text { Under } \\
\text { ditch }\end{array}$ & $\begin{array}{l}\text { Irri- } \\
\text { gated }\end{array}$ \\
\hline $\begin{array}{l}\text { Gunnison Tunnel. } \\
\text { North Delta } \\
\text { Relief } \\
\text { Bona Fide } \\
\text { Hartland } \\
\text { Trial } \\
\text { Redlands. }\end{array}$ & $\begin{array}{r}10 \\
4 \\
6 \\
1 \\
8 \\
10 \\
35\end{array}$ & $\begin{array}{l}49 \mathrm{~N} . \\
15 \mathrm{~S} . \\
15 \mathrm{~S} . \\
15 \mathrm{~S} . \\
15 \mathrm{~S} . \\
15 \mathrm{~S} . \\
11 \mathrm{~S} .\end{array}$ & $\begin{array}{l}7 \text { W. N. Mex. P. M... } \\
94 \text { W. 6th P. M. } \\
95 \text { Wo. } 6 \text { th P. M M } \\
96 \text { W. } 6 \text { th P. M. } \\
1 \text { W. Ute P. M. }\end{array}$ & $\begin{array}{r}1,000 \\
50 \\
60 \\
65 \\
45 \\
60 \\
620\end{array}$ & $\begin{array}{l}\left({ }^{*}\right) \\
4,000 \\
3,700 \\
4,100 \\
3,200 \\
1,200 \\
4,500\end{array}$ & $\begin{array}{l}1,900 \\
3,300 \\
3,800 \\
3,000 \\
1,200 \\
3,800\end{array}$ \\
\hline
\end{tabular}

- Annual diversion in acre-feet through tunnel as follows:

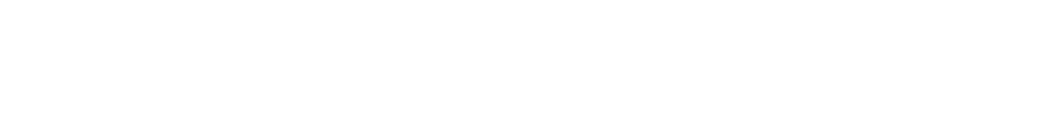

The Gunnison Tunnel is described on page 116, and the Redlands project, which irrigates land by pumping, on page 122 . The other diversions are in the vicinity of Delta and irrigate land close to the river. The North Delta Canal is on the north side of the river, and $46013-29-10$ 
the others are on the south side. The remaining land under ditches in the Gunnison Valley, which amounts to 12,500 acres, of which 8,800 acres are irrigated, lies chiefly in narrow strips along the river from Almont nearly to Cebolla.

Stock-raising is practically the only industry in this valley, and agriculture is confined to forage crops. Irrigation is practiced only on the bottom lands, where the soil consists of alluvial silt and gravel on which wild hay, timothy, and clorer are raised. Flooding is the common method of irrigation. The crop yields per acre range from half a ton in the poorer lands to 3 tons on the better timothy and clover fields. Alfalfa is grown on a few small tracts but not very successfully, owing to the frequent occurrence of frosts, the growing season being about 70 days.

The tributaries of the Gunnison River are extensively used for irrigation, some of the largest private projects in the Colorado River Basin being in that portion of the Gunnison Basin drained by the North Fork. On the tributaries of the Gunnison exclusive of the Uncompahgre, 219,000 acres are under ditches, of which 157,000 acres are irrigated. The following table shows the principal projects:

Principal irrigation projects on tributary streams in Gunnison River. Basin

\begin{tabular}{|c|c|c|c|c|c|c|c|}
\hline \multirow{2}{*}{ Project } & \multirow{2}{*}{ Source of supply } & \multicolumn{3}{|c|}{ Head-gate location } & \multirow{2}{*}{$\begin{array}{l}\text { Capacity } \\
\text { (second- } \\
\text { feet) }\end{array}$} & \multicolumn{2}{|c|}{ Arẹa (acres) } \\
\hline & & Sec. & $\mathrm{T}$. & R. & & $\begin{array}{l}\text { Under } \\
\text { ditch }\end{array}$ & $\begin{array}{l}\text { Irri- } \\
\text { gated }\end{array}$ \\
\hline Arch & $\begin{array}{l}\text { Tomichi Creek } \\
\text { Cochetopa Creek }\end{array}$ & \multirow{9}{*}{$\begin{array}{c}16 \\
3 \\
21 \\
5 \\
35 \\
\\
34 \\
32 \\
17 \\
22 \\
16 \\
22 \\
29 \\
34\end{array}$} & \multirow{3}{*}{$\begin{array}{l}48 \mathrm{~N} \\
43 \mathrm{~N} \\
45 \\
46 \\
50 \mathrm{~N}\end{array}$} & $\begin{array}{l}4 \text { E.N. Mex.P.M. } \\
2 \text { E. N. Mex.P.M. }\end{array}$ & \multirow{3}{*}{$\begin{array}{r}40 \\
40 \\
54 \\
100 \\
50\end{array}$} & \multirow{3}{*}{$\begin{array}{r}2,000 \\
(\bullet) \\
1,700 \\
10,000 \\
3,000\end{array}$} & \multirow{3}{*}{\begin{tabular}{r}
1,950 \\
\hdashline 1,600 \\
5,920 \\
2,500
\end{tabular}} \\
\hline $\begin{array}{l}\text { Mesa_..... } \\
\text { Cimarron } \mathrm{di}\end{array}$ & Cimarron Creek & & & $6 \mathrm{~d}$ & & & \\
\hline Cedar Canyon and & Crystal Creek ... & & & ow.do.Mex. P. M & & & \\
\hline $\begin{array}{l}\text { Iron Springs. } \\
\text { Fruitland }\end{array}$ & & & & $\therefore$ do $\ldots$ & & & \\
\hline $\begin{array}{l}\text { Orawford-Clipper-- } \\
\text { Fire Mountain }\end{array}$ & Smith Fork & & $15 \mathrm{~S}$ & $91 \mathrm{~W} .6 \mathrm{th} \mathrm{P} . \mathrm{M}$ & 96 & 4,400 & 2,600 \\
\hline $\begin{array}{l}\text { Fire Mountain...... } \\
\text { Stewart_............ }\end{array}$ & North Fork & & $13 \mathrm{~s}$. & 90 W. 6 th P. M & 80 & $\begin{array}{l}6,000 \\
3,000\end{array}$ & 5,000 \\
\hline Overland.- & Leroux Creek. & & $13 \mathrm{~s}$ & 93 W. 6 th P.M & 120 & 5,000 & 3,000 \\
\hline & & & $14 \mathrm{~S}$. & $\mathrm{do}_{\mathrm{O}}$ & 90 & 5,000 & 4,000 \\
\hline $\begin{array}{l}\text { Alfalfa } \\
\text { Lone Pine. }\end{array}$ & Surface Creek & & $12 \mathrm{~s}$. & $94 \mathrm{~W}, 6$ th P.M. & $\begin{array}{l}60 \\
60\end{array}$ & $\begin{array}{l}3,000 \\
2,200\end{array}$ & $\begin{array}{l}2,200 \\
1,400\end{array}$ \\
\hline
\end{tabular}

- Water diverted for irrigation of land in San Luis Valley.

TOMICHI CREEK

Of the 31,000 acres irrigated in the Tomichi Creek Basin, 12,100 acres is supplied with water from the main stream. This area is confined to the bottom lands, which extend in an almost continuous strip from a point 5 miles below Whitepine to the mouth. The ditches are small except the Arch ditch, which diverts water in the NE. 1/4 SW. $1 / 4$ sec. 16, T. 48 N., R. 4 E. New Mexico principal meridian, and extends 10 miles to Razor Creek, irrigating a strip of land having an average width of 1 mile between the ditch and Tomichi Creek. The ditch has a capacity of 40 second-feet. An extension irrigates a few hundred acres beyond Razor Creek. 
Cochetopa Creek, a tributary of Tomichi Creek, is used almost as extensively for irrigation as the main stream, the ditches from it covering 10,000 acres, of which 9,620 acres are irrigated. This area does not include 1,500 acres irrigated by the Tarbell ditch in the San Luis Valley. The largest projeot is that under the Mesa ditch, which has a capacity of 54 second-feet and a length of 4 miles. It diverts water in sec. 21, T. 45 N., R. 2 E. New Mexico principal meridian, and irrigates 1,600 acres in that township between Cochetopa Creek and Van Tassel Gulch.

The soil in the Tomichi Creek Basin is principally alluvial silt and gravel. Wild hay, timothy, and clover are practically the only crops and are raised by the flooding method of irrigation. The yields range from half a ton to 3 tons to the acre.

\section{CIMARRON CRERK}

Of the 10,000 acres irrigated from Cimarron Creek, 5,920 acres lies outside the basin, under the Cimarron ditch, which diverts water from Cimarron Creek 15 miles above its mouth. This ditch divides 10 miles below its head, one branch leading to Vernal Mesa, just south of the Gunnison River, where the greater part of the irrigated land is located, and the other branch supplying land lying just east of that irrigated under the Uncompahgre project. No storage has been provided, and the water supply is insufficient for additional land under the ditch until reservoirs are constructed. (For discussion of agriculture, see p. 117.)

\section{CRYSTAL CREEK}

A small amount of land is irrigated along Crystal Creek, but the great bulk of the irrigated area, supplied with water from this stream, is in the vicinity of Maher and Crawford, in the Smith Fork Basin. The largest project is that of the Fruitland Irrigation Co., which diverts water from Crystal Creek by means of a wooden diversion dam and headworks in sec. 34, T. 50 N., R. 6 W. New Mexico principal meridian, near the point where the stream leaves the mountains. The water is carried 7 miles in a canal having a capacity of 80 secondfeet, to the Onion Valley Reservoir, in secs. 7, 17, and 18, T. $50 \mathrm{~N}$., R. $6 \mathrm{~W}$., which has a present capacity of 4,770 acre-feet with a 50 -foot earth dam on Iron Creek. From the reservoir a distributing canal leads to the lands of the project, which lies south of Smith Fork, chiefly in T. 15 S., R. 93 W. sixth principal meridian, and the north half of T. 51 N., R. $8 \mathrm{~W}$. New Mexico principal meridian. The capacity of the distributing ditch is controlled by that of a tunnel 2,625 feet long, which has a capacity of 100 second-feet. The project at present covers 5,000 acres, of which 2,650 acres are irrigated. Possible enlargement is considered on page 143.

The Cedar Canyon and Iron Springs ditch, which has a capacity of 50 second-feet, has its head gate in sec. 35, T. 50 N., R. 6 W. New 
Mexico principal meridian, three-quartere of a mile above the Fruitland ditch. The ditch skirts the east side of the Onion Valley-Resesvoir and covers 3,000 acres between Maher and Crawford, chiefly in T. 51 N., R. 6 W. (For discussion of agriculture see p. 117.)

\section{SHITH FORK}

The greater part of the area irrigated from the Smith Fork lies: under two large ditches and the remainder under a number of small ditches, which irrigate land near the stream. The Crawford Clipperditch, which has a capacity of 96 second-feet, diverts water in sec. 32, T. 15 S., R. 91 W. sixth principal meridian, near the mouth of the canyon, and covers 4,400 acres, of which 2,600 acres is irrigated, northwest of Crawford, on the divide between Smith Fork and the. North Fork of the Gunnison.

The region included in the basins of Cimarron and Crystal Creeks. and the Smith Fork is rough and mountainous and is dexated princi-. pally to stock-raising. Farming is confined chiefly to the irrigated areas along the streams and to the mesas bordering the Smith Fork. The bottom lands have an an alluvial soil composed of silt and gravel; the mesa lands have a red clay-loam soil. From 80 to 90 per cent of the cultivated area produces hay and forage crops, consisting of alfalfa, wheat, and oats. Alfalfa is cut twice during normal years.and yields from 2 to $2 \frac{1}{2}$ tons to the acre. Wheat and oats are used chiefly for stock feed. In the vicinity of South Fork, although alfalfa is the principal crop, the climate is favorable for the production of apples, peaches, cherries, and berries. Potatoes and other vegetables are raised for local consumption.

\section{NORTH FORK}

Irrigation in the North Fork Valley extends from the mouth of the. canyon nearly to the mouth of the river. Not only are the bottom: lands irrigated but also a number of mesas bordering the river, particularly on the north side. Near the mouths of the principal tributaries the land is irrigated from these streams. Of the 16,900 acres. under ditches directly from the North Fork, 9,000 aeres is covered by two ditches. The Fire Mountain Canal, which has a eapacity of 80 second-feet, diverts water near Somerset, in sec. 17, T. 13 S., R: $90 \mathrm{~W}$. sixth principal meridian, and irrigates a strip of land on the north side gradually increasing in width to 3 miles at its end near. Leroux Creek. The main canal crosses tributary streams by inverted. siphons, the largest of which is 1,000 feet long and 4 feet in diameter. The Stewart ditch diverts water in sec. 22, T. 13 S., R. 91 W., and irrigates a triangular area on the south side of the river extending 5 , miles along the valley. About three-quarters of a mile below the head gate the ditch is carried through a hill by a tunnel, to avoid a sliding hillside, and toward the lower end of the ditch several flumes. have been constructed along sliding hillsides. 
The area irrigated from Leroux Creek lies chiefly on the west side of the creek, between the Overland ditch and the North Fork. Two ditches cover 10,000 acres and irrigate 7,000 acres. The Overland ditch, which diverts water from Leroux Creek in sec. 16, T. $13 \mathrm{~S}$, R. 93 W., has its ultimate source in Hubbard or West Muddy Creek, in tercepting a number of small streams between. From Leroux Creek its capacity is 120 second-feet, and its course is southward across the mesa lands to Paynes Mesa, where it irrigates 3,000 acres. The Overland Reservoir, in sec. 23, T. 11 S., R. 92 W., on Cow and Habbard Creeks at the head of the Overland ditch, affords storage of 4,000 acre-feet. The Leroux Creek ditch diverts from Lieroux Creek by means of a concrete dam and head gate in sec. 22 , T. 14 S., R. 93 W., and irrigates 4,000 acres between the creek and North Fork. The water supply is augmented by that from the Fire Mountain Canal, the lower end of which empties into the Leroux Creek ditch.

On the headwaters of Leroux Creek are 26 small reservoirs, formed by damming natural lakes and depressions on top of Grand Mesa. These reservoirs have a combined capacity of 2,170 acre-feet. Water from them is released to several ditches in the basin, either under ownership rights or by temporary rental.

Except for the irrigated areas in the bottom lands of the North Fork and its principal tributaries and the mesas bordering them, the basin is suitable only for grazing. The soils of the bottom lands are chiefly alluvial silt and gravel. On the mesas the soils range from sandy loam to red clay loam. The growing season exceeds 150 days, and a wide diversity of crops can be produced. The greatest cash income is derived from apples, peaches, pears, cherries, apricots, and berries. Sugar beetr and alfalfa are next in importance, and grains are produced in sufficient quantity to meet the local demand.

In the upper end of the basin, along Muddy Creek, the growing season is shorter, and crops are limited to wild hay, timothy, and clover, with small tracts in alfalfa, wheat, and 'oats. These crops are all fed locally.

\section{SURFACE CREEK}

Surface Creek is a tributary of Forked Tongue Creek, which flows into the Gunnison below North Fork. Of 34,200 acres under ditches in the Forked Tongue Basin, 19,300 acres is irrigated by Surface Creek. From a point 2 miles above Cedaredge to the mouth of the creek the irrigated area has a width of about 4 miles, extending from Forked Tongue Creek on the west to a point halfway between Surface and Dry Creeks on the east. Irrigation has reached a high state of development in this district, and the duty of water is high. Five ditches cover 10,000 acres in the basin, and the remaining ditches cover less. than 500 acres each. In an ordinary year surplus water sells for $\$ 2.50$ an acre-foot. 
The Alfalfa Ditch diverts water in sec. 29, T. 13 S., R. 94 W. sixth principal meridian, by means of a loose-rock wing dam, and irrigates mesa lands bordering the east side of the Surface Creek. The ditch is also used as a feeder for the Fruit Growers Reservoir, on Alfalfa Run, in secs. 7, 17, 18, and 19, T. 14 S., R. 94 W. The Long River Ditch, like the Alfalfa Ditch, irrigates the high mesa lands east of Surface Creek.

The upper basin of Surface Creek lies on the Grand Mesa, in a region of many small lakes. These lakes have been converted into reservoirs by building low earth dams across their outlets. Stock in these reservoirs is owned by the owners of the several ditches and water is delivered to the ditches as needed. Practically all the reservoirs in the basin are controlled by the Surface Creek Ditch \& Reservoir Co., which has 15 reservoirs with a total capacity of 8,550 acrefeet, and the Grand Mesa Water Users Association, which has 37 reservoirs with a total capacity of 9,650 acre-feet.' The larger reservoirs are listed on page 66 . In addition, 11 reservoirs on the head of Dirty George Creek, a tributary of Forked Tongue Creek, have a capacity of 3,760 acre-feet.

This district is utilized for mixed farming and stock raising, and in addition to producing forage for stock the residents derive a large income from cash crops. Farming is confined to irrigated lands on the benches and bottoms adjacent to Surface and Currant Creeks. The soil on the mesas is principally a red clay loam, in places rocky and containing considerable alluvial material. The soil of the bottom areas is principally a heavy clay loam. The growing season is about 140 days in length. The Surface Creek Mesa is a productive fruit-growing section, where apples, peaches, cherries, apricots, and berries all do well. Alfalfa, wheat, and oats also yield good crops, and sugar beets are widely grown on the heavier soils on the southern part of the mesa. The Currant Creek bottoms are too far from a shipping point for the extensive production of cash crops, and accordingly alfalfa, wheat, and oats are the leading crops and are mostly used locally. On 75 per cent of the irrigated area of the mesa east of : Currant Creek alfalfa is grown. The uncertainty of the water supply on this mesa precludes the large expenditures that are necessary in setting out fruit orchards.

\section{UNCOMPAHGRB RIVER}

Of the 72,800 acres irrigated from the Uncompahgre River 67,000 acres are in the Uncompahgre Valley, extending from a point 8 miles above Montrose to the mouth at Delta, and the remaining 5,800 acres lie in a nearly continuous strip along the river from the upper end of the main valley nearly to Ouray. 
The 67,000 acres irrigated in the main valley ${ }^{26}$ lie in a compact body 25 miles long with an average width of 10 miles. All but 5,000 acres close to the river are included in the Uncompahgre project of the Bureau of Reclamation. (See pl. 10.) The irrigation plan provides for the diversion of water from the Black Canyon of the Gunnison by means of a 6-mile tunnel and a canal 11.7 miles long to supplement the flow of the Uncompahgre for irrigation of the land in the Uncompahgre Valley. To distribute the waters of the Gunnison and Uncompahgre Rivers, the larger private canals in the valley have been purchased, enlarged, and extended by the Government, and in addition high-line lateral systems have been constructed on each side of the valley. The most notable feature of the project is the Gunnison Tunnel, which has a length of 30,645 feet on a uniform grade of 2.02 feet to 1,000 feet. The entire crosssection area is 122 square feet, and the water cross-section area 100 square feet, giving a carrying capacity of 1,000 second-feet. The west-portal cut of the tunnel is 2,050 feet long and is lined with concrete. From the portal cut the South Canal, which consists of 35,943 feet of earth section, 19,343 feet of concrete-lined section, five tunnels aggregating 2,663 feet, and a wooden flume of 336 feet, conveys the water to the Uncompahgre River in sec. $36, \mathrm{~T} .48 \mathrm{~N}$., R. 9 W. New Mexico principal meridian, 8 miles above Montrose. Its capacity is 1,300 second-feet. The principal canals, all of which divert water from the Uncompahgre below the mouth of the South Canal, are the West, Montrose and Delta, Loutsenhizer, Selig, Ironstone, East, and Garnet: The head gates of these canals are so located that all return and seepage water from the project is largely rediverted and utilized. The irrigation season is from April 1 to October 31 except under the Loutsenhizer system, for which it is extended to November 15 . The following table is taken from a compilation by the Bureau of Reclamation:

Monthly and annual duty of water on the Uncompahgre project, 1916-1925

\begin{tabular}{|c|c|c|c|c|c|c|c|c|c|c|c|}
\hline \multirow{2}{*}{ Year } & \multirow{2}{*}{$\begin{array}{c}\text { Area } \\
\text { irrigated } \\
\text { (acres) }\end{array}$} & \multicolumn{8}{|c|}{ Water delivered to farms (acre-feet per acre) } & \multirow{2}{*}{$\begin{array}{l}\text { Precipi- } \\
\text { tation } \\
\text { April to } \\
\text { October } \\
\text { (feet) }\end{array}$} & \multirow{2}{*}{$\begin{array}{c}\text { Total } \\
\text { water } \\
\text { on farms } \\
\text { (acre-feet) }\end{array}$} \\
\hline & & Apr. & May & June & July & Aug. & Sept. & Oct. & Total & & \\
\hline $\begin{array}{l}1916 \ldots \ldots \\
1917 \\
1918 \\
1919 \\
1920 \\
1921 \\
1922 \\
1923 \\
1924 \\
1925\end{array}$ & $\begin{array}{l}49,273 \\
53,108 \\
58,270 \\
60,906 \\
64,186 \\
63,759 \\
64,730 \\
64,324 \\
62,184 \\
61,637\end{array}$ & $\begin{array}{l}0.43 \\
.23 \\
.39 \\
.41 \\
.14 \\
.52 \\
.45 \\
.45 \\
.39 \\
.58\end{array}$ & $\begin{array}{l}1.17 \\
.72 \\
1.32 . \\
1.30 \\
.88 \\
1.32 \\
1.21 \\
.93 \\
1.11 \\
1.16\end{array}$ & $\begin{array}{l}1.27 \\
1.34 \\
1.31 \\
1.21 \\
1.27 \\
1.10 \\
1.33 \\
1.16 \\
1.00 \\
.98\end{array}$ & $\begin{array}{l}1.26 \\
1.35 \\
1.20 \\
1.29 \\
1.17 \\
1.34 \\
1.12 \\
1.14 \\
1.10 \\
1.11\end{array}$ & $\begin{array}{l}0.85 \\
1.11 \\
.95 \\
1.01 \\
1.06 \\
.95 \\
1.08 \\
.74 \\
.76 \\
.72\end{array}$ & $\begin{array}{l}0.77 \\
.77 \\
.68 \\
.71 \\
.86 \\
.76 \\
.84 \\
.58 \\
.45 \\
.18\end{array}$ & $\begin{array}{l}0.33 \\
.44 \\
.45 \\
.49 \\
.32 \\
.53 \\
.50 \\
.13 \\
.08 \\
.11\end{array}$ & $\begin{array}{l}6.08 \\
5.96 \\
6.30 \\
6.42 \\
5.70 \\
6.52 \\
6.53 \\
5.11 \\
4.89 \\
4.84 \\
\end{array}$ & $\begin{array}{l}0.81 \\
.53 \\
.55 \\
.46 \\
.68 \\
.65 \\
.29 \\
.55 \\
.52 \\
.64\end{array}$ & $\begin{array}{l}6.89 \\
6.49 \\
6.85 \\
6.88 \\
6.38 \\
7.17 \\
6.82 \\
5.66 \\
5.41 \\
5.46\end{array}$ \\
\hline \multicolumn{2}{|c|}{$\begin{array}{l}\text { Mean } \\
\text { Per cent of total } \\
\text { delivery }\end{array}$} & $\begin{array}{l}.40 \\
6.9\end{array}$ & $\begin{array}{c}1.11 \\
19.0\end{array}$ & $\begin{array}{l}1.20 \\
20.6\end{array}$ & $\begin{array}{c}1.21 \\
20.7\end{array}$ & $\begin{array}{r}.92 \\
15.7\end{array}$ & $\begin{array}{r}.66 \\
11.3\end{array}$ & $\begin{array}{c}.34 \\
5.8\end{array}$ & $100^{5.84}$ & .56 & 6. 40 \\
\hline
\end{tabular}

* Data furnished chiefly by L. J. Foster, superintendent of Uncompahgre project, Montrose, Colo. 
The water supply for this project is so abundant that the quantity delivered at the farms has been nearly 6 acre-feet to the acre. The table shows, however, that in the last three years of the period considered there was a marked reduction in the amount delivered, the duty for 1925 being 4.8 acre-feet. The excessive use of water has resulted in 15,000 acres in the Uncompahgre Valley becoming seeped. Of this amount, about 6,000 acres has been drained by the individual owners.

On the mesas west of the river the soil is a sandy loam, and the chief crops are alfalfa, grains, potatoes, apples, cherries, peaches, and berries. East of the river the land is chiefly river bottom having a heavy clay soil, a part of which contains considerable alkali. Where the land is suitable for crops, sugar beets, alfalfa, grains, onions, and potatoes are grown. Garnet Mesa, east of Delta, has in general a sandy-loam soil on which are extensive orchards of apples, cherries, and peaches. The crop areas on the project are divided between alfalfa, hay, and pasturage, 48 per cent; sugar beets, corn, and vegetables, 25 per cent; small grains, 24 per cent; fruits, 3 per cent. The yields per acre of the chief crops, exclusive of fruits, are corn, 18 bushels; oats, 28 bushels; alfalfa, 2.2 tons; beans, 9 bushels; onions, 276 bushels; potatoes, 160 bushels; sugar beets, 7.3 tons. There are sugar factories at Montrose and Delta.

In the upper Uncompahgre Valley, between Ouray and Colona, cultivation is confined to the bottom lands along the river and its tributaries. The soil is a clay loam of good fertility, and the crops raised are timothy, clover, alfalfa, wheat, oats, barley, and native hay. The climate is too rigorous for fruit production.

\section{DOLORES RIVER}

The valley of the Dolores River is so narrow that of the 62,500 acres under ditch from the river, only 2,400 acres lies adjacent to it, in isolated tracts between the mouth of Bear Creek and the DoloresMontezuma County line. The remainder lies in that portion of the San Juan Basin known as the Montezuma Valley.

The Dolores River Basin, exclusive of the area drained by the San Miguel, is a mixed farming and stock-raising region, where considerable dry farming is beeing done in addition to the production of crops on irrigated lands. There is a wide difference in climatic conditions and resultant crop production in the region. Above Dolores along the river are small patches of irrigated land limited to the production of native hay by the shortness of the growing season. Below Dolores there are also small bottoms along the river where alfalfa is the principal crop grown. Small tracts are irrigated along Disappointment Creek and in .Paradox Valley, two isolated areas where alfalfa is principally produced and fed to livestock. The largest irrigated sec- 
tion lies in the vicinity of Cortez and includes a series of mesas and small valley areas irrigated from the Dolores River. The soil ranges from a clay to a clay loam and is particularly heavy in the southern part. Alfalfa, wheat, and oats are the principal crops, although both. tree and bush fruits and garden truck are widely produced for local consumption. North and west of Cortez, in the vicinity of DoveCreek and extending westward to Monticello, Utah, is one of the best-known dry-farming districts in the southern plateau region. The annual rainfall ranges from 18 to 20 inches, and excellent yields. of wheat, oats, corn, and alfalfa have been produced. The country is handicapped by the great distance from a market, and under present conditions it is impracticable to attempt the production of small grains as a cash crop. The raising of livestock is essential in order to insure a living, and on both dry and irrigated lands only such crops as are necessary for the feeding of livestock or other local use should be produced.

\section{MONTEZUMA VALIEY}

The Montezuma Valley Irrigation Co. is a mutual company, the outgrowth of the Montezuma Irrigation District, which was dissolved in 1920. The total area in the system is 60,000 acres, chiefly in Tps. 35-37 N., R. $16 \mathrm{~W}$. New Mexico principal meridian, in the vicinity of Cortez. Scattered through this area are small irrigated tracts amounting to 20,000 acres. Much of the land formerly irrigated has been abandoned for different reasons, seepage accounting for 3,000 acres. Water is diverted from the Dolores River by means. of a concrete diversion dam and head gates in sec. 17, T. 37 N., R. $15 \mathrm{~W} ., 1$ mile below the town of Dolores. Just below the head gate the water divides, part flowing through a tunnel in the San Juan divide into Montezuma Valley, which is drained by McElmo Canyon, a tributary of the Mancos River, which in turn is tributary to the San Juan River. The tunnel is driven through solid rock and is unlined. Its length is 5,480 feet on a 1 per cent grade, its cross section 7 by 9 feet, and its capacity about 700 second-feet. A quarter of a mile below the tunnel outlet the water is divided into three laterals, which carry the water to the project. The land under this system is so rough that several sets of main laterals have been built across the district from east to west, and from these sublaterals lead at right angles. The canal leading from the head gate to the reservoir has a capacity of 600 second-feet, but at the present time the capacity is reduced to 250 second-feet by 5,400 feet of semicircular wood stave flume.

Storage of 9,300 acre-feet is afforded by the Narraguinnep Reservoir, in sec. $4, T .37$ N., R. $16 \mathrm{~W}$. This reservoir is formed by two earth dams 1,320 feet long, with a maximum height of 70 feet. A tunnel 500 feet long through the main dam releases the water to one of the 
main laterals. A second reservoir known as the Ground Hog Reservoir has been partly constructed in secs. 21 and 22, T. 41 N., R. 13 W., on the West Fork of the Dolores River, but abandoned because of dangerous leaks. In addition there is a regulating reservoir having a capacity of 1,000 acre-feet capacity, known as Totton Lake, in sec. 20, T. 36 N., R. 15 W. Surveys have been made for the Dawson Reservoir, with a capacity of 60,000 acre-feet or more, to be located just west of the Narraguinnep Reservoir.

At the time the mutual company took over the project, in 1920, the structures were in very poor condition, but since that time the head works have been replaced by a concrete structure and the system has been generally improved.

Owing to the abundant water supply the duty of water is low on this project, 90,000 acre-feet being diverted from the Dolores annually for the irrigation of 15,000 acres, or 6 acre-feet to the acre.

\section{LOST CANYON CREEK}

The land irrigated from Lost Canyon Creek is chiefly under the Summit Reservoir \& Irrigation Co.'s project. The main ditch diverts water in sec. 35, T. 38 N., R. 12 W. New Mexico principal meridian, and, tapping several tributaries in its course, extends 17 miles to a system of three reservoirs having a combined capacity of 4,000 acre-feet at the upper edge of the project. Of the 8,000 acres in the project 3,500 acres are irrigated, chiefly in Tps. 36 and $37 \mathrm{~N}$, R. $15 \mathrm{~W}$., just east of Montezuma Valley project. Before the entire project can be irrigated, additional storage must be provided. The entire area irrigated from Lost Canyon Creek is 3,700 acres.

\section{WEST PARADOX CREEK}

In Paradox Valley the chief irrigation system is that of the Paradox Valley Irrigated Land \& Improvement Co. The project, which originally covered 13,000 acres, has been built for the irrigation of 1,500 acres. Individual ditches irrigate an additional 1,960 acres making a total irrigated area of 3,460 acres, with 4,600 acres under ditch. The land lies on both sides of the creek from Paradox to the Dolores River. The supply is diverted from Geyser and Taylor Creeks, tributaries of West Paradox Creek. Storage amounting to 3,000 acre-feet is afforded by the Buckeye Reservoir, in sec. 2, T. 48 N., R. 20 W.

\section{SAN MIGUEL RIVER}

Main stream.-The valley of the San Miguel above Naturita is so narrow that practically none of it is irrigated, but below Naturita 1,200 acres is under small ditches, of which 900 acres in isolated tracts near the river is irrigated. This land is all irrigated by gravity ditches except one area of 350 acres near Naturita, to which the water is pumped. A 45 -inch Leffel turbine under a head of 7 . feet 
operates a triplex pump to raise the water 54 feet. In addition to the area under the small ditches, 4,000 acres in the vicinity of Nucla is irrigated by the Colorado Cooperative Canal Co., which diverts water from the San Miguel in sec. 31, T. 47 N., R. 14 W., by a canal of 70 second-feet capacity.

Beacer Creek.-Although little land is irrigated in the immediate vicinity of Beaver Creek, its waters are used extensively for irrigation. The largest project is that of the Farmers Water Development Co., which controls the Naturita Canal and Naturita (Gurley) Reservoir. The canal diverts water from the headwaters of Beaver Creek and flows northward to sec. 36, T. 44 N., R. 13 W., where a branch leads to the reservoir. The main canal, which has a capacity of 200 second-feet, continues northward until it reaches Norwood Mesa, irrigating that section for a distance of 12 miles. From the Gurley Reservoir, in sec. 36 , T. 44 N., R. 13 W., which has a capacity of 3,200 acre-feet, water is released into Maverick Draw and diverted on Norwood Mesa. The entire project covers 15,000 acres, of which 10,000 acres is irrigated.

Naturita Creek.-Ditches have been partly constructed to cover a large area on Naturita Creek, of which only 7,375 acres is irrigated. The largest project is that of the Lilylands Canal Co., which diverts water from Naturita Creek in sec. 7, T. 42 N., R. 13 W., by a canal having a capacity of 100 second-feet, which leads to the 10,000 acres under the main project on Lilylands Mesa, chiefly in T. 45 N., Rs. 14 and $15 \mathrm{~W}$. About 2,500 acres is irrigated, and the water supply is insufficient for any considerable increase in this area. No storage is provided at present.

The Lone Cone Ditch Co. has a project of 3,500 acres, of which 3,470 acres is irrigated, on the east side of Naturita Creek, extending from Norwood to Redvale. The ditch diverts water from Naturita Creek in sec. 10, T. 42 N., R. 13 W., and leads to the Lone Cone Reservoir, in secs. 1 and 12, T. 43 N., R. 13 W., which has a capacity of 1,830 acre-feet. From the reservoir the Lone Cone ditch, with a capacity of 45 second-feet, leads to the lands irrigated.

Agriculture.-The San Miguel Basin comprises an extensive stock country limited in tillable land by its rough, broken character. The principal farming district includes several irrigated mesas in the vicinity of Norwood. These lands have a red clay-loam soil of good fertility, and from 65 to 70 per cent of them are utilized for the production of alfalfa. Wheat and oats are grown on most of the remaining areas, and small orchards of apples, cherries, peaches, and pears, in addition to berries and garden truck, are raised for local consumption.

Dry farming that may be said to be still in the experimental stage has been carried on with surprising results on several mesas in the 
vicinity of Placerville. These lands lie at an altitude ranging from 8,500 to $\dot{9}, 500$ feet and have a frost-free period of approximately 65 days. Barley and Colorado bluestem wheat seem to be able to withstand the rigorous climate at this altitude, and yields from small tracts averaging 20 bushels to the acre have been reported by ranchers, with little or no damage from frost. The crop is planted in August. and harvested the following year in September,

\section{FUTURE EXTENSION OF IRRIGATION}

\section{GENERAL CONDITIONS}

The future extension of irrigation will be brought about by a complete settlement of existing projects, the enlargement of some of these projects to cover additional land, and the construction of new projects. The magnitude of this extension is a subject upon which there inevitably exists a wide difference of opinion, because the future trend of the factors determining the feasibility of any given project is so uncertain. The additional area due to a complete settlement of existing projects can be determined most accurately, but even here the insufficient water supply of some projects, which can not in every instance be corrected by storage, and the rough topography and poor soil of certajn areas under other projects make it certain that all the land under ditch will not be irrigated. For the purpose of this report it is assumed that 75 per cent of the land under ditch in the existing projects will ultimately be irrigated. Thus the areas. for completion of existing projects in the following table are taken as. 75 per cent of the unirrigated areas under ditch.

The extension of the many existing small projects and private ditches to cover land not under ditches can not be accurately estimated, but it is believed that the additional area will be 15 per cent, or 135,000 acres. The most uncertain factor in the future extension of irrigation relates to the new projects that may prove feasible. Those considered in this report have been taken chiefly from the filings in the State engineer's office, augmented by studies made by the Bureau of Reclamation. ${ }^{27}$ Where necessary, the proposed areas have been reduced to conform to the available water supply, as. determined by the writer. It is probable that many of the projects. listed here are not feasible at this time on account of economic conditions, but it is believed that within a period of possibly 50 years either these projects or others covering similar areas that are not now considered will be built. What additional projects may prove feasible in the more remote future, under economic conditions that may be radically different from those with which our present-day knowledge is familiar, the writer does not care to predict.

\footnotetext{
" Problems of Imperial Valley and vicinity, 1924 (unpublished report).
} 
In estimating the water requirements of the new projects a diversion duty of 2 acre-feet to the acre has been generally assumed, which makes an allowance for considerable reuse of water within each proj.ect. This duty is the same as that used by the Bureau of Reclamation. That organization recognizes that a diversion duty of 2 acre-feet is less than its present accepted standards, but it is known that large irrigated areas have been built up successfully on a comparatively small amount of water, and it is not too mueh to hope that with the lapse of years the same efficiency will come on the future projects in the upper Colorado River Basin. Where a consumptive duty has been used this has been estimated by the writer as 1.5 acre-feet to the acre.

Probable future extension of irrigated areas in upper Colorado River Basin

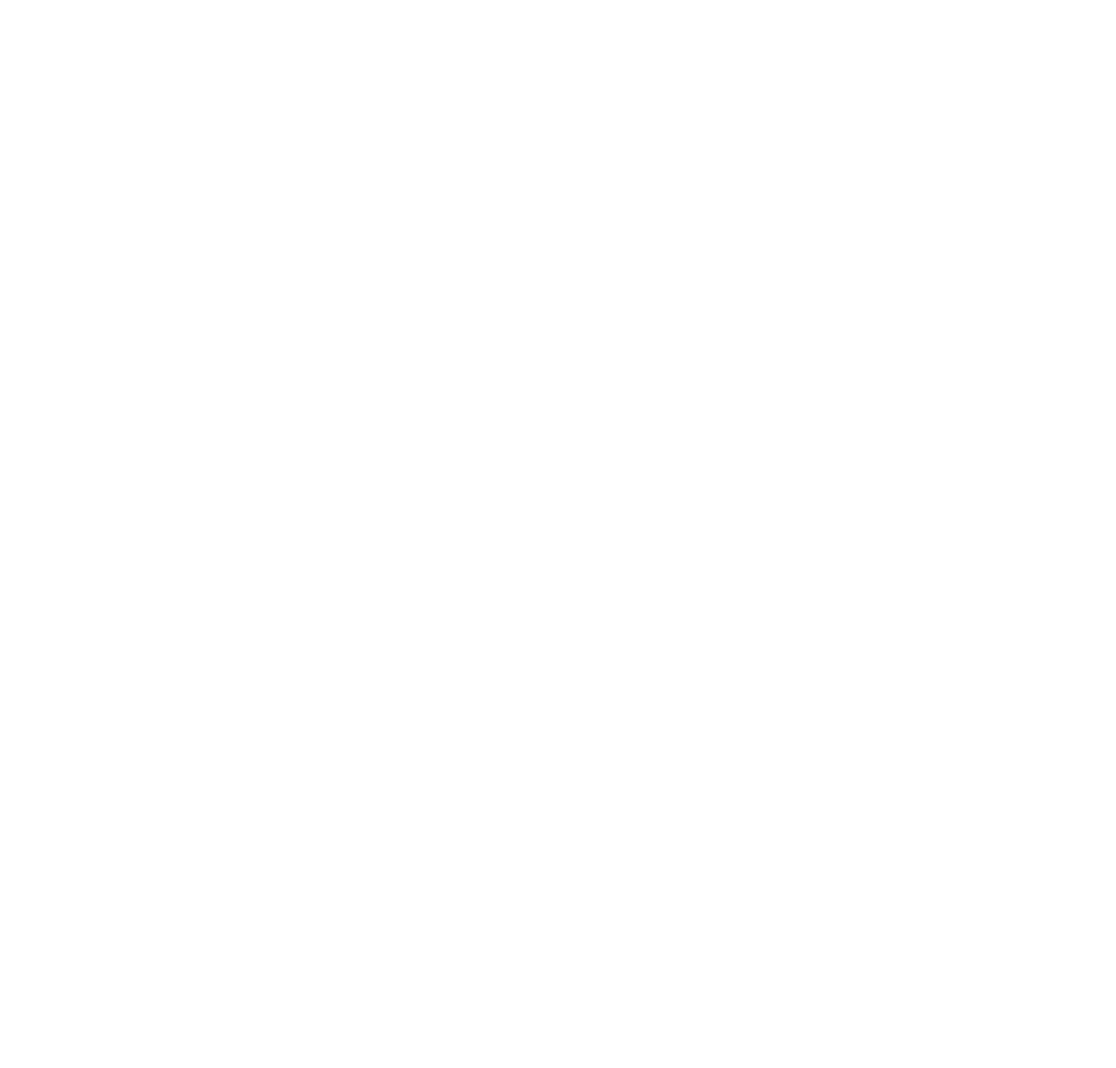

\section{THE MAIN RIVER}

Except in Middle Park, and the vicinity of the town of Grand Valley, practically all the valley land along the Colorado is now irriated or under ditch, and with the further exception of the proposed rojects to irrigate those areas, which are described below, the only 
opportunity for the irrigation of new land from the main river in the Utah mesa land lying west of the Excelsior divide, at the lower end the Grand Valley project. This project was investigated about 1903 by the Reclamation Service but rejected at that time on account of its high cost. The land west of the Excelsior divide is from 150 to 200 feet higher than that east of the divide, and water must be pumped to it either from an extension of the Grand Valley Canal or directly from the Colorado River. In either event the cost will make this project impracticable for many years, so it is not here considered.

Foster-Grande project (9DA).-The Foster-Grande project covers about 8,000 aeres on the north side of the Colorado River, extending from a point a few miles. west of Parshall nearly to Muddy Creek. The land lies on the mesa from 20 to 40 feet above the river. Water can be diverted from the Colorado River in sec. 16, T. 1 N., R. 78 W. sixth principal meridian, near Parshall, or from Troublesome Creek. If it is diverted from the Colorado River, no storage will be required, but if from Troublesome Creek it will be necessary to provide storage for about 4,000 acre-feet, as the available run-off in July and August is insufficient. for this project. The mean annual run-off at the mouth of Troublesome Creek is about 40,000 acre-feet, which insures an ample supply for storage.

Willcox project (9DG).-The Willcox project was originally started about 1892 and after many vicissitudes was nearly completed in 1912, when the diversion dam in the Colorado River was washed out. This event put an end to construction, as funds were not available to replace the dam, and the few settlers upon the project moved away. The project covers a narrow strip comprising 6,000 . acres on the north side of the Colorado River between the river and the Book Cliffs, which form the northern limit of the valley, and extending from Rifle nearly to De Beque. The water supply from the Colorado River will be sufficient to irrigate the project.

\section{TRIBUTARIES ABOVE GUNNISON RIVER}

Two projects have been proposed on tributary streams-the Sunnyside project, in the Plateau Creek Basin, and the Hunter Mesa project, in the Mamm Creek Basin, but receiving its principal supply from Buzzard Creek, a tributary of Plateau Creek.

Sunnyside project (9DJ).--It is proposed to irrigate 10,000 acres on the mesa. bordering Plateau Creek on the north, west of the present irrigated area in the valley. Water is to be stored in the Vega Reservoir, which has been surveyed for a capacity of 43,600 acre-feet (p. 89). From the reservoir water will be released to Plateau Creek and diverted at a point 6 miles downstream. A study of the water supply available for the Vega Reservoir (p. 89) shows a mean annual run-off of 93,000 acre-feet at the point of diversion for this project, of which 85,000 acre-feet can be stored at the reservoir. About 20,000 acres is under ditch from Plateau and Buzzard Creeks, and with a consumptive duty of 1.5 acre-feet, 30,000 acre-feet will, be required to satisfy these prior rights, leaving: 62,000 acre-feet available for the new project. Only the high-water dischargeis available for the new project, however, as prior rights utilize the flow from July to September. To meet this need, net storage of not less than 10,000 aere-feet will be required.

Hunter Mesa project (9DG).-Water is to be diverted from upper Buzzard

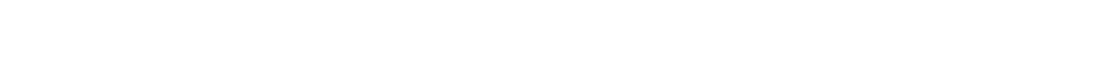


Mamm Creek. From East Mamm. Creek. water is to be diverted to the proposed reservoir in the channel of 'West Mamm Creek ( $p: 88$ ). Thence the water will be conveyed to the land to be irrigated on Hunter Mesa, in Tps. 6 and $7 \mathrm{~S}$., Rs. 92 and $93 \mathrm{~W}$. Additional storage could be provided by the Colorado No. 1 Reservoir (p. 114), in the channel of Buzzard Creek just above the proposed point of diversion.

About 20,000 acres is irrigated in the Plateau Creek Basin, and the only available water supply for the new project from that source is the run-off during May and June. Records of Buzzard Creek at a point several miles below the proposed diversion show for the 6-year period 1922-1927 a mean run-off for May and June of 29,200 acre-feet. By a comparison with the 11-year record of Surface Creek, which drains the opposite side of Grand Mesa, the estimated mean annual run-off for May and June has been increased to 36,000 acre-feet, or 265 acre-feet to the square mile. At the proposed point of diversion the drainage area is $\mathbf{5 0}$ square miles, and the unit run-off is estimated at $\mathbf{4 0 0}$ acre-feet, giving a total of 20,000 acre-feet. With a diversion duty of 2 acre-feet to the acre, 10,000 acres on the project could be irrigated in a mean year. Although 2 acrefeet to the acre seems a relatively small amount to be diverted for storage in a reservoir not in the main stream, it is probable that some additional water will be available from Mamm Creek, although no records are available to substantiate this opinion.

\section{GUNNISON RIVER BASIN}

The chief additional areas to be irrigated in the Gunnison River Basin are covered by a proposed extension of the existing Uncompahgre and Fruitland projects and the construction of the Gunnison Valley and Montrose Chief projects, The new projects are indicated by filings in the State engineer's office."

Uncompahgre project.-It is proposed to increase the irrigated area of the Uncompahgre project from its present size of 67,000 acres to an ultimate area of 97,000 acres. This may require storage, - which can be provided at the Taylor Park site, where a reservoir having a capacity of 150,000 acre-feet has been surveyed (p. 90).

Gunnison Valley project (9 EG).-The Gunnison Valley project contemplates the irrigation of land on the east side of the Gunnison Valley south of Kahnah Creek. It is proposed to divert water from Kahnah Creek and store it in the Gunnison Valley Reservoir, capacity 9,650 acre-feet, to be located on Indian Creek, and the Wabash No. 2 Reservoir, capacity 32,000 acre-feet, to be located on Deer Creek. From records of the Kahnah Creek gaging station it is estimated that the mean annual discharge available for storage, after deducting 14,000 acre-feet for prior rights, is 43,000 acre-feet. With a consumptive duty of 1.5 acre-feet to the acre, about 29,000 acres could be irrigated.

Fruitland project (9EC).-The project of the Fruitland Irrigation Co. was originally intended to irrigate 15,000 acres, and the Fruitland or Onion Valley Reservoir (9EC 1) was to be enlarged to a capacity of 20,000 acre-feet. Discharge records of Crystal Creek just above the intake from 1917 to 1919 show that the mean annual run-off for that period was 24,000 acre-feet. A comparison with the 11-year record on Surface Creek at Cedaredge indicates that the mean annual run-off for that 3-year period was somewhat less than normal, and it is estimated that a mean of 27,000 acre-feet may be expected. With a diversion duty of 2 acre-feet to the acre, 13,500 acres could be irrigated in the entire project. TT2 do this, howgver it will be necessary to construct the Fruitland Reservoir as

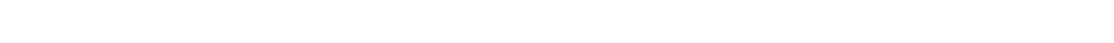


Montrose Chief project (9EF).-The Montrose Chief project lies on the western :slope of the Uncompahgre Valley south of Montrose. Water is to be diverted ffrom the head of Dallas Creek, where storage amounting to 11,400 acre-feet is to be provided in the Van Hagen No. 1 Reservoir (p. 98). A second ditch is to divert water from the tributaries of Dallas Creek. No records of these streams are available, but it is estimated that 25,000 acre-feet can be diverted from both streams without interfering with prior rights upon them. With a diversion duty of 2 acre-feet to the acre, 12,500 acres can be irrigated, which is only a small part of the available land.

Escalante project (9EG). - The land included in the Escalante project lies on the mesa forming the eastern slope of the Uncompahgre Plateau between Dry Fork of Escalante Creek and Cottonwood Creek and covers 8,000 acres. It is proposed to irrigate this land from the headwaters of Escalante Creek, which are in a canyon. A gaging station was maintained near the mouth of the creek during 1922 and 1923 and showed a mean annual run-off of 40,000 acre-feet. It appears probable that 20,000 feet would be available at the proposed diversion point. The run-off occurs chiefly during the spring, and storage of at least $\mathbf{4 , 0 0 0}$ acre-feet would be required for the complete irrigation of 8,000 acres. Construction was started on this project about 1915 but was stopped before the heavy work necessary to take the water out of the canyon was done. The original plan contemplated the construction of three reservoirs having a combined capacity of 1,500 acre-feet. No other reservoir filings in the Esealante drainage basin have been made.

\section{DOLORES RIVER BASIN}

\section{MAIN RTVRR}

The chief areas for additional irrigation in the Dolores River Basin are covered by an extension of the Montezuma project and a new project known as the Dolores project.

Montezuma Valley Irrigation Co.-The Montezuma project covers 60,000 acres, of which only 15,000 acres is irrigated at present. Of the remainder 3,000 acres is now seeped, and as the land is rough it is probable that not more than 30,000 acres additional will be irrigated. With a diversion duty of 2 acre-feet to the acre, 120,000 acre-feet will be required for the entire 60,000 acres.

Dolores project $(9 G H)$. - It was originally proposed to irrigate under the Carey Act 200,000 acres of land on the San Juan.slope.southwest of Dolores, ehiefly in Tps. 37-39 N., Rs. 17-20 W., in what is known as the Dove Creek region. The soil is of a heavy red sandy nature, similar to that on the Montezuma project. The project was not constructed, and the lands were thrown open to entry. At the present time $\mathbf{8 0}$ per cent of the irrigable land on the old project has been entered and is being tilled by dry-farming methods. The settlers are apparently successful and do not favor irrigation.

In a study of possible projects in the Dolores River Basin the Bureau of Reclamation has proposed to construct a reservoir in the canyon of the-Dolores River at a dam site 10 miles below the town of Dolores. The water level will be raised 220 feet, which is the maximum height possible without submerging the diversion works of the Montezuma Valley project, and the diversion made at 173 feet above the stream bed will create an active storage capacity of 120,000 acre-feet. To increase this capacity would necessitate lowering the altitude of the diversion, which would increase the cost of the canal by lowering its grade and increasing its size. The canal will follow the south side of the canyon for 14 miles and pass through a 4,800-foot tunnel to the headwaters of Montezuma Creek, in the San Juan Basin. From this point the main canal will branch to the south and north- 
west. The lands to be irrigated (pl. 1) consist of mesas sloping toward the San Juan River and separated by deeply eut drainage channels. The canal from the reeervoir to the point where the irrigable lands are reached will be built throngh a very difficult country, with a large amount of flume and tunnel work. After passing the San Juan divide, the canal system will not be difficult of construotion.28

The Bureau of Reclamation states that a diversion duty of 2 acre-feet to the acre will probably prove sufficient, as much of the area has recently been whocessfully cultivated by dry farming. The amount of land in the project will be imited by the available water supply from the Dolores River. The discussion of storage for this site (p.|102) indicates that although 120,000 acres could be irrigated in an average year the reservoir would not refill during dry years, but by irrigating only 60,000 acres sufficient hold-over storage would be available for the complete irrigation of 50,000 acres during the dry years, except such unusually dry years as 1899 , when 35,000 acres could have been irrigated, and 1902, when this area would have been reduced to 23,000 acres.

\section{MINOR TIRIBUTARIES ABOVE SAN MIGUBL RIVRR}

Disappointment Valley $(9 D L)$.- - It is proposed to irrigate an area in Disappointment Valley that will be limited by the available water supply of Disappointment and Spring Creeks. Water will be diverted from Disappointment Creek in T. 42 N., R. 16 W., and carried by a canal 6 miles long to the Custer Reservoir, which will have a capacity of 17,400 acre-feet in the channel of Spring Creek. The lands to be irrigated lie in Disappointment Valley below the reservoir, chiefly in T. 43 N., R. 17 W.

No records of the flow of Disappointment Creek are available, and it is impossible to estimate closely the water supply of the project. The Bureau of Reclamation has estimated the annual run-off as 35,000 acre-feet, which with a diversion duty of 2 acre-feet to the acre would irrigate 17,500 acres.

West Paradox Valley $(9 D L)$.-The project in West Paradox Valley was originally planned to irrigate 13,000 acres, but only 3,300 acres is now under ditches (p. 138). The plan was to construct 20 miles of collection ditches and divert water from West Paradox, Deep, Geyser, and Rock Creeks into reservoirs from which the water was to be released during the late irrigation months. Three reservoir sites, having a combined capacity of 10,000 acre-feet, have been surveyed, and one of the proposed reservoirs, known as the Buckeye, having a capacity of 3,000 acre-feet, has been constructed. No discharge records of these streams are available, but they drain the slopes of the La Sal Mountains, which reach an altitude of 12,000 feet, and as the combined drainage area above the proposed points of diversion is nearly 200 square miles, it is estimated that the mean annual run-off is 50,000 acre-feet. With a diversion duty of 2 acre-feet to the acre, this would irrigate 25,000 acres, or 22,000 acres in addition to the 3,000 acres being irrigated at the present time.

\section{SAN MIGUEL RIVER BASIN}

The valley of the San Miguel is so narrow that the only opportunity for additional irrigation from the main river appears to be an extension of the Colorado Cooperative Canal and the irrigation of the: mesa lands bordering the valley on the west. The latter project has been proposed under the name San Miguel project.

Colorado Cooperative Canal $(9 D K)$. - The project of the Nucla Colony is intended to irrigate 20,000 acres by a canal skirting the foot of the second mesa 
just north of Nucla and diverting water in sec. 30, T. 46 N., R. 13 W. New Mexico principal meridian. The canal has been partly constructed and now. irrigates about 7,000 acres. This project has a prior right to the flow of the: San Miguel River, and with a diversion duty of 2 acre-feet to the acre the flow: is sufficient for the entire project except during September of an unusually dry. year, when a slight shortage may occur.

San Miguel project $(9 D K)$. - It was originally proposed to irrigate in two units, under the Carey Act, 94,000 acres south and west of Norwood. The main unit was to be irrigated by water diverted from the San Miguel River 7: miles below Placerville and carried in a flume along the south side of the Ban. Miguel Canyon for 15 miles, thence through a tunnel and canal onto mesa. lands near Redvale, and thence across Naturita Canyon into the Dry Creek Basin, Gypsum Valley, and East Paradox Valley. A second unit was to irrigate. land above the San Miguel Canal by means of flood water from West Beaver. and Naturita Creeks stored in the Miramonte Reservoir and from Basin Creek. in the Stone Cabin Reservoir. The only construction work done on the main unit was the preparation of the flume site along the canyon. The second unit, comprising 10,000 acres, has been partly constructed, the Nelson ditch, which heads in Beaver Creek, having been built for a distance of 30 miles. It is not now used to irrigate land in the San Miguel project but to supply old rights from Beaver Creek.

To determine the water supply, records of the San Miguel River are available for stations at Fall Creek, 1896-1899; near Placerville, 1911-12; and at Naturita, 1918-1927. The Fall Creek records have been referred to Naturita by adding 78,000 acre-feet and the Placerville records referred to Naturita by adding 116,000 acre-feet. The reason for the small additions to the Fall Creek records is that they were made during fairly dry years, when the run-off of intervening tributaries must have been considerably less than normal. The annual run-off is presented in the following table:

Estimated yearly discharge of San Miguel River at Nuturita 1896-1899, 1911-12, and 1918-1927

\begin{tabular}{|c|c|c|c|c|c|}
\hline Year & $\begin{array}{l}\text { Acre- } \\
\text { feet }\end{array}$ & $\begin{array}{l}\text { Per cent } \\
\text { of mean }\end{array}$ & Year & $\begin{array}{l}\text { Acre- } \\
\text { feet }\end{array}$ & $\begin{array}{l}\text { Per cent } \\
\text { of mean }\end{array}$ \\
\hline $\begin{array}{l}1896 \\
1897 \\
1898 \\
1911 \\
1912 \\
1918\end{array}$ & $\begin{array}{l}191,000 \\
239,000 \\
221,000 \\
187,000 \\
330,000 \\
353,000 \\
170,000 \\
231,000\end{array}$ & $\begin{array}{r}70 \\
88 \\
81 \\
69 \\
121 \\
130 \\
63 \\
85\end{array}$ & $\begin{array}{l}1921 \\
1922 \\
1924 \\
1925 \\
1927\end{array}$ & $\begin{array}{l}417,000 \\
311,000 \\
252,000 \\
247,000 \\
213,000 \\
290,000 \\
323,000\end{array}$ & $\begin{array}{r}153 \\
114 \\
93 \\
91 \\
78 \\
106 \\
119\end{array}$ \\
\hline 1920 & 379,000 & 139 & Mean...... & 272,000 & 1. \\
\hline
\end{tabular}

The proposed intake for the San Miguel project is 7 miles below Placerville, at a point where the Placerville records apply directly. On the assumption that the mean annual run-off between Placerville and Naturita is 116,000 acre-feet, the mean for the 10-year Naturita record referred to Placerville is 167,000 acrefeet. Combining this record with the 2-year record at Placerville gives a 12-year mean of 177,000 acre-feet at the proposed foint of diversion. The following table shows the mean monthly discharge at the diversion point and the requirements for a 90,000-acre project under a diversion duty of 2 acre-feet to the acre: 
Mean monthly discharge and irrigation requirements on San Miguel project in acre-feet

\begin{tabular}{|c|c|c|c|c|c|c|}
\hline & April & May & Jun $\theta$ & July & August & Septem- \\
\hline $\begin{array}{l}\text { Mean diseharge } \\
\text { Requirements for } 90,000 \text { acres. }\end{array}$ & $\begin{array}{l}20,500 \\
14,400\end{array}$ & $\begin{array}{l}54,600 \\
36,000\end{array}$ & $\begin{array}{l}59,500 \\
54,000\end{array}$ & $\begin{array}{l}27,100 \\
36,000\end{array}$ & $\begin{array}{l}11,900 \\
27,000\end{array}$ & $\begin{array}{r}5,960 \\
12,600\end{array}$ \\
\hline Surplus or deficitt..... & $+6,100$ & $+18,600$ & $+5,500$ & $-8,900$ & $-15,100$ & $-8,640$ \\
\hline
\end{tabular}

The mean annual discharge of 177,000 acre-feet would irrigate nearly 90,000 acres, with the assumed diversion duty of 2 acre-feet, if the monthly run-off corresponded with the irrigation requirements, but the above table shows a serious shortage during July, August, and September, a shortage that will be increased somewhat when the area under the Colorado Cooperative Canal is fully irrigated.

It is possible that the requisite water for the irrigation of 90,000 acres could be obtained by storage of flood water of Beaver, Naturita, and Basin Creeks in the proposed Miramonte and Stone Cabin Reservoirs, but those streams are already used for irrigation, and no records of the surplus water are available. Another possibility is to build a reservoir in the narrow valley of the San Miguel and store the flood waters there. Not only will it be necessary to store the flood water for use later in the season, but water must be carried over from wet to dry years. Records for individual years at the proposed point of diversion are not sufficiently accurate to determine closely the amount of hold-over storage needed for the dry years. Without any considerable storage, $\mathbf{4 0 , 0 0 0}$ acres could be irrigated in the main unit of the San Miguel project.

Naturita and Beaver Creeks.-Two projects have been proposed on Naturita and Beaver Creeks, and a beginning of construction has been made, but as the water supply is insufficient for more than a small part of the available land, it is doubtful whether they will be carried much further. On the Lilylands project a diversion ditch has been built from Naturita Creek and other small streams for a distance of 32 miles, with the original expectation of extending it to cover 50,000 acres and to obtain additional supplies of water from Fall and Beaver Croeks. At present about 3,500 acres is irrigated. As no records of these streams are available, it is impossible to state what additional area can be irrigated. The upper or high-line unit of the San Miguel project is described on page 138, but owing to the meager water supply it is doubtful whether this project will be extended beyond its present limits of furnishing water for 1,000 acres covered by prior rights.

\section{EFFECT ON DISCHARGE OF COLORADO RIVER}

With a consumptive duty of 1.5 acre-feet to the acre, the irrigation of the 669,000 acres considered as probably to be covered by the extensions and new projects described above would require $1,000,000$ acre-feet annually, which is 15 per cent of the mean annual discharge of the Colorado River near Cisco $(6,600,000$ acre-feet). 
WATER POWTR

\section{FACTORS AFTECTING DEVELOPMENT}

\section{TOPOGRAPHY}

The topography of the upper Colorado River Basin is fairly well suited to the development of water power, as the streams have steep gradients, particularly in their upper reaches, and flow through canyons that afford suitable sites for dams of great height. Large sites for the regulation of the stream flow are scarce, however, owing to the narrow, steep-sided valleys through which most of the streams flow.

\section{CONFLICT BETWEEN POWIR AND IRRIGATION USE}

As the power sites are generally above irrigated areas, little conflict will arise between these two major uses of the streams if only the direct flow is used for power. If storage of considerable magnitude is effected, a conflict may arise in years of low flow during the later part of the irrigation season, but it is believed that such conflict will occur so infrequently that it can best be avoided by releasing from storage the natural flow during those periods.

\section{NECESSITY FOR STORAGE}

The great bulk of the run-off occurs during the late spring and early summer, after which it steadily decreases until the next spring. The nonuniform character of the run-off is shown by the relation of the discharge for 90 per cent of the time (Q90) to that for 50 per cent of the time (Q50), and to the mean annual discharge (QM) as given in the following table:

Relation of Q90 to Q50 and QM at stations in upper Colorado River Basin

\begin{tabular}{|c|c|c|}
\hline Stream & $\frac{Q 90}{Q 50}$ & $\frac{Q_{90}}{Q \mathbf{M}}$ \\
\hline $\begin{array}{l}\text { Colorado River at Glenwood Springs_. } \\
\text { Blue River below Dillon } \\
\text { Eagle River at Eagle } \\
\text { Roaring Fork at Glenwood Springs } \\
\text { Gunnison River near Grand Junction } \\
\text { Taylor River at Almont_. } \\
\text { Dolores River at Dolores } \\
\text { Dolores River at Bedrock }\end{array}$ & $\begin{array}{r}0.41 \\
.50 \\
.52 \\
.58 \\
.63 \\
.59 \\
.39 \\
.50\end{array}$ & $\begin{array}{r}0.22 \\
.21 \\
.19 \\
.24 \\
.26 \\
.30 \\
.19 \\
.08\end{array}$ \\
\hline
\end{tabular}

This table shows that the low-water discharge is about half that of the six highest months and about one-fifth of the mean annual discharge. With the flow unregulated, the value of the streams for continuous or primary power is relatively small. But by the construction of storage reservoirs the primary power may be greatly increased, the maximum limit being from 300 to 400 per cent where storage is sufficient to equalize the flow. 


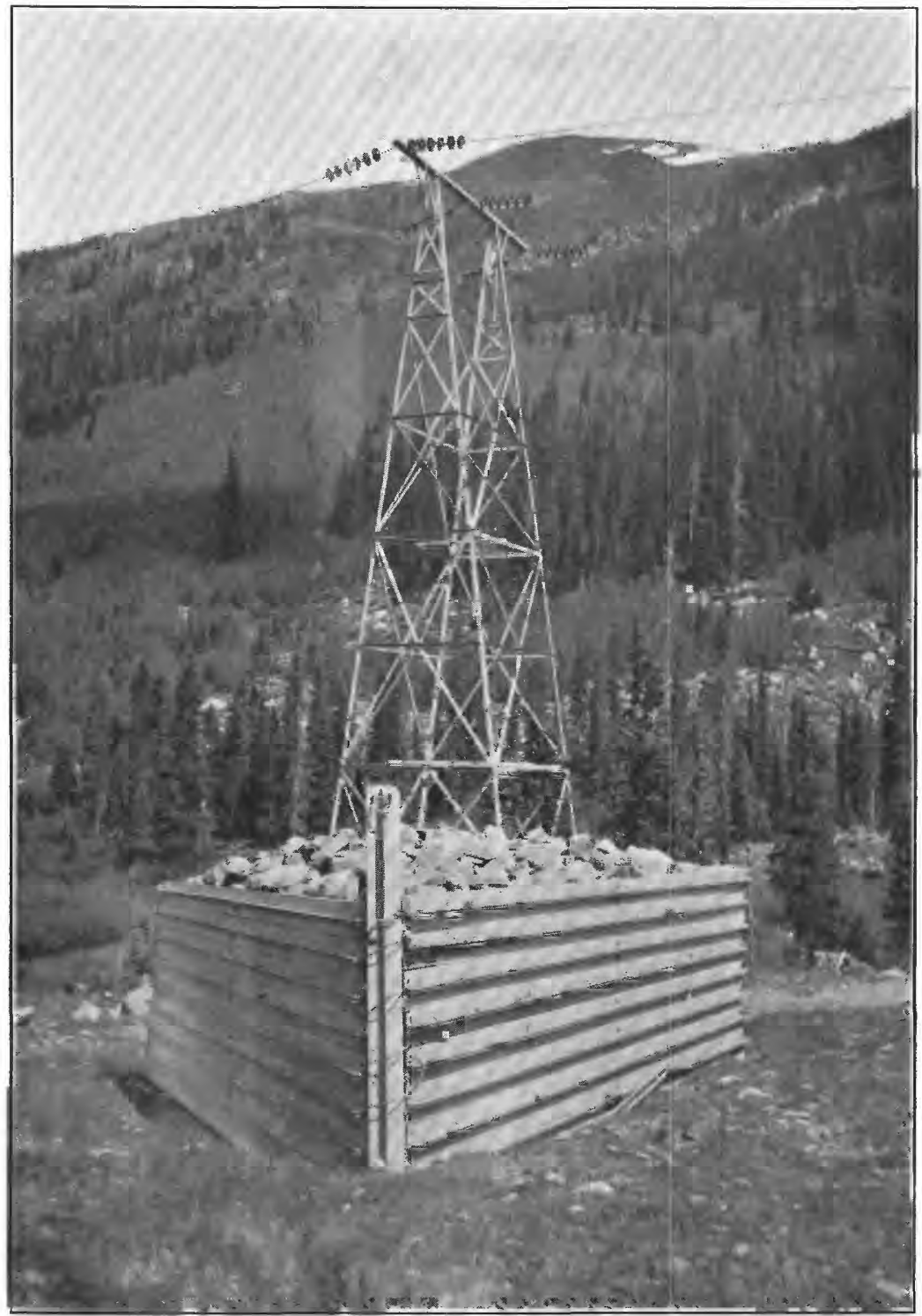

TRANSMISSION-LINE TOWER OF PUBLIC SERVICE CO. OF COLORADO PROTECTED AGAINST SNOWSIIDES BY PIER 


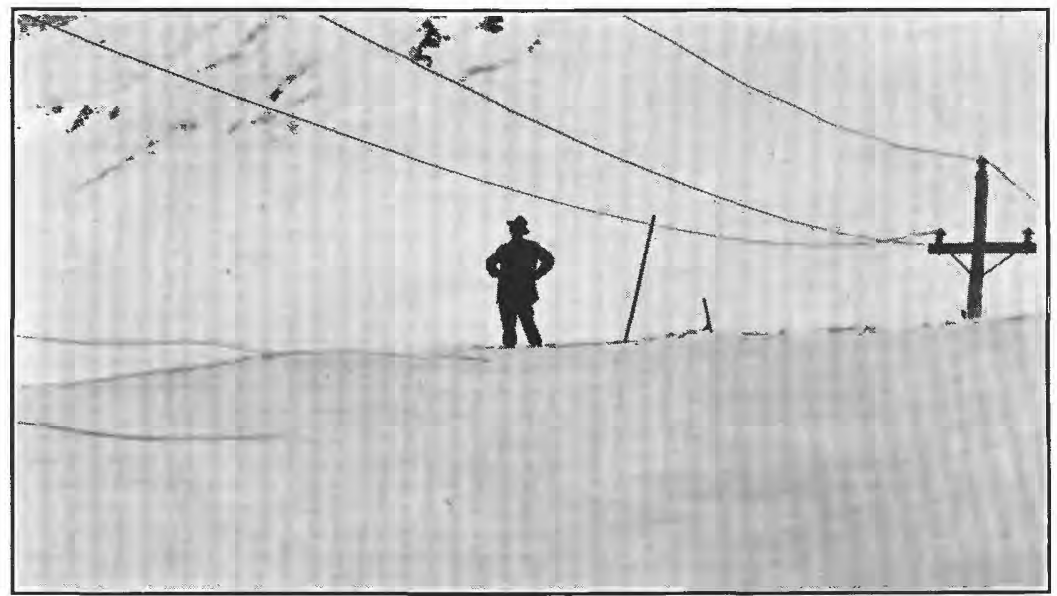

$A$

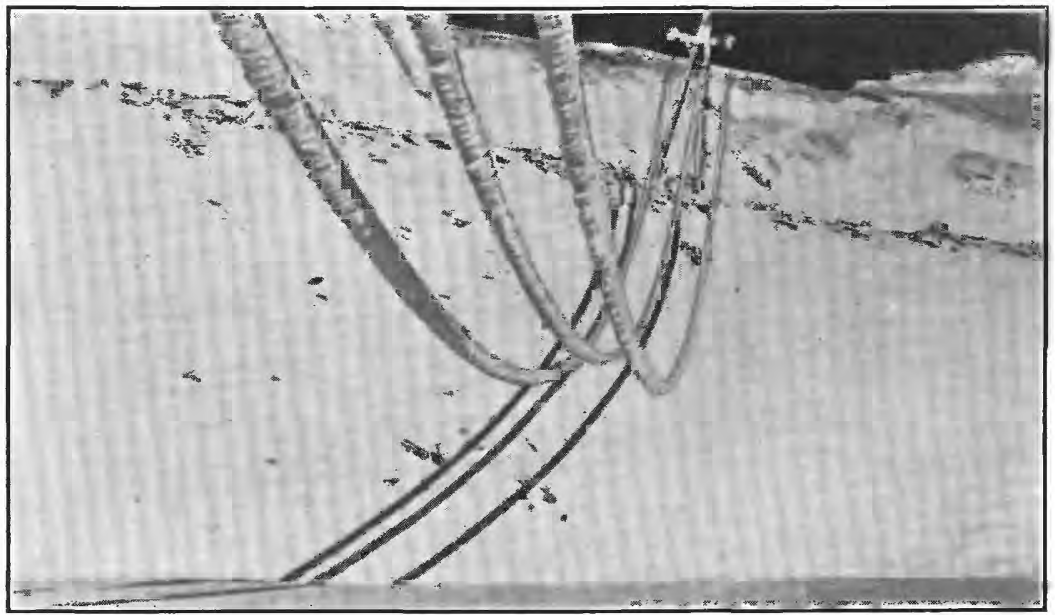

$B$

EFFECT OF SNOW ON TRANSMISSION LINES OF WESTERN COLORADO POWER CO. AT ALTITUDE OF 13,000 FEET 


\section{CLIMATE}

The development of water power with electrical transmission systems in the upper Colorado River Basin is attended with considerable difficulty, owing to the wide range in annual temperature (from $85^{\circ}$ above to $40^{\circ}$ below zero), electric disturbances, heavy snowfall, rock slides, and high wind velocities. In sections of heavy snowfall conduits laid along steep mountain sides are subject to destruction by snowslides. To prevent such losses, the Western Colorado Power Co. has built on its covered Trout Lake flume a timber platform extending from the mountain side above the flume to the lower side of the flume itself. The destruction of timber flume by rock slides was one reason for abandoning the water-power plant of the Silver Lake mill, in the San Juan Basin.

With transmission lines, ${ }^{29}$ winter conditions frequently give more trouble than the severe electric storms of summer, which can be very largely guarded against by lightning arresters. In the San Juan region electric disturbances are so frequent that more than 100 distinct discharges have been counted within a single hour. The great wind velocity at the higher divides, with the drifting of the heavy snowfall, necessitates specially constructed transmission lines. (See pls. 11, 12.) At Argentine Pass, which has an altitude of 13,600 feet, the wind attains a velocity of $\mathbf{7 0}$ miles an hour, and to guard against trouble from this source the 90,000-volt transmission line of the Public Service Co. has been constructed in duplicate for a distance of 2.4 miles, the duplicate lines taking different routes. Sleet and snow freeze the cables, giving them a diameter of as much as 6 inches, and ice and snow accumulating on the insulators freeze them solid to the towers. At high altitudes in cold weather dry snow blowing across the line sometimes causes an arc between overhead ground wire and a line instlator, the effect of which is a slight drop in voltage for an instant at the substation. In the San Juan region the high winds occasionally produce a short circuit by swinging the wires. To overcome this difficulty shorter spans are being used, and in localities where this condition is especially severe the wires are separated by a 4-foot spacing. In this region the snow sometimes drifts nearly to the cross arms of the poles, a height of 25 feet.

\section{COMPETITION OF STEAM POWER}

The abundance of coal in nearly all parts of Colorado makes it possible to develop steam power close to the markets at a cost which, taken in connection with the elimination of the long transmission lines, is generally cheaper than that at which water power can be developed at the present time. The modern trend of water-power

n See also McDonald, V.M., Operation and maintenance of Rocky Mountain transmission line: Electrical West, vol. 60, p. 595, 1928. 
development in other sections of the United States leads to the belief that water power will be developed in the upper Colorado River Basin for the purpose of supplementing steam power by carrying peak loads rather than competing with it for primary power.

\section{FACTORS AFFECTING HYDRAUIC STRUCTURES}

\section{ICE}

Except where local hot springs prevent freezing, all the streams are subject to ice during the winter. At the higher altitudes, where the mean monthly winter temperature is less than $20^{\circ}$ (p. 25), the ice conditions are severe, the nature and thickness of the ice depending chiefly upon the swiftness of the current, but at the lower altitudes, particularly in the vicinity of Grand Valley, the ice frequently lasts for only a few weeks. On the smaller streams, notably those above Aspen, anchor ice sometimes forms to such an extent that the flow is held back entirely during the coldest nights.

Ice may be present in one or more of three forms-sheet ice, frazil or needle ice, and anchor ice..$^{30}$. Sheet ice causes much less trouble than the other forms and is easier to handle.

On reservoir surfaces the expansion of the ice due to changes in temperature may exert an overturning effect on the dam,. allowance for which should be made in the design. When the ice sheet melts it breaks up into cakes of large size, which float down to the intake of the power plant, where provision must be made for their removal through ice chutes or over the dam.

Frazil and anchor ice take the form of small ice crystals floating in the water. At the intake they have a tendency to adhere tightly to all substances having a temperature equal to or less than that at which water freezes, completely closing all openings within a short time. As these types of ice form only where no ice cover is present, it is necessary to have sufficient pondage at the intake to allow the formation of a complete ice cover.

With the elimination of the floating ice crystals, little trouble is experienced in the operation of hydroelectric plants even at low temperatures, particularly where the intake is a reservoir of considerable size. At the Victor plant of the Southern Colorado Power Co., which lies at an altitude of 9,000 feet, ice causes no trouble in the operation of a lightly covered wood-stave pipe line. To prevent deterioration of the line by freezing, it is necessary to cover the pipe at exposed places on trestles. The Western Colorado Power Co. experiences little trouble at its Ames plant in the operation of a timber flume at an altitude of 9,000 feet. Although ice causes little

\footnotetext{
${ }^{20}$ For discussion of formation and action of these forms, see Hoyt, W. G., Effect of ice on stream flow:
} U. S. Geol. Survey Water-Supply Paper 238, pp. 24-30, 1913. 
trouble in the operation of wood-stave pipes and timber flumes the leakage from such lines is increased by the expansion of the cracks through freezing.

Open ditches can be operated if the temperature is sufficiently low and the velocity sufficiently small to maintain a complete ice cover, and if in addition the flow is sufficiently uniform to prevent sudden changes of stage from breaking of the ice cover.

At the higher altitudes, particularly above 10,000 feet, the winters are so severe that it is practically impossible to release from reservoirs into the natural channels small quantities of water to be utilized farther downstream. The water overflows the ice in the channel and freezes, practically none of it reaching the lower intake.

The daily mean temperature is so constant that little or no ice gorging due to sudden breaking up of the ice caused by thaws occurs on the streams during the winter.

\section{FLOODS}

The Colorado River above the Green reached its highest known stage in 1884. The United States Weather Bureau records show that on July 4, 1884, a high stage occurred near Fruita which was later determined from high-water marks to be 18.5 feet on the Geological Survey gage at that point. By running a line of levels across the area flooded at that time and extending the Fruita rating curve, the maximum discharge of this flood has been determined by the writer to be 125,000 second-feet. No record of the duration of this high water exists, nor are precipitation records available. From the writer's personal interviews with old settlers, it has been ascertained that during that year all streams in the upper Colorado River Basin were at the highest stages known and that the flood stages remained for weeks. The few small bridges spanning the Colorado and Roaring Fork and several bridges along the lower Gunnison were all destroyed. The Denver \& Rio Grande Railroad had four wooden railroad bridges destroyed between Delta and Grand Junction, the one near Escalante Creek collapsing as a passenger train reached it, with the result that the engine and two cars went into the river and several lives were lost. At Delta the Gunnison rose at least 10 feet above the bank-full stage and overflowed an area nearly threequarters of a mile wide. As the banks were covered with trees and underbrush, the water was retarded. This retardation was aided by the closing in of the sides of the valley a short distance below. Delta to form a canyon, through which the Gunnison flows nearly to its mouth. The railroad is in this canyon, and although the flood destroyed four bridges, as previously stated, the water did not reach the rails, which are not more than 15 feet above low water. Neither the Gunnison nor the Colorado overflowed its banks at Grand Junction. 
From press notices at that time it appears that the peak discharge of the Gunnison occurred within a few days of that of the Colorado near Fruita (below the Gunnison), indicating that both streams reached their maximum at practically the same time.

From a comparison of the dates of maximum discharge of this flood with the usual dates of maximum discharge (p. 45) it will be seen that the flood occurred unusually late in the season. This was due to the late spring, which held back the run-off from the very heavy snowfall of the previous winter. The settlers interviewed

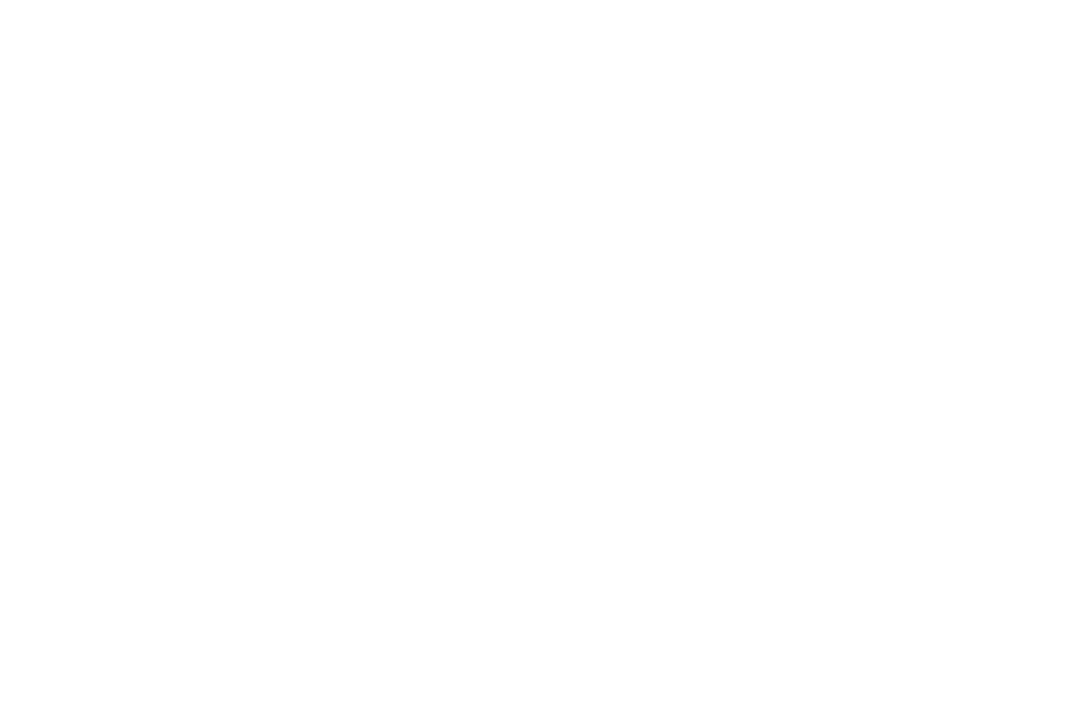

Figure 4.-Hydrographs of the Cache la Poudre River for 1884 and a normal year (1912)

stated that the early snowfall had been unusually heavy, and this was followed by a snow in April, which in the valley near Delta was 11/2 feet deep. Judge John L. Noonan, of Glenwood Springs, stated that he crossed Independence Pass (at the head of the Roaring Fork) early in July, 1884, and found drifts from 12 to 15 feet deep at that time. Mr. Robert Kelso, a stockman of Delta, stated that the snowfall was so deep that he was unable to take the cattle to the summer range in the mountains until July.

That the heavy snowfall of the winter of 1883-84 was general throughout the central Rocky Mountain region is shown by the runoff of the Cache la Poudre, which rises on the eastern slope of the Continental Divide, just east of the Colorado River Basin. Incomplete records for 1884 indicate that the total run-off of the Cache la Poudre for that year was the greatest in 41 years of record, being 217 per cent of the 41-year mean. The 1884 hydrograph for that stream is presented in Figure 4, together with the hydrograph for a 
normal year (1912), to show the relatively greater discharge during 1884. It is believed that these hydrographs also represent closely the relative discharge of the Colorado during those years. The maximum discharge occurring at the headwaters on June 28 agrees substantially with the maximum stage of the Colorado at Fruita on July 4. In further confirmation of the general character of the heavy snowfall, W. W. Follett, ${ }^{31}$ civil engineer, states that the flood of 1884 on the Rio Grande was the greatest since white settlers came to that region.

There is no record of unusual high water in other years, but the settlers interviewed stated that the stage of 1885 was nearly as high as that of 1884 and was due to the same cause but did not last as long. As a matter of passing interest, it may be relat that when Delta was first settled, an Indian squaw, Chipeta, the wife of the famous Ute chief Ouray, stated that within her lifetime of 50 years she had seen the Uncompahgre Valley at Delta "flooded from bluff to bluff" (a favorite expression of the Indians in describing prehistoric floods).

Although heavy general rains over the upper Colorado River Basin are of infrequent occurrence, there have been four periods of such rains during the last 20 years-September 3-6, 1909; October 4-6, 1911; and June 3-7, and 14-15, 1921.

Practically no records of stream flow were kept in the basin during 1909 , but records of precipitation show that the greatest rainfall and greatest flood flow occurred in the San Juan Mountain region between Durango, Silverton, and the upper Lake Fork of the San Miguel. The maximum rainfall recorded for the four-day period, September 3-6, was about 3 inches. The resulting flood was especially severe in the San Juan River Basin, which is outside the scope of this report, and also on the Lake Fork of the San Miguel River, where two power reservoirs were destroyed. ${ }^{32}$ No definite estimate of the maximum discharge of Lake Fork is available. In no other part of the region was the rainfall as much as 1.5 inches.

, For the period October 4-6, 1911, the heaviest rainfall again occurred in the upper San Juan Basin and the headwater region on the northern slope of the San Juan Mountains, where the recorded precipitation ranged from 3 to 8 inches. ${ }^{33}$ The greatest floods accurred outside the area covered by this report, but floods of considerable size occurred on the Dolores and Uncompahgre Rivers, that on the Dolores at Dolores being estimated at 10,000 second-feet, which was much greater than the maximum discharge of the Uncompahgre

\footnotetext{
31 Equitable distribution of the waters of the Rio Grande: 55th Cong., 2d sess., S. Doc. 229, p. 90, 1898.

a For description of flood in San Juan Basin in 1909, see U. S. Geol. Survey Water-Supply Paper 260, pp. 187-191, 1911.

* For description of flood in San Juan Basin in 1911 see Water-Supply Paper 309, pp. 246-249, 1914.
} 
River. The only other areas where the rainfall exceeded 2 inches were at Marble and on the Uncompahgre Plateau and Grand Mesa, and the resulting high water in the streams was not extreme.

During the two periods of general rain in June; 1921, the rainfall was not so heavy as in 1909 and 1911. The highest rainfall recorded June 3-7 was 2.50 inches at Ashcroft, near Aspen; 2.21 inches at Trout Lake, in the upper San Miguel Basin; and 2.04 inches on Grand Mesa. Severe floods occurred in the Dolores River, Henson Creek, Lake.Fork, and East and West Rifle Creeks. On the Dolores River and Lake Fork many miles of railroad track were washed out, and at Lake City considerable damage was done by Henson Creek cutting a new channel through the lower end of the town. No records of the maximum discharges on these streams exist. From June 13 to 15,1921 , the rainfall was heaviest in the San Juan region and the southwestern part of the State generally. An inspection of the dates of maximum discharge at regular gaging stations (p. 45) shows that the highest stages recorded on the Colorado at Hot Sulphur Springs, the Roaring Fork at Glenwood Springs, Tomichi Creek at Sargents, the Lake Fork at Lake City, the Uncompahgre River below Ouray, the San Miguel River at Naturita, and Kahnah Creek near Whitewater occurred in June, 1921.

During none of the periods of general rains described above was the rainfall in the Colorado River Basin above Glenwood Springs sufficient to cause the streams to overflow their banks to any extent.

Within the basin are several regions subject to cloudburst floods from very small areas. The region of greatest frequency lies along the western foothills, especially in the extreme upper end of the Uncompahgre Valley, where the sides converge and join the main mass of the San Juan Mountains above Ouray. Cloudbursts have been noted in this area from Dallas Creek near Ridgway southward to and including the streams draining the almost vertical walls of the mountain amphitheater that nearly surround Ouray. A flood of 2,000 second-feet from 1 square mile drained by Skyrocket Creek has been described in connection with floods in the Rocky Mountain region. $^{34}$ Several cloudbursts have been noted on small streams that drain the sides of the Uncompahgre Plateau and Grand Mesa near Delta, and on streams that drain the slopes of the Grand Hogback and Book Cliffs from Rifle to De Beque.

\section{SEDIMENT}

The quantity of suspended material in the upper Colorado and its tributaries is small compared with that in the streams in the lower basin. Above the Blue, Troublesome, and Muddy, near the western

\footnotetext{
14 Follansbee, Robert, and Hodges, P. V., Some floods in the Rocky Mountain region: U. S. Geol. Surrey Water-Supply Paper 520, pp. 124-125, 1925.
} 
edge of Middle Park, the Colorado carries little or no sediment; but those tributaries contribute considerable sediment to the river water, although at Kremmling the sediment content is low. Below Kremmling this content does not increase rapidly until the water of the tributary streams below the Eagle River is received. At the intake to the Shoshone power plant, near Glenwood Springs, the Colorado carries much sediment during periods of high water, but no analysis of the water at this point has been made. Below the Palisade station the content increases more rapidly. Samples of water have been analyzed for sediment as follows:

Colorado River near Kremmling, 262 samples from April 23, 1905, to May 15, 1906.

Colorado River near Palisade, 172 samples from March 15, 1905, to April 5, 1906.

Gunnison River at Whitewater, 199 samples from April 2 to October 31, 1905.

The results of these analyses are expressed by Stabler ${ }^{35}$ as tons per day of suspended material. The writer has reduced these results to acre-feet by assuming the weight of the material to be 85 pounds to the cubic foot, and has estimated the silt for the days when analyses were not made. The annual load of suspended material passing the measuring point near Cisco, Utah, is determined from one year's investigations of the sediment in Colorado River in the Dewey reservoir site, near Cisco, ${ }^{36}$ lasting from August, 1914, to July, 1915.

Annual load of suspended material in Colcrado and Gunnison Rivers

Acre-feet

Colorado River near Kremmling, Colo

Colorado River near Palisede, Colo.....

Gunnison River at Whitewater, Colo ................. 1, 200

Colorado River near Cisea, Utah. . . . . . . . . . . . . . 8, 175

The great increase in the suspended load near Cisco over that at the upper stations may be accounted for in small part by the fact that the records represent different years and were computed by somewhat different methods.

The annual variation in the sediment of the upper Colorado is not known, but a comparison between sediment and discharge for a 16year period in the Rio Grande indicates that it may vary between wide limits but not in accordance with the discharge.

The foregoing records represent only the material carried in suspension. In addition there is a considerable quantity of sediment and coarser material which is rolled along the bottom. No method has

\footnotetext{
a Stabler, Herman, Some stream waters of the Western United States: U. S. Geol. Survey Water-Supply Paper 274, pp. 42-50, 1911.

* Unpublished data compiled by Bureau of Reclamation.
} 
yet been devised for measuring this moving material, and a close estimate of its magnitude is impossible. The upper courses of the tributary streams have gradients so steep that although the water may be free from suspended material, sand, gravel, and even small boulders are rolled along the bottom by the swiftness of the current. Not only can this be observed, but such material is found deposited in front of diversion dams, usually piling up against the upstream face flush with the spillway.

Some of the mountain streams carry tailings from concentration mills, and these tailings may contain an appreciable quantity of sand. The percentage of sand in the tailings in upper Canyon Creek above Ouray was so high that the nozzles on the Pelton water wheels in the Revenue Tunnel plant were worn out in $\mathbf{1 0}$ days by the action of the sand at high velocities. ${ }^{37}$

\section{BASIS OF FSTIMATES OF POWER CAPACITY}

At the present time there is no generally accepted basis for rating the power capacity of a stream. In an endeavor to reach such a basis, the American Engineering Standards Committee on Rating of Rivers is investigating the subject. The following quotation from a statement by the sectional committee sums up the requirements for such a common basis:

The rating of a river should be

1. Something that will show within reasonable limits the water-power resourees of the region, basin, or political entity, $(a)$ for statistical purposes of various kinds, (b) for broad surveys of power supply as against present or future demand, (c) for economic comparisons of various kinds, $(d)$ for guidance in determination of public policy.

2. Something that will give the engineer, manufacturer, or power, devetoper * * * a fairly close expression from which he may derive an over-all idea of the power possibilities of several streams.

In accordance with the tentative recommendations of the sectional committee, the power capacity as stated in this report is based upon the discharge for 90 per cent and 50 per cent of the time, the former approximating primary power and the latter representing more nearly the probable wheel installation. To determine the 90 per cent and 50 per cent discharge for the streams considered in this report, the mean monthly discharges are arranged in order of magnitude, and from them a duration curve is constructed. (See fig. 5.) From this curve the required values are readily determined. For more detailed studies daily records should be used.

37 Rickard, T. A., Across the San Juan Mountains: Eng. and Min. Jour., vol. 76, p. 82, July 18, 1908 
The present standard of the Geological Survey is to express power as horsepower at 70 per cent efficiency under the gross head. The formula used is

Horsepower $=$ second-feet $\times$ gross head $\times 0.08$.

Power capacities for different sections of a stream are based upon the discharge at the upper end of each section.

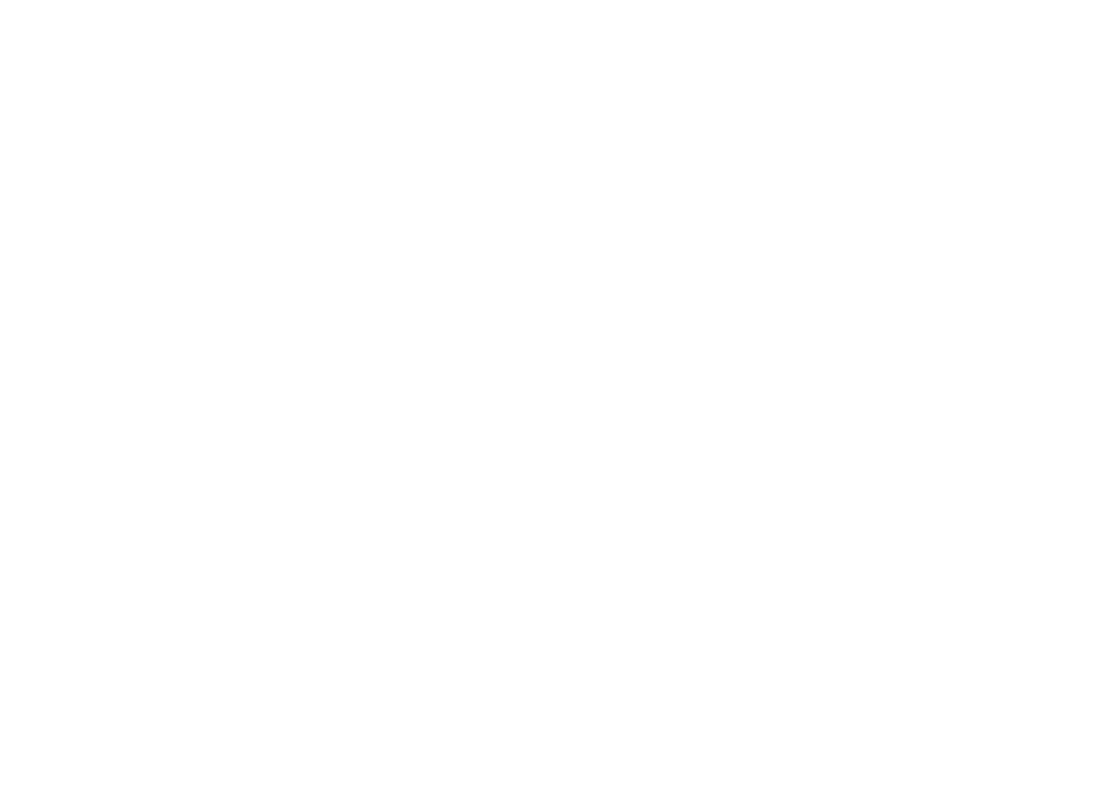

Figure 5.-Duration curve for the Colorado River at Glenwood Springs, Colo.

MARKETS

POPULATION AND INDUSTRY

The population of the upper Colorado River Basin is shown by counties in the following table:

Population of upper Colorado River Basin, 1910 and 1920

\begin{tabular}{|c|c|c|c|c|c|c|c|}
\hline \multirow{2}{*}{ County } & \multicolumn{2}{|c|}{ Population } & \multirow{2}{*}{$\begin{array}{l}\text { Percent- } \\
\text { age of } \\
\text { increase } \\
\text { or de- } \\
\text { crease }\end{array}$} & \multirow{2}{*}{ County } & \multicolumn{2}{|c|}{ Population } & \multirow{2}{*}{$\begin{array}{l}\text { Percent- } \\
\text { age of } \\
\text { increase } \\
\text { or do- } \\
\text { crease }\end{array}$} \\
\hline & 1910 & 1920 & & & 1910 & 1920 & \\
\hline \multirow{2}{*}{ 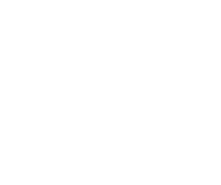 } & \multirow{2}{*}{$\begin{array}{r}1,862 \\
2,003 \\
2,985 \\
4,566 \\
10,144 \\
13,688 \\
22,197 \\
1,595\end{array}$} & \multirow{2}{*}{$\begin{array}{r}2,650 \\
1,724 \\
3,385 \\
2,707 \\
9,304 \\
13,668 \\
22,281 \\
1,808\end{array}$} & \multirow{2}{*}{$\begin{array}{l}+43 \\
-15 \\
+13 \\
-41 \\
-8 \\
-.1 \\
+14 \\
+.4\end{array}$} & \multirow[t]{2}{*}{$\begin{array}{l}\text { Gunnison } \\
\text { Montrose........... } \\
\text { Ouray } \\
\text { San Miguei...... } \\
\text { Dolores }\end{array}$} & $\begin{array}{r}5,897 \\
10,291 \\
3,514 \\
4,700 \\
642 \\
\end{array}$ & $\begin{array}{r}5,590 \\
11,852 \\
2,620 \\
5,281 \\
1,243 \\
\end{array}$ & $\begin{array}{r}-6 \\
+16 \\
+28 \\
+12 \\
+94 \\
\end{array}$ \\
\hline & & & & & 84,084 & 84,122 & +.05 \\
\hline
\end{tabular}


In the 10-year period ending 1920 the population showed practically no increase. This is accounted for by the decline in mining, as shown by the losses in the counties in which mining is the principal industry. Those counties in which stock raising and general agriculture are the chief industries have shown either a stationary population or an increase.

In the past the chief industry in the basin has been mining. According to statistics compiled by Henderson ${ }^{38}$ the value of the total mineral production in the upper Colorado River Basin to 1923, inclusive, was as follows:

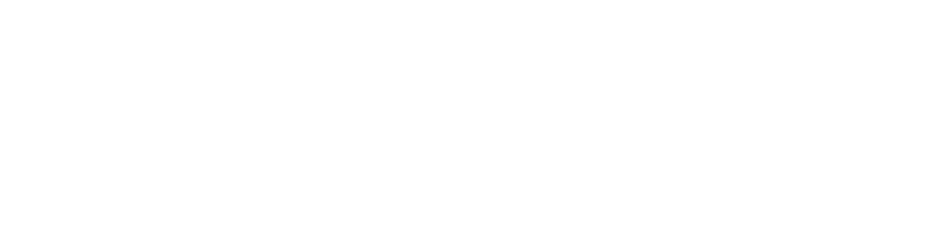

For the last few years the mining industry has been at low ebb, but it appears that the existing power plants will be able to care for most of the market afforded by a revival of that industry. From the slow growth of the population it is probable that the public-utilities market will expand but slowly for some years, at least. The future market for power in this basin will probably be furnished by industries in north-central Colorado east of the Continental Divide and by the electrification of the railroads traversing the basin.

\section{NORTH-CENTRAL COLORADO}

The area extending from the foothills eastward for a distance of $\mathbf{4 0}$ miles and from Denver northward nearly to the Wyoming line is the most thickly. populated portion of Colorado, nearly all of which is irrigated by the South Platte and its tributaries. The following table shows the population of the area:

Population of north-central Colorado, 1910 and 1920

\begin{tabular}{|c|c|c|c|c|c|}
\hline County & 1910 & 1920 & County & 1910 & 1920 \\
\hline \multirow{2}{*}{$\begin{array}{l}\text { Denver- } \\
\text { Jefferson } \\
\text { Adams } \\
\text { Arapahoe }\end{array}$} & \multirow{2}{*}{$\begin{array}{r}213,381 \\
14,231 \\
8,882 \\
10,263\end{array}$} & \multirow{2}{*}{$\begin{array}{r}256,491 \\
14,400 \\
14,430 \\
13,766\end{array}$} & \multirow[t]{2}{*}{$\begin{array}{l}\text { Boulder-1.. } \\
\text { Larimer } \\
\text { Weld- }\end{array}$} & $\begin{array}{l}30,330 \\
25,270 \\
39,177\end{array}$ & $\begin{array}{l}31,861 \\
27,872 \\
54,059\end{array}$ \\
\hline & & & & 341,544 & 412,879 \\
\hline
\end{tabular}

Of the total population, 62 per cent is contained in the city and county of Denver.

This market is now supplied chiefly by the Public Service Co., of Colorado, which has an installation for this part of its system of about

ss Henderson, C. W., Mining in Colorado: U. S. Geol. Survey Prof. Paper 138, p. 103, 1926. 
90,000 horsepower, of which 41,000 horsepower is furnished by hydroelectric plants, the Shoshone plant, on the Colorado River (p.165); having an installation of 18,000 horsepower. The next largest power system is that of the Denver Tramway Co., which has a steam installation of 7,500 horsepower.

The following table shows the growth of total production of electricity by public-utility companies operating in north-central Colorado during the 10-year period 1918-1927:

Electricity produced by public utilities in north-central Colorado, 1918-1927

\begin{tabular}{|c|c|c|c|c|c|}
\hline Year & $\begin{array}{c}\text { Kilowatt- } \\
\text { hours }\end{array}$ & $\begin{array}{l}\text { Per cent } \\
\text { increase } \\
\text { each year }\end{array}$ & Year & $\begin{array}{l}\text { Kilowatt- } \\
\text { hours }\end{array}$ & $\begin{array}{l}\text { Per cent } \\
\text { increase } \\
\text { each year }\end{array}$ \\
\hline $\begin{array}{l}1918 \\
1019 \\
1920 \\
1921\end{array}$ & $\begin{array}{l}112,380,000 \\
124,310,000 \\
128,290,000 \\
132,310,000 \\
154,140,000\end{array}$ & $\begin{array}{r}8 \\
11 \\
3 \\
3 \\
17\end{array}$ & $\begin{array}{l}1923 \\
1924 \\
1925 \\
1926 \\
1927\end{array}$ & $\begin{array}{l}163,110,000 \\
178,830,000 \\
189,060,000 \\
201,270,000 \\
212,820,000\end{array}$ & $\begin{array}{l}6 \\
9 \\
6 \\
6 \\
6\end{array}$ \\
\hline
\end{tabular}

\section{RAILROAD ELECTRIFICATION}

The upper Colorado River Basin is traversed by the Denver \& Rio Grande Western Railroad, the main line of which extends from Denver to Ogden, a distance of 782 miles, and by the Denver \& Salt Lake Railroad, which extends from Denver to Craig, a distance of 255 miles. Now that the Moffat tunnel on the Denver \& Salt Lake Railroad is an accomplished fact, it is expected that within a few years the so-called "Dotsero cut-off" will be built to join the two existing roads. The following table shows the principal features of these railroads:

Mileage, grade, and traffic density of railroads in upper Colorado River Basin

\begin{tabular}{|c|c|c|c|c|c|c|c|c|}
\hline \multirow{3}{*}{\multicolumn{4}{|c|}{ Road }} & \multirow{3}{*}{$\begin{array}{c}\text { Total } \\
\text { milleage } \\
\text { operated }\end{array}$} & \multicolumn{4}{|c|}{ - Grade (per cent) } \\
\hline & & & & & \multicolumn{2}{|c|}{ Maximum } & \multicolumn{2}{|c|}{ Ruling } \\
\hline & & & & & East & West & East & West \\
\hline \multicolumn{4}{|c|}{$\begin{array}{l}\text { Denver \& Rio Grande Western } \\
\text { Denver \& Salt Lake } \\
\text { Dotsero cut-off b }\end{array}$} & $\begin{array}{r}2,600 \\
255 \\
44\end{array}$ & $\begin{array}{l}3 \\
2 \\
.5\end{array}$ & $\begin{array}{l}2.4 \\
2\end{array}$ & $\begin{array}{l}1 \\
2 \\
.5\end{array}$ & $\begin{array}{l}1.42 \\
2\end{array}$ \\
\hline \multirow{3}{*}{ Road } & \multicolumn{8}{|c|}{ Traffic density } \\
\hline & \multicolumn{4}{|c|}{ Revenue, passenger } & \multicolumn{4}{|c|}{ Revenue, freight } \\
\hline & 1915 & 1920 & 1924 & 1927 & 1015 & 1920 & 1924 & 1027 \\
\hline $\begin{array}{l}\text { Denver \& Rio Grande Western..- } \\
\text { Denver \& Salt Lake }\end{array}$ & $\begin{array}{l}89,541 \\
33,203\end{array}$ & $\begin{array}{r}103,533 \\
36,810\end{array}$ & $\begin{array}{l}70,013 \\
24,510\end{array}$ & $\begin{array}{l}61,5158 \\
22,574\end{array}$ & $\begin{array}{l}321,778 \\
496,985\end{array}$ & $\begin{array}{l}793,418 \\
689,610\end{array}$ & $\begin{array}{l}681,058 \\
641,737\end{array}$ & $\begin{array}{l}797,700 \\
\mathbf{3 2 5 ,} 374\end{array}$ \\
\hline
\end{tabular}

- Traffic density is total passenger-miles or ton-miles divided by number of miles of road operated.

- Uniform grade of 0.5 per cent for entire line. 
It appears that the electrification of these railroads will be delayed for some years, at least, as both roads have but recently emerged from receiverships and are not financially able to bear the heavy cost of electrification, even if the present traffic density should warrant it. However, the construction of the proposed Dotsero cut-off will give a route from Denver to Salt Lake City 173 miles shorter than that of the Denver \& Rio Grande Western, with a reduction in maximum grade from 3 to 2 per cent. This new route will in all probability attract much more traffic than is now being handled, and this increase may hasten electrification.

From his experience with electrification as chief engineer of the Chicago, Milwaukee, St. Paul \& Pacific Railway, Loweth ${ }^{39}$ has recently discussed the general subject of electrification of railroads, and from his paper the following paragraphs are quoted:

The electrification thus far, at least, in the United States, has come about more largely from causes other than cheapness of electric power. *** However, it is not improbable that conditions in this respect may change; doubtless increase in volume of railway traffic and the known economies of electrification will tend to increase the use of electricity for the operation of railroads in localities where cheap and reliable hydroelectric power is available.

Something more than a mere showing of economy will be necessary to bring about a change from steam to electric operation of railroads. Electrification will involve a large increase of invested capital and at the same time the retirement of many facilities which would not be needed with a change of power. * * * The admitted economies of electrification have to contend with a constantly increasing efficiency of steam locomotivès. $* * *$ This, together with revision of gradients, additional and bette: facilities, and improved methods of operation, tends constantly to reduce the margin of economy which would justify electrification.

To the extent that hydroelectric power is more readily available, more reliable, and cheaper than steam-generated power, to the same extent, approximately, will it be a more important factor. Even so at this time it does not appear probable that the change from steam to electric operation would be justified for existing railroads except where the volume of traffic is large, where it can be moved in large units for long distances, where fuel costs are high, and where operating costs due to adverse gradients and congestion of track and other facilities make steam operation somewhat more than ordinarily expensive.

The ability to contract for an ample and reliable supply of hydroelectric power at favorable prices extending over a long term might easily prove a controlling factor in the electrification of railroads, especially for new railroads, where the cost of coal, water, and engine terminals as well as other facilities incident to steam operation would be eliminated.

The abundance and cheapness of hydroelectric power, especially as compared with steam-generated power, have probably been more the controlling factors in the electrification of steam railroads in foreign countries than in the United States.

It would seem reasonably safe to assume that hydroelectric power would be an important factor in steam-railway electrification under the following conditions:

${ }^{30}$ Loweth, O. F., Hydroelectric-power development as related to the electrification of railroads: Am. 8oc. Oivil Eng. Trans., vol. 86, pp. 829-835, 1923. 
(a) When cheap and available over such an extended area as would include a large main-track mileage for the individual road under consideration;

(b) When supplied from several sources tied together to insure reliability;

(c) When it can be contracted for long periods;

(d) When its cost reduced to terms of locomotive tractive effort is cheaper than that of steam-generated power.

\section{DEVELOPED POWER}

\section{GENERAL FEA TURES}

The capacity of installed water wheels in this area, classified according to use, is as follows:

Capaeity of installed water-power plants in upper Colorado River Basin

\begin{tabular}{|c|c|c|}
\hline Plants & $\begin{array}{l}\text { Number } \\
\text { of plants }\end{array}$ & $\begin{array}{l}\text { Installed } \\
\text { horse } \\
\text { power }\end{array}$ \\
\hline \multirow[t]{2}{*}{ 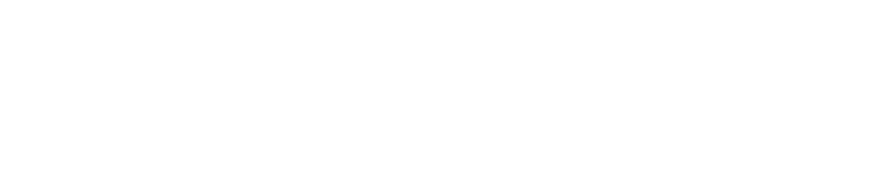 } & $\begin{array}{r}7 \\
7 \\
20 \\
4 \\
2 \\
1\end{array}$ & $\begin{array}{r}19,034 \\
18,050 \\
6,718 \\
3,350 \\
100 \\
100\end{array}$ \\
\hline & 41 & 47,352 \\
\hline
\end{tabular}

The power is used mainly for mining, with 24,768 horsepower. Public utility, chiefly urban, with 19,034 , horsepower, is a close second, and of this capacity, one plant furnishes 18,000 horsepower, which is transmitted chiefly to Denver, on the eastern slope. (See pl. 1.) Of the total installation, more than half, or 29,450 horsepower, is comprised within the systems of two public-utility companies, the Public Service Co. of Colorado and the Western Colorado Power Co.

The Shoshone plant (pl. 13, $A$ ) on the Colorado River, with an installation of 18,000 horsepower; the Rifle plant, of 247 horsepower; and the Tonopah plant, of 100 horsepower, are the only plants of the Public Service Co. of Colorado within the area covered by this report. The Blue River plant, of 1,600 horsepower, is owned by a subsidiary company. The company, which is controlled by Henry L. Doherty \& Co., of New York, acquired the Shoshone plant and the Boulder and Georgetown hydroelectric plants, on the eastern slope, together with the transmission line and steam plants of the Colorado Power Co., through an exchange of stock in 1923. The chief territory of the Public Service Co., which operates a number of steam plants in addition to the water-power plants, is the region just east of the mountains, extending from Denver north to Fort Collins and Wellington and east to Greeley and Fort Lupton. It also serves the mining regions in central Colorado. 
The Western Colorado Power Co. owns the old and new Ames, Ilium, Ouray, and Tacoma water-power plants and the Durango, steam plant (the Tacoma and Durango plants outside the area covered by this report), together with 300 miles of transmission lines. The company serves the mining districts of Ouray, Telluride, and Silverton and furnishes power and light for Durango, Ridgway, Montrose, and Delta. It was organized in 1913 as a subsidiary of the Utah Power \& Light Co., controlled by the Electric Bond \& Share Co., and now owns the properties in Colorado formerly owned by the Telluride Power Co. and the local utility companies in Durango, Telluride, Ridgway, Montrose, and Delta.

Many of the individual mining plants were installed long ago and have been idle for considerable periods, owing to the low ebb of the mining industry in recent years. The utility and pumping plants are all modern.

\section{HISTORY OF DEVELOPMENT}

Water-power development in this basin dates back to early lodemining days, in the Montezuma district, one of the first mining regions to be discovered in the basin. The first lode mining was done on Glacier Mountain, near Montezuma, in 1864. A short time afterward the Sukey Silver Mining Co. erected a 5-stamp mill run by water power. ${ }^{40}$ Although details of this installation are lacking, it is known that the power was developed by means of overshot water wheels built at the site and was transmitted to the machinery through spur-wheel gearing by means of belt or pulleys. . The wheel capacity was probably not more than 25 horsepower. In 1869 another mill of similar character was erected on French Creek at Lincoln..1 Although no record of other early developed powers has been found, it is probable that the small stamp mill operated by a water wheel was common in the early days.

Apparently the first modern water wheel installed was the reaction turbine which operated Munn Bros.' sampling mill at Ouray under a head of about 15 feet. This plant was built prior to 1883 and is still used occasionally. The first high-head installation appears to have been plant No. 1 of the Caroline Mining Co. at Sneffels, which consisted of a Pelton wheel operating under a head of several hundred feet and connected to an air compressor. This plant was installed in 1887 .

The first hydroelectric development was at Aspen, which experienced a boom after the discovery of very rich ore in 1884. The Aspen Electric Co. installed in 1885 a Pelton wheel operating under

\footnotetext{
$\omega$ Henderson, O. W., Mining in Colorado: U. S. Geol. Survey Prof. Paper 138, p. 228, 1926.

1 Ransome, F. L., Geology and ore deposits of the Breckenridge distriet, Colo.: U. S. Geol. Survey Prof. Paper 75, p. 17, 1911.
} 
a head of 70 feet, to which was attached a 50-light dynamo. In 1886 a second plant was constructed, which consisted of a Victor turbine operating under a head of 55 feet furnished by a flume half a mile long. The Consumers Light \& Power Co, was organized in 1886 and constructed a small plant on Hunter Creek, where a flume 1,500 feet long gave a head of 125 feet. By one or more of these early plants Aspen was lighted, being one of the first towns in the world to have its buildings and streets generally lighted. The two companies were consolidated into the Roaring Fork Electric Light \& Power Co. in 1887. The next year the second high-head waterpower plant in the State was built. An 8,750-foot flume diverting water from Hunter Creek 3 miles above its mouth and a 4,000-foot pipe line gave a head of 880 feet, which was utilized by nine Pelton wheels 2 feet in diameter, each having a capacity of 150 horsepower. The electrical equipment consisted of two 1,150 Brush direct-current incandescent dynamos, three 1,200-light Westinghouse alternatingeurrent dynamos, and one 110-kilowatt 550-volt Edison power generator. ${ }^{42}$ The power was used chiefly for the operation of mine hoists, the one in the Veteran Tunnel being the first electric hoist in the country and probably in the world. In 1892 the present Roaring Fork plant was built at a site 1 mile distant from the Hunter Creek plant.

The success of the first Aspen plants was followed in 1889 by the construction of the Glenwood Springs plant, which had installed a 100-horsepower Pelton wheel attached to a generator for a purpose of lighting Glenwood Springs. The only feature of this plant worthy of note was the utilization of the municipal water-supply conduit to generate power.

In 1890 the Caroline Mining Co., operating the Virginius and other mines on the slope of Mount Sneffels, installed a hydroelectric plant on Canyon Creek 4 miles below the mine. For that distance the cost of wire for 500 volts was so expensive that the company tried the experiment of adopting a tension of 900 volts, which was much higher than had ever been used in work of that kind. ${ }^{43}$ In that plant, which is still in existence and is known as Revenue Tunnel plant No. 2 (p. 175), wires were first run into mines and power used for electric drills and motors.

The next plant to be installed was the famous Ames plant, which was built during the winter of 1890-91 at the junction of the Lake and Howard Forks. It was constructed by L. L. Nunn for the San Miguel Consolidated Gold Mining Co., of Telluride, for the purpose of supplying power and light to the Gold King stamp mill, 2.6 miles

\footnotetext{
4 Elec. Review, Jan. 5, 1907, p. 410.

is Hale, Irving, Electric mining in Rocky Mountaingregion: Am. Inst. Min. Eng. Trans., vol. 26, pp. 402 et sea.. 1897 .
} 
distant. The plant consisted of a 6-foot Pelton wheel having a capacity of 100 horsepower, operating under a head of 320 feet, housed in a small building constructed of wood slabs. The cost of wire for direct-current transmission being prohibitive, a single-phase alternating-current system of 3,000 volts was adopted. The Pelton wheel was belt-connected to a 100-horsepower 3,000-volt single-phase Westinghouse alternator, and the power was transmitted at that voltage to a similar generator used as a synchronous motor in the stamp mill. This was the first hydroelectric plant, in this country at least, to transmit alternating current at high voltage for the purpose of operating a motor at a considerable distance. It was not the first plant to transmit alternating current at a high voltage, as a plant was installed near Portland, Oreg., in 1889, which transmitted alternating current at 4,000 volts for lighting only. The Ames plant was used by both Westinghouse and General Electric companies as a field laboratory, in which problems of high-tension transmission were solved. The successful operation of the plant was received with astonishment by the electrical world, as many prominent engineers. had predicted that the experiment would be an utter failure.44 In 1892 a 600 -horsepower generator of the same type was installed, and by that time the transmission line had been extended so far that at a mill on Bear Creek, 10 miles distant, a 250-horsepower motor was used. The Ames plant was rebuilt with its present 2-phase equipment operating at 11,000 volts in 1896 (see description of old Ames plant, p. 177), and the transmission line was extended to the Camp Bird mine, a distance of 17 miles.

While hydroelectric plants were being installed in the mining regions, settlement was taking place in Grand Valley and near-by tributary valleys to the Colorado. The first water-power development in that section occurred in 1885 and 1886, when a water wheel was installed to run a flour mill near Snipes in Plateau Valley and another to run a flour mill at Glenwood Springs. Soon after the first settlement in Grand Valley the ranchers began to irrigate small areas of land lying on mesas at some distance above the river. To avoid the construction of long gravity ditches, water was raised to the distributing ditches by pumping plants. These plants consisted of vertical Victor turbines operating under a low head by a large quantity of water from the Colorado River, attached to pumps that lifted a small quantity of water through vertical distances as great as 80 feet. The first pumping plant was that of James Smith, built in 1886, at a point 3 miles upstream from Grand Junction, to irrigate a small area across the river from Grand Junction. The second plant was that of Frank Burger, 7 miles east of Palisade, which was

4 The Bulletin (official pablication of the Utah Power \& Light Co., Salt Lake City, Utah), February. 1918. 


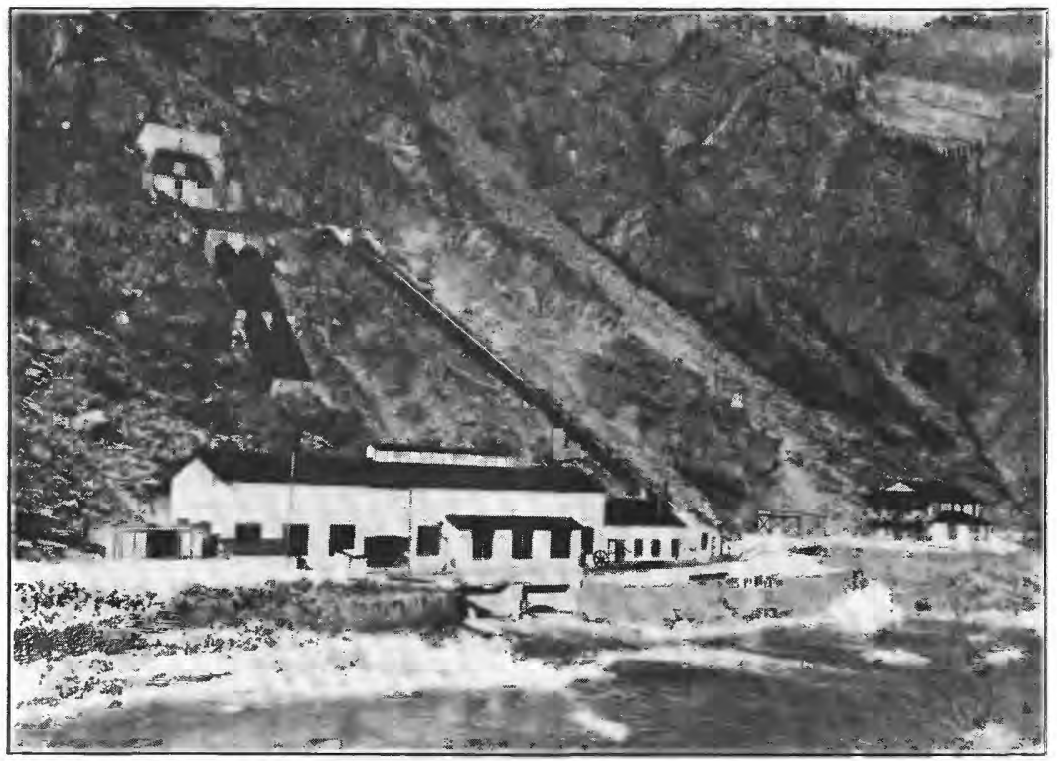

A. SHOSHONE PLANT OF PUBLIC SERVICE CO. OF COLORADO

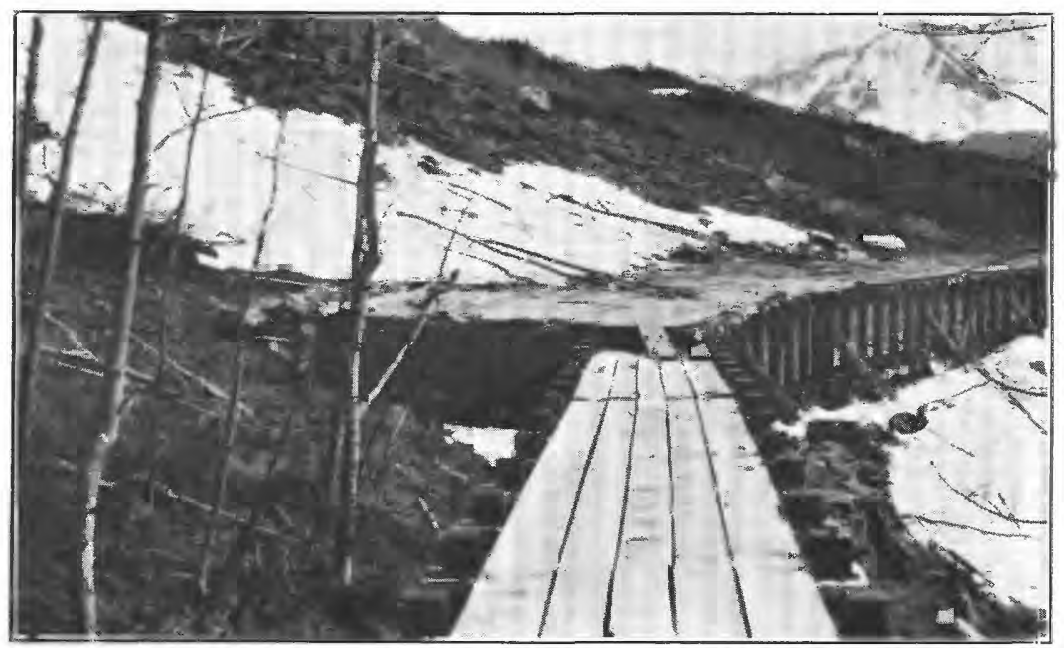

B. SNOWSLIDE COVERING ON TIMBER FLUME FROM TROUT LAKE RESERVOIR OF WESTERN COLORADO POWER CO. 

installed in 1888, and the next was that of C. N. Cox, in 1888 . The Cox plant had a canal with a capacity of 1,000 second-feet, half a mile long, creating a head of 12 feet. 'A 44-inch 159-horsepower' Victor turbine attached to a Smith-Vaile pump lifted the water 84 feet to irrigate 400 acres. These plants were discontinued in the arily years of the present century, when the small areas irrigated by them were incorporated in larger irrigation systems.

The successful operation of the hydroelectric plants already described was followed by the construction of other plants, the periods of greatest activity being 1896-1901, when nine plants now in existence were installed in addition to a number of others. long since abandoned; $1905-1909$, when ten plants were installed; and 1911-1914, when five plants were installed. The latest installation was that of the Standard Chemical mill in 1917.

\section{WATER-POWER PLANTS}

\section{SHOSHONE PLART (9DE 2) 45}

[See pl. 18, A]

Location and plan of development.-In the Colorado River Canyon 6 miles above Glenwood Springs; tunnel 2.36 miles long in north wall of canyon leading to penstock and power house in SE. $1 / 4$ sec. 31 , T. 5 S., R. 87 W. sixth principal meridian.

Ownership and market.-Owned by Public Service Co. of Colorado. (For market see p. 158.)

Chronologic summary.-Plant started in 1907, completed in 1909 by Central Colorado Power Co., which became Colorado Power Co. at termination of receivership in 1913 and was acquired by Public Service Co. of Colorado in 1923.

Water supply. - The Colorado River, which is unregulated except for pondage to take care of capacity discharge of 1,250 second-feet for $2 \frac{1}{2}$ hours in addition to regular flow of river at low storage, or about 500 acre-feet. The 90 per cent and 50 per cent discharges are 700 and 1,260 second-feet respectively; corresponding power capacity, 9,520 and 17,100 horsepower.

Hydraulic features.-Diversion dam in sec. 28 , T. 5 S., R. 87 W., having a crest length of 245 feet, which is the entire available width in canyon; heavy concrete base 74 feet wide with concrete apron extending 43 feet downstream. Bottom of concrete cut-off wall is 23 feet below permanent crest. Downstream from wall piles are driven among boulders in bottom of river, and below apron rock was filled in to make uniform slope to natural bed of stream. During periods of low. water 9-foot flashboards are used to afford required pondage. Rack dimensions at intake are 12 by 60 feet, and intake consists of four gates, each 7 by 11 feet. The tunnel, which is driven through sound granite, has a capacity of 1,250 second-feet under gravity flow; the cross section has a top width of 16 feet 8 inches and a bottom width of 15 feet 8 inches; the roof and floor are curved, with a maximum distance between them at centers of 11 feet. The tunnel is 12,453 feet long on a 0.05 per cent grade. It ends in two penstocks of rivetedsteel pipe 9 feet in diameter, 287 feet long, laid on a 1:1 slope. At bottom of penstock is a heavy anchorage, which takes the entire pipe-line thrust.

W Eng. Record, June 25, 1910, pp. 806-809; Elec. World, Jan. 27, 1910, pp. 217-220. 
Power house and transmission system.-Power house, including repair shop, is a structural frame building 178 by 37 feet, having corrugated-steel sides and: Carey roofing. Installation consists of two special 43-inch horizontal turbines built by I. P. Morris \& Co., controlled by Morris governors. Rated capacity of each turbine is $\mathbf{9 , 0 0 0}$ horsepower under a static head of 170 feet. Each turbine is direct-connected to a 5,000-kilovolt-ampere 4,000-volt 3-phase 60-cycle General Electric generator. On each main shaft is a 125-kilowatt exciter. generator. The main transmission line, leading from Shoshone to Denver, a distance of 153 miles, carries the current at 90,000 volts and crosses the Continental Divide three times at altitudes of $12,000,12,500$, and 13,600 feet. The climate at the highest pass is so severe that a duplicate line by a different route has been constructed for 2.4 miles. The wires are suspended from steel towers 44 feet high. Each conductor consists of a hemp-core 6-wire cable equivalent to No. 0 wire. Cables have spans ranging from 300 to 2,930 feet, with an average of 800 feet. From a substation at Dillon.one secondary line at 13,000 volts extends to Redeliff and Minturn, and another, which crosses the Continental Divide at 11,000 feet, extends to Fairplay. At Leadville secondary lines supply power to the mines in that region. A 44,000-volt line extends westward from Shoshone to Rifle.

MONARCH MINE PLANT (ODA 1)

The Monarch Copper Mining \& Development Co. during 1905 installed in sec. 14, T. 2 N., R. 75 W. sixth principal meridian, a power plant on the Roaring Fork of Arapaho Creek, a tributary of Colorado River. A pipe line with a capacity of about 12 second-feet leads to a 36-inch Pelton wheel of 150 horsepower under a static head of $\mathbf{5 2 0}$ feet. It is operated by a Sturgess oil governoi and is connected to a 75-kilowatt 2,300-volt 3-phase 60-cycle Crocker-Wheeler generator. The power is used to operate the mine and mill. The water supply, which is the unregulated flow of Roaring Fork, is stated to be sufficient for eight months in the year.

\section{TONOPAH SHOPS PLANT (ODB 1)}

Location and plan of development.-In NW. 1/4 sec. 6, T. 7 S., R. 77 W. sixth principal meridian, at Breckenridge. From diversion dam on the Blue River 4 miles of canal and pipe line lead to power house.

Ownership and market.-Owned by Public Service Co, of Colorado. Plant is closed at present, as the Breckenridge maxkat is supplied by other plants of the company.

Chronologic summary.-Gold Pan Mining Co. built canal and pipe line in 1900 for purpose of conveying water to hydraulic dredges and furnishing water to turbine for operation of company shops. Property acquired some years later' by Tonopah Placers Co., and sold to town of Breckenridge in 1925, which later transferred it to Public Service Co.

Water supply.-The Blue River and Pennsylvania and Indiana Gulches, 'which' are unregulated. One year's records of the Blue River above diversions at' Breckenridge indicate 90 per cent and 50 per cent discharges of 8 and 20 secondfeet, respectively; corresponding power capacities, 184 and 461 horsepower. Since 1916 water has been taken from Indiana Gulch only.

Hydraulic features.-Diversion dam on the Blue River in sec. 19, T. 7 8., R. 77 W. sixth principal meridian; canal having a capacity of 130 second-feet, 13,700 feet long, leads to pressure box in NE. $1 / 4$ sec. 7 , tapping Pennsylvania and Indiana Gulches on the way. From pressure box a riveted-steel pipe line 7,300: feet long leads to river. Near lower end a 16-inch pipe line branches to power house. 
Power house and transmission line.-In power house a 36-inch Pelton wheel having a single nozzle and generating 100 horsepower under the static head of 288 feet is belt-connected to one 50-kilowatt and one 200-kilowatt 2-phare 2,200volt Westinghouse generator. The transmission line for lighting Breckenridge carries current at 2,200 volts.

\section{SUMMTT COUNTY POWER CO. PLANT (9DB 2)}

Location and plan of development.-In NE. $1 / 4$ sec. 13, T. 5 S., R. 78 W. sixth principal meridian, $1 \frac{1}{2}$ miles below Dillon. Water is diverted from the Snake River just below the North Fork and from Straight Creek and conveyed to joint pressure box from which a pipe line leads to power house.

Ownership and market.-Owned by Summit County Power Co., which is controlled by Public Service Co. of Colorado. Market, mining district of Montezuma and mines as far east as Vidler Tunnel, on west slope of Continental Divide.

Chronologic summary.-Water filings for development made in April, 1899, but nothing done. Filings made by present company in January, 1907, for 100 second-feet from the Snake River and 100 second-feet from Straight Creek. Plant placed in operation in 1907.

Water supply.--Unregulated flow of the Snake River and Straight Creek. From records of the Snake River at Dillon from 1911 to 1919 and records of diversion through the Snake River Canal of the power company the estimated 90 per cent and 50 per cent discharges are 16 and 37 second-feet, respectively; corresponding power capacities, 576 and 1,330 horsepower.

Hydraulic features.-From wooden intakes and spillways on the Snake River in sec. 19, T. 5 S., R. 76 W., and on Straight Creek in the NW. 1/4 sec. 4, T. 5 S., R. $77 \mathrm{~W}$., canals having an area of 24 square feet, a grade of 0.02 per cent, and a capacity of 100 second-feet each lead to a pressure box 7 miles from the Snake River intake and 1.8 miles from Straight Creek intake. Pressure box is timber structure 16 feet long, 20 feet high, and 17 feet wide, having a trash rack in upper corner and penstock entrance in opposite lower corner. The penstock is 54-inch riveted-steel pipe, 1.8 miles long on grade of 4.7 per cent, with a capacity of $\mathbf{2 0 0}$ second-feet.

Power house and transmission line.-Power house is brick structure in which are installed two 36-inch Pelton wheels, each controlled by a Pelton oil-type governor, operated by three nozzles, and developing 800 horsepower under a static head of 450 feet. Each wheel is direct connected to a 500-kilowatt 2,300volt 3-phase 60-cyole General Electric generator. An auxiliary steam plant consists of a 625-kilovolt-ampere 2,300-volt 3-phase 60-cycle General Electric generator direct connected to a Westinghouse-Parsons steam turbine, supplied by a 700horsepower Babcock \& Wilcox boiler. Additional power is also purchased from Publio Service Co., connection being made at the Dillon substation of that company. From power house a transmission line, consisting of two copper wires in circuit and one ground wire, supported on wooden poles 35 feet high and spaced 132 feet apart, leads up the Snake River Valley to Peru Creek, where it branches, one branch going to Montezuma and mines in the vicinity and the other up Peru Creek, past Argentine, nearly to the Vidler Tunnel through the Continental Divide, in sec. 16, T. 5 S., R. 75 W. Current is transmitted at 13,000 volts. A second line leads up the Blue and Swan Rivers for a distance of 22 miles.

\section{EXCELSIOR MIII PLANT (9DB 3)}

The Excelsior mill, now owned by the Excelsior Mines \& Electric Co., is operated by a water-power plant installed in 1899. It is in sec. 34, T. 5 S., R. 78 W. sixth principal meridian, on North Tenmile Creek at Frisco, Summit County. From a reservoir having a capacity of a few acre-feet a pipe line leads to the power 
house, in which is installed a Hug impulse wheel, manufactured by the William A. Box Iron Works, of Denver, which develops about 100 horsepower under a static head of 380 feet. The water wheel is connected to one 110-kilowatt General Electric and one 110-kilowatt Bullock direct-current generator. Auxiliary power is furnished by a small steam plant. The water supply, which is the unregulated flow of the North Fork, is stated to be sufficient for eight months in the year.

\section{YOUNG \& HODGE PLANT (9DD 1)}

An old water-power plant 11/2 miles below Gilman, on the Eagle River, has recently been repaired and placed in operation. From a timber crib diversion dam in the $\mathrm{SW} .1 / 4$ sec. 12 , T. 6 S., R. 81 W. sixth principal meridian, a pipe line 2,000 feet long leads to a power house in which are installed two Walker Bros. turbines, each having a capacity of 100 horsepower under a static head of 45 feet. These are used to operate the machinery for a concentrating mill. Reeords of the Eagle River and Turkey and Homestake Creeks at Redcliff indicate 90 per cent and 50 per cent discharges of 30 and 68 second-feet, respectively; corresponding power capacities, 108 and 245 horsepower.

\section{EAGLE MHL PLANT (9DD 2)}

The plant at the Eagle mill, owned by the Empire Zinc Co., was installed in 1911. It is in sec. 13, T. 6 N., R. 81 W. sixth principal meridian, on Fall Creek, a tributary of the Eagle River near Gilman. Water is conveyed through a 16-inch riveted steel pipe line 3,100 feet long to a 24-inch Pelton wheel, which develops 220 horsepower under a static head of 660 feet. It is operated by a Pelton type 0-1 oil governor. The power is used to drive an Ingersoll-Rand air compressor. The water supply, which is the unregulated flow of Fall Creek, is stated to be sufficient for six months in the year. During the remainder of the year power is obtained from the Public Service Co.

\section{GYPSUM CREEK PLANT (9DD 8)}

Location.-In the SW. $1 / 4$ sec. 4 , T. 6 S., R. 85 W. sixth principal meridian, 7 miles south of Gypsum, Eagle County.

Ownership and market.-Owned by the Eagle River Electric Co., of Gypsum, which is owned by the Commonwealth Utilities Corporation. Market is towns of Gypsum and Eagle, also some pumping for irrigation.

Chronologic summary.-Plant built in 1914.

Water supply.-Unregulated flow of Gypsum Creek; shortage occurs during winter months. During nonirrigation season a hydroelectric plant in Gypsum, having a 68-horsepower turbine, belt-connected to a 371/2-kilowatt generator, is used.

Hydraulic features.-Diversion dam is concrete structure 5 feet high and 26 feet long. Conduit is 36 -inch pipe line with a capacity of 31 second-feet, 900 feet long.

Power house and transmission line.-A Samson-Leffel turbine 17 inches in diameter, developing 104 horsepower, under a static head of 45 feet, is controlled by a Woodward governor. Turbine is connected to a 75-kilowatt 2,300-volt 3-phase 60-cycle Fort Wayne generator. Transmission line of No. 8 and No. 10 wire on Oregon cedar poles carries power at 6,600 volts to Gypsum and to a point 4 miles east of Eagle, a distance of 19 miles.

\section{GLBNWOOD ITGHT \& WATER CO. PLANT (9DE 2)}

Location and plan of development.-In Glenwood Springs. Water is obtained from surplus water in the municipal pipe line of Glenwood Springs.

Ownership and market.-Owned by Glenwood Light \& Water Co. Market is Glenwood Springs and Cardiff. 
Chronologic summary.-Glenwood Light \& Power Co., organized in 1889, constructed water system and power plant during that year. Charter of company expired in 1909, and present company organized. Water system sold to city in 1914, but power plant retained.

Water supply.-Unregulated flow of Grizzly and No Name Creeks, two. small tributaries of the Colorado River.

Hydraulic features.-From a diversion dam on Grizzly Creek in sec. 21, T. 5 S., R. $88 \mathrm{~W}$. sixth principal meridian, a conduit consisting of 1,415 feet of pipe and 2,864 feet of tunnel diverts water to No Name Creek. Water is diverted from No Name Creek in about sec. 32, T. 55 S., R. 88 W., and brought to Glenwood Springs by a tunnel 4,109 feet long having a cross section $441 / 2$ by 6 feet, a steel flume 880 feet long, and a riveted-steel pipe line 18 to 24 inches in diameter and 6,300 feet long. It passes under the power house. where two valves supply water to water wheels.

Power house and transmission lines.-Power house is brick building 58 by 42 feet. Three 40-inch Doble water wheels, each developing 120 horsepower under a static head of 360 feet, are direct connected to a horizontal shaft. A 200-kilowatt 2,200-volt 3-phase 60-cycle Westinghouse generator and a 22-kilowatt 125-volt direct-current General Electric generator are belt connected to the power shaft. Transmission line of No. 4 bare-strand copper wire on steel poles, carrying a current of 13,000 volts, reaches Shoshone plant of Public Service Co. on the east. and Cardiff on the west, a total distance of 9.4 miles. This line is used not only to obtain peak-load power from Shoshone plant but Public Service Co. uses the line in transmitting power to Carbondale, the line serving that territory joining it at Cardiff.

\section{ROARING FORK ELECTRIC IIGHT \& POWER CO. PLANT (9DF 1) 46}

Location and plan of development.-In sec. 12, T. 10 S., R. 85 W. sixth principal meridian, just west of Aspen. Water is diverted from Hunter, Maroon, and Castle Creeks and brought to power house.

Ownership and market.-Owned by Roaring Fork Electric Light \& Power Co. Market is Aspen and mines in vicinity.

Chronologic summary.-For early history see page 162. Plant built in 1892 and at first connected only with pipe lines from Maroon and Castle Creeks. At presont the Hunter Creek plant is not in use, and the pipe line supplying it has been extended to the Castle Creek plant. Both hydraulic and electrical equipment have been modernized since the original installations in 1892 . The continuous operation of this plant by the same company is worthy of note.

Water supply.-Records of Maroon and Castle Creeks above points of diversion and estimates of run-off from Hunter Creek indicate total 90 per cent and 50 per cent discharges of 68 and 115 second-feet, respectively; corresponding power capacities, 2,610 and 4,450 horsepower.

Hydraulic features. - From a small reservoir of 7 acres in sec. 4, T. 10 S., R. 84 W., 3 miles above mouth of Hunter Creek, a conduit having a capacity of 8 secondfeet, consisting of a wooden flume 7,650 feet long, a 20-inch spiral riveted-steel pipe 1,100 feet long, a 14-inch wrought-iron pipe 4,300 feet long, and a 14-inch lapwelded steel pipe 5,300 feet long, leads to the power house. From a diversion dam on Castle Creek in sec. 23, T. 10 S., R. 85 W., a conduit having a capacity of 35 second-feet, consisting of a covered timber flume, 10,150 feet long buried in the ground and a riveted-steel pipe 22 to 26 inches in diameter and 3,600 feet long, leads to the power house. From a diversion dam on Maroon Creek in sec. 22, T. 10 S., R. 85 W., a conduit having a capacity of 50 second-feet, consisting of a

Elec. Review, Jan. 5, 1907, pp. 52 . 
covered timber flume 11,700 feet long, an inverted aiphon 1,200 feet long, a metal flume 2,680 feet long, and two riveted-steel pipes 26 to 32 inches in diameter and 3,900 feet long, leads to the power house. The static heads on the three pipe lines are 880, 350, and 364 feet, respectively. The Castle Creek and Maroon Creek pipe lines are cross-connected in the power house, so that water wheels can be operated by either or both. As a reserve supply in case water is temporarily shut off by snowslides, a small reservoir with a capacity of 500,000 cubic feet, 20 feet deep, is located near the head of the Maroon Creek pressure pipe.

Power house and transmission line.-Power house is brick structure 110 by 36 feet, in which are installed four 700-horsepower Doble impulse wheels, three 500horsepower Doble wheels, and one 500-horsepower Pelton wheel. All wheels but one 500-horsepower Doble wheel are connected to the Hunter Creek pipe line under an effective head of 800 feet and operate under an effective head of 320 feet. Each 700-horsepower wheel is direct-connected by horizontal shaft to a 400-kilowatt, 600-volt, direct-current General Electric generator, and two 500-horsepower wheels are similarly connected to two 200-kilowatt, 600-volt, direct-current General Electric generators. At one end of each shaft is a large cast-steel fiywheel. In addition to these six units, one Doble and one Pelton wheel, each of 500 horsepower, are belt connected to two 200-kilowatt 1,100-volt 3-phase 60-cycle Westinghouse generators. Transmission lines for Aspen and mines in vicinity consist of 5 miles of three-wire system direct current at 600 to 1,200 volts and 8 miles of alternating current at 1,100 volts suspended from red-spruce poles.

\section{CONSOIIDATED COLORADO YULR MARBLE CO. PLANT NO. 1 (9DF 2)}

Location and plan of development.-In sec. 25, T. 11 S., R. 88 W. sixth principal meridian, 1 mile above Marble. From diversion dam on the Crystal River pipe line leads to power house.

Ownership and market.-Owned by Consolidated Colorado Yule Marble Co. Power used in operation of marble quarries and mill and lighting town of Marble.

Chronologic summary.-Built in 1908 by Colorado Yule Marble Co., which was succeeded by present company.

Water supply.-Unregulated flow of the Crystal River above Yule and Lost Trail Creeks. Flow from these streams diverted for plant No. 2 and connected with plant No. 1. Records of flow indicate that total. 90 per cent and 50 per cent discharges are 25 and 68 second-feet, respectively; corresponding power capacities, 720 and 1,960 horsepower.

Hydraulic and electric features.-From diversion dam in the SE. 1/4 sec. 25, T. 11 S., R. 88 W., riveted-steel pipe from 36 to 30 inches in diameter, 3,500 feet long, leads to power house, in which are installed a 48-inch DeRemer impulse wheel having two sets of runners and two nozzles for each set. The rated capacity of the wheel under a static head of 360 feet is 550 horsepower. Beltconnected to the water wheel are two 200-kilowatt 2,300-volt 3-phase 60-cycle General Electric generators. Transmission line at 2,300 volts leads to mill 1 mile distant and line at 6,600 volts leads to quarries 2.7 miles distant.

\section{CONSOLIDATED COLORADO YULE MARBLE CO. PLANT NO. 2 (9DF 3)}

Location and plan of develop ment.-Close to plant No. 1. Water diverted from Yule and Lost Trail Creeks by pipe lines that unite a short distance above power house.

Chronologic summary. - Built in 1909 by Crystal River Marble Co., which was succeeded by Colorado Yule Marble Co. and finally by the present company.

Water supply.-Unregulated flow of Yule and Lost Trail Creeks. (See plant No. 1.) 
Hydraulic and electric features.-From Yule Creek in the NW. 1/4 sec. 36, T. 11 S., R. 88 W., a pipe line 16 inches in diameter leads nearly to the power house, where it is joined by another pipe line 16 inches in diameter, which diverts water from Lost Trail Creek in the NW. 1/4 sec. 30, T. $11 \mathrm{~S} ., \mathrm{R} .87 \mathrm{~W}$. The joint line leads to the power house, in which are installed two DeRemer impulse wheels, of 600 horsepower each, under a static head of 360 feet. Direct-conwed to the water wheels are two 450-kilowatt 2,300-volt 3-phase 60-cyele General Electric generators.

Remarks.-Both plants have operated intermittently, with long periods of idleness.

\section{OSGOOD PLANT (ODF 4)}

J. C. Osgood began construction of a plant in 1911 to furnish power for his private estate, near Redstone, but the installation was not complete until 1925 . Water is diverted from the Crystal River in sec. 29 , T. 10 S., R. $88 \mathrm{~W}$. sixth principal meridian, where a pondage of 20 acre-feet is available, by a 30-inch wood-stave pipe line, having a capacity of 40 second-feet, 2,250 feet long, which leads to the power house. An 18-inch S. Morgan Smith turbine of 100 horsepower under a static head of 30 feet is direct connected to a 75-kilovolt-ampere 2,300-volt 3-phase 60-cycle General Electric generator.

\section{RIPLE PLANT (9DG 1)}

Location and plan of development.-In sec. 27, T. 4 S., R. 92 W. sixth principal meridian, 12 miles north of Rifle. Water diverted from East Rifle Creek by ditch and pipe line.

Ownership and market.-Owned by Public Service Co. of Colorado, which purchased Rifle Light, Heat \& Power Co. in 1926. Market is town of Rifle and mines in vicinity.

Chronologic summary.-Plant constructed in 1909; present turbine installed in 1912.

Water supply.-Unregulated flow of East Rifle Creek. Entire flow of creek available, as intake is above all diversions. Company reports a shortage of water for peak loads during February and March.

Hydraulic and electric features.-An open ditch half a mile long takes entire flow of creek, and from ditch a 36-inch riveted-steel pipe line having a capacity of 30 second-feet, 400 feet long, leads to the power house. A 36-inch Leffel turbine having a rated capacity of 247 horsepower under a static head of 70 feet is controlled by a Woodward compensating governor. Direct connected to the turbine is a 150-kilowatt 2,300-volt 3-phase 60-cycle General Electric generator. The power is transmitted at 11,000 volts by a 12-mile line consisting of No. 6 wire, suspended from wooden poles.

\section{PRIOR-STUB PUMPING PLANT (GDJ 1)}

Location and plan of development.-On main canal of Bureau of Reclamation's Grand Valley project in sec. 3, T. 11 S., R. 98 W. sixth principal meridian, near Palisade. Canal diverts water from the Colorado River in sec. 13, T. $10 \mathrm{~S}$., R. $98 \mathrm{~W}$.

From the canal 80 second-feet of water is passed through the power house to Bupply the Price ditch of the Palisade irrigation district, and the power generated is used to raise 25 second-feet from the main canal to the Stub ditch of the Mesa County irrigation district, through a vertical distance of 31 feet.

Ownership and market.-Owned by United States. Market is irrigation of 'lands of Mesa County and Palisade irrigation districts. (See p. 122.)

Chronologic summary.-Originally the two irrigation districts had independent pumping plants and irrigation rights of 120 second-feet and power rights for 
1,200 second-feet from the Colorado River. Under contracts made in 1918 the Bureau of Reciamation agreed to furnish the 120 second-feet of irrigation water by a new plant, thereby releasing the 1,200 second-feet of power water. Plant constructed in 1919.

Water supply.-Obtained from main canal of Grand Valley project, which has a capacity of 1,425 second-feet. Supply is sufficient throughout the irrigation season.

Hydraulic features.-A concrete penstock 5 feet square having an operating capacity of 100 second-feet leads to a concrete power house in which is located a 251/2-inch S. Morgan Smith vertical turbine having a capacity of 125 horsepower under a head of 17 feet. The turbine is direct connected to a centrifugal pump, having a capacity of 28 second-feet.

\section{ORCHARD MESA PUMPING PLANT (9DJ 2)}

Location and plan of development.-On main canal of Orchard Mesa irrigation district in the NW. $1 / 4$ sec. 2 , T. 1 S., R. 2 E. Ute principal meridian, across the Colorado River from Palisade. Main canal receives water supply from main canal of Grand Valley project of Bureau of Reclamation. Power generated is used to raise 80 second-feet of water through a vertical distance of 40 feet and 60 second-feet through a distance of $\mathbf{1 3 0}$ feet into two distributing canals.

Ownership and market.-Owned by Orchard Mesa irrigation district. Market is irrigation of lands in district. (See p. 122.)

Chronologic summary.-Originally constructed in 1911, with water rights of 125 second-feet for irrigation and 325 second-feet for power. Under contract with Bureau of Reclamation dated February 18, 1922, the bureau took over the irrigation system and rebuilt it, enlarging the canal and installing new units in pumping station, during 1924 and 1926.

Water supply.-Obtained from power canal having a capacity of 800 secondfeet, of which 400 second-feet are available for the Orchard Mesa plant, the remaining 400 second-feet being reserved for future use of the Government project.

Hydraulic features. - The power canal, which has a grade of 0.02 per cent above the power house, is connected with the main Government canal by a concrete siphon 9 feet in diameter under the Colorado River. From the power canal two 60-inch and two 48-inch riveted steel pipes, having a combined capacity of 450 second-feet (the capacity of the original canal), lead to the turbines.

Power house and pumping.-In the power house, which is a brick structure with galvanized-iron roof, are four Worthington vertical combined turbine and pump units. Two turbines are 43 inches in diameter and have with the pumps a capacity of 30 second-feet under 130 feet total head, and the others are 24-inch turbines having a capacity of 40 second-feet under 41 feet total head. The turbin'es are hand governed and operate under a static head of 75 feet, which may be reduced to $\mathbf{7 1}$ feet during periods of high water in the Colorado.

\section{CRESTED BUTTE PLANT (OEA 1)}

The Crested Butte Light \& Water Co., about 1893, constructed in sec. 34, T. 13 S., R. 86 W. sixth principal meridian, near Created Butte, a hydroelectric plant which is now owned by the town. Water is diverted from Coal Creek in sec. 5, T. 14 S., R. $86 \mathrm{~W}$., and conveyed to a small reservoir by a conduit consisting of 4,000 feet of pipe line and 2,500 feet of flume, having a capacity of 4 second-feet. From the reservoir a pipe line leads to the power house, in which are installed one 36-inch Pelton and one 36-inch Hug water wheel, the latter manufactured by the William A. Box Iron Works, of Denver. Each wheel is rated at 75 horsepower under the static head of 300 feet. To the whater 
wheels are conneeted two Edison generators and one General Electrio directconnected generator, having a combined capacity of 85 kilowatts at 110 , volts.

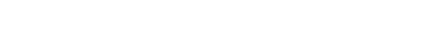

Location and plan of development.-In sec. 19, T. 50 N., R. 4 E. New Mexico principal meridian, 2 miles northeast of Ohio City. Water diverted from Quartz Creek, a tributary of Tomichi Creek, and carried to power house by woodstave pipe line.

Oxnership and market.-Owned by Roosevelt Mines \& Electric Co. Power used in operation of mine, including air compressor, pumping and sawmill machinery, lighting, and heating.

Chronologic summary.-Plant installed in 1914 by the Brant Independent Mining Co. Property acquired by present owners in 1920.

Water supply. - Unregulated flow of Quartz Creek. Records at Pitkin during 1911-1913 indicate the 90 per cent and 50 per cent discharges to be 22 and 32 second-feet, respectively; corresponding power capacities, 215 and 312 horsepower. Company states that water supply for present installation is sufficient for eight months in the year.

Hydraulic features.-From a timber diversion dam in sec. 17, T. 50 N., R. 3 E., 6,625 feet of 44-inch wood-stave pipe line having an operating capacity of 42 second-feet terminates in a steel $Y$ feeder pipe, of which each branch is 24 inches in diameter.

Power house and transmission line.-Power house is concrete structure 28 by 40 feet, in which are installed two 15-inch horizontal double-discharge turbines, each having a capacity of 300 horsepower under the static head of 122 feet. Each turbine is controlled by two Woodward oil-pressure governors and is direct connected to a 150-kilowatt 2,300-volt 3-phase 60-cycle generator. Transmission line 2.2 miles long consists of No. 5 bare copper wire suspended from nativepine poles. Current transmitted at 6,600 volts.

\section{CARTER HMTES PLANT (9EB 2)}

The Carter Mines Co. has a power plant in sec. 36, T. 51 N. R. 3 E. New Mexico principal meridian. Water is diverted some distance upstream and conveyed by means of a wood-stave pipe line to the power house. Here are installed three Pelton wheels having a combined capacity of 300 horsepower under a static head of 185 feet. Power is used to operate the mill and an air compressor for the near-by mine. The discharges for 90 per cent and 50 per cent of the time are estimated at 9 and 14 second-feet, respectively, which will develop 133 and 207 horsepower.

\section{GOLD IINKS MIIL PLANT (9EB 3)}

A power plant for the Gold Links mill, now owned by the Reynolds-Morse Corporation, was constructed in 1909 . It is in sec. 2, T. 50 N., R. 3 E. New Mexico principal meridian, 4 miles north of Ohio City. Water is diverted from Gold Creek, a tributary of Quartz Creek, and brought to the mill, in which is installed a 24-inch Leffel turbine having a rated capacity of 370 horsepower under a static head of 115 feet. The power was used to operate the mill, which has been closed since 1913. The discharges for 90 per cent and 50 per cent of the time are estimated at 9 and 14 second-feet, respectively, which will develop 83 and 129 horsepower.

\section{LAKE CITY PLANT (9DC l)}

Location and plan of development.-In sec. 3, T. 43 N., R. 4 W. New Mexico principal meridian, at Granite Falls, $1 \frac{1}{2}$ miles south of Lake City. A short pipe line around the fall leads to a power house at the base. 
Ownership and market.-Owned by Hinsdale Mining \& Development Co., Power used to light town of Lake City.

Chronologic summary.-Plant originally built in 1901 to operate under head of 60 feet. Moved 300 feet downstream in 1916, and present pipe line installed

Water supply.-Obtained from Lake Fork as naturally regulated by Lake San Cristobal. Records for 1918 to 1924 show the 90 per cent and 50 per cent dis -: charges to be 14 and 35 second-feet, respectively; corresponding power capacities,' 103 and 258 horsepower.

Hydraulic and electric features.-Timber dam 20 feet high at crest of Granite Falls creates pondage of a few acre-feet. Conduit consisting of 460 feet of steel:" pipe from 28 to 32 inches in diameter, having an operating capacity of 20 secondfeet, leads to power house, in which are installed two 72-inch DeRemer impulse wheels. The wheels, which are hand regulated, are on the same shaft, and each has two nozzles, developing 100 horsepower under the static head of 92 feet. To the wheel shaft is belt-connected a 150-kilowatt 2,300-volt 3-phase 60-cycle: General Electric generator. Transmission line $1 \frac{1}{2}$ miles long conveys the current to Lake City at 110 volts.

\section{UTE \& ULAY PLANT (OEC 2)}

Construction has been started on a power plant on Henson Creek in sec. 35, T. 44 N., R. 5 W. New Mexico principal meridian, a short distance upstream from the Hidden Treasure plant. Water is conveyed to the power house by a semicircular flume and pressure pipe 1,000 feet long, creating a head of 54 feet. It is expected that two Leffel turbines having a capacity of 120 horsepower each will be installed, and the power generated will be used in the Ute \& Ulay mine near by.

\section{HIDDEN TREASURE PLANT (9EO 3)}

Location and plan of development.-Power plant in sec. 31, T. 44 N., R. 4 W. New Mexico principal meridian, $2 \frac{1}{2}$ miles west of Lake City. Concrete dam 85 feet high oreates head which is utilized a short distance downstream.

Ownership and market.-Owned by McCarthy-Hidden Treasure Mining Co. Power used in operation of mine and mill.

Chronologic summary.-Timber dam constructed in 1897 by Hidden Treasure: Mining \& Milling Co. When present owners took the plant, they added a concrete facing to the timber base. The upper part of the dam was washed out. about 1918, and the destroyed portion was replaced by concrete.

Water supply.-Obtained from Henson Creek, in channel of which dam creates a reservoir having a capacity of 735 acre-feet. Fragmentary records indicate that 90 per cent and 50 per cent discharges are 14 and 33 second-feet, respectively; corresponding power capacities, 102 and 224 horsepower.

Hydraulic and electric features.-From dam a 28-inch wood-stave pipe line 1,000 feet long leads to the power house, in which are one 48-inch and one 72-inch Pelton wheel, each having two nozzles, rated at 125 and 150 horsepower, respec-: tively, under the static head of 85 feet. The 48-inch wheel is direct connected to the air compressor, which forces air through a 4-inch pipe to the mine. The 72-inch wheel, which has an automatio governor, is belt connected to on 45kilowatt 550-volt and one 75-kilowatt 440-volt direct-current General Electric generator.

\section{OURAY PLANT (BEF 1)}

Location and plan of development.-In Ouray. Water diverted from Uncompahgre River above canyon section and conveyed to power house by pipe line.

Ownership and market.-Owned by Western Colorado Power Co. Originally constructed by Ouray Electric Power \& Light Co., which leased it in 1905 to Telluride Power Co., the predecessor of present owner. (For market, see p. 168.) 
Chronologic summary.-Plant constructed in 1903 to replace a plant constructed a short distance downstream in the nineties, which had its intake in Sneffels Creok, above Box Canyon on Canyon Creek.

Water supply.-Obtained from unregulated flow of the Uncompahgre River above Canyon Creek. Records covering period 1911-1924 show 90 per cent and: 50 per cent discharges to be 13 and 30 second-feet, respectively; corresponding power capacities, 456 and 1,050 horsepower.

Hydraulic features.-A rubble masonry diversion dam 73 feet high and 72 feet long in the NE. $1 / 4$ sec. $8, T$ T. $43 \mathrm{~N}$., R. $7 \mathrm{~W}$. New Mexico principal meridian, creates a pondage of 20 acre-feet. A conduit 6,074 feet long, consisting of 2,090 feet of 40-inch wood-stave pipe, 1,815 feet of 36-inch wood-stave pipe, 738 feet of 34 -inch riveted-steel pipe, 704 feet of 32-inch, and 727 feet of 30 -inch rivetedsteel pipe and having an operating capacity of 50 second-feet, leads to the power house.

Power house and transmission system.-Power house is frame structure 44 by 37 feet, having corrugated-iron sides. A 72-inch Pelton wheel having double runners has a rated capacity of 1,250 horsepower under the static head of $\mathbf{4 4 0}$ feet. Direct connected to wheel is one 300-kilowatt 2,200-volt 2-phase Westinghouse generator and one 180-kilowatt 2,300-volt 3-phase 60-cycle General Electric generator. (For transmission line, see New Ames plant, p. 177.)

\section{REVRNUE TUNNEL PLANT NO. 2 (9EF 2)}

Location and plan of development.-In sec. 22, T. 43 N., R. 8 W. New Mexico principal meridian, 1 mile east of Sneffels. Water is diverted from Canyon Creek just below Sneffels and conveyed to the power house.

Ownership and market.-Owned by Reynolds-Morse Corparation. Power used in operation of mine.

Chronologic summary.-Plant constructed by Caroline Mining Co. in 1890. (See p. 163 for early history.)

Water supply.-Obtained from unregulated flow of Canyon Creek. Records of Canyon Creek for 1911-1915 indicate 90 per cent and 50 per cent discharges of 1 and 7 second-feet, respectively; corresponding power capacities, 36 and 252 horsepower.

Hydraulic and electric features.-From diversion dam in sec. 16, T. 43 N., R. $8 \mathrm{~W}$., a riveted-steel pipe line from 20 to 31 inches in diameter, 1 mile long, leads : to the power house, in which is installed a 60-inch Pelton wheel having a rated capacity of 448 horsepower under the static head of 450 feet and a small generator.

REDLANDS PUMPING PLANT (9EG 1)

Location and plan of development.-In the SE. 1/4 sec. 16, T. 1 S., R. 1 W Ute principal meridian, 1 mile west of Grand Junction. Water is diverted from the Gunnison River and carried by a canal to the power house, where it is used to pump 25 second-feet of water 127 feet to the main irrigation canal. From. this canal a portion of the water is pumped by electric power an additional height of $\mathbf{8 0}$ feet to a second canal, and from this in turn a smaller quantity of water is pumped an additional height of $\mathbf{5 0}$ feet to a third canal.

Owmoksip , and market.-Owned by Redlands Irrigation Co. Market is pumping of water for irrigation of 3,800 acres of mesa land and sale of surplus power to Grand Junction Electric, Gas \& Manufacturing Ca. Plant not eperated during winter.

Chronologic summary.-Construction started in 1906, and plant was first operated in 1908 by Redlands Irrigation \& Power Co. Original plans contemplated lowering the tailrace $6 \mathrm{feet}$, but this has not been done. The pumping machinery was replaced in 1916. In 1925 the company was succeeded by the Redlands Irrigation Co., a mutual organization. 
Water supply.- Unregulated flow of the Gunnison River. Records from 1918 to 1927 show 90 per cent and 50 per cent discharges to be 830 and 1,350 secondfeet, respectively; corresponding power capacities, 2,390 and 3,890 horsepower. Owing to depletion of the river by irrigation above the plant, the period of lowest water oceurs during August and September.

Hydraulic features.-Diversion dam 21/2 miles above mouth of river in see. 35 , T. 1 S., R. 1 W. Ute principal meridian, consists of reinforced-concrete structure, 8 feet high and 308 feet long. A canal $3 \frac{1}{2}$ miles long having a eross-section area of 195 square feet with a grade of 0.02 per cent and a capacity of 620 second-feet ends in a 30-foot cut at the edge of the river bluff, without being enlarged to form a forebay. Just above the penstock entrance a wasteway having a capacity of 500 second-feet connects with the tailrace by means of a concrete-lined channel and chute. Two riveted-steel penstocks 7 feet in diameter and 60 feet long lead to the power house.

Power house and pumping system.-Power house is a brick and concrete structure 42 by 56 feet, in which are installed two 30-inch style 21 Samson-Leffel turbines having double runners and rated at 786 horsepower each under the static head of 36 feet. The turbines are controlled by one Lombard and one Woodward oil-pressure governor. Direct connected to the turbines are two 450-kilowatt. 2,300-volt 3-phase 60-cycle General Electric generators, operating at 360 revolutions a minute. Connected to one turbine by an "increaser" gear is a Worthington single-stage volute pump running at 700 revolutions a minute, which delivers 26.7 second-feet of water to the first lift ditch through 1,620 feet of 48-inch wood-stave pipe against a static head of 127 feet. The water is taken from the under side of the steel penstock directly over the turbine. Power from the generators is used to operate two American single-stage volute pumps, each direct connected to a 300-horsepower 2,300-volt 3-phase General Electric induction motor running at 1,200 revolutions a minute. Each pump has a capacity of 12.5 second-feet and discharges into the same pipe line as the Worthington pump. The two smaller pumps are in a concrete building on the edge of the power canal 200 feet above the penstocks. A transmission line at 11,000 volts, with a total length of 4 miles, leads to substations, where motor-driven pumps lift water to the second and third ditch levels. Two motor-driven Worthington pumps having a combined eapacity of 12 second-feet against a head of 80 feet supply the second-level ditch, and two motor-driven pumps having a capacity of 4 second-feet against a head of $\mathbf{5 0}$ feet supply the two third-level ditches. The transmission line also connects with the plant of the Grand Junction Electrie Gas \& Manufacturing Co.

\section{STANDARD CHEMTCAI PLANT (ODK 1)}

The Standard Chemical mill, which was built in 1917, in sec. 29, T. 48 N., R. $17 \mathrm{~W}$. New Mexico principal meridian, 20 miles below Naturita on the San Miguel River, has installed a 51-inch S. Morgan Smith turbine having a capacity of 225 horsepower under the static head of 12 feet. Water is supplied by a canal half a mile long having a capacity of 240 second-feet. The turbine has a vertieal shaft, which is bevel geared to a flywheel, which in turn is belt connected to a 200-kilovolt-ampere 430-volt 3-phase Westinghouse generator. Power is used in the operation of the company's ore mill.

\section{SMUGGLER UNION PLANT (ODK 2)}

Location and plan of development.-In sec. 8, T. 42 N., R. 8 W. New Mexico principal meridian, 3 miles southeast of Telluride. Water is diverted from:Bridal Veil Creek and conveyed to power house.

Oronership and market.-Owned by Smuggler Union Mining Co. Power used to operate mine and mill. 
Chronologic summary.-Construction of plant/started by Smuggler Union Mining Co. in 1903 and finished in 1906, when it was first operated.

Water supply.-Obtained from Bridal Veil Creek, altitude of drainage basin ranges from 10,500 to 13,500 feet. No records of discharge available, but company states that it is sufficient from May to October.

Hydraulic and electric features.-From a dam in sec. 17, T. 42 N., R. 9 W., which creates a reservoir having an area of 50 acres, a pipe line consisting of riveted and seamless steel pipe 2,800 feet long, with a capacity of 25 second-feet, leads to the power house. A 72-inch Doble wheel rated at 525 horsepower and a 60-inch Allis-Chalmers wheel rated at 700 horsepower under the static head of 2,000 feet are direct connected to one 250-kilowatt 220-volt 3-phase 60-cycle Westinghouse generator and one 350-kilowatt 2,300-volt 3-phase 60-cycle Bullock generator. A transmission line 9 miles long, consisting of No. 4, No. 6, and No. 8 wire, carries current at 10,000 volts to mill and mine.

\section{CIMARRON MINe PLANT (9DK 3)}

The Cimarron mine is in sec. 33, T. 43 N., R. 8 W., New Mexico principal meridian, 3 miles east of Telluride. A riveted steel pipe line 1,000 feet long diverts water from Marshall Creek and leads to the power house, in which is installed a 60-inch Pelton wheel having a capacity of 240 horsepower under the static head of 300 feet. The plant was installed about 1891.

\section{OLD AMES PLANT (9DK 4)}

Location and plan of development.-(See new Ames plant, which is elose to this plant and has superseded it, this plant being held for emergency use only.)

Ounership and market.-(See new Ames plant.)

Chronologic summary. - First plant built in 1800 . (See p. 163 for early history.) The plant was entirely rebuilt in 1896, when present equipment was in talled.

Water supply.-(See new Ames plant.)

Hydraulic features.-From penstocks supplying the new Ames plant short iron-pipe lines connect with wheels in the old Ames plant.

Power house.-Power house is a frame strueture 75 by 53 feet, which cantains one 66-inoh and one 78-inch Peltan whel, one operating under a static head of 928 feet and the other under a static head of 648 feet; the combined capacity is 2,000 horsepower. Each wheel is direct connected to a 600 -kilowatt 500-volt 2-phase 60-cycle Weatinghouse generator.

\section{NEW AMES PLANT (9DK 5)}

Location and plan of development.-Power house in the NE. $1 / 4$ sec. 32 , T. 42 N., R. $9 \mathrm{~W}$. New Mexico principal meridian, at junction of the Lake Fork and Howard Fork of the San Miguel River. A conduit from each stream leads to the power house, where each conduit supplies a single water wheel.

Ownership and market.-Owned by Western Colorado Power Co. (For market, see p. 162.)

Chronologic summary.-Plant constructed in 1906 to replace old Ames plant, which had become obsolete. Power house partly destroyed by flood of September 5, 1909, owing to failure of Trout Lake Dam. Both structures rebuilt in 1910. Timber flume rebuilt in 1913.

Water supply.-Obtained from Lake Fork and Howard Fork. Storage amounting to 5,040 acre-feet afforded by Trout Lake and Lake Hope, two reservoirs on Lake Fork. Lake Hope, near source of stream, is natural lake in old volcano crater, across outlet of which a rock-fill dam 10 feet high and 100 feet long has been built. Outlet is tunnel 5 by 6 feet, 971 feet long, through solid $46013-29-13$ 
rock 113 feet below water surface, giving a reservoir capacity of 2,300 acre-feet. Trout Lake at head of conduit is formed by an earth dam 35 feet high and 1,175 feet long. Outlet is through 40-inch pipe line.- Capacity of reservoir, 2,470 acre-feet. No discharge records of these streams are available, but company states that storage is drawn on from August to April, the natural flow being sufficient during remainder of year..

Hydraulic features.-From outlet of Trout Lake, in sec. 8, T. 41 N., R. 9 W., a short pipe line leads to a covered timber flume (pl. 13, $B$ ) having a cross section of 38 by 40 inches on a 0.4 per cent grade, with a capacity of 55 second-feet. It is 13,000 feet in length and leads to a steel surge tank 30 feet in diameter and. 20 feet high. From the tank a riveted-steel pipe line 2,623 feet long with a diameter of 26 to 30 inches leads to the power house, creating a head of 928 feet. Operating capacity of pipe line, 60 second-feet. From an earth diversion dam with a concrete intake on Howard Fork in sec. 33, T. 42 N., R. 9 W., a pipe line consisting of 4,600 feet of 36 -inch wood-stave pipe on a 0.65 per cent grade, having a capacity of 50 second-feet, leads to a steel surge tank 20 feet in diameter and 35 feet high. From the tank a riveted-steel pipe line 2,074 feet long and 18 to 24 inches in diameter, having an operating capacity of 30 second-feet, leads to the power house, creating a head of 648 feet.

Power house.-Power house is masonry and steel structure 57 by 48 feet. The Lake Fork conduit with its static head of 928 feet is connected to a 120-inch Pelton wheel having a rated capacity of 5,000 horsepower. The Howard Fork conduit with its static head of 648 feet is connected to a 78-inch Pelton wheel rated at 1,200 horsepower. The notable feature of this installation is that both wheels, operating under widely different heads, are on the same shaft.. . The Howard Fork wheel is operated by a Pelton governor, but the chief regulation comes from the fact that the plant is in synchronism with other plants in the system. Direct connected to the water wheels is a 3,600-kilowatt 2,400-volt 3-phase 60-cycle General Electric generator.

Western Colorado Power Co.'s transmission system.-Chiefly within the so-ealled San Juan triangle, which includes the most rugged country in the Rocky Mountain region. The system consists of 106 miles of 44,000-volt lines and 300 miles of $17,000,11,000,6,600$, and 2,300 volt lines. The 44,000 -volt lines comprise two separate lines between Tacoma and Silverton, outside the area covered by. this report. In general the main lines leading from generating stations, except as first noted, have 11,000-volt current and converge at the Savage Basin switch house, near Telluride. Wires are suspended from cedar and native-pine poles from 35 to 55 feet high, spaced generally from 150 to 300 feet apart. Some of the divides are crossed at an altitude of 13,000 feet and are inaccessible in winter, being composed of bare rocky slopes swept by frequent snowslides. Spans up to 1,150 feet are used to reach safe points for support. The longest span consists of No. 1 hand-drawn copper wire supported by $1 / 2$-inch plow-steel cable. The deflection is about 35 feet on a $31^{\circ}$ slope.

\section{IIIUM PLANT (ODK B)}

Location and plan of development.-Power house in sec. 6, T. 42 N., R. 9 W. New Mexico principal meridian, at Vance Junction on the Rio Grande Southern Railroad. Water is diverted from Lake Fork just below the Ames plant and conveyed to the power house.

Ownership and market.-Owned by Western Colorado Power Co. (For market, see p. 162.)

Chronologic summary.-Plant constructed by Telluride Power Co. in 1901.

Water supply.-Obtained from tailrace of Ames plant and a small quantity from Wilson Creek. 
Hydraulic features.-From diversion dam just below Ames plant a covered timber flume, 27,390 feet long, having a cross section 40 by 40 inches and a grade of 0.43 per cent for the first 3,400 feet and 0.32 per cent for the remainder of the distance, with a capacity of 50 second-feet, ends in a pipe line consisting of 1,562 feet of riveted steel pipe from 40 to 32 inches in diameter, which leads to the power house.

Power house.-In the power house, which is a masonry and steel structure 74 by 30 feet, is installed a 96-inch Pelton wheel having two sets of runners in the same case. The rated capacity of the wheel is 2,000 horsepower under the static head of 510 feet. Hand levers operate deflecting nozzle on one side of wheel, but under normal operation the Tacoma plant governs the entire system. Direct connected to the wheel is a 1,200-kilowatt 1,060-volt 3-phase 60-cycle General Electric generator.

\section{MINOR PLANTS}

Nine plants having a capacity of less than 100 horsepower each and a total capacity of 518 horsepower are listed in the summary of developed water-power plants (p. 181). 


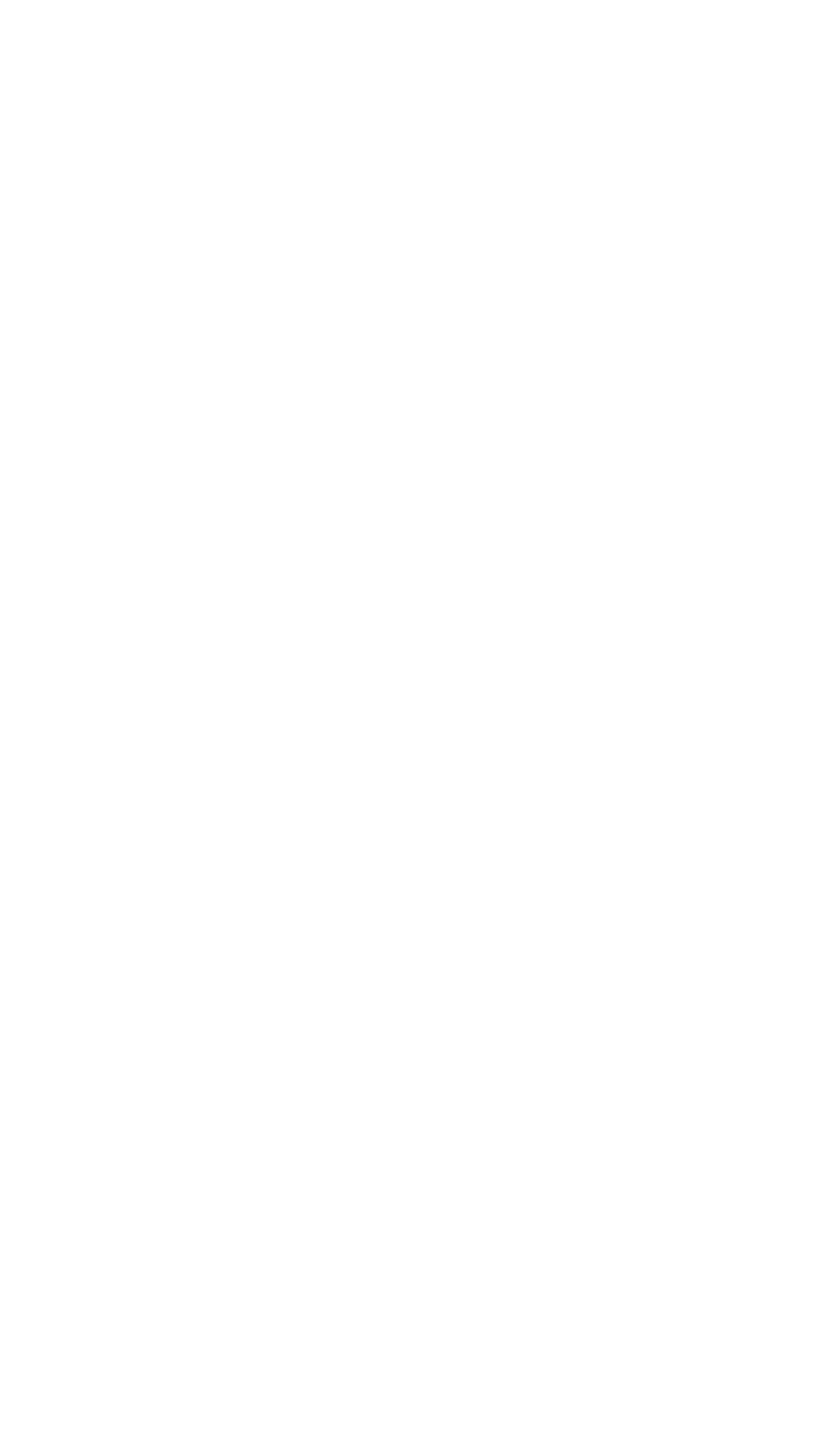




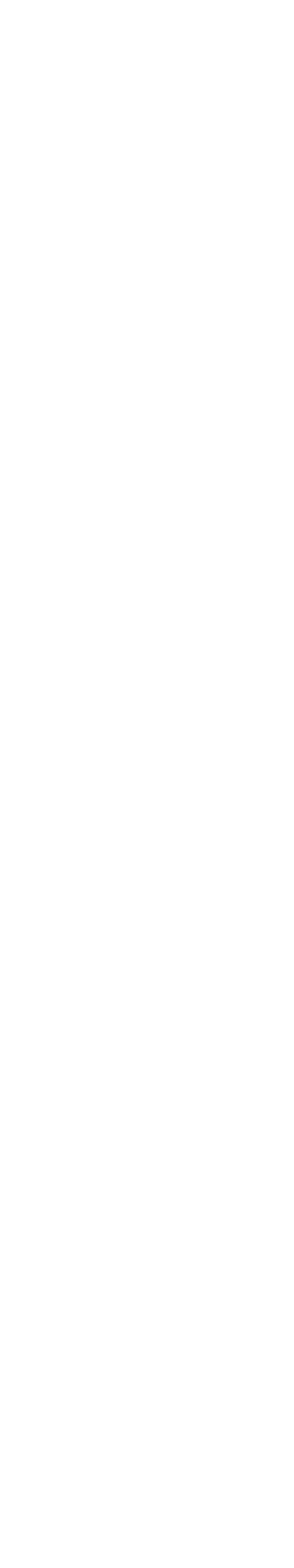




\section{UNDEVELOPED POWER}

\section{SCOPE OF INVESTIGATIONS}

In the discussion of the undeveloped power resources an endeavor has been made to include all sites that may eventually be used for the production of electric energy. Unquestionably most of the power sites discussed have little if any present value. However, as it is impossible to foresee changes which may make the development more feasible than it is at the present time, the physical facts are presented. and the user of the data is left free to decide the present economic feasibility of the sites. The base data used in the discussion include all available stream-flow records and plan and profile surveys of the principal streams in the basin. In the section devoted to storage (pp. 61-114) studies of the use of existing reservoir sites to increase the power value of the sites here described are presented. The value of the Dewey site, on Colorado River, in reducing floods at Yuma is pointed out. No attempt has been made to discuss the power value of the smaller streams, as the necessary information is generally not available.

\section{THE MAIN RIVER}

The section of the Colorado River above the mouth of Fraser River is covered by the topographic map of the Rocky Mountain National Park, and the sections from Kremmling to Glenwood Springs and from Grand Junction to the mouth of the Green River are covered by special river surveys. ${ }^{47}$ From these maps and from railroad profiles for the sections not otherwise covered the following table has been compiled:

Altitudes and distances along Colorado River from source to mouth of Green River

\begin{tabular}{|c|c|c|c|c|c|}
\hline & \multicolumn{2}{|c|}{ Distance (miles) } & \multirow{2}{*}{$\begin{array}{c}\text { Altitude } \\
\text { above } \\
\text { sea level } \\
\text { (feet) }\end{array}$} & \multicolumn{2}{|c|}{ Descent (feet) } \\
\hline & $\underset{\text { source }}{\text { From }}$ & $\mid \begin{array}{c}\text { Point } \\
\text { to point }\end{array}$ & & Total & $\begin{array}{c}\text { Per } \\
\text { mile }\end{array}$ \\
\hline $\begin{array}{l}\text { Source at La Poudre Pass } \\
\text { Contour crossing } \\
\text { Grand Lake outlet } \\
\text { Mouth of Arapaho Creek } \\
\text { Mouth of Fraser River } \\
\text { Railroad crossing above } \mathrm{Hot} \text { Sulphur Springs } \\
\text { Mouth of Williams River } \\
\text { Entrance to Gore Canyon } \\
\text { End of Gore Canyon } \\
\text { Grand-Eagle County line } \\
\text { State Bridge } \\
\text { Mouth of Rock Creek } \\
\text { Mouth of Cabin Creek } \\
\text { Mouth of Poison Creek } \\
\text { Mouth of Sweetwater Creek } \\
\text { Mouth of Eagle River } \\
\text { Crest of Shoshone Dam } \\
\text { Tailrace of Shoshone plant } \\
\text { Mouth of Roaring Fork }\end{array}$ & $\begin{array}{l}0 \\
6 \\
22 \\
27.5 \\
36 \\
43 \\
51 \\
72 \\
77 \\
84 \\
92 \\
100 \\
113 \\
123 \\
130 \\
138 \\
147 \\
149 \\
156\end{array}$ & \begin{tabular}{|c|}
6 \\
16 \\
5.5 \\
8.5 \\
7 \\
8 \\
21 \\
5 \\
7 \\
8 \\
8 \\
13 \\
10 \\
7 \\
8 \\
9 \\
2 \\
7
\end{tabular} & $\begin{array}{r}10,190 \\
9,000 \\
8,330 \\
8,120 \\
7,820 \\
7,690 \\
7,460 \\
7,300 \\
6,940 \\
6,800 \\
6,710 \\
6,600 \\
6,450 \\
6,290 \\
6,220 \\
6,125 \\
6,095 \\
5,920 \\
5,715\end{array}$ & $\begin{array}{r}1,190 \\
670 \\
210 \\
300 \\
130 \\
230 \\
160 \\
360 \\
140 \\
90 \\
110 \\
150 \\
160 \\
70 \\
95 \\
30 \\
a 175 \\
205\end{array}$ & $\begin{array}{r}198 \\
42 \\
38 \\
35 \\
19 \\
29 \\
8 \\
72 \\
20 \\
11 \\
14 \\
12 \\
16 \\
10 \\
12 \\
3 \\
88 \\
29\end{array}$ \\
\hline
\end{tabular}

4. S. Geol. Survey Water-Supply Paper 396, pls. 22-37, 1917. 
Altitudes and distances along Colorado River from source to mouth of Green RiverContinued

\begin{tabular}{|c|c|c|c|c|c|}
\hline & \multicolumn{2}{|c|}{ Distance (miles) } & \multirow{2}{*}{$\begin{array}{l}\text { Altitude } \\
\text { above } \\
\text { sea level } \\
\text { (feet) }\end{array}$} & \multicolumn{2}{|c|}{ Descent (feet) } \\
\hline & $\begin{array}{l}\text { From } \\
\text { source }\end{array}$ & $\begin{array}{c}\text { Point } \\
\text { to point }\end{array}$ & & Total & $\begin{array}{l}\text { Per } \\
\text { mile }\end{array}$ \\
\hline $\begin{array}{l}\text { Mouth of Elk Creek } \\
\text { Mouth of Rifle Creek } \\
\text { Mouth of Parachute Creek } \\
\text { Mouth of Roan Creek } \\
\text { Palisade } \\
\text { Mouth of Gunnison River } \\
\text { Bridge south of Fruita } \\
\text { Mouth of Salt Creek } \\
\text { Colorado-Utah line } \\
\text { Mouth of Little Dolores River }\end{array}$ & $\begin{array}{l}169 \\
184 \\
201 \\
214 \\
234 \\
248 \\
261 \\
275 \\
287 \\
293\end{array}$ & $\begin{array}{l}13 \\
15 \\
17 \\
13 \\
20 \\
14 \\
13 \\
14 \\
12 \\
6\end{array}$ & $\begin{array}{l}5,540 \\
5,300 \\
5,070 \\
4,900 \\
4,720 \\
4,550 \\
4,470 \\
4,396 \\
4,330 \\
4,298\end{array}$ & $\begin{array}{r}175 \\
240 \\
230 \\
170 \\
180 \\
170 \\
80 \\
74 \\
66 \\
32\end{array}$ & $\begin{array}{r}13 \\
16 \\
14 \\
13 \\
9 \\
12 \\
6 \\
5 \\
5 \\
5\end{array}$ \\
\hline $\begin{array}{l}\text { Dewey Dam site ( } 3 \text { miles below Dolores River) } \\
\text { Mouth of Rock Creek } \\
\text { Mouth of Castle Creek }\end{array}$ & $\begin{array}{l}305 \\
327 \\
336 \\
342\end{array}$ & $\begin{array}{r}10 \\
24 \\
9 \\
6\end{array}$ & $\begin{array}{l}4,172 \\
4,084 \\
4,050 \\
4,005\end{array}$ & $\begin{array}{l}88 \\
34 \\
45\end{array}$ & $\begin{array}{r}13 \\
4 \\
8\end{array}$ \\
\hline $\begin{array}{l}\text { Mouth of Mill Creek } \\
\text { Grand-San Juan County line } \\
\text { Mouth of Loekhart Canyon } \\
\text { Mouth of Indian Creek } \\
\text { Mouth of Green River }\end{array}$ & $\begin{array}{l}350 \\
358 \\
375 \\
394 \\
404 \\
421\end{array}$ & $\begin{array}{r}8 \\
8 \\
17 \\
19 \\
10 \\
17\end{array}$ & $\begin{array}{l}3,907 \\
3,924 \\
3,908 \\
3,900 \\
3,876\end{array}$ & $\begin{array}{r}48 \\
17 \\
16 \\
16 \\
8 \\
24\end{array}$ & $\begin{array}{l}1 \\
1 \\
1 \\
1\end{array}$ \\
\hline
\end{tabular}

Above the mouth of the Fraser River the discharge of the Colorado River is too small to have any considerable value for power. From the Fraser River to Westwater, a few miles beyond the Utah line, the river is closely paralleled by one or the other of two main railroads, except for a distance of 41 miles between State Bridge and the mouth of the Eagle River. In this 41-mile stretch the average fall is only 13 feet to the mile, making it of little value for power. To avoid railroad interference in the sections of river having power value, development must be accomplished by means of low diversion dams and relatively long conduits. Below the mouth of the Roaring Fork, at Glenwood Springs, the fall per mile is $\mathbf{1 6}$ feet or less, which is too slight for diversions of this type. It is evident that the only sections of the upper Colorado River offering power possibilities lie between the mouth of the Fraser River and State Bridge and between the mouths of the Eagle River and the Roaring Fork.

In the first of these two sections, the fall of the river is heaviest between Hot Sulphur Springs and the mouth of the Williams River. Here the river flows through a canyon with a fall of 230 feet in 8 miles. As the 90 per cent discharge in this stretch, based on the Hot Sulphur Springs records, is 105 second-feet, the total power is only 1,930 horsepower, which is negligible considering the length of conduit necessary for development. Below Gore Canyon the fall decreases to 20 feet to the mile, which is too slight to permit power development with the long conduits required.

In the second of the two sections the heaviest fall is utilized by the Shoshone plant (p. 165). Therefore, from the two sections offering water-power possibilities all stretches of the river have been eliminated for power discussion except two power sites, one at Gore 
Canyon and the other between the Shoshone plant and Glenwood Springs. The additional areas that can be irrigated from the Colorado River above these proposed power sites will require so small a percentage of the flow that there will be practically no effect on the water supply available for power.

Gore Canyon site (9DC 1).-In a distance of 5 miles, beginning at the entrance to Gore Canyon, in sec. 36, T. 2 N., R. 81 W. sixth principal meridian, the Colorado River falls 360 feet between precipitous walls of granite, which in places are not more than 200 feet apart at the base. The presence of the Denver \& Salt Lake Railroad requires development by means of a low diversion dam and either a conduit along the canyon walls or a tunnel through them similar to that of the Shoshone plant (p. 165), terminating in a high-head pressure line. The discharge records at the entrance to the canyon, near Kremmling, which have been extended back from 1904 to 1900 and forward from 1918 by comparison with the Glenwood Springs records, show the flow for 90 per cent and 50 per cent of the time to be 345 and 732 second-feet, respectively. Under the static head of 360 feet the corresponding power capacities are 9,940 and 21,100 horsepower. The power capacity of this site with storage at several possible sites is discussed on pages 71-72 and ranges from 32,000 to 50,600 horsepower for 90 per cent of the time and from 48,800 to 57,200 horsepower for 50 per cent of the time.

If the return from this project should not be commensurate with the expense necessary to construct a conduit 5 miles long through the canyon, the development might be confined to the first 3 miles, where the fall is heaviest and amounts to 270 feet. This method of construction would develop 7,450 and 15,800 horsepower for 90 per cent and 50 per cent of the time respectively.

Glenvood Springs site (9.DE 1).-From the tailrace of the Shoshone plant, in sec. 31, T. 5 S., R. 87 W., to the mouth of the Roaring Fork, in Glenwood Springs, the river falls 205 feet in 7 miles of narrow canyon cut in granitic rocks, with sides nearly vertical in many places. The presence of the main line of the Denver \& Rio Grande Western Railroad along the south side of the canyon and the Pikes Peak Ocean to Ocean Highway along the north side requires a low diversion and long conduit type of development in one or more stages. The precipitousness of the granite walls may make it necessary to tunnel through the sides for the construction of the conduit throughout a censiderable part of its length. The records of flow. at Glenwood Springs from 1900 to date show the discharges for 90 per cent and 50 per cent of the time to be 700 and 1,260 secondfeet, respectively. Under the static head of 205 feet the corresponding power capacities are 11,500 and 20,700 horsepower. The power capacity of the site with storage at several possible sites is discussed on pages 70-71 and ranges from 19,200 to 26,400 horsepower for 90 per cent of the time, and from 26,000 to 32,400 horse-power for 50 per cent of the time.

\section{TRIBUTARIES ABOVE GUNNISON RIVER}

\section{BIUE RIVER}

A preliminary reconnaissance power survey of the Blue River from Breckenridge to the mouth has been made by the Geological Survey for the purpose of determining the power value of public lands adjacent to the river, and from the report of that survey ${ }^{48}$ the following table has been compiled:

48 Jones, E. E., unpublished report on power resources of the Blue River, U. S. Geol. Survey, 1925. 
Altitudes and distances along Blue River from Breckenridge to mouth

\begin{tabular}{|c|c|c|c|c|c|}
\hline \multirow{2}{*}{ Point on river } & \multicolumn{2}{|c|}{$\begin{array}{l}\text { Distance } \\
\text { (miles) }\end{array}$} & \multirow{2}{*}{$\begin{array}{l}\text { Altitude } \\
\text { above } \\
\text { sea level } \\
\text { (feet)a }\end{array}$} & \multicolumn{2}{|c|}{$\begin{array}{c}\text { Descent } \\
\text { (feet) }\end{array}$} \\
\hline & $\begin{array}{l}\text { From } \\
\text { Breck- } \\
\text { enridge }\end{array}$ & $\begin{array}{l}\text { Point } \\
\text { to } \\
\text { point }\end{array}$ & & Total & $\begin{array}{l}\text { Per } \\
\text { mile }\end{array}$ \\
\hline 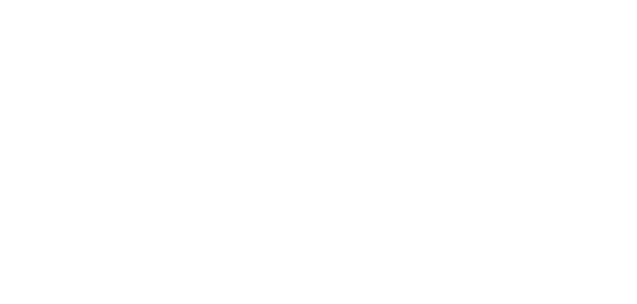 & $\begin{array}{r}4.5 \\
7 \\
10.2 \\
10.9 \\
15.2 \\
19.4 \\
25.1 \\
28.1 \\
34.3 \\
40.4 \\
43.2 \\
50.2 \\
58.0\end{array}$ & $\begin{array}{r}4.5 \\
2.5 \\
3.2 \\
.7 \\
4.3 \\
4.2 \\
5.7 \\
3.0 \\
6.2 \\
6.1 \\
2.8 \\
6.8 \\
7.8\end{array}$ & $\begin{array}{l}9,250 \\
9,152 \\
8,995 \\
8,816 \\
8,780 \\
8,604 \\
8,390 \\
8.90 \\
8,95 \\
7,912 \\
7,750 \\
7,500 \\
7,363 \\
7,310\end{array}$ & $\begin{array}{r}368 \\
157 \\
179 \\
36 \\
176 \\
214 \\
210 \\
135 \\
133 \\
162 \\
250 \\
137 \\
53\end{array}$ & $\begin{array}{r}74 \\
63 \\
56 \\
51 \\
41 \\
51 \\
37 \\
45 \\
21 \\
27 \\
89 \\
20 \\
7\end{array}$ \\
\hline
\end{tabular}

a Approximate only; subject to correction based on more detailed surveys.

The section above Dillon has the heaviest fall, but the discharge in that section is too small to be of any considerable value for power development. Below Dillon the fall of the river and the topography of the valley are favorable for power development by means of low diversion dams and long conduits. Five power sites, which cover the sections of the river most favorable to power development, are described below. Of the total fall, amounting to 1,470 feet between the tailrace of the Summit County Power Co. and the mouth of the river, 1,030 feet is comprised in these sites. In general, the banks along the river are of such a character that a pipe line can be easily constructed and if necessary covered with earth. Material for rockfill dams can be obtained from the river channel. Very little rock ar tunnel work will be required, and stream crossings can be made easily. The presence of a well-constructed highway along the Blue River, with railroad stations at Dillon and Kremmling, makes the entire valley readily accessible.

The estimates of available water supply are based on combined records of the Blue and Snake Rivers and Tenmile Creek at Dillon (1911-1919) and of the Blue River at the Green Mountain site, near Kremmling (1905-1908). The additional areas susceptible of irrigation above the three upper power sites are too small to affect the water supply available for power development.

Straight Creek site (9DB 1).-The proposed diversion for the Straight Creek site is in the NE. $1 / 4$ NE. $1 / 4$ sec. 13 , T. 5 S., R. 78 W. sixth principal meridian, just below the tailrace of the Summit County Power Co.'s plant (p. 167) and half a mile above Straight Creek. From this point a pressure line along the east bank of the river to a point in the SW. $1 / 4$ NW. $1 / 4$ sec. 36, T. 4 S., R. 78 W., would have a length of 3 miles and would cross Straight Creek and one minor tributary. A static head of 120 feet would be developed. The discharges for 90 per cent and 50 per cent of the time are 74 and 173 second-feet, respectively, 
which would develop 710 and 1,660 horsepower. If the transmountain diver sions from the Blue River and Tenmile Creek (p. 59) are made, the 50 per cent discharge would be reduced to 102 second-feet, corresponding to a development of 979 horsepower.

Willow Creek site (9DB 2).-From a point below the tailrace of the Straight Creek project, in the SW. $1 / 4 \mathrm{NW} .1 / 4$ sec. 36, T. 4 S., R. $78 \mathrm{~W}$., 1 mile below Willow Creek, a pressure line along the west side of the river, ending in the SE. $1 / 4$ N.E. $1 / 4$ sec. 9, T. 4 S., R. 78 W., would have a length of 5 miles and develop a static head of 252 feet. Crossings for Maryland Creek and four minor tributaries would be required. The discharges for 90 per cent and 50 per cent of the time are 87 and 189 second-feet, respectively, which would develop 1,750 and 3,810 horsepower. With the transmountain diversions as proposed (p. 58) the 50 per cent discharge would be reduced to 132 second-feet, corresponding to a development of 2,660 horsepower.

Rock Creek site (9DB 3).-The proposed diversion for the Rock Creek site is just below the tailrace of the Willow Creek project, in the SE. $1 / 4$ NE. $1 / 4$ sec. 9 , T. 4 S., R. 78 W., half a mile above Rock Creek. A pressure line 5 miles long on the west side of the river would lead to the proposed power house in the NE. $1 / 4$ NW. $1 / 4$ sec. 29 , T. 3 S., R. 78 W., and develop a static head of 173 feet. Crossings for Rock, Boulder, and Harrigan Creeks would be required. The discharges for 90 per cent and 50 per cent of the time are 105 and 220 second-feet, respectively, which would develop 1,450 and 3,040 horsepower. The proposed transmountain diversions (pp. 58-59) would reduce the 50 per cent power to 2,520 horsepower.

Acorn Creek site (9DB 4).- The proposed diversion point for the Acorn Creek site is just below the tailrace of the Rock Creek project and a quarter of a mile below Acorn Creek, in the NE. $1 / 4$ NW. $1 / 4$ sec. 29, T. 3 S., R. 78 W. A pressure line $41 / 2$ miles long on the west side of the river, leading to the tailrace in the NE. $1 / 4$ NW. $1 / 4$ sec. 12 , T. 3 S., R. 79 W., would develop a static head of 235 feet. Crossings for Slate and Ute Creeks and one minor tributary would be required. The discharges for 90 per cent and 50 per cent of the time are 109 and 228 secondfeet, respectively, which would develop 2,050 and 4,290 horsepower. With the proposed transmountain diversions (pp. 58-59) the 50 per cent power would be reduced to 3,630 horsepower. The possible completion of the Green Mountain Canal (p. 125) might also reduce slightly the water supply available for 50 per cent of the time.

Green Mountain site (9DB 5).- The heaviest fall below Dillon is in Green Mountain Canyon, where the river descends 250 feet in 3 miles. It is possible to construct a high dam at this point which would store water for the development of power not only on the Blue River but also on the Colorado River. A discussion of a reservoir at this site (9DB 2; see p. 83) indicates that it would not be of as much value in developing power on the Colorado River as other available sites, and for that reason the power value of this site is considered here, without storage. From a diversion dam at the head of the canyon, in the NE. $1 / 4$ NW. $1 / 4$ sec. 15, T. 2 S., R. 80 W., a pressure line 3 miles long through the canyon to its mouth, in the NW. 1/4 SW. 1/4 sec. 34, T. 1 S., R. 80 W., would have a static head of 250 feet. The discharges for 90 per cent and 50 per cent of the time are 130 and 254 second-feet, respectively, which would develop 2,600 and 5,080 horsepower. With the proposed transmountain diversions (pp. 58-59) the 50 per cent power would be reduced to 4,840 horsepower. The possible completion of the Green Mountain Canal (p. 125) might also reduce slightly the water supply available for 50 per cent of the time.

Although storage in the Green Mountain Reservoir is not considered, the presence of several small mountain lakes on Slate, Brush, Black Lake, and 
Cataract Creeks might make it possible to store the run-off from about 20 square miles to increase the 90 per cent flow at this site. As no surveys of these sites have been made, it is impossible to make a detailed estimate of increased power that might be available.

Below Green Mountain the slope of the river is too slight to be of any considerable value.

Summary of undeveloped sites on Blue River

\begin{tabular}{|c|c|c|c|c|c|c|c|c|}
\hline \multirow{4}{*}{ Site } & \multirow{4}{*}{$\begin{array}{l}\text { Static } \\
\text { head } \\
\text { (feet) }\end{array}$} & \multirow{4}{*}{$\begin{array}{c}\text { Length } \\
\text { of con- } \\
\text { duit } \\
\text { (miles) }\end{array}$} & \multicolumn{6}{|c|}{ Run-off and available power } \\
\hline & & & \multicolumn{2}{|c|}{$\begin{array}{l}90 \text { per cent of } \\
\text { the time }\end{array}$} & \multicolumn{4}{|c|}{50 per cent of the time } \\
\hline & & & \multirow{2}{*}{$\begin{array}{c}\text { Second- } \\
\text { feet }\end{array}$} & \multirow{2}{*}{$\begin{array}{l}\text { Horse- } \\
\text { power }\end{array}$} & \multicolumn{2}{|c|}{$\begin{array}{c}\text { Without diver- } \\
\text { sion }\end{array}$} & \multicolumn{2}{|c|}{ With diversion } \\
\hline & & & & & $\begin{array}{l}\text { Second- } \\
\text { feet }\end{array}$ & $\begin{array}{l}\text { Horse- } \\
\text { power }\end{array}$ & $\begin{array}{c}\text { Second- } \\
\text { feet }\end{array}$ & $\begin{array}{l}\text { Horse- } \\
\text { power }\end{array}$ \\
\hline \multirow[t]{2}{*}{$\begin{array}{l}\text { Straight Creek } \\
\text { Willow Creek } \\
\text { Rock Creek } \\
\text { Acorn Creek } \\
\text { Green Mountain }\end{array}$} & $\begin{array}{l}120 \\
252 \\
173 \\
235 \\
250 \\
\end{array}$ & \begin{tabular}{l|l|}
3 \\
5 \\
5 \\
$41 / 2$ \\
3 \\
\end{tabular} & $\begin{array}{r}74 \\
87 \\
105 \\
109 \\
130 \\
\end{array}$ & $\begin{array}{r}710 \\
1,750 \\
1,450 \\
2,050 \\
2,600 \\
\end{array}$ & $\begin{array}{l}173 \\
189 \\
220 \\
228 \\
254 \\
\end{array}$ & $\begin{array}{l}1,660 \\
3,810 \\
3,040 \\
4,290 \\
\mathbf{5}, 080 \\
\end{array}$ & $\begin{array}{l}102 \\
132 \\
182 \\
193 \\
242 \\
\end{array}$ & $\begin{array}{r}979 \\
2,660 \\
2,520 \\
3,630 \\
4,840 \\
\end{array}$ \\
\hline & & & & 8,560 & 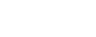 & 17,900 & $|\ldots . . .|$. & 14,600 \\
\hline
\end{tabular}

RAGLR RIVER

A preliminary reconnaissance power survey of the Eagle River from Redcliff to the mouth has been made by the Geological Survey for the purpose of determining the power value of public lands adjacent to the river, and from the report of that survey ${ }^{49}$ and the Leadville topographic map for the section above Redcliff the following table has been compiled:

\section{Altitudes and distances along Eagle River from Mitchell to mouth}

\begin{tabular}{|c|c|c|c|c|c|}
\hline \multirow{2}{*}{ Point on river } & \multicolumn{2}{|c|}{ Distance (miles) } & \multirow{2}{*}{$\begin{array}{c}\text { Altitude } \\
\text { above } \\
\text { sea level } \\
\text { (feet) }\end{array}$} & \multicolumn{2}{|c|}{ Descent (feet) } \\
\hline & $\begin{array}{c}\text { From } \\
\text { Mitchell }\end{array}$ & $\begin{array}{l}\text { Point to } \\
\text { point }\end{array}$ & & Total & Per mile \\
\hline $\begin{array}{l}\text { Mitchell } \\
\text { Opper end of Eagle Park } \\
\text { Pando } \\
\text { Redecliff (Homestake Creek) } \\
\text { Mouth of Eagle River Canyon. } \\
\text { Minturn } \\
\text { Mouth of Gore Creek } \\
\text { Avon } \\
\text { Edwards } \\
\text { Wolcott } \\
\text { Mouth of Red Canyon } \\
\text { Mouth of Brush Creek } \\
\text { Mouth of Gypsum Creek } \\
\text { Colorado River }\end{array}$ & $\begin{array}{r}1.5 \\
4.7 \\
9.0 \\
12.9 \\
17.5 \\
18.8 \\
23.8 \\
27.5 \\
35.0 \\
40.3 \\
46.8 \\
53.8 \\
64.0\end{array}$ & $\begin{array}{r}1.5 \\
3.2 \\
4.3 \\
3.9 \\
4.6 \\
1.3 \\
5.0 \\
3.7 \\
7.5 \\
5.3 \\
6.5 \\
7.0 \\
10.2\end{array}$ & $\begin{array}{l}9,700 \\
9,400 \\
9,100 \\
8,554 \\
8,144 \\
7,785 \\
7,707 \\
7,400 \\
7,150 \\
6,938 \\
6,750 \\
6,530 \\
6,287 \\
6,115\end{array}$ & $\begin{array}{r}300 \\
300 \\
546 \\
410 \\
359 \\
78 \\
307 \\
250 \\
212 \\
188 \\
220 \\
243 \\
172\end{array}$ & $\begin{array}{r}200 \\
04 \\
127 \\
105 \\
77 \\
60 \\
61 \\
68 \\
28 \\
35 \\
34 \\
35 \\
17\end{array}$ \\
\hline
\end{tabular}

-Approximate only; subject to correction based on more detailed surveys.

1) Jones, E. E., unpublished report on power resources of the Eagle River, U. S. Geol. Survey, 1825. 
The main line of the Denver \& Rio Grande Western Railroad follows the entire river, and the small valleys that alternate with the canyons are extensively irrigated. To avoid conflict, therefore, power development must be limited to low diversion dams and relatively long conduits to utilize the available head.

Although the heaviest fall is above the mouth of Homestake Creek, at Redcliff, the discharge of the Eagle River above that point is too small to make power development there feasible. Through that portion of the Eagle River Canyon extending for a distance of 4 miles below Redcliff the fall and discharge are sufficient, but the presence of a railroad track on each bank makes it almost impossible to develop power without interference with the railroad. Below Gypsum the average fall is only 17 feet to the mile, which is too slight for power development. Accordingly, the power sections of the river may be considered to lie below the canyon and above Gypsum, where five sites have been selected. These sites comprise 1,379 feet of the total fall of 1,857 feet within that section. In view of the severe winter climate of the upper part of the Eagle River it is believed that covered conduits will be required for the three upper sites. For the two lower sites, however, the milder winter temperature and the character of the topography are favorable for open ditches.

The estimates of available water supply are based on the combined records of the Eagle River and Turkey and Homestake Creeks at Redcliff (1911-1925), the Eagle River at Eagle (1911-1924), and the Eagle River at Gypsum (1905-1909). The additional areas in the Eagle River Basin susceptible to irrigation are so small that the water supply required will have no effect on the 90 per cent flow for power and but little effect on the 50 per cent flow.

Minturn site (9DD 1).-From a diversion dam at the mouth of the canyon, in the NW. $1 / 4$ sec. 13, T. 6 S., R. 81 W. sixth principal meridian, $4 \frac{1}{2}$ miles of conduit along the steep slope north of the Eagle River leading to the power-house site at Minturn would develop a static head of 359 feet. A crossing of Two Elk Creek would be required. The railroad is on the same side, and along the lower end is a highway. The discharges for 90 per cent and 50 per cent of the time are 32 and 75 second-feet, respectively, which would develop 919 and 2,150 horsepower.

Avon site (9DD 2).-Gore Creek enters the Eagle River 1.3 miles below Minturn, in the NW. $1 / 4$ sec. 22 , T. 5 S., R. 81 W., and as its low-water discharge is at least 12 second-feet, the diversion point is placed just below its mouth. A conduit on the north side of the river leading to the power house at Avon, in the NW. $1 / 4$ sec. 12 , T. 5 S., R. 81 W., would be 5 miles long and require crossings at two small streams. For the first mile the conduit would run along a steep, rocky canyon side, but beyond that it would cross a gravel bench. The railroad lies on the same side of the river, and there is a highway on the opposite side. The static head created would be 307 feet. The discharges for 90 per cent and 50 per cent of the time are 48 and 105 second-feet, respectively, which would develop 1,180 and 2,580 horsepower.

Edwards site (9DD 3). - The proposed diversion point is just below the tailrace for the Avon site, in the NW. 1/4 sec. 12, T. 5 S., R. 81 W. A conduit on the 
north side of the river would run along the side of a gently sloping valley in easily excavated material. Ending at the power-house site near Edwards, in the NE. $1 / 4$ sec. 5, T. 5 S., R. 82 W., its length would be 4 miles, crossing two small drainage channels. The railroad occupies the north side of the river, and the highway the south side. The static head created would be 250 feet. The discharges for 90 per cent and 50 per cent of the time are 53 and 119 second-feet, respectively, which would develop 1,060 and 2,380 horsepower.

Between Edwards and Red Canyon the river falls 400 feet in 12.8 miles. The total power in this section is 2,400 horsepower for 90 per cent of the time and 5,340 horsepower for 50 per cent of the time. It is believed that the length of conduit required to develop this power renders this site less feasible than the other site described.

Brush Creek site (9DD 4). - From a diversion point at the mouth of Red Canyon, in the SE. $1 / 4$ sec. 24, T. 4 S., R. 84 W., to the power-house site at the mouth of Brush Creek, in the NE. $1 / 4$ sec. 6, T. 5 S., R. 84 W., a conduit on the south side of the river would cross only one small tributary channel and would be $5 \frac{1}{2}$ miles long. Material for construction of a rock-fill diversion dam can be obtained from the sides of the canyon. The conduit would be located in easily excavated material. Both the railroad and the highway are on the opposite side of the river. The static head created would be 220 feet. The discharges for 90 per cent and 50 per cent of the time are 94 and 210 second-feet, respectively, which would develop 1,650 and 3,700 horsepower.

Gypsum Creek site (9DD 5).-Below Brush Creek the discharge of the Eagle River is considerably greater, as the winter discharge of Brush Creek is about 35 second-feet. The proposed diversion point is just below the mouth of Brush Creek, in the NE. 1/4 sec. 6, T. 5 S., R. 84 W. A conduit 6 miles long on the south side of the river, leading to the power house at the mouth of Gypsum Creek, in Gypsum, would be constructed along a valley with gently sloping ides and cross three small tributary channels. The static head created would be 243 feet. The discharges for 90 per cent and 50 per cent of the time are 135 and 300 second-feet, respectively, which would develop 2,620 and 5,830 horsepower.

Summary of undeveloped sites on Eagle River

\begin{tabular}{|c|c|c|c|c|c|c|}
\hline \multirow{3}{*}{ Site } & \multirow{3}{*}{$\begin{array}{l}\text { Static } \\
\text { head } \\
\text { (feet) }\end{array}$} & \multirow{3}{*}{$\begin{array}{l}\text { Length } \\
\text { cf ccnduit } \\
\text { (miles) }\end{array}$} & \multicolumn{4}{|c|}{ Run-off and available power } \\
\hline & & & \multicolumn{2}{|c|}{$\begin{array}{l}90 \text { per cent of the } \\
\text { time }\end{array}$} & \multicolumn{2}{|c|}{50 per cent of the } \\
\hline & & & $\begin{array}{l}\text { Second- } \\
\text { feet }\end{array}$ & $\begin{array}{l}\text { Horse- } \\
\text { power }\end{array}$ & $\begin{array}{l}\text { Second- } \\
\text { feet }\end{array}$ & $\begin{array}{l}\text { Horse- } \\
\text { power }\end{array}$ \\
\hline \multirow[t]{2}{*}{$\begin{array}{l}\text { Minturn } \\
\text { A von } \\
\text { Edwards } \\
\text { Brush Creek } \\
\text { Gypsum Creek }\end{array}$} & $\begin{array}{l}359 \\
307 \\
250 \\
220 \\
243\end{array}$ & $\begin{array}{l}4.5 \\
5 \\
4 \\
5.5 \\
6\end{array}$ & $\begin{array}{r}32 \\
48 \\
53 \\
94 \\
135\end{array}$ & $\begin{array}{r}919 \\
1,180 \\
1,080 \\
1,650 \\
2,620\end{array}$ & $\begin{array}{r}75 \\
105 \\
119 \\
210 \\
300\end{array}$ & $\begin{array}{l}\mathbf{2}, 150 \\
2,580 \\
2,380 \\
3,700 \\
\mathbf{5}, 830\end{array}$ \\
\hline & 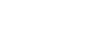 & 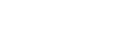 & 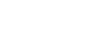 & 7,430 & 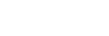 & 16,600 \\
\hline
\end{tabular}

If the proposed transmountain diversion from the Eagle River is made (p. 58), the only effect on power development will be a slight reduction in power for 50 per cent of the time.

A small reservoir site having a capacity of about 1,200 acre-feet exists on Homestake Creek just above the mouth at Redcliff. If 
this site were utilized to increase the low-water flow at the five power sites, the total power for 90 per cent of the time would be increased 2,200 horsepower.

\section{ROARING FORK}

A preliminary reconnaissance power survey of the Roaring Fork from Snowmass to the mouth has been made by the Geological Survey ${ }^{50}$ for the purpose of determining the power value of public lands adjacent to the river, and the part of the river above Snowmass is shown on the Mount Jackson topographic map. From these sources the following table has been compiled:

Altitudes and distances along Roaring Fork from Independence to mouth

\begin{tabular}{|c|c|c|c|c|c|}
\hline \multirow[b]{2}{*}{ Point on river } & \multicolumn{2}{|c|}{ Distance (miles) } & \multirow{2}{*}{$\begin{array}{l}\text { Altitude } \\
\text { above } \\
\text { sea level } \\
\text { (feet) a }\end{array}$} & \multicolumn{2}{|c|}{ Descent (feet) } \\
\hline & $\begin{array}{c}\text { From } \\
\text { Inde- } \\
\text { pendence }\end{array}$ & $\begin{array}{c}\text { Point to } \\
\text { point }\end{array}$ & & Total & $\begin{array}{l}\text { Per } \\
\text { mile }\end{array}$ \\
\hline 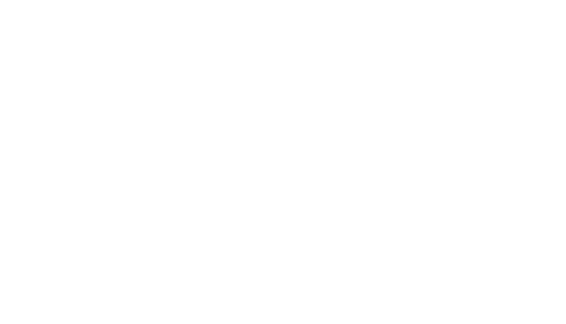 & $\begin{array}{r}2.0 \\
5.9 \\
11.2 \\
14.5 \\
17.3 \\
23.7 \\
30.2 \\
34.0 \\
37.2 \\
42.1 \\
46.8 \\
50.7 \\
56.5 \\
59.2\end{array}$ & $\begin{array}{l}2.0 \\
3.9 \\
5.3 \\
3.3 \\
2.8 \\
6.4 \\
6.5 \\
3.8 \\
3.2 \\
4.9 \\
4.7 \\
3.9 \\
5.8 \\
2.7\end{array}$ & $\begin{array}{r}10,900 \\
10,500 \\
9,680 \\
8,200 \\
8,140 \\
7,735 \\
7,310 \\
6,860 \\
6,612 \\
6,468 \\
6,260 \\
6,056 \\
5,945 \\
5,796 \\
5,712\end{array}$ & $\begin{array}{r}400 \\
820 \\
1,480 \\
60 \\
405 \\
425 \\
450 \\
248 \\
144 \\
208 \\
204 \\
111 \\
149 \\
684\end{array}$ & $\begin{array}{r}200 \\
21 C \\
280 \\
1 \varepsilon \\
145 \\
67 \\
6 \AA \\
65 \\
45 \\
4 \AA \\
4 \hat{\varepsilon} \\
2 \xi \\
28 \\
31\end{array}$ \\
\hline
\end{tabular}

approximate only; subject to correction based on more detailed surveys.

$b 17$ feet of fall in the lowest section is utilized by the power plant of the Farmers Milling \& Power Co.

Above Lincoln Gulch the run-off is too small for power development, but below that point the discharge is sufficient to make the river of considerable value for that use, although there are no outstanding sites on the river. Because of the topography of the valley development will probably be accomplished by means of low diversion dams with conduits and penstocks leading to power house. At most. of the sites material for construction of the dam can be obtained near by. It appears probable that in general open conduits can be used. The presence of a State highway throughout the length of the valley and of a branch of the Denver \& Rio Grande Western Railroad between Aspen and Glenwood Springs makes the power sites very accessible.

Eleven sites have been selected, which will develop practically the entire head from Lincoln Gulch above Aspen to the mouth. The estimates of available water supply are based on the records of the Roaring Fork at Aspen (1911-1921) and at Glenwood Springs

\footnotetext{
50 Jones, E. E., unpublished report on power resources of the Roaring Fork, U. S. Geol. Survey, 1925
} 
(1906-1927). The additional areas in the Roaring Fork Basin susceptible of irrigation are so small that the water supply required for them will have no effect on the 90 per cent flow and but little effect on the 50 per cent flow.

Lincoln Gulch site (9DF 1).-From Lincoln Gulch to the mouth of Difficult Creek the river is in a canyon. From a diversion dam just below the mouth of Lincoln Gulch, in sec. 6, T. 11 S., R. 83 W. sixth principal meridian, a conduit 4 miles long on the north side of the river leading to the power house at the mouth of Difficult Creek, in sec. 33, T. 10 S., R. 84 W., would create a static head of 1,490 feet. Crossings for three minor tributaries would be required. The highway is on this side of the river. The discharges for 90 per cent and 50 per cent of the time are 18 and 32 second-feet, respectively, which would develop 2,150 and 3,810 horsepower.

Aspen site (9DF 2).-The point of diversion for the Aspen site is 1 mile above Aspen, in sec. 18, T. 10 S., R. 84 W., at the lower end of a narrow valley which is the site of the proposed Aspen Reservoir No. $1^{\prime}$ (p. 85). A conduit 4 miles in length along the mountain slope northeast of Aspen, leading to the power house at the mouth of Castle Creek, in the SW. 1/4 sec. 1, T. $10 \mathrm{~S} .$, R. 85 W., would require a crossing at Hunter Creek. It would develop a static head of 405 feet. Being on the outskirts of Aspen, this site is very accessible. The 90 per cent and 50 per cent discharges are 29 and 55 second-feet, respectively, which would develop 940 and 1,780 horsepower.

Castle Creek site (9DF 3).-From a diversion point just below Castle Creek, in the SW. $1 / 4$ sec. 1, T. $10 \mathrm{~S}$., R. $85 \mathrm{~W}$., a conduit about 6 miles long to a powerhouse site at the mouth of Woody Creek, in the SW. $1 / 4$ sec. 9 , T. 9 S., R. 85 W., would create a static head of 425 feet. If constructed along the east side of the river a crossing under the Denver \& Rio Grande Western Railroad would be required, but no tributary streams would be encountered. The highway is also on the east side of the river. The discharges for 90 per cent and 50 per cent of the time are 62 and 116 second-feet, respectively, which would develop 2,110 and 3,940 horsepower.

Woody Creek site (9DF 4).-For a distance of 3 miles below Woody Creek the Roaring Fork flows through a wide valley, which narrows to a canyon that extends for another 3 miles to the mouth of Snowmass Creek. From a diversion dam just below Woody Creek, in the SW. $1 / 4$ sec. 9, T. 9 S., R. 85 W., a conduit could be constructed along either side of the river. The west side appears preferable, because at the expense of less than 1 mile of additional length the necessity of crossing a railroad, a highway, and three tributary streams would be eliminated. The static head created would be 450 feet. The discharges for 90 per cent and 50 per cent of the time are 102 and 190 second-feet, respectively, which would develop 3,670 and 6,840 horsepower.

Snowmass Creek site (9DF 5).-From a diversion dam in the NW. $1 / 4$ sec. 27, T. 8 S., R. 86 W., to a power-house site in the SE. 1/4 sec. 7, T. 8 S., R. 86 W., just below Fryingpan Creek, a conduit 5 miles long on the east side of the river would run along the base of the mountain in easily excavated material. Crossings would be required for the Denver \& Rio Grande Western Railroad, the State highway, Fryingpan Creek; and one minor tributary. The static head developed would be 248 feet. The discharges for 90 per cent and 50 per cent of the time are 140 and 260 second-feet, respectively, which would develop 2,880 and 5,160 horsepower.

Basalt site (9DF 6) -From a diversion dam in the SE. $1 / 4$ sec. 7, T. 8 S., R. 86 W., at Basalt, just below the tailrace for the Snowmass site, a conduit 3 miles long on the east side of the river to a point in the SW. $1 / 4$ sec. 11, T. $8 \mathrm{~S}$., R. $87 \mathrm{~W}$., 
would create a static head of 132 feet. For the first mile the location of the conduit would be along a steep mountain side, involving heavy excavation, but the remainder of the distance would offer no difficulty. No crossings would be required. The State highway is on the same side of the river. The discharges for 90 per cent and 50 per cent of the time are 223 and 416 second-feet, respectively, which would develop 2,350 and 4,390 horsepower.

Emma site (9DF 7).-At a point 1 mile west of Emma, just below the tailrace for the Basalt site, in the $\mathrm{SW} .1 / 4$ sec. 11, T. $8 \mathrm{~S} ., \mathrm{R} .87 \mathrm{~W}$., is the proposed diversion point for the Emma site. A conduit 5 miles long on the west side of the river to a power-house site in the SW. $1 / 4$ sec. 31 , T. $7 \mathrm{~S} ., \mathrm{R} .87 \mathrm{~W}$, would develop a static head of 222 feet. Material for the dam can be obtained half a mile northeast of the dam site. For the first 3 miles the conduit would run across the level valley, but the last 2 miles would be along a steep mountain side, all in easily excavated material. The railroad and highway are on the same side of the river, and crossings would be required for them and for several minor tributaries. The discharges for 90 per cent and 50 per cent of the time are 239 and 443 second-feet, respectively, which would develop 4,240 and 7,870 horsepower.

Carbondale site (9DF 8).-The diversion point proposed for the Carbondale site is just below the tailrace for the Emma site, in the SW. $1 / 4$ sec. 31, T. $7 \mathrm{~S}$., R. $87 \mathrm{~W}$., 3 miles east of Carbondale, A conduit 5 miles long on the east side of the river leading to a power-house site in the NW. $1 / 4$ sec. 28, T. $7 \mathrm{~S}$., R. $88 \mathrm{~W}$., a short distance below the mouth of the Crystal River, would create a static head of 202 feet. The conduit would run across the level valley for 3 miles and along the mountain side for the remaining distance, all in easily excavated material. Several minor tributaries would have to be crossed. The highway lies on the same side of the river as the suggested conduit, but the railroad is on the other side. The discharges for 90 per cent and 50 per cent of the time are 249 and 462 second-feet, respectively, developing 4,020 and 7,470 horsepower.

Crystal River site (9DF 9).-From the proposed point of diversion for the Crystal River site, just below the tailrace of the Carbondale site, in the NW. $1 / 4$ sec. 28 , T. 7 S., R. 88 W., half a mile below the mouth of the Crystal River, a conduit 5 miles long on the east side of the river leading to a power-house site in the NW. $1 / 4$ sec. 1, T. 7 S., R. 89 W., would develop a static head of 149 feet. The conduit would lie across the valley floor in easily excavated material. Two crossings of the railroad would be required, in addition to a crossing at Cattle Creek. The highway is also on this side of the river. The discharges for 90 per cent and 50 per cent of the time are 353 and 655 second-feet, respectively, which would develop 4,210 and 7,810 horsepower.

Red Canyon site (9DF 10). - The proposed diversion point for the Red Canyon site is 2 miles southeast of the mouth of Red Canyon and just below the tailrace for the Crystal River site, in the NW. 1/4 sec. 1, T. 7 S., R. 89 W. A conduit 4 miles long on the east side of the river to a power-house site in the SW. $1 / 4$ sec. 22, T. 6 S., R. 89 W. (unsurveyed), opposite Cardiff, would create a static head of 103 feet. The conduit would lie along the valley floor in easily excavated material. Two crossings of the railroad would be required, in addition to a crossing at Red Canyon. The highway is also on this side of the river. The discharges for 90 per cent and 50 per cent of the time are 384 and 712 secondfeet, respectively, which would develop 3,160 and 5,870 horsepower.

Cardiff site (9DF 11). - From a diversion point half a mile northwest of Cardiff, in the SW. $1 / 4$ sec. 22 , T. 6 S., R. 89 W. (unsurveyed), a conduit 3 miles long on the west side of the river leading to a power-house site near the mouth, in Glenwood Springs, would create a static head of 94 feet. The conduit would run along the edge of the valley in easily excavated material, except in the last 
mile, where hillside excavation would be necessary. Crossings at Threemile Creek and five minor tributaries would be required. Within this section the Farmers Milling \& Power Co. develops 17 feet of head with a diversion of about 60 second-feet. After deducting this amount, the discharges for 90 per cent and 50 per cent of the time available for the Cardiff project are 340 and 683 secondfeet, respectively, which would develop 2,560 and 5,140 horsepower.

Summary of undeveloped sites on Roaring Fork

\begin{tabular}{|c|c|c|c|c|c|c|}
\hline \multirow{3}{*}{ Site } & \multirow{3}{*}{$\begin{array}{l}\text { Static } \\
\text { head } \\
\text { (feet) }\end{array}$} & \multirow{3}{*}{$\begin{array}{l}\text { Length } \\
\text { of } \\
\text { conduit } \\
\text { (miles) }\end{array}$} & \multicolumn{4}{|c|}{ Run-off and available power } \\
\hline & & & \multicolumn{2}{|c|}{$\begin{array}{l}90 \text { per cent of the } \\
\text { time }\end{array}$} & \multicolumn{2}{|c|}{50 per cent of the } \\
\hline & & & $\begin{array}{l}\text { Second- } \\
\text { feet }\end{array}$ & $\begin{array}{l}\text { Horse- } \\
\text { power }\end{array}$ & $\begin{array}{l}\text { Second- } \\
\text { feet }\end{array}$ & $\begin{array}{l}\text { Horse- } \\
\text { powrer }\end{array}$ \\
\hline $\begin{array}{l}\text { Lincoln Gulch } \\
\text { Aspen } \\
\text { Castle Creek } \\
\text { Woody Creek } \\
\text { Snowmass Creek } \\
\text { Basalt. } \\
\text { Emna } \\
\text { Carbondale } \\
\text { Crystal River } \\
\text { Red Canyon } \\
\text { Cardiffe }\end{array}$ & $\begin{array}{r}1,490 \\
405 \\
425 \\
450 \\
248 \\
132 \\
222 \\
202 \\
149 \\
103 \\
94\end{array}$ & $\begin{array}{l}4 \\
4 \\
6 \\
6.5 \\
5 \\
3 \\
5 \\
5 \\
5 \\
4 \\
\mathbf{3}\end{array}$ & $\begin{array}{r}18 \\
29 \\
62 \\
102 \\
140 \\
223 \\
239 \\
249 \\
353 \\
384 \\
\mathbf{3 4 0}\end{array}$ & $\begin{array}{l}2,150 \\
940 \\
2,110 \\
3,670 \\
2,880 \\
2,350 \\
4,240 \\
4,020 \\
4,210 \\
3,160 \\
2,560\end{array}$ & $\begin{array}{r}32 \\
55 \\
116 \\
190 \\
260 \\
416 \\
443 \\
462 \\
655 \\
712 \\
-683\end{array}$ & $\begin{array}{l}3,810 \\
1,780 \\
3,940 \\
6,840 \\
5,160 \\
4,300 \\
7,870 \\
7,470 \\
7,810 \\
5,870 \\
5,140\end{array}$ \\
\hline Total.. & ...... & ..... & - & 32,300 & - & 60,100 \\
\hline
\end{tabular}

- 60 second-feet deducted for rights of Farmers Milling \& Power Co.

The Aspen No. 1 reservoir site affords an opportunity for storage in connection with power development, and a discussion of the use of that reservoir (p. 86) shows that it would increase the total capacity of the 10 power sites below Aspen 12,600 horsepower for 90 per cent of the time and 9,500 horsepower for 50 per cent of the time.

\section{GUNNISON RIVER}

Altitudes and distances along the Gunnison River from its headwater stream, the Taylor River, to its mouth are available from surveys made at different times and referred to different datum planes. Along the Taylor River the altitudes are based on a topographic map and levels along the Taylor River, those between Illinois Creek and Almont being only approximate. From the junction of the Taylor and East Rivers to form the Gunnison at Almont, to the mouth of Cimarron Creek, and from the mouth of Uncompahgre River to the mouth of the Gunnison River, at Grand Junction, altitudes and distances are available from the profile survey of the Denver \& Rio Grande Western Railroad, which parallels the river throughout those sections. The intermediate section is covered by the topographic map of the Uncompahgre project surveyed by the Bureau of Reclamation. By means of overlapping profiles, the altitudes have been reduced to the same datum. The following table shows the adjusted results of these various surveys: 
Altitudes and distances along Taylor and Gunnison Rivers from Bowman Creek to mouth

\begin{tabular}{|c|c|c|c|c|c|}
\hline \multirow[b]{2}{*}{ Point on river } & \multicolumn{2}{|c|}{ Distance (miles) } & \multirow{2}{*}{$\begin{array}{c}\text { Altitude } \\
\text { above } \\
\text { sea level } \\
\text { (feet) }\end{array}$} & \multicolumn{2}{|c|}{ Descent (feet) } \\
\hline & $\begin{array}{l}\text { From } \\
\text { Bowman } \\
\text { Creek }\end{array}$ & to point & & Total & $\underset{\text { mile }}{\text { Per }}$ \\
\hline Mouth of Bowman Creek & & & 16,050 & & \\
\hline Mouth of Italian Creek & & 6.4 & 9,770 & 280 & 44 \\
\hline Mouth of Red Mountain & 10.2 & 3.8 & 9,670 & 100 & 26 \\
\hline Mouth of Illinois Creek & 14.2 & 4. 0 & 9,420 & 250 & 18 \\
\hline $\begin{array}{l}\text { Entrance to canyon } \\
\text { Sec. } 25 \text {, T. } 14 \text { S., R. } 83 \text { W }\end{array}$ & $\begin{array}{l}19.3 \\
21.3\end{array}$ & $\begin{array}{l}5.1 \\
2.0\end{array}$ & $\begin{array}{l}9,145 \\
9,055\end{array}$ & $\begin{array}{r}275 \\
90\end{array}$ & $\begin{array}{l}54 \\
45\end{array}$ \\
\hline Mouth of Crystal Creek... & 27.5 & 6.2 & 8,740 & 315 & 51 \\
\hline $\begin{array}{l}\text { Spring Creek } \\
\text { Mouth of East River (Ä) }\end{array}$ & $\begin{array}{l}32.8 \\
39.4\end{array}$ & $\begin{array}{l}5.3 \\
6.6\end{array}$ & $\begin{array}{l}8,300 \\
8,000\end{array}$ & $\begin{array}{l}440 \\
300\end{array}$ & $\begin{array}{l}83 \\
46\end{array}$ \\
\hline Railroad btfdge in SW. $1 / 4 \mathrm{sec}$. 2 & $\begin{array}{l}39.4 \\
42.0\end{array}$ & $\begin{aligned} 0.0 \\
12.6\end{aligned}$ & 7,677 & 323 & $\begin{array}{l}40 \\
26\end{array}$ \\
\hline Railroad bridge in sw. $1 / 4$ sec. & 54.6 & 2.6 & 7,617 & 60 & 23 \\
\hline Railroad bridge near Keza & 61.2 & 6. 6 & 7,437 & 180 & 27 \\
\hline Mouth of East Elk River. & 66.2 & 5.0 & 7,377 & 60 & 12 \\
\hline & 69.2 & $\begin{array}{l}1.0 \\
2.0\end{array}$ & $\begin{array}{l}7,365 \\
7,347\end{array}$ & $\begin{array}{l}12 \\
18\end{array}$ & $\begin{array}{r}12 \\
9\end{array}$ \\
\hline Mouth of Red Creek & 72.0 & 2.8 & 7,317 & $\begin{array}{l}30 \\
30\end{array}$ & 11 \\
\hline Mouth of Sapinero (Soap) Cree & $\begin{array}{l}74.0 \\
76.0\end{array}$ & $\begin{array}{l}2.5 \\
1.5\end{array}$ & 7,262 & 25 & $\begin{array}{l}12 \\
17\end{array}$ \\
\hline Mouth of Lake Fork & 78.0 & 2.0 & 7,215 & 47 & 23 \\
\hline Mouth of Curecanti Creek....... & 83.5 & 4.0 & 7,100 & 97 & 24 \\
\hline Railroad bridge in sec. $5, \mathrm{~T} .48$ & 91.5 & 8.0 & & & \\
\hline Mouth of Crystal Creek & 95.5 & 4.0 & $6,650 \pm$ & 152 & 38 \\
\hline East portal of Gunnison Tunne & 100.5 & 5.0 & $6,540 \pm$ & 110 & 22 \\
\hline Mouth of Red Rock Canyon & 111. 3 & 10.8 & 5,380 & 1,160 & 107 \\
\hline $\begin{array}{l}\text { NW. } 1 / 4 \mathrm{sec} .35, \mathrm{~T} .51 \mathrm{~N} ., \mathrm{R} .9 \mathrm{~W} \\
\text { Mouth of Crystal Creek }\end{array}$ & $\begin{array}{l}116.8 \\
120.0\end{array}$ & $\begin{array}{l}5.5 \\
3.2\end{array}$ & $\begin{array}{l}5,350 \\
5,305\end{array}$ & $\begin{array}{l}30 \\
45\end{array}$ & $\begin{array}{r}5 \\
14\end{array}$ \\
\hline Mouth of Smith Fork. & 124.4 & 4.4 & 5,240 & 85 & 15 \\
\hline Mouth of North Fork & 127.8 & 3.4 & 5,145 & 95 & 28 \\
\hline $\begin{array}{l}\text { SW. } 1 \text { 1/4 sec. 2, T. } 15 \text { S., R. } 94 \text { W } \\
\text { Highway bridge near Cory }\end{array}$ & $\begin{array}{l}130.9 \\
135.7\end{array}$ & $\begin{array}{l}3.1 \\
4.8\end{array}$ & $\begin{array}{l}5,100 \\
5,040\end{array}$ & $\begin{array}{l}45 \\
60\end{array}$ & $\begin{array}{l}15 \\
12\end{array}$ \\
\hline $\mathrm{SE} .1 / 4 \mathrm{sec} .5, \mathrm{~T} .15 \mathrm{~S} ., \mathrm{R} .95 \mathrm{~W}$ & 141.7 & 6.0 & 4,980 & 60 & 10 \\
\hline $\begin{array}{l}\text { Mouth of Uncompahgre River } \\
\text { SE. } 1 / 4 \text { sec. } 16, \text { T. } 15 \text { S., R. } 96 \text { W }\end{array}$ & $\begin{array}{l}146.4 \\
150.8\end{array}$ & $\begin{array}{l}4.7 \\
4.4\end{array}$ & $\begin{array}{l}4,935 \\
4,910\end{array}$ & $\begin{array}{l}45 \\
25\end{array}$ & $\begin{array}{r}10 \\
6\end{array}$ \\
\hline NE. $1 / 4$ sec. 18, T. 15 S., R. 96 W & 153.3 & 2.5 & 4,888 & 22 & $\stackrel{9}{8}$ \\
\hline Mouth of Escalante Creek. & 160.3 & $\begin{array}{l}7.0 \\
3.0\end{array}$ & 4,842 & 13 & 4 \\
\hline Mouth of Kahnah Creek.. & 184.8 & $\begin{array}{r}1.0 \\
7.5\end{array}$ & $\begin{array}{l}4,711 \\
4,666\end{array}$ & $\begin{array}{r}131 \\
45\end{array}$ & 6 \\
\hline Colorado River...... & $\begin{array}{l}192.8 \\
201.3\end{array}$ & $\begin{array}{l}8.0 \\
8.5\end{array}$ & $\begin{array}{l}4,020 \\
4,550\end{array}$ & 56 & $\begin{array}{l}0 \\
7\end{array}$ \\
\hline
\end{tabular}

From Almont to the mouth of the river, at Grand Junction, the Gunnison Valley is traversed by branch lines of the Denver \& Rio Grande Western Railroad, except for a distance of 36 miles between Cimarron Creek and the North Fork. Any power development except between those points would consist of low diversion dams and long conduits to avoid conflict with the railroad.

In the absence of topographic maps or reconnaissance surveys, it is impossible to select definite sites for development, but from the available information regarding fall and discharge, it is apparent that the only section that can be considered for power is the 35-mile stretch between the mouth of the Lake Fork, in sec. 32 , T. 49 N., R. 4 W. New Mexico principal meridian, and the mouth of Red Rock Canyon, in sec. 17 , T. 50 N., R. 8 W., throughout which the river flows in the Black Canyon, one of the most inaccessible canyons in the Rocky Mountain region. 
Between the Lake Fork and Curecanti Creek, in sec. 3, T. 48 N., R. $5 \mathrm{~W}$., a distance of $51 / 2$ miles, the river falls 115 feet. With 90 per cent and 50 per cent discharges of 390 and 700 second-feet, respectively, the available power is 3,590 and 6,440 horsepower. From Curecanti Creek to Cimarron Creek, in sec. 5, T. 48 N., R. 6 W., a distance of $81 / 2$ miles, the fall is 300 feet. With 90 per cent and 50 per cent discharges of 410 and 740 second-feet, respectively, the available power is 9,840 and 17,800 horsepower. The rugged topography of the canyon walls would make conduits of the sizes required so expensive that the feasibility of power development in these sections is very doubtful.

As the railroad leaves the canyon at the mouth of Cimarron Creek, power development below that point would not be limited to the lowdiversion type. In the 9-mile section between Cimarron Creek and the east portal of the Gunnison Tunnel, in sec. 10, T. 49 N., R. 7 W., the total fall is about 260 feet. The discharges for 90 per cent and 50 per cent of the time are 450 and 760 second-feet, respectively, which would develop 9,360 and 15,800 horsepower. From the height of dam required it appears that the development can not be considered feasible. A low-head development would also prove unfeasible, owing to the heavy expense of conduit entailed by the nearly vertical walls of the canyon.

Between the east portal and the mouth of Red Rock Canyon the Gunnison falls about 1,160 feet in a distance of 10.8 miles. At infrequent intervals during the irrigation season the river below the tunnel becomes nearly dry, thus largely destroying the power value of this section. During the winter, the period of 90 per cent discharge at other power sites in the Colorado River Basin, 41,600 horsepower could be developed.

\section{TAYLOR RIVER}

Above the Taylor Park reservoir site (p. 90) both the discharge and the fall are too small to make power development feasible. Between the entrance to the canyon below the reservoir site and Almont, three sites have been selected, which develop most of the fall. The diversion point at each site is just below the tailrace location for the next site upstream. These sites can not be definitely located by land descriptions, owing to the uncertainty of the section corners. Owing to the low winter temperature in the Taylor River Basin closed conduits, probably pipe lines, will be required. The Taylor River sites are not as accessible as those on most of the other streams, as the nearest railroad point is Almont. A fair highway which lies in a canyon for the greater part of the distance between Almont and Taylor Park, runs along the east side of the Taylor River. 
The estimates of available water supply are based on the records of the Taylor River at Almont (1910-1927) and fragmentary records at several points near Taylor Park. These indicate that the unit run-off at Taylor Park and that at Almont are essentially the same. The short growing season and the small additional area susceptible to irrigation make it extremely improbable that the future water supply available for power will be depleted materially unless the Taylor Park Reservoir is constructed for the Uncompahgre project.

Crystal Creek site (9EA 1).-Between the proposed Taylor Park dam site and the mouth of Crystal Creek the river flows through a narrow canyon, which widens out somewhat on the east side of the river below Lottis Creek. The total fall is $\mathbf{4 0 0}$ feet in 8 miles. In the upper 2 miles in this section the fall is less than through the lower 6 miles, and for that reason the proposed diversion point is located about in sec. 25, T. 14 S., R. 83 W. sixth principal meridian. A conduit along the west side would run along steep mountain slopes and would require crossings for four minor tributaries. The highway occupies the opposite side of the canyon. The discharges for 90 per cent and 50 per cent of the time are 64 and 110 second-feet, respectively, which would develop 1,610 and 2,770 horsepower under the static head of 315 feet. The long conduit required may make this project unfeasible without storage.

Spring Creek site (9EA 2).-Between Crystal Creek and Spring Creek the canyon walls are close together, and in this section the river falls 440 feet in 5.3 miles. Material for a low diversion dam can be obtained at the dam site. The conduit beginning just below the mouth of Crystal Creek, in sec. 17, T. 15 S., R. $83 \mathrm{~W}$., could be located on the east side with no particular difficulties but would require crossing of three minor tributaries. It would create a static head of 440 feet. The discharges for 90 per cent and 50 per cent of the time are 90 and 155 second-feet, respectively, which would develop 3,170 and 5,460 horsepower.

Almont site (9EA 3).-From the mouth of Spring Creek to Almont the river has a total fall of 300 feet in 6.6 miles. For the first 2 miles the river flows through a valley half a mile in width, but for the remainder of the distance it flows through a canyon to its mouth at Almont. The location of the conduit on the east side would present no particular difficulties, as it would be in alluvial deposits and glacial drift. Crossings for two minor tributaries would be required. The discharges for 90 per cent and 50 per cent of the time are 94 and 161 second-feet, respectively, which would develop 2,260 and 3,860 horsepower.

Summary of undeveloped sites on Taylor River

\begin{tabular}{|c|c|c|c|c|c|c|}
\hline \multirow{3}{*}{ Site } & \multirow{3}{*}{$\begin{array}{l}\text { Static } \\
\text { head } \\
\text { (feet) }\end{array}$} & \multirow{3}{*}{$\begin{array}{l}\text { Length } \\
\text { of } \\
\text { conduit } \\
\text { (miles) }\end{array}$} & \multicolumn{4}{|c|}{ Run-off and available power } \\
\hline & & & \multicolumn{2}{|c|}{$\begin{array}{l}90 \text { per cent of } \\
\text { the time }\end{array}$} & \multicolumn{2}{|c|}{$\begin{array}{l}50 \text { per cent of } \\
\text { the time }\end{array}$} \\
\hline & & & $\begin{array}{l}\text { Second- } \\
\text { feet }\end{array}$ & $\begin{array}{l}\text { Horse- } \\
\text { power }\end{array}$ & Second- & $\begin{array}{l}\text { Horse- } \\
\text { power }\end{array}$ \\
\hline \multirow[t]{2}{*}{$\begin{array}{l}\text { Crystal Creek } \\
\text { Spring Creek } \\
\text { Almont }\end{array}$} & $\begin{array}{l}315 \\
440 \\
300\end{array}$ & $\begin{array}{l}6 \\
5 \\
6.6\end{array}$ & $\begin{array}{l}64 \\
90 \\
94\end{array}$ & $\begin{array}{l}1,610 \\
3,170 \\
2,260\end{array}$ & $\begin{array}{l}110 \\
155 \\
161\end{array}$ & $\begin{array}{l}\mathbf{2}, \mathbf{7 7 0} \\
\mathbf{5}, \mathbf{4 6 0} \\
\mathbf{3}, \mathbf{8 6 0}\end{array}$ \\
\hline & & & & 7,040 & $\ldots \ldots$ & 12,100 \\
\hline
\end{tabular}


The only reservoir site of considerable size on the Taylor River is the Taylor Park site, now reserved by the Bureau of Reclamation for the use of the Uncompahgre project. It is proposed to enlarge that project at some future date by an addition of 30,000 acres, and much of the water for the new area must be provided by storage in the reservoir. The gross duty of water on that project is low, being about 5 acre-feet to the acre, and this may require an ultimate storage supply of 150,000 acre-feet, which would make the reservoir of little value for power development. The value of this reservoir if used wholly for power is discussed on page 195; the increased power at the three power sites would be 13,100 horsepower for 90 per cent of the time and 13,400 horsepower for 50 per cent of the time.

\section{LAKE FORK}

No reconnaissance power survey of the Lake Fork has been made, but the altitudes and distances along that stream are available from topographic maps. These are presented in the following table:

Altitudes and distances along Lake Fork from Sherman to the mouth

\begin{tabular}{|c|c|c|c|c|c|}
\hline \multirow{2}{*}{ Point on river } & \multicolumn{2}{|c|}{ Distance (miles) } & \multirow{2}{*}{$\begin{array}{c}\text { Altitude } \\
\text { above } \\
\text { sea level } \\
\text { (feet) }\end{array}$} & \multicolumn{2}{|c|}{ Descent (feet) } \\
\hline & $\begin{array}{l}\text { From } \\
\text { Sherman }\end{array}$ & $\begin{array}{c}\text { Point to } \\
\text { point }\end{array}$ & & Total & Per mile \\
\hline $\begin{array}{l}\text { Sherman } \\
\text { Mouth of Wager Gulch } \\
\text { Head of Lake San Cristobail } \\
\text { Foot of Lake San Cristobal } \\
\text { Head of Argenta Falls } \\
\text { Foot of Argenta Falls } \\
\text { Head of Granite Falls } \\
\text { Tailrace Lake City power plant } \\
\text { Mouth of Henson Creek (Lake City) } \\
\text { Mouth of Independence Gulch } \\
\text { Youman } \\
\text { Mouth of Trout Creek } \\
\text { Gateview } \\
\text { Vanguard } \\
\text { Mouth of Lake Gulch }\end{array}$ & $\begin{array}{r}3.5 \\
9.2 \\
11.2 \\
11.6 \\
11.6 \\
13.9 \\
14.0 \\
15.2 \\
20.7 \\
26.2 \\
31.4 \\
36.8 \\
41.8 \\
44.5 \\
50.7\end{array}$ & $\begin{array}{r}3.5 \\
5.7 \\
2.0 \\
.4 \\
.0 \\
2.3 \\
.1 \\
1.2 \\
5.5 \\
5.5 \\
5.2 \\
5.4 \\
5.0 \\
2.7 \\
6.2\end{array}$ & $\begin{array}{l}9,550 \\
9,340 \\
8,997 \\
8,997 \\
8,970 \\
8,880 \\
8,775 \\
8 ; 683 \\
8,650 \\
8,450 \\
8,220 \\
8,010 \\
7,880 \\
7,550 \\
7,480 \\
7,215\end{array}$ & $\begin{array}{r}210 \\
343 \\
0 \\
27 \\
90 \\
105 \\
92 \\
33 \\
200 \\
230 \\
210 \\
130 \\
330 \\
70 \\
265\end{array}$ & $\begin{array}{r}60 \\
60 \\
0 \\
67 \\
0 \\
46 \\
-7 \\
27 \\
36 \\
42 \\
40 \\
24 \\
66 \\
26 \\
4\end{array}$ \\
\hline
\end{tabular}

From the topography and fall of the stream it is apparent that there are two power sites on the Lake Fork. The estimates of the available water supply for these sites are based on records of the Lake Fork at Lake City (1918-1924). The additional area susceptible of irrigation is so small that its development would not affect the water supply for power.

Lake San Cristobal site (9EC 1).-From Lake San Cristobal to the tailrace of the Lake City power plant (pp. 173-174) the Lake Fork has a total fall of 314 feet in a distance of $\mathbf{2 . 8}$ miles, concentrated chiefly at Argenta Falls, just below the lake, and at Granite Falls, just above the power house. The 92 feet at Granite Falls is utilized by the Lake City plant. A conduit could be located on the west side of the stream with little difficulty and would require no crossings of tributary streams. A State highway along this side makes the site readily 
accessible. With natural flow the discharges for 90 per cent and 50 per centof the time are 14 and 35 second-feet, respectively, developing 207 and 518 . horsepower under the total head of $\mathbf{3 1 4}$ feet.

Gateview site (9EC 2).-Half a mile below Gateview the Lake Fork enters a canyon, through which it flows to the mouth. Between the mouth of Indian Creek, in sec. 28 , T. 47 N., R. 3 W. New Mexico principal meridian, and Vanguard, a distance of about 5 miles, a conduit along the side of the canyon would encounter very rough topography in developing 330 feet of fall and would require two crossings at the railroad and two at minor tributary streams. There is no road along either side of the canyon. The discharges for 90 per cent and 50 per cent of the time are 48 and 117 second-feet, respectively, which would develop 1,270 and 3,090 horsepower.

Neither of the foregoing sites appears feasible without storage. A discussion of the use of Lake San Cristobal (p. 96) shows that the available power at the two sites here described would thereby be increased 4,620 horsepower for 90 per cent of the time and 4,840 horsepower for 50 per cent of the time.

\section{UNCOMPAHGRE RIVER}

Topographic maps cover the entire length of the Uncompahgre River, and from these the following table has been compiled:

\section{Altitudes and distances along Uncompahgre River from Lake Como to mouth}

\begin{tabular}{|c|c|c|c|c|c|}
\hline \multirow{2}{*}{ Point on river } & \multicolumn{2}{|c|}{ Distance( miles) } & \multirow{2}{*}{$\begin{array}{l}\text { Altitude } \\
\text { above } \\
\text { sea level } \\
\text { (feet) }\end{array}$} & \multicolumn{2}{|c|}{ Descent (feet) } \\
\hline & $\begin{array}{l}\text { From } \\
\text { Lake } \\
\text { Como }\end{array}$ & $\begin{array}{l}\text { Point } \\
\text { to point }\end{array}$ & & Total & $\begin{array}{c}\text { Per } \\
\text { mille }\end{array}$ \\
\hline Lake Como & & & 12,250 & & \\
\hline 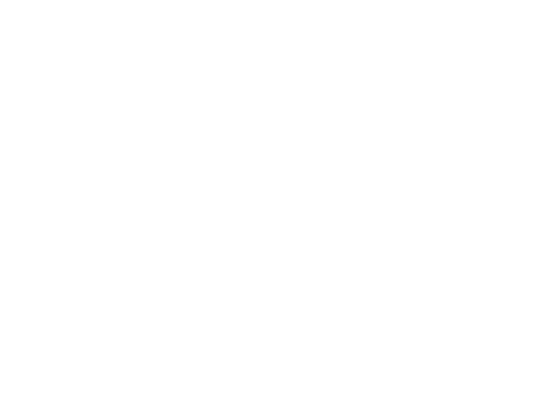 & $\begin{array}{r}1.8 \\
3.5 \\
5.7 \\
6.5 \\
8.1 \\
9.0 \\
10.7 \\
12.9 \\
15.4 \\
18.7 \\
22.9 \\
28.4 \\
34.9 \\
40.2 \\
47.1 \\
55.5 \\
63.3 \\
74.1 \\
85.1\end{array}$ & $\begin{array}{r}1.8 \\
1.7 \\
2.2 \\
.8 \\
1.6 \\
.9 \\
1.7 \\
2.2 \\
2.5 \\
3.3 \\
4.2 \\
5.5 \\
6.5 \\
5.3 \\
6.9 \\
8.4 \\
7.8 \\
10.8 \\
11.0\end{array}$ & $\begin{array}{r}11,000 \\
10,000 \\
8,490 \\
8,220 \\
7,780 \\
7,680 \\
7,575 \\
7,255 \\
7,100 \\
6,985 \\
6,800 \\
6,510 \\
6,200 \\
6,000 \\
5,790 \\
5,540 \\
5,350 \\
5,140 \\
4,935\end{array}$ & $\begin{array}{r}1,250 \\
1,000 \\
1,510 \\
270 \\
-440 \\
100 \\
105 \\
320 \\
155 \\
115 \\
185 \\
290 \\
310 \\
200 \\
210 \\
250 \\
190 \\
210 \\
205\end{array}$ & $\begin{array}{r}694 \\
388 \\
687 \\
338 \\
275 \\
111 \\
62 \\
145 \\
62 \\
35 \\
44 \\
53 \\
48 \\
38 \\
30 \\
30 \\
24 \\
19 \\
19\end{array}$ \\
\hline
\end{tabular}

- Entire fall utilized by Ouray plant (p. 174).

From a point a few miles above Montrose to the mouth the course of the Uncompahgre is so winding that its fall does not represent the general slope of the valley, which is 50 per cent greater. The section of river best suited to power development lies above Portland. Not only is this the section of heaviest fall, but it is above diversions 
for irrigation, which begin near that point. In this section are two power sites, which are made readily accessible by a State highway. The estimates of available water supply are based on the records of the Uncompahgre River at Ouray (1911-1925) and below Ouray (1913-1927).

Ouray site (9EF 1).-Between the mouth of Red Mountain Creek and Canyon Creek the Uncompahgre flows through a canyon, the lower part of 'which is a vertiable box canyon with vertical walls. Of the total fall in this section, amounting to 770 feet in $2 \frac{1}{2}$ miles, the lower 440 feet is utilized by the Ouray plant of the Western Colorado Power Co. (p. 174). The discharges for 90 per cent and 50 per cent of the time are 11 and 24 second-feet, respectively, which would develop 678 and 1,850 horsepower. It is evident that without storage the extension of the existing plant to develop the total head at this site would hardly be warranted.

Bachelor Switch site (9EF 2).-From a low diversion dam in Ouray, just below the tailrace of the Ouray plant, a conduit 5 miles long on the east side of the valley to Portland, in the NE. $1 / 4$ sec. 11, T. 44 N., R. 8 W. New Mexico principal meridian, would create a static head of 475 feet. The conduit location would present no difficulty. Crossings for Dexter Creek and small minor tributaries would be required. The discharges for 90 per cent and 50 per cent of the time are 25 and 50 second-feet, respectively, which would develop 950 and 1,900 horsepower. The length of conduit required would probably make this development unfeasible without storage.

The effect of storage at Ironton Park on power at these sites is discussed on page 98; the total 90 per cent and 50 per cent power would be increased 2,490 and 920 horsepower respectively.

DOLORES RIVER

Portions of the Dolores River are shown on the topographic maps of the Telluride, Rico, and Paradox Valley quadrangles, and a reconnaissance survey of the river from Paradox Valley to the mouth has been made. ${ }^{51}$ From these sources, together with approximate altitudes of the river between Bear Creek and the Dolores dam site based on the Rio Grande Southern Railroad levels, the following table has been compiled:

11 Jones, E. E., unpublished report on power resources of the Dolores River, U. S. Geol. Survey, 1925. 
Altitudes and distances along Dolores River from Barlow Creek to mouth

\begin{tabular}{|c|c|c|c|c|c|}
\hline \multirow{2}{*}{ Point on river } & \multicolumn{2}{|c|}{ Distance (miles) } & \multirow{2}{*}{$\begin{array}{c}\text { Altitude } \\
\text { above } \\
\text { sea level } \\
\text { (feet) }\end{array}$} & \multicolumn{2}{|c|}{ Descent (feet) } \\
\hline & $\begin{array}{c}\text { From } \\
\text { Barlow } \\
\text { Creok }\end{array}$ & $\begin{array}{l}\text { Point to } \\
\text { point }\end{array}$ & & Total & $\begin{array}{l}\text { Per } \\
\text { mille }\end{array}$ \\
\hline 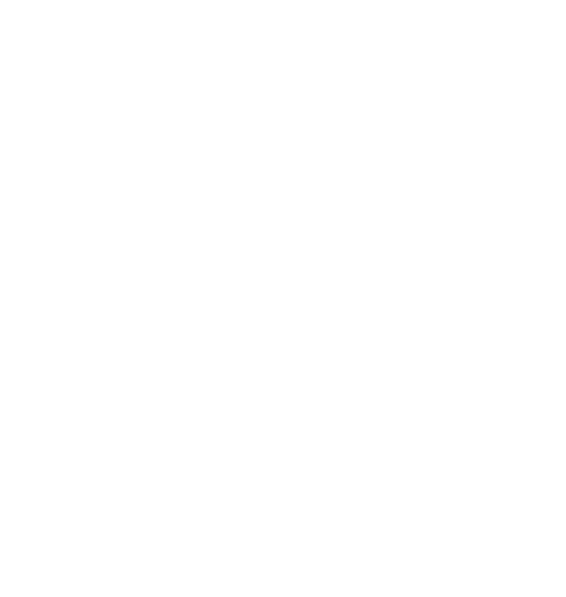 & $\begin{array}{r}3.1 \\
7.1 \\
10.1 \\
14.6 \\
20.9 \\
28.1 \\
37.0 \\
43.0 \\
53.0 \\
104.0 \\
114.5 \\
120.0 \\
126.5 \\
142.0 \\
150.5 \\
157.5 \\
168.2 \\
168.9 \\
177.6 \\
187.9 \\
195.7 \\
200.7 \\
207.2 \\
208.3 \\
211.0 \\
220.5 \\
229.5\end{array}$ & $\begin{array}{r}3.1 \\
4.0 \\
3.0 \\
4.5 \\
6.3 \\
7.2 \\
8.9 \\
6.0 \\
10.0 \\
51.0 \\
10.5 \\
5.5 \\
6.5 \\
15.5 \\
8.5 \\
7.0 \\
10.7 \\
.7 \\
8.7 \\
10.3 \\
7.8 \\
5.0 \\
6.5 \\
1.1 \\
2.7 \\
9.5 \\
9.0\end{array}$ & $\begin{array}{l}9,615 \\
9,070 \\
8,700 \\
8,520 \\
8,280 \\
7,900 \\
7,480 \\
7,140 \\
6,945 \\
6,715 \\
5,510 \\
5,390 \\
5,330 \\
5,260 \\
5,090 \\
5,000 \\
4,962 \\
4,850 \\
4,800 \\
4,742 \\
4,682 \\
4,650 \\
4,558 \\
4,450 \\
4,364 \\
4,200 \\
4,160 \\
4,090\end{array}$ & $\begin{array}{r}545 \\
370 \\
180 \\
240 \\
380 \\
420 \\
340 \\
195 \\
230 \\
1,205 \\
120 \\
60 \\
70 \\
170 \\
90 \\
38 \\
112 \\
50 \\
58 \\
60 \\
32 \\
92 \\
108 \\
86 \\
164 \\
40 \\
70\end{array}$ & $\begin{array}{r}160 \\
93 \\
60 \\
53 \\
60 \\
58 \\
38 \\
33 \\
23 \\
24 \\
12 \\
11 \\
11 \\
11 \\
11 \\
5 \\
10 \\
72 \\
7 \\
6 \\
4 \\
18 \\
17 \\
78 \\
61 \\
4 \\
8\end{array}$ \\
\hline
\end{tabular}

Above the town of Dolores the discharge of the river is too small to be of value for water power, and between Dolores and the mouth of the San Miguel River the fall is too slight. Below the San Miguel the Dolores flows through a narrow canyon for 24 miles, to a point 1 mile above Bull Canyon. - In this section the fall is 198 feet. A dam to utilize the entire fall at the lower end of the section would have a crest length of about 1,000 feet. The discharges for 90 per cent and 50 per cent of the time are 128 and 250 second-feet, respectively, which would develop 2,030 and 3,960 horsepower. These capacities are too small for the size of dam required. In addition it would be necessary to relocate the State highway through the entire section. This site is not considered feasible.

Below Bull Canyon the canyon widens to such an extent that a high dam to develop the fall would not be feasible except near the mouth of the river; where the canyon again contracts. Also, except in a 5-mile section at the Colorado-Utah line, the slope is too small to make development feasible by means of a low dam and conduit. The estimates of available water supply in these two sections are based on a combination of the records for the Dolores River at Bedrock (1918-1922) and the San Miguel River at Naturita (1918-1927), to which have been added relatively small quantities representing the increase in run-off below the two gaging stations. If the proposed irrigation projects are constructed, the water supply will be so depleted as to destroy very largely the value of these power sites. 
Colorado-Utah line site (9DK 1).-Beginning in the NE. $1 / 4$ NE. $1 / 4$ sec. 21 , T. 15 S., R. $104 \mathrm{~W}$. sixth principal meridian, at a point 1.9 miles above the State line, the Dolores River has a fall of 265 feet in 5 miles, and a conduit on the south side of the river leading to a power house in the center of the $\mathrm{SW} .1 / 4 \mathrm{sec} .6, \mathrm{~T}$. 24 S., R. 26 E. Salt Lake principal meridian, would create a static head of that amount. Material for the construction of a low diversion dam is available within a quarter of a mile of the dam site. The conduit, which would probably be an open canal, could be constructed without special difficulty and would require no crossings of tributary streams. A State highway 45 miles long from Grand Junction to Gateview, 6 miles above the proposed diversion, and a fair road on the north side of the river to that point make the project accessible to trucks. The nearest railroad station is Grand Junction. The discharges for 90 per cent and 50 per cent of the time are 134 and 255 second-feet, respectively, which would develop 2,840 and 5,410 horsepower. If the Dewey Reservoir (p. 74) is constructed for a capacity of $2,270,000$ acre-feet, backwater would reduce the head at this site to 165 feet, and if it is constructed for a capacity of 4,000,000 acre-feet the head will be reduced to 115 feet. In the former event the power capacity of this site will be 1,770 and 3,370 horsepower for 90 per cent and 50 per cent of the time, respectively, and in the latter event, 1,230 and 2,350 horsepower.

Colorado River site (9DK 2).-From the tailrace for the State line site to the mouth of the river the total fall is 110 feet in a distance of 18.5 miles through a canyon. As the Colorado River has a range in stage of about 15 feet, the power house would have to be placed that distance above the altitude of the Dolores River at its mouth, to be above backwater. This would reduce the available head to 95 feet, which could be utilized only by a high dam 1 mile upstream from the mouth. The nearest railroad point is Cisco, Utah, about 15 miles from the mouth of the Dolores, on the opposite side of the Colorado River. A fair road leads from Cisco to the river, which at this point is unbridged. The discharges for 90 per cent and 50 per cent of the time are 140 and 260 second-feet, respectively, which would create 1,060 and 1,980 horsepower. If the upper 5 feet of the reservoir were reserved for storage this would amount to some 11,000 acrefeet, which would increase the 90 per cent flow from 140 to 190 second-feet. With the head reduced to 90 feet the 90 per cent power would be 1,370 horsepower. It is evident that even with the storage suggested this development is not feasible. If the Dewey Reservoir (p. 74) is constructed this site will be destroyed.

Power possibilities through storage are discussed on pages 104 and 105 and show that with storage at both the Bedrock and Fiftymile reservoir sites the available power at the Colorado-Utah line and Colorado River sites would be 23,400 horsepower for both 90 per cent and 50 per cent of the time.

\section{SAN MIGUEL RIVER}

The San Miguel River above Sawpit is shown on the topographic map of the Telluride quadrangle, and between Sawpit and the mouth a reconnaissance survey has been made. ${ }^{52}$ From these sources the following table along the river has been compiled:

62 Jones, E. E., unpublished report on power resources of the San Miguel River, U. S. Geol. Survey, 1925. 
Altitudes and distances along San Miguel River from Lake Fork to mouth

\begin{tabular}{|c|c|c|c|c|c|}
\hline \multirow[b]{2}{*}{ Point on river } & \multicolumn{2}{|c|}{ Distance (miles) } & \multirow{2}{*}{$\begin{array}{c}\text { Altitude } \\
\text { above } \\
\text { sea level } \\
\text { (feet) }\end{array}$} & \multicolumn{2}{|c|}{ Descent (feet) } \\
\hline & $\begin{array}{l}\text { From } \\
\text { Lake } \\
\text { Fork }\end{array}$ & $\begin{array}{c}\text { Point to } \\
\text { point }\end{array}$ & & Total & Per mile \\
\hline 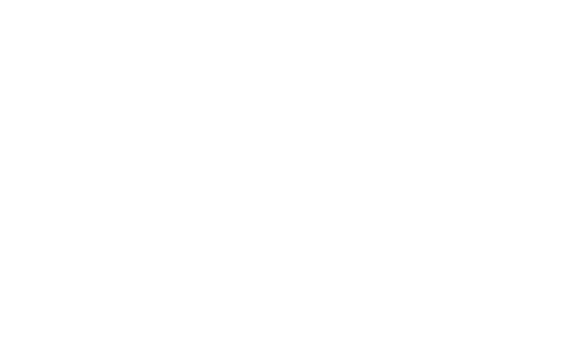 & $\begin{array}{r}3.4 \\
5.9 \\
11.1 \\
16.8 \\
20.7 \\
23.2 \\
31.0 \\
33.8 \\
38.9 \\
46.2 \\
52.4 \\
61.3 \\
65.6 \\
72.0\end{array}$ & $\begin{array}{l}3.4 \\
2.5 \\
5.2 \\
5.7 \\
3.9 \\
2.5 \\
7.8 \\
2.8 \\
5.1 \\
7.3 \\
6.2 \\
8.9 \\
4.3 \\
6.4\end{array}$ & $\begin{array}{l}8,040 \\
7,750 \\
7,550 \\
7,250 \\
6,926 \\
6,674 \\
6,500 \\
6,094 \\
6,015 \\
5,830 \\
5,530 \\
5,352 \\
5,100 \\
5,002 \\
4,850\end{array}$ & $\begin{array}{r}290 \\
200 \\
300 \\
324 \\
252 \\
174 \\
406 \\
79 \\
185 \\
300 \\
178 \\
252 \\
98 \\
152\end{array}$ & $\begin{array}{l}-85 \\
80 \\
58 \\
57 \\
65 \\
70 \\
52 \\
28 \\
36 \\
41 \\
29 \\
28 \\
23 \\
24\end{array}$ \\
\hline
\end{tabular}

- Approximate only; subject to correction based on more detailed surveys.

The section of river best suited to power development lies above Horsefly Creek. Below that point the fall is about half as great as above, with no material increase in discharge to compensate for it. Throughout the power section the river flows in a canyon, and above Placerville the presence of the narrow-gage line of the Rio Grande Southern Railroad limits power development to low diversion dams and relatively long conduits. Material for the construction of these dams can be obtained near the dam sites. A favorable factor in power development is the fairly uniform low-water discharge of the San Miguel, which is increased by the operation of the Lake Hope and Trout Lake Reservoirs (pp. 64-65).

Five sites have been selected, which utilize the entire fall of the San Miguel from the mouth of the Lake Fork to the mouth of Horsefly Creek. The estimates of available water supply are based on records of the San Miguel River at Fall Creek (1895-1899), near Placerville (1909, 1911-12), and at Naturita (1918-1927).

Sawpit site (9DK 3).-From the proposed point of diversion below the mouth of the Lake Fork, in sec. 36, T. 43 N., T. 10 W. New Mexico principal meridian, a conduit along the west side of the river leading to a power-house site at Sawpit, in sec. 13, T. 43 N., R. 10 W., would be 6 miles long and create a static head of 490 feet. For the first $3 \frac{1}{2}$ miles the conduit would run along the gentle slope of the narrow valley, but for the remainder of the distance it would run along steep slopes, which would require some difficult construction. Crossings would be required for the narrow-gage railroad, Bilk and Bear Creeks, and 10 minor streams. Except near the head of this section the railroad lies on the opposite side of the river, as does also the State highway. The discharges for 90 per cent and 50 per cent of the time are 62 and 115 second-feet, respectively, which would develop 2,430 and 4,510 horsepower.

Placerville site (9DK 4).-From the point of diversion at Sawpit, in the NW. $1 / 4$ sec. 13, T. 43 N., R. 10 W., just below the mouth of Fall Creek, a conduit extending to a power-house site at Old Placerville, near the line between secs. 
33 and 34, T. 43 N., R. 11 W., half a mile below the mouth of Leopard Creek, would have a length of 5 miles and create a static head of 300 feet. If constructed along the north side of the river, the conduit could be located along the comparatively level floor of the narrow valley in easily excavated material. Two crossings of the narrow-gage line of the railroad and one of Leopard Creek would be required. The creek crossing might afford an opportunity of diversion into the conduit during periods of low water. The highway is also on this side of the river. The discharges for 90 per cent and 50 per cent of the time are 65 and 120 second-feet respectively which would develop 1,560 and 2;880 horsepower.

Saltado Creek site (9DK 5).--The proposed diversion point for the Saltado Creek site is just below the tailrace for the Placerville site, near the west line of sec. 34, T. 44 N., R. 11 W., and the power-house site is at the mouth of Saltado Creek, in the NE. 1/4 sec. 23, T. 44 N., R. 12 W. A conduit along the north side of the river would have a length of 6 miles and would create a static head of 324 feet. The nature of the topography along the north side indicates that it would probably be advisable to construct an open conduit in connection with flumes and pipe line. Several sandstone ledges protrude into the valley, and at other points alluvial fans from side streams will be encountered. The highway, being on the same side, gives ready access to this site. The discharges for 90 per cent and 50 per cent of the time are 68 and 124 second-feet, respectively, which would develop 1,760 and 3,210 horsepower.

McKenzie Creek site (9DK 6).-Between the mouth of Saltado Creek, in the NE. $1 / 4$ sec. 23, T. 44 N., R. 12 W., and the south line of the SW. $1 / 4$ sec. 20 , T. 45 N., R. 12 W., three-quarters of a mile below the mouth of McKenzie Creek, the San Miguel falls 426 feet. A conduit on the north side of the river would be $61 / 2$ miles long. The topography indicates that a combination of open conduit and bench-cut flume would be necessary. Crossings would be required for MoKenzie Creek and four minor tributaries. The State highway follows the north side of the river nearly to McKenzie Creek. The discharges for 90 per cent and 50 per cent of the time are 69 and 126 second-feet, respectively, which would develop 2,350 and 4,290 horsepower. The construction of the San Miguel irrigation project (p. 146) would reduce the 50 per cent power at this site, and if storage reservoirs were constructed the $\subseteq 0$ fer cent fower would also ke materially reduced.

Horsefly Creek site (9DK 7).-Between the tailrace for the McKenzie Creek site and the mouth of Horsefly Creek, in the NW. 1/4 sec. 33, T. 46 N., R. 13 W., the river has a fall of 406 feet. A conduit along the north side would have a . length of $7 \frac{1}{2}$ miles. The conduit would probably consist of a combination of open ditch and bench-cut flume and pipe line. The soil is loose sandy material, and where bench cutting is required the rock is a coarse-grained sandstone. Crossings would be required at Clay Creek and three minor tributaries. A fair road extends to the mouth of Clay Creek, and beyond that point a pack trail leads to Horsefly Creek. The discharges for 90 per cent and 50 per cent of the time are 70 and 128 second-feet, respectively, which would develop 2,270 and 4,160 horsepower. The construction of the San Miguel irrigation project (p. 146) would reduce the 50 per cent power at this site, and if storage reservoirs were constructed the 90 per cent flow would also be materially reduced. 
Summary of undeveloped sites on San Miguel River

\begin{tabular}{|c|c|c|c|c|c|c|}
\hline \multirow{3}{*}{ Site } & \multirow{3}{*}{$\begin{array}{l}\text { Static } \\
\text { head } \\
\text { (foet) }\end{array}$} & \multirow{3}{*}{$\begin{array}{l}\text { Length } \\
\text { of } \\
\text { conduit } \\
\text { (miles) }\end{array}$} & \multicolumn{4}{|c|}{ Run-off and available power } \\
\hline & & & \multicolumn{2}{|c|}{$\begin{array}{l}90 \text { per cent of the } \\
\text { time }\end{array}$} & \multicolumn{2}{|c|}{$\begin{array}{l}50 \text { per cent of the } \\
\text { time }\end{array}$} \\
\hline & & & $\begin{array}{l}\text { Second- } \\
\text { feet }\end{array}$ & $\begin{array}{l}\text { Horse- } \\
\text { power }\end{array}$ & $\begin{array}{l}\text { Second- } \\
\text { feet }\end{array}$ & $\begin{array}{l}\text { Horse- } \\
\text { power }\end{array}$ \\
\hline \multirow[t]{2}{*}{$\begin{array}{l}\text { Sawpit } \\
\text { Placerville } \\
\text { Saltado Creek } \\
\text { McKenzie Creek } \\
\text { Horsefly Creek }\end{array}$} & $\begin{array}{l}490 \\
300 \\
324 \\
426 \\
406\end{array}$ & $\begin{array}{l}6 \\
5 \\
6 \\
6.5 \\
7.5\end{array}$ & $\begin{array}{l}62 \\
65 \\
68 \\
69 \\
70\end{array}$ & $\begin{array}{l}2,430 \\
1,560 \\
1,760 \\
2,350 \\
2,270\end{array}$ & $\begin{array}{l}115 \\
120 \\
124 \\
126 \\
128\end{array}$ & $\begin{array}{l}4,510 \\
2,880 \\
3,210 \\
4,290 \\
4,460\end{array}$ \\
\hline & & & & 10,400 & - & 19,000 \\
\hline
\end{tabular}

The absence of reservoir sites on the San Miguel makes it impossible to increase the value of these sites by additional storage.

\section{RECAPITULATION}

Summary of undeveloped water power in upper Colorado River Basin, in horsepower

\begin{tabular}{|c|c|c|c|c|c|}
\hline \multirow[b]{2}{*}{ Stream } & \multirow{2}{*}{$\begin{array}{l}\text { Num- } \\
\text { ber of } \\
\text { sites }\end{array}$} & \multicolumn{2}{|c|}{ Without storage } & \multicolumn{2}{|c|}{ With storage } \\
\hline & & $\begin{array}{c}90 \text { per } \\
\text { cent } \\
\text { power }\end{array}$ & $\begin{array}{l}50 \text { per } \\
\text { cent } \\
\text { power }\end{array}$ & $\begin{array}{c}90 \text { per } \\
\text { cent } \\
\text { power }\end{array}$ & $\begin{array}{c}50 \text { per } \\
\text { cent } \\
\text { power }\end{array}$ \\
\hline 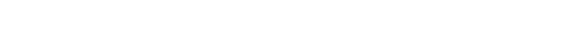 & \multirow[b]{2}{*}{$\begin{array}{r}23 \\
5 \\
5 \\
11 \\
1 \\
3 \\
3 \\
3 \\
2 \\
2 \\
2 \\
5 \\
5\end{array}$} & 21,400 & 41,800 & \multirow[b]{2}{*}{$\begin{array}{l}141,200 \\
167,000 \\
(b) \\
(b) \\
44,800 \\
6,850 \\
20,200 \\
(d) \\
6,090 \\
4,120 \\
23,400 \\
(0)\end{array}$} & $\begin{array}{l}165,000 \\
180,000\end{array}$ \\
\hline \multirow[t]{2}{*}{$\begin{array}{l}\text { Blue River } \\
\text { Eagle River } \\
\text { Roaring Fork } \\
\text { Middle Elk Creek } \\
\text { Taylor River } \\
\text { Gunnison River } \\
\text { Lake Fork } \\
\text { Uncompahge River } \\
\text { Dolores River } \\
\text { San Miguel River }\end{array}$} & & $\begin{array}{r}8,560 \\
7,430 \\
32,300 \\
-7,040 \\
22,800 \\
1,480 \\
1,630 \\
3,900 \\
10,400\end{array}$ & $\begin{array}{r}17,000 \\
16,600 \\
60,100 \\
-12,100 \\
40,000 \\
3,610 \\
8,750 \\
7,390 \\
19,000\end{array}$ & & $\begin{array}{r}69,000 \\
6,350 \\
25,400 \\
8,450 \\
4,670 \\
23,400 \\
\end{array}$ \\
\hline & 40 & 117,000 & 222,000 & $\left\{\begin{array}{l}296,000 \\
382,000\end{array}\right.$ & $\begin{array}{l}396,000 \\
410,000\end{array}$ \\
\hline
\end{tabular}

a Includes Dewey reservoir site, which has no power value without storage.

- Small amount of undetermined storage available.

- These sites are of very doubtful feasibility.

No storage considered.

- No storage available.

Nors.-Tha total power with storage includes for those streams where storage is not used the correspond ing power without storage. Braced figures indicate variation in pewer depending on which of the reservoirs described on pages 83-92 are utilized. 


\section{APPENDIX}

\section{RECORDS OF STREAM FLOW}

Records of stream flow have been obtained at stations in the upper Colorado River Basin named in the following list. Prior to 1918 the work was done almost entirely by the United States Geological Survey, but since that time the State engineer has contributed substantially to the work and has maintained some of the stations independently.

In this report only the records of monthly discharge are presented, as more detailed information is published either in the water-supply papers of the Geological Survey or the biennial reports of the State engineer. The stations are arranged in downstream order, and tributaries are indicated by indentation.

Colorado River near Grand Lake, Colo.

Colorado River near Granby, Colo.

Colorado River at Hot Sulphur Springs, Colo.

Colorado River near Kremmling, Colo.

Colorado River at State Bridge, Colo.

Colorado River at Glenwood Springs, Colo.

Colorado River near Palisade, Colo.

Colorado River at Grand Junction, Colo.

Colorado River near Fruita, Colo.

Colorado River near Cisco, Utah.

North Inlet to Grand Lake at Grand Lake, Colo.

Grand Lake Outlet at Grand Lake, Colo.

Fraser River near West Portal, Colo.

Fraser River near Granby, Colo.

Williams River near Scholl, Colo.

Williams River near Parshall, Colo.

Troublesome Creek near Troublesome, Colo.

Blue River at Breckenridge, Colo.

Blue River at Dillon, Colo.

Blue River near Kremmling, Colo.

Snake River at Dillon, Colo.

Tenmile Creek near Kokomo, Colo.

Tenmile Creek at Dillon, Colo.

Muddy Creek at Kremmling, Colo.

Eagle River at Redeliff, Colo.

Eagle River at Eagle, Colo.

Eagle River at Gypsum, Colo.

Turkey Creek at Redeliff, Colo.

Homestake Creek at Redeliff, Colo.

Brush Creek at Eagle, Colo.

Roaring Fork at Aspen, Colo.

Roaring Fork below Aspen, Colo.

Roaring Fork near Emma, Colo.

Roaring Fork at Glenwood Springs, Colo.

Castle Creek near Aspen, Colo.

Maroon Creek near Aspen, Colo. 
Colorado River-Continued.

Roaring Fork-Continued.

Maroon Creek at lower station near Aspen, Colo.

Snowmass Creek at Snowmass, Colo.

Fryingpan Creek at Norrie, Colo.

Fryingpan Creek at Thomasville, Colo.

Fryingpan Creek at Basalt, Colo.

North Fork of Fryingpan Creek near Norrie, Colo.

Crystal River at Marble, Colo.

Crystal River near Carbondale, Colo.

East Elk Creek near New Castle, Colo.

Elk Creek at New Castle, Colo.

West Divide Creek at Beard ranch near Raven, Colo.

West Divide Creek at Raven, Colo.

Parachute Creek at Grand Valley, Colo.

Roan Creek near De Beque, Colo.

Plateau Creek near Collbran, Colo.

Buzzard Creek near Collbran, Colo.

Taylor River above Almont, Colo.

Taylor River at Almont, Colo.

Gunnison River near Gunnison, Colo.

Gunnison River at Iola, Colo.

Gunnison River near Cimarron, Colo.

Gunnison River at East Portal of Gunnison Tunnel, Colo.

Gunnison River near Cory, Colo.

Gunnison River near Grand Junction, Colo.

East River at Almont, Colo.

Cement Creek near Crested Butte, Colo.

Tomichi Creek at Sargents, Colo.

Quartz Creek near Pitkin, Colo.

Sapinero Creek at Sapinero, Colo.

Lake Fork at Lake City, Colo.

Henson Creek at Lake City, Colo.

Cimarron Creek at Cimarron, Colo.

Crystal Creek near Maher, Colo.

North Fork of Gunnison River near Paonia, Colo.

North Fork of Gunnison River near Hotchkiss, Colo.

Leroux Creek near Lazear, Colo.

Surface Creek at Cedaredge, Colo.

Uncompahgre River at Ouray, Colo.

Uncompahgre River below Ouray, Colo.

Uncompahgre River near Colona, Colo.

Uncompahgre River at Delta, Colo.

Canyon Creek at Ouray, Colo.

Dallas Creek near Ridgway, Colo.

Escalante Creek near Delta, Colo.

Kahnah Creek near Whitewater, Colo.

Dolores River at Rico, Colo.

Dolores River at Dolores, Colo.

Dolores River at Bedrock, Colo.

Lost Canyon Creek at Dolores, Colo.

San Miguel River at Fall. Creek, Colo.

San Miguel River near Placerville, Colo.

San Miguel River at Naturita, Colo. 


\section{COLORADO RIVER BASIN}

COLORADO RIVER NEAR GRAND LAKE, COLO.

Location.-In sec. 13, T. 3 N., R. 76 W., at old highway bridge 200 feet downstream from bridge on stage road to Grand Lake, Grand County. Nearest tributary, Grand Lake outlet, enters some distance below.

Dratnagm arma.-101 square miles (measured on topographic map).

Records available.-August 1, 1904, to September 30, 1909; October 1, 1910, to September 30, 1918.

GAGE.--Vertical staff on downstream side of bridge.

ConTroL.-Slightly shifting.

Extremes of Discharge.-Maximum stage recorded, 7.0 feet at $6 \mathrm{p}$. m. June 15 and 16, 1918 (discharge, 1,840 second-feet); minimum discharge recorded, 10 second-feet December 4-9, 1907.

Diversions.- Water diverted for irrigation of several thousand acres above station. In addition Grand River ditch diverts water to the Cache la Poudre Basin. (See p. 50 for annual diversions.)

Accuracr.-Gage read once daily. Rating curve well defined. Records good, except during high-water period for which they are fair.

. Monthly discharge of Colorado River near Grand Lake, Colo., 1904-1909 and 19101918

\begin{tabular}{|c|c|c|c|c|}
\hline \multirow{2}{*}{ Month } & \multicolumn{3}{|c|}{ Discharge in second-feet } & \multirow{2}{*}{$\begin{array}{l}\text { Run-off in } \\
\text { acre-feet }\end{array}$} \\
\hline & Maximum & Minimum & Mean & \\
\hline $\begin{array}{ll}\text { August } & 1904 \\
\text { September } & \end{array}$ & $\begin{array}{l}156 \\
176\end{array}$ & $\begin{array}{l}73 \\
47\end{array}$ & $\begin{array}{l}88.2 \\
62.1\end{array}$ & $\begin{array}{l}5,420 \\
8,700\end{array}$ \\
\hline $\begin{array}{l}\text { Ootober- } \\
\text { November } \\
\text { December } \\
\text { January } \\
\text { February } \\
\text { Mareh } \\
\text { April } \\
\text { May } \\
\text { June } \\
\text { July } \\
\text { August } \\
\text { September }\end{array}$ & $\begin{array}{r}145 \\
526 \\
1,220 \\
502 \\
110 \\
53\end{array}$ & $\begin{array}{r}33 \\
\\
\\
17 \\
95 \\
575 \\
118 \\
43 \\
28\end{array}$ & $\begin{array}{c}42.3 \\
235 \\
225 \\
220 \\
218 \\
\cdot 18 \\
35.8 \\
291 \\
816 \\
254 \\
67.5 \\
35.7\end{array}$ & $\begin{array}{r}2,600 \\
2,080 \\
1,340 \\
1,230 \\
1,000 \\
1,110 \\
2,130 \\
17,900 \\
48,600 \\
15,600 \\
4,150 \\
2,120\end{array}$ \\
\hline The year....... & 1,220 & $\ldots$ & 138 & 100,000 \\
\hline $\begin{array}{l}\text { October- } \\
\text { November } \\
\text { December } \\
\text { January } \\
\text { February } \\
\text { March } \\
\text { April } \\
\text { Magy } \\
\text { June } \\
\text { July } \\
\text { August } \\
\text { September }\end{array}$ & $\begin{array}{r}53 \\
53 \\
\\
\\
\\
221 \\
625 \\
1,030 \\
472 \\
178 \\
129\end{array}$ & $\begin{array}{r}26 \\
20 \\
20 \\
104 \\
373 \\
123 \\
62 \\
47\end{array}$ & $\begin{array}{c}34.2 \\
31.1 \\
\therefore 22 \\
a 220 \\
\therefore 20 \\
\therefore 20 \\
76.8 \\
388 \\
612 \\
278 \\
101 \\
83.8\end{array}$ & $\begin{array}{r}2,100 \\
1,850 \\
1,350 \\
1,230 \\
1,110 \\
1,230 \\
4,570 \\
23,900 \\
36,400 \\
17,100 \\
6,210 \\
4,990\end{array}$ \\
\hline be year..... & 1,030 & ( & 141 & 102,000 \\
\hline
\end{tabular}

- Estimated. 
Monthly discharge of Colorado River near Grand Lake, Colo., 1904-1909 and 19101918-Continued

\begin{tabular}{l} 
Month \\
\hline October. \\
November \\
December \\
January \\
February \\
March \\
April \\
May \\
June \\
July \\
August \\
September.
\end{tabular}

The year.

\section{$1907-8$}

Qctober

November

December

January

February

March

April

May.

June-

July

September

The year.

\section{8-9}

October

November

December

January.

February

March

April

May.

June.

July -

August.

September.

The year.

October

November

December

January

February

March

May.

June.

July

Angust.

September

The year.

\section{October.}

November

December

January.

Februar

March

April

May.

June

July ..

August.

September

The year.

\section{0-11}

Estimated.

1911-12

\begin{tabular}{|c|c|c|c|}
\hline \multicolumn{3}{|c|}{ Discharge in second-feet } & \multirow{2}{*}{$\begin{array}{c}\text { Run-off in } \\
\text { acre-feet }\end{array}$} \\
\hline Maximum & Minimum & Mean & \\
\hline $\begin{array}{r}104 \\
62 \\
35 \\
24 \\
24 \\
62 \\
248 \\
528 \\
1,110 \\
1,110 \\
286 \\
89\end{array}$ & $\begin{array}{r}41 \\
35 \\
26 \\
20 \\
16 \\
20 \\
41 \\
66 \\
260 \\
267 \\
62 \\
35\end{array}$ & $\begin{array}{c}62.9 \\
42.5 \\
30.3 \\
22.8 \\
19.1 \\
31.1 \\
104 \\
233 \\
764 \\
603 \\
132 \\
52.3\end{array}$ & $\begin{array}{r}3,870 \\
2,530 \\
1,860 \\
1,400 \\
1,060 \\
1,910 \\
6,190 \\
14,400 \\
45,500 \\
37,100 \\
8,120 \\
3,110\end{array}$ \\
\hline 1,110 & 16 & 176 & 127,000 \\
\hline $\begin{array}{r}69 \\
43 \\
22 \\
24 \\
33 \\
43 \\
165 \\
266 \\
425 \\
266 \\
195 \\
59\end{array}$ & $\begin{array}{r}38 \\
13 \\
10 \\
16 \\
16 \\
16 \\
20 \\
77 \\
179 \\
95 \\
45 \\
26\end{array}$ & $\begin{array}{c}46.6 \\
24.4 \\
13.9 \\
16.8 \\
18.9 \\
24.3 \\
87.7 \\
145 \\
319 \\
162 \\
96.3 \\
36.5\end{array}$ & $\begin{array}{r}2,870 \\
1,450 \\
855 \\
1,030 \\
1,000 \\
1,490 \\
5,220 \\
8,920 \\
19,000 \\
9,960 \\
5,920 \\
2,170\end{array}$ \\
\hline 425 & 10 & 83.0 & 60,000 \\
\hline $\begin{array}{r}32 \\
20 \\
18 \\
19 \\
19 \\
30 \\
55 \\
528 \\
1,620 \\
1,190 \\
230 \\
160\end{array}$ & $\begin{array}{r}12 \\
12 \\
12 \\
12 \\
12 \\
12 \\
15 \\
65 \\
347 \\
145 \\
69 \\
49\end{array}$ & $\begin{array}{c}24.6 \\
16.4 \\
15.2 \\
15.6 \\
13.7 \\
16.0 \\
19.7 \\
280 \\
944 \\
465 \\
104 \\
74.3\end{array}$ & $\begin{array}{r}1,510 \\
976 \\
935 \\
959 \\
761 \\
984 \\
1,170 \\
17,200 \\
56,200 \\
28,600 \\
6,400 \\
4,420\end{array}$ \\
\hline 1,620 & 12 & 166 & 120,000 \\
\hline & & $\begin{array}{r}\text { a } 35 \\
<25 \\
<25 \\
a 30 \\
a 28 \\
\therefore \quad 30 \\
68 \\
560 \\
890 \\
200 \\
82 \\
50\end{array}$ & $\begin{array}{r}2,150 \\
1,490 \\
1,540 \\
1,840 \\
1,560 \\
1,840 \\
4,050 \\
34,400 \\
53,000 \\
12,300 \\
5,040 \\
2,980\end{array}$ \\
\hline - & - & 168 & 122,000 \\
\hline 22 & 17 & $\begin{array}{r}a 55 \\
a \quad 45 \\
a 30 \\
a \quad 30 \\
a \quad 20\end{array}$ & $\begin{array}{l}3,380 \\
2,680 \\
1,840 \\
1,230 \\
1,150\end{array}$ \\
\hline $\begin{array}{r}55 \\
570 \\
1,060 \\
500 \\
278 \\
72\end{array}$ & $\begin{array}{r}23 \\
58 \\
-305 \\
65 \\
55\end{array}$ & $\begin{array}{c}020 \\
31.8 \\
273 \\
770 \\
397 \\
132 \\
61.6\end{array}$ & $\begin{array}{r}1,230 \\
1,890 \\
16,800 \\
45,800 \\
24,400 \\
8,120 \\
3,670\end{array}$ \\
\hline 1,060 & - & 155 & 112,000 \\
\hline
\end{tabular}


Monthly discharge of Colorado River near Grand Lake, Colo., 1904-1909 and 19101918-Continued

\begin{tabular}{|c|c|c|c|c|}
\hline \multirow{2}{*}{ Month } & \multicolumn{3}{|c|}{ Discharge in second-feet } & \multirow{2}{*}{$\begin{array}{c}\text { Run-off in } \\
\text { acre-feet }\end{array}$} \\
\hline & Maximum & Minimum & Mean & \\
\hline $\begin{array}{l}\text { October } \\
\text { November } \\
\text { December } \\
\text { January } \\
\text { February. } \\
\text { March } \\
\text { April } \\
\text { May } \\
\text { June } \\
\text { July } \\
\text { August } \\
\text { September. }\end{array}$ & $\begin{array}{r}184 \\
680 \\
740 \\
280 \\
90 \\
105\end{array}$ & $\begin{array}{r}28 \\
154 \\
225 \\
82 \\
49 \\
62\end{array}$ & $\begin{array}{l}50 \\
40 \\
30 \\
25 \\
25 \\
25 \\
82.2 \\
329 \\
389 \\
149 \\
61.8 \\
74.5\end{array}$ & $\begin{array}{r}3,070 \\
2,380 \\
1,840 \\
1,540 \\
1,390 \\
1,540 \\
4,890 \\
20,200 \\
23,100 \\
9,160 \\
3,800 \\
\mathbf{4 , 4 3 0}\end{array}$ \\
\hline The year........ & 740 & & 107 & 77,300 \\
\hline $\begin{array}{l}\text { October. } \\
\text { November. } \\
\text { December. } \\
\text { January } \\
\text { February } \\
\text { March } \\
\text { Anril } \\
\text { May } \\
\text { June } \\
\text { July } \\
\text { August } \\
\text { September }\end{array}$ & $\begin{array}{r}87 \\
72 \\
30 \\
170 \\
1,470 \\
1,700 \\
685 \\
145 \\
140\end{array}$ & $\begin{array}{rr}49 \\
31\end{array}$ & $\begin{array}{l}68.0 \\
50.0 \\
35 \\
25 \\
25 \\
25 \\
26 \\
82.2 \\
563 \\
908 \\
265 \\
94.0 \\
73.0\end{array}$ & $\begin{array}{r}4,180 \\
2,880 \\
2,150 \\
1,540 \\
1,390 \\
1,600 \\
4,890 \\
34,600 \\
54,000 \\
16,300 \\
5,780 \\
4,340\end{array}$ \\
\hline 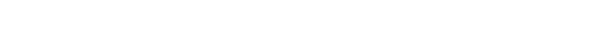 & 1,700 & & 185 & 134,000 \\
\hline $\begin{array}{l}\text { October } \\
\text { November } \\
\text { December } \\
\text { January } \\
\text { February } \\
\text { Mareh } \\
\text { April } \\
\text { May } \\
\text { June } \\
\text { July } \\
\text { August } \\
\text { September }\end{array}$ & $\begin{array}{r}85 \\
52 \\
252 \\
332 \\
565 \\
332 \\
120 \\
85\end{array}$ & $\begin{array}{r}52 \\
20 \\
20 \\
\mathbf{2 0} \\
\mathbf{2 0} \\
\mathbf{8 1} \\
\mathbf{6 1} \\
\mathbf{3 9}\end{array}$ & $\begin{array}{r}65.0 \\
40 \\
22 \\
18 \\
18 \\
20 \\
123 \\
200 \\
350 \\
188 \\
78.8 \\
58.4\end{array}$ & $\begin{array}{r}4,000 \\
2,380 \\
1,540 \\
1,110 \\
1,000 \\
1,230 \\
7,320 \\
12,300 \\
20,800 \\
11,600 \\
4,860 \\
3,480 K\end{array}$ \\
\hline The year. & 565 & 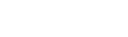 & 98.0 & 71,000 \\
\hline $\begin{array}{l}\text { October } \\
\text { November } \\
\text { December. } \\
\text { January. } \\
\text { February } \\
\text { March } \\
\text { April } \\
\text { May } \\
\text { June } \\
\text { July } \\
\text { August } \\
\text { September }\end{array}$ & $\begin{array}{r}66 \\
49 \\
41 \\
38 \\
36 \\
53 \\
345 \\
560 \\
652 \\
322 \\
197 \\
107\end{array}$ & $\begin{array}{r}48 \\
42 \\
\mathbf{3 5} \\
\mathbf{3 5} \\
\mathbf{3 3} \\
\mathbf{3 4} \\
\mathbf{4 1} \\
\mathbf{1 3 5} \\
\mathbf{3 2 2} \\
\mathbf{8 8} \\
55 \\
\mathbf{5 6}\end{array}$ & $\begin{array}{c}54.6 \\
46.1 \\
36.8 \\
36.4 \\
34.3 \\
39.5 \\
122 \\
285 \\
443 \\
171 \\
95.0 \\
74.9\end{array}$ & $\begin{array}{r}3,360 \\
2,740 \\
2,260 \\
2,240 \\
1,970 \\
2,430 \\
7,260 \\
17,500 \\
26,400 \\
10,500 \\
5,840 \\
4,460\end{array}$ \\
\hline The year. & 652 & 33 & 120 & 87,000 \\
\hline $\begin{array}{l}\text { October } \\
\text { November } \\
\text { December. } \\
\text { January } \\
\text { Fobrewary } \\
\text { March } \\
\text { April } \\
\text { May } \\
\text { June } \\
\text { July } \\
\text { August } \\
\text { September }\end{array}$ & $\begin{array}{r}80 \\
60 \\
43 \\
41 \\
29 \\
29 \\
210 \\
555 \\
1,620 \\
1,170 \\
175 \\
71\end{array}$ & $\begin{array}{r}55 \\
38 \\
40 \\
28 \\
27 \\
27 \\
27 \\
67 \\
175 \\
175 \\
64 \\
50\end{array}$ & $\begin{array}{c}66.0 \\
51.4 \\
40.8 \\
31.9 \\
28.4 \\
27.6 \\
71.7 \\
220 \\
930 \\
436 \\
91.0 \\
56.1\end{array}$ & $\begin{array}{r}\mathbf{4}, 060 \\
\mathbf{3}, 060 \\
\mathbf{2}, \mathbf{5 1 0} \\
\mathbf{1}, \mathbf{9 6 0} \\
\mathbf{1}, 580 \\
\mathbf{1}, \mathbf{7 0 0} \\
\mathbf{4}, \mathbf{2 7 0} \\
\mathbf{1 3}, \mathbf{5 0 0} \\
\mathbf{5 5}, \mathbf{3 0 0} \\
\mathbf{2 6}, \mathbf{8 0 0} \\
\mathbf{5}, 600 \\
\mathbf{3}, \mathbf{3 4 0}\end{array}$ \\
\hline The ye & 1,620 & 27 & 171 & 124,000 \\
\hline
\end{tabular}

- Estimated. 
Monthly discharge of Colorado River near Grand Lake, Colo., $1904-1909$ and 19101918-Continued

\begin{tabular}{|c|c|c|c|c|}
\hline \multirow{2}{*}{ Month } & \multicolumn{3}{|c|}{ Discharge in second-feet } & \multirow{2}{*}{$\begin{array}{c}\text { Run-off in } \\
\text { acre-feet }\end{array}$} \\
\hline & Maximum & Minimum & Mean & \\
\hline $\begin{array}{l}\text { October } \\
\text { November } \\
\text { December } \\
\text { January } \\
\text { February } \\
\text { March } \\
\text { April } \\
\text { May } \\
\text { June } \\
\text { July } \\
\text { August } \\
\text { September }\end{array}$ & $\begin{array}{r}60 \\
52 \\
49 \\
30 \\
15 \\
43 \\
87 \\
-750 \\
1,840 \\
290 \\
100 \\
84\end{array}$ & $\begin{array}{r}36 \\
35 \\
26 \\
15 \\
11 \\
12 \\
43 \\
100 \\
290 \\
84 \\
39 \\
33\end{array}$ & $\begin{array}{c}41.4 \\
39.9 \\
31.6 \\
19.4 \\
13.5 \\
21.1 \\
61.9 \\
407 \\
943 \\
178 \\
65.3 \\
50.2\end{array}$ & $\begin{array}{r}2,550 \\
2,370 \\
1,940 \\
1,190 \\
1,750 \\
1,300 \\
3,680 \\
25,000 \\
56,100 \\
10,900 \\
4,020 \\
-2,990\end{array}$ \\
\hline The year..... & 1,840 & 11 & 156 & 113,000 \\
\hline
\end{tabular}

NoTe.-Records fragmentary from April 1, 1911, to July 5, 1912; mean discharge based on comparison with flow at near-by stations.

COLORADO RIVER IEAR GRANBY, COLO.

Location.-In sec. 22, T. 2 N., R. 76 W., at Switzer ranch $3 \frac{132}{2}$ miles northeast. of Granby, Grand County. Willow Creek enters 11/2 miles downstream.

Drainage area. - 322 square miles (measured on topographic map).

Records available.-June 10, 1908, to September 30, 1911.

GAGE.-Vertical and inclined staff.

Control.-Slightly shifting.

EXTREMES OF DISCHARGE.-Maximum stage recorded, 5.5 feet at $8 \mathrm{a}$. m. June-20, 1909 (discharge, 4,100 second-feet); minimum discharge occurred during winter.

Diversions.-Water diverted from Colorado River between the Grand Lake and Granby stations for irrigation of several thousand acres.

Accuracy.-Gage read twice daily. Rating curves well defined. Records good.

Monthly discharge of Colorado River near Granby, Colo., 1908-1911

\begin{tabular}{|c|c|c|c|c|}
\hline \multirow{2}{*}{ Month } & \multicolumn{3}{|c|}{ Discharge in second-feot } & \multirow{2}{*}{$\begin{array}{l}\text { Run-off in } \\
\text { acre-feet }\end{array}$} \\
\hline & Maximum & Minimum & Mean & \\
\hline $\begin{array}{l}\text { June } 10-30 \\
\text { July } \\
\text { August }\end{array}$ & $\begin{array}{r}1,430 \\
780 \\
640 \\
178\end{array}$ & $\begin{array}{r}920 \\
316 \\
192 \\
88\end{array}$ & $\begin{array}{r}1,200 \\
559 \\
380 \\
127\end{array}$ & $\begin{array}{r}50,000 \\
34,400 \\
23,400 \\
7,560\end{array}$ \\
\hline The period. & (n) & $\ldots$ & -......... & 115,000 \\
\hline $\begin{array}{l}\text { October } \\
\text { November } \\
\text { December } \\
\text { January } \\
\text { February } \\
\text { March } \\
\text { April } \\
\text { May } \\
\text { June } \\
\text { July } \\
\text { August } \\
\text { September }\end{array}$ & $\begin{array}{r}108 \\
88 \\
70 \\
1,290 \\
4,000 \\
3,250 \\
570 \\
430\end{array}$ & 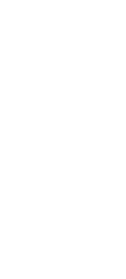 & $\begin{array}{r}94.8 \\
71.1 \\
55.6 \\
\approx 47 \\
\approx 38 \\
\approx 41 \\
\approx 91 \\
694 \\
644 \\
2,540 \\
1,350 \\
387 \\
250\end{array}$ & $\begin{array}{r}5,830 \\
4,230 \\
3,420 \\
2,890 \\
2,110 \\
2,520 \\
5,420 \\
39,600 \\
151,000 \\
83,000 \\
23,800 \\
14,900\end{array}$ \\
\hline The year............ & 4.000 & - & 468 & 339,000 \\
\hline
\end{tabular}

a Estimated. 
Monthly discharge of Colorado River near Granby, Colo., 1908-1911-Continued

\begin{tabular}{|c|c|c|c|c|}
\hline \multirow{2}{*}{ Month } & \multicolumn{3}{|c|}{ Discharge in second-feet } & \multirow{2}{*}{$\begin{array}{c}\text { Run-off in } \\
\text { acre-feet }\end{array}$} \\
\hline & Maximum & Minimum & Mean & \\
\hline 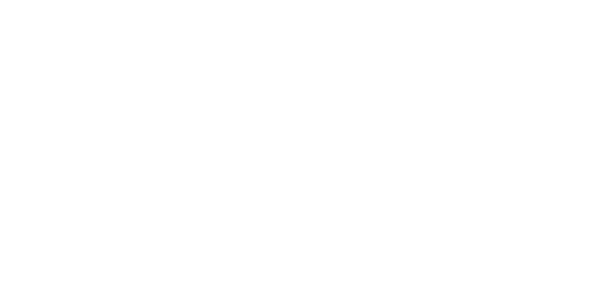 & $\begin{array}{r}132 \\
70 \\
\\
\end{array}$ & $\begin{array}{l}168 \\
505 \\
695 \\
182 \\
108 \\
119\end{array}$ & $\begin{array}{c}103 \\
67 \\
045.9 \\
045 \\
042 \\
050 \\
327 \\
903 \\
1,120 \\
332 \\
186 \\
206\end{array}$ & $\begin{array}{r}6,330 \\
3,990 \\
2,820 \\
2,770 \\
2,330 \\
3,070 \\
19,500 \\
55,500 \\
66,600 \\
20,400 \\
11,400 \\
12,300\end{array}$ \\
\hline The year. & 2,320 & -............. & 286 & 207,000 \\
\hline $\begin{array}{l}\text { October. } \\
\text { November } \\
\text { December } \\
\text { January } \\
\text { February } \\
\text { March } \\
\text { April } \\
\text { May } \\
\text { June } \\
\text { July } \\
\text { Auguist } \\
\text { September }\end{array}$ & $\begin{array}{r}182 \\
108 \\
1,850 \\
2,800 \\
1,000 \\
\end{array}$ & $\begin{array}{r}130 \\
88\end{array}$ & $\begin{array}{c}135 \\
92.7 \\
a 75.0 \\
a 65 \\
a 85 \\
a 115 \\
212 \\
1,160 \\
1,800 \\
620 \\
200 \\
125\end{array}$ & $\begin{array}{r}8,300 \\
5,520 \\
4,610 \\
4,000 \\
4,720 \\
7,070 \\
12,600 \\
71,300 \\
107,000 \\
38,100 \\
12,300 \\
7,440\end{array}$ \\
\hline The year. & 2,800 & & 392 & 283,000 \\
\hline
\end{tabular}

- Estimated.

COLORADO RIVER AT HOT SULPHUR SPRIVGS, COLO.

Location.-In sec. 2 , T. 1 N., R. 78 W., at highway bridge near railroad station in Hot Sulphur Springs, Grand County. Nearest tributary, Ute Bill Creek, enters some distance upstream. From 1904 to 1909, station at bridge 1,000 feet downstream.

Drainage area.-785 square miles (measured on base map of Colorado).

Records avaILABLe.-August 1, 1904, to September 30, 1909; September 17, 1910, to September 30,1924; and October 1, 1925, to September 30, 1927. GAGE.-Chain since 1910. Vertical staff from 1904 to 1909.

CoNTroL.-Slightly shifting.

Extremes of Discharge.-Maximum stage recorded, 8.7 feet at 5 a. m. June 15, 1921 (discharge, 10,300 second-feet); minimum discharge recorded, 63 secondfeet February 25 and 26, 1908.

Diversions.-Water diverted for irrigation of 10,000 acres from Colorado River and tributaries between Hot Sulphur Springs and station near Granby.

Accuracr.-Gage read twice daily beginning in 1914. Rating curves well defined. Prior to 1914 records fair. Subsequent records good, except during winter for which they are fair.

Cooperation.-Since 1926 station maintained in cooperation with State engineer. 
Monthly discharge of Colorado River at Hot Sulphur Springs, Colo., for 1904-1909, 1910-1924, and 1925-1927

\begin{tabular}{|c|c|c|c|c|}
\hline \multirow{2}{*}{ Month } & \multicolumn{3}{|c|}{ Discharge in second-feet } & \multirow{2}{*}{$\begin{array}{l}\text { Run-off in } \\
\text { aere-feet }\end{array}$} \\
\hline & Maximum & Minimum & Mean & \\
\hline $\begin{array}{l}\text { August } \\
\text { September }\end{array}$ & $\begin{array}{r}995 \\
1,030\end{array}$ & $\begin{array}{l}554 \\
313\end{array}$ & $\begin{array}{l}685 \\
491\end{array}$ & $\begin{array}{l}42,100 \\
29,200\end{array}$ \\
\hline $\begin{array}{l}\text { October. } \\
\text { November } \\
\text { December } \\
\text { January } \\
\text { February } \\
\text { March } \\
\text { April } \\
\text { May } \\
\text { June }\end{array}$ & $\begin{array}{r}364 \\
\\
\end{array}$ & \begin{tabular}{|r|}
245 \\
\\
200 \\
736 \\
3,240 \\
632 \\
174 \\
95
\end{tabular} & $\begin{array}{r}320 \\
a 150 \\
a 100 \\
1100 \\
\quad 105 \\
\times 130 \\
550 \\
1,780 \\
4,140 \\
1,260 \\
410 \\
164\end{array}$ & $\begin{array}{r}19,700 \\
8,930 \\
6,150 \\
6,150 \\
5,830 \\
8,000 \\
32,700 \\
110,000 \\
246,000 \\
77,800 \\
25,200 \\
9,760\end{array}$ \\
\hline The year. - & 5,600 & 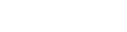 & 768 & 556,000 \\
\hline $\begin{array}{l}\text { October } \\
\text { November } \\
\text { December } \\
\text { January } \\
\text { February } \\
\text { March } \\
\text { April } \\
\text { May } \\
\text { June } \\
\text { August } \\
\text { September }\end{array}$ & $\begin{array}{r}210 \\
210 \\
\\
\\
\mathbf{1}, 480 \\
3,700 \\
\mathbf{5 , 3 5 0} \\
\mathbf{2 , 6 5 0} \\
\mathbf{7 5 0} \\
\quad 750 \\
\end{array}$ & \begin{tabular}{|r} 
\\
180 \\
\\
\\
234 \\
648 \\
2,020 \\
715 \\
316 \\
240
\end{tabular} & $\begin{array}{r}186 \\
140 \\
105 \\
100 \\
a 110 \\
\times 175 \\
\quad 1901 \\
2,160 \\
3,210 \\
1,530 \\
491 \\
457\end{array}$ & $\begin{array}{r}11,400 \\
8,330 \\
6,460 \\
6,150 \\
6,110 \\
10,800 \\
41,400 \\
133,000 \\
191.000 \\
94,100 \\
30,200 \\
27,200\end{array}$ \\
\hline The y & 5,350 & 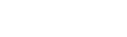 & 783 & 566,000 \\
\hline $\begin{array}{l}\text { October } \\
\text { November } \\
\text { December } \\
\text { January } \\
\text { February } \\
\text { March } \\
\text { April } \\
\text { May } \\
\text { June } \\
\text { July } \\
\text { August } \\
\text { September }\end{array}$ & $\begin{array}{r}490 \\
289 \\
810 \\
1,990 \\
4,030 \\
5,430 \\
4,670 \\
1,240 \\
411\end{array}$ & $\begin{array}{r}240 \\
\\
\\
375 \\
667 \\
1,770 \\
1,520 \\
391 \\
150\end{array}$ & $\begin{array}{r}338 \\
180 \\
-155 \\
-125 \\
-150 \\
300 \\
863 \\
1,710 \\
4,390 \\
2,750 \\
701 \\
246\end{array}$ & $\begin{array}{r}20,800 \\
10,700 \\
9,530 \\
7,690 \\
8,330 \\
18,400 \\
51,400 \\
105,000 \\
261,000 \\
169,000 \\
43,100 \\
14,600\end{array}$ \\
\hline The year. & 5,430 & 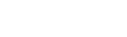 & 995 & 720,000 \\
\hline $\begin{array}{l}\text { October } \\
\text { November } \\
\text { December } \\
\text { January } \\
\text { February } \\
\text { March } \\
\text { April } \\
\text { May } \\
\text { June } \\
\text { July } \\
\text { August } \\
\text { September }\end{array}$ & $\begin{array}{r}\mathbf{9 3} \\
\mathbf{5 2 8} \\
\mathbf{6 4 8} \\
1,290 \\
\mathbf{2}, \mathbf{6 3 0} \\
\mathbf{1 , 2 1 0} \\
\mathbf{8 4 6} \\
\mathbf{3 2 0}\end{array}$ & $\begin{array}{r}63 \\
72 \\
421 \\
473 \\
1,060 \\
421 \\
345 \\
150\end{array}$ & $\begin{array}{r}288 \\
135 \\
075 \\
799.2 \\
73.5 \\
198 \\
529 \\
805 \\
1,880 \\
819 \\
553 \\
220\end{array}$ & $\begin{array}{r}17,700 \\
8,030 \\
4,610 \\
6,100 \\
4,230 \\
12,200 \\
31,500 \\
49,500 \\
112,000 \\
50,400 \\
34,000 \\
13,100\end{array}$ \\
\hline 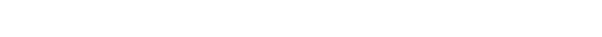 & 2,630 & | & 473 & 343,000 \\
\hline
\end{tabular}

- Estimated. 
Monthly discharge of Colorado River at Hot Sulphur Springs, Colo., for 1904-1909, 1910-1924, and 1925-1927-Continued

\begin{tabular}{|c|c|c|c|c|}
\hline \multirow{2}{*}{ Month } & \multicolumn{3}{|c|}{ Discharge in second-feet } & \multirow{2}{*}{$\begin{array}{l}\text { Run-off in } \\
\text { acre-feet }\end{array}$} \\
\hline & Maximum & Minimum & Mean & \\
\hline $\begin{array}{l}\text { October } \\
\text { November. } \\
\text { December. } \\
\text { January } \\
\text { February } \\
\text { Maxch } \\
\text { April } \\
\text { May } \\
\text { June } \\
\text { July } \\
\text { August } \\
\text { September }\end{array}$ & $\begin{array}{r}206 \\
150 \\
120 \\
2,930 \\
\mathbf{6}, 420 \\
\mathbf{5}, 350 \\
1,040 \\
555\end{array}$ & $\begin{array}{r}\mathbf{1 3 4} \\
\mathbf{9 2} \\
\mathbf{9 9} \\
\mathbf{r} \\
\mathbf{2 7 1} \\
\mathbf{4 0 1} \\
\mathbf{1 , 0 6 0} \\
\mathbf{1 0 0} \\
\mathbf{4 7 2} \\
\mathbf{3 4 0}\end{array}$ & $\begin{array}{r}166 \\
125 \\
110 \\
\times 110 \\
a \quad 105 \\
a 145 \\
475 \\
1,530 \\
4,950 \\
2,560 \\
735 \\
441\end{array}$ & $\begin{array}{r}10,200 \\
7,440 \\
6,700 \\
6,700 \\
5,830 \\
8,920 \\
28,300 \\
94,100 \\
205,000 \\
157,000 \\
45,200 \\
26,200\end{array}$ \\
\hline The year. & 6, 420 & & 957 & 692,000 \\
\hline September 17-30 1910 & 388 & 235 & 306 & 8,500 \\
\hline $\begin{array}{l}\text { Ootober. } \\
\text { November } \\
\text { December. } \\
\text { January } \\
\text { February } \\
\text { March } \\
\text { April } \\
\text { May } \\
\text { June } \\
\text { July } \\
\text { August } \\
\text { September }\end{array}$ & \begin{tabular}{|l} 
\\
\end{tabular} & 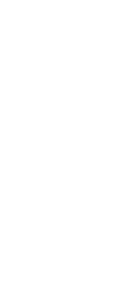 & $\begin{array}{r}196 \\
148 \\
125 \\
100 \\
100 \\
120 \\
318 \\
1,890 \\
3,240 \\
1,300 \\
390 \\
300\end{array}$ & $\begin{array}{r}12,100 \\
8,810 \\
7,690 \\
6,150 \\
6,550 \\
7,380 \\
18,900 \\
116,000 \\
193,000 \\
79,900 \\
24,000 \\
17,900\end{array}$ \\
\hline The year.................... & -non & & 687 & 497,000 \\
\hline $\begin{array}{l}\text { October. } \\
\text { November } \\
\text { December. } \\
\text { January } \\
\text { February } \\
\text { March } \\
\text { April } \\
\text { May } \\
\text { June } \\
\text { July } \\
\text { August } \\
\text { September }\end{array}$ & 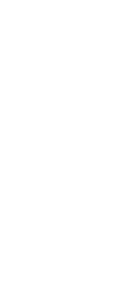 & 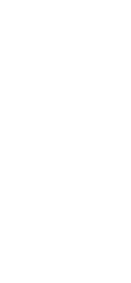 & $\begin{array}{r}286 \\
175 \\
125 \\
110 \\
105 \\
120 \\
300 \\
1,800 \\
4,440 \\
2,430 \\
869 \\
350\end{array}$ & $\begin{array}{r}17,600 \\
10,400 \\
7,690 \\
6,760 \\
6,040 \\
7,380 \\
17,000 \\
111,000 \\
264,000 \\
149,000 \\
53,400 \\
20,800\end{array}$ \\
\hline The year. . . . . . & 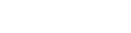 & 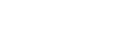 & 920 & 672,000 \\
\hline $\begin{array}{l}\text { October } \\
\text { November } \\
\text { December. } \\
\text { January } \\
\text { February } \\
\text { March } \\
\text { April } \\
\text { May } \\
\text { June } \\
\text { July } \\
\text { August } \\
\text { September }\end{array}$ & $\begin{array}{r}3,900 \\
3,760 \\
1,250 \\
472 \\
400\end{array}$ & $\begin{array}{r}1,190 \\
550 \\
246 \\
246\end{array}$ & $\begin{array}{r}.250 \\
\text { a } 150 \\
\text { a } 135 \\
\text { a } 130 \\
\text { a } 120 \\
\text { a } 125 \\
\text { a } 500 \\
1,840 \\
1,970 \\
877 \\
324 \\
307\end{array}$ & $\begin{array}{r}15,400 \\
8,930 \\
8,300 \\
7,990 \\
6,660 \\
7,690 \\
29,800 \\
113,000 \\
117,000 \\
53,900 \\
19,900 \\
18,300\end{array}$ \\
\hline The year... & & & 652 & 407,000 \\
\hline
\end{tabular}

- Estimated. 
Monthly discharge of Colorado River at Hot Sulphur Springs, Colo., for 1904-1909, 1. 1910-1924, and 1925-1987-Continued

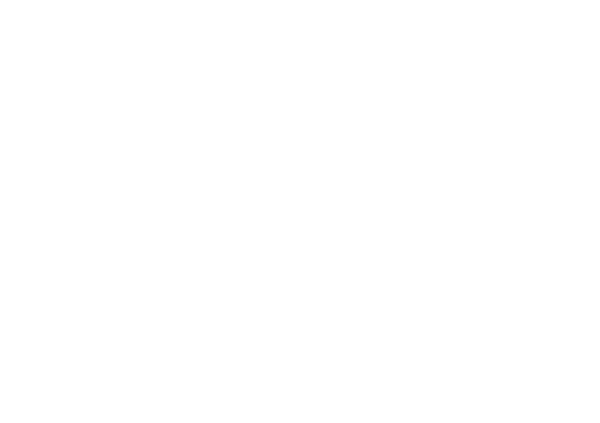

The year.

October

1914-15

December

January

February

March

May

June

July -

September

The year

October--

December

January.......

February

March

April

May

July..

August.

September

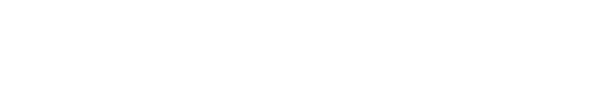

$1916-16$

November

Tovember.

January

February

March

April

May

June

July.

August

September

The year

October

November.

December

January.

February

March

April

May

June.

July--

August

September

The year

\begin{tabular}{|c|c|c|c|}
\hline \multicolumn{3}{|c|}{ Discharge in second-feet } & \multirow{2}{*}{$\begin{array}{l}\text { Run-off in } \\
\text { acre-feet }\end{array}$} \\
\hline Maximum & Minimum & Mean & \\
\hline $\begin{array}{r}378 \\
280 \\
\\
\\
\\
1,280 \\
6,330 \\
8,000 \\
2,550 \\
1,020 \\
391\end{array}$ & $\begin{array}{r}246 \\
200 \\
29 \\
290 \\
790 \\
790 \\
349 \\
227\end{array}$ & $\begin{array}{r}311 \\
230 \\
\therefore 120 \\
: 120 \\
\cdot 125 \\
\cdot 175 \\
610 \\
3,220 \\
4,780 \\
1,430 \\
506 \\
288\end{array}$ & $\begin{array}{r}19,100 \\
13,700 \\
7,380 \\
7,380 \\
6,940 \\
10,800 \\
36,300 \\
198,000 \\
284,000 \\
87,900 \\
31,110 \\
17,100\end{array}$ \\
\hline 8,000 & - & 1,590 & $1,150,000$ \\
\hline $\begin{array}{r}317 \\
246 \\
\\
\\
1,280 \\
1,600 \\
3,980 \\
2,550 \\
606 \\
357\end{array}$ & $\begin{array}{r}230 \\
90\end{array}$ & $\begin{array}{r}268 \\
150 \\
880 \\
280 \\
\quad 85 \\
\times 125 \\
559 \\
884 \\
2,680 \\
1,370 \\
378 \\
259\end{array}$ & $\begin{array}{r}16,500 \\
8,930 \\
4,920 \\
4,920 \\
4,720 \\
7,690 \\
33,300 \\
60,500 \\
159,000 \\
84,200 \\
23,200 \\
.15,400\end{array}$ \\
\hline 3,980 & $\ldots$ & 586 & 423,000 \\
\hline $\begin{array}{r}735 \\
1,700 \\
\mathbf{3}, 460 \\
\mathbf{3}, \mathbf{3 1 0} \\
1,820 \\
735 \\
\mathbf{4 7 2}\end{array}$ & $\begin{array}{r}172 \\
125 \\
1,940 \\
497 \\
765 \\
298 \\
246\end{array}$ & $\begin{array}{r}237 \\
140 \\
0105 \\
-115 \\
-119 \\
232 \\
530 \\
1,830 \\
2,710 \\
930 \\
483 \\
326\end{array}$ & $\begin{array}{r}14,600 \\
8,330 \\
6,460 \\
7,070 \\
6,840 \\
14,300 \\
31,300 \\
113,000 \\
161,000 \\
57,200 \\
29,700 \\
19,400\end{array}$ \\
\hline 3,460 & 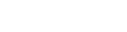 & 648 & 469,000 \\
\hline $\begin{array}{r}1,160 \\
3,610 \\
6,870 \\
5,770 \\
1,160 \\
337\end{array}$ & $\begin{array}{r}280 \\
378 \\
1,360 \\
1,160 \\
337 \\
202\end{array}$ & $\begin{array}{r}297 \\
192 \\
-125 \\
125 \\
125 \\
125 \\
125 \\
578 \\
1,380 \\
4,730 \\
2,700 \\
548 \\
257\end{array}$ & $\begin{array}{r}18,300 \\
11,400 \\
7,690 \\
7,690 \\
6,660 \\
7,690 \\
34,400 \\
84,800 \\
281,000 \\
166,000 \\
33,700 \\
15,300\end{array}$ \\
\hline 6,870 & (n) & 932 & 675,000 \\
\hline $\begin{array}{r}665 \\
4,060 \\
8,580 \\
2,400 \\
635 \\
337\end{array}$ & $\begin{array}{r}141 \\
424 \\
2,600 \\
550 \\
200 \\
210\end{array}$ & $\begin{array}{r}178 \\
154 \\
135 \\
2125 \\
a 115 \\
a 114 \\
333 \\
2,290 \\
5,140 \\
1,380 \\
371 \\
271\end{array}$ & $\begin{array}{r}10,900 \\
9,160 \\
8,300 \\
7,070 \\
6,390 \\
7,010 \\
10,800 \\
141,000 \\
306,000 \\
84,800 \\
22,800 \\
16,100\end{array}$ \\
\hline 8,580 & 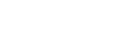 & 883 & 639,000 \\
\hline
\end{tabular}

c Estrated.

\section{7-18}


Monthly discharge of Colorado River at Hot Sulphur Springs, Colo., for 1904-1909, 1910-1924, and 1925-1927-Continued

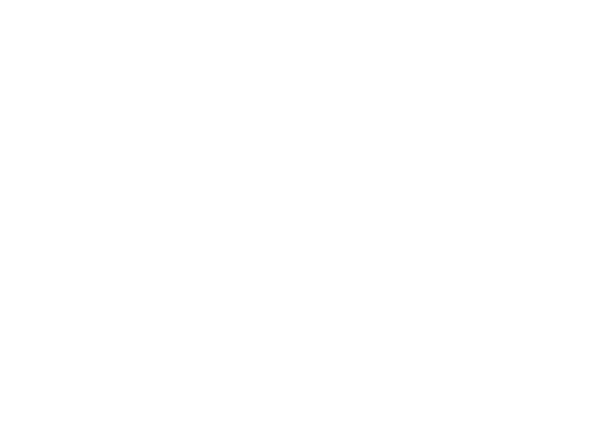

The year. $1919-20$

November

December

January.

Mareh.

April

May.

June.

August.

September.

The year

October
November
December
January
Fobruary
March
April.
May.
June.
July
August.
September

$$
\text { September. }
$$

The year

October.-

November

January.

February

March

April

June

July -

August -.

September.

The year

\section{October.}

November

December

January.

March

April.

Mane

June

August

September

The year

$1920-21$

\begin{tabular}{|c|c|c|c|}
\hline \multicolumn{3}{|c|}{ Discharge in second-feet } & \multirow{2}{*}{$\underset{\text { acre-feet }}{\underset{\text { Run-ofin in }}{ }}$} \\
\hline Maximum & Minimum & Moan & \\
\hline $\begin{array}{r}424 \\
310 \\
1,240 \\
3,400 \\
2,390 \\
940 \\
940 \\
350\end{array}$ & $\begin{array}{r}118 \\
118 \\
158 \\
780 \\
1,020 \\
292 \\
167 \\
181\end{array}$ & $\begin{array}{r}329 \\
201 \\
\times 122 \\
106 \\
\mathbf{1 0 1} \\
\mathbf{1 0 1} \\
\mathbf{5 0 5} \\
1, \mathbf{8 6 0} \\
1, \mathbf{5 1 0} \\
\mathbf{5 4 7} \\
\mathbf{3 2 7} \\
\mathbf{2 1 7}\end{array}$ & $\begin{array}{r}20,200 \\
12,000 \\
7,500 \\
6,520 \\
5,610 \\
7,600 \\
30,000 \\
114,000 \\
89,800 \\
33,600 \\
20,100 \\
12,900\end{array}$ \\
\hline 3,400 & n.m.n. & 498 & 360,000 \\
\hline $\begin{array}{r}205 \\
202 \\
114 \\
1,290 \\
5,580 \\
6,660 \\
3,550 \\
940 \\
418\end{array}$ & $\begin{array}{r}158 \\
83 \\
81\end{array}$ & $\begin{array}{r}176 \\
125 \\
92 \\
697 \\
105 \\
1042 \\
342 \\
653 \\
2,940 \\
4,370 \\
1,560 \\
625 \\
348\end{array}$ & $\begin{array}{r}10,800 \\
7,440 \\
5,660 \\
5,980 \\
6,040 \\
21,000 \\
38,900 \\
181,000 \\
260,000 \\
95,900 \\
38,400 \\
20,700\end{array}$ \\
\hline 6,660 & $\cdots$ & 952 & 692,000 \\
\hline $\begin{array}{r}310 \\
192 \\
565 \\
5,400 \\
9,280 \\
2,020 \\
822\end{array}$ & $\begin{array}{r}181 \\
127 \\
141 \\
740 \\
2,310 \\
822 \\
540 \\
\end{array}$ & $\begin{array}{r}236 \\
162 \\
153 \\
133 \\
111 \\
1118 \\
405 \\
2,400 \\
5,620 \\
1,200 \\
615 \\
330 .\end{array}$ & $\begin{array}{r}14,800 \\
9,640 \\
9,410 \\
8,180 \\
6,160 \\
7,260 \\
24,100 \\
148,000 \\
334,000 \\
79,800 \\
37,800 \\
19,600\end{array}$ \\
\hline 9,280 & 111 & 964 & 608,000 \\
\hline $\begin{array}{r}358 \\
170\end{array}$ & $\begin{array}{r}180 \\
1,800 \\
358 \\
272 \\
100\end{array}$ & $\begin{array}{r}282 \\
128 \\
126 \\
126 \\
112 \\
131 \\
\mathbf{3 0 9} \\
1,590 \\
2,270 \\
651 \\
354 \\
183\end{array}$ & $\begin{array}{r}14,300 \\
7,620 \\
7,750 \\
7,750 \\
6,220 \\
8,060 \\
18,400 \\
97,800 \\
135,000 \\
40,000 \\
21,800 \\
10,900\end{array}$ \\
\hline 3,560 & $\ldots$ & $\cdot 519$ & 376,000 \\
\hline $\begin{array}{r}778 \\
3,640 \\
6,220 \\
2,360 \\
905 \\
428\end{array}$ & $\begin{array}{r}\mathbf{9 5} \\
\mathbf{8 6}\end{array}$ & $\begin{array}{r}110 \\
111 \\
100 \\
+95 \\
\cdot 95 \\
\cdot 100 \\
330 \\
1,820 \\
3,680 \\
1,580 \\
578 \\
328\end{array}$ & $\begin{array}{r}6,760 \\
5,950 \\
6,150 \\
5,840 \\
5,280 \\
6,160 \\
17,600 \\
112,000 \\
219,000 \\
97,200 \\
35,500 \\
19,400\end{array}$ \\
\hline 6,220 & 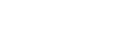 & 744 & 589,000 \\
\hline
\end{tabular}

- Estimated.

\section{1-22}

-

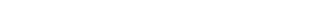

-

$-1$

(1)

(1)

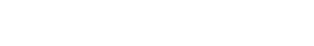

ar...

\section{$1922-23$}


Monthly discharge of Colorado River at Hot Sulphur Springs, Colo., for 1904-1909, 1910-1924, and 1925-1927-Continued

\begin{tabular}{|c|c|c|c|c|}
\hline \multirow{2}{*}{ Month } & \multicolumn{3}{|c|}{ Discharge in second-feet } & \multirow{2}{*}{$\begin{array}{c}\text { Run-off in } \\
\text { acre-feet }\end{array}$} \\
\hline & Maximum & Minimum & Mean & \\
\hline $\begin{array}{l}\text { October } \\
\text { Nov. 1-15 } \\
\text { May 15-31 } \\
\text { June } \\
\text { July } \\
\text { August_- } \\
\text { September. }\end{array}$ & $\begin{array}{r}414 \\
259 \\
3,000 \\
8,310 \\
2,020 \\
315 \\
133\end{array}$ & $\begin{array}{r}148 \\
117 \\
1,840 \\
1,590 \\
336 \\
117 \\
100\end{array}$ & $\begin{array}{r}282 \\
167 \\
2,360 \\
3,780 \\
1,020 \\
182 \\
106\end{array}$ & $\begin{array}{r}17,300 \\
4,970 \\
79,600 \\
225,000 \\
62,790 \\
11,200 \\
6,310\end{array}$ \\
\hline $\begin{array}{l}\text { October } \\
\text { November } \\
\text { December } \\
\text { January } \\
\text { February } \\
\text { March } \\
\text { April } \\
\text { May } \\
\text { June } \\
\text { July } \\
\text { August } \\
\text { September }\end{array}$ & \begin{tabular}{|r|}
271 \\
292 \\
\\
\hdashline \\
5,080 \\
2,930 \\
856 \\
310
\end{tabular} & $\begin{array}{r}275 \\
1,090 \\
2,080 \\
838 \\
263 \\
149\end{array}$ & 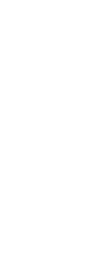 & $\begin{array}{r}22,800 \\
11,300 \\
8,300 \\
7,600 \\
6,660 \\
9,840 \\
47,300 \\
160,000 \\
230,000 \\
107,000 \\
31,900 \\
13,000\end{array}$ \\
\hline The year... & 5,910 & (n) & 905 & 656,000 \\
\hline $\begin{array}{l}\text { October } \\
\text { November } \\
\text { December } \\
\text { January } \\
\text { February } \\
\text { March } \\
\text { April } \\
\text { May } \\
\text { June } \\
\text { July } \\
\text { Auguste } \\
\text { September }\end{array}$ & $\begin{array}{r}1, \mathbf{5 3 0} \\
4,450 \\
3,610 \\
1,870 \\
883 \\
\mathbf{3 8 1}\end{array}$ & $\begin{array}{r}223 \\
1,600 \\
1,970 \\
605 \\
\mathbf{3 6 8} \\
\mathbf{2 0 4}\end{array}$ & $\begin{array}{r}187 \\
160 \\
2138 \\
2100 \\
395 \\
\cdot 126 \\
498 \\
2,680 \\
2,730 \\
1,050 \\
550 \\
286\end{array}$ & $\begin{array}{r}11,500 \\
98,880 \\
8,460 \\
6,150 \\
5,280 \\
7,750 \\
29,600 \\
165,000 \\
162,000 \\
64,600 \\
33,800 \\
17,000\end{array}$ \\
\hline The year..... & 4,450 & & 720 & 521,000 \\
\hline
\end{tabular}

- Estimated.

Nork.-Records fragmentary from Oct. 1, 1910, to Sept. 30, 1912; mean discharge based on comparison with flow of Colorado River near Kremmling.

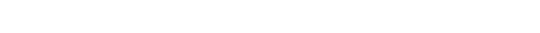

Location.-In sec. 23 , T. 1 N., R. 81 W.; at entrance to Gore Canyon, 3 miles - southwest of Kremmling, Grand County. Nearest tributary, Blue River, enters 2 miles above.

Drainage area.-2,360 square miles (measured on base map of Colorado).

Records available.-August 1, 1904, to September 30, 1918.

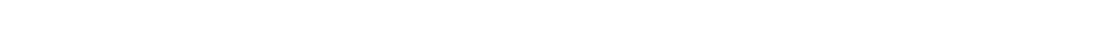
Control.-Slightly shifting.

Extremes of Discharge.-Maximum stage during period, 21.8 feet from 2 to 4 p. m. June 9, 1912 (discharge, 21,500 second-feet); minimum discharge recorded, 166 second-feet December 19, 1907.

Diversions.- Water diverted from Colorado River and tributaries between Hot Sulphur Springs and Kremmling stations for irrigation of 24,000 acres.

Accuracy.-Gage heights from continuous records, except for short periods, since 1910. Rating curves well defined. Records good.

Cooperation.- Since 1910 station maintained in cooperation with State engineer. 
Monthly discharge of Colorado River near Kremmling, Colo., for 1904-1918

\begin{tabular}{|c|c|c|c|c|}
\hline \multirow{2}{*}{ Month } & \multicolumn{3}{|c|}{ Discharge in second-feet } & \multirow{2}{*}{$\begin{array}{l}\text { Run-off in } \\
\text { acre-feet }\end{array}$} \\
\hline & Maximum & Minimum & Mean & \\
\hline $\begin{array}{l}\text { August } \\
\text { September }\end{array}$ & $\begin{array}{l}1,800 \\
1,820\end{array}$ & $\begin{array}{r}1,010 \\
662\end{array}$ & $\begin{array}{r}1,310 \\
893\end{array}$ & $\begin{array}{l}80,400 \\
53,100\end{array}$ \\
\hline $\begin{array}{l}\text { October } \\
\text { November } \\
\text { December } \\
\text { January } \\
\text { February } \\
\text { March } \\
\text { April. } \\
\text { May } \\
\text { Jume } \\
\text { July } \\
\text { August }\end{array}$ & \begin{tabular}{r}
790 \\
554 \\
\hdashline 402 \\
340 \\
550 \\
1,980 \\
6,430 \\
11,800 \\
4,340 \\
1,390 \\
800
\end{tabular} & \begin{tabular}{r}
535 \\
399 \\
\hdashline-287 \\
282 \\
332 \\
426 \\
1,660 \\
4,850 \\
1,340 \\
617 \\
436
\end{tabular} & $\begin{array}{r}646 \\
470 \\
a 312 \\
314 \\
316 \\
390 \\
\quad 924 \\
\mathbf{8}, 520 \\
8,000 \\
2,050 \\
866 \\
532\end{array}$ & $\begin{array}{r}39,700 \\
24,200 \\
19,200 \\
19,300 \\
17,600 \\
24,000 \\
55,000 \\
217,000 \\
476,000 \\
126,000 \\
53,200 \\
31,700\end{array}$ \\
\hline The & 11,800 & $\ldots$ & 1,530 & $1,100,000$ \\
\hline $\begin{array}{l}\text { October. } \\
\text { November } \\
\text { December } \\
\text { January } \\
\text { February } \\
\text { March } \\
\text { April } \\
\text { May } \\
\text { June } \\
\text { Juify } \\
\text { August } \\
\text { September }\end{array}$ & $\begin{array}{r}3,020 \\
8,350 \\
11,600 \\
4,710 \\
1,990 \\
1,680\end{array}$ & \begin{tabular}{r}
368 \\
272 \\
228 \\
\\
\hdashline \\
1,425 \\
4,440 \\
1,820 \\
960 \\
785
\end{tabular} & $\begin{array}{r}475 \\
419 \\
325 \\
\times 305 \\
2342 \\
\approx 525 \\
1,440 \\
5,000 \\
7,080 \\
3,290 \\
1,400 \\
1,160\end{array}$ & $\begin{array}{r}29,200 \\
24,900 \\
20,000 \\
18,800 \\
19,000 \\
32,300 \\
86,700 \\
311,000 \\
421,000 \\
202,000 \\
86,100 \\
69,000\end{array}$ \\
\hline The year.- & 11,600 & $\ldots$ & 1,820 & $1,320,000$ \\
\hline $\begin{array}{l}\text { October } \\
\text { November } \\
\text { December } \\
\text { January } \\
\text { February } \\
\text { March } \\
\text { April } \\
\text { May } \\
\text { June } \\
\text { August } \\
\text { September }\end{array}$ & \begin{tabular}{r}
1,140 \\
755 \\
565 \\
\hdashline \\
2,520 \\
3,010 \\
8,210 \\
11,700 \\
11,400 \\
2,810 \\
1,140
\end{tabular} & $\begin{array}{r}395 \\
734 \\
1,420 \\
4,040 \\
3,120 \\
1,140 \\
585\end{array}$ & $\begin{array}{r}817 \\
646 \\
477 \\
\times 377 \\
\times 375 \\
874 \\
1,690 \\
3,680 \\
9,170 \\
6,220 \\
1,700 \\
784\end{array}$ & $\begin{array}{r}50,200 \\
32,500 \\
2,300 \\
28,200 \\
20,800 \\
53,700 \\
101,000 \\
226,000 \\
546,000 \\
382,000 \\
105,000 \\
48,700\end{array}$ \\
\hline The year.- & 11,700 & 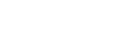 & 2,240 & $1,690,000$ \\
\hline $\begin{array}{l}\text { October } \\
\text { November } \\
\text { December } \\
\text { January } \\
\text { February } \\
\text { March } \\
\text { April } \\
\text { May } \\
\text { June } \\
\text { July } \\
\text { August } \\
\text { September }\end{array}$ & $\begin{array}{r}1,100 \\
5900 \\
300 \\
350 \\
330 \\
740 \\
2,300 \\
3,650 \\
6,510 \\
3,150 \\
2,220 \\
755\end{array}$ & $\begin{array}{r}540 \\
220 \\
166 \\
300 \\
265 \\
265 \\
265 \\
415 \\
1,170 \\
3,120 \\
1,170 \\
816 \\
465\end{array}$ & $\begin{array}{r}719 \\
407 \\
259 \\
304 \\
306 \\
419 \\
1,290 \\
2,390 \\
4,720 \\
2,010 \\
1,310 \\
597\end{array}$ & $\begin{array}{r}4,000 \\
24,000 \\
18,000 \\
18,700 \\
17,000 \\
26,800 \\
76,800 \\
147,000 \\
281,000 \\
124,000 \\
80,000 \\
\$ 5,500\end{array}$ \\
\hline The year... & 6,510 & 166 & 1,230 & 891,000 \\
\hline
\end{tabular}

\footnotetext{
- Estimated by comparison with flow at Glenwood Springs.
} 
Monthly discharge of Colorado River near Kremmling, Colo., for 1904-1918-Con.

\begin{tabular}{|c|c|c|c|c|}
\hline \multirow{2}{*}{ Month } & \multicolumn{3}{|c|}{ Discharge in second-feet } & \multirow{2}{*}{$\begin{array}{l}\text { Run-off in } \\
\text { acre-feet }\end{array}$} \\
\hline & Maximum & Minimum & Mean & \\
\hline $\begin{array}{l}\text { October } \\
\text { November } \\
\text { December } \\
\text { January } \\
\text { Mabruary } \\
\text { April } \\
\text { Jay } \\
\text { June } \\
\text { August } \\
\text { September }\end{array}$ & $\begin{array}{r}540 \\
502 \\
1,680 \\
6,860 \\
15,300 \\
11,500 \\
3,120 \\
2,280\end{array}$ & $\begin{array}{r}415 \\
260 \\
490 \\
978 \\
4,960 \\
2,020 \\
1,380 \\
908\end{array}$ & $\begin{array}{r}488 \\
390 \\
\times 303 \\
\times 382 \\
6329 \\
\times 429 \\
864 \\
4,040 \\
11,700 \\
5,270 \\
1,890 \\
1,410\end{array}$ & $\begin{array}{r}30,000 \\
23,200 \\
18,600 \\
28,500 \\
18,300 \\
26,400 \\
51,400 \\
248,000 \\
696,000 \\
324,000 \\
116,000 \\
83,900\end{array}$ \\
\hline 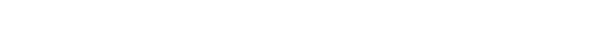 & 15,300 & - & 2,290 & $1,660,000$ \\
\hline $\begin{array}{l}\text { October. } \\
\text { November } \\
\text { December } \\
\text { January } \\
\text { February. } \\
\text { March } \\
\text { April } \\
\text { May } \\
\text { June } \\
\text { July } \\
\text { August } \\
\text { September }\end{array}$ & $\begin{array}{r}908 \\
680 \\
\mathbf{5 1 5} \\
\mathbf{1 , 4 8 0} \\
\mathbf{4}, 020 \\
\mathbf{7}, 280 \\
\mathbf{7}, 600 \\
2,420 \\
\mathbf{1 , 4 4 0} \\
960\end{array}$ & \begin{tabular}{r|r|}
$\mathbf{5 2 8}$ \\
$\mathbf{3 6 5}$ \\
$\mathbf{3 0 2}$ \\
$\mathbf{3 6 0}$ \\
$\mathbf{8 0 0}$ \\
$\mathbf{2 , 4 4 0}$ \\
$\mathbf{1 , 9 9 0}$ \\
$\mathbf{7 1 0}$ \\
$\mathbf{5 0 2}$ \\
$\mathbf{4 7 8}$
\end{tabular} & $\begin{array}{r}739 \\
533 \\
437 \\
a 420 \\
\times 360 \\
905 \\
1,620 \\
3,600 \\
4,010 \\
1,270 \\
784 \\
706\end{array}$ & $\begin{array}{r}45,400 \\
31,700 \\
27,000 \\
25,800 \\
20,000 \\
55,600 \\
96,400 \\
221,000 \\
239,000 \\
78,100 \\
38,200 \\
42,000\end{array}$ \\
\hline The year & 7,600 & 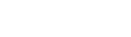 & 1,280 & 930,000 \\
\hline $\begin{array}{l}\text { October. } \\
\text { November. } \\
\text { December. } \\
\text { January } \\
\text { February } \\
\text { March } \\
\text { April } \\
\text { May } \\
\text { June } \\
\text { July } \\
\text { August } \\
\text { September. }\end{array}$ & $\begin{array}{r}578 \\
490 \\
650 \\
590 \\
635 \\
2,550 \\
6,550 \\
8,350 \\
5,850 \\
1,680 \\
965\end{array}$ & $\begin{array}{r}485 \\
377 \\
330 \\
350 \\
380 \\
620 \\
1,800 \\
3,200 \\
1,480 \\
950 \\
695\end{array}$ & $\begin{array}{r}513 \\
435 \\
\times 366 \\
426 \\
405 \\
525 \\
1,150 \\
4,440 \\
6,370 \\
2,930 \\
1,180 \\
804\end{array}$ & $\begin{array}{r}31,500 \\
25,900 \\
22,500 \\
26,200 \\
22,500 \\
32,300 \\
68,400 \\
273,000 \\
379,000 \\
180,000 \\
72,600 \\
47,800 \\
\end{array}$ \\
\hline The yeax & 8,350 & 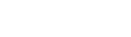 & 1,630 & $1,180,000$ \\
\hline $\begin{array}{l}\text { October. } \\
\text { November } \\
\text { December } \\
\text { January } \\
\text { February. } \\
\text { March } \\
\text { April } \\
\text { May } \\
\text { Juno } \\
\text { July } \\
\text { August. } \\
\text { September }\end{array}$ & $\begin{array}{r}1,340 \\
755 \\
502 \\
1,24 \\
11,000 \\
21,000 \\
11,300 \\
4,780 \\
1,200\end{array}$ & $\begin{array}{r}\mathbf{3 4 0} \\
\mathbf{3 4 0} \\
\mathbf{7 1 8} \\
\mathbf{1 , 4 2 0} \\
\mathbf{5 , 0 0 0} \\
\mathbf{4}, \mathbf{2 2 0} \\
\mathbf{1 ,}, \mathbf{9 0 0} \\
\mathbf{9 0 0} \\
\end{array}$ & $\begin{array}{r}863 \\
562 \\
393 \\
434 \\
465 \\
465 \\
894 \\
4,450 \\
11,400 \\
6,040 \\
2,070 \\
1,000\end{array}$ & $\begin{array}{r}53,100 \\
33,400 \\
24,200 \\
26,700 \\
24,500 \\
28,600 \\
53,200 \\
273,000 \\
678,000 \\
372,000 \\
127,000 \\
61,400\end{array}$ \\
\hline The year. & 21,000 & 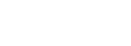 & 3,190 & $1,760,000$ \\
\hline $\begin{array}{l}\text { October } \\
\text { November } \\
\text { December } \\
\text { January } \\
\text { February } \\
\text { March } \\
\text { April. } \\
\text { May } \\
\text { June } \\
\text { July } \\
\text { August. } \\
\text { September }\end{array}$ & $\begin{array}{r}988 \\
880 \\
7,610 \\
7,730 \\
2,720 \\
1,250 \\
1,170\end{array}$ & $\begin{array}{r}\mathbf{7 8 5} \\
\mathbf{6 7 2} \\
\mathbf{3}, \mathbf{0 2 0} \\
\mathbf{1 , 2 9 0} \\
\mathbf{8 1 2} \\
\mathbf{7 8 2}\end{array}$ & $\begin{array}{r}908 \\
734 \\
\cdot 446 \\
\cdot 421 \\
=321 \\
\cdot 388 \\
\cdot 1,850 \\
4,160 \\
4,610 \\
1,970 \\
949 \\
918\end{array}$ & $\begin{array}{r}55,900 \\
43,700 \\
27,400 \\
25,900 \\
17,800 \\
23,900 \\
110,000 \\
256,000 \\
274,000 \\
121,000 \\
58,400 \\
54,600\end{array}$ \\
\hline The year. & 7,730 & 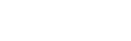 & 1,480 & $1,070,000$ \\
\hline
\end{tabular}

$a$ Estimated by comparison with flow at Glenwood Springs. 
Monthly discharge of Colorado River near Kremmling, Colo., for 1904-1918-Con.

\begin{tabular}{|c|c|c|c|c|}
\hline \multirow{2}{*}{ Month } & \multicolumn{3}{|c|}{ Discharge in second-feat } & \multirow{2}{*}{$\underset{\text { acre-feet }}{\text { Run-off in }}$} \\
\hline & Maximum & Minimum & Mean & \\
\hline $\begin{array}{l}\text { Oetober. } \\
\text { November } \\
\text { December. } \\
\text { January } \\
\text { February } \\
\text { March } \\
\text { April } \\
\text { May } \\
\text { June } \\
\text { July } \\
\text { August } \\
\text { September }\end{array}$ & $\begin{array}{r}1,050 \\
752 \\
4487 \\
474 \\
875 \\
2,420 \\
13,700 \\
16,300 \\
5,290 \\
3,080 \\
1,190\end{array}$ & $\begin{array}{r}622 \\
461 \\
313 \\
301 \\
461 \\
843 \\
2,100 \\
5,500 \\
2,370 \\
1,160 \\
707\end{array}$ & $\begin{array}{r}822 \\
653 \\
\times 375 \\
374 \\
447 \\
545 \\
1,520 \\
7,320 \\
10,500 \\
3,450 \\
1,380 \\
871\end{array}$ & $\begin{array}{r}50,500 \\
38,900 \\
23,100 \\
23,000 \\
24,800 \\
33,500 \\
90,400 \\
450,000 \\
625,000 \\
212,000 \\
97,200 \\
51,800\end{array}$ \\
\hline The year.................. & 16,300 & & 2,380 & $1,720,000$ \\
\hline $\begin{array}{l}\text { October. } \\
\text { November } \\
\text { December } \\
\text { January } \\
\text { February } \\
\text { March } \\
\text { April } \\
\text { May } \\
\text { June } \\
\text { July } \\
\text { August } \\
\text { September }\end{array}$ & $\begin{array}{r}940 \\
707 \\
342 \\
268 \\
330 \\
635 \\
2,820 \\
3,900 \\
8,110 \\
4,990 \\
1,680 \\
910\end{array}$ & $\begin{array}{r}739 \\
375 \\
180 \\
192 \\
218 \\
268 \\
650 \\
1,280 \\
3,330 \\
1,240 \\
680 \\
500\end{array}$ & $\begin{array}{r}802 \\
511 \\
255 \\
241 \\
279 \\
372 \\
1,420 \\
2,620 \\
5,640 \\
2,800 \\
964 \\
673\end{array}$ & $\begin{array}{r}49,300 \\
30,400 \\
15,700 \\
14,800 \\
15,500 \\
22,900 \\
84,500 \\
161,000 \\
336,000 \\
172,000 \\
59,300 \\
40,000\end{array}$ \\
\hline The year. & 8,110 & 180 & 1,380 & $1,000,000$ \\
\hline $\begin{array}{l}\text { October } \\
\text { November } \\
\text { December. } \\
\text { January } \\
\text { February } \\
\text { March } \\
\text { April } \\
\text { May } \\
\text { June } \\
\text { July } \\
\text { August } \\
\text { September }\end{array}$ & $\begin{array}{r}858 \\
560 \\
450 \\
460 \\
378 \\
1,330 \\
\mathbf{3}, 570 \\
7,120 \\
\mathbf{8}, 100 \\
\mathbf{4}, 490 \\
\mathbf{2 , 6 5 0} \\
\mathbf{1 , 3 7 0}\end{array}$ & $\begin{array}{r}545 \\
230 \\
200 \\
285 \\
290 \\
328 \\
570 \\
2,130 \\
4,760 \\
1,580 \\
940 \\
695\end{array}$ & $\begin{array}{r}672 \\
489 \\
329 \\
353 \\
332 \\
646 \\
1,360 \\
4,080 \\
6,380 \\
2,660 \\
1,650 \\
950\end{array}$ & $\begin{array}{r}41,300 \\
26,100 \\
20,200 \\
21,700 \\
19,100 \\
39,700 \\
80,900 \\
251,000 \\
380,000 \\
164,000 \\
101,000 \\
56,500\end{array}$ \\
\hline 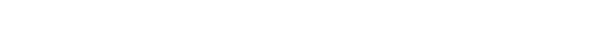 & 8,100 & 200 & 1,650 & $1,200,000$ \\
\hline $\begin{array}{l}\text { October } \\
\text { November } \\
\text { December } \\
\text { January } \\
\text { February } \\
\text { March } \\
\text { April } \\
\text { May } \\
\text { June } \\
\text { July } \\
\text { August } \\
\text { September }\end{array}$ & $\begin{array}{r}1,090 \\
678 \\
465 \\
420 \\
435 \\
900 \\
3,340 \\
8,440 \\
15,000 \\
12,300 \\
2,490 \\
940\end{array}$ & $\begin{array}{r}615 \\
840 \\
352 \\
365 \\
352 \\
300 \\
435 \\
1,330 \\
4,050 \\
2,610 \\
975 \\
585\end{array}$ & $\begin{array}{r}817 \\
492 \\
386 \\
389 \\
381 \\
396 \\
1,720 \\
3,740 \\
10,900 \\
5,590 \\
1,430 \\
760\end{array}$ & $\begin{array}{r}50,200 \\
29,300 \\
23,700 \\
23,000 \\
21,200 \\
24,800 \\
102,000 \\
230,000 \\
649,000 \\
844,000 \\
87,900 \\
45,200\end{array}$ \\
\hline The year & 15,000 & 300 & 2,260 & $1,630,000$ \\
\hline $\begin{array}{l}\text { October } \\
\text { November } \\
\text { December } \\
\text { January } \\
\text { February } \\
\text { March } \\
\text { April } \\
\text { May } \\
\text { June } \\
\text { July } \\
\text { August } \\
\text { September }\end{array}$ & $\begin{array}{r}670 \\
1,780 \\
8,680 \\
16,500 \\
5,360 \\
1,680 \\
1,050\end{array}$ & $\begin{array}{r}450 \\
370 \\
1,250 \\
6,210 \\
1,580 \\
730 \\
730\end{array}$ & $\begin{array}{r}539 \\
515 \\
a 412 \\
374 \\
3375 \\
a 510 \\
1,160 \\
5,540 \\
11,600 \\
3,250 \\
1,180 \\
880\end{array}$ & $\begin{array}{r}33,100 \\
30,600 \\
25,300 \\
23,000 \\
20,800 \\
31,400 \\
69,000 \\
341,000 \\
690,000 \\
200,000 \\
72,600 \\
52,400\end{array}$ \\
\hline 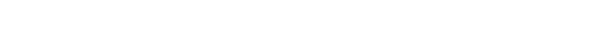 & 16,500 & & 2,200 & $1,690,000$ \\
\hline
\end{tabular}

a Estimatediby comparison with flow at Glenwood Springs. 
COLORADO RIVER AT STATE BRIDGE, COLO.

Locarion.-About sec. 23, T. 2 S., R. 83 W., at highway bridge at State Bridge,

Eagle County. Nearest tributary, Piney Creek, enters some distance upstream.

Drainage area.-2,670 square miles (measured on base map of Colorado). Records available.-May 27, 1906, to May 20, 1908.

GAGE.-Chain on bridge.

Control.-Somewhat shifting.

Extremes of Discharge.--Maximum stage recorded, 9.0 feet at $7 \mathrm{p} . \mathrm{m}$. June 15, 1906 (discharge, 12,600 second-feet); minimum stage occurred during winter.

Diversions. - Water diverted from tributaries entering Colorado River between State Bridge and Kremmling stations for irrigation of 3,000 acres.

Accuracr.-Gage read twice daily. Rating curves well defined. Records good.

Monthly discharge of Colorado River at State Bridge, Colo., 1906-1908

\begin{tabular}{|c|c|c|c|c|}
\hline \multirow{2}{*}{ Month } & \multicolumn{3}{|c|}{ Discharge in second-feet } & \multirow{2}{*}{$\begin{array}{l}\text { Run-off in } \\
\text { acre-feet }\end{array}$} \\
\hline & Maximunt & Minimum & Mean & \\
\hline \multirow{2}{*}{$\begin{array}{l}\text { May } 27-31 \\
\text { June } \\
\text { Judy } \\
\text { August } \\
\text { September } \\
\quad \text { The period }\end{array}$} & $\begin{array}{r}7,790 \\
12,300 \\
5,370 \\
1,900 \\
2,010\end{array}$ & $\begin{array}{r}6,340 \\
4,840 \\
1,860 \\
943 \\
733\end{array}$ & $\begin{array}{l}6,960 \\
7,480 \\
3,440 \\
1,320 \\
1,200\end{array}$ & $\begin{array}{r}69,000 \\
445,000 \\
212,000 \\
81,200 \\
71,400\end{array}$ \\
\hline & $\ldots$ & - & $-\ldots \ldots$ & 879,000 \\
\hline $\begin{array}{l}\text { Oetober } \\
\text { November } \\
\text { December. } \\
\text { January } \\
\text { February } \\
\text { March } \\
\text { April } \\
\text { May } \\
\text { June } \\
\text { July } \\
\text { August } \\
\text { September }\end{array}$ & $\begin{array}{r}1,450 \\
800 \\
608 \\
472 \\
495 \\
3,040 \\
3,380 \\
11,300 \\
12,300 \\
11,500 \\
3,240 \\
1,270\end{array}$ & $\begin{array}{r}608 \\
410 \\
410 \\
343 \\
359 \\
495 \\
1,140 \\
2,170 \\
5,010 \\
3,380 \\
1,270 \\
669\end{array}$ & $\begin{array}{r}883 \\
553 \\
522 \\
397 \\
408 \\
1,300 \\
1,880 \\
4,870 \\
10,100 \\
6,700 \\
1,900 \\
896\end{array}$ & $\begin{array}{r}54,300 \\
32,900 \\
32,100 \\
24,400 \\
22,700 \\
79,900 \\
112,000 \\
299,000 \\
601,000 \\
412,000 \\
117,000 \\
53,300\end{array}$ \\
\hline The year. & 12,300 & 343 & 2,540 & $1,840,000$ \\
\hline $\begin{array}{l}\text { October. } \\
\text { November. } \\
\text { December } \\
\text { January } \\
\text { February } \\
\text { March } \\
\text { April } \\
\text { May } 1-200\end{array}$ & $\begin{array}{r}1,360 \\
550 \\
-380 \\
375 \\
733 \\
2,670 \\
4,190\end{array}$ & $\begin{array}{r}550 \\
285 \\
345 \\
313 \\
313 \\
410 \\
1,400\end{array}$ & $\begin{array}{r}814 \\
425 \\
275 \\
353 \\
337 \\
491 \\
1,480 \\
2,390\end{array}$ & $\begin{array}{l}50,100 \\
25,300 \\
16,900 \\
21,700 \\
19,400 \\
30,200 \\
88,100 \\
94,800\end{array}$ \\
\hline The period. & & & & 346,000 \\
\hline
\end{tabular}

COLORADO RIVER AT GLENWOOD SPRINGS, COLO.

Location.-In sec. 9, T. 6 S., R. 89 W., in front of power house at Glenwood Springs, Garfield County. Nearest tributary, Roaring Fork, enters half a mile downstream.

Drainage area. - 4,560 square miles (measured on base map of Colorado).

Records available.- January 1, 1900, to September 30, 1927; also from May 12 to July 17, 1899, at point just above Roaring Fork.

GAGr.-Friez water-stage recorder since May 17, 1910; staff gage prior to that. date.

Controu.--Slightly shifting. 
Extremes of Discharge.-Maximum stage, 12.55 feet at noon June 14 and 15 , 1918 (discharge, 30,100 second-feet); minimum stage, 1.6 feet at $5 \mathrm{p}$. m. February 6,1921 , when flow was held back at Shoshone power plant (discharge, 80 second-feet).

ICE.-Stage-discharge relation not affected by ice; hot springs prevent ice.

Diversions.-Between Kremmling and Glenwood Springs stations, practically no diversion for irrigation. Colorado Power Co. has decree for diversion of 1,250 second-feet for power at Shoshone. This diversion is returned to stream above Glenwood Springs.

AcCURACY.-Gage heights from continuous records since 1910. Rating curves well defined. Records excellent since 1910, except below 1,000 second-feet, for which they are good. Prior to 1910, records good.

Cooperation.- Station maintained in cooperation with Colorado Power Co., from 1910 to 1924, and with Public Service Co. and State engineer from 19251927.

Monthly discharge of Colorado River at Glenwood Springs, Colo., for 1900-1927

\begin{tabular}{|c|c|c|c|c|}
\hline \multirow{2}{*}{ Month. } & \multicolumn{3}{|c|}{ Discharge in second-feet } & \multirow{2}{*}{$\begin{array}{l}\text { Run-off in } \\
\text { acre-foet }\end{array}$} \\
\hline & Maximum & Minimum & Mean & \\
\hline $\begin{array}{l}\text { January } \\
\text { February }\end{array}$ & $\begin{array}{r}920 \\
880 \\
1,440 \\
3,110 \\
19,700 \\
19,300 \\
6,500 \\
1,620 \\
920\end{array}$ & $\begin{array}{r}730 \\
730 \\
840 \\
1,100 \\
2,930 \\
6,800 \\
1,680 \\
1,000 \\
765\end{array}$ & $\begin{array}{r}825 \\
816 \\
1,150 \\
1,760 \\
9,970 \\
13,300 \\
3,110 \\
1,250 \\
826\end{array}$ & $\begin{array}{r}50,700 \\
45,300 \\
70,700 \\
105,000 \\
613,000 \\
791,000 \\
191,000 \\
76,000 \\
40,200\end{array}$ \\
\hline The period & $\ldots$. & 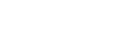 & $\ldots-n$ & $1,990,000$ \\
\hline 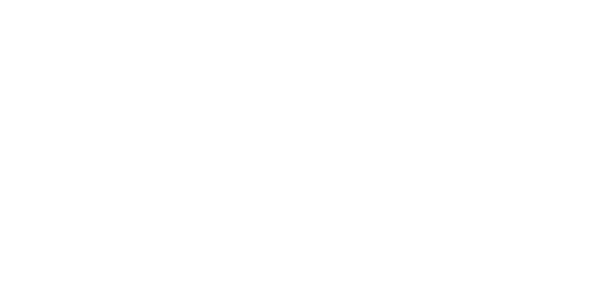 & $\begin{array}{r}1,000 \\
882 \\
845 \\
1,040 \\
1,040^{\prime} \\
6,030 \\
19,700 \\
13,500 \\
9,140 \\
3,550 \\
1,590\end{array}$ & $\begin{array}{r}742 \\
540 \\
518 \\
690 \\
742 \\
742 \\
5,510 \\
8,120 \\
2,240 \\
1,480 \\
882\end{array}$ & $\begin{array}{r}830 \\
839 \\
688 \\
693 \\
705 \\
878 \\
1,860 \\
11,800 \\
10,400 \\
4,470 \\
2,030 \\
1,130\end{array}$ & $\begin{array}{r}51,000 \\
49,900 \\
42,300 \\
42,600 \\
49,590 \\
54,000 \\
110,000 \\
726,000 \\
619,030 \\
275,000 \\
165,600 \\
67,200\end{array}$ \\
\hline The year. . . . . & 19,700 & - n-...... & 3,050 & 2, 205,800 \\
\hline 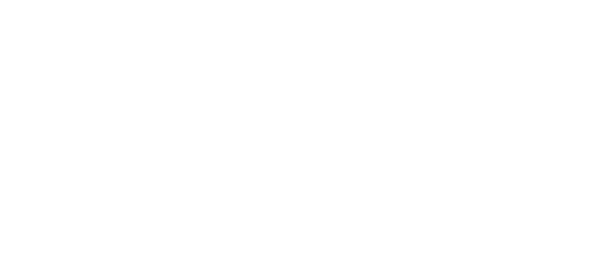 & $\begin{array}{r}1,040 \\
1,000 \\
1,000 \\
882 \\
845 \\
882 \\
2,720 \\
12,000 \\
10,400 \\
2,900\end{array}$ & $\begin{array}{r}\mathbf{9 2 0} \\
\mathbf{8 4 5} \\
\mathbf{6 2 0} \\
\mathbf{5 9 0} \\
\mathbf{5 9 0} \\
\mathbf{7 1 0} \\
\mathbf{7 4 9} \\
\mathbf{3 , 6 5 0} \\
\mathbf{2 , 7 2 0} \\
\mathbf{1 , 1 0 0} \\
\end{array}$ & $\begin{array}{r}979 \\
982 \\
817 \\
721 \\
775 \\
805 \\
1,430 \\
8,390 \\
6,330 \\
1,780 \\
1,000 \\
1,000\end{array}$ & $\begin{array}{l}60,200 \\
55,500 \\
50,200 \\
44,300 \\
43,600 \\
43,400 \\
85,100 \\
516,600 \\
277,600 \\
109,090 \\
65,690 \\
59,60\end{array}$ \\
\hline The year... & 12,000 & $-\ldots+\ldots+\ldots$ & 2,090 & $1,510,000$ \\
\hline
\end{tabular}


Monthly discharge of Colorado River at Glenwood Springs, Colo., for 1900-1927Continued

\begin{tabular}{|c|c|c|c|c|}
\hline \multirow{2}{*}{ Month } & \multicolumn{3}{|c|}{ Discharge in second-fest } & \multirow{2}{*}{$\begin{array}{c}\text { Run-off in } \\
\text { acr } \theta \text {-feet }\end{array}$} \\
\hline & Maximum & Minimum & Mean & \\
\hline $\begin{array}{l}\text { October } \\
\text { November- } \\
\text { December } \\
\text { January } \\
\text { February } \\
\text { March } \\
\text { April } \\
\text { May } \\
\text { June } \\
\text { July } \\
\text { August } \\
\text { September }\end{array}$ & $\begin{array}{r}775 \\
620 \\
605 \\
950 \\
3,900 \\
11,400 \\
16,500 \\
9,650 \\
2,440 \\
1,690\end{array}$ & $\begin{array}{r}402 \\
450 \\
472 \\
515 \\
894 \\
2,890 \\
8,460 \\
2,590 \\
1,240 \\
1,040\end{array}$ & $\begin{array}{r}1,270 \\
700 \\
646 \\
534 \\
547 \\
738 \\
1,690 \\
5,910 \\
12,600 \\
5,020 \\
1,600 \\
1,420\end{array}$ & $\begin{array}{r}78,100 \\
41,700 \\
39,700 \\
32,800 \\
30,400 \\
45,400 \\
101,000 \\
363,000 \\
750,000 \\
309,000 \\
98,400 \\
84,500\end{array}$ \\
\hline The year. & 16,500 & (n.............. & 2,720 & $1,970,000$ \\
\hline $\begin{array}{l}\text { October } \\
\text { November } \\
\text { December } \\
\text { January } \\
\text { February } \\
\text { March } \\
\text { April } \\
\text { May } \\
\text { June } \\
\text { July } \\
\text { August } \\
\text { September }\end{array}$ & $\begin{array}{r}1,570 \\
1,190 \\
960 \\
830 \\
558 \\
1,240 \\
4,730 \\
16,100 \\
13,900 \\
8,720 \\
3,110 \\
3,110\end{array}$ & $\begin{array}{r}1,040 \\
672 \\
455 \\
485 \\
475 \\
760 \\
774 \\
3,300 \\
7,420 \\
2,930 \\
1,920 \\
1,440\end{array}$ & $\begin{array}{r}1,340 \\
958 \\
595 \\
583 \\
619 \\
911 \\
2,470 \\
7,980 \\
10,900 \\
4,860 \\
2,380 \\
1,820\end{array}$ & $\begin{array}{r}82,400 \\
57,000 \\
36,600 \\
35,800 \\
35,600 \\
56,000 \\
147,000 \\
491,000 \\
649,000 \\
299,000 \\
146,000 \\
108,000\end{array}$ \\
\hline The year. & 16,100 & 455 & 2,950 & $2,140,000$ \\
\hline $\begin{array}{l}\text { October } \\
\text { November } \\
\text { December } \\
\text { January } \\
\text { February } \\
\text { March } \\
\text { A pril } \\
\text { May } \\
\text { June } \\
\text { July } \\
\text { August } \\
\text { September }\end{array}$ & $\begin{array}{r}1,470 \\
1,150 \\
746 \\
739 \\
684 \\
1,050 \\
3,300 \\
13,300 \\
22,100 \\
8,160 \\
2,520 \\
1,660\end{array}$ & $\begin{array}{r}1,120 \\
642 \\
355 \\
590 \\
460 \\
666 \\
894 \\
3,300 \\
8,500 \\
2,430 \\
1,280 \\
1,080\end{array}$ & $\begin{array}{r}1,290 \\
854 \\
599 \\
674 \\
591 \\
843 \\
1,600 \\
7,070 \\
14,900 \\
3,770 \\
1,690 \\
1,300\end{array}$ & $\begin{array}{r}79,300 \\
50,800 \\
36,800 \\
41,400 \\
32,800 \\
51,800 \\
95,200 \\
435,000 \\
887,000 \\
232,000 \\
104,000 \\
77,400\end{array}$ \\
\hline The year. & 22,100 & 355 & 2,980 & $2,120,000$ \\
\hline $\begin{array}{l}\text { Oetober } \\
\text { November } \\
\text { December } \\
\text { January } \\
\text { February } \\
\text { March } \\
\text { April } \\
\text { May } \\
\text { June } \\
\text { July } \\
\text { August } \\
\text { September }\end{array}$ & $\begin{array}{r}1,190 \\
1,170 \\
690 \\
660 \\
760 \\
1,780 \\
6,180 \\
15,700 \\
22,100 \\
8,500 \\
4,430 \\
5,480\end{array}$ & $\begin{array}{r}1,010 \\
540 \\
430 \\
505 \\
630 \\
690 \\
1,330 \\
2,870 \\
8,160 \\
4,080 \\
1,850 \\
1,850 .\end{array}$ & $\begin{array}{r}1,090 \\
1,010 \\
603 \\
610 \\
685 \\
1,050 \\
2,800 \\
9,750 \\
13,100 \\
6,390 \\
2,800 \\
3,460\end{array}$ & $\begin{array}{r}67,000 \\
60,100 \\
37,100 \\
37,500 \\
38,000 \\
64,600 \\
167,000 \\
600,000 \\
780,000 \\
393,000 \\
172,000 \\
206,000\end{array}$ \\
\hline The year. & 22,100 & 430 & 3,620 & $2,620,000$ \\
\hline $\begin{array}{l}\text { October } \\
\text { Novernber } \\
\text { December } \\
\text { January } \\
\text { February } \\
\text { March } \\
\text { April } \\
\text { May } \\
\text { June } \\
\text { July } \\
\text { August }\end{array}$ & $\begin{array}{r}3,960 \\
1,360 \\
1,010 \\
802 \\
1,010 \\
3,640 \\
6,040 \\
15,200 \\
20,400 \\
18,700 \\
6,040 \\
2,350\end{array}$ & $\begin{array}{r}1,010 \\
642 \\
455 \\
520 \\
760 \\
809 \\
1,420 \\
2,870 \\
8,500 \\
6,610 \\
2,200 \\
1,420\end{array}$ & $\begin{array}{r}1,720 \\
1,090 \\
801 \\
686 \\
902 \\
1,570 \\
3,300 \\
6,960 \\
16,400 \\
11,100 \\
3,420 \\
1,800\end{array}$ & $\begin{array}{r}106,00 \mathrm{C} \\
64,90 \mathrm{C} \\
49,30 \mathrm{C} \\
42,20 \mathrm{C} \\
50,10 \mathrm{C} \\
86,50 \mathrm{C} \\
196,00 \mathrm{C} \\
428,00 \mathrm{C} \\
976,00 \mathrm{C} \\
682,0 \mathrm{c} \\
210,00 \mathrm{C} \\
107,00 \mathrm{C}\end{array}$ \\
\hline The year. & 20,400 & 455 & 4,160 & $3,010,00 \mathrm{r}$ \\
\hline
\end{tabular}


Monthly discharge of Colorado River at Glenwood Springs, Colo., for 1900-1927Continued

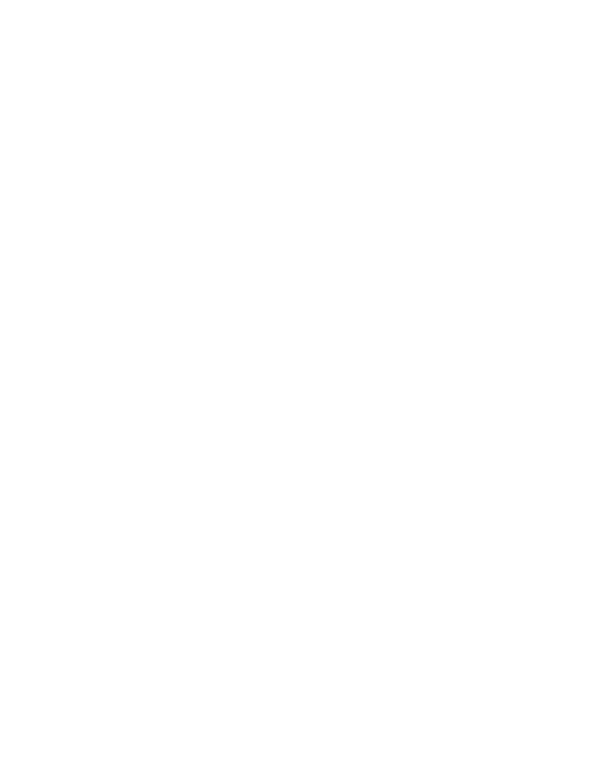

\begin{tabular}{|c|c|c|c|}
\hline \multicolumn{3}{|c|}{ Discharge in second-feet } & \multirow{2}{*}{$\begin{array}{l}\text { Run-off in } \\
\text { acre-feet }\end{array}$} \\
\hline Maximum & Minimum & Mean & \\
\hline $\begin{array}{r}2,000 \\
1,400 \\
1,020 \\
1,070 \\
810 \\
1,360 \\
3,760 \\
6,430 \\
11,500 \\
6,7200 \\
2,940 \\
1,360\end{array}$ & $\begin{array}{r}1,210 \\
740 \\
505 \\
620 \\
516 \\
740 \\
810 \\
1,780 \\
\mathbf{5}, 260 \\
1,990 \\
1,470 \\
810\end{array}$ & $\begin{array}{r}1,460 \\
1,000 \\
750 \\
838 \\
708 \\
1,020 \\
2,150 \\
3,880 \\
8,420 \\
3,360 \\
2,050 \\
984\end{array}$ & $\begin{array}{r}89,800 \\
59,500 \\
46,100 \\
52,800 \\
40,400 \\
62,700 \\
128,000 \\
239,000 \\
501,000 \\
207,000 \\
126,000 \\
58,000\end{array}$ \\
\hline 11,500 & 505 & 2,220 & $1,610,000$ \\
\hline $\begin{array}{r}980 \\
980 \\
890 \\
1,120 \\
775 \\
1,120 \\
2,940 \\
11,100 \\
27,300 \\
18,200 \\
4,850 \\
3,710\end{array}$ & $\begin{array}{r}775 \\
560 \\
405 \\
532 \\
590 \\
620 \\
810 \\
1,990 \\
8,160 \\
3,130 \\
2,450 \\
1,740\end{array}$ & $\begin{array}{r}889 \\
777 \\
678 \\
797 \\
685 \\
694 \\
1,490 \\
6,740 \\
20,400 \\
8,690 \\
3,010 \\
2,440\end{array}$ & $\begin{array}{r}54,700 \\
46,200 \\
41,700 \\
49,000 \\
88,000 \\
55,000 \\
88,700 \\
414,000 \\
1,210,000 \\
534,000 \\
185,000 \\
145,000\end{array}$ \\
\hline 27,300 & 405 & 3,860 & $2,860,000$ \\
\hline $\begin{array}{r}1,750 \\
\mathbf{1}, 240 \\
1,090 \\
\mathbf{1}, 190 \\
810 \\
2,680 \\
\mathbf{7}, 660 \\
13,400\end{array}$ & $\begin{array}{r}1,140 \\
845 \\
520 \\
740 \\
580 \\
775 \\
1,630 \\
\hdashline \\
\hdashline\end{array}$ & $\begin{array}{r}1,460 \\
1,110 \\
772 \\
841 \\
730 \\
1,860 \\
3,190 \\
6,760 \\
7,690 \\
2,230 \\
1,330 \\
1,370\end{array}$ & $\begin{array}{r}89,800 \\
66,000 \\
47,500 \\
51,700 \\
40,800 \\
114,000 \\
190,000 \\
416,000 \\
458,000 \\
137,000 \\
81,860 \\
81.500\end{array}$ \\
\hline n-n & 520 & 2,370 & $1,720,000$ \\
\hline $\begin{array}{r}1,360 \\
1,490 \\
1,360 \\
4,160 \\
11,600 \\
15,200 \\
9,150 \\
2,700 \\
1,490\end{array}$ & $\begin{array}{r}510 \\
600 \\
660 \\
1,030 \\
3,030 \\
5,500 \\
2,700 \\
1,490 \\
1,030\end{array}$ & $\begin{array}{r}988 \\
903 \\
665 \\
701 \\
749 \\
942 \\
1,790 \\
7,910 \\
11,700 \\
5,020 \\
1,930 \\
1,280\end{array}$ & $\begin{array}{r}60,800 \\
53,700 \\
40,900 \\
43,100 \\
41,600 \\
57,900 \\
107,000 \\
486,000 \\
696,000 \\
309,000 \\
119,000 \\
76,900\end{array}$ \\
\hline 15,200 & 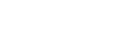 & 2,890 . & $2,090,000$ \\
\hline $\begin{array}{r}2,540 \\
1,240 \\
860 \\
940 \\
940 \\
1,030 \\
1,930 \\
18,700 \\
29,700 \\
18,700 \\
6,980 \\
1,930\end{array}$ & $\begin{array}{r}940 \\
450 \\
470 \\
630 \\
575 \\
630 \\
860 \\
2,380 \\
9,580 \\
6,430 \\
1,780 \\
1,490\end{array}$ & $\begin{array}{r}1,440 \\
915 \\
653 \\
768 \\
754 \\
805 \\
1,410 \\
7,510 \\
19,100 \\
9,490 \\
3,240 \\
1,660\end{array}$ & $\begin{array}{r}88,500 \\
54,400 \\
40,000 \\
47,200 \\
43,400 \\
48,500 \\
83,900 \\
462,000 \\
1,140,000 \\
584,000 \\
199,000 \\
98,800\end{array}$ \\
\hline 29,700 & 450 & 4,000 & $2,890,000$ \\
\hline
\end{tabular}

The year.

1911-12

Qctober

November

January

February

March

April

June.-

July-

August.

September

\section{$1909-10$}

November

January.

March.

May

uly.--

The year

1910-11

November

anuary

March

$85-$

ingust

The year 
Monthly discharge of Colorado River at Glenwood Springs, Colo., for 1200-1927Continued

\begin{tabular}{|c|c|c|c|c|}
\hline \multirow{2}{*}{ Month } & \multicolumn{3}{|c|}{ Discharge in second-feet } & \multirow{2}{*}{$\underset{\text { acre-feet }}{\text { Run-off in }}$} \\
\hline & Maximum & Minimum & Mean & \\
\hline $\begin{array}{l}\text { October } \\
\text { November } \\
\text { December } \\
\text { January } \\
\text { February } \\
\text { March } \\
\text { April } \\
\text { Jayno }\end{array}$ & $\begin{array}{r}1,640 \\
1,510 \\
905 \\
890 \\
782 \\
1,370 \\
4,540 \\
11,500 \\
12,100 \\
4,660 \\
2,060 \\
1,730\end{array}$ & $\begin{array}{r}1,280 \\
655 \\
600 \\
627 \\
556 \\
426 \\
1,220 \\
4,550 \\
4,690 \\
2,220 \\
940 \\
1,030\end{array}$ & $\begin{array}{r}1,470 \\
1,090 \\
745 \\
725 \\
674 \\
705 \\
2,980 \\
7,020 \\
7,120 \\
3,220 \\
1,430 \\
1,390\end{array}$ & $\begin{array}{r}99,400 \\
94,900 \\
45,800 \\
44,600 \\
87,400 \\
48,300 \\
177,000 \\
432,000 \\
424,000 \\
198,000 \\
87,900 \\
82,700\end{array}$ \\
\hline The yeat. & 12,100 & 426 & 2,370 & $1,720,000$ \\
\hline $\begin{array}{l}\text { October } \\
\text { November } \\
\text { December } \\
\text { January } \\
\text { February } \\
\text { March } \\
\text { April } \\
\text { May } \\
\text { Jume } \\
\text { July } \\
\text { Auguist } \\
\text { September }\end{array}$ & $\begin{array}{r}1,820 \\
1,290 \\
857 \\
891 \\
802 \\
2,000 \\
3,770 \\
24,200 \\
29,700 \\
8,870 \\
4,570 \\
2,240\end{array}$ & $\begin{array}{r}1,050 \\
803 \\
529 \\
613 \\
672 \\
725 \\
1,340 \\
3,490 \\
9,220 \\
3,990 \\
2,010 \\
1,340\end{array}$ & $\begin{array}{r}1,410 \\
1,060 \\
682 \\
733 \\
754 \\
1,010 \\
2,600 \\
12,500 \\
18,700 \\
5,83 \\
2,71 \\
1,70\end{array}$ & $\begin{array}{r}86,700 \\
63,100 \\
4,900 \\
15,100 \\
41,900 \\
62,100 \\
15 \%, 000 \\
769,000 \\
1,110,000 \\
358,000 \\
167,000 \\
101,000\end{array}$ \\
\hline The year.............. & 29,700 & 529 & $4,15^{0}$ & $3,000,000$ \\
\hline 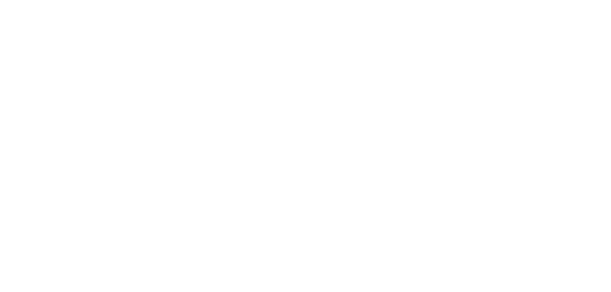 & $\begin{array}{r}1,940 \\
1,450 \\
778 \\
791 \\
770 \\
1,020 \\
4,140 \\
7,020 \\
13,000 \\
7,890 \\
2,570 \\
1,390\end{array}$ & $\begin{array}{r}1,320 \\
727 \\
470 \\
540 \\
582 \\
.692 \\
\quad 994 \\
2,080 \\
6,200 \\
2,010 \\
1,020 \\
800\end{array}$ & $\begin{array}{r}1,640 \\
979 \\
618 \\
627 \\
668 \\
744 \\
2,260 \\
4,620 \\
9,530 \\
4,440 \\
1,550 \\
1,020\end{array}$ & $\begin{array}{r}101,000 \\
88,300 \\
38,000 \\
88,600 \\
87,100 \\
45,700 \\
13 \%, 000 \\
284,000 \\
567,000 \\
273,000 \\
95,300 \\
60,700\end{array}$ \\
\hline The year. & 13,000 & 470 & 2,400 & $1,730,000$ \\
\hline $\begin{array}{l}\text { October } \\
\text { November } \\
\text { December } \\
\text { January } \\
\begin{array}{l}\text { February } \\
\text { March } \\
\text { April }\end{array} \\
\text { May } \\
\text { June } \\
\text { July } \\
\text { August } \\
\text { September }\end{array}$ & $\begin{array}{r}1,430 \\
1,000 \\
838 \\
837 \\
792 \\
2,290 \\
6,550 \\
12,600 \\
14,600 \\
8,300 \\
4,440 \\
2,600 \\
\end{array}$ & $\begin{array}{r}808 \\
543 \\
490 \\
602 \\
566 \\
633 \\
1,100 \\
3,870 \\
9,000 \\
2,950 \\
1,610 \\
1,360\end{array}$ & $\begin{array}{r}1,120 \\
806 \\
694 \\
722 \\
686 \\
1,250 \\
2,400 \\
7,390 \\
11,809 \\
6,90 \\
3,960 \\
1,770\end{array}$ & 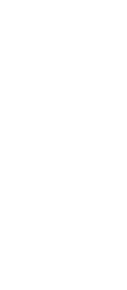 \\
\hline The year. & 14,600 & 490 & 3,040 & $2,210,000$ \\
\hline $\begin{array}{l}\text { October } \\
\text { Notrember } \\
\text { December } \\
\text { January } \\
\text { February } \\
\text { March } \\
\text { April } \\
\text { May } \\
\text { June } \\
\text { July } \\
\text { August } \\
\text { September }\end{array}$ & $\begin{array}{r}1,940 \\
1,340 \\
1,070 \\
824 \\
880 \\
1,860 \\
5,630 \\
15,200 \\
28,600 \\
20,800 \\
4,490 \\
1,800\end{array}$ & $\begin{array}{r}1,360 \\
626 \\
560 \\
520 \\
609 \\
560 \\
1,010 \\
2,450 \\
7,740 \\
4,490 \\
1,860 \\
1,240\end{array}$ & $\begin{array}{r}1,570 \\
1,050 \\
785 \\
694 \\
736 \\
783 \\
2,900 \\
6,870 \\
19,900 \\
9,490 \\
2,520 \\
1,520\end{array}$ & $\begin{array}{r}96,500 \\
62,500 \\
48,300 \\
42,700 \\
40,900 \\
48,100 \\
173,000 \\
422,000 \\
1,189,000 \\
584,000 \\
155,000 \\
90,400\end{array}$ \\
\hline The yes & 28,600 & 520 & 4,070 & $2,940,000$ \\
\hline
\end{tabular}


Monthly discharge of Colorado River at Glenwood Springs, Colo., for 1900-1927Continued

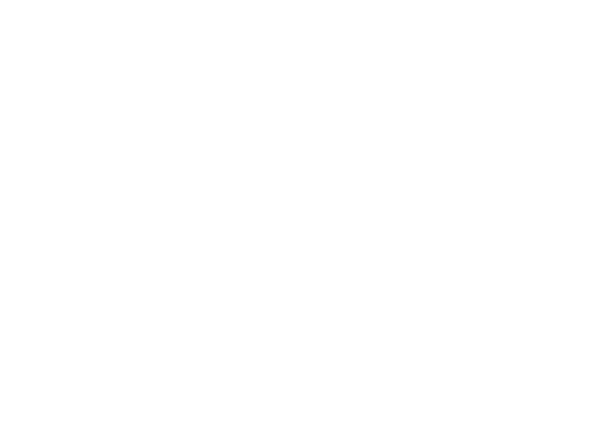

The year

\section{8-19}

October-

November

December

February

Mapch

April.

May-

June.

August

September.

The year.

$1910-20$

October-

December

Janugary .

Fetruary -

March

April

June

July

August -

September

The yoar

October-

November

December

Jenuary .

Teiruary

March

April.

Jupe-

Jupe.

Aurtust.

September

The year.

Octeber._.
November
Becember
Jannary
Fobruary
March
April
May
June
July
August
September

The year

\begin{tabular}{|c|c|c|c|}
\hline \multicolumn{3}{|c|}{ Discharge in second-feet } & \multirow{2}{*}{$\begin{array}{c}\text { Run-off in } \\
\text { acre-feet }\end{array}$} \\
\hline Maximum & Minimum & Mean & \\
\hline $\begin{array}{r}1,360 \\
1,260 \\
1,180 \\
952 \\
1,100 \\
1,920 \\
3,110 \\
14,400 \\
29,400 \\
8,720 \\
2,600 \\
2,180\end{array}$ & $\begin{array}{r}1,030 \\
956 \\
764 \\
606 \\
737 \\
737 \\
1,500 \\
2,240 \\
10,100 \\
2,680 \\
1,180 \\
1,190\end{array}$ & $\begin{array}{r}1,180 \\
1,160 \\
965 \\
826 \\
882 \\
1,280 \\
2,120 \\
9,210 \\
19,600 \\
5,330 \\
1,820 \\
1,680\end{array}$ & $\begin{array}{r}72,600 \\
69,000 \\
69,300 \\
80,800 \\
40,000 \\
78,700 \\
128,000 \\
566,000 \\
1,170,000 \\
338,000 \\
112,000 \\
100,000\end{array}$ \\
\hline 29,400 & 606 & 3,840 & $2,780,000$ \\
\hline $\begin{array}{r}1,680 \\
1,500 \\
1,120 \\
888 \\
811 \\
2,180 \\
5,560 \\
12,300 \\
9,060 \\
4,140 \\
2,930 \\
1,840\end{array}$ & $\begin{array}{r}1,240 \\
751 \\
554 \\
624 \\
618 \\
630 \\
1,110 \\
3,920 \\
3.600 \\
1,360 \\
828 \\
880\end{array}$ & $\begin{array}{r}1,450 \\
1,140 \\
846 \\
764 \\
7723 \\
1,030 \\
2,690 \\
7,420 \\
5,370 \\
2,340 \\
1,490 \\
1,150\end{array}$ & $\begin{array}{r}89,200 \\
67,800 \\
52,000 \\
47,000 \\
.40,000 \\
65,300 \\
150,000 \\
456,000 \\
320,000 \\
144,000 \\
91,600 \\
68,400\end{array}$ \\
\hline 12,300 & 554 & 2,200 & $1,000,000$ \\
\hline $\begin{array}{r}1,120 \\
1,240 \\
1,090 \\
880 \\
832 \\
944 \\
2,170 \\
23,000 \\
23,800 \\
10,800 \\
3,710 \\
1,920\end{array}$ & $\begin{array}{r}936 \\
510 \\
612 \\
600 \\
575 \\
515 \\
606 \\
1,800 \\
10,800 \\
3,500 \\
1,680 \\
1,440\end{array}$ & $\begin{array}{r}1,030 \\
1,010 \\
840 \\
725 \\
691 \\
764 \\
1,260 \\
11 ; 800 \\
16,600 \\
5,850 \\
2,520 \\
1,620\end{array}$ & $\begin{array}{r}63,200 \\
60,100 \\
31,600 \\
4,600 \\
39,760 \\
47,000 \\
75,000 \\
700 \\
760,600 \\
360,000 \\
155,000 \\
96,400\end{array}$ \\
\hline 23,800 & 510 & 8,730 & $2,7 \pi 0,000$ \\
\hline $\begin{array}{r}1,500 \\
1,260 \\
1,050 \\
983 \\
919 \\
1,740 \\
2,760 \\
21,200 \\
27,700 \\
8,720 \\
4,260 \\
3,800\end{array}$ & $\begin{array}{r}1,180 \\
820 \\
573 \\
631 \\
539 \\
774 \\
1,080 \\
2,180 \\
9,400 \\
3,020 \\
2,450 \\
1,210\end{array}$ & $\begin{array}{r}1,330 \\
1,140 \\
825 \\
806 \\
700 \\
1,250 \\
1,730 \\
10,200 \\
19,400 \\
5,550 \\
2,980 \\
1,910\end{array}$ & $\begin{array}{r}81,800 \\
67,890 \\
66,700 \\
1,600 \\
38,900 \\
76,900 \\
109,000 \\
69,000 \\
1,160,000 \\
341,000 \\
183,000 \\
114,000\end{array}$ \\
\hline 27,700 & 539 & 8,890 & $2,880,000$ \\
\hline $\begin{array}{r}1,320 \\
1,230 \\
1,510 \\
1,130 \\
1,110 \\
2,240 \\
3,020 \\
15,700 \\
15,700 \\
1,760 \\
2,520 \\
1,810\end{array}$ & $\begin{array}{r}944 \\
740 \\
633 \\
538 \\
600 \\
714 \\
714 \\
1,160 \\
3,500 \\
5,910 \\
5,910 \\
1,380 \\
927\end{array}$ & $\begin{array}{r}1,140 \\
1,060 \\
1,060 \\
814 \\
844 \\
1,230 \\
1,720 \\
7, \mathbf{4 6 0} \\
11,200 \\
3,090 \\
1,800 \\
1,250\end{array}$ & $\begin{array}{r}79,100 \\
88,100 \\
65,200 \\
60,100 \\
46,000 \\
76,000 \\
109,000 \\
469,000 \\
606,000 \\
190,000 \\
111,000 \\
74,400\end{array}$ \\
\hline 1,570 & 628 & 2,720 & $1,970,000$ \\
\hline
\end{tabular}


Monthly discharge of Colorado River at Glenwood Springs, Colo., for 1900-1927Continued

\begin{tabular}{l} 
Month \\
\hline \\
\hline October. $1922-23$ \\
November \\
December \\
January \\
February \\
March \\
April \\
May \\
June \\
July \\
August \\
September
\end{tabular}

The year

October

November

December

January

February

April

May

June

August

September.

The year

\section{$1923-24$}

October.

November

December

January.

February

March

Aay.

June.

July.-

September

The year

\section{5-26}

October

November

December

January

February

March

April

June.

July-

August.

September

The year

October.

Navember

December

January.

February

March.

A pril.

May..

June.

July...

August

September.

The year

\begin{tabular}{|c|c|c|c|}
\hline \multicolumn{3}{|c|}{ Discharge in second-feet } & \multirow{2}{*}{$\underset{\text { acre-feet }}{\text { Run-off in }}$} \\
\hline Maximum & Minimum & Mean & \\
\hline $\begin{array}{r}1,030 \\
1,030 \\
932 \\
948 \\
880 \\
1,050 \\
2,640 \\
15,700 \\
20,000 \\
9,910 \\
4,840 \\
2,220\end{array}$ & $\begin{array}{r}850 \\
711 \\
646 \\
415 \\
535 \\
613 \\
858 \\
3,090 \\
10,200 \\
3,190 \\
1,860 \\
1,420 \\
\end{array}$ & $\begin{array}{r}912 \\
864 \\
796 \\
762 \\
739 \\
764 \\
1,560 \\
8,230 \\
15,100 \\
6,780 \\
3,030 \\
1,700\end{array}$ & $\begin{array}{r}56,100 \\
51,400 \\
48,900 \\
46,000 \\
41,000 \\
47,000 \\
92,800 \\
506,000 \\
898,000 \\
417,000 \\
186,000 \\
101,000\end{array}$ \\
\hline 20,000 & 415 & 3,450 & $2,490,000$ \\
\hline $\begin{array}{r}1,970 \\
1,600 \\
1,090 \\
970 \\
1,020 \\
1,050 \\
4,940 \\
11,700 \\
23,400 \\
6,990 \\
1,870 \\
1,260\end{array}$ & $\begin{array}{r}1,058 \\
935 \\
684 \\
602 \\
635 \\
602 \\
796 \\
2,280 \\
7,300 \\
1,920 \\
958 \\
775\end{array}$ & $\begin{array}{r}1,800 \\
1,280 \\
856 \\
850 \\
844 \\
840 \\
2,510 \\
7,970 \\
13,200 \\
3,680 \\
1,260 \\
1,030\end{array}$ & $\begin{array}{r}111,000 \\
76,200 \\
52,600 \\
52,300 \\
48,500 \\
51,600 \\
149,000 \\
490,000 \\
786,000 \\
223,000 \\
77,500 \\
61,300\end{array}$ \\
\hline 28,400 & 602 & 3,000 & $2,180,000$ \\
\hline $\begin{array}{r}1,700 \\
1,300 \\
995 \\
964 \\
848 \\
2,340 \\
3,840 \\
11,000 \\
10,200 \\
5,530 \\
2,270 \\
2,340\end{array}$ & $\begin{array}{r}958 \\
831 \\
433 \\
564 \\
690 \\
763 \\
1,720 \\
3,080 \\
5,250 \\
1,720 \\
1,360 \\
1,320\end{array}$ & $\begin{array}{r}1,370 \\
1,140 \\
734 \\
735 \\
735 \\
1,270 \\
2,760 \\
6,450 \\
7,390 \\
3,330 \\
1,700 \\
1,700\end{array}$ & $\begin{array}{r}84,200 \\
67,800 \\
45,100 \\
45,200 \\
40,800 \\
78,100 \\
164,000 \\
397,900 \\
440,000 \\
205,000 \\
105,000 \\
101,000\end{array}$ \\
\hline 11,000 & 433 & 2,450 & $1,770,000$ \\
\hline $\begin{array}{r}1,720 \\
1,420 \\
1,040 \\
922 \\
774 \\
1,410 \\
6,390 \\
17,000 \\
22,700 \\
11,000 \\
3,290 \\
1,400\end{array}$ & $\begin{array}{r}1,220 \\
858 \\
627 \\
570 \\
612 \\
590 \\
769 \\
4,070 \\
8,250 \\
3,090 \\
1,360 \\
742\end{array}$ & $\begin{array}{r}1,480 \\
1,090 \\
790 \\
739 \\
702 \\
890 \\
3,310 \\
9,650 \\
14,400 \\
6,260 \\
2,240 \\
983\end{array}$ & $\begin{array}{r}91,000 \\
64,900 \\
48,600 \\
45,400 \\
39,000 \\
54,700 \\
197,000 \\
593,000 \\
857,000 \\
385,000 \\
138,000 \\
58,600\end{array}$ \\
\hline 22,700 & 527 & 3,550 & $2,570,000$ \\
\hline $\begin{array}{r}1,290 \\
1,120 \\
1,210 \\
844 \\
908 \\
1,920 \\
5,810 \\
17,800 \\
14,400 \\
9,570 \\
4,320 \\
2,100\end{array}$ & $\begin{array}{r}758 \\
734 \\
419 \\
584 \\
537 \\
602 \\
1,330 \\
6,690 \\
9,570 \\
2,830 \\
1,980 \\
1,320 \\
\end{array}$ & $\begin{array}{r}1,020 \\
957 \\
745 \\
706 \\
700 \\
860 \\
2,280 \\
11,400 \\
11,600 \\
4,820 \\
2,750 \\
1,620 \\
\end{array}$ & $\begin{array}{r}62,700 \\
56,900 \\
45,800 \\
43,400 \\
38,900 \\
52,900 \\
136,000 \\
701,000 \\
690,000 \\
296,000 \\
169,000 \\
94,400\end{array}$ \\
\hline 17,800 & 419 & 3,300 & $2,380,000$ \\
\hline
\end{tabular}

Note.-Records from Jan. 1, 1900, to Sept. 30, 1909, revised. Monthly mean discharge from June to December, 1910, based on current-meter measurements and flow at other stations on Colorado River. Low-water records from 1913 to 1927 , except 1923 to 1925 inclusive, determined chiefly from bihourly discharges. 
COLORADO RIVER IRAR PAIISADE, colo.

Location.-In sec. 2, T. 11 S., R. 98 W., at highway bridge 2 miles east of Palisade, Mesa County. Nearest important tributary, Plateau Creek, enters 6 miles above.

Drainage area. -8,790 square miles (measured on base map of Colorado).

Records available.-Ootober 1, 1901, to September 30, 1927.

GAGE.-Chain on bridge.

Control.-Practically permanent.

Extremes of Discharge.-Maximum stage recorded, 24.4 feet at 7 a. m. June 16, 1921 (discharge, 52,400 second-feet); minimum stage, 11.4 feet September 2, 1924 (discharge, 630 second-feet).

Drversions.-Principal diversion between Glenwood Springs and Palisade stations is the Government high-line canal which has a capacity of 1,425 secondfeet. Some of the water diverted for power is returned to the river to supply a priority of 521 second-feet for Grand Valley Canal.

Regulation.-None.

Cooperation.-Complete records furnished by Bureau of Reclamation.

Monthly discharge of Colorado River near Palisade, Colo., for 1901-1927

\begin{tabular}{|c|c|c|c|c|}
\hline \multirow{2}{*}{$\begin{array}{c}\text { Month } \\
\text {. }\end{array}$} & \multicolumn{3}{|c|}{ Discharge in second-feet } & \multirow{2}{*}{$\begin{array}{c}\text { Run-off in } \\
\text { acre-feet }\end{array}$} \\
\hline & Maximum & Minimum & Mean & \\
\hline $\begin{array}{l}\text { October } \\
\text { November } \\
\text { December } \\
\text { January } \\
\text { February } \\
\text { March } \\
\text { April } \\
\text { May } \\
\text { June } \\
\text { August } \\
\text { Eeptember }\end{array}$ & $\begin{array}{r}3,230 \\
18,000 \\
14,500 \\
3,600 \\
1,460 \\
1,550\end{array}$ & $\begin{array}{r}1,080 \\
4,400 \\
3,420 \\
1,350 \\
1,030 \\
1,080\end{array}$ & $\begin{array}{r}1,650 \\
1,600 \\
1,400 \\
1,250 \\
1,200 \\
1,200 \\
1,700 \\
12,200 \\
8,650 \\
2,200 \\
1,210 \\
1,220\end{array}$ & $\begin{array}{r}101,000 \\
95,000 \\
86,100 \\
76,900 \\
66,600 \\
73,800 \\
101,000 \\
750,000 \\
515,000 \\
135,000 \\
74,400 \\
72,000\end{array}$ \\
\hline The year... & 18,000 & & 2,970 & $2,150,000$ \\
\hline $\begin{array}{l}\text { October. } \\
\text { November } \\
\text { Deeember } \\
\text { January } \\
\text { February } \\
\text { March } \\
\text { April } \\
\text { May } \\
\text { June } \\
\text { July } \\
\text { August } \\
\text { Geptember }\end{array}$ & $\begin{array}{r}5,150 \\
16,500 \\
25,100 \\
16,100 \\
3,800 \\
3,320\end{array}$ & $\begin{array}{r}1,340 \\
1,380 \\
4,190 \\
13,000 \\
4,190 \\
1,700 \\
1,650\end{array}$ & $\begin{array}{r}1,410 \\
1,100 \\
1,050 \\
950 \\
950 \\
1,200 \\
2,320 \\
8,980 \\
19,600 \\
8,780 \\
2,220 \\
2,270\end{array}$ & $\begin{array}{r}86,700 \\
65,500 \\
64,600 \\
58,400 \\
52,800 \\
73,800 \\
138,000 \\
552,000 \\
1,170,000 \\
540,000 \\
136,000 \\
135,000\end{array}$ \\
\hline The year. & 25,100 & (n) & 4,240 & $3,070,000$ \\
\hline $\begin{array}{l}\text { October- } \\
\text { November } \\
\text { December- } \\
\text { January } \\
\text { February- } \\
\text { Mareh } \\
\text { April } \\
\text { Mogy } \\
\text { June } \\
\text { July } \\
\text { Angust } \\
\text { Boptermber }\end{array}$ & $\begin{array}{r}2,880 \\
7,640 \\
24,800 \\
20,800 \\
13,200 \\
4,460 \\
4,680\end{array}$ & $\begin{array}{r}1,320 \\
5,520 \\
11,400 \\
4,240 \\
2,390 \\
1,830\end{array}$ & $\begin{array}{r}2,050 \\
1,650 \\
1,100 \\
1,100 \\
1,150 \\
1,500 \\
3,910 \\
12,800 \\
16,500 \\
7,400 \\
3,240 \\
2,650\end{array}$ & $\begin{array}{r}126,000 \\
98,200 \\
67,600 \\
67,600 \\
66,200 \\
92,200 \\
235,000 \\
787,000 \\
982,000 \\
455,000 \\
199,000 \\
158,000\end{array}$ \\
\hline The year. & 24,800 & & 4,600 & $3,330,000$ \\
\hline
\end{tabular}


Monthly discharge of Colorado River near Palisade, Colo., for 1901-1927-Con-

\begin{tabular}{|c|c|c|c|c|}
\hline \multirow{2}{*}{ Month } & \multicolumn{3}{|c|}{ Discharge in second-feet } & \multirow{2}{*}{$\begin{array}{l}\text { Run-off in } \\
\text { acre-ftet }\end{array}$} \\
\hline & Maximum & Minimum & Mean & \\
\hline $\begin{array}{l}\text { October } \\
\text { November } \\
\text { December. } \\
\text { January } \\
\text { February. } \\
\text { March } \\
\text { April } \\
\text { May. } \\
\text { June } \\
\text { July } \\
\text { August } \\
\text { September }\end{array}$ & $\begin{array}{r}2,630 \\
6,000 \\
24,900 \\
85,900 \\
12,400 \\
4,600 \\
2,200\end{array}$ & $\begin{array}{r}1,710 \\
1,500 \\
6,120 \\
13,500 \\
3,440 \\
1,720 \\
1,610\end{array}$ & $\begin{array}{r}2,140 \\
1,500 \\
1,150 \\
1,200 \\
1,100 \\
1,450 \\
2,640 \\
13,100 \\
24,400 \\
6,080 \\
2,580 \\
1,830\end{array}$ & $\begin{array}{r}132,000 \\
89,300 \\
70,700 \\
73,800 \\
61,100 \\
89,200 \\
157,000 \\
806,000 \\
1,450,000 \\
374,000 \\
156,000 \\
109,000\end{array}$ \\
\hline The year.. & 35,900 & & 4,940 & $3,570,000$ \\
\hline $\begin{array}{l}\text { October. } \\
\text { Octor } \\
\text { November } \\
\text { December. } \\
\text { January } \\
\text { February } \\
\text { March } \\
\text { April } \\
\text { May } \\
\text { June } \\
\text { July } \\
\text { August } \\
\text { September }\end{array}$ & $\begin{array}{r}1,890 \\
10,200 \\
28,900 \\
37,000 \\
12,700 \\
5,640 \\
4,940\end{array}$ & $\begin{array}{r}1,610 \\
1,950 \\
5,760 \\
12,000 \\
5,400 \\
2,350 \\
2,350\end{array}$ & $\begin{array}{r}1,750 \\
1,650 \\
1,150 \\
1,150 \\
1,220 \\
1,800 \\
4,730 \\
18,600 \\
23,500 \\
9,820 \\
3,800 \\
3,340\end{array}$ & $\begin{array}{r}108,000 \\
98,200 \\
70,700 \\
70,700 \\
67,800 \\
111,000 \\
281,000 \\
1,140,000 \\
1,400,000 \\
604,000 \\
284,000 \\
199,000\end{array}$ \\
\hline The year.............. & 37,000 & 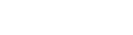 & 6,190 & $4,380,000$ \\
\hline $\begin{array}{l}\text { October. } \\
\text { November } \\
\text { December. } \\
\text { January } \\
\text { February. } \\
\text { March } \\
\text { April } \\
\text { May } \\
\text { June } \\
\text { Julig } \\
\text { A'ugast } \\
\text { September }\end{array}$ & $\begin{array}{r}4,060 \\
4,840 \\
9,340 \\
23,200 \\
30,200 \\
29,300 \\
8,30 \\
3,460\end{array}$ & $\begin{array}{r}2,140 \\
\mathbf{1}, 350 \\
2,200 \\
4,540 \\
13,400 \\
9,030 \\
3,380 \\
2,130\end{array}$ & $\begin{array}{r}2,850 \\
1,820 \\
1,450 \\
1,320 \\
1,550 \\
2,240 \\
5,250 \\
10,500 \\
24,800 \\
17,000 \\
4,850 \\
2,600\end{array}$ & $\begin{array}{r}175,000 \\
108,000 \\
89,200 \\
81,200 \\
86,100 \\
138,000 \\
312,000 \\
646,000 \\
1,480,000 \\
1,040,060 \\
301,000 \\
155,090\end{array}$ \\
\hline The year... & 30,200 & 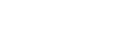 & $6, \mathbf{3 6 0}$ & $4,610,000$ \\
\hline $\begin{array}{l}\text { October } \\
\text { November } \\
\text { December } \\
\text { January } \\
\text { February } \\
\text { March } \\
\text { April } \\
\text { May } \\
\text { June } \\
\text { July } \\
\text { August } \\
\text { September }\end{array}$ & $\begin{array}{r}3,900 \\
2,270 \\
1,550 \\
1,820 \\
2,000 \\
6,930 \\
10,600 \\
20,300 \\
9,810 \\
4,840 \\
2,270\end{array}$ & $\begin{array}{r}2,270 \\
1,460 \\
1,260 \\
1,300 \\
1,550 \\
3,640 \\
\mathbf{8}, 180 \\
3,210 \\
2,270 \\
1,550\end{array}$ & $\begin{array}{r}2,640 \\
1,820 \\
1,370 \\
1,450 \\
1,320 \\
1,630 \\
3,900 \\
6,720 \\
14,600 \\
5,670 \\
3,550 \\
1,760\end{array}$ & $\begin{array}{r}162,000 \\
108,000 \\
84,200 \\
89,200 \\
75,000 \\
100,000 \\
232,000 \\
418,060 \\
869,000 \\
349,000 \\
218,000 \\
105,000\end{array}$ \\
\hline The year. & 20,300 & 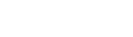 & 3,880 & $2,810,000$ \\
\hline $\begin{array}{l}\text { October. } \\
\text { November } \\
\text { December. } \\
\text { January } \\
\text { February } \\
\text { March } \\
\text { April } \\
\text { May } \\
\text { June } \\
\text { July } \\
\text { August } \\
\text { September }\end{array}$ & $\begin{array}{r}3,210 \\
1,820 \\
1,760 \\
2,280 \\
5,680 \\
20,800 \\
43,000 \\
29,300 \\
7,290 \\
7,410\end{array}$ & \begin{tabular}{r|r|}
1,550 \\
1,350 \\
1,170 \\
1,120 \\
1,420 \\
3,800 \\
14,600 \\
5,790 \\
3,990 \\
3,070
\end{tabular} & $\begin{array}{r}1,990 \\
1,600 \\
1,320 \\
1,340 \\
1,200 \\
1,560 \\
2,690 \\
13,100 \\
38,300 \\
14,400 \\
5,190 \\
4,870\end{array}$ & $\begin{array}{r}116,900 \\
94,50 \\
81,200 \\
82,400 \\
66,600 \\
95,900 \\
160,000 \\
806,000 \\
1,980,030 \\
885,000 \\
819,000 \\
250,000\end{array}$ \\
\hline The year & 43,000 & & 6,880 & $4,980,000$ \\
\hline
\end{tabular}


Monthly discharge of Colorado River near Palisade, Colo., for 1901-1927-Con.

\begin{tabular}{|c|c|c|c|c|}
\hline \multirow{2}{*}{ Month } & \multicolumn{3}{|c|}{ Discharge in second-feet } & \multirow{2}{*}{$\begin{array}{l}\text { Run-off in } \\
\text { acre-feet }\end{array}$} \\
\hline & Maximum & Minimum & Mean & \\
\hline $\begin{array}{l}\text { October } \\
\text { November } \\
\text { December } \\
\text { January } \\
\text { February } \\
\text { March } \\
\text { April } \\
\text { May } \\
\text { June } \\
\text { July } \\
\text { August } \\
\text { September }\end{array}$ & $\begin{array}{r}3,070 \\
2,570 \\
2,080 \\
4,810 \\
15,400 \\
22,500 \\
27,100 \\
6,810 \\
4,290 \\
2,900\end{array}$ & $\begin{array}{r}2,140 \\
2,010 \\
2,280 \\
3,070 \\
9,650 \\
6,580 \\
2,010 \\
1,530 \\
1,530\end{array}$ & $\begin{array}{r}\mathbf{2}, 570 \\
\mathbf{2}, 080 \\
1,450 \\
\mathbf{1}, 500 \\
\mathbf{1}, 400 \\
\mathbf{3}, 470 \\
\mathbf{5}, 850 \\
13,100 \\
\mathbf{1 4}, \mathbf{3 0 0} \\
\mathbf{3}, \mathbf{7 1 0} \\
\mathbf{2}, \mathbf{3 3 0} \\
\mathbf{2}, 240\end{array}$ & $\begin{array}{r}158,000 \\
124,000 \\
89,200 \\
92,200 \\
77,800 \\
213,000 \\
348,000 \\
806,000 \\
851,000 \\
228,000 \\
143,000 \\
133,000\end{array}$ \\
\hline The year............. & 27,100 & 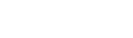 & 4,500 & $3,260,000$ \\
\hline $\begin{array}{l}\text { October } \\
\text { November } \\
\text { December. } \\
\text { January } \\
\text { February } \\
\text { March } \\
\text { April } \\
\text { May } \\
\text { June } \\
\text { July } \\
\text { August } \\
\text { September }\end{array}$ & $\begin{array}{r}2,570 \\
2,500 \\
1,530 \\
3,440 \\
3,790 \\
6,770 \\
18,600 \\
24,800 \\
16,400 \\
4,350 \\
3,270\end{array}$ & $\begin{array}{r}1,530 \\
1,370 \\
1,050 \\
1,030 \\
1,100 \\
1,370 \\
4,750 \\
10,400 \\
4,350 \\
1,960 \\
1,590\end{array}$ & $\begin{array}{r}1,830 \\
1,660 \\
1,260 \\
1,350 \\
1,470 \\
1,860 \\
3,050 \\
12,700 \\
19,900 \\
8,570 \\
2,640 \\
2,070\end{array}$ & $\begin{array}{r}113,000 \\
98,800 \\
77,500 \\
83,000 \\
81,600 \\
114,000 \\
181,000 \\
781,000 \\
1,180,000 \\
527,000 \\
162,000 \\
123,000\end{array}$ \\
\hline The year............. & 24,800 & $-\cdots$ & 4,870 & $3,520,000$ \\
\hline $\begin{array}{l}\text { October. } \\
\text { November } \\
\text { December. } \\
\text { January } \\
\text { Pebruary } \\
\text { Mareh } \\
\text { April } \\
\text { May } \\
\text { Jume } \\
\text { July } \\
\text { August } \\
\text { September }\end{array}$ & $\begin{array}{r}9,770 \\
2,220 \\
4,050 \\
3,650 \\
33,600 \\
43,400 \\
28,900 \\
12,200 \\
3,280\end{array}$ & $\begin{array}{r}1,960 \\
1,590 \\
1,320 \\
2,080 \\
4,260 \\
17,200 \\
11,200 \\
2,620 \\
2,080\end{array}$ & $\begin{array}{r}3,420 \\
1,920 \\
1,350 \\
1,400 \\
1,380 \\
1,760 \\
2,710 \\
15,600 \\
30,600 \\
17,200 \\
5,460 \\
2,450\end{array}$ & $\begin{array}{r}210,000 \\
114,000 \\
83,000 \\
86,100 \\
79,400 \\
108,000 \\
161,000 \\
959,000 \\
1,820,000 \\
1,060,000 \\
336,000 \\
146,000\end{array}$ \\
\hline rear... & 43,400 & & 7,110 & $5,160,000$ \\
\hline $\begin{array}{l}\text { Oetober } \\
\text { November } \\
\text { December } \\
\text { January } \\
\text { Pebruary } \\
\text { March } \\
\text { April } \\
\text { June } \\
\text { July } \\
\text { August } \\
\text { September }\end{array}$ & $\begin{array}{r}3,480 \\
2,480 \\
2,700 \\
8,030 \\
20,800 \\
20,300 \\
7,880 \\
2,620 \\
3,780\end{array}$ & $\begin{array}{r}2,210 \\
1,590 \\
1,350 \\
2,700 \\
8,180 \\
8,640 \\
2,780 \\
1,280 \\
1,280\end{array}$ & $\begin{array}{r}2,520 \\
2,020 \\
1,350 \\
1,340 \\
1,300 \\
1,860 \\
5,250 \\
13,300 \\
13,200 \\
4,930 \\
1,850 \\
2,250\end{array}$ & $\begin{array}{r}155,000 \\
120,000 \\
83,000 \\
82,400 \\
72,200 \\
114,000 \\
312,000 \\
818,010 \\
786,000 \\
303,000 \\
114,000 \\
134,000\end{array}$ \\
\hline The year. & 20,800 & & 4,280 & $3,090,000$ \\
\hline 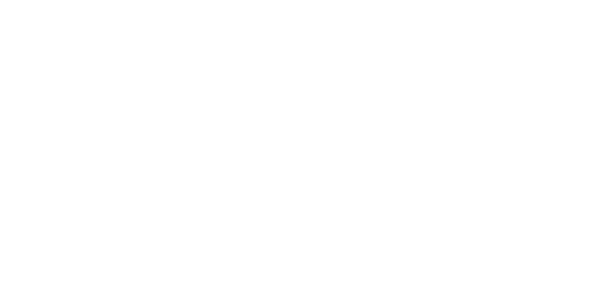 & $\begin{array}{r}2,780 \\
2,540 \\
2,700 \\
6,080 \\
38,800 \\
42,800 \\
17,400 \\
8,640 \\
3,580\end{array}$ & $\mid$\begin{tabular}{r|}
1,640 \\
1,370 \\
$\mathbf{1}, 320$ \\
$\mathbf{2}, 250$ \\
$\mathbf{5}, 720$ \\
17,800 \\
6,880 \\
2,780 \\
$\mathbf{2}, 120$
\end{tabular} & $\begin{array}{r}2,120 \\
1,710 \\
1,250 \\
1,300 \\
1,350 \\
1,870 \\
4,340 \\
20,800 \\
29,700 \\
10,800 \\
4,200 \\
2,530\end{array}$ & $\begin{array}{r}130,000 \\
102,000 \\
76,900 \\
79,000 \\
75,000 \\
115,000 \\
258,000 \\
1,280,000 \\
1,770,000 \\
664,000 \\
264,000 \\
151,000\end{array}$ \\
\hline & & & & $4,970,000$ \\
\hline
\end{tabular}


Monthly discharge of Colorado River near Palisade, Colo., for 1901-1927-Con.

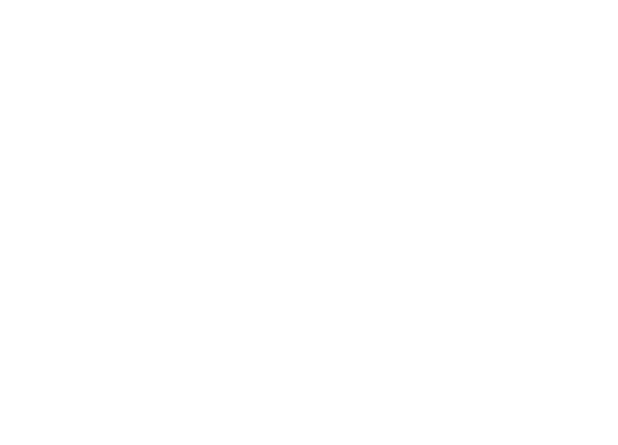

The year.

\section{5-16}

October

November

December

January ...

February

March

May.

June

July.--

September

The year

October.
November
December
January
February
March
April
May
June.17
July
August
September

The year

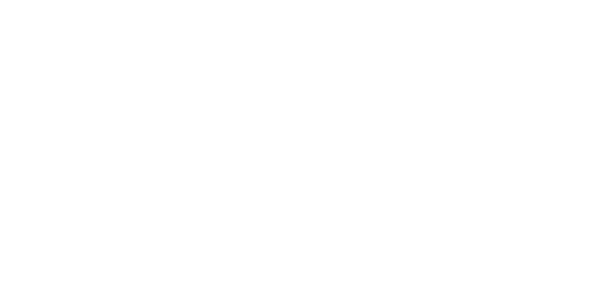

The year.

1918-19

October.

November

December

January.

February

March

April

May.

June

July -.

August.

September

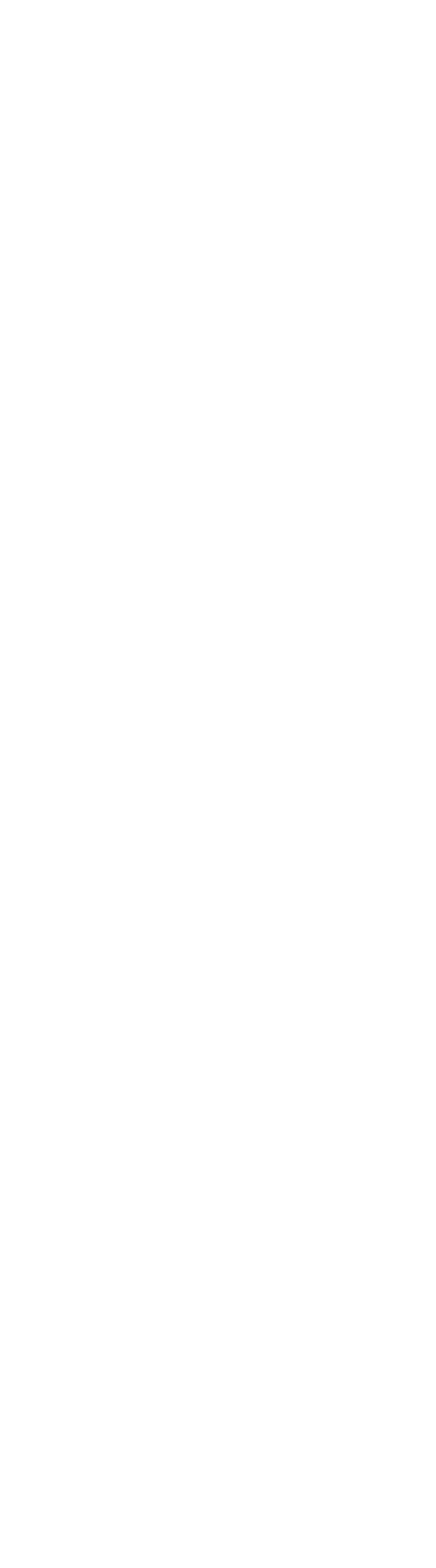

The year. 
Monthly discharge of Colorado River near Palisade, Colo., for 1901-1927-Con.

\begin{tabular}{|c|c|c|c|c|}
\hline \multirow{2}{*}{ Month } & \multicolumn{3}{|c|}{ Discharge in second-feet } & \multirow{2}{*}{$\begin{array}{l}\text { Run-off in } \\
\text { acre-feet }\end{array}$} \\
\hline & Maximum & Minimum & Mean & \\
\hline $\begin{array}{l}\text { October } \\
\text { November } \\
\text { December } \\
\text { January } \\
\text { February } \\
\text { March } \\
\text { April } \\
\text { May } \\
\text { June } \\
\text { July } \\
\text { August } \\
\text { September }\end{array}$ & $\begin{array}{r}1,580 \\
1,880 \\
2,250 \\
4,600 \\
40,-200 \\
41,600 \\
19,200 \\
6,880 \\
3,120\end{array}$ & $\begin{array}{r}1,190 \\
1,480 \\
1,230 \\
1,230 \\
1,480 \\
3,390 \\
19,700 \\
5,960 \\
2,700\end{array}$ & $\begin{array}{r}1,380 \\
1,650 \\
1,500 \\
1,350 \\
1,280 \\
1,600 \\
2,380 \\
21,600 \\
28,200 \\
10,700 \\
4,040 \\
2,270\end{array}$ & $\begin{array}{r}84,800 \\
98,200 \\
92,200 \\
83,000 \\
73,600 \\
98,400 \\
142,000 \\
1,830,000 \\
1,680,000 \\
658,000 \\
248,000 \\
135,000\end{array}$ \\
\hline & 41,600 & $\ldots$ & 6,530 & $4,720,000$ \\
\hline $\begin{array}{l}\text { October } \\
\text { November } \\
\text { December } \\
\text { January } \\
\text { February } \\
\text { March } \\
\text { April } \\
\text { May } \\
\text { June } \\
\text { July } \\
\text { Auguist } \\
\text { Soptember }\end{array}$ & \begin{tabular}{r}
2,320 \\
4,180 \\
\hdashline 2,460 \\
2,940 \\
4,600 \\
34,000 \\
50,800 \\
18,000 \\
8,030 \\
7,160
\end{tabular} & $\begin{array}{r}1,940 \\
1,760 \\
1,320 \\
1,820 \\
1,820 \\
3,980 \\
18,600 \\
4,920 \\
3,120 \\
1,760\end{array}$ & $\begin{array}{r}2,070 \\
2,210 \\
1,380 \\
1,290 \\
1,700 \\
2,410 \\
3,030 \\
17,600 \\
32,800 \\
10,200 \\
4,720 \\
3,050\end{array}$ & $\begin{array}{r}127,000 \\
132,000 \\
84,800 \\
79,300 \\
94,400 \\
148,000 \\
180,000 \\
1,080,000 \\
1,950,000 \\
627,000 \\
290,000 \\
181,000\end{array}$ \\
\hline The year & 50,800 & - & 6,870 & $4,970,000$ \\
\hline $\begin{array}{l}\text { Oetober } \\
\text { November } \\
\text { December } \\
\text { January } \\
\text { February } \\
\text { March } \\
\text { April } \\
\text { May } \\
\text { June } \\
\text { July } \\
\text { August } \\
\text { September }\end{array}$ & $\begin{array}{r}2,180 \\
2,320 \\
2,700 \\
3,120 \\
6,880 \\
31,000 \\
27,400 \\
11,000 \\
4,080 \\
2,780\end{array}$ & \begin{tabular}{r}
1,880 \\
1,680 \\
1,420 \\
\hdashline 1,530 \\
1,880 \\
7,880 \\
11,500 \\
2,460 \\
1,880 \\
1,150
\end{tabular} & $\begin{array}{r}2,010 \\
1,960 \\
1,900 \\
1,300 \\
1,320 \\
2,140 \\
3,070 \\
16,400 \\
20,400 \\
5,370 \\
2,650 \\
1,770\end{array}$ & $\begin{array}{r}124,000 \\
117,000 \\
117,000 \\
79,900 \\
73,300 \\
132,000 \\
183,000 \\
1,010,000 \\
1,210,000 \\
330,000 \\
168,000 \\
105,000\end{array}$ \\
\hline The & 31,000 & - & 5,020 & $3,640,000$ \\
\hline $\begin{array}{l}\text { October. } \\
\text { November. } \\
\text { December } \\
\text { January } \\
\text { February } \\
\text { March } \\
\text { April } \\
\text { May } \\
\text { June } \\
\text { July } \\
\text { August }\end{array}$ & $\begin{array}{r}1,640 \\
2,120 \\
1,940 \\
1,880 \\
1,820 \\
2,000 \\
5,030 \\
27,400 \\
30,400 \\
17,800 \\
7,880 \\
3,480\end{array}$ & $\begin{array}{r}1,320 \\
1,480 \\
1,370 \\
1,280 \\
1,190 \\
1,320 \\
1,760 . \\
\mathbf{5}, 360 \\
18,600 \\
5,030 \\
2,860 \\
2,120\end{array}$ & $\begin{array}{r}1,510 \\
1,780 \\
1,630 \\
1,570 \\
1,510 \\
1,710 \\
3,020 \\
14,900 \\
24,800 \\
11,800 \\
5,020 \\
2,740\end{array}$ & $\begin{array}{r}92,800 \\
106,000 \\
100,000 \\
96,500 \\
83,900 \\
105,000 \\
180,000 \\
916,000 \\
1,480,000 \\
726,000 \\
809,000 \\
163,000\end{array}$ \\
\hline The year. & 30,400 & 1,190 & 6,030 & $4,360,000$ \\
\hline $\begin{array}{l}\text { October. } \\
\text { November. } \\
\text { December } \\
\text { January } \\
\text { February } \\
\text { March } \\
\text { April }\end{array}$ & $\begin{array}{r}3,480 \\
2,700 \\
2,180 \\
1,920 \\
7,300 \\
19,700 \\
34,600 \\
11,900 \\
1,980 \\
1,640\end{array}$ & $\begin{array}{r}2,540 \\
1,700 \\
1,540 \\
1,590 \\
1,540 \\
3,000 \\
12,600 \\
1,980 \\
750 \\
630\end{array}$ & $\begin{array}{r}2,920 \\
2,200 \\
\mathbf{2}, 800 \\
1,770 \\
1,660 \\
1,710 \\
3,790 \\
13,500 \\
21,200 \\
\mathbf{5}, 640 \\
1,230 \\
1,190\end{array}$ & $\begin{array}{r}180,000 \\
134,000 \\
11,, 000 \\
109,000 \\
95,500 \\
105,000 \\
228,000 \\
830,000 \\
1,260,000 \\
347,000 \\
75,600 \\
70,800\end{array}$ \\
\hline The year. & 34,600 & & 4,880 & $3,540,000$ \\
\hline
\end{tabular}


Monthly discharge of Colorado River near Palisade, Colo, for 1901-1927-Con.

\begin{tabular}{|c|c|c|c|c|}
\hline \multirow{2}{*}{ Month } & \multicolumn{3}{|c|}{ Discharge in second-feet } & \multirow{2}{*}{$\begin{array}{l}\text { Run-off in } \\
\text { acre-feet }\end{array}$} \\
\hline & Maximum & Minimum & Mean & \\
\hline $\begin{array}{l}\text { October } \\
\text { November } \\
\text { December } \\
\text { January } \\
\text { February } \\
\text { March } \\
\text { April } \\
\text { May } \\
\text { June } \\
\text { July } \\
\text { August } \\
\text { September }\end{array}$ & $\begin{array}{r}2,430 \\
2,160 \\
1,700 \\
7,300 \\
18,600 \\
18,200 \\
11,400 \\
4,300 \\
4,600\end{array}$ & $\begin{array}{r}1,290 \\
1,340 \\
3,340 \\
4,600 \\
9,740 \\
2,570 \\
1,390 \\
2,040 \\
\end{array}$ & $\begin{array}{r}1,950 \\
1,870 \\
1,500 \\
1,500 \\
1,500 \\
2,370 \\
4,880 \\
11,000 \\
12,800 \\
5,760 \\
2,580 \\
2,950\end{array}$ & $\begin{array}{r}120,000 \\
111,000 \\
92,200 \\
92,200 \\
83,300 \\
146,000 \\
290,000 \\
676,000 \\
762,000 \\
354,000 \\
159,000 \\
176,000\end{array}$ \\
\hline The y & 18,600 & 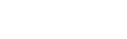 & 4,230 & $3,060,000$ \\
\hline $\begin{array}{l}\text { October } \\
\text { November } \\
\text { December } \\
\text { January } \\
\text { February } \\
\text { March } \\
\text { April } \\
\text { May } \\
\text { June } \\
\text { July } \\
\text { August } \\
\text { September }\end{array}$ & $\begin{array}{r}3,980 \\
3,000 \\
1,860 \\
1,760 \\
1,540 \\
2,100 \\
11,200 \\
27,100 \\
33,400 \\
16,600 \\
4,920 \\
1,640\end{array}$ & $\begin{array}{r}1,810 \\
1,440 \\
1,240 \\
1,060 \\
1,340 \\
1,340 \\
1,540 \\
6,470 \\
12,900 \\
3,780 \\
1,070 \\
950\end{array}$ & $\begin{array}{r}2,580 \\
2,100 \\
1,580 \\
1,420 \\
1,410 \\
1,710 \\
5,070 \\
15,400 \\
22,500 \\
9,080 \\
2,450 \\
1,190\end{array}$ & $\begin{array}{r}159,000 \\
125,000 \\
97,200 \\
87,300 \\
78,300 \\
105,000 \\
302,000 \\
947,000 \\
1,340,000 \\
558,000 \\
151,000 \\
70,800\end{array}$ \\
\hline The year..... & 33,400 & 950 & 5,560 & $4,020,000$ \\
\hline $\begin{array}{l}\text { October } \\
\text { November } \\
\text { Docember } \\
\text { January } \\
\text { February } \\
\text { Manch } \\
\text { April } \\
\text { May } \\
\text { June } \\
\text { August } \\
\text { September }\end{array}$ & $\begin{array}{r}2,460 \\
9,580 \\
30,400 \\
26,000 \\
18,200 \\
7,300 \\
4,920\end{array}$ & $\begin{array}{r}1,150 \\
1,820 \\
10,600 \\
17,400 \\
4,500 \\
2,120 \\
2,180\end{array}$ & $\begin{array}{r}1,510 \\
1,610 \\
1,370 \\
1,250 \\
1,400 \\
1,580 \\
3,300 \\
19,500 \\
21,500 \\
8,580 \\
4,390 \\
2,910\end{array}$ & $\begin{array}{r}92,800 \\
95,800 \\
84,200 \\
76,900 \\
77,800 \\
97,200 \\
196,000 \\
1,200,000 \\
1,280,000 \\
528,000 \\
270,000 \\
173,000\end{array}$ \\
\hline The year... & 30,400 & & 5,750 & $4,170,000$ \\
\hline
\end{tabular}

Nore. - Records for winter based on discharge of Colorado River and Roaring Fork at Glenwood Springs with an allowance for inflow between.

\section{COLORADO RIVER AT GRAND JUHCTION, COLO.}

Lock' - At highway bridge 300 feet from pump house of city waterworks at Grand Junction, Mesa County. Gunnison River enters a short distance below.

Drainage area.-8,910 square miles (measured on base map of Colorado).

Records available.-October 1, 1896, to September 30, 1899.

GAGE.-Vertical staff fastened to stone pier; auxiliary wire gage in second channel.

Control. - Water flows in two channels at medium and high stages. Control shifting and subject to backwater from Gunnison River when that stream is at extreme high stages.

Diversions.--See Colorado River near Palisade.

AccuracY.-Records fair, owing to shifting control. 
Monthly discharge of Colorado River at Grand Junction, Colo., 1896-1899

\begin{tabular}{|c|c|c|c|c|}
\hline \multirow{2}{*}{ Month } & \multicolumn{3}{|c|}{ Discharge in second-feet } & \multirow{2}{*}{$\begin{array}{l}\text { Run-off in } \\
\text { acre-feet }\end{array}$} \\
\hline & Maximum & Minimum & Mean & \\
\hline $\begin{array}{l}\text { October. } \\
\text { November } \\
\text { December. } \\
\text { Jenuary } \\
\text { February } \\
\text { Marcin } \\
\text { April } \\
\text { Jay } \\
\text { June } \\
\text { July } \\
\text { August }\end{array}$ & $\begin{array}{r}1,890 \\
1,430 \\
\mathbf{9}, 900 \\
\mathbf{3 7}, \mathbf{2 0 0} \\
\mathbf{3 6}, \mathbf{0 0 0} \\
\mathbf{1 3}, \mathbf{3 0 0} \\
\mathbf{5}, 650 \\
\mathbf{2}, 940\end{array}$ & $\begin{array}{r}1,360 \\
11,000 \\
13,300 \\
3,730 \\
1,840 \\
1,720\end{array}$ & $\begin{array}{r}1,530 \\
1,280 \\
1,100 \\
1,000 \\
1,150 \\
1,380 \\
3,480 \\
27,500 \\
23,300 \\
7,970 \\
3,240 \\
1,940\end{array}$ & $\begin{array}{r}94,100 \\
76,200 \\
67,600 \\
61,500 \\
63,900 \\
84,800 \\
207,000 \\
1,690,000 \\
1,360,000 \\
490,000 \\
199,000 \\
115,000\end{array}$ \\
\hline The year. & 37,200 & |ron & 6,260 & $4,540,000$ \\
\hline $\begin{array}{l}\text { October } \\
\text { November } \\
\text { December. } \\
\text { January. } \\
\text { February } \\
\text { March } \\
\text { April } \\
\text { May } \\
\text { June } \\
\text { July } \\
\text { August } \\
\text { September }\end{array}$ & $\begin{array}{r}\mathbf{2}, \mathbf{5 9 0} \\
\mathbf{1 , 9 7 0} \\
12,600 \\
17,300 \\
\mathbf{7}, 610 \\
1,720 \\
1,140\end{array}$ & $\begin{array}{r}1,610 \\
1,450 \\
\mathbf{8}, 280 \\
1,720 \\
949 \\
\mathbf{5 6 1}\end{array}$ & $\begin{array}{r}1,950 \\
1,750 \\
1,600 \\
2,940 \\
2,980 \\
2,110 \\
4,300 \\
7,130 \\
13,700 \\
4,440 \\
1,130 \\
807\end{array}$ & $\begin{array}{r}120,000 \\
104,000 \\
98,400 \\
181,000 \\
166,000 \\
130,000 \\
256,000 \\
438,000 \\
815,000 \\
273,000 \\
69,300 \\
54,900\end{array}$ \\
\hline The year. ................. & 17,300 & 561 & 3,740 & $2,700,000$ \\
\hline $\begin{array}{l}\text { October } \\
\text { November. } \\
\text { December. } \\
\text { January } \\
\text { February } \\
\text { March } \\
\text { April. } \\
\text { May } \\
\text { June } \\
\text { July } \\
\text { August } \\
\text { September }\end{array}$ & $\begin{array}{r}1,140 \\
1,340 \\
\\
\end{array}$ & $\begin{array}{r}\begin{array}{r}561 \\
\mathbf{7 5 5}\end{array} \\
\\
\\
\\
\\
\\
\end{array}$ & $\begin{array}{r}915 \\
1,070 \\
1,010 \\
1,000 \\
\mathbf{2}, 000 \\
1,800 \\
3,940 \\
19,400 \\
31,300 \\
14,100 \\
4,580 \\
2,160\end{array}$ & $\begin{array}{r}56, \mathbf{3 0 0} \\
63, \mathbf{8 0 0} \\
62, \mathbf{2 0 0} \\
61, \mathbf{6 0 0} \\
111, \mathbf{0 0 0} \\
111, \mathbf{0 0 0} \\
234,000 \\
1,190, \mathbf{0 0 0} \\
1,860,000 \\
865, \mathbf{0 0 0} \\
281, \mathbf{0 0 0} \\
129,000\end{array}$ \\
\hline The year.- & & & 6,940 & $5,020,000$ \\
\hline
\end{tabular}

Nort.-Mean monthly discharge estimated đuring winter. From April to September, 1899, only mean monthly discharge given since gage heights were too incomplete to permit maximum and minimum monthly discharge being given.

COLORADO RIVER IRAR FRUITA, COLO.

Location.-In sec. 20, T. 1 N., R. 2 W., at highway bridge 11/2 miles south of Fruita, Mesa County. Nearest tributary, Little Salt Wash, enters 1 mile downstream.

Drainage arma.-17,100 square miles (measured on base map of Colorado).

Records available.-Flood records during 1908, 1909, and 1910; continuous records from April 1, 1911, to September 30, 1923.

GAGE.-Chain on bridge.

Controu.-Somewhat shifting

ExTremes of Discharge.-Maximum stage recorded during period, 15.2 feet at ${ }^{\circ}$ 8 a. m. and 5 p. m. June 16, 1921 (discharge, 81,000 second-feet). Weather Bureau reports show highest stage known was about 18.5 feet on July 4, 1884 (discharge estimated from extension of rating curve and levels across area of overflow, 125,000 second-feet); minimum stage recorded, 1.9 feet on several days during August, 1919 (discharge, 1,270 second-feet). 
Drversions.- Only diversion from Colorado River between Palisade and Fruita stations is that of Grand Valley Canal, which has a decree for 521 secondfeet.

ACCURACY.-Gage read twice daily. Rating curves fairly well defined, except that prior to 1918 high-water curves were probably 10 to 15 per cent too small. Records good, except that prior to 1918 those above 40,000 secondfeet are fair. Estimated records fair.

Cooperation.-Gage heights furnished by United States Weather Bureau. Discharge measurements during 1923 furnished by State engineer.

\section{Monthly discharge of Colorado River near Fruita, Colo., for 1907-192s}

\begin{tabular}{|c|c|c|c|c|}
\hline \multirow{2}{*}{ Month } & \multicolumn{3}{|c|}{ Discharge in second-feet } & \multirow{2}{*}{$\begin{array}{l}\text { Run-off in } \\
\text { acro-feet }\end{array}$} \\
\hline & Maximum & Minimum & Mean & \\
\hline $\begin{array}{l}\text { October } \\
\text { November } \\
\text { December } \\
\text { January } \\
\text { February } \\
\text { March } \\
\text { Aprij } \\
\text { May } \\
\text { June } \\
\text { July } \\
\text { August } \\
\text { September. }\end{array}$ & 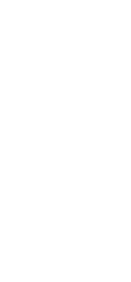 & $\begin{array}{r}r, 560 \\
6,630 \\
13,600 \\
4,560 \\
4 \\
4\end{array}$ & $\begin{array}{r}3,650 \\
2,800 \\
2,600 \\
2,500 \\
2,600 \\
4,000 \\
8,130 \\
10,900 \\
20,100 \\
8,350 \\
2,800 \\
2,700\end{array}$ & $\begin{array}{r}224,000 \\
167,000 \\
160,000 \\
154,000 \\
150,000 \\
246,000 \\
484,000 \\
670,000 \\
1,200,000 \\
513,000 \\
172,000 \\
161,000\end{array}$ \\
\hline The year.................. & & & .......... & $4,300,000$ \\
\hline $\begin{array}{l}\text { October } \\
\text { November } \\
\text { December } \\
\text { January } \\
\text { February } \\
\text { March } \\
\text { April } \\
\text { May } \\
\text { June } \\
\text { July } \\
\text { August } \\
\text { September }\end{array}$ & $\begin{array}{r}84,100 \\
63,600 \\
37,700 \\
- \\
\hdashline\end{array}$ & $\begin{array}{r}4,560 \\
6,630 \\
21,300 \\
8,800 \\
\hdashline \\
\hdashline\end{array}$ & $\begin{array}{r}3,000 \\
2,800 \\
2,600 \\
2,500 \\
2,150 \\
2,800 \\
6,530 \\
23,200 \\
45,500 \\
19,100 \\
7,000 \\
5,500\end{array}$ & $\begin{array}{r}184,000 \\
167,000 \\
160,000 \\
154,000 \\
119,000 \\
172,000 \\
389,000 \\
1,430,000 \\
2,710,000 \\
1,170,000 \\
430,000 \\
327,000\end{array}$ \\
\hline 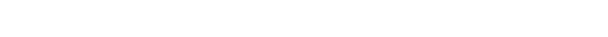 & 63,600 & $\ldots$ & 10,200 & $7,410,000$ \\
\hline $\begin{array}{l}\text { October } \\
\text { November. } \\
\text { December. } \\
\text { January } \\
\text { February } \\
\text { March } \\
\text { A pril } \\
\text { May } \\
\text { June } \\
\text { July } \\
\text { August } \\
\text { September }\end{array}$ & 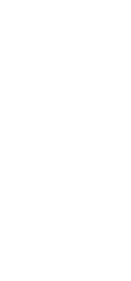 & $\begin{array}{r}15,700 \\
9,060 \\
4,560 \\
0 \\
0\end{array}$ & $\begin{array}{r}3,600 \\
3,000 \\
2,750 \\
2,800 \\
2,700 \\
6,250 \\
10,800 \\
21,400 \\
19,300 \\
6,360 \\
=3,000 \\
3,000\end{array}$ & $\begin{array}{r}221,000 \\
179,000 \\
169,000 \\
172,000 \\
160,000 \\
384,000 \\
643,000 \\
1,820,000 \\
1,150,000 \\
391,000 \\
184,000 \\
179,000\end{array}$ \\
\hline The year & 34,000 & & 7,100 & $5,140,000$ \\
\hline $\begin{array}{l}\text { October } \\
\text { November. } \\
\text { December } \\
\text { January } \\
\text { February } \\
\text { March } \\
\text { Aprili } \\
\text { May } \\
\text { Jung } \\
\text { July } \\
\text { September }\end{array}$ & $\begin{array}{r}31,000 \\
38,800 \\
23,900 \\
7,200 \\
8,160\end{array}$ & $\begin{array}{r}14,200 \\
15,900 \\
8,160 \\
3,010 \\
2,690\end{array}$ & $\begin{array}{r}3,400 \\
2,900 \\
2,600 \\
2,600 \\
2,800 \\
65,000 \\
6,000 \\
22,500 \\
29,000 \\
14,000 \\
4,460 \\
3,400\end{array}$ & $\begin{array}{r}209,000 \\
173,000 \\
160,000 \\
169,000 \\
156,000 \\
307,000 \\
357,000 \\
1,380,000 \\
1,730,000 \\
861,000 \\
274,000 \\
202,000\end{array}$ \\
\hline 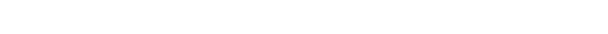 & 88,800 & - nn & 8,230 & $5,970,000$ \\
\hline
\end{tabular}

- Estimated. 
Monthly discharge of Colorado River near Fruita, Colo., for 190\%-1923-Continued

\begin{tabular}{|c|c|c|c|c|}
\hline \multirow{2}{*}{ Month } & \multicolumn{3}{|c|}{ Discharge in second-feet } & \multirow{2}{*}{$\begin{array}{l}\text { Run-off in } \\
\text { acre-feet }\end{array}$} \\
\hline & Maximum & Minimum & Mean & \\
\hline $\begin{array}{l}\text { October } \\
\text { November } \\
\text { December } \\
\text { January } \\
\text { Februgry } \\
\text { March } \\
\text { April } \\
\text { May } \\
\text { June } \\
\text { July } \\
\text { August } \\
\text { September }\end{array}$ & $\begin{array}{r}13,800 \\
4,470 \\
6,740 \\
8,410 \\
53,600 \\
58,100 \\
38,800 \\
16,400 \\
4,660\end{array}$ & $\begin{array}{r}4,660 \\
2,880 \\
2,630 \\
3,770 \\
8,160 \\
25,100 \\
15,900 \\
3,610 \\
3,010\end{array}$ & $\begin{array}{r}6,980 \\
3,410 \\
22,700 \\
2,700 \\
2,600 \\
3,350 \\
5,660 \\
28,400 \\
42,800 \\
21,600 \\
7,510 \\
4,000\end{array}$ & $\begin{array}{r}429,000 \\
203,000 \\
166,000 \\
166,000 \\
150,000 \\
206,000 \\
337,000 \\
1,750,000 \\
2,550,000 \\
1,330,000 \\
462,000 \\
238,000\end{array}$ \\
\hline The year................ & 58,100 & & 11,000 & $7,990,000$ \\
\hline $\begin{array}{l}\text { October } \\
\text { November } \\
\text { December } \\
\text { January } \\
\text { February } \\
\text { March } \\
\text { April } \\
\text { May } \\
\text { June }\end{array}$ & $\begin{array}{r}4,850 \\
4,290 \\
16,600 \\
27,300 \\
26,000 \\
10,500 \\
4,110 \\
4,950\end{array}$ & $\begin{array}{r}3,770 \\
2,750 \\
5,050 \\
13,500 \\
11,900 \\
4,470 \\
2,100 \\
2,320\end{array}$ & $\begin{array}{r}4,340 \\
3,630 \\
\times 2,550 \\
22,550 \\
2,500 \\
2,950 \\
10,400 \\
10,200 \\
17,800 \\
6,930 \\
2,660 \\
3,670\end{array}$ & $\begin{array}{r}267,000 \\
216,000 \\
157,000 \\
157,000 \\
139,000 \\
181,000 \\
618,000 \\
1,180,000 \\
1,060,000 \\
426,000 \\
164,000 \\
218,000\end{array}$ \\
\hline The year. & 27,300 & $-\infty-\infty-\infty$ & 6,600 & $4,780,000$ \\
\hline $\begin{array}{l}\text { October. } \\
\text { November } \\
\text { December. } \\
\text { January } \\
\text { February } \\
\text { Mareh } \\
\text { April } \\
\text { May } \\
\text { June } \\
\text { July } \\
\text { August } \\
\text { September. }\end{array}$ & $\begin{array}{r}4,660 \\
3,860 \\
3,010 \\
4,290 \\
12,400 \\
53,600 \\
58,100 \\
22,700 \\
12,000 \\
6,020\end{array}$ & $\begin{array}{r}3,150 \\
2,690 \\
\mathbf{2}, 880 \\
\mathbf{3}, 610 \\
11,000 \\
23,900 \\
10,400 \\
3,660 \\
\mathbf{3}, 360\end{array}$ & $\begin{array}{r}3,800 \\
\mathbf{3}, 200 \\
2,460 \\
\mathbf{2}, 500 \\
\mathbf{2}, 550 \\
\mathbf{3}, 400 \\
\mathbf{8}, 480 \\
33,500 \\
41,400 \\
15,700 \\
6,730 \\
\mathbf{3}, 960\end{array}$ & $\begin{array}{r}239,000 \\
190,000 \\
151,000 \\
154,000 \\
142,000 \\
209,000 \\
505,000 \\
2,060,000 \\
2,460,000 \\
965,000 \\
414,000 \\
236,000\end{array}$ \\
\hline The year................... & 58,100 & - & 10,600 & $7,720,000$ \\
\hline $\begin{array}{l}\text { October } \\
\text { November } \\
\text { December } \\
\text { January } \\
\text { February } \\
\text { March } \\
\text { April } \\
\text { May } \\
\text { June } \\
\text { July } \\
\text { August } \\
\text { September }\end{array}$ & $\begin{array}{r}16,400 \\
4,010 \\
13,100 \\
18,900 \\
26,900 \\
16,400 \\
4,470 \\
3,290\end{array}$ & $\begin{array}{r}3,510 \\
2,760 \\
\mathbf{3}, \mathbf{1 4 0} \\
\mathbf{5}, \mathbf{8 7 0} \\
1 \mathbf{6}, \mathbf{0 0 0} \\
\mathbf{4}, 110 \\
1,730 \\
1,540\end{array}$ & $\begin{array}{r}5,540 \\
3,290 \\
\times 2,560 \\
\times 2,300 \\
22,400 \\
a 2,690 \\
6,970 \\
12,800 \\
21,500 \\
8,910 \\
2,740 \\
1,990\end{array}$ & $\begin{array}{r}341,000 \\
106,000 \\
157,000 \\
141,000 \\
133,000 \\
165,000 \\
415,000 \\
787,000 \\
1,280,000 \\
548,000 \\
168,000 \\
118,000\end{array}$ \\
\hline The year. & 26,800 & nan & 6,150 & $4,450,000$ \\
\hline $\begin{array}{l}\text { October... } \\
\text { November } \\
\text { December. } \\
\text { January } \\
\text { February } \\
\text { March } \\
\text { April } \\
\text { May. } \\
\text { June } \\
\text { July } \\
\text { August } \\
\text { September. }\end{array}$ & $\begin{array}{r}\mathbf{3}, 290 \\
3,140 \\
10,000 \\
22,200 \\
38,100 \\
39,600 \\
21,400 \\
12,900 \\
5,870\end{array}$ & $\begin{array}{r}2,300 \\
2,170 \\
2,660 \\
4,660 \\
14,000 \\
22,800 \\
6,750 \\
3,770 \\
3,200\end{array}$ & $\begin{array}{r}2,710 \\
2,690 \\
2,580 \\
2,650 \\
2,850 \\
4,920 \\
9,270 \\
23,000 \\
32,100 \\
12,500 \\
8,710 \\
4,040\end{array}$ & $\begin{array}{r}167,000 \\
160,000 \\
156,000 \\
163,000 \\
164,000 \\
303,000 \\
552,000 \\
1,410,000 \\
1,910,000 \\
768,000 \\
586,000 \\
240,000\end{array}$ \\
\hline (2.2. & 39,600 & 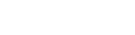 & 9,000 & $6,530,000$ \\
\hline
\end{tabular}

- Estimated. 
Monthly discharge of Colorado River near Fruita, Colo., for 190\%-1928-Continued

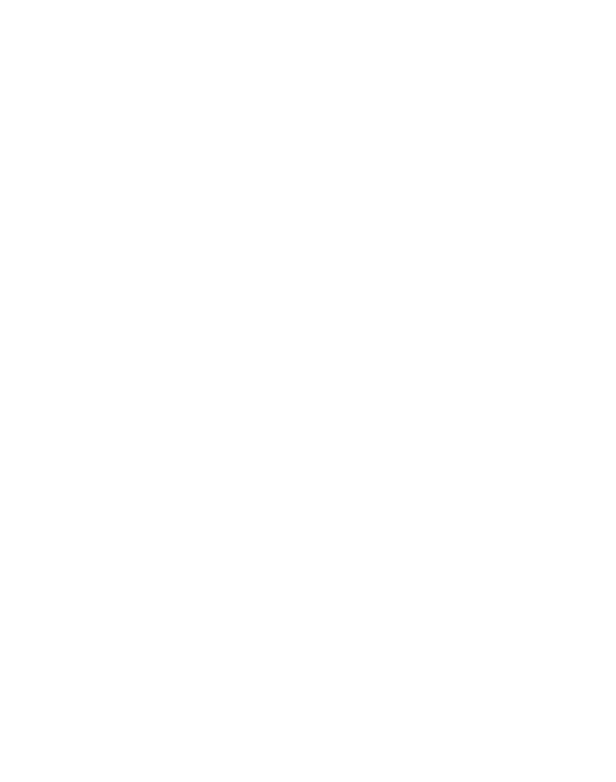

The year-

October
November
December
January
February
March
April
May
June
July
August
September

The year.

October.

1919-20

November

December

January..

February

March.

April

Mane.

July.

August.

September

The year.

October -

November

December

January.

February

March.

April.

June.

July.

August.

September

The year.

1920-21

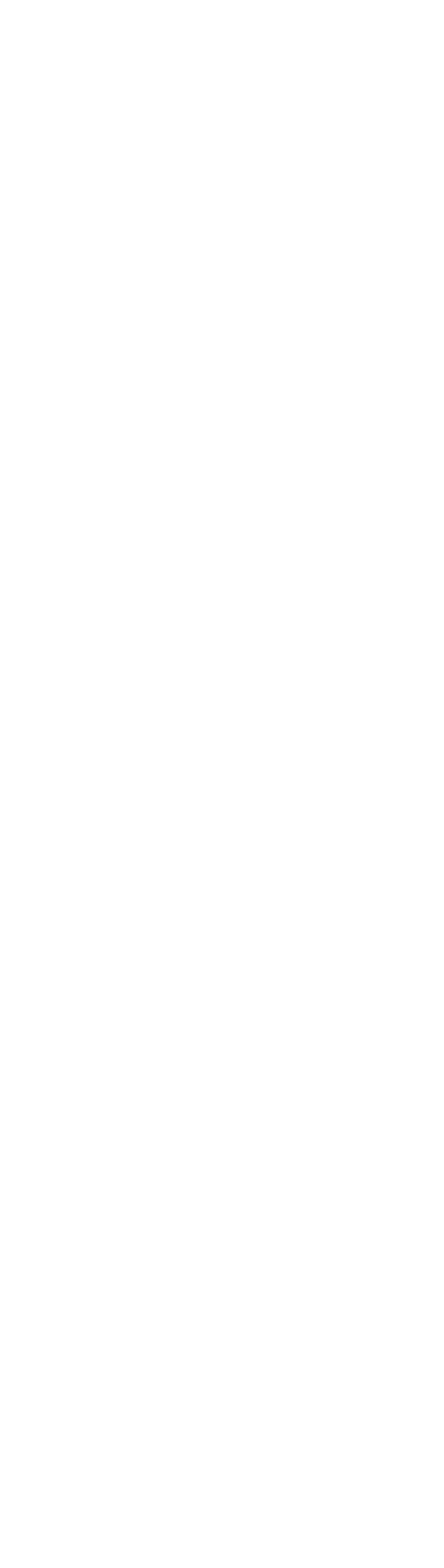

- Estimated. 
Monthly discharge of Colorado River near Fruita, Colo., for 1907-1923-Continued

\begin{tabular}{|c|c|c|c|c|}
\hline \multirow{2}{*}{ Month } & \multicolumn{3}{|c|}{ Discharge in second-feet } & \multirow{2}{*}{$\underset{\text { acre-feet }}{\text { Run-off in }}$} \\
\hline & Maximum & Miniminm & Mean & \\
\hline $\begin{array}{l}\text { October. } \\
\text { November. } \\
\text { December. } \\
\text { January } \\
\text { February } \\
\text { March } \\
\text { April. } \\
\text { May } \\
\text { June } \\
\text { July } \\
\text { August. } \\
\text { Beptember }\end{array}$ & $\begin{array}{r}3,370 \\
3,720 \\
4,000 \\
3,540 \\
6,150 \\
16,600 \\
53,100 \\
43,200 \\
14,700 \\
5,270 \\
3,720\end{array}$ & $\begin{array}{r}2,730 \\
3,040 \\
2,880 \\
3,720 \\
16,200 \\
15,700 \\
3,370 \\
2,300 \\
1,860\end{array}$ & $\begin{array}{r}3,050 \\
3,410 \\
3,280 \\
2,590 \\
\times 2,390 \\
3,730 \\
6,550 \\
32,000 \\
30,600 \\
7,000 \\
3,740 \\
2,500\end{array}$ & $\begin{array}{r}188,000 \\
203,000 \\
202,000 \\
159,000 \\
133,000 \\
229,000 \\
390,000 \\
1,970,000 \\
1,820,000 \\
430,000 \\
230,000 \\
149,000\end{array}$ \\
\hline The year........... & 53,100 & 1,860 & 8,430 & $6,100,000$ \\
\hline 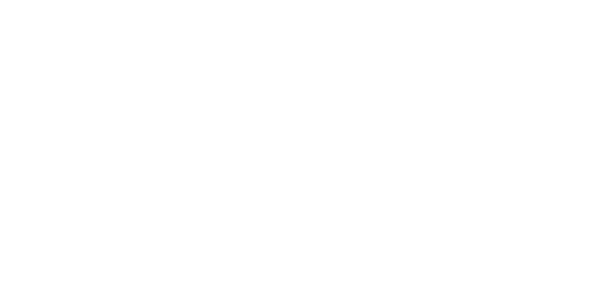 & $\begin{array}{r}2,600 \\
2,960 \\
3,240 \\
2,950 \\
2,660 \\
2,790 \\
8,780 \\
49,600 \\
45,900 \\
24,000 \\
9,660 \\
4,800\end{array}$ & $\begin{array}{r}1,930 \\
2,600 \\
2,280 \\
2,050 \\
2,180 \\
2,080 \\
2,600 \\
8,440 \\
27,000 \\
6,110 \\
3,670 \\
2,600 .\end{array}$ & $\begin{array}{r}2,130 \\
2,800 \\
2,660 \\
2,560 \\
2,390 \\
2,420 \\
4,620 \\
25,800 \\
36,900 \\
14,900 \\
6,720 \\
3,780\end{array}$ & $\begin{array}{r}131,000 \\
167,000 \\
164,000 \\
157,000 \\
133,000 \\
149,000 \\
275,000 \\
1,590,000 \\
2,200,000 \\
916,000 \\
413,000 \\
205,000\end{array}$ \\
\hline The year. & 49,600 & 1,930 & 8,990 & $6,520,000$ \\
\hline
\end{tabular}

- Estimated.

\section{COLORADO RIVER IFAR CISCO, UTAH}

Location.-About sec. 7, T. 23 S., R. 24 E., at Dewey Ferry, 14 miles southeast of Cisco, Grand County. Dolores River enters three-quarters of a mile upstream.

Drainage area.-24,100 square miles (measured on base maps of Utah and Colorado).

Neconds avallable.-November 10, 1914, to September 30, 1917; October 1, 1922, to September 30, 1927. From October 1, 1913, to November 10, 1914, station maintained 25 miles downstream at. Moab; flow at two points practically comparable.

GAGE.-Continuous water-stage recorder at present site; staff and chain gages at Moab.

Control.-Somewhat shifting.

Extremes of pischarge.-Maximum discharge during period, 76,800 secondfeet at 9 p. m. June 19, 1917; minimum discharge, 866 second-feet September 4, 1924.

Diversions.--Practically no water diverted from Colorado River between Fruita and Cisco stations.

Accuracy.-Records good, except those for months for which mean discharge was estimated, which are fair. 
Monthly discharge of Colorado River near Cisco, Utah, for 1913-1917 and 1982-1987

\begin{tabular}{|c|c|c|c|c|}
\hline \multirow{2}{*}{ Month } & \multicolumn{3}{|c|}{ Discharge in second-feet } & \multirow{2}{*}{$\begin{array}{l}\text { Run-ofi in } \\
\text { acte-feet }\end{array}$} \\
\hline & Maximum & Minimum & Mean & \\
\hline $\begin{array}{l}\text { October } \\
\text { November. } \\
\text { December... } \\
\text { January } \\
\text { February. } \\
\text { March } \\
\text { April } \\
\text { May. } \\
\text { June } \\
\text { July } \\
\text { August. } \\
\text { September }\end{array}$ & $\begin{array}{r}4,700 \\
4,240 \\
3,190 \\
6,400 \\
8,350 \\
5,300 \\
14,100 \\
58,800 \\
65,600 \\
29,200 \\
13,800 \\
6,940\end{array}$ & $\begin{array}{r}3,640 \\
3,040 \\
1,560 \\
1,650 \\
1,950 \\
2,050 \\
4,400 \\
10,500 \\
28,600 \\
12,000 \\
4,660 \\
3,660\end{array}$ & $\begin{array}{r}4,050 \\
3,610 \\
2,310 \\
2,930 \\
2,730 \\
3,640 \\
9,810 \\
33,800 \\
47,200 \\
18,400 \\
8,120 \\
4,460\end{array}$ & $\begin{array}{r}249,000 \\
215,000 \\
142,000 \\
180,000 \\
152,000 \\
224,000 \\
584,000 \\
2,080,000 \\
2,810,000 \\
1,130,000 \\
499,000 \\
265,000\end{array}$ \\
\hline The year. & 65,600 & 1,560 & 11,800 & $8,530,000$ \\
\hline $\begin{array}{l}\text { October } \\
\text { November } \\
\text { December. } \\
\text { January } \\
\text { February } \\
\text { March } \\
\text { April. } \\
\text { May } \\
\text { June } \\
\text { July } \\
\text { August } \\
\text { September }\end{array}$ & $\begin{array}{r}13,800 \\
4,660 \\
2,880 \\
\mathbf{3}, 970 \\
17,700 \\
25,600 \\
33,600 \\
19,400 \\
4,820 \\
\mathbf{4}, 640\end{array}$ & $\begin{array}{r}3,660 \\
2,800 \\
2,200 \\
3,840 \\
8,560 \\
19,900 \\
5,260 \\
1,670 \\
1,520\end{array}$ & $\begin{array}{r}6,080 \\
3,520 \\
2,350 \\
2,120 \\
2,540 \\
2,870 \\
9,710 \\
18,200 \\
26,000 \\
10,000 \\
3,000 \\
2,170\end{array}$ & $\begin{array}{r}374,000 \\
209,000 \\
144,000 \\
130,000 \\
141,000 \\
176,000 \\
578,000 \\
1,120,000 \\
1,550,000 \\
615,000 \\
184,000 \\
129,000\end{array}$ \\
\hline The year. . & 33,600 & & & $5,350,000$ \\
\hline $\begin{array}{l}\text { October } \\
\text { November } \\
\text { December. } \\
\text { January } \\
\text { February. } \\
\text { March } \\
\text { April } \\
\text { May } \\
\text { June } \\
\text { July } \\
\text { August. } \\
\text { September }\end{array}$ & $\begin{array}{r}3,340 \\
3,550 \\
2,940 \\
16,100 \\
30,900 \\
46,900 \\
41,600 \\
23,700 \\
17,300 \\
6,600\end{array}$ & $\begin{array}{r}2,380 \\
2,290 \\
2,750 \\
6,080 \\
17,300 \\
24,200 \\
\mathbf{8}, 270 \\
4,760 \\
\mathbf{3}, \mathbf{7 6 0}\end{array}$ & $\begin{array}{r}2,790 \\
2,770 \\
2,530 \\
2,950 \\
23,240 \\
6,870 \\
12,700 \\
27,300 \\
33,800 \\
13,900 \\
10,300 \\
4,810\end{array}$ & $\begin{array}{r}172,000 \\
165,000 \\
156,000 \\
181,000 \\
186,000 \\
422,000 \\
756,000 \\
1,680,000 \\
2,010,000 \\
855,000 \\
633,000 \\
286,000\end{array}$ \\
\hline The year............. & 46,900 & & 10,300 & $7,500,000$ \\
\hline $\begin{array}{l}\text { October } \\
\text { November } \\
\text { December } \\
\text { January } \\
\text { February. } \\
\text { March } \\
\text { April } \\
\text { May } \\
\text { June } \\
\text { July } \\
\text { August } \\
\text { September }\end{array}$ & $\begin{array}{r}14,200 \\
5,580 \\
19,800 \\
54,700 \\
73,200 \\
53,700 \\
13,100 \\
5,340\end{array}$ & $\begin{array}{r}3,870 \\
3,550 \\
10,800 \\
12,800 \\
3,760 \\
3,040 \\
\end{array}$ & $\begin{array}{r}6,890 \\
3,460 \\
2,710 \\
2,000 \\
2,500 \\
3,140 \\
8,910 \\
24,700 \\
55,500 \\
24,600 \\
6,870 \\
3,890\end{array}$ & $\begin{array}{r}424,000 \\
206,000 \\
167,000 \\
123,000 \\
139,000 \\
193,000 \\
530,000 \\
1 ; 520,000 \\
3,300,000 \\
1,510,000 \\
422,000 \\
231,000\end{array}$ \\
\hline The year. & 73,200 & - non & 12,100 & $8,760,000$ \\
\hline $\begin{array}{l}\text { October. } \\
\text { November } \\
\text { December. } \\
\text { January } \\
\text { February } \\
\text { March } \\
\text { April } \\
\text { May } \\
\text { June } \\
\text { July } \\
\text { August } \\
\text { September }\end{array}$ & $\begin{array}{r}2,780 \\
3,590 \\
3,770 \\
4,000 \\
3,070 \\
3,220 \\
12,200 \\
47,100 \\
44,200 \\
27,100 \\
13,300 \\
7,040\end{array}$ & $\begin{array}{r}2,870 \\
2,400 \\
2,400 \\
2,200 \\
2,460 \\
3,330 \\
11,900 \\
29,500 \\
7,680 \\
4,830 \\
3,770\end{array}$ & $\begin{array}{r}2,250 \\
3,160 \\
3,070 \\
2,990 \\
2,780 \\
2,790 \\
7,250 \\
28,500 \\
37,100 \\
16,900 \\
8,520 \\
5,000\end{array}$ & $\begin{array}{r}138,0 \\
188,000 \\
189,000 \\
184,000 \\
154,000 \\
172,000 \\
432,000 \\
1,750,000 \\
2,210,000 \\
1,040,000 \\
524,000 \\
298,000\end{array}$ \\
\hline & 47,100 & & 10,000 & $7,280,000$ \\
\hline
\end{tabular}

- Estimated. 
Monthly discharge of Colorado River near Cisco, Utah, for 1913-1917 and 1928-1987Continued

\begin{tabular}{|c|c|c|c|c|}
\hline \multirow{2}{*}{ Month } & \multicolumn{3}{|c|}{ Discharge in second-feet. } & \multirow{2}{*}{$\begin{array}{l}\text { Run-off in } \\
\text { acte-feet }\end{array}$} \\
\hline & Maximum & Minimum & Mean & \\
\hline $\begin{array}{l}\text { October } \\
\text { November } \\
\text { Decomber } \\
\text { January } \\
\text { February } \\
\text { March } \\
\text { April } \\
\text { May } \\
\text { June } \\
\text { July } \\
\text { August } \\
\text { September }\end{array}$ & $\begin{array}{r}5,590 \\
7,020 \\
3,590 \\
2,880 \\
-3,180 \\
18,000 \\
33,100 \\
49,900 \\
15,200 \\
2,850 \\
7,840\end{array}$ & $\begin{array}{r}4,130 \\
3,260 \\
2,460 \\
2,430 \\
2,450 \\
9,830 \\
16,400 \\
2,870 \\
958 \\
866\end{array}$ & $\begin{array}{r}4,880 \\
4,090 \\
3,150 \\
2,440 \\
-3,280 \\
2,770 \\
10,400 \\
25,500 \\
29,600 \\
7,650 \\
1,830 \\
2,060\end{array}$ & $\begin{array}{r}300,000 \\
243,000 \\
194,000 \\
150,000 \\
189,000 \\
170,000 \\
619,000 \\
1,570,000 \\
1,760,000 \\
470,000 \\
113,000 \\
125,000\end{array}$ \\
\hline The y & 49,900 & 866 & 8,140 & $5,800,000$ \\
\hline $\begin{array}{l}\text { October } \\
\text { November } \\
\text { December } \\
\text { January } \\
\text { February-a } \\
\text { Mareh } \\
\text { April } \\
\text { May } \\
\text { June } \\
\text { July } \\
\text { August } \\
\text { September }\end{array}$ & $\begin{array}{r}3,960 \\
3,530 \\
3,260 \\
6,090 \\
13,400 \\
25,900 \\
27,700 \\
13,300 \\
7,910 \\
10,900\end{array}$ & $\begin{array}{r}2,070 \\
2,580 \\
2,560 \\
6,040 \\
10,200 \\
12,800 \\
4,360 \\
2,880 \\
4,130\end{array}$ & $\begin{array}{r}3,200 \\
3,190 \\
2,430 \\
2,200 \\
2,2,600 \\
3,560 \\
9,490 \\
17,800 \\
18,500 \\
8,920 \\
5,000 \\
6,290\end{array}$ & $\begin{array}{r}197,000 \\
190,000 \\
149,000 \\
135,060 \\
144,000 \\
219,000 \\
565,000 \\
1,090,000 \\
1,100,000 \\
548,000 \\
307,000 \\
374,000\end{array}$ \\
\hline The year... & 27,700 & - & 6,980 & $5,020,000$ \\
\hline $\begin{array}{l}\text { October } \\
\text { November } \\
\text { December } \\
\text { January } \\
\text { February } \\
\text { March } \\
\text { April } \\
\text { May } \\
\text { June } \\
\text { July } \\
\text { August } \\
\text { September }\end{array}$ & \begin{tabular}{r}
13,000 \\
4,890 \\
3,350 \\
\hdashline 2,740 \\
5,060 \\
25,100 \\
47,500 \\
46,800 \\
22,700 \\
5,500 \\
1,940
\end{tabular} & $\begin{array}{r}3,270 \\
3,140 \\
2,540 \\
-2,100 \\
2,100 \\
2,220 \\
3,290 \\
13,400 \\
17,800 \\
5,000 \\
1,670 \\
1,460\end{array}$ & $\begin{array}{r}5,170 \\
3,760 \\
2,830 \\
-2,240 \\
2,430 \\
3,330 \\
12,900 \\
27,400 \\
31,800 \\
12,000 \\
3,420 \\
1,690\end{array}$ & $\begin{array}{r}318,000 \\
224,000 \\
174,000 \\
138,000 \\
135,000 \\
205,000 \\
768,000 \\
1,680,060 \\
1,890,000 \\
738,000 \\
210,000 \\
.101,000\end{array}$ \\
\hline The year... & 47,500 & (n) & 9,050 & $6,600,000$ \\
\hline $\begin{array}{l}\text { October } \\
\text { November } \\
\text { December } \\
\text { January } \\
\text { February } \\
\text { March } \\
\text { April } \\
\text { May } \\
\text { June } \\
\text { July } \\
\text { August } \\
\text { September }\end{array}$ & $\begin{array}{r}4,520 \\
\mathbf{5 , 7 5 0} \\
27,700 \\
48,400 \\
42,800 \\
36,000 \\
11,500 \\
21,900\end{array}$ & $\begin{array}{r}2,580 \\
2,610 \\
5,200 \\
19,800 \\
25,800 \\
7,440 \\
4,000 \\
3,920\end{array}$ & $\begin{array}{r}3,430 \\
\alpha 2,900 \\
\alpha 2,820 \\
2,660 \\
2,2,830 \\
3,390 \\
10,500 \\
33,700 \\
31,600 \\
14,300 \\
7,470 \\
8,870\end{array}$ & $\begin{array}{r}211,000 \\
173,000 \\
173,000 \\
164,000 \\
157,000 \\
208,000 \\
625,000 \\
2,070,000 \\
1,880,000 \\
879,000 \\
459,000 \\
528,000\end{array}$ \\
\hline The year...... & 48,400 & & 10,400 & $7,530,000$ \\
\hline
\end{tabular}

- Estimated.

NORTH INLET TO GRAND IAKE AT GRAND IAKE, COLO.

Location.-In sec. 5, T. 3 N., R. 75 W., 100 yards above Grand Lake, in Grand County.

Drainage area. -47 square miles (measured on topographic map).

Records available.-August 1, 1905, to December 31, 1908, and October 1, . 1910, to September 30, 1912.

GaGe.-Vertical staff. 
Control.-Somewhat shifting at long intervals.

Extremes of Discharge.-Records too fragmentary to determine.

Drversions.- Water diverted for irrigation of small area above station.

ACcoracy.-Gage read at irregular intervals. Rating curves fairly well defined. Records fair.

Monthly discharge of North Inlet to Grand Lake at Grand Lake, Colo., for 1905-1908 and 1910-1912

\begin{tabular}{|c|c|c|c|c|}
\hline \multirow{2}{*}{ Month } & \multicolumn{3}{|c|}{ Discharge in second-feet } & \multirow{2}{*}{$\begin{array}{c}\text { Run-ofi in } \\
\text { acre-feet }\end{array}$} \\
\hline & Maximum & Minimum & Mean & \\
\hline $\begin{array}{l}\text { August } \\
\text { September }\end{array}$ & $\begin{array}{l}60 \\
17\end{array}$ & $\begin{array}{r}17 \\
7\end{array}$ & $\begin{array}{l}33.7 \\
10.7\end{array}$ & $\begin{array}{r}2,080 \\
637\end{array}$ \\
\hline $\begin{array}{l}\text { October } \\
\text { November } \\
\text { December } \\
\text { January. } \\
\text { February } \\
\text { March } \\
\text { April } \\
\text { May } \\
\text { June } \\
\text { July } \\
\text { August. }\end{array}$ & 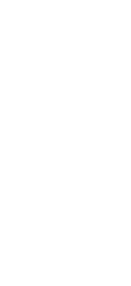 & 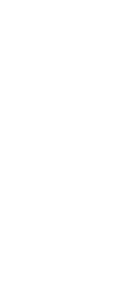 & $\begin{array}{r}8.2 \\
10.7 \\
7.6 \\
a 6 \\
a 5 \\
55 \\
18 \\
185 \\
351 \\
322 \\
100 \\
20\end{array}$ & $\begin{array}{r}504 \\
637 \\
467 \\
369 \\
278 \\
307 \\
1,070 \\
11,400 \\
20,900 \\
19,800 \\
6,150 \\
1,190\end{array}$ \\
\hline The year..- & & & 87.0 & 63,100 \\
\hline $\begin{array}{l}\text { March. } \\
\text { A pril. }\end{array}$ & $\begin{array}{r}70 \\
125\end{array}$ & $\begin{array}{r}42 \\
60 \\
\end{array}$ & $\begin{array}{l}30 \\
85.1 \\
103\end{array}$ & $\begin{array}{l}1,910 \\
5,060 \\
6,330\end{array}$ \\
\hline $\begin{array}{l}\text { October } \\
\text { November } \\
\text { December } \\
\text { January } \\
\text { February } \\
\text { March } \\
\text { April } \\
\text { Auny } \\
\text { June } \\
\text { July } \\
\text { August. } \\
\text { September }\end{array}$ & \begin{tabular}{r|}
19 \\
4 \\
205 \\
\end{tabular} & 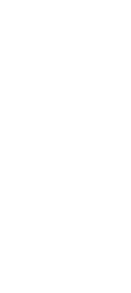 & $\begin{array}{c}17.7 \\
10 \\
4 \\
5.5 \\
5.5 \\
7.0 \\
35 \\
58 \\
125 \\
110 \\
80 \\
25\end{array}$ & $\begin{array}{r}1,090 \\
595 \\
246 \\
338 \\
316 \\
430 \\
2,080 \\
3,590 \\
7,940 \\
6,760 \\
4,920 \\
1,490\end{array}$ \\
\hline The year. & (n) & - & 404 & 29,300 \\
\hline $\begin{array}{l}\text { October } 1908 \\
\text { November } \\
\text { December }\end{array}$ & & & $\begin{array}{r}15 \\
8 \\
6\end{array}$ & $\begin{array}{l}922 \\
476 \\
369\end{array}$ \\
\hline $\begin{array}{l}\text { October. } \\
\text { November } \\
\text { December } \\
\text { January } \\
\text { February } \\
\text { March } \\
\text { April } \\
\text { May } \\
\text { June } \\
\text { July } \\
\text { August }\end{array}$ & $\begin{array}{r}35 \\
20 \\
69 \\
340 \\
775 \\
400 \\
115 \\
35\end{array}$ & $\begin{array}{r}16 \\
16 \\
38 \\
205 \\
62 \\
28 \\
19\end{array}$ & $\begin{array}{c}22.6 \\
18.5 \\
10 \\
a 6 \\
a 6 \\
a 6 \\
24.2 \\
200 \\
492 \\
158 \\
52.1 \\
24.2\end{array}$ & $\begin{array}{r}1,390 \\
1,100 \\
615 \\
369 \\
333 \\
369 \\
1,440 \\
12,300 \\
29,300 \\
9,720 \\
3,200 \\
1,440\end{array}$ \\
\hline The year. ............. & 775 & 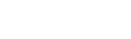 & 84.8 & 61,600 \\
\hline
\end{tabular}

- Estimated. 
Monthly discharge of North Inlet to Grand Lake at Grand Lake, Colo., for 1905-1908 and 1910-1912-Continued

\begin{tabular}{|c|c|c|c|c|}
\hline \multirow{2}{*}{ Month } & \multicolumn{3}{|c|}{ Discharge in second-feet } & \multirow{2}{*}{$\begin{array}{c}\text { Run-off in } \\
\text { acre-feet }\end{array}$} \\
\hline & Maximum & Minimum & Mean & \\
\hline $\begin{array}{l}\text { October. } \\
\text { November } \\
\text { December. } \\
\text { January } \\
\text { February } \\
\text { March } \\
\text { April } \\
\text { May } \\
\text { June } \\
\text { July } \\
\text { August. } \\
\text { September }\end{array}$ & 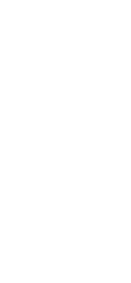 & 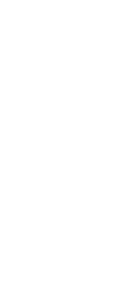 & $\begin{array}{c}24 \\
\text { a } 15 \\
\text { a } 10 \\
a 6 \\
a 5.4 \\
\text { a } 5.0 \\
14.8 \\
113 \\
442 \\
329 \\
107 \\
30\end{array}$ & $\begin{array}{r}1,480 \\
893 \\
615 \\
369 \\
259 \\
307 \\
881 \\
6,950 \\
26,300 \\
20,200 \\
6,580 \\
1,790\end{array}$ \\
\hline The year. & 602 & $\ldots$ & 91.8 & $66, \$ 0$ \\
\hline
\end{tabular}

a Estimated.

NotE.-Records fragmentary during 1908, mean discharge based on flow of Colorado River near Grand Lake.

GRAND LAKE OUTLET AT GRAND LAKE, COLO.

Location.-In sec. 6, T. 3 N., R. 75 W., at footbridge at outlet of Grand Lake, half a mile south of Grand Lake post office, Grand County. No tributary between lake and mouth of North Fork of Colorado River.

Drainage area. -79 square miles (measured in topographic map).

Records available.-August 1, 1904, to September 30, 1909, and October 1, 1910, to September 30, 1913.

GaGE.-Vertical staff.

Control.-Practically permanent.

Extremes of discharge.-Maximum stage recorded, 4.6 feet June 19 and 20, 1909 (discharge, 1,220 second-feet); minimum stage, 1.15 feet from December 5-24, 1907 (discharge, 3 second-feet).

Ice.-Stage-discharge relation practically unaffected by ice.

Regulation.-Flow partly regulated by Grand Lake, which has an area of $\mathbf{7 0 0}$ acres.

Accoracr.-Gage read once daily. Rating curve well defined. Records good.

Monthly discharge at Grand Lake Outlet at Grand Lake, Colo., for 1904-1909 and 1910-1913

\begin{tabular}{|c|c|c|c|c|}
\hline \multirow{2}{*}{ Month } & \multicolumn{3}{|c|}{ Discharge in second-feet } & \multirow{2}{*}{$\begin{array}{l}\text { Run-off in } \\
\text { acre-feet }\end{array}$} \\
\hline & Maximum & Minimum & Mean & \\
\hline $\begin{array}{l}\text { August } \\
\text { September } \\
\text { Ser }\end{array}$ & $\begin{array}{l}148 \\
173\end{array}$ & $\begin{array}{l}83 \\
34 \\
\end{array}$ & $\begin{array}{c}109 \\
63.7 \\
\end{array}$ & $\begin{array}{r}6,700 \\
8,790 \\
\end{array}$ \\
\hline $\begin{array}{l}\text { October } \\
\text { November } \\
\text { December } \\
\text { January } \\
\text { February } \\
\text { March } \\
\text { April } \\
\text { Mune } \\
\text { July } \\
\text { August } \\
\text { September }\end{array}$ & $\begin{array}{r}49 \\
416 \\
1,150 \\
563 \\
159 \\
41\end{array}$ & $\begin{array}{r}11 \\
52 \\
489 \\
170 \\
44 \\
15\end{array}$ & $\begin{array}{c}36.3 \\
13.4 \\
a 10 \\
a 9 \\
a 9 \\
\times 10 \\
22.7 \\
168 \\
785 \\
267 \\
76.2 \\
23.7\end{array}$ & $\begin{array}{r}2,930 \\
797 \\
615 \\
653 \\
500 \\
615 \\
1,350 \\
10,300 \\
46,700 \\
16,400 \\
4,680 \\
1,410\end{array}$ \\
\hline The year............... & 1.150 & $=$ & 119 & 86,100 \\
\hline
\end{tabular}

- Estimated. 
Monthly discharge at Grand Lake Outlet at Grand Lake, Colo., for 1904-1909 and 1910-1913-Continued

\begin{tabular}{|c|c|c|c|c|}
\hline \multirow{2}{*}{ Month } & \multicolumn{3}{|c|}{ Discharge in second-feet } & \multirow{2}{*}{$\begin{array}{l}\text { Run-off in } \\
\text { acre-feet }\end{array}$} \\
\hline & Maximum & Minimum & Mean & \\
\hline $\begin{array}{l}\text { October. } \\
\text { November } \\
\text { December } \\
\text { January } \\
\text { February } \\
\text { March } \\
\text { April } \\
\text { May } \\
\text { June } \\
\text { July } \\
\text { August. } \\
\text { September }\end{array}$ & \begin{tabular}{r|}
17 \\
131 \\
659 \\
1,100 \\
670 \\
174 \\
145
\end{tabular} & \begin{tabular}{r|}
3 \\
56 \\
346 \\
174 \\
40 \\
33
\end{tabular} & $\begin{array}{l}14.7 \\
.11 \\
10 \\
\text { a } 8 \\
\text { a } \\
\text { a } \\
40.6 \\
296 \\
628 \\
402 \\
107 \\
79.2\end{array}$ & $\begin{array}{r}950 \\
594 \\
615 \\
492 \\
389 \\
369 \\
2,420 \\
18,200 \\
37,400 \\
24,700 \\
6,580 \\
4,710\end{array}$ \\
\hline 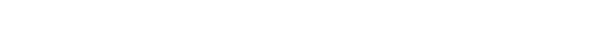 & 1,100 & $-\cdots+-$ & 135 & 97,400 \\
\hline $\begin{array}{l}\text { October. } \\
\text { November } \\
\text { December } \\
\text { January } \\
\text { February } \\
\text { March } \\
\text { April } \\
\text { May } \\
\text { June } \\
\text { July } \\
\text { Augustist } \\
\text { September }\end{array}$ & $\begin{array}{r}106 \\
33 \\
14 \\
11 \\
12 \\
28 \\
84 \\
456 \\
1,030 \\
1,040 \\
358 \\
74\end{array}$ & $\begin{array}{r}28 \\
14 \\
9 \\
7 \\
7 \\
7 \\
20 \\
28 \\
159 \\
379 \\
74 \\
28\end{array}$ & $\begin{array}{r}48.5 \\
21.0 \\
11.2 \\
8.3 \\
9.4 \\
13.3 \\
42.9 \\
147 \\
685 \\
698 \\
175 \\
41.3\end{array}$ & $\begin{array}{r}2,980 \\
1,250 \\
689 \\
510 \\
522 \\
818 \\
2,550 \\
9,040 \\
40,800 \\
42,900 \\
10,800 \\
2,460\end{array}$ \\
\hline The year. & 1,040 & 7 & 159 & 115,000 \\
\hline $\begin{array}{l}\text { October. } \\
\text { November } \\
\text { December } \\
\text { January } \\
\text { February } \\
\text { March } \\
\text { April } \\
\text { May } \\
\text { June } \\
\text { July } \\
\text { August } \\
\text { September }\end{array}$ & $\begin{array}{r}61 \\
20 \\
5.5 \\
7.5 \\
7.5 \\
7.5 \\
119 \\
263 \\
656 \\
333 \\
297 \\
77\end{array}$ & $\begin{array}{r}20 \\
4.6 \\
3.0 \\
6.0 \\
6.0 \\
6.0 \\
6.0 \\
38 \\
184 \\
119 \\
97 \\
27\end{array}$ & $\begin{array}{r}34.9 \\
10.4 \\
3.4 \\
6.9 \\
6.6 \\
6.2 \\
47.3 \\
119 \\
424 \\
231 \\
174 \\
44.0\end{array}$ & $\begin{array}{r}2,150 \\
619 \\
200 \\
422 \\
381 \\
384 \\
2,810 \\
7,320 \\
25,200 \\
14,200 \\
10,700 \\
2,620\end{array}$ \\
\hline The year. & 656 & 3 & 92.5 & 67,000 \\
\hline $\begin{array}{l}\text { October } \\
\text { November } \\
\text { December } \\
\text { January } \\
\text { February } \\
\text { March } \\
\text { April } \\
\text { May } \\
\text { June } \\
\text { July } \\
\text { August } \\
\text { September. }\end{array}$ & $\begin{array}{r}32 \\
18 \\
13 \\
13 \\
11 \\
9 \\
16 \\
297 \\
1,220 \\
1,140 \\
156 \\
170\end{array}$ & $\begin{array}{r}16 \\
11 \\
11 \\
9 \\
9 \\
6 \\
9 \\
16 \\
170 \\
170 \\
87 \\
38\end{array}$ & $\begin{array}{r}21.5 \\
13.9 \\
12.0 \\
10.7 \\
9.9 \\
7.3 \\
11.0 \\
92.7 \\
805 \\
491 \\
127 \\
79.8\end{array}$ & $\begin{array}{r}1,320 \\
827 \\
738 \\
658 \\
548 \\
446 \\
655 \\
5,700 \\
47,900 \\
30,200 \\
7,810 \\
4,750\end{array}$ \\
\hline The year. & 1,220 & 6 & 141 & 102,006 \\
\hline $\begin{array}{l}\text { October } \\
\text { November } \\
\text { December. } \\
\text { January } \\
\text { February } \\
\text { March } \\
\text { April } \\
\text { May } \\
\text { June } \\
\text { July } \\
\text { August } \\
\text { September }\end{array}$ & $\begin{array}{rr} & 15 \\
. & 105 \\
. & 482 \\
& 870 \\
\cdots & 550 \\
. & 130 \\
& 53\end{array}$ & $\begin{array}{r}10 \\
15 \\
79 \\
350 \\
140 \\
53 \\
25\end{array}$ & $\begin{array}{l}38 \\
\times 20 \\
\times 17 \\
.12 \\
.12 \\
11.5 \\
35.4 \\
282 \\
632 \\
268 \\
79.3 \\
39.6\end{array}$ & $\begin{array}{r}2,340 \\
1,190 \\
1,040 \\
738 \\
666 \\
707 \\
2,110 \\
17,300 \\
37,600 \\
16,500 \\
4,880 \\
2,860\end{array}$ \\
\hline & 870 & & 121 & 87,400 \\
\hline
\end{tabular}

a Estimated. 
Monthly discharge at Grand Lake Outlet at Grand Lake, Colo., for 1904-1909 and 1910-1913-Continued

\begin{tabular}{|c|c|c|c|c|}
\hline \multirow{2}{*}{ Month } & \multicolumn{3}{|c|}{ Discharge in second-feet } & \multirow{2}{*}{$\begin{array}{c}\text { Run-off in } \\
\text { aere-feet }\end{array}$} \\
\hline & Maximum & Minimum & Mean & \\
\hline $\begin{array}{l}\text { October } \\
\text { November } \\
\text { December } \\
\text { January } \\
\text { February } \\
\text { March } \\
\text { April } \\
\text { May } \\
\text { June } \\
\text { July } \\
\text { August } \\
\text { September }\end{array}$ & $\begin{array}{r}\mathbf{9 5} \\
\mathbf{2 7} \\
\mathbf{1 ,} 150 \\
\mathbf{7 5 0} \\
\mathbf{3 9 0} \\
\mathbf{6 3}\end{array}$ & 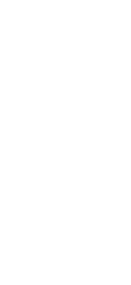 & $\begin{array}{l}56.3 \\
19.6 \\
=12 \\
=10 \\
=11 \\
11 \\
=13 \\
140 \\
830 \\
520 \\
183 \\
42.3\end{array}$ & $\begin{array}{r}3,460 \\
1,170 \\
738 \\
615 \\
633 \\
670 \\
774 \\
8,610 \\
49,400 \\
32,000 \\
11,800 \\
2,820\end{array}$ \\
\hline The year. & 1,150 & - & 155 & 112,000 \\
\hline $\begin{array}{l}\text { October } \\
\text { November } \\
\text { December } \\
\text { January } \\
\text { February } \\
\text { March } \\
\text { April } \\
\text { May } \\
\text { June } \\
\text { July } \\
\text { August } \\
\text { September }\end{array}$ & \begin{tabular}{|r|}
35 \\
21
\end{tabular} & 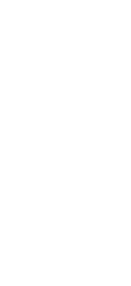 & $\begin{array}{c}28.7 \\
15.6 \\
a 10 \\
\circ 9 \\
08 \\
07 \\
32.3 \\
281 \\
398 \\
183 \\
56.6 \\
45\end{array}$ & $\begin{array}{r}1,760 \\
928 \\
615 \\
568 \\
544 \\
444 \\
430 \\
1,920 \\
17,300 \\
\quad 23,700 \\
11,300 \\
3 \quad 480 \\
2,690\end{array}$ \\
\hline The year. & 880 & -non & 90 . & 65,100 \\
\hline
\end{tabular}

a Estimated.

FRASER RIVER-NEAR WEST PORTAL, COIO.

Location.-In NE. $1 / 4$ sec. 4 , T. 2 S., R. 75 W., a quarter of a mile from Vasquez siding on Denver \& Salt Lake Railroad and 11/2. miles northwest of West Portal, Grand County. Nearest tributary, Buck Creek, enters 1 mile upstream. During parts of 1907,1908 , and 1909, a station was maintained 2 miles upstream at a point just below mouth of Jim Creek.

Drainage AREA.-28 square miles at regular station (measured on topographic map) and about 24 square miles at upper station.

Records available.-June 1, 1907, to November 14, 1909; October 1; 1910 , to September 30, 1927.

GAGE.-Friez water-stage recorder used since June 3, 1916, excèpt during winter, when staff gage at railroad bridge 1 mile upstream is used. Prior to that date, staff gage attached to bridge half a mile above railroad bridge was used.

ConTroL.-Fairly permanent.

Extremes of Discharge.- - Maximum discharge recorded; 820 second-feet on 9 p. m. June 13, 1918 (gage height, 2.9 feet); minimum discharge, 2 secondfeet March 30, 1912 (gage height, 0.60 foot).

Diversions.-Berthoud ditch diverts water to Clear Creek. (See p. 49 for amount diverted each year.)

Accuracr.-Gage heights from continuous records since 1916; rating curves. well defined. Records since 1916 excellent except during winter, for which they are fair; prior to 1916 records fair.

Cooperation.- Since 1925 station maintained in cooperation with State engineer, who furnished complete records. 


\section{UPPER COLORADO RIVER AND ITS UTILIZATION}

Monthly discharge of Fraser River near West Portal, Colo., for 1907-1909 and 1910-1927

\begin{tabular}{|c|c|c|c|c|}
\hline \multirow{2}{*}{ Month } & \multicolumn{3}{|c|}{ Discharge in second-feet } & \multirow{2}{*}{$\begin{array}{l}\text { Run-off in } \\
\text { acre-feet }\end{array}$} \\
\hline & Maximum & Minimum & Mean & \\
\hline $\begin{array}{l}\text { June } \\
\text { July } \\
\text { August... }\end{array}$ & $\begin{array}{r}250 \\
200 \\
49 \\
\end{array}$ & $\begin{array}{l}35 \\
75 \\
15\end{array}$ & $\begin{array}{l}160 \\
100 \\
30.0\end{array}$ & $\begin{array}{l}9,590 \\
8,600 \\
1,870\end{array}$ \\
\hline $\begin{array}{l}\text { May } \\
\text { June }\end{array}$ & $\begin{array}{r}95 \\
238 \\
108 \\
55 \\
25 \\
\end{array}$ & $\begin{array}{l}25 \\
76 \\
55 \\
33 \\
20\end{array}$ & $\begin{array}{r}53.5 \\
173 \\
72.9 \\
42.2 \\
23.1\end{array}$ & $\begin{array}{r}3,290 \\
10,300 \\
4,480 \\
2,600 \\
1,370 \\
\end{array}$ \\
\hline $\begin{array}{l}\text { October 1-14 } \\
\text { July } \\
\text { August }\end{array}$ & $\begin{array}{r}20 \\
420 \\
115 \\
72\end{array}$ & $\begin{array}{l}20 \\
72 \\
47 \\
47\end{array}$ & $\begin{array}{r}20.0 \\
175 \\
63.1 \\
57.1\end{array}$ & $\begin{array}{r}555 \\
10,800 \\
3,880 \\
3,400 \\
\end{array}$ \\
\hline $\begin{array}{l}\text { October. } \\
\text { November } 1-14\end{array}$ & $\begin{array}{l}47 \\
25 \\
\end{array}$ & $\begin{array}{l}23 \\
23 \\
\end{array}$ & $\begin{array}{l}29.2 \\
23.6\end{array}$ & $\begin{array}{r}1,800 \\
655 \\
\end{array}$ \\
\hline 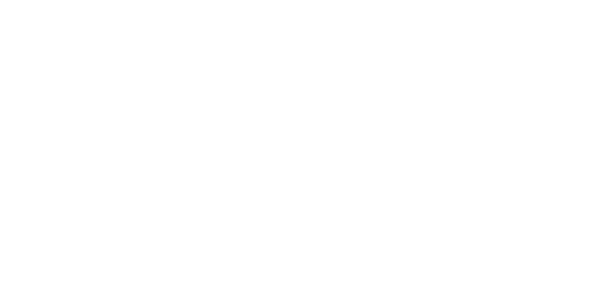 & $\begin{array}{r}34 \\
192 \\
234 \\
234 \\
60 \\
44\end{array}$ & $\begin{array}{r}14 \\
8 \\
97 \\
57 \\
38 \\
25\end{array}$ & $\begin{array}{c}12 \\
8 \\
8 \\
7 \\
6 \\
10 \\
28.4 \\
85.4 \\
173 \\
98.8 \\
46.4 \\
32.2\end{array}$ & $\begin{array}{r}738 \\
476 \\
492 \\
430 \\
333 \\
615 \\
1,690 \\
5,250 \\
10,300 \\
6,080 \\
2,850 \\
1,920 \\
\end{array}$ \\
\hline The year................. & 234 & - & 43. 2 & 31,200 \\
\hline $\begin{array}{l}\text { October } \\
\text { November } \\
\text { December } \\
\text { January } \\
\text { Tebruary } \\
\text { March } \\
\text { April } \\
\text { May } \\
\text { June } \\
\text { July } \\
\text { August } \\
\text { September }\end{array}$ & \begin{tabular}{|r|}
31 \\
\\
\\
\end{tabular} & $\begin{array}{c}19 \\
0 \\
93 \\
30 \\
20\end{array}$ & $\begin{array}{c}23.7 \\
15.0 \\
9.0 \\
8 \\
8 \\
7 \\
9 \\
80 \\
250 \\
166 \\
59.8 \\
28.7\end{array}$ & $\begin{array}{r}1,460 \\
893 \\
553 \\
492 \\
460 \\
430 \\
536 \\
4,920 \\
14,900 \\
10,200 \\
3,680 \\
1,710\end{array}$ \\
\hline The year............... & & $-\ldots \ldots$ & 55.5 & 40,200 \\
\hline $\begin{array}{l}\text { October } \\
\text { November } \\
\text { December } \\
\text { January } \\
\text { February } \\
\text { March } \\
\text { April } \\
\text { May } \\
\text { June } \\
\text { Auly } \\
\text { August }\end{array}$ & \begin{tabular}{|r|}
30 \\
\\
\end{tabular} & \begin{tabular}{|c|}
4 \\
\\
\end{tabular} & $\begin{array}{c}16.9 \\
12.0 \\
8 \\
7 \\
6 \\
6 \\
12 \\
81.0 \\
131 \\
65.4 \\
32.7 \\
87.3\end{array}$ & $\begin{array}{r}1,040 \\
714 \\
492 \\
430 \\
333 \\
369 \\
: 714 \\
4,980 \\
7,800 \\
4,020 \\
2,010 \\
2,220\end{array}$ \\
\hline & 208 & & 34. 7 & 25,100 \\
\hline
\end{tabular}


Monthly discharge of Fraser River near West Portal, Colo., for 1907-1909 and 1910-1927-Continued

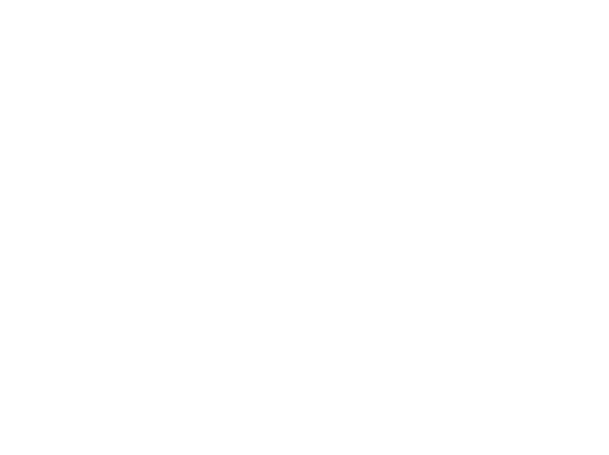

The year.

October--.-

1914-15

November

January.

February

March.

April.

May.

June.

August

September

The year

\section{$1915-16$}

October

November

December

January.

February

March

April.

May.

June-

July -

Beptember

The year

\section{6-17}

October

November

December

January.

Marchary

April

June.

July .

August.

Beptember

The year

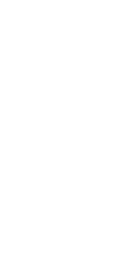

\section{7-18}

November

December

February

April

May-

July

eptember

The year.

\begin{tabular}{|c|c|c|c|}
\hline \multicolumn{3}{|c|}{ Discharge in second-feet } & \multirow{2}{*}{$\begin{array}{c}\text { Run-off in } \\
\text { acre-feet }\end{array}$} \\
\hline Maximum & Minimum & Mean & \\
\hline & ? & \multirow{4}{*}{$\begin{array}{c}31.0 \\
17.5 \\
9 \\
7.4 \\
7.6 \\
6.3 \\
10.1 \\
130 \\
327 \\
99.8 \\
55.2 \\
30.2\end{array}$} & \multirow{4}{*}{$\begin{array}{r}1,910 \\
1,040 \\
553 \\
465 \\
422 \\
387 \\
601 \\
7,990 \\
19,500 \\
6,140 \\
3,300 \\
1,800\end{array}$} \\
\hline $\begin{array}{l}57 \\
28\end{array}$ & $\begin{array}{l}16 \\
13\end{array}$ & & \\
\hline & & & \\
\hline $\begin{array}{r}14 \\
415 \\
507 \\
184 \\
82 \\
46\end{array}$ & $\begin{array}{r}7 \\
9 \\
199 \\
69 \\
40 \\
26\end{array}$ & & \\
\hline 507 & -............ & 61.0 & 44,200 \\
\hline $\begin{array}{l}26 \\
20\end{array}$ & $\begin{array}{r}20 \\
5\end{array}$ & \multirow{3}{*}{$\begin{array}{r}22.6 \\
11.1 \\
4.0 \\
4.0 \\
4.0 \\
4.9 \\
22.2 \\
72.2 \\
30.2 \\
153 \\
38.8 \\
24.3\end{array}$} & \multirow{3}{*}{$\begin{array}{r}1,390 \\
660 \\
246 \\
246 \\
222 \\
298 \\
1,320 \\
4,440 \\
18,100 \\
9,410 \\
2,390 \\
1,450\end{array}$} \\
\hline & & & \\
\hline $\begin{array}{r}6 \\
69 \\
141 \\
609 \\
275 \\
81 \\
36\end{array}$ & $\begin{array}{r}4 \\
6 \\
8 \\
84 \\
62 \\
25 \\
20\end{array}$ & & \\
\hline 609 & $-\cdots$ & 55.5 & 40,200 \\
\hline $\begin{array}{r}20 \\
20 \\
14 \\
12 \\
11 \\
10 \\
74 \\
260 \\
230 \\
109 \\
56 \\
30\end{array}$ & $\begin{array}{r}16 \\
13 \\
12 \\
9 \\
9 \\
7 \\
8 \\
74 \\
111 \\
43 \\
26 \\
19\end{array}$ & $\begin{array}{r}16.1 \\
15.5 \\
12.4 \\
10.8 \\
9.7 \\
7.6 \\
20.8 \\
130 \\
157 \\
65.2 \\
41.3 \\
22.8\end{array}$ & $\begin{array}{r}990 \\
\times \quad 929 \\
762 \\
664 \\
557 \\
467 \\
1,240 \\
7,990 \\
9,840 \\
4,010 \\
2,540 \\
1,360 \\
\end{array}$ \\
\hline 260 & 7 & 42.5 & 30,800 \\
\hline $\begin{array}{r}22 \\
21 \\
13 \\
9 \\
9 \\
7 \\
21 \\
43 \\
320 \\
254 \\
73 \\
29\end{array}$ & $\begin{array}{r}16 \\
17 \\
6 \\
6 \\
4 \\
5 \\
5 \\
11 \\
42 \\
80 \\
29 \\
15\end{array}$ & $\begin{array}{c}18.7 \\
15 \\
10 \\
7.4 \\
6.1 \\
5.8 \\
9.6 \\
31.2 \\
211 \\
139 \\
46.6 \\
19.2\end{array}$ & $\begin{array}{r}1,150 \\
898 \\
615 \\
455 \\
339 \\
357 \\
571 \\
1,920 \\
12,600 \\
8,550 \\
2,870 \\
1,140\end{array}$ \\
\hline 320 & - & 43.5 & 31,500 \\
\hline $\begin{array}{r}10 \\
6 \\
23 \\
39 \\
199 \\
622 \\
161 \\
50 \\
28\end{array}$ & $\begin{array}{r}6 \\
6 \\
6 \\
26 \\
41 \\
151 \\
48 \\
24 \\
15\end{array}$ & $\begin{array}{c}13 \\
11 \\
9 \\
6.4 \\
6.0 \\
13.6 \\
30.3 \\
122 \\
354 \\
96.2 \\
35.3 \\
23.1\end{array}$ & $\begin{array}{r}799 \\
655 \\
553 \\
394 \\
338 \\
836 \\
1,800 \\
7,500 \\
21,100 \\
5,920 \\
2,170 \\
1,970\end{array}$ \\
\hline 622 & |-nonen & 60.1 & 43,400 \\
\hline
\end{tabular}


Monthly discharge of Fraser River near West Portal, Colo., for 1907-1909 and 1910-1987-Continued

\begin{tabular}{|c|c|c|c|c|}
\hline \multirow{2}{*}{ Month } & \multicolumn{3}{|c|}{ Discharge in second-feet } & \multirow{2}{*}{$\begin{array}{l}\text { Run-off in } \\
\text { acre-feet }\end{array}$} \\
\hline & Maximum & Minimum & Mean & \\
\hline $\begin{array}{l}\text { October. } \\
\text { November } \\
\text { December. } \\
\text { January } \\
\text { February } \\
\text { March } \\
\text { April } \\
\text { May } \\
\text { June } \\
\text { July } \\
\text { August } \\
\text { Beptember. }\end{array}$ & $\begin{array}{c}41 \\
38 \\
12 \\
8.3 \\
7.8 \\
8.0 \\
62 \\
156 \\
118 \\
81 \\
60 \\
36\end{array}$ & $\begin{array}{l}21 \\
12 \\
8.3 \\
7.0 \\
6.2 \\
6.0 \\
8.0 \\
33 \\
70 \\
40 \\
21 \\
17\end{array}$ & $\begin{array}{c}26.3 \\
19.9 \\
9.71 \\
7.80 \\
6.77 \\
6.18 \\
23.1 \\
85.5 \\
95.9 \\
53.5 \\
34.0 \\
24.2\end{array}$ & $\begin{array}{r}1,620 \\
1,180 \\
597 \\
480 \\
376 \\
380 \\
1,370 \\
5,260 \\
5,710 \\
3,290 \\
2,090 \\
1,440\end{array}$ \\
\hline The year. & 156 & 6 & 32.8 & 23,800 \\
\hline $\begin{array}{l}\text { October } \\
\text { November } \\
\text { December } \\
\text { January } \\
\text { February } \\
\text { Mareh } \\
\text { April } \\
\text { May } \\
\text { June } \\
\text { July } \\
\text { August } \\
\text { Beptember }\end{array}$ & $\begin{array}{r}21 \\
18 \\
10 \\
8 \\
12 \\
8 \\
11 \\
226 \\
288 \\
168 \\
56 \\
34\end{array}$ & $\begin{array}{r}12 \\
9 \\
8 \\
7 \\
7 \\
6 \\
6 \\
12 \\
129 \\
54 \\
32 \\
21\end{array}$ & $\begin{array}{r}17.0 \\
11.8 \\
8.7 \\
8.0 \\
9.2 \\
6.3 \\
7.4 \\
72.5 \\
198 \\
92.0 \\
45.0 \\
25.6\end{array}$ & $\begin{array}{r}1,050 \\
702 \\
535 \\
492 \\
559 \\
387 \\
440 \\
4,460 \\
11,800 \\
5,660 \\
2,770 \\
1,520\end{array}$ \\
\hline The year. & 288 & 6 & 41.8 & 30,300 \\
\hline $\begin{array}{l}\text { October. } \\
\text { November } \\
\text { December. } \\
\text { January } \\
\text { February } \\
\text { Mareh } \\
\text { April } \\
\text { May } \\
\text { June } \\
\text { July } \\
\text { August } \\
\text { September }\end{array}$ & \begin{tabular}{|c|}
29 \\
31 \\
12 \\
18 \\
307 \\
473 \\
162 \\
52 \\
38
\end{tabular} & \begin{tabular}{|r|}
13 \\
12 \\
7 \\
13 \\
15 \\
170 \\
45 \\
25 \\
18
\end{tabular} & $\begin{array}{c}15.7 \\
18.5 \\
8.6 \\
7 \\
6 \\
10.7 \\
14.5 \\
118 \\
304 \\
88.7 \\
36.4 \\
24.1\end{array}$ & $\begin{array}{r}9 f 5 \\
1,100 \\
529 \\
430 \\
333 \\
658 \\
863 \\
7,260 \\
18,100 \\
5,450 \\
2,240 \\
1,430\end{array}$ \\
\hline • & 473 & $-\ldots-n-1$ & 54.4 & 39,400 \\
\hline $\begin{array}{l}\text { October } \\
\text { November } \\
\text { December } \\
\text { January } \\
\text { February } \\
\text { March } \\
\text { April } \\
\text { May } \\
\text { Jume } \\
\text { July } \\
\text { August } \\
\text { September }\end{array}$ & $\begin{array}{r}21 \\
23 \\
15 \\
7 \\
8 \\
8 \\
8 \\
230 \\
267 \\
90 \\
33 \\
26\end{array}$ & $\begin{array}{r}14 \\
8 \\
4 \\
5 \\
6 \\
3 \\
3 \\
14 \\
95 \\
28 \\
22 \\
13\end{array}$ & $\begin{array}{r}16.2 \\
15.0 \\
9.2 \\
6.2 \\
6.5 \\
5.3 \\
6.5 \\
89.5 \\
170 \\
48.3 \\
27.5 \\
17.2\end{array}$ & $\begin{array}{r}996 \\
893 \\
566 \\
381 \\
361 \\
326 \\
387 \\
5,500 \\
10,100 \\
2,970 \\
1,690 \\
1,020\end{array}$ \\
\hline The year............ & 267 & $\mathbf{3}$ & 34.8 & 25,200 \\
\hline $\begin{array}{l}\text { October. } \\
\text { November } \\
\text { December. } \\
\text { January } \\
\text { February } \\
\text { March } \\
\text { April } \\
\text { May } \\
\text { June. } \\
\text { July } \\
\text { August. } \\
\text { September. }\end{array}$ & \begin{tabular}{|c|}
17 \\
17 \\
16 \\
200 \\
423 \\
154 \\
56 \\
31 \\
\end{tabular} & \begin{tabular}{|r|}
12 \\
17 \\
161 \\
43 \\
28 \\
18 \\
\end{tabular} & $\begin{array}{c}13.3 \\
14.5 \\
9 \\
8 \\
8 \\
7 \\
10.3 \\
76.3 \\
240 \\
92.4 \\
40.6 \\
221\end{array}$ & $\begin{array}{r}818 \\
863 \\
553 \\
492 \\
444 \\
430 \\
613 \\
4,600 \\
14,300 \\
5,680 \\
2,500 \\
1,320\end{array}$ \\
\hline 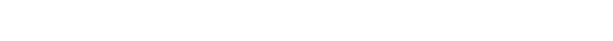 & 423 & $\mid-1-2-10-2$ & 45.1 & 32,700 \\
\hline
\end{tabular}


Monthly discharge of Fraser River near West Portal, Colo., for 1907-1909 and 1910-1927-Continued

\begin{tabular}{|c|c|c|c|c|}
\hline \multirow{2}{*}{ Month } & \multicolumn{3}{|c|}{ Discharge in second-feet } & \multirow{2}{*}{$\begin{array}{l}\text { Run-off in } \\
\text { acre-feet }\end{array}$} \\
\hline & Maximum & Minimum & Mean & \\
\hline $\begin{array}{l}\text { October } \\
\text { November } \\
\text { December } \\
\text { January } \\
\text { February } \\
\text { March } \\
\text { April } \\
\text { May } \\
\text { June } \\
\text { July } \\
\text { August } \\
\text { September. }\end{array}$ & $\begin{array}{c}31 \\
13 \\
7.1 \\
13 \\
166 \\
388 \\
110 \\
33 \\
17\end{array}$ & \begin{tabular}{|r|}
14 \\
10 \\
6.8 \\
6.5 \\
6.2 \\
17 \\
117 \\
34 \\
14 \\
12
\end{tabular} & $\begin{array}{l}20.1 \\
14.0 \\
13.3 \\
11.7 \\
8.22 \\
6.56 \\
7.90 \\
98.1 \\
223 \\
61.8 \\
22.8 \\
14.6\end{array}$ & $\begin{array}{r}1,240 \\
833 \\
818 \\
719 \\
473 \\
403 \\
470 \\
6,030 \\
13,300 \\
3,800 \\
1,400 \\
869\end{array}$ \\
\hline The year & 388 & 6.2 & 41. 8 & 30,400 \\
\hline $\begin{array}{l}\text { October } \\
\text { November } \\
\text { December } \\
\text { January } \\
\text { February } \\
\text { March } \\
\text { April } \\
\text { May } \\
\text { June } \\
\text { July: } \\
\text { August } \\
\text { September }\end{array}$ & $\begin{array}{r}21 \\
16 \\
12 \\
10 \\
10 \\
13 \\
52 \\
180 \\
196 \\
98 \\
53 \\
96\end{array}$ & $\begin{array}{c}11 \\
10 \\
10 \\
9\end{array}$ & $\begin{array}{c}15.6 \\
13.5 \\
10.6 \\
9.61 \\
8.11 \\
8.0 \\
31.5 \\
85.1 \\
147 \\
61.3 \\
34.3 \\
46.0\end{array}$ & $\begin{array}{r}959 \\
803 \\
652 \\
591 \\
450 \\
492 \\
1,870 \\
5,230 \\
8,750 \\
3,770 \\
2,110 \\
2,740\end{array}$ \\
\hline The year & 196 & -................ & 39.3 & 28,400 \\
\hline $\begin{array}{l}\text { October } \\
\text { November } \\
\text { December } \\
\text { January } \\
\text { February } \\
\text { March } \\
\text { April } \\
\text { May } \\
\text { June } \\
\text { July } \\
\text { August } \\
\text { September }\end{array}$ & $\begin{array}{r}31 \\
25 \\
15 \\
8 \\
11 \\
10 \\
52 \\
220 \\
349 \\
227 \\
65 \\
26\end{array}$ & $\begin{array}{r}24 \\
13 \\
7 \\
5 \\
7 \\
8 \\
9 \\
49 \\
186 \\
59 \\
26 \\
19\end{array}$ & $\begin{array}{l}25.9 \\
18.6 \\
11.0 \\
6.35 \\
7.79 \\
9.06 \\
20.2 \\
104 \\
249 \\
130 \\
45.1 \\
21.3\end{array}$ & $\begin{array}{r}1,590 \\
1,110 \\
676 \\
390 \\
433 \\
557 \\
1,200 \\
6,400 \\
14,800 \\
7,900 \\
2,770 \\
1,270\end{array}$ \\
\hline 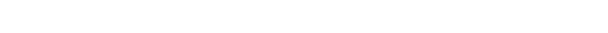 & $\mathbf{3 4 9}$ & $\mathbf{5}$ & 54.2 & 39,200 \\
\hline $\begin{array}{l}\text { October. } \\
\text { November } \\
\text { December. } \\
\text { January } \\
\text { February } \\
\text { March } \\
\text { April } \\
\text { May } \\
\text { June } \\
\text { July } \\
\text { August } \\
\text { Beptember }\end{array}$ & $\begin{array}{r}23 \\
22 \\
11 \\
8 \\
8 \\
10 \\
43 \\
176 \\
184 \\
128 \\
71 \\
53\end{array}$ & $\begin{array}{r}\mathbf{1 3} \\
10 \\
\mathbf{8} \\
7 \\
7 \\
7 \\
9 \\
\mathbf{5 3} \\
138 \\
\mathbf{5 1} \\
\mathbf{2 9} \\
\mathbf{2 8}\end{array}$ & $\begin{array}{c}18.7 \\
12.7 \\
9.39 \\
7.13 \\
7.07 \\
8.03 \\
17.1 \\
118 \\
159 \\
79.6 \\
46.2 \\
37.4\end{array}$ & $\begin{array}{r}1,150 \\
756 \\
577 \\
438 \\
393 \\
494 \\
1,020 \\
7,290 \\
9,460 \\
4,890 \\
2,840 \\
2,230\end{array}$ \\
\hline The year & 184 & 7 & 43. 5 & 31,500 \\
\hline
\end{tabular}

NoTE.-Monthly mean discharge during winter based on current-meter measurements, daily gage heights, and temperature records.

FRASER RIVER NEAR GRANBY, COLO.

Location.-In sec. 5, T. 1 N., R. 76 W., at highway bridge 1 mile southeast of Granby. Nearest important tributary, Tenmile Creek, enters 2 miles downstream.

Drainage area.-253 square miles (measured on base map of Colorado). 
Records available.-August 1, 1904, to September 30, 1909.

GAGE.-Vertical staff at bridge.

Control.- - Shifting during low water, due to presence of temporary dam 50 feet below station.

EXTREMES OF DISCHARGE.-Maximum stage recorded, 6.85 feet on June 14 and

15, 1906 (discharge, 1,860 second-feet); minimum discharge occurred during winter.

Diversions. - Water diverted from Fraser River for irrigation of 9,300 acres.

Accuracy.-Gage read once daily. Rating curves fairly well defined. Records fair.

Monthly discharge of Fraser River at Granby, Colo., for 1904-1909

\begin{tabular}{|c|c|c|c|c|}
\hline \multirow{2}{*}{ Month } & \multicolumn{3}{|c|}{ Discharge in second-feet } & \multirow{2}{*}{$\begin{array}{l}\text { Run-off in } \\
\text { acre-feet }\end{array}$} \\
\hline & Maximum & Minimum & Mean & \\
\hline $\begin{array}{l}\text { August } \\
\text { September }\end{array}$ & $\begin{array}{l}470 \\
550\end{array}$ & $\begin{array}{r}128 \\
91\end{array}$ & $\begin{array}{l}181 \\
158\end{array}$ & $\begin{array}{r}11,100 \\
9,400\end{array}$ \\
\hline $\begin{array}{l}\text { October } \\
\text { November } \\
\text { December } \\
\text { January } \\
\text { February } \\
\text { March } \\
\text { April } \\
\text { May } \\
\text { June } \\
\text { July } \\
\text { August } \\
\text { September }\end{array}$ & $\begin{array}{r}102 \\
1,590 \\
465 \\
179 \\
95\end{array}$ & $\begin{array}{r}52 \\
149 \\
74 \\
46\end{array}$ & $\begin{array}{l}84.9 \\
52 \\
45 \\
45 \\
40 \\
45 \\
90 \\
408 \\
1,030 \\
250 \\
110 \\
70.1\end{array}$ & $\begin{array}{r}5,200 \\
3,090 \\
2,770 \\
2,770 \\
2,220 \\
2,770 \\
5,360 \\
25,100 \\
61,300 \\
15,400 \\
6,760 \\
4,170\end{array}$ \\
\hline 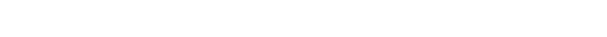 & 1,590 & $-\ldots \ldots$ & 189 & 137,000 \\
\hline $\begin{array}{l}\text { October. } \\
\text { November } \\
\text { December } \\
\text { January } \\
\text { February } \\
\text { Mareh } \\
\text { April } \\
\text { May } \\
\text { June } \\
\text { July } \\
\text { August } \\
\text { September }\end{array}$ & $\begin{array}{r}74 \\
1,000 \\
1,860 \\
630 \\
230 \\
210\end{array}$ & $\begin{array}{r}30 \\
140 \\
630 \\
172 \\
125 \\
80\end{array}$ & $\begin{array}{r}47 \\
45 \\
42 \\
40 \\
35 \\
38 \\
235 \\
568 \\
1,040 \\
357 \\
152 \\
112\end{array}$ & $\begin{array}{r}2,890 \\
2,680 \\
2,580 \\
2,460 \\
1,940 \\
2,340 \\
14,000 \\
34,900 \\
61,900 \\
22,000 \\
9,350 \\
6,660\end{array}$ \\
\hline The year ...................... & 1,860 & (n-n & 225 & 164,000 \\
\hline $\begin{array}{l}\text { October } \\
\text { November } \\
\text { December } \\
\text { January } \\
\text { February } \\
\text { March } \\
\text { April } \\
\text { May } \\
\text { June } \\
\text { July } \\
\text { August } \\
\text { September }\end{array}$ & $\begin{array}{r}155 \\
100 \\
120 \\
340 \\
1,210 \\
1,610 \\
1,280 \\
340 \\
120\end{array}$ & $\begin{array}{r}100 \\
50 \\
100 \\
150 \\
650 \\
240 \\
120 \\
80\end{array}$ & $\begin{array}{c}110 \\
70.9 \\
45 \\
42 \\
40 \\
73 \\
190 \\
494 \\
1,180 \\
680 \\
175 \\
102\end{array}$ & $\begin{array}{r}6,760 \\
4,220 \\
2,770 \\
2,580 \\
2,220 \\
4,490 \\
11,300 \\
30,400 \\
70,200 \\
41,800 \\
10,800 \\
6,070\end{array}$ \\
\hline The year. & 1,610 & $-\cdots$ & 268 & 194,000 \\
\hline
\end{tabular}


Monthly discharge of Fraser River at Granby, Colo., for 1904-1909-Continued

\begin{tabular}{|c|c|c|c|c|}
\hline & \multicolumn{3}{|c|}{ Discharge in second-feet } & \multirow{2}{*}{$\begin{array}{l}\text { Run-off in } \\
\text { acre-feet }\end{array}$} \\
\hline & Maximum & Minimum & Mean & \\
\hline $\begin{array}{l}\text { October... } \\
\text { November } \\
\text { December } \\
\text { January } \\
\text { February } \\
\text { March } \\
\text { April } \\
\text { May } \\
\text { June } \\
\text { July } \\
\text { August } \\
\text { September }\end{array}$ & $\begin{array}{r}80 \\
80 \\
105 \\
332 \\
950 \\
391 \\
190 \\
86\end{array}$ & $\begin{array}{r}80 \\
66 \\
83 \\
332 \\
140 \\
70 \\
50\end{array}$ & $\begin{array}{c}80.0 \\
49.7 \\
45.0 \\
45.0 \\
37.6 \\
45.1 \\
90.6 \\
194 \\
580 \\
232 \\
123 \\
64.6\end{array}$ & $\begin{array}{r}4,920 \\
2,960 \\
2,770 \\
2,770 \\
2,160 \\
2,770 \\
5,390 \\
11,900 \\
34,500 \\
14,300 \\
7,560 \\
3,840\end{array}$ \\
\hline The year............ & 950 & (n) & 132 & 8,800 \\
\hline $\begin{array}{l}\text { October } \\
\text { November } \\
\text { December } \\
\text { January } \\
\text { February. } \\
\text { March } \\
\text { April } \\
\text { May } \\
\text { June } \\
\text { July } \\
\text { August } \\
\text { September }\end{array}$ & $\begin{array}{r}70 \\
1,840 \\
1,510 \\
380 \\
226 \\
\end{array}$ & $\begin{array}{r}83 \\
581 \\
226 \\
185 \\
120\end{array}$ & $\begin{array}{c}57.4 \\
49.6 \\
52.3 \\
45 \\
45 \\
45 \\
83.6 \\
473 \\
1,390 \\
653 \\
230 \\
167\end{array}$ & $\begin{array}{r}3,530 \\
2,950 \\
3,210 \\
2,770 \\
2,500 \\
2,770 \\
4,970 \\
29,100 \\
82,700 \\
40,200 \\
14,100 \\
9,940\end{array}$ \\
\hline The year..- & 1,840 & & 275 & 199,000 \\
\hline
\end{tabular}

NoTr.-Winter means discharge from 1905 to 1907 estimated; for 1908 and 1909 mean discharge based ou current-meter measurements and temperature records.

\section{WILIIAMS RIVER NRAR SCHOIL, COLO.}

Location.-In sec. 3, T. 2 S., R. 78 W., at Horseshoe ranger station, 5 miles southeast of Scholl, Grand County. Nearest tributary, Keyser Creek, enters three-qual ters of a mile upstream.

Drainage area.-143 square miles (revised; measured on Forest Servioe map). Records aVailable.-October 1, 1910, to May 31, 1917.

GAGE.-Vertical staff.

ControL.-Slightly shifting.

Extremes of Discharae.-Maximum stage recorded during period, 4.4 feet at 6 a. m. June 2, 1914 (discharge, 1,680 second-feet); minimum discharge recorded, 19 second-feet for short periods during 1915 (gage height, 0.91 second-foot).

Drvensions.-Water diverted for irrigation of small area above station.

AccuracY.-Gage read twice daily. Rating curves well defined. Records fair owing to uncertain gage heights.

Cooperation.-Station maintained in ccoperation with United States Forest Service. 
Monthly discharge of Williams River near Scholl, Colo., for 1910-1917

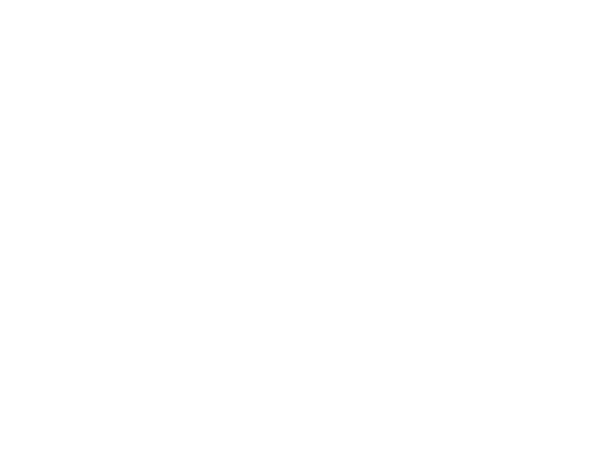

The year

1911-12

October...

November

December

January

February

March

April

June..

July -

August.

September

The year

October-.

1912-13

December

January.

February

March

April

May -

July .

August.

September.

The year.

October.

November

December

January.

February

Mareh

April

Maye

July.

August

September.

The year

October
November
December.
January
February
March
April
May
June
July
August.

September.

The year.

$1913-14$

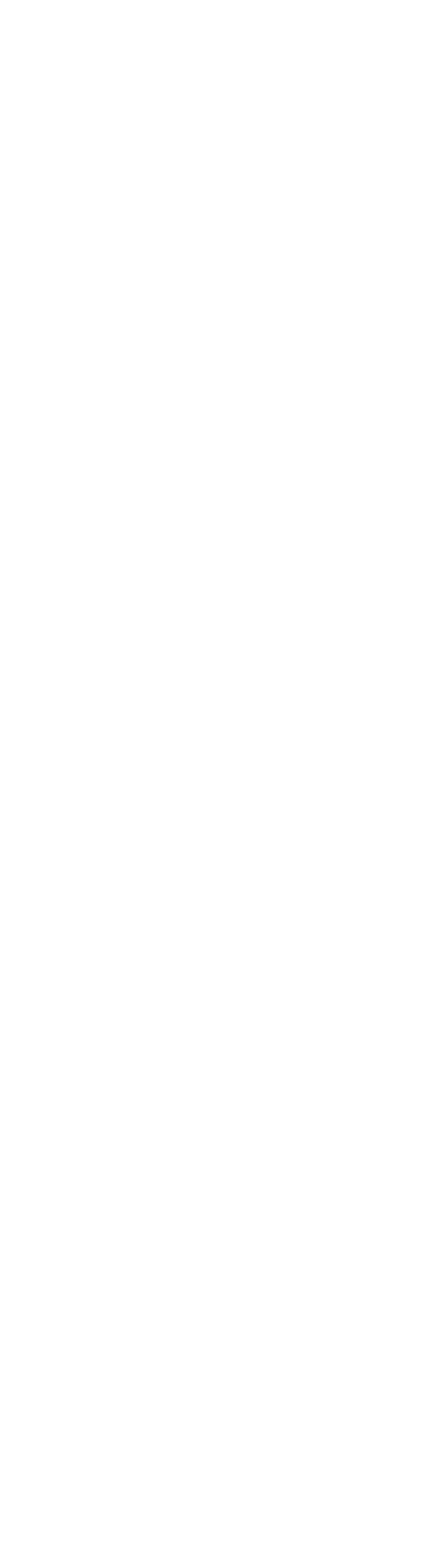




\begin{tabular}{|c|c|c|c|c|}
\hline \multirow{2}{*}{ Month } & \multicolumn{3}{|c|}{ Discharge in second-feet } & \multirow{2}{*}{$\begin{array}{c}\text { Run-ofi in } \\
\text { acre-foet }\end{array}$} \\
\hline & Maximum & Minimum & Mean & \\
\hline $\begin{array}{l}\text { October } \\
\text { November } \\
\text { December } \\
\text { January } \\
\text { February } \\
\text { March } \\
\text { April } \\
\text { May } \\
\text { June } \\
\text { July } \\
\text { August } \\
\text { September }\end{array}$ & $\begin{array}{r}85 \\
136 \\
412 \\
804 \\
469 \\
266 \\
122\end{array}$ & \begin{tabular}{r|r|}
54 \\
39 \\
136 \\
440 \\
266 \\
120 \\
72
\end{tabular} & $\begin{array}{l}69.9 \\
60 \\
35 \\
30 \\
35 \\
46.6 \\
73.8 \\
245 \\
597 \\
336 \\
185 \\
91.8\end{array}$ & $\begin{array}{r}4,300 \\
3,570 \\
2,150 \\
1,840 \\
2,010 \\
2,870 \\
4,390 \\
15,100 \\
35,500 \\
20,700 \\
11,400 \\
5,460\end{array}$ \\
\hline The year. & 804 & 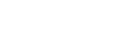 & 151 & 109,000 \\
\hline $\begin{array}{l}\text { October } \\
\text { November } \\
\text { December } \\
\text { January } \\
\text { February } \\
\text { March } \\
\text { April } \\
\text { May }\end{array}$ & $\begin{array}{r}100 \\
82 \\
61 \\
59 \\
45 \\
39 \\
224 \\
558\end{array}$ & $\begin{array}{l}71 \\
56 \\
44 \\
45 \\
39 \\
30 \\
30 \\
70\end{array}$ & $\begin{array}{r}81.7 \\
64.5 \\
55.8 \\
52.8 \\
42.0 \\
34.8 \\
77.8 \\
263\end{array}$ & $\begin{array}{r}5,020 \\
3,840 \\
3,430 \\
3,250 \\
2,330 \\
2,140 \\
4,630 \\
16,200\end{array}$ \\
\hline The period. & $\ldots$ & & & 40,800 \\
\hline
\end{tabular}

Nore.-Monthly mean discharge from July, 1912, to April, 1913, and November, 1915, to February, 1916, based on flow of Williams River near Parshall.

\section{WILIIAMS RIVER NEAR PARSHALL, COLO.}

Location.-About sec. 36, T. 1 N., R. 79 W., at Field ranch, 4 miles south of Parshall, Grand County. Nearest tributary, Battle Creek, enters from west 2 miles below station.

Drainage area.-196 square miles (revised; measured on Forest Service map). Records available.-July 25, 1904, to September 30, 1924.

GaGe.-Bristol float-type water-stage recorder used since October 18, 1919, except during winter, when original staff gage was used.

Controu.-Slightly shifting at long intervals.

Extremes of Discharae.-Maximum stage recorded, 6.0 feet at 9.45 a. $m$ June 14, 1918 (discharge, 2,520 second-feet); minimum stage, 2.1 feet November 7, 1919 (discharge, 15 second-feet).

Diversions.- Water diverted from Williams River for irrigation of 5,000 acres, chiefly above station.

Accuracy.-Gage read twice daily prior to 1918; continuous record since that time. Rating curves well defined. Records good or excellent, except dur: ing winter, for which they are fair.

Cooperation.--Subsequent to 1913, station maintained in cooperation with State engineer. 
Monthly discharge of Williams River near Parshall, Colo., 1904-1924

\begin{tabular}{|c|c|c|c|c|}
\hline \multirow{2}{*}{ Month } & \multicolumn{3}{|c|}{ Discharge in second-feet } & \multirow{2}{*}{$\begin{array}{l}\text { Run-off in } \\
\text { acre-feet }\end{array}$} \\
\hline & Maximum & Minimum & Mean & \\
\hline $\begin{array}{l}\text { July } 25-31 \\
\text { August } \\
\text { September }\end{array}$ & $\begin{array}{l}266 \\
172 \\
150\end{array}$ & $\begin{array}{r}183 \\
114 \\
93\end{array}$ & $\begin{array}{l}220 \\
129 \\
109\end{array}$ & $\begin{array}{l}3,060 \\
7,930 \\
6,490\end{array}$ \\
\hline The period & & $\ldots$ & & $\ldots . . .$. \\
\hline 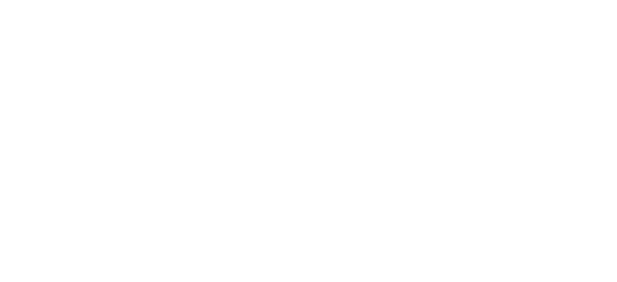 & $\begin{array}{r}98 \\
192 \\
456 \\
891 \\
379 \\
125 \\
76\end{array}$ & \begin{tabular}{|r|}
69 \\
28 \\
122 \\
374 \\
125 \\
56 \\
42
\end{tabular} & $\begin{array}{c}84 \\
65 \\
60 \\
50 \\
45 \\
40 \\
74.1 \\
253 \\
628 \\
201 \\
87.6 \\
56.5\end{array}$ & $\begin{array}{r}5,160 \\
3,870 \\
3,690 \\
3,070 \\
2,500 \\
2,460 \\
4,410 \\
15,600 \\
37,400 \\
12,400 \\
5,390 \\
3,360\end{array}$ \\
\hline The year. & 891 & -........... & 137 & 99,300 \\
\hline 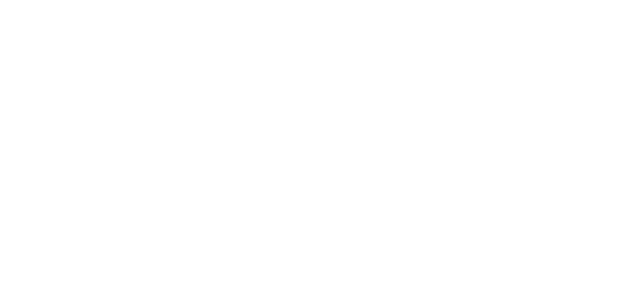 & $\begin{array}{r}64 \\
1,150 \\
594 \\
566 \\
200 \\
168\end{array}$ & $\begin{array}{r}25 \\
115 \\
432 \\
184 \\
92 \\
60\end{array}$ & $\begin{array}{l}46.6 \\
55 \\
50 \\
45 \\
40 \\
45 \\
115 \\
374 \\
661 \\
355 \\
126 \\
107\end{array}$ & $\begin{array}{r}2,860 \\
3,270 \\
3,070 \\
2,770 \\
2,220 \\
2,770 \\
6,840 \\
23,000 \\
39,300 \\
21,800 \\
7,750 \\
6,370\end{array}$ \\
\hline The year.......................... & 1,150 & $\ldots+\cdots+\cdots$ & 160 & 122,000 \\
\hline 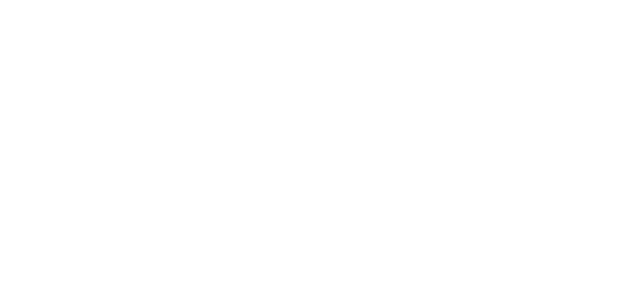 & $\begin{array}{r}120 \\
100 \\
68 \\
57 \\
49 \\
250 \\
216 \\
530 \\
1,100 \\
1,190 \\
232 \\
100\end{array}$ & $\begin{array}{r}58 \\
37 \\
38 \\
40 \\
43 \\
69 \\
105 \\
312 \\
255 \\
105 \\
64\end{array}$ & $\begin{array}{l}95.5 \\
65.6 \\
46 \\
46.7 \\
43.6 \\
76.3 \\
120 \\
249 \\
786 \\
580 \\
154 \\
74.0\end{array}$ & $\begin{array}{r}5,870 \\
3,900 \\
2,830 \\
2,870 \\
2,420 \\
4,690 \\
7,140 \\
15,890 \\
46,800 \\
35,700 \\
9,470 \\
4,460\end{array}$ \\
\hline The year. & 1,190 & $|-\ldots \ldots+\ldots|$ & 195 & 141,000 \\
\hline $\begin{array}{l}\text { October. } \\
\text { Nonember. } \\
\text { December. } \\
\text { January } \\
\text { February } \\
\text { Mareh } \\
\text { April } \\
\text { May } \\
\text { June }\end{array}$ & $\begin{array}{r}103 \\
64 \\
64 \\
50 \\
38 \\
57 \\
154 \\
293 \\
749 \\
360 \\
126 \\
72\end{array}$ & $\begin{array}{r}66 \\
30 \\
36 \\
38 \\
34 \\
30 \\
34 \\
102 \\
293 \\
102 \\
82 \\
48\end{array}$ & $\begin{array}{c}77.8 \\
48.7 \\
47.8 \\
44.0 \\
37.3 \\
41.5 \\
98.5 \\
190 \\
511 \\
207 \\
101 \\
56.4\end{array}$ & $\begin{array}{r}4,780 \\
2,900 \\
2,940 \\
2,710 \\
2,150 \\
2,550 \\
5,860 \\
11,700 \\
30,400 \\
12,700 \\
6,210 \\
3,360\end{array}$ \\
\hline 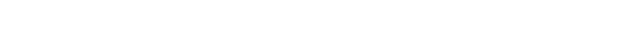 & 749 & - & 122 & 88,300 \\
\hline
\end{tabular}


Monthly discharge of Williams River near Parshall, Colo., 1904-1924-Continwed

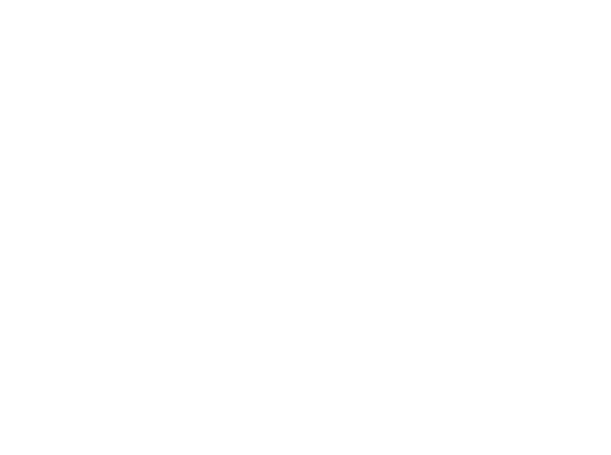

\begin{tabular}{|c|c|c|c|}
\hline \multicolumn{3}{|c|}{ Discharge in second-feet } & \multirow{2}{*}{$\underset{\text { acr } \theta \text {-feet }}{\text { Run-off in }}$} \\
\hline Maximum & Minimnm & Mean & \\
\hline $\begin{array}{l}82 \\
71\end{array}$ & $\begin{array}{l}44 \\
48\end{array}$ & \multirow{2}{*}{$\begin{array}{c}63.4 \\
57.4 \\
57.5 \\
39.3 \\
35.3 \\
45.4 \\
64.0 \\
230 \\
962 \\
517 \\
169 \\
153\end{array}$} & \multirow{2}{*}{$\begin{array}{r}3,900 \\
3,420 \\
3,540 \\
2,420 \\
1,960 \\
2,790 \\
3,810 \\
14,100 \\
57,200 \\
31,800 \\
10,100 \\
8,100\end{array}$} \\
\hline $\begin{array}{r}51 \\
44 \\
55 \\
95 \\
395 \\
1,410 \\
1,110 \\
264 \\
218\end{array}$ & $\begin{array}{r}32 \\
32 \\
36 \\
47 \\
66 \\
306 \\
172 \\
130 \\
113\end{array}$ & & \\
\hline 1,410 & 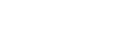 & 199 & 144,000 \\
\hline $\begin{array}{r}113 \\
95 \\
75 \\
66 \\
52 \\
166 \\
277 \\
720 \\
845 \\
210 \\
120 \\
103\end{array}$ & $\begin{array}{r}83 \\
58 \\
58 \\
50 \\
47 \\
50 \\
72 \\
180 \\
210 \\
58 \\
50 \\
53\end{array}$ & $\begin{array}{r}98.9 \\
.74 .7 \\
60.7 \\
59.5 \\
49.6 \\
87.8 \\
119 \\
303 \\
477 \\
115 \\
70.1 \\
79.5\end{array}$ & $\begin{array}{r}6,080 \\
4,440 \\
3,760 \\
3,690 \\
3,760 \\
5,400 \\
7,060 \\
18,600 \\
22,400 \\
7,070 \\
4,340 \\
4,790\end{array}$ \\
\hline 845 & $\ldots$ & 133 & 96,300 \\
\hline $\begin{array}{r}89 \\
62 \\
62 \\
55 \\
56 \\
85 \\
153 \\
465 \\
665 \\
472 \\
162 \\
99 .\end{array}$ & $\begin{array}{r}54 \\
50 \\
44 \\
41 \\
45 \\
50 \\
51 \\
97 \\
272 \\
125 \\
80 \\
66\end{array}$ & $\begin{array}{c}69.9 \\
58.2 \\
53.4 \\
46.1 \\
49.9 \\
59.2 \\
81.3 \\
286.3 \\
522 \\
265 \\
98.7 \\
75.1\end{array}$ & $\begin{array}{r}5,300 \\
3,400 \\
3,20 \\
3,280 \\
3,770 \\
3,640 \\
4,840 \\
17,600 \\
31,100 \\
16,200 \\
6,070 \\
4,470\end{array}$ \\
\hline 665 & $\cdots$ & 140 & 101,000 \\
\hline $\begin{array}{r}128 \\
80\end{array}$ & $\begin{array}{l}68 \\
52\end{array}$ & \multirow{2}{*}{$\begin{array}{l}84.0 \\
66.5 \\
57 \\
56.6 \\
53.9 \\
53.6 \\
66.4 \\
292 \\
966 \\
661 \\
227 \\
100\end{array}$} & \multirow{2}{*}{$\begin{array}{r}5,100 \\
3,900 \\
3,500 \\
3,480 \\
3,100 \\
3,300 \\
3,960 \\
18,000 \\
57,500 \\
40,600 \\
14,000 \\
6,400\end{array}$} \\
\hline $\begin{array}{r}64 \\
58 \\
62 \\
95 \\
805 \\
1,270 \\
1,120 \\
587 \\
116\end{array}$ & $\begin{array}{r}52 \\
49 \\
51 \\
55 \\
89 \\
622 \\
439 \\
122 \\
94\end{array}$ & & \\
\hline 1,270 & 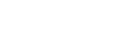 & 226 & 163,000 \\
\hline $\begin{array}{l}246 \\
795 \\
850 \\
364 \\
122 \\
\mathbf{1 4 2}\end{array}$ & $\begin{array}{r}195 \\
369 \\
108 \\
73 \\
73\end{array}$ & $\begin{array}{l}91.2 \\
70.7 \\
58 \\
47 \\
45 \\
55 \\
126 \\
280 \\
588 \\
200 \\
87.5 \\
94.0\end{array}$ & $\begin{array}{r}5,610 \\
4,210 \\
3,200 \\
2,800 \\
2,500 \\
3,380 \\
7,500 \\
23,400 \\
32,000 \\
12,000 \\
5,800 \\
5,500\end{array}$ \\
\hline 850 & | & 151 & $109,000=$ \\
\hline
\end{tabular}

The year.

1909-10

October.

November

December

January

February

March

April.

June

July -

August.

September

The year.

1910-11

October

November

December

February

March

April

May

July -

August

The year.

\section{1-12}

October.

November

January.

February

March.

April.

June.

July .

August.

September

The year

October
November
December.
January
February
March
April
May
June
July
August
Sentember




\section{Monthly discharge of Williams River near Parshall, Colo., 1904-1924-Continued}

\begin{tabular}{|c|c|c|c|c|}
\hline \multirow{2}{*}{ Month } & \multicolumn{3}{|c|}{ Discharge in second-feet } & \multirow{2}{*}{$\begin{array}{l}\text { Run-off in } \\
\text { acre-feet }\end{array}$} \\
\hline & Maximum & Minimum & Mean & \\
\hline $\begin{array}{l}\text { October } \\
\text { November } \\
\text { December } \\
\text { January } \\
\text { February } \\
\text { March } \\
\text { April } \\
\text { May } \\
\text { June } \\
\text { July. } \\
\text { August } \\
\text { September }\end{array}$ & $\begin{array}{r}127 \\
82 \\
770 \\
63 \\
66 \\
151 \\
1,240 \\
1,610 \\
735 \\
232 \\
117\end{array}$ & \begin{tabular}{|r|}
58 \\
36 \\
42 \\
41 \\
39 \\
59 \\
124 \\
735 \\
221 \\
94 \\
75
\end{tabular} & $\begin{array}{r}92.6 \\
69.2 \\
57.2 \\
53.3 \\
50.9 \\
47.4 \\
86.4 \\
563 \\
1,100 \\
410 \\
134 \\
87.3\end{array}$ & $\begin{array}{r}5,690 \\
4,000 \\
3,640 \\
3,230 \\
2,830 \\
2,910 \\
5,740 \\
34,600 \\
65,500 \\
25,200 \\
8,240 \\
5,190\end{array}$ \\
\hline The year.............. & 1,610 & 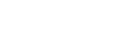 & 230 & 167,000 \\
\hline $\begin{array}{l}\text { October } \\
\text { November } \\
\text { December. } \\
\text { January } \\
\text { February } \\
\text { March } \\
\text { April }\end{array}$ & $\begin{array}{r}107 \\
94 \\
71 \\
46 \\
46 \\
50 \\
256 \\
375 \\
1,220 \\
840 \\
172 \\
105\end{array}$ & $\begin{array}{r}63 \\
56 \\
37 \\
37 \\
41 \\
37 \\
49 \\
71 \\
375 \\
151 \\
74 \\
52\end{array}$ & $\begin{array}{c}88.5 \\
69.7 \\
52.9 \\
41.6 \\
42.1 \\
42.1 \\
102 \\
219 \\
757 \\
438 \\
101 \\
67.8\end{array}$ & $\begin{array}{r}5,440 \\
4,150 \\
3,250 \\
2,560 \\
2,340 \\
2,590 \\
6,070 \\
13,500 \\
45,000 \\
26,900 \\
6,210 \\
4,030\end{array}$ \\
\hline The year..... & 1,220 & 37 & 169 & 122,000 \\
\hline $\begin{array}{l}\text { October } \\
\text { November. } \\
\text { December. } \\
\text { January } \\
\text { February. } \\
\text { March } \\
\text { April. } \\
\text { May } \\
\text { June } \\
\text { July } \\
\text { August } \\
\text { September }\end{array}$ & $\begin{array}{r}100 \\
89 \\
61 \\
48 \\
52 \\
89 \\
252 \\
510 \\
940 \\
590 \\
300 \\
134\end{array}$ & $\begin{array}{r}64 \\
30 \\
30 \\
30 \\
31 \\
46 \\
58 \\
134 \\
440 \\
132 \\
98 \\
91\end{array}$ & $\begin{array}{c}78.9 \\
65.6 \\
44.8 \\
37.3 \\
41.9 \\
63.4 \\
105 \\
292 \\
652 \\
286 \\
162 \\
104\end{array}$ & $\begin{array}{r}4,850 \\
3,900 \\
2,750 \\
2,290 \\
2,410 \\
3,900 \\
6,250 \\
18,000 \\
38,800 \\
17,600 \\
9,960 \\
6,190\end{array}$ \\
\hline The year............ & 940 & 30 & 161 & 117,000 \\
\hline $\begin{array}{l}\text { October. } \\
\text { November. } \\
\text { December. } \\
\text { January } \\
\text { February } \\
\text { March } \\
\text { April } \\
\text { May } \\
\text { June } \\
\text { July } \\
\text { August }\end{array}$ & $\begin{array}{r}114 \\
84 \\
61 \\
59 \\
45 \\
60 \\
234 \\
630 \\
1,690 \\
1,200 \\
\mathbf{2 3 8} \\
94\end{array}$ & $\begin{array}{r}80 \\
46 \\
37 \\
36 \\
32 \\
40 \\
52 \\
71 \\
.266 \\
256 \\
104 \\
68\end{array}$ & $\begin{array}{c}91.5 \\
61.6 \\
52.8 \\
52.2 \\
41.1 \\
45.1 \\
104 \\
256 \\
1,040 \\
611 \\
151 \\
79.7\end{array}$ & $\begin{array}{r}5,630 \\
3,670 \\
3,250 \\
3,210 \\
2,280 \\
2,770 \\
6,190 \\
15,700 \\
61,900 \\
37,600 \\
9,280 \\
4,740\end{array}$ \\
\hline The year & 1,690 & 32 & 216 & 156,000 \\
\hline $\begin{array}{l}\text { October. } \\
\text { November. } \\
\text { Decomber. } \\
\text { January. } \\
\text { February } \\
\text { March } \\
\text { April } \\
\text { May } \\
\text { June } \\
\text { July } \\
\text { Aúgust. } \\
\text { September }\end{array}$ & $\begin{array}{r}98 \\
100 \\
65 \\
64 \\
55 \\
96 \\
135 \\
730 \\
2,600 \\
712 \\
156 \\
121\end{array}$ & $\begin{array}{r}67 \\
64 \\
45 \\
25 \\
44 \\
44 \\
74 \\
112 \\
540 \\
158 \\
80 \\
85\end{array}$ & $\begin{array}{c}76.7 \\
77.3 \\
55.5 \\
48.9 \\
46.5 \\
57.0 \\
92.0 \\
442 \\
1,330 \\
374 \\
113 \\
98.3\end{array}$ & $\begin{array}{r}4,720 \\
4,600 . \\
3,410 \\
3,010 \\
2,580 \\
3,500 \\
5,470 \\
27,200 \\
79,100 \\
23,000 \\
6,950 \\
5,850\end{array}$ \\
\hline The year & 2,600 & 25 & 234 & 169,000 \\
\hline
\end{tabular}


Monthly discharge of Williams River near Parshall, Colo., 1901-1924-Continued

\begin{tabular}{|c|c|c|c|c|}
\hline \multirow{2}{*}{ Month } & \multicolumn{3}{|c|}{ Discharge in second-feet } & \multirow{2}{*}{$\begin{array}{c}\text { Run-off in } \\
\text { acre-feet }\end{array}$} \\
\hline & Maximum & Minimum & Mean & \\
\hline $\begin{array}{l}\text { October. } \\
\text { November } \\
\text { December } \\
\text { January } \\
\text { February } \\
\text { March } \\
\text { April } \\
\text { May } \\
\text { June } \\
\text { July } \\
\text { August } \\
\text { September }\end{array}$ & $\begin{array}{r}102 \\
95 \\
76 \\
74 \\
532 \\
548 \\
910 \\
486 \\
93 \\
98\end{array}$ & $\begin{array}{r}72 \\
54 \\
61 \\
132 \\
376 \\
74 \\
32 \\
41\end{array}$ & $\begin{array}{c}86.2 \\
67.7 \\
48.8 \\
47.1 \\
44.6 \\
50.2 \\
139 \\
363 \\
703 \\
242 \\
60.5 \\
76.8\end{array}$ & $\begin{array}{r}5,300 \\
4,030 \\
3,000 \\
2,900 \\
2,570 \\
3,090 \\
8,270 \\
22,300 \\
41,800 \\
14,900 \\
3,720 \\
4,570\end{array}$ \\
\hline The year....... & 910 & 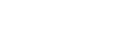 & 160 & 116,000 \\
\hline
\end{tabular}

Nore.-Winter records prior to 1907 and for 1913 estimated; records subsequent to 1921 based on current meter measurements, daily gage heights, and temperatıre records.

\section{TROUBLESOME CREEK NEAR TROUBLESOME, COLO.}

Location.-In sec. 12 , T. 1 N., R. 80 W., at highway bridge 1 mile north of Troublesome, Grand County. No tributary between station and mouth, $1 \frac{1}{2}$ miles downstream.

DRAINAGE AREA.-172 square miles (measured on base map of Colorado).

Records AVAILABLe.--July 22, 1904, to October 31, 1905; October 1, 1921, to September 30, 1924.

GAGE.- Vertical staff.

ControL.-Practically permanent.

EXTREMEs of DISCHARGe.-Maximum stage recorded during period, 3.32 feet at 7 a. m. May 27 and 28, 1923 (discharge, 672 second-feet); minimum stage recorded, 1.28 feet at 5.30 p. m., July 30, 1922 (discharge, 1 second-foot).

Diversions.-Water is diverted above station for irrigation of 6,500 acres.

Accuracy.-Gage read twice daily. Rating curves well defined, Records good. Cooperation.-Since 1922 station maintained in cooperation with State engineer.

Monthly discharge of Troublesome Creek near Troublesome, Colo., for 1904-5 and 1921-1924

\begin{tabular}{|c|c|c|c|c|}
\hline \multirow{2}{*}{ Month } & \multicolumn{3}{|c|}{ Discharge in second-feet } & \multirow{2}{*}{$\begin{array}{l}\text { Run-off in } \\
\text { acre-feet }\end{array}$} \\
\hline & Maximum & Minimum & Mean & \\
\hline $\begin{array}{l}\text { July } 22-31 \\
\text { August } \\
\text { September }\end{array}$ & $\begin{array}{r}30 \\
100 \\
41\end{array}$ & $\begin{array}{l}15 \\
14 \\
17\end{array}$ & $\begin{array}{l}20.8 \\
24.3 \\
22.2\end{array}$ & $\begin{array}{r}412 \\
1,490 \\
1,320\end{array}$ \\
\hline $\begin{array}{l}\text { October } \\
\text { November } \\
\text { December } \\
\text { January } \\
\text { February } \\
\text { March } \\
\text { April } \\
\text { May } \\
\text { June } \\
\text { July } \\
\text { August } \\
\text { September }\end{array}$ & $\begin{array}{r}30 \\
800 \\
604 \\
62 \\
62 \\
20 \\
22 \\
0\end{array}$ & $\begin{array}{c}14 \\
14 \\
78 \\
52 \\
15 \\
14 \\
14\end{array}$ & $\begin{array}{ll} & 20.4 \\
a & 15 \\
\text { a } & 12 \\
\text { a } 10 \\
\text {. } 10 \\
\text { a } 15 \\
35.1 \\
270 \\
259 \\
17.5 \\
18.0 \\
17.3\end{array}$ & $\begin{array}{r}1,260 \\
893 \\
738 \\
615 \\
555 \\
922 \\
2,090 \\
16,600 \\
15,400 \\
1,080 \\
1,110 \\
1,030\end{array}$ \\
\hline The yea & 604 & & & 42,300 \\
\hline
\end{tabular}

- Estimated. 
Monthly discharge of Troublesome Creek, near Troublesome, Colo., for 1904-5 and 1921-1924-Continued

\begin{tabular}{|c|c|c|c|c|}
\hline \multirow{2}{*}{ Month } & \multicolumn{3}{|c|}{ Discharge in second-feet } & \multirow{2}{*}{$\begin{array}{l}\text { Run-off in } \\
\text { acre-feet }\end{array}$} \\
\hline & Maximum & Minimum & Mean & \\
\hline October $\quad \begin{array}{c}c \\
\text { On }\end{array}$ & 29 & 10 & 19.1 & 1,170 \\
\hline $\begin{array}{l}\text { October } \\
\text { November } \\
\text { December } \\
\text { January } \\
\text { February } \\
\text { March } \\
\text { April } \\
\text { May } \\
\text { June } \\
\text { July } \\
\text { August } \\
\text { September }\end{array}$ & $\begin{array}{r}335 \\
149 \\
19 \\
43 \\
30\end{array}$ & $\begin{array}{r}138 \\
1 \\
1 \\
15\end{array}$ & $\begin{array}{r}\text { a } 20 \\
\text { a } 25 \\
\text { a } 20 \\
\text { a } 15 \\
\text { a } 15 \\
\text { a } 25 \\
85 \\
228 \\
89.7 \\
6.1 \\
32.2 \\
18.0\end{array}$ & $\begin{array}{r}1,230 \\
1,490 \\
1,230 \\
922 \\
833 \\
1,540 \\
5,060 \\
14,000 \\
5,340 \\
375 \\
1,980 \\
1,070\end{array}$ \\
\hline The year............... & 335 & 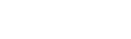 & 43.5 & 35,100 \\
\hline $\begin{array}{l}\text { October. } \\
\text { November } \\
\text { December. } \\
\text { January } \\
\text { February } \\
\text { March } \\
\text { April } \\
\text { May } \\
\text { June } \\
\text { July } \\
\text { August } \\
\text { September }\end{array}$ & $\begin{array}{r}26 \\
31 \\
\\
184 \\
660 \\
550 \\
86 \\
59 \\
32\end{array}$ & $\begin{array}{r}16 \\
80 \\
181 \\
57 \\
26 \\
25 \\
22\end{array}$ & $\begin{array}{c}17.9 \\
25 \\
a \quad 20 \\
a \\
\text { a } 15 \\
\text { a } 20 \\
90 \\
384 \\
384 \\
296 \\
43.5 \\
37.1 \\
25.0\end{array}$ & $\begin{array}{r}1,100 \\
1,490 \\
1,230 \\
922 \\
833 \\
1,230 \\
5,360 \\
23,600 \\
17,600 \\
2,670 \\
2,280 \\
1,490\end{array}$ \\
\hline 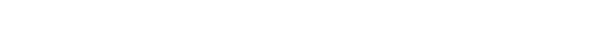 & 660 & 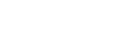 & 82.7 & 59,800 \\
\hline $\begin{array}{l}\text { October } \\
\text { November } \\
\text { December } \\
\text { January } \\
\text { February } \\
\text { March } \\
\text { April } \\
\text { May } \\
\text { June } \\
\text { July } \\
\text { August } \\
\text { September }\end{array}$ & $\begin{array}{r}48 \\
37 \\
330 \\
440 \\
75 \\
29 \\
28\end{array}$ & $\begin{array}{r}26 \\
131 \\
24 \\
9 \\
16 \\
15\end{array}$ & $\begin{array}{c}37.1 \\
28 \\
a 20 \\
\text { a } 15 \\
a 15 \\
\text { a } 25 \\
\text { a } 85 \\
240 \\
184 \\
23.0 \\
21.7 \\
18.7\end{array}$ & $\begin{array}{r}2,280 \\
1,670 \\
1,230 \\
922 \\
863 \\
1,540 \\
5,060 \\
14,800 \\
10,900 \\
1,110 \\
1,330 \\
1,110\end{array}$ \\
\hline The year...................... & 440 & 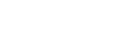 & 59.7 & 43,100 \\
\hline
\end{tabular}

a Estimated.

BIUB RIVER AT BRECKENRIDGE, COLO.

Location.-At outlet of Gold Pan pit in Breckenridge, Summit County. Illinois

Creek enters a short distance below.

Drainage area. -49 square miles.

Reconds available.-June 1, 1914, to March 31, 1915.

GAGE.-Vertical staff.

Control.-Permanent.

Drversions.-Above Gold Pan pit are two diversions, one through -Gold River ditch and the other through the power-house ditch. The quantity of water in the ditches is added to the measured flow of the river to show the total run-off.

Regulation.-None.

Cooperation.--Records furnished by S. C. Hulse, consulting engineer for Tonopah Placers Co. 
Monthly discharge of Blue River above diversions at Breckenridge, Colo., for 1914-15

\begin{tabular}{|c|c|c|c|c|c|}
\hline \multirow{2}{*}{ Month } & \multicolumn{4}{|c|}{ Discharge in second-feet } & \multirow{2}{*}{$\begin{array}{c}\text { Run-off } \\
\text { in acre- } \\
\text { feet }\end{array}$} \\
\hline & $\begin{array}{l}\text { Blue } \\
\text { River }\end{array}$ & $\begin{array}{l}\text { Gold } \\
\text { Run } \\
\text { ditch }\end{array}$ & $\begin{array}{l}\text { Power } \\
\text { ditch }\end{array}$ & Total & \\
\hline $\begin{array}{l}\text { June__. } \\
\text { July } \\
\text { August } \\
\text { September- }\end{array}$ & $\begin{array}{l}436 \\
186 \\
92.5 \\
35.6\end{array}$ & $\begin{array}{l}12 \\
12 \\
12 \\
10\end{array}$ & $\begin{array}{l}8 \\
7 \\
6 \\
5\end{array}$ & $\begin{array}{l}456 \\
205 \\
110 \\
50.6\end{array}$ & $\begin{array}{r}27,100 \\
12,600 \\
6,760 \\
3,010\end{array}$ \\
\hline The period ..... & $\cdots \cdots$ & 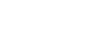 & $\cdots+\cdots+\cdots$ & (n) & 49,500 \\
\hline $\begin{array}{l}\text { October } \\
\text { November } \\
\text { December } \\
\text { January } \\
\text { February } \\
\text { March }\end{array}$ & $\begin{array}{r}15.4 \\
9.11 \\
6.94 \\
6.02 \\
6.50 \\
6.51\end{array}$ & $\begin{array}{l}9 \\
2.51 \\
0 \\
0 \\
0 \\
0\end{array}$ & $\begin{array}{l}2.5 \\
1.01 \\
1.10 \\
1.09 \\
1.30 \\
2.36\end{array}$ & $\begin{array}{r}26.9 \\
12.6 \\
8.04 \\
7.11 \\
7.80 \\
8.77\end{array}$ & $\begin{array}{r}1,650 \\
750 \\
494 \\
437 \\
433 \\
539\end{array}$ \\
\hline The period. - & & & - & .......... & 4,300 \\
\hline
\end{tabular}

BLUE RIVER AT DILION, COLO.

Location.-In sec. 18, T. 5 S., R. 77 W., at highway bridge on edge of Dillon, Summit County. Nearest tributaries, Snake River and Tenmile Creek, enter a short distance downstream.

Drainage area. - 129 square miles (revised; measured on Forest Service map). RECORDS aVAILABLE.-October 1, 1910, to September 30, 1927.

GAGE.-Gurley water-stage recorder installed April 21, 1920, and referred to vertical staff used previously.

Controu.- Shifting at long intervals.

Extremes of Discharge.-Maximum discharge recorded, 1,180 second-feet at 1 p. m. June 14, 1924 (gage height, 3.6 feet); minimum discharge, 14 secondfeet on January 30 and February 9, 1915 (gage height, 1.10 feet).

Diversions.-Except for a small diversion across Boreas Pass, practically no diversions above station which do not return water to river.

Accoracr.-Gage read at irregular intervals, from 1911 to 1914 , and twice daily from 1915 to 1919; continuous records beginning with 1920. Rating curves well defined. Records 1911 to 1914 fair, from 1915 to 1924 good except during winter, for which they are fair.

Cooperation.- Since 1925 station maintained in cooperation with State engineer, who furnished complete records.

Monthly discharge of Blue River at Dillon, Colo., for 1910-1927

\begin{tabular}{|c|c|c|c|c|}
\hline \multirow{2}{*}{ Month } & \multicolumn{3}{|c|}{ Discharge in second-feot } & \multirow{2}{*}{$\underset{\text { acre-feet }}{\text { Run-off in }}$} \\
\hline & Maximum & Minimum & Mean & \\
\hline $\begin{array}{l}\text { October. } \\
\text { November } \\
\text { December } \\
\text { January } \\
\text { February } \\
\text { March } \\
\text { April } \\
\text { May } \\
\text { June } \\
\text { July } \\
\text { August } \\
\text { September }\end{array}$ & $\begin{array}{r}145 \\
405 \\
455 \\
840 \\
175 \\
102\end{array}$ & $\begin{array}{r}30 \\
23 \\
23 \\
58 \\
245 \\
175 \\
81 \\
58\end{array}$ & $\begin{array}{l}40.2 \\
30 \\
20 \\
20 \\
20 \\
20 \\
46.4 \\
268 \\
373 \\
333 \\
111 \\
82.3\end{array}$ & $\begin{array}{r}2,470 \\
1,790 \\
1,230 \\
1,230 \\
1,110 \\
1,230 \\
2,760 \\
16,500 \\
22,200 \\
20,500 \\
6,820 \\
4,900\end{array}$ \\
\hline The year & 840 & $-\ldots+\ldots \ldots$ & 114 & 82,700 \\
\hline
\end{tabular}


Monthly discharge of Blue River at Dillon, Colo., for 1910-1927-Continued

\begin{tabular}{|c|c|c|c|c|}
\hline \multirow{2}{*}{ Month } & \multicolumn{3}{|c|}{ Discharge in second-feet } & \multirow{2}{*}{$\begin{array}{l}\text { Run-off in } \\
\text { acre-feet }\end{array}$} \\
\hline & Maximum & Minimum & Mean & \\
\hline $\begin{array}{l}\text { October } \\
\text { November } \\
\text { December } \\
\text { January } \\
\text { February } \\
\text { March } \\
\text { April } \\
\text { May } \\
\text { June } \\
\text { July } \\
\text { August } \\
\text { September }\end{array}$ & \begin{tabular}{r|r|}
90 \\
46 \\
1,020 \\
725 \\
405 \\
88
\end{tabular} & $\begin{array}{r}30 \\
27 \\
50 \\
430 \\
320 \\
88 \\
58\end{array}$ & $\begin{array}{l}53.8 \\
30 \\
33 \\
30 \\
30 \\
28 \\
31.0 \\
335 \\
631 \\
419 \\
212 \\
75.0\end{array}$ & $\begin{array}{r}3,310 \\
1,790 \\
2,030 \\
1,840 \\
1,730 \\
1,720 \\
1,840 \\
20,600 \\
37,000 \\
26,800 \\
13,000 \\
4,460\end{array}$ \\
\hline The year...... & 1,020 & $---n$ & 160 & 116,000 \\
\hline $\begin{array}{l}\text { October } \\
\text { November } \\
\text { December } \\
\text { January } \\
\text { February } \\
\text { March } \\
\text { April } \\
\text { May } \\
\text { June } \\
\text { July } \\
\text { August } \\
\text { September }\end{array}$ & $\begin{array}{r}70 \\
58 \\
225 \\
480 \\
548 \\
305 \\
131 \\
225\end{array}$ & $\begin{array}{r}53 \\
191 \\
325 \\
113 \\
70 \\
70\end{array}$ & $\begin{array}{l}62.2 \\
44.3 \\
35 \\
30 \\
30 \\
28 \\
66.6 \\
391 \\
430 \\
211 \\
90.5 \\
120\end{array}$ & $\begin{array}{r}3,820 \\
2,640 \\
2,150 \\
1,840 \\
1,670 \\
1,720 \\
3,960 \\
17,900 \\
25,600 \\
13,000 \\
5,560 \\
7,140\end{array}$ \\
\hline The year............. & 548 & .......... & 120 & 87,000 \\
\hline $\begin{array}{l}\text { October } \\
\text { November } \\
\text { December. } \\
\text { January } \\
\text { February } \\
\text { March } \\
\text { April } \\
\text { May } \\
\text { June } \\
\text { July } \\
\text { August. } \\
\text { September }\end{array}$ & $\begin{array}{r}86 \\
58 \\
1.090 \\
1,180 \\
412 \\
360 \\
131\end{array}$ & \begin{tabular}{rr|}
57 \\
96 \\
418 \\
305 \\
102 \\
58
\end{tabular} & $\begin{array}{l}69.6 \\
51 \\
35 \\
30 \\
28 \\
28 \\
51 \\
530 \\
780 \\
344 \\
194 \\
81.8\end{array}$ & $\begin{array}{r}4,280 \\
3,040 \\
2,150 \\
1,840 \\
1,560 \\
1,720 \\
3,040 \\
32,600 \\
46,400 \\
21,200 \\
11,900 \\
4,870\end{array}$ \\
\hline The year.............. & 1,180 & 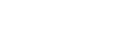 & 186 & 135,000 \\
\hline $\begin{array}{l}\text { October. } \\
\text { November } \\
\text { December } \\
\text { January } \\
\text { February } \\
\text { March } \\
\text { April } \\
\text { May } \\
\text { June } \\
\text { July } \\
\text { August } \\
\text { September }\end{array}$ & $\begin{array}{c}68 \\
111 \\
502 \\
665 \\
458 \\
208 \\
167\end{array}$ & \begin{tabular}{|r|}
46 \\
\\
33 \\
76 \\
305 \\
149 \\
70 \\
48
\end{tabular} & $\begin{array}{l}54.3 \\
45 \\
30 \\
25 \\
18 \\
22 \\
55.6 \\
203 \\
454 \\
265 \\
121 \\
81.7\end{array}$ & $\begin{array}{r}3,340 \\
2,680 \\
1,840 \\
1,540 \\
1,000 \\
1,350 \\
3,310 \\
12,500 \\
27,000 \\
16,300 \\
7,440 \\
4,860\end{array}$ \\
\hline The year............... & 665 & $\ldots$ & 115 & 83,200 \\
\hline $\begin{array}{l}\text { October } \\
\text { November } \\
\text { Not5-16 } \\
\text { December } \\
\text { January } \\
\text { February } \\
\text { March } \\
\text { April } \\
\text { May } \\
\text { June } \\
\text { July } \\
\text { August. } \\
\text { September }\end{array}$ & $\begin{array}{r}78 \\
53\end{array} \mid$ & \begin{tabular}{r|r|}
53 \\
45 \\
18 \\
92 \\
305 \\
152 \\
94 \\
64
\end{tabular} & $\begin{array}{c}68.9 \\
47.7 \\
38.3 \\
29.0 \\
26.2 \\
23.9 \\
55.5 \\
236 \\
409 \\
234 \\
171 . \\
79.3\end{array}$ & $\begin{array}{r}4,240 \\
2,840 \\
2,860 \\
1,780 \\
1,510 \\
1,470 \\
3,300 \\
14,500 \\
24,300 \\
14,400 \\
10,500 \\
4,720\end{array}$ \\
\hline The year....... & 502 & 18 & 118 & 85,900 \\
\hline
\end{tabular}


Monthly discharge of Blue River at Dillon, Colo., for 1910-1927-Continued

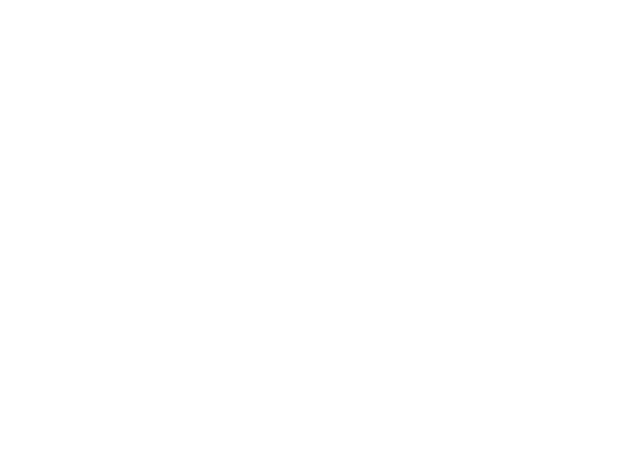

The year

October
November
December
January
February
March
April
May
June
July
August
September

The year.

October
November
December $1918-19$
January
February
March
April
May
June
July
August
September...

The year.

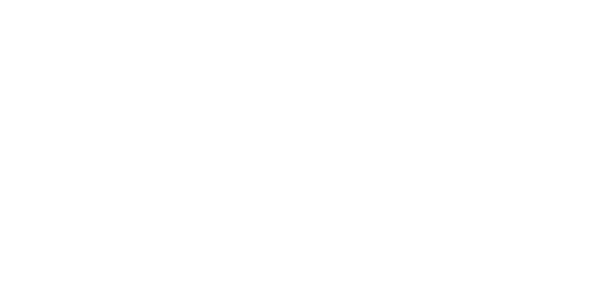

The year.

1920-21

October.

November

December

January.

March.

April.

May -

June

July.-

September

The year.

\begin{tabular}{|c|c|c|c|}
\hline \multicolumn{3}{|c|}{ Discharge in second-feet } & \multirow{2}{*}{$\begin{array}{l}\text { Run-off in } \\
\text { acre-feet }\end{array}$} \\
\hline Maximum & Minimum & Mean & \\
\hline $\begin{array}{r}69 \\
53 \\
48 \\
42 \\
-2 .- \\
-131 \\
390 \\
900 \\
650 \\
236 \\
84\end{array}$ & \begin{tabular}{r}
51 \\
36 \\
40 \\
34 \\
\hdashline-25 \\
73 \\
208 \\
255 \\
87 \\
53
\end{tabular} & $\begin{array}{c}57.8 \\
43.7 \\
44.3 \\
38.8 \\
30.4 \\
35.2 \\
68.0 \\
197 \\
624 \\
428 \\
139 \\
61.9\end{array}$ & $\begin{array}{r}3,550 \\
2,600 \\
2,720 \\
2,390 \\
1,690 \\
2,160 \\
4,050 \\
12,100 \\
37,100 \\
26,300 \\
8,550 \\
3,680\end{array}$ \\
\hline 900 & $\therefore \ldots$ & 148 & 107,000 \\
\hline $\begin{array}{r}142 \\
600 \\
900 \\
442 \\
158 \\
73\end{array}$ & $\begin{array}{r}32 \\
170 \\
488 \\
172 \\
60 \\
60\end{array}$ & $\begin{array}{c}47.9 \\
36.6 \\
30.0 \\
26.7 \\
26.3 \\
24.1 \\
55.2 \\
403 \\
740 \\
295 \\
112 \\
64.5\end{array}$ & $\begin{array}{r}2,950 \\
2,180 \\
1,840 \\
1,640 \\
1,460 \\
1,480 \\
3,280 \\
24,800 \\
44,000 \\
18,100 \\
6,890 \\
3,840\end{array}$ \\
\hline 900 & (................ & 155 & 112,000 \\
\hline $\begin{array}{l}184 \\
510 \\
390 \\
458 \\
146 \\
106\end{array}$ & $\begin{array}{r}27 \\
104 \\
200 \\
86 \\
44 \\
40\end{array}$ & $\begin{array}{c}52.8 \\
47.2 \\
36.0 \\
27.9 \\
20.0 \\
19.9 \\
69.6 \\
287 \\
290 \\
171 . \\
71.8 \\
\mathbf{5 5 . 8}\end{array}$ & $\begin{array}{r}3,250 \\
2,810 \\
2,210 \\
1,720 \\
1,110 \\
1,220 \\
4,140 \\
17,600 \\
17,300 \\
10,800 \\
4,410 \\
3,320\end{array}$ \\
\hline 510 & $\mid$ & 96.1 & 69,600 \\
\hline $\begin{array}{r}675 \\
700 \\
375 \\
207 \\
81\end{array}$ & $\begin{array}{r}-43 \\
375 \\
155 \\
87 \\
56\end{array}$ & $\begin{array}{r}45 \\
40 \\
35 \\
30 \\
.28 \\
25 \\
25 \\
274 \\
510 \\
245 \\
128 \\
68.9\end{array}$ & $\begin{array}{r}2,770 \\
2,380 \\
2,150 \\
1,840 \\
1,610 \\
1,540 \\
1,490 \\
16,800 \\
30,300 \\
15,100 \\
7,870 \\
4,100\end{array}$ \\
\hline 700 & (............... & 121 & 88,000 \\
\hline $\begin{array}{r}53 \\
625 \\
1,070 \\
490 \\
277 \\
261\end{array}$ & $\begin{array}{r}37 \\
55 \\
499 \\
236 \\
130 \\
78\end{array}$ & $\begin{array}{l}46.8 \\
40.6 \\
35 \\
30 \\
26 \\
23 \\
45.4 \\
296 \\
793 \\
362 \\
197 \\
130\end{array}$ & $\begin{array}{r}2,880 \\
2,420 \\
2,150 \\
1,840 \\
1,440 \\
1,410 \\
2,700 \\
18,200 \\
47,200 \\
22,300 \\
12,100 \\
7,740\end{array}$ \\
\hline 1,050 & $\ldots$ & 169 & 122,000 \\
\hline
\end{tabular}


Monthly discharge of Blue River at Dillon, Colo., for 1910-1927-Continued

Month
October.
November
December.
Fanuary
March
April.
May.
June.
July
August.
September.

The year

1922-23

October...

November

December

January

February

Mareh

April.

June.

July

August....

September

The year-

1923-24
October
November.
December
January
February
March
April
May
June
July.
August
September

The year.

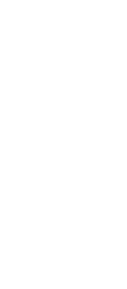

The year.

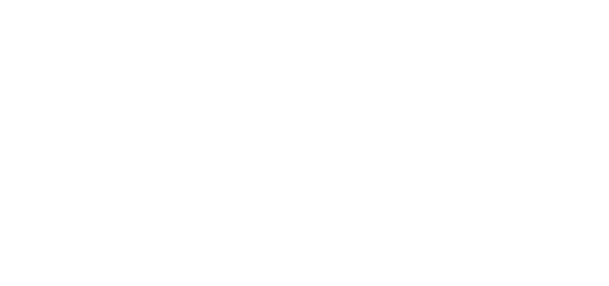

The year.

1924-25

\begin{tabular}{|c|c|c|c|}
\hline \multicolumn{3}{|c|}{ Discharge in second-feet } & \multirow{2}{*}{$\begin{array}{l}\text { Run-off in } \\
\text { acre-feet }\end{array}$} \\
\hline Maximum & Minimum & Mean & \\
\hline $\begin{array}{r}81 \\
61 \\
-9 \\
83 \\
430 \\
460 \\
239 \\
209 \\
88\end{array}$ & \begin{tabular}{r}
61 \\
\\
\hdashline \\
\\
\hdashline 45 \\
91 \\
242 \\
98 \\
86 \\
60
\end{tabular} & $\begin{array}{l}70.0 \\
48 \\
40 \\
35 \\
35 \\
35 \\
56.7 \\
201 \\
343 \\
154 \\
116 \\
69.1\end{array}$ & $\begin{array}{r}4,300 \\
2,950 \\
2,460 \\
2,150 \\
1,940 \\
2,150 \\
3,370 \\
12,400 \\
20,400 \\
9,470 \\
7,130 \\
4,110\end{array}$ \\
\hline 460 & $\ldots$ & 100 & 72,800 \\
\hline $\begin{array}{r}61 \\
50 \\
\\
-.- \\
69 \\
418 \\
695 \\
461 \\
252 \\
113\end{array}$ & 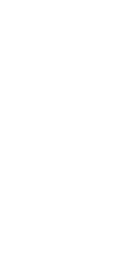 & $\begin{array}{c}54.5 \\
45 \\
40 \\
35 \\
35 \\
35 \\
47 \\
220 \\
520 \\
371 \\
174 \\
92.8\end{array}$ & $\begin{array}{r}3,350 \\
2,680 \\
2,460 \\
2,150 \\
1,940 \\
2,150 \\
2,800 \\
13,500 \\
30,900 \\
22,800 \\
10,700 \\
5,520\end{array}$ \\
\hline 695 & (n) & 139 & 101,000 \\
\hline \begin{tabular}{r}
80 \\
\hdashline 0. \\
64 \\
392 \\
976 \\
414 \\
131 \\
69
\end{tabular} & $\begin{array}{r}0 . \\
53 \\
225 \\
133 \\
68 \\
62\end{array}$ & $\begin{array}{c}77 \\
55 \\
45 \\
45 \\
35 \\
35 \\
48 \\
243 \\
508 \\
232 \\
91.4 \\
65.0\end{array}$ & $\begin{array}{r}7,440 \\
3,270 \\
\cdot 2,770 \\
2,420 \\
2,010 \\
2,150 \\
2,860 \\
14,900 \\
30,200 \\
14,300 \\
5,620 \\
3,870\end{array}$ \\
\hline 976 & $\ldots$ & 123 & 89,100 \\
\hline \begin{tabular}{l}
69 \\
\hdashline 111 \\
374 \\
365 \\
225 \\
188 \\
136
\end{tabular} & $\begin{array}{r}102 \\
216 \\
103 \\
94 \\
83\end{array}$ & $\begin{array}{l}62.0 \\
40 \\
35 \\
30 \\
30 \\
35 \\
74.4 \\
205 \\
274 \\
168 \\
119 \\
100\end{array}$ & $\begin{array}{r}3,810 \\
2,380 \\
2,150 \\
1,840 \\
1,670 \\
2,150 \\
4,430 \\
1,600 \\
16,300 \\
10,300 \\
7,320 \\
5,950\end{array}$ \\
\hline 374 & (n............. & 97.9 & 70,900 \\
\hline $\begin{array}{r}175 \\
737 \\
1,050 \\
536 \\
234 \\
90\end{array}$ & $\begin{array}{r}190 \\
467 \\
180 \\
92 \\
59\end{array}$ & $\begin{array}{l}70.9 \\
50.5 \\
39 \\
28 \\
29 \\
30 \\
74.4 \\
382 \\
701 \\
364 \\
146 \\
71.7\end{array}$ & $\begin{array}{r}4,360 \\
3,000 \\
2,400 \\
1,720 \\
1,610 \\
1,840 \\
4,430 \\
23,500 \\
41,700 \\
22,400 \\
8,980 \\
4,270\end{array}$ \\
\hline 1,050 & | & 166 & 120,000 \\
\hline
\end{tabular}


Monthly discharge of Blue River at Dillon, Colo., for 1910-1927-Continued

\begin{tabular}{|c|c|c|c|c|}
\hline \multirow{2}{*}{ Month } & \multicolumn{3}{|c|}{ Discharge in second-feet } & \multirow{2}{*}{$\begin{array}{c}\text { Run-off in } \\
\text { acre-feet }\end{array}$} \\
\hline & Maximum & Minimum & Mean & \\
\hline $\begin{array}{l}\text { October } \\
\text { November } \\
\text { December } \\
\text { January } \\
\text { February } \\
\text { March } \\
\text { April } \\
\text { May } \\
\text { June } \\
\text { July } \\
\text { August } \\
\text { September }\end{array}$ & \begin{tabular}{|r|}
61 \\
61 \\
132 \\
615 \\
500 \\
410 \\
214 \\
91
\end{tabular} & \begin{tabular}{|r|r} 
& 42 \\
& \\
& \\
& 151 \\
346 \\
178 \\
92 \\
62
\end{tabular} & $\begin{array}{c}51.5 \\
38.8 \\
35 \\
28 \\
24 \\
27 \\
45.1 \\
369 \\
430 \\
255 \\
139 \\
72.1\end{array}$ & $\begin{array}{r}3,170 \\
2,310 \\
2,150 \\
1,720 \\
1,330 \\
1,660 \\
2,680 \\
22,700 \\
25,600 \\
15,700 \\
8,550 \\
4,290\end{array}$ \\
\hline The year. & 615 & $\mid$ & 127 & 91,900 \\
\hline
\end{tabular}

Note.-Mean discharge for winter based on current-meter measurements, gage heights, and temperature records.

\section{BLUE RIVER NEAR KREMMIING, COLO.}

Location.-In sec. 13, T. 2 S., R. 80 W., at highway bridge 16 miles south of

Kremmling, Grand County. Nearest tributary, Cataract Creek, enters 1 mile upstream.

Drainage area. - 560 square miles (measured on base map of Colorado).

Records available.-July 21, 1904, to November 30, 1908.

GAGE.-Chain on highway bridge.

Controu.--Somewhat shifting.

Extremes of Discharge.-Maximum stage recorded, 5.2 feet at 8 a. $\mathrm{m}$. June 14, 1906 (discharge, 7,820 second-feet); minimum discharge recorded, 80 second-feet December 5 and $6,1905$.

Diversions.-Water diverted from Blue River and tributaries for irrigation of 7,000 acres; part above station not known.

AccuRAcy.-Gage read once daily. Rating curves fairly well defined. Records fair.

Monthly discharge of Blue River near Kremmling, Colo., for 1904-1908

\begin{tabular}{|c|c|c|c|c|}
\hline \multirow{2}{*}{ Month } & \multicolumn{3}{|c|}{ Discharge in second-feet } & \multirow{2}{*}{$\begin{array}{c}\text { Run-off in } \\
\text { acre-feet }\end{array}$} \\
\hline & Maximum & Minimum & Mean & \\
\hline 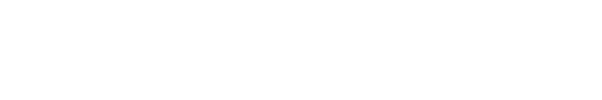 & $\begin{array}{r}1,180 \\
1,180 \\
725\end{array}$ & $\begin{array}{l}824 \\
470 \\
280\end{array}$ & $\begin{array}{l}999 \\
727 \\
411 \\
\end{array}$ & $\begin{array}{l}21,800 \\
44,700 \\
24,500\end{array}$ \\
\hline $\begin{array}{l}\text { October } \\
\text { November } \\
\text { December } \\
\text { January } \\
\text { February } \\
\text { March } \\
\text { April } \\
\text { May } \\
\text { June } \\
\text { July } \\
\text { August } \\
\text { September }\end{array}$ & \begin{tabular}{|r}
435 \\
\\
\\
\end{tabular} & \begin{tabular}{|r}
260 \\
\\
150 \\
1,590 \\
560 \\
295 \\
180 \\
\end{tabular} & $\begin{array}{r}327 \\
220 \\
200 \\
180 \\
160 \\
155 \\
242 \\
1,270 \\
2,900 \\
772 \\
398 \\
260\end{array}$ & $\begin{array}{r}20,100 \\
13,100 \\
12,300 \\
11,100 \\
8,890 \\
9,530 \\
14,400 \\
78,100 \\
173,000 \\
47,500 \\
24,500 \\
15,500\end{array}$ \\
\hline The year & 4,860 & 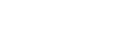 & 592 & 428,000 \\
\hline
\end{tabular}


Monthly discharge of Blue River near Kremmling, Colo., for 1904-1908-Contd.

\begin{tabular}{|c|c|c|c|c|}
\hline \multirow{2}{*}{ Month } & \multicolumn{3}{|c|}{ Discharge in second-feet } & \multirow{2}{*}{$\begin{array}{l}\text { Run-off in } \\
\text { acre-feet }\end{array}$} \\
\hline & Maximum & Minimum & Mean & \\
\hline $\begin{array}{l}\text { October } \\
\text { November } \\
\text { December } \\
\text { January. } \\
\text { February } \\
\text { March } \\
\text { April } \\
\text { May } \\
\text { June } \\
\text { July } \\
\text { August } \\
\text { September. }\end{array}$ & $\begin{array}{r}220 \\
180 \\
852 \\
2,990 \\
6,020 \\
1,980 \\
1,1600 \\
1,900\end{array}$ & $\begin{array}{r}152 \\
130 \\
80 \\
152 \\
305 \\
1,480 \\
792 \\
334 \\
367\end{array}$ & $\begin{array}{r}193 \\
172 \\
104 \\
110 \\
110 \\
150 \\
387 \\
1,710 \\
2,700 \\
1,350 \\
602 \\
522\end{array}$ & $\begin{array}{r}11,900 \\
10,200 \\
6,400 \\
6,760 \\
6,110 \\
9,220 \\
23,000 \\
105,000 \\
161,000 \\
83,000 \\
37,000 \\
31,100\end{array}$ \\
\hline The year. . & 6, 020 & -...........- & 678 & 401,000 \\
\hline $\begin{array}{l}\text { October } \\
\text { November } \\
\text { December } \\
\text { January } \\
\text { February } \\
\text { March } \\
\text { April } \\
\text { May } \\
\text { June } \\
\text { July } \\
\text { August } \\
\text { September }\end{array}$ & $\begin{array}{r}540 \\
315 \\
190 \\
660 \\
2,200 \\
4,660 \\
5,050 \\
1,650 \\
480\end{array}$ & $\begin{array}{r}256 \\
152 \\
140 \\
210 \\
318 \\
780 \\
1,610 \\
480 \\
238\end{array}$ & $\begin{array}{r}344 \\
230 \\
157 \\
135 \\
140 \\
175 \\
323 \\
928 \\
2,980 \\
2,770 \\
922 \\
324\end{array}$ & $\begin{array}{r}21,200 \\
13,700 \\
9,650 \\
8,300 \\
7,780 \\
10,800 \\
19,200 \\
57,100 \\
177,000 \\
170,000 \\
56,700 \\
19,300\end{array}$ \\
\hline The year. & 5,050 & -n........... & 790 & 571,000 \\
\hline $\begin{array}{l}\text { October. } \\
\text { November } \\
\text { December } \\
\text { January } \\
\text { February } \\
\text { March } \\
\text { April } \\
\text { May } \\
\text { June } \\
\text { July } \\
\text { August } \\
\text { September }\end{array}$ & $\begin{array}{r}345 \\
218 \\
155 \\
1,400 \\
3,520 \\
1,290 \\
660 \\
290\end{array}$ & $\begin{array}{r}174 \\
138 \\
120 \\
120 \\
290 \\
430 \\
410 \\
290 \\
183\end{array}$ & $\begin{array}{r}243 \\
176 \\
136 \\
150 \\
125 \\
110 \\
295 \\
656 \\
1,690 \\
806 \\
410 \\
222\end{array}$ & $\begin{array}{r}14,900 \\
10,500 \\
8,360 \\
9,220 \\
7,190 \\
6,760 \\
17,600 \\
40,300 \\
101,000 \\
49,600 \\
25,800 \\
13,200\end{array}$ \\
\hline The year. & 3,520 & 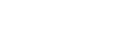 & 419 & 304,000 \\
\hline October 1908 & $\begin{array}{l}218 \\
168\end{array}$ & $\begin{array}{l}142 \\
120\end{array}$ & $\begin{array}{l}181 \\
149\end{array}$ & $\begin{array}{r}11,100 \\
8,870\end{array}$ \\
\hline
\end{tabular}

Note.-Records revised; estimated during winter.

ST AKE RIVER AT DILION, COLO.

Location.-In sec. 18, T. 5 S., R. 77 W., at highway bridge 100 yards above mouth, in Dillon, Summit County.

Drainage area.-90 square miles (revised; measured on Forest Service map).

Records available.-October 1, 1910, to September 30, 1919.

$\mathrm{G}_{\mathrm{AGE}}$-Vertical staff.

Control. - Somewhat shifting.

Extremes of Discharge.-Maximum stage recorded, 3.1 feet at $7 \mathrm{a} . \mathrm{m}$. and 7 p. m. June 15, 1918 (discharge, 1,170 second-feet); minimum discharge, 3 second-feet November 9, 1912.

Drversion.-Snake River ditch of Summit County Power Cọ. diverts about 30 second-feet above Dillon.

ACCURACY.-Gage read at irregular intervals from 1911 to 1914; twice daily for remainder of period. Rating curves well defined. Records from 1911 to 1914 fair; from 1915 to 1919 good, except during winter, for which they are fair. 
Monthly discharge of Snake River at Dillon, Colo., for 1910-1919

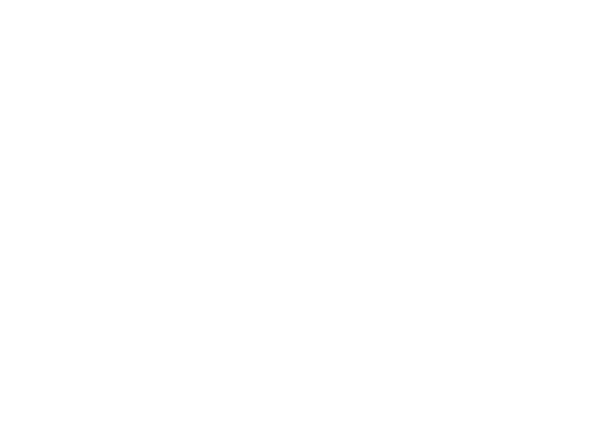

The year.

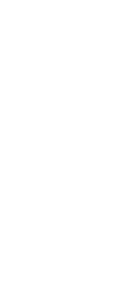

1911-12

October

December.

January.

March

April

June

August

\section{The year}

October

December

January.

February

March

April

May-

June

Angust

September

The year

October-.

November

January.

February

March.

April.

May.

July .

July --

September

The year

October-..-

December

January -

February

March.

April .

May.

June-

July -

August

September

The year

\section{3-14}

\section{2-13}

-...-13

non

(1)

-

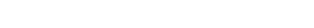


Monthly discharge of Snake River at Dillon, Colo., for 1910-1919-.Continued

\begin{tabular}{|c|c|c|c|c|}
\hline \multirow{2}{*}{ Month } & \multicolumn{3}{|c|}{ Discharge in second-feet } & \multirow{2}{*}{$\begin{array}{c}\text { Run-off in } \\
\text { acre-feet }\end{array}$} \\
\hline & Maximum & Minimum & Mean & \\
\hline $\begin{array}{l}\text { October } \\
\text { November } \\
\text { December } \\
\text { January } \\
\text { February } \\
\text { March } \\
\text { April } \\
\text { May } \\
\text { June } \\
\text { July } \\
\text { August } \\
\text { September }\end{array}$ & $\begin{array}{r}15 \\
14 \\
11 \\
12 \\
11 \\
72 \\
212 \\
430 \\
262 \\
136 \\
49\end{array}$ & $\begin{array}{r}13 \\
10 \\
10 \\
11 \\
37 \\
196 \\
85 \\
46 \\
14\end{array}$ & $\begin{array}{l}13.6 \\
12.3 \\
12.0 \\
10.3 \\
11.3 \\
10.9 \\
24.6 \\
120 \\
316 \\
162 \\
88.3 \\
29.1\end{array}$ & $\begin{array}{r}836 \\
732 \\
738 \\
633 \\
650 \\
670 \\
1,460 \\
7,380 \\
18,800 \\
9,960 \\
5,430 \\
1,730\end{array}$ \\
\hline The year. & 430 & 10 & 69.0 & 50,100 \\
\hline $\begin{array}{l}\text { October } \\
\text { November } \\
\text { December } \\
\text { January } \\
\text { February } \\
\text { March } \\
\text { April } \\
\text { May } \\
\text { June } \\
\text { July } \\
\text { August } \\
\text { September }\end{array}$ & $\begin{array}{r}27 \\
18 \\
14 \\
15 \\
16 \\
14 \\
76 \\
128 \\
750 \\
540 \\
111 \\
24\end{array}$ & $\begin{array}{r}11 \\
12 \\
11 \\
13 \\
12 \\
9 \\
12 \\
38 \\
58 \\
128 \\
26 \\
13\end{array}$ & $\begin{array}{c}14.8 \\
13.9 \\
12.7 \\
13.7 \\
13.9 \\
12.3 \\
31.9 \\
69.0 \\
442 \\
256 \\
61.1 \\
17.0\end{array}$ & $\begin{array}{r}910 \\
827 \\
781 \\
842 \\
772 \\
756 \\
1,900 \\
4,240 \\
26,300 \\
15,700 \\
3,760 \\
1,010\end{array}$ \\
\hline The year. & 750 & 9 & 79.9 & 57,800 \\
\hline $\begin{array}{l}\text { October } \\
\text { November } \\
\text { December. } \\
\text { January } \\
\text { February. } \\
\text { March } \\
\text { April } \\
\text { May } \\
\text { June } \\
\text { July } \\
\text { August } \\
\text { September }\end{array}$ & $\begin{array}{r}16 \\
52 \\
16 \\
13 \\
13 \\
14 \\
43 \\
276 \\
1,170 \\
355 \\
92 \\
58\end{array}$ & $\begin{array}{r}12 \\
10 \\
8 \\
8 \\
9 \\
8 \\
11 \\
47 \\
196 \\
92 \\
58 \\
24\end{array}$ & $\begin{array}{l}13.5 \\
20.8 \\
11.8 \\
10.2 \\
10.4 \\
11.4 \\
18.1 \\
149 \\
729 \\
194 \\
74.6 \\
33.4\end{array}$ & $\begin{array}{r}830 \\
1,240 \\
726 \\
627 \\
578 \\
701 \\
1,080 \\
9,160 \\
43,400 \\
11,900 \\
4,590 \\
1,990\end{array}$ \\
\hline The year..................... & 1,170 & 8 & 106 & 76,800 \\
\hline $\begin{array}{l}\text { October } \\
\text { November } \\
\text { December } \\
\text { January } \\
\text { February } \\
\text { March } \\
\text { April } \\
\text { May } \\
\text { June } \\
\text { July } \\
\text { August } \\
\text { September }\end{array}$ & $\begin{array}{r}26 \\
25 \\
17 \\
14 \\
16 \\
22 \\
76 \\
375 \\
175 \\
137 \\
168 \\
78\end{array}$ & $\begin{array}{l}16 \\
18 \\
14 \\
12 \\
11 \\
12 \\
14 \\
20 \\
96 \\
35 \\
18 \\
13\end{array}$ & $\begin{array}{c}20.0 \\
18.8 \\
14.3 \\
13.5 \\
12.2 \\
12.9 \\
35.1 \\
139 \\
134 \\
71.9 \\
53.7 \\
21.3\end{array}$ & $\begin{array}{r}1,230 \\
1,120 \\
879 \\
830 \\
678 \\
793 \\
2,090 \\
8,550 \\
7,970 \\
4,420 \\
3,300 \\
1,270\end{array}$ \\
\hline The year & 375 & 11 & 45.8 & 33,100 \\
\hline
\end{tabular}

- Estimated.

TENMILE CREEK NEAR KOKOMO, COYO.

Location.-In sec. 17, T. $6 \mathrm{~S}$., R. $78 \mathrm{~W}$., at bridge at Admiral mine, 8 miles below Kokomo, Summit County.

Drainage area.-67 square miles (measured on Forest Service map).

ReCoRds AVAILABLE.-March 6 to November 20, 1904.

GaGe.-Vertical staff.

Control.-Shifting.

Diversions.-None.

Accuracy.-Gage read twice daily. Rating curve not well defined. Records

fair. 
Monthly discharge of Tenmile Creek near Kokomo, Colo., for 1904

\begin{tabular}{|c|c|c|c|c|}
\hline \multirow{2}{*}{ Month } & \multicolumn{3}{|c|}{ Discharge in second-feet } & \multirow{2}{*}{$\begin{array}{l}\text { Run-off in } \\
\text { acre-feet }\end{array}$} \\
\hline & Maximum & Minimum & Mean & \\
\hline $\begin{array}{l}\text { March } 6-31 \\
\text { April } \\
\text { May } \\
\text { June } \\
\text { July } \\
\text { August } \\
\text { September } \\
\text { Oetober- } \\
\text { November } 1-20\end{array}$ & $\begin{array}{r}16 \\
168 \\
1,060 \\
710 \\
256 \\
135 \\
86 \\
41 \\
25\end{array}$ & $\begin{array}{r}2 \\
1 \\
40 \\
227 \\
80 \\
61 \\
32 \\
18 \\
10\end{array}$ & $\begin{array}{c}5.3 \\
50.4 \\
374 \\
421 \\
149 \\
82.6 \\
45.6 \\
33.3 \\
13.8\end{array}$ & $\begin{array}{r}273 \\
3,000 \\
23,000 \\
25,000 \\
9,160 \\
5,080 \\
2,710 \\
2,050 \\
547\end{array}$ \\
\hline The period...... & & & 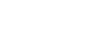 & 70,900 \\
\hline
\end{tabular}

TEN MIIE CREEK AT DILION, COLO.

Location.-In sec. 18, T. 5 S., R. 77 W., at highway bridge 300 yards above mouth, in Dillon, Summit County.

Drainage AREA.-109 square miles (revised; measured on Forest Service map). ReCords available.-October 1, 1910, to September 30, 1919.

GAGE.-Vertical staff.

ConTroL.-Slightly shifting.

Extremes of Discharge.-Maximum stage recorded, 4.25 feet at $6 \mathrm{p}$. m. June 16, 1917 (discharge, 1,630 second-feet); minimum discharge estimated at 2 second-feet February 15-17 and 20, 1918.

Diversions.- Small amount of water diverted from Tenmile Creek above station. ACCURACY.-Gage read at irregular intervals from 1911 to 1914; twice daily for remainder of period. Rating curves well defined. Records from 1911 to 1914 fair; from 1915 to 1919 good except during winter, for which they are fair.

Monthly discharge of Tenmile Creek at Dillon, Colo., for 1910-1919

\begin{tabular}{|c|c|c|c|c|}
\hline \multirow{2}{*}{ Month } & \multicolumn{3}{|c|}{ Discharge in second-feet } & \multirow{2}{*}{$\begin{array}{l}\text { Run-off in } \\
\text { acre-feet }\end{array}$} \\
\hline & Maximum & Minimum & Mean & \\
\hline $1910-11$ & & & & \\
\hline November. & 27 & 20 & $\begin{array}{l}50.0 \\
21.6\end{array}$ & $\begin{array}{l}1,840 \\
1,290\end{array}$ \\
\hline December.. & & & 18 & 1,110 \\
\hline $\begin{array}{l}\text { January } \\
\text { February }\end{array}$ & & ( & 18 & 1,110 \\
\hline Mareh. & & & 31 & $\begin{array}{l}1,390 \\
1,910\end{array}$ \\
\hline April & & & 61.5 & 3,660 \\
\hline May...................... & 1,010 & 69 & 566 & 34,800 \\
\hline June & 1,160 & $\begin{array}{l}289 \\
144\end{array}$ & 704 & 41,900 \\
\hline August................ & 1,110 & $\begin{array}{r}144 \\
69\end{array}$ & $\begin{array}{r}341 \\
98.2\end{array}$ & 6, 040 \\
\hline September........... & & 42 & 55.2 & 3,280 \\
\hline The year- & 1,160 & ... & 164 & 119,000 \\
\hline Oetaher & & & & \\
\hline $\begin{array}{l}\text { October } \\
\text { November..... }\end{array}$ & $\begin{array}{r}115 \\
53\end{array}$ & 42 & $\begin{array}{l}52.8 \\
23.5\end{array}$ & $\begin{array}{l}3,250 \\
1,400\end{array}$ \\
\hline December... & & & 15 & 922 \\
\hline $\begin{array}{l}\text { January } \\
\text { February }\end{array}$ & $\ldots-\ldots$ & & 15 & \\
\hline $\begin{array}{l}\text { Fepruary ... } \\
\text { March }\end{array}$ & & & 100 & 1,230 \\
\hline April & 102 & & 48.8 & 2,900 \\
\hline May & 1,060 & 97 & 437 & 26,900 \\
\hline June & 1,310 & 532 & 788 & 46,900 \\
\hline July & 1,010 & 331 & 537 & $\begin{array}{r}33,000 \\
7,990\end{array}$ \\
\hline September & $\begin{array}{r}289 \\
69\end{array}$ & $\begin{array}{l}68 \\
40\end{array}$ & $\begin{array}{r}130 \\
55.6\end{array}$ & 3,310 \\
\hline The year............. & 1,310 & ..... & 179 & 130,000 \\
\hline
\end{tabular}




\section{Monthly discharge of Tenmile Creek at Dillon, Colo., for 1910-1919-Continued}

\begin{tabular}{|c|c|c|c|c|}
\hline \multirow{2}{*}{ Month } & \multicolumn{3}{|c|}{ Discharge in second-feet } & \multirow{2}{*}{$\begin{array}{l}\text { Run-off in } \\
\text { acre-feet }\end{array}$} \\
\hline & Maximum & Minimum & Mean & \\
\hline $\begin{array}{l}\text { October. } \\
\text { November } \\
\text { December } \\
\text { January } \\
\text { February } \\
\text { Mareh } \\
\text { April } \\
\text { May } \\
\text { June } \\
\text { July } \\
\text { August }\end{array}$ & $\begin{array}{r}53 \\
1,160 \\
715 \\
265 \\
89 \\
129\end{array}$ & $\begin{array}{r}42 \\
177 \\
289 \\
79 \\
42 \\
48\end{array}$ & $\begin{array}{l}43.7 \\
29.6 \\
25 \\
23 \\
23 \\
25 \\
75 \\
435 \\
478 \\
145 \\
57.2 \\
60.0\end{array}$ & $\begin{array}{r}2,690 \\
1,760 \\
1,540 \\
1,410 \\
1,280 \\
1,540 \\
4,460 \\
26,700 \\
28,400 \\
8,920 \\
3,520 \\
3,570\end{array}$ \\
\hline The year. & 1,160 & :- & 119 & 85,800 \\
\hline $\begin{array}{l}\text { October. } \\
\text { November } \\
\text { December } \\
\text { January } \\
\text { February } \\
\text { March } \\
\text { April } \\
\text { May } \\
\text { June } \\
\text { July } \\
\text { August } \\
\text { September }\end{array}$ & \begin{tabular}{rr} 
\\
\hdashline 1,340 \\
1,440 \\
485 \\
184 \\
70
\end{tabular} & $\begin{array}{r}36 \\
\\
\end{array}$ & $\begin{array}{c}44.0 \\
33 \\
27 \\
25 \\
24 \\
22 \\
35 \\
634 \\
1,050 \\
255 \\
96.5 \\
55.5\end{array}$ & $\begin{array}{r}3,700 \\
1,960 \\
1,660 \\
1,540 \\
1,330 \\
1,350 \\
2,080 \\
39,000 \\
62,500 \\
15,700 \\
5,930 \\
3,300\end{array}$ \\
\hline The year.... & 1,440 & 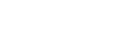 & 192 & 139,000 \\
\hline $\begin{array}{l}\text { October } \\
\text { November } \\
\text { December } \\
\text { January } \\
\text { February } \\
\text { March } \\
\text { April } \\
\text { May } \\
\text { June } \\
\text { July } \\
\text { August } \\
\text { September }\end{array}$ & \begin{tabular}{r}
95 \\
53 \\
\hdashline 92 \\
670 \\
945 \\
400 \\
340 \\
123 \\
\end{tabular} & $\begin{array}{r}43 \\
57 \\
312 \\
90 \\
43 \\
38\end{array}$ & $\begin{array}{l}48.0 \\
45 \\
35 \\
23 \\
25 \\
25 \\
45 \\
320 \\
537 \\
202 \\
85.3 \\
58.3\end{array}$ & $\begin{array}{r}2,950 \\
2,680 \\
2,150 \\
1,410 \\
1,390 \\
1,540 \\
2,680 \\
18,600 \\
32,090 \\
12,400 \\
5,240 \\
3,470\end{array}$ \\
\hline The year & 955 & |- non & 120 & 86,500 \\
\hline $\begin{array}{l}\text { October } \\
\text { November } \\
\text { December. } \\
\text { January } \\
\text { February } \\
\text { March } \\
\text { April } \\
\text { May } \\
\text { June } \\
\text { July } \\
\text { August. } \\
\text { September. }\end{array}$ & $\begin{array}{r}225 \\
690 \\
898 \\
540 \\
192 \\
92\end{array}$ & \begin{tabular}{|r|}
36 \\
35
\end{tabular} & $\begin{array}{c}41.9 \\
36.5 \\
30.8 \\
24.0 \\
25.2 \\
25.8 \\
64.7 \\
325 \\
662 \\
245 \\
117 \\
56.0\end{array}$ & $\begin{array}{r}2,580 \\
2,170 \\
1,890 \\
1,480 \\
1,450 \\
1,590 \\
3,850 \\
20,000 \\
39,400 \\
15,100 \\
7,190 \\
3,330\end{array}$ \\
\hline The year & 898 & 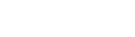 & 138 & 100,000 \\
\hline $\begin{array}{l}\text { October } \\
\text { November. } \\
\text { December. } \\
\text { January } \\
\text { February } \\
\text { Mareh } \\
\text { April } \\
\text { May } \\
\text { June } \\
\text { July } \\
\text { August } \\
\text { September. }\end{array}$ & $\begin{array}{r}64 \\
124 \\
560 \\
1,400 \\
865 \\
151 \\
04\end{array}$ & \begin{tabular}{|r|}
33 \\
\\
26 \\
70 \\
177 \\
170 \\
55 \\
40
\end{tabular} & $\begin{array}{c}48.4 \\
39.9 \\
34.6 \\
30.8 \\
20.6 \\
19.6 \\
50.9 \\
203 \\
884 \\
386 \\
89.4 \\
46.5\end{array}$ & $\begin{array}{r}2,980 \\
2,370 \\
2,130 \\
1,890 \\
1,140 \\
1,210 \\
3,030 \\
12,500 \\
52,600 \\
23,700 \\
5,500 \\
2,770\end{array}$ \\
\hline 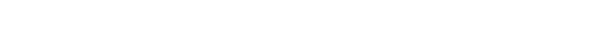 & 1,400 & $\ldots$ & 154 & 112,000 \\
\hline
\end{tabular}


Monthly discharge of Tenmile Creek at Dillon, Colo., for 1910-1919-Continued

\begin{tabular}{|c|c|c|c|c|}
\hline \multirow{2}{*}{ Month } & \multicolumn{3}{|c|}{ Discharge in second-feet } & \multirow{2}{*}{$\begin{array}{l}\text { Run-off in } \\
\text { acre-feet }\end{array}$} \\
\hline & Maximum & Minimum & Mean & \\
\hline $\begin{array}{l}\text { October } \\
\text { November } \\
\text { December } \\
\text { January } \\
\text { February } \\
\text { March } \\
\text { April } \\
\text { May } \\
\text { June } \\
\text { July } \\
\text { August } \\
\text { September }\end{array}$ & \begin{tabular}{|r}
40 \\
39 \\
\\
\\
115 \\
921 \\
1,530 \\
442 \\
110 \\
64
\end{tabular} & $\begin{array}{rr} & 29 \\
29 \\
\end{array}$ & $\begin{array}{r}37.2 \\
31.3 \\
22.8 \\
18.8 \\
9.0 \\
25.1 \\
56.5 \\
466 \\
1,100 \\
243 \\
70.7 \\
57.0\end{array}$ & $\begin{array}{r}2,290 \\
1,860 \\
1,400 \\
1,160 \\
500 \\
1,540 \\
3,360 \\
28,700 \\
65,500 \\
14,900 \\
4,350 \\
3,390\end{array}$ \\
\hline The year..... & 1,530 & $\ldots . .$. & 178 & 129,000 \\
\hline $\begin{array}{l}\text { October } \\
\text { November } \\
\text { December } \\
\text { January } \\
\text { February } \\
\text { March } \\
\text { April } \\
\text { May } \\
\text { June }\end{array}$ & $\begin{array}{r}64 \\
48 \\
27 \\
314 \\
738 \\
372 \\
324 \\
155 \\
127\end{array}$ & $\begin{array}{r}22 \\
35 \\
127 \\
190 \\
85 \\
49 \\
43\end{array}$ & $\begin{array}{c}50.2 \\
37.6 \\
25 \\
23 \\
23 \\
24.7 \\
108 \\
402 \\
273 \\
161 \\
76.9 \\
55.8\end{array}$ & $\begin{array}{r}3,090 \\
2,240 \\
1,540 \\
1,410 \\
1,280 \\
1,520 \\
6,430 \\
24,700 \\
16,200 \\
9,900 \\
4,730 \\
3,320\end{array}$ \\
\hline The year. & 738 & $\ldots$ & 106 & 76,400 \\
\hline
\end{tabular}

NoTE. $\rightarrow$ Mean discharge for winter based on current-meter measurements, gage heights, and temperature records.

\section{MODDY CREEK AT KREMMLING, COLO.}

Location.-In sec. 7, T. 1 N., R. 80 W., at highway bridge just west of Kremm-

ling, Grand County. No tributary between station and mouth.

Drainage area.-Not measured.

Records available.-July 25, 1904, to September 30, 1905.

GAGE.-Vertical staff.

Control.-Fairly permanent.

Accuracr.-Records good.

Monthly discharge of Muddy Creek at Kremmling, Colo., for 1904-5

\begin{tabular}{|c|c|c|c|c|}
\hline \multirow{2}{*}{ Month } & \multicolumn{3}{|c|}{ Discharge in second-feet } & \multirow{2}{*}{$\begin{array}{l}\text { Run-offi in } \\
\text { acre-feet }\end{array}$} \\
\hline & Maximum & Minimum & Mean & \\
\hline $\begin{array}{l}\text { July } 25-31 \\
\text { August } \\
\text { September }\end{array}$ & $\begin{array}{c}8 \\
29 \\
36.4 \\
\end{array}$ & $\begin{array}{l}5.6 \\
5 \\
5\end{array}$ & $\begin{array}{r}6.9 \\
11.4 \\
14.8\end{array}$ & $\begin{array}{r}96 \\
701 \\
881\end{array}$ \\
\hline $\begin{array}{l}\text { April_... } \\
\text { May } \\
\text { June } \\
\text { Jury } \\
\text { August } \\
\text { September }\end{array}$ & $\begin{array}{r}19 \\
308 \\
772 \\
696 \\
44 \\
16 \\
7\end{array}$ & $\begin{array}{r}8 \\
38 \\
186 \\
50 \\
7 \\
3 \\
.5\end{array}$ & $\begin{array}{c}13 \\
121 \\
408 \\
337 \\
14 \\
7.1 \\
2.7\end{array}$ & $\begin{array}{r}799 \\
7,200 \\
25,100 \\
20,000 \\
861 \\
436 \\
161\end{array}$ \\
\hline
\end{tabular}




\section{FAGLE RIVER AT RRDCLIFF, COLO.}

Location.-In sec. 29, T. 6 S., R. 80 W., at footbridge in Redcliff; Eagle Countùt.

Nearest tributary, Turkey Creek, enters 100 yards below station; Homestake

Creek enters 1 mile downstream.

Drainage AREA.-74 square miles (measured on topographic map).

Records avatrable.-October 1, 1910, to September 30, 1925.

GAGE.-Chain and vertical staff.

CoNTRoL.-Shifting at long intervals.

EXTREMms OF DISCHARge.--Maximum stage recorded, 4.0 feet on June 5, 1912

(discharge, 1,010 second-feet); minimum stage, 0.01 foot at $7 \mathrm{a}$. m. October

15, 1917 (discharge, 1 second-foot).

ICE.-Stage-discharge relation practically unaffected by ice.

Drversion.--Ewing ditch diverts water from headwaters of Eagle River to

Arkansas River basin (see p. - for amount diverted each year). Very

little land irrigated above station.

Regulation.-Filling of Pando ice pond in fall reduces flow for a few days.

Accuracy.-Gage read twice daily. Rating curves well defined. Records good,

except during estimated periods, for which they are fair.

Monthly discharge of Eagle River at Redcliff, Colo., 1910-1925

\begin{tabular}{|c|c|c|c|c|}
\hline \multirow{2}{*}{ Month } & \multicolumn{3}{|c|}{ Discharge in second-feet } & \multirow{2}{*}{$\begin{array}{l}\text { Run-off in } \\
\text { acre-feet }\end{array}$} \\
\hline & Maximum & Minimum & Mean & \\
\hline $\begin{array}{l}\text { October } \\
\text { November } \\
\text { December } \\
\text { January } \\
\text { February. } \\
\text { March } \\
\text { April. } \\
\text { May } \\
\text { Ju yu } \\
\text { Aulgust. } \\
\text { September }\end{array}$ & $\begin{array}{r}13 \\
12 \\
20 \\
205 \\
850 \\
750 \\
390 \\
80 \\
40\end{array}$ & $\begin{array}{c}8.8 \\
9.0 \\
10 \\
20 \\
128 \\
90 \\
54 \\
28 \\
20\end{array}$ & $\begin{array}{r}\text { c } 20 \\
\text { c } 15 \\
\text { c } 12 \\
9.9 \\
10.5 \\
13.9 \\
64.9 \\
386 \\
298 \\
107 \\
35.0 \\
24.1\end{array}$ & $\begin{array}{r}1,230 \\
893 \\
738 \\
614 \\
583 \\
855 \\
3,860 \\
23,700 \\
17,700 \\
6,580 \\
2,150 \\
1,430\end{array}$ \\
\hline The year.......... & 850 & 8.8 & 83.1 & 60,300 \\
\hline $\begin{array}{l}\text { October } \\
\text { November } \\
\text { December } \\
\text { January } \\
\text { February } \\
\text { March } \\
\text { April } \\
\text { May } \\
\text { June } \\
\text { July } \\
\text { August } \\
\text { September }\end{array}$ & $\begin{array}{r}54 \\
28 \\
15 \\
13 \\
19 \\
15 \\
95 \\
875 \\
900 \\
150 \\
62 \\
30\end{array}$ & $\begin{array}{r}14 \\
12 \\
9 \\
12 \\
10 \\
12 \\
14 \\
90 \\
140 \\
62 \\
28 \\
11\end{array}$ & $\begin{array}{l}22.0 \\
17.0 \\
12.6 \\
12.5 \\
12.7 \\
12.7 \\
33.7 \\
384 \\
422 \\
87.4 \\
38.6 \\
25.0\end{array}$ & $\begin{array}{r}1,350 \\
1,010 \\
775 \\
769 \\
730 \\
781 \\
2,010 \\
23,600 \\
25,100 \\
5,370 \\
2,370 \\
1,490\end{array}$ \\
\hline The year & 900 & 9 & 20.3 & 65,400 \\
\hline $\begin{array}{l}\text { Oetober } \\
\text { November } \\
\text { December } \\
\text { January } \\
\text { February } \\
\text { March } \\
\text { April } \\
\text { May } \\
\text { June } \\
\text { July } \\
\text { August } \\
\text { September }\end{array}$ & $\begin{array}{r}28 \\
24 \\
180 \\
390 \\
370 \\
78 \\
31 \\
34\end{array}$ & \begin{tabular}{|c|}
22 \\
17 \\
\hdashline \\
\\
\hdashline 98 \\
78 \\
34 \\
18 \\
18 \\
\end{tabular} & $\begin{array}{l}27.0 \\
20.4 \\
\text { a } 15 \\
\text { a } 12 \\
\text { a } 10 \\
\text { a } 15 \\
65 \\
235 \\
180 \\
54.3 \\
54.9 \\
23.9 \\
23.3\end{array}$ & $\begin{array}{r}1,660 \\
1,210 \\
922 \\
738 \\
555 \\
922 \\
2,800 \\
14,400 \\
10,700 \\
3,340 \\
1,530 \\
1,390\end{array}$ \\
\hline & 390 & 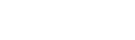 & 57 & 41,300 \\
\hline
\end{tabular}

. Estimated. 
Monthly discharge of Eagle River at Redcliff, Colo., 1910-1925-Continued

\begin{tabular}{|c|c|c|c|c|}
\hline \multirow{2}{*}{ Month } & \multicolumn{3}{|c|}{ Discharge in second-feet } & \multirow{2}{*}{$\begin{array}{l}\text { Run-off in } \\
\text { acre-feet }\end{array}$} \\
\hline & Maximum & Minimum & Mean & \\
\hline $\begin{array}{l}\text { October } \\
\text { November. } \\
\text { December } \\
\text { January } \\
\text { February } \\
\text { March } \\
\text { A pril } \\
\text { May } \\
\text { June } \\
\text { July } \\
\text { August } \\
\text { September }\end{array}$ & $\begin{array}{r}38 \\
18 \\
18 \\
12 \\
24 \\
155 \\
750 \\
750 \\
119 \\
53 \\
33\end{array}$ & $\begin{array}{r}3 \\
12 \\
4 \\
7 \\
4 \\
17 \\
72 \\
120 \\
43 \\
26 \\
20\end{array}$ & $\begin{array}{r}18.7 \\
13.7 \\
8.7 \\
9.1 \\
10.2 \\
12.1 \\
52.8 \\
353 \\
353 \\
69.3 \\
33.9 \\
23.5\end{array}$ & $\begin{array}{r}1,150 \\
815 \\
537 \\
560 \\
566 \\
744 \\
3,140 \\
21,700 \\
21,000 \\
4,260 \\
2,080 \\
1,400\end{array}$ \\
\hline The year & 750 & 3 & 80.1 & 58,000 \\
\hline $\begin{array}{l}\text { October } \\
\text { November } \\
\text { December } \\
\text { January } \\
\text { February } \\
\text { Mareh } \\
\text { A pril } \\
\text { May } \\
\text { June } \\
\text { July } \\
\text { August } \\
\text { September }\end{array}$ & $\begin{array}{r}34 \\
23 \\
14 \\
8 \\
11 \\
15 \\
156 \\
298 \\
375 \\
86 \\
67 \\
23\end{array}$ & $\begin{array}{r}4 \\
5 \\
4 \\
3 \\
5 \\
8 \\
15 \\
57 \\
93 \\
36 \\
23 \\
2\end{array}$ & $\begin{array}{r}18.8 \\
14.4 \\
7.5 \\
5.3 \\
8.9 \\
11.5 \\
51.8 \\
146 \\
194 \\
54.1 \\
30.9 \\
15.4\end{array}$ & $\begin{array}{r}1,160 \\
857 \\
461 \\
326 \\
494 \\
707 \\
3,080 \\
8,980 \\
11,500 \\
3,330 \\
1,900 \\
916\end{array}$ \\
\hline The year & 375 & 2 & 46.6 & 33,700 \\
\hline $\begin{array}{l}\text { October } \\
\text { November } \\
\text { December. } \\
\text { January } \\
\text { February } \\
\text { March } \\
\text { April } \\
\text { May } \\
\text { June } \\
\text { July } \\
\text { August } \\
\text { September }\end{array}$ & $\begin{array}{r}21 \\
16 \\
15 \\
16 \\
37 \\
39 \\
208 \\
550 \\
470 \\
127 \\
64 \\
38\end{array}$ & $\begin{array}{r}14 \\
5 \\
12 \\
10 \\
12 \\
15 \\
27 \\
147 \\
137 \\
43 \\
24 \\
22\end{array}$ & $\begin{array}{l}18.0 \\
11.6 \\
13.1 \\
13.2 \\
19.7 \\
25.6 \\
81.3 \\
246 \\
278 \\
79.4 \\
37.1 \\
26.0\end{array}$ & $\begin{array}{r}1,110 \\
690 \\
800 \\
812 \\
1,170 \\
1,570 \\
4,840 \\
15,100 \\
16,500 \\
4,880 \\
2,280 \\
1,550\end{array}$ \\
\hline 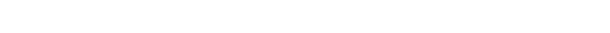 & 550 & 5 & 70.7 & 51,300 \\
\hline $\begin{array}{l}\text { October } \\
\text { November } \\
\text { December } \\
\text { January } \\
\text { February } \\
\text { March } \\
\text { April } \\
\text { May } \\
\text { June } \\
\text { July } \\
\text { August } \\
\text { September }\end{array}$ & $\begin{array}{r}26 \\
20 \\
19 \\
19 \\
17 \\
27 \\
144 \\
303 \\
635 \\
220 \\
49 \\
21\end{array}$ & $\begin{array}{r}19 \\
6 \\
16 \\
13 \\
12 \\
13 \\
13 \\
52 \\
168 \\
55 \\
20 \\
15\end{array}$ & $\begin{array}{c}22.3 \\
15.0 \\
18.3 \\
15.6 \\
15.2 \\
15.9 \\
60.9 \\
140 \\
405 \\
114 \\
28.4 \\
17.4\end{array}$ & $\begin{array}{r}1,370 \\
893 \\
1,130 \\
959 \\
844 \\
978 \\
3,620 \\
8,610 \\
24,100 \\
7,010 \\
1,750 \\
1,040\end{array}$ \\
\hline The year & 635 & 6 & 72.2 & 52,300 \\
\hline $\begin{array}{l}\text { October } \\
\text { November } \\
\text { December } \\
\text { January } \\
\text { February } \\
\text { March } \\
\text { April } \\
\text { May } \\
\text { June } \\
\text { July } \\
\text { August } \\
\text { September }\end{array}$ & $\begin{array}{r}17 \\
16 \\
16 \\
20 \\
16 \\
38 \\
94 \\
677 \\
631 \\
186 \\
38 . \\
41\end{array}$ & $\begin{array}{r}1 \\
8 \\
9 \\
11 \\
10 \\
11 \\
26 \\
81 \\
196 \\
38 \\
24 \\
24\end{array}$ & $\begin{array}{c}11.0 \\
13.3 \\
13.2 \\
16.3 \\
11.8 \\
18.5 \\
49.8 \\
346 \\
406 \\
99.3 \\
29.4 \\
28.9\end{array}$ & $\begin{array}{r}676 \\
791 \\
812 \\
1,000 \\
655 \\
1,140 \\
2,960 \\
21,300 \\
24,900 \\
6,110 \\
1,810 \\
1,720\end{array}$ \\
\hline The year................... & $\cdots \cdots 677$ & $-\cdots$ & 87.1 & 63,200 \\
\hline
\end{tabular}

- Estimated. 
Monthly discharge of Eagle River at Redcliff, Colo., 1910-1925-Continued

\begin{tabular}{|c|c|c|c|c|}
\hline \multirow{2}{*}{ Month } & \multicolumn{3}{|c|}{ Discharge in second-feet } & \multirow{2}{*}{$\begin{array}{l}\text { Run-off in } \\
\text { acre-feet }\end{array}$} \\
\hline & Maximum & Minimum & Mean & \\
\hline $\begin{array}{l}\text { October } \\
\text { November } \\
\text { December } \\
\text { January } \\
\text { February } \\
\text { March } \\
\text { April } \\
\text { May } \\
\text { June } \\
\text { July } \\
\text { August } \\
\text { September }\end{array}$ & $\begin{array}{r}28 \\
24 \\
16 \\
14 \\
180 \\
380 \\
260 \\
116 \\
85\end{array}$ & $\begin{array}{r}20 \\
5 \\
7 \\
11 \\
18 \\
122 \\
73 \\
27 \\
21 \\
\end{array}$ & $\begin{array}{c}24.6 \\
18.0 \\
12.2 \\
13.2 \\
13.0 \\
15.0 \\
72.9 \\
246 \\
148 \\
56.9 \\
35.5 \\
28\end{array}$ & $\begin{array}{r}1,510 \\
1,070 \\
750 \\
812 \\
72 \\
922 \\
4,340 \\
15,100 \\
8,810 \\
3,500 \\
2,180 \\
1,670\end{array}$ \\
\hline The year. & 380 & 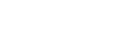 & 57.2 & 41,400 \\
\hline $\begin{array}{l}\text { October. } \\
\text { November } \\
\text { December } \\
\text { January } \\
\text { February } \\
\text { March } \\
\text { Aprif } \\
\text { May } \\
\text { June } \\
\text { July } \\
\text { August } \\
\text { September }\end{array}$ & $\begin{array}{r}24 \\
32 \\
14 \\
14 \\
11 \\
23 \\
26 \\
617 \\
617 \\
151 \\
62 \\
30\end{array}$ & \begin{tabular}{r|}
3.2 \\
4.6 \\
11 \\
9.2 \\
7.6 \\
7.4 \\
10 \\
37 \\
162 \\
55 \\
30 \\
20
\end{tabular} & $\begin{array}{r}15.8 \\
14.3 \\
13.3 \\
11.2 \\
9.7 \\
11.2 \\
18.1 \\
313 \\
312 \\
89.2 \\
36.4 \\
27.7\end{array}$ & $\begin{array}{r}972 \\
851 \\
818 \\
689 \\
558 \\
689 \\
1,080 \\
19,200 \\
18,600 \\
5,480 \\
2,240 \\
1,650\end{array}$ \\
\hline The year & 617 & 3.2 & 72.8 & 52,800 \\
\hline $\begin{array}{l}\text { October } \\
\text { November } \\
\text { December. } \\
\text { January } \\
\text { February } \\
\text { March } \\
\text { April } \\
\text { May } \\
\text { June } \\
\text { July } \\
\text { August } \\
\text { September }\end{array}$ & $\begin{array}{r}20 \\
13 \\
12 \\
16 \\
34 \\
41 \\
620 \\
700 \\
\end{array}$ & $\begin{array}{r}\mid \begin{array}{r}13 \\
8\end{array} \\
10 \\
8 \\
7 \\
10 \\
52 \\
144 \\
\\
\end{array}$ & $\begin{array}{c}16.7 \\
9 \\
a 9 \\
11.5 \\
11.2 \\
12.8 \\
22.6 \\
290 \\
383 \\
\text { a } 83 \\
\text { a } 43 \\
\text { a } 39\end{array}$ & $\begin{array}{r}1,030 \\
536 \\
553 \\
707 \\
622 \\
787 \\
1,340 \\
17,800 \\
22,800 \\
5,100 \\
2,640 \\
2,320\end{array}$ \\
\hline The year.... & 700 & 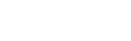 & 77.8 & 56,200 \\
\hline $\begin{array}{l}\text { October } \\
\text { November } \\
\text { December } \\
\text { January } \\
\text { February } \\
\text { March } \\
\text { April } \\
\text { May } \\
\text { June } \\
\text { July } \\
\text { August } \\
\text { September }\end{array}$ & $\begin{array}{r}24 \\
22 \\
19 \\
15 \\
16 \\
22 \\
80 \\
400 \\
272 \\
89 \\
69 \\
\quad 25\end{array}$ & $\begin{array}{r}9 \\
19 \\
6 \\
12 \\
12 \\
12 \\
15 \\
92 \\
90 \\
26 \\
22 \\
15\end{array}$ & $\begin{array}{r}19.4 \\
19.5 \\
14.6 \\
13.8 \\
13.1 \\
15.8 \\
\quad \mathbf{3 7 . 3} \\
\mathbf{1 8 4} \\
\mathbf{1 8 2} \\
\quad 52.4 \\
\mathbf{3 3 . 3} \\
\mathbf{1 8 . 0}\end{array}$ & $\begin{array}{r}1,190 \\
1,160 \\
898 \\
848 \\
7 \mathbf{7 2 8} \\
\mathbf{9 7 2} \\
\mathbf{2}, \mathbf{2 0 0} \\
11,300 \\
10,800 \\
3,220 \\
2,050 \\
1,070\end{array}$ \\
\hline The year.......... & 400 & 6 & 50.4 & 36,500 \\
\hline $\begin{array}{l}\text { Oetober } \\
\text { November } \\
\text { December. } \\
\text { January } \\
\text { February } \\
\text { March } \\
\text { April } \\
\text { May } \\
\text { June } \\
\text { July } \\
\text { August } \\
\text { September }\end{array}$ & $\begin{array}{r}17 \\
15 \\
14 \\
17 \\
18 \\
18 \\
89 \\
370 \\
528 \\
142 \\
58 \\
40\end{array}$ & $\begin{array}{r}5 \\
10 \\
8 \\
9 \\
15 \\
14 \\
16 \\
89 \\
150 \\
51 \\
22 \\
20\end{array}$ & $\begin{array}{c}13.0 \\
13.5 \\
11.9 \\
14.2 \\
17.1 \\
16.3 \\
40.7 \\
187 \\
361 \\
97.4 \\
43.1 \\
25.2\end{array}$ & $\begin{array}{r}790 \\
803 \\
732 \\
873 \\
950 \\
1,000 \\
2,420 \\
11,500 \\
21,500 \\
5,890 \\
2,650 \\
1,500\end{array}$ \\
\hline 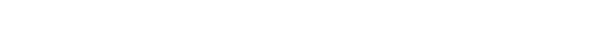 & 528 & 5 & 70.1 & 50,700 \\
\hline
\end{tabular}

- Estimatcd. 
Monthly discharge of Eagle River at Redcliff, Colo., 1910-1925-Continued

\begin{tabular}{|c|c|c|c|c|}
\hline \multirow{2}{*}{ Month } & \multicolumn{3}{|c|}{ Discharge in second-feet } & \multirow{2}{*}{$\begin{array}{l}\text { Run-off in } \\
\text { acre-feet }\end{array}$} \\
\hline & Maximum & Minimum & Mean & \\
\hline $\begin{array}{l}\text { October } \\
\text { November } \\
\text { December } \\
\text { January } \\
\text { February } \\
\text { March } \\
\text { April } \\
\text { May } \\
\text { June } \\
\text { July } \\
\text { August } \\
\text { September }\end{array}$ & $\begin{array}{r}26 \\
22 \\
19 \\
15 \\
15 \\
12 \\
107 \\
325 \\
420 \\
99 \\
30 \\
22\end{array}$ & $\begin{array}{r}6 \\
14 \\
13 \\
12 \\
10 \\
10 \\
14 \\
56 \\
99 \\
30 \\
18 \\
8\end{array}$ & $\begin{array}{c}16.9 \\
17.2 \\
14.7 \\
12.9 \\
12.1 \\
11.5 \\
50.2 \\
206 \\
231 \\
60.8 \\
21.8 \\
17.8\end{array}$ & $\begin{array}{r}1,040 \\
1,020 \\
904 \\
793 \\
696 \\
707 \\
2,990 \\
12,700 \\
13,700 \\
3,740 \\
1,340 \\
1,060\end{array}$ \\
\hline The year. & 420 & 6 & 56.0 & 40,700 \\
\hline $\begin{array}{l}\text { October } \\
\text { November } \\
\text { December } \\
\text { January } \\
\text { February } \\
\text { March } \\
\text { April } \\
\text { May } \\
\text { June } \\
\text { July } \\
\text { August } \\
\text { September }\end{array}$ & $\begin{array}{r}29 \\
26 \\
20 \\
15 \\
12 \\
36 \\
79 \\
308 \\
252 \\
87 \\
36 \\
29\end{array}$ & $\begin{array}{r}7 \\
11 \\
11 \\
11 \\
10 \\
9 \\
28 \\
93 \\
89 \\
24 \\
21 \\
20\end{array}$ & $\begin{array}{c}22.4 \\
17.4 \\
13.8 \\
12.5 \\
10.8 \\
15.6 \\
55.9 \\
191 \\
149 \\
50.7 \\
24.9 \\
23.3\end{array}$ & $\begin{array}{r}1,380 \\
1,040 \\
848 \\
796 \\
600 \\
959 \\
3,330 \\
11,700 \\
8,870 \\
3,120 \\
1,530 \\
1,390\end{array}$ \\
\hline The year. & 308 & 7 & 49.1 & 35,500 \\
\hline
\end{tabular}

EAGLE RIVER AT EAGLE, COLO.

Location.-In sec. 33, T. 4 S., R. 84 W:, 500 feet below highway bridge in Eagle, Eagle County. Nearest tributary, Brush Creek, enters threequarters of a mile downstream.

Drainage area. - 650 square miles (measured on base map of Colorado).

ReCORDS A FarlaBLE.-October 1, 1910, to September 30, 1924.

GAGE.-Gurley water-stage recorder installed April 5, 1919. Prior to that date, chain gage on highway bridge.

CoN'rRoL.-Shifting at present site; permanent at original site.

Extremes of Discharge.-Maximum stage recorded, 6.3 feet at 6 a. m. June 3, 1914 (discharge, 6,760 second-feet); minimum discharge recorded, 61 secondfeet January 18, 1911.

Diversions.-Water diverted for irrigation of 2,700 acres from Eagle River and 16,000 acres from tributaries, chiefly between Redeliff and Eagle.

ACCURACY.-Gage read once daily prior to 1919, continuous gage-height record since that date. Rating curves well defined. Records prior to 1919 fair; for remainder of period good, except during winter, for which they are fair. 
Monthly discharge of Eagle River at Eagle, Colo., for 1910-1924

\begin{tabular}{|c|c|c|c|c|}
\hline \multirow{2}{*}{ Month } & \multicolumn{3}{|c|}{ Discharge in second-feet } & \multirow{2}{*}{$\begin{array}{l}\text { Run-off in } \\
\text { acre-feet }\end{array}$} \\
\hline & Maximum & Minimum & Mean & \\
\hline $\begin{array}{l}\text { October } \\
\text { November } \\
\text { December } \\
\text { January } \\
\text { February } \\
\text { March } \\
\text { April } \\
\text { May } \\
\text { June } \\
\text { July } \\
\text { Augustite } \\
\text { September }\end{array}$ & $\begin{array}{r}95 \\
137 \\
1,090 \\
2,600 \\
2,790 \\
625 \\
336\end{array}$ & $\begin{array}{r}60 \\
90 \\
146 \\
1,180 \\
1,180 \\
555 \\
300 \\
205\end{array}$ & $\begin{array}{c}180 \\
\times 140 \\
<90 \\
\times 60 \\
74.8 \\
111 \\
403 \\
1,950 \\
2,250 \\
831 \\
406 \\
258\end{array}$ & $\begin{array}{r}11,100 \\
8,330 \\
5,530 \\
3,690 \\
4,150 \\
6,820 \\
24,000 \\
120,000 \\
134,000 \\
51,100 \\
25,000 \\
15,400\end{array}$ \\
\hline The & 2,790 & -........ & 409 & 409,000 \\
\hline $\begin{array}{l}\text { October } \\
\text { November } \\
\text { December } \\
\text { January } \\
\text { February } \\
\text { March } \\
\text { April } \\
\text { May } \\
\text { June } \\
\text { July } \\
\text { August } \\
\text { September }\end{array}$ & $\begin{array}{r}300 \\
255 \\
225 \\
- \\
140 \\
525 \\
3,800 \\
4,300 \\
3,100 \\
1,900 \\
275\end{array}$ & $\begin{array}{r}210 \\
230 \\
105 \\
125 \\
562 \\
2,200 \\
1,810 \\
198 \\
140\end{array}$ & $\begin{array}{r}237 \\
246 \\
165 \\
100 \\
90 \\
106 \\
275 \\
1,630 \\
3,370 \\
\mathbf{2}, \mathbf{3 4 0} \\
\mathbf{5 1 2} \\
180\end{array}$ & $\begin{array}{r}14,600 \\
14,600 \\
10,100 \\
6,150 \\
5,180 \\
6,520 \\
16,400 \\
100,000 \\
201,000 \\
144,000 \\
81,500 \\
10,700\end{array}$ \\
\hline The year........... & $4,300^{\prime}$ & - & 774 & 561,000 \\
\hline $\begin{array}{l}\text { October } \\
\text { Novemaber } \\
\text { December } \\
\text { January } \\
\text { February } \\
\text { March } \\
\text { April } \\
\text { May } \\
\text { June } \\
\text { July } \\
\text { August } \\
\text { September }\end{array}$ & $\begin{array}{r}1,000 \\
3,550 \\
3,410 \\
1,550 \\
490 \\
385\end{array}$ & $\begin{array}{r}156 \\
190 \\
1,180 \\
490 \\
251 \\
208 \\
\end{array}$ & $\begin{array}{r}200 \\
184 \\
120 \\
100 \\
100 \\
140 \\
439 \\
1,890 \\
2,040 \\
959 \\
342 \\
312\end{array}$ & $\begin{array}{r}12,300 \\
10,900 \\
7,380 \\
6,150 \\
5,550 \\
8,610 \\
26,100 \\
116,000 \\
121,000 \\
59,000 \\
21,000 \\
18,600\end{array}$ \\
\hline The year............. & 3,550 & $\ldots \ldots \ldots$ & 572 & 413,000 \\
\hline $\begin{array}{l}\text { Oetober- } \\
\text { November } \\
\text { December } \\
\text { January } \\
\text { February } \\
\text { March } \\
\text { A pril } \\
\text { May } \\
\text { June } \\
\text { July } \\
\text { Angust } \\
\text { September }\end{array}$ & $\begin{array}{r}385 \\
295 \\
\\
\\
650 \\
6,010 \\
6,610 \\
2,070 \\
1,180 \\
435 \\
\end{array}$ & $\begin{array}{r}295 \\
146 \\
\\
\\
251 \\
615 \\
1,860 \\
1,000 \\
410 \\
318 \\
\end{array}$ & $\begin{array}{r}330 \\
220 \\
125 \\
100 \\
100 \\
130 \\
425 \\
2,750 \\
3,910 \\
1,440 \\
574 \\
370\end{array}$ & $\begin{array}{r}20,300 \\
13,100 \\
7,600 \\
6,150 \\
5,050 \\
8,000 \\
25,300 \\
169,000 \\
233,000 \\
88,600 \\
35,300 \\
22,000\end{array}$ \\
\hline The year & 6,610 & - & 877 & 684,000 \\
\hline $\begin{array}{l}\text { Oetober } \\
\text { November } \\
\text { December } \\
\text { January } \\
\text { February } \\
\text { March } \\
\text { April } \\
\text { May } \\
\text { June } \\
\text { July } \\
\text { Auguste } \\
\text { September }\end{array}$ & $\begin{array}{r}126 \\
1,160 \\
2,220 \\
3,760 \\
1,860 \\
940 \\
338\end{array}$ & $\begin{array}{r}251 \\
109 \\
128 \\
314 \\
1,310 \\
338 \\
147 \\
147\end{array}$ & $\begin{array}{r}302 \\
190 \\
110 \\
100 \\
100 \\
118 \\
334 \\
1,220 \\
2,570 \\
1,090 \\
326 \\
184\end{array}$ & $\begin{array}{r}18,600 \\
11,300 \\
6,760 \\
6,150 \\
5,530 \\
7,200 \\
19,900 \\
75,000 \\
153,000 \\
67,000 \\
20000 \\
10,000\end{array}$ \\
\hline & 3,760 & - & 554 & 401,000 \\
\hline
\end{tabular}

- Estimated. 
Monthly discharge of Eagle River at Eagle, Colo., for 1910-1924-Continued

\begin{tabular}{|c|c|c|c|c|}
\hline \multirow{2}{*}{ Month } & \multicolumn{3}{|c|}{ Discharge in second-feet } & \multirow{2}{*}{$\begin{array}{l}\text { Run-off in } \\
\text { acre-feet }\end{array}$} \\
\hline & Maximum & Minimum & Mean & \\
\hline $\begin{array}{l}\text { October } \\
\text { November } \\
\text { December } \\
\text { January } \\
\text { February } \\
\text { March } \\
\text { April } \\
\text { May } \\
\text { June } \\
\text { July } \\
\text { August } \\
\text { September }\end{array}$ & \begin{tabular}{r|}
265 \\
158 \\
1,160 \\
3,110 \\
3,760 \\
2,660 \\
1,120 \\
400
\end{tabular} & $\begin{array}{r}158 \\
147 \\
195 \\
748 \\
2,220 \\
988 \\
400 \\
188\end{array}$ & $\begin{array}{r}197 \\
153 \\
120 \\
100 \\
95 \\
180 \\
451 \\
1,740 \\
2,990 \\
1,480 \\
708 \\
275\end{array}$ & $\begin{array}{r}12,100 \\
9,100 \\
7,380 \\
6,150 \\
54,600 \\
11,100 \\
26,800 \\
107,000 \\
178,000 \\
91,000 \\
43,500 \\
16,400\end{array}$ \\
\hline The year............. & 3,760 & 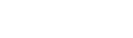 & 710 & 514,000 \\
\hline $\begin{array}{l}\text { October. } \\
\text { November } \\
\text { December } \\
\text { January } \\
\text { February. } \\
\text { March } \\
\text { April } \\
\text { May } \\
\text { June } \\
\text { July } \\
\text { August } \\
\text { September }\end{array}$ & \begin{tabular}{r|r|}
328 \\
265 \\
217 \\
785 \\
2,590 \\
6,300 \\
4,480 \\
785 \\
390
\end{tabular} & $\begin{array}{r}180 \\
142 \\
380 \\
988 \\
865 \\
305 \\
217\end{array}$ & $\begin{array}{r}260 \\
185 \\
110 \\
100 \\
90 \\
120 \\
369 \\
1,160 \\
4,190 \\
2,150 \\
470 \\
288\end{array}$ & $\begin{array}{r}16,000 \\
11,000 \\
6,760 \\
6,150 \\
5,000 \\
7,380 \\
22,000 \\
71,300 \\
249,000 \\
132,000 \\
28,000 \\
17,100\end{array}$ \\
\hline The year............... & 6,300 & -................ & 792 & 573,000 \\
\hline $\begin{array}{l}\text { October } \\
\text { November } \\
\text { December } \\
\text { January } \\
\text { February } \\
\text { March } \\
\text { April } \\
\text { May } \\
\text { June } \\
\text { July } \\
\text { August } \\
\text { September }\end{array}$ & $\begin{array}{r}221 \\
182 \\
281 \\
608 \\
3,370 \\
6,300 \\
2,800 \\
400 \\
455\end{array}$ & \begin{tabular}{r|r|}
163 \\
152 \\
227 \\
455 \\
1,980 \\
375 \\
165 \\
161
\end{tabular} & $\begin{array}{r}175 \\
167 \\
120 \\
100 \\
100 \\
165 \\
377 \\
2,110 \\
4,510 \\
1,120 \\
269 \\
262\end{array}$ & $\begin{array}{r}10,800 \\
9,940 \\
7,380 \\
6,150 \\
5,550 \\
10,100 \\
22,400 \\
130,000 \\
168,000 \\
68,900 \\
16,500 \\
15,600\end{array}$ \\
\hline 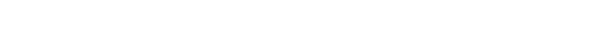 & 6,300 & 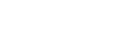 & 788 & 571,000 \\
\hline $\begin{array}{l}\text { October } \\
\text { November } \\
\text { December. } \\
\text { January } \\
\text { February. } \\
\text { March } \\
\text { April } \\
\text { May } \\
\text { June } \\
\text { July } \\
\text { August } \\
\text { September }\end{array}$ & $\begin{array}{r}208 \\
1,210 \\
3,240 \\
2,220 \\
1,120 \\
590 \\
\mathbf{3 6 4}\end{array}$ & \begin{tabular}{|r|}
156 \\
203 \\
748 \\
945 \\
413 \\
210 \\
150
\end{tabular} & $\begin{array}{r}183 \\
150 \\
110 \\
100 \\
90 \\
150 \\
486 \\
1,880 \\
1,350 \\
645 \\
352 \\
255\end{array}$ & $\begin{array}{r}11,300 \\
8,930 \\
6,760 \\
6,150 \\
\mathbf{5}, 000 \\
9,220 \\
28,900 \\
116,000 \\
80,300 \\
39,700 \\
21,600 \\
15,200\end{array}$ \\
\hline The year. & 3,240 & 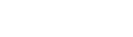 & 483 & 349,000 \\
\hline $\begin{array}{l}\text { October } \\
\text { November. } \\
\text { December } \\
\text { January } \\
\text { February } \\
\text { March } \\
\text { April } \\
\text { May } \\
\text { June } \\
\text { July } \\
\text { August } \\
\text { September }\end{array}$ & $\begin{array}{r}208 \\
165 \\
114 \\
179 \\
272 \\
4,550 \\
5,000 \\
2,400 \\
799 \\
325\end{array}$ & $\begin{array}{r}145 \\
95 \\
85 \\
92 \\
108 \\
294 \\
2,040 \\
673 \\
319 \\
230\end{array}$ & $\begin{array}{r}183 \\
125 \\
109 \\
103 \\
106 \\
114 \\
182 \\
2,000 \\
3,430 \\
1,220 \\
475 \\
264\end{array}$ & $\begin{array}{r}11,300 \\
7,440 \\
6,700 \\
6,330 \\
5,750 \\
7,010 \\
10,800 \\
123,000 \\
204,000 \\
75,000 \\
29,200 \\
15,700\end{array}$ \\
\hline The year. & 5,000 & 85 & 692 & 502,000 \\
\hline
\end{tabular}


Monthly discharge of Eagle River at Eagle, Colo., for 1910-1924-Continued

\begin{tabular}{|c|c|c|c|c|}
\hline \multirow{2}{*}{ Month } & \multicolumn{3}{|c|}{ Discharge in second-leet } & \multirow{2}{*}{$\begin{array}{l}\text { Run-off in } \\
\text { acre-feet }\end{array}$} \\
\hline & Maximum & Minimum & Mean & \\
\hline $\begin{array}{l}\text { October } \\
\text { November } \\
\text { December } \\
\text { January } \\
\text { February } \\
\text { March } \\
\text { April } \\
\text { May } \\
\text { June } \\
\text { July } \\
\text { August } \\
\text { September }\end{array}$ & $\begin{array}{r}227 \\
176 \\
144 \\
114 \\
182 \\
243 \\
395 \\
4,550 \\
5,750 \\
2,070 \\
785 \\
1,170\end{array}$ & \begin{tabular}{|r|}
157 \\
116 \\
147 \\
152 \\
405 \\
2,230 \\
552 \\
332 \\
211
\end{tabular} & $\begin{array}{r}198 \\
143 \\
108 \\
98 \\
111 \\
176 \\
245 \\
1,820 \\
3,830 \\
1,200 \\
528 \\
431\end{array}$ & $\begin{array}{r}12,200 \\
8,510 \\
6,640 \\
6,030 \\
6,160 \\
10,800 \\
14,600^{\circ} \\
112,000 \\
228,000 \\
73,800 \\
32,500 \\
25,600\end{array}$ \\
\hline The year & 5,750 & 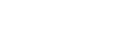 & 741 & 537,000 \\
\hline $\begin{array}{l}\text { October } \\
\text { November } \\
\text { December } \\
\text { January } \\
\text { February } \\
\text { March } \\
\text { April } \\
\text { Mang } \\
\text { June } \\
\text { July } \\
\text { August } \\
\text { September }\end{array}$ & $\begin{array}{r}209 \\
175 \\
144 \\
270 \\
\mathbf{5 7 8} \\
\mathbf{3}, 570 \\
\mathbf{3}, \mathbf{4 7 0} \\
\mathbf{1}, 200 \\
791 \\
380\end{array}$ & $\begin{array}{r}144 \\
134 \\
140 \\
721 \\
1,270 \\
375 \\
262 \\
149\end{array}$ & $\begin{array}{r}174 \\
149 \\
138 \\
115 \\
117 \\
167 \\
252 \\
1,650 \\
2,250 \\
711 \\
406 \\
217\end{array}$ & $\begin{array}{r}10,700 \\
8,870 \\
8,480 \\
7,070 \\
6,500 \\
10,300 \\
15,000 \\
101,000 \\
134,000 \\
43,700 \\
25,000 \\
12,900\end{array}$ \\
\hline The year. . & 3,570 & 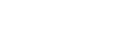 & 530 & 384,000 \\
\hline $\begin{array}{l}\text { October } \\
\text { November } \\
\text { December } \\
\text { January } \\
\text { February } \\
\text { March } \\
\text { April } \\
\text { May } \\
\text { June } \\
\text { July } \\
\text { August } \\
\text { September }\end{array}$ & $\begin{array}{r}154 \\
147 \\
152 \\
\mathbf{2 7 8} \\
500 \\
3,660 \\
4,280 \\
\mathbf{2}, \mathbf{3 4 0} \\
1,130 \\
\mathbf{3} 94\end{array}$ & $\begin{array}{r}121 \\
110 \\
162 \\
200 \\
520 \\
2,480 \\
584 \\
356 \\
255\end{array}$ & $\begin{array}{r}142 \\
127 \\
122 \\
115 \\
135 \\
185 \\
303 \\
1,650 \\
3,400 \\
1,470 \\
667 \\
300\end{array}$ & $\begin{array}{r}8,730 \\
7,560 \\
7,500 \\
7,070 \\
7,500 \\
11,400 \\
18,000 \\
101,000 \\
202,000 \\
90,400 \\
41,000 \\
17,900\end{array}$ \\
\hline The year.............. & 4,280 & $-\ldots$ & 717 & 520,000 \\
\hline $\begin{array}{l}\text { October } \\
\text { November } \\
\text { December. } \\
\text { January } \\
\text { February } \\
\text { March } \\
\text { Apri1 } \\
\text { May } \\
\text { June } \\
\text { July } \\
\text { August } \\
\text { September }\end{array}$ & $\begin{array}{r}296 \\
223 \\
159 \\
209 \\
640 \\
2,700 \\
5,020 \\
1,550 \\
309 \\
183\end{array}$ & $\begin{array}{r}226 \\
100 \\
591 \\
892 \\
428 \\
121 \\
108\end{array}$ & $\begin{array}{r}260 \\
156 \\
127 \\
75 \\
110 \\
140 \\
360 \\
1,620 \\
2,560 \\
1,090 \\
171 \\
125\end{array}$ & $\begin{array}{r}16,000 \\
9,280 \\
7,810 \\
4,610 \\
6,330 \\
8,610 \\
21,400 \\
99,600 \\
152,000 \\
67,000 \\
10,500 \\
7,440\end{array}$ \\
\hline The year. . . . . . . & 5,020 & & 568 & 411,000 \\
\hline
\end{tabular}

Nors.-Monthly mean discharge during winter based chiefly on current-meter measurements and temperature records.

\section{EAGLE RIVDR AT GYPSUM, COLO.}

Locatron.-In sec. 5, T. 5 S.; R. $85 \mathrm{~W}$., at highway bridge a quarter of a mile north of railroad station at Gypsum. Nearest tributary, Gypsum Creek, enters a short distance downstream. Prior to February 7, 1907, station located in sec. 1, T. 5 S., R. 85 W., 5 miles upstream. Records at two points comparable. 
Drainage aria.-844 square miles (measured on base map).

Records avaILable.-April 1, 1905, to December 31, 1909.

GAGE.-Vertical staff at upper section; chain at lower section.

CoNTroL.-Slightly shifting.

Extremes of Dischargw.-Maximum stage recorded, 6.0 feet at 6 a. m. June 4, 1905 (discharge, 6,600 second-feet); minimum discharge, 60 second-feet December 19, 1907.

Diversions.- Water diverted for irrigation of 150 acres between Eagle and Gypsum; none below Gypsum.

Accoracy.-Gage read twice daily. Rating curves well defined. Reeords good, except during winter for which they are fair.

Monthly discharge of Eagle River near Gypsum, Colo., for 1905-1909

\begin{tabular}{|c|c|c|c|c|}
\hline \multirow{2}{*}{ Month } & \multicolumn{3}{|c|}{ Discharge in second-feet } & \multirow{2}{*}{$\begin{array}{l}\text { Run-off in } \\
\text { acre-feet }\end{array}$} \\
\hline & Maximum & Minimum & Mean & \\
\hline $\begin{array}{l}\text { April } \\
\text { May } \\
\text { June } \\
\text { July } \\
\text { August } \\
\text { September }\end{array}$ & $\begin{array}{r}790 \\
2,870 \\
6,040 \\
1,420 \\
475 \\
358\end{array}$ & $\begin{array}{r}154 \\
591 \\
1,550 \\
432 \\
218 \\
218\end{array}$ & $\begin{array}{r}301 \\
1,470 \\
3,160 \\
697 \\
348 \\
273\end{array}$ & $\begin{array}{r}17,900 \\
90,400 \\
188,000 \\
42,900 \\
21,400 \\
16,200\end{array}$ \\
\hline The period. & (n) & -............... & (n............. & 377,000 \\
\hline $\begin{array}{l}\text { October } \\
\text { November } \\
\text { December } \\
\text { January } \\
\text { February } \\
\text { March } \\
\text { A pril } \\
\text { May } \\
\text { June } \\
\text { July } \\
\text { August } \\
\text { September }\end{array}$ & $\begin{array}{r}268 \\
230 \\
218\end{array}$ & \begin{tabular}{r}
205 \\
183 \\
163 \\
\hdashline$\ldots$ \\
\hdashline 1,780 \\
5918 \\
510 \\
310 \\
310
\end{tabular} & $\begin{array}{r}228 \\
205 \\
177 \\
\times 150 \\
\times 150 \\
\times 160 \\
499 \\
2,050 \\
2,750 \\
1,230 \\
518 \\
467\end{array}$ & $\begin{array}{r}14,000 \\
12,200 \\
10,900 \\
9,220 \\
8,330 \\
9,840 \\
29,700 \\
126,000 \\
164,000 \\
75,600 \\
31,900 \\
27,800\end{array}$ \\
\hline The year............ & 5,740 & - & 718 & 519,000 \\
\hline $\begin{array}{l}\text { October.1906-7 } \\
\text { November } \\
\text { December } \\
\text { January } \\
\text { February } \\
\text { March } \\
\text { April } \\
\text { May } \\
\text { June } \\
\text { July } \\
\text { August } \\
\text { September }\end{array}$ & $\begin{array}{r}521 \\
375 \\
268 \\
255 \\
-370 \\
1,010 \\
2,520 \\
3,660 \\
3,500 \\
1,010 \\
491\end{array}$ & $\begin{array}{r}122 \\
272 \\
464 \\
1,060 \\
1,060 \\
389 \\
272\end{array}$ & $\begin{array}{r}381 \\
300 \\
223 \\
197 \\
\times 150 \\
200 \\
540 \\
1,080 \\
2,890 \\
2,160 \\
562 \\
342\end{array}$ & $\begin{array}{r}23,400 \\
17,900 \\
13,700 \\
12,100 \\
8,330 \\
12,300 \\
32,100 \\
66,400 \\
172,000 \\
133,000 \\
34,600 \\
20,400\end{array}$ \\
\hline The year........ & 3,660 & 122 & 755 & 546,000 \\
\hline $\begin{array}{l}\text { October. } \\
\text { November } \\
\text { December } \\
\text { January } \\
\text { February } \\
\text { March } \\
\text { April } \\
\text { May } \\
\text { June } \\
\text { July } \\
\text { August } \\
\text { September }\end{array}$ & $\begin{array}{r}438 \\
239 \\
155 \\
181 \\
239 \\
155 \\
890 \\
1,340 \\
2,890 \\
1,190 \\
548 \\
307\end{array}$ & $\begin{array}{r}239 \\
111 \\
60 \\
155 \\
111 \\
92 \\
132 \\
368 \\
1,100 \\
326 \\
290 \\
181\end{array}$ & $\begin{array}{r}299 \\
182 \\
131 \\
170 \\
142 \\
128 \\
436 \\
806 \\
2,010 \\
675 \\
375 \\
226\end{array}$ & $\begin{array}{r}18,400 \\
10,800 \\
8,060 \\
10,300 \\
8,170 \\
7,870 \\
25,900 \\
49,600 \\
120,000 \\
41,500 \\
23,100 \\
13,400\end{array}$ \\
\hline The year. & 2,860 & 60 & 465 & 337,000 \\
\hline
\end{tabular}

- Estimated. 
Monthly discharge of Eagle River near Gypsum, Colo., for 1905-1909-Continued

\begin{tabular}{|c|c|c|c|c|}
\hline \multirow{2}{*}{ Month } & \multicolumn{3}{|c|}{ Discharge in second-feet } & \multirow{2}{*}{$\begin{array}{c}\text { Run-off in } \\
\text { acre-feet }\end{array}$} \\
\hline & Maximum & Minimum & Mean & \\
\hline $\begin{array}{l}\text { October } \\
\text { November } \\
\text { December } \\
\text { January } \\
\text { February } \\
\text { March } \\
\text { April } \\
\text { May } \\
\text { June }\end{array}$ & $\begin{array}{r}209 \\
155 \\
155 \\
144 \\
181 \\
209 \\
520 \\
2,520 \\
5,190 \\
3,860 \\
1,170 \\
820\end{array}$ & $\begin{array}{r}155 \\
122 \\
75 \\
132 \\
144 \\
155 \\
307 \\
1,240 \\
782 \\
462 \\
300\end{array}$ & $\begin{array}{r}176 \\
146 \\
119 \\
123 \\
148 \\
159 \\
262 \\
1,270 \\
3,570 \\
1,740 \\
611 \\
501\end{array}$ & $\begin{array}{r}10,800 \\
8,690 \\
7,320 \\
7,560 \\
8,220 \\
9,780 \\
15,600 \\
78,100 \\
212,000 \\
107,000 \\
37,600 \\
29,800\end{array}$ \\
\hline The year. & 3,860 & 75 & 735 & 532,000 \\
\hline $\begin{array}{l}\text { October } 1909 \\
\text { November } \\
\text { December }\end{array}$ & $\begin{array}{l}282 \\
200 \\
200\end{array}$ & $\begin{array}{l}200 \\
185 \\
185\end{array}$ & $\begin{array}{l}246 \\
198 \\
196\end{array}$ & $\begin{array}{l}15,100 \\
11,800 \\
12,100\end{array}$ \\
\hline
\end{tabular}

- Estimated.

TURKBY CRGES AT REDCLIFF, COLO.

Location.-In sec. 19, T. 6 S., R. 80 W., at highway bridge in Redcliff, Eagle

County, 800 feet above mouth of creek.

Drainage area.-27 square miles (measured on Forest Service map).

Records aVailable.-July 1, 1913, to September 30, 1921.

GAGE.-Vertical staff and chain.

Control.-Shifting.

Extremes of Discharge.-Maximum stage recorded during period, 4.7 feet at 7.15 p. m. June 13, 1918 (discharge, 670 second-feet); minimum stage recorded, 1.10 feet at 8 a. m. March 9, 1921 (discharge, 3 second-feet).

Ice.-Stage-discharge relation unaffected by ice except for a few days during winter.

Diversions.-A few small diversions from Turkey Creek.

ACCURACY.-Gage read twice daily. Rating curves fairly well defined. Records good except during 1914, 1918, and 1921, for which they are fair.

Monthly discharge of Turkey Creek at Redcliff, Colo., 1913-1921

\begin{tabular}{|c|c|c|c|c|}
\hline \multirow{2}{*}{ Month } & \multicolumn{3}{|c|}{ Discharge in second-feet } & \multirow{2}{*}{$\begin{array}{c}\text { Run-off in } \\
\text { acre-feet }\end{array}$} \\
\hline & Maximum & Minimum & Mean & \\
\hline $\begin{array}{l}\text { July } \\
\text { Jugust } \\
\text { Augut }\end{array}$ & $\begin{array}{r}55 \\
19 \\
14 \\
\end{array}$ & $\begin{array}{r}19 \\
12 \\
10 \\
\end{array}$ & $\begin{array}{r}31.9 \\
14.9 \\
11.7 \\
\end{array}$ & $\begin{array}{r}1,960 \\
996 \\
690 \\
\end{array}$ \\
\hline The period.............. & $\ldots \ldots$ & $-\ldots \ldots \ldots$ & $-\ldots \ldots$ & 3,570 \\
\hline $\begin{array}{l}\text { October } \\
\text { November } \\
\text { December } \\
\text { January } \\
\text { February } \\
\text { March } \\
\text { April } \\
\text { May } \\
\text { June } \\
\text { July } \\
\text { August } \\
\text { September }\end{array}$ & $\begin{array}{r}20 \\
292 \\
314 \\
120 \\
33 \\
16 \\
\end{array}$ & $\begin{array}{r}8 \\
15 \\
127 \\
35 \\
15 \\
13 \\
\end{array}$ & $\begin{array}{c}10.2 \\
8.2 \\
: 7.0 \\
55 \\
55 \\
7 \\
13.9 \\
125 \\
237 \\
64.7 \\
21.1 \\
14.1 \\
\end{array}$ & $\begin{array}{r}627 \\
488 \\
430 \\
307 \\
278 \\
430 \\
827 \\
7,690 \\
14,100 \\
3,980 \\
1,300 \\
839 \\
\end{array}$ \\
\hline The year.................................. & 314 & - & 43.2 & 31,300 \\
\hline
\end{tabular}

- Estimated. 


\section{Monthly discharge of Turkey Creek at Redcliff, Colo., 1918-1921-Continued}

Month
October
November
December
January
February
March
April
Mung
Jung
Jugust
Auptember

The year.

October.

November

December

January

February

March.

April

May -

June

July

September

The year.

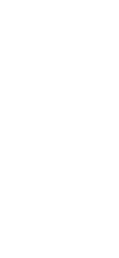

September

The year

October.

November

December.

January

February.

March

April

June

July

August

September

The year.

\section{5-16}

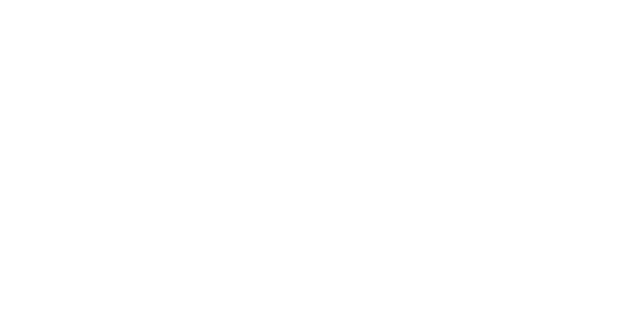

The year

\section{6-17}

\section{7-18}

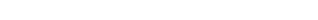

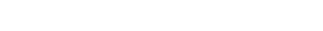

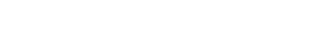

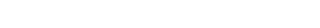

\begin{tabular}{|c|c|c|c|}
\hline \multicolumn{3}{|c|}{ Discharge in second-feet } & \multirow{2}{*}{$\begin{array}{l}\text { Run-off in } \\
\text { acre-feet }\end{array}$} \\
\hline Maximum & Minimum & Mean & \\
\hline $\begin{array}{r}15 \\
7 \\
5 \\
5 \\
7 \\
10 \\
53 \\
134 \\
213 \\
110 \\
23 \\
12\end{array}$ & $\begin{array}{r}7 \\
3 \\
2 \\
3 \\
4 \\
5 \\
10 \\
30 \\
92 \\
21 \\
10 \\
8\end{array}$ & $\begin{array}{c}9.45 \\
4.47 \\
4.00 \\
3.74 \\
4.82 \\
7.39 \\
23.4 \\
78.5 \\
161 \\
47.5 \\
14.8 \\
9.47\end{array}$ & $\begin{array}{r}581 \\
266 \\
246 \\
230 \\
268 \\
454 \\
1,390 \\
4,830 \\
9,580 \\
2,920 \\
910 \\
564\end{array}$ \\
\hline 213 & 2 & 30.7 & 22,200 \\
\hline $\begin{array}{r}10 \\
7 \\
5 \\
5 \\
5 \\
9 \\
62 \\
174 \\
302 \\
94 \\
17 \\
16\end{array}$ & $\begin{array}{r}7 \\
4 \\
4 \\
4 \\
4 \\
4 \\
6 \\
25 \\
98 \\
16 \\
10 \\
9\end{array}$ & $\begin{array}{r}8.03 \\
4.97 \\
4.13 \\
4.03 \\
4.28 \\
5.90 \\
17.4 \\
88.3 \\
195 \\
37.5 \\
12.7 \\
11.0\end{array}$ & $\begin{array}{r}494 \\
296 \\
254 \\
248 \\
246 \\
363 \\
1,040 \\
5,430 \\
11,600 \\
2,310 \\
781 \\
655\end{array}$ \\
\hline 302 & 4 & 32.7 & 23,700 \\
\hline $\begin{array}{c}11 \\
7.0 \\
7.2 \\
6.4 \\
5.6 \\
8.0 \\
27 \\
93 \\
316 \\
204 \\
18 \\
8.9\end{array}$ & $\begin{array}{c}7.0 \\
4.5 \\
5.4 \\
4.0 \\
4.2 \\
4.2 \\
4.8 \\
12 \\
35 \\
19 \\
10 \\
5.2\end{array}$ & $\begin{array}{r}8.82 \\
5.63 \\
6.13 \\
4.77 \\
4.57 \\
5.22 \\
12.6 \\
34.7 \\
206 \\
68.5 \\
13.1 \\
6.75\end{array}$ & $\begin{array}{r}542 \\
335 \\
377 \\
293 \\
254 \\
321 \\
750 \\
2,130 \\
12,300 \\
4,210 \\
806 \\
402\end{array}$ \\
\hline 316 & 4.0 & 31.3 & 22,700 \\
\hline $\begin{array}{c}5.4 \\
7.2 \\
4.4 \\
4.4 \\
5.0 \\
10 \\
20 \\
197 \\
485 \\
104 \\
28 \\
9\end{array}$ & $\begin{array}{r}3.9 \\
4.0 \\
3.8 \\
3.9 \\
4.0 \\
4.6 \\
10 \\
16 \\
118 \\
26 \\
3 \\
4\end{array}$ & $\begin{array}{c}4.17 \\
4.87 \\
4.15 \\
4.25 \\
4.34 \\
6.03 \\
13.6 \\
101 \\
256 \\
46.6 \\
11.3 \\
5.8\end{array}$ & $\begin{array}{r}256 \\
290 \\
255 \\
261 \\
241 \\
371 \\
809 \\
6,210 \\
15,200 \\
2,870 \\
695 \\
345\end{array}$ \\
\hline 485 & 3 & 38.4 & 27,800 \\
\hline $\begin{array}{r}42 \\
232 \\
104 \\
46 \\
23\end{array}$ & $\begin{array}{l}6 \\
28 \\
46 \\
22 \\
13\end{array}$ & $\begin{array}{c}7.1 \\
6.3 \\
5.1 \\
4.1 \\
04 \\
a 5 \\
18.2 \\
97.7 \\
74.4 \\
31.2 \\
16.3 \\
17.0\end{array}$ & $\begin{array}{r}437 \\
375 \\
314 \\
252 \\
222 \\
307 \\
1,080 \\
6,010 \\
4,430 \\
1,920 \\
1,000 \\
1,010\end{array}$ \\
\hline 232 & 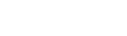 & 24.0 & 17,400 \\
\hline
\end{tabular}

astimated. 
Monthly discharge of Turkey Creek at Redcliff, Colo., 1918-1921-Continued

\begin{tabular}{|c|c|c|c|c|}
\hline \multirow{2}{*}{ Month } & \multicolumn{3}{|c|}{ Discharge in second-feet } & \multirow{2}{*}{$\begin{array}{c}\text { Run-off in } \\
\text { acre-feet }\end{array}$} \\
\hline & Maximum & Minimam & Mean & \\
\hline $\begin{array}{l}\text { October. } \\
\text { November } \\
\text { December } \\
\text { January- } \\
\text { February } \\
\text { March } \\
\text { April } \\
\text { May } \\
\text { June } \\
\text { July } \\
\text { August } \\
\text { September }\end{array}$ & $\begin{array}{r}10 \\
9 \\
6 \\
4 \\
3 \\
12 \\
14 \\
251 \\
333 \\
91 \\
24 \\
12\end{array}$ & $\begin{array}{r}2 \\
4 \\
2 \\
2 \\
2 \\
2 \\
2 \\
18 \\
91 \\
24 \\
12 \\
9\end{array}$ & $\begin{array}{r}7.0 \\
6.3 \\
3.6 \\
2.5 \\
2.3 \\
4.3 \\
6.0 \\
96.5 \\
189 \\
49.9 \\
16.9 \\
10.7\end{array}$ & $\begin{array}{r}430 \\
375 \\
221 \\
154 \\
132 \\
264 \\
357 \\
5,930 \\
11,200 \\
3,070 \\
1,040 \\
637\end{array}$ \\
\hline 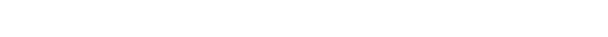 & 333 & 2 & 33. 0 & 23,800 \\
\hline $\begin{array}{l}\text { October. } \\
\text { November } \\
\text { December } \\
\text { January } \\
\text { February } \\
\text { March. } \\
\text { April } \\
\text { May } \\
\text { June } \\
\text { July } \\
\text { August } \\
\text { September }\end{array}$ & $\begin{array}{r}5 \\
6 \\
8 \\
19 \\
250 \\
420 \\
80 \\
38 \\
13\end{array}$ & \begin{tabular}{rr|}
4 \\
4 \\
4 \\
5 \\
6 \\
17 \\
86 \\
40 \\
10 \\
7
\end{tabular} & $\begin{array}{r}7.0 \\
6.0 \\
5.0 \\
4.3 \\
5.1 \\
6.6 \\
13.4 \\
72.7 \\
253 \\
51.5 \\
19.7 \\
8.4\end{array}$ & $\begin{array}{r}430 \\
357 \\
307 \\
264 \\
283 \\
406 \\
797 \\
4,470 \\
15,100 \\
3,170 \\
1,210 \\
500\end{array}$ \\
\hline The year...... & 420 & - & 37.7 & 27,300 \\
\hline
\end{tabular}

- Estimated.

HOMESTAKE CREGE AT REDCLIFF, CONO.

Locamion.-In sec. 30, T. 6 S., R. 80 W., a quarter of a mile above mouth of creek, at first Forest Service bridge, and 1 mile from Redcliff, Eagle County.

Drainagt area. - 64 square miles (measured on topographic map).

Records avatlable.-October 1, 1910, to September 30, 1918.

GAGE.-Vertical staff; from August 17, 1914, to October 17, 1917, gage situated a quarter of a mile upstream where flow was the same.

Controu.-Practically permanent at both sites.

Extremes of Discharat.-Maximum stage recorded, 6.2 feet at 9 a. $\mathrm{m}$. June 24, 1918 (discharge, 1,300 second-feet); minimum discharge recorded, 0.6 second-foot January 25, 1915, from current-meter measurement.

Diversions. - No water diverted from Homestake Creek.

Accoracy.-Gage read once daily from April to July for years 1911 to 1913 inclusive, and at irregular intervals during remainder of period. Rating curves fairly well defined. Records fair. 
Monthly discharge of Homestake Creek at Redcliff, Colo., for 1910-1918

\begin{tabular}{|c|c|c|c|c|}
\hline \multirow{2}{*}{ Month } & \multicolumn{3}{|c|}{ Discharge in second-feet } & \multirow{2}{*}{$\begin{array}{l}\text { Run-off in } \\
\text { acre-feot }\end{array}$} \\
\hline & Maximum & Minimum & Mean & \\
\hline $\begin{array}{l}\text { October } \\
\text { November } \\
\text { December } \\
\text { January } \\
\text { February } \\
\text { March } \\
\text { April } \\
\text { May } \\
\text { June } \\
\text { July } \\
\text { August } \\
\text { September }\end{array}$ & \begin{tabular}{r|r|}
30 \\
370 \\
630 \\
890 \\
510 \\
79 \\
27 \\
\end{tabular} & $\begin{array}{r}10 \\
45 \\
149 \\
262 \\
93 \\
25 \\
15\end{array}$ & $\begin{array}{l}220 \\
\times 15 \\
\times 10 \\
a 8 \\
\times 10 \\
12.0 \\
114 \\
418 \\
575 \\
230 \\
42.3 \\
18.0\end{array}$ & $\begin{array}{r}1,230 \\
893 \\
615 \\
492 \\
555 \\
738 \\
6,780 \\
25,700 \\
34,200 \\
14,100 \\
2,600 \\
1,070\end{array}$ \\
\hline The year & 890 & & 123 & 89,000 \\
\hline $\begin{array}{l}\text { October } \\
\text { November } \\
\text { December } \\
\text { January } \\
\text { February } \\
\text { March } \\
\text { April } \\
\text { May } \\
\text { June } \\
\text { July } \\
\text { August } \\
\text { September }\end{array}$ & $\begin{array}{r}158 \\
20 \\
165 \\
715 \\
950 \\
465 \\
190 \\
30 \\
\end{array}$ & $\begin{array}{r}15 \\
15 \\
26 \\
93 \\
290 \\
200 \\
26 \\
15 \\
\end{array}$ & $\begin{array}{c}48.0 \\
18.2 \\
: 13 \\
613 \\
a 13 \\
\therefore 13 \\
56.9 \\
308 \\
645 \\
325 \\
68.1 \\
17.8\end{array}$ & $\begin{array}{r}2,950 \\
1,080 \\
799 \\
799 \\
748 \\
799 \\
3,390 \\
18,900 \\
38,400 \\
20,000 \\
4,190 \\
1,060 \\
\end{array}$ \\
\hline $\begin{array}{l}\text { The year.. } \\
\text { October. } \\
\text { November } \\
\text { December } \\
\text { January } \\
\text { February } \\
\text { March } \\
\text { Mpri1 } \\
\text { Muy } \\
\text { June } \\
\text { July } \\
\text { Bugust }\end{array}$ & $\begin{array}{r}950 \\
20 \\
195 \\
670 \\
450 \\
260 \\
79 \\
51\end{array}$ & 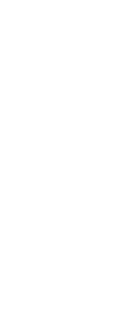 & $\begin{array}{l}128 \\
17.4 \\
\text { a } 14 \\
a 13 \\
\text { a } 12 \\
\text { a } 10 \\
\text { a } 14 \\
80.5 \\
329 \\
321 \\
136 \\
31.5 \\
30.1\end{array}$ & $\begin{array}{r}92,100 \\
1,070 \\
833 \\
799 \\
738 \\
555 \\
861 \\
4,790 \\
20,200 \\
19,100 \\
8,360 \\
1,940 \\
1,790\end{array}$ \\
\hline The year & 670 & & 84.2 & 61,000 \\
\hline $\begin{array}{l}\text { October } \\
\text { November } \\
\text { December } \\
\text { January } \\
\text { February } \\
\text { March } \\
\text { April } \\
\text { May } \\
\text { June } \\
\text { July } \\
\text { August } \\
\text { September }\end{array}$ & $\begin{array}{r}100 \\
760 \\
940 \\
430 \\
218 \\
49\end{array}$ & \begin{tabular}{|r|}
23 \\
8 \\
19 \\
80 \\
395 \\
131 \\
42 \\
10 \\
\end{tabular} & $\begin{array}{r}30.8 \\
16.0 \\
a 10.0 \\
a 8.0 \\
a 9.0 \\
a 11.0 \\
63.4 \\
431 \\
620 \\
254 \\
77.6 \\
29.9\end{array}$ & $\begin{array}{r}1,890 \\
952 \\
615 \\
492 \\
500 \\
676 \\
3,770 \\
26,500 \\
36,900 \\
15,600 \\
4,770 \\
1,780 \\
\end{array}$ \\
\hline The year. & 940 & $\ldots \ldots$ & 130 & 94,400 \\
\hline $\begin{array}{l}\text { October } \\
\text { November } \\
\text { December } \\
\text { January } \\
\text { February } \\
\text { March } \\
\text { April } \\
\text { May } \\
\text { June } \\
\text { July } \\
\text { August } \\
\text { September }\end{array}$ & $\begin{array}{r}28 \\
18 \\
4 \\
\\
176 \\
485 \\
670 \\
218 \\
161 \\
50\end{array}$ & \begin{tabular}{r}
13 \\
4 \\
2 \\
\hdashline-9 \\
56 \\
142 \\
49 \\
12 \\
7 \\
\end{tabular} & $\begin{array}{c}22.3 \\
6.87 \\
3.00 \\
.1 \\
11 \\
22 \\
56.8 \\
195 \\
352 \\
123 \\
36.6 \\
18.6\end{array}$ & $\begin{array}{r}1,370 \\
409 \\
119 \\
61 \\
56 \\
123 \\
3,350 \\
12,000 \\
20,900 \\
7,560 \\
2,250 \\
1,110\end{array}$ \\
\hline The year & 670 & $\ldots$ & 68.0 & 49,300 \\
\hline
\end{tabular}

- Estimated. 
Monthly discharge of Homestake Creek at Redcliff, Colo., for 1910-1918-Contd.

\begin{tabular}{|c|c|c|c|c|}
\hline \multirow{2}{*}{ Month } & \multicolumn{3}{|c|}{ Discharge in second-feet } & \multirow{2}{*}{$\begin{array}{l}\text { Run-ofi in } \\
\text { acre-feet }\end{array}$} \\
\hline & Maximum & Minimum & Mean & \\
\hline $\begin{array}{l}\text { October. } \\
\text { November } \\
\text { December } \\
\text { January } \\
\text { February } \\
\text { March } \\
\text { April } \\
\text { May } \\
\text { June } \\
\text { July } \\
\text { August } \\
\text { September }\end{array}$ & $\begin{array}{r}37 \\
10 \\
172 \\
520 \\
650 \\
347 \\
118 \\
50\end{array}$ & $\begin{array}{r}8 \\
1 \\
\mathbf{3 8} \\
\mathbf{3 4} \\
\mathbf{1 0 4} \\
\mathbf{3 9} \\
\mathbf{2 7}\end{array}$ & $\begin{array}{r}16.4 \\
6.40 \\
.8 \\
09 \\
.9 \\
15 \\
87.3 \\
229 \\
458 \\
177 \\
70.1 \\
34.9\end{array}$ & $\begin{array}{r}1,010 \\
381 \\
402 \\
558 \\
518 \\
022 \\
5,190 \\
14,100 \\
27,000 \\
10,000 \\
4,810 \\
2,080\end{array}$ \\
\hline The yesr............. & 650 & $-\ldots-n$ & 93.3 & 67,800 \\
\hline $\begin{array}{l}\text { October. } \\
\text { November } \\
\text { December. } \\
\text { January } \\
\text { February } \\
\text { March } \\
\text { April } \\
\text { May } \\
\text { June } \\
\text { July } \\
\text { August. } \\
\text { September }\end{array}$ & $\begin{array}{r}40 \\
120 \\
335 \\
750 \\
500 \\
90 \\
33\end{array}$ & $\begin{array}{r}22 \\
19 \\
128 \\
111 \\
26 \\
14\end{array}$ & $\begin{array}{l}29.8 \\
23 \\
20 \\
22 \\
20 \\
20 \\
20 \\
52.4 \\
156 \\
498 \\
258 \\
49.8 \\
20.6\end{array}$ & $\begin{array}{r}1,890 \\
1,370 \\
1,900 \\
1,250 \\
1,110 \\
1,230 \\
3,120 \\
9,500 \\
29,800 \\
15,900 \\
3,060 \\
1,230\end{array}$ \\
\hline The year. ............. & 750 & & 97.0 & 70,300 \\
\hline $\begin{array}{l}\text { October. } \\
\text { November } \\
\text { December. } \\
\text { January } \\
\text { February } \\
\text { March } \\
\text { April } \\
\text { May } \\
\text { June. } \\
\text { July } \\
\text { August } \\
\text { September. }\end{array}$ & $\begin{array}{r}14 \\
24 \\
38 \\
87 \\
542 \\
1,300 \\
320 \\
80 \\
100\end{array}$ & $\begin{array}{r}8 \\
10 \\
36 \\
65 \\
55 \\
15 \\
16\end{array}$ & $\begin{array}{c}10.5 \\
16.1 \\
10 \\
29 \\
07 \\
15 \\
55.4 \\
275 \\
708 \\
145 \\
36.7 \\
47.9\end{array}$ & $\begin{array}{r}646 \\
958 \\
615 \\
553 \\
389 \\
928 \\
8,800 \\
16,900 \\
42,100 \\
8,920 \\
2,260 \\
2,850\end{array}$ \\
\hline The year. & 1,300 & & 111 & 80,400 \\
\hline
\end{tabular}

BRUSH CREEKIAT BAGLE, COLO.

Location.-In sec. 6, T. 5 S., R. 84 W., at railroad bridge 300 yards above mouth and three-quarters of a mile west of Eagle, Eagle County.

Dratnage arma. - 146 square miles (measured on Forest Service map).

Records avallable.-October 1, 1910, to November 30, 1913.

GAGE.-Vertical staff.

Control.-Shifting.

Diversion.-Water diverted from Brush Creek and tributaries above station for irrigation of 2,700 acres.

AccuracY.-Gage read at irregular intervals. Rating curves not well defined. Records poor. 
Monthly discharge of Brush Creek at Eagle, Colo., for 1910-1913

\begin{tabular}{|c|c|c|c|c|}
\hline \multirow{2}{*}{ Month } & \multicolumn{3}{|c|}{ Discharge in second-feet } & \multirow{2}{*}{$\begin{array}{l}\text { Run-off in } \\
\text { aere-feet }\end{array}$} \\
\hline & Maximum & Minimum & Mean & \\
\hline $\begin{array}{l}\text { October. } \\
\text { November. } \\
\text { December } \\
\text { January } \\
\text { February } \\
\text { March } \\
\text { April } \\
\text { May } \\
\text { June } \\
\text { July } \\
\text { August } \\
\text { September }\end{array}$ & $\begin{array}{r}38 \\
44 \\
53 \\
76 \\
117 \\
192 \\
68 \\
6 \quad 38 \\
62\end{array}$ & $\begin{array}{r}32 \\
30 \\
30 \\
32 \\
77 \\
62 \\
38 \\
5 \\
30\end{array}$ & $\begin{array}{r}a 50 \\
a 60 \\
\propto 40 \\
35.3 \\
36.6 \\
39.0 \\
40.4 \\
90.4 \\
101 \\
58.7 \\
18.7 \\
40.9\end{array}$ & $\begin{array}{l}3,070 \\
3,570 \\
2,460 \\
2,170 \\
2,030 \\
2,400 \\
2,400 \\
5,560 \\
6,010 \\
3,610 \\
1,150 \\
2,430\end{array}$ \\
\hline The y & 192 & 5 & 51.1 & 36,900 \\
\hline 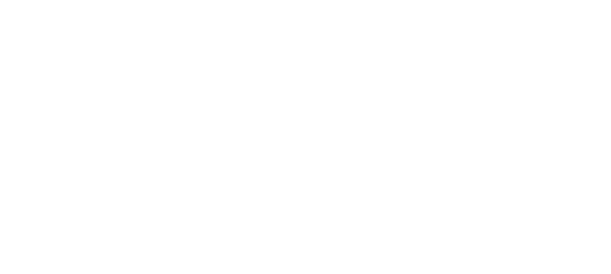 & $\begin{array}{r}65 \\
70 \\
\\
52 \\
300 \\
665 \\
490 \\
72 \\
72\end{array}$ & \begin{tabular}{|r}
49 \\
50 \\
\\
\end{tabular} & $\begin{array}{c}52.7 \\
59.2 \\
a 33 \\
a 25 \\
a 22 \\
a 25 \\
31.7 \\
117 \\
402 \\
219 \\
35.7 \\
57.2\end{array}$ & $\begin{array}{r}3,240 \\
3,520 \\
2,030 \\
1,540 \\
1,260 \\
1,540 \\
1,890 \\
7,190 \\
23,900 \\
13,500 \\
2,200 \\
3,400\end{array}$ \\
\hline The year. & 665 & - & 89.9 & 65,200 \\
\hline $\begin{array}{l}\text { October } \\
\text { November } \\
\text { December } \\
\text { January } \\
\text { February } \\
\text { March } \\
\text { April } \\
\text { May } \\
\text { June } \\
\text { July } \\
\text { August } \\
\text { September }\end{array}$ & $\begin{array}{r}140 \\
150 \\
280 \\
43\end{array}$ & $\begin{array}{r}90 \\
18 \\
1 \\
1\end{array}$ & $\begin{array}{l}a 50 \\
a 59 \\
a 40 \\
a 35 \\
a 30 \\
a 35 \\
a 40 \\
112 \\
119 \\
64.2 \\
64.9 \\
11.9\end{array}$ & $\begin{array}{l}3,070 \\
3,510 \\
2,460 \\
2,150 \\
1,670 \\
2,150 \\
2,380 \\
6,890 \\
7,080 \\
3,950 \\
732 \\
3,870\end{array}$ \\
\hline The year. & 280 & 1 & 55.2 & 39,900 \\
\hline $\begin{array}{l}\text { October } \\
\text { November } \\
\text { Nol }\end{array}$ & $\begin{array}{l}100 \\
100\end{array}$ & $\begin{array}{l}77 \\
40\end{array}$ & $\begin{array}{l}85 \\
60\end{array}$ & $\begin{array}{l}\mathbf{5}, 230 \\
\mathbf{3}, 570\end{array}$ \\
\hline
\end{tabular}

- Estimated.

ROARING FORK AT ASPEN, COLO.

Location.-In sec. 7, T. 10 S., R. 84 W., at bridge near old power plant in Aspen, Pitkin County. Castle, Maroon, and Hunter Creeks enter below. Prior to February 24, 1915, station maintained three-quarters of a mile upstream.

Dratnage area.-109 square miles (measured on topographic map).

Records aVaIlable.-October 1, 1910, to September 30, 1921.

GAGE.-Vertical staff.

Controu.-Practically permanent.

Extremes of Discharge.-Maximum stage recorded, 7.1 feet during night of June 18, 1917 (discharge, 3,170 second-feet); minimum discharge recorded, 15 second-feet on March 11, 1919 (gage height, 0.25 foot).

IcE.- Stage-discharge relation practically unaffected by ice. 
Drversions.-Salvation ditch diverts water for irrigation of 2,800 acres above station. Prior to April 15, 1919, the mines at Aspen pumped about 6 second-feet into river above station.

Accuract.-Gage read at irregular intervals prior to March 31, 1916; twice daily subsequently. Rating curves well defined. Records prior to March, 1916, fair, and for the remainder of period, good.

Cooperation.-Station maintained in cooperation with United States Forest Service.

Monthly discharge of Roaring Fork at Aspen, Colo., for 1910-1921

\begin{tabular}{|c|c|c|c|c|}
\hline \multirow{2}{*}{ Month } & \multicolumn{3}{|c|}{ Discharge in second-feet } & \multirow{2}{*}{$\begin{array}{l}\text { Run-off in } \\
\text { acre-feet }\end{array}$} \\
\hline & Maximum & Minimum & Mean . & \\
\hline $\begin{array}{l}\text { October } \\
\text { November } \\
\text { December } \\
\text { January } \\
\text { February } \\
\text { March } \\
\text { April } \\
\text { May } \\
\text { June } \\
\text { July } \\
\text { August } \\
\text { September }\end{array}$ & 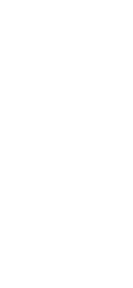 & 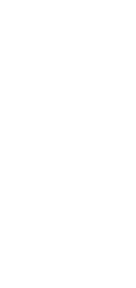 & $\begin{array}{l}-65 \\
\therefore 55 \\
: 40 \\
-30.0 \\
\times 25.0 \\
32.9 \\
80.3 \\
358 \\
712 \\
340 \\
110 \\
68.0\end{array}$ & $\begin{array}{r}4,000 \\
3,270 \\
2,460 \\
1,840 \\
1,390 \\
2,020 \\
4,780 \\
22,000 \\
42,400 \\
20,900 \\
6,760 \\
4,060\end{array}$ \\
\hline The y & 885 & $\ldots$ & 160 & 116,000 \\
\hline $\begin{array}{l}\text { October } \\
\text { November } \\
\text { December } \\
\text { January } \\
\text { February } \\
\text { March } \\
\text { April } \\
\text { May } \\
\text { June } \\
\text { July } \\
\text { August } \\
\text { September }\end{array}$ & $\begin{array}{r}63 \\
60 \\
38 \\
38 \\
63 \\
946 \\
1,490 \\
1,010 \\
380 \\
90\end{array}$ & $\begin{array}{r}52- \\
25 \\
-25- \\
25 \\
33 \\
38 \\
67 \\
570 \\
400 \\
78 \\
59\end{array}$ & $\begin{array}{r}113 \\
60.9 \\
44.0 \\
\times 25 \\
36.0 \\
34.7 \\
49.0 \\
302 \\
1,010 \\
604 \\
172 \\
71.9\end{array}$ & $\begin{array}{r}6,950 \\
3,620 \\
2,710 \\
1,540 \\
2,070 \\
2,130 \\
2,920 \\
18,600 \\
60,100 \\
37,100 \\
10,600 \\
4,280\end{array}$ \\
\hline The y & 1,490 & - & 211 & 153,000 \\
\hline $\begin{array}{l}\text { October-... } \\
\text { November } \\
\text { December } \\
\text { January } \\
\text { February } \\
\text { March } \\
\text { April } \\
\text { May } \\
\text { June } \\
\text { July } \\
\text { August } \\
\text { September }\end{array}$ & $\begin{array}{r}78 \\
59 \\
\\
\\
\\
160 \\
885 \\
885 \\
423 \\
125 \\
160\end{array}$ & \begin{tabular}{|r|}
47 \\
44 \\
\\
\hdashline \\
\\
\hdashline \\
142 \\
394 \\
109 \\
45 \\
55
\end{tabular} & $\begin{array}{c}60.3 \\
54.6 \\
a 40 \\
a 35 \\
a 35 \\
a 35 \\
89.2 \\
441 \\
631 \\
239 \\
72.0 \\
108\end{array}$ & $\begin{array}{r}3,710 \\
3,250 \\
2,460 \\
2,150 \\
1,940 \\
2,150 \\
5,310 \\
27,100 \\
37,500 \\
14,700 \\
4,430 \\
6,430\end{array}$ \\
\hline The year.......... & 885 & $\ldots$ & 153 & 111,000 \\
\hline $\begin{array}{l}\text { October } \\
\text { November } \\
\text { December } \\
\text { January } \\
\text { February } \\
\text { March } \\
\text { April } \\
\text { May } \\
\text { June } \\
\text { July } \\
\text { Augusst } \\
\text { September }\end{array}$ & $\begin{array}{r}132 \\
1,360 \\
1,700 \\
560 \\
308 \\
123\end{array}$ & $\begin{array}{r}57 \\
45 \\
\\
\\
\\
37 \\
87 \\
445 \\
294 \\
88 \\
51 \\
\end{array}$ & $\begin{array}{c}78.4 \\
52.2 \\
40 \\
40 \\
30 \\
30 \\
30 \\
30 \\
68.4 \\
595 \\
1,070 \\
373 \\
139 \\
80.1\end{array}$ & $\begin{array}{r}4,820 \\
3,110 \\
2,460 \\
1,840 \\
1,670 \\
1,840 \\
4,070 \\
36,600 \\
63,700 \\
22,900 \\
8,550 \\
4,770\end{array}$ \\
\hline The year. & 1,700 & $\ldots$ & 216 & 156,000 \\
\hline
\end{tabular}

a Estimated. 


\section{Monthly discharge of Roaring Fork at Aspen, Colo., for 1910-1921-Continued}

\begin{tabular}{|c|c|c|c|c|}
\hline \multirow{2}{*}{ Month } & \multicolumn{3}{|c|}{ Discharge in second-feet } & \multirow{2}{*}{$\begin{array}{l}\text { Run-off in } \\
\text { acre-feet }\end{array}$} \\
\hline & Maximum & Minimum & Mean & \\
\hline $\begin{array}{l}f \\
\text { October. } \\
\text { November } \\
\text { December. } \\
\text { January } \\
\text { February } \\
\text { Mareh } \\
\text { April } \\
\text { May } \\
\text { June } \\
\text { July } \\
\text { August } \\
\text { September }\end{array}$ & \begin{tabular}{r|r|}
106 \\
65 \\
32 \\
39 \\
146 \\
512 \\
1,250 \\
655 \\
195 \\
74
\end{tabular} & $\begin{array}{r}65 \\
30 \\
19 \\
23 \\
30 \\
65 \\
283 \\
102 \\
53 \\
41\end{array}$ & $\begin{array}{l}88.9 \\
50.0 \\
a 28 \\
\text { a } 25 \\
\text { a } 24.3 \\
31.6 \\
55.5 \\
239 \\
720 \\
363 \\
84.6 \\
54.7\end{array}$ & $\begin{array}{r}5,470 \\
2,980 \\
1,720 \\
1,540 \\
1,350 \\
1,940 \\
3,300 \\
14,700 \\
42,800 \\
22,300 \\
5,200 \\
3,250\end{array}$ \\
\hline The year. & 1,250 & 19 & 148 & 107,000 \\
\hline $\begin{array}{l}\text { October. } \\
\text { November } \\
\text { December. } \\
\text { January } \\
\text { February } \\
\text { March } \\
\text { April } \\
\text { May } \\
\text { June } \\
\text { July } \\
\text { August } \\
\text { September }\end{array}$ & $\begin{array}{r}65 \\
39 \\
45 \\
39 \\
53 \\
60 \\
212 \\
\mathbf{5 7 5} \\
\mathbf{1 2 0} \\
\mathbf{8 7 5} \\
\mathbf{3 2 5} \\
152\end{array}$ & $\begin{array}{r}39 \\
30 \\
32 \\
28 \\
27 \\
26 \\
40 \\
112 \\
625 \\
200 \\
75 \\
55\end{array}$ & $\begin{array}{l}54.2 \\
36.0 \\
39.6 \\
31.9 \\
33.6 \\
41.2 \\
81.8 \\
300 \\
922 \\
421 \\
171 \\
86.0\end{array}$ & $\begin{array}{r}3,330 \\
2,140 \\
2,430 \\
1,960 \\
1,930 \\
2,530 \\
\mathbf{4}, 870 \\
18,400 \\
54,900 \\
25,900 \\
10,500 \\
\mathbf{5}, 120\end{array}$ \\
\hline The year. & 1,320 & 26 & 185 & 134,000 \\
\hline $\begin{array}{l}\text { October. } \\
\text { November } \\
\text { December. } \\
\text { January } \\
\text { February. } \\
\text { March. } \\
\text { April } \\
\text { May } \\
\text { June } \\
\text { July } \\
\text { August } \\
\text { September }\end{array}$ & $\begin{array}{r}139 \\
97 \\
83 \\
66 \\
51 \\
59 \\
112 \\
552 \\
2,050 \\
1,440 \\
290 \\
82\end{array}$ & $\begin{array}{r}76 \\
43 \\
39 \\
36 \\
23 \\
19 \\
27 \\
59 \\
137 \\
325 \\
74 \\
54\end{array}$ & $\begin{array}{c}106 \\
63.1 \\
49.8 \\
48.4 \\
40.4 \\
37.8 \\
56.2 \\
165 \\
1,240 \\
718 \\
140 \\
63.5\end{array}$ & $\begin{array}{r}6,520 \\
3,750 \\
3,060 \\
2,980 \\
2,240 \\
2,320 \\
3,340 \\
10,100 \\
73,800 \\
44,100 \\
8,610 \\
3,780\end{array}$ \\
\hline The year. & 2,050 & 19 & 228 & 165,000 \\
\hline $\begin{array}{l}\text { October. } \\
\text { November } \\
\text { December. } \\
\text { January } \\
\text { February } \\
\text { March } \\
\text { April } \\
\text { May } \\
\text { June } \\
\text { July } \\
\text { August } \\
\text { September }\end{array}$ & $\begin{array}{r}62 \\
60 \\
54 \\
43 \\
47 \\
54 \\
86 \\
802 \\
2,170 \\
690 \\
183 \\
193\end{array}$ & $\begin{array}{r}40 \\
39 \\
35 \\
31 \\
33 \\
33 \\
36 \\
82 \\
485 \\
120 \\
37 \\
47\end{array}$ & $\begin{array}{l}50.1 \\
51.4 \\
44.6 \\
39.5 \\
39.4 \\
40.9 \\
64.0 \\
384 \\
1,430 \\
374 \\
85.2 \\
87.2\end{array}$ & $\begin{array}{r}3,080 \\
3,060 \\
2,740 \\
2,430 \\
2,190 \\
2,510 \\
3,810 \\
23,600 \\
85,100 \\
23,000 \\
5,240 \\
5,190\end{array}$ \\
\hline 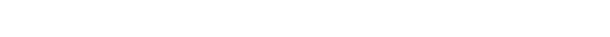 & 2,170 & 31 & 224 & 162,000 \\
\hline $\begin{array}{l}\text { October } \\
\text { November } \\
\text { December. } \\
\text { January } \\
\text { February } \\
\text { March } \\
\text { April } \\
\text { May } \\
\text { June } \\
\text { July } \\
\text { August } \\
\text { September }\end{array}$ & $\begin{array}{r}79 \\
68 \\
58 \\
37 \\
33 \\
35 \\
228 \\
980 \\
575 \\
350 \\
190 \\
111\end{array}$ & $\begin{array}{r}63 \\
49 \\
28 \\
24 \\
24 \\
21 \\
28 \\
133 \\
257 \\
79 \\
29 \\
26\end{array}$ & $\begin{array}{c}70.3 \\
60.3 \\
40.9 \\
31.0 \\
28.1 \\
26.7 \\
87.0 \\
471 \\
418 \\
171 \\
74.3 \\
50.1\end{array}$ & $\begin{array}{r}4,320 \\
3,500 \\
2,510 \\
1,910 \\
1,560 \\
1,640 \\
5,180 \\
29,000 \\
24,900 \\
10,500 \\
4,570 \\
2,980\end{array}$ \\
\hline 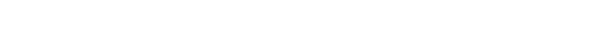 & 980 & 21 & 128 & 92,700 \\
\hline
\end{tabular}

astimated. 
Monthly discharge of Roaring Fork at Aspen, Colo., for 1910-1921-Continued

\begin{tabular}{|c|c|c|c|c|}
\hline \multirow{2}{*}{ Month } & \multicolumn{3}{|c|}{ Discharge in second-feet } & \multirow{2}{*}{$\begin{array}{l}\text { Run-off jn } \\
\text { acre-feet }\end{array}$} \\
\hline & Maximum & Minimum & Mean & \\
\hline $\begin{array}{l}\text { October } \\
\text { November } \\
\text { December } \\
\text { January } \\
\text { February } \\
\text { Mareh } \\
\text { April } \\
\text { May } \\
\text { June } \\
\text { July } \\
\text { August } \\
\text { September }\end{array}$ & $\begin{array}{r}58 \\
43 \\
40 \\
34 \\
40 \\
40 \\
56 \\
1,120 \\
1,430 \\
785 \\
237 \\
208\end{array}$ & $\begin{array}{r}35 \\
30 \\
28 \\
21 \\
24 \\
24 \\
29 \\
72 \\
670 \\
208 \\
84 \\
46\end{array}$ & $\begin{array}{l}44.0 \\
37.7 \\
35.0 \\
27.0 \\
32.2 \\
33.7 \\
39.2 \\
359 \\
961 \\
420 \\
139 \\
70.3\end{array}$ & 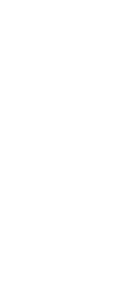 \\
\hline The year . . & 1,430 & 21 & 183 & 133,000 \\
\hline $\begin{array}{l}\text { October } \\
\text { November } \\
\text { December } \\
\text { January } \\
\text { February } \\
\text { March } \\
\text { April } \\
\text { May } \\
\text { June } \\
\text { July } \\
\text { August }\end{array}$ & $\begin{array}{r}70 \\
58 \\
53 \\
62 \\
56 \\
72 \\
77 \\
910 \\
2,310 \\
670 \\
197 \\
178\end{array}$ & $\begin{array}{r}41 \\
49 \\
40 \\
26 \\
45 \\
34 \\
47 \\
75 \\
670 \\
164 \\
87 \\
53\end{array}$ & $\begin{array}{c}57.0 \\
54.6 \\
51.3 \\
51.8 \\
51.0 \\
54.0 \\
60.3 \\
311 \\
1,130 \\
367 \\
130 \\
82.2\end{array}$ & $\begin{array}{r}3,500 \\
3,250 \\
3,150 \\
3,190 \\
2,830 \\
3,320 \\
3,590 \\
19,100 \\
67,200 \\
22,600 \\
7,990 \\
4,890\end{array}$ \\
\hline The year. & $2, \mathbf{3 1 0}$ & 26 & 199 & 145,000 \\
\hline
\end{tabular}

ROARING FORK BELOW ASPEN, COLO.

Location.-In sec. 2, T. $10 \mathrm{~S}$., R. 85 W., at highway bridge 2 miles below Aspen,

Pitkin County. Castle Creek enters above station and Maroon Creek, below.

Drainage area. - 223 square miles (measured on topographic map).

ReCORDS AVAILABLE.-October 1, 1913, to September 30, 1918.

GAGE.-Vertical staff.

ConTroL.-Slightly shifting.

Ict.-Stage-discharge relation unaffected by ice.

Diversions.-Roaring Fork Light \& Power Co. diverts water from Maroon

Creek and thence into Roaring Fork above station.

AccuracY. - Gage read semiweekly. Rating curves well defined. Records fair. Cooperation.-Station maintained in cooperation with United States Forest Service.

Monthly discharge of Roaring Fork below Aspen, Colo., 1913-1918

\begin{tabular}{|c|c|c|c|c|}
\hline \multirow{2}{*}{ Month } & \multicolumn{3}{|c|}{ Discharge in second-feet } & \multirow{2}{*}{$\begin{array}{l}\text { Run-off in } \\
\text { acre-feet }\end{array}$} \\
\hline & Maximum & Minimum & Mean & \\
\hline 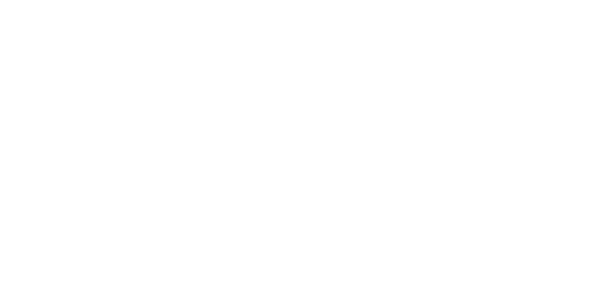 & $\begin{array}{r}174 \\
198 \\
267 \\
137 \\
121 \\
118 \\
285 \\
3,220 \\
4,030 \\
1,400 \\
530 \\
275\end{array}$ & $\begin{array}{r}170 \\
121 \\
126 \\
105 \\
99 \\
105 \\
106 \\
233 \\
905 \\
578 \\
175 \\
174\end{array}$ & $\begin{array}{r}175 \\
161 \\
166 \\
115 \\
106 \\
109 \\
178 \\
1,290 \\
2,300 \\
857 \\
264 \\
198\end{array}$ & $\begin{array}{r}10,800 \\
19,580 \\
10,200 \\
7,070 \\
5,890 \\
6,700 \\
10,600 \\
79,300 \\
137,000 \\
52,700 \\
16,200 \\
11,800\end{array}$ \\
\hline The year & 4,030 & 99 & 492 & 358,000 \\
\hline
\end{tabular}


Monthly discharge of Roaring Fork below Aspen, Colo., 1913-1918-Continued

\begin{tabular}{|c|c|c|c|c|}
\hline \multirow{2}{*}{ Month } & \multicolumn{3}{|c|}{ Discharge in second-feet } & \multirow{2}{*}{$\begin{array}{l}\text { Run-off in } \\
\text { acre-feet }\end{array}$} \\
\hline & Maximum & Minimum & Mean & \\
\hline $\begin{array}{l}\text { October } \\
\text { November } \\
\text { December } \\
\text { January } \\
\text { February } \\
\text { Mareh } \\
\text { April } \\
\text { May } \\
\text { June } \\
\text { July } \\
\text { August } \\
\text { September }\end{array}$ & $\begin{array}{r}220 \\
154 \\
125 \\
105 \\
100 \\
112 \\
325 \\
838 \\
2,070 \\
1,060 \\
400 \\
250\end{array}$ & $\begin{array}{r}156 \\
112 \\
100 \\
94 \\
92 \\
88 \\
92 \\
181 \\
555 \\
250 \\
137 \\
110\end{array}$ & $\begin{array}{c}185 \\
135 \\
111 \\
99.1 \\
96.4 \\
93.1 \\
157 \\
468 \\
1,260 \\
639 \\
195 \\
141\end{array}$ & $\begin{array}{r}11,400 \\
8,030 \\
6,820 \\
6,090 \\
5,350 \\
5,720 \\
9,340 \\
28,800 \\
75,000 \\
39,300 \\
12,000 \\
8,390\end{array}$ \\
\hline The year............. & 2,070 & 88 & 298 & 216,000 \\
\hline $\begin{array}{l}\text { October } \\
\text { November } \\
\text { December } \\
\text { January } \\
\text { February- } \\
\text { March } \\
\text { April } \\
\text { May } \\
\text { June } \\
\text { July } \\
\text { August }\end{array}$ & $\begin{array}{r}188 \\
165 \\
144 \\
118 \\
114 \\
161 \\
468 \\
1,020 \\
2,200 \\
1,350 \\
685 \\
327\end{array}$ & $\begin{array}{r}141 \\
130 \\
104 \\
97 \\
92 \\
87 \\
114 \\
260 \\
985 \\
555 \\
260 \\
200\end{array}$ & $\begin{array}{r}166 \\
144 \\
125 \\
105 \\
102 \\
118 \\
200 \\
628 \\
1,550 \\
850 \\
405 \\
257\end{array}$ & $\begin{array}{r}10,200 \\
8,570 \\
7,690 \\
6,460 \\
5,870 \\
7,260 \\
11,900 \\
38,600 \\
92,200 \\
52,300 \\
24,900 \\
15,300\end{array}$ \\
\hline The year........... & 2,200 & 87 & 388 & 281,000 \\
\hline $\begin{array}{l}\text { October. } \\
\text { Novernber } \\
\text { December } \\
\text { January } \\
\text { February } \\
\text { March } \\
\text { April } \\
\text { May } \\
\text { June } \\
\text { July } \\
\text { August } \\
\text { September }\end{array}$ & $\begin{array}{r}290 \\
250 \\
225 \\
185 \\
128 \\
140 \\
275 \\
760 \\
2,960 \\
2,690 \\
660 \\
278\end{array}$ & $\begin{array}{l}225 \\
177 \\
128 \\
115 \\
105 \\
104 \\
104 \\
169 \\
370 \\
720 \\
280 \\
213\end{array}$ & $\begin{array}{r}261 \\
211 \\
150 \\
140 \\
120 \\
116 \\
152 \\
354 \\
1,900 \\
1,180 \\
411 \\
226\end{array}$ & $\begin{array}{r}16,000 \\
12,600 \\
9,220 \\
8,610 \\
6,660 \\
7,130 \\
9,040 \\
21,800 \\
113,000 \\
72,600 \\
25,300 \\
13,400\end{array}$ \\
\hline The year... & 2,960 & 104 & 436 & 315,000 \\
\hline $\begin{array}{l}\text { Oetober-19 } \\
\text { November } \\
\text { December } \\
\text { January } \\
\text { February } \\
\text { March } \\
\text { April } \\
\text { May } \\
\text { June } \\
\text { July } \\
\text { August } \\
\text { September }\end{array}$ & $\begin{array}{r}414 \\
194 \\
158 \\
141 \\
135 \\
.154 \\
234 \\
1,500 \\
5,000\end{array}$ & $\begin{array}{r}148 \\
154 \\
126 \\
76 \\
106 \\
114 \\
141 \\
217 \\
785 \\
-.-\end{array}$ & $\begin{array}{r}204 \\
174 \\
141 \\
125 \\
120 \\
130 \\
187 \\
783 \\
2,990 \\
a 750 \\
190 \\
\times 180\end{array}$ & $\begin{array}{r}12,500 \\
10,400 \\
8,670 \\
7,690 \\
6,660 \\
7,990 \\
11,100 \\
48,100 \\
178,000 \\
46,100 \\
11,700 \\
10,700\end{array}$ \\
\hline The year. & 5,000 & 76 & 498 & 360,000 \\
\hline
\end{tabular}

astimated.

ROARING FORK IEAR EMHA, COLO.

Location.-About sec. 11, T. 8 S., R. 87 W., at highway bridge 11/2 miles northwest of Emma, Eagle County. Nearest tributary, Sopris Creek, enters 1 mile upstream.

Drainage area.-853 square miles (measured on Forest Service map).

Records avaILABLE.-July 19, 1908, to September 30, 1909.

GAGE.-Chain.

ControL.-Slightly shifting. 
IcE.-Stage-discharge relation slightly affected by ice.

Drversions.-Water diverted from Roaring Fork between Emma and Aspen for irrigation of 2,000 acres and from intervening tributaries for irrigation of 11,500 acres.

Accuracr.-Gage read twice daily. Rating curves well defined. Records good.

Monthly discharge of Roaring Fork near Emma, Colo., for 1908-8

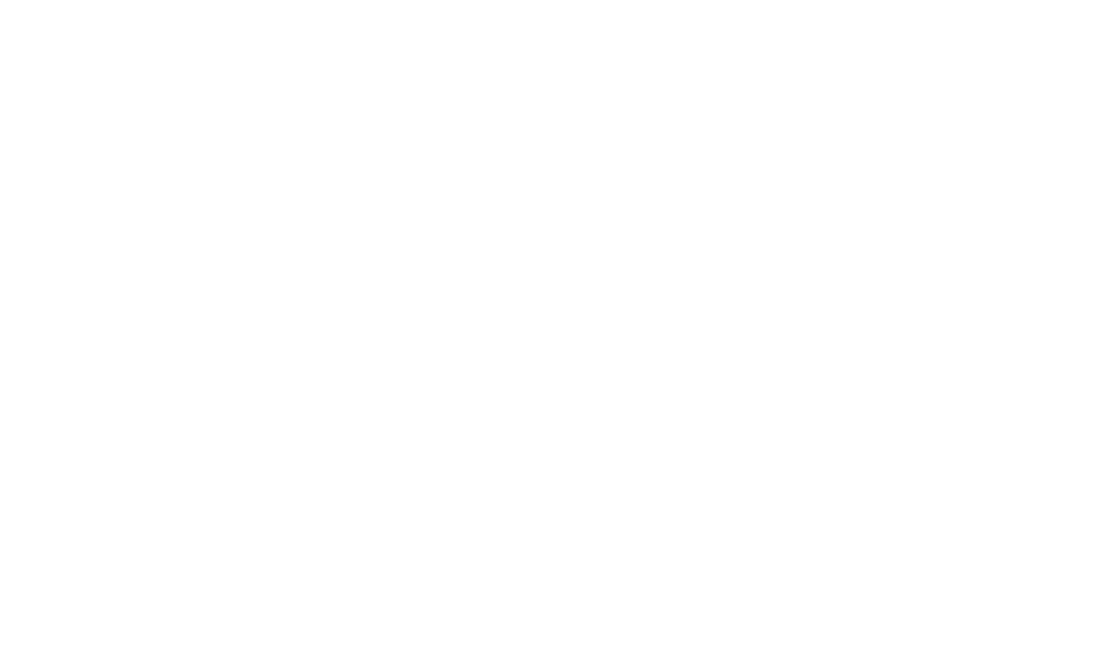

ROARING FORK AT GLENWOOD SPRINGS, COLO.

Locatron.-In sec. 9, T. 6 S., R. 89 W., at Glenwood Springs, Garfield County, 1,500 feet above mouth of river.

Drainage area.-1,460 square miles (measured on base map of Colorado).

Records avaluable.-October 1, 1905, to September 30, 1910; October 1, 1911, to September 30, 1927.

GAGE.-Gurley water-stage recorder used since October 27, 1917. Prior to that time, chain gage on bridge 800 feet downstream.

Controu.-Shifting at long intervals.

EXtremes of Discharae.-Maximum stage recorded during period, 8.7 feet June 14, 1918, and June 14, 1921, from high-water mark (discharge, 17,600 secondfeet); minimum discharge, 225 second-feet on December 16, 1906 (gage height, 1.15 feet).

ICw.-Stage-discharge relation not seriously affected by ice, except for short periods.

Diversions.-Water diverted from Roaring Fork for irrigation of 5,600 acres and from tributaries for the irrigation of 19,000 acres, all above station.

ACCURACY.-Gage read twice daily 1906-1909; once daily 1910-1917; continuous record 1918-1926. Rating curves well defined. Records 1906-1909 good, 1910-1917 fair, 1918-1926 excellent, except during winter for which they are good.

Cooprration.-Since 1925 station maintained in cooperation with State engineer. 
Monthly discharge of Roaring Fork at Glenwood Springs, Colo., for 1905-1910 and 1911-1927

Month
October
November
December
January
February
March
April
Jung
July
August
September..

The year.

$1906-7$

October.

November

December

February

March

April

May

July

August.

September -

The year.

October.

November

December

January

Februarch.

April

May.

June

July.--

September

The year

October
November
December
January
February
March
April
May
June
July
August
September

The year

\section{7-8}

October-1909-10

Nocember

Fanuary.

March

April

Maye

June

Angust

September.

The year.

\begin{tabular}{|c|c|c|c|}
\hline \multicolumn{3}{|c|}{ Discharge in second-feet } & \multirow{2}{*}{$\underset{\text { \&cre-feet }}{\text { Run-off in }}$} \\
\hline Maximum & Minimum & Mean & \\
\hline $\begin{array}{r}2,530 \\
6,940 \\
11,400 \\
6,060 \\
2,640 \\
1,870\end{array}$ & $\begin{array}{r}1,280 \\
4,740 \\
2,220 \\
910 \\
784\end{array}$ & $\begin{array}{l}\text { a } 700 \\
\text { a } 600 \\
a 475 \\
a 425 \\
a 400 \\
a \quad 400 \\
a \\
1,200 \\
4,290 \\
7,060 \\
4,000 \\
1,590 \\
1,150\end{array}$ & $\begin{array}{r}43,000 \\
35,700 \\
29,200 \\
26,100 \\
22 ; 200 \\
30,700 \\
71,400 \\
264,000 \\
420,000 \\
246,000 \\
97,800 \\
68,400\end{array}$ \\
\hline 11,400 & $-\cdots$ & 1,860 & $1,350,000$ \\
\hline $\begin{array}{r}1,340 \\
858 \\
520 \\
450 \\
450 \\
995 \\
2,640 \\
5,300 \\
8,040 \\
8,000 \\
3,120 \\
1,290\end{array}$ & $\begin{array}{r}700 \\
375 \\
225 \\
266 \\
290 \\
330 \\
670 \\
\mathbf{1}, 090 \\
\mathbf{2 , 7 5 0} \\
\mathbf{3}, 600 \\
1,240 \\
805\end{array}$ & $\begin{array}{r}943 \\
604 \\
421 \\
368 \\
367 \\
554 \\
1,490 \\
2,410 \\
6,270 \\
5,500 \\
1,980 \\
1,030\end{array}$ & $\begin{array}{r}58,000 \\
35,900 \\
25,900 \\
22,600 \\
20,400 \\
34,100 \\
88,700 \\
148,000 \\
373,000 \\
338,000 \\
122,000 \\
61,300\end{array}$ \\
\hline 8,040 & 225 & 1,830 & $1,330,000$ \\
\hline $\begin{array}{r}1,040 \\
670 \\
486 \\
510 \\
450 \\
650 \\
1,980 \\
3,190 \\
6,320 \\
3,510 \\
1,680 \\
625\end{array}$ & $\begin{array}{r}670 \\
375 \\
360 \\
400 \\
350 \\
400 \\
400 \\
1,190 \\
\mathbf{2 , 6 2 0} \\
1,190 \\
670 \\
455\end{array}$ & $\begin{array}{r}802 \\
504 \\
453 \\
433 \\
400 \\
500 \\
1,160 \\
1,870 \\
4,380 \\
2,170 \\
1,210 \\
534\end{array}$ & $\begin{array}{r}49,300 \\
30,000 \\
27,900 \\
26,600 \\
23,000 \\
30,700 \\
69,000 \\
115,000 \\
261,000 \\
133,000 \\
\mathbf{7 4 , 4 0 0} \\
\mathbf{3 1}, 800\end{array}$ \\
\hline 6,320 & 350 & 1,200 & 872,000 \\
\hline $\begin{array}{r}625 \\
540 \\
555 \\
510 \\
400 \\
450 \\
1,500 \\
4,730 \\
11,300 \\
\mathbf{8 , 7 4 0} \\
2,000 \\
2,840\end{array}$ & $\begin{array}{r}455 \\
390 \\
375 \\
300 \\
300 \\
350 \\
450 \\
\mathbf{9 9 5} \\
\mathbf{2 , 8 2 0} \\
1,700 \\
1,220 \\
\mathbf{9 3 5}\end{array}$ & $\begin{array}{r}530 \\
547 \\
455 \\
410 \\
362 \\
421 \\
782 \\
2,910 \\
8,350 \\
4,070 \\
1,480 \\
1,530\end{array}$ & $\begin{array}{r}32,600 \\
26,600 \\
28,000 \\
25,200 \\
20,100 \\
28,900 \\
46,500 \\
179,000 \\
497,000 \\
250,000 \\
91,000 \\
91,000\end{array}$ \\
\hline 11,300 & 300 & 1,810 & $1,310,000$ \\
\hline $\begin{array}{l}760 \\
655\end{array}$ & $\begin{array}{l}485 \\
380\end{array}$ & $\begin{array}{l}587 \\
494\end{array}$ & $\begin{array}{l}36,100 \\
29,400\end{array}$ \\
\hline $\begin{array}{r}680 \\
680 \\
790 \\
2,530 \\
5,430\end{array}$ & $\begin{array}{r}270 \\
315 \\
365 \\
645 \\
1,500\end{array}$ & $\begin{array}{r}403 \\
389 \\
514 \\
1,040 \\
3,820 \\
7,500 \\
33,250 \\
1,000 \\
2850\end{array}$ & $\begin{array}{r}25,000 \\
24,800 \\
21,600 \\
31,600 \\
61,900 \\
235,000 \\
446,000 \\
200,000 \\
61,500 \\
50,600\end{array}$ \\
\hline & & 1,690 & $1,220,000$ \\
\hline
\end{tabular}

- Estimate based on comparison with discharge of Colorado River at Glenwood Springs. 
Monthly discharge of Roaring Fork at Glenwood Springs, Colo., for 1905-1910 and 1911-1927-Continued

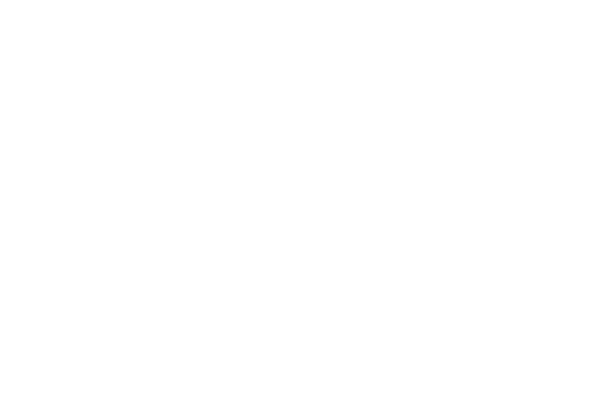

The year

1912-13

October.

November

December

January

Fobruar

Mareb

May.

Mane

July.

Angust

September

The year

October.

November

Decembe

January

February

March

April

June.

July -

August

September

The year

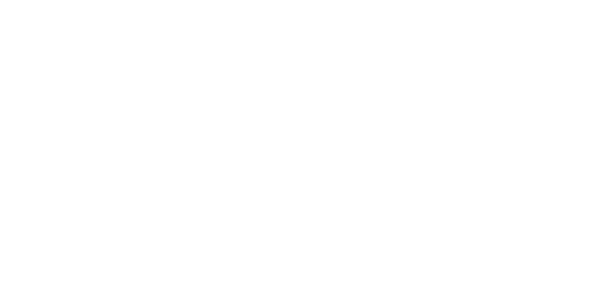

The year.

\section{3-14}

\section{October.}

November

December.

January.

February

March.

April.

May.

$\operatorname{Jun} \theta$.

July -

August.-

September

The year.

\begin{tabular}{|c|c|c|c|}
\hline \multicolumn{3}{|c|}{ Discharge in second-feet } & \multirow{2}{*}{$\begin{array}{c}\text { Run-off in } \\
\text { acre-feet }\end{array}$} \\
\hline Maximum & Minimum & Mean & \\
\hline $\begin{array}{r}4,800 \\
1,120 \\
680 \\
535 \\
460 \\
585 \\
1,380 \\
9,840 \\
12,800 \\
5,840 \\
3,270 \\
1,370\end{array}$ & $\begin{array}{r}680 \\
365 \\
365 \\
370 \\
330 \\
370 \\
435 \\
1,750 \\
7,270 \\
3,650 \\
1,420 \\
785\end{array}$ & $\begin{array}{r}1,490 \\
653 \\
521 \\
445 \\
385 \\
423 \\
900 \\
4,040 \\
10,000 \\
5,000 \\
2,160 \\
988\end{array}$ & $\begin{array}{r}91,600 \\
38,900 \\
32,000 \\
27,400 \\
22,100 \\
26,000 \\
58,600 \\
248,000 \\
595,000 \\
307,000 \\
133,000 \\
58,500\end{array}$ \\
\hline 12,800 & 330 & 2,250 & $1,630,000$ \\
\hline $\begin{array}{r}900 \\
820 \\
620\end{array}$ & $\begin{array}{r}750 \\
535 \\
410 \\
\mathbf{3 5 0} \\
\mathbf{5 3 5} \\
\mathbf{1 , 9 6 0} \\
\mathbf{3 , 2 8 0} \\
\mathbf{6 2 0} \\
\mathbf{6 2 0}\end{array}$ & $\begin{array}{r}812 \\
689 \\
542 \\
6450 \\
6420 \\
426 \\
1,120 \\
3,880 \\
4,640 \\
2,200 \\
773 \\
801\end{array}$ & $\begin{array}{r}49,900 \\
41,000 \\
33,300 \\
27,700 \\
23,300 \\
26,200 \\
66,600 \\
239,000 \\
276,000 \\
135,000 \\
47,500 \\
47,700\end{array}$ \\
\hline 7,270 & 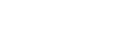 & 1,400 & $1,010,000$ \\
\hline $\begin{array}{r}820 \\
650 \\
560\end{array}$ & $\begin{array}{r}590 \\
560 \\
\mathbf{3 5 0}\end{array}$ & $\begin{array}{r}702 \\
614 \\
472 \\
\times 400 \\
a 450 \\
\times 500 \\
\times 1,000 \\
\sigma 7,040 \\
11,000 \\
6,230 \\
1,310 \\
791\end{array}$ & $\begin{array}{r}43,200 \\
36,500 \\
29,000 \\
24,600 \\
25,000 \\
30,700 \\
59,500 \\
433,000 \\
655,000 \\
383,000 \\
80,600 \\
47,100\end{array}$ \\
\hline 14,200 & & 2,550 & $1,850,000$ \\
\hline $\begin{array}{r}927 \\
602 \\
485 \\
-405 \\
405 \\
430 \\
1,480 \\
2,550 \\
6,530 \\
3,680 \\
1,370 \\
735\end{array}$ & $\begin{array}{r}578 \\
440 \\
358 \\
350 \\
350 \\
370 \\
560 \\
2,210 \\
835 \\
455 \\
405\end{array}$ & $\begin{array}{r}727 \\
506 \\
431 \\
\times 370 \\
369 \\
371 \\
654 \\
1,390 \\
4,310 \\
2,060 \\
680 \\
526\end{array}$ & $\begin{array}{r}44,700 \\
30,160 \\
26,500 \\
22,800 \\
20,500 \\
22,800 \\
38,900 \\
85,500 \\
256,000 \\
127,000 \\
41,800 \\
31,300\end{array}$ \\
\hline 6,530 & n. & 1,030 & 748,000 \\
\hline $\begin{array}{r}615 \\
588 \\
485 \\
485 \\
390 \\
1,260 \\
\mathbf{3}, 030 \\
5,280 \\
8,520 \\
\mathbf{5}, 990 \\
\mathbf{3}, 030 \\
\mathbf{1}, 470\end{array}$ & $\begin{array}{r}430 \\
390 \\
360 \\
335 \\
330 \\
300 \\
592 \\
1,470 \\
4,830 \\
2,220 \\
875 \\
790\end{array}$ & $\begin{array}{r}499 \\
469 \\
425 \\
404 \\
369 \\
609 \\
1,160 \\
3,080 \\
6,750 \\
3,730 \\
1,870 \\
989\end{array}$ & $\begin{array}{r}30,700 \\
27,900 \\
26,100 \\
24,800 \\
21,200 \\
37,400 \\
69,000 \\
189,000 \\
402,000 \\
229,000 \\
115,000 \\
58,800\end{array}$ \\
\hline 8,520 & 300 & 1,700 & $1,230,000$ \\
\hline
\end{tabular}

- Estimate based on comparison with discharge of Colorado River at Glenwood Springs. 
Monthly discharge of Roaring Fork at Glenwood Springs, Colo., for 1905-1910 and 1911-1927-Continued

\begin{tabular}{l} 
Month \\
\hline \\
October \\
November \\
December \\
January \\
Mabruary \\
April \\
May \\
June-16 \\
July \\
August \\
September
\end{tabular}

The year

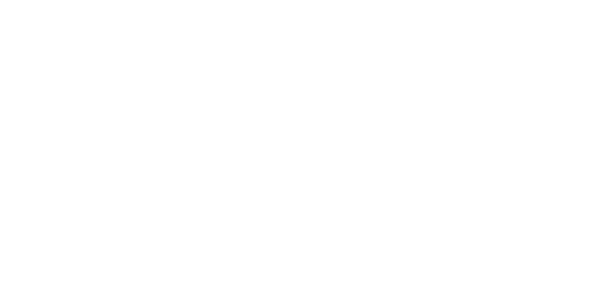

The year

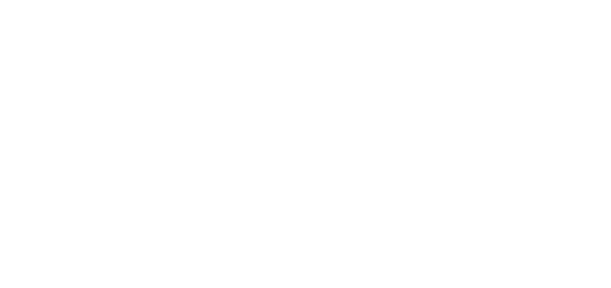

The year

October
November-1919-20
December-1
January
February
March
April May
June
July
August
September

The year.

October-

$1920-21$

November

December

January

February

March

April.

May.

June

Angust

September

The year.

\begin{tabular}{|c|c|c|c|}
\hline \multicolumn{3}{|c|}{ Discharge in second-feet } & \multirow{2}{*}{$\begin{array}{l}\text { Run-off in } \\
\text { acre-feet }\end{array}$} \\
\hline Maximum & Minimum & Mean & \\
\hline $\begin{array}{r}1,320 \\
815 \\
610 \\
575 \\
540 \\
1,060 \\
2,540 \\
5,460 \\
11,100 \\
9,640 \\
2,860 \\
1,590\end{array}$ & $\begin{array}{r}860 \\
475 \\
445 \\
445 \\
415 \\
390 \\
475 \\
1,160 \\
2,700 \\
3,400 \\
1,010 \\
910\end{array}$ & $\begin{array}{r}1,080 \\
638 \\
541 \\
520 \\
469 \\
523 \\
980 \\
2,760 \\
8,380 \\
5,550 \\
1,670 \\
1,090\end{array}$ & $\begin{array}{r}66,400 \\
38,000 \\
33,300 \\
32,000 \\
26,000 \\
32,200 \\
58,300 \\
170,000 \\
499,000 \\
341,000 \\
103,000 \\
64,900\end{array}$ \\
\hline 11,100 & 390 & 2,020 & $1,460,000$ \\
\hline $\begin{array}{r}910 \\
770 \\
589 \\
527 \\
501 \\
920 \\
1,420 \\
6,190 \\
15,200 \\
4,590 \\
1,260 \\
1,780\end{array}$ & $\begin{array}{r}685 \\
540 \\
475 \\
380 \\
380 \\
410 \\
685 \\
1,280 \\
3,210 \\
1,320 \\
685 \\
685\end{array}$ & $\begin{array}{r}763 \\
625 \\
519 \\
480 \\
442 \\
599 \\
978 \\
3,690 \\
9,720 \\
2,720 \\
994 \\
1,060\end{array}$ & $\begin{array}{r}46,900 \\
37,200 \\
31,900 \\
29,500 \\
24,500 \\
36,800 \\
58,200 \\
227,000 \\
578,000 \\
167,000 \\
61,100 \\
63,100\end{array}$ \\
\hline 15,200 & 380 & 1,880 & $1,360,000$ \\
\hline $\begin{array}{r}920 \\
851 \\
640 \\
540 \\
494 \\
788 \\
2,540 \\
6,940 \\
4,480 \\
2,700 \\
1,900 \\
1,280\end{array}$ & $\begin{array}{r}788 \\
554 \\
469 \\
475 \\
400 \\
390 \\
561 \\
1,900 \\
2,170 \\
890 \\
531 \\
512\end{array}$ & $\begin{array}{r}838 \\
697 \\
547 \\
510 \\
432 \\
507 \\
1,200 \\
3,760 \\
3,360 \\
1,580 \\
889 \\
780\end{array}$ & $\begin{array}{r}51,500 \\
41,500 \\
33,600 \\
31,400 \\
24,000 \\
31,200 \\
71,400 \\
231,000 \\
200,000 \\
97,200 \\
54,700 \\
46,400\end{array}$ \\
\hline 6,940 & 390 & 1,260 & 914,000 \\
\hline $\begin{array}{r}\mathbf{7 3 2} \\
640 \\
582 \\
568 \\
457 \\
554 \\
806 \\
9,920 \\
10,800 \\
6,440 \\
\mathbf{2 , 3 9 0} \\
\mathbf{9 4 0}\end{array}$ & $\begin{array}{r}.633 \\
538 \\
390 \\
. \quad 427 \\
380 \\
380 \\
439 \\
1,130 \\
5,460 \\
1,900 \\
980 \\
747\end{array}$ & $\begin{array}{r}686 \\
580 \\
512 \\
487 \\
418 \\
450 \\
607 \\
4,970 \\
7,650 \\
3,750 \\
1,450 \\
838\end{array}$ & $\begin{array}{r}42,200 \\
34,500 \\
31,500 \\
29,900 \\
24,000 \\
27,700 \\
36,100 \\
306,000 \\
455,000 \\
231,000 \\
89,200 \\
49,900\end{array}$ \\
\hline 10,800 & 380 & 1,870 & $1,360,000$ \\
\hline $\begin{array}{r}792 \\
688 \\
598 \\
514 \\
412 \\
600 \\
909 \\
7,380 \\
17,300 \\
6,100 \\
2,020 \\
2,090 \\
\end{array}$ & $\begin{array}{r}656 \\
451 \\
382 \\
330 \\
330 \\
418 \\
500 \\
1,030 \\
5,720 \\
1,720 \\
1,160 \\
688 \\
\end{array}$ & $\begin{array}{r}700 \\
589 \\
479 \\
416 \\
375 \\
504 \\
673 \\
3,200 \\
8,590 \\
3,230 \\
1,490 \\
1,040 \\
\end{array}$ & $\begin{array}{r}43,000 \\
35,000 \\
29,500 \\
25,600 \\
20,800 \\
31,000 \\
40,000 \\
197,000 \\
511,000 \\
199,000 \\
91,600 \\
61,900\end{array}$ \\
\hline 17,300 & 330 & 1,770 & $1,290,000$ \\
\hline
\end{tabular}


Monthly discharge of Roaring Fork at Glenwood Springs, Colo., for 1905-1910 and 1911-1927-Continued

Month
October
November
December
January
Mebruary
March
April
May-21-22
June-y
August
September.

\begin{tabular}{|c|c|c|c|}
\hline \multicolumn{3}{|c|}{ Discharge in second-feet } & \multirow{2}{*}{$\begin{array}{l}\text { Run-off in } \\
\text { acre-feet }\end{array}$} \\
\hline Maximum & Minimum & Mean & \\
\hline $\begin{array}{r}720 \\
626 \\
588 \\
440 \\
528 \\
744 \\
1,760 \\
\mathbf{9}, 000 \\
\mathbf{9}, 000 \\
\mathbf{3}, 740 \\
1,620 \\
1,090\end{array}$ & $\begin{array}{r}570 \\
400 \\
370 \\
365 \\
340 \\
385 \\
540 \\
1,840 \\
3,110 \\
1,270 \\
930 \\
685\end{array}$ & $\begin{array}{r}646 \\
510 \\
439 \\
416 \\
401 \\
523 \\
870 \\
4,190 \\
5,650 \\
2,100 \\
1,160 \\
834\end{array}$ & $\begin{array}{r}39,700 \\
30,300 \\
27,000 \\
25,600 \\
22,300 \\
32,200 \\
51,800 \\
258,000 \\
336,000 \\
129,000 \\
71,300 \\
49,600\end{array}$ \\
\hline 9,000 & 340 & 1,480 & $1,070,000$ \\
\hline $\begin{array}{l}699 \\
635 \\
578\end{array}$ & $\begin{array}{l}564 \\
522 \\
474\end{array}$ & \multirow{2}{*}{$\begin{array}{r}632 \\
571 \\
546 \\
a 468 \\
362 \\
419 \\
792 \\
3,550 \\
6,730 \\
\mathbf{3}, 800 \\
1,620 \\
\mathbf{9 4 3}\end{array}$} & \multirow{2}{*}{$\begin{array}{r}38,900 \\
34,000 \\
33,600 \\
28,800 \\
20,100 \\
25,800 \\
47,100 \\
218,000 \\
400,000 \\
234,000 \\
99,600 \\
56,100\end{array}$} \\
\hline $\begin{array}{r}406 \\
578 \\
1,120 \\
7,600 \\
8,600 \\
6,080 \\
2,250 \\
1,260\end{array}$ & $\begin{array}{r}350 \\
543 \\
1,120 \\
4,760 \\
1,650 \\
1,050 \\
791\end{array}$ & & \\
\hline 8,600 & - & 1,710 & $1,240,000$ \\
\hline $\begin{array}{r}998 \\
736 \\
580 \\
666 \\
619 \\
448 \\
1,350 \\
5,010 \\
11,100 \\
3,540 \\
847 \\
697\end{array}$ & $\begin{array}{r}572 \\
425 \\
433 \\
417 \\
342 \\
349 \\
410 \\
972 \\
2,900 \\
895 \\
464 \\
410\end{array}$ & $\begin{array}{r}767 \\
584 \\
527 \\
525 \\
418 \\
393 \\
813 \\
3,230 \\
6,060 \\
1,910 \\
600 \\
562\end{array}$ & $\begin{array}{r}47,200 \\
34,800 \\
32,400 \\
32,300 \\
24,000 \\
24,200 \\
48,400 \\
199,000 \\
361,000 \\
117,000 \\
36,900 \\
33,400\end{array}$ \\
\hline 11,100 & 342 & 1,360 & 991,000 \\
\hline $\begin{array}{l}737 \\
580 \\
482\end{array}$ & $\begin{array}{l}538 \\
450\end{array}$ & \multirow{2}{*}{$\begin{array}{r}621 \\
525 \\
419 \\
\times 380 \\
382 \\
483 \\
1,110 \\
3,190 \\
4,060 \\
2,380 \\
1,280 \\
1,340 \\
\end{array}$} & \multirow{2}{*}{$\begin{array}{r}38,200 \\
31,200 \\
25,800 \\
23,400 \\
21,200 \\
29,700 \\
66,000 \\
196,000 \\
242,000 \\
146,000 \\
78,700 \\
79,700\end{array}$} \\
\hline $\begin{array}{r}420 \\
645 \\
1,910 \\
6,360 \\
8,040 \\
3,740 \\
1,790 \\
2,240\end{array}$ & $\begin{array}{r}350 \\
366 \\
580 \\
1,560 \\
2,300 \\
1,330 \\
872 \\
1,020 \\
\end{array}$ & & \\
\hline 8,040 & - & 1,350 & 978,000 \\
\hline $\begin{array}{r}1,250 \\
852 \\
593 \\
432 \\
390 \\
500 \\
2,170 \\
6,000 \\
8,440 \\
5,120 \\
1,300 \\
600\end{array}$ & $\begin{array}{r}824 \\
580 \\
352 \\
330 \\
335 \\
338 \\
\mathbf{3 7 0} \\
1,130 \\
\mathbf{3}, \mathbf{1 1 0} \\
\mathbf{1}, 200 \\
\mathbf{5 3 5} \\
\mathbf{5 0 0}\end{array}$ & $\begin{array}{r}966 \\
692 \\
456 \\
380 \\
360 \\
411 \\
971 \\
2,840 \\
\mathbf{5 ,}, 170 \\
\mathbf{2}, 650 \\
\mathbf{8 8 9} \\
\mathbf{5 4 6}\end{array}$ & $\begin{array}{r}59,400 \\
41,200 \\
28,000 \\
23,400 \\
20,000 \\
26,300 \\
57,800 \\
175,000 \\
308,000 \\
163,000 \\
54,700 \\
32,500\end{array}$ \\
\hline 8,440 & 330 & 1,360 & 988,000 \\
\hline
\end{tabular}

The year

1923-24

October.

1922-23

October-.

November

January

March

May.

July -

August.

The year

November

December

January

March

A pril.

May

June

August

September

The year

\section{4-25}

October

November

January

March

Apri

May

June.

August

September

The year

\section{5-26}

October.

November

January

February

March

April

May

June

July -

August

- Estimate based on comparison with discharge of Colorado River at Glenwood Springs. 
Monthly discharge of Roaring Fork at Glenwood Springs, Colo., for 1905-1910 and 1911-19:7-Continued

\begin{tabular}{|c|c|c|c|c|}
\hline \multirow{2}{*}{ Month } & \multicolumn{3}{|c|}{ Discharge in second-feet } & \multirow{2}{*}{$\begin{array}{l}\text { Run-off in } \\
\text { acre-feet }\end{array}$} \\
\hline & Maximum & Minimum & Mean & \\
\hline $\begin{array}{l}\text { October } \\
\text { November } \\
\text { December } \\
\text { January } \\
\text { February } \\
\text { March } \\
\text { April } \\
\text { May } \\
\text { June } \\
\text { July } \\
\text { August } \\
\text { September }\end{array}$ & $\begin{array}{r}895 \\
\mathbf{5 9 2} \\
\mathbf{5 5 2} \\
505 \\
432 \\
\mathbf{5 3 6} \\
\mathbf{2 , 3 0 0} \\
\mathbf{7 , 0 5 0} \\
\mathbf{8 , 2 8 0} \\
\mathbf{4 , 0 3 0} \\
\mathbf{2 , 2 2 0} \\
\mathbf{1 , 7 8 0}\end{array}$ & $\begin{array}{r}530 \\
510 \\
406 \\
385 \\
355 \\
359 \\
475 \\
1,880 \\
4,510 \\
1,630 \\
950 \\
890\end{array}$ & $\begin{array}{r}680 \\
555 \\
487 \\
437 \\
400 \\
413 \\
806 \\
4,190 \\
6,050 \\
2,690 \\
1,460 \\
1,190\end{array}$ & $\begin{array}{r}41,800 \\
33,000 \\
29,900 \\
26,900 \\
22,200 \\
25,400 \\
48,000 \\
258,000 \\
360,000 \\
165,000 \\
89,800 \\
70,800\end{array}$ \\
\hline The year....... & 8,280 & $\mathbf{3 5 5}$ & 1,620 & $1,170,000$ \\
\hline
\end{tabular}

CASTLE CREER NEAR ASPEN, COLO.

Location.-In sec. 35, T. 10 S., R. 85 W., 75 feet below highway bridge $4 \frac{1}{2}$ miles south of Aspen, Pitkin County. Nearest tributary, Conundrum Creek, enters 1 mile upstream.

Drainage AREA. - 62 square miles (measured on topographic map).

ReCORDS AVAILABLE.-October 1, 1911, to January 31, 1920.

GAGE.-Gurley water-stage recorder installed April 11, 1915. Staff gage used prior to that date.

Control.-Shifting.

EXtremes OF DISCHARge.-Maximum stage recorded during period, 3.9 feet at 7 p. m. June 15, 1918 (discharge, 1,090 second-feet); minimum discharge recorded, 23 second-feet November 7 and December 5, 1912.

IcE.--Stage-discharge relation not seriously affected by ice.

Diversions.-No diversions above station.

ACCURACY.-Gage read at irregular intervals 1912-1914; continuous record 1915

to 1920. Rating curves fairly well defined. Records prior to 1915 fair; subsequent records good, except during winter, for which they are fair.

Cooperation.--Station maintained in cooperation with United States Forest Service.

Monthly discharge of Castle Creek near Aspen, Colo., for 1911-1920

\begin{tabular}{|c|c|c|c|c|}
\hline \multirow{2}{*}{ Month } & \multicolumn{3}{|c|}{ Discharge in second-feet } & \multirow{2}{*}{$\begin{array}{l}\text { Run-off in } \\
\text { acre-feot }\end{array}$} \\
\hline & Maximum & Minimum & Mean & \\
\hline $\begin{array}{l}\text { October-1911-12 } \\
\text { November } \\
\text { December- } \\
\text { January } \\
\text { February } \\
\text { March } \\
\text { April } \\
\text { May } \\
\text { June } \\
\text { July } \\
\text { August } \\
\text { September }\end{array}$ & $\begin{array}{r}27 \\
30 \\
380 \\
+\quad 500 \\
455 \\
275 \\
135\end{array}$ & \begin{tabular}{r|r|}
24 \\
24 \\
25 \\
165 \\
280 \\
127 \\
71
\end{tabular} & $\begin{array}{c}\text { a } 50 \\
\text { a } 45 \\
\text { a } 40 \\
\text { a } 30 \\
\text { e } 25 \\
24.9 \\
26.1 \\
111 \\
395 \\
363 \\
168 \\
97.0\end{array}$ & $\begin{array}{r}3,070 \\
2,680 \\
2,460 \\
1,840 \\
1,440 \\
1,530 \\
1,550 \\
6,820 \\
23,500 \\
22,300 \\
10,300 \\
5,770\end{array}$ \\
\hline The year & 500 & - & 115 & 83,300 \\
\hline
\end{tabular}

a Estimated. 
Monthly discharge of Castle Creek near Aspen, Colo., for 1911-1920-Continued

\begin{tabular}{|c|c|c|c|c|}
\hline \multirow{2}{*}{ Month } & \multicolumn{3}{|c|}{ Discharge in second-feet } & \multirow{2}{*}{$\begin{array}{l}\text { Run-ofi in } \\
\text { acre-feet }\end{array}$} \\
\hline & Maximum & Minimum & Mean & \\
\hline $\begin{array}{l}\text { ctober. } \\
\text { Jovember } \\
\text { vecember. } \\
\text { anuary. } \\
\text { Pebruary } \\
\text { Mareh }\end{array}$ & 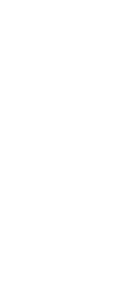 & 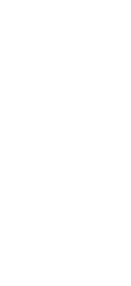 & $\begin{array}{l}61.9 \\
\text { a } 30 \\
25 \\
\text { a } 25 \\
\text { e } 25 \\
\text { C } 25 \\
35 \\
161 \\
252 \\
202 \\
108 \\
106\end{array}$ & $\begin{array}{r}3,810 \\
1,790 \\
1,540 \\
1,540 \\
1,890 \\
1,540 \\
2,080 \\
9,900 \\
15,000 \\
12,400 \\
6,640 \\
6,310\end{array}$ \\
\hline The year. & 305 & 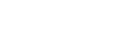 & 88. 8 & 63,900 \\
\hline $\begin{array}{l}\text { October } \\
\text { November. } \\
\text { December } \\
\text { January- } \\
\text { February. } \\
\text { March } \\
\text { April } \\
\text { May } \\
\text { June } \\
\text { July } \\
\text { August } \\
\text { September }\end{array}$ & $\begin{array}{r}64 \\
43 \\
43 \\
37 \\
40 \\
36 \\
408 \\
455 \\
342 \\
200 \\
85\end{array}$ & $\begin{array}{r}25 \\
\mathbf{3 2} \\
38 \\
30 \\
\mathbf{2 3} \\
\mathbf{3 1} \\
\mathbf{5 4} \\
\mathbf{2 3 6} \\
\mathbf{2 1 6} \\
\mathbf{8 5} \\
\mathbf{5 2}\end{array}$ & $\begin{array}{c}46.8 \\
41.1 \\
40.5 \\
32.5 \\
32.7 \\
32.5 \\
38 \\
179 \\
384 \\
269 \\
114 \\
68.7\end{array}$ & $\begin{array}{r}2,880 \\
2,450 \\
2,490 \\
2,000 \\
1,820 \\
2,000 \\
2,260 \\
11,000 \\
22,800 \\
16,500 \\
7,010 \\
4,000 \\
\end{array}$ \\
\hline The year & 455 & 23 & 107 & 77,300 \\
\hline $\begin{array}{l}\text { ctober. } \\
\text { ovember. } \\
\text { ecember. } \\
\text { anuary } \\
\text { ebruary } \\
\text { farch } \\
\text { pril } \\
\text { lay } \\
\text { lne } \\
\text { ly }\end{array}$ & $\begin{array}{r}65 \\
55 \\
35 \\
35 \\
36 \\
32 \\
40 \\
105 \\
374 \\
310 \\
184 \\
71\end{array}$ & $\begin{array}{r}41 \\
35 \\
24 \\
26 \\
30 \\
30 \\
29 \\
33 \\
66 \\
115 \\
62 \\
50\end{array}$ & $\begin{array}{l}53.6 \\
44.5 \\
30.1 \\
27.4 \\
33.1 \\
30.7 \\
31.3 \\
58.3 \\
220 \\
221 \\
89.1 \\
58.5\end{array}$ & $\begin{array}{r}3,300 \\
2,650 \\
1,860 \\
1,680 \\
1,840 \\
1,890 \\
1,860 \\
3,580 \\
13,100 \\
13,600 \\
5,480 \\
3,480\end{array}$ \\
\hline The year...................... & 374 & 24 & $\mathbf{7 5 .} 0$ & 54,300 \\
\hline $\begin{array}{l}\text { ctober } \\
\text { ovember } \\
\text { ecember } \\
\text { nuary } \\
\text { ebruary } \\
\text { Larch } \\
\text { pril }\end{array}$ & $\begin{array}{r}53 \\
41 \\
36 \\
34 \\
36 \\
37 \\
92 \\
199 \\
510 \\
502 \\
\mathbf{2 9 0} \\
\mathbf{1 5 0}\end{array}$ & $\begin{array}{r}37 \\
31 \\
31 \\
29 \\
31 \\
32 \\
33 \\
68 \\
206 \\
244 \\
109 \\
64\end{array}$ & $\begin{array}{c}44.2 \\
36.4 \\
33.1 \\
32.2 \\
32.8 \\
33.6 \\
44.4 \\
130 \\
393 \\
351 \\
182 \\
90.4\end{array}$ & $\begin{array}{r}2,720 \\
2,170 \\
2,040 \\
1,980 \\
1,890 \\
2,070 \\
2,640 \\
7,900 \\
23,400 \\
21,600 \\
11,200 \\
5,380\end{array}$ \\
\hline The year................ & 510 & 29 & 117 & 85,100 \\
\hline 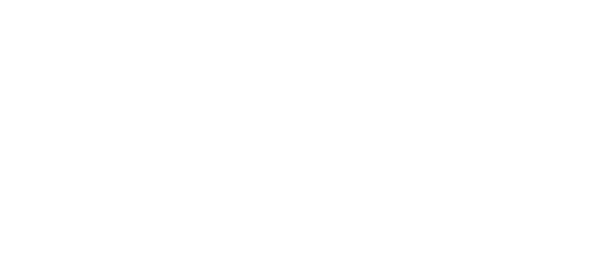 & $\begin{array}{r}90 \\
59 \\
47 \\
34 \\
29 \\
87 \\
56 \\
201 \\
752 \\
680 \\
236 \\
126\end{array}$ & $\begin{array}{r}61 \\
41 \\
28 \\
27 \\
25 \\
24 \\
30 \\
41 \\
117 \\
282 \\
109 \\
58\end{array}$ & $\begin{array}{c}70.3 \\
50.2 \\
39.6 \\
30.7 \\
27.5 \\
28.9 \\
37.9 \\
105 \\
450 \\
436 \\
165 \\
85.4\end{array}$ & $\begin{array}{r}4,320 \\
2,990 \\
2,480 \\
1,890 \\
1,530 \\
1,780 \\
2,260 \\
6,460 \\
26,800 \\
26,800 \\
10,100 \\
6,080\end{array}$ \\
\hline & 752 & 24 & 128 & 92,400 \\
\hline
\end{tabular}

- Estimated. 
Monthly discharge of Castle Creek near Aspen, Colo., for 1911-1920-Continued

\begin{tabular}{|c|c|c|c|c|}
\hline \multirow{2}{*}{ Month } & \multicolumn{3}{|c|}{ Discharge in second-feet } & \multirow{2}{*}{$\begin{array}{c}\text { Run-off in } \\
\text { acre-feet }\end{array}$} \\
\hline & Maximum & Minimum & Mean & \\
\hline $\begin{array}{l}\text { October. } \\
\text { November-1917-18 } \\
\text { December } \\
\text { January } \\
\text { February } \\
\text { March } \\
\text { April. } \\
\text { May } \\
\text { June } \\
\text { July } \\
\text { August } \\
\text { September. }\end{array}$ & $\begin{array}{r}70 \\
52 \\
45 \\
40 \\
35 \\
38 \\
49 \\
290 \\
970 \\
362 \\
149 \\
158\end{array}$ & $\begin{array}{r}50 \\
43 \\
40 \\
26 \\
26 \\
32 \\
34 \\
54 \\
194 \\
114 \\
73 \\
62\end{array}$ & $\begin{array}{c}58.5 \\
47.3 \\
42.4 \\
32.0 \\
31.5 \\
34.5 \\
40.5 \\
168 \\
554 \\
235 \\
108 \\
89.9\end{array}$ & $\begin{array}{r}3,600 \\
2,820 \\
2,610 \\
1,970 \\
1,750 \\
2,120 \\
2,410 \\
10,300 \\
33,000 \\
14,400 \\
6,640 \\
5,350\end{array}$ \\
\hline The year... & 970 & 26 & 120 & 87,000 \\
\hline $\begin{array}{l}\text { October- } \\
\text { November } \\
\text { December } \\
\text { January } \\
\text { February } \\
\text { March } \\
\text { April } \\
\text { May } \\
\text { June } \\
\text { July } \\
\text { August } \\
\text { September }\end{array}$ & $\begin{array}{r}68 \\
55 \\
42 \\
37 \\
34 \\
35 \\
102 \\
365 \\
348 \\
295 \\
225 \\
161\end{array}$ & $\begin{array}{r}54 \\
38 \\
28 \\
29 \\
28 \\
25 \\
28 \\
72 \\
150 \\
106 \\
66 \\
61\end{array}$ & $\begin{array}{c}60.8 \\
44.2 \\
37.4 \\
34.1 \\
30.9 \\
31.3 \\
49.2 \\
187 \\
258 \\
173 \\
102 \\
83.4\end{array}$ & $\begin{array}{r}3,740 \\
2,630 \\
2,300 \\
2,100 \\
1,720 \\
1,920 \\
2,930 \\
11,500 \\
15,400 \\
10,600 \\
6,270 \\
4,960\end{array}$ \\
\hline The year... & 365 & 25 & 91.2 & 66,100 \\
\hline $\begin{array}{l}\text { October } \\
\text { November } \\
\text { December } \\
\text { January }\end{array}$ & $\begin{array}{l}61 \\
52 \\
48 \\
41\end{array}$ & $\begin{array}{l}50 \\
45 \\
30 \\
36\end{array}$ & $\begin{array}{l}55.5 \\
49.4 \\
43.1 \\
37.5\end{array}$ & $\begin{array}{l}3,410 \\
\mathbf{2}, 940 \\
\mathbf{2}, 650 \\
\mathbf{2}, 300\end{array}$ \\
\hline The period... & $\ldots$ & & & 11,300 \\
\hline
\end{tabular}

MAROON CREEK NEAR ASPEN, COLO.

Location.--In sec. 22 , T. 10 S., R. 85 W., a short distance above head gate of

Roaring Fork Light \& Power Co. and 5 miles south of Aspen, Pitkin County .

Nearest tributary, Willow Creek, enters just below station.

Drainage area. - 42 square miles (measured on topographic map).

Records availlable.-October 1, 1910, to May 31, 1917.

GAGE.-Vertical staff.

Control.-Shifting.

Extremes of Discharge.-Maximum stage recorded during period, 2.30 feet on June 13 and 15, 1911 (discharge, 420. second-feet); minimum stage, 0.3 foot on March 26, 1911 (discharge, 14 second-feet).

IcE.-Stage-discharge relation unaffected by ice except for occasional short periods.

Diversions.-Practically no water diverted above station.

AcCURACY.-Gage read at irregular intervals prior to May 14, 1914; beginning on that date gage read twice daily. Rating curves fairly well defined. Records fair prior to May 14, 1914, and good after that date. 
Monthly discharge of Maroon Creek near Aspen, Colo., 1910-1917

\begin{tabular}{|c|c|c|c|c|}
\hline \multirow[t]{2}{*}{ - } & \multicolumn{3}{|c|}{ Diseharge in second-feet } & \multirow{2}{*}{$\underset{\text { acre-feet }}{\text { Run-off in }}$} \\
\hline & Maximum & Minimum & Mean & \\
\hline $\begin{array}{l}\text { October } \\
\text { November } \\
\text { December. } \\
\text { January } \\
\text { February } \\
\text { March } \\
\text { April } \\
\text { May } \\
\text { June } \\
\text { July } \\
\text { August } \\
\text { September }\end{array}$ & $\begin{array}{r}56 \\
32 \\
24 \\
69 \\
265 \\
420 \\
350 \\
192 \\
134\end{array}$ & \begin{tabular}{r|r|}
22 \\
22 \\
14 \\
22 \\
56 \\
273 \\
195 \\
134 \\
80
\end{tabular} & $\begin{array}{l}-55 \\
.45 \\
\text { - } 40 \\
33.8 \\
26.5 \\
21.3 \\
35.3 \\
147 \\
363 \\
262 \\
159 \\
96\end{array}$ & $\begin{array}{r}3,380 \\
2,680 \\
2,460 \\
2,080 \\
1,470 \\
1,310 \\
2,100 \\
9,040 \\
21,600 \\
16,100 \\
9,780 \\
\mathbf{5}, 710\end{array}$ \\
\hline The year & 420 & 14 & 107 & 77,700 \\
\hline $\begin{array}{l}\text { October } \\
\text { November } \\
\text { December } \\
\text { January } \\
\text { February } \\
\text { March } \\
\text { April } \\
\text { May } \\
\text { June } \\
\text { July } \\
\text { August } \\
\text { September }\end{array}$ & $\begin{array}{r}175 \\
83 \\
72 \\
38 \\
38 \\
34 \\
35 \\
170 \\
365 \\
365 \\
245 \\
152\end{array}$ & $\begin{array}{r}69 \\
58 \\
44 \\
30 \\
30 \\
23 \\
30 \\
37 \\
165 \\
250 \\
127 \\
68\end{array}$ & $\begin{array}{l}122 \\
69.2 \\
57.1 \\
33.0 \\
31.2 \\
26.0 \\
30.4 \\
87.6 \\
283 \\
319 \\
166 \\
112\end{array}$ & $\begin{array}{r}7,500 \\
4,120 \\
3,510 \\
2,030 \\
1,790 \\
1,600 \\
1,810 \\
5,390 \\
16,800 \\
19,600 \\
10,200 \\
6,660\end{array}$ \\
\hline The year................... & 365 & 23 & 111 & 81,000 \\
\hline $\begin{array}{l}\text { October. } \\
\text { November } \\
\text { December. } \\
\text { January } \\
\text { February } \\
\text { March } \\
\text { April. } \\
\text { May } \\
\text { June } \\
\text { July } \\
\text { August } \\
\text { September }\end{array}$ & $\begin{array}{r}68 \\
41 \\
39 \\
233 \\
263 \\
204 \\
124 \\
149\end{array}$ & $\begin{array}{r}42 \\
18 \\
20 \\
39 \\
176 \\
127 \\
67 \\
\mathbf{3 5}\end{array}$ & $\begin{aligned} & 55.3 \\
& 34.4 \\
&-20 \\
& \cdot 20 \\
& \text { a } 18 \\
& \text { - } 22 \\
& 29 \\
& 119 \\
& 215 \\
& 168 \\
& 84.2 \\
& 69.6\end{aligned}$ & $\begin{array}{r}3,400 \\
2,050 \\
1,230 \\
1,230 \\
1,000 \\
1,350 \\
1,730 \\
7,320 \\
12,800 \\
10,300 \\
5,180 \\
4,140\end{array}$ \\
\hline The year. & 263 & & 71.2 & 51,700 \\
\hline $\begin{array}{l}\text { October } \\
\text { November } \\
\text { December. } \\
\text { January } \\
\text { February } \\
\text { March } \\
\text { April } \\
\text { May } \\
\text { June } \\
\text { July } \\
\text { August } \\
\text { September }\end{array}$ & $\begin{array}{r}34 \\
31 \\
31 \\
31 \\
25 \\
20 \\
38 \\
312 \\
382 \\
330 \\
196 \\
74\end{array}$ & $\begin{array}{r}28 \\
25 \\
25 \\
20 \\
19 \\
16 \\
17 \\
38 \\
210 \\
198 \\
78 \\
43\end{array}$ & $\begin{array}{c}30.7 \\
28.4 \\
28.1 \\
26.3 \\
21.8 \\
18.8 \\
23.4 \\
130 \\
322 \\
276 \\
123 \\
55.5\end{array}$ & $\begin{array}{r}1,890 \\
1,690 \\
1,730 \\
1,620 \\
1,210 \\
1,160 \\
1,390 \\
7,990 \\
19,200 \\
17,000 \\
7,560 \\
3,300\end{array}$ \\
\hline The year & 382 & 16 & 44.0 & 68,200 \\
\hline $\begin{array}{l}\text { October. } \\
\text { November. } \\
\text { December. } \\
\text { January } \\
\text { February } \\
\text { March } \\
\text { April } \\
\text { May } \\
\text { June } \\
\text { July } \\
\text { August } \\
\text { September. }\end{array}$ & $\begin{array}{r}59 \\
36 \\
36 \\
39 \\
26 \\
24 \\
31 \\
90 \\
256 \\
241 \\
102 \\
47\end{array}$ & \begin{tabular}{r|}
36 \\
33 \\
30 \\
25 \\
24 \\
22 \\
23 \\
27 \\
109 \\
106 \\
47 \\
36
\end{tabular} & $\begin{array}{c}41.4 \\
34.5 \\
32.3 \\
28.8 \\
24.3 \\
23.3 \\
25.1 \\
55.4 \\
182 \\
177 \\
70.0 \\
41.8\end{array}$ & $\begin{array}{r}2,550 \\
2,050 \\
1,990 \\
1,770 \\
1,350 \\
1,430 \\
1,490 \\
3,410 \\
10,800 \\
10,900 \\
4,300 \\
2,490\end{array}$ \\
\hline The year..... & 256 & 22 & 61.5 & 44,500 \\
\hline
\end{tabular}

- Estimated. 
Monthly discharge of Maroon Creek near Aspen, Colo., 1910-1917-Continued

\begin{tabular}{|c|c|c|c|c|}
\hline \multirow{2}{*}{ Month } & \multicolumn{3}{|c|}{ Discharge in second-feet } & \multirow{2}{*}{$\begin{array}{l}\text { Run-off in } \\
\text { acre-feet }\end{array}$} \\
\hline & Maximum & Minimum & Mean & \\
\hline $\begin{array}{l}\text { October } \\
\text { November- } \\
\text { December } \\
\text { January } \\
\text { February } \\
\text { March } \\
\text { April } \\
\text { May } \\
\text { June } \\
\text { July } \\
\text { Angust } \\
\text { September }\end{array}$ & $\begin{array}{r}38 \\
31 \\
30 \\
30 \\
27 \\
28 \\
45 \\
145 \\
334 \\
365 \\
288 \\
129\end{array}$ & $\begin{array}{r}30 \\
28 \\
26 \\
24 \\
22 \\
22 \\
23 \\
39 \\
155 \\
272 \\
145 \\
61\end{array}$ & $\begin{array}{c}33.9 \\
28.9 \\
27.1 \\
25.2 \\
23.2 \\
23.3 \\
28.2 \\
95.1 \\
268 \\
311 \\
218 \\
89.5\end{array}$ & $\begin{array}{r}2,080 \\
1,720 \\
1,670 \\
1,550 \\
1,330 \\
1,430 \\
1,680 \\
5,850 \\
15,900 \\
19,100 \\
13,400 \\
5,330\end{array}$ \\
\hline The year............ & 365 & 22 & 97.9 & 71,000 \\
\hline $\begin{array}{l}\text { October } \\
\text { November } \\
\text { December } \\
\text { January } \\
\text { February } \\
\text { March } \\
\text { April } \\
\text { Moy }\end{array}$ & $\begin{array}{l}75 \\
55 \\
45 \\
38 \\
31 \\
29 \\
36 \\
86\end{array}$ & $\begin{array}{l}55 \\
42 \\
37 \\
30 \\
28 \\
27 \\
28 \\
32\end{array}$ & $\begin{array}{l}65.7 \\
47.6 \\
40.6 \\
32.6 \\
29.2 \\
28.0 \\
30.2 \\
57.2\end{array}$ & $\begin{array}{l}4,040 \\
2,830 \\
2,500 \\
2,000 \\
1,620 \\
1,720 \\
1,800 \\
3,520\end{array}$ \\
\hline The period. & & & & 20,000 \\
\hline
\end{tabular}

MAROON CREEK AT LOWER STATION NEAR ASPEN, COLO.

Location.-In sec. 15, T. 10 S., R. 85 W., at highway bridge $2 \frac{1}{2}$ miles southeast of Aspen, Pitkin County. Nearest tributary, Willow Creek, enters a mile above.

Drainage area. -54 square miles (measured on topographic map).

Records available.-October 1, 1913, to November 30, 1915.

GAGE.-Vertical staff at bridge abutment.

Controu.-Slightly shifting.

EXTremes of DIscharge.-Maximum stage recorded, 3.4 feet from high-water mark during night of June 19, 1914 (discharge, 810 second-feet); minimum discharge, 5 second-feet November 12 and 26, 1915.

ICE.-Stage-discharge relations practically unaffected by ice.

ACCURACY.-Records fair.

Cooperation.-Station maintained in cooperation with United States Forest Service.

Monthly discharge of Maroon Creek at lower station near Aspen, Colo., for 1913-1915

\begin{tabular}{|c|c|c|c|c|}
\hline \multirow{2}{*}{ Month } & \multicolumn{3}{|c|}{ Discharge in second-feet } & \multirow{2}{*}{$\begin{array}{l}\text { Run-off in } \\
\text { acre-fBet }\end{array}$} \\
\hline & Maximum & Minimum & Mean & \\
\hline $\begin{array}{l}\text { October } \\
\text { November } \\
\text { Docember } \\
\text { January } \\
\text { February } \\
\text { March } \\
\text { April. } \\
\text { May } \\
\text { June } \\
\text { July } \\
\text { August } \\
\text { September }\end{array}$ & $\begin{array}{r}15 \\
57 \\
540 \\
706 \\
435 \\
230 \\
112\end{array}$ & $\begin{array}{r}r 8 \\
8 \\
8 \\
87 \\
57 \\
260 \\
226 \\
118 \\
62\end{array}$ & $\begin{array}{c}a 25 \\
\text { a } 15 \\
\approx 10 \\
\approx 10 \\
10 \\
11.3 \\
21.2 \\
25.6 \\
518 \\
339 \\
170 \\
77.8\end{array}$ & $\begin{array}{r}1,540 \\
893 \\
615 \\
615 \\
555 \\
695 \\
1,200 \\
15,700 \\
30,800 \\
20,800 \\
10,500 \\
4,630\end{array}$ \\
\hline The year & 706 & - & 122 & 88,600 \\
\hline
\end{tabular}

a Estimated. 
Monthly discharge of Maroon Creek at lower station near Aspen, Colo., for 19131915 - Continued

\begin{tabular}{|c|c|c|c|c|}
\hline \multirow{2}{*}{ Month } & \multicolumn{3}{|c|}{ Discharge in second-feet } & \multirow{2}{*}{$\begin{array}{c}\text { Run-ofi in } \\
\text { acre-feet }\end{array}$} \\
\hline & Maximum & Minimum & Mean & \\
\hline $\begin{array}{l}\text { October. } \\
\text { November } \\
\text { December. } \\
\text { January } \\
\text { February. } \\
\text { March } \\
\text { April } \\
\text { May } \\
\text { June } \\
\text { July } \\
\text { August } \\
\text { September }\end{array}$ & $\begin{array}{r}87 \\
41 \\
22 \\
13 \\
13 \\
12 \\
17 \\
85 \\
290 \\
555 \\
260 \\
61\end{array}$ & $\begin{array}{l}49 \\
23 \\
10 \\
10 \\
10 \\
11 \\
11 \\
12 \\
93 \\
78 \\
42 \\
15\end{array}$ & $\begin{array}{c}66.4 \\
30.3 \\
14.4 \\
11.8 \\
11.9 \\
11.3 \\
12.4 \\
46.5 \\
193 \\
186 \\
63.2 \\
25.9\end{array}$ & $\begin{array}{r}4,080 \\
1,800 \\
+\quad 885 \\
726 \\
661 \\
695 \\
738 \\
2,860 \\
11,500 \\
11,400 \\
3,890 \\
1,540\end{array}$ \\
\hline The year. & 555 & 10 & 56.4 & 40,800 \\
\hline $\begin{array}{l}\text { October } 1915 \\
\text { November }\end{array}$ & $\begin{array}{r}60 \\
8\end{array}$ & $\begin{array}{l}9 \\
5\end{array}$ & $\frac{24.9}{7}$ & $\begin{array}{r}1,530 \\
417\end{array}$ \\
\hline
\end{tabular}

SNOWMASS CREHK AT SNOWMASS, COLO.

Location.-In sec. 27 , T. 8 S., R. $86 \mathrm{~W}$, at private bridge half a mile south of Snowmass, Pitkin County.

Drainage AREA.-89 square miles (measured on topographic map and Forest Service map).

Records avallable.-October 1, 1910, to November 30, 1913.

GAGE.-Vertical staff.

ConTrol.-Practically permanent.

Diversions.-Water diverted for irrigation of 2,000 acres above station.

Accuracy.-Gage read at irregular intervals. Rating curves well defined.

Records poor owing to infrequent gage heights.

Monthly discharge of Snowmass Creek at Snowmass, Colo., for 1910-1913

\begin{tabular}{|c|c|c|c|c|}
\hline \multirow{2}{*}{ Month } & \multicolumn{3}{|c|}{ Discharge in second-feet } & \multirow{2}{*}{$\begin{array}{c}\text { Run-off in } \\
\text { acre-feet }\end{array}$} \\
\hline & Maximum & Mimimum & Mean & \\
\hline $\begin{array}{l}\text { October } \\
\text { November } \\
\text { December } \\
\text { January } \\
\text { February } \\
\text { March } \\
\text { April } \\
\text { May } \\
\text { June } \\
\text { July } \\
\text { August. } \\
\text { September }\end{array}$ & \begin{tabular}{|c|}
-120 \\
\end{tabular} & |- & $\begin{array}{c}80 \\
60 \\
50 \\
40 \\
40.0 \\
53.1 \\
47.3 \\
133 \\
618 \\
329 \\
163 \\
85.9\end{array}$ & $\begin{array}{r}4,920 \\
3,570 \\
3,070 \\
2,460 \\
2,220 \\
3,260 \\
2,810 \\
8,180 \\
36,800 \\
20,200 \\
10,000 \\
5,110\end{array}$ \\
\hline The year................ & 1,020 & & 142 & 103,000 \\
\hline $\begin{array}{l}\text { October } \\
\text { November } \\
\text { December } \\
\text { January } \\
\text { February } \\
\text { March. } \\
\text { April } \\
\text { May } \\
\text { June } \\
\text { July } \\
\text { August. } \\
\text { September. }\end{array}$ & 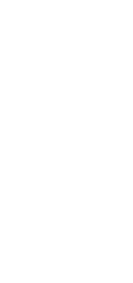 & 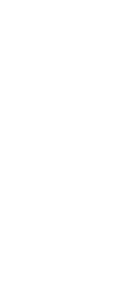 & $\begin{array}{c}167 \\
82.3 \\
60 \\
50 \\
45 \\
50 \\
55 \\
215 \\
451 \\
296 \\
158 \\
86.4\end{array}$ & $\begin{array}{r}10,300 \\
4,900 \\
3,690 \\
3,070 \\
2,590 \\
\mathbf{3}, 070 \\
3,270 \\
13,200 \\
26,800 \\
18,200 \\
9,710 \\
5,140\end{array}$ \\
\hline The year. & - & -- & 143 & 104,000 \\
\hline
\end{tabular}


Monthly discharge of Snowmass Creek at Snowmass, Colo., for 1910-1919-Contd.

\begin{tabular}{|c|c|c|c|c|}
\hline \multirow{2}{*}{ Month } & \multicolumn{3}{|c|}{ Discharge in second-feet } & \multirow{2}{*}{$\begin{array}{l}\text { Run-off in } \\
\text { acre-feet }\end{array}$} \\
\hline & Maximum & Minimum & Mean & \\
\hline $\begin{array}{l}\text { October } \\
\text { November } \\
\text { December } \\
\text { January } \\
\text { February } \\
\text { March } \\
\text { April } \\
\text { May } \\
\text { June } \\
\text { July } \\
\text { August. } \\
\text { September }\end{array}$ & 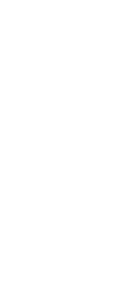 & 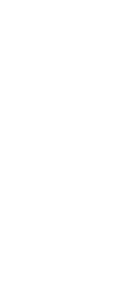 & $\begin{array}{c}72.7 \\
65 \\
60 \\
55 \\
50 \\
50 \\
55 \\
168 \\
219 \\
144 \\
100 \\
75\end{array}$ & $\begin{array}{r}4,470 \\
3,870 \\
3,690 \\
3,380 \\
2,780 \\
3,070 \\
3,270 \\
10,300 \\
13,000 \\
8,850 \\
6,150 \\
4,460\end{array}$ \\
\hline The year & -non & 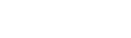 & 92.8 & 67,300 \\
\hline $\begin{array}{c}\text { October } \\
\text { November } 1913 \\
\text { Nove }\end{array}$ & $\cdots$ & & $\begin{array}{l}65 \\
60\end{array}$ & $\begin{array}{l}4,000 \\
3,570\end{array}$ \\
\hline
\end{tabular}

NoTz.-Owing to infrequent gage heights, only the monthly mean discharge is given.

FRYINGPAN CREEK AT NORRIE, COLO.

Location.-In sec. 28, T. 8 S., R. 83 W., at highway bridge in Norrie, Pitkin

County. North Fork enters 1 mile downstream.

Drainage area.-92 square miles (measured on topographic map).

ReCords available.-October 1, 1910, to March 31, 1917.

GAGE.-Vertical staff.

ConTroL.-Practically permanent.

EXTREMEs of Discharge.-Maximum stage recorded, 6.4 feet on June 25 and 26, 1912 (discharge, 1,440 second-feet); minimum stage occurred during winter.

Diversions.- None above station.

ACCURACY.-Gage read at irregular intervals. Rating curves well defined.

Records good except during winter for which they are fair.

Monthly discharge of Fryingpan Creek at Norrie, Colo., for 1910-1917

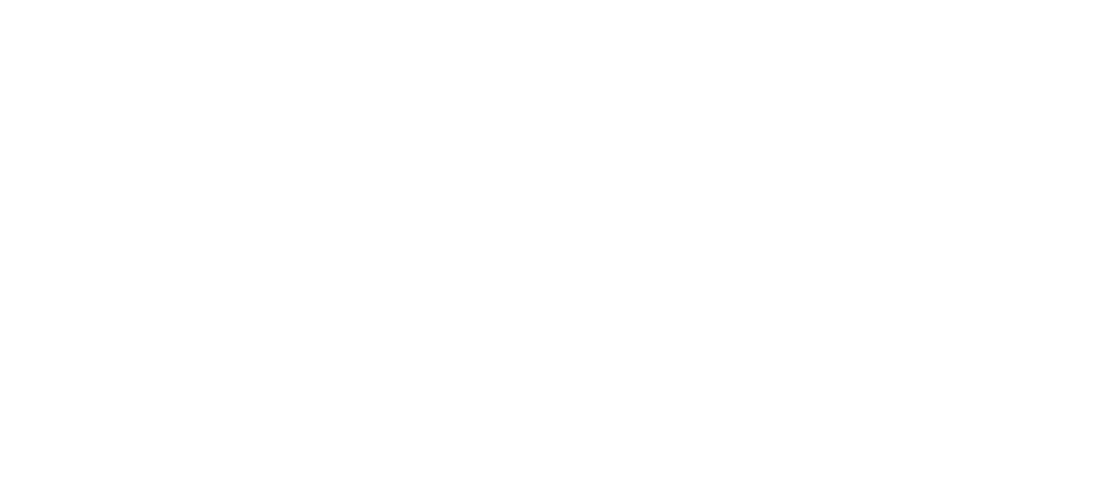

a Estimated. 
Monthly discharge of Fryingpan Creek at Norrie, Colo., for 1910-1917-Continued

\begin{tabular}{|c|c|c|c|c|}
\hline \multirow{2}{*}{ Month } & \multicolumn{3}{|c|}{ Discharge in second-feet } & \multirow{2}{*}{$\begin{array}{c}\text { Run-off in } \\
\text { acre-feet }\end{array}$} \\
\hline & Maximum & Minimum & Mean & \\
\hline $\begin{array}{l}\text { October. } \\
\text { November } \\
\text { December } \\
\text { January. } \\
\text { February } \\
\text { March } \\
\text { April } \\
\text { May } \\
\text { June } \\
\text { July } \\
\text { August } \\
\text { September }\end{array}$ & $\begin{array}{r}130 \\
62 \\
62 \\
100 \\
860 \\
1,440 \\
810 \\
430 \\
62\end{array}$ & $\begin{array}{r}37 \\
31 \\
35 \\
45 \\
90 \\
430 \\
290 \\
62 \\
34\end{array}$ & $\begin{array}{r}60.9 \\
48.0 \\
47.4 \\
\times 27 \\
227 \\
-27 \\
69.8 \\
348 \\
948 \\
516 \\
136 \\
46.4\end{array}$ & $\begin{array}{r}3,740 \\
2,860 \\
2,910 \\
1,660 \\
1,550 \\
1,660 \\
4,150 \\
21,400 \\
56,400 \\
31,700 \\
8,360 \\
2,760\end{array}$ \\
\hline The year. & 1,440 & - n- & 192 & 139,000 \\
\hline $\begin{array}{l}\text { October } \\
\text { November } \\
\text { December } \\
\text { January } \\
\text { February } \\
\text { March } \\
\text { April } \\
\text { May } \\
\text { June } \\
\text { July } \\
\text { August } \\
\text { September }\end{array}$ & $\begin{array}{r}45 \\
45 \\
188 \\
760 \\
600 \\
167 \\
61 \\
61\end{array}$ & $\begin{array}{r}40 \\
40 \\
148 \\
167 \\
42 \\
42 \\
42\end{array}$ & $\begin{array}{c}41.1 \\
40.2 \\
a 35 \\
\text { a } 28 \\
a 24 \\
\text { a } 25 \\
100 \\
335 \\
273 \\
91.8 \\
47.5 \\
49.2\end{array}$ & $\begin{array}{r}2,530 \\
2,390 \\
2,150 \\
1,720 \\
1,330 \\
1,540 \\
5,950 \\
20,600 \\
16,200 \\
5,640 \\
2,920 \\
2,930\end{array}$ \\
\hline The & 760 & & 90.8 & $65, \infty 00$ \\
\hline $\begin{array}{l}\text { October. } \\
\text { November } \\
\text { December } \\
\text { January } \\
\text { February } \\
\text { March } \\
\text { April } \\
\text { May } \\
\text { June } \\
\text { July } \\
\text { August } \\
\text { September }\end{array}$ & $\begin{array}{r}51 \\
42 \\
1,310 \\
1,410 \\
395 \\
188 \\
86\end{array}$ & $\begin{array}{r}34 \\
34 \\
\\
\\
25 \\
395 \\
148 \\
67 \\
51\end{array}$ & $\begin{array}{r}40.7 \\
38.3 \\
\times 34 \\
028 \\
027 \\
027 \\
57.9 \\
516 \\
831 \\
258 \\
105 \\
57.6\end{array}$ & $\begin{array}{r}2,500 \\
2,280 \\
2,000 \\
1,720 \\
1,500 \\
1,660 \\
3,450 \\
31,700 \\
49,400 \\
15,900 \\
6,460 \\
3,430\end{array}$ \\
\hline The year... & 1,410 & מnon & 168 & 122,000 \\
\hline $\begin{array}{l}\text { October. } \\
\text { November. } \\
\text { December. } \\
\text { January } \\
\text { February } \\
\text { March } \\
\text { April } \\
\text { May } \\
\text { June } \\
\text { July } \\
\text { August } \\
\text { September. }\end{array}$ & $\begin{array}{r}51 \\
46 \\
105 \\
542 \\
910 \\
325 \\
167 \\
75\end{array}$ & $\begin{array}{r}38 \\
24 \\
\\
\\
34 \\
80 \\
235 \\
77 \\
53 \\
46\end{array}$ & $\begin{array}{l}44.0 \\
33.9 \\
a 26 \\
a 16 \\
a \quad 19 \\
a 21 \\
71.7 \\
234 \\
568 \\
170 \\
73.3 \\
53.4\end{array}$ & $\begin{array}{r}\mathbf{2}, 710 \\
2,020 \\
1,600 \\
984 \\
1,060 \\
1,290 \\
4,270 \\
14,400 \\
33,800 \\
10,500 \\
4,510 \\
3,180\end{array}$ \\
\hline The year...... & 910 & 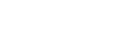 & 111 & 80,300 \\
\hline $\begin{array}{l}\text { October. } \\
\text { November } \\
\text { December. } \\
\text { January } \\
\text { February } \\
\text { March } \\
\text { April } \\
\text { May } \\
\text { June } \\
\text { July } \\
\text { August } \\
\text { September }\end{array}$ & $\begin{array}{r}55 \\
32 \\
28 \\
26 \\
32 \\
139 \\
287 \\
628 \\
1,040 \\
650 \\
298 \\
126\end{array}$ & $\begin{array}{r}26 \\
17 \\
22 \\
22 \\
24 \\
32 \\
37 \\
103 \\
550 \\
180 \\
90 \\
50\end{array}$ & $\begin{array}{r}38.0 \\
24.5 \\
25.0 \\
23.6 \\
27.0 \\
56.7 \\
95.0 \\
363 \\
698 \\
327 \\
166 \\
74.7\end{array}$ & $\begin{array}{r}2,340 \\
1,460 \\
1,540 \\
1,450 \\
1,550 \\
3,490 \\
5,650 \\
22,300 \\
41,200 \\
20,100 \\
10,200 \\
4,440\end{array}$ \\
\hline The $\mathbf{y}$ & 1,040 & 17 & 159 & 116,000 \\
\hline
\end{tabular}

- Estimated. 
Monthly discharge of Fryingpan Creek at Norrie, Colo., for 1910-1917-Continued

\begin{tabular}{|c|c|c|c|c|}
\hline \multirow{2}{*}{ Month } & \multicolumn{3}{|c|}{ Discharge in second-feet } & \multirow{2}{*}{$\begin{array}{l}\text { Run-off in } \\
\text { acre-feet }\end{array}$} \\
\hline & Maximum & Minimum & Mean & \\
\hline $\begin{array}{l}\text { October-1916-17 } \\
\text { November } \\
\text { December } \\
\text { January } \\
\text { February } \\
\text { March }\end{array}$ & $\begin{array}{l}87 \\
65 \\
44 \\
37 \\
26 \\
44\end{array}$ & $\begin{array}{l}58 \\
32 \\
26 \\
26 \\
22 \\
18\end{array}$ & $\begin{array}{l}72.4 \\
40.5 \\
35.2 \\
30.0 \\
24.2 \\
23.0\end{array}$ & $\begin{array}{l}4,450 \\
2,410 \\
2,160 \\
1,840 \\
1,340 \\
1,410\end{array}$ \\
\hline The period............ & 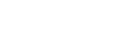 & 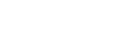 & . & 13,600 \\
\hline
\end{tabular}

FRYINGPAN CREEK AT THOMASVILE, COLO.

Location.-In sec. 7, T. 8 S., R. 83 W., at private bridge 1,000 feet southwest of railroad station at Thomasville, Pitkin County. Nearest tributary, Deadman Gulch, enters a quarter of a mile downstream. Prior to February 25, 1915 , station situated 1 mile downstream.

Drainage AREA.-175 square miles at upper station; 190 square miles at lower station (measured on topographic map and Forest Service map).

Records avallable.-October 1, 1910, to September 30, 1920.

GAGE.-Stevens water-stage recorder installed May 11, 1918; vertical staff used previously.

Control.-Practically permanent.

Extremes of DISChARge.-Maximum stage recorded, 7.0 feet at 9 a. m. June 18, 1917 (discharge, 2,780 second-feet); minimum stage occurred during winter. Diversions.- None above station.

ACcuracy.-Gage read at irregular intervals prior to May 31, 1915; morning and evening readings June 1, 1915, to May 10, 1918; continuous records May 11, 1918, to June 30, 1920. Rating curves well defined. Records for 1918, good; for remainder of period, fair.

Monthly discharge of Fryingpan Creek at Thomasville, Colo., for 1910-1920

\begin{tabular}{|c|c|c|c|c|}
\hline \multirow{2}{*}{ Month } & \multicolumn{3}{|c|}{ Discharge in second-feet } & \multirow{2}{*}{$\underset{\text { acre-feet }}{\text { Run-off in }}$} \\
\hline & Maximum & Minimum & Mean & \\
\hline $\begin{array}{l}\text { October-1910-11 } \\
\text { November } \\
\text { December } \\
\text { January } \\
\text { February } \\
\text { March } \\
\text { April } \\
\text { May } \\
\text { June } \\
\text { July } \\
\text { August } \\
\text { September }\end{array}$ & $\begin{array}{r}80 \\
580 \\
1,470 \\
1,870 \\
760 \\
230 \\
\mathbf{1 7 0}\end{array}$ & $\begin{array}{r}33 \\
25 \\
265 \\
530 \\
265 \\
145 \\
80\end{array}$ & $\begin{array}{c}a 80 \\
860 \\
630 \\
319.9 \\
a 19.9 \\
33.0 \\
51.6 \\
212 \\
859 \\
1,020 \\
464 \\
185 \\
117\end{array}$ & $\begin{array}{r}4,920 \\
3,570 \\
1,840 \\
1,220 \\
1,830 \\
3,170 \\
12,600 \\
52,800 \\
60,700 \\
28,500 \\
11,400 \\
6,960\end{array}$ \\
\hline The year... & 1,870 & 16 & 262 & 190,000 \\
\hline
\end{tabular}

- Estimated by comparison with Roaring Fork below Aspen. 
Monthly discharge of Fryingpan Creele at Thomasville, Colo., for 1910-1920-Contd.

\begin{tabular}{|c|c|c|c|c|}
\hline \multirow{2}{*}{ Month } & \multicolumn{3}{|c|}{ Discharge in second-feet } & \multirow{2}{*}{$\begin{array}{l}\text { Run-off in } \\
\text { acre-feet }\end{array}$} \\
\hline & Maximnm & Minimum & Mean & \\
\hline $\begin{array}{l}\text { October. } \\
\text { November } \\
\text { December. } \\
\text { January } \\
\text { February } \\
\text { March } \\
\text { April } \\
\text { May } \\
\text { June } \\
\text { July } \\
\text { August } \\
\text { September. }\end{array}$ & $\begin{array}{r}300 \\
120 \\
120 \\
56 \\
56 \\
56 \\
200 \\
1,550 \\
2,120 \\
1,240 \\
700 \\
145\end{array}$ & $\begin{array}{r}60 \\
45 \\
45 \\
56 \\
56 \\
48 \\
56 \\
200 \\
890 \\
700 \\
145 \\
88\end{array}$ & $\begin{array}{r}148 \\
80.0 \\
65.2 \\
56.0 \\
56.0 \\
53.7 \\
108 \\
633 \\
1,480 \\
866 \\
280 \\
110\end{array}$ & $\begin{array}{r}9,100 \\
4,760 \\
4,010 \\
3,440 \\
3,220 \\
3,300 \\
6,430 \\
38,900 \\
88,100 \\
53,200 \\
17,200 \\
6,550\end{array}$ \\
\hline The year. & 2,120 & 45 & 328 & 238,000 \\
\hline $\begin{array}{l}\text { October. } \\
\text { November. } \\
\text { December. } \\
\text { January-1912-13 } \\
\text { February } \\
\text { March } \\
\text { April } \\
\text { May } \\
\text { June } \\
\text { July } \\
\text { August } \\
\text { September }\end{array}$ & $\begin{array}{r}104 \\
104 \\
1,960 \\
895 \\
520 \\
124 \\
101 \\
\end{array}$ & $\begin{array}{r}72 \\
44 \\
\\
\\
\end{array}$ & $\begin{array}{l}90.1 \\
64.8 \\
a 40 \\
\times 33 \\
=30 \\
=40 \\
\times 185 \\
743 \\
696 \\
254 \\
97.8 \\
87.2\end{array}$ & $\begin{array}{r}5,540 \\
3,860 \\
2,460 \\
2,030 \\
1,670 \\
2,460 \\
11,000 \\
45,700 \\
41,400 \\
15,600 \\
6,010 \\
5,190\end{array}$ \\
\hline The year............ & 1,960 & $-\ldots$ & 197 & 143,000 \\
\hline $\begin{array}{l}\text { October } \\
\text { November. } \\
\text { December } \\
\text { January } \\
\text { February } \\
\text { March } \\
\text { April } \\
\text { May } \\
\text { June } \\
\text { July } \\
\text { August.jer } \\
\text { September }\end{array}$ & $\begin{array}{r}117 \\
79 \\
1,950 \\
2,200 \\
850 \\
465 \\
180 \\
\end{array}$ & $\begin{array}{r}66 \\
42 \\
117 \\
895 \\
390 \\
168 \\
101 \\
\end{array}$ & $\begin{array}{r}85.2 \\
56.4 \\
\times 40.0 \\
\times 35.0 \\
\propto 33.0 \\
\times 38.0 \\
122 \\
817 \\
1,330 \\
599 \\
250 \\
130\end{array}$ & $\begin{array}{r}5,240 \\
3,360 \\
2,460 \\
2,150 \\
1,830 \\
2,340 \\
7,260 \\
50,200 \\
79,100 \\
36,890 \\
15,400 \\
7,740\end{array}$ \\
\hline The year..................... & 2,200 & & 295 & 214,000 \\
\hline $\begin{array}{l}\text { October } \\
\text { November. } \\
\text { December. } \\
\text { January } \\
\text { February } \\
\text { March } \\
\text { April } \\
\text { May } \\
\text { June } \\
\text { July } \\
\text { August } \\
\text { September. }\end{array}$ & $\begin{array}{r}117 \\
83 \\
40 \\
23 \\
28 \\
31 \\
435 \\
625 \\
1,400 \\
600 \\
355 \\
105\end{array}$ & $\begin{array}{r}83 \\
39 \\
21 \\
20 \\
22 \\
25 \\
30 \\
151 \\
435 \\
146 \\
78 \\
56\end{array}$ & $\begin{array}{c}102 \\
51.9 \\
31.6 \\
21.4 \\
24.9 \\
26.7 \\
145 \\
382 \\
887 \\
339 \\
135 \\
71.0 \\
\end{array}$ & $\begin{array}{r}6,270 \\
3,090 \\
1,940 \\
1,320 \\
1,380 \\
1,640 \\
8,630 \\
23,500 \\
52,800 \\
20,800 \\
8,300 \\
4,220\end{array}$ \\
\hline The year & 1,400 & 20 & 185 & 134,000 \\
\hline $\begin{array}{l}\text { October. } \\
\text { November } \\
\text { December } \\
\text { Januarg } \\
\text { February } \\
\text { March } \\
\text { April. } \\
\text { May } \\
\text { June } \\
\text { July } \\
\text { August. } \\
\text { September. }\end{array}$ & $\begin{array}{r}87 \\
57 \\
50 \\
44 \\
77 \\
192 \\
221 \\
625 \\
1,520 \\
575 \\
480 \\
221\end{array}$ & $\begin{array}{r}49 \\
41 \\
33 \\
36 \\
40 \\
81 \\
102 \\
285 \\
625 \\
285 \\
106 \\
81\end{array}$ & $\begin{array}{c}66.7 \\
47.5 \\
40.3 \\
39.7 \\
54.1 \\
121 \\
153 \\
523 \\
1,020 \\
419 \\
292 \\
123\end{array}$ & $\begin{array}{r}4,100 \\
2,830 \\
2,480 \\
2,440 \\
3,110 \\
7,440 \\
9,100 \\
32,200 \\
60,700 \\
25,800 \\
15,500 \\
7,320\end{array}$ \\
\hline The year & $\mathbf{1}, \mathbf{5 2 0}$ & 33 & 238 & 173,000 \\
\hline
\end{tabular}

a Estimated by comparison with Roaring Fork below Aspen. 
Monthly discharge of Fryingpan Creek at Thomasville, Colo., for 1910-1920-Contd.

\begin{tabular}{|c|c|c|c|c|}
\hline \multirow[t]{2}{*}{1} & \multicolumn{3}{|c|}{ Discharge in second-feet } & \multirow{2}{*}{$\begin{array}{c}\text { Run-off in } \\
\text { acre-feet }\end{array}$} \\
\hline & Maximum & Minimum & Mean & \\
\hline $\begin{array}{l}\text { October. } \\
\text { November } \\
\text { December... } \\
\text { January. } \\
\text { February } \\
\text { March } \\
\text { April } \\
\text { May } \\
\text { June } \\
\text { July } \\
\text { August. } \\
\text { September. }\end{array}$ & $\begin{array}{r}137 \\
84 \\
69 \\
56 \\
44 \\
50 \\
61 \\
1,160 \\
2,500 \\
2,000 \\
285 \\
87\end{array}$ & $\begin{array}{r}84 \\
54 \\
56 \\
40 \\
36 \\
34 \\
39 \\
165 \\
1,160 \\
252 \\
84 \\
62\end{array}$ & $\begin{array}{r}109 \\
58.9 \\
60.9 \\
46.5 \\
40.8 \\
39.0 \\
45.4 \\
396 \\
2,010 \\
909 \\
162 \\
71.6\end{array}$ & $\begin{array}{r}6,700 \\
3,500 \\
3,740 \\
2,860 \\
2,270 \\
2,400 \\
2,700 \\
24,300 \\
120,000 \\
55,900 \\
9,960 \\
4,260\end{array}$ \\
\hline The year........... & 2,500 & 34 & 329 & 239,000 \\
\hline $\begin{array}{l}\text { October } \\
\text { November } \\
\text { December } \\
\text { January. } \\
\text { February } \\
\text { March } \\
\text { April } \\
\text { May } \\
\text { June } \\
\text { July } \\
\text { August } \\
\text { September }\end{array}$ & $\begin{array}{r}69 \\
56 \\
56 \\
47 \\
49 \\
134 \\
168 \\
805 \\
205 \\
338\end{array}$ & $\begin{array}{r}44 \\
30 \\
39 \\
38 \\
39 \\
43 \\
112 \\
194 \\
76 \\
79\end{array}$ & $\begin{array}{r}58.3 \\
43.8 \\
43.8 \\
42.6 \\
42.2 \\
75.7 \\
140 \\
700 \\
2,100 \\
436 \\
131 \\
138\end{array}$ & $\begin{array}{r}3,580 \\
2,610 \\
2,690 \\
2,620 \\
2,340 \\
4,650 \\
8,330 \\
43,000 \\
125,000 \\
26,800 \\
8,060 \\
8,210\end{array}$ \\
\hline The year....... & $-\ldots \ldots$ & 30 & 322 & 238,000 \\
\hline $\begin{array}{l}\text { October } \\
\text { November } \\
\text { December } \\
\text { January } \\
\text { February } \\
\text { March } \\
\text { April } \\
\text { May } \\
\text { June } \\
\text { July } \\
\text { August } \\
\text { September }\end{array}$ & $\begin{array}{r}110 \\
560 \\
1,440 \\
925 \\
462 \\
338 \\
166\end{array}$ & $\begin{array}{r}71 \\
39 \\
310 \\
418 \\
119 \\
53 \\
50\end{array}$ & $\begin{array}{l}88.4 \\
\cdot 70 \\
\cdot 55 \\
\cdot 50 \\
445 \\
440 \\
191 \\
807 \\
665 \\
232 \\
120 \\
75.2\end{array}$ & $\begin{array}{r}5,440 \\
4,170 \\
3,380 \\
3,070 \\
2,500 \\
2,460 \\
11,400 \\
49,600 \\
39,600 \\
14,300 \\
7,380 \\
4,470\end{array}$ \\
\hline The year............. & 1,440 & & 204 & 148,000 \\
\hline $\begin{array}{l}\text { October } \\
\text { November } \\
\text { December. } \\
\text { January } \\
\text { February } \\
\text { March } \\
\text { April } \\
\text { May } \\
\text { June } \\
\text { July } \\
\text { August } \\
\text { September }\end{array}$ & $\begin{array}{r}66 \\
49\end{array}$ & 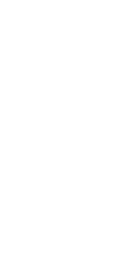 & $\begin{array}{l}49.5 \\
40.5 \\
42 \\
39 \\
41 \\
444 \\
886 \\
893 \\
1,360 \\
700 \\
=250 \\
100\end{array}$ & $\begin{array}{r}3,040 \\
2,410 \\
2,580 \\
2,400 \\
2,360 \\
2,700 \\
5,120 \\
54,900 \\
80,900 \\
43,000 \\
15,400 \\
5,950\end{array}$ \\
\hline The year & 1,860 & $-2-2-2-2-2$ & 305 & 221,000 \\
\hline
\end{tabular}

- Estimated by comparison with Roaring Fork below Aspen.

FRYINGPAN CREFK AT BASALT, COLO.

Location.-In sec. 8, T. 8 S., R. 86 W., at Basalt, Eagle County. No tributary between station and mouth, a short distance downstream.

Drainage AREa.-272 square miles (measured on base map of Colorado).

Records available.-July 19, 1908, to September 30, 1909.

GAGE.-Vertical staff.

ConTroL.-Slightly shifting.

Diversions.- Water diverted for irrigation of 1,430 acres above station.

Accuracy.-Gage read twice daily. Rating curve fairly well defined. Records good. 
Monthly discharge of Fryingpan Creek at Basalt, Colo., for 1908-9

\begin{tabular}{|c|c|c|c|c|}
\hline \multirow{2}{*}{ Month } & \multicolumn{3}{|c|}{ Discharge in second-feet } & \multirow{2}{*}{$\begin{array}{l}\text { Run-off in } \\
\text { acre-feet }\end{array}$} \\
\hline & Maximum & Minimum & Mean & \\
\hline $\begin{array}{l}\text { July } 19-31.21908 . \\
\text { August } \\
\text { September. }\end{array}$ & $\begin{array}{l}302 \\
287 \\
128\end{array}$ & $\begin{array}{r}187 \\
128 \\
83\end{array}$ & $\begin{array}{l}230 \\
202 \\
105\end{array}$ & $\begin{array}{r}5,930 \\
12,000 \\
6,250\end{array}$ \\
\hline The period......... & - & 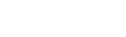 & - & 24,200 \\
\hline $\begin{array}{l}\text { October. } \\
\text { November } \\
\text { December } \\
\text { January } \\
\text { February } \\
\text { March } \\
\text { April } \\
\text { May } \\
\text { June } \\
\text { July } \\
\text { August } \\
\text { September }\end{array}$ & $\begin{array}{r}91 \\
83 \\
\\
\\
98 \\
1,298 \\
3,300 \\
1,880 \\
375 \\
375\end{array}$ & $\begin{array}{r}68 \\
68 \\
-0 \\
65 \\
60 \\
177 \\
660 \\
218 \\
190 \\
118\end{array}$ & $\begin{array}{r}83.5 \\
74.0 \\
a 56.9 \\
a 69.8 \\
a 74.1 \\
73.8 \\
146 \\
682 \\
2,150 \\
676 \\
238 \\
240\end{array}$ & $\begin{array}{r}5,130 \\
4,400 \\
3,500 \\
4,290 \\
4,120 \\
4,540 \\
8,690 \\
41,900 \\
128,000 \\
41,600 \\
14,600 \\
14,300\end{array}$ \\
\hline The year......... & 3,300 & . & 380 & 275,000 \\
\hline
\end{tabular}

- Estimated.

\section{NORTH FORK OF FRYINGPAN CREEK NEAR NORRIR, COLO.}

Location.-In sec. 31 , T. 8 S., R. 83 W., at highway bridge 1 mile west of

Norrie, Pitkin County. No tributary between station and mouth.

Dratnage area.-42 square miles (measured on topographic map).

Records available.-October 1, 1910, to March 31, 1917.

GAGE.-Vertical staff.

Consrol.-Practically permanent.

Extremes of Discharge.-Maximum stage recorded, 3.0 feet on June 1, 1914 (discharge, 595 second-feet); minimum stage occurred during winter.

Diversions. - None.

Accuracy.-Gage read at irregular intervals. Rating curves well defined. Records fair.

Cooperation.- Station maintained in cooperation with United States Forest Service.

Monthly discharre of North Fork of Fryingpan Creek near Norrie, Colo., for 19101917

\begin{tabular}{|c|c|c|c|c|}
\hline \multirow{2}{*}{ Month } & \multicolumn{3}{|c|}{ Discharge in second-feet } & \multirow{2}{*}{$\begin{array}{c}\text { Run-off in } \\
\text { acre-feet }\end{array}$} \\
\hline & Maximum & Minimum & Mean & \\
\hline $1910-11$ & & & & \\
\hline $\begin{array}{l}\text { October } \\
\text { November } \\
\text { December } \\
\text { January } \\
\text { February } \\
\text { March } \\
\text { April } \\
\text { May } \\
\text { June } \\
\text { July } \\
\text { August } \\
\text { September }\end{array}$ & $\begin{array}{r}12 \\
155 \\
318 \\
765 \\
205 \\
34 \\
22\end{array}$ & $\begin{array}{r}16 \\
61 \\
113 \\
34 \\
13 \\
7\end{array}$ & $\begin{array}{l}12 \\
10 \\
10 \\
a 6 \\
5.0 \\
47.6 \\
8.58 \\
45.4 \\
211 \\
308 \\
81.7 \\
21.9 \\
11.1\end{array}$ & $\begin{array}{r}738 \\
595 \\
369 \\
307 \\
422 \\
528 \\
2,700 \\
13,000 \\
18,300 \\
5,020 \\
1,350 \\
660\end{array}$ \\
\hline The year............... & 765 & . & 60.7 & 44,000 \\
\hline
\end{tabular}

- Estimated. 
Monthly discharge of North Fork of Fryingpan Creek near Norrie, Colo., for 19101917-Continued

\begin{tabular}{l} 
Month \\
\hline October \\
November \\
December \\
January \\
February \\
March \\
April \\
May \\
June \\
July \\
August \\
September
\end{tabular}

The year

\section{2-13}

October.

November

January

February

March

April

May

July.

July.-.

September

The year

1913-14

October-.

November

January

February

March

April

May.

June.

July -

August....

September

The year

\begin{tabular}{|c|c|c|c|}
\hline \multicolumn{3}{|c|}{ Discharge in second-feet } & \multirow{2}{*}{$\begin{array}{l}\text { Run-off in } \\
\text { acre-feet }\end{array}$} \\
\hline Maximum & Minimum & Mean & \\
\hline $\begin{array}{r}55 \\
26 \\
9 \\
7 \\
7 \\
6 \\
60 \\
420 \\
480 \\
300 \\
118 \\
i 19 \\
\end{array}$ & $\begin{array}{r}13 \\
9 \\
7 \\
6 \\
6 \\
6 \\
7 \\
70 \\
230 \\
125 \\
13 \\
9\end{array}$ & $\begin{array}{c}27.6 \\
14.8 \\
7.7 \\
6.4 \\
6.2 \\
6.0 \\
20.2 \\
186 \\
358 \\
200 \\
39.3 \\
11.7\end{array}$ & $\begin{array}{r}1,700 \\
881 \\
473 \\
394 \\
357 \\
369 \\
1,200 \\
11,400 \\
21,300 \\
12,300 \\
2,420 \\
606\end{array}$ \\
\hline 480 & 6 & 73.7 & 53,500 \\
\hline \begin{tabular}{r|}
13 \\
120 \\
550 \\
296 \\
185 \\
18 \\
18
\end{tabular} & $\begin{array}{r}9 \\
90 \\
50 \\
120 \\
105 \\
20 \\
10 \\
10\end{array}$ & $\begin{array}{c}11.5 \\
.11 \\
116 \\
a 5 \\
a 6 \\
a 15 \\
83 \\
229 \\
201 \\
73.0 \\
11.8 \\
12.7\end{array}$ & $\begin{array}{r}707 \\
655 \\
369 \\
307 \\
333 \\
922 \\
4,940 \\
14,100 \\
12,000 \\
4,490 \\
726 \\
756\end{array}$ \\
\hline 550 & (n) & 55.8 & 40,300 \\
\hline $\begin{array}{r}26 \\
13 \\
-9 \\
510 \\
595 \\
174 \\
92 \\
35\end{array}$ & \begin{tabular}{r}
13 \\
10 \\
\hdashline \\
\hdashline-12 \\
\hdashline 16 \\
56 \\
168 \\
76 \\
22 \\
13
\end{tabular} & $\begin{array}{c}19.9 \\
10.1 \\
a 6 \\
a 5 \\
a 6 \\
a 7 \\
44.2 \\
256 \\
343 \\
123 \\
43.0 \\
16.7\end{array}$ & $\begin{array}{r}1,220 \\
601 \\
369 \\
307 \\
333 \\
430 \\
2,630 \\
15,700 \\
20,400 \\
7,560 \\
2,640 \\
994\end{array}$ \\
\hline 595 & -.............. & 73.4 & 53,200 \\
\hline \begin{tabular}{r}
18 \\
13 \\
\hdashline-9 \\
7 \\
84 \\
300 \\
425 \\
200 \\
100 \\
40
\end{tabular} & \begin{tabular}{r}
12 \\
7 \\
\hdashline-- \\
6 \\
6 \\
6 \\
56 \\
120 \\
26 \\
10 \\
8
\end{tabular} & $\begin{array}{c}14.3 \\
9.33 \\
a 6 \\
05 \\
6.18 \\
6.1 \\
45.5 \\
128 \\
255 \\
91.5 \\
22.4 \\
13.2\end{array}$ & $\begin{array}{r}879 \\
555 \\
369 \\
307 \\
343 \\
375 \\
\mathbf{3}, 710 \\
7,870 \\
15,200 \\
5,630 \\
1,380 \\
786\end{array}$ \\
\hline 425 & - & 50.3 & 36,400 \\
\hline $\begin{array}{r}17 \\
14 \\
13 \\
7 \\
9 \\
101 \\
174 \\
319 \\
400 \\
198 \\
120 \\
52\end{array}$ & $\begin{array}{r}8 \\
8 \\
7 \\
6 \\
6 \\
8 \\
25 \\
58 \\
210 \\
52 \\
22 \\
16\end{array}$ & $\begin{array}{c}11.3 \\
10.7 \\
10.1 \\
6.29 \\
7.41 \\
25.1 \\
67.8 \\
108 \\
296 \\
106 \\
48.5 \\
23.2\end{array}$ & $\begin{array}{r}695 \\
637 \\
621 \\
387 \\
426 \\
1,540 \\
4,050 \\
10,300 \\
17,600 \\
6,520 \\
2,980 \\
1,380\end{array}$ \\
\hline 400 & 6 & 64.9 & 47,100 \\
\hline
\end{tabular}

The year.

\section{4-15}

October.

November -.......-.

December

January

February

March

April

June.

July -

August

September

The year

October

1915-16

November

January

February

March

April

May

July.

Auguist

September

- Estimated. 
Monthly discharge of North Fork of Fryingpan Creek near Norrie, Colo., for 19101917 -Continued

\begin{tabular}{|c|c|c|c|c|}
\hline \multirow{2}{*}{ Month } & \multicolumn{3}{|c|}{ Discharge in second-feet } & \multirow{2}{*}{$\begin{array}{c}\text { Run-off in } \\
\text { acre-feet }\end{array}$} \\
\hline & Maximum & Minimum & Mean & \\
\hline $\begin{array}{l}\text { October } \\
\text { November } \\
\text { December } \\
\text { January } \\
\text { February } \\
\text { March }\end{array}$ & $\begin{array}{r}52 \\
19 \\
13 \\
8 \\
7 \\
8\end{array}$ & $\begin{array}{r}16 \\
12 \\
9 \\
7 \\
7 \\
6\end{array}$ & $\begin{array}{r}31 \\
14.5 \\
10.3 \\
7.4 \\
7 \\
6.6\end{array}$ & $\begin{array}{r}1,910 \\
863 \\
633 \\
455 \\
389 \\
406\end{array}$ \\
\hline The period..... & & & & 4,660 \\
\hline
\end{tabular}

CRYSTAL RIVER AT MARBLE, COLO.

Locatron.-In sec. 26, T. 11 S., R. 88 W., at electric railway bridge in Marble, Gunnison County. Nearest tributary, Carbonate Creek, enters a short distance upstream.

Drainage area. - 77 square miles (measured on Forest Service map).

Rmcords avaILABLE.-October 1, 1910, to September 30, 1917 (records for 1916 not computed).

GAGE.--Vertical staff.

Controx.-Somewhat shifting.

EXTREMEs of DISchaRge.-Maximum stage recorded, 6.15 feet at $5.30 \mathrm{p} . \mathrm{m}$. June 19, 1914 (discharge, 1,960 second-feet); minimum stage recorded, 1.40

- feet at 7.30 a. m. January 28, 1914 (discharge, 13 second-feet).

ICE.-Stage-discharge relation practically unaffected by ice.

Diversions.-None above station.

Accoracy.-Gage read twice daily. Rating curves well defined. Records good except for 1917, for which they are fair.

Monthly discharge of Crystal River at Marble, Colo., for 1910-1915 and 1916-17

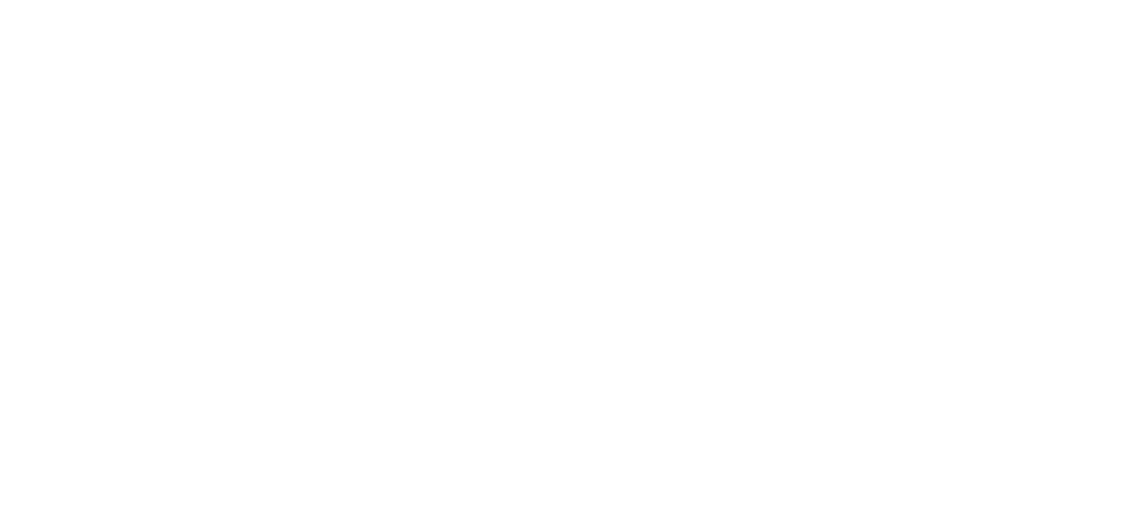

astimated.

$46013-29-21$ 
Monthly discharge of Crystal River at Marble, Colo., for 1910-1915 and 1916-17Continued

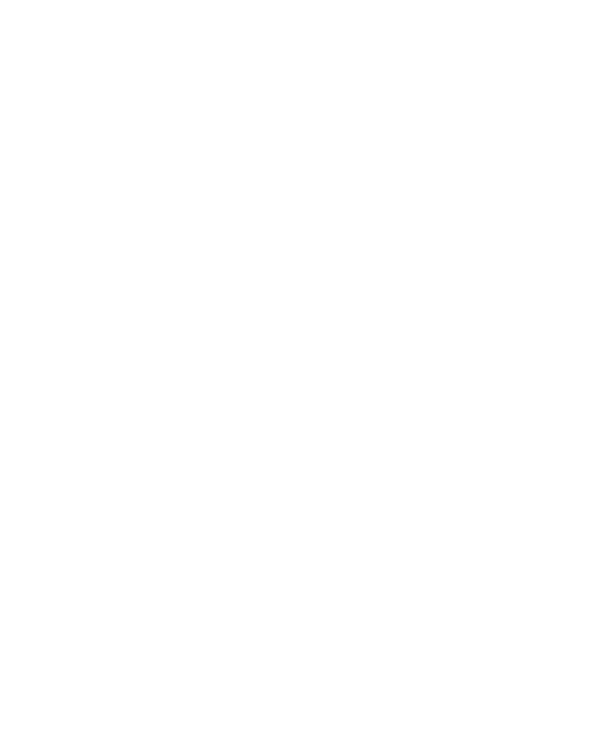

The year

\section{3-14}

October

November

December

January

Februar

March

April

May

June

July -

gust

September.

The year

October
November
December
January
February
March
April
May
June
July
August
September

The year

1916-17

October-

November

December

January.

February

March

April

May

June

July..

August

September

The yoar

\begin{tabular}{|c|c|c|c|}
\hline \multicolumn{3}{|c|}{ Discharge in second-feet } & \multirow{2}{*}{$\begin{array}{l}\text { Run-off in } \\
\text { acre-feet }\end{array}$} \\
\hline Maximum & Minimum & Mean & \\
\hline $\begin{array}{r}1,220 \\
79 \\
51 \\
36 \\
30 \\
32 \\
78 \\
987 \\
1,880 \\
1,530 \\
652 \\
187\end{array}$ & $\begin{array}{r}74 \\
41 \\
26 \\
27 \\
22 \\
18 \\
32 \\
73 \\
450 \\
575 \\
145 \\
68\end{array}$ & $\begin{array}{c}224 \\
61.3 \\
38.8 \\
30.1 \\
26.1 \\
26.3 \\
48.9 \\
367 \\
1,190 \\
984 \\
259 \\
99.2\end{array}$ & $\begin{array}{r}13,800 \\
3,650 \\
2,390 \\
1,850 \\
1,500 \\
1,620 \\
2,910 \\
22,600 \\
70,800 \\
60,500 \\
15,000 \\
5,900\end{array}$ \\
\hline 1,880 & 18 & 299 & 203,900 \\
\hline $\begin{array}{r}82 \\
63 \\
46 \\
38 \\
32 \\
42 \\
189 \\
1,160 \\
1,100 \\
575 \\
189 \\
146\end{array}$ & $\begin{array}{r}54 \\
42 \\
35 \\
28 \\
20 \\
22 \\
35 \\
167 \\
430 \\
136 \\
84 \\
48\end{array}$ & $\begin{array}{c}68.4 \\
53.9 \\
35.4 \\
32.0 \\
28.7 \\
28.6 \\
86.6 \\
522 \\
780 \\
328 \\
118 \\
72.8\end{array}$ & $\begin{array}{r}4,210 \\
3,210 \\
2,150 \\
1,970 \\
1,590 \\
1,760 \\
5,150 \\
32,100 \\
46,400 \\
20,200 \\
7,260 \\
4,330\end{array}$ \\
\hline 1,160 & 20 & 181 & 130,000 \\
\hline $\begin{array}{r}64 \\
48 \\
41 \\
33 \\
36 \\
64 \\
146 \\
1,600 \\
1,920 \\
1,720 \\
525 \\
127\end{array}$ & $\begin{array}{r}39 \\
24 \\
24 \\
14 \\
20 \\
35 \\
53 \\
118 \\
550 \\
525 \\
136 \\
77\end{array}$ & $\begin{array}{c}53.2 \\
39.9 \\
33.0 \\
28.2 \\
26.1 \\
49.9 \\
104 \\
641 \\
1,390 \\
984 \\
235 \\
102\end{array}$ & $\begin{array}{r}3,270 \\
2,370 \\
2,030 \\
1,730 \\
1,450 \\
3,070 \\
6,190 \\
39,400 \\
82,700 \\
60,500 \\
14,400 \\
6,070\end{array}$ \\
\hline 1,920 & 14 & 308 & 223,000 \\
\hline $\begin{array}{r}226 \\
80 \\
58 \\
49 \\
28 \\
24 \\
345 \\
525 \\
1,340 \\
1,100 \\
305 \\
200\end{array}$ & $\begin{array}{r}67 \\
55 \\
42 \\
24 \\
18 \\
22 \\
24 \\
60 \\
288 \\
340 \\
78 \\
58\end{array}$ & $\begin{array}{c}98.6 \\
64.3 \\
51.5 \\
35.1 \\
23.7 \\
22.2 \\
79.2 \\
265 \\
898 \\
785 \\
152 \\
79.2\end{array}$ & $\begin{array}{r}6,060 \\
3,830 \\
3,170 \\
2,160 \\
1,320 \\
1,360 \\
4,710 \\
16,300 \\
53,400 \\
48,300 \\
9,350 \\
4,710\end{array}$ \\
\hline 1,340 & 18 & 214 & 155,000 \\
\hline $\begin{array}{r}218 \\
75 \\
56 \\
55 \\
42 \\
40 \\
122 \\
416 \\
2,110 \\
1,960 \\
369\end{array}$ & $\begin{array}{r}74 \\
44 \\
32 \\
22 \\
22 \\
18 \\
25 \\
49 \\
129 \\
517 \\
240\end{array}$ & $\begin{array}{c}129 \\
59.4 \\
41.0 \\
31.3 \\
28.5 \\
25.9 \\
58.0 \\
162 \\
1,230 \\
1,070 \\
a \quad 222 \\
a 100\end{array}$ & $\begin{array}{r}7,920 \\
3,530 \\
2,520 \\
1,920 \\
1,580 \\
1,590 \\
3,450 \\
9,960 \\
73,200 \\
65,800 \\
13,600 \\
5,960\end{array}$ \\
\hline 2,110 & 18 & 263 & 191,000 \\
\hline
\end{tabular}

\footnotetext{
a Estimated.
} 
CRYSTAL RIVER NGAR CARBONDALE, COLO.

Locatron.-In sec. 27, T. 8 S., R. 88 W., at highway bridge 5 miles south of

Carbondale, Pitkin County. Nearest tributary, Thompson Creek, enters just above station.

Drainage area. - 239 square miles (measured on Forest Service map).

Records available.-July 18, 1908, to September 30, 1909.

GAGE.-Vertical staff.

ConTrou.-Practically permanent.

IcE.-Stage-discharge relation unaffected by ice.

Diversions.- - Water diverted for irrigation of 3,300 acres above station.

AccuracY.-Gage read twice daily. Rating curve well defined. Records good.

Monthly discharge of Crystal River, near Carbondale, Colo., for 1908-9

\begin{tabular}{|c|c|c|c|c|}
\hline \multirow{2}{*}{ Month } & \multicolumn{3}{|c|}{ Discharge in second-feet } & \multirow{2}{*}{$\begin{array}{l}\text { Run-off in } \\
\text { acre-foet }\end{array}$} \\
\hline & Maximum & Minimum & Mean & \\
\hline $\begin{array}{l}\text { July 18-31.... } 1908 \\
\text { August } \\
\text { September }\end{array}$ & $\begin{array}{l}531 \\
617 \\
176\end{array}$ & $\begin{array}{l}357 \\
176 \\
103\end{array}$ & $\begin{array}{l}428 \\
342 \\
138\end{array}$ & $\begin{array}{r}11,900 \\
21,000 \\
8,210\end{array}$ \\
\hline The period........ & - & - & - & 41,100 \\
\hline $\begin{array}{l}\text { October-. } \\
\text { November } \\
\text { December } \\
\text { January } \\
\text { February } \\
\text { March } \\
\text { April } \\
\text { May } \\
\text { June } \\
\text { July } \\
\text { August } \\
\text { Septomber }\end{array}$ & $\begin{array}{r}176 \\
141 \\
189 \\
121 \\
121 \\
121 \\
559 \\
1,840 \\
4,970 \\
3,100 \\
531 \\
890\end{array}$ & $\begin{array}{r}103 \\
87 \\
56 \\
67 \\
73 \\
87 \\
112 \\
357 \\
1,040 \\
503 \\
278 \\
73\end{array}$ & $\begin{array}{r}135 \\
114 \\
107 \\
91.8 \\
98.8 \\
106 \\
269 \\
1,180 \\
3,320 \\
1,440 \\
393 \\
372\end{array}$ & $\begin{array}{r}8,300 \\
6,780 \\
6,580 \\
5,640 \\
5,490 \\
6,520 \\
16,000 \\
72,600 \\
198,000 \\
88,500 \\
24,200 \\
22,100\end{array}$ \\
\hline The year. & 4,970 & 56 & 637 & 461,000 \\
\hline
\end{tabular}

EAST FLK CREER NEAR NEW CASTLE, COLO.

Location.-On line between secs. 24 and 25, T. 5 S., R. 91 W., at highway bridge $2 \frac{1}{2}$ miles northwest of New Castle, Garfield County. No tributaries below station.

Drainage area. -51 square miles (revised; measured on Forest Service map).

Records available.-October 1, 1910, to September 30, 1915.

GAGE.-Vertical staff.

ControL.-Shifting at long intervals.

ICE.-Stage-discharge relation slightly affected by ice.

Divarsions.- Water diverted for irrigation of 1,010 acres from East Elk Creek; practically all above station.

Accuracr. - Gage read at irregular intervals. Rating curves not well defined. Records poor. 
Monthly discharge of East Elk Creek near New Castle, Colo., for 1910-1915

\begin{tabular}{|c|c|c|c|c|}
\hline \multirow{2}{*}{ Month } & \multicolumn{3}{|c|}{ Discharge in second-feet } & \multirow{2}{*}{$\begin{array}{l}\text { Run-off in } \\
\text { acre-feet }\end{array}$} \\
\hline & Maximum & Minimum & Mean & \\
\hline $\begin{array}{l}\text { October. } \\
\text { November } \\
\text { December. } \\
\text { January. } \\
\text { February } \\
\text { March. } \\
\text { April } \\
\text { May } \\
\text { June } \\
\text { July } \\
\text { August } \\
\text { September. }\end{array}$ & 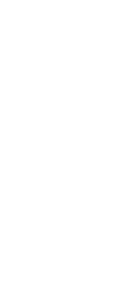 & $\mid$ & $\begin{array}{r}13 \\
12 \\
11 \\
10 \\
9.5 \\
9.9 \\
25.3 \\
138 \\
273 \\
34 \\
5.0 \\
5.7\end{array}$ & $\begin{array}{r}799 \\
714 \\
676 \\
616 \\
528 \\
609 \\
1,510 \\
8,480 \\
16,200 \\
2,090 \\
307 \\
339\end{array}$ \\
\hline 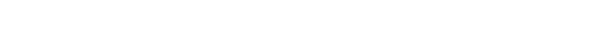 & & & 45.5 & 32,900 \\
\hline $\begin{array}{l}\text { October } \\
\text { November } \\
\text { December. } \\
\text { January } \\
\text { February } \\
\text { March } \\
\text { April } \\
\text { May } \\
\text { June } \\
\text { July } \\
\text { August. } \\
\text { September }\end{array}$ & 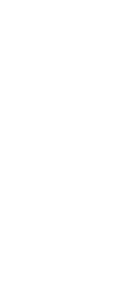 & 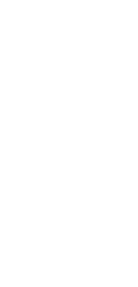 & $\begin{array}{c}18.7 \\
18.7 \\
11.3 \\
8 \\
9.2 \\
7.5 \\
14.8 \\
92 \\
281 \\
111 \\
11.8 \\
8.4\end{array}$ & $\begin{array}{r}1,150 \\
1,110 \\
695 \\
492 \\
529 \\
461 \\
881 \\
5,660 \\
16,700 \\
6,820 \\
726 \\
500\end{array}$ \\
\hline 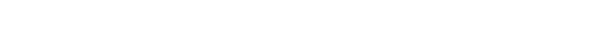 & & & 49.3 & 35,700 \\
\hline $\begin{array}{l}\text { October } \\
\text { November } \\
\text { December. } \\
\text { January. } \\
\text { February } \\
\text { March } \\
\text { April. } \\
\text { May } \\
\text { June } \\
\text { July } \\
\text { August. } \\
\text { September }\end{array}$ & \begin{tabular}{|l|l|}
0 \\
\end{tabular} & 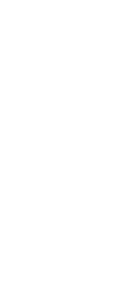 & $\begin{array}{r}9.1 \\
8.9 \\
8.2 \\
7 \\
6.9 \\
7.7 \\
18.0 \\
126 \\
127 \\
115 \\
3.0 \\
4.4\end{array}$ & $\begin{array}{r}560 \\
530 \\
504 \\
430 \\
383 \\
474 \\
1,070 \\
7,750 \\
7,560 \\
7,070 \\
184 \\
262\end{array}$ \\
\hline The year........ & $\ldots$ & & 37.0 & 26,800 \\
\hline $\begin{array}{l}\text { October } \\
\text { November. } \\
\text { Decomber } \\
\text { January. } \\
\text { February } \\
\text { March } \\
\text { April } \\
\text { May } \\
\text { June } \\
\text { July } \\
\text { August } \\
\text { September }\end{array}$ & 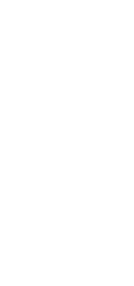 & $\mid$ & $\begin{array}{r}8.2 \\
7.0 \\
7.0 \\
6.8 \\
6.5 \\
7.4 \\
19.3 \\
161 \\
373 \\
123 \\
11.4 \\
8.9\end{array}$ & $\begin{array}{r}504 \\
417 \\
430 \\
418 \\
361 \\
455 \\
1,150 \\
9,900 \\
22,200 \\
7,560 \\
701 \\
494\end{array}$ \\
\hline The year & - & $-\cdots$ & 61.7 & 44,600 \\
\hline $\begin{array}{l}\text { October } \\
\text { November } \\
\text { December. } \\
\text { January } \\
\text { February } \\
\text { March } \\
\text { April } \\
\text { May } \\
\text { June } \\
\text { July } \\
\text { August } \\
\text { September }\end{array}$ & \begin{tabular}{|l|l|} 
\\
\end{tabular} \mid & \begin{tabular}{|c|} 
\\
\\
\end{tabular} & $\begin{array}{c}43.4 \\
22.5 \\
16.5 \\
11.5 \\
10.0 \\
9.3 \\
32.6 \\
68.7 \\
195 \\
30 \\
10 \\
5\end{array}$ & $\begin{array}{r}2,670 \\
1,340 \\
1,010 \\
707 \\
555 \\
572 \\
1,940 \\
4,220 \\
11,600 \\
1,840 \\
615 \\
298\end{array}$ \\
\hline The year. . . & & $\ldots-\ldots$ & 37.8 & 27,400 \\
\hline
\end{tabular}

Note.-Owing to infrequent gage heights only the monthly mean determinations are presented. 
BLK CRERK AT NEW OASTIE, COIO.

Location.-In sec. 31 , T. $5 \mathrm{~S}$., R. $90 \mathrm{~W}$., at highway bridge in New Castle, Garfield County, a quarter of a mile above mouth.

Drainage area.-177 square miles.

ReCords avatlable.-March 17, 1922, to September 30, 1924.

GAGE.-Vertical staff.

Extremes of Discharge.-Maximum stage recorded, 3.3 feet at $6 \mathrm{p}$. m. May 27 and 9 a. $\mathrm{m}$. May 28 (discharge, 1,400 second-feet); minimum discharge estimated at 2 second-feet August 21-31, 1924.

Diversions. - Water diverted above station for irrigation of 3,400 acres.

Cooperation.-Complete records furnished by State engineer.

Monthly discharge of Elk Creek at Newcastle, Colo., 1922-1924

\begin{tabular}{|c|c|c|c|c|}
\hline \multirow{2}{*}{ Month } & \multicolumn{3}{|c|}{ Discharge in second-feet } & \multirow{2}{*}{$\begin{array}{l}\text { Run-off in } \\
\text { acre-feet }\end{array}$} \\
\hline & Maximum & Minimum & Mean & \\
\hline $\begin{array}{l}\text { March } 17-31 . \ldots \ldots \\
\text { April } \\
\text { May } \\
\text { June } \\
\text { July } \\
\text { August } \\
\text { September... }\end{array}$ & $\begin{array}{r}110 \\
99 \\
1,360 \\
1,320 \\
308 \\
15 \\
28\end{array}$ & $\begin{array}{c}28 \\
36 \\
148 \\
330 \\
15 \\
5.3 \\
10\end{array}$ & $\begin{array}{c}56.8 \\
46.7 \\
558 \\
818 \\
76.9 \\
7.88 \\
17.5\end{array}$ & $\begin{array}{r}1,690 \\
2,780 \\
34,300 \\
48,700 \\
4,730 \\
485 \\
1,040\end{array}$ \\
\hline The period. - & (n............ & (n.............. & (n) & 93,700 \\
\hline 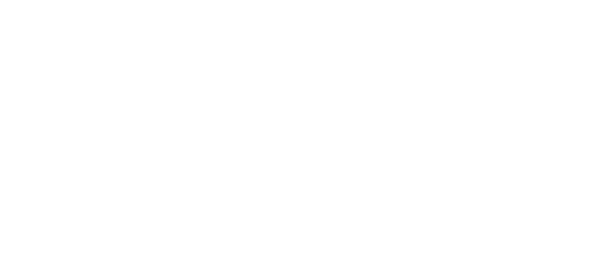 & \begin{tabular}{|r|}
36 \\
38 \\
\\
41 \\
60 \\
850 \\
778 \\
206 \\
29 \\
43
\end{tabular} & \begin{tabular}{|r|}
24 \\
30 \\
\\
24 \\
31 \\
66 \\
206 \\
13 \\
5 \\
5
\end{tabular} & $\begin{array}{c}29.7 \\
34.6 \\
a 30 \\
a 28 \\
a 32 \\
30.3 \\
40.4 \\
390 \\
461 \\
83.4 \\
12.3 \\
19.3\end{array}$ & $\begin{array}{r}1,830 \\
2,060 \\
1,840 \\
1,720 \\
1,780 \\
1,860 \\
2,400 \\
24,000 \\
27,400 \\
5,130 \\
756 \\
1,150\end{array}$ \\
\hline The year... & 850 & 5 & 99.3 & 71,900 \\
\hline $\begin{array}{l}\text { Oetober } \\
\text { November } \\
\text { December } \\
\text { January } \\
\text { February } \\
\text { March } \\
\text { April } \\
\text { May } \\
\text { June } \\
\text { July } \\
\text { August } \\
\text { September }\end{array}$ & $\begin{array}{r}34 \\
65 \\
710 \\
767 \\
114 \\
6 \\
24\end{array}$ & $\begin{array}{r}24 \\
24 \\
58 \\
104 \\
6 \\
2 \\
3\end{array}$ & $\begin{array}{c}41.9 \\
28.0 \\
a 30 \\
a 30 \\
a 34 \\
25.2 \\
43 \\
354 \\
435 \\
50.7 \\
4.19 \\
10.3\end{array}$ & $\begin{array}{r}2,580 \\
1,670 \\
1,840 \\
1,840 \\
1,960 \\
1,550 \\
2,560 \\
21,800 \\
25,900 \\
3,120 \\
258 \\
613\end{array}$ \\
\hline The year. & 767 & 2 & 90.9 & 65,700 \\
\hline
\end{tabular}

astimated. 


\section{WEST DIVIDE CREEK AT BEARD RANCH, NEAR RAVEN, COLO.}

Location.-At Beard ranch, about sec. 36, T. 7 S., R. 2 W., 4 miles south of Raven, Garfield County.

Drainage area.-90 square miles (measured on Forest Service map).

Records available.-May 1, 1910, to September 30, 1911.

GAGE.-Vertical staff.

ConTrol.-Fairly permanent.

Extremes of discharge.-Maximum stage recorded, 3.45 feet at 5 a. m. May 10, 1911 (discharge, 345 second-feet); minimum stage, no flow during several periods in 1910.

Drversions.-Only diversion above station is Highline Canal, which diverts water for about 2,000 acres.

Accoracy.-Gage read twice daily. Rating curves fairly well defined. Records good.

Monthly discharge of West Divide Creek at Beard Ranch, near Raven, Colo., 1910-11

\begin{tabular}{|c|c|c|c|c|}
\hline \multirow{2}{*}{ Month } & \multicolumn{3}{|c|}{ Discharge in second-feet } & \multirow{2}{*}{$\begin{array}{l}\text { Run-off in } \\
\text { acre-feet }\end{array}$} \\
\hline & Maximum & Minimum & Mean & \\
\hline $\begin{array}{l}\text { May } \\
\text { June } \\
\text { July } \\
\text { August } \\
\text { September }\end{array}$ & $\begin{array}{l}218 \\
103 \\
7.5 \\
4 \\
6\end{array}$ & $\begin{array}{r}60 \\
9 \\
0 \\
0 \\
0\end{array}$ & $\begin{array}{r}136 \\
32.0 \\
3.11 \\
1.25 \\
\quad 1.38\end{array}$ & $\begin{array}{r}8,360 \\
1,900 \\
191 \\
77 \\
82\end{array}$ \\
\hline$T^{2}=$ period. ......... & & & & 10,600 \\
\hline $\begin{array}{l}\text { October } \\
\text { November } \\
\text { December. } \\
\text { January } \\
\text { February. } \\
\text { March. } \\
\text { April } \\
\text { May } \\
\text { June } \\
\text { July } \\
\text { August } \\
\text { September }\end{array}$ & $\begin{array}{r}17 \\
13 \\
13 \\
14 \\
11 \\
24 \\
118 \\
330 \\
125 \\
26 \\
6.6\end{array}$ & $\begin{array}{r}1 \\
5 \\
5 \\
7.5 \\
6.6 \\
8.4 \\
24 \\
66 \\
10 \\
7.2 \\
.9\end{array}$ & $\begin{array}{c}6.56 \\
7.97 \\
8.84 \\
9.4 \\
8.6 \\
15.5 \\
49.8 \\
161 \\
54.6 \\
13.6 \\
4.02 \\
61\end{array}$ & $\begin{array}{r}403 \\
474 \\
544 \\
578 \\
478 \\
953 \\
2,960 \\
9,900 \\
\mathbf{3}, 250 \\
836 \\
247 \\
60\end{array}$ \\
\hline The year. & 330 & $-1-n-n-n$ & 28.6 & 20,700 \\
\hline
\end{tabular}

- Estimated.

WRST DIVIDE CREEK AT RAVRN, COLO.

Location.-In sec. 13, T. 7 S., R. 92 W., at Raven, Garfield County. Drainage area.-120 square miles (measured on Forest Service map).

Records available.-July 27, 1909, to September 30, 1910.

GAGE.-Vertical staff.

Control.-Slightly shifting.

Diversions. - Numerous diversions above and below station.

Accuracy.- Gage read twice daily. Rating curve fairly well defined. Records good. 
- Monthly discharge of West Divide Creek at Raven, Colo., 1909-10

\begin{tabular}{|c|c|c|c|c|}
\hline \multirow{2}{*}{ Month } & \multicolumn{3}{|c|}{ Discharge in second-feet } & \multirow{2}{*}{$\begin{array}{l}\text { Run-off in } \\
\text { acre-feet }\end{array}$} \\
\hline & Maximum & Minimum & Mean & \\
\hline $\begin{array}{l}\text { July 27-31. } \\
\text { August } \\
\text { September }\end{array}$ & $\begin{array}{r}5 \\
61 \\
28\end{array}$ & $\begin{array}{l}1 \\
1 \\
5\end{array}$ & $\begin{array}{r}3.5 \\
6.7 \\
11.4\end{array}$ & $\begin{array}{l}84 \\
412 \\
678\end{array}$ \\
\hline $\begin{array}{l}\text { October } \\
\text { November } \\
\text { December } \\
\text { January } \\
\text { Thoruary. } \\
\text { Mareh } \\
\text { April } \\
\text { May } \\
\text { June } \\
\text { July } \\
\text { August } \\
\text { September }\end{array}$ & $\begin{array}{r}5 \\
5 \\
5 \\
8.5 \\
5 \\
56 \\
344 \\
240 \\
61 \\
3.8\end{array}$ & $\begin{array}{r}5 \\
5 \\
5 \\
5 \\
5 \\
5 \\
45 \\
32 \\
1.8 \\
.3 \\
\end{array}$ & $\begin{array}{l}5.0 \\
5.0 \\
5.0 \\
5.8 \\
5.0 \\
33.4 \\
157 \\
122 \\
12.5 \\
1.66 \\
=1 \\
1\end{array}$ & $\begin{array}{r}307 \\
298 \\
307 \\
357 \\
278 \\
2,050 \\
9,340 \\
7,500 \\
744 \\
102 \\
61 \\
60\end{array}$ \\
\hline The year......... & 344 & & 29.6 & 21,400 \\
\hline
\end{tabular}

- Estimated.

PARACHUTK CRERK AT GRAND VALLEY, COLO.

Location.-In NW. $1 / 4$ sec. 12, T. 7 S., R. 96 W., half a mile northwest of Grand Valley, Garfield County. No tributary between station and mouth, 1 mile downstream.

Drainage area.-196 square miles (measured on base map of Colorado).

Records avarlable.-April 7, 1921, to September 30, 1927.

GAGE.-Vertical staff.

ControL.-Slightly shifting.

Extremes of Discharge.-Maximum stage recorded, 3.0 feet at 5 p. m. May 9 , 1922 (discharge, 790 second-feet); minimum discharge, creek dry during part of August and September, 1926, and August 2-5, 1927.

Diversions.- Water diverted for irrigation of 1,900 acres above station.

Accuracr.-Gage read twice daily. Rating curves well defined. Records good.

Cooperation.--Since 1923 records furnished by State engineer.

Monthly discharge of Parachute Creek at Grand Valley, Colo., for 1921-1927

\begin{tabular}{|c|c|c|c|c|}
\hline \multirow{2}{*}{ Month } & \multicolumn{3}{|c|}{ Discharge in second-feet } & \multirow{2}{*}{$\underset{\text { Bcre-feet }}{\text { Run-off in }}$} \\
\hline & Maximum & Minimum & Mean & \\
\hline $\begin{array}{l}\text { April } 7-30 . \\
\text { May } \\
\text { June } \\
\text { July } \\
\text { August } \\
\text { September }\end{array}$ & $\begin{array}{r}118 \\
545 \\
176 \\
28 \\
90 \\
64\end{array}$ & $\begin{array}{r}47 \\
122 \\
35 \\
11 \\
13 \\
11\end{array}$ & $\begin{array}{l}77.7 \\
322 \\
103 \\
18.0 \\
25.5 \\
17.5\end{array}$ & $\begin{array}{r}8,700 \\
19,800 \\
6,180 \\
1,110 \\
1,570 \\
1,040\end{array}$ \\
\hline The year...- & - & (n) & $-\ldots . . . .-$ & 33,400 \\
\hline $\begin{array}{l}\text { October } \\
\text { November } \\
\text { December } \\
\text { January } \\
\text { February } \\
\text { March } \\
\text { April } \\
\text { May } \\
\text { June } \\
\text { July } \\
\text { Angust } \\
\text { September }\end{array}$ & $\begin{array}{r}16 \\
15 \\
15 \\
47 \\
318 \\
790 \\
250 \\
36 \\
50 \\
6\end{array}$ & $\begin{array}{r}13 \\
13 \\
13 \\
26 \\
280 \\
36 \\
6 \\
6 \\
6\end{array}$ & $\begin{aligned} & 14.5 \\
& 13.7 \\
& a 12 \\
& a 12 \\
& \therefore 14 \\
& \therefore 14.4 \\
& 83.2 \\
& 514 \\
& 98.9 \\
& 18.8 \\
& 16.5 \\
& 6.0\end{aligned}$ & $\begin{array}{r}892 \\
816 \\
738 \\
738 \\
778 \\
1,620 \\
4,050 \\
81,600 \\
5,880 \\
1,160 \\
1,010 \\
357\end{array}$ \\
\hline The year............... & 318 & 6 & 69.9 & 50,500 \\
\hline
\end{tabular}

- Estimated. 
Monthly discharge of Parachute Creek at Grand Valley, Colo., for 1921-1927-Con.

\begin{tabular}{|c|c|c|c|c|}
\hline \multirow{2}{*}{ Month } & \multicolumn{3}{|c|}{ Discharge in second-feet } & \multirow{2}{*}{$\begin{array}{c}\text { Run-off in } \\
\text { acre-feet }\end{array}$} \\
\hline & Maximum & Minimum & Mean & \\
\hline $\begin{array}{l}\text { Oetober. } \\
\text { November } \\
\text { December. } \\
\text { January... } \\
\text { February } \\
\text { March } \\
\text { April } \\
\text { May } \\
\text { June } \\
\text { July } \\
\text { August } \\
\text { September }\end{array}$ & $\begin{array}{r}18 \\
18 \\
24 \\
142 \\
425 \\
155 \\
27 \\
10 \\
27\end{array}$ & $\begin{array}{r}12 \\
10 \\
15 \\
21 \\
142 \\
18 \\
10 \\
10 \\
10\end{array}$ & $\begin{array}{l}14.1 \\
14.0 \\
12 \\
12 \\
14 \\
18.1 \\
60.2 \\
308 . \\
59.3 \\
12.1 \\
10.0 \\
12.9\end{array}$ & $\begin{array}{r}867 \\
833 \\
738 \\
738 \\
778 \\
1,110 \\
3,580 \\
18,900 \\
3,530 \\
744 \\
615 \\
768\end{array}$ \\
\hline The year........................ & 425 & $\ldots$ & 45.8 & 33,200 \\
\hline $\begin{array}{l}\text { October. } \\
\text { November. } \\
\text { December } \\
\text { January } \\
\text { February } \\
\text { Mareh } \\
\text { April } \\
\text { May } \\
\text { June } \\
\text { July } \\
\text { August } \\
\text { September }\end{array}$ & $\begin{array}{c}24 \\
21 \\
16 \\
18 \\
328 \\
155 \\
60 \\
10 \\
1.8 \\
19 \\
\end{array}$ & $\begin{array}{r}18 \\
13 \\
11 \\
15 \\
14 \\
12 \\
1.8 \\
.8 \\
.1 \\
.5 \\
\end{array}$ & $\begin{array}{c}21.5 \\
17.1 \\
13.0 \\
a 12 \\
015 \\
16.6 \\
96.9 \\
673 \\
21.9 \\
1.93 \\
.85 \\
6.76\end{array}$ & $\begin{array}{r}1,320 \\
1,020 \\
799 \\
738 \\
863 \\
1,020 \\
5,770 \\
4,140 \\
1,300 \\
119 \\
52 \\
402\end{array}$ \\
\hline The year. & 328 & .1 & 24.2 & 17,500 \\
\hline $\begin{array}{l}\text { October } \\
\text { November } \\
\text { December. } \\
\text { January } \\
\text { February } \\
\text { March } \\
\text { April } \\
\text { May } \\
\text { June } \\
\text { July } \\
\text { August. } \\
\text { September }\end{array}$ & \begin{tabular}{|c}
12 \\
12 \\
38 \\
78 \\
20 \\
17 \\
33 \\
24 \\
24 \\
\end{tabular} & $\begin{array}{r} \\
\\
12 \\
1.4 \\
1.1 \\
.3 \\
.3 \\
.8 \\
2.4 \\
\end{array}$ & $\begin{array}{c}11.2 \\
12 \\
a 9 \\
a 8 \\
012 \\
18.6 \\
46.5 \\
9.95 \\
5.42 \\
2.01 \\
3.60 \\
10.5\end{array}$ & $\begin{array}{r}689 \\
714 \\
553 \\
492 \\
666 \\
1,140 \\
2,770 \\
\cdot 612 \\
323 \\
124 \\
221 \\
625\end{array}$ \\
\hline The year. & 78 & .3 & 12.4 & 8,930 \\
\hline $\begin{array}{l}\text { October. } \\
\text { November. } \\
\text { December. } \\
\text { January-25-26 } \\
\text { February } \\
\text { March } \\
\text { April } \\
\text { May } \\
\text { June } \\
\text { July } \\
\text { August. } \\
\text { September }\end{array}$ & \begin{tabular}{|r|}
33 \\
$\mathbf{5 8}$ \\
$\mathbf{3 8}$ \\
$\mathbf{2 2 6}$ \\
$\mathbf{1 4 0}$ \\
$\mathbf{2 8}$ \\
$\mathbf{2 0}$ \\
24 \\
$\mathbf{3 3}$
\end{tabular} & $\begin{array}{r}12 \\
44 \\
17 \\
24 \\
18 \\
1 \\
1 \\
0 \\
0\end{array}$ & $\begin{array}{c}17.0 \\
56.8 \\
a \quad 30 \\
\text { a } 25 \\
\text { a } 24 \\
23.0 \\
113 \\
59.7 \\
12.2 \\
1.90 \\
2.19 \\
2.03\end{array}$ & $\begin{array}{r}1,050 \\
3,380 \\
1,840 \\
1,540 \\
1,330 \\
1,410 \\
6,720 \\
3,670 \\
726 \\
117 \\
135 \\
.121 \\
\end{array}$ \\
\hline The year. & 226 & 0 & 30.4 & 22,000 \\
\hline $\begin{array}{l}\text { October } \\
\text { November } \\
\text { December. } \\
\text { January } \\
\text { February } \\
\text { March } \\
\text { April } \\
\text { May } \\
\text { June } \\
\text { July } \\
\text { August } \\
\text { September }\end{array}$ & $\begin{array}{r}41 \\
302 \\
351 \\
77 \\
29 \\
22 \\
108 \\
\end{array}$ & $\begin{array}{r}14 \\
22 \\
82 \\
29 \\
1 \\
0 \\
20\end{array}$ & $\begin{array}{c}18.8 \\
14.0 \\
\text { a } 12 \\
\text { a } 11 \\
\text { a } 14 \\
24.8 \\
87.6 \\
185 \\
42.9 \\
7.87 \\
6.97 \\
26.5\end{array}$ & $\begin{array}{r}1,160 \\
833 \\
738 \\
676 \\
778 \\
1,520 \\
5,210 \\
11,400 \\
2,550 \\
484 \\
429 \\
1,580 \\
\end{array}$ \\
\hline The year. ........ & 351 & 0 & 37.8 & 27,400 \\
\hline
\end{tabular}

\footnotetext{
a Estimated.
} 


\section{ROAN CBATE HRAR DE BRQUE, COLO.}

Location.-On line between secs. 10 and 15, T. 7 S., R. 98 W., at highway bridge

11 miles north of De Beque, Mesa County. Nearest tributary, Kimball

Creek, enters half a mile upstream.

Drain age AREA. -210 square miles (measured on base map of Colorado).

Riconds avaruable.-April 8, 1921, to September 30, 1926.

GAGE.-Chain.

Controu.-Shifting.

ExTREMES OP DISCHARGE.-Maximum discharge recorded, 1,110 second-feet at

7.30 p. m. May 21, 1922 (gage height, 3.77 feet); minimum discharge recorded, 8 second-feet at 7.30 p. m. August 4, 1922 (gage height, 1.67 feet).

Diversions.- Water diverted by Roan Creek and tributaries above station for irrigation of 4,000 acres.

Accunscy.-Gage read twice daily. Rating curves not well defined. Records fair.

Cooperatron.-Since 1923 records furnished by State engineer.

Monthly discharge of Roan Creek near De Beque, Colo., 1921-1926

\begin{tabular}{|c|c|c|c|c|}
\hline \multirow{2}{*}{ Month } & \multicolumn{3}{|c|}{ Discharge in second-feet } & \multirow{2}{*}{$\underset{\text { acre-teet }}{\text { Run-off in }}$} \\
\hline & Maximum & Minimum & Mean & \\
\hline $\begin{array}{l}\text { April 8-30.. } \\
\text { May } \\
\text { June } \\
\text { July } \\
\text { August } \\
\text { September. }\end{array}$ & $\begin{array}{l}100 \\
615 \\
404 \\
.80 \\
72 \\
72\end{array}$ & $\begin{array}{r}48 \\
132 \\
65 \\
32 \\
27 \\
24\end{array}$ & $\begin{array}{l}77.0 \\
438 \\
157 \\
54.2 \\
37.5 \\
36.1\end{array}$ & $\begin{array}{r}3,510 \\
26,900 \\
9,340 \\
3,830 \\
2,310 \\
\mathbf{2}, 150\end{array}$ \\
\hline The period........ & - & | & n. & 47,500 \\
\hline $\begin{array}{l}\text { October } \\
\text { Nevember } \\
\text { December } \\
\text { January } \\
\text { Pebruary } \\
\text { March } \\
\text { April } \\
\text { May } \\
\text { June } \\
\text { July } \\
\text { August } \\
\text { September }\end{array}$ & \begin{tabular}{|r}
38 \\
28 \\
\\
172 \\
376 \\
1,080 \\
454 \\
86 \\
49 \\
66
\end{tabular} & $\begin{array}{r}24 \\
20 \\
19 \\
74 \\
465 \\
22 \\
17 \\
10 \\
26 \\
\end{array}$ & $\begin{array}{c}29.7 \\
24.9 \\
a 20 \\
a 18 \\
a 18 \\
63.0 \\
122 \\
785 \\
148 \\
42.2 \\
32.0 \\
35.2\end{array}$ & $\begin{array}{r}1,830 \\
1,480 \\
1,230 \\
1,110 \\
1,000 \\
3,870 \\
7,260 \\
48,300 \\
8,810 \\
2,590 \\
1,970 \\
2,090\end{array}$ \\
\hline The year... & 1,080 & (............... & 112 & 81,500 \\
\hline $\begin{array}{l}\text { October. } \\
\text { November } \\
\text { December } \\
\text { January } \\
\text { February } \\
\text { March } \\
\text { April } \\
\text { May } \\
\text { June } \\
\text { July } \\
\text { August } \\
\text { September }\end{array}$ & $\begin{array}{r}41 \\
257 \\
883 \\
328 \\
82 \\
51 \\
61\end{array}$ & $\begin{array}{r}-17 \\
43 \\
266 \\
84 \\
30 \\
26 \\
38\end{array}$ & $\begin{array}{c}33.6 \\
33.4 \\
a 25 \\
222 \\
020 \\
28.5 \\
111 \\
524 \\
169 \\
55.3 \\
38.2 \\
44.1\end{array}$ & $\begin{array}{r}2,070 \\
1,930 \\
1,340 \\
1,350 \\
1,110 \\
1,750 \\
6,600 \\
32,200 \\
10,100 \\
3,400 \\
2,350 \\
2,620\end{array}$ \\
\hline The year. & 883 & - & 92.5 & 67,000 \\
\hline
\end{tabular}

- Estimated. 
Monthly discharge of Roan Creek near De Beque, Colo., 1921-1926-Continued

\begin{tabular}{|c|c|c|c|c|}
\hline \multirow{2}{*}{ Month } & \multicolumn{3}{|c|}{ Discharge in second-feet } & \multirow{2}{*}{$\underset{\text { acre-feet }}{\text { Run-off in }}$} \\
\hline & Maximum & Minimum & Mean & \\
\hline $\begin{array}{l}\text { October. } \\
\text { November } \\
\text { December. } \\
\text { January } \\
\text { February } \\
\text { March } \\
\text { April } \\
\text { May } \\
\text { June } \\
\text { July } \\
\text { August } \\
\text { September. }\end{array}$ & $\begin{array}{r}43 \\
42 \\
41 \\
167 \\
91 \\
72 \\
28 \\
19 \\
27\end{array}$ & $\begin{array}{r}33 \\
45 \\
25 \\
31 \\
27 \\
30 \\
18 \\
17 \\
16\end{array}$ & $\begin{array}{r}35.5 \\
33.0 \\
\text { a } 27 \\
30 \\
\text { 33 } \\
31.0 \\
91.3 \\
59.9 \\
51.2 \\
21.5 \\
17.6 \\
22.9\end{array}$ & $\begin{array}{l}2,180 \\
1,960 \\
1,610 \\
1,840 \\
1,900 \\
1,910 \\
5,430 \\
3,680 \\
3,050 \\
1,320 \\
1,080 \\
1,360\end{array}$ \\
\hline The year & 167 & & 37.7 & 27,300 \\
\hline $\begin{array}{l}\text { October. } \\
\text { November } \\
\text { December. } \\
\text { January } \\
\text { February } \\
\text { March } \\
\text { April } \\
\text { May } \\
\text { June } \\
\text { July } \\
\text { August } \\
\text { September }\end{array}$ & $\begin{array}{r}27 \\
27 \\
43 \\
47 \\
32 \\
32 \\
56 \\
41 \\
33\end{array}$ & $\begin{array}{r}17 \\
20 \\
18 \\
19 \\
16 \\
20 \\
16 \\
18 \\
20\end{array}$ & $\begin{array}{l}22.2 \\
22.5 \\
\times 21 \\
\cdot 18 \\
\times 21 \\
25.2 \\
35.6 \\
24.9 \\
25.1 \\
24.0 \\
22.7 \\
24.5\end{array}$ & $\begin{array}{l}1,360 \\
1,340 \\
1,290 \\
1,110 \\
1,170 \\
1,550 \\
2,120 \\
1,530 \\
1,490 \\
1,480 \\
1,400 \\
1,460\end{array}$ \\
\hline The year.............. & 56 & & 23.9 & 17,300 \\
\hline $\begin{array}{l}\text { October. } \\
\text { November. } \\
\text { December. } \\
\text { January } \\
\text { February } \\
\text { March } \\
\text { April } \\
\text { May } \\
\text { June } \\
\text { July } \\
\text { August } \\
\text { September }\end{array}$ & \begin{tabular}{r|r|}
33 \\
21 \\
56 \\
179 \\
193 \\
36 \\
148 \\
19 \\
16
\end{tabular} & $\begin{array}{r}15 \\
17 \\
15 \\
16 \\
32 \\
21 \\
14 \\
14 \\
12\end{array}$ & $\begin{array}{l}21.3 \\
18.4 \\
a \\
17 \\
16 \\
a 15 \\
28.3 \\
91.9 \\
89.7 \\
30.7 \\
30.7 \\
16.0 \\
14.0\end{array}$ & $\begin{array}{r}1,310 \\
1,090 \\
1,050 \\
984 \\
833 \\
1,740 \\
5,470 \\
5,520 \\
1,830 \\
1,890 \\
984 \\
833\end{array}$ \\
\hline The year. & 193 & 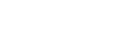 & 32.5 & 23,500 \\
\hline
\end{tabular}

astimated.

platead CREgk near colthBan, colo.

Location.-In sec. 23 , T. 9 S., R. 94 W., at private bridge 5 miles east of Collbran, Garfield County. Nearest tributary, Buzzard Creek, enters at Collbran.

Drainage area.-88 square miles (measured on Forest Service map).

ReCords AVAILABLe.-August 20, 1921, to, September 30, 1927.

GAGE.-Bristol float-type recorder.

Control.-Practically permanent.

Extremes OF DISCHARGE.-Maximum stage during period, 6.72 feet at 7.45

a. m. May 28, 1922 (discharge, 2,800 second-feet); minimum discharge,

3 second-feet September 21, 1926.

Diversions.-Two small ditches divert water above station.

Cooperation.-Complete records furnished by State engineer. 
Monthly discharge of Plateau Creek near Collbran, Colo., 1921-1927

\begin{tabular}{|c|c|c|c|c|}
\hline \multirow{2}{*}{ Month } & \multicolumn{3}{|c|}{ Discharge in second-feet } & \multirow{2}{*}{$\begin{array}{l}\text { Run-off in } \\
\text { acre-feet }\end{array}$} \\
\hline & Maximum & Minimum & Mean & \\
\hline $\begin{array}{l}\text { August } 20-31 \\
\text { September }\end{array}$ & $\begin{array}{l}222 \\
124 \\
\end{array}$ & $\begin{array}{l}27 \\
28\end{array}$ & $\begin{array}{l}89.2 \\
44.3\end{array}$ & $\begin{array}{l}2,120 \\
2,640\end{array}$ \\
\hline $\begin{array}{l}\text { October. } \\
\text { November. } \\
\text { December } \\
\text { January } \\
\text { February } \\
\text { March. } \\
\text { April } \\
\text { May } \\
\text { June } \\
\text { July } \\
\text { August } \\
\text { September }\end{array}$ & $\begin{array}{r}35 \\
42 \\
1,700 \\
263 \\
33 \\
15\end{array}$ & $\begin{array}{r}23 \\
20 \\
14 \\
205 \\
314 \\
30 \\
10 \\
6\end{array}$ & $\begin{array}{c}29.3 \\
27.6 \\
\text { a } 29 \\
\text { a } 25 \\
\text { a } 22 \\
\text { a } 23 \\
44.1 \\
770 \\
888 \\
77.2 \\
17.3 \\
10.2\end{array}$ & $\begin{array}{r}1,800 \\
1,640 \\
1,780 \\
1,540 \\
1,220 \\
1,350 \\
2,620 \\
47,300 \\
52,800 \\
4,750 \\
1,060 \\
607\end{array}$ \\
\hline The year................. & 2,000 & 6 & 163 & 118,000 \\
\hline $\begin{array}{l}\text { October. } \\
\text { November } \\
\text { December } \\
\text { January } \\
\text { February } \\
\text { March } \\
\text { A pril } \\
\text { May. } \\
\text { June } \\
\text { July } \\
\text { August. } \\
\text { September }\end{array}$ & $\begin{array}{r}8 \\
1 \\
117 \\
988 \\
960 \\
242 \\
150 \\
45\end{array}$ & $\begin{array}{r}5 \\
6 \\
16 \\
112 \\
146 \\
18 \\
14 \\
14 \\
\end{array}$ & $\begin{array}{l}\text { 6. } 45 \\
10.5 \\
12 \\
10 \\
\text { a } 10 \\
\text { a } 20 \\
54.7 \\
486 \\
592 \\
105 \\
45.2 \\
28.7\end{array}$ & $\begin{array}{r}397 \\
625 \\
738 \\
615 \\
555 \\
1,230 \\
3,260 \\
29,900 \\
35,200 \\
6,460 \\
2,780 \\
1,710\end{array}$ \\
\hline The year. & 988 & 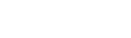 & 115 & 83,500 \\
\hline $\begin{array}{l}\text { October } \\
\text { November } \\
\text { December } \\
\text { January } \\
\text { February } \\
\text { March } \\
\text { April } \\
\text { May } \\
\text { June } \\
\text { July } \\
\text { August } \\
\text { September }\end{array}$ & $\begin{array}{r}81 \\
30 \\
165 \\
918 \\
658 \\
47 \\
29 \\
36\end{array}$ & $\begin{array}{r}26 \\
17 \\
19 \\
114 \\
22 \\
13 \\
7 \\
9\end{array}$ & 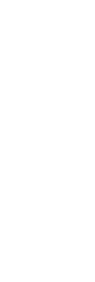 & $\begin{array}{r}2,740 \\
1,580 \\
1,480 \\
984 \\
863 \\
1,230 \\
4,430 \\
34,100 \\
14,800 \\
1,290 \\
701 \\
780\end{array}$ \\
\hline The year. & 918 & 7 & 90.0 & 65,000 \\
\hline $\begin{array}{l}\text { Ootober } \\
\text { November } \\
\text { December } \\
\text { January } \\
\text { February } \\
\text { March } \\
\text { April } \\
\text { May } \\
\text { June } \\
\text { July } \\
\text { August } \\
\text { September }\end{array}$ & $\begin{array}{r}26 \\
307 \\
586 \\
258 \\
88 \\
160 \\
477\end{array}$ & \begin{tabular}{r|r|}
11 \\
14 \\
12 \\
27 \\
182 \\
31 \\
14 \\
10 \\
18
\end{tabular} & $\begin{array}{l}16.0 \\
24.4 \\
25 \\
21 \\
18 \\
17.0 \\
143 \\
397 \\
140 \\
30.1 \\
33.9 \\
64.8\end{array}$ & $\begin{array}{r}984 \\
1,450 \\
1,540 \\
1,290 \\
1,000 \\
1,050 \\
8,510 \\
24,400 \\
8,330 \\
1,850 \\
2,080 \\
3,860\end{array}$ \\
\hline The year. & 586 & & 77.7 & 56,300 \\
\hline $\begin{array}{l}\text { October. } \\
\text { November } \\
\text { December. } \\
\text { January. } \\
\text { February. } \\
\text { March } \\
\text { April } \\
\text { May } \\
\text { June } \\
\text { July } \\
\text { August. } \\
\text { September. }\end{array}$ & $\begin{array}{r}\mathbf{3 2 2} \\
\mathbf{8 3}\end{array}$ & $\begin{array}{r}19 \\
29 \\
197 \\
80 \\
17 \\
7 \\
3\end{array}$ & $\begin{array}{l}87.4 \\
54.2 \\
=30 \\
\text { a } 25 \\
\text { a } 23 \\
\text { a } 28 \\
154 \\
588 \\
371 \\
60.8 \\
17.1 \\
10.4\end{array}$ & $\begin{array}{r}5,370 \\
3,230 \\
1,840 \\
1,540 \\
1,280 \\
1,720 \\
9,160 \\
36,200 \\
22,100 \\
3,740 \\
1,050 \\
619\end{array}$ \\
\hline & 995 & - n............. & 121 & 87,800 \\
\hline
\end{tabular}

a Estimated. 
Monthly discharge of Plateau Creek near Collbran, Colo., 1921-1927-Continued

\begin{tabular}{|c|c|c|c|c|}
\hline \multirow{2}{*}{ Month } & \multicolumn{3}{|c|}{ Discharge in second-feet } & \multirow{2}{*}{$\underset{\text { acre-feet }}{\text { Run-off in }}$} \\
\hline & Maximum & Minimum & Mean & \\
\hline $\begin{array}{l}\text { October.. } \\
\text { November } \\
\text { December } \\
\text { January } \\
\text { February } \\
\text { March } \\
\text { April } \\
\text { May } \\
\text { June } \\
\text { July } \\
\text { August } \\
\text { September. }\end{array}$ & $\begin{array}{r}137 \\
32 \\
32 \\
359 \\
140 \\
726 \\
182 \\
148 \\
66\end{array}$ & $\begin{array}{r}12 \\
8 \\
16 \\
27 \\
263 \\
182 \\
33 \\
26 \\
16\end{array}$ & $\begin{array}{c}32.2 \\
17.1 \\
16 \\
015 \\
-16 \\
18.5 \\
86.3 \\
670 \\
416 \\
89.4 \\
55.3 \\
38.2\end{array}$ & $\begin{array}{r}1,980 \\
1,020 \\
984 \\
922 \\
880 \\
1,140 \\
5,140 \\
41,200 \\
24,800 \\
5,500 \\
3,400 \\
2,270\end{array}$ \\
\hline The year.............. & 1,140 & -1 & 123 & 89,200 \\
\hline
\end{tabular}

- Estimated.

BUZzard CREEK NEAR COLLbRAN, colo.

Location.--In sec. 14, T. 9 S., R. 94 W., at highway bridge 7 miles northeast of Collbran, Garfield County. Nearest tributary, Lenox Creek, enters 1 mile downstream.

Drainage area.-136 square miles (measured on Forest Service map).

Records available.-August 18, 1921, to September 30, 1927.

GAGE.-Bristol float-type recorder.

Control.-Fairly permanent.

EXTREMes OF DISCHARge.-Maximum stage during period, 7.8 feet at 5.30 a. m.

May 18, 1922 (discharge, 1,270 second-feet); minimum stage, 0.82 foot at

3 p. m. August 28, 1924 (discharge, 0.5 second-foot).

Diversions.-Practically none above station.

Cooperation.-Complete records furnished by State engineer.

Monthly discharge of Buzzard Creek near Collbran, Colo., for 1921-1927

\begin{tabular}{|c|c|c|c|c|}
\hline \multirow{2}{*}{ Month } & \multicolumn{3}{|c|}{ Discharge in second-feet } & \multirow{2}{*}{$\begin{array}{l}\text { Run-ofi in } \\
\text { acre-feet }\end{array}$} \\
\hline & Maximum & Minimum & Mean & \\
\hline $\begin{array}{l}\text { August 18-31 } \\
\text { September } 1921 \\
\end{array}$ & $\begin{array}{r}66 \\
44 \\
\end{array}$ & $\begin{array}{c}11 \\
5.8 \\
\end{array}$ & $\begin{array}{r}25.8 \\
13.4 \\
\end{array}$ & $\begin{array}{l}716 \\
797 \\
\end{array}$ \\
\hline $\begin{array}{l}\text { October } \\
\text { November } \\
\text { December } \\
\text { January } \\
\text { February } \\
\text { March } \\
\text { April } \\
\text { May } \\
\text { June } \\
\text { July } \\
\text { August } \\
\text { September }\end{array}$ & $\begin{array}{c}481 \\
833 \\
428 \\
56 \\
13 \\
5.8\end{array}$ & \begin{tabular}{|r|}
3.9 \\
4.4 \\
22 \\
33 \\
52 \\
4.4 \\
1.4 \\
.5
\end{tabular} & $\begin{array}{l}\quad \\
8.86 \\
10.1 \\
15 \\
224 \\
30 \\
a 44 \\
118 \\
582 \\
201 \\
15.8 \\
4.87 \\
2.57\end{array}$ & $\begin{array}{r}545 \\
601 \\
922 \\
1,480 \\
1,670 \\
2,710 \\
7,020 \\
35,800 \\
12,000 \\
972 \\
299 \\
153\end{array}$ \\
\hline The year. & 833 & .5 & 88.5 & 64,200 \\
\hline
\end{tabular}

- Estimated. 
Monthly discharge of Buzzard Creek near Collbran, Colo., for 1921-1927-Contd.

\begin{tabular}{|c|c|c|c|c|}
\hline \multirow{2}{*}{ Month } & \multicolumn{3}{|c|}{ Discharge in second-feet } & \multirow{2}{*}{$\begin{array}{l}\text { Run-off in } \\
\text { acre-feet }\end{array}$} \\
\hline & Maximum & Minimum & Mean & \\
\hline $\begin{array}{l}\text { October } \\
\text { November } \\
\text { December } \\
\text { January } \\
\text { February } \\
\text { March } \\
\text { April } \\
\text { May } \\
\text { June } \\
\text { July } \\
\text { August } \\
\text { September }\end{array}$ & $\begin{array}{r}218 \\
584 \\
389 \\
44 \\
54 \\
30\end{array}$ & \begin{tabular}{|r|}
2.0 \\
5.6 \\
\hdashline \\
\hdashline 162 \\
48 \\
8 \\
9 \\
7 \\
\end{tabular} & $\begin{array}{c}3.4 \\
8.2 \\
\cdot 14 \\
220 \\
226 \\
232 \\
95.7 \\
403 \\
184 \\
25.5 \\
22.7 \\
11.6\end{array}$ & $\begin{array}{r}209 \\
488 \\
861 \\
1,230 \\
1,440 \\
1,970 \\
5,690 \\
24,800 \\
10,900 \\
1,570 \\
400 \\
690\end{array}$ \\
\hline The year... & 584 & 2 & 69.3 & 50,200 \\
\hline $\begin{array}{l}\text { October. } \\
\text { November } \\
\text { December } \\
\text { January } \\
\text { February } \\
\text { Marreh } \\
\text { Aprld } \\
\text { May } \\
\text { June } \\
\text { July } \\
\text { August } \\
\text { September }\end{array}$ & $\begin{array}{c}24 \\
15 \\
\\
\\
252 \\
545 \\
276 \\
18 \\
2.6 \\
8.3\end{array}$ & $\begin{array}{r}19 \\
143 \\
12 \\
1.7 \\
.6 \\
.7\end{array}$ & $\begin{array}{c}17.2 \\
9.01 \\
\cdot 14 \\
222 \\
a 19 \\
211 \\
104 \\
359 \\
115 \\
5.31 \\
1.08 \\
1.36\end{array}$ & $\begin{array}{r}1,060 \\
536 \\
861 \\
1,350 \\
1,090 \\
678 \\
6,190 \\
22,100 \\
684 \\
326 \\
66 \\
81\end{array}$ \\
\hline Thes & 545 & .6 & 48.3 & 35,000 \\
\hline $\begin{array}{l}\text { October } \\
\text { November } \\
\text { December } \\
\text { January } \\
\text { February } \\
\text { April } \\
\text { Jayne }\end{array}$ & $\begin{array}{r}12 \\
\\
92 \\
269 \\
261 \\
99 \\
44 \\
28 \\
50\end{array}$ & $\begin{array}{r}7 \\
53 \\
74 \\
8 \\
3 \\
2 \\
6\end{array}$ & 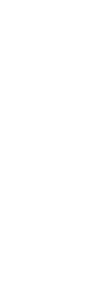 & $\begin{array}{r}323 \\
720 \\
984 \\
861 \\
611 \\
1,730 \\
8,570 \\
10,000 \\
3,030 \\
1,060 \\
526 \\
970\end{array}$ \\
\hline The year & 269 & 1 & 40.7 & 29,400 \\
\hline $\begin{array}{l}\text { October } \\
\text { November } \\
\text { December } \\
\text { January } \\
\text { February } \\
\text { March } \\
\text { April. } \\
\text { May } \\
\text { June } \\
\text { July } \\
\text { August } \\
\text { September }\end{array}$ & $\begin{array}{r}469 \\
462 \\
311 \\
118 \\
7 \\
2\end{array}$ & $\begin{array}{r}26 \\
188 \\
24 \\
4 \\
1 \\
1\end{array}$ & $\begin{array}{c}31.0 \\
20.8 \\
017 \\
020 \\
a 19.6 \\
030 \\
225 \\
320 \\
118 \\
25.2 \\
2.68 \\
1.23\end{array}$ & $\begin{array}{r}1,910 \\
1,240 \\
1,050 \\
1,230 \\
1,090 \\
1,840 \\
18,400 \\
19,700 \\
7,020 \\
1,550 \\
165 \\
73\end{array}$ \\
\hline The year. & 469 & 1 & 69.7 & 50,300 \\
\hline $\begin{array}{l}\text { October } \\
\text { November } \\
\text { December } \\
\text { January } \\
\text { February } \\
\text { March } \\
\text { April } \\
\text { May } \\
\text { June } \\
\text { July } \\
\text { August } \\
\text { September }\end{array}$ & $\begin{array}{r}60 \\
337 \\
530 \\
300 \\
103 \\
49 \\
66\end{array}$ & $\begin{array}{r}7 \\
10 \\
38 \\
180 \\
97 \\
9 \\
5 \\
6\end{array}$ & $\begin{array}{c}22 \\
9.67 \\
a 12 \\
a 12 \\
a 12 \\
18.3 \\
131 \\
340 \\
141 \\
39.6 \\
19.9 \\
27.1\end{array}$ & $\begin{array}{r}1,350 \\
575 \\
738 \\
738 \\
666 \\
1,130 \\
7,800 \\
20,900 \\
8,390 \\
2,430 \\
1,220 \\
1,610\end{array}$ \\
\hline The year. & 530 & & 65.8 & 47,500 \\
\hline
\end{tabular}

- Estimated. 
TAYLOR RIVER ABOVE ALMONT, COLO,

Location.-In sec. 8 , T. 15 S., R. 83 W., at private bridge 10 miles northeast of Almont, Gunnison County. Nearest tributary, South Lottis Creek, enters a short distance upstream.

Drainage area.-317 square miles (measured on Forest Service map).

Records available.-April 17 to November 24, 1905.

GAGE.-Vertical staff.

ControL.-Shifting.

Diversions. - Water diverted for irrigation of a few hundred acres above station. AcCURACY.-Gage read twice daily. Rating curves well defined. Records good.

Monthly discharge of Taylor River above Almont, Colo., for 1905

\begin{tabular}{|c|c|c|c|c|}
\hline \multirow{2}{*}{ Month } & \multicolumn{3}{|c|}{ Discharge in second-feet } & \multirow{2}{*}{$\begin{array}{l}\text { Run-off in } \\
\text { acre-feet }\end{array}$} \\
\hline & Maximum & Minimum & Mean & \\
\hline $\begin{array}{l}\text { April } 17-30 . \\
\text { May } \\
\text { June } \\
\text { July } \\
\text { August } \\
\text { September } \\
\text { October } \\
\text { November } 1-24\end{array}$ & $\begin{array}{r}628 \\
1,370 \\
2,790 \\
535 \\
310 \\
200 \\
200 \\
175\end{array}$ & $\begin{array}{r}115 \\
168 \\
692 \\
272 \\
200 \\
200 \\
175 \\
70\end{array}$ & $\begin{array}{r}248 \\
650 \\
1,520 \\
351 \\
229 \\
200 \\
182 \\
156\end{array}$ & $\begin{array}{r}6,890 \\
40,000 \\
90,400 \\
21,600 \\
14,100 \\
11,900 \\
11,200 \\
7,430\end{array}$ \\
\hline The period......... & $\ldots$ & & . & 204,000 \\
\hline
\end{tabular}

TAYLOR RIVER AT ALMONT, COLO.

Location.-In sec. 22, T. 51 N., R. 1 E., at highway bridge in Almont, Gunnison County, 300 yards above junction of Taylor and East Rivers.

Drainage area. - 440 square miles (revised; measured on base map of Colorado). Records available.-July 27, 1910, to September 30, 1927.

GAGE.-Bristol float-type water-stage recorder installed April 16, 1922; vertical staff used previously.

Contror.-Slightly shifting.

Extremis of Discharge.-Maximum stage recorded, 5.0 feet at 7.30 a. m. June 9, 1920 (discharge, 3,760 second-feet); minimum stage, 1.2 feet for several days during August, 1913 (discharge, 50 second-feet).

Diversions. - Water diverted for irrigation of 1,800 acres by Taylor River.

ACCURACY.-Gage read twice daily prior to 1922; continuous record since that time except during winter. Rating curves well defined. Records good except during winter; for which they are fair.

Cooperation.- Station maintained in cooperation with Bureau of Reclamation and State engineer. 
Monthly discharge of Taylor River at Almont, Colo., for 1910-1927

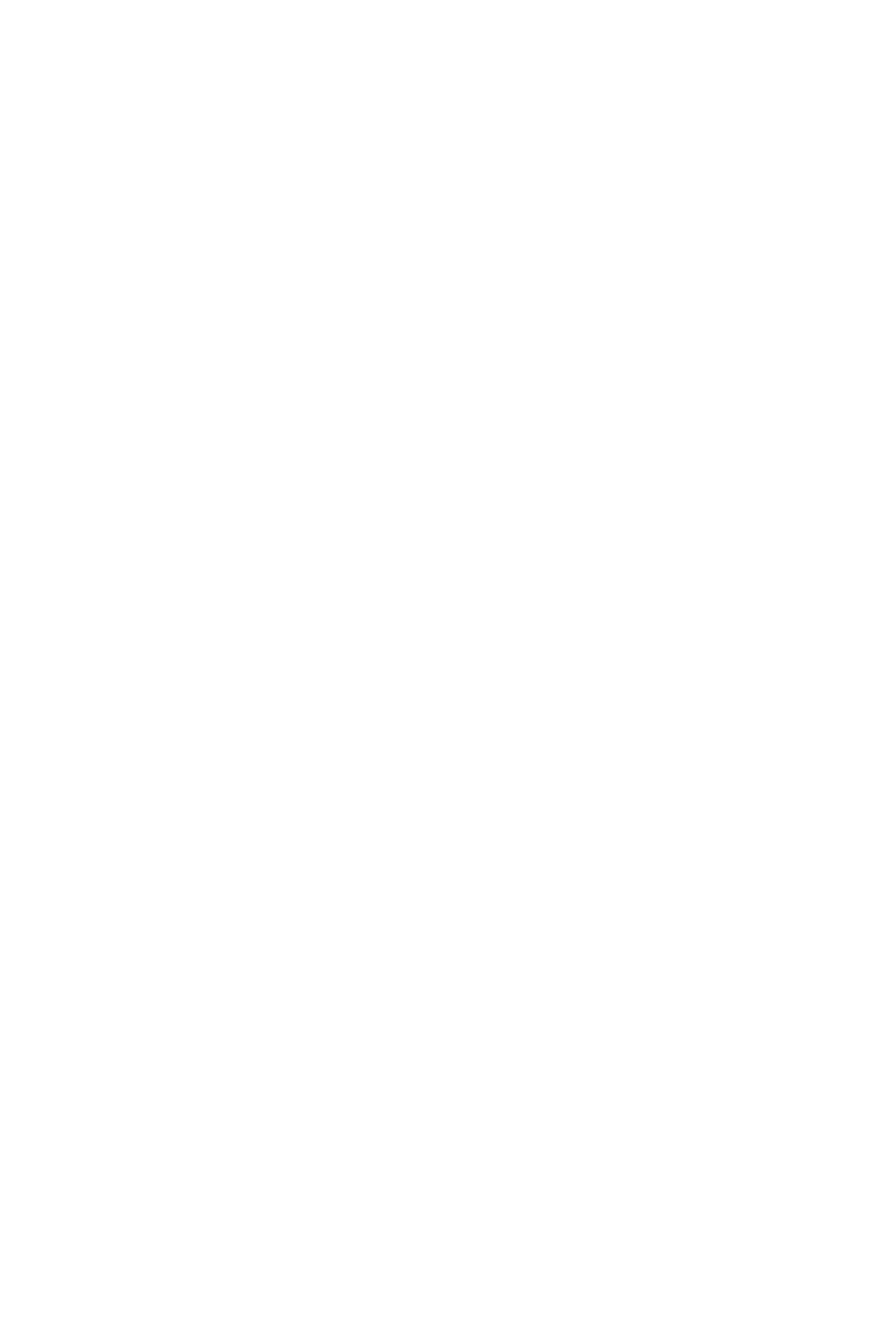


Monthly discharge of Taylor River at Almont, Colo., for 1910-1927-Continued

\begin{tabular}{|c|c|c|c|c|}
\hline \multirow{2}{*}{ Month } & \multicolumn{3}{|c|}{ Discharge in second-feet } & \multirow{2}{*}{$\begin{array}{l}\text { Run-off in } \\
\text { acre-feet }\end{array}$} \\
\hline & Maximum & Minimum & Mean & \\
\hline $\begin{array}{l}\text { October } \\
\text { November } \\
\text { December } \\
\text { January } \\
\text { February } \\
\text { March } \\
\text { April } \\
\text { May } \\
\text { June } \\
\text { July } \\
\text { August } \\
\text { September }\end{array}$ & \begin{tabular}{|r|}
415 \\
235 \\
\hdashline 215 \\
\hdashline $\mathbf{4 7 8}$ \\
$\mathbf{8 2 0}$ \\
1,560 \\
$\mathbf{8 6 8}$ \\
$\mathbf{3 8 5}$ \\
$\mathbf{3 5 8}$
\end{tabular} & $\begin{array}{r}215 \\
178 \\
178 \\
215 \\
258 \\
545 \\
258 \\
215 \\
178\end{array}$ & $\begin{array}{r}271 \\
209 \\
160 \\
155 \\
160 \\
182 \\
333 \\
438 \\
1,040 \\
462 \\
270 \\
207\end{array}$ & $\begin{array}{r}16,700 \\
12,400 \\
9,840 \\
9,530 \\
9,200 \\
11,200 \\
19,800 \\
26,900 \\
61,900 \\
28,400 \\
16,600 \\
12,300\end{array}$ \\
\hline The year.............. & 1,560 & - & 325 & 235,000 \\
\hline $\begin{array}{l}\text { October } \\
\text { November } \\
\text { December } \\
\text { January } \\
\text { February } \\
\text { March } \\
\text { April } \\
\text { May } \\
\text { June } \\
\text { July } \\
\text { August } \\
\text { September }\end{array}$ & $\begin{array}{r}305 \\
695 \\
1,780 \\
2,740 \\
1,380 \\
780 \\
405\end{array}$ & $\begin{array}{r}178 \\
178 \\
215 \\
258 \\
385 \\
1,140 \\
435 \\
276 \\
232\end{array}$ & $\begin{array}{r}188 \\
179 \\
118 \\
107 \\
95 \\
264 \\
359 \\
948 \\
1,760 \\
837 \\
447 \\
301\end{array}$ & $\begin{array}{r}11,600 \\
10,700 \\
7,260 \\
6,580 \\
5,460 \\
16,200 \\
21,400 \\
58,300 \\
105,000 \\
51,500 \\
27,500 \\
17,900\end{array}$ \\
\hline The y & 2,740 & $\mid-\ldots$ & 468 & 339,000 \\
\hline $\begin{array}{l}\text { October } \\
\text { November } \\
\text { December } \\
\text { January } \\
\begin{array}{l}\text { February } \\
\text { March } \\
\text { April } \\
\text { May }\end{array} \text { June } \\
\text { July } \\
\text { August } \\
\text { September }\end{array}$ & $\begin{array}{r}170 \\
690 \\
1,380 \\
3,300 \\
2,100 \\
610 \\
291\end{array}$ & \begin{tabular}{|r|}
210 \\
132 \\
117 \\
132 \\
151 \\
610 \\
690 \\
300 \\
186
\end{tabular} & $\begin{array}{r}316 \\
172 \\
141 \\
124 \\
137 \\
139 \\
248 \\
583 \\
2,040 \\
1,130 \\
410 \\
251\end{array}$ & $\begin{array}{r}19,400 \\
10,200 \\
8,670 \\
7,620 \\
7,610 \\
8,550 \\
14,800 \\
35,800 \\
121,000 \\
69,500 \\
25,200 \\
14,900\end{array}$ \\
\hline The yes & 3,300 & 77 & 475 & 343,000 \\
\hline $\begin{array}{l}\text { October } \\
\text { November } \\
\text { December } \\
\text { January } \\
\text { February } \\
\text { March } \\
\text { April } \\
\text { May } \\
\text { June } \\
\text { July } \\
\text { August } \\
\text { September }\end{array}$ & $\begin{array}{r}190 \\
190 \\
175 \\
325 \\
1,540 \\
\mathbf{3}, \mathbf{2 2 0} \\
935 \\
\mathbf{3 5 5} \\
\mathbf{6 5 2}\end{array}$ & \begin{tabular}{|r|}
190 \\
160 \\
\\
\end{tabular} & $\begin{array}{r}190 \\
165 \\
124 \\
123 \\
145 \\
138 \\
184 \\
966 \\
2,130 \\
623 \\
300 \\
303\end{array}$ & $\begin{array}{r}11,700 \\
9,820 \\
7,620 \\
7,560 \\
8,050 \\
8,480 \\
10,900 \\
69,400 \\
127,000 \\
38,300 \\
18,400 \\
18,000\end{array}$ \\
\hline The year. & 3,220 & 100 & 449 & 325,000 \\
\hline $\begin{array}{l}\text { October } \\
\text { November } \\
\text { December } \\
\text { January- } \\
\text { February } \\
\text { March } \\
\text { April } \\
\text { May } \\
\text { June } \\
\text { July } \\
\text { August } \\
\text { September }\end{array}$ & \begin{tabular}{|r|}
248 \\
218 \\
\\
\hdashline \\
166 \\
530 \\
1,600 \\
1,000 \\
945 \\
498 \\
315 \\
\end{tabular} & $\begin{array}{r}211 \\
160 \\
92 \\
143 \\
380 \\
605 \\
270 \\
176 \\
158\end{array}$ & $\begin{array}{l}221 \\
193 \\
130 \\
98.3 \\
103 \\
117 \\
292 \\
915 \\
766 \\
419 \\
269 \\
193\end{array}$ & $\begin{array}{r}13,600 \\
11,500 \\
7,990 \\
6,040 \\
5,720 \\
7,190 \\
17,400 \\
56,300 \\
45,600 \\
25,800 \\
16,500 \\
11,500\end{array}$ \\
\hline The year. & 1,600 & 90 & 311 & 225,000 \\
\hline
\end{tabular}


Monthly discharge of Taylor River at Almont, Colo., for 1910-1927-Continued

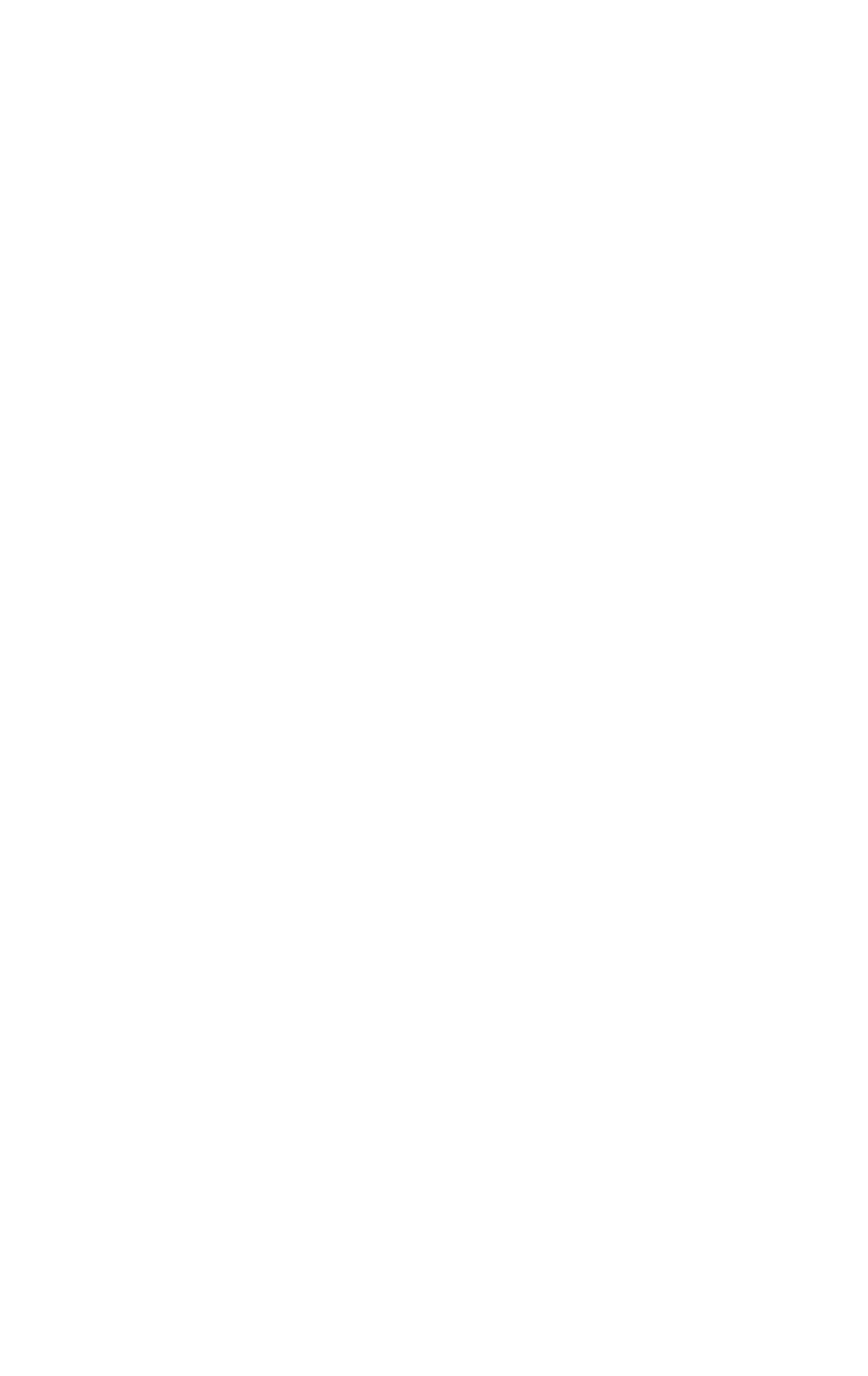


Monthly discharge of Taylor River at Almont, Colo., for 1910-1987-Continued

\begin{tabular}{|c|c|c|c|c|}
\hline \multirow{2}{*}{ Month } & \multicolumn{3}{|c|}{ Discharge in second-feet } & \multirow{2}{*}{$\begin{array}{c}\text { Run-off in } \\
\text { acre-feet }\end{array}$} \\
\hline & Maximum & Minimum & Mean & \\
\hline $\begin{array}{l}\text { October } \\
\text { November } \\
\text { December } \\
\text { January } \\
\text { February } \\
\text { March } \\
\text { April } \\
\text { May } \\
\text { June } \\
\text { July } \\
\text { August } \\
\text { September }\end{array}$ & \begin{tabular}{r|r|}
270 \\
186 \\
158 \\
760 \\
1,230 \\
1,140 \\
802 \\
452 \\
275
\end{tabular} & \begin{tabular}{|r|}
164 \\
135 \\
466 \\
565 \\
245 \\
230 \\
158
\end{tabular} & $\begin{array}{l}210 \\
161 \\
123 \\
107 \\
105 \\
119 \\
377 \\
786 \\
807 \\
472 \\
291 \\
203\end{array}$ & $\begin{array}{r}12,900 \\
9,580 \\
7,560 \\
6,580 \\
5,880 \\
7,320 \\
22,400 \\
48,300 \\
48,000 \\
29,000 \\
17,900 \\
12,100\end{array}$ \\
\hline The year. . . & 1,230 & and & 314 & 227,000 \\
\hline $\begin{array}{l}\text { October } \\
\text { November } \\
\text { December } \\
\text { January } \\
\text { February } \\
\text { March } \\
\text { April } \\
\text { May } \\
\text { June } \\
\text { July } \\
\text { August } \\
\text { September }\end{array}$ & $\begin{array}{r}284 \\
220 \\
136 \\
486 \\
1,320 \\
1,910 \\
927 \\
435 \\
294\end{array}$ & $\begin{array}{r}180 \\
103 \\
57 \\
100 \\
289 \\
644 \\
303 \\
188 \\
171\end{array}$ & $\begin{array}{r}232 \\
155 \\
106 \\
84 \\
95 \\
102 \\
254 \\
697 \\
1,150 \\
541 \\
286 \\
202\end{array}$ & $\begin{array}{r}14,300 \\
9,220 \\
6,520 \\
5,160 \\
5,280 \\
6,270 \\
15,100 \\
42,900 \\
68,400 \\
33,300 \\
17,600 \\
12,000\end{array}$ \\
\hline The year & 1,910 & 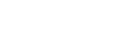 & 326 & 236,000 \\
\hline $\begin{array}{l}\text { October } \\
\text { November. } \\
\text { December. } \\
\text { January } \\
\text { February } \\
\text { March } \\
\text { April } \\
\text { May } \\
\text { June } \\
\text { July } \\
\text { August } \\
\text { September. }\end{array}$ & $\begin{array}{r}200 \\
136 \\
155 \\
169 \\
139 \\
638 \\
1,910 \\
1,820 \\
990 \\
585 \\
446\end{array}$ & \begin{tabular}{|r}
136 \\
118 \\
74 \\
118 \\
66 \\
622 \\
1,080 \\
410 \\
277 \\
251
\end{tabular} & $\begin{array}{r}159 \\
125 \\
117 \\
117 \\
123 \\
116 \\
203 \\
1,180 \\
1,420 \\
611 \\
372 \\
338\end{array}$ & $\begin{array}{r}9,780 \\
7,440 \\
7,190 \\
7,100 \\
6,830 \\
7,180 \\
12,100 \\
72,600 \\
84,500 \\
37,600 \\
22,900 \\
20,100\end{array}$ \\
\hline 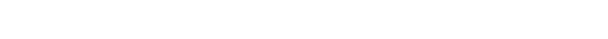 & 1,910 & $-\ldots$. & 407 & 295,000 \\
\hline
\end{tabular}

Note.-Records during winter based on current-meter measurements, daily gage heights, and temperature records.

GUNIISON RIVER NEAR GUNNISON, COLO.

Location.-In sec. 3, T. 49 N., R. 1 W., at highway bridge 2 miles southwest of Gunnison, Gunnison County. Nearest tributary, Tomichi Creek, enters 1 mile downstream.

Drainage area.-1,010 square miles (measured on Forest Atlas).

Records avallable.-October 1, 1910, to November 30, 1914; October 1, 1915, to September 30, 1927.

GAGQ.-Chain. During 1916 and 1917 Bristol pressure gage used.

ControL.-Shifting at intervals.

Extremes of discharge - Maximum stage recorded during period, 5.05 feet at 8 a. m. June 13, 1918 (discharge, 11,400 second-feet); minimum discharge recorded, 136 second-feet January 8,1919 , from current-meter measurement.

Diversions.- Water diverted for irrigation of 8,800 acres by Gunnison River between this station and Almont.

Accuracy.-Gage read twice daily. Rating curves fairly well defined. Records range from fair to good.

Cooperatron.-Station maintained in cooperation with State engineer. 
Monthly discharge of Gunnison River near Gunnison, Colo., for 1910-1914 and 1915-1927

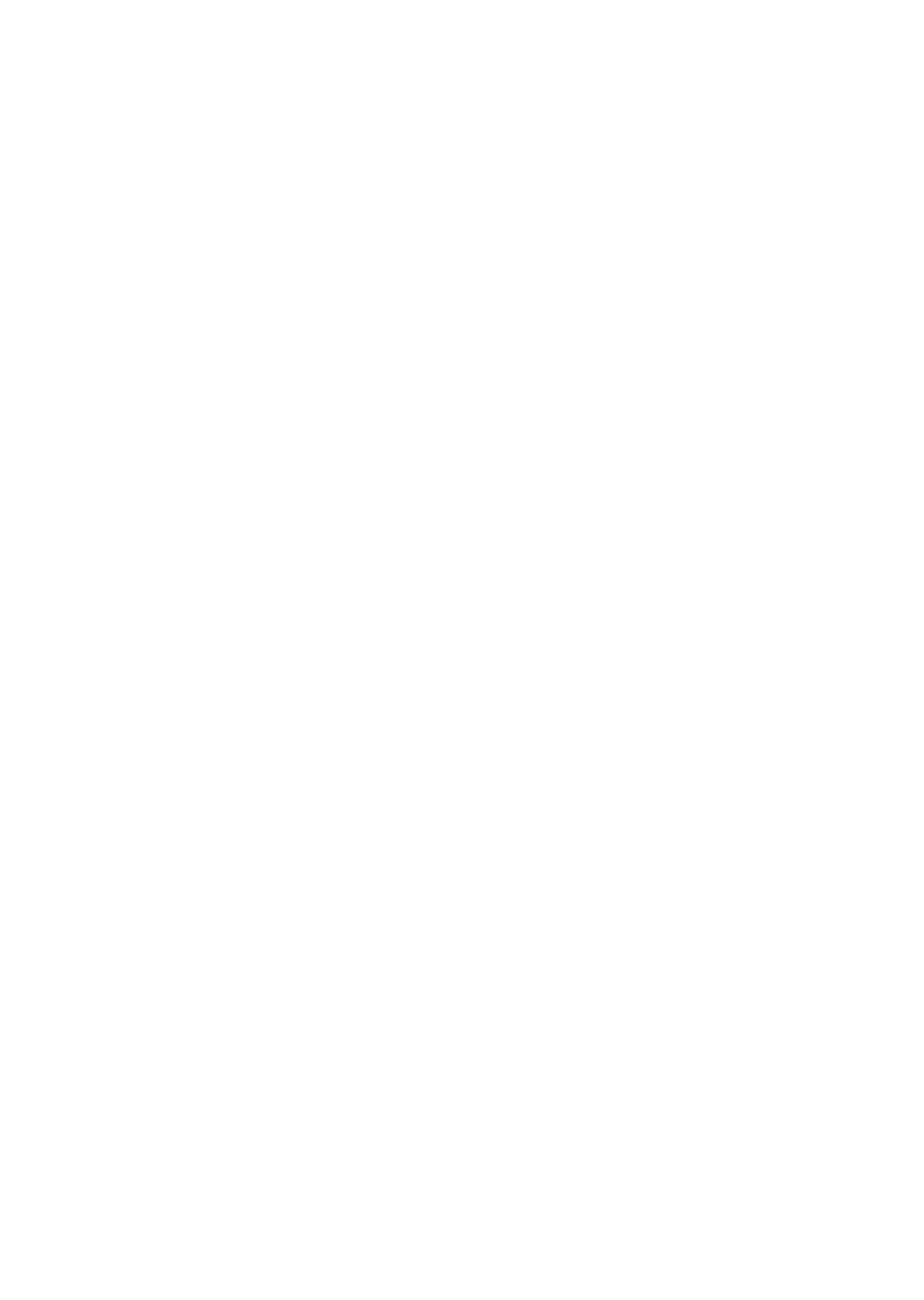

astimated by comparison with flow of East and Taylor Rivers at Almont.

- Revised. 
Monthly discharge of Gunnison River near Gunnison, Colo., for 1910-1914 and 1915-1927-Continued

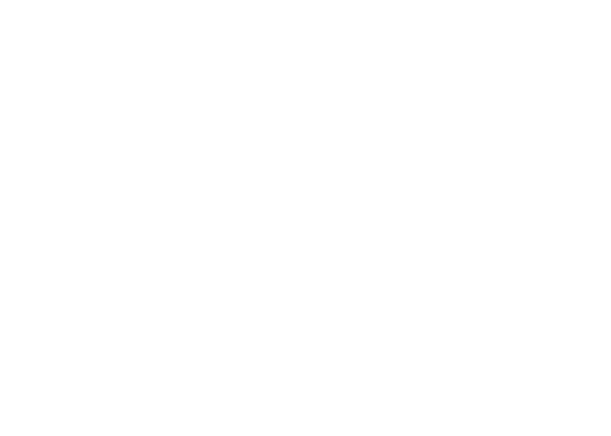

The year

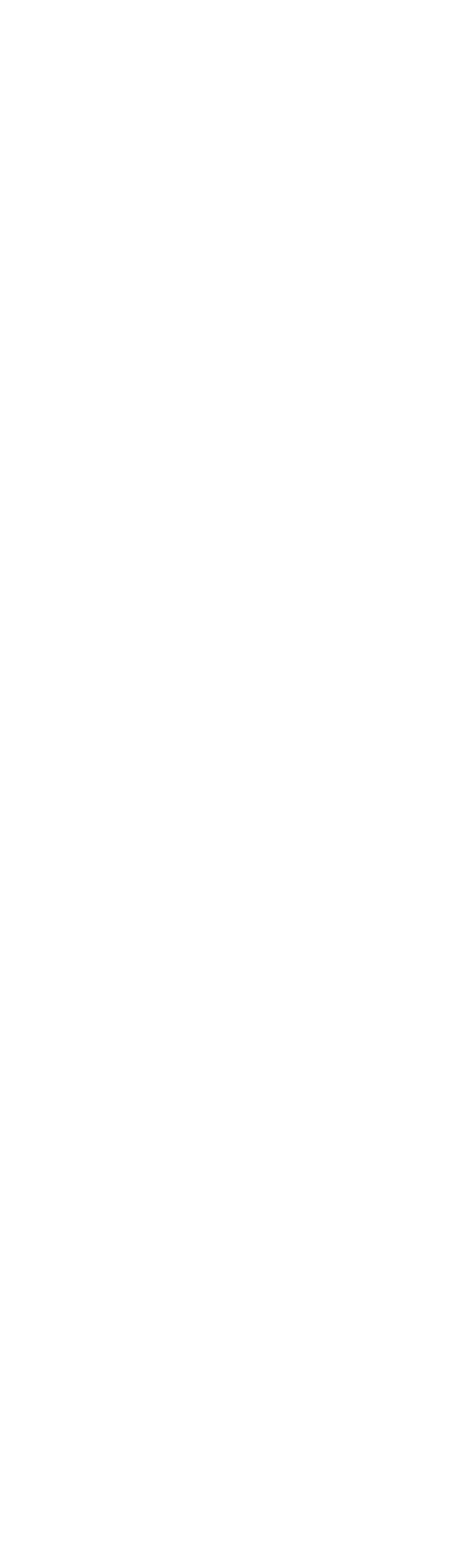

The year.

\section{6-17}

October........

December

January

Februar

A pril.

May

June.

Angust

September

The year.

$1917-18$

October

November

January.

Tarch

A pril.

May

Juny

Jugust

September

The year.

1918-19

October

November

December

January.

March.

April-

May -

July.

August.

September

The year.

October.
November
December
January-2919-20
February
March
April
May
June
July
August
September

- Estimated by comparison with flow of East and Taylor Rivers at Almont. 
Monthly discharge of Gunnison River near Gunnison, Colo., for 1910-1914 and 1915-1987-Continued

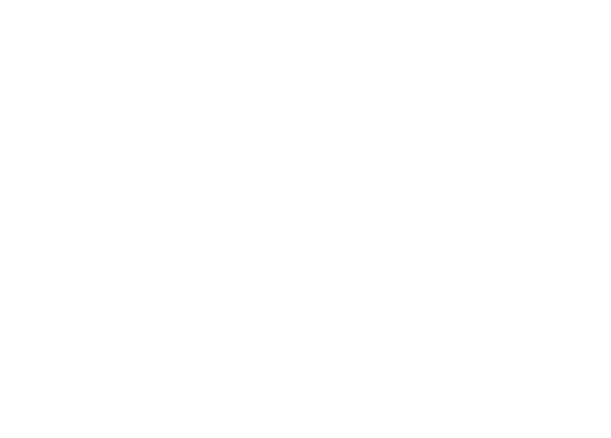

The year.

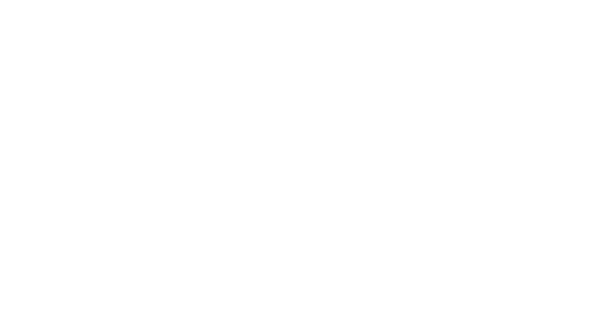

October.

November.

December

January-

March

April.

May

June

August

September.

The year

1922-23

October.

November

December

Jappary

February

March

April

May-

July

August

September

The year

October-1924-25
November
December
January
February
March
April
May
June
July
August
September

The year

\begin{tabular}{|c|c|c|c|}
\hline \multicolumn{3}{|c|}{ Discharge in second-feet } & \multirow{2}{*}{$\begin{array}{l}\text { Run-off in } \\
\text { acre-foet }\end{array}$} \\
\hline Maximum & Minimum & Mean & \\
\hline $\begin{array}{r}393 \\
356 \\
284 \\
\ldots-0 \\
340 \\
740 \\
4,050 \\
6,380 \\
2,440 \\
1,100 \\
1,050\end{array}$ & $\begin{array}{r}330 \\
275 \\
165 \\
\ldots \\
310 \\
790 \\
2,600 \\
890 \\
570 \\
322\end{array}$ & $\begin{array}{r}344 \\
315 \\
227 \\
233 \\
213 \\
269 \\
421 \\
2,040 \\
4,130 \\
1,500 \\
784 \\
518\end{array}$ & $\begin{array}{r}21,200 \\
18,700 \\
14,000 \\
14,300 \\
11,800 \\
16,500 \\
25,100 \\
125,000 \\
246,000 \\
92,200 \\
48,200 \\
30,800\end{array}$ \\
\hline 6,380 & - & 918 & 664,000 \\
\hline $\begin{array}{r}1,200 \\
4,780 \\
4,350 \\
1,820 \\
740 \\
425\end{array}$ & $\begin{array}{r}300 \\
1,870 \\
1,820 \\
460 \\
360 \\
208\end{array}$ & $\begin{array}{r}332 \\
283 \\
238 \\
268 \\
304 \\
250 \\
494 \\
2,760 \\
3,020 \\
889 \\
508 \\
287\end{array}$ & $\begin{array}{r}28,400 \\
16,800 \\
14,600 \\
16,500 \\
16,900 \\
15,400 \\
29,400 \\
170,000 \\
180,000 \\
54,700 \\
31,200 \\
17,100\end{array}$ \\
\hline 4,780 & .....- & 805 & 583,000 \\
\hline $\begin{array}{r}349 \\
995 \\
4,930 \\
4,870 \\
3,190 \\
1,330 \\
731\end{array}$ & \begin{tabular}{r}
181 \\
167 \\
$\cdots$ \\
\\
\hdashline 250 \\
984 \\
2,970 \\
930 \\
713 \\
467
\end{tabular} & $\begin{array}{r}189 \\
214 \\
171 \\
169 \\
179 \\
202 \\
468 \\
2,850 \\
3,880 \\
2,170 \\
1,050 \\
608\end{array}$ & $\begin{array}{r}11,600 \\
12,700 \\
10,500 \\
10,400 \\
9,940 \\
12,400 \\
27,800 \\
175,000 \\
231,000 \\
133,000 \\
64,600 \\
36,200\end{array}$ \\
\hline 4,930 & - & 1,020 & 735,000 \\
\hline \begin{tabular}{r}
610 \\
460 \\
285 \\
\hdashline$-:$ \\
1,876 \\
1,870 \\
4,270 \\
1,400 \\
425 \\
270
\end{tabular} & $\begin{array}{r}285 \\
1,310 \\
1,580 \\
392 \\
241 \\
193\end{array}$ & $\begin{array}{r}514 \\
330 \\
231 \\
230 \\
225 \\
223 \\
880 \\
2,260 \\
2,720 \\
790 \\
329 \\
221\end{array}$ & $\begin{array}{r}31,600 \\
19,600 \\
14,200 \\
14,100 \\
12,900 \\
13,700 \\
52,400 \\
139,000 \\
162,000 \\
48,600 \\
20,200 \\
13,200\end{array}$ \\
\hline 4,270 & 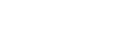 & 745 & 542,000 \\
\hline $\begin{array}{r}482 \\
1,580 \\
2,460 \\
2,350 \\
1,130 \\
935 \\
639\end{array}$ & $\begin{array}{r}360 \\
1,260 \\
1,020 \\
582 \\
498 \\
286\end{array}$ & $\begin{array}{r}328 \\
324 \\
227 \\
209 \\
187 \\
279 \\
895 \\
\mathbf{1}, 720 \\
1,570 \\
818 \\
577 \\
451\end{array}$ & $\begin{array}{r}20,200 \\
19,300 \\
14,000 \\
12,900 \\
10,400 \\
17,200 \\
53,300 \\
106,000 \\
93,400 \\
50,300 \\
35,500 \\
26,800\end{array}$ \\
\hline 2,460 & (n) & 633 & 459,000 \\
\hline
\end{tabular}


Monthly discharge of Gunnison River near Gunnison, Colo., for 1910-191't and 1915-1927-Continued

\begin{tabular}{|c|c|c|c|c|}
\hline \multirow{2}{*}{ Month } & \multicolumn{3}{|c|}{ Discharge in secend-feet } & \multirow{2}{*}{$\begin{array}{l}\text { Run-off in } \\
\text { acre-feet }\end{array}$} \\
\hline & Maximum & Minimum & Mean & \\
\hline $\begin{array}{l}\text { October } \\
\text { November } \\
\text { December } \\
\text { January } \\
\text { February } \\
\text { March } \\
\text { April } \\
\text { May } \\
\text { June } \\
\text { July } \\
\text { August } \\
\text { September }\end{array}$ & $\begin{array}{r}435 \\
378 \\
1,560 \\
2,980 \\
3,530 \\
1,430 \\
709 \\
455\end{array}$ & \begin{tabular}{|r}
277 \\
153 \\
206 \\
770 \\
1,100 \\
442 \\
263 \\
244
\end{tabular} & $\begin{array}{r}385 \\
289 \\
207 \\
166 \\
194 \\
209 \\
685 \\
1,750 \\
2,200 \\
865 \\
448 \\
306\end{array}$ & $\begin{array}{r}23,700 \\
17,200 \\
12,700 \\
10,200 \\
10,800 \\
12,900 \\
40,800 \\
.108,000 \\
131,000 \\
53,200 \\
27,500 \\
18,200\end{array}$ \\
\hline The year... & 3,530 & 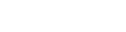 & 643 & 466,000 \\
\hline $\begin{array}{l}\text { October } \\
\text { November } \\
\text { December } \\
\text { January } \\
\text { February } \\
\text { March } \\
\text { April } \\
\text { May } \\
\text { June } \\
\text { July } \\
\text { August } \\
\text { September }\end{array}$ & $\begin{array}{r}382 \\
335 \\
320 \\
320 \\
2,020 \\
4,800 \\
3,990 \\
2,780 \\
1,460 \\
1,160\end{array}$ & $\begin{array}{r}257 \\
229 \\
\\
1,600 \\
2,720 \\
930 \\
555 \\
455\end{array}$ & $\begin{array}{r}313 \\
291 \\
237 \\
223 \\
210 \\
213 \\
621 \\
2,140 \\
3,100 \\
1,570 \\
836 \\
664\end{array}$ & $\begin{array}{r}19,200 \\
17,300 \\
14,600 \\
13,700 \\
11,700 \\
13,100 \\
37,000 \\
193,000 \\
190,000 \\
98,500 \\
51,400 \\
39,500\end{array}$ \\
\hline The year..... & 4,800 & $\ldots$ & 963 & 697,000 \\
\hline
\end{tabular}

NoTE.-Monthly mean discharge during winter based on gage heights, current-meter measurements, and temperature records.

GUNFISON RIVER AT IOLA, COLO.

Location.-In sec. 28, R. 2 W., R. 49 S., at highway bridge at Iola, Gunnison

County. Nearest tributary, Willow Creek, enters from north, 1 mile downstream.

Drainage AREa. - 2,360 square miles (measured on base map of Colorado).

Records available.-October 1, 1899, to December 31, 1903.

GAGE.-Vertical staff.

ConTrox.-Practically permanent.

Extremes of Discharge.-Maximum stage recorded, 6.0 feet on June 18, 1903 (discharge, 6,130 second-feet); minimum discharge occurred during winter.

Diversions.-Practically no diversion from Gunnison River between Gunnison and Iola stations.

Accuracy.-Gage read once daily. Rating curve not well defined. Records fair. 
Monthly discharge of Ginnison River at Iola, Colo., for 1899-1903

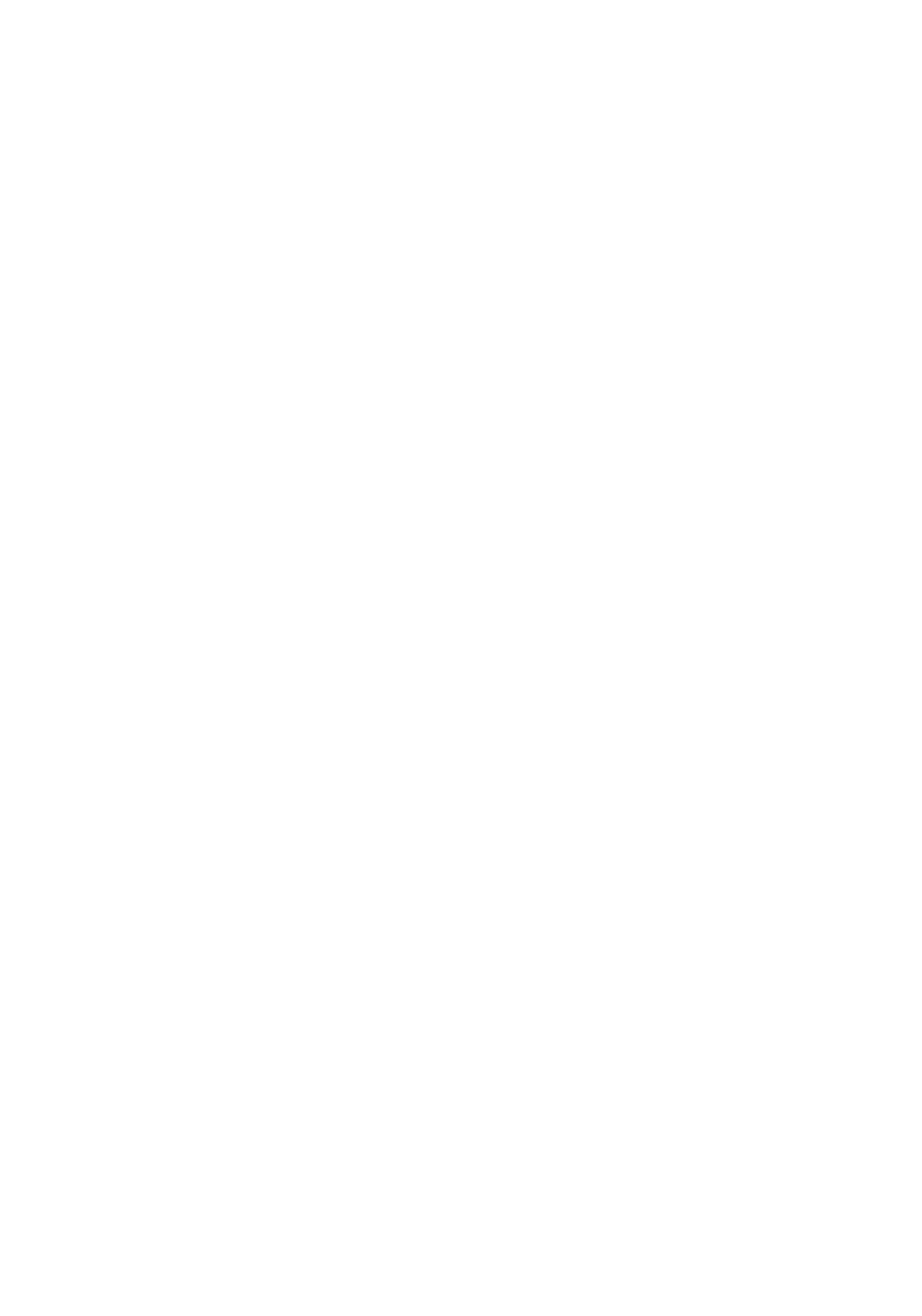

a Estimated.

Nore.-Monthly mean discharge during winter based on normal winter flow at Gunnison station, an allowance being made for discharge of intervening tributaries. 
GUNNISON RIVER ITAR CIMARRON, COLO.

Location.-In sec. 3, T. 48 N., R. 6. W., 1,000 feet above mouth of Cimarron

River and 1 mile northeast of Cimarron, Montrose County.

Drainage area. - 3,650 square miles (measured on base map of Colorado).

Records available.-September 19, 1903, to December 17, 1905.

GAGE.-Chain on railroad bridge.

Control.-Practically permanent.

Extremes of DISCHARGI.-Maximum stage recorded, 17.9 feet on June 5, 1905

(discharge, 13,600 second-feet); minimum stage occurred during winter.

Diversions.- None between Iola and Cimarron stations.

Accuracy.-Gage read twice daily. Rating curves well defined below 7,000 second-feet. Records good.

Monthly discharge of Gunnison River near Cimarron, Colo., for 1908-1905

\begin{tabular}{|c|c|c|c|c|}
\hline \multirow{2}{*}{ Month } & \multicolumn{3}{|c|}{ Discharge in second-feet } & \multirow{2}{*}{$\begin{array}{l}\text { Ran-off in } \\
\text { acre-feet }\end{array}$} \\
\hline & Maximum & Minimum & Mean & \\
\hline September 19-30......... & 802 & 605 & 869 & 15,900 \\
\hline $\begin{array}{l}\text { October. } \\
\text { November } \\
\text { December. } \\
\text { January } \\
\text { February } \\
\text { March } \\
\text { April } \\
\text { May } \\
\text { June } \\
\text { July } \\
\text { August } \\
\text { September }\end{array}$ & \begin{tabular}{|r|}
652 \\
583 \\
432 \\
\\
565 \\
$\mathbf{5 6 0}$ \\
6,750 \\
4,130 \\
1,700 \\
1,520 \\
1,520 \\
\end{tabular} & \begin{tabular}{|r|}
$\mathbf{4 4 8}$ \\
$\mathbf{3 8 3}$ \\
$\mathbf{3 2 2}$ \\
\hdashline-910 \\
$\mathbf{4 3 0}$ \\
$1, \mathbf{3 7 0}$ \\
$\mathbf{1 , 9 0 0}$ \\
$\mathbf{6 7 0}$ \\
$\mathbf{9 1 0}$ \\
$\mathbf{5 8 0}$ \\
\end{tabular} & $\begin{array}{r}583 \\
451 \\
363 \\
3350 \\
e 380 \\
\quad 380 \\
484 \\
1,370 \\
3,470 \\
2,890 \\
995 \\
1,150 \\
805\end{array}$ & $\begin{array}{r}35,800 \\
28,800 \\
22,300 \\
21,500 \\
21,900 \\
29,800 \\
81,400 \\
213,000 \\
172,000 \\
61,200 \\
70,500 \\
47,900\end{array}$ \\
\hline The year. & 6,750 & - & 1,110 & 804,000 \\
\hline $\begin{array}{l}\text { October } \\
\text { November- } \\
\text { December } \\
\text { January } \\
\text { February } \\
\text { March } \\
\text { April } \\
\text { May } \\
\text { June } \\
\text { July } \\
\text { August } \\
\text { September }\end{array}$ & \begin{tabular}{|r|}
, 430 \\
640 \\
$\mathbf{8 5 5}$ \\
$\mathbf{3}, 820$ \\
9,820 \\
13,600 \\
3,720 \\
2,720 \\
688
\end{tabular} & \begin{tabular}{r}
625 \\
330 \\
\hdashline \\
\hdashline 500 \\
2,180 \\
4,480 \\
1,240 \\
625 \\
500 \\
\end{tabular} & $\begin{array}{r}951 \\
437 \\
-300 \\
2290 \\
-300 \\
625 \\
1,120 \\
\mathbf{5}, 510 \\
\mathbf{8}, 870 \\
1,860 \\
1,100 \\
576\end{array}$ & $\begin{array}{r}58,500 \\
26,000 \\
18,400 \\
17,800 \\
16,700 \\
38,400 \\
66,600 \\
339,000 \\
528,000 \\
114,000 \\
67,600 \\
34,300\end{array}$ \\
\hline The year......... & 13,600 & -........... & 1,840 & $1,330,000$ \\
\hline $\begin{array}{l}\text { October } \\
\text { November } \\
\text { December } 1-177\end{array}$ & $\begin{array}{l}740 \\
595 \\
500\end{array}$ & $\begin{array}{l}462 \\
330 \\
310\end{array}$ & $\begin{array}{l}540 \\
472 \\
424\end{array}$ & $\begin{array}{l}33,200 \\
28,100 \\
14,300\end{array}$ \\
\hline
\end{tabular}

a Estimated.

GUNNISON RIVER AT EAST PORTAL OF GUNIISON TUNNEL, COLO.

Location.--In sec. 10, T. 49 N., R. 7 W. New Mexico principal meridian, 300 feet above east portal of Gunnison Tunnel of Bureau of Reclamation. Nearest tributary, Crystal Creek, enters 5 miles upstream.

Drainage area.-3,980 square miles (measured on base map of Colorado).

Records available.-April 9, 1905, to September 30, 1927. (Beginning with 1912 the records were affected by diversions through the tunnel and for that reason are not published in this report.) 
GAGE.-Vertical staff.

ConTrou.-Slightly shifting.

EXTREMEs of DIscharge.-Maximum discharge probably occurred during June, 1909 , for which no record is available. Minimum discharge occurred during winter, for which no records are available.

Drversions.-None between Cimarron and East Portal stations.

Cooperation.-Complete records furnished by Bureau of Reclamation.

Monthly discharge of Gunnison River at east portal of Gunnison Tunnel, Colo., for 1905-1911

\begin{tabular}{|c|c|c|c|c|}
\hline \multirow{2}{*}{ Month } & \multicolumn{3}{|c|}{ Discharge in second-feet } & \multirow{2}{*}{$\begin{array}{l}\text { Run-off in } \\
\text { acre-feet }\end{array}$} \\
\hline & Maximum & Minimum & Mean & \\
\hline $\begin{array}{l}\text { April } 9-\mathbf{3 0} \\
\text { May } \\
\text { June } \\
\text { July } \\
\text { August } \\
\text { September }\end{array}$ & $\begin{array}{r}3,320 \\
9,040 \\
13,800 \\
3,800 \\
2,760 \\
745 \\
\end{array}$ & $\begin{array}{r}950 \\
2,490 \\
4,200 \\
1,440 \\
680 \\
450\end{array}$ & $\begin{array}{l}1,430 \\
5,220 \\
8,360 \\
2,040 \\
1,130 \\
560\end{array}$ & $\begin{array}{r}62,400 \\
321,000 \\
497,000 \\
125,000 \\
69,500 \\
33,300\end{array}$ \\
\hline The period.-. & (n........... & (-1, & (n) & $1,110,000$ \\
\hline $\begin{array}{l}\text { Oatober } \\
\text { November } \\
\text { December } \\
\text { January } \\
\text { February } \\
\text { March } \\
\text { April } \\
\text { May } \\
\text { June } \\
\text { July } \\
\text { August } \\
\text { September }\end{array}$ & \begin{tabular}{|r|}
712 \\
560 \\
1,360 \\
4,500 \\
10,000 \\
14,700 \\
5,370 \\
2,180 \\
1,880 \\
\end{tabular} & $\begin{array}{r}450 \\
400 \\
\\
\\
1,360 \\
2,590 \\
5,540 \\
2,340 \\
930 \\
660\end{array}$ & $\begin{array}{r}519 \\
491 \\
475 \\
465 \\
460 \\
750 \\
2,270 \\
6,620 \\
8,830 \\
3,510 \\
1,470 \\
1,060\end{array}$ & $\begin{array}{r}31,000 \\
29,200 \\
29,200 \\
28,600 \\
25,500 \\
46,100 \\
135,000 \\
407,000 \\
525,000 \\
216,000 \\
90,400 \\
63,100\end{array}$ \\
\hline The year. & 10,000 & (n) & 1,180 & $1,630,000$ \\
\hline $\begin{array}{l}\text { Oetober.... } \\
\text { November- } \\
\text { December } \\
\text { January } \\
\text { February } \\
\text { March } \\
\text { April } \\
\text { May } \\
\text { June } \\
\text { July } \\
\text { August } \\
\text { September }\end{array}$ & $\begin{array}{r}1,320 \\
860 \\
2,080 \\
4,720 \\
10,200 \\
12,700 \\
12,400 \\
3,640 \\
1,860 \\
\end{array}$ & $\begin{array}{r}595 \\
380 \\
1,090 \\
2,120 \\
4,540 \\
3,250 \\
1,600 \\
1,020\end{array}$ & $\begin{array}{r}905 \\
620 \\
475 \\
470 \\
460 \\
990 \\
2,500 \\
4,400 \\
10,500 \\
6,620 \\
2,400 \\
1,310\end{array}$ & $\begin{array}{r}55,600 \\
36,900 \\
29,200 \\
28,900 \\
25,500 \\
60,900 \\
149,000 \\
271,000 \\
625,000 \\
407,000 \\
148,000 \\
78,000\end{array}$ \\
\hline The year.... & 12,700 & (n) & 1,400 & $1,920,000$ \\
\hline $\begin{array}{l}\text { October-1907-8 } \\
\text { November } \\
\text { December } \\
\text { January } \\
\text { Febraary } \\
\text { March } \\
\text { April } \\
\text { May } \\
\text { June } \\
\text { July } \\
\text { Angust } \\
\text { September }\end{array}$ & \begin{tabular}{r}
1,240 \\
880 \\
\hdashline \\
\hdashline $\mathbf{3}, 030$ \\
$\mathbf{3}, \mathbf{0 8 0}$ \\
$\mathbf{6}, \mathbf{8 3 0}$ \\
$\mathbf{3}, \mathbf{5 8 0}$ \\
$\mathbf{2}, \mathbf{5 4 0}$ \\
$\mathbf{9 5 0}$
\end{tabular} & $\begin{array}{r}810 \\
1,860 \\
3,420 \\
1,280 \\
950 \\
630\end{array}$ & $\begin{array}{r}986 \\
640 \\
450 \\
450 \\
450 \\
700 \\
1,940 \\
2,690 \\
4,880 \\
2,170 \\
1,630 \\
698\end{array}$ & $\begin{array}{r}60,600 \\
38,100 \\
29,700 \\
29,700 \\
25,900 \\
43,000 \\
115,000 \\
165,000 \\
290,000 \\
133,000 \\
100,000 \\
41,500\end{array}$ \\
\hline The year. & 6,830 & 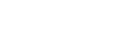 & 779 & $1,070,000$ \\
\hline
\end{tabular}


Monthly discharge of Gunnison River at east portal of Gunnison Tunnel, Colo., for 1905-1911-Continued

\begin{tabular}{|c|c|c|c|c|}
\hline \multirow{2}{*}{ Month } & \multicolumn{3}{|c|}{ Discharge in second-feet } & \multirow{2}{*}{ Run-off in $_{\text {acre-feet }}$} \\
\hline & Maximum & Minimum & Mean & \\
\hline $\begin{array}{l}\text { October } \\
\text { November } \\
\text { December } \\
\text { January } \\
\text { February } \\
\text { March } \\
\text { April } \\
\text { May } \\
\text { June } \\
\text { July } \\
\text { Auguist } \\
\text { September }\end{array}$ & $\begin{array}{r}3,790 \\
10,200\end{array}$ & $\begin{array}{r}575 \\
2,300 \\
865 \\
1,560 \\
\end{array}$ & $\begin{array}{r}634 \\
510 \\
475 \\
460 \\
450 \\
750 \\
1,950 \\
7,160 \\
10,800 \\
5,470 \\
1,880 \\
2,600\end{array}$ & $\begin{array}{r}39,000 \\
30,300 \\
29,700 \\
28,300 \\
25,000 \\
46,100 \\
116,000 \\
440,000 \\
643,000 \\
336,000 \\
116,000 \\
155,000\end{array}$ \\
\hline The year.-. & $\ldots$ & |- & 1,450 & $2,000,000$ \\
\hline $\begin{array}{l}\text { October- } \\
\text { November } \\
\text { December } \\
\text { January } \\
\text { February } \\
\text { March } \\
\text { April } \\
\text { May }\end{array}$ & $\begin{array}{r}4,180 \\
8,410 \\
9,980 \\
9,900 \\
2,300 \\
1,560 \\
925\end{array}$ & $\begin{array}{r}785 \\
\\
1,740 \\
4,050 \\
2,460 \\
838 \\
710 \\
580\end{array}$ & $\begin{array}{r}1,270 \\
610 \\
470 \\
460 \\
460 \\
1,730 \\
3,700 \\
6,290 \\
5,340 \\
1,400 \\
1,050 \\
678\end{array}$ & $\begin{array}{r}78,100 \\
36,300 \\
28,000 \\
28,300 \\
25,500 \\
106,000 \\
220,000 \\
387,000 \\
318,000 \\
86,100 \\
64,600 \\
40,300\end{array}$ \\
\hline The year.. & 9,980 & 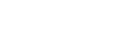 & 1,030 & $1,420,000$ \\
\hline $\begin{array}{l}\text { October } \\
\text { November } \\
\text { December } \\
\text { January } \\
\text { February } \\
\text { March } \\
\text { April } \\
\text { May } \\
\text { June } \\
\text { July } \\
\text { August } \\
\text { September }\end{array}$ & $\begin{array}{r}5,240 \\
9,280 \\
11,200 \\
7,360 \\
2,420 \\
1,470\end{array}$ & $\begin{array}{rr} & 505 \\
& \\
& \\
1,040 \\
3,120 \\
5,080 \\
2,640 \\
1,180 \\
925\end{array}$ & $\begin{array}{r}610 \\
550 \\
480 \\
470 \\
460 \\
700 \\
2,310 \\
6,520 \\
8,750 \\
4,480 \\
1,670 \\
1,090\end{array}$ & $\begin{array}{r}37,500 \\
32,700 \\
29,500 \\
28,900 \\
25,500 \\
43,000 \\
137,000 \\
401,000 \\
521,000 \\
275,000 \\
103,000 \\
64,900\end{array}$ \\
\hline The year....... & 11,200 & $-\cdots$ & 1,240 & $1,700,000$ \\
\hline
\end{tabular}

Noт1-Mean discharge estimated for winter. Mean discharge estimated by comparison with discharge of Roaring Fork, June to August, 1909.

GUNMSON RIVER NEAR CORY, COLO.

Location.-In sec. 3, T. 15 S., R. $95 \mathrm{~W}$., at highway bridge $1 \frac{1}{2}$ miles south of Cory, Delta County. Nearest tributary, Surface Creek, enters 1 mile downstream.

Dratnagt. - 5,410 square miles (measured on base map of Colorado).

Records available.-May 1, 1903, to December 21, 1905.

GAGE.-Chain.

ConTrol.-Practically permanent.

Extremes of DIscharge.-Maximum stage recorded, 13.2 feet at 7 a. $\mathrm{m}$. June

5, 1905 (discharge, 23,200 second-feet); minimum stage, 5.0 feet at 7 a. m.

December 29, 1904 (discharge, 300 second-feet).

IcE.-Stage-discharge relation unaffected by ice except for short periods.

Diversions.- None between East Portal and Cory stations during period covered by these records.

Accuracy.-Gage read twice daily. Rating curves well defined. Records good. 
Monthly discharge of Gunnison River near Cory, Colo., for 1908-1905

\begin{tabular}{|c|c|c|c|c|}
\hline \multirow{2}{*}{ Month } & \multicolumn{3}{|c|}{ Discharge in second-feet } & \multirow{2}{*}{$\underset{\text { acre-feet }}{\text { Run-off in }}$} \\
\hline & Maximum & Minimum & Mean & \\
\hline $\begin{array}{l}\text { May. } \\
\text { June } \\
\text { July } \\
\text { July } \\
\text { August, } \\
\text { September }\end{array}$ & $\begin{array}{r}14,400 \\
18,700 \\
7,600 \\
1,560 \\
1,910\end{array}$ & $\begin{array}{r}3,830 \\
8,770 \\
1,680 \\
880 \\
800\end{array}$ & $\begin{array}{r}7,550 \\
12,900 \\
3,770 \\
1,060 \\
1,060\end{array}$ & $\begin{array}{r}464,000 \\
768,000 \\
282,000 \\
65,200 \\
63,100\end{array}$ \\
\hline . The period...... & 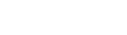 & 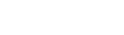 & ........... & $1,590,000$ \\
\hline 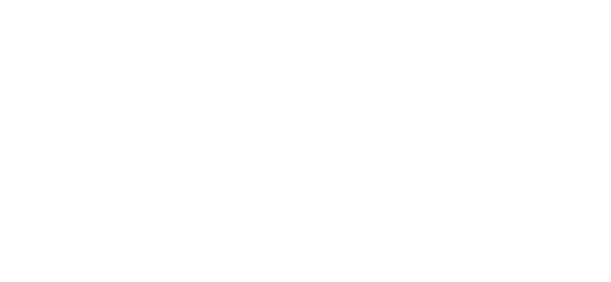 & $\begin{array}{r}880 \\
840 \\
765 \\
580 \\
620 \\
880 \\
5,260 \\
10,500 \\
7,160 \\
2,460 \\
1,650 \\
2,160\end{array}$ & $\begin{array}{r}660 \\
515 \\
450 \\
500 \\
500 \\
540 \\
700 \\
2,780 \\
2,530 \\
835 \\
970 \\
790\end{array}$ & $\begin{array}{r}765 \\
723 \\
609 \\
534 \\
568 \\
658 \\
2,420 \\
5,900 \\
4,590 \\
1,290 \\
1,320 \\
1,080\end{array}$ & $\begin{array}{r}47,000 \\
43,000 \\
37,400 \\
32,800 \\
32,700 \\
40,500 \\
144,000 \\
363,000 \\
273,000 \\
79,300 \\
81,200 \\
64,300\end{array}$ \\
\hline The year........ & 10,500 & 450 & 1,710 & $1,240,000$ \\
\hline $\begin{array}{l}\text { October. } \\
\text { Nowember } \\
\text { December } \\
\text { January } \\
\text { February } \\
\text { March. } \\
\text { April } \\
\text { May } \\
\text { June } \\
\text { July } \\
\text { August } \\
\text { September }\end{array}$ & $\begin{array}{r}1,930 \\
835 \\
580 \\
590 \\
590 \\
1,290 \\
6,740 \\
19,200 \\
23,200 \\
5,420 \\
3,070 \\
945\end{array}$ & $\begin{array}{r}835 \\
440 \\
310 \\
455 \\
530 \\
660 \\
900 \\
4,310 \\
5,790 \\
1,750 \\
730 \\
730\end{array}$ & $\begin{array}{r}1,250 \\
578 \\
422 \\
503 \\
563 \\
1,010 \\
2,250 \\
10,300 \\
14,100 \\
2,640 \\
1,310 \\
775\end{array}$ & $\begin{array}{r}76,900 \\
34,400 \\
26,000 \\
30,900 \\
31,300 \\
62,100 \\
134,000 \\
633,000 \\
839,000 \\
162,000 \\
80,600 \\
46,100\end{array}$ \\
\hline The year................. & 23,200 & 310 & 2,980 & $2,160,000$ \\
\hline $\begin{array}{l}\text { October } 1905 \\
\text { November } \\
\text { December } 1-21\end{array}$ & $\begin{array}{l}810 \\
770 \\
560\end{array}$ & $\begin{array}{l}660 \\
560 \\
480\end{array}$ & $\begin{array}{l}744 \\
645 \\
517\end{array}$ & $\begin{array}{l}45,800 \\
38,400 \\
21,500\end{array}$ \\
\hline
\end{tabular}

GUNNISON RIVER NEAR GRANI JUNCTION, COLO.

Location.-In sec. 35, T. 1 S., R. 1 W., half a mile below the Redlands Co.'s canal and 2 miles above mouth, in Grand Junction, Mesa County.

Drainage area. - 8,020 square miles (measured on base map of Colorado).

Records avatlable.-October 1, 1896, to September 30, 1899; October 1, 1901, to. October 31, 1906; October 1, 1916, to September 30, 1927.

GAGE.-From 1897 to 1899 vertical staff on highway bridge 1 mile downstream; 1902 to 1906 chain at Whitewater 12 miles upstream; 1917. to 1926, vertical staff at site described above. Flow at different points comparable.

Conmrol.-At original site within influence of backwater from Colorado River during extreme high water; slightly shifting at other sites.

Extremes of discharqe.-Maximum stage recorded during period, 14.95 feet at 8 a. m. and noon May 23, 1920 (discharge, 35,700 second-feet); minimum discharge recorded, 155 second-feet September 6, 1924.

Diversions.- Water diverted for irrigation of 270,000 acres from Gunnison River and tributaries.

Combined FLow.-Combined flow of Gunnison River and Redlands power canal represents flow of Gunnison River entering Colorado River, less about 25 second-feet, which is used during irrigation season. 
ACCURACY.-1917-1926; gage read twice daily; rating curves well defined; records good, except during winter, for which they are fair. Records from 1897 to 1906 not better than fair.

Cooperation.- Station maintained in cooperation with State engineer and Redlands Irrigation Co.

Monthly discharge of Gunnison River near Grand Junction, Colo., for 1896-1899, 1901-1906, and 1916-1927

\begin{tabular}{|c|c|c|c|c|}
\hline \multirow{2}{*}{ Month } & \multicolumn{3}{|c|}{ Discharge in second-feet } & \multirow{2}{*}{$\begin{array}{l}\text { Run-off in } \\
\text { acre-feet }\end{array}$} \\
\hline & Maximum & Minimum & Mean & \\
\hline $\begin{array}{l}\text { October } \\
\text { November } \\
\text { December } \\
\text { January } \\
\text { February } \\
\text { March } \\
\text { April } \\
\text { May } \\
\text { June } \\
\text { July } \\
\text { August } \\
\text { September }\end{array}$ & $\begin{array}{r}20,700 \\
19,100 \\
5,370 \\
1,850 \\
1,510\end{array}$ & $\begin{array}{r}10,000 \\
5,370 \\
1,510 \\
325 \\
325\end{array}$ & $\begin{array}{r}a 1,100 \\
\text { a } 1,050 \\
\text { a } 1,000 \\
a \\
950 \\
a 900 \\
\text { a } 1,200 \\
a 6,000 \\
16,700 \\
11,200 \\
3,230 \\
1,030 \\
712\end{array}$ & $\begin{array}{r}67,600 \\
62,500 \\
61,500 \\
58,400 \\
50,000 \\
73,800 \\
357,000 \\
1,030,000 \\
664,000 \\
199,000 \\
63,300 \\
42,700\end{array}$ \\
\hline The year. & 20,700 & 325 & 3,770 & $2,730,000$ \\
\hline $\begin{array}{l}\text { October } \\
\text { November } \\
\text { December } \\
\text { January } \\
\text { February } \\
\text { March } \\
\text { April } \\
\text { May } \\
\text { June } \\
\text { August } \\
\text { September }\end{array}$ & $\begin{array}{r}\mathbf{9}, 000 \\
11,400 \\
3,960 \\
\mathbf{9 6 8} \\
\mathbf{5 7 8}\end{array}$ & $\begin{array}{r}3,960 \\
4,160 \\
1,080 \\
578 \\
399\end{array}$ & $\begin{array}{r}1,470 \\
963 \\
a 850 \\
a 800 \\
a 750 \\
\times 1,200 \\
a 2,500 \\
5,320 \\
8,850 \\
2,540 \\
689 \\
479\end{array}$ & $\begin{array}{r}90,500 \\
57,300 \\
52,300 \\
49,200 \\
41,700 \\
73,800 \\
149,000 \\
327,000 \\
527,000 \\
156,000 \\
42,400 \\
28,500\end{array}$ \\
\hline The year. & 11,400 & 395 & 2,190 & $1,590,000$ \\
\hline $\begin{array}{l}\text { October } \\
\text { November } \\
\text { December } \\
\text { January } \\
\text { February } \\
\text { March } \\
\text { April }\end{array}$ & $\begin{array}{r}8,790 \\
15,700 \\
14,700 \\
7,410 \\
4,560 \\
1,000\end{array}$ & $\begin{array}{r}968 \\
3,900 \\
7,740 \\
2,250 \\
908 \\
758\end{array}$ & $\begin{array}{r}533 \\
497 \\
-500 \\
\therefore 500 \\
a 500 \\
\therefore 800 \\
3,550 \\
9,670 \\
10,800 \\
4,170 \\
1,920 \\
875\end{array}$ & $\begin{array}{r}32,800 \\
29,600 \\
30,700 \\
30,700 \\
87,800 \\
49,200 \\
211,000 \\
595,000 \\
643,000 \\
256,000 \\
118,000 \\
52,100\end{array}$ \\
\hline The year.- & 15,700 & 314 & 2,870 & $2,080,000$ \\
\hline $\begin{array}{l}\text { October } \\
\text { November } \\
\text { December } \\
\text { January } \\
\text { February- } \\
\text { March } \\
\text { April } \\
\text { May } \\
\text { June } \\
\text { July } \\
\text { August } \\
\text { September }\end{array}$ & $\begin{array}{r}3,790 \\
8,350 \\
5,920 \\
1,000 \\
1,170 \\
1,460\end{array}$ & $\begin{array}{r}860 \\
2,580 \\
623 \\
383 \\
341 \\
427\end{array}$ & $\begin{array}{r}\because 1,000 \\
\therefore 1,000 \\
; 950 \\
\quad 900 \\
a 900 \\
2850 \\
2,080 \\
5,930 \\
2,970 \\
570 \\
610 \\
667\end{array}$ & $\begin{array}{r}61,500 \\
59,500 \\
58,400 \\
55,300 \\
50,000 \\
52,300 \\
124,000 \\
365,000 \\
177,000 \\
35,000 \\
37,500 \\
39,700\end{array}$ \\
\hline he & 8,350 & 341 & 1,550 & $1,120,000$ \\
\hline
\end{tabular}

- Estimated. 
Monthly discharge of Gunnison River near Grand Junction, Colo., for 1896-1899, 1901-1906, and 1916-1927-Continued

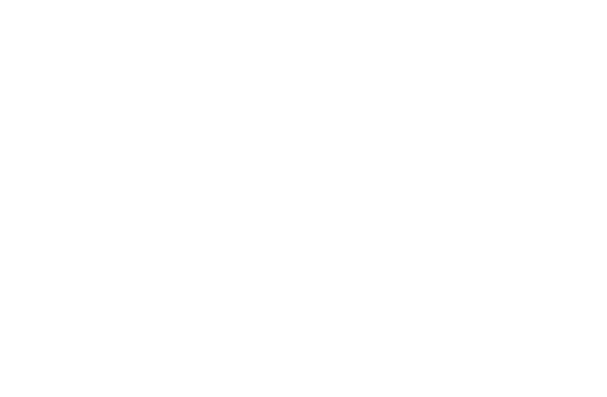

The year.

$1903-4$

October-.--

Discharge in second-feet

I

December

January.

February

March

May-

June-

July.-.

September

\section{The year.}

\section{4-5}

October
November
December
January
February
March A
Mpril
Muy
June
Jugu
September

\begin{tabular}{|c|c|c|c|}
\hline \multicolumn{3}{|c|}{ Discharge in second-feet } & \multirow{2}{*}{$\begin{array}{l}\text { Run-off in } \\
\text { acre-feet }\end{array}$} \\
\hline Maximum & Minimum & Mean & \\
\hline $\begin{array}{r}5,790 \\
14,000 \\
17,800 \\
8,770 \\
4,470 \\
2,130\end{array}$ & $\begin{array}{r}670 \\
5,040 \\
8,770 \\
3,860 \\
740 \\
740\end{array}$ & $\begin{array}{r}504 \\
\quad 500 \\
\Rightarrow 500 \\
\Rightarrow 500 \\
\Rightarrow 500 \\
\Rightarrow 500 \\
2,260 \\
8,160 \\
12,500 \\
5,130 \\
1,310 \\
1,280\end{array}$ & $\begin{array}{r}31,000 \\
29,800 \\
30,700 \\
30,700 \\
27,800 \\
30,700 \\
135,000 \\
502,000 \\
746,000 \\
316,000 \\
80,700 \\
76,400\end{array}$ \\
\hline 17,800 & 383 & 2,820 & $2,040,000$ \\
\hline $\begin{array}{r}1,130 \\
1,210 \\
890 \\
1,000 \\
1,050 \\
920 \\
4,600 \\
8,630 \\
6,880 \\
3,220 \\
2,640 \\
3,140\end{array}$ & $\begin{array}{r}740 \\
635 \\
670 \\
570 \\
600 \\
510 \\
570 \\
2,920 \\
\mathbf{2 ,} 572 \\
\mathbf{6 3 0} \\
1,190 \\
\mathbf{6 9 5}\end{array}$ & $\begin{array}{r}890 \\
844 \\
810 \\
724 \\
774 \\
648 \\
2,250 \\
5,620 \\
4,600 \\
1,320 \\
1,640 \\
1,100\end{array}$ & $\begin{array}{r}54,700 \\
50,200 \\
49,800 \\
44,500 \\
44,500 \\
39,800 \\
134,000 \\
346,000 \\
274,000 \\
81,200 \\
101,000 \\
65,700\end{array}$ \\
\hline 8,630 & 510 & 1,780 & $1,290,000$ \\
\hline $\begin{array}{r}7,940 \\
22,700 \\
28,100 \\
6,130 \\
3,780 \\
1,470\end{array}$ & $\begin{array}{r}840 \\
6,030 \\
6,760 \\
1,520 \\
720 \\
720\end{array}$ & $\begin{array}{r}1,300 \\
: 770 \\
\therefore 560 \\
\therefore 670 \\
\therefore 750 \\
-1,200 \\
2,490 \\
12,700 \\
16,800 \\
2,780 \\
1,430 \\
962\end{array}$ & $\begin{array}{r}80,000 \\
45,800 \\
34,400 \\
41,200 \\
41,700 \\
73,800 \\
148,000 \\
781,000 \\
1,000,000 \\
171,000 \\
87,900 \\
57,200\end{array}$ \\
\hline 28,100 & 720 & 3,540 & $2,560,000$ \\
\hline 1,520 & 870 & 1,100 & 67,800 \\
\hline & & $\begin{array}{r}1,000 \\
\quad 950 \\
\times 900 \\
\times 1,100\end{array}$ & $\begin{array}{l}61,500 \\
58,400 \\
50,000 \\
67,600\end{array}$ \\
\hline $\begin{array}{r}10,700 \\
21,700 \\
21,900 \\
7,350 \\
3,400 \\
2,860\end{array}$ & $\begin{array}{l}1,730 \\
5,130 \\
6,920 \\
3,190 \\
1,290 \\
1,050\end{array}$ & $\begin{array}{r}4,590 \\
14,800 \\
14,400 \\
4,710 \\
2,080 \\
1,680\end{array}$ & $\begin{array}{l}273,000 \\
910,000 \\
857,000 \\
290,000 \\
128,000 \\
100,000\end{array}$ \\
\hline 21,900 & - & 4,050 & $2,930,000$ \\
\hline 2,300 & 1,420 & 1,690 & 104,000 \\
\hline $\begin{array}{r}8,280 \\
21,400 \\
24,800 \\
15,000 \\
3,690 \\
1,220\end{array}$ & $\begin{array}{r}1,180 \\
3,420 \\
9,080 \\
3,300 \\
698 \\
505\end{array}$ & $\begin{array}{r}-1,000 \\
a 950 \\
a 900 \\
\therefore 850 \\
\therefore 900 \\
-1,300 \\
3,480 \\
10,300 \\
18,300 \\
6,610 \\
1,770 \\
838\end{array}$ & $\begin{array}{r}61,500 \\
56,500 \\
55,300 \\
52,300 \\
50,000 \\
72,200 \\
207,000 \\
633,000 \\
1,090,000 \\
406,000 \\
109,000 \\
49,900\end{array}$ \\
\hline 24,800 & & 3,920 & $2,840,000$ \\
\hline
\end{tabular}

The year.

1905-6

October

December.

January.

February

April.

April

June.

July.:-

August

September

The year.

October 1906
October
November
Decemaber $1916-17$
January
February.
March
April
May-
June
July
August
September.

- Estimated. 
Monthly discharge of Gunnison River near Grand Junction, Colo., for 1896-1899, 1901-1906, and 1916-1927-Continued

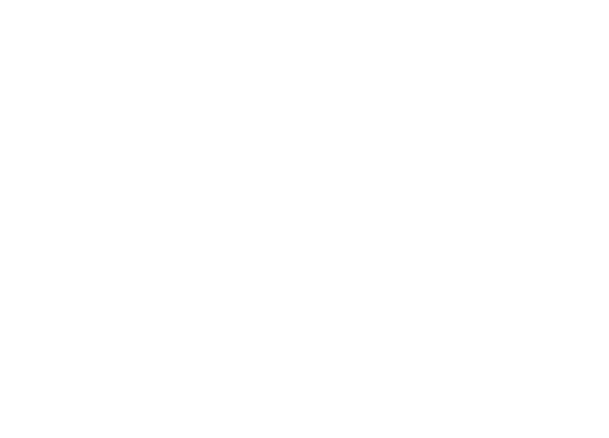

The year

\section{8-19}

October

November

December

January

February

March

April

June.

July.

August.

September

The year

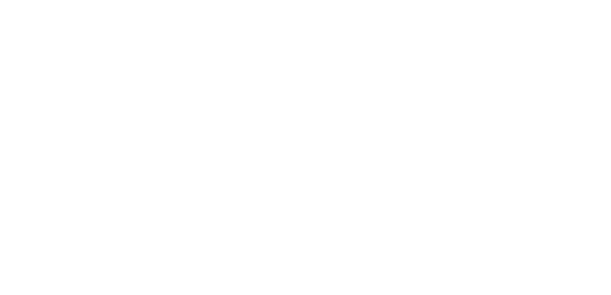

The year.

1920-21

October

November

December

January

February

March

April

May-

June

July

September

The year

October

November

December

January

February

March.

April

May -

June

July -..

August..

September.

The year.

Discharge in second-feet

Maxi

\begin{tabular}{|c|c|c|}
\hline \multicolumn{3}{|c|}{ - } \\
\hline DISLI & Age Ill decol & teet \\
\hline 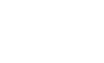 & 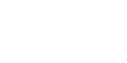 & $\ldots$ \\
\hline
\end{tabular}

\begin{tabular}{|c|c|c|c|}
\hline $\begin{array}{l}2,210 \\
4,100\end{array}$ & $\begin{array}{l}275 \\
290\end{array}$ & $\begin{array}{r}760 \\
1,310\end{array}$ & $\begin{array}{l}46,700 \\
78,000\end{array}$ \\
\hline 16,900 & 275 & 2,800 & $2,020,000$ \\
\hline $\begin{array}{r}1,710 \\
1,490 \\
1,710 \\
910 \\
950 \\
2,080 \\
9,560 \\
11,200 \\
8,310 \\
3,350 \\
3,850 \\
1,200\end{array}$ & $\begin{array}{r}760 \\
990 \\
910 \\
700 \\
800 \\
760 \\
1,460 \\
5,230 \\
3,190 \\
840 \\
326 \\
411\end{array}$ & $\begin{array}{r}1,020 \\
1,250 \\
1,110 \\
812 \\
880 \\
1,320 \\
4,310 \\
8,220 \\
4,910 \\
2,050 \\
1,110 \\
716\end{array}$ & $\begin{array}{r}62,700 \\
74,400 \\
68,200 \\
49,900 \\
48,900 \\
81,200 \\
256,000 \\
505,000 \\
292,000 \\
126,000 \\
68,200 \\
42,600\end{array}$ \\
\hline 11,200 & 326 & 2,320 & $1,680,000$ \\
\hline $\begin{array}{r}1,300 \\
1,330 \\
1,200 \\
1,030 \\
1,860 \\
1,660 \\
3,450 \\
35,200 \\
27,400 \\
11,300 \\
2,930 \\
1,460\end{array}$ & $\begin{array}{r}620 \\
630 \\
854 \\
776 \\
870 \\
870 \\
1,020 \\
4,520 \\
9,780 \\
1,920 \\
652 \\
480\end{array}$ & $\begin{array}{r}905 \\
1,190 \\
975 \\
919 \\
1,310 \\
1,080 \\
1,860 \\
18,900 \\
16,000 \\
4,620 \\
1,440 \\
744\end{array}$ & $\begin{array}{r}55,600 \\
70,800 \\
60,000 \\
56,500 \\
75,400 \\
66,400 \\
111,000 \\
1,160,000 \\
952,000 \\
284,000 \\
88,500 \\
44,300\end{array}$ \\
\hline 35,200 & 480 & 4,170 & $3,020,000$ \\
\hline $\begin{array}{r}1,700 \\
1,860 \\
1,150 \\
1,510 \\
2,110 \\
4,720 \\
18,800 \\
29,800 \\
7,270 \\
6,740 \\
3,350\end{array}$ & $\begin{array}{r}1,000 \\
896 \\
820 \\
-790 \\
1,030 \\
1,300 \\
3,240 \\
7,740 \\
2,610 \\
1,200 \\
870\end{array}$ & $\begin{array}{r}1,300 \\
1,390 \\
929 \\
1,050 \\
1,070 \\
1,460 \\
2,150 \\
10,300 \\
17,300 \\
4,660 \\
2,510 \\
1,530\end{array}$ & $\begin{array}{r}79,900 \\
82,700 \\
57,100 \\
64,600 \\
59,400 \\
89,800 \\
128,000 \\
633,000 \\
1,030,000 \\
287,000 \\
154,000 \\
91,000\end{array}$ \\
\hline 29,800 & 820 & 3,810 & $2,760,000$ \\
\hline $\begin{array}{r}1,510 \\
1,560 \\
1,460 \\
1,460 \\
1,300 \\
1,940 \\
12,000 \\
22,200 \\
15,400 \\
5,470 \\
2,980 \\
559\end{array}$ & $\begin{array}{r}820 \\
965 \\
953 \\
610 \\
642 \\
830 \\
1,090 \\
7,000 \\
4,760 \\
690 \\
559 \\
448\end{array}$ & $\begin{array}{r}1,070 \\
1,290 \\
1,220 \\
994 \\
923 \\
1,210 \\
2,980 \\
14,900 \\
10,200 \\
1,860 \\
928 \\
493\end{array}$ & $\begin{array}{r}65,800 \\
76,800 \\
75,000 \\
61,100 \\
51,300 \\
74,400 \\
177,000 \\
916,000 \\
607,000 \\
114,000 \\
57,100 \\
29,300\end{array}$ \\
\hline 22,200 & 448 & 3,190 & $2,300,000$ \\
\hline
\end{tabular}


Monthly discharge of Gunnison River near Grand Junction, Colo., for 1896-1899, 1901-1906, and 1916-1927-Continued

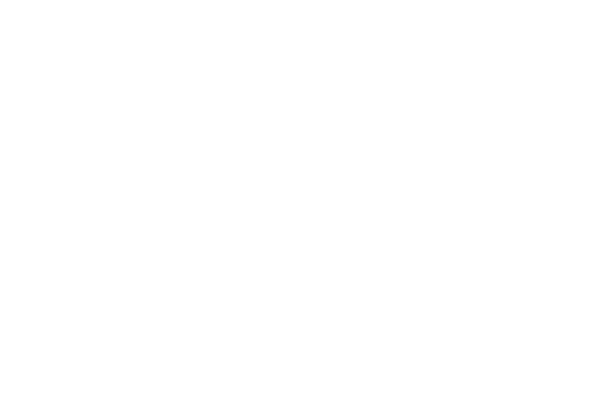

The year.

\section{3-24}

October

November

December

January

February -....

March

April

May.

July

August

September

The year

\begin{tabular}{|c|c|c|c|}
\hline \multicolumn{3}{|c|}{ Discharge in second-feet } & \multirow{2}{*}{$\begin{array}{c}\text { Run-off in } \\
\text { acre-feet }\end{array}$} \\
\hline Maximum & Minimum & Mean & \\
\hline $\begin{array}{r}1,110 \\
1,150 \\
1,280 \\
-946 \\
4,400 \\
18,100 \\
14,800 \\
7,550 \\
4,120 \\
2,820\end{array}$ & $\begin{array}{r}452 \\
962 \\
96 \\
979 \\
3,310 \\
8,040 \\
2,330 \\
2,110 \\
1,020\end{array}$ & $\begin{array}{r}743 \\
1,040 \\
997 \\
891 \\
808 \\
828 \\
2,160 \\
11,600 \\
11,300 \\
4,670 \\
2,940 \\
1,770\end{array}$ & $\begin{array}{r}45,700 \\
61,900 \\
61,300 \\
54,800 \\
44,900 \\
50,900 \\
129,000 \\
713,000 \\
-672,000 \\
287,000 \\
181,000 \\
105,000\end{array}$ \\
\hline 18,100 & 452 & 3,330 & $2,410,000$ \\
\hline $\begin{array}{r}1,200 \\
6,610 \\
12,600 \\
15,000 \\
3,460 \\
525 \\
654\end{array}$ & $\begin{array}{r}708 \\
701 \\
2,870 \\
4,300 \\
460 \\
163 \\
160\end{array}$ & $\begin{array}{r}1,860 \\
1,500 \\
1,060 \\
977 \\
993 \\
905 \\
3,480 \\
10,300 \\
9,750 \\
1,550 \\
285 \\
375\end{array}$ & $\begin{array}{r}114,000 \\
89,300 \\
65,200 \\
60,100 \\
57,100 \\
55,600 \\
207,000 \\
633,000 \\
580,000 \\
95,300 \\
17,500 \\
22,300\end{array}$ \\
\hline 15,000 & 160 & 2,750 & $2,000,000$ \\
\hline $\begin{array}{r}1,530 \\
1,440 \\
1,260 \\
-2,800 \\
8,660 \\
7,690 \\
8,180 \\
4,210 \\
2,860 \\
3,850\end{array}$ & 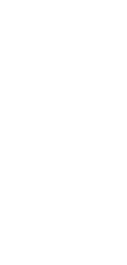 & $\begin{array}{r}1,230 \\
1,350 \\
982 \\
945 \\
1,030 \\
1,520 \\
4,180 \\
6,130 \\
5,210 \\
2,410 \\
1,550 \\
2,020\end{array}$ & $\begin{array}{r}75,600 \\
80,300 \\
60,400 \\
58,100 \\
57,200 \\
93,500 \\
249,000 \\
377,000 \\
310,000 \\
148,000 \\
95,300 \\
120,000\end{array}$ \\
\hline 8,660 & $\ldots$ & 2,380 & $1,720,000$ \\
\hline $\begin{array}{r}1,180 \\
2,020 \\
9,490 \\
13,600 \\
13,900 \\
5,070 \\
1,870 \\
599\end{array}$ & $\begin{array}{r}870 \\
746 \\
1,100 \\
3,920 \\
3,520 \\
1,040 \\
347 \\
327\end{array}$ & $\begin{array}{r}2,100 \\
1,350 \\
1,000 \\
800 \\
1,010 \\
1,130 \\
4,410 \\
8,840 \\
8,610 \\
2,540 \\
810 \\
402\end{array}$ & $\begin{array}{r}129,000 \\
80,300 \\
61,500 \\
49,200 \\
56,100 \\
69,500 \\
262,000 \\
544,000 \\
512,000 \\
156,000 \\
49,800 \\
23,900\end{array}$ \\
\hline 13,900 & ......... & 2,750 & $1,990,000$ \\
\hline $\begin{array}{l}1,610 \\
1,220 \\
1,220\end{array}$ & $\begin{array}{l}823 \\
970 \\
734\end{array}$ & $\begin{array}{r}1,220 \\
1,120 \\
925\end{array}$ & $\begin{array}{l}75,000 \\
66,600 \\
56,900\end{array}$ \\
\hline $\begin{array}{r}1,060 \\
2,160 \\
10,800 \\
17,700 \\
14,300 \\
10,300 \\
2,520 \\
5,430\end{array}$ & $\begin{array}{r}812 \\
1,330 \\
7,240 \\
6,870 \\
1,760 \\
1,300 \\
1,010\end{array}$ & $\begin{array}{r}020 \\
908 \\
1,110 \\
3,660 \\
11,900 \\
9,200 \\
3,830 \\
1,820 \\
2,900\end{array}$ & $\begin{array}{r}50,400 \\
68,200 \\
218,000 \\
732,000 \\
547,000 \\
236,000 \\
112,000 \\
173,000\end{array}$ \\
\hline 17,700 & & 3,290 & $2,390,000$ \\
\hline
\end{tabular}

The year.

1925-26

October

November

January.

February

March

April

June.

July -

August

September

The year

1924-25

October

1926-27

November

January.

February

March.

April.

Juno.

July.

Angust

September

Nork.-Records for August, September, and November, 1897, revised. Records for May, June, and July, 1899, revised to allow for backwater from Colorado River. Winter records from 1917 to 1925 based on daily gage heights, current-meter measurements, and temperatu re records. 
EAST RIVER AT ALMONT, COLO.

Location.-In sec. 22, T. 51 N., R. 1 E., at highway bridge at Almont, Gunnison County, 100 feet above junction of East and Taylor Rivers.

Drainage area. - 295 square miles (measured on Forest Service map).

Records avarlable.-April 16 to September 30, 1905; July 27, 1910, to April $30,1922$.

GAGE.-Vertical staff.

Controt.-Shifting.

Extremes of Discharge.-Maximum stage recorded during period, 5.7 feet on June 12, 13, and 14, 1918 (discharge, 6,000 second-feet); minimum stage recorded, 0.30 foot on August 13, 1913 (discharge, 19 second-feet).

Diversions.-Water diverted for irrigation of 2,700 acres from East River above station.

Accuracx.-Gage read twice daily. Rating curves fairly well defined. Records fair, except during medium stages, for which they are good.

Cooperation.-Station maintained by Bureau of Reclamation prior to 1916.

Monthly discharge of East River at Almont, Colo., for 1905, 1910-1913, and 1914-1922

\begin{tabular}{|c|c|c|c|c|}
\hline \multirow{2}{*}{ Month } & \multicolumn{3}{|c|}{ Discharge in second-feet } & \multirow{2}{*}{$\begin{array}{l}\text { Run-off in } \\
\text { acre-feet }\end{array}$} \\
\hline & Maximum & Minimum & Mean & \\
\hline $\begin{array}{l}\text { April 16-30 } \\
\text { May } \\
\text { June } \\
\text { July } \\
\text { August } \\
\text { September }\end{array}$ & $\begin{array}{r}495 \\
2,220 \\
4,870 \\
940 \\
530 \\
180\end{array}$ & $\begin{array}{r}180 \\
340 \\
940 \\
390 \\
220 \\
80\end{array}$ & $\begin{array}{r}249 \\
910 \\
2,330 \\
537 \\
280 \\
117\end{array}$ & $\begin{array}{r}7,410 \\
56,000 \\
139,000 \\
33,000 \\
17,200 \\
6,960\end{array}$ \\
\hline The period............ & - & - & 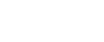 & 260,000 \\
\hline $\begin{array}{l}\text { July } 27-31 \\
\text { August } \\
\text { September }\end{array}$ & $\begin{array}{l}205 \\
205 \\
150\end{array}$ & $\begin{array}{r}140 \\
110 \\
90\end{array}$ & $\begin{array}{l}178 \\
154 \\
107\end{array}$ & $\begin{array}{l}1,760 \\
9,470 \\
6,370\end{array}$ \\
\hline $\begin{array}{l}\text { October } \\
\text { November } \\
\text { December } \\
\text { January } \\
\text { February } \\
\text { Mareh } \\
\text { April } \\
\text { May } \\
\text { June } \\
\text { July } \\
\text { August } \\
\text { September }\end{array}$ & $\begin{array}{r}70 \\
70 \\
150 \\
860 \\
1,660 \\
2,540 \\
1,710 \\
355 \\
245\end{array}$ & $\begin{array}{r}50 \\
50 \\
35 \\
110 \\
505 \\
960 \\
355 \\
175 \\
150\end{array}$ & $\begin{array}{r}94.2 \\
73.7 \\
60.0 \\
59.7 \\
52.9 \\
64.7 \\
268 \\
1,180 \\
1,850 \\
740 \\
272 \\
169\end{array}$ & $\begin{array}{r}5,790 \\
4,390 \\
3,690 \\
3,670 \\
2,940 \\
3,980 \\
15,900 \\
72,600 \\
110,000 \\
45,500 \\
16,700 \\
10,100\end{array}$ \\
\hline The year. & 2,540 & | & 409 & 296,000 \\
\hline $\begin{array}{l}\text { October } \\
\text { November } \\
\text { December } \\
\text { January } \\
\text { February } \\
\text { March } \\
\text { April } \\
\text { May } \\
\text { June } \\
\text { July } \\
\text { August } \\
\text { September }\end{array}$ & \begin{tabular}{r}
670 \\
150 \\
130 \\
\hdashline-90 \\
815 \\
2,200 \\
3,160 \\
1,300 \\
630 \\
205
\end{tabular} & $\begin{array}{r}150 \\
100 \\
120 \\
1,000 \\
65 \\
70 \\
315 \\
630 \\
225 \\
155\end{array}$ & $\begin{array}{c}279 \\
122 \\
124 \\
83 \\
60 \\
63.6 \\
174 \\
971 \\
1,820 \\
921 \\
357 \\
171\end{array}$ & $\begin{array}{r}17,200 \\
7,260 \\
7,620 \\
5,100 \\
3,690 \\
8,910 \\
10,400 \\
59,700 \\
108,000 \\
56,600 \\
22,000 \\
10,200\end{array}$ \\
\hline The year & 3,160 & 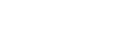 & 431 & 312,000 \\
\hline
\end{tabular}


Monthly discharge of East River at Almont, Colo., for $11905,1910-1918$, and 1914-1922-Continued

\begin{tabular}{|c|c|c|c|c|}
\hline \multirow{2}{*}{ Month } & \multicolumn{3}{|c|}{ Discharge in second-feet } & \multirow{2}{*}{$\begin{array}{l}\text { Run-off in } \\
\text { acre-feet }\end{array}$} \\
\hline & Maximum & Minimum & Mean & \\
\hline $\begin{array}{l}\text { October } \\
\text { November } \\
\text { December. } \\
\text { January. } \\
\text { Nebruary } \\
\text { March } \\
\text { Maril } \\
\text { Muye } \\
\text { July } \\
\text { August } \\
\text { September }\end{array}$ & \begin{tabular}{|r|}
170 \\
135 \\
1,430 \\
1,520 \\
550 \\
45 \\
140
\end{tabular} & 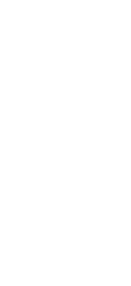 & $\begin{array}{c}137 \\
72.7 \\
57 \\
57 \\
54 \\
57 \\
406 \\
1,120 \\
1,090 \\
266 \\
25.0 \\
104\end{array}$ & $\begin{array}{r}8,420 \\
4,380 \\
3,500 \\
3,500 \\
3,000 \\
3,500 \\
24,200 \\
68,900 \\
64,900 \\
16,400 \\
1,540 \\
6,100\end{array}$ \\
\hline The year..... & 1,520 & & 287 & 208,000 \\
\hline ctober 1913 & $\begin{array}{r}140 \\
90\end{array}$ & $\begin{array}{l}90 \\
20\end{array}$ & $\begin{array}{r}186 \\
90\end{array}$ & $\begin{array}{l}8,360 \\
5,360\end{array}$ \\
\hline 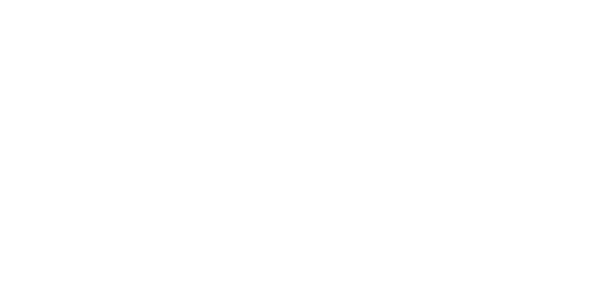 & \begin{tabular}{r|r|}
450 \\
192 \\
160 \\
795 \\
1,020 \\
1,530 \\
850 \\
380 \\
192
\end{tabular} & $\begin{array}{r}192 \\
175 \\
380 \\
745 \\
238 \\
160 \\
132\end{array}$ & $\begin{array}{r}250 \\
164 \\
100 \\
70 \\
100 \\
134 \\
330 \\
615 \\
1,090 \\
532 \\
216 \\
154\end{array}$ & $\begin{array}{r}15,900 \\
9,760 \\
6,150 \\
4,300 \\
5,560 \\
8,240 \\
19,600 \\
37,800 \\
64,800 \\
32,700 \\
13,300 \\
9,160\end{array}$ \\
\hline 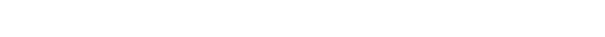 & 1,530 & - מ-n & 314 & 227,000 \\
\hline $\begin{array}{l}\text { October. } \\
\text { November } \\
\text { December } \\
\text { Ianuary } \\
\text { Pebruary } \\
\text { March } \\
\text { Mpril } \\
\text { May } \\
\text { Uuly }\end{array}$ & $\begin{array}{r}1,200 \\
2,110 \\
3,060 \\
1,260 \\
850 \\
380\end{array}$ & $\begin{array}{r}192 \\
850 \\
1,400 \\
525 \\
232 \\
192\end{array}$ & $\begin{array}{r}127 \\
77 \\
65 \\
57 \\
55 \\
103 \\
434 \\
1,340 \\
2,100 \\
884 \\
499 \\
239\end{array}$ & $\begin{array}{r}7,800 \\
4,580 \\
4,000 \\
3,500 \\
3,160 \\
6,390 \\
25,800 \\
82,400 \\
125,000 \\
54,400 \\
30,700 \\
14,200\end{array}$ \\
\hline The year. & 3,080 & & 500 & 362,000 \\
\hline $\begin{array}{l}\text { October. } \\
\text { November } \\
\text { Desermber. } \\
\text { January } \\
\text { February } \\
\text { March } \\
\text { April } \\
\text { May } \\
\text { June } \\
\text { July } \\
\text { August } \\
\text { September }\end{array}$ & $\begin{array}{r}380 \\
192 \\
120 \\
85 \\
525 \\
1,600 \\
3,540 \\
2,060 \\
605 \\
175\end{array}$ & $\begin{array}{r}192 \\
85 \\
47 \\
75 \\
85 \\
255 \\
745 \\
605 \\
175 \\
120\end{array}$ & $\begin{array}{c}221 \\
148 \\
97.0 \\
52.9 \\
66.8 \\
77.6 \\
194 \\
782 \\
2,260 \\
1,060 \\
346 \\
159\end{array}$ & $\begin{array}{r}13,600 \\
8,450 \\
5,960 \\
3,250 \\
3,710 \\
4,770 \\
11,500 \\
48,100 \\
134,000 \\
65,200 \\
21,200 \\
9,460\end{array}$ \\
\hline The year. & 3,540 & $r=0+\infty$ & 456 & 329 , \\
\hline
\end{tabular}


Monthly discharge of East River at Almont, Colo., for 1905, 1910-1913, and 1914-1922-Continued

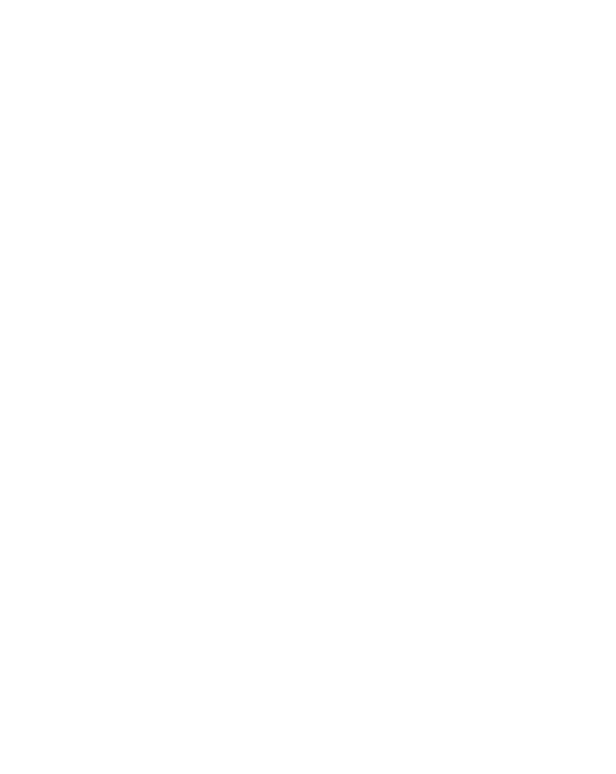

\begin{tabular}{|c|c|c|c|}
\hline \multicolumn{3}{|c|}{ Discharge in second-feet } & \multirow{2}{*}{$\begin{array}{l}\text { Run-off in } \\
\text { acre-1eet }\end{array}$} \\
\hline Maximum & Minimum & Mean & \\
\hline $\begin{array}{r}120 \\
100 \\
92 \\
415 \\
1,770 \\
5,000 \\
962 \\
285 \\
525\end{array}$ & $\begin{array}{r}100 \\
100\end{array}$ & $\begin{array}{c}110 \\
100 \\
71.5 \\
66.3 \\
69.0 \\
76.8 \\
208 \\
1,340 \\
2,600 \\
553 \\
207 \\
211\end{array}$ & $\begin{array}{r}6,760 \\
5,050 \\
4,400 \\
4,000 \\
3,890 \\
4,720 \\
12,400 \\
82,400 \\
155,000 \\
34,000 \\
12,700 \\
12,600\end{array}$ \\
\hline 5,000 & & 467 & $.339,000$ \\
\hline $\begin{array}{r}163 \\
135 \\
996 \\
850 \\
1,710 \\
962 \\
745 \\
408 \\
246\end{array}$ & $\begin{array}{r}135 \\
77 \\
53 \\
96 \\
650 \\
695 \\
169 \\
120 \\
108\end{array}$ & $\begin{array}{c}142 \\
114 \\
83.6 \\
54.6 \\
60.3 \\
66.7 \\
339 \\
1,150 \\
802 \\
329 \\
196 \\
130\end{array}$ & $\begin{array}{r}8,730 \\
6,780 \\
5,140 \\
3,360 \\
3,350 \\
4,100 \\
20,200 \\
70,700 \\
47,700 \\
20,200 \\
12,100 \\
7,740\end{array}$ \\
\hline 1,710 & & 291 & 210,000 \\
\hline $\begin{array}{r}130 \\
120 \\
85\end{array}$ & $\begin{array}{r}108 \\
81 \\
60 \\
85 \\
85 \\
297 \\
1,940 \\
565 \\
200 \\
112\end{array}$ & $\begin{array}{c}118 \\
105 \\
73.5 \\
71.4 \\
75.0 \\
85.0 \\
117 \\
1,650 \\
2,670 \\
1,060 \\
365 \\
151\end{array}$ & $\begin{array}{r}7,260 \\
6,250 \\
4,520 \\
4,390 \\
4,310 \\
5,230 \\
6,900 \\
101,000 \\
159,000 \\
65,200 \\
22,400 \\
8,900\end{array}$ \\
\hline 3,870 & $\ldots$ & 546 & 396,000 \\
\hline 303 & $\mid--$ & $\begin{array}{c}106 \\
90 \\
83.4 \\
74.7 \\
64.1 \\
89.0 \\
140 \\
1,040 \\
2,100 \\
685 \\
320 \\
180\end{array}$ & $\begin{array}{r}6,520 \\
5,360 \\
5,130 \\
4,590 \\
3,560 \\
5,470 \\
8,300 \\
64,000 \\
128,000 \\
42 ; 100 \\
19,700 \\
10,700\end{array}$ \\
\hline & $\ldots$ & 415 & 300,000 \\
\hline $\begin{array}{r}79 \\
650\end{array}$ & - & $\begin{array}{c}103 \\
83.7 \\
62.1 \\
64.0 \\
66.4 \\
68.4 \\
172\end{array}$ & $\begin{array}{r}6,390 \\
4,980 \\
3,820 \\
3,940 \\
3,690 \\
4,210 \\
10,200\end{array}$ \\
\hline & & & $\ldots .37$ \\
\hline
\end{tabular}

The year

October
November
December
January
February
Mareh
April
May
June
July
August
September.

The year

\begin{tabular}{|c|c|c|c|c|}
\hline & & & & \\
\hline $\begin{array}{l}\text { October } \\
\text { November } \\
\text { December } \\
\text { January } \\
\text { February } \\
\text { March } \\
\text { April } \\
\text { May } \\
\text { June } \\
\text { July } \\
\text { August } \\
\text { September }\end{array}$ & 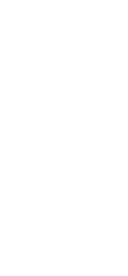 & 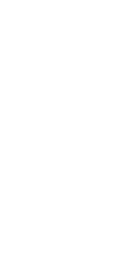 & $\begin{array}{l}106 \\
90 \\
83.4 \\
74.7 \\
64.1 \\
89.0 \\
140 \\
1,040 \\
2,100 \\
685 \\
320 \\
180\end{array}$ & $\begin{array}{r}6,520 \\
5,360 \\
5,130 \\
4,590 \\
3,560 \\
5,470 \\
8,300 \\
64,000 \\
128,000 \\
42 ; 100 \\
19,700 \\
10,700\end{array}$ \\
\hline The year................ & & - n- & 415 & 300,000 \\
\hline $\begin{array}{l}\text { October } \\
\text { November } \\
\text { December } \\
\text { January } \\
\text { February } \\
\text { Mareh } \\
\text { April }\end{array}$ & $\begin{array}{r}116 \\
100 \\
79 \\
70\end{array}$ & $\begin{array}{r}100 \\
70 \\
73\end{array}$ & $\begin{array}{r}103 \\
83.7 \\
62.1 \\
64.0 \\
66.4 \\
68.4 \\
172\end{array}$ & $\begin{array}{r}6,390 \\
4,980 \\
3,820 \\
3,940 \\
3,690 \\
4,210 \\
10,200\end{array}$ \\
\hline The period... & & & & 200 \\
\hline
\end{tabular}

NoTE.- Winter records based on daily gage heights, current-meter measurements, and temperature reaords. Monthly mean discharge May to September, 1921, based on comparison between discharge of Gunnison River near Gunnison and Taylor River at Almont as determined from records for previous year. 
CEMENT CREGK NEAR CRESTRD BUTTE, colo.

1.ocation.-In sec. 22, T. 14 S., R. 85 W., about 7 miles southeast of Crested Butte, Gunnison County. No tributary between station and mouth, 11/4 miles downstream.

Drainage area.-32 square miles (measured on Forest Service map).

Records avallable.-October 1, 1910, to November 30, 1913.

GaGe.-Vertical staff.

Control. - Sbifting at long intervals.

ICE.-Stage-discharge relation unaffected by ice.

Diversions.-Water diverted from Cement Creek for irrigation of 240 acres.

ACCURACY.- Gage read at irregular intervals. Rating curves fairly well defined.

Records fair.

Cooperation.-Station maintained in cooperation with United States Forest Service.

Monthly discharge of Cement Creek near Crested Butte, Colo., for 1910-1913

\begin{tabular}{|c|c|c|c|c|}
\hline \multirow{2}{*}{ Month } & \multicolumn{3}{|c|}{ Discharge in second-feet } & \multirow{2}{*}{$\begin{array}{l}\text { Run-off in } \\
\text { acre-feet }\end{array}$} \\
\hline & Maximum & Minimum & Mean & \\
\hline $\begin{array}{l}\text { October } \\
\text { November } \\
\text { December } \\
\text { January } \\
\text { February } \\
\text { March } \\
\text { April } \\
\text { May } \\
\text { June } \\
\text { July } \\
\text { August } \\
\text { September }\end{array}$ & $\begin{array}{r}11 \\
17 \\
17 \\
21 \\
200 \\
285 \\
208 \\
61 \\
47\end{array}$ & $\begin{array}{r}11 \\
11 \\
11 \\
12 \\
35 \\
138 \\
61 \\
35 \\
25\end{array}$ & $\begin{array}{c}022 \\
615 \\
11.0 \\
11.9 \\
13.2 \\
14.3 \\
\text { a } 30.0 \\
114 \\
214 \\
108 \\
46.3 \\
30.5\end{array}$ & $\begin{array}{r}1,350 \\
893 \\
676 \\
732 \\
733 \\
879 \\
1,790 \\
7,010 \\
12,700 \\
6,640 \\
2,850 \\
1,810\end{array}$ \\
\hline The year. & 285 & 11 & 627 & 38,100 \\
\hline $\begin{array}{l}\text { October..1911-12 } \\
\text { November } \\
\text { December } \\
\text { January } \\
\text { February } \\
\text { March } \\
\text { April } \\
\text { May } \\
\text { June } \\
\text { July } \\
\text { August } \\
\text { September }\end{array}$ & $\begin{array}{r}47 \\
21 \\
21 \\
18 \\
18 \\
18 \\
35 \\
300 \\
330 \\
165 \\
58 \\
29\end{array}$ & $\begin{array}{r}17 \\
17 \\
16 \\
18 \\
12 \\
12 \\
12 \\
25 \\
174 \\
58 \\
31 \\
23\end{array}$ & $\begin{array}{c}28.3 \\
17.3 \\
17.0 \\
18.0 \\
14.7 \\
13.9 \\
19.3 \\
108 \\
240 . \\
117 \\
38.1 \\
24.0\end{array}$ & $\begin{array}{r}1,740 \\
1,030 \\
1,050 \\
1,110 \\
846 \\
855 \\
1,150 \\
6,640 \\
14,300 \\
7,190 \\
2,340 \\
1,430\end{array}$ \\
\hline The year............ & 330 & 12 & 54.8 & 39,700 \\
\hline 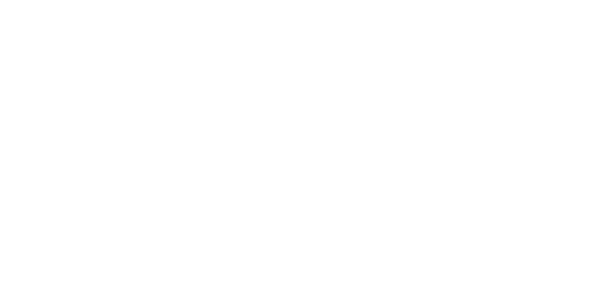 & \begin{tabular}{r}
23 \\
23 \\
11 \\
\hdashline \\
\hdashline 190 \\
165 \\
86 \\
40 \\
27
\end{tabular} & $\begin{array}{r}\begin{array}{r}16 \\
11 \\
9\end{array} \\
\\
\\
\\
67 \\
31 \\
16 \\
16 \\
\end{array}$ & $\begin{array}{c}21.7 \\
14.8 \\
10.5 \\
08 \\
66 \\
26 \\
200 \\
93.9 \\
121 \\
52.9 \\
27.0 \\
19.3\end{array}$ & $\begin{array}{r}1,330 \\
881 \\
646 \\
492 \\
333 \\
369 \\
1,190 \\
5,740 \\
7,200 \\
3,250 \\
1,660 \\
1,150\end{array}$ \\
\hline The year & 190 & - nn & 33.5 & 24,200 \\
\hline $\begin{array}{l}\text { October-1913 } \\
\text { November } \\
\text { Nove }\end{array}$ & $\begin{array}{l}25 \\
14\end{array}$ & 11 & $\begin{array}{l}16.0 \\
10.0\end{array}$ & $\begin{array}{l}984 \\
595\end{array}$ \\
\hline
\end{tabular}

- Estimated. 
TOMTCHI CREEK AT SARGETTS, COLO.

Location.-In NW. 1/4 sec. 28 , T. 48 N., R. 5 E., at railroad bridge three-quarters of a mile west of Sargents, Saguache County. Nearest tributary, Marshall

Creek, enters a quarter of a mile above.

Drainage area.-165 square miles (measured on Forest Service map).

Records avallable.-May 12, 1917, to September 30, 1922.

GAGE.-Lallie and Stevens water-stage recorders.

Control.-Shifting.

Extrames of Discharge.-Maximum stage during period, 4.05 feet on June 9, 1921 (discharge, 792 second-feet); minimum discharge recorded from currentmeter measurement, 6.5 second-feet November 16, 1920.

Drversions. - Water diverted from Tomichi Creek above station for irrigation of 780 acres and from tributaries entering above for several hundred acres.

Accuracy.-Gage heights from continuous records except for short periods.

Records good except.during 1920 and 1921, for which they are fair.

Cooperation.-Station maintained in cooperation with State engineer.

Monthly discharge of Tomichi Creek at Sargents, Colo., for 1917-1922

\begin{tabular}{|c|c|c|c|c|}
\hline \multirow{2}{*}{ Month } & \multicolumn{3}{|c|}{ Discharge in second-feet } & \multirow{2}{*}{$\begin{array}{l}\text { Run-off in } \\
\text { acre-feet }\end{array}$} \\
\hline & Maximum & Minimum & Mean & \\
\hline $\begin{array}{l}\text { May 12-31 } \\
\text { June } \\
\text { July } \\
\text { August } \\
\text { September }\end{array}$ & $\begin{array}{r}200 \\
604 \\
170 \\
89 \\
49\end{array}$ & $\begin{array}{r}64 \\
126 \\
82 \\
44 \\
30\end{array}$ & $\begin{array}{c}141 \\
335 \\
111 \\
59.2 \\
35.8\end{array}$ & $\begin{array}{r}5,800 \\
19,000 \\
6,820 \\
3,640 \\
2,130\end{array}$ \\
\hline The period..... & n...... & - & n............. & 38,100 \\
\hline $\begin{array}{l}\text { October. } \\
\text { November } \\
\text { December } \\
\text { January } \\
\text { February } \\
\text { March } \\
\text { April } \\
\text { May } \\
\text { June } \\
\text { July } \\
\text { Auguast } \\
\text { September }\end{array}$ & $\begin{array}{r}45 \\
\\
\\
\\
\\
\\
382 \\
312 \\
96 \\
52 \\
78\end{array}$ & \begin{tabular}{|r|}
29 \\
\\
\end{tabular} & $\begin{array}{l}33.6 \\
331 \\
a 30 \\
a 30 \\
a 32 \\
a 32 \\
a 31 \\
a \quad 41 \\
236 \\
227 \\
70.6 \\
35.2 \\
40.1\end{array}$ & $\begin{array}{r}2,070 \\
1,840 \\
1,840 \\
1,840 \\
1,780 \\
1,970 \\
2,440 \\
14,500 \\
13,500 \\
4,340 \\
2,160 \\
2,300\end{array}$ \\
\hline The year... & 382 & | & 70.1 & 50,700 \\
\hline $\begin{array}{l}\text { October. } \\
\text { November } \\
\text { December } \\
\text { January } \\
\text { February } \\
\text { March } \\
\text { April } \\
\text { May } \\
\text { June } \\
\text { July } \\
\text { August } \\
\text { September }\end{array}$ & \begin{tabular}{|r|}
38 \\
\\
\end{tabular} \mid $\begin{array}{r}132 \\
470 \\
309 \\
125 \\
69 \\
47\end{array}$ & \begin{tabular}{|r|}
20 \\
\\
\end{tabular} \mid $\begin{array}{r}125 \\
77 \\
63 \\
33 \\
25 \\
\end{array}$ & $\begin{array}{rl} & 27.5 \\
2 & 22 \\
0 & 23 \\
2 & 25 \\
2 & 25 \\
a & 28 \\
70 \\
262 \\
142 \\
71.2 \\
45.0 \\
37.1\end{array}$ & $\begin{array}{r}1,690 \\
1,310 \\
1,410 \\
1,540 \\
1,390 \\
1,720 \\
4,170 \\
16,100 \\
8,400 \\
4,380 \\
2,770 \\
2,210\end{array}$ \\
\hline The & $\mathbf{4 7 0}$ & 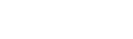 & 65.1 & 47,100 \\
\hline
\end{tabular}

- Istimated. 
Monthly discharge of Tomichi Creek at Sargents, Colo., for 191\%-1922-Contd.

\begin{tabular}{|c|c|c|c|c|}
\hline \multirow{2}{*}{ Month } & \multicolumn{3}{|c|}{ Discharge in second-feet } & \multirow{2}{*}{$\begin{array}{c}\text { Run-off in } \\
\text { acre-feet }\end{array}$} \\
\hline & Maximum & Minimum & Mean & \\
\hline $\begin{array}{l}\text { October. } \\
\text { November } \\
\text { December. } \\
\text { January } \\
\text { February } \\
\text { Mareh } \\
\text { Aprill } \\
\text { May }\end{array}$ & $\begin{array}{r}46 \\
495 \\
50 \\
142 \\
80 \\
37\end{array}$ & $\begin{array}{r}24 \\
109 \\
100 \\
50 \\
30 \\
22\end{array}$ & $\begin{array}{l}29.0 \\
.25 \\
\text { a } 25 \\
225 \\
=25 \\
30 \\
335 \\
276 \\
301 \\
83.3 \\
50.2 \\
30.1\end{array}$ & $\begin{array}{r}1,780 \\
1,490 \\
1,540 \\
1,540 \\
1,800 \\
1,840 \\
2,080 \\
17,000 \\
17,900 \\
5,120 \\
3,000 \\
1,700\end{array}$ \\
\hline 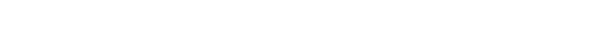 & 550 & & 78.1 & 56,600 \\
\hline $\begin{array}{l}\text { October. } \\
\text { November. } \\
\text { December. } \\
\text { January } \\
\text { February } \\
\text { Mareh } \\
\text { April } \\
\text { May } \\
\text { June } \\
\text { July } \\
\text { August }\end{array}$ & $\begin{array}{r}34 \\
86 \\
180 \\
740 \\
792 \\
204 \\
89 \\
56\end{array}$ & $\begin{array}{r}17 \\
6 \\
195 \\
192 \\
91 \\
58 \\
30\end{array}$ & $\begin{array}{l}22.2 \\
20.4 \\
a 23 \\
230 \\
30 \\
30 \\
45 \\
100 \\
380 \\
538 \\
142 \\
72.6 \\
42.8\end{array}$ & $\begin{array}{r}1,360 \\
1,210 \\
1,410 \\
1,840 \\
1,670 \\
2,770 \\
5,950 \\
23,400 \\
33,200 \\
8,730 \\
4,460 \\
2,550\end{array}$ \\
\hline The year. & 792 & & 122 & 88,600 \\
\hline $\begin{array}{l}\text { October } \\
\text { November } \\
\text { December. } \\
\text { January } \\
\text { February } \\
\text { March } \\
\text { April } \\
\text { Jay } \\
\text { June } \\
\text { Juy } \\
\text { August }\end{array}$ & $\begin{array}{r}230 \\
63 \\
56 \\
27 \\
27\end{array}$ & 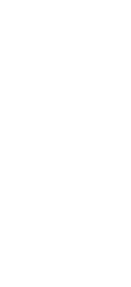 & 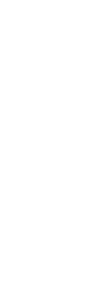 & $\begin{array}{r}2,340 \\
2,090 \\
1,350 \\
1,840 \\
1,300 \\
1,540 \\
3,570 \\
12,400 \\
8,510 \\
2,370 \\
1,770 \\
940\end{array}$ \\
\hline The year. & 305 & 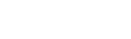 & 54.0 & 39,800 \\
\hline
\end{tabular}

- Estimated.

QUARTZ CRERK NBAR PITKIN, COLO.

Location.-In see. 8, T. 50 N., R. $4 \mathrm{E}_{\phi}$, at highway bridge 1 mile southwest of Pitkin, Gunnison County.

Drainage area. -66 square miles (revised; measured on Forest Service map).

Records available.-October 1, 1910, ito December 31, 1913.

GAGE.-Vertical staff.

Controu.-Somewhat shifting.

ICE.-Stage-discharge relation unaffected by ice.

Diversions.-None above station.

AccoracY.-Gage read once daily, except during 1912 and 1913, when it was read at irregular intervals. Rating curves fairly well defined. Records for 1911 and 1912, fair; for 1913, poor.

Cooperation.-Station maintained in cooperation with United States Forest Service. 
Monthly discharge of Quartz Creek near Pitkin, Colo., for 1910-1915

\begin{tabular}{|c|c|c|c|c|}
\hline \multirow{2}{*}{ Month } & \multicolumn{3}{|c|}{ Discharge in second-feet } & \multirow{2}{*}{$\underset{\text { acre-feet }}{\text { Run-off in }}$} \\
\hline & Maximum & Minimum & Mean & \\
\hline $\begin{array}{l}\text { October } \\
\text { November } \\
\text { December } \\
\text { January } \\
\text { February } \\
\text { March } \\
\text { April } \\
\text { May } \\
\text { June } \\
\text { July } \\
\text { August } \\
\text { September }\end{array}$ & $\begin{array}{r}27 \\
27 \\
23 \\
56 \\
138 \\
112 \\
61 \\
37\end{array}$ & $\begin{array}{r}20 \\
20 \\
20 \\
23 \\
46 \\
-61 \\
33 \\
30\end{array}$ & $\begin{array}{l}35 \\
30 \\
25 \\
20.9 \\
22.0 \\
21.1 \\
31.2 \\
92.6 \\
213 \\
79.1 \\
40.6 \\
32.5\end{array}$ & $\begin{array}{r}2,150 \\
1,790 \\
1,540 \\
1,290 \\
1,220 \\
1,300 \\
1,860 \\
5,690 \\
12,700 \\
4,860 \\
2,500 \\
1,930\end{array}$ \\
\hline The year.... & $\ldots$ & n-2n-n & 53.5 & 38,800 \\
\hline $\begin{array}{l}\text { October } \\
\text { November } \\
\text { December. } \\
\text { January } \\
\text { February } \\
\text { March } \\
\text { April } \\
\text { May } \\
\text { June } \\
\text { July } \\
\text { August, } \\
\text { Beptember }\end{array}$ & $\begin{array}{r}61 \\
33 \\
27 \\
25 \\
23 \\
22 \\
27 \\
296 \\
296 \\
112 \\
61 \\
50\end{array}$ & $\begin{array}{r}\mathbf{2 7} \\
\mathbf{2 7} \\
25 \\
20 \\
20 \\
22 \\
22 \\
\mathbf{2 7} \\
138 \\
64 \\
\mathbf{3 7} \\
\mathbf{2 7}\end{array}$ & $\begin{array}{c}38.7 \\
27.8 \\
26.2 \\
23.5 \\
20.8 \\
22.0 \\
23.1 \\
102 \\
210 \\
83.9 \\
42.7 \\
36.5\end{array}$ & $\begin{array}{r}2,380 \\
1,650 \\
1,610 \\
1,440 \\
1,200 \\
1,350 \\
1,370 \\
6,270 \\
12,500 \\
5,160 \\
2,630 \\
2,170\end{array}$ \\
\hline The year.............. & 290 & 20 & 55.0 & 39,700 \\
\hline $\begin{array}{l}\text { October } \\
\text { November } \\
\text { December } \\
\text { January } \\
\text { February } \\
\text { March } \\
\text { April } \\
\text { May } \\
\text { June } \\
\text { July } \\
\text { A ugust } \\
\text { Beptember }\end{array}$ & $\begin{array}{r}35 \\
41 \\
27 \\
05 \\
267 \\
210 \\
99 \\
72 \\
50\end{array}$ & 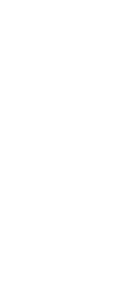 & $\begin{array}{c}32.2 \\
27.9 \\
24.0 \\
\times 23 \\
\times 22 \\
\times 22 \\
35 \\
106 \\
140 \\
70.8 \\
56.5 \\
48.1\end{array}$ & $\begin{array}{l}1,980 \\
1,660 \\
1,480 \\
1,410 \\
1,220 \\
1,350 \\
2,080 \\
6,460 \\
8,330 \\
4,350 \\
3,470 \\
2,860\end{array}$ \\
\hline 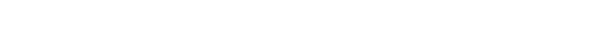 & 267 & and & 50.5 & 36,600 \\
\hline $\begin{array}{l}\text { October } 1913 \\
\text { November } \\
\text { December }\end{array}$ & $\begin{array}{l}49 \\
43 \\
36\end{array}$ & 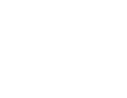 & $\begin{array}{l}45.2 \\
38.0 \\
32\end{array}$ & $\begin{array}{l}2,770 \\
2,260 \\
1,970\end{array}$ \\
\hline
\end{tabular}

a Estimated.

SAPINERO CREER AT SAPINERO, COLO.

Location.-In sec. 28 , T. 49 N., R. 4 W., 250 feet above highway bridge half a mile northeast of Sapinero, Gunnison County. Creek enters Gunnison River a short distance below bridge.

Drainage area.-84 square miles (measured on Forest Serviee map).

Records available.- October 1, 1910, to September 30, 1914.

Gage.-Chain. Prior to July 22, 1913, staff gage at bridge.

Control.-Somewhat shifting.

Diversions.- Water diverted for irrigation of 450 acres above station.

Accoracy.-Gage read at irregular intervals. Rating curves not well defined.

Records poor. 
Monthly discharge of Sapinero Creek at Sapinero, Colo., 1910-1914

\begin{tabular}{|c|c|c|c|c|}
\hline \multirow{2}{*}{ Month } & \multicolumn{3}{|c|}{ Discharge in second-feet } & \multirow{2}{*}{$\underset{\text { acre-feet }}{\text { Run-ofi in }}$} \\
\hline & Maximum & Minimum & Mean & \\
\hline $\begin{array}{l}\text { October. } \\
\text { November } \\
\text { December. } \\
\text { January. } \\
\text { February } \\
\text { March } \\
\text { April } \\
\text { May } \\
\text { June } \\
\text { July } \\
\text { August } \\
\text { September }\end{array}$ & $\begin{array}{r}141 \\
460 \\
421 \\
445 \\
142 \\
32 \\
21\end{array}$ & $\begin{array}{r}18 \\
108 \\
205 \\
120 \\
34 \\
14 \\
14\end{array}$ & $\begin{array}{r}18 \\
14 \\
12 \\
14 \\
14 \\
42 \\
232 \\
331 \\
319 \\
72 \\
20 \\
15\end{array}$ & $\begin{array}{r}1,110 \\
833 \\
738 \\
861 \\
778 \\
2,580 \\
13,800 \\
20,400 \\
19,000 \\
4,430 \\
1,230 \\
893\end{array}$ \\
\hline The year.............. & 460 & a....... & 91.8 & 66,700 \\
\hline $\begin{array}{l}\text { October. } \\
\text { November } \\
\text { December. } \\
\text { January } \\
\text { February } \\
\text { March } \\
\text { April. } \\
\text { May } \\
\text { June } \\
\text { July } \\
\text { August } \\
\text { September }\end{array}$ & $\begin{array}{r}72 \\
19 \\
35 \\
110 \\
490 \\
540 \\
300 \\
60 \\
26\end{array}$ & $\begin{array}{r}17 \\
12 \\
\mathbf{3 2} \\
\mathbf{3 3 5} \\
60 \\
11 \\
9\end{array}$ & $\begin{array}{r}28 \\
15 \\
\text { a } 14 \\
13 \\
12 \\
22 \\
62 \\
252 \\
435 \\
138 \\
28 \\
13\end{array}$ & $\begin{array}{r}1,720 \\
893 \\
801 \\
799 \\
696 \\
1,860 \\
3,690 \\
15,500 \\
25,900 \\
8,480 \\
1,720 \\
774\end{array}$ \\
\hline The year...... & 640 & & 86.1 & 62,400 \\
\hline $\begin{array}{l}\text { October. } \\
\text { November. } \\
\text { December. } \\
\text { January } \\
\text { Pebruary } \\
\text { Mateh } \\
\text { April. } \\
\text { May } \\
\text { June } \\
\text { July } \\
\text { August } \\
\text { September }\end{array}$ & $\begin{array}{r}16 \\
20 \\
265 \\
75 \\
23 \\
30\end{array}$ & $\begin{array}{r}16 \\
11 \\
17 \\
8 \\
8\end{array}$ & 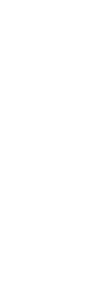 & $\begin{array}{r}984 \\
818 \\
676 \\
615 \\
600 \\
738 \\
3,150 \\
9,840 \\
8,390 \\
2,000 \\
861 \\
1,130\end{array}$ \\
\hline The year. & & & 41.1 & 29,900 \\
\hline $\begin{array}{l}\text { October. } \\
\text { November. } \\
\text { December. } \\
\text { January } \\
\text { February } \\
\text { March } \\
\text { April } \\
\text { May } \\
\text { June } \\
\text { July } \\
\text { August } \\
\text { September }\end{array}$ & $\begin{array}{r}21 \\
24 \\
16 \\
63 \\
246 \\
790 \\
650 \\
163 \\
56 \\
30\end{array}$ & \begin{tabular}{r|r|}
16 \\
12 \\
14 \\
80 \\
182 \\
190 \\
56 \\
39 \\
16
\end{tabular} & $\begin{array}{r}16 \\
17 \\
14 \\
\times \quad 11 \\
\times \quad 12 \\
27 \\
169 \\
479 \\
367 \\
83 \\
40 \\
21\end{array}$ & $\begin{array}{r}984 \\
1,010 \\
861 \\
676 \\
666 \\
1,660 \\
10,100 \\
29,500 \\
21,800 \\
5,100 \\
2,460 \\
1,250\end{array}$ \\
\hline The year...... & 790 & - & 105 & 76,100 \\
\hline
\end{tabular}

- Estimated.

\section{IAKB FORK AT IAKE CTTY, COLO.}

Location.-In sec. 34, T. 44 N., R. 4 W., at private bridge a third of a mile mile above Henson Creek, in Lake City, Hinsdale County.

Drainage area.-126 square miles (measured on topographic map).

Ricords available.-October 1, 1917, to September 30, 1924.

GAGE.-Vertical staff.

Contror.-Somewhat shifting at long intervals. 
Extremes of discharge.-Maximum stage recorded during period, 3.0 feet at 8 a. $\mathrm{m}$. June 16 and 17, 1921 (discharge, 1,560 second-feet); minimum stage recorded, 0.42 foot October 15,1922 (discharge, 10 second-feet).

Drversions.- Practically none above station.

Reguration.-Flow naturally regulated by Lake San Cristobal, 4 miles upstream; area 1 square mile.

Accuracy.-Gage read twice daily. Rating curves well defined. Records good.

Monthly discharge of Lake Fork at Lake City, Colo., for 1917-1924

\begin{tabular}{|c|c|c|c|c|}
\hline \multirow{2}{*}{ Month } & \multicolumn{3}{|c|}{ Diseharge in second-feet } & \multirow{2}{*}{$\begin{array}{l}\text { Run-off in } \\
\text { acre-feet }\end{array}$} \\
\hline & Maximum & Minimum & Mean & \\
\hline $\begin{array}{l}\text { October } \\
\text { November } \\
\text { December } \\
\text { January } \\
\text { February } \\
\text { March } \\
\text { April } \\
\text { May } \\
\text { June } \\
\text { July } \\
\text { August } \\
\text { September }\end{array}$ & $\begin{array}{r}0 . \\
60 \\
756 \\
212 \\
103 \\
186\end{array}$ & $\begin{array}{r}70 \\
193 \\
66 \\
55 \\
50\end{array}$ & $\begin{array}{c}=35 \\
a 25 \\
a 20 \\
a 18 \\
a 16 \\
a 15 \\
27 \\
208 \\
497 \\
147 \\
78.2 \\
91.6\end{array}$ & $\begin{array}{r}2,150 \\
1,490 \\
1,230 \\
1,110 \\
880 \\
922 \\
1,610 \\
12,800 \\
29,960 \\
9,040 \\
4,810 \\
5,450\end{array}$ \\
\hline ear............. & 756 & $\cdots$ & 98.0 & 71,100 \\
\hline $\begin{array}{l}\text { Oetober- } \\
\text { November } \\
\text { December } \\
\text { January } \\
\text { Pebruary } \\
\text { March } \\
\text { April. } \\
\text { May } \\
\text { June } \\
\text { July } \\
\text { August } \\
\text { September. }\end{array}$ & 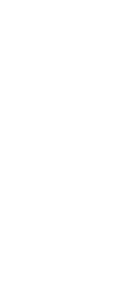 & $\begin{array}{r}29 \\
22 \\
12 \\
84 \\
261 \\
136 \\
52 \\
43\end{array}$ & $\begin{array}{c}35.3 \\
26.4 \\
a 18 \\
-16 \\
-14 \\
a 13 \\
48.9 \\
348 \\
508 \\
279 \\
113 \\
65.1\end{array}$ & $\begin{array}{r}2,170 \\
1,570 \\
1,110 \\
984 \\
.778 \\
700 \\
2,900 \\
21,000 \\
17,000 \\
17,000 \\
6,960 \\
3,280\end{array}$ \\
\hline year.............. & 780 & $\ldots \ldots$ & 123 & 89,400 \\
\hline $\begin{array}{l}\text { Ootober } \\
\text { November } \\
\text { Docember } \\
\text { January } \\
\text { February } \\
\text { March } \\
\text { April } \\
\text { May } \\
\text { June } \\
\text { July } \\
\text { August } \\
\text { September }\end{array}$ & $\begin{array}{r}47 \\
28 \\
9 \\
34 \\
780 \\
900 \\
560 \\
172 \\
61\end{array}$ & $\begin{array}{r}24 \\
18 \\
12 \\
12 \\
21 \\
560 \\
169 \\
57 \\
20\end{array}$ & $\begin{array}{c}33.1 \\
21.7 \\
a 17 \\
a 16 \\
a 18 \\
20.6 \\
17.7 \\
312 \\
677 \\
313 \\
105 \\
33.7\end{array}$ & $\begin{array}{r}2,040 \\
1,290 \\
1,050 \\
984 \\
1,040 \\
1,270 \\
1,050 \\
19,200 \\
40,800 \\
19,200 \\
6,400 \\
3,010\end{array}$ \\
\hline The year......... & 900 & 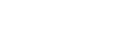 & 132 & 96,600 \\
\hline $\begin{array}{l}\text { October } \\
\text { November } \\
\text { December. } \\
\text { January } \\
\text { Tebruary } \\
\text { March } \\
\text { April } \\
\text { May } \\
\text { June } \\
\text { July } \\
\text { August } \\
\text { Deptember }\end{array}$ & 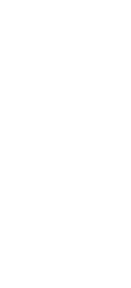 & \begin{tabular}{|r|r|}
31 \\
29 \\
21 \\
54 \\
470 \\
310 \\
112 \\
50
\end{tabular} & $\begin{array}{c}38.6 \\
33.3 \\
18.9 \\
19 \\
19 \\
17 \\
222.0 \\
37.0 \\
253 \\
950 \\
440 \\
185 \\
97.4\end{array}$ & $\begin{array}{r}2,370 \\
1,980 \\
1,160 \\
1,170 \\
1,940 \\
1,850 \\
2,200 \\
1,600 \\
56,500 \\
27,100 \\
\mathbf{1 1}, 400 \\
5,800\end{array}$ \\
\hline The year. & 1,560 & " & 176 & 128,000 \\
\hline
\end{tabular}

- Inotimatod. 
Monthly discharge of Lake Fork at Lake City, Cobo., for 1917-1994-Continued

\begin{tabular}{|c|c|c|c|c|}
\hline \multirow{2}{*}{ Month } & \multicolumn{3}{|c|}{ Discharge in second-feet } & \multirow{2}{*}{$\begin{array}{c}\text { Run-ofi in } \\
\text { acre-feet }\end{array}$} \\
\hline & Maximum & Minimuin & Mean & \\
\hline $\begin{array}{l}\text { October. } \\
\text { November } \\
\text { December } \\
\text { January. } \\
\text { February } \\
\text { Mareh } \\
\text { April } \\
\text { May } \\
\text { June } \\
\text { July } \\
\text { August } \\
\text { September }\end{array}$ & $\begin{array}{r}50 \\
30 \\
31\end{array}$ & $\begin{array}{r}24 \\
17 \\
13 \\
169 \\
162 \\
114 \\
58 \\
20\end{array}$ & $\begin{array}{r}39.3 \\
28.0 \\
22.2 \\
-13.7 \\
13.2 \\
13.1 \\
58.0 \\
340 \\
71 \\
2.3 \\
34.0\end{array}$ & $\begin{array}{r}2,490 \\
1,370 \\
1,360 \\
890 \\
733 \\
867 \\
3,460 \\
22,500 \\
44,100 \\
14,900 \\
5,720 \\
2,000\end{array}$ \\
\hline The year.............. & 1,000 & & 189 & 100,030 \\
\hline $\begin{array}{l}\text { October. } \\
\text { November } \\
\text { December, } \\
\text { January } \\
\text { Bebruary } \\
\text { March } \\
\text { April } \\
\text { May } \\
\text { June } \\
\text { July. } \\
\text { August } \\
\text { September }\end{array}$ & $\begin{array}{r}36 \\
23 \\
84 \\
700 \\
755 \\
498 \\
335 \\
105\end{array}$ & $\begin{array}{r}10 \\
11 \\
12 \\
44 \\
409 \\
158 \\
92 \\
61\end{array}$ & $\begin{array}{l}18.1 \\
15.3 \\
114 \\
.14 \\
18 \\
12 \\
28.5 \\
26.1 \\
564 \\
389 \\
175 \\
80.3\end{array}$ & $\begin{array}{r}1,110 \\
910 \\
861 \\
861 \\
722 \\
788 \\
1,700 \\
16,000 \\
33,600 \\
20,800 \\
10,800 \\
4,780\end{array}$ \\
\hline The year............. & 755 & & 128 & $\mathbf{2 2}$ \\
\hline $\begin{array}{l}\text { October } \\
\text { November } \\
\text { December } \\
\text { January } \\
\text { Tebruary } \\
\text { March } \\
\text { April } \\
\text { May } \\
\text { June } \\
\text { July } \\
\text { August } \\
\text { Beptamber }\end{array}$ & 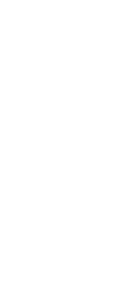 & $\begin{array}{r}27 \\
215 \\
78 \\
78 \\
18 \\
18\end{array}$ & $\begin{array}{c}34.7 \\
81 \\
-22 \\
-18 \\
-15 \\
\cdot 14 \\
70.5 \\
819 \\
578 \\
179 \\
45.5 \\
18.7\end{array}$ & $\begin{array}{r}8,980 \\
1,840 \\
1,340 \\
1,110 \\
863 \\
801 \\
4,210 \\
19,600 \\
84,100 \\
11,000 \\
2,800 \\
1,110\end{array}$ \\
\hline The year. & 1,150 & 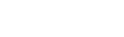 & 114 & 82,800 \\
\hline
\end{tabular}

- Estimated.

HBTsOT ORER AT LAKE CTT, COTO.

Locatron.-In sec. 34, T. 44 N., R. 4 W., at first highway bridge above mouth

in Lake City, Hinsdale County. No tributary between station and mouth

a quarter of a mile below.

Drainage arma.-83 square miles (measured on topographic map).

Rieconds avallable.-April 21, 1918, to September 30, 1919.

GAGE.- Vertical steff on pile abutment.

ConTroL.-Shifting during high water.

Extremes of Discharge.-Maximum discharge recorded, 1,180 second-feet at

6 p. m. June 11, 1918; minimum discharge occurred during winter.

Drversions.-Practically none that do not return water to creek above station. Accuracr.-Gage read twice daily. Rating curve not well defined. Records fair. 
Monthly discharge of Henson Creek at Lake City, Calo., for 1918-19

\begin{tabular}{|c|c|c|c|c|}
\hline \multirow{2}{*}{ Month } & \multicolumn{3}{|c|}{ Discharge in second-feet } & \multirow{2}{*}{$\underset{\text { acre-feet }}{\text { Run-off in }}$} \\
\hline & Maximum & Minimum & Mean & \\
\hline $\begin{array}{l}\text { April } 21-30 \\
\text { May } \\
\text { June } \\
\text { July } \\
\text { August } \\
\text { September }\end{array}$ & $\begin{array}{r}78 \\
384 \\
896 \\
221 \\
130 \\
186\end{array}$ & $\begin{array}{r}24 \\
94 \\
202 \\
76 \\
36 \\
30\end{array}$ & $\begin{array}{l}47.0 \\
250 \\
539 \\
145 \\
88.0 \\
70.4\end{array}$ & $\begin{array}{r}982 \\
15,400 \\
32,100 \\
8,920 \\
5,410 \\
4,190\end{array}$ \\
\hline The period.. & $\cdots$ & $\ldots$ & - & 67,000 \\
\hline $\begin{array}{l}\text { October } \\
\text { November } \\
\text { December } \\
\text { January } \\
\text { February } \\
\text { March } \\
\text { April } \\
\text { May } \\
\text { June } \\
\text { July } \\
\text { Auguist } \\
\text { September }\end{array}$ & $\begin{array}{r}34 \\
142 \\
678 \\
588 \\
440 \\
210 \\
93\end{array}$ & $\begin{array}{r}21 \\
\\
17 \\
131 \\
258 \\
154 \\
56 \\
37\end{array}$ & $\begin{array}{c}33.9 \\
29 \\
220 \\
218 \\
-15 \\
17 \\
61.5 \\
343 \\
447 \\
270 \\
121 \\
60.9\end{array}$ & $\begin{array}{r}2,080 \\
1,730 \\
1,230 \\
1,110 \\
833 \\
1,040 \\
3,660 \\
21,100 \\
26,600 \\
16,600 \\
7,440 \\
\mathbf{8 , 6 2 0}\end{array}$ \\
\hline The year.- & . 678 & -............... & 120 & 87,000 \\
\hline
\end{tabular}

- Estimated.

CIMARRON CREBK AT CMMARRON, COLO.

Location.-In sec. 5, T. 48 N., R. 6 W., 1,200 feet above railroad station at Cimarron, Montrose County. Nearest tributary, Squaw Creek, enters near railrgad station.

Dratnage area.-212 square miles (measured on topographic maps).

ReCords aVaIlable.-October 1, 1902, to November 30, 1905.

GAGE.-Vertical staff.

Controu.-Shifting during high water.

Extremes of Discharge.-Maximum stage recorded, 4.3 feet at 8 a. m. June 5, 1905 (discharge, 1,300 second-feet); minimum discharge recorded, 20 secondfeet on September 16, 1905.

Accoracr.-Gage read twice daily. Rating curves well defined. Records good.

Monthly discharge of Cimarron Creek at Cimarron, Colo., for 1902-1905

\begin{tabular}{|c|c|c|c|c|}
\hline \multirow{2}{*}{ Month } & \multicolumn{3}{|c|}{ Discharge in second-feet } & \multirow{2}{*}{$\begin{array}{l}\text { Run-off in } \\
\text { acre-feet }\end{array}$} \\
\hline & Maximum & Minimum & Meán & \\
\hline $\begin{array}{l}\text { October. } \\
\text { November } \\
\text { December- } \\
\text { January } \\
\text { February } \\
\text { March } \\
\text { April } \\
\text { May } \\
\text { June } \\
\text { July } \\
\text { August } \\
\text { September }\end{array}$ & $\begin{array}{r}729 \\
1,000 \\
391 \\
187 \\
\mathbf{3 1 1}\end{array}$ & $\begin{array}{r}231 \\
310 \\
218 \\
48 \\
32\end{array}$ & $\begin{array}{r}635 \\
830 \\
630 \\
625 \\
235 \\
635 \\
660 \\
401 \\
\quad 596 \\
322 \\
104 \\
106\end{array}$ & $\begin{array}{r}2,150 \\
1,790 \\
1,840 \\
1,540 \\
1,890 \\
2,150 \\
3,870 \\
.24,700 \\
35,500 \\
19,800 \\
6,400 \\
6,310\end{array}$ \\
\hline The year. & 1,000 & - & 148 & 107,000 \\
\hline
\end{tabular}

- Estimated. 
Monthly discharge of Cimarron Creek at Cimarron, Colo., for 190\%-1905-Continued

\begin{tabular}{|c|c|c|c|c|}
\hline \multirow{2}{*}{ Month } & \multicolumn{3}{|c|}{ Discharge in second-feet } & \multirow{2}{*}{ Run-off in } \\
\hline & Maximum & Minimum & Mean & \\
\hline $\begin{array}{l}\text { October } \\
\text { November } \\
\text { December } \\
\text { January } \\
\text { February } \\
\text { March } \\
\text { April } \\
\text { May } \\
\text { June } \\
\text { July } \\
\text { August } \\
\text { September }\end{array}$ & $\begin{array}{r}94 \\
125 \\
262 \\
693 \\
785 \\
168 \\
290 \\
310\end{array}$ & $\begin{array}{r}32 \\
60 \\
40 \\
127 \\
199 \\
64 \\
29 \\
48\end{array}$ & $\begin{array}{c}59 \\
69 \\
\times 50 \\
440 \\
435 \\
50 \\
135 \\
387 \\
402 \\
108 \\
105 \\
91.1\end{array}$ & $\begin{array}{r}3,630 \\
4,110 \\
3,070 \\
2,460 \\
2,010 \\
3,070 \\
8,030 \\
23,800 \\
23,900 \\
6,640 \\
6,460 \\
.640\end{array}$ \\
\hline The year. & 785 & (n) & 128 & 92,600 \\
\hline $\begin{array}{l}\text { October } \\
\text { November } \\
\text { December } \\
\text { January } \\
\text { February } \\
\text { March } \\
\text { April } \\
\text { May } \\
\text { June } \\
\text { July } \\
\text { August }\end{array}$ & $\begin{array}{r}111 \\
56 \\
\\
\\
65 \\
181 \\
796 \\
1,260 \\
397 \\
213 \\
93\end{array}$ & \begin{tabular}{|r}
33 \\
\\
\end{tabular} & $\begin{array}{c}68.6 \\
31 \\
\times 30 \\
a 30 \\
a 30 \\
47 \\
57.5 \\
389 \\
796 \\
185 \\
59.4 \\
32.4\end{array}$ & $\begin{array}{r}4,220 \\
1,840 \\
1,840 \\
1,840 \\
1,670 \\
2,800 \\
3,420 \\
23,000 \\
47,400 \\
11,400 \\
3,650 \\
1,930\end{array}$ \\
\hline The year. & 1,260 & (n) & 147 & 106,000 \\
\hline $\begin{array}{l}\text { October } 1905 \\
\text { November }\end{array}$ & $\begin{array}{l}65 \\
32\end{array}$ & $\begin{array}{l}24 \\
22\end{array}$ & $\begin{array}{l}33.4 \\
26.7\end{array}$ & $\begin{array}{l}2,050 \\
1,590\end{array}$ \\
\hline
\end{tabular}

- Estimated.

Note.-Records from June 10 to July 27,1903 , based on two discharge measurements and comparison with discharge of Uncompahgre River near Colona.

\section{CRYSTAL CREGK NRAR MAHER, colo.}

LOCATION.-In sec. 35, T. 50 N., R. 6 W., at bridge 300 feet above head gate of Fruitland Irrigation Co.'s ditch, 8 miles southeast of Maher, Montrose County. Nearest tributary, North Fork, enters 1 mile upstream.

Drainage area.-26 square miles (measured on Forest Service map).

Records available.-October 1, 1916, to September 30, 1919.

GaGE.-Vertical staff.

Controu.-Shifting at long intervals.

Extremes of Discharge.-Maximum stage recorded, 3.2 feet at 8.30 p. m. July 13, 1917 (discharge, 419 second-feet); minimum stage, creek practically dry in August, 1918.

Diversions.-Above station Cedar Canyon and Iron Springs ditch diverts water for 6,400 acres.

AccoracY.-Gage read twice daily. Rating curves fairly well defined. Records good, except during low-water periods, for which they are fair.

Cooperation.-Station maintained in cooperation with Fruitland Irrigation Co. 
Monthly discharge of Crystal Creek near Maher, Colo., for 1916-1919

\begin{tabular}{|c|c|c|c|c|}
\hline \multirow{2}{*}{ Month } & \multicolumn{3}{|c|}{ Discharge in second-foet } & \multirow{2}{*}{$\begin{array}{c}\text { Run-ofi in } \\
\text { acre-feet }\end{array}$} \\
\hline & Maximum & Minimum & Mean & \\
\hline $\begin{array}{l}\text { October } \\
\text { November } \\
\text { December. } \\
\text { January } \\
\text { Pebruary } \\
\text { March } \\
\text { April } \\
\text { May } \\
\text { June } \\
\text { July } \\
\text { August } \\
\text { September }\end{array}$ & $\begin{array}{c}187 \\
332 \\
405 \\
107 \\
0.5 \\
16\end{array}$ & 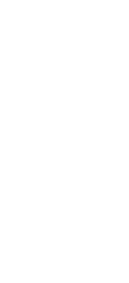 & $\begin{array}{l}.8 \\
5 \\
54 \\
.4 \\
.4 \\
5 \\
36 \\
132 \\
282 \\
14.7 \\
.31 \\
\text { b. } 37\end{array}$ & $\begin{array}{r}493 \\
208 \\
246 \\
246 \\
220 \\
307 \\
2,140 \\
8,120 \\
16,800 \\
904 \\
19 \\
320\end{array}$ \\
\hline The year. . . & 405 & .1 & 41.6 & 30,100 \\
\hline $\begin{array}{l}\text { October. } \\
\text { November. } \\
\text { December. } \\
\text { January } \\
\text { February. } \\
\text { March } \\
\text { April. } \\
\text { May. } \\
\text { June } \\
\text { July } \\
\text { August } \\
\text { September }\end{array}$ & $\begin{array}{c}15 \\
8 \\
171 \\
157 \\
121 \\
10 \\
4 \\
40\end{array}$ & $\begin{array}{r}5 \\
35 \\
56 \\
2 \\
1 \\
0 \\
4\end{array}$ & $\begin{array}{c}12.4 \\
5.3 \\
a 4 \\
.4 \\
.5 \\
30 \\
92.4 \\
108 \\
55.2 \\
4.2 \\
1.3 \\
6.8\end{array}$ & $\begin{array}{r}762 \\
315 \\
246 \\
246 \\
278 \\
1,840 \\
5,500 \\
6,640 \\
3,280 \\
288 \\
80 \\
406\end{array}$ \\
\hline 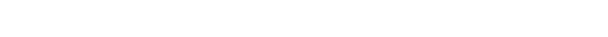 & 171 & 0 & 27.4 & 19,800 \\
\hline $\begin{array}{l}\text { October. } \\
\text { November. } \\
\text { December. } \\
\text { January } \\
\text { February } \\
\text { March } \\
\text { April } \\
\text { May } \\
\text { June } \\
\text { July } \\
\text { August } \\
\text { September }\end{array}$ & $\begin{array}{r}8 \\
11 \\
273 \\
237 \\
78 \\
9 \\
18 \\
4\end{array}$ & 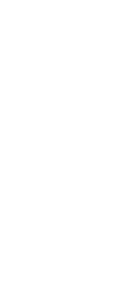 & $\begin{array}{c}5.7 \\
5.8 \\
\times 3 \\
33 \\
63 \\
18 \\
120 \\
163 \\
36.0 \\
3.7 \\
3.1 \\
3.0\end{array}$ & $\begin{array}{r}350 \\
345 \\
184 \\
184 \\
167 \\
1,110 \\
7,149 \\
10,000 \\
2,140 \\
228 \\
191 \\
179\end{array}$ \\
\hline The year. & 273 & $\ldots$ & 30.7 & 22,200 \\
\hline
\end{tabular}

- Estimated.

MORTH FORK OF GUNNISON RTVR TEAR PAONIA, OOLO.

Locatron.-In sec. 18, T. 13 S., R. 91 W., at highway bridge 2 miles northeast of Paonia, Delta County. Nearest tributary, Minnesota Creek, enters a short distance below.

Drainage AREA.-702 square miles.

Records avatlable.-January 1, 1922, to September 30, 1927.

GAGE.-Chain on bridge.

ConTrol.-Slightly shifting.

Extremes of Discharge.-Maximum stage recorded, 6.9 feet at 5 p. m. May 6 and 8 a. m. and 5 p. m. May 7, 1922 (discharge, 5,130 second-feet); minimum discharge, 2 second-feet September 1, 1926.

Diversions.-Fire Mountain Canal diverts water from North Fork above station for irrigation of 5,000 acres.

Cooperation.-Complete records furnished by State engineer. 
Monthly disoharge of North Fork of Gunnison River near Paonia, Colo., for 19811987

\begin{tabular}{|c|c|c|c|c|}
\hline \multirow{2}{*}{ Month } & \multicolumn{3}{|c|}{ Discharge in second-feet } & \multirow{2}{*}{$\begin{array}{l}\text { Run-ofi in } \\
\text { acre-feet }\end{array}$} \\
\hline & Maximam & Minimum & Mean & \\
\hline $\begin{array}{l}\text { Odtober } \\
\text { November } \\
\text { December } \\
\text { January } \\
\text { February } \\
\text { March } \\
\text { Apiril } \\
\text { Jay } \\
\text { June } \\
\text { Jugust } \\
\text { September }\end{array}$ & $\begin{array}{r}127 \\
118 \\
345 \\
2,970 \\
5,130 \\
2,940 \\
682 \\
183 \\
18\end{array}$ & \begin{tabular}{r|}
49 \\
48 \\
39 \\
118 \\
2,080 \\
782 \\
31 \\
5.2 \\
3.3
\end{tabular} & $\begin{array}{c}* 69 \\
* 70 \\
* 65 \\
80.7 \\
77.8 \\
127 \\
793 \\
3,620 \\
1,830 \\
230 \\
45.7 \\
8.73\end{array}$ & $\begin{array}{r}3,690 \\
4,170 \\
4,000 \\
4,000 \\
4,320 \\
7,810 \\
47,200 \\
223,000 \\
116,000 \\
14,100 \\
2,810 \\
510\end{array}$ \\
\hline The year & $\mathbf{5}, 130$ & 3.3 & 597 & 432,000 \\
\hline $\begin{array}{l}\text { October } \\
\text { November } \\
\text { December } \\
\text { January } \\
\text { Pobruary } \\
\text { March } \\
\text { April } \\
\text { May } \\
\text { June. }\end{array}$ & \begin{tabular}{r|r|}
52 \\
112 \\
175 \\
1,620 \\
4,290 \\
3,440 \\
1,300 \\
$\mathbf{4 6 4}$ \\
53
\end{tabular} & \begin{tabular}{|c|}
20 \\
52 \\
142 \\
1,400 \\
1,440 \\
112 \\
16 \\
16
\end{tabular} & $\begin{array}{l}12.3 \\
74.9 \\
80 \\
=75 \\
8.0 \\
92.8 \\
693 \\
3,050 \\
2,240 \\
630 \\
154 \\
27.9\end{array}$ & $\begin{array}{r}567 \\
4,460 \\
4,920 \\
4,610 \\
4,440 \\
5,710 \\
41,200 \\
188,000 \\
133,000 \\
38,700 \\
0,470 \\
1,660\end{array}$ \\
\hline The year... & 4,230 & 5 & $603^{\prime}$ & 437,000 \\
\hline $\begin{array}{l}\text { October } \\
\text { November } \\
\text { December } \\
\text { January } \\
\text { February } \\
\text { March } \\
\text { April } \\
\text { May } \\
\text { June } \\
\text { July } \\
\text { August } \\
\text { September }\end{array}$ & $\begin{array}{r}193 \\
110 \\
110 \\
148 \\
78 \\
1,740 \\
3,040 \\
2,740 \\
382 \\
15 \\
8\end{array}$ & $\begin{array}{r}69 \\
78 \\
78 \\
54 \\
42 \\
48 \\
1,190 \\
452 \\
12 \\
5 \\
5\end{array}$ & $\begin{array}{c}117 \\
91.2 \\
89.5 \\
681 \\
88.3 \\
61.1 \\
603 \\
2,370 \\
1,530 \\
151 \\
8.08 \\
6.77\end{array}$ & $\begin{array}{r}7,190 \\
5,430 \\
5,500 \\
5,160 \\
5,080 \\
3,760 \\
35,900 \\
146,000 \\
91,000 \\
9,280 \\
494 \\
403\end{array}$ \\
\hline The year......... & 3,040 & 5 & 435 & 315,000 \\
\hline $\begin{array}{l}\text { October. } \\
\text { November } \\
\text { December } \\
\text { January. } \\
\text { February } \\
\text { March } \\
\text { April } \\
\text { May } \\
\text { June } \\
\text { July } \\
\text { August. } \\
\text { September }\end{array}$ & \begin{tabular}{r|r|}
201 \\
136 \\
2,210 \\
2,040 \\
1,340 \\
435 \\
350 \\
884
\end{tabular} & \begin{tabular}{r|r|}
13 \\
58 \\
100 \\
391 \\
1,220 \\
481 \\
27 \\
19 \\
50
\end{tabular} & $\begin{array}{c}106 \\
96.5 \\
\cdot 75 \\
75 \\
110 \\
205 \\
1,150 \\
1,640 \\
934 \\
103 \\
104 \\
167\end{array}$ & $\begin{array}{r}6,520 \\
5,740 \\
4,610 \\
4,610 \\
6,110 \\
12,600 \\
68,400 \\
101,000 \\
55,600 \\
11,900 \\
6,400 \\
0,940\end{array}$ \\
\hline The year. & 2,210 & 13 & 406 & 293,000 \\
\hline
\end{tabular}

- Estimated. 
Monthly discharge of North Fork of Gunnison River near Paonia, Colo., for 19211927-Continued

\begin{tabular}{|c|c|c|c|c|}
\hline \multirow{2}{*}{ Month } & \multicolumn{3}{|c|}{ Discharge in second-feet } & \multirow{2}{*}{$\begin{array}{l}\text { Run-off in } \\
\text { acro-feet }\end{array}$} \\
\hline & Maximum & Minimum & Mean & \\
\hline $\begin{array}{l}\text { October-a } \\
\text { November } \\
\text { Docember } \\
\text { January } \\
\text { February- } \\
\text { March } \\
\text { Aprtl } \\
\text { May } \\
\text { June } \\
\text { July } \\
\text { August } \\
\text { September }\end{array}$ & $\begin{array}{r}259 \\
150 \\
80 \\
388 \\
2,670 \\
3,440 \\
2,460 \\
736 \\
119 \\
13 \\
\end{array}$ & \begin{tabular}{|r|}
60 \\
52 \\
1,180 \\
504 \\
60 \\
3 \\
2 \\
2 \\
\end{tabular} & $\begin{array}{c}138 \\
a 86.4 \\
a 75 \\
70 \\
65.5 \\
199 \\
1,330 \\
2,240 \\
1,410 \\
\quad 317 \\
37.1 \\
6.27\end{array}$ & $\begin{array}{r}8,480 \\
5,140 \\
4,610 \\
4,300 \\
3,640 \\
12,200 \\
79,100 \\
138,000 \\
83,900 \\
19,500 \\
2,280 \\
373\end{array}$ \\
\hline The year... & 3,440 & 2 & 500 & 362,000 \\
\hline $\begin{array}{l}\text { October } \\
\text { November } \\
\text { December } \\
\text { January } \\
\text { February } \\
\text { March } \\
\text { April } \\
\text { May } \\
\text { June } \\
\text { July } \\
\text { August } \\
\text { September. }\end{array}$ & $\begin{array}{r}424 \\
3,250 \\
4,500 \\
2,670 \\
1,220 \\
410 \\
410 \\
\end{array}$ & $\begin{array}{r}87 \\
301 \\
1,870 \\
1,180 \\
119 \\
13 \\
10 \\
\end{array}$ & $\begin{array}{c}95.5 \\
89.6 \\
a 88 \\
a 85 \\
a 90 \\
162 \\
1,080 \\
3,250 \\
1,810 \\
453 \\
172 \\
151\end{array}$ & $\begin{array}{r}5,870 \\
5,330 \\
5,410 \\
5,230 \\
5,000 \\
9,960 \\
64,300 \\
200,000 \\
108,000 \\
27,900 \\
10,600 \\
8,980\end{array}$ \\
\hline The year.. & 4,500 & 6 & 631 & 457,000 \\
\hline
\end{tabular}

a Estimated.

NORTH FORK OF GUNNISON RIVER IEAR HOTCHKISS, COLO.

Location.-About sec. 2, T. 15 S., R. 93 W., 3 miles southwest of Hotchkiss, Delta County. Nearest tributary, Leroux Creek, enters just below Hotchkiss.

Drainage area.-835 square miles at 1903 section; 933 square miles at 19041905 section (measured on base map of Colorado).

Records available.-May 1, 1903, to December 31, 1905.

GAGE.-Inclined staff; during 1903 vertical staff on highway bridge at Hotchkiss.

CoNTROL.-Shifting during extremely high water.

ExTREMes OF Discharge.-Maximum stage recorded, 6.3 feet at 6.30 a. m. May 23, 24, and June 5. 1905 (discharge 8,140 second-feet); minimum stage, 1.15 feet on September 3, 1905 (discharge, 5 second-feet).

Diversions.-Water diverted from North Fork, practically all above station, for irrigation of 9,400 acres, also diversion from tributaries entering above station for irrigation of 35,000 acres.

AccuracY.-Gage read twice daily. Rating curves well defined. Records good except during 1903, for which they are fair. 
Monthly discharge of North Fork of Gunnison River near Hotchkiss, Colo., 1903-1905

\begin{tabular}{|c|c|c|c|c|}
\hline \multirow{2}{*}{ Month } & \multicolumn{3}{|c|}{ Discharge in second-feet } & \multirow{2}{*}{$\begin{array}{l}\text { Run-off in } \\
\text { acre-feet }\end{array}$} \\
\hline & Maximum & Minimum & Mean & \\
\hline $\begin{array}{l}\text { May } \\
\text { June } \\
\text { Juty } \\
\text { August } \\
\text { September }\end{array}$ & $\begin{array}{r}4,540 \\
5,820 \\
1,820 \\
148 \\
\mathbf{3 7 1}\end{array}$ & $\begin{array}{r}1,400 \\
2,390 \\
162 \\
45 \\
45\end{array}$ & $\begin{array}{r}2,710 \\
3,740 \\
686 \\
73 \\
142\end{array}$ & $\begin{array}{r}167,000 \\
223,000 \\
42,200 \\
4,490 \\
8,400\end{array}$ \\
\hline The period......... & & & $-\infty$ & $\quad 445,000$ \\
\hline $\begin{array}{l}\text { October. } \\
\text { November } \\
\text { December. } \\
\text { January } \\
\text { February. } \\
\text { March } \\
\text { April } \\
\text { May } \\
\text { June } \\
\text { July } \\
\text { August } \\
\text { September. }\end{array}$ & $\begin{array}{r}133 \\
108 \\
2,120 \\
2,970 \\
1,630 \\
459 \\
311 \\
550\end{array}$ & $\begin{array}{r}88 \\
88 \\
1,220 \\
520 \\
52 \\
85 \\
72\end{array}$ & $\begin{array}{r}107 \\
97 \\
105 \\
100 \\
109 \\
133 \\
850 \\
2,040 \\
1,100 \\
180 \\
166 \\
174\end{array}$ & $\begin{array}{r}6,580 \\
5,770 \\
6,460 \\
6,150 \\
6,270 \\
8,180 \\
50,600 \\
126,000 \\
65,600 \\
11,100 \\
10,200 \\
10,400\end{array}$ \\
\hline 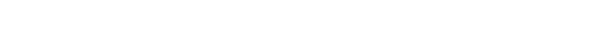 & 2,970 & 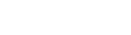 & 430 & 313,000 \\
\hline $\begin{array}{l}\text { October } \\
\text { November } \\
\text { December. } \\
\text { January } \\
\text { February } \\
\text { March } \\
\text { April } \\
\text { May } \\
\text { June } \\
\text { July } \\
\text { August } \\
\text { September }\end{array}$ & $\begin{array}{r}395 \\
144 \\
133 \\
170 \\
190 \\
460 \\
3,640 \\
7,300 \\
7,160 \\
1,340 \\
500 \\
142\end{array}$ & $\begin{array}{r}133 \\
116 \\
85 \\
110 \\
120 \\
240 \\
252 \\
1,920 \\
1,480 \\
190 \\
8 \\
5\end{array}$ & $\begin{array}{c}239 \\
119 \\
109 \\
126 \\
146 \\
292 \\
1,160 \\
4,480 \\
3,990 \\
577 \\
125 \\
27.5\end{array}$ & $\begin{array}{r}14,700 \\
7,080 \\
6,700 \\
7,750 \\
8,110 \\
18,000 \\
69,100 \\
275,000 \\
237,000 \\
35,500 \\
7,690 \\
1,640\end{array}$ \\
\hline The year. & 7,300 & 5 & 950 & 688,000 \\
\hline $\begin{array}{l}\text { October } 1905 \\
\text { November } \\
\text { December }\end{array}$ & $\begin{array}{l}163 \\
210 \\
135\end{array}$ & $\begin{array}{r}75 \\
90 \\
100\end{array}$ & $\begin{array}{l}108 \\
121 \\
110\end{array}$ & $\begin{array}{l}6,640 \\
7,200 \\
6,760\end{array}$ \\
\hline
\end{tabular}

- Estimated.

\section{LEROUX ORGEK NEAR IAZEAR, COLO.}

Location.-In sec. 33, T. 13 S., R. 93 W., at highway bridge 8 miles north of Lazear, Delta County. No important tributary within several miles.

Drainage area. - 52 square miles (measured on Forest Service map).

Records avallable.-May 15, 1917, to September 30, 1926.

GAGE.-Lallie and Stevens water-stage recorders.

Control.-Shifting during high water.

EXTREMEs of DISCHARGE.- Maximum stage recorded during period, 4.0 feet at

5 p. m. May 29, 1921 (discharge, 1,420 second-feet); minimum stage, creek practically dry during winter, as water is stored in reservoirs.

Diversions.-Water diverted for irrigation of 8,000 acres above station and 5,500 acres below.

Accuracy.-Gage heights from continuous records. Rating curves well defined. Records good.

Cooperation.-Complete records furnished by State engineer since 1921. 
Monthly discharge of Leroux Cresk near Lazear, Colo., for 1917-1926

\begin{tabular}{|c|c|c|c|c|}
\hline & \multicolumn{3}{|c|}{ Discharge in second-feet } & \multirow{2}{*}{ Run-off in } \\
\hline & Maximum & Minimum & Mean & \\
\hline $\begin{array}{l}\text { May } 15-31 \\
\text { June }\end{array}$ & $\begin{array}{r}310 \\
1,300 \\
\end{array}$ & $\begin{array}{l}77 \\
00\end{array}$ & $\begin{array}{l}210 \\
735 \\
\end{array}$ & $\begin{array}{r}7,080 \\
43,700 \\
\end{array}$ \\
\hline $\begin{array}{l}\text { April } 23-30 \ldots \\
\text { May } \\
\text { June } \\
\text { July } \\
\text { August } \\
\text { September }\end{array}$ & $\begin{array}{r}117 \\
665 \\
280 \\
51 \\
20 \\
39\end{array}$ & $\begin{array}{l}42 \\
79 \\
28 \\
12 \\
2.8 \\
2.6\end{array}$ & $\begin{array}{c}74.8 \\
259 \\
127 \\
28.5 \\
10.8 \\
5.59\end{array}$ & $\begin{array}{r}1,100 \\
15,900 \\
7,560 \\
1,750 \\
664 \\
333\end{array}$ \\
\hline The period. & & $-\ldots . .$. & (n............ & 27,400 \\
\hline $\begin{array}{l}\text { October } \\
\text { Novem } \\
\text { Deceminer } \\
\text { Jannary } \\
\text { February } \\
\text { March } \\
\text { April } \\
\text { May } \\
\text { June } \\
\text { July } \\
\text { August } \\
\text { September }\end{array}$ & $\begin{array}{c}9.6 \\
3.4 \\
.4 \\
12 \\
467 \\
368 \\
76 \\
39 \\
16 \\
6.2\end{array}$ & \begin{tabular}{|c}
1.6 \\
1.9 \\
12 \\
120 \\
18 \\
6.6 \\
2.3 \\
2.1
\end{tabular} & $\begin{array}{c}2.59 \\
2.35 \\
23 \\
a 3 \\
a 3 \\
a 3.5 \\
7 \\
121 \\
221 \\
37.9 \\
18.4 \\
8.42 \\
3.51\end{array}$ & $\begin{array}{r}159 \\
140 \\
184 \\
184 \\
196 \\
\mathbf{4 2 5} \\
7,200 \\
13,600 \\
2,260 \\
1,130 \\
518 \\
209\end{array}$ \\
\hline The year... & 467 & $\ldots \ldots$ & 26.2 & 28,290 \\
\hline $\begin{array}{l}\text { October } \\
\text { November } \\
\text { December } \\
\text { January } \\
\text { Pebruary } \\
\text { March } \\
\text { April. }\end{array}$ & $\begin{array}{r}3.0 \\
1.6 \\
6.2 \\
55 \\
998 \\
837 \\
125 \\
81 \\
19\end{array}$ & $\begin{array}{c}.7 \\
.8 \\
3.4 \\
3.4 \\
103 \\
106 \\
14 \\
10 \\
6.0\end{array}$ & $\begin{array}{l}1.89 \\
1.06 \\
a .8 \\
a 1 \\
a 2 \\
3.90 \\
6.82 \\
480 \\
472 \\
42.3 \\
17.7 \\
10.4\end{array}$ & $\begin{array}{r}116 \\
63 \\
49 \\
61 \\
119 \\
240 \\
406 \\
29,500 \\
28,100 \\
2,600 \\
1,090 \\
619\end{array}$ \\
\hline The y & 898 & (n........... & 87.2 & 63,000 \\
\hline $\begin{array}{l}\text { October } \\
\text { November } \\
\text { December } \\
\text { January } \\
\text { Tebruary } \\
\text { March } \\
\text { April } \\
\text { May } \\
\text { June } \\
\text { July } \\
\text { August } \\
\text { September }\end{array}$ & $\begin{array}{r}8.3 \\
\\
\\
20 \\
71 \\
971 \\
830 \\
60 \\
77 \\
41\end{array}$ & \begin{tabular}{|c|}
2.0 \\
7.5 \\
13 \\
103 \\
41 \\
18 \\
9.2 \\
7.9
\end{tabular} & $\begin{array}{c}5.07 \\
01.1 \\
a 2.5 \\
a 3 \\
5.1 \\
12.7 \\
38.0 \\
438 \\
340 \\
32.1 \\
24.5 \\
17.0\end{array}$ & $\begin{array}{r}312 \\
65 \\
153 \\
184 \\
287 \\
781 \\
2,260 \\
26,900 \\
20,200 \\
1,970 \\
1,510 \\
1,010\end{array}$ \\
\hline The year... & 971 & $-\ldots$ & 78.2 & 55,600 \\
\hline $\begin{array}{l}\text { October } \\
\text { November } \\
\text { December } \\
\text { January } \\
\text { February } \\
\text { March } \\
\text { April } \\
\text { May } \\
\text { June } \\
\text { July } \\
\text { August } \\
\text { September }\end{array}$ & $\begin{array}{l}318 \\
856 \\
562 \\
74 \\
22 \\
25\end{array}$ & 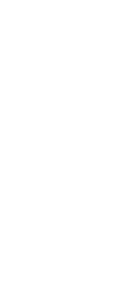 & $\begin{array}{c}3.58 \\
2.51 \\
a 2 \\
a 2 \\
a 2.6 \\
a 3.4 \\
64 \\
464 \\
256 \\
38.4 \\
13.0 \\
4.72\end{array}$ & $\begin{array}{r}220 \\
149 \\
123 \\
123 \\
144 \\
209 \\
3,200 \\
28,500 \\
15,200 \\
2,360 \\
799 \\
281\end{array}$ \\
\hline The year. & 856 & $\ldots \ldots \ldots \ldots$ & 71.0 & 51,300 \\
\hline
\end{tabular}

astimated. 
Monthly discharge of Leroux Creek near Lazear, Colo., for 1917-1926-Continued

\begin{tabular}{|c|c|c|c|c|}
\hline \multirow{2}{*}{ Menth } & \multicolumn{3}{|c|}{ Discharge in second-feet } & \multirow{2}{*}{$\begin{array}{l}\text { Run-off in } \\
\text { acre-feet }\end{array}$} \\
\hline & Maximum & Minimum & Mean & \\
\hline $\begin{array}{l}\text { October. } \\
\text { November } \\
\text { December. } \\
\text { January. } \\
\text { Fobruary } \\
\text { March. } \\
\text { April } \\
\text { May } \\
\text { June. } \\
\text { July } \\
\text { August } \\
\text { Septembar. }\end{array}$ & \begin{tabular}{|r|}
4 \\
4 \\
612 \\
416 \\
46 \\
88 \\
36
\end{tabular} & \begin{tabular}{|c|}
1 \\
1 \\
49 \\
46 \\
25 \\
14 \\
24
\end{tabular} & $\begin{array}{l}2.58 \\
2.90 \\
-3.5 \\
-3.0 \\
=3.5 \\
=4.7 \\
220 \\
328 \\
150 \\
34.0 \\
33.8 \\
28.0\end{array}$ & $\begin{array}{r}159 \\
173 \\
215 \\
184 \\
194 \\
299 \\
1,190 \\
20,000 \\
8,930 \\
2,090 \\
2,080 \\
1,670\end{array}$ \\
\hline 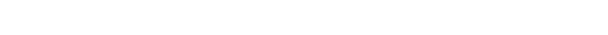 & 612 & 1 & 51.5 & 37,200 \\
\hline $\begin{array}{l}\text { October } \\
\text { November } \\
\text { December. } \\
\text { January } \\
\text { February } \\
\text { March } \\
\text { April } \\
\text { May }\end{array}$ & \begin{tabular}{|r|}
18 \\
18 \\
8 \\
102 \\
544 \\
341 \\
26 \\
10 \\
18
\end{tabular} & \begin{tabular}{|c|} 
\\
4 \\
4 \\
10 \\
10 \\
10 \\
10 \\
1 \\
1
\end{tabular} & $\begin{array}{r}10.3 \\
6.70 \\
4 \\
4 \\
4.1 \\
4.97 \\
26.2 \\
337 \\
93.3 \\
15.5 \\
5.81 \\
3.73\end{array}$ & $\begin{array}{r}628 \\
399 \\
246 \\
240 \\
230 \\
306 \\
1,560 \\
20,700 \\
5,560 \\
863 \\
357 \\
222\end{array}$ \\
\hline The year & 544 & 1 & 43.4 & 31,400 \\
\hline $\begin{array}{l}\text { October. } \\
\text { November } \\
\text { December. } \\
\text { January } \\
\text { February } \\
\text { March. } \\
\text { April. } \\
\text { May } \\
\text { June } \\
\text { July } \\
\text { August } \\
\text { Beptember. }\end{array}$ & \begin{tabular}{|r|}
9.5 \\
5.6 \\
8.5 \\
217 \\
306 \\
168 \\
34 \\
57 \\
233
\end{tabular} & $\begin{array}{r}1.0 \\
1.0 \\
3.8 \\
2.3 \\
4.1 \\
90 \\
30 \\
14 \\
10 \\
16\end{array}$ & $\begin{array}{c}4.13 \\
2.44 \\
2.58 \\
22.4 \\
04.0 \\
4.68 \\
78.2 \\
178 \\
81.2 \\
21.3 \\
29.6 \\
53.9\end{array}$ & $\begin{array}{r}254 \\
145 \\
159 \\
148 \\
222 \\
288 \\
4,650 \\
10,900 \\
4,830 \\
1,310 \\
1,820 \\
3,210\end{array}$ \\
\hline The year. & 306 & 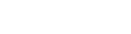 & 38.6 & 27,900 \\
\hline $\begin{array}{l}\text { October. } \\
\text { November. } \\
\text { December } \\
\text { January. } \\
\text { February } \\
\text { Mareh } \\
\text { April. } \\
\text { May } \\
\text { June. } \\
\text { July } \\
\text { August } \\
\text { September }\end{array}$ & \begin{tabular}{|r|}
37 \\
37 \\
17 \\
242 \\
316 \\
301 \\
32 \\
19 \\
17
\end{tabular} & $\begin{array}{r}17 \\
11 \\
7 \\
29 \\
30 \\
8 \\
4 \\
2 \\
2\end{array}$ & $\begin{array}{l}42.8 \\
19.2 \\
-14.5 \\
14 \\
a 16 \\
10.9 \\
96.1 \\
202 \\
121 \\
18.3 \\
12.5 \\
5.47\end{array}$ & $\begin{array}{r}2,960 \\
1,140 \\
892 \\
861 \\
889 \\
670 \\
5,720 \\
12,400 \\
7,200 \\
1,130 \\
769 \\
328\end{array}$ \\
\hline The year. & 316 & 2 & 48.4 & 35,000 \\
\hline
\end{tabular}

- Estimated.

SURFAOE CRERK AT ORDAREDGE, COLO.

Location.-About sec. 29, T. 13 S., R. 94 W., 400 feet upstream from highway bridge, at Cedaredge, Delta County. Nearest tributary, Mill Creek, enters

4 miles upstream.

Drainage area.-43 square miles (measured on Forest Service map).

Records available.-May 16, 1917, to September 30, 1927.

GAGE.-Stevens water-stage recorder. 
Control.-Practically permanent except during 1922.

EXTREMes of DISChARGE.-Maximum stage during period, 1.8 feet at $7 \mathrm{a} . \mathrm{m}$.

May 24, 1920 (discharge, 715 second-feet); minimum stage, creek prac-

tically dry during winter, as water is stored in reservoirs.

Diversions.- Water diverted for irrigation of 18,000 acres above station.

AcCuraCY.-Gage heights from continuous records. Rating curves well defined.

Records excellent, except during 1922, for which they are fair.

Cooperation.-Complete records furnished by State engineer since 1921.

Monthly discharge of Surface Creek at Cedaredge, Colo., for 1917-1987

\begin{tabular}{|c|c|c|c|c|}
\hline \multirow{2}{*}{ Month } & \multicolumn{3}{|c|}{ Discharge in second-feet } & \multirow{2}{*}{ Run-ofi in } \\
\hline & Maximum & Minimum & Mean & \\
\hline $\begin{array}{l}\text { May 16-31 } \\
\text { June } \\
\text { July } \\
\text { August } \\
\text { September. }\end{array}$ & $\begin{array}{r}338 \\
550 \\
226 \\
56 \\
40\end{array}$ & $\begin{array}{r}106 \\
34 \\
11 \\
2.0\end{array}$ & $\begin{array}{r}194 \\
341 \\
103 \\
29.5 \\
10.7\end{array}$ & $\begin{array}{r}6,160 \\
20,300 \\
6,830 \\
1,810 \\
637\end{array}$ \\
\hline The period...- & $\ldots$ & $-\ldots, \ldots$ & $\ldots$ & $35, \mathbf{2 0 0}$ \\
\hline $\begin{array}{l}\text { October } \\
\text { November } \\
\text { December. } \\
\text { January } \\
\text { February } \\
\text { March } \\
\text { April } \\
\text { May. } \\
\text { June } \\
\text { July } \\
\text { August } \\
\text { September }\end{array}$ & \begin{tabular}{|r|}
$\mathbf{3} .5$ \\
$\mathbf{3 . 5}$ \\
$\mathbf{6 1}$ \\
190 \\
88 \\
71 \\
$\mathbf{3 1}$ \\
\end{tabular} & 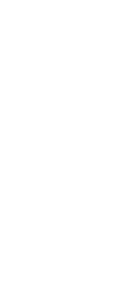 & $\begin{array}{l}2.64 \\
3 \\
3 \\
3 \\
3 \\
3 \\
\text { a } 3 \\
21.4 \\
118 \\
72.3 \\
41.0 \\
13.5 \\
5\end{array}$ & $\begin{array}{r}162 \\
179 \\
184 \\
184 \\
167 \\
184 \\
1,270 \\
7,260 \\
4,300 \\
2,520 \\
830 \\
298\end{array}$ \\
\hline The year............... & 190 & 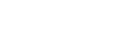 & 24.2 & 17,500 \\
\hline $\begin{array}{l}\text { October-. } \\
\text { November. } \\
\text { December. } \\
\text { January. } \\
\text { February. } \\
\text { March } \\
\text { April } \\
\text { May } \\
\text { June } \\
\text { July } \\
\text { August. } \\
\text { September }\end{array}$ & \begin{tabular}{|r|}
2.4 \\
2.4 \\
130 \\
100 \\
70 \\
44 \\
26 \\
20
\end{tabular} & \begin{tabular}{|r}
1.0 \\
2.0 \\
2.8 \\
38 \\
20 \\
12 \\
5.0 \\
3.0
\end{tabular} & $\begin{array}{l}2 \\
1.72 \\
\text { a } 2 \\
\text { a } 2 \\
\text { a } 2 \\
\text { a } 2 \\
44.5 \\
58.4 \\
45.3 \\
20.9 \\
13.8 \\
8.44\end{array}$ & $\begin{array}{r}123 \\
102 \\
123 \\
123 \\
111 \\
123 \\
2,650 \\
3,590 \\
2,700 \\
1,290 \\
848 \\
502\end{array}$ \\
\hline The year. & 130 & $\cdots-\cdots$ & 17.0 & 12,300 \\
\hline $\begin{array}{l}\text { October. } \\
\text { November } \\
\text { December. } \\
\text { January. } \\
\text { February } \\
\text { March. } \\
\text { April. } \\
\text { May } \\
\text { June } \\
\text { July } \\
\text { August. } \\
\text { September }\end{array}$ & $\begin{array}{r}4.0 \\
6.0 \\
7.2 \\
640 \\
414 \\
89 \\
66 \\
21\end{array}$ & $\begin{array}{r}1.8 \\
1.0 \\
49 \\
18 \\
14 \\
4.8\end{array}$ & $\begin{array}{l}2.41 \\
2.18 \\
\cdot 1 \\
=1 \\
a 1 \\
1 \\
1 \\
302 \\
166 \\
49.6 \\
39.0 \\
11.7\end{array}$ & $\begin{array}{r}148 \\
130 \\
61 \\
61 \\
58 \\
61 \\
60 \\
18,600 \\
9,880 \\
3,050 \\
2,400 \\
696\end{array}$ \\
\hline year. & 640 & -............ & 48.7 & 35,200 \\
\hline
\end{tabular}

- Estimated. 
Monthly discharge of Surface Creek at Cedaredge, Colo., for 191\%-1927-Continued

\begin{tabular}{|c|c|c|c|c|}
\hline \multirow{2}{*}{ Month } & \multicolumn{3}{|c|}{ Discharge in second-feet } & \multirow{2}{*}{$\begin{array}{l}\text { Run-off in } \\
\text { acre-feet }\end{array}$} \\
\hline & Maximum & Minimum & Mean & \\
\hline $\begin{array}{l}\text { October } \\
\text { November } \\
\text { December } \\
\text { January } \\
\text { February } \\
\text { March } \\
\text { April } \\
\text { May } \\
\text { June } \\
\text { July } \\
\text { August } \\
\text { September }\end{array}$ & \begin{tabular}{|c|}
10 \\
13 \\
3.5 \\
59 \\
323 \\
390 \\
110 \\
91.0 \\
51.0
\end{tabular} & \begin{tabular}{|r|}
3.4 \\
1.6 \\
$61^{.3}$ \\
72 \\
11 \\
2.6 \\
8.4
\end{tabular} & $\begin{array}{l}5.35 \\
3.73 \\
\times 2 \\
a 2 \\
\text { a } \\
2 \\
10.9 \\
187 \\
211 \\
61.0 \\
30.8 \\
26.1\end{array}$ & $\begin{array}{r}329 \\
222 \\
123 \\
123 \\
111 \\
123 \\
649 \\
11,500 \\
12,600 \\
3,750 \\
1,890 \\
1,550\end{array}$ \\
\hline The year................. & 390 & 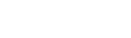 & 45.7 & 33,000 \\
\hline $\begin{array}{l}\text { October. } \\
\text { November. } \\
\text { December. } \\
\text { January } \\
\text { February } \\
\text { March } \\
\text { April } \\
\text { May }\end{array}$ & \begin{tabular}{|r|} 
\\
3.0 \\
38 \\
540 \\
290 \\
88 \\
51 \\
32
\end{tabular} & \begin{tabular}{|c|}
5 \\
2 \\
72 \\
60 \\
6.7 \\
10 \\
5
\end{tabular} & 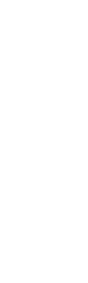 & $\begin{array}{r}322 \\
56 \\
61 \\
61 \\
56 \\
123 \\
1,790 \\
16,000 \\
8,450 \\
2,910 \\
1,800 \\
940\end{array}$ \\
\hline The year. & 540 & & 45.1 & 32,600 \\
\hline $\begin{array}{l}\text { October } \\
\text { November } \\
\text { December. } \\
\text { January } \\
\text { February } \\
\text { March } \\
\text { April } \\
\text { May } \\
\text { June } \\
\text { July } \\
\text { August } \\
\text { September }\end{array}$ & \begin{tabular}{r|}
10 \\
10 \\
6 \\
40 \\
225 \\
130 \\
63 \\
63 \\
42
\end{tabular} & $\begin{array}{c}5 \\
4 \\
3 \\
4 \\
4 \\
35 \\
46 \\
16 \\
11 \\
9\end{array}$ & $\begin{array}{l}7.87 \\
6.17 \\
3 \\
=3 \\
=3 \\
4.55 \\
10.4 \\
150 \\
82.1 \\
33.7 \\
30.8 \\
19.2\end{array}$ & $\begin{array}{r}484 \\
367 \\
184 \\
184 \\
167 \\
280 \\
619 \\
9,220 \\
4,890 \\
2,070 \\
1,890 \\
1,140\end{array}$ \\
\hline The year....... & 225 & $-\infty-\infty$ & 29.7 & 21,500 \\
\hline $\begin{array}{l}\text { October } \\
\text { November } \\
\text { December } \\
\text { January } \\
\text { February } \\
\text { March } \\
\text { April } \\
\text { May } \\
\text { June } \\
\text { July } \\
\text { August } \\
\text { September }\end{array}$ & \begin{tabular}{|r|}
14 \\
7.2 \\
98 \\
123 \\
87 \\
68 \\
24 \\
21
\end{tabular} & \begin{tabular}{|c|} 
\\
7 \\
\end{tabular} & $\begin{array}{l}10.0 \\
\text { a } 7 \\
\text { a } 7 \\
\text { c } 7 \\
\text { a } 7.6 \\
6.30 \\
26.9 \\
79.9 \\
44.0 \\
31.2 \\
15.9 \\
10.3\end{array}$ & $\begin{array}{r}615 \\
417 \\
430 \\
430 \\
437 \\
387 \\
1,600 \\
4,910 \\
2,620 \\
1,920 \\
978 \\
613\end{array}$ \\
\hline The year. & 123 & & 212 & 15,400 \\
\hline $\begin{array}{l}\text { October. } \\
\text { November. } \\
\text { December. } \\
\text { January } \\
\text { February } \\
\text { March } \\
\text { April. } \\
\text { May } \\
\text { Jume } \\
\text { July } \\
\text { August } \\
\text { September }\end{array}$ & \begin{tabular}{r|}
12 \\
99 \\
99 \\
73 \\
73 \\
49 \\
172
\end{tabular} & \begin{tabular}{|r|}
3.6 \\
3.6 \\
1.0 \\
.8 \\
60 \\
16 \\
8 \\
5 \\
8
\end{tabular} & $\begin{array}{c}6.02 \\
3.2 \\
\times 2.0 \\
a-2.0 \\
\times 2.5 \\
2.07 \\
37.8 \\
93.5 \\
43.7 \\
20.5 \\
17.9 \\
26.7\end{array}$ & $\begin{array}{r}370 \\
190 \\
123 \\
123 \\
139 \\
127 \\
2,260 \\
5,750 \\
2,600 \\
1,260 \\
1,100 \\
1,590\end{array}$ \\
\hline 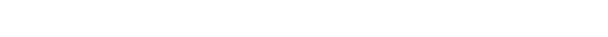 & 172 & - - & 21.6 & 15,600 \\
\hline
\end{tabular}

astimated. 
Monthly discharge of Surface Creek at Cedaredge, Colo., for 1917-1987-Continued

\begin{tabular}{|c|c|c|c|c|}
\hline \multirow{2}{*}{ Month } & \multicolumn{3}{|c|}{ Discharge in second-feet } & \multirow{2}{*}{$\begin{array}{l}\text { Run-off in } \\
\text { acre-feet }\end{array}$} \\
\hline & Maximum & Minimum & Mean & \\
\hline $\begin{array}{l}\text { October } \\
\text { November } \\
\text { December } \\
\text { January } \\
\text { Pebruary } \\
\text { March } \\
\text { April }\end{array}$ & $\begin{array}{r}88 \\
31 \\
11 \\
183 \\
207 \\
207 \\
77 \\
92 \\
41\end{array}$ & \begin{tabular}{r|r|}
7 \\
14 \\
2 \\
21 \\
41 \\
10 \\
9 \\
6
\end{tabular} & $\begin{array}{l}22.3 \\
22.6 \\
15 \\
8 \\
4 \\
4.39 \\
67.5 \\
183 \\
92.1 \\
39.1 \\
36.2 \\
19.5\end{array}$ & $\begin{array}{r}1,370 \\
1,340 \\
022 \\
492 \\
292 \\
270 \\
4,020 \\
8,180 \\
5,480 \\
2,400 \\
2,200 \\
1,160\end{array}$ \\
\hline 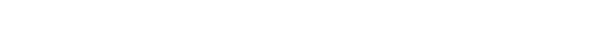 & 207 & $-\cdots-1-n$ & 38.8 & 28,100 \\
\hline $\begin{array}{l}\text { October. } \\
\text { November } \\
\text { December } \\
\text { January } \\
\text { February } \\
\text { March } \\
\text { April } \\
\text { May } \\
\text { June } \\
\text { July } \\
\text { August } \\
\text { September }\end{array}$ & \begin{tabular}{|r|}
20 \\
318 \\
409 \\
223 \\
53 \\
66 \\
56
\end{tabular} & \begin{tabular}{|r|}
2 \\
\\
2 \\
32 \\
10 \\
16 \\
9 \\
4
\end{tabular} & 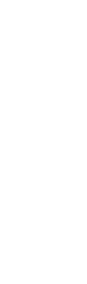 & $\begin{array}{r}351 \\
119 \\
123 . \\
123 . \\
111 \\
123 \\
3,100 \\
10,100 \\
4,610 \\
2,090 \\
1,970 \\
982\end{array}$ \\
\hline The year. & 409 & n-non & 32.8 . & 23,900 \\
\hline
\end{tabular}

astimated.

UNCOMPAHGRE RIVER AT OURAY, COLO.

Location.-In sec. 31, T. 44 N., R. 7 W., in box canyon a short distance upstream from highway bridge half a mile south of Ouray, Ouray County. Nearest tributary, Canyon Creek, enters 150 feet below.

Drainage area.-44 square miles (measured on topographic map).

RECORDS AVAILABLE.-October 1, 1910, to September 30, 1924.

GAGE.-Stevens water-stage recorder installed April 22, 1919; vertical staff used previously, Vertical staff in power-house flume.

ConTroL.-Shifting at long intervals.

EXTREMES OF DISCHARGE.-Maximum stage recorded during period, 6.0 feet at 8 . a. $\mathrm{m}$. October 5, 1911 (discharge, 1,980 second-feet); minimum discharge, 6 . second-feet on December 31, 1920, and January 19, 1921.

ICE.-Stage-discharge relation unaffected by ice.

Drversions.-Western Colorado Power Co. diverts water from river above. station and returns water to stream below Canyon Creek. Flow through pipe line added to river records to show entire flow. No other diversions. above station.

ACCURACY.-Gage read once daily prior to installation of recorder; continuous. records for remainder of period. Rating curves generally well defined. Records 1911 to 1916 good for medium stage, fair for high and low stages; subsequent to 1916 records good, except during 1919 and 1920, for which they are excellent.

Cooperation.-Station maintained in cooperation with United States Forest, Service, State engineer, and Western Colorado Power Co. 
Monthly discharge of Uncompahgre River at Ouray, Colo., 1910-1924

\begin{tabular}{|c|c|c|c|c|}
\hline \multirow{2}{*}{ Month } & \multicolumn{3}{|c|}{ Discharge in second-feet } & \multirow{2}{*}{$\begin{array}{l}\text { Run-ofi in } \\
\text { acre-feet }\end{array}$} \\
\hline & Maximum & Minimutm & Mean & \\
\hline $\begin{array}{l}\text { October } \\
\text { November } \\
\text { December.19 } \\
\text { January } \\
\text { February } \\
\text { March } \\
\text { April } \\
\text { May }\end{array}$ & 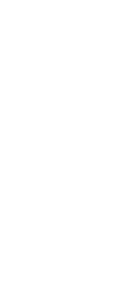 & 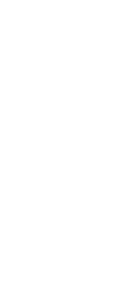 & $\begin{array}{r}41 \\
15 \\
12 \\
12 \\
16 \\
19 \\
68 \\
200 \\
370 \\
215 \\
90 \\
55\end{array}$ & $\begin{array}{r}2,520 \\
898 \\
738 \\
738 \\
880 \\
1,170 \\
4,050 \\
12,300 \\
22,000 \\
13,200 \\
5,530 \\
3,270\end{array}$ \\
\hline The year................ & & & 93.0 & 67,300 \\
\hline $\begin{array}{l}\text { October. } \\
\text { November } \\
\text { December } \\
\text { January } \\
\text { February } \\
\text { March. } \\
\text { April } \\
\text { May } \\
\text { June } \\
\text { July } \\
\text { August } \\
\text { September }\end{array}$ & $\mid$ & 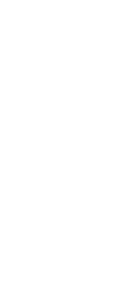 & $\begin{array}{r}155 \\
25 \\
15 \\
13 \\
10 \\
11 \\
26 \\
235 \\
368 \\
195 \\
66 \\
38\end{array}$ & $\begin{array}{r}9,530 \\
1,490 \\
920 \\
799 \\
575 \\
676 \\
1,560 \\
14,400 \\
21,900 \\
12,000 \\
4,000 \\
2,260\end{array}$ \\
\hline The year... & & $\ldots$ & 96.7 & 70,200 \\
\hline 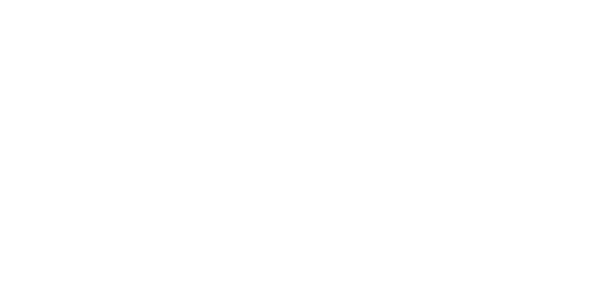 & 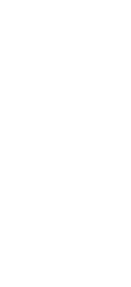 & 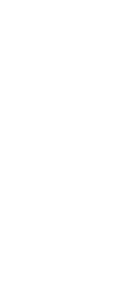 & $\begin{array}{r}31 \\
16 \\
12 \\
9 \\
12 \\
12 \\
45 \\
225 \\
225 \\
100 \\
40 \\
57\end{array}$ & $\begin{array}{r}1,910 \\
969 \\
738 \\
568 \\
660 \\
738 \\
2,690 \\
13,800 \\
13,400 \\
6,150 \\
2,400 \\
3,300\end{array}$ \\
\hline The year............ & $\ldots$ & $\ldots \ldots \ldots \ldots$ & 65.4 & 47,400 \\
\hline $\begin{array}{l}\text { October } \\
\text { November. } \\
\text { December. } \\
\text { January } \\
\text { February } \\
\text { March } \\
\text { April } \\
\text { May } \\
\text { June } \\
\text { July } \\
\text { August } \\
\text { September. }\end{array}$ & \begin{tabular}{|l} 
\\
\end{tabular} & \begin{tabular}{|c|c|} 
& \\
&
\end{tabular} & $\begin{array}{r}81 \\
16 \\
15 \\
15 \\
13 \\
21 \\
50 \\
306 \\
500 \\
190 \\
65 \\
41\end{array}$ & $\begin{array}{r}1,910 \\
983 \\
992 \\
922 \\
722 \\
1,290 \\
2,900 \\
18,800 \\
29,800 \\
11,700 \\
4,000 \\
2,440\end{array}$ \\
\hline The year. & - n... & & 106 & 76,400 \\
\hline $\begin{array}{l}\text { October. } \\
\text { November } \\
\text { December. } \\
\text { January. } \\
\text { Pebruary } \\
\text { March } \\
\text { April } \\
\text { May } \\
\text { June } \\
\text { July } \\
\text { August. } \\
\text { September }\end{array}$ & 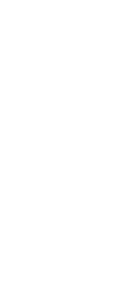 & $\mid$ & $\begin{array}{r}48 \\
21 \\
12 \\
11 \\
13 \\
18 \\
75 \\
150 \\
380 \\
185 \\
50 \\
30\end{array}$ & $\begin{array}{r}2,950 \\
1,250 \\
738 \\
676 \\
722 \\
1,110 \\
4,460 \\
9,200 \\
22,600 \\
11,400 \\
3,070 \\
1,790\end{array}$ \\
\hline The year & & & 82.9 & 60,000 \\
\hline
\end{tabular}


Monthly discharge of Uncompahgre River at Ouray, Colo., 1910-1924-Continued.

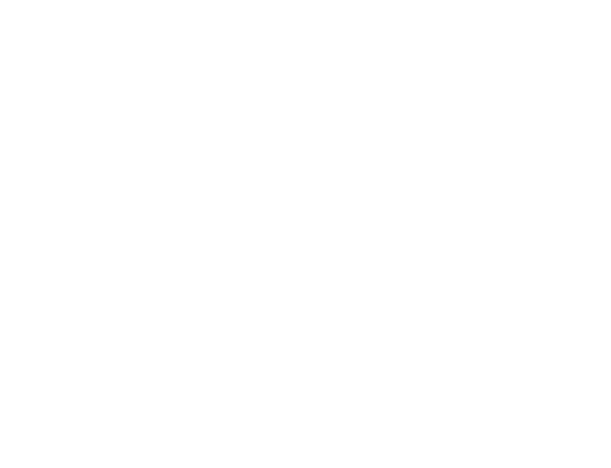

The year

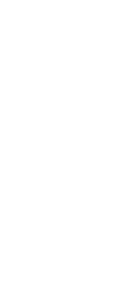

The year

\section{6-17}

October

November

December

January

February

March -

April

Maye

June

August

September

The year.

1918-19

October.

November

December

January

February

March

April.

May

June

July

August

September.

The year.

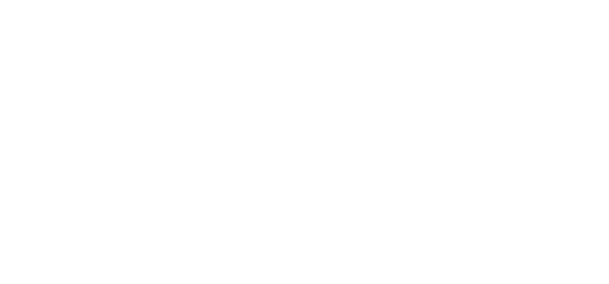

The year.

\begin{tabular}{|c|c|c|c|}
\hline \multicolumn{3}{|c|}{ Discharge in second-feet } & \multirow{2}{*}{$\underset{\text { acr } \theta \text {-feet }}{\text { Run-oft in }}$} \\
\hline Maximum & Minimum & Mean & \\
\hline & $-12-2-1$ & $\begin{array}{r}20 \\
15 \\
14 \\
14 \\
16 \\
29 \\
70 \\
184 \\
360 \\
125 \\
86 \\
57\end{array}$ & $\begin{array}{r}1,230 \\
893 \\
861 \\
861 \\
920 \\
1,780 \\
4,170 \\
11,300 \\
21,400 \\
7,690 \\
5,290 \\
3,390\end{array}$ \\
\hline ....... & (n.......... & 82.4 & 59,800 \\
\hline $\begin{array}{r}256 \\
38 \\
27 \\
24 \\
25 \\
31 \\
63 \\
293 \\
945 \\
650 \\
144 \\
41\end{array}$ & $\begin{array}{r}29 \\
17 \\
10 \\
8 \\
12 \\
11 \\
10 \\
36 \\
97 \\
135 \\
29 \\
22\end{array}$ & $\begin{array}{c}95.0 \\
28.7 \\
20.8 \\
16.8 \\
17.1 \\
15.5 \\
34.1 \\
106 \\
621 \\
293 \\
64.4 \\
27.4\end{array}$ & $\begin{array}{r}5,840 \\
1,710 \\
1,280 \\
1,030 \\
950 \\
953 \\
2,030 \\
6,520 \\
37,000 \\
18,000 \\
3,960 \\
1,630\end{array}$ \\
\hline 945 & 8 & 112 & 80,900 \\
\hline $\begin{array}{r}33 \\
18 \\
17 \\
21 \\
17 \\
27 \\
76 \\
354 \\
996 \\
163 \\
69 \\
244\end{array}$ & $\begin{array}{r}17 \\
8.9 \\
9.2 \\
11 \\
11 \\
10 \\
18 \\
72 \\
152 \\
39 \\
23 \\
30\end{array}$ & $\begin{array}{c}22.5 \\
15.0 \\
11.8 \\
15.1 \\
15.1 \\
16.7 \\
36.0 \\
236 \\
463 \\
93.1 \\
37.6 \\
50.2\end{array}$ & $\begin{array}{r}1,380 \\
.893 \\
726 \\
928 \\
839 \\
1,030 \\
2,140 \\
14,500 \\
27,600 \\
5,720 \\
2,310 \\
2,990\end{array}$ \\
\hline 996 & 8. 9 & 84.3 & 61,100 \\
\hline $\begin{array}{r}28 \\
22 \\
19 \\
16 \\
17 \\
16 \\
142 \\
526 \\
396 \\
236 \\
92 \\
66\end{array}$ & $\begin{array}{r}19 \\
13 \\
12 \\
12 \\
10 \\
12 \\
19 \\
80 \\
163 \\
58 \\
14 \\
10\end{array}$ & $\begin{array}{c}22.0 \\
18.1 \\
15.6 \\
12.5 \\
12.4 \\
14.3 \\
56.4 \\
258 \\
275 \\
125 \\
41.3 \\
22.5\end{array}$ & $\begin{array}{r}1,350 \\
1,080 \\
959 \\
769 \\
689 \\
879 \\
3,360 \\
15,900 \\
16,400 \\
7,690 \\
2,540 \\
1,340\end{array}$ \\
\hline 526 & 10 & 73.0 & 53,000 \\
\hline $\begin{array}{r}25 \\
24 \\
19 \\
22 \\
17 \\
35 \\
74 \\
636 \\
621 \\
307 \\
111 \\
47\end{array}$ & $\begin{array}{r}18 \\
16 \\
16 \\
11 \\
16 \\
16 \\
22 \\
68 \\
254 \\
79 \\
31 \\
26\end{array}$ & $\begin{array}{c}21.2 \\
18.6 \\
17.0 \\
17.1 \\
16.3 \\
22.4 \\
26.2 \\
295 \\
384 \\
159 \\
59.2 \\
32.1\end{array}$ & $\begin{array}{r}1,300 \\
1,110 \\
1,050 \\
1,050 \\
938 \\
1,380 \\
1,560 \\
18,100 \\
22,800 \\
9,780 \\
3,640 \\
1,910\end{array}$ \\
\hline 636 & 11 & 89.1 & 64,600 \\
\hline
\end{tabular}


Monthly discharge of Uncompahgre River at Ouray, Colo., 1910-1924-Continued

\begin{tabular}{|c|c|c|c|c|}
\hline \multirow{2}{*}{ Month } & \multicolumn{3}{|c|}{ Diseharge in second-feet } & \multirow{2}{*}{$\begin{array}{l}\text { Run-off in } \\
\text { acre-foet }\end{array}$} \\
\hline & Maximum & Minimum & Mean & \\
\hline $\begin{array}{l}\text { October } \\
\text { November } \\
\text { December } \\
\text { January } \\
\text { February } \\
\text { March. } \\
\text { April } \\
\text { May } \\
\text { June } \\
\text { July } \\
\text { August }\end{array}$ & $\begin{array}{r}31 \\
29 \\
23 \\
18 \\
27 \\
39 \\
71 \\
526 \\
1,370 \\
385 \\
122 \\
84\end{array}$ & $\begin{array}{r}17 \\
23 \\
6 \\
6 \\
11 \\
18 \\
28 \\
106 \\
254 \\
95 \\
42 \\
31\end{array}$ & $\begin{array}{l}21.7 \\
25.9 \\
19.8 \\
13.3 \\
15.9 \\
25.7 \\
41.8 \\
225 \\
635 \\
188 \\
76.3 \\
44.5\end{array}$ & $\begin{array}{r}1,330 \\
1,540 \\
1,220 \\
818 \\
883 \\
1,580 \\
2,490 \\
13,800 \\
37,800 \\
11,600 \\
4,690 \\
2,650\end{array}$ \\
\hline The year & 1,370 & 6 & 111 & 80,400 \\
\hline 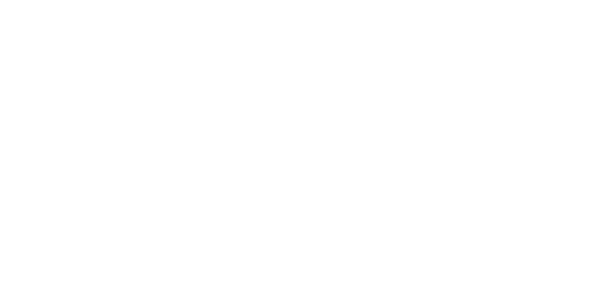 & $\begin{array}{r}34 \\
24 \\
23 \\
28 \\
19 \\
28 \\
158 \\
486 \\
615 \\
360 \\
90 \\
40\end{array}$ & $\begin{array}{r}21 \\
10 \\
15 \\
13 \\
15 \\
13 \\
18 \\
75 \\
201 \\
64 \\
36 \\
26\end{array}$ & $\begin{array}{c}26.3 \\
15.8 \\
20.7 \\
18.1 \\
16.4 \\
18.7 \\
48.5 \\
261 \\
436 \\
143 \\
52.0 \\
30.5\end{array}$ & $\begin{array}{r}1,620 \\
940 \\
1,270 \\
1,110 \\
911 \\
1,150 \\
2,800 \\
16,000 \\
25,900 \\
8,790 \\
3,200 \\
1,810\end{array}$ \\
\hline The year. & 615 & 10 & 90.6 & 65,600 \\
\hline $\begin{array}{l}\text { October } \\
\text { November } \\
\text { Decamber } \\
\text { Panuary } \\
\text { February } \\
\text { March. } \\
\text { April } \\
\text { May } \\
\text { July } \\
\text { August } \\
\text { September }\end{array}$ & $\begin{array}{r}28 \\
29 \\
20 \\
22 \\
21 \\
21 \\
75 \\
498 \\
490 \\
289 \\
106 \\
104\end{array}$ & $\begin{array}{r}20 \\
16 \\
15 \\
13 \\
13 \\
11 \\
14 \\
74 \\
214 \\
70 \\
49 \\
45\end{array}$ & $\begin{array}{l}24.2 \\
25.3 \\
17.3 \\
16.5 \\
14.8 \\
12.9 \\
38.0 \\
216 \\
365 \\
147 \\
69.1 \\
60.3\end{array}$ & $\begin{array}{r}1,490 \\
1,510 \\
1,060 \\
1,010 \\
822 \\
793 \\
2,260 \\
13,300 \\
21,700 \\
9,040 \\
4,250 \\
3,590\end{array}$ \\
\hline The year. & 498 & 11 & 84.0 & 60,800 \\
\hline $\begin{array}{l}\text { Oetober } \\
\text { November } \\
\text { December. } \\
\text { January } \\
\text { February } \\
\text { March } \\
\text { April } \\
\text { May } \\
\text { June }\end{array}$ & $\begin{array}{r}62 \\
38 \\
24 \\
20 \\
21 \\
22 \\
113 \\
361 \\
633 \\
211 \\
50 \\
22\end{array}$ & $\begin{array}{r}33 \\
23 \\
17 \\
18 \\
18 \\
18 \\
23 \\
86 \\
164 \\
40 \\
18 \\
15\end{array}$ & $\begin{array}{c}42.0 \\
28.5 \\
20.9 \\
18.4 \\
19.1 \\
18.8 \\
49.2 \\
248 \\
368 \\
103 \\
30.8 \\
17.6\end{array}$ & $\begin{array}{r}2,580 \\
1,700 \\
1,290 \\
1,130 \\
1,100 \\
1,160 \\
2,930 \\
15,200 \\
21,900 \\
6,330 \\
1,890 \\
1,060\end{array}$ \\
\hline 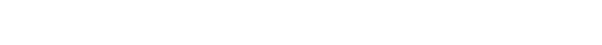 & 633 & 15 & 80.3 & 58,300 \\
\hline
\end{tabular}

Note.-Records from 1911 to 1916 have been revised, and now include flow through pipe line.

DNCONPAHGRE RIVRR BELOW OURAY, COLO.

Location.-In sec. 30, T. 44 N., R. 7 W., near lowest bridge in Ouray, a third of a mile below railroad station. Below all tributaries in Ouray.

Drainage area. - 76 square miles (measured on topographic map).

Records a vailable.-June 1, 1913, to September 30, 1927.

GAGE.-Gurley water-stage recorder installed May 28, 1917. Original gage, staff at bridge, 500 feet downstream.

Controx.-Shifting at intervals. 
Extremes of discharge.-Maximum discharge during period, 2,530 second-feet at 1 a. $\mathrm{m}$. June 14; 1918 (gage height, 5.5 feet); minimum discharge, 10 second-feet February 5 and 6, 1915, March 18, 1922, and January 21, 1923.

ICE.-Stage-discharge relation unaffected by ice.

Drversions.-Practically all diversions returned to river above station.

ACcuracy.-Gage read once daily 1913-1916; gage heights from continuous records 1917-1927. Rating curves generally well defined. Records good.

Cooperation.-Station maintained in cooperation with United States Forest Service, State engineer, and Western Colorado Power Co.

Monthly discharge of Uncompahgre River below Ouray, Colo., 1918-1927

\begin{tabular}{|c|c|c|c|c|}
\hline \multirow{2}{*}{ Month } & \multicolumn{3}{|c|}{ Discharge in second-feet } & \multirow{2}{*}{$\begin{array}{l}\text { Run-off in } \\
\text { acre-feet }\end{array}$} \\
\hline & Maximum & Minimum & - Mean & \\
\hline $\begin{array}{l}\text { June } \\
\text { July } \\
\text { August } \\
\text { September }\end{array}$ & $\begin{array}{l}845 \\
435 \\
155 \\
285\end{array}$ & $\begin{array}{r}308 \\
104 \\
71 \\
61\end{array}$ & $\begin{array}{l}573 \\
256 \\
87.6 \\
109\end{array}$ & $\begin{array}{r}34,100 \\
15,700 \\
5,390 \\
6,490\end{array}$ \\
\hline The period... & $\ldots$ & $\ldots \ldots$ & - & 61,700 \\
\hline $\begin{array}{l}\text { October } \\
\text { November } \\
\text { December } \\
\text { January } \\
\text { February } \\
\text { March } \\
\text { April }\end{array}$ & $\begin{array}{r}75 \\
42 \\
35 \\
33 \\
30 \\
69 \\
116 \\
1,610 \\
\mathbf{1 , 6 5 0} \\
615 \\
\mathbf{2 8 5} \\
92\end{array}$ & $\begin{array}{r}42 \\
20 \\
17 \\
27 \\
20 \\
20 \\
34 \\
69 \\
380 \\
210 \\
91 \\
70\end{array}$ & $\begin{array}{c}57.4 \\
33.1 \\
29.6 \\
29.1 \\
24.8 \\
37.8 \\
76.0 \\
494 \\
905 \\
409 \\
142 \\
77.6\end{array}$ & $\begin{array}{r}3,880 \\
1,970 \\
1,820 \\
1,790 \\
1,380 \\
2,320 \\
4,520 \\
30,400 \\
53,900 \\
25,100 \\
8,780 \\
4,620\end{array}$ \\
\hline The yea & 1,650 & 17 & 194 & 140,000 \\
\hline $\begin{array}{l}\text { October } \\
\text { November } \\
\text { December } \\
\text { January } \\
\text { February } \\
\text { March } \\
\text { April } \\
\text { May } \\
\text { June } \\
\text { July } \\
\text { August } \\
\text { September }\end{array}$ & $\begin{array}{r}118 \\
66 \\
29 \\
25 \\
29 \\
43 \\
43 \\
259 \\
416 \\
1,180 \\
478 \\
141 \\
278\end{array}$ & $\begin{array}{r}59 \\
31 \\
21 \\
17 \\
10 \\
27 \\
40 \\
72 \\
172 \\
149 \\
58 \\
31\end{array}$ & $\begin{array}{c}76.2 \\
43.1 \\
23.8 \\
20.7 \\
23.9 \\
32.1 \\
96.2 \\
180 \\
637 \\
312 \\
86.5 \\
57.0\end{array}$ & $\begin{array}{r}4,680 \\
2,660 \\
1,460 \\
1,270 \\
1,330 \\
1,970 \\
5,720 \\
11,100 \\
87,900 \\
19,200 \\
8,320 \\
3,300\end{array}$ \\
\hline The year. & 1,180 & 10 & 138 & 95,900 \\
\hline $\begin{array}{l}\text { October } \\
\text { November } \\
\text { December } \\
\text { January } \\
\text { February } \\
\text { March } \\
\text { April } \\
\text { May } \\
\text { June } \\
\text { July } \\
\text { August } \\
\text { September }\end{array}$ & $\begin{array}{r}51 \\
36 \\
32 \\
31 \\
36 \\
77 \\
321 \\
582 \\
1,070 \\
408 \\
296 \\
96\end{array}$ & $\begin{array}{r}31 \\
21 \\
25 \\
18 \\
21 \\
32 \\
39 \\
107 \\
402 \\
170 \\
82 \\
54\end{array}$ & $\begin{array}{c}37.6 \\
30.7 \\
27.6 \\
27.5 \\
30.3 \\
52.1 \\
112 \\
277 \\
703 \\
812 \\
189 \\
72.9\end{array}$ & $\begin{array}{r}2,810 \\
1,880 \\
1,700 \\
1,690 \\
1,740 \\
3,200 \\
6,660 \\
17,000 \\
41,800 \\
19,200 \\
11,600 \\
4,340\end{array}$ \\
\hline The year... & 1,070 & 18 & 156 & 113,000 \\
\hline
\end{tabular}


Monthly discharge of Uncompahgre River below Ouray, Colo., 1913-1927-Contd.

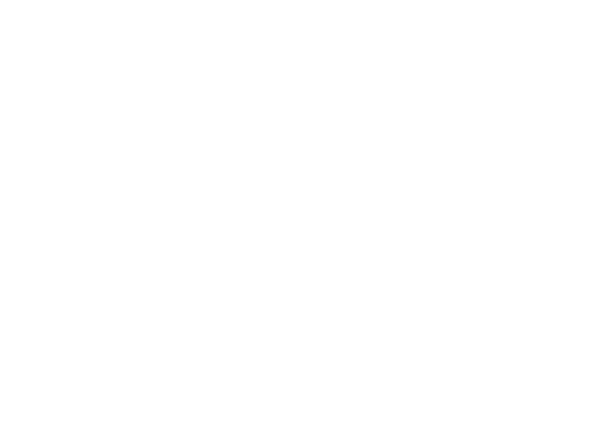

The year

1917-18

October.

November

December

January

Pebruary

March

May

June

July..

September

The year

\begin{tabular}{|c|c|c|c|}
\hline \multicolumn{3}{|c|}{ Discharge in second-feet } & \multirow{2}{*}{$\begin{array}{l}\text { Run-off in } \\
\text { acre-feet }\end{array}$} \\
\hline Maximum & Minimum & Mean & \\
\hline $\begin{array}{r}274 \\
63 \\
40 \\
39 \\
88 \\
69 \\
158 \\
410 \\
1,680 \\
1,400 \\
270 \\
91\end{array}$ & $\begin{array}{r}54 \\
35 \\
24 \\
26 \\
26 \\
24 \\
35 \\
84 \\
169 \\
260 \\
83 \\
53\end{array}$ & $\begin{array}{c}120 \\
47.6 \\
34.8 \\
31.0 \\
29.5 \\
30.3 \\
82.4 \\
181 \\
1,050 \\
669 \\
154 \\
68.3\end{array}$ & $\begin{array}{r}7,380 \\
2,830 \\
2,140 \\
1,910 \\
1,640 \\
1,860 \\
4,900 \\
11,100 \\
62,500 \\
41,100 \\
9,470 \\
4,060\end{array}$ \\
\hline 1,680 & 24 & 209 & 151,000 \\
\hline $\begin{array}{r}66 \\
36 \\
83 \\
31 \\
31 \\
60 \\
123 \\
538 \\
1,270 \\
868 \\
137 \\
361\end{array}$ & $\begin{array}{r}33 \\
27 \\
25 \\
26 \\
23 \\
26 \\
36 \\
158 \\
264 \\
78 \\
53 \\
54\end{array}$ & $\begin{array}{c}43.6 \\
32.6 \\
29.4 \\
27.5 \\
27.0 \\
36.0 \\
67.7 \\
357 \\
746 \\
177 \\
86.8 \\
98.6\end{array}$ & $\begin{array}{r}2,680 \\
1,940 \\
1,810 \\
1,690 \\
1,500 \\
2,210 \\
4,030 \\
22,000 \\
44,400 \\
10,900 \\
5,340 \\
5,870\end{array}$ \\
\hline 1,270 & 23 & 144 & 104,000 \\
\hline $\begin{array}{r}58 \\
60 \\
41 \\
33 \\
34 \\
.61 \\
261 \\
685 \\
635 \\
478 \\
169 \\
111\end{array}$ & $\begin{array}{r}41 \\
37 \\
33 \\
31 \\
29 \\
-\quad 31 \\
39 \\
129 \\
228 \\
135 \\
46 \\
24\end{array}$ & $\begin{array}{c}46.5 \\
43.3 \\
35.8 \\
32.6 \\
31.2 \\
35.4 \\
104 \\
373 \\
462 \\
265 \\
88.8 \\
45.9\end{array}$ & $\begin{array}{r}2,860 \\
2,680 \\
2,200 \\
2,000 \\
1,730 \\
2,180 \\
6,190 \\
22,900 \\
27,500 \\
16,300 \\
5,460 \\
2,730\end{array}$ \\
\hline 685 & 24 & 131 & 94,600 \\
\hline $\begin{array}{r}41 \\
41 \\
33 \\
31 \\
32 \\
51 \\
90 \\
962 \\
990 \\
755 \\
285 \\
100\end{array}$ & $\begin{array}{r}27 \\
26 \\
23 \\
24 \\
24 \\
20 \\
27 \\
87 \\
590 \\
165 \\
68 \\
60\end{array}$ & $\begin{array}{c}34.4 \\
34.2 \\
28.2 \\
26.9 \\
28.0 \\
29.5 \\
34.7 \\
437 \\
766 \\
354 \\
134 \\
69.2\end{array}$ & $\begin{array}{r}2,120 \\
2,040 \\
1,730 \\
1,650 \\
1,610 \\
1,810 \\
2,060 \\
26,900 \\
46,600 \\
21,800 \\
8,240 \\
4,120\end{array}$ \\
\hline 990 & 20 & 165 & 120,000 \\
\hline $\begin{array}{r}74 \\
58 \\
39 \\
35 \\
67 \\
84 \\
111 \\
865 \\
1,550 \\
676 \\
222 \\
122\end{array}$ & $\begin{array}{r}51 \\
34 \\
31 \\
23 \\
27 \\
31 \\
40 \\
153 \\
504 \\
210 \\
105 \\
50\end{array}$ & $\begin{array}{c}58.6 \\
47.4 \\
34.9 \\
30.7 \\
34.9 \\
43.9 \\
64.6 \\
388 \\
867 \\
389 \\
145 \\
71.1\end{array}$ & $\begin{array}{r}8,600 \\
2,820 \\
2,160 \\
1,890 \\
1,940 \\
3,700 \\
3,840 \\
23,900 \\
51,600 \\
23,900 \\
8,920 \\
4,280 \\
\end{array}$ \\
\hline 1,550 & 23 & 182 & 131,000 \\
\hline
\end{tabular}

The year.

\section{8-19}

October

Decomber

January.

Februar

March

April

Jume.

Juty.

August

September

The year

October..

1910-20

December.

January.

February

March

April

May

June

uny

Bupterinber

The year

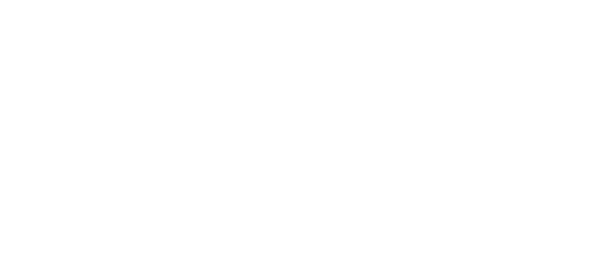

\section{.}

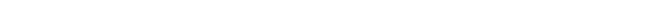

\section{1} . 
Monthly discharge of Uncompahgre River below Ouray, Colo., 1913-1927-Contd.

\begin{tabular}{|c|c|c|c|c|}
\hline \multirow{2}{*}{ Month } & \multicolumn{3}{|c|}{ Discharge in second-feet } & \multirow{2}{*}{$\begin{array}{l}\text { Run-off in } \\
\text { acre-feet }\end{array}$} \\
\hline & Maximum & Minimum & Mean & \\
\hline $\begin{array}{l}\text { October } \\
\text { November } \\
\text { December } \\
\text { January } \\
\text { February } \\
\text { March } \\
\text { April } \\
\text { May } \\
\text { June }\end{array}$ & $\begin{array}{r}65 \\
50 \\
42 \\
42 \\
28 \\
45 \\
226 \\
720 \\
1,090 \\
705 \\
184 \\
81\end{array}$ & $\begin{array}{r}37 \\
27 \\
29 \\
24 \\
22 \\
16 \\
28 \\
216 \\
466 \\
157 \\
78 \\
42\end{array}$ & $\begin{array}{l}48.7 \\
39.3 \\
36.5 \\
31.0 \\
26.1 \\
28.1 \\
73.6 \\
441 \\
818 \\
312 \\
126 \\
53.8\end{array}$ & $\begin{array}{r}2,990 \\
2,340 \\
2,240 \\
1,910 \\
1,390 \\
1,790 \\
4,380 \\
27,100 \\
48,700 \\
19,200 \\
7,750 \\
3,200\end{array}$ \\
\hline The & 1,090 & 16 & 171 & 123,000 \\
\hline $\begin{array}{l}\text { October } \\
\text { November } \\
\text { December } \\
\text { January } \\
\text { February } \\
\text { March } \\
\text { April } \\
\text { May } \\
\text { June } \\
\text { July } \\
\text { August }\end{array}$ & $\begin{array}{r}43 \\
35 \\
36 \\
36 \\
33 \\
52 \\
134 \\
655 \\
872 \\
670 \\
275 \\
180\end{array}$ & $\begin{array}{r}29 \\
28 \\
27 \\
25 \\
25 \\
22 \\
29 \\
120 \\
399 \\
142 \\
105 \\
72\end{array}$ & $\begin{array}{c}35.7 \\
32.2 \\
32.9 \\
29.8 \\
29.1 \\
29.0 \\
65.9 \\
331 \\
685 \\
883 \\
158 \\
104\end{array}$ & $\begin{array}{r}2.200 \\
1,920 \\
20,020 \\
1,830 \\
1,620 \\
1,780 \\
3,920 \\
20,400 \\
40,800 \\
23,600 \\
9,720 \\
6,190\end{array}$ \\
\hline 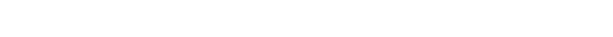 & 872 & 22 & 160 & 116,000 \\
\hline $\begin{array}{l}\text { October. } \\
\text { November } \\
\text { December } \\
\text { January } \\
\text { February } \\
\text { March } \\
\text { April } \\
\text { May } \\
\text { June } \\
\text { July } \\
\text { August } \\
\text { September }\end{array}$ & $\begin{array}{r}100 \\
59 \\
32 \\
27 \\
28 \\
28 \\
201 \\
548 \\
1,030 \\
413 \\
100 \\
70\end{array}$ & $\begin{array}{r}48 \\
31 \\
28 \\
28 \\
25 \\
25 \\
28 \\
149 \\
222 \\
120 \\
48 \\
37\end{array}$ & $\begin{array}{l}\text { 68. } 9 \\
\text { 40.2 } \\
30.5 \\
26.6 \\
26.3 \\
26.1 \\
97.9 \\
365 \\
627 \\
236 \\
83.9 \\
\mathbf{4 6 . 2}\end{array}$ & $\begin{array}{r}4,240 \\
2,390 \\
\mathbf{1}, 890 \\
\mathbf{1}, 640 \\
\mathbf{1}, 510 \\
\mathbf{1}, \mathbf{6 0 0} \\
\mathbf{5}, 830 \\
\mathbf{2 9}, \mathbf{4 0 0} \\
\mathbf{3 7}, \mathbf{3 0 0} \\
\mathbf{1 4 , 5 0 0} \\
\mathbf{5}, \mathbf{1 6 0} \\
\mathbf{2}, 750\end{array}$ \\
\hline The year & 1,030 & $\mathbf{2 5}$ & 139 & 101,000 \\
\hline $\begin{array}{l}\text { October. } \\
\text { November } \\
\text { December } \\
\text { January } \\
\text { February } \\
\text { March } \\
\text { April } \\
\text { May } \\
\text { June } \\
\text { July } \\
\text { August }\end{array}$ & $\begin{array}{r}68 \\
51 \\
44 \\
34 \\
34 \\
95 \\
359 \\
920 \\
890 \\
442 \\
181 \\
382\end{array}$ & $\begin{array}{r}35 \\
\mathbf{3 2} \\
\mathbf{3 2} \\
23 \\
\mathbf{2 5} \\
\mathbf{2 6} \\
\mathbf{8 2} \\
247 \\
218 \\
\mathbf{1 3 3} \\
\mathbf{1 0 0} \\
98\end{array}$ & $\begin{array}{r}44.7 \\
37.2 \\
34.9 \\
27.8 \\
26.8 \\
49.5 \\
204 \\
498 \\
506 \\
266 \\
132 \\
155\end{array}$ & $\begin{array}{r}2,750 \\
2,210 \\
2,150 \\
1,710 \\
1,490 \\
3,040 \\
12,100 \\
30,600 \\
30,100 \\
16,400 \\
8,120 \\
9,200\end{array}$ \\
\hline The year... & 920 & $\mathbf{2 3}$ & 166 & 120,000 \\
\hline $\begin{array}{l}\text { October. } \\
\text { November } \\
\text { December } \\
\text { January } \\
\text { February } \\
\text { March } \\
\text { April. } \\
\text { May } \\
\text { June } \\
\text { July } \\
\text { August } \\
\text { September }\end{array}$ & $\begin{array}{r}173 \\
78 \\
48 \\
41 \\
42 \\
65 \\
267 \\
620 \\
902 \\
464 \\
129 \\
129\end{array}$ & $\begin{array}{r}79 \\
33 \\
29 \\
33 \\
35 \\
140 \\
413 \\
144 \\
58 \\
44\end{array}$ & $\begin{array}{c}114 \\
56.2 \\
43.8 \\
37.2 \\
34.6 \\
43.3 \\
116 \\
335 \\
617 \\
278 \\
90.5 \\
58.3\end{array}$ & $\begin{array}{r}7,010 \\
3,340 \\
2,690 \\
2,290 \\
1,920 \\
2,660 \\
6,900 \\
20,600 \\
36,700 \\
17,100 \\
5,560 \\
3,470\end{array}$ \\
\hline The & 902 & 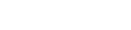 & 152 & 110,000 \\
\hline
\end{tabular}


Monthly discharge of Uncompahgre River below Ouray, Colo., 1913-1927-Contd.

\begin{tabular}{|c|c|c|c|c|}
\hline \multirow{2}{*}{ Month } & \multicolumn{3}{|c|}{ Discharge in second-feet } & \multirow{2}{*}{$\begin{array}{l}\text { Run-off in } \\
\text { acre-feet }\end{array}$} \\
\hline & Maximum & Minimum & Mean & \\
\hline $\begin{array}{l}\text { October. } \\
\text { November } \\
\text { December } \\
\text { January } \\
\text { February } \\
\text { March } \\
\text { April } \\
\text { Muy } \\
\text { July } \\
\text { August } \\
\text { September }\end{array}$ & $\begin{array}{r}185 \\
52 \\
44 \\
31 \\
30 \\
78 \\
382 \\
675 \\
1,620 \\
600 \\
520 \\
1,130\end{array}$ & $\begin{array}{r}48 \\
29 \\
24 \\
24 \\
18 \\
26 \\
47 \\
244 \\
315 \\
200 \\
120 \\
115\end{array}$ & $\begin{array}{c}82.1 \\
40.7 \\
32.8 \\
27.6 \\
24.9 \\
36.4 \\
131 \\
459 \\
517 \\
310 \\
220 \\
306\end{array}$ & $\begin{array}{r}5,050 \\
2,420 \\
2,020 \\
1,700 \\
1,380 \\
2,240 \\
7,800 \\
28,200 \\
30,800 \\
19,100 \\
13,500 \\
18,200\end{array}$ \\
\hline The year............... & 1,620 & 18 & 183 & 132,000 \\
\hline
\end{tabular}

UNCOMPAHGRE RIVER NEAR COLONA, COLO.

Location.-In NE. $1 / 4$ sec. 32 , T. 47 N., R. 8 W., 3 miles south of Colona, Ouray County. Nearest tributary, Billy Creek, enters a short distance upstream.

Drínagf aRea.-419 square miles (measured on topographic map).

Regords avarlable.-April 1, 1904, to November 30, 1905; April 1, 1917, to September 30, 1927.

GAGE.-Friez water-stage recorder at present site. Prior to April 14, 1926, staff or chain gage located 2 miles upstream near highway bridge. Billy Creek, an unimportant tributary, enters between the two sites.

Controu. - Somewhat shifting.

Extremes of discharge.-Maximum discharge recorded, 4,080 second-feet June

13 and 14, 1921; minimum discharge, 16 second-feet on September 3, 1918. Diversions.-A few small diversions above station.

Cooperation.-Records of daily discharge furnished by Bureau of Reclamation.

Monthly discharge of Uncompahgre River near Colona, Colo., for 1904-5 and $1917-1927$

\begin{tabular}{|c|c|c|c|c|}
\hline \multirow{2}{*}{ Month } & \multicolumn{3}{|c|}{ Discharge in second-feet } & \multirow{2}{*}{$\begin{array}{l}\text { Run-off in } \\
\text { acre-foet }\end{array}$} \\
\hline & Maximum & Minimnm & Mean & \\
\hline $\begin{array}{l}\text { April. } \\
\text { May }\end{array}$ & $\begin{array}{r}635 \\
1,240 \\
1,080 \\
710 \\
635\end{array}$ & $\begin{array}{r}69 \\
209 \\
291 \\
-96 \\
96\end{array}$ & $\begin{array}{l}149 \\
567 \\
691 \\
240 \\
310 \\
224\end{array}$ & $\begin{array}{r}8,870 \\
34,900 \\
41,100 \\
14,800 \\
19,100 \\
13,300\end{array}$ \\
\hline The period............. & 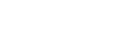 & - nententen & ............. & 132,000 \\
\hline $\begin{array}{l}\text { October. } \\
\text { November } \\
\text { December } \\
\text { January } \\
\text { Fobruary } \\
\text { March } \\
\text { April. } \\
\text { May } \\
\text { June } \\
\text { July } \\
\text { August } \\
\text { September }\end{array}$ & \begin{tabular}{r|r|}
313 \\
165 \\
460 \\
860 \\
1,800 \\
844 \\
408 \\
$\mathbf{2 0 2}$
\end{tabular} & $\begin{array}{r}116 \\
100 \\
110 \\
293 \\
805 \\
317 \\
140 \\
120\end{array}$ & $\begin{array}{r}172 \\
105 \\
95 \\
90 \\
95 \\
85 \\
122 \\
197 \\
543 \\
1,280 \\
436 \\
246 \\
161\end{array}$ & $\begin{array}{r}10,600 \\
6,250 \\
5,840 \\
5,530 \\
4,720 \\
7,500 \\
11,700 \\
33,400 \\
76,100 \\
26,800 \\
15,100 \\
9,580\end{array}$ \\
\hline The year. & 1,800 & - n. & 308 & 223,000 \\
\hline
\end{tabular}


Monthly discharge of Uncompahgre River near Colona, Colo., for 1904-5 and 1917-1927-Continued

\begin{tabular}{|c|c|c|c|c|}
\hline \multirow{2}{*}{ Month } & \multicolumn{3}{|c|}{ Discharge in second-feet } & \multirow{2}{*}{$\underset{\text { gere-feet }}{\text { Run-off in }}$} \\
\hline & Maximum & Minimum & Mean & \\
\hline $\begin{array}{l}\text { October } \\
\text { November }\end{array}$ & $\begin{array}{l}236 \\
143\end{array}$ & $\begin{array}{l}114 \\
112\end{array}$ & $\begin{array}{l}161 \\
121\end{array}$ & $\begin{array}{l}9,900 \\
7,200\end{array}$ \\
\hline $\begin{array}{l}\text { April.... } \\
\text { May } \\
\text { June } \\
\text { July } \\
\text { August } \\
\text { September... }\end{array}$ & $\begin{array}{r}495 \\
800 \\
2,320 \\
1,610 \\
705 \\
145\end{array}$ & $\begin{array}{r}93 \\
246 \\
498 \\
485 \\
145 \\
110\end{array}$ & $\begin{array}{r}225 \\
456 \\
1,460 \\
882 \\
330 \\
114\end{array}$ & $\begin{array}{r}13,400 \\
28,000 \\
86,900 \\
54,200 \\
20,300 \\
6,780 \\
\end{array}$ \\
\hline The period.. & $\ldots \ldots$ & ......... & 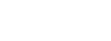 & 210,000 \\
\hline $\begin{array}{l}\text { October } \\
\text { November } \\
\text { December } \\
\text { January } \\
\text { February } \\
\text { March } \\
\text { April } \\
\text { May } \\
\text { Junne } \\
\text { July } \\
\text { August } \\
\text { September }\end{array}$ & 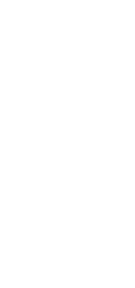 & 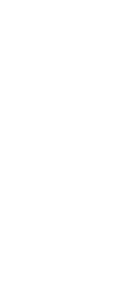 & $\begin{array}{c}68.7 \\
80 \\
75 \\
75 \\
75 \\
85 \\
117 \\
509 \\
1,100 \\
417 \\
94.6 \\
147\end{array}$ & $\begin{array}{r}4,220 . \\
4,760 \\
4,610 \\
4,610 \\
4,160 \\
5,230 \\
6,960 \\
31,300 \\
65,500 \\
25,600 \\
5,820 \\
8,750\end{array}$ \\
\hline The & 2,270 & $\ldots$ & 238 & 172,000 \\
\hline $\begin{array}{l}\text { October } \\
\text { November } \\
\text { December } \\
\text { January } \\
\text { February } \\
\text { March } \\
\text { April } \\
\text { May } \\
\text { June } \\
\text { July } \\
\text { Auguist } \\
\text { September }\end{array}$ & 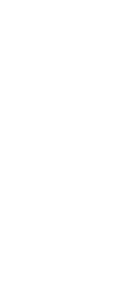 & \begin{tabular}{r|}
115 \\
\\
\\
365 \\
327 \\
250 \\
47 \\
40 \\
\end{tabular} & $\begin{array}{c}125 \\
100 \\
90 \\
85 \\
75 \\
100 \\
332 \\
606 \\
732 \\
513 \\
218 \\
31.6\end{array}$ & $\begin{array}{r}7,690 \\
5,950 \\
5,530 \\
5,230 \\
4,160 \\
6,150 \\
19,800 \\
37,300 \\
43,600 \\
31,500 \\
13,400 \\
4,860\end{array}$ \\
\hline The ye & 1,300 & -............. & 256 & 185,000 \\
\hline $\begin{array}{l}\text { October-. } \\
\text { November } \\
\text { December } \\
\text { January } \\
\text { February } \\
\text { March } \\
\text { April } \\
\text { May } \\
\text { June } \\
\text { July } \\
\text { August } \\
\text { September }\end{array}$ & $\begin{array}{r}150 \\
\\
1,600 \\
1,600 \\
1,100 \\
485 \\
157\end{array}$ & $\begin{array}{r}146 \\
861 \\
1,110 \\
605 \\
279 \\
119\end{array}$ & $\begin{array}{r}107 \\
80 \\
80 \\
75 \\
75 \\
80 \\
146 \\
861 \\
1,110 \\
605 \\
279 \\
119\end{array}$ & $\begin{array}{r}6,580 \\
4,760 \\
4,920 \\
4,610 \\
4,310 \\
4,920 \\
8,690 \\
52,990 \\
66,000 \\
37,200 \\
17,200 \\
7,080 \\
\end{array}$ \\
\hline The year... & 1,600 & …............. & 302 & 219,000 \\
\hline $\begin{array}{l}\text { October-. } \\
\text { November } \\
\text { December } \\
\text { January } \\
\text { February } \\
\text { March } \\
\text { April } \\
\text { Mayg } \\
\text { June } \\
\text { July } \\
\text { August }\end{array}$ & $\begin{array}{r}166 \\
140 \\
105 \\
1,400 \\
1,080 \\
1,370 \\
670 \\
521 \\
\end{array}$ & $\begin{array}{r}170 \\
477 \\
1,030 \\
627 \\
256 \\
119 \\
\end{array}$ & $\begin{array}{r}129 \\
117 \\
84.8 \\
78 \\
80 \\
90 \\
263 \\
869 \\
2,180 \\
908 \\
438 \\
246 \\
\end{array}$ & $\begin{array}{r}7,930 \\
6,960 \\
5,210 \\
4,800 \\
4,440 \\
5,590 \\
15,600 \\
53,400 \\
130,900 \\
55,800 \\
28 ; 900 \\
14,600 \\
\end{array}$ \\
\hline The year. & 4,080 & 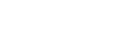 & 458 & 381,000 \\
\hline
\end{tabular}


Monthly discharge of Uncompahgre River near Colona, Colo., for 1904-5 and 1917-1927-Continued

\begin{tabular}{|c|c|c|c|c|}
\hline \multirow{2}{*}{ Month } & \multicolumn{3}{|c|}{ Discharge in socond-feet } & \multirow{2}{*}{$\begin{array}{l}\text { Run-off in } \\
\text { acre-feet }\end{array}$} \\
\hline & Maximum & Minimum & Mean & \\
\hline $\begin{array}{l}\text { October } \\
\text { November } \\
\text { December } \\
\text { January } \\
\text { February } \\
\text { March } \\
\text { April } \\
\text { May }\end{array}$ & $\begin{array}{r}140 \\
1,070 \\
1,500 \\
1,200 \\
565 \\
183\end{array}$ & $\begin{array}{r}95 \\
100 \\
524 \\
660 \\
270 \\
186 \\
81\end{array}$ & $\begin{array}{r}113 \\
95 \\
90 \\
85 \\
90 \\
95 \\
231 \\
771 \\
1,180 \\
590 \\
311 \\
121\end{array}$ & $\begin{array}{r}6,950 \\
5,650 \\
5,530 \\
5,250 \\
5,000 \\
5,840 \\
13,700 \\
47,400 \\
70,200 \\
36,300 \\
19,100 \\
7,200\end{array}$ \\
\hline The year............. & 1,500 & - & 317 & 228,000 \\
\hline $\begin{array}{l}\text { October. } \\
\text { November } \\
\text { December } \\
\text { January } \\
\text { February } \\
\text { March } \\
\text { April } \\
\text { May } \\
\text { June } \\
\text { July } \\
\text { August } \\
\text { September. }\end{array}$ & $\begin{array}{r}84 \\
277 \\
1,380 \\
1,020 \\
690 \\
330\end{array}$ & \begin{tabular}{r|r|} 
& 65 \\
& 98 \\
& 265 \\
605 \\
320 \\
212 \\
180
\end{tabular} & $\begin{array}{l}73.4 \\
85 \\
85 \\
80 \\
80 \\
85 \\
158 \\
552 \\
977 \\
705 \\
358 \\
225\end{array}$ & $\begin{array}{r}4,510 \\
5,060 \\
5,230 \\
4,920 \\
4,440 \\
5,230 \\
9,400 \\
33,900 \\
58,100 \\
43,300 \\
22,000 \\
13,400\end{array}$ \\
\hline The year........... & 1,380 & & 289 & 200,000 \\
\hline $\begin{array}{l}\text { October. } \\
\text { November. } \\
\text { December. } \\
\text { January } \\
\text { February } \\
\text { March } \\
\text { April } \\
\text { May } \\
\text { June. } \\
\text { July } \\
\text { August } \\
\text { September. }\end{array}$ & $\begin{array}{r}203 \\
156 \\
755 \\
935 \\
1,620 \\
566 \\
243 \\
188\end{array}$ & $\begin{array}{r}125 \\
104 \\
105 \\
501 \\
550 \\
121 \\
101 \\
93\end{array}$ & $\begin{array}{r}160 \\
120 \\
100 \\
95 \\
95 \\
95 \\
377 \\
770 \\
1,000 \\
345 \\
155 \\
121\end{array}$ & $\begin{array}{r}9,840 \\
7,140 \\
6,150 \\
5,840 \\
5,460 \\
5,840 \\
22,400 \\
47,300 \\
59,500 \\
21,200 \\
9,530 \\
7,200\end{array}$ \\
\hline The year............. & 1,620 & n. & 287 & 207,000 \\
\hline $\begin{array}{l}\text { October. } \\
\text { November. } \\
\text { December } \\
\text { January } \\
\text { February } \\
\text { March } \\
\text { April. } \\
\text { May } \\
\text { June } \\
\text { July } \\
\text { August } \\
\text { September }\end{array}$ & $\begin{array}{r}160 \\
1, \\
1,9030 \\
900 \\
915 \\
395 \\
722\end{array}$ & $\begin{array}{r}102 \\
492 \\
462 \\
355 \\
195 \\
182\end{array}$ & $\begin{array}{r}125 \\
100 \\
95 \\
85 \\
82 \\
135 \\
522 \\
788 \\
820 \\
615 \\
291 \\
318\end{array}$ & $\begin{array}{r}7,690 \\
5,950 \\
5,840 \\
5,230 \\
4,550 \\
8,300 \\
31,100 \\
48,500 \\
48,800 \\
37,800 \\
17,900 \\
18,900\end{array}$ \\
\hline The year. & 1,400 & $\ldots$ & 333 & 241,000 \\
\hline $\begin{array}{l}\text { October. } \\
\text { November } \\
\text { December } \\
\text { January } \\
\text { February } \\
\text { March } \\
\text { April. } \\
\text { May } \\
\text { June } \\
\text { July } \\
\text { August }\end{array}$ & $\begin{array}{r}265 \\
148 \\
1,200 \\
1,730 \\
1,080 \\
2252 \\
100\end{array}$ & $\begin{array}{r}138 \\
104 \\
114 \\
410 \\
850 \\
240 \\
98 \\
69\end{array}$ & $\begin{array}{c}180 \\
116 \\
94 \\
75 \\
75 \\
85 \\
384 \\
761 \\
1,250 \\
603 \\
176 \\
94.6\end{array}$ & $\begin{array}{r}11,100 \\
6,900 \\
5,780 \\
4,610 \\
4,160 \\
5,230 \\
22,800 \\
46,800 \\
74,400 \\
37,100 \\
10,800 \\
5,630\end{array}$ \\
\hline & 1,730 & $2-20-2$ & 324 & 235,000 \\
\hline
\end{tabular}


Monthly discharge of Uncompahgre River near Colona, Colo., for 1904-5 and 1917-1927-Continued

\begin{tabular}{|c|c|c|c|c|}
\hline \multirow{2}{*}{ Month } & \multicolumn{3}{|c|}{ Discharge in second-feet } & \multirow{2}{*}{$\begin{array}{l}\text { Run-off in } \\
\text { acr } \theta \text {-feet }\end{array}$} \\
\hline & Maximum & Minimum & Mean & \\
\hline $\begin{array}{l}\text { October } \\
\text { November } \\
\text { Decernber } \\
\text { January } \\
\text { February } \\
\text { Mareh } \\
\text { April } \\
\text { May } \\
\text { June } \\
\text { July } \\
\text { August } \\
\text { Beptember }\end{array}$ & $\begin{array}{r}353 \\
126 \\
170 \\
713 \\
1,240 \\
2,680 \\
1,060 \\
1,190 \\
\end{array}$ & $\begin{array}{r}113 \\
94 \\
\\
\\
143 \\
415 \\
575 \\
340 \\
270 \\
200 \\
\end{array}$ & $\begin{array}{r}174 \\
112 \\
90 \\
85 \\
80 \\
110 \\
297 \\
791 \\
\mathbf{1}, 000 \\
538 \\
424 \\
509\end{array}$ & $\begin{array}{r}16,700 \\
6,660 \\
5,530 \\
5,230 \\
4,440 \\
6,760 \\
17,700 \\
48,600 \\
59,500 \\
33,100 \\
26,100 \\
30,300\end{array}$ \\
\hline The year. & 2,680 & 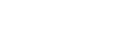 & 352 & 255,000 \\
\hline
\end{tabular}

NoTE.-Records during winter based on discharge of Uncompahgre River below Ouray.

UTCOMPAHGRE RIVER AT DELTA, COLO.

Location.-In NW. $1 / 4$ sec. 24 , T. 15 S., R. 96 W., at railroad bridge half a mile west of Delta, Delta County. No tributary between station and mouth, $1 \frac{1}{2}$ miles downstream.

Drainage AREa.-1,110 square miles (measured on base map of Colorado).

Records available.-May 1, 1903, to September 30, 1927.

GAGE.-Bristol flaat-type gage. Prior to 1924, staff gage at highway bridge $31 / 2$ miles upstream, where records are comparable, except for return seepage water.

Control.- Shifting during extreme high water at present site; shifting at frequent intervals at original site.

EXTREMES of DISCHARGE.- Maximum discharge recorded, 2,490 second-feet at 7.30 p. m. June 12,1921 ; minimum discharge since diversion through Gunnison Tunnel began in 1910, 7 second-feet on several days during July, 1910.

Diversions.-Normal flow diverted above station during irrigation season; records represent chiefly return seepage water.

Cooperation.--Station maintained in cooperation with Bureau of Reclamation and State engineer. Prior to 1924 complete records furnished by Bureau of Reclamation.

Monthly discharge of Uncompahgre River at Delta, Colo., for 1908-1927

\begin{tabular}{|c|c|c|c|c|}
\hline \multirow{2}{*}{ Month } & \multicolumn{3}{|c|}{ Discharge in second-feet } & \multirow{2}{*}{$\begin{array}{c}\text { Run-off in } \\
\text { acre-feet }\end{array}$} \\
\hline & Maximum & Minimum & Mean & \\
\hline $\begin{array}{l}\text { May } 1903 \\
\text { June } \\
\text { July } \\
\text { August } \\
\text { September }\end{array}$ & $\begin{array}{r}514 \\
2,410 \\
773 \\
40 \\
324 \\
\end{array}$ & $\begin{array}{r}10 \\
89 \\
45 \\
21 \\
7 \\
\end{array}$ & $\begin{array}{c}\mathbf{1 9 2} \\
918 \\
340 \\
25.0 \\
\mathbf{4 8 . 6} \\
\end{array}$ & $\begin{array}{r}11,800 \\
54,600 \\
20,900 \\
1,540 \\
2,800 \\
\end{array}$ \\
\hline $\begin{array}{l}\text { October } \\
\text { November } \\
\text { December } \\
\text { March } \\
\text { April } \\
\text { May } \\
\text { June } \\
\text { July } \\
\text { August } \\
\text { September }\end{array}$ & $\begin{array}{r}20 \\
114 \\
148 \\
28 \\
10 \\
145 \\
95 \\
7 \\
98 \\
557 \\
\end{array}$ & $\begin{array}{r}4 \\
6 \\
89 \\
7 \\
1 \\
1 \\
3 \\
2 \\
3 \\
9 \\
\end{array}$ & $\begin{array}{r}6.3 \\
59.9 \\
118 \\
12.0 \\
4.2 \\
12.7 \\
19.4 \\
3.4 \\
15.3 \\
67.0 \\
\end{array}$ & $\begin{array}{r}389 \\
3,210 \\
7,260 \\
738 \\
250 \\
781 \\
1,160 \\
\quad 209 \\
3941 \\
3,990 \\
\end{array}$ \\
\hline
\end{tabular}


Monthly discharge of Uncompahgre River at Delta, Colo., for 1903-1927-Contd.

\begin{tabular}{|c|c|c|c|c|}
\hline \multirow{2}{*}{ Month } & \multicolumn{3}{|c|}{ Discharge In second-feet } & \multirow{2}{*}{$\begin{array}{l}\text { Run-off in } \\
\text { acre-foet }\end{array}$} \\
\hline & Maxímum & Minimum & Mean & \\
\hline $\begin{array}{l}\text { October } \\
\text { November. } \\
\text { Pecember. } \\
\text { March. } \\
\text { April } \\
\text { May. } \\
\text { June } \\
\text { July } \\
\text { August. } \\
\text { September. }\end{array}$ & $\begin{array}{r}332 \\
168 \\
190 \\
363 \\
449 \\
1,260 \\
1,780 \\
121 \\
56 \\
26\end{array}$ & $\begin{array}{r}22 \\
35 \\
120 \\
111 \\
6 \\
89 \\
180 \\
6 \\
8 \\
8\end{array}$ & $\begin{array}{c}77.5 \\
78.0 \\
156 \\
161 \\
88.1 \\
597 \\
894 \\
21.0 \\
15.3 \\
15.8\end{array}$ & $\begin{array}{r}4,760 \\
4,640 \\
9,500 \\
9,900 \\
5,240 \\
36,700 \\
58,200 \\
1,290 \\
941 \\
940\end{array}$ \\
\hline $\begin{array}{l}\text { October } \\
\text { November } \\
\text { December 1-24 } \\
\text { March. } \\
\text { April } \\
\text { May } \\
\text { June } \\
\text { July } \\
\text { August } \\
\text { September }\end{array}$ & $\begin{array}{r}34 \\
\$ 3 \\
254 \\
130 \\
858 \\
1,510 \\
1,350 \\
280 \\
208 \\
242\end{array}$ & $\begin{array}{r}14 \\
15 \\
119 \\
29 \\
25 \\
157 \\
205 \\
46 \\
37 \\
36\end{array}$ & $\begin{array}{l}18.1 \\
27.9 \\
156 \\
65.6 \\
175 \\
827 \\
629 \\
108 \\
82.8 \\
97.7\end{array}$ & $\begin{array}{r}1,110 \\
1,660 \\
7,430 \\
4,030 \\
10,400 \\
50,800 \\
37,400 \\
6,640 \\
5,000 \\
5,810\end{array}$ \\
\hline $\begin{array}{l}\text { October. } \\
\text { April } 21-3006-7 \\
\text { Jany } \\
\text { July } \\
\text { August } \\
\text { September }\end{array}$ & $\begin{array}{r}224 \\
55 \\
359 \\
960 \\
1,150 \\
400 \\
127\end{array}$ & $\begin{array}{r}97 \\
8 \\
6 \\
11 \\
101 \\
77 \\
36\end{array}$ & $\begin{array}{l}1451 / 2 \\
19.1 \\
66.5 \\
368 \\
526 \\
196 \\
72.5\end{array}$ & $\begin{array}{r}8,920 \\
379 \\
4,000 \\
21,800 \\
32,300 \\
12,100 \\
4,310\end{array}$ \\
\hline $\begin{array}{l}\text { October. } \\
\text { November } \\
\text { January } \\
\text { February } \\
\text { March } \\
\text { April. } \\
\text { May } \\
\text { June } \\
\text { July } \\
\text { August } \\
\text { September. }\end{array}$ & $\begin{array}{r}170 \\
283 \\
215 \\
200 \\
215 \\
42 \\
12 \\
380 \\
114 \\
515 \\
33\end{array}$ & $\begin{array}{r}55 \\
66 \\
127 \\
100 \\
33 \\
0 \\
0 \\
0 \\
1 \\
4 \\
1\end{array}$ & $\begin{array}{c}81.0 \\
140 \\
162 \\
132 \\
119 \\
12.2 \\
2.0 \\
75.2 \\
9.0 \\
180 \\
14.1\end{array}$ & $\begin{array}{r}4,980 \\
8,330 \\
9,960 \\
7,690 \\
7,320 \\
720 \\
123 \\
4,470 \\
853 \\
9,220 \\
839\end{array}$ \\
\hline $\begin{array}{l}\text { October. } \\
\text { November } \\
\text { April } \\
\text { May } \\
\text { June } \\
\text { July }\end{array}$ & $\begin{array}{r}302 \\
184 \\
590 \\
690 \\
1,100 \\
770 \\
430\end{array}$ & $\begin{array}{r}4 \\
74 \\
51 \\
51 \\
80 \\
27 \\
27\end{array}$ & $\begin{array}{l}68.2 \\
122 \\
170 \\
285 \\
725 \\
243 \\
160\end{array}$ & $\begin{array}{r}3,890 \\
7,260 \\
10,100 \\
17,500 \\
43,100 \\
14,900 \\
9,840\end{array}$ \\
\hline 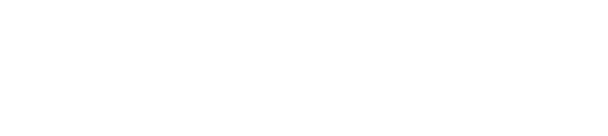 & $\begin{array}{l}750 \\
770 \\
165 \\
460 \\
135\end{array}$ & $\begin{array}{r}20 \\
23 \\
7 \\
15 \\
15\end{array}$ & $\begin{array}{r}218 \\
365 \\
17 \\
58 \\
41\end{array}$ & $\begin{array}{r}13,400 \\
21,700 \\
1,040 \\
3,600 \\
2,440\end{array}$ \\
\hline $\begin{array}{l}\text { October. } \\
\text { April } \\
\text { May } \\
\text { June } \\
\text { Jaly } \\
\text { Angust } \\
\text { September }\end{array}$ & $\begin{array}{l}540 \\
200 \\
560 \\
650 \\
770 \\
187 \\
570\end{array}$ & $\begin{array}{r}\mathbf{3 5} \\
\mathbf{3 0} \\
\mathbf{5 5} \\
\mathbf{5 5} \\
\mathbf{1 3 5} \\
\mathbf{1 8} \\
\mathbf{3 6}\end{array}$ & $\begin{array}{l}154 \\
146 \\
160 \\
365 \\
430 \\
53.8 \\
158\end{array}$ & $\begin{array}{r}9,470 \\
8,690 \\
9,840 \\
21,700 \\
26,400 \\
3,310 \\
9,400\end{array}$ \\
\hline $\begin{array}{l}\text { October } \\
\text { April } 1611-12 \\
\text { May } \\
\text { June } \\
\text { July } \\
\text { August } \\
\text { September }\end{array}$ & $\begin{array}{r}1,740 \\
280 \\
1,830 \\
1,670 \\
1,080 \\
300 \\
245\end{array}$ & $\begin{array}{r}\mathbf{2 6 4} \\
\mathbf{3 0} \\
\quad \mathbf{2 3 5} \\
\because \quad \mathbf{1 8 0} \\
\quad \mathbf{5 0} \\
\quad \mathbf{3 5} \\
\quad \mathbf{3 5}\end{array}$ & $\begin{array}{l}565 \\
86.5 \\
895 \\
868 \\
437 \\
82.3 \\
131\end{array}$ & $\begin{array}{r}34,700 \\
\mathbf{3}, 680 \\
55,000 \\
51,600 \\
26,000 \\
5,000 \\
7,800\end{array}$ \\
\hline
\end{tabular}


Monthly discharge of Uncompahgre River at Delta, Colo., for 1908-1927-Contd.

\begin{tabular}{|c|c|c|c|c|}
\hline \multirow{2}{*}{ Month } & \multicolumn{3}{|c|}{ Discharge in second-foet } & \multirow{2}{*}{$\begin{array}{l}\text { Run-off in } \\
\text { acre-feet }\end{array}$} \\
\hline & Maximum & Minimum & Mean & \\
\hline $\begin{array}{l}\text { April } 15-30 \\
\text { May } \\
\text { June } \\
\text { July } \\
\text { Angust } \\
\text { September } \\
\text { October } \\
\text { November } \\
\text { December } 1-1813\end{array}$ & $\begin{array}{r}620 \\
268 \\
205 \\
448 \\
68 \\
620 \\
325 \\
220 \\
220 \\
\end{array}$ & $\begin{array}{r}77 \\
60 \\
68 \\
37 \\
18 \\
37 \\
105 \\
126 \\
162 \\
\end{array}$ & $\begin{array}{l}305 \\
127 \\
145 \\
105 \\
46.4 \\
203 \\
182 \\
156 \\
181 \\
\end{array}$ & $\begin{array}{r}9,680 \\
7,810 \\
8,630 \\
6,460 \\
2,850 \\
12,100 \\
11,200 \\
9,280 \\
6,460 \\
\end{array}$ \\
\hline $\begin{array}{l}\text { October } \\
\text { November } 1-1014-15 \\
\text { March } 8-31 \\
\text { April } \\
\text { May } \\
\text { June- } \\
\text { July } \\
\text { August } \\
\text { September }\end{array}$ & $\begin{array}{l}365 \\
285 \\
164 \\
750 \\
750 \\
810 \\
152 \\
191 \\
410 \\
\end{array}$ & $\begin{array}{r}220 \\
108 \\
57 \\
57 \\
80 \\
118 \\
57 \\
57 \\
50 \\
\end{array}$ & $\begin{array}{c}294 \\
218 \\
126 \\
127 \\
209 \\
372 \\
105 \\
94.3 \\
106 \\
\end{array}$ & $\begin{array}{r}18,100 \\
7,780 \\
6,000 \\
7,560 \\
12,900 \\
22,100 \\
6,460 \\
5,800 \\
6,310 \\
\end{array}$ \\
\hline 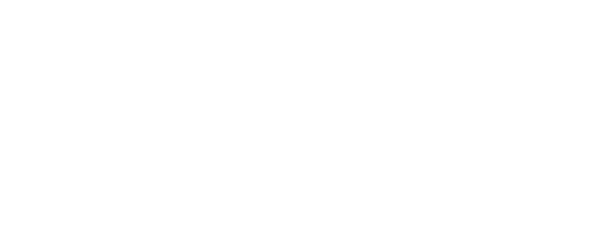 & $\begin{array}{r}365 \\
220 \\
206 \\
367 \\
452 \\
410 \\
410 \\
1,210 \\
402 \\
\end{array}$ & $\begin{array}{r}98 \\
98 \\
152 \\
-48 \\
82 \\
73 \\
40 \\
92 \\
92 \\
\end{array}$ & $\begin{array}{l}187 \\
177 \\
195 \\
179 \\
239 \\
168 \\
142 \\
340 \\
161 \\
\end{array}$ & $\begin{array}{r}11,500 \\
10,500 \\
5,800 \\
5,330 \\
14,700 \\
10,000 \\
8,730 \\
20,900 \\
9,580 \\
\end{array}$ \\
\hline $\begin{array}{l}\text { October 1-28. } \\
\text { April. } \\
\text { May } \\
\text { June } \\
\text { July } \\
\text { August } \\
\text { September }\end{array}$ & $\begin{array}{l}700 \\
503 \\
916 \\
865 \\
769 \\
648 \\
356 \\
\end{array}$ & $\begin{array}{r}102 \\
126 \\
156 \\
248 \\
77 \\
59 \\
48 \\
\end{array}$ & $\begin{array}{l}364 \\
248 \\
451 \\
537 \\
230 \\
163 \\
170 \\
\end{array}$ & $\begin{array}{l}20,200 \\
14,800 \\
27,700 \\
32,000 \\
14,100 \\
10,000 \\
10,100 \\
\end{array}$ \\
\hline $\begin{array}{l}\text { October } \\
\text { April } 22-30 \\
\text { May } \\
\text { June } \\
\text { July } \\
\text { August } \\
\text { September }\end{array}$ & $\begin{array}{r}435 \\
1,100 \\
1035 \\
335 \\
335 \\
535 \\
\end{array}$ & $\begin{array}{r}47 \\
37 \\
67 \\
58 \\
10 \\
70 \\
\end{array}$ & $\begin{array}{r}194 \\
85.8 \\
102 \\
390 \\
108 \\
99.1 \\
199 \\
\end{array}$ & $\begin{array}{r}71,900 \\
1,530 \\
6,270 \\
23,700 \\
6,640 \\
6,090 \\
11,800 \\
\end{array}$ \\
\hline $\begin{array}{l}\text { October. } \\
\text { April } 7-30 \\
\text { May } \\
\text { June } \\
\text { July } \\
\text { August } \\
\text { September. }\end{array}$ & $\begin{array}{l}308 \\
490 \\
771 \\
402 \\
670 \\
672 \\
445 \\
\end{array}$ & $\begin{array}{r}40 ! \\
25 \\
51 \\
100 \\
135 \\
106 \\
87 \\
\end{array}$ & $\begin{array}{l}164 \\
174 \\
317 \\
209 \\
268 \\
253 \\
245 \\
\end{array}$ & $\begin{array}{r}10,100 \\
8,200 \\
19,500 \\
12,400 \\
16,800 \\
15,600 \\
14,600 \\
\end{array}$ \\
\hline $\begin{array}{l}\text { October } \\
\text { April } \\
\text { May } \\
\text { June } \\
\text { July } \\
\text { August } \\
\text { Soptember. }\end{array}$ & $\begin{array}{r}417 \\
587 \\
2,000 \\
880 \\
370 \\
742 \\
695 \\
\end{array}$ & $\begin{array}{r}140 \\
23 \\
165 \\
54 \\
34 \\
78 \\
57 \\
\end{array}$ & $\begin{array}{l}286 \\
122 \\
956 \\
353 \\
122 \\
244 \\
238 \\
\end{array}$ & $\begin{array}{r}17,600 \\
7,200 \\
68,800 \\
21,000 \\
7,500 \\
15,000 \\
14,200 \\
\end{array}$ \\
\hline $\begin{array}{l}\text { October-1920-21 } \\
\text { November } \\
\text { December } \\
\text { Jenuam } \\
\text { February } \\
\text { March } \\
\text { April } \\
\text { May } \\
\text { June } \\
\text { July } \\
\text { August } \\
\text { September }\end{array}$ & $\begin{array}{r}520 \\
211^{-} \\
220 \\
214 \\
234 \\
835 \\
793 \\
2.300 \\
588 \\
532 \\
442\end{array}$ & $\begin{array}{r}141 \\
130 \\
104 \\
22 \\
24 \\
21 \\
69 \\
28 \\
28 \\
30\end{array}$ & $\begin{array}{l}210 \\
194 \\
168 \\
160 \\
138 \\
80.4 \\
145 \\
475 \\
855 \\
251 \\
244 \\
150\end{array}$ & $\begin{array}{r}12,900 \\
11,700 \\
10,200 \\
9,840 \\
7,660 \\
5,860 \\
8,690 \\
20,200 \\
60,000 \\
15,400 \\
15,000 \\
9,400\end{array}$ \\
\hline The year. & 2,300 & 21 & $\cdots$ & 186,000 \\
\hline
\end{tabular}


Monthly discharge of Uncompahgre River at Delta, Colo., for 1908-1927-Contd.

\begin{tabular}{|c|c|c|c|c|}
\hline \multirow{2}{*}{ Month } & \multicolumn{3}{|c|}{ Discharge in second-feet } & \multirow{2}{*}{$\begin{array}{c}\text { Run-off in } \\
\text { acre-feet }\end{array}$} \\
\hline & Maximum & Minimum & Mean & \\
\hline $\begin{array}{l}\text { October.-1921-22 } \\
\text { April_- } \\
\text { May } \\
\text { June } \\
\text { July } \\
\text { August } \\
\text { September }\end{array}$ & $\begin{array}{r}250 \\
280 \\
1,180 \\
930 \\
334 \\
472 \\
225 \\
\end{array}$ & $\begin{array}{r}128 \\
35 \\
125 \\
117 \\
23 \\
111 \\
132 \\
\end{array}$ & $\begin{array}{l}189 \\
128 \\
542 \\
411 \\
135 \\
225 \\
178 \\
\end{array}$ & $\begin{array}{r}11,600 \\
7,620 \\
33,300 \\
24,600 \\
8,300 \\
13,800 \\
10,600 \\
\end{array}$ \\
\hline $\begin{array}{l}\text { October._. } \\
\text { May } \\
\text { June } \\
\text { July } \\
\text { August } \\
\text { September. }\end{array}$ & $\begin{array}{r}550 \\
1,510 \\
1,050 \\
745 \\
1,500 \\
715\end{array}$ & $\begin{array}{r}146 \\
60 \\
250 \\
80 \\
148 \\
92\end{array}$ & $\begin{array}{l}328 \\
691 \\
594 \\
437 \\
581 \\
416\end{array}$ & $\begin{array}{l}20,200 \\
42,500 \\
35,300 \\
26,900 \\
35,700 \\
24,800\end{array}$ \\
\hline $\begin{array}{l}\text { October } \\
\text { April 26-30 } \\
\text { May } \\
\text { June } \\
\text { July } \\
\text { August. } \\
\text { September }\end{array}$ & $\begin{array}{r}715 \\
261 \\
1,430 \\
1,040 \\
277 \\
128 \\
270\end{array}$ & $\begin{array}{r}487 \\
119 \\
126 \\
171 \\
105 \\
77 \\
79\end{array}$ & $\begin{array}{l}565 \\
161 \\
472 \\
568 \\
128 \\
99.4 \\
125\end{array}$ & $\begin{array}{r}34,700 \\
1,600 \\
29,000 \\
33,800 \\
7,870 \\
6,110 \\
7,440\end{array}$ \\
\hline $\begin{array}{l}\text { October } \\
\text { November } \\
\text { April } \\
\text { May } \\
\text { June } \\
\text { July } \\
\text { August } \\
\text { September }\end{array}$ & $\begin{array}{r}478 \\
\mathbf{3 0 1} \\
\mathbf{5 9 5} \\
\mathbf{5 4 5} \\
\mathbf{8 2 6} \\
\mathbf{1}, \mathbf{3 6 0} \\
\mathbf{1}, \mathbf{2 4 0} \\
\mathbf{1}, \mathbf{1 8 0}\end{array}$ & $\begin{array}{r}223 \\
223 \\
59 \\
77 \\
185 \\
187 \\
190 \\
370\end{array}$ & $\begin{array}{l}306 \\
258 \\
231 \\
244 \\
428 \\
530 \\
561 \\
643\end{array}$ & $\begin{array}{l}18,800 \\
15,400 \\
13,700 \\
15,000 \\
25,500 \\
32,600 \\
34,500 \\
38,300\end{array}$ \\
\hline 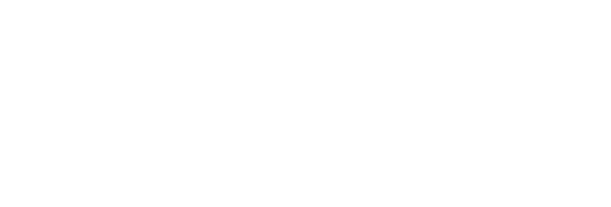 & $\begin{array}{r}527 \\
407 \\
891 \\
857 \\
1,160 \\
775 \\
471 \\
160\end{array}$ & $\begin{array}{r}164 \\
145 \\
51 \\
156 \\
172 \\
156 \\
111 \\
91\end{array}$ & $\begin{array}{l}400 \\
264 \\
351 \\
414 \\
586 \\
337 \\
199 \\
115\end{array}$ & $\begin{array}{r}24,600 \\
8,380 \\
20,900 \\
25,500 \\
34,900 \\
20,700 \\
12,200 \\
6,840\end{array}$ \\
\hline $\begin{array}{l}\text { October } \\
\text { April } \\
\text { May } \\
\text { June } \\
\text { July } \\
\text { Jugust } \\
\text { Augtember } \\
\text { September }\end{array}$ & $\begin{array}{r}646 \\
843 \\
864 \\
2,530 \\
770 \\
1,310 \\
1,540\end{array}$ & $\begin{array}{r}181 \\
66 \\
229 \\
202 \\
95 \\
205 \\
324\end{array}$ & $\begin{array}{l}407 \\
196 \\
455 \\
765 \\
298 \\
497 \\
670\end{array}$ & $\begin{array}{l}25,000 \\
11,700 \\
28,000 \\
45,500 \\
18,300 \\
30,600 \\
39,900\end{array}$ \\
\hline
\end{tabular}

Note.-Records for 1903 revised.

CANYON CREEK AT OURAY, COLO.

Location.-In sec. 31, T. 44 N., R. 7 W., at Ouray, Ouray County, 200 feet above mouth.

Drainage area.-26 square miles (measured on topographic map).

Records available.-October 1, 1910, to November 30, 1915.

GAGE.-Vertical staff.

Controu.-Shifting.

Extremes of discharge.-Maximum stage recorded during period, 4.4 feet during night of June 21, 1915, as determined from high-water mark (discharge, 580 second-feet); minimum discharge recorded, 2 second-feet on February 3, 1915. 
ICE.-Stage-discharge relation unaffected by ice.

Diversions.-None.

AcCURACY.-Gage read once daily except high-water period of 1915, when it was: read twice. Rating curves not well defined. Records fair.

Cooperatron.-Station maintained in cooperation with United States Forest. Service.

Monthly discharge of Canyon Creek at Ouray, Colo., for 1910-1915

\begin{tabular}{|c|c|c|c|c|}
\hline \multirow{2}{*}{ Month } & \multicolumn{3}{|c|}{ Discharge in second-feet } & \multirow{2}{*}{$\begin{array}{l}\text { Run-off in } \\
\text { acre-feet }\end{array}$} \\
\hline & Maximum & Minimum & Mean & \\
\hline $\begin{array}{l}\text { October } \\
\text { November } \\
\text { December } \\
\text { January } \\
\text { February } \\
\text { March } \\
\text { April } \\
\text { May } \\
\text { June } \\
\text { July } \\
\text { August } \\
\text { September }\end{array}$ & $\begin{array}{r}14 \\
50 \\
92 \\
172 \\
296 \\
368 \\
138 \\
172\end{array}$ & $\begin{array}{r}6 \\
8 \\
20 \\
38 \\
155 \\
138 \\
38 \\
28\end{array}$ & $\begin{array}{rl}a & 22 \\
a & 8 \\
2 & 6 \\
a & 7 \\
8.8 \\
11.5 \\
45.3 \\
105 \\
235 \\
211 \\
91.5 \\
42.0\end{array}$ & $\begin{array}{r}1,350 \\
476 \\
369 \\
430 \\
490 \\
707 \\
2,700 \\
6,460 \\
14,000 \\
13,000 \\
5,630 \\
2,500\end{array}$ \\
\hline The year.... & 368 & (n) & 66.1 & 47,800 \\
\hline $\begin{array}{l}\text { October } \\
\text { November } \\
\text { December } \\
\text { January } \\
\text { February } \\
\text { March } \\
\text { April } \\
\text { May } \\
\text { June } \\
\text { July } \\
\text { August } \\
\text { September }\end{array}$ & $\begin{array}{r}510 \\
20 \\
8 \\
10 \\
8 \\
9 \\
43 \\
320 \\
392 \\
284 \\
127 \\
49\end{array}$ & $\begin{array}{r}20 \\
8 \\
6 \\
6 \\
5 \\
3 \\
9 \\
23 \\
142 \\
142 \\
40 \\
14\end{array}$ & $\begin{array}{c}104 \\
12.9 \\
7.29 \\
7.48 \\
6.03 \\
6.45 \\
17.6 \\
149 \\
254 \\
186 \\
62.6 \\
23.8\end{array}$ & $\begin{array}{r}6,400 \\
768 \\
448 \\
460 \\
347 \\
397 \\
1,050 \\
9,160 \\
15,100 \\
11,400 \\
3,850 \\
1,420\end{array}$ \\
\hline The year.......... & 392 & 3 & 70.3 & 50,800 \\
\hline $\begin{array}{l}\text { October. } \\
\text { November } \\
\text { December } \\
\text { January } \\
\text { February } \\
\text { Mareh } \\
\text { April } \\
\text { May } \\
\text { June } \\
\text { July } \\
\text { August } \\
\text { September }\end{array}$ & $\begin{array}{r}31 \\
12 \\
8 \\
6 \\
7 \\
12 \\
40 \\
346 \\
298 \\
175 \\
102 \\
115\end{array}$ & $\begin{array}{r}14 \\
5 \\
5 \\
4 \\
6 \\
5 \\
10 \\
32 \\
118 \\
38 \\
21 \\
22\end{array}$ & $\begin{array}{c}16.6 \\
8.07 \\
5.87 \\
4.9 \\
6.6 \\
6.6 \\
24.9 \\
153 \\
228 \\
104 \\
35.2 \\
39.4\end{array}$ & $\begin{array}{r}1,020 \\
480 \\
361 \\
301 \\
366 \\
406 \\
1,480 \\
9,410 \\
13,600 \\
6,400 \\
2,160 \\
2,340\end{array}$ \\
\hline The year. & 346 & 4 & 52.9 & 38,300 \\
\hline $\begin{array}{l}\text { October. } \\
\text { November } \\
\text { December } \\
\text { January } \\
\text { February } \\
\text { March } \\
\text { April } \\
\text { May } \\
\text { June } \\
\text { July } \\
\text { August } \\
\text { September }\end{array}$ & $\begin{array}{r}27 \\
14 \\
12 \\
9 \\
6 \\
19 \\
34 \\
475 \\
490 \\
255 \\
90 \\
58\end{array}$ & $\begin{array}{r}13 \\
8 \\
6 \\
6 \\
3 \\
3 \\
13 \\
21 \\
106 \\
73 \\
35 \\
12\end{array}$ & $\begin{array}{c}19.1 \\
11.4 \\
8.19 \\
6.22 \\
5.89 \\
11.9 \\
21.5 \\
129 \\
331 \\
173 \\
58.1 \\
23.8\end{array}$ & $\begin{array}{r}1,170 \\
678 \\
504 \\
382 \\
327 \\
732 \\
1,280 \\
7,930 \\
19,700 \\
10,600 \\
3,570 \\
1,420\end{array}$ \\
\hline 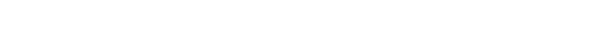 & 490 & 3 & 66. 7 & 48,300 \\
\hline
\end{tabular}

- Estimated. 
Monthly discharge of Canyon Creek at Ouray, Colo., for 1910-1915-Continued

\begin{tabular}{|c|c|c|c|c|}
\hline \multirow{2}{*}{ Month } & \multicolumn{3}{|c|}{ Discharge in second-feet } & \multirow{2}{*}{$\begin{array}{l}\text { Run-off in } \\
\text { acre-feet }\end{array}$} \\
\hline & Maximum & Minimum & Mean & \\
\hline $\begin{array}{l}\text { October. } \\
\text { November } \\
\text { December } \\
\text { January. } \\
\text { February } \\
\text { March } \\
\text { April } \\
\text { May } \\
\text { June } \\
\text { July } \\
\text { August } \\
\text { September. }\end{array}$ & $\begin{array}{r}45 \\
11 \\
8 \\
11 \\
11 \\
21 \\
143 \\
145 \\
469 \\
314 \\
79 \\
111\end{array}$ & \begin{tabular}{r|}
12 \\
4 \\
3 \\
3 \\
2 \\
8 \\
20 \\
21 \\
84 \\
83 \\
24 \\
11
\end{tabular} & $\begin{array}{r}22.5 \\
6.4 \\
5.5 \\
7.9 \\
8.4 \\
11.4 \\
47.7 \\
67.9 \\
270 \\
211 \\
41.1 \\
18.5\end{array}$ & $\begin{array}{r}1,380 \\
381 \\
338 \\
486 \\
467 \\
701 \\
2,840 \\
4,180 \\
16,100 \\
13,000 \\
2,530 \\
1,100\end{array}$ \\
\hline The year............ & 469 & - 2 & 60.0 & 43,500 \\
\hline $\begin{array}{c}\text { October.. } 1915 \\
\text { November }\end{array}$ & $\begin{array}{l}16 \\
12\end{array}$ & $\begin{array}{l}5 \\
4\end{array}$ & $\begin{array}{l}9.2 \\
7.9\end{array}$ & $\begin{array}{l}566 \\
470\end{array}$ \\
\hline
\end{tabular}

DALLAS CREEK NEAR RIDGWAY, COLO.

Locatron.-In sec. 5, T. 48 S., R. 8 W., at highway bridge 11/2 miles northwest of Ridgway, Ouray County. No tributary between station and mouth, $11 / 2$ miles downstream.

Drainage area.-90 square miles.

Records available.-March 1, 1922, to September 30, 1927.

GAGE.-Vertical staff.

Drversions.-Water diverted above station for irrigation of 4,500 acres.

Cooperation.-Complete records furnished by State engineer.

Monthly discharge of Dallas Creek at Ridgway, Colo., for 1922-1927

\begin{tabular}{|c|c|c|c|c|}
\hline \multirow{2}{*}{ Month } & \multicolumn{3}{|c|}{ Discharge in second-feet } & \multirow{2}{*}{$\begin{array}{l}\text { Run-off in } \\
\text { acre-feet }\end{array}$} \\
\hline & Maximum & Minimum & Mean & \\
\hline $\begin{array}{l}\text { March } \\
\text { April } \\
\text { May } \\
\text { June } \\
\text { July } \\
\text { August } \\
\text { September }\end{array}$ & $\begin{array}{r}55 \\
322 \\
229 \\
186 \\
207 \\
207 \\
63\end{array}$ & $\begin{array}{l}17 \\
15 \\
16 \\
5.3 \\
50 \\
63 \\
9.5\end{array}$ & $\begin{array}{r}26.2 \\
51.7 \\
82.7 \\
103 \\
104 \\
94.3 \\
27.6\end{array}$ & $\begin{array}{l}1,610 \\
3,080 \\
5,090 \\
6,130 \\
6,400 \\
5,800 \\
1,640\end{array}$ \\
\hline The period...... & 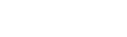 & (n) & $\ldots$ & 29,800 \\
\hline $\begin{array}{l}\text { October } \\
\text { November } \\
\text { December } \\
\text { January } \\
\text { February } \\
\text { March } \\
\text { April } \\
\text { May } \\
\text { June } \\
\text { July } \\
\text { August } \\
\text { September }\end{array}$ & $\begin{array}{r}27 \\
129 \\
98 \\
139 \\
269 \\
481 \\
134\end{array}$ & $\begin{array}{r}14 \\
14 \\
13 \\
1 \\
55 \\
40 \\
41\end{array}$ & $\begin{array}{c}7.65 \\
24.3 \\
a 22 \\
a 22 \\
a 20 \\
19.1 \\
42.0 \\
41.8 \\
39.7 \\
114 \\
109 \\
56.9\end{array}$ & $\begin{array}{r}470 \\
1,450 \\
1,350 \\
1,350 \\
1,110 \\
1,170 \\
2,500 \\
2,570 \\
2,360 \\
7,010 \\
6,700 \\
3,390\end{array}$ \\
\hline The year.- & 481 & 1 & 43.4 & 31,400 \\
\hline
\end{tabular}

Estimated. 
Monthly discharge of Dallas Creek at Ridgway, Colo., for 1922-1927-Continued

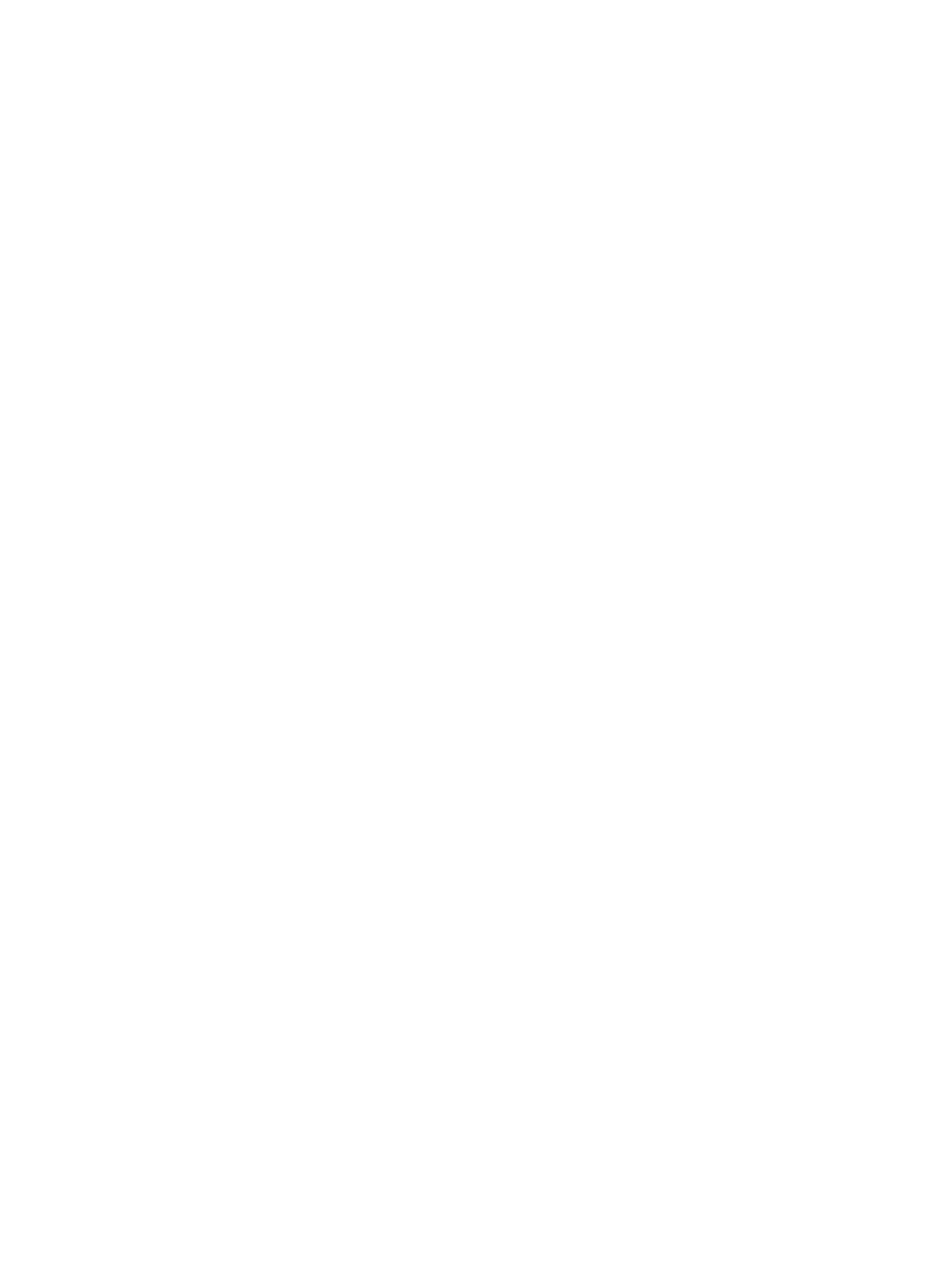

- Estimated.

BSCALANTE CREEK NEAR DELTA, COLO.

Location.-In sec. 20 , T. 15 S., R. 97 W., at highway bridge 12 miles west

of Delta, Delta County. Creek enters Gunnison River 2 miles downstream.

Records available.-April 1, 1922, to September 30, 1923.

GAGE.-Chain on bridge.

Control.-Shifting.

Drversions.-Water diverted for irrigation of 1,200 acres above station.

Cooperation.-Complete records furnished by State engineer. 
Monthly discharge of Escalante Creek near Delta, Colo., for 1922 and 1923

\begin{tabular}{|c|c|c|c|c|}
\hline \multirow{2}{*}{ Month } & \multicolumn{3}{|c|}{ Discharge in second-feet } & \multirow{2}{*}{$\begin{array}{l}\text { Run-off in } \\
\text { acre-feet }\end{array}$} \\
\hline & Maximum & Minimum & Mean & \\
\hline $\begin{array}{l}\text { April. } \\
\text { May } \\
\text { June } \\
\text { July } \\
\text { August } \\
\text { September. }\end{array}$ & $\begin{array}{r}454 \\
1,250 \\
265 \\
28 \\
21 \\
7\end{array}$ & $\begin{array}{r}23 \\
279 \\
15 \\
.9 \\
1.4 \\
1.9\end{array}$ & $\begin{array}{r}79.8 \\
588 \\
88.9 \\
6.7 \\
7.7 \\
3.8\end{array}$ & $\begin{array}{r}4,750 \\
36,200 \\
5,290 \\
413 \\
475 \\
227\end{array}$ \\
\hline The period...... & 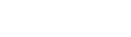 & - & -n.n. & 47,400 \\
\hline $\begin{array}{l}\text { October } \\
\text { November } \\
\text { December. } \\
\text { January } \\
\text { February } \\
\text { March } \\
\text { April. } \\
\text { May } \\
\text { June } \\
\text { July } \\
\text { August } \\
\text { September }\end{array}$ & 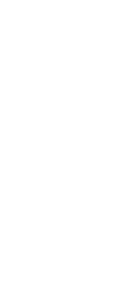 & 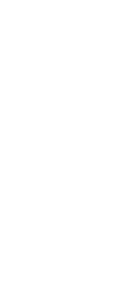 & $\begin{array}{c}7.1 \\
12.9 \\
10 \\
a 8 \\
a 8 \\
19.3 \\
79.7 \\
350 \\
45.8 \\
18.6 \\
28 \\
7\end{array}$ & $\begin{array}{r}437 \\
768 \\
615 \\
492 \\
444 \\
1,190 \\
4,740 \\
21,500 \\
2,720 \\
1,140 \\
1,720 \\
417\end{array}$ \\
\hline The year.... & 582 & $-\ldots-\infty$ & 50.0 & 36,200 \\
\hline
\end{tabular}

a Estimated.

KAHN AH CREEK NEAR WHITEWATER, COLO.

Location.-In sec. 34, T. 12 S., R. 97 W., a quarter of a mile below intake for

Grand Junction water supply and 17 miles east of Whitewater, Mesa County.

Nearest tributary, Coal Creek, enters a short distance above station.

Drainage area. - 55 square miles (revised; measured on Forest Service map). Records avarlable.-October 1, 1917, to September 30, 1921; August 17, 1922, to September 30, 1927.

GAGE.-Vertical staff at right bank 300 feet above foot bridge.

Control.-Shifting at long intervals.

Extremes of DIscharge.-Maximum stage recorded, 4.5 feet at $11 \mathrm{p}$. $\mathrm{m}$. June 6, 1921 (discharge, 1,630 second-feet); minimum stage recorded, 0.00 foot at 9 a. m. February 20, 1920, creek dry.

Diversions.-City of Grand Junction diverts an average of 5.5 second-feet above station for domestic use. Flow measured over Cippoletti weir. 6,600 acres irrigated from Kahnah Creek all below station.

AccuracY.-Gage read twice daily. Rating curves well defined except for extremely high stage. Records good except during high stage, for which they are fair.

Cooperation.-Since 1922 complete records furnished by State engineer. 
Monthly discharge of Kahnah Creek near Whitewater, Colo., for 1917-1927

\begin{tabular}{|c|c|c|c|c|}
\hline \multirow{2}{*}{ Month } & \multicolumn{3}{|c|}{ Discharge in second-feet } & \multirow{2}{*}{$\begin{array}{c}\text { Run-off in } \\
\text { acre-feet }\end{array}$} \\
\hline & Maximum & Minimum & Mean & \\
\hline $\begin{array}{l}\text { October. } \\
\text { November } \\
\text { December. } \\
\text { January } \\
\text { February } \\
\text { March } \\
\text { April } \\
\text { May } \\
\text { June } \\
\text { July } \\
\text { August } \\
\text { September }\end{array}$ & \begin{tabular}{r|}
8.2 \\
7.4 \\
7.0 \\
7.0 \\
12 \\
19 \\
336 \\
105 \\
50 \\
22 \\
40
\end{tabular} & $\begin{array}{r}3.6 \\
4.0 \\
1.4 \\
2.4 \\
6.4 \\
4.6 \\
7.4 \\
18 \\
40 \\
22 \\
10 \\
10\end{array}$ & $\begin{array}{r}9 \\
5.66 \\
5.46 \\
5.62 \\
6.42 \\
7.62 \\
14.0 \\
184 \\
86.9 \\
32.1 \\
16.0 \\
16.1\end{array}$ & $\begin{array}{r}553 \\
337 \\
336 \\
346 \\
357 \\
469 \\
833 \\
11,300 \\
5,170 \\
1,970 \\
984 \\
958\end{array}$ \\
\hline The year. & 336 & 1.4 & 32.6 & 23,600 \\
\hline $\begin{array}{l}\text { October. } \\
\text { November } \\
\text { December. } \\
\text { January } \\
\text { February } \\
\text { Mareh } \\
\text { April } \\
\text { May } \\
\text { June } \\
\text { July } \\
\text { August } \\
\text { September }\end{array}$ & $\begin{array}{r}11 \\
11 \\
11 \\
12 \\
7 \\
16 \\
66 \\
550 \\
127 \\
50 \\
70 \\
14 \\
\end{array}$ & $\begin{array}{c}10 \\
7.0 \\
8.6 \\
4.0 \\
4.0 \\
7.0 \\
11 \\
62 \\
31 \\
30 \\
13 \\
13 \\
\end{array}$ & $\begin{array}{c}10.6 \\
10.3 \\
9.43 \\
5.04 \\
6.09 \\
10.4 \\
33.6 \\
271 \\
59.6 \\
37.8 \\
28.7 \\
13.1 \\
\end{array}$ & $\begin{array}{r}652 \\
613 \\
580 \\
310 \\
338 \\
640 \\
2,000 \\
16,700 \\
3,550 \\
2.320 \\
1,760 \\
780 \\
\end{array}$ \\
\hline The year. & 550 & 4.0 & 41. 7 & 30,200 \\
\hline $\begin{array}{l}\text { October. } \\
\text { November } \\
\text { December } \\
\text { January } \\
\text { February } \\
\text { March } \\
\text { April } \\
\text { May } \\
\text { June } \\
\text { July } \\
\text { August } \\
\text { September. }\end{array}$ & \begin{tabular}{r|}
13 \\
13 \\
13 \\
8.2 \\
11 \\
11 \\
39 \\
990 \\
110 \\
58 \\
44 \\
20
\end{tabular} & \begin{tabular}{l|}
11 \\
11 \\
1.5 \\
3.8 \\
4.3 \\
5.2 \\
11 \\
54 \\
59 \\
36 \\
16 \\
7.0
\end{tabular} & $\begin{array}{r}120 \\
12.2 \\
9.30 \\
6.26 \\
8.59 \\
9.31 \\
14.1 \\
288 \\
409 \\
49.4 \\
28.3 \\
11.2\end{array}$ & $\begin{array}{r}738 \\
726 \\
572 \\
385 \\
494 \\
572 \\
839 \\
17,700 \\
24,800 \\
3,040 \\
1,740 \\
666\end{array}$ \\
\hline The year. & 1,110 & 1.5 & 71.3 & 51,800 \\
\hline $\begin{array}{l}\text { October } \\
\text { November } \\
\text { December } \\
\text { January } \\
\text { February } \\
\text { Mareh } \\
\text { April. } \\
\text { May } \\
\text { June } \\
\text { July } \\
\text { August } \\
\text { September }\end{array}$ & $\begin{array}{r}11 \\
11 \\
7 \\
9 \\
11 \\
88 \\
880 \\
1,390 \\
63 \\
243 \\
36 \\
\end{array}$ & $\begin{array}{c}8 \\
5 \\
4 \\
5 \\
6 \\
7 \\
76 \\
58 \\
27 \\
28 \\
11 \\
\end{array}$ & $\begin{array}{c}9.3 \\
8.7 \\
3.0 \\
6.1 \\
6.9 \\
8.5 \\
20.5 \\
190 \\
552 \\
37.2 \\
48.5 \\
21.8 \\
\end{array}$ & $\begin{array}{r}572 \\
518 \\
184 \\
375 \\
383 \\
523 \\
1,220 \\
11,700 \\
32,800 \\
2,290 \\
2,980 \\
1,300 \\
\end{array}$ \\
\hline 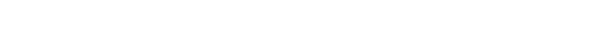 & 1,390 & $\ldots \ldots \ldots$ & 75.8 & 54,800 \\
\hline $\begin{array}{l}\text { Angust 17-31 } 1922 \\
\text { September. }\end{array}$ & $\begin{array}{l}54 \\
30 \\
\end{array}$ & $\begin{array}{r}23 \\
9 \\
\end{array}$ & $\begin{array}{l}29.1 \\
17.1 \\
\end{array}$ & $\begin{array}{r}866 \\
1,020 \\
\end{array}$ \\
\hline $\begin{array}{l}\text { October } \\
\text { November. } \\
\text { December. } \\
\text { January } \\
\text { February } \\
\text { Mareh } \\
\text { April } \\
\text { May. } \\
\text { June } \\
\text { July } \\
\text { August } \\
\text { September. }\end{array}$ & $\begin{array}{r}12 \\
9 \\
9 \\
8 \\
10 \\
25 \\
713 \\
233 \\
64 \\
286 \\
32 \\
\end{array}$ & $\begin{array}{c}7 \\
8 \\
8 \\
6 \\
6 \\
8 \\
29 \\
31 \\
24 \\
19 \\
13 \\
\end{array}$ & $\begin{array}{r}9.8 \\
8.4 \\
8.1 \\
a 8 \\
7.5 \\
8.2 \\
12.3 \\
181 \\
116 \\
41.5 \\
35.7 \\
19.2 \\
\end{array}$ & $\begin{array}{r}603 \\
500 \\
498 \\
492 \\
416 \\
504 \\
732 \\
11,100 \\
6,900 \\
2,550 \\
2,200 \\
1,140 \\
\end{array}$ \\
\hline The year & 713 & & 38.1 & 27,600 \\
\hline
\end{tabular}

a Estimated. 
Monthly discharge of Kahnah Creek near Whitewater, Colo., for 1917-1927-Con.

\begin{tabular}{|c|c|c|c|c|}
\hline \multirow{2}{*}{ Month } & \multicolumn{3}{|c|}{ Discharge in second-feet } & \multirow{2}{*}{$\begin{array}{l}\text { Run-off in } \\
\text { acre-feet }\end{array}$} \\
\hline & Maximum & Mintmum & Mean & \\
\hline $\begin{array}{l}\text { October. } \\
\text { November } \\
\text { December } \\
\text { Fanuary } \\
\text { Mebruary } \\
\text { Aprch } \\
\text { Aay } \\
\text { June } \\
\text { July } \\
\text { August. } \\
\text { September. }\end{array}$ & $\begin{array}{r}16 \\
19 \\
9 \\
14 \\
14 \\
554 \\
159 \\
48 \\
29 \\
16\end{array}$ & $\begin{array}{r}10 \\
12 \\
8 \\
7 \\
27 \\
28 \\
23 \\
10 \\
9\end{array}$ & $\begin{array}{r}12.0 \\
13.9 \\
8.5 \\
\times 9 \\
8.2 \\
6.5 \\
613 \\
235 \\
67.3 \\
34.3 \\
17.8 \\
11.1\end{array}$ & $\begin{array}{r}738 \\
827 \\
523 \\
553 \\
472 \\
584 \\
774 \\
14,400 \\
4,000 \\
2,110 \\
1,090 \\
660\end{array}$ \\
\hline The year... & 554 & $\mid-\ldots+\ldots+\ldots$ & 36.9 & 26,700 \\
\hline $\begin{array}{l}\text { October. } \\
\text { November } \\
\text { December } \\
\text { January } \\
\text { February } \\
\text { March } \\
\text { April. } \\
\text { May } \\
\text { June } \\
\text { July } \\
\text { Auguist }\end{array}$ & $\begin{array}{r}13 \\
15 \\
\\
11 \\
76 \\
85 \\
44 \\
51 \\
94\end{array}$ & \begin{tabular}{|r|}
6 \\
71 \\
11 \\
30 \\
18 \\
17 \\
17
\end{tabular} & $\begin{array}{c}11.4 \\
12.0 \\
10.5 \\
69 \\
68 \\
8.8 \\
34.2 \\
3152 \\
52.6 \\
35.2 \\
27.5 \\
29.2\end{array}$ & $\begin{array}{r}701 \\
714 \\
646 \\
553 \\
444 \\
542 \\
2,040 \\
9,350 \\
3,130 \\
2,160 \\
1,600 \\
1,740\end{array}$ \\
\hline The year. & & & 32.7 & 23,700 \\
\hline $\begin{array}{l}\text { October } \\
\text { November } \\
\text { December } \\
\text { January } \\
\text { February } \\
\text { March } \\
\text { April } \\
\text { May } \\
\text { June } \\
\text { July } \\
\text { August } \\
\text { September }\end{array}$ & $\begin{array}{r}27 \\
21 \\
10 \\
15 \\
183 \\
567 \\
247 \\
66 \\
33 \\
32\end{array}$ & \begin{tabular}{r|r|}
10 \\
5 \\
8 \\
15 \\
133 \\
33 \\
28 \\
23 \\
10
\end{tabular} & $\begin{array}{r}19.3 \\
13.8 \\
e 9.1 \\
\bullet 8.4 \\
9.2 \\
10.7 \\
43.2 \\
264 \\
91.9 \\
38.4 \\
26.3 \\
17.8\end{array}$ & $\begin{array}{r}1,190 \\
821 \\
560 \\
518 \\
511 \\
658 \\
2,570 \\
16,200 \\
5,470 \\
2,360 \\
1,620 \\
1,060\end{array}$ \\
\hline The year. & 567 & -.................. & 46.2 & 33,500 \\
\hline $\begin{array}{l}\text { October. } \\
\text { November } \\
\text { December } \\
\text { January } \\
\text { February } \\
\text { March } \\
\text { April } \\
\text { May } \\
\text { June } \\
\text { July } \\
\text { August } \\
\text { September }\end{array}$ & $\begin{array}{r}21 \\
13 \\
12 \\
10 \\
10 \\
13 \\
64 \\
478 \\
356 \\
63 \\
42 \\
45\end{array}$ & $\begin{array}{r}10 \\
8 \\
8 \\
8 \\
8 \\
8 \\
9 \\
74 \\
46 \\
27 \\
24 \\
22\end{array}$ & $\begin{array}{c}13.2 \\
10.7 \\
10.3 \\
8.71 \\
8.82 \\
9.58 \\
22.4 \\
210 \\
110 \\
40.8 \\
32.7 \\
32.4\end{array}$ & $\begin{array}{r}812 \\
637 \\
633 \\
536 \\
490 \\
589 \\
1,330 \\
12,900 \\
6,550 \\
2,510 \\
2,010 \\
1,930\end{array}$ \\
\hline The year................. & 478 & 8 & 42.7 & 30,900 \\
\hline
\end{tabular}

- Estimated.

\section{DOLORES RIVER AT RICO, COLO.}

Location.-In sec. 36, T. 40 N., R. 11 W., at highway bridge at upper edge of

Rico, Dolores County. Silver Creek enters just above station.

DrajNAGE AREA.-83 square miles (measured on topographic map).

Records avaluable.-June 9 to December 31, 1914; June: 1, 1919, to June 10,

1921, when gage was destroyed by high water.

GAGE.-Vertical staff.

CoNTroz.-Shifting during high water. 
ExTremes of Discharge.-Maximum mean daily discharge recorded, 1,360 second-feet June 18, 1914 (maximum discharge in 1921 not recorded, as gage was destroyed); minimum discharge recorded, 9 second-feet on several days during November and December, 1914.

Drversions.- No diversions from Dolores River above station. About 2 secondfeet diverted from Horse Creek above station and returned to river below; diversion made from April to November.

Accoracr.-Gage read twice daily. Rating curves fairly well defined. Records good, except during 1914, for which they are fair.

Monthly discharge of Dobres River at Rico, Colo., for 1914 and 1919-1921

\begin{tabular}{|c|c|c|c|c|}
\hline \multirow{2}{*}{ Month } & \multicolumn{3}{|c|}{ Discharge in second-feet } & \multirow{2}{*}{$\underset{\text { acre-feet }}{\text { Run-off in }}$} \\
\hline & Maximum & Minimum & Mean & \\
\hline $\begin{array}{l}\text { June } 9-30 \\
\text { July } \\
\text { August } \\
\text { September } \\
\text { October- } \\
\text { November } \\
\text { December }\end{array}$ & $\begin{array}{r}1,360 \\
880 \\
955 \\
253 \\
680 \\
33 \\
20\end{array}$ & $\begin{array}{r}475 \\
450 \\
253 \\
103 \\
21 \\
9 \\
9\end{array}$ & $\begin{array}{c}1,000 \\
642 \\
376 \\
205 \\
176 \\
17.0 \\
13.5\end{array}$ & $\begin{array}{r}43,600 \\
39,500 \\
23,100 \\
12,200 \\
10,800 \\
1,010 \\
830\end{array}$ \\
\hline $\begin{array}{l}\text { June } \\
\text { July } \\
\text { August } \\
\text { September }\end{array}$ & $\begin{array}{r}381 \\
235 \\
167 \\
46\end{array}$ & $\begin{array}{r}167 \\
106 \\
40 \\
35\end{array}$ & $\begin{array}{r}284 \\
162 \\
79.3 \\
38.7\end{array}$ & $\begin{array}{r}16,900 \\
9,960 \\
4,880 \\
2,300\end{array}$ \\
\hline The period. & 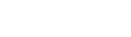 & & & 34,000 \\
\hline $\begin{array}{l}\text { October } \\
\text { November } \\
\text { December } \\
\text { January } \\
\text { February } \\
\text { March } \\
\text { April } \\
\text { May } \\
\text { June } \\
\text { July } \\
\text { August } \\
\text { September }\end{array}$ & $\begin{array}{r}41 \\
50 \\
30 \\
28 \\
24 \\
24 \\
113 \\
1,060 \\
1,000 \\
471 \\
115 \\
48\end{array}$ & $\begin{array}{r}35 \\
19 \\
18 \\
16 \\
15 \\
14 \\
21 \\
190 \\
525 \\
109 \\
40 \\
28\end{array}$ & $\begin{array}{r}37.6 \\
24.4 \\
23.5 \\
19.5 \\
18.6 \\
17.8 \\
34.8 \\
588 \\
681 \\
177 \\
78.8 \\
35.6\end{array}$ & $\begin{array}{r}2,310 \\
1,450 \\
1,440 \\
1,200 \\
1,070 \\
1,090 \\
2,070 \\
36,200 \\
40,500 \\
10,900 \\
4,850 \\
2,120\end{array}$ \\
\hline The year......... & 1,060 & 14 & 145 & 105,000 \\
\hline $\begin{array}{l}\text { October-1920-21 } \\
\text { November } \\
\text { December } \\
\text { January } \\
\text { February } \\
\text { March } \\
\text { April } \\
\text { May } \\
\text { June } 1-10\end{array}$ & $\begin{array}{r}46 \\
41 \\
26 \\
19 \\
32 \\
42 \\
177 \\
750 \\
930\end{array}$ & $\begin{array}{r}23 \\
24 \\
16 \\
14 \\
13 \\
20 \\
41 \\
306 \\
510\end{array}$ & $\begin{array}{r}30.4 \\
28.4 \\
21.6 \\
15.1 \\
18.6 \\
30.7 \\
94.0 \\
427 \\
726\end{array}$ & $\begin{array}{r}1,870 \\
1,690 \\
1,330 \\
928 \\
1,030 \\
1,890 \\
5,590 \\
26,300 \\
14,400\end{array}$ \\
\hline & & & & $-.55,000$ \\
\hline
\end{tabular}

DOLORES RIVER AT DOLORES, COLO.

Location.-In sec. 16 , T. 37 N., R. 15 W., at highway bridge near railroad depot at Dolores, Montezuma County. Nearest tributary, Lost Canyon Creek, enters below station.

Drainage area.-514 square miles (measured on base map of Colorado).

Reconds available.-June 23, 1895, to October 31, 1903; August 27, 1910, to November 30, 1912; May 1, 1922, to September 30, 1927.

GAGE.-Chain gage. From 1895 to 1903 , vertical staff at footbridge half a mile east of Dolores.

Controc.-Practically permanent. 
ExTremes of Discharge,-Maximum stage recorded, 7.0 feet at 6.30 a. $\mathrm{m}$. May 4, 1922 (discharge, 7,400 second-feet); minimum discharge, 8 secondfeet August 16, 1896.

Diversions.- - Water diverted for irrigation of a few hundred acres above station. One mile below station about 90,000 acre-feet diverted annually for irrigation of Montezuma project.

Cooperation.--Since 1910 complete records furnished by istate engineer.

Monthly discharge of Dolores River at Dolores, Colo., for 1395-1903, 1910-1912, and 1922-1927

\begin{tabular}{|c|c|c|c|c|}
\hline \multirow{2}{*}{ Month } & \multicolumn{3}{|c|}{ Discharge in second-feet } & \multirow{2}{*}{$\begin{array}{l}\text { Run-off in } \\
\text { acre-feet }\end{array}$} \\
\hline & Maximum & Miniunum & Mean & \\
\hline $\begin{array}{l}\text { June } 23-30 \\
\text { July } \\
\text { August } \\
\text { September }\end{array}$ & $\begin{array}{l}848 \\
490 \\
548 \\
177\end{array}$ & $\begin{array}{r}605 \\
127 \\
97 \\
68\end{array}$ & $\begin{array}{r}702 \\
270 \\
248 \\
99\end{array}$ & $\begin{array}{r}17,100 \\
16,600 \\
15,200 \\
5,890\end{array}$ \\
\hline The period... & $\ldots$ & $-\ldots$ & (n)- & 48,800 \\
\hline $\begin{array}{l}\text { October } \\
\text { November } \\
\text { December } \\
\text { January } \\
\text { February-are } \\
\text { March } \\
\text { April } \\
\text { May } \\
\text { June } \\
\text { July } \\
\text { August } \\
\text { September }\end{array}$ & $\begin{array}{r}557 \\
1,570 \\
1,450 \\
781 \\
480 \\
180 \\
1,180\end{array}$ & \begin{tabular}{|r|}
68 \\
68 \\
60 \\
34 \\
44 \\
44 \\
8 \\
28 \\
\end{tabular} & $\begin{array}{r}79 \\
\therefore 75 \\
-70 \\
265 \\
a 65 \\
200 \\
747 \\
952 \\
263 \\
130 \\
38 \\
195\end{array}$ & $\begin{array}{r}4,860 \\
4,460 \\
4,300 \\
4,000 \\
3,740 \\
12,300 \\
44,400 \\
58,900 \\
15,600 \\
7,990 \\
2,340 \\
11,600\end{array}$ \\
\hline The yea & 1,570 & - & 240 & 174,000 \\
\hline $\begin{array}{l}\text { October } \\
\text { November } \\
\text { December- } \\
\text { January } \\
\text { February } \\
\text { March } \\
\text { April } \\
\text { Maj } \\
\text { Jume } \\
\text { July } \\
\text { August } \\
\text { September }\end{array}$ & $\begin{array}{r}2,940 \\
2,840 \\
2,520 \\
608 \\
235 \\
852\end{array}$ & $\begin{array}{r}235 \\
., 990 \\
570 \\
186 \\
76 \\
76\end{array}$ & $\begin{array}{r}113 \\
a 65 \\
a 60 \\
a 60 \\
a 60 \\
a 100 \\
1,480 \\
2,440 \\
1,460 \\
368 \\
148 \\
394\end{array}$ & $\begin{array}{r}6,950 \\
3,870 \\
3,690 \\
3,690 \\
3,330 \\
6,150 \\
88,100 \\
150,000 \\
86,900 \\
22,600 \\
9,100 \\
23,400\end{array}$ \\
\hline The year.. & 2,940 & 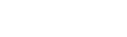 & 564 & 408,000 \\
\hline $\begin{array}{l}\text { October } \\
\text { November } \\
\text { December } \\
\text { January } \\
\text { February } \\
\text { March } \\
\text { April. } \\
\text { May } \\
\text { June } \\
\text { July } \\
\text { August } \\
\text { September }\end{array}$ & $\begin{array}{r}1,980 \\
1,870 \\
2,030 \\
1,230 \\
228 \\
293\end{array}$ & $\begin{array}{r}235 \\
108 \\
198 \\
912 \\
784 \\
144 \\
102 \\
34\end{array}$ & $\begin{array}{r}391 \\
172 \\
a 80 \\
a 75 \\
a 75 \\
a 150 \\
1,090 \\
1,210 \\
1,510 \\
490 \\
120 \\
78\end{array}$ & $\begin{array}{r}24,000 \\
10,200 \\
4,920 \\
4,610 \\
4,160 \\
9,220 \\
64,900 \\
74,400 \\
89,900 \\
30,100 \\
7,380 \\
4,640\end{array}$ \\
\hline The year. & 2,030 & 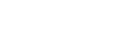 & 452 & 328,000 \\
\hline
\end{tabular}

- Estimated. 
Monthly discharge of Dolores River at Dolores, Colo., for 1895-1903, 1910-1912, and 1922-1927-Continued

\begin{tabular}{|c|c|c|c|c|}
\hline \multirow{2}{*}{ Month } & \multicolumn{3}{|c|}{ Discharge in second-feet } & \multirow{2}{*}{$\begin{array}{l}\text { Run-off in } \\
\text { acre-feet }\end{array}$} \\
\hline & Maximum & Minimum & Mean & \\
\hline $\begin{array}{l}\text { October } \\
\text { November } \\
\text { December } \\
\text { January } \\
\text { February } \\
\text { March } \\
\text { April } \\
\text { May } \\
\text { June } \\
\text { July } \\
\text { August } \\
\text { September }\end{array}$ & $\begin{array}{r}50 \\
72 \\
1,460 \\
810 \\
412 \\
736 \\
82\end{array}$ & $\begin{array}{r}34 \\
34 \\
37 \\
118 \\
220 \\
100 \\
30 \\
23\end{array}$ & $\begin{array}{r}37 \\
48 \\
\text { a } 50 \\
455 \\
\text { a } 35 \\
25 \\
437 \\
785 \\
499 \\
207 \\
204 \\
33\end{array}$ & $\begin{array}{r}2,280 \\
2,860 \\
3,070 \\
2,770 \\
1,940 \\
1,540 \\
26,000 \\
48,300 \\
29,700 \\
12,700 \\
12,500 \\
1,960\end{array}$ \\
\hline The year. & 1,460 & $\ldots \ldots \ldots$ & 201 & 146,000 \\
\hline $\begin{array}{l}\text { October } \\
\text { November } \\
\text { December. } \\
\text { January } \\
\text { February } \\
\text { March } \\
\text { April } \\
\text { May } \\
\text { June } \\
\text { July } \\
\text { August } \\
\text { September }\end{array}$ & $\begin{array}{r}343 \\
82 \\
192 \\
555 \\
1,740 \\
1,600 \\
200 \\
37 \\
220\end{array}$ & $\begin{array}{r}23 \\
37 \\
30 \\
100 \\
483 \\
280 \\
37 \\
20 \\
23\end{array}$ & $\begin{array}{r}93 \\
49 \\
40 \\
\times 40 \\
040 \\
100 \\
284 \\
1,320 \\
808 \\
84 \\
29 \\
89 \\
\end{array}$ & $\begin{array}{r}5,720 \\
2,920 \\
2,460 \\
2,460 \\
2,220 \\
6,150 \\
16,900 \\
81,100 \\
48,100 \\
5,160 \\
1,780 \\
5,300\end{array}$ \\
\hline The year. & 1,740 & 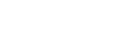 & 249 & 180,000 \\
\hline $\begin{array}{l}\text { October. } \\
\text { November } \\
\text { December } \\
\text { January } \\
\text { February } \\
\text { March } \\
\text { April } \\
\text { May } \\
\text { June } \\
\text { Júly } \\
\text { August } \\
\text { September }\end{array}$ & $\begin{array}{r}118 \\
2,290 \\
2,790 \\
1,640 \\
627 \\
311 \\
192\end{array}$ & $\begin{array}{r}56 \\
82 \\
1,370 \\
810 \\
141 \\
100 \\
19\end{array}$ & $\begin{array}{r}83 \\
a 50 \\
a 45 \\
a 45 \\
a 45 \\
95 \\
878 \\
2,080 \\
1,210 \\
266 \\
174 \\
42\end{array}$ & $\begin{array}{r}5,100 \\
2,980 \\
2,770 \\
2,770 \\
2,500 \\
5,840 \\
52,200 \\
128,000 \\
71,500 \\
16,400 \\
10,700 \\
2,500\end{array}$ \\
\hline The year............. & 2,790 & - & 419 & $.303,000$ \\
\hline $\begin{array}{l}\text { October. } \\
\text { Ocol-2 } \\
\text { November. } \\
\text { December. } \\
\text { January } \\
\text { February } \\
\text { March } \\
\text { April } \\
\text { May } \\
\text { June } \\
\text { Tuly } \\
\text { August } \\
\text { September. }\end{array}$ & $\begin{array}{r}37 \\
1,160 \\
1,320 \\
811 \\
106 \\
341 \\
237\end{array}$ & $\begin{array}{r}19 \\
51 \\
484 \\
106 \\
28 \\
20 \\
28\end{array}$ & $\begin{array}{rr} & 26 \\
\text { a } 20 \\
\text { a } 20 \\
\text { a } 20 \\
\text { a } 20 \\
\text { a } 40 \\
497 \\
857 \\
342 \\
56 \\
92 \\
62\end{array}$ & $\begin{array}{r}1,600 \\
1,190 \\
1,230 \\
1,230 \\
1,110 \\
2,460 \\
29,600 \\
52,700 \\
20,400 \\
3,440 \\
5,660 \\
3,690\end{array}$ \\
\hline The year. & 1,320 & 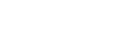 & 171 & 124,000 \\
\hline $\begin{array}{l}\text { Ootober. } \\
\text { November } \\
\text { Necember. } \\
\text { January } \\
\text { February } \\
\text { March } \\
\text { April } \\
\text { May } \\
\text { June } \\
\text { July } \\
\text { August. } \\
\text { September. }\end{array}$ & $\begin{array}{r}1,480 \\
2,630 \\
2,820 \\
1,660 \\
206 \\
557\end{array}$ & $\begin{array}{r}28 \\
206 \\
997 \\
1,720 \\
206 \\
116 \\
80\end{array}$ & $\begin{array}{r}34 \\
\text { a } 35 \\
\text { a } 35 \\
\text { a } 30 \\
a 30 \\
\times 100 \\
629 \\
1,750 \\
2,260 \\
662 \\
137 \\
155\end{array}$ & $\begin{array}{r}2,090 \\
2,080 \\
2,150 \\
1,840 \\
1,670 \\
6,150 \\
37,400 \\
108,000 \\
134,000 \\
40,700 \\
8,420 \\
9,220\end{array}$ \\
\hline 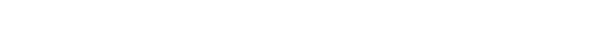 & 2,820 & 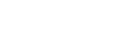 & 488 & 354,000 \\
\hline
\end{tabular}

a Estimated. 
Monthly discharge of Dolores River at Dolores, Colo., for 1895-1908, 1910-1912, and 1922-1927-Continued

\begin{tabular}{|c|c|c|c|c|}
\hline \multirow{2}{*}{ Month } & \multicolumn{3}{|c|}{ Discharge in second-feet } & \multirow{2}{*}{$\begin{array}{l}\text { Run-off in } \\
\text { acre-feet }\end{array}$} \\
\hline & Maximum & Minimum & Mean & \\
\hline 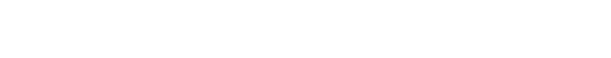 & 116 & 43 & 71 & 4,370 \\
\hline $\begin{array}{l}\text { August 27-31. } \\
\text { September }\end{array}$ & $\begin{array}{r}84 \\
141 \\
\end{array}$ & $\begin{array}{r}55 \\
69 \\
\end{array}$ & $\begin{array}{l}69.2 \\
85.0 \\
\end{array}$ & $\begin{array}{r}686 \\
5,060 \\
\end{array}$ \\
\hline $\begin{array}{l}\text { October } \\
\text { November } \\
\text { December. } \\
\text { January } \\
\text { February } \\
\text { March } \\
\text { April } \\
\text { May } \\
\text { June } \\
\text { July } \\
\text { August } \\
\text { September }\end{array}$ & $\begin{array}{r}291 \\
112 \\
880 \\
113 \\
692 \\
2,060 \\
2,860 \\
2,220 \\
1,840 \\
695 \\
1,040 \\
\end{array}$ & $\begin{array}{r}69 \\
62 \\
60 \\
65 \\
67 \\
548 \\
1,390 \\
895 \\
605 \\
180 \\
82 \\
\end{array}$ & $\begin{array}{c}113 \\
89.4 \\
a 82.2 \\
70 \\
73 \\
245 \\
1,080 \\
2,160 \\
1,620 \\
1,040 \\
339 \\
191 \\
\end{array}$ & $\begin{array}{r}6,960 \\
5,320 \\
5,050 \\
4,320 \\
4,050 \\
15,100 \\
64,300 \\
133,000 \\
96,400 \\
64,000 \\
20,800 \\
11,400 \\
\end{array}$ \\
\hline The year. & 2,860 & $\cdots \cdots$ & 593 & 431,000 \\
\hline $\begin{array}{l}\text { October } \\
\text { November } \\
\text { December } \\
\text { January } \\
\text { Tebruary } \\
\text { March } \\
\text { April } \\
\text { May } \\
\text { June } \\
\text { July } \\
\text { August } \\
\text { September }\end{array}$ & $\begin{array}{r}85 \\
80 \\
340 \\
855 \\
3,790 \\
2,500 \\
1,260 \\
740 \\
740 \\
\end{array}$ & $\begin{array}{r}75 \\
70 \\
80 \\
260 \\
1,100 \\
915 \\
390 \\
70 \\
70 \\
\end{array}$ & $\begin{array}{r}a 450 \\
a 125 \\
a 85 \\
81 \\
73 \\
188 \\
451 \\
2,560 \\
1,680 \\
685 \\
272 \\
115 \\
\end{array}$ & $\begin{array}{r}27,700 \\
7,440 \\
5,230 \\
4,980 \\
4,23_{0} \\
11,600 \\
26,800 \\
157,000 \\
100,000 \\
42,200 \\
16,800 \\
6,860 \\
\end{array}$ \\
\hline The year........ & 3,790 & $\ldots \ldots \ldots \ldots$ & 567 & 411,000 \\
\hline $\begin{array}{l}1912 \\
\text { Covember }\end{array}$ & $\begin{array}{l}335 \\
450 \\
\end{array}$ & $\begin{array}{l}70 \\
35 \\
\end{array}$ & $\begin{array}{l}127 \\
107\end{array}$ & $\begin{array}{l}7,800 \\
6,370 \\
\end{array}$ \\
\hline $\begin{array}{l}\text { Iay } \\
\text { une } \\
\text { uly } \\
\text { uly } \\
\text { ugust } \\
\text { eptember }\end{array}$ & $\begin{array}{r}6,950 \\
3,380 \\
716 \\
400 \\
116 \\
\end{array}$ & $\begin{array}{r}1,760 \\
764 \\
154 \\
109 \\
66 \\
\end{array}$ & $\begin{array}{r}3,630 \\
2,210 \\
375 \\
178 \\
80.2 \\
\end{array}$ & $\begin{array}{r}223,000 \\
132,000 \\
23,100 \\
10,900 \\
4,770 \\
\end{array}$ \\
\hline The period & 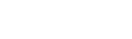 & $\ldots \ldots$ & 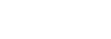 & 394,000 \\
\hline $\begin{array}{l}\text { October } \\
\text { November } \\
\text { December } \\
\text { January } \\
\text { February } \\
\text { March } \\
\text { April } \\
\text { May } \\
\text { June } \\
\text { July } \\
\text { August } \\
\text { September }\end{array}$ & $\begin{array}{r}73 \\
83 \\
1,480 \\
4,550 \\
3,930 \\
1,300 \\
1,300 \\
430 \\
\end{array}$ & $\begin{array}{r}60 \\
46 \\
1,380 \\
1,300 \\
363 \\
190 \\
190 \\
\end{array}$ & $\begin{array}{l}64.3 \\
60.1 \\
\text { a } 62 \\
\text { a } 64 \\
\text { a } 68 \\
\text { a } 80 \\
650 \\
3,130 \\
2,380 \\
745 \\
597 \\
268 \\
\end{array}$ & $\begin{array}{r}3,950 \\
2,580 \\
3,810 \\
3,940 \\
3,780 \\
4,920 \\
38,700 \\
192,000 \\
142,000 \\
45,800 \\
36,700 \\
15,900\end{array}$ \\
\hline The year & 4,550 & - & 682 & 494,000 \\
\hline $\begin{array}{l}\text { October. } \\
\text { November. } \\
\text { December. } \\
\text { January } \\
\text { Tebruary } \\
\text { March } \\
\text { A pril } \\
\text { May } \\
\text { June } \\
\text { July } \\
\text { August. }\end{array}$ & $\begin{array}{r}215 \\
120 \\
165 \\
2,240 \\
8,540 \\
2,800 \\
429 \\
155 \\
60 \\
\end{array}$ & $\begin{array}{r}120 \\
50 \\
1,600 \\
120 \\
256 \\
115 \\
53 \\
51 \\
\end{array}$ & $\begin{array}{r}160 \\
78.0 \\
a 91.9 \\
a 58.8 \\
\text { a } 75.2 \\
93.1 \\
1,080 \\
2,580 \\
1,100 \\
194 \\
98.6 \\
53.0 \\
\end{array}$ & $\begin{array}{r}9,840 \\
4,640 \\
5,650 \\
3,620 \\
4,330 \\
5,720 \\
64,300 \\
159,000 \\
65,500 \\
11,900 \\
6,060 \\
3,150 \\
\end{array}$ \\
\hline The year. & 3,540 & $\begin{array}{lll}\cdots & \ldots & \ldots\end{array}$ & 474 & 344,000 \\
\hline
\end{tabular}

astimated. 
Monthly discharge of Dolores River at Dolores, Colo., for 1895-1903, 1910-1912, and 1922-1927-Continued

\begin{tabular}{|c|c|c|c|c|}
\hline \multirow{2}{*}{ Month } & \multicolumn{3}{|c|}{ Discharge in second-feet } & \multirow{2}{*}{$\begin{array}{l}\text { Run-off in } \\
\text { acre-feet }\end{array}$} \\
\hline & Maximum & Minimum & Mean & \\
\hline $\begin{array}{l}\text { October } \\
\text { November } \\
\text { December } \\
\text { January } \\
\text { February } \\
\text { March } \\
\text { April } \\
\text { May }\end{array}$ & \begin{tabular}{|r|}
49 \\
88 \\
52 \\
\\
2,360 \\
2,380 \\
1,530 \\
642 \\
458 \\
4,310 \\
\end{tabular} & $\begin{array}{r}40 \\
44 \\
32 \\
37 \\
1,100 \\
370 \\
154 \\
124 \\
146\end{array}$ & $\begin{array}{r}41.9 \\
58.7 \\
36.1 \\
a 40 \\
a 68 \\
106 \\
961 \\
1,790 \\
907 \\
259 \\
239 \\
682\end{array}$ & $\begin{array}{r}2,580 \\
3,490 \\
2,220 \\
2,460 \\
3,780 \\
6,520 \\
57,200 \\
110,000 \\
54,000 \\
15,900 \\
14,700 \\
40,600\end{array}$ \\
\hline The year.... & 4,310 & -............. & 432 & 313,000 \\
\hline $\begin{array}{l}\text { October } \\
\text { November } \\
\text { December } \\
\text { January } \\
\text { February } \\
\text { March } \\
\text { April } \\
\text { May } \\
\text { June } \\
\text { July } \\
\text { August } \\
\text { September }\end{array}$ & $\begin{array}{r}340 \\
293 \\
2,250 \\
4,780 \\
4,520 \\
1,940 \\
375 \\
120\end{array}$ & $\begin{array}{r}152 \\
\\
156 \\
1,600 \\
1,590 \\
375 \\
35 \\
35\end{array}$ & $\begin{array}{r}238 \\
a 166 \\
a 95 \\
a 74 \\
a 78 \\
156 \\
968 \\
2,820 \\
2,970 \\
1,060 \\
117 \\
75.8\end{array}$ & $\begin{array}{r}14,600 \\
9,880 \\
5,840 \\
4,550 \\
4,330 \\
9,590 \\
57,600 \\
173,000 \\
177,000 \\
65,200 \\
7,190 \\
4,510\end{array}$ \\
\hline The year... & 4,780 & - & 737 & 533,000 \\
\hline $\begin{array}{l}\text { March } \\
\text { April } \\
\text { May } \\
\text { June } \\
\text { July } \\
\text { August } \\
\text { September }\end{array}$ & $\begin{array}{r}2,820 \\
3,580 \\
5,200 \\
2,010 \\
438 \\
3,920\end{array}$ & $\begin{array}{r}1,030 \\
1,420 \\
826 \\
268 \\
144 \\
179\end{array}$ & $\begin{array}{r}165 \\
1,610 \\
2,390 \\
1,570 \\
595 \\
245 \\
1,350\end{array}$ & $\begin{array}{r}10,100 \\
95,800 \\
147,000 \\
93,400 \\
36,600 \\
15,100 \\
80,300\end{array}$ \\
\hline The period. & & & & 478,000 \\
\hline
\end{tabular}

astimated.

DOLORES RIVER AT BEDROCK, COLO.

Location.-In sec. 17, T. 47 N., R. 18 W., at highway bridge at Bedrock, Montrose County. Nearest important tributary, West Paradox Creek, enters below.

Drainage area.-2,040 square miles (measured on base map of Colorado).

Records avaitable.-October 1, 1917, to September 30, 1922.

GAGE.-Chain.

Control.-Shifting during high water.

ExTREMES OF DISCHARGE.-Maximum stage recorded during period, 8.3 feet at 5.30 p. m. May 1, 1922 (discharge, 5,460 second-feet); minimum discharge recorded, 3 second-feet September 7 and 8, 1919.

Drversions.-Water is diverted from Dolores River and tributaries above station for irrigation of 20,000 acres, of which $\mathbf{1 5 , 0 0 0}$ acres is in Montezuma Valley.

Accuracr.-Gage read twice daily. Rating curves fairly well defined. Records good.

Cooperation.-Station maintained in cooperation with State engineer. 
Monthly discharge of Dolores River at Bedrock, Colo., 1917-1922

\begin{tabular}{|c|c|c|c|c|}
\hline \multirow{2}{*}{ Month } & \multicolumn{3}{|c|}{ Discharge in second-feet } & \multirow{2}{*}{$\begin{array}{l}\text { Run-off in } \\
\text { acre-feet }\end{array}$} \\
\hline & Maximum & Minimum & Mean & \\
\hline $\begin{array}{l}\text { October } \\
\text { November } \\
\text { December. } \\
\text { January } \\
\text { February } \\
\text { March } \\
\text { April } \\
\text { May } \\
\text { June } \\
\text { July } \\
\text { August } \\
\text { September }\end{array}$ & $\begin{array}{r}480 \\
1,460 \\
1,460 \\
865 \\
134 \\
230\end{array}$ & \begin{tabular}{r|}
0 \\
465 \\
208 \\
25 \\
25 \\
6
\end{tabular} & $\begin{array}{r}\text { a } 80 \\
\text { a } \\
\text { a } 70 \\
\text { a } 70 \\
100 \\
280 \\
926 \\
855 \\
184 \\
34.5 \\
42.0\end{array}$ & $\begin{array}{r}4,920 \\
4,760 \\
4,610 \\
4,300 \\
3,890 \\
6,150 \\
16,700 \\
56,900 \\
50,900 \\
11,300 \\
2,120 \\
2,500\end{array}$ \\
\hline The year....... & 1,460 & 6 & 233 & 169,000 \\
\hline $\begin{array}{l}\text { October } \\
\text { November } \\
\text { December. } \\
\text { Jenuary } \\
\text { February } \\
\text { March } \\
\text { April } \\
\text { May } \\
\text { June } \\
\text { July } \\
\text { August } \\
\text { September }\end{array}$ & $\begin{array}{r}44 \\
51\end{array} \mid$ & \begin{tabular}{|r|}
6 \\
16 \\
1,420 \\
154 \\
75 \\
16 \\
10 \\
\end{tabular} & $\begin{array}{c}18.0 \\
31.8 \\
\text { a } 25 \\
\text { a } 25 \\
a 25 \\
a 200 \\
1,290 \\
1,890 \\
607 \\
278 \\
136 \\
47.0 \\
\end{array}$ & $\begin{array}{r}1,110 \\
1,890 \\
1,540 \\
1,540 \\
1,390 \\
12,300 \\
76,800 \\
116,000 \\
36,100 \\
17,100 \\
8,360 \\
2,800 \\
\end{array}$ \\
\hline The year & 2,300 & 6 & 381 & 277,000 \\
\hline $\begin{array}{l}\text { October. } \\
\text { November } \\
\text { December } \\
\text { January-20 } \\
\text { February. } \\
\text { March } \\
\text { April } \\
\text { May } \\
\text { June } \\
\text { July } \\
\text { August } \\
\text { September }\end{array}$ & $\begin{array}{r}154 \\
124 \\
\mathbf{6 2 0} \\
3,200 \\
4,040 \\
3,690 \\
1,720 \\
310 \\
94 \\
\end{array}$ & \begin{tabular}{|r|}
16 \\
\\
1,780 \\
49 \\
23 \\
17 \\
325 \\
\end{tabular} & $\begin{array}{c}84.5 \\
93 \\
a 60 \\
a 75 \\
100 \\
238 \\
1,380 \\
3,390 \\
2,750 \\
541 \\
98.5 \\
32.7 \\
\end{array}$ & $\begin{array}{r}5,200 \\
5,530 \\
3,690 \\
4,610 \\
5,750 \\
14,600 \\
82,100 \\
208,000 \\
164,000 \\
33,300 \\
6,060 \\
1,950 \\
\end{array}$ \\
\hline 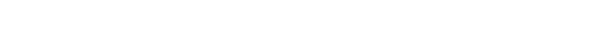 & 4,040 & 16 & 738 & 535,000 \\
\hline $\begin{array}{l}\text { October. } \\
\text { November. } \\
\text { December. } \\
\text { January } \\
\text { February } \\
\text { March } \\
\text { April } \\
\text { May } \\
\text { June } \\
\text { July } \\
\text { August } \\
\text { September }\end{array}$ & $\begin{array}{r}154 \\
134 \\
1,820 \\
3,730 \\
3,610 \\
1,200 \\
1,790 \\
602 \\
\end{array}$ & $\begin{array}{r}14 \\
49 \\
1,340 \\
1,160 \\
92 \\
11 \\
11 \\
\end{array}$ & $\begin{array}{r}67.5 \\
115 \\
a 50 \\
a 70 \\
=100 \\
a 100 \\
970 \\
2,670 \\
2,640 \\
490 \\
469 \\
126 \\
\end{array}$ & $\begin{array}{r}4,150 \\
6,840 \\
3,070 \\
4,300 \\
5,550 \\
6,150 \\
57,700 \\
164,000 \\
157,000 \\
30,100 \\
28,800 \\
7,500 \\
\end{array}$ \\
\hline The year & 3,730 & 11 & 655 & 475,000 \\
\hline $\begin{array}{l}\text { October } \\
\text { November } \\
\text { December. } \\
\text { January. } \\
\text { February } \\
\text { March } \\
\text { April } \\
\text { May } \\
\text { June } \\
\text { July } \\
\text { August } \\
\text { September }\end{array}$ & $\begin{array}{r}410 \\
114 \\
81\end{array}$ & $\begin{array}{r}20 \\
32 \\
81\end{array} \mid$ & $\begin{array}{c}111 \\
86.5 \\
81 \\
a 80 \\
a 85 \\
a 125 \\
a 1,000 \\
4,170 \\
1,850 \\
104 \\
23.4 \\
4.43 \\
\end{array}$ & $\begin{array}{r}6,820 \\
5,150 \\
4,980 \\
4,920 \\
4,720 \\
7,690 \\
59,500 \\
256,000 \\
110,000 \\
6,400 \\
1,440 \\
264 \\
\end{array}$ \\
\hline The year. & 5,390 & 4 & 646 & 468,000 \\
\hline
\end{tabular}

- Istimated. 
IOST CANYON CREEK AT DOLORES, COLO.

Location.-In sec. 16, T. 37 S., R. 15 W., at railroad bridge a mile south of

Dolores, Montezuma County.

Drainage area. - 81 square miles.

Records available.-April 1, 1922, to September 30, 1927. No flow except during spring and summer.

GaGe.-Vertical staff.

Diversions.-Water diverted for irrigation of 3,700 acres, all above station.

Cooperation.-Complete records furnished by State engineer.

Monthly discharge of Lost Canyon Creek at Dolores, Colo., for 1922-1927

\begin{tabular}{|c|c|c|c|c|}
\hline \multirow{2}{*}{ Month } & \multicolumn{3}{|c|}{ Discharge in second-feet } & \multirow{2}{*}{$\begin{array}{l}\text { Run-off in } \\
\text { acre-feet }\end{array}$} \\
\hline & Maximum & Minimum & Maan & \\
\hline $\begin{array}{l}\text { April__. } \\
\text { May } \\
\text { June } \\
\text { July } \\
\text { August }\end{array}$ & $\begin{array}{r}566 \\
576 \\
47 \\
2 \\
2 \\
0\end{array}$ & $\begin{array}{r}23 \\
66 \\
2 \\
1 \\
1 \\
0\end{array}$ & $\begin{array}{r}183 \\
299 \\
13.8 \\
.3 \\
0 \\
0\end{array}$ & $\begin{array}{r}10,900 \\
18,400 \\
821 \\
20 \\
6 \\
0\end{array}$ \\
\hline The period... & $\ldots$ & (-n, & (............. & 30,100 \\
\hline $\begin{array}{l}\text { March } \\
\text { April } \\
\text { May } \\
\text { June } \\
\text { July } \\
\text { August } \\
\text { September. }\end{array}$ & $\begin{array}{r}37 \\
268 \\
415 \\
58 \\
1 \\
2\end{array}$ & $\begin{array}{r}1 \\
24 \\
52 \\
1 \\
1 \\
1\end{array}$ & $\begin{array}{c}4.35 \\
95 \\
228 \\
9 \\
1 \\
1.1\end{array}$ & $\begin{array}{r}267 \\
5,650 \\
14,000 \\
536 \\
61 \\
67\end{array}$ \\
\hline The period. & $\ldots$ & - & $\ldots$ & 20,600 \\
\hline $\begin{array}{l}\text { March. } \\
\text { April } \\
\text { May } \\
\text { June }\end{array}$ & $\begin{array}{r}42 \\
646 \\
350 \\
47\end{array}$ & $\begin{array}{l}1 \\
4 \\
7 \\
0\end{array}$ & $\begin{array}{l}5.1 \\
292 \\
103 \\
5.1\end{array}$ & $\begin{array}{r}314 \\
17,400 \\
6,330 \\
305\end{array}$ \\
\hline The period..... & ......- & $\mid-\ldots+\ldots+\ldots$ & - & 24,000 \\
\hline $\begin{array}{l}\text { February } \\
\text { Maroh } \\
\text { Mpril } \\
\text { May } \\
\text { June } \\
\text { Jun }\end{array}$ & $\begin{array}{r}15 \\
157 \\
56 \\
5\end{array}$ & $\begin{array}{l}2 \\
0 \\
0\end{array}$ & $\begin{array}{l}4.03 \\
5.03 \\
67.3 \\
23.5 \\
.73\end{array}$ & $\begin{array}{r}2222 \\
309 \\
4,000 \\
1,440 \\
43\end{array}$ \\
\hline The period........ & - & - & .............. & 6,010 \\
\hline $\begin{array}{l}\text { March } 21-31 . \ldots 2 \\
\text { April } \\
\text { May } \\
\text { June }\end{array}$ & $\begin{array}{r}935 \\
494 \\
64\end{array}$ & $\begin{array}{r}5 \\
68 \\
0\end{array}$ & $\begin{array}{l}16.2 \\
262 \\
263 \\
12.5\end{array}$ & $\begin{array}{r}350 \\
15,600 \\
16,200 \\
744\end{array}$ \\
\hline The period.......... & (n) & - & $\ldots$ & 32,900 \\
\hline $\begin{array}{l}\text { April } \\
\text { May-_. } \\
\text { June } \\
\text { July } \\
\text { August } \\
\text { September }\end{array}$ & $\begin{array}{r}590 \\
474 \\
76 \\
42 \\
1 \\
125\end{array}$ & $\begin{array}{r}18 \\
4 \\
0 \\
0 \\
0 \\
0\end{array}$ & $\begin{array}{l}299 \\
123 \\
7.77 \\
2.90 \\
13.06 \\
13.4\end{array}$ & $\begin{array}{r}17,800 \\
7,560 \\
462 \\
178 \\
4 \\
797\end{array}$ \\
\hline The period... & & $\mathbf{0}$ & - & 26,800 \\
\hline
\end{tabular}




\section{SAN MITGEL RIVER AT FALI CREEK, COLO.}

Location.-In sec. 7, T. 43 N., R. 10 W., at highway bridge at Fall Creek station on Rio Grande Southern Railroad, San Miguel County, 200 feet above mouth of Fall Creek.

Drainage area.-172 square miles (measured on base map of Colorado).

Records available.-June 25, 1895, to September 30, 1899.

GAGE.-Vertical staff.

Control.-Slightly shifting.

Extremes of Discharge.-Maximum stage recorded, 5.0 feet at $6 \mathrm{p}$. m. May 27, 1896 (discharge, 2,570 second-feet); minimum discharge occurred during winter.

Diversions.-Practically no water diverted from San Miguel River above Fall Creek for irrigation.

Monthly discharge of San. Miguel River at Fall Creek, Colo., for 1895-1899

\begin{tabular}{|c|c|c|c|c|}
\hline \multirow{2}{*}{ Month } & \multicolumn{3}{|c|}{ Discharge in second-feet } & \multirow{2}{*}{$\begin{array}{l}\text { Run-off in } \\
\text { acre-feet }\end{array}$} \\
\hline & Maximum & Minimum & Mean & \\
\hline $\begin{array}{l}\text { June 25-30.19 } \\
\text { July } \\
\text { August } \\
\text { September }\end{array}$ & $\begin{array}{r}605 \\
675 \\
312 \\
-168\end{array}$ & $\begin{array}{r}512 \\
219 \\
145 \\
61\end{array}$ & $\begin{array}{l}555 \\
347 \\
230 \\
100\end{array}$ & $\begin{array}{r}6,600 \\
21,300 \\
14,100 \\
5,950\end{array}$ \\
\hline The period.. & 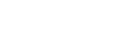 & -....- & $\ldots$ & 48,000 \\
\hline $\begin{array}{l}\text { October } \\
\text { November } \\
\text { December } \\
\text { January } \\
\text { February. } \\
\text { March } \\
\text { April } \\
\text { Mug } \\
\text { July } \\
\text { August } \\
\text { September }\end{array}$ & $\begin{array}{r}101 \\
180 \\
30 \\
2,400 \\
684 \\
320 \\
113 \\
1,780\end{array}$ & 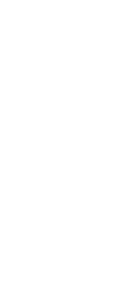 & $\begin{array}{r}64 \\
47 \\
7.7 \\
65 \\
a 5 \\
620 \\
205 \\
770 \\
349 \\
157 \\
65 \\
176\end{array}$ & $\begin{array}{r}3,940 \\
2,800 \\
474 \\
307 \\
288 \\
1,230 \\
17,200 \\
47,300 \\
20,800 \\
9,650 \\
4,000 \\
10,500\end{array}$ \\
\hline The year......... & 2,400 & n. & (n............... & 113,000 \\
\hline $\begin{array}{l}\text { October } \\
\text { November } \\
\text { December } \\
\text { January- } \\
\text { February } \\
\text { March } \\
\text { April } \\
\text { May } \\
\text { June } \\
\text { July } \\
\text { August } \\
\text { September }\end{array}$ & $\begin{array}{r}135 \\
69 \\
-933 \\
962 \\
997 \\
621 \\
288 \\
304 \\
\end{array}$ & $\begin{array}{r}\mathbf{4 9} \\
22 \\
52 \\
369 \\
504 \\
243 \\
122 \\
132\end{array}$ & $\begin{array}{r}82 \\
50 \\
a 40 \\
a 35 \\
a 30 \\
a 35 \\
213 \\
626 \\
774 \\
375 \\
183 \\
215\end{array}$ & $\begin{array}{r}5,040 \\
2,980 \\
2,460 \\
2,150 \\
1,670 \\
2,150 \\
12,700 \\
38,500 \\
46,100 \\
23,100 \\
11,300 \\
12,800\end{array}$ \\
\hline The year..... & 997 & - & - $\therefore$ - nnen & 161,000 \\
\hline $\begin{array}{l}\text { October- } \\
\text { November } \\
\text { December } \\
\text { January } \\
\text { February } \\
\begin{array}{l}\text { March } \\
\text { April }\end{array} \\
\text { May } \\
\text { June } \\
\text { July } \\
\text { August } \\
\text { September }\end{array}$ & \begin{tabular}{r|}
273 \\
132 \\
\\
\\
447 \\
545 \\
1,340 \\
760 \\
183 \\
121
\end{tabular} & \begin{tabular}{|r|}
122 \\
62 \\
\\
\\
196 \\
571 \\
109 \\
109 \\
66 \\
\end{tabular} & $\begin{array}{r}184 \\
96 \\
a 45 \\
a 40 \\
a 35 \\
a 40 \\
215 \\
296 \\
813 \\
380 \\
133 \\
89\end{array}$ & $\begin{array}{r}11,300 \\
5,710 \\
2,770 \\
2,460 \\
1,940 \\
2,460 \\
12,800 \\
18,200 \\
48,400 \\
23,400 \\
8,180 \\
5,300\end{array}$ \\
\hline The year...... & 1,340 & 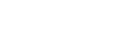 & (n) & 143,000 \\
\hline
\end{tabular}

astimated. 
Monthly discharge of San Miguel River at Fall Creek, Colo., for 1895-1899Continued

\begin{tabular}{|c|c|c|c|c|}
\hline \multirow{2}{*}{ Month } & \multicolumn{3}{|c|}{ Discharge in second-feet } & \multirow{2}{*}{$\begin{array}{c}\text { Run-off in } \\
\text { acre-feet }\end{array}$} \\
\hline & Maximum & Minimum & Mean & \\
\hline $\begin{array}{l}\text { October. } \\
\text { November } \\
\text { December } \\
\text { January } \\
\text { February } \\
\text { March } \\
\text { April. } \\
\text { May } \\
\text { June } \\
\text { July } \\
\text { August } \\
\text { September }\end{array}$ & \begin{tabular}{|r}
66 \\
47 \\
\\
\\
\end{tabular} & \begin{tabular}{|r|}
30 \\
22 \\
\\
\hdashline \\
125 \\
1249 \\
176 \\
105 \\
64 \\
\end{tabular} & $\begin{array}{r}50 \\
35 \\
e 30 \\
e 25 \\
\therefore 20 \\
a 25 \\
134 \\
414 \\
538 \\
238 \\
195 \\
101\end{array}$ & $\begin{array}{r}3,070 \\
2,080 \\
1,840 \\
1,540 \\
1,110 \\
1,540 \\
7,970 \\
25,500 \\
32,000 \\
14,600 \\
12,000 \\
6,000\end{array}$ \\
\hline The year................ & 995 & $\mid-\infty+\infty$ & & 109,000 \\
\hline
\end{tabular}

a Estimated.

SAN MIGUEL RIVER NEAR PLACERTILLE, COLO.

Location.-In sec. 34, T. 44 N., R. 11 W., at highway bridge three-quarters of a mile below Placerville, San Miguel County. Nearest tributary, Leopard Creek, enters at Placerville.

Drainage aRea.-280 square miles for upper station (measured on base map of Colorado).

Records avainable.-September 1, 1910, to November 30, 1912. From January 1 to December 31, 1909, station maintained at Saltado Ranch 7 miles below Placerville in NE. $1 / 4$ sec. 23, T. 44 N., R. 12 W., where discharge is practically the same.

GaGe.-Vertical staff.

Control.-Permanent.

Extremes of Dischargt.-Maximum discharge during period, 10,000 secondfeet on September 5, 1909, owing to breaking of Trout Lake Reservoir; minimum discharge, 50 second-feet December 21-25, 1911.

Drversions.-Practically no water diverted above station that does not return to river.

Regulation.- Winter discharge regulated by release of water from two power reservoirs on headwaters.

Cooperation.-Complete records furnished by State engineer, except those for 1909, which were furnished by Mr. R. I. Meeker.

Monthly discharge of San Miguel River near Placerville, Colo., for 1909-1912

\begin{tabular}{|c|c|c|c|c|c|}
\hline \multirow{2}{*}{1} & \multirow{2}{*}{ Month } & \multicolumn{3}{|c|}{ Discharge in second-feet } & \multirow{2}{*}{$\begin{array}{l}\text { Run-off in } \\
\text { acre-feet }\end{array}$} \\
\hline & & Maximum & Minimum & Mean & \\
\hline \multirow{2}{*}{\multicolumn{2}{|c|}{$\begin{array}{l}\text { January } \\
\text { February } \\
\text { March } \\
\text { April } \\
\text { May } \\
\text { June } \\
\text { July } \\
\text { August } \\
\text { September } \\
\quad \text { The period }\end{array}$}} & $\begin{array}{r}940 \\
1,460 \\
1,170 \\
470 \\
10,000\end{array}$ & $\begin{array}{r}310 \\
645 \\
270 \\
210 \\
250\end{array}$ & $\begin{array}{r}60 \\
60 \\
80 \\
160 \\
706 \\
1,250 \\
635 \\
326 \\
506\end{array}$ & $\begin{array}{r}3,690 \\
3,330 \\
4,920 \\
9,520 \\
43,400 \\
74,400 \\
39,000 \\
20,000 \\
30,100\end{array}$ \\
\hline & & - & (n................. & ............ & 228,000 \\
\hline
\end{tabular}


Monthly discharge of San Miguel River near Placerville, Colo., for 1909-1912-Con.

\begin{tabular}{|c|c|c|c|c|}
\hline \multirow{2}{*}{ Month } & \multicolumn{3}{|c|}{ Discharge in second-feet } & \multirow{2}{*}{$\begin{array}{l}\text { Run-off in } \\
\text { acr }- \text {-feet }\end{array}$} \\
\hline & Maximum & Minimum & Mean & \\
\hline $\begin{array}{l}\text { October. } \\
\text { November } \\
\text { December } \\
\text { September }\end{array}$ & $\begin{array}{r}240 \\
115 \\
-1 \overrightarrow{85} \\
\end{array}$ & $\begin{array}{r}107 \\
92 \\
95\end{array}$ & $\begin{array}{r}156 \\
103 \\
67 \\
125 \\
\end{array}$ & $\begin{array}{l}9,590 \\
6,130 \\
4,120 \\
7,440 \\
\end{array}$ \\
\hline $\begin{array}{l}\text { October-1910 } \\
\text { November } \\
\text { December } \\
\text { January } \\
\text { February } \\
\text { March } \\
\text { April } \\
\text { May } \\
\text { June } \\
\text { July } \\
\text { August } \\
\text { September. }\end{array}$ & $\begin{array}{r}245 \\
111 \\
88 \\
127 \\
91 \\
148 \\
438 \\
706 \\
910 \\
1,500 \\
650 \\
571\end{array}$ & $\begin{array}{r}95 \\
65 \\
58 \\
60 \\
54 \\
60 \\
118 \\
306 \\
600 \\
514 \\
184 \\
124\end{array}$ & $\begin{array}{r}121 \\
94.8 \\
76.5 \\
78.8 \\
64.4 \\
81.1 \\
245 \\
557 \\
744 \\
938 \\
349 \\
175\end{array}$ & $\begin{array}{r}7,420 \\
5,640 \\
4,700 \\
4,850 \\
3,580 \\
4,990 \\
14,600 \\
34,200 \\
44,300 \\
57,700 \\
21,500 \\
10,400\end{array}$ \\
\hline The year. & 1,500 & 54 & 296 & 214,000 \\
\hline $\begin{array}{l}\text { October. } \\
\text { November } \\
\text { December } \\
\text { January } \\
\text { February } \\
\text { March } \\
\text { April } \\
\text { May } \\
\text { June } \\
\text { July } \\
\text { August } \\
\text { September }\end{array}$ & $\begin{array}{r}1,540 \\
162 \\
85 \\
100 \\
174 \\
92 \\
328 \\
1,500 \\
1,530 \\
935 \\
447 \\
212\end{array}$ & $\begin{array}{r}142 \\
85 \\
50 \\
55 \\
66 \\
60 \\
78 \\
447 \\
582 \\
483 \\
162 \\
100\end{array}$ & $\begin{array}{c}399 \\
126 \\
63.4 \\
70 \\
82 \\
73 \\
154 \\
977 \\
973 \\
602 \\
253 \\
134\end{array}$ & $\begin{array}{r}24,500 \\
7,500 \\
3,900 \\
4,320 \\
4,740 \\
4,510 \\
9,180 \\
60,000 \\
57,900 \\
37,000 \\
15,500 \\
7,960\end{array}$ \\
\hline The year...... & 1,540 & 50 & 327 & 237,000 \\
\hline $\begin{array}{l}\text { October-19 } \\
\text { November } \\
\text { Nove }\end{array}$ & $\begin{array}{l}151 \\
100\end{array}$ & $\begin{array}{l}92 \\
60\end{array}$ & $\begin{array}{r}105 \\
83\end{array}$ & $\begin{array}{l}6,470 \\
4,940\end{array}$ \\
\hline
\end{tabular}

Nork.-Monthly means for January, February, March, April, and December, 1909, based on currentmoter measurements.

SAN MIGUEL RIVER AT WATURITA, COLO,

Location.-On line between Rs. 15 and 16 W., T. 46 N., at highway bridge in

Naturita, Montrose County. Nearest tributary, Basin Creek, enters half

a mile downstream.

Drainage area.-1,080 square miles (measured on base map of Colorado).

Records avairable.-October 1, 1917, to September 30, 1927.

GAGE.-Chain.

Control.-Shifting at long intervals.

ExTremes of Discharge.-Maximum stage recorded during period, 7.5 feet from high-water mark during night of May 4, 1921 (discharge, 6,000 secondfeet); minimum stage recorded, 0.05 foot on August 31,1918 (discharge, 38 second-feet.)

Diversions.-Water diverted for irrigation of 8,100 acres by San Miguel River, the greater part of which is above station. Also, 15,000 acres irrigated by tributaries above station.

Accuracy.-Gage read twice daily. Rating curves well defined. Records good.

Cooperation.-Complete records furnished by State engineer since 1921. 46013-29-26 
Monthly discharge of San Miguel River at Naturita, Colo., for 1917-1927

\begin{tabular}{|c|c|c|c|c|}
\hline \multirow{2}{*}{ Month } & \multicolumn{3}{|c|}{ Discharge in second-feet } & \multirow{2}{*}{$\begin{array}{c}\text { Run-off in } \\
\text { acre-feet } \\
\end{array}$} \\
\hline & Maximum & Minimum & Mean & \\
\hline $\begin{array}{l}\text { October } \\
\text { November } \\
\text { December } \\
\text { January } \\
\text { February } \\
\text { March } \\
\text { April } \\
\text { May } \\
\text { June } \\
\text { July } \\
\text { August } \\
\text { September }\end{array}$ & \begin{tabular}{r|r|}
369 \\
746 \\
1,980 \\
920 \\
227 \\
1,150
\end{tabular} & \begin{tabular}{r|r} 
\\
\\
330 \\
330 \\
76 \\
38 \\
40
\end{tabular} & $\begin{array}{r}a 100 \\
a 100 \\
a 85 \\
a 90 \\
a 95 \\
a 125 \\
250 \\
513 \\
927 \\
294 \\
103 \\
133\end{array}$ & $\begin{array}{r}6,150 \\
5,950 \\
5,230 \\
5,530 \\
\mathbf{5}, 280 \\
7,690 \\
14,900 \\
31,500 \\
55,200 \\
18,100 \\
6,330 \\
7,910\end{array}$ \\
\hline The year. & 1,980 & - & 234 & 170,000 \\
\hline $\begin{array}{l}\text { October } \\
\text { November } \\
\text { December } \\
\text { January } \\
\text { February } \\
\text { March } \\
\text { April } \\
\text { May } \\
\text { June } \\
\text { July } \\
\text { August } \\
\text { September }\end{array}$ & $\begin{array}{r}64 \\
91 \\
187 \\
1,650 \\
1,350 \\
883 \\
784 \\
190\end{array}$ & $\begin{array}{r}\begin{array}{r}42 \\
47\end{array} \\
\\
\\
\end{array}$ & $\begin{aligned} & 48.8 \\
& 60.8 \\
& 84 \\
& a 55 \\
& a 75 \\
& 183 \\
& 733 \\
& 1,060 \\
& 659 \\
& 499 \\
& a \quad 200 \\
& \text { a } 150\end{aligned}$ & $\begin{array}{r}3,000 \\
3,620 \\
5,160 \\
3,380 \\
4,160 \\
11,300 \\
43,600 \\
65,200 \\
39,200 \\
30,700 \\
12,300 \\
8,930\end{array}$ \\
\hline The year... & 1,650 & - & 319 & 231,000 \\
\hline $\begin{array}{l}\text { October } \\
\text { November } \\
\text { December } \\
\text { January } \\
\text { February } \\
\text { March } \\
\text { April } \\
\text { May } \\
\text { June } \\
\text { July } \\
\text { August } \\
\text { September }\end{array}$ & $\begin{array}{r}114 \\
139 \\
130 \\
135 \\
156 \\
271 \\
2,000 \\
4,180 \\
2,870 \\
1,500 \\
615 \\
440\end{array}$ & $\begin{array}{r}67 \\
80 \\
52 \\
54 \\
105 \\
102 \\
106 \\
1,400 \\
1,210 \\
330 \\
92 \\
67\end{array}$ & $\begin{array}{c}93.1 \\
105 \\
70.0 \\
92.8 \\
135 \\
135 \\
388 \\
2,400 \\
1,740 \\
689 \\
259 \\
121\end{array}$ & $\begin{array}{r}5,720 \\
6,250 \\
4,300 \\
5,710 \\
7,760 \\
8,300 \\
23,100 \\
148,000 \\
104,000 \\
42,400 \\
15,900 \\
7,200\end{array}$ \\
\hline The year. & 4,180 & & 520 & 379,000 \\
\hline $\begin{array}{l}\text { October } \\
\text { November } \\
\text { December } \\
\text { January } \\
\text { February } \\
\text { March } \\
\text { April } \\
\text { May } \\
\text { June } \\
\text { Suly } \\
\text { August }\end{array}$ & $\begin{array}{r}152 \\
144 \\
106 \\
120 \\
202 \\
348 \\
1,120 \\
2,610 \\
4,160 \\
1,510 \\
1,340 \\
640\end{array}$ & $\begin{array}{r}92 \\
84 \\
40 \\
88 \\
99 \\
114 \\
240 \\
960 \\
1,460 \\
580 \\
326 \\
97\end{array}$ & $\begin{array}{c}117 \\
109 \\
85.5 \\
99.4 \\
125 \\
219 \\
550 \\
1,610 \\
2,160 \\
1,010 \\
591 \\
214\end{array}$ & $\begin{array}{r}7,190 \\
6,490 \\
5,260 \\
6,110 \\
6,940 \\
13,500 \\
32,700 \\
99,000 \\
129,000 \\
62,100 \\
36,300 \\
12,700\end{array}$ \\
\hline The year...... & 4,160 & 40 & 575 & 417,000 \\
\hline $\begin{array}{l}\text { October } \\
\text { November } \\
\text { December } \\
\text { January } \\
\text { February } \\
\text { March } \\
\text { April } \\
\text { May }\end{array}$ & $\begin{array}{r}300 \\
2,540 \\
2,590 \\
1,810 \\
975 \\
621 \\
102\end{array}$ & $\begin{array}{r}50 \\
148 \\
1,040 \\
806 \\
170 \\
79 \\
46\end{array}$ & $\begin{array}{c}118 \\
110 \\
113 \\
a 59.6 \\
a 97.5 \\
131 \\
739 \\
1,820 \\
1,310 \\
389 \\
182 \\
59.3\end{array}$ & $\begin{array}{r}7,260 \\
6,550 \\
6,950 \\
3,660 \\
5,410 \\
8,060 \\
44,000 \\
112,000 \\
78,000 \\
23,900 \\
11,200 \\
3,530\end{array}$ \\
\hline & 2,590 & & 429 & 311,000 \\
\hline
\end{tabular}

a Estimated. 
Monthly discharge of San Miguel River at Naturita, Colo., for 1917-1927-Contd.

\begin{tabular}{|c|c|c|c|c|}
\hline \multirow{2}{*}{ Month } & \multicolumn{3}{|c|}{ Discharge in second-feet } & \multirow{2}{*}{$\begin{array}{c}\text { Run-off in } \\
\text { acre-feet }\end{array}$} \\
\hline & Maximum & Minimum & Mean & \\
\hline $\begin{array}{l}\text { October } \\
\text { November } \\
\text { December. } \\
\text { January } \\
\text { February } \\
\text { March } \\
\text { April } \\
\text { May } \\
\text { June } \\
\text { July } \\
\text { August } \\
\text { September }\end{array}$ & $\begin{array}{r}\begin{array}{r}95 \\
110\end{array} \\
178 \\
1,080 \\
1,630 \\
1,200 \\
1,000 \\
\mathbf{5 7 4} \\
\mathbf{4 1 0}\end{array}$ & \begin{tabular}{|r|}
51 \\
55 \\
70 \\
131 \\
489 \\
821 \\
283 \\
170 \\
102
\end{tabular} & $\begin{array}{l}59.1 \\
74.3 \\
\text { 110 } \\
105 \\
105 \\
102 \\
464 \\
1,040 \\
1,040 \\
602 \\
306 \\
164\end{array}$ & $\begin{array}{r}3,650 \\
4,490 \\
6,760 \\
6,400 \\
5,280 \\
6,270 \\
27,600 \\
64,000 \\
61,900 \\
37,000 \\
18,800 \\
9,760\end{array}$ \\
\hline The y & 1,630 & 51 & 348 & 252,000 \\
\hline $\begin{array}{l}\text { October } \\
\text { November } \\
\text { December } \\
\text { January } \\
\text { February } \\
\text { March } \\
\text { April } \\
\text { May } \\
\text { June } \\
\text { July } \\
\text { August }\end{array}$ & $\begin{array}{r}132 \\
111 \\
100 \\
93 \\
276 \\
150 \\
2,540 \\
1,690 \\
1,380 \\
442 \\
218 \\
62\end{array}$ & $\begin{array}{r}93 \\
82 \\
64 \\
60 \\
74 \\
72 \\
76 \\
744 \\
489 \\
74 \\
50 \\
41\end{array}$ & $\begin{array}{c}111 \\
93.1 \\
78.5 \\
70.5 \\
112 \\
83.8 \\
948 \\
1,340 \\
869 \\
231 \\
89.3 \\
54.8\end{array}$ & $\begin{array}{r}6,820 \\
5,540 \\
4,830 \\
4,330 \\
6,440 \\
5,150 \\
56,400 \\
82,400 \\
51,700 \\
14,200 \\
5,490 \\
3,260\end{array}$ \\
\hline The year.. & 2,540 & 41 & 339 & 247,000 \\
\hline $\begin{array}{l}\text { October. } \\
\text { November } \\
\text { December. } \\
\text { January } \\
\text { February } \\
\text { March } \\
\text { April }\end{array}$ & $\begin{array}{r}103 \\
80 \\
1,340 \\
1,080 \\
1,100 \\
821 \\
420 \\
1,580\end{array}$ & \begin{tabular}{r|r|}
58 \\
55 \\
74 \\
218 \\
514 \\
335 \\
154 \\
108 \\
146
\end{tabular} & $\begin{array}{l}81.4 \\
73.1 \\
\times 70 \\
65 \\
662 \\
133 \\
595 \\
825 \\
683 \\
408 \\
200 \\
333\end{array}$ & $\begin{array}{r}5,010 \\
4,350 \\
4,300 \\
4,000 \\
3,440 \\
8,180 \\
35,400 \\
50,700 \\
40,600 \\
25,100 \\
12,300 \\
19,800\end{array}$ \\
\hline The year. - & 1,580 & 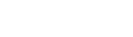 & 295 & 213,000 \\
\hline $\begin{array}{l}\text { October. } \\
\text { November } \\
\text { December } \\
\text { January. } \\
\text { February } \\
\text { March } \\
\text { April } \\
\text { May } \\
\text { June } \\
\text { July } \\
\text { August } \\
\text { September }\end{array}$ & $\begin{array}{r}381 \\
205 \\
213 \\
246 \\
1,520 \\
1,620 \\
1,670 \\
947 \\
326 \\
132\end{array}$ & \begin{tabular}{|r|r}
187 \\
63 \\
63 \\
89 \\
114 \\
866 \\
762 \\
224 \\
66 \\
47
\end{tabular} & $\begin{array}{c}240 \\
153 \\
a 80 \\
a 78 \\
10 \\
145 \\
763 \\
1,260 \\
1,230 \\
528 \\
152 \\
63.9\end{array}$ & $\begin{array}{r}14,800 \\
9,100 \\
4,920 \\
4,610 \\
6,000 \\
8,920 \\
45,400 \\
77,500 \\
73,200 \\
32,500 \\
9,350 \\
3,800\end{array}$ \\
\hline The year... & 1,670 & 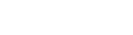 & 400 & 290,000 \\
\hline $\begin{array}{l}\text { October } \\
\text { November } \\
\text { December. } \\
\text { January } \\
\text { February } \\
\text { March } \\
\text { April } \\
\text { May } \\
\text { June } \\
\text { July } \\
\text { August } \\
\text { September }\end{array}$ & $\begin{array}{r}202 \\
126 \\
1,320 \\
1,550 \\
2,610 \\
1,130 \\
679 \\
1,870\end{array}$ & 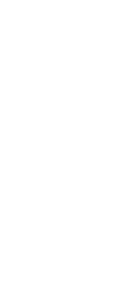 & $\begin{array}{r}140 \\
107 \\
105 \\
100 \\
105 \\
139 \\
788 \\
1,150 \\
982 \\
501 \\
416 \\
817\end{array}$ & $\begin{array}{r}8,610 \\
6,370 \\
6,460 \\
6,150 \\
5,830 \\
8,550 \\
46,900 \\
70,700 \\
58,400 \\
30,800 \\
25,600 \\
48,600\end{array}$ \\
\hline 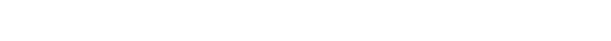 & 2,610 & - & 447 & 323,000 \\
\hline
\end{tabular}





\section{INDEX}

$A$

Acknowledgments......................... 3

Acorn Creek power site, description of....... 186

Agriculture in the area, character of....... 117, 120

Almont, Colo., East River at................ 336-338

Taylor River above . ................. 318

Taylor River at. ......................... 318-322

Almont power site, description of............ 196

Altitudes, along Blue River.................... 185

along Colorado River from source to

Green River...................... 182-183

along Dolores River. . ...................... 200

along Eagle River........................ 187

along Gunnison River.................... 194

along Lake Fork. .

along Roaring Fork . . . . . . . . .

along San Miguel River.................... 202

along Uncompahgre River................. 198

Ames power plants, description of . ........ 177-178

Aspen, Colo., Castle Creek near........... 292-294

Maroon Creek near. . . . ................. 294-297

Roaring Fork at......................... 282-285

Roaring Fork near. ................... 285-286

Aspen power site, description of.............. $\quad 191$

Aspen reservoir site No. 1, description of .... 85-86

Avon power site, description of .............. 188

B

Bachelor switch power site.................... $\quad 199$ Basalt, Colo., Fryingpan Creek at......... 302-303

Basalt Creek power site, description of .... 191-192

Beaver Creek, irrigation from.............. 139, 147

Beaver Creek reservoir site, description of... 107

Beaver Mesa reservoir site, location of ........ 108

Bedrock, Colo., Dolores River at........... 380-382

Bedrock reservoir site, contour map of........ 104

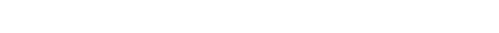

Berthoud ditch, diversion through............ 52-63

Bibliography.................................. 3-5

Black Canyon, location and features of ..... 14

Blue River, altitudes and distances along.-.. $\quad 185$

diversions from......................... $53,56-58$

flow of, at Breckenridge, Colo......... 257-258

at Dillon, Colo....................... 258-262

near Kremmling, Colo............. 262-263

Blue River Basin, irrigation and agriculture

in. .............................. 125-126

location and features of.................. 9-10

power sites in, developed................. 166-168 undeveloped......................... 184-187

reservoir sites in ............................ 82-85

Boreas Pass ditch, diversion through......... 53

Boundaries of the upper Colorado River Basin.

6
$-257-258$

Breckenridgé, Colo., Blue River at......... 257-258

Bridal Veil Creek, power from............. 176-177

Brush Creek at Eagle, Colo................. 281-282

Brush Creek power site, description of....... 189

Buckeye Reservoir, description of............. 65

Busk-Ivanhoe tunnel, diversion through.....- 50-51
Pare

Butte Mesa reservoir site, disadvantage of.... 86-87

Buzzard Creek, course of .................... 13

flow of, near Collbran, Colo............ 316-317

\section{C}

C. M. reservoir site, unfeasibility of ......... 85

Cache la Poudre River, hydrograph of....... 152

Campbell, M. R., quoted.................... 20

Canyon Creek, flow of, at Ouray, Colo.... 369-371 power from................................. 175

Carbondale, Colo., Crystal River near....... 307

Carbondale power site, description of........ 192

Cardiff power site, description of............. 192-193

Carter mines power plant, descriptio. of ..... 173

Castle Creek, flow of, near Aspen, Colo.... 292-294 power from......................... 169-170

Castle Creek power site on Roaring Fork, de. scription of..................... 191

Cebolla reservoir site.......................... 94-85

Cedar reservoir site No. 4, description of ..... 107

Cedar reservoir site No. 5, description of..... 107

Cedaredge, Colo, Surface Creek near....... 353-356

Cement Creek near Crested Butte, Colo..... 339

Cimarron, Colo., Cimarron Creek at...... 346-347 Gunnison River near....................... 328

Cimarron Creek, course and features of...... 15 flow of, at Cimarron, Colo.............. 346-347 irrigation from.............................. 131

Cimarron mine power plant............... 177

Cisco, Utah, Colorado River near........... 237-239

Climate of the area.......................... 230 effect upon electrical transmission systems.................................... 149

effect upon hydraulic structures. ....... 150-151 summary of . ............................... XI

Coal Creek, power from................... 172-173

Collbran, Colo., Buzzard Creek near....... 316-317 Plateau Creek near..................... 314-316

Colona, Colo., Uncompahgre River near... 363-366 Colorado Cooperative Canal................. 145-146 Colorado reservoir site No. 1, disadvantage of. $\quad 87$ Colorado River, altitude and distances along, from source to Green River..... 182-183 diversions from, for irrigation, summaries of............... XII, 49, 117-120, 147

plate showing diversion dam near Palisade........................... 122

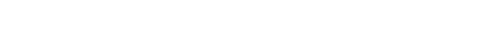
flow of, at Glenwood Springs, Colo.... 220-226 at Glenwood Springs, Colo., duration

curve for......................... 157 at Grand Junction, Colo............ 232-233 at Hot Sulphur Springs, Colo...... 211-216 at State Bridge, Colo_............... 220 near Cisco, Utah..................... 237-239 near Fruita, Colo................... 233-237 near Granby, Colo .................. 210-211 near Grand Lake, Colo............. 207-210 near Kremmling, Colo........... 73, 216-219 near Palisade, Colo.................. 227-232 
Page

Colorado River, flow of, records of... 41-48, 207-239 variations in............... 43-48,148, 151-154 irrigation from, summary of . .......... 117-120 physical features of ...................... 7-8 power from, developed . ............... 165-166 undeveloped........................... 183-184 reservoir sites on ....................... 68-79 contour maps showing.............. 68.74 sediment in ................................ 154-156 source of.

7

tributaries of ............................ 8-19

See also names of tributaries.

Colorado River Basin, index to subdivisions of.

irrigation in, summary of ............ 117-120 map showing utilization of water resources and lines of equal precipitation..................... In pocket.

power sites in, summaries of developed power ....................... 161, 180-181

summaries of undeveloped power... 182, 204 reservoir sites in, summaries of developed sites_......................... 61, 66-67

summaries of undeveloped sites..... 68 , 111-114

Colorado River power site at mouth of Dolores River......................

Colorado-Utah State line power site, description of ............................

Consolidated Colorado Yule Marble 'Co. power plant No. 1, description of. 170

Consolidated Colorado Yule Marble Co.power plant No. 2, description of...... 170-171

Continental Divide, ranges forming........ 6

Corral reservoir site, description of.......... 87

Cory, Colo., Gunnison River near.......... 330-331

Crested Butte, Colo., Cement Creek near.- 339

Crested Butte power plant, description of.. 172-173

Crystal Creek, course and features of ...... 15-16 flow of, near Maher, Colo............... 347-348 irrigation from.... ....................... 131-132

Crystal. Creek power site on Taylor River, description of ....... 196

Crystal River, flow of, at Marble, Colo..... 305-306 flow of, near Carbondale, Colo.......... 307 power from............................. 171, 192

Cartis reservoir site No. 1, description of.... 82 Custer reservoir site, description of.......... 107-108

\section{D}

Dallas Creek, flow of, near Ridgway, Colo. 371-372 reservoir sites on ......... 98-99

De Beque, Colo., Roan Creek near........... 313-314

Delta, Colo., Escalante Creek near......... 372-373 Uncompahgre River at.................. 366-369

Denver, Colo., diversions of water for....... $54-$ $55,56-58$

Dewey reservoir site, contour map of ........ 74 description of......................... 74-79

Dillon, Colo., Blue River at............ 258-262 Snake River at. ......................... 263-265 Tenmile Creek at....................... 266-268

Dillon reservoir site............................ 82

Disappointment Creek, irrigation from...... 145 reservoir sites on ..................... 107-108
Discharge of Colorado River above Green River............................. 41-48

Diversion of water from upper Colorado River, decreed rights, in Grand Valley............................. 123 future development of .................. 53-61 present development of .................. 49-53

Divide Creek Basin, irrigation in............. 128 location of ............................... 12

Dolores, Colo., Dolores River at............ 376-380 Lost Canyon Creek at...................... 382

Dolores irrigation project, description of ... 144-145

Dolores reservoir site, contour map of....... 102 description of.............................. 101-102

Dolores River, altitudes and distances along - $\quad 200$ course and features of ...................... 17-18 flow of, at Bedrock, Colo............. 380-382 at Dolores, Colo.................. 376-380 at Rico, Colo...................... 375-376

Dolores River Basin, agriculture in........ 136-137 irrigation in ................... 136-140, 144-147 location and features of.................. 17 power sites in, developed............... 176-179 undeveloped........................... 199-204 precipitation in......................... 27 reservoir sites in, developed............... 64-65 undeveloped......................... 101-110 temperature in...................... 24, 25, 26

Dorchester reservoir site, description of ..... 90 Dotsero reservoir site, unfeasibility of......... 68 Drainage ditches, Grand Valley............ 124-125 Dunton reservoir site, description of........ 106-107

\section{$\mathbf{E}$}

Eagle, Colo., Brush Creek at.............. 281-282 Eagle River at.............................. 272-275

Eagle mill power plant, description of......- 168

Eagle River, altitude and distances along.... $\quad 187$ course and features of ................... 10-11 diversion from....................... 51-52, 58-59 flow of, at Eagle, Colo................ 272-275 at Gypsum, Colo.................... 275-277 at Redcliffe, Colo................... 269-272

Eagle River Basin, irrigation and agriculture

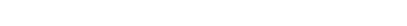
location and features of ................. 10-11 power sites in, developed................. 168 undeveloped........................... 187-190

reservoir sites in ........................... 85 East Elk Creek near New Castle, Colo..... 307-308 East Muddy reservoir site, description of.... $\quad 97$ East Rifle Creek, power from............... 171 East River at Almont, Colo................. 336-338 East River reservoir site, description of...... 92-93 Edwards power site, description of ........ 188-189 Electra reservoir site, description of........... 87-88 Elk Creek, flow of, at New Castle, Colo..... 309 source and tributaries of.................. $\quad 12$ Eunma, Colo., Roaring Fork near........... 286-287 Emma power site, description of ........... 192 Escalante Creek near Delta, Colo........... 372-373 Escalante irrigation project, description of ... 144 Evaporation, factors influencing ............... 39-41

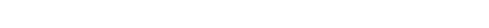
summary of............................ 
Page

Ewing ditch, diversion through

51-52

Excelsior mill power plant, description of -. 167-168 Excelsior reservoir sites No. 4 and No. 5, un. feasibility of......................................

\section{F}

Fall Creek, power from

Fall Creek, Colo., San Miguel River at... 383-384 Fauna of the area........................... 22 Fiftymile reservoir site, contour map of ...... 104 description of........................... 104-106 Finch reservoir site No. 2, description of.. 108-109

Floods in the area......................... 151-154 control of, effect of proposed reservoir at

Dewey site on...................... 77-79 reports on .................................. 4

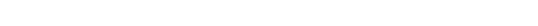

Forestation in the area....................... 19

Foster:Grande irrigation project............. 142

Fraser River, diversions from........... 52-53, 54-55 flow of, near Granby, Colo............. 247-249

near West Portal, Colo............. 243-247

location and features of ................. 8 -9

Frost in the area............................. 26

Fruit Growers reservoir, description of....... 63

Fruita, Colo., Colorado River near......... 233-237

Fruitland irrigation project, description of... 143

Fruitland Reservoir. See Onion Valley Reservoir.

Fryingpan Creek, flow of, at Basalt, Colo.. 302-303 flow of, at Norrie, Colo................. 298-300 at Thomasville, Colo............... 300-302 North Fork of, near Norrie, Colo...... 303-305

\section{G}

Gateview power site, unfeasibility of........ 198

Gateview reservoir site, unfeasibility of...... 95

Glenwood Light \& Water Co. plant, description of .............................. 168

Glenwood Springs, Colo., Colorado River at, duration curve for

Colorado River at, flow of 220-226

Roaring Fork at

287-292

Glenwood Springs power site, descrjption of.. 184

Gold Links mill power plant, description of.- 173

Gore Canyon power site, description of...... 184

Granby, Colo., Colorado River near....... 210-211

Fraser River near................... 247-249

Grand Junction, Colo., Colorado River at. 232-233 Gunnison River near..................... 331-335

Grand Lake, location and features of ..... $\quad 8,80$ North Inlet to........................ 239-241 outlet of ....... 241-243

Grand Lake reservoir site, description of.... 80-81

Grand Mesa, features and drainage of .... 12,17,21 reservoirs on.

Grand River, change of name of ........... 5

Grand River ditch, diversion through....... 49-50

Grand Valley, agriculture in.............. 124 irrigation in......................... 120-125 location and extent of .................... 8 water rights in ............................ 123

Grand Valley irrigation project, diversion dam for, plate showing ........... 122 power from canals of . ................... 171-172

Grass Valley Reservoir, description of....... 62
Page

Grebu Canyon reservoir site, unfeasibility of. $\quad 110$ Green Mountain power site, description of.. 186-187 Green Mountain reservoir site, description of

Grizzly Creek, power from.................. 168-169

Grover, Nathan C., Preface..................... viI

Gunnison, Colo., Gunnison River near. .... 822-326

Gunnison River, altitudes and distances along................................ 194

diversions from, for irrigation............. 129

flow of, at east portal of Gunnison Tunnel, Colo.......................... 328-330 at Iola, Colo........................ 326-327 near Címarron, Colo.................. 328 near Cory, Colo.................... 330-331 near Grand Junction, Colo........ 331-335 near Gunnison, Colo................. 322-326

North Fork of, near Hotchkiss, Colo... 350-351 near Paonia, Colo.................... 348-350 See also North Fork Basin.

source of

valley of.......................................... 13-15

Gunnison River Basin, irrigation in....... 129-136, 143-144

location and features of $\ldots . . . . . . . . . . . . . . . .13$

power sites in, developed................ 172-175 undeveloped............................ $193 \cdot 199$

precipitation in

reservoir sites in, developed......... 62-63, 66-67 undeveloped......................... 90-100

temperature in ......................... 24, 25, 26

Gunnison Tunnel, Colo, features of........... 135

Gunnison River at east portal of........ 328-330

Gunnison Valley irrigation project............ 143

Gunnison Valley reservoir site, description of

Gurley Reservoir, description of............. 65

Gypsum, Colo., Eagle River at............. 275-277 Gypsum Creek, power from............... 168, 189

\section{H}

Hartman reservoir site, unfeasibility of....... 68

Henson Creek, flow of, at Lake City, Colo_ 345-346 power from.................................. 174

Hidden Treasure power plant, description of. 174 Hine reservoir site No. 1, comparison with other sites........................ 84

contour map of .......................... 82

description of ................................. 81-82

Hine reservoir site No. 2, comparison with other sites....................... 84-85

contour map of ........................... 68

description of .......................... 68-70

Homestake Creek, at Redcliff, Colo........ 279-281

Horsefly Creek, power site on............ 203 reservoir site on ............................ 108-109

Hot Sulphur Springs, Colo., Colorado River at. . . 211-216

Hotchkiss, Colo., North Fork of Gunnison River near....................... 350-351

Howard Fork, power from ................. 177-178

Hunter Creek, power from.................. 169-170 Hunter Mesa irrigation project, description of ................................. 142-143

Hydroelectric plants. See Water-power plants. 
I

Ice, effect of, upon hydraulic structures.... 150-151 Ilium power plant, description of ......... 178-179 Iola, Colo., Gunnison River at. ............ 326-327 Ironton Park reservoir site, description of.... 97-98 Irrigation in the area, descriptions by valleys 119-140 early history of . ....................... 115-116 extent of, summary ................... 117-119 future development of, summary ...... 140-141 reports on. 4

summary of _....................... XIII-XIV water power in relation to ............... 148 Ivanhoe Reservoir, description of .......... 61

\section{J}

Joe More Reservoir,description of............. John Bull reservoir site, unfeasibility of ......

\section{$\mathbf{K}$}

Kahnah Creek, course and features of........ 17 flow of, near Whitewater, Colo ........ 373-375 reservoir sites on

Kernahan reservoir site No. 2 , location of.... 99

Kokomo, Colo., Tenmile Creek near....... 265-266

Kremmling, Colo., Blue River near. ...... 262-263 Colorado River near................. 73, 216-219 Muddy Creek at...

Kremmling reservoir site, comparison with other sites....................... 84-85 description of.

\section{L}

Lake City, Colo., Henson Creek at_....... 345-346 Lake Fork at......................... 343-345

Lake City power plant, description of ..... 173-174

Lake Fork, altitudes and distances along.... 197 course and features of....................... 15 flow of, at Lake City, Colo ............. 343-345 Lake Fork Basin, power sites in, developed.. 173$174,177-179$ power sites in, undeveloped. . . . ........ 197-198 reservoir sites in......................... 95-96

Lake Hope Reservoir, description of......... 64

Lake San Cristobal, location and area of..... 15

Lake San Cristobal power site, description of

Lake San Cristobal reservoir site............. 95-96

Lakes of the area . ............................. 21

La Rne, E. C., quoted .................... VII

Lazear, Colo., Leroux Creek near........... 351-353

Le man reservoir site. See Hine reservoir site No. 2.

Leroux Creek near Lazear, Colo ............ 351-353 Lin coln Gulch power site, description of..... 191 Little Dolores reservoir site, description of.-- 110 Lone Cone Reservoir, description of.......... 65

Lost Canyon Creek, flow of, at Dolores, Colo_ $\quad 382$

irrigation from............................. 138

Lost Trail Creek, power from ................ 170-171

Loweth, C. F., quoted .................. 160-161

\section{M}

McKenzie Creek power site, description of ..
Mamm Creek Basin, irrigation in........ 142-143 reservoir site in ........................ 88-89 Map of upper Colorado River Basin showing utilization of water resources and lines of equal precipitation.. In pocket. Marble, Colo., Crystal River at ............ 305-306 Markets, publications relating to............. 4 Maroon Creek, flow of, near Aspen, Colo_. 294-297 power from............................ 169-170

Marshall Creek, power from.................. $\quad 177$ Matthes, G. H., quoted..................... 72,80

Maxwell reservoir site, unfeasibility of....... 68 Middle Elk Creek Basin, reservoir site in.... 87-88 Minturn power site, description of............ 188 Miramonte reservoir site, description of...... $\quad 109$ Monarch mine power plant, description of.. $\quad 166$ Montezuma Valley, irrigation in....... 137-138, 144

Montrose Chief irrigation project............ 144

Mountains of the area.................. 6, 20-21

Muddy Creek, course and physical features of

flow of, at Kremmling, Colo............ $\quad 268$

\section{$\mathrm{N}$}

Narraguinnep Reservoir, description of.......

National forest areas in the Colorado River Basin.............................. 19 Naturita, Colo., San Miguel River at..._... 385-387 Naturita Creek, irrigation from............ 139, 147 New Castle, Colo., East Elk Creek near... 307-308 Elk Creek at............................ 309 No Name Creek, power from............... 168-169 Norrie, Colo., Fryingpan Creek at......... 298-300

North Fork of Fryingpan Creek near.- 303-305 North Fork Basin, irrigation and agriculture

in . .................... 132-133

location and physical features of......... 16

reservoir sites in.......................... 97

North Inlet to Grand Lake. See Grand Lake.

o

Onion Valley Reservoir, description of....... 62 Orchard Mesa pumping plant, description of. $\quad 172$ Osgood power plant, descriptior of .......... 171 Ouray, Colo., Canyon Creek at............ 369-371 Uncompahgre River at.................. 356-359

Uncompahgre River below . . . . . . . . . . 359-363 Ouray power plant, description of ......... 174-175 possible extension of ...................... 199 Overland Reservoir, description of........... 63 Oversteg reservoir site, unfeasibility of ....... 90

\section{$\mathbf{P}$}

Palisade, Colo., Colorado River near...... 227-232 Paonia, Colo., North Fork of Gunnison River near............................ 348-350

Parachute Creek, course of ................ 12

flow of, at Grand Valley, Colo......... 311-312

Paradox Valley, irrigation in............... 138, 145 Park reservoir site, comparison with other sites............................... 84-85

description of ............................ 70-72

Parlin, reservoir site near..................... 93

Parshall, Colo., Williams River near. ...... 251-256 
Page

Peale, A. C., quoted

91

Pitkin, Colo., Quartz Creek near $341-342$

Pitkin reservoir site, description of . ......... 94

Placerville, Colo., San Miguel River near.. 384-385

Placerville power site, description of........ 202-203

Plateau Creek, flow of, near Collbran, Colo_ 314-316

Plateau Creek Basin, Irrigation and agriculture in............... 128-129, 142-143

location and physical features of .......... 12-13

reservoir sites in, developed................ $\quad 66$

undeveloped....................... 89

Population of the area..................... 157-158

Power, cost of steam power in comparison with water power................ 149-150

transmission of, effect of climate on...... $\quad 149$

See also Water power.

Power plants. See Water-power plants.

Precipitation in the area computations of

floods in relation to. 152-154

map showing ........................... In pocket.

variations in, figure showing........ 29

Price-Stub pumping plant, description of.- 171-172

Puitt Reservoir, description of

\section{Q}

Quartz Creek, flow of, near Pitkin, Colo.... 341-342 power.from

\section{$\mathbf{R}$}

Railroads, electrification of . .

$159-161$

Raven, Colo., West Divide Creek at...... 310-311

West Divide Creek at Beard ranch near. 310

Recreational features of the area........... 21, 22-23

Red Canyon power site, description of....... 192

Red Mesa reservoir site, unfeasibility of.... 85

Red Mountain Creek, reservoir site on ...... 97-98

Redcliff, Colo., Eagle River at.............. 269-272 Homestake Creek at..................... 279-281

Turkey Creek at........................ 277-279

Redlands pumping plant, description of ... 175-176

Redstone reservoir sites No. 3 and No. 4, unfeasibility of ..................... 85

Reservoirs, developed sites.................. 61-67

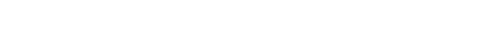

undeveloped sites........................ 68-114

Revenue Tunnel power plant No. 2, description of

Rico, Colo., Dolores River at.

$375-376$

Ridgway, Colo., Dallas Creek near.

$371-372$

Rifle Creek Basin, irrigation and agriculture

in .................................... 128

reservoir in............................... 62

Rifle power plant, description of............ 171

Roan Creek, course of ....................... 12

flow of, near De Beqne, Colo.......... 313-314

Roaring Fork, altitudes and distances along. 190

flow of, at and below Aspen, Colo ....- 282-286 at Glenwood Springs, Colo ......... 287-292

near Emma, Colo................... 286-287

Roaring Fork Basin, irrigation and agriculture in................. 127

location and physical features of .......... 11-12 power sites in, developed. $160-171$
Roaring Fork Basin, power sites in, undeveloped....................... 190-193

reservoir sites in, developed............... 61-62 undeveioped............................ 85-86

Roaring Fork Electric Light \& Power Co. plant, description of ............. 169-170

Rock Creek power site, description of......... 186 Rocky Mountain National Park, features of. 20 Roosevelt Tunnel power plant, description of. $\quad 173$ Ruby Lee Reservoir, features of ............. 63 Run-off, records of ..................... 41-43, 205-387 variation in. $43-48,148$

$\mathbf{S}$

Salt Wash Basin, reservoir in Saltado Creek power site, description of..... 203 Sand Flat reservoir site, location of ........... 108 San Miguel irrigation project, description of

San Miguel River, altitudes and distances along

course and features of

flow of, at Fall Creek, Colo............. 383-384 at Naturita, Colo.................... 385-387 near Placerville, Colo.............. 384-385

San Miguel River Basin, agriculture in.... 139-140 irrigation in.................... 138-139, 145-147 power sites in, developed............... 176 undeveloped . . . .

reservoir sites in.......................... 108-110

Sapinero, Colo., Sapinero Creek at ......... 342-343

Sapinero Creek, course of.................... 15

flow of, at Sapinero, Colo............... 342-343

Sargents, Colo., Tomichi Creek at.......... 340-341

Sawpit power site, description of ............ 202

Scenic features of the area.................. 20-21

Scholl, Colo., Williams River near. ....... 249-251

Shoshone power plant, description of ...... 165-166 plate showing.......................... 164

Smith Fork Basin, irrigation and agriculture in . . ............................ 131-132

Smuggler Union power plant, description of ................................. 176-177

Snake River, flow of, at Dillon, Colo ...... 263-265

power from.................................. 167

source of 10

Snow on transmission lines of Western Colorado Power Co., plate showing.. 148 Snowmass Creek, at Snowmass, Colo...... 297-298 Snowmass Creek power site, description of .. 191 Snowslides, protection against, plates show-

$$
\text { ing .................................. 149, } 164
$$

Spring Creek power site, description of...... 196 Spring Park Reservoir, description of........ 62 Standard Chemical power plant, description of ................................ 176

State Bridge, Colo., Colorado River at....- 220 Steam power, cost of, as compared with water power ........................... 149-150

Stone Cabin reservoir site, description of . . 109-110 Storage of water, necessity for ............... 148 sites for, developed..................... 61-67

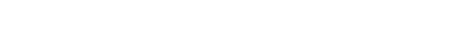
summary of ............................ XII 
Page

Straight Creek power site, description of.. 185-186 Stream flow, effect of ice upon.............. 150-151 records of .......................... 41-48, 205-387

Summit County Power Co. plant, description of ............................. 167

Summit Reservoir, description of............. 64 Sunnyside irrigation project, description of.. 142 Surface Creek, frow of, near Cedaredge, Colo... 353-356

irrigation from ........................ 133-134 source and features of.

$\mathrm{T}$

Tarbell ditch, diversion through.

Taylor Park reservoir site, contour map of description of............................. 90-92

- Taylor River, course and features of......... 13 flow of, above Almont, Colo............ 318

at Almont, Colo..................... 318-322

Taylor Ríver Basin, power sites in ........ 195-197 reservoir sites in..................... 90-91

Temperature of the area..................... 24-26

Tenmile Creek, course of .................. 10 flow of, at Dillon, Colo................... 266-268 near Kokomo, Colo............... 265-266

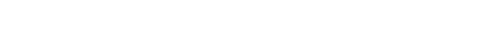

Thomasville, Colo., Fryingpan Creek at.-. 300-302 Tomichi Creek, flow of, at Sargents, Colo.. 340-341

Tomichi Creek Basin, irrigation in......... 130-131 location and physical features of.......... 15 power sites in............................ 173 reservoirs sites in .......................... 93-94

Tonopah shops power plant............... 166-167

Topography of the area........................ 6-19 relation to water power................... 148 reports on

Totton Lake Reservoir, description of........ Transmission lines, effect of snow on, plate showing.

protection of tower against snow, plate showing.

Transportation in the region

Troublesome Creek, course and physical features of.

near Troublesome, Colo_............... 256-257

Trout Creek, reservoir site near............... 95

Trout Lake Reservoir, description of......... 65

flume from, plate showing

Turkey Creek, at Redcliff, Colo............. 277-279

\section{U}

Uncompahgre irrigation project, canal on, plate showing .................... 123

description of $135-136,143$

ranch on, plate showing

Uncompahgre Plateau, location and features of

Uncompahgre River, altitudes and distances along.

17

course and features of $-2-2-2-20-00-2-2-2$

flow of, at Delta, Colo............. at Ouray, Colo_..................... 356-359 below Ouray, Colo............... 359-363 near Colona, Colo
Page

Uncompahgre River Basin, agriculture in... 136 features of . ................................. 16 irrigation in ........................ 134-136, 143 power sites in, developed............... 174-175 undeveloped........................... 198-199 reservoir sites in............................ 97-99

Ute \& Ulay power plant, description of...... 174

$$
\mathrm{V}
$$

Vega reservoir site, description of.

Von Hagen reservoir site No. 1, description of

Von Hagen reservoir site No. 2, unfeasibility of

W

Wabash reservoir site No. 2, description of...-

Water for irrigation, duty of, Grand Valley..

Water power, capacity of streams, estimates

of

competition with steam power......... 149-150

factors affecting development of....... 148-156

irrigation in relation to.................. 148

market for

summary of .............................. XIV-XV

developed.......................... 180-181

undeveloped.......................... 204

topography in relation to ................ 148

Water-power plants, capacity of............ 161-162 climatic difficulties affecting the operation of descriptions of.............................. 165-181

history of publications relating to................... 4

Water rights, decreed rights in Grand Valley_ $\quad 123$

Water supply of the area...................... 41-48 map showing utilization of.......... In pocket. summary of ............................. XII

West Divide Creek, flow of, at Beard Ranch, near Raven, Colo................ 310

flow of, at Raven, Colo.......... 310-311

reservoir site on . . ..................... 88

West Mamm Creek reservoir site, description of $88-89$

West Paradox Creek, irrigation from ...... 138, 145

West Portal, Colo., Fraser River near..... 243-247

Whitewater, Colo., Kahnah Creek near... 373-375.

Willcox irrigation project, description of ..... $\quad 142$ Williams River, diversions from............. 55-56.

flow of, near Parshall, Colo............ 251-256. near Scholl, Colo.................. 249-251

Williams River Basin, location and features

of..................................

Willow Creek power site, description of...... $\quad 186$ Willow Swamp reservoir site, description of. 98 Windy Gap reservoir site. See Park reservoir site.

Wolcott reservoir site, description of .......... 88 Woody Creek power site, description of...... $\quad 191$

\section{$\mathbf{Y}$}

Young \& Hodge power plant, description of. 168. Yule Creek, power from. 

